\title{
INTERNATIONAL GONFERENGE ON EURASIAN ECONOMIES 2011
}





\section{INTERNATIONAL GONFERENGE ON EURASIAN ECONOMIES 2011}

\section{Bishkek - Kyrgyzstan 12-14 October 2011}


Beykent University Publication: 82

Kyrgyzstan-Turkey Manas University Publication: 151

Conference Series: 22

\title{
INTERNATIONAL CONFERENCE ON EURASIAN ECONOMIES \\ 2011
}

\author{
Editors: \\ Selahattin Sarı \\ Jusup Pirimbaev \\ Alp H. Gencer \\ Aynura Turdalieva
}

\author{
Copyright (C) 2011 \\ Beykent University and \\ Kyrgyzstan-Turkey Manas University
}

\begin{abstract}
ALL RIGHTS RESERVED.
This book contains material protected under International and Federal Copyright Laws and Treaties. Any unauthorized reprint or use of this material is prohibited. No part of this book may be reproduced or transmitted in any form or by any means, electronic or mechanical, including photocopying, recording, or by any information storage and retrieval system without express written permission from the publisher.
\end{abstract}

ISBN: 978-975-6319-14-7

Typesetting: Alp H. Gencer

Printing: Manas University Press 


\section{FOREWORD}

It is a great pleasure to welcome you to the International Conference on Eurasian Economies 2011, jointly organized this year by the Economics Departments of Beykent University and KyrgyzstanTurkey Manas University. We want to express our pride in seeing that this conference became a traditional international academic event with increasing interest and support by international institutions, academicians and researchers in Eurasia.

We are very happy to organize the International Conference on Eurasian Economies 2011 at Kyrgyzstan-Turkey Manas University located in Bishkek, the capital and the largest city of Kyrgyzstan. On the path of historic Silk Road between the East and the West and located at the heart of Central Asia, Kyrgyzstan is a magnificent country with snow-capped mountains, deep valleys, thousands of rivers, mountain lakes and historical monuments. We believe that organizing the conference in a country at the heart of Asia that played a critical role throughout centuries will provide an important basis for investigating issues, evaluating problems and developing policies for the Eurasian economies. The topics to be presented at the conference cover a wide variety of subjects with vital impact on the region such as globalization and its impact on Eurasia, integration of Eurasian economies to the world economy, economic growth and development strategies in Eurasian economies, international trade, migration, financial markets and institutions and public policies.

Our aim is that the annual series of International Conferences on Eurasian Economies will provide a basis for collaboration of decision makers and academicians in Eurasia and will establish a scientific discussion platform regarding the economic development process faced by the Eurasian economies. We hope that the 2011 conference will constitute the basis for the formation of an Eurasian economists association for collaboration of researchers, academicians and decision makers from different universities and institutions in order to develop analyses and propose policies.

For the 2011 conference, we received 145 abstracts from over 20 countries, such as Kazakhstan, Uzbekistan, Tajikistan, Russia, Ukraine, Moldova, Georgia, India, Germany, Poland, Japan, as well as Turkey and Kyrgyzstan. You will find 80 selected papers in this proceedings book. We would like to present our gratitude to the advisory board and the scientific board for their dedicated efforts throughout the review process.

We are grateful to the Promotion Fund members of the Turkish Prime Ministry, to the governors and experts of the Central Bank of Turkey and to the Turkish International Cooperation and Development Agency for their support in organizing this conference. We also want to thank to the Boards of Trustees, to the distinguished rectors, to the respected faculty deans and to faculty members and administrative personnel of Beykent and Kyrgyzstan-Turkey Manas Universities.

We are indebted to all the researchers and academicians who participated at the conference by submitting their distinguished work for presentation. We believe that their contributions will be greatly beneficial to the economies of Eurasian countries. We are looking forward to meeting you in another Eurasian country at the International Conference on Eurasian Economies 2012.

\section{Prof. Dr. Selahattin Sarı}

Vice Rector

Beykent University

Istanbul, Turkey
Prof. Dr. Jusup Pirimbaev

Head of Department of Economics

Kyrgyzstan-Turkey Manas University

Bishkek, Kyrgyzstan 


\section{ÖNSÖZ}

Sizleri Beykent Üniversitesi ve Kırgızistan-Türkiye Manas Üniversitesi İktisat Bölümleri tarafından organize edilen Uluslararas1 Avrasya Ekonomileri Konferans1 2011'de aramızda görmekten gurur duyuyoruz. Konferansın geleneksel bir uluslararası konferansa dönüştüğünü, ve Avrasya akademisyenleri, araştırmacıları ve çeşitli kurumlarca artan ilgi ve destekle karşılandığını görmekten duyduğumuz gururu sizlerle paylaşmak istiyoruz.

Uluslararası Avrasya Ekonomileri Konferansı 2011'i Kırgızistan'ın en büyük şehri ve başkenti olan Bişkek’te, Kırgızistan-Türkiye Manas Üniversitesi ev sahipliğinde organize etmekten mutluluk duyuyoruz. Doğu ile batı arasında önemli bir köprü olan tarihi İpek Yolu üzerinde ve Orta Asya'nın kalbinde yer alan Kırgızistan, zirveleri karla kaplı dağları, derin vadileri, binlerce nehri, dağ gölleri ve tarihi anıtları ile muhteşem bir ülkedir. İnanıyoruz ki bu konferans, Avrasya'nın kalbinde ve tarih boyunca merkezi rolü ile öne çıkan bir ülkede gerçekleșmesi bağlamında Avrasya ekonomilerinin karşılaştığı problemlerin incelenmesi ve çözüm politikalarının değerlendirilmesi açısından önemli bir rol oynayacaktır. Konferans çerçevesinde sunulacak çalışmaların başlıkları geniş bir çeşitliliğe sahip ve bölge açısından hayati önem taşıyan konularda toplanmaktadır: Küreselleşme ve Avrasya ekonomileri üzerine etkileri, Avrasya ekonomilerinin dünya ekonomisine entegrasyonu, Avrasya ekonomileri için iktisadi büyüme ve kalkınma stratejileri, uluslararası ticaret, göç, finans piyasaları ve kurumları ve kamu politikaları.

Her yıl düzenlenmesi planlanan Uluslararası Avrasya Ekonomileri Konferans1 serisi ile Avrasya ekonomileri karar alıcıları ve akademisyenleri arasında Avrasya ekonomilerinde iktisadi kalkınmaya ilişkin, bilimsel kriterleri esas alan bir çalışma platformu oluşturulmasını hedeflemekteyiz. Bu amaç doğrultusunda, işlevi Avrasya ekonomilerinin analizi ve iktisadi politikaların önerilmesi olan bir Avrasya ekonomistler birliğinin 2011 konferansı çerçevesinde oluşturulması dileğimizdir.

2011 konferansına başta Kazakistan, Özbekistan, Tacikistan, Rusya, Ukrayna, Moldova, Gürcistan, Hindistan, Almanya, Polonya, Japonya, Türkiye ve Kırgızistan olmak üzere 20'den fazla ülkeden 145 özet gelmiş olduğunu belirtmekten gurur duyuyoruz. Bu kitapta özenle seçilmiş 80 çalışmanın tam metnini bulacaksınız. Bu bağlamda, danışma kurulunun ve bilim kurulunun değerli üyelerine çalışmaların değerlendirilmesinde gösterdikleri özveri ve verdikleri emek için teşekkürlerimizi sunmak isteriz.

Türkiye Cumhuriyeti Başbakanlık Tanıtma Fonu Kurulu üye ve bürokratlarına, Türkiye Cumhuriyeti Merkez Bankası yöneticileri ve uzmanlarına, Türk İşbirliği ve Kalkınma İdaresi Başkanlığı yetkililerine konferansın sponsorluğu ve hazırlanma aşamasında değerli destekleri için teşekkürlerimizi sunarız. Beykent Üniversitesi ve Manas Üniversitesi Mütevelli Heyetlerine ve değerli rektörlerine, ilgili fakültelerin dekanlarına, konferansın düzenlenmesinde ve yürütülmesinde her türlü desteği veren akademisyen ve idari personele katkılarından dolayı teşekkür ederiz.

Konferansa ilgi gösteren araştırmacı, akademisyen ve katılımcılara içten teşekkürlerimizi sunarız. Konferansda sunulan değerli bildiri ve çalışmaların Avrasya ülkeleri için yararlı olacağı inancını bir kez daha paylaşmak isteriz. Uluslararası Avrasya Ekonomileri Konferansı 2012 için bir başka Avrasya ülkesinde buluşmak dileğiyle.

\section{Prof. Dr. Selahattin Sarı}

Rektör Yardımcısı

Beykent Üniversitesi

İstanbul, Türkiye
Prof. Dr. Jusup Pirimbaev

İktisat Bölümü Bölüm Başkanı

Kırgizistan-Türkiye Manas Üniversitesi

Bişkek, Kırgızistan 


\section{ПРЕДИСЛОВИЕ}

Для нас большая гордость видеть Вас на международной конференции «Экономика Евразии 2011», организованной университетом Бейкент и Кыргызско-Турецким университетом «Манас». Вместе с тем мы хотим порадоваться тому, что проведение конференции стало традицией и постоянно растет интерес и поддержка академических работников, исследователей и различных международных институтов Евразии.

Мы рады совместному участию университета Бейкент и Кыргызско-Турецкого университета «Манас» в организации международной конференции «Экономика Евразии 2011» в столице Кыргызстана городе Бишкеке. Кыргызстан расположен в Центральной Азии, на Великом Шелковом пути, который является важным мостом между Востоком и Западом, а его природа восхищает снежными горами, глубокими долинами, многочисленными реками и горными озерами, историческими памятниками. Мы верим, что конференция, организуемая в сердце Евразии, в стране, которая в течение истории играла центральную роль, сыграет важную роль и в изучении проблем, с которыми столкнулись евразийские страны, и в оценке политики, направленной на решение этих проблем. В этой связи тематика докладов конференции разнообразна и сосредоточена вокруг таких жизненно важных проблем, как глобализация и ее влияние на экономику евразийских стран, интеграция евразийских стран в мировую экономику, стратегия экономического роста и развития евразийских экономик, международная торговля, миграция, финансовые рынки и институты, государственная политика. Планируя ежегодное проведение конференции, мы поставили цель международной конференции «Экономика Евразии 2011» - создать среди ученых и среди тех, кто принимает решения в евразийских странах, единую рабочую платформу по экономическому развитию, основывающуюся на научных критериях. Согласно этой цели, мы хотим в рамках конференции создать Ассоциацию экономистов Евразии, функциями которой явились бы экономический анализ евразийских экономик и выработке предложений по экономической политике.

Мы хотим сообщить, что к нам поступило 145 аннотаций докладов из более 20 стран мира: Казахстана, Узбекистана, Таджикистана, России, Украины, Молдовы, Грузии, Индии, Германии, Польши, Японии, Турции и Кыргызстана. В этом сборнике вы найдете полные тексты отобранных 80 работ. Мы хотим поблагодарить уважаемый консультационный и научноредакционный комитеты за большой труд и самоотверженность в подготовке конференции и оценке работ.

Мы хотим выразить свою благодарность членам и сотрудникам Совета Фонда содействия при премьер-министре Турецкой Республики, управляющим и специалистам Центрального банка Турецкой Республики за оказанную спонсорскую помощь и поддержку в подготовке конференции. Университет Бейкент и Кыргызско-Турецкий университет «Манас» благодарят попечительские советы и ректоров, деканов факультетов, академических работников за поддержку в организации и проведении конференции, а также административных работников за их вклад.

И в заключение хотим выразить искреннюю благодарность исследователям, академическим работникам и участникам за проявленный интерес к конференции. Мы надеемся, что доклады и статьи, представленные на конференции, будут полезны для стран Евразии. Мы надеемся встретиться на следующей международной конференции «Экономика Евразии 2011» в одной из стран Евразии.

проф., др. Селахаттин Сары, проректор,

Университет Бейкент, Стамбул, Турция проф., д.э.н. Жусуп Пиримбаев, зав. кафедрой «Экономика», Кыргызско-Турецкий университет «Манас», Бишкек, Кыргызстан 


\section{FROM THE RECTORS}

We are pleased and honored to welcome you all to the International Conference on Eurasian Economies 2011. This year's event is organized by collaboration of Beykent University with Kyrgyzstan-Turkey Manas University and is hosted by the Kyrgyzstan-Turkey Manas University in Bishkek, Kyrgyzstan on October 12-14, 2011.

We would hereby like to inform you briefly about the two universities organizing this meeting. Kyrgyzstan-Turkey Manas University was founded in accordance with an agreement signed in 1995 between the government of the Republic of Turkey and the Republic of Kyrgyzstan. Diplomas earned at Kyrgyzstan-Turkey Manas University are recognized by both Turkey and Kyrgyzstan. There are students from 14 different countries, mainly from the Turkish Republics, within 9 faculties, 2 institutes and 4 high schools and 1 vocational school at the university, which brings the opportunity for cultural diversity and richness. Educational activities started in 1997-1998 and are held in Turkish and Kyrgyz. With its 51 professors, 33 associate professors and 14 assistant professors coming from Turkey, Kyrgyzstan and other countries, Kyrgyzstan-Turkey Manas University's vision is "to be a university which is respected and well known in the international sphere".

Beykent University was established in 1997 by Adem Çelik-Beykent Educational Foundation. Today, Beykent University is a dynamic institution with about 300 academicians and 15,000 students within 7 faculties, 2 institutes, a distance education center with various undergraduate and masters programs and associate's degree vocational school. The language of instruction at Beykent University is Turkish and English. Since its establishment in 1997, Beykent University's long run vision is to become one of the top worldwide universities. At Beykent University, all academic and administrative personnel work in a family environment with great ambition and enthusiasm for accomplishing this vision.

We would like to thank to the Promotion Fund of the Turkish Prime Ministry, to the Central Bank of Turkey and to the Turkish International Cooperation and Development Agency for their financial support. We would also like to express great appreciation to the organization committee, the advisory board and the scientific board who dedicated their work to the realization of this conference. Lastly, all academicians and researchers deserve our gratitude for their contribution. We believe that this conference will foster great interest and further research in this area.

Prof. Dr. Mehmet Emin Karahan

Rector

Beykent University, Istanbul, Turkey

\section{Prof. Dr. Sebahattin Balcı}

Rector

Kyrgyzstan-Turkey Manas University

Bishkek, Kyrgyzstan 


\section{REKTÖRLER'DEN}

Sizleri, düzenlediğimiz Uluslararası Avrasya Ekonomileri Konferans1 2011'de aramızda görmekten mutluluk ve şeref duyuyoruz. Bu y1l, Kırgızistan-Türkiye Manas Üniversitesi ve Beykent Üniversitesi ortaklığında organize edilen Uluslararası Avrasya Ekonomileri Konferans1 2011, 12-14 Ekim 2011 tarihlerinde Kırgızistan-Türkiye Manas Üniversitesi'nin ev sahipliğinde düzenlenmektedir.

$\mathrm{Bu}$ vesileyle sizleri, bu buluşmayı düzenleyen Kırgızistan-Türkiye Manas Üniversitesi ve Beykent Üniversitesi hakkında kısaca bilgilendirmek isteriz. Kırgızistan-Türkiye Manas Üniversitesi 1995'te Türkiye Cumhuriyeti ile Kırgızistan Cumhuriyeti hükümeti tarafından imzalanan bir anlaşmay1 müteakip kurulmuştur. Kırgızistan-Türkiye Manas Üniversitesi bünyesinde alınan diplomalar hem Türkiye'de hem de Kırgızistan'da tanınmaktadır. 14 ayrı ülkeden gelen öğrenciler, 9 fakülte, 2 enstitü ve 4 yüksekokul ve 1 meslek yüksekokulu dahilinde öğrenim görmeye devam etmektedir. Bu da kültürel çeşitliliğe ve zenginliğe firsat tanımaktadır. 1997-1998 yılında başlayan eğitim ve öğretim faaliyetleri Türkiye Türkçesi ve Kırgızca yapılmaktadır. Türkiye'den, Kırgızistan'dan ve diğer ülkelerden gelen 51 profesör, 33 doçent ve 14 yardımcı doçent ile Kırgızistan-Türkiye Manas Üniversitesinin vizyonu "uluslararası düzeyde saygın ve tanınan bir üniversite" olmaktır.

Beykent Üniversitesi, 1997 yılında Adem Çelik - Beykent Eğitim Vakfı tarafından kurulmuştur. Bugün, Beykent Üniversitesi, 7 fakülte, 2 enstitü, 1 meslek yüksekokulu ve uzaktan eğitim merkezinde çalışan 300 civarında kadrolu öğretim üyesi ve öğrenim gören yaklaşık 15000 öğrencisiyle dinamik bir kurumdur. Öğrenim dili Türkçe ve İngilizcedir. 1997'deki kuruluşundan beri, Beykent Üniversitesinin uzun vadeli vizyonu dünya çapında en iyi üniversitelerden biri olmaktır. Bütün akademik ve idari personel bu vizyonu gerçekleştirmek amacıyla büyük bir hevesle ve gayretle bir aile ortamı içerisinde çalışmaktadır.

Sağladıkları maddi destek için Türkiye Cumhuriyeti Başbakanlık Tanıtma Fonu kuruluna, Türkiye Cumhuriyet Merkez Bankası'na ve Türk İşbirliği ve Kalkınma İdaresi Başkanlığı'na teşekkür etmek isteriz. Bununla birlikte, bu konferansın gerçekleşmesi için çalışmış olan organizasyon komitesine, danışma kuruluna ve bilim kuruluna minnettarlı̆̆ımızı ifade etmek isteriz. Son olarak, katılımları için bütün akademisyenler ve araştırmacılara takdirlerimizi sunarız. İnanıyoruz ki, bu konferans bu alana karşı olan büyük ilginin ve araştırmaların gelişmesine yardım edecektir.

Prof. Dr. Mehmet Emin Karahan

Rektör

Beykent Üniversitesi

İstanbul, Türkiye

\section{Prof. Dr. Sebahattin Balcı}

Rektör

Kırgızistan-Türkiye Manas Üniversitesi

Bişkek, Kırgızistan 


\section{OT РЕКTOPOB}

Для нас большая честь видеть Вас на международной конференции «Экономика Евразии 2011». В этом году международная конференция «Экономика Евразии 2011» организована совместно университетом Бейкент и Кыргызско-Турецким университетом «Манас» 12-14 октября 2011 года в Кыргызско-Турецком университете «Манас».

Мы хотим дать краткую информацию об организаторах этой встречи: об университете Бейкент и Кыргызско-Турецком университете «Манас». Кыргызско-Турецкий университет «Манас» был создан в 1995 году на основании соглашения, подписанного Турецкой и Кыргызской Республиками. Диплом Кыргызско-Турецкого университета «Манас» признается в Кыргызстане и Турции. В университете обучаются студенты из 14 стран, работают 9 факультетов, 2 института, 4 высшие школы, 1 высшая профессиональная школа. С 1997-1998 учебного года началось обучение в КТУ «Манас», и ведется на кыргызском и турецком языках. В университете работает 51 профессор, 33 доцента и 14 и.о. доцента из Кыргызстана, Турции и других стран. Целью университета является стремление «стать почитаемым и известным университетом на международном уровне».

Университет Бейкент был создан в 1997 году Образовательным фондом Адем Челик-Бейкент. Сегодня университет Бейкент является динамичным университетом, в его структуре 7 факультетов, 2 института, 1 профессиональная школа, центр дистанционного образования, около 300 преподавателей обучают 15000 студентов. Обучение проводится на турецком и английском языках. Образование осуществляется с 1997 года. Целью университета Бейкент является стремление «стать одним из лучших университетов в мире». Для достижения этой цели весь академический и административный персонал университета работает с большим желанием и усердием, как одна большая семья.

Мы хотим поблагодарить Фонд содействия Турецкой Республики и Центральный банк Турецкой Республики за оказанную финансовую поддержку. Вместе с тем хотим выразить свою признательность организационному комитету, консультационному и научно-редакционному комитетам за организацию конференции. И в заключение выражаем искреннюю благодарность всем исследователям, академическим работникам. Мы верим, что конференция поможет развитию исследований и повысит интерес к этой сфере.

проф., др. Мехмет Эмин Карахан, ректор,

университет Бейкент, Стамбул, Турция проф., др. Себахаттин Балжы, ректор,

Кыргызско-Турецкий университет «Манас», Бишкек, Кыргызстан 


\section{ADVISORY BOARD}

- Prof. Dr. Mehmet Emin Karahan (Rector, Beykent University)

- Prof. Dr. Sebahattin Balc1 (Rector, Kyrgyzstan-Turkey Manas University)

- Prof. Dr. Selahattin Sarı (Vice Rector, Beykent University)

- Prof. Dr. Erol Eren (Dean, Faculty of Economic and Administrative Sciences, Beykent University)

- Prof. Dr. Musin Halis (Dean, Faculty of Economic and Administrative Sciences, Kyrgyzstan-Turkey Manas University)

- Prof. Dr. Jusup Pirimbaev (Chair, Department of Economics, Kyrgyzstan-Turkey Manas University)

- Prof. Dr. Ahmed Güner Sayar (Chair, Department of Economics, Beykent University)

\section{ORGANIZING COMMITTEE}

- Asst. Prof. Dr. Mustafa Ercilasun

- Asst. Prof. Dr. Ayşen Hiç Gencer

- Asst. Prof. Dr. Özgür Ömer Ersin

- Asst. Prof. Dr. İlyas Sözen

- Asst. Prof. Dr. Tuncer Özdil

- Asst. Prof. Dr. Volkan Öngel

- Ph.D. Candidate Bekir Aşık

- Ph.D. Candidate Aynura Turdalieva

\section{WEB \& PRINT DESIGN}

- Dr. Alp Gencer

- Dr. Cunus Ganiev 


\section{SCIENTIFIC BOARD}

- Prof. Dr. Şahin Akkaya (Istanbul University, Turkey)

- Prof. Dr. Ahmet Aksoy (Gazi University, Turkey)

- Prof. Dr. Sudi Apak (Beykent University, Turkey)

- Assoc. Prof. Dr. Turusbek Asanov (Kyrgyzstan-Turkey Manas University, Kyrgyzstan)

- Assoc. Prof. Dr. Ahmet Ay (Selçuk University, Turkey)

- Asst. Prof. Dr. Cipar Aytuganova (Kyrgyzstan-Turkey Manas University, Kyrgyzstan)

- Assoc. Prof. Dr. Mehmet Balcilar (Eastern Mediterranean University, Cyprus)

- Prof. Dr. Tansu Barker (Brock University, Canada)

- Prof. Dr. Cem Behar (Boğaziçi University, Turkey)

- Prof. Dr. Damira Bektenova (Kyrgyz-Russian Slavic University, Kyrgyzstan)

- Prof. Dr. Melike Bildirici (Yıldız Technical University, Turkey)

- Prof. Dr. Faik Bilgili (Erciyes University, Turkey)

- Prof. Dr. Ersan Bocutoğlu (Karadeniz Technical University, Turkey)

- Prof. Dr. Cumabek Cailov (Kyrgyz Economic Research Center, Kyrgyzstan)

- Prof. Dr. Seyfullah Çevik (Gediz University, Turkey)

- Prof. Dr. İrfan Civcir (Ankara University, Turkey)

- Prof. Dr. Ömer Selçuk Emsen (Erzurum Atatürk University, Turkey)

- Assoc. Prof. Dr. Alpay Filiztekin (Sabancı University, Turkey)

- Prof. Dr. Şaziye Gazioğlu (Hatay M.Kemal University \& Middle Eastern Technical University, Turkey)

- Prof. Dr. Cevat Gerni (Gebze Institute of Technology, Turkey)

- Prof. Dr. Süreyya Hiç (Kocaeli University, Turkey)

- Prof. Dr. Mükerrem Hiç (Beykent University, Turkey)

- Prof. Dr. Ahmet Incekara (Istanbul University, Turkey)

- Prof. Dr. Danijela Jacimovic (University of Montenegro, Montenegro)

- Assoc. Prof. Dr. Damira Japarova (Kyrgyzstan-Turkey Manas University, Kyrgyzstan)

- Assoc. Prof. Dr. Metin Karadağ (Ege University, Turkey)

- Prof. Dr. Ridvan Karluk (Eskişehir Anadolu University, Turkey)

- Prof. Dr. Mehmet Kaytaz (Işık University, Turkey)

- Prof. Dr. Nuriddin Kayumov (Tajikistan Academy of Sciences, Tajikistan)

- Prof. Dr. Gülten Kazgan (Bilgi University, Turkey)

- Prof. Dr. Recep Kök (Dokuz Eylül University, Turkey)

- Prof. Dr. Turar Koychuev (Kyrgyzstan-Turkey Manas University, Kyrgyzstan)

- Prof. Dr. Ali Özgüven (Kültür University, Turkey)

- Prof. Dr. Stanislav Polouček (VŠB-Technical University of Ostrava, Czech Republic)

- Prof. Dr. Mihai Roman (Bucharest Academy of Economic Studies, Romania)

- Prof. Dr. Muammer Tekeoğlu (Çukurova University, Turkey)

- Prof. Dr. Mehmet Sinan Temurlenk (Atatürk University, Turkey)

- Assoc. Prof. Dr. Arman Tevfik (Kyrgyzstan-Turkey Manas University, Kyrgyzstan)

- Prof. Dr. Bahadir Umurzakov (G.V. Plekhanov Russian University of Economics in Tashkent, Uzbekistan)

- Prof. Dr. Anarkül Urdaletova (Kyrgyzstan-Turkey Manas University, Kyrgyzstan)

- Prof. Dr. Ahmet Yörük (Kadir Has University, Turkey) 


\section{Contents}

SESSION 1A: Global Financial Integration

Session Chair: Prof. Dr. Ahmet Incekara

Recent Monetary Policy in Turkey: Capital Flow, Reserves and Exchange Rate

- Prof. Dr. Şaziye Gazioğlu, Hatay M.Kemal University \& Middle Eastern Technical University, Turkey

The Development and Interregional Integration Processes of Afghanistan

- Prof. Dr. Nuriddin Kayumov, Tajikistan Academy of Sciences, Tajikistan

Kyrgyzstan's Relations with International Financial Organizations: Curse or Curve?

- Asst. Prof. Dr. Yaşar Sarı, Kyrgyzstan-Turkey Manas University, Kyrgyzstan

Multilateralism versus Regionalism in Eurasia: Theoretical Reasons of Choosing Sides for Kyrgyzstan

- Ph.D. Candidate Zamirbek Manasov, Middle East Technical University, Turkey

SESSION 1B: Uluslararası İlişkiler

Session Chair: Prof. Dr. Doğan Nadi Leblebici

Türkiye'deki Gençliğin Şangay İşbirliği Örgütüne Yönelik Tutumuna Pazarlama Perspektifiyle Bakış

- Asst. Prof. Dr. Burak Kartal, Celal Bayar University, Turkey

- Asst. Prof. Dr. Çiğdem Sofyalığlu, Celal Bayar University, Turkey

Orta Asya ve Güney Kafkasya'daki Türk Cumhuriyetlerinin Küresel Dünyaya Entegrasyonunun Ekonomi

Politiği

- Dr. Özlem Arzu Azer, Istanbul University, Turkey

Devi Bağlayan Bağlar: Çin'in Orta Asya Enerji Kaynaklarındaki Çıkarı

- Asst. Prof. Dr. Hasan Duran, Dumlupınar University, Turkey

- Mr. Kadir Kürşat Yılmaz, Dumlupinar University, Turkey

Orta Asya'da Büyük Oyun: Kırgızistan

- Ph.D. Candidate Tevfik Orçun Özgün, Hacettepe Üniversity, Turkey

- Ph.D. Candidate Meral Uçmaz, Hacettepe University, Turkey

SESSION 1C: Uluslararası Ticaret

Session Chair: Prof. Dr. Ömer Selçuk Emsen

Küresel Krizin Kırgızistan Ekonomisine Etkisi ve Türkiye Kırgızistan Ekonomik İlişkilerindeki Gelişmeler ....47

- Prof. Dr. Rıdvan Karluk, Eskişehir Anadolu University, Turkey

Kırgızistan’ın Dış Ticaret Sorunları

- Dr. Cunus Ganiyev, Kyrgyzstan-Turkey Manas University, Kyrgyzstan

- Damira Baigonushova, Kyrgyzstan-Turkey Manas University, Kyrgyzstan

Kırgizistan ile Türkiye Arasındaki İlişkilerin Ekonomik ve Ticari Açıdan İncelenmesi

- Ph.D. Candidate Semih Çetin, Hitit University, Turkey

- Ph.D. Candidate Burak Sertkaya, Hitit University, Turkey

Küreselleşmenin Ekonomik Entegrasyon Üzerine Etkileri

- Asst. Prof. Dr. C. Erdem Hepaktan, Celal Bayar University, Turkey

- Ph.D. Candidate Serkan Çınar, Celal Bayar University, Turkey 
SESSION 1D: Финансы

Session Chair: Prof. Dr. Turar Koychuev

Совершенствование финансово - кредитных механизмов регулирования развития АПК 78

- Prof. Dr. Dzhumabek Dzhailov, Ministry of Agriculture, Kyrgyzstan

- Mr. Farkhad Sariev, Zh. Alyshbaev Cooperation Institute of Issykkul, Kyrgyzstan

- Mrs. Elmira Kupsuralieva, Kyrgyzstan-Turkey Manas University, Kyrgyzstan

Современное состояние аудиторских услуг в Кыргызской Республике

- Assoc. Prof. Dr. Kylychbek Supataev, Kyrgyz Academy of Law, Kyrgyzstan

Проблемы применения налога на прибыль в Кыргызской Республике

- Ph.D. Candidate Larisa Macarenko, Kyrgyz-Russian Slavic University, Kyrgyzstan

Сфера защиты депозитов: Евразийский опыт и его адаптация в Кыргызстане

- Mr. Ruslan Gaidarov, Kyrgyz-Russian Slavic University, Kyrgyzstan

SESSION 2A: Growth \& Development

Session Chair: Asst. Prof. Dr. Mustafa Ercilasun

Depleting Water Resources of Indian Punjab Agriculture: Lessons for High Potential Areas and Policy Options

- Prof. Dr. Joginder Singh, Centre for Agricultural Reseach \& Rural Development, India

Parental Perception of School Education and Human Capital Formation: A Case Study in Selected Villages

of Pakistan

- Ph.D. Candidate Abdul Salam Lodhi, (ZEF b) University of Bonn, Germany

Agriculture Cooperatives of Russia: Present State and Perspectives under the Contemporary Conditions

- Ph.D. Candidate Igor Tonkoshkurov, Khakassia State University named after Nikolaj Katanov, Russia

Economic Growth and Democracy in Moldova

- Prof. Dr. Tatiana Pyshkina, Academy of Economic Studies of Moldova (ASEM), Moldova

SESSION 2B: Finans

Session Chair: Prof. Dr. Hüseyin Avni Egeli

Geçiş Ekonomilerinde Dış Borçlulukta Değişmeler

- Asst. Prof. Dr. Çă̆atay Karaköy, Cumhuriyet University, Turkey

- Prof. Dr. Ahmet Uzun, Cumhuriyet University, Turkey

- Prof. Dr. Ömer Selçuk Emsen, Erzurum Atatürk University, Turkey

Likidite Azlığg Priminin Menkul Kıymet Getirileri Üzerinde Etkileri ve Avrasya İçin Önemi

- Ph.D. Candidate Serdar Kuzu, Istanbul University, Turkey

Türkiye Sigorta Sektörü ve Analizi

- Mr. Sinan Kuşçu, Prime Ministry Maritime Undersecretary, Turkey

- Ph.D. Candidate Galip Afsin Ravanoglu, Kyrgyzstan-Turkey Manas University, Kyrgyzstan

Çevre Hakkı ve Uygulaması

- Assoc. Prof. Dr. Faruk Bilir, Selcuk University, Turkey

- Mr. Berkan Hamdemir, Selcuk University, Turkey 
SESSION 2C: Çalışma Ekonomisi

Session Chair: Prof. Dr. Mustafa Topaloğlu

Azgelişmiş Ülkelerde İşsizlik Sigortası'nın Önemi

- Prof. Dr. Faruk Andaç, Çağ Üniversitesi, Turkey

Türkiye'de Yeşil Yakalı Mesleklerin Gelişiminde Güncel Eğilimler

- Asst. Prof. Dr. Zerrin Sungur, Anadolu University, Turkey

Türkiye'de Değere Bağlı Sağlık Sistemi Temelinde Kamu ve Özel Sektör Açısından Algılanan Hizmet

- Dr. Müjgan Hacıoğlu Deniz, Istanbul University, Turkey

- Asst. Prof. Dr. Elif Haykır Hobikoğlu, Istanbul University, Turkey

Büyüme ve İstihdam Arasindaki İlişki: Türkiye Örneği

- Mr. Yusuf Muratoğlu, Hitit University, Turkey

SESSION 2D: Рост и развитие

Session Chair: Prof. Dr. Nuriddin Kayumov

Макроэкономическая оценка постсоветского развития в Таджикистане

- Prof. Dr. Khodjamakhmad Umarov, Institute of Economics, Tajikistan

Проблемы продовольственной безопасности Казахстана

- Prof. Dr. Gani Kaliev, Academy of Agricultural Sciences, Kazakhstan

Роль животноводства в обеспечении продовольственной безопасности Казахстана

- Prof. Dr. Altynbek Moldashev, Research Institute of Agricultural Economics and Rural Development,

Kazakhstan

Реформирование системы здравоохранения Кыргызстана: проблемы и перспективы ... 186

- Assoc. Prof. Dr. Damira Japarova, Kyrgyzstan-Turkey Manas University, Kyrgyzstan

SESSION 3A: International Trade

Session Chair: Asst. Prof. Dr. Ayşen Hiç Gencer

The Benefits and Problems of International Trade in the Context of Global Crisis

- Dr. Ercan Ekmekçioğlu, Kyrgyzstan-Turkey Manas University, Kyrgyzstan

Developing Country Concerns on Multinational Trade: Problems of Kyrgyzstan's Trade Development

- Mrs. Aidai Budaichieva, International Ataturk-Alatoo University, Kyrgyzstan

- Ph.D. Candidate Kiyalbek Akmoldoev, International Ataturk Alatoo University, Kyrgyzstan

- Mrs. Jarkyn Junushbaeva, International Ataturk-Alatoo University, Kyrgyzstan

Budget Deficits and Trade Deficits in Turkey: An Empirical Investigation of Causality.....

- Ph.D. Candidate H. Zeynep Budak, Bahçeşehir University, Turkey

SESSION 3B: Turizm ve Mikroekonomi

Session Chair: Prof. Dr. Mehmet Balcllar

Turizmin Türk Ekonomisine Etkilerinin Girdi-Çıktı Analizi ile Değerlendirilmesi

- Assoc. Prof. Dr. Mehmet Sarışık, Sakarya University, Turkey

- Asst. Prof. Dr. Orhan Akova, Istanbul University, Turkey

- Asst. Prof. Dr. Oğuz Türkay, Sakarya University, Turkey

- Ph.D. Candidate Didar Sarı, Sakarya University, Turkey

Marmara Bölgesinde Turizm Lisans Öğrencilerinin Konaklama Sektöründe Cinsiyete Göre Kariyer

Düşünceleriyle İlgili Bir Araştırma

- Asst. Prof. Dr. Burhanettin Zengin, Sakarya University, Turkey

- Mr. Lütfi Mustafa Şen, Sakarya University, Turkey

- Mr. Osman Taşar, Sakarya University, Turkey 
Firmaların Bankalara İlişkin Algılarında Sektörel ve Aylık İşlem Sayısı Farklılıklarının İncelenmesi

- Asst. Prof. Dr. İbrahim Halil Ekşi, Kilis 7 Aralık University, Turkey

- Ph.D. Candidate Yavuz Akçi, Gaziantep University, Turkey

Kümelenme Modeli ve Politikaları Çerçevesinde Bilgi Yapılanması ve Rekabet İlişkisi

- Asst. Prof. Dr. Elif Haykır Hobikoğlu, Istanbul University, Turkey

- Dr. Müjgan Hacıoğlu Deniz, Istanbul University, Turkey

SESSION 3C: Orta Asya Ekonomileri I

Session Chair: Prof. Dr. Jusup Pirimbaev

2005-2009 Döneminde Kırgızistan Ekonomisindeki Yapısal Değişimin Girdi-Çıktı Analiziyle İncelenmesi ...238

- Ph.D. Candidate Aynura Turdalieva, Kyrgyzstan-Turkey Manas University, Kyrgyzstan

- Asst. Prof. Dr. Tuncer Özdil, Kyrgyzstan-Turkey Manas University, Kyrgyzstan

Kamu-Özel İşbirliği Projeleri ve Kırgızistan Ekonomisi Açısından Önemi

- Prof. Dr. Ahmet Burçin Yereli, Hacettepe University, Turkey

- Mr. Mustafa Kızıltan, Hacettepe Üniversitesi, Turkey

Geçiş Ekonomilerinde Liberalizm ve Büyüme İlişkileri

- Prof. Dr. Cevat Gerni, Gebze Institute of Technology, Turkey

- Prof. Dr. Selahattin Sarı, Beykent University, Turkey

- Assoc. Prof. Dr. Mustafa Kemal Değer, Karadeniz Technical University, Turkey

- Prof. Dr. Ömer Selçuk Emsen, Erzurum Atatürk University, Turkey

Orta Asya Türk Cumhuriyetleri’nde Sürdürülebilir İktisadi Büyümenin Belirleyicileri .260

- Asst. Prof. Dr. Fahri Solak, Marmara University, Turkey

- Dr. Ercan Sarıdoğan, Marmara University, Turkey

SESSION 3D: Международные отношения

Session Chair: Prof. Dr. Gani Kaliev

Национальные особенности формирования экономической политики в условиях мирового кризиса и посткризисный период

- Prof. Dr. Alisher Rasulev, Institute of Economics, Uzbekistan

Евразийское экономическое сообщество: современное состояние и перспективы развития

- Prof. Dr. Orazaly Sabden, Institute of Economics, Kazakhstan

О возможностях развития Кыргызско-Грузинского сотрудничества

- Dr. Iuri Tsuladze, State Committee for Science and Technologies, Georgia

- Prof. Dr. Turar Koychuev, Kyrgyzstan-Turkey Manas University, Kyrgyzstan

Rusça ve Türkçe'de Çokanlamlı Ekonomi Terimlerinin Analizi

- Assoc. Prof. Dr. Larysa Zakharova, Beykent University, Turkey

SESSION 5A: Finance

Session Chair: Prof. Dr. Şaziye Gazioğlu

Stock Valuation: Dividend Discount Models

- Prof. Dr. Syrgak Kydyraliev, American University of Central Asia, Kyrgyzstan

- Prof. Dr. Anarkül Urdaletova, Kyrgyzstan-Turkey Manas University, Kyrgyzstan

Implications of the Global Financial Crisis on the Banking Sector in Eastern Europe and Baltic States 287

- Assoc. Prof. Dr. Eva Banincova, Kobe University, Japan

Ukraine Pension System and Financial Markets: Conceptualization Problems

- Dr. Nataliya Rad, Donetsk National University of Economics and Trade, Ukraine 
The Importance of Ethics in the Sphere of Employment in Polish Banking Sector

- Ph.D. Candidate Jerzy Kaźmierczyk, Poznań University of Economics, Poland

- Asst. Prof. Dr. Mirosław Świt, University of Zielona Gora, Poland

SESSION 5B: Büyüme ve Gelişme I

Session Chair: Assoc. Prof. Dr. Mehmet Sarılşık

Gelişen Liberal Ekonomilerde Bürokrasinin Maliyeti: Türkiye Örneği

- Prof. Dr. Doğan Nadi Leblebici, Hacettepe University, Turkey

- Mrs. Ayşegül Kurban, Hacettepe University, Turkey

Sosyal Parafiskal Yük Açısından Avrupa Birliği ve Türkiye Karşılaştırması (1995-2008)

- Ph.D. Candidate Sevilay Gümüş, Hacettepe University, Turkey

Türkiye'deki İç Göçleri Belirleyen Faktörlerin Modellenmesi

- Asst. Prof. Dr. Mustafa Ercilasun, Beykent University, Turkey

- Asst. Prof. Dr. Ayşen Hiç Gencer, Istanbul Aydın University, Turkey

- Asst. Prof. Dr. Özgür Ömer Ersin, Beykent University, Turkey

Zorunlu Göç ve Fakirliğin Diğer Adı: Mülteciliğin Dünya'da ve Türkiye'deki Gelişimi (2004-2007)

- Mr. Yunus Koç, Muş Alparslan University, Turkey

- Mr. Adem Palabıyık, Muş Alparslan University, Turkey

SESSION 5C: Orta Asya Ekonomileri II

Session Chair: Prof. Dr. Muhsin Halis

Kırgızistan'da Vergi Kültürü ve Belirleyenleri

- Dr. Raziahan Abdieva, Kyrgyzstan-Turkey Manas University, Kyrgyzstan

- Prof. Dr. Jusup Pirimbaev, Kyrgyzstan-Turkey Manas University, Kyrgyzstan

- Asst. Prof. Dr. Tuncer Özdil, Kyrgyzstan-Turkey Manas University, Kyrgyzstan

McKinnon'ın Para ve Fiziki Sermaye Arasında Tamamlayıcılık Hipotezinin Kırgızistan Örneğinde Testi

- Asst. Prof. Dr. Harun Doğan, Kyrgyzstan-Turkey Manas University, Kyrgyzstan

Türk Cumhuriyetlerinde Kurumsal Yeniden Yapılanma ile Ekonomik Büyüme / Beşeri Gelişmişlik Düzeyi

Arasındaki İlişkiler

- Assoc. Prof. Dr. Mine Gerni, Marmara University, Turkey

- Asst. Prof. Dr. Ş. Mustafa Ersungur, Atatürk University, Turkey

- Ph.D. Candidate Dilek Özdemir, Atatürk University, Turkey

- Prof. Dr. Ömer Selçuk Emsen, Erzurum Atatürk University, Turkey

Avrasya Ülkelerinde Kurumsal Faktörlerin İktisadi Büyüme Üzerindeki Etkileri

- Ph.D. Candidate Irem Yendi, Hacettepe University, Turkey

SESSION 5D: Экономика труда

Session Chair: Prof. Dr. Alisher Rasulev

Образование - фундамент качественного человеческого капитала

- Prof. Dr. Turar Koychuev, Kyrgyzstan-Turkey Manas University, Kyrgyzstan

Кыргызстандагы жумушчу күчү сапатынын азыркы кездеги проблемалары

- Asst. Prof. Dr. Cipar Aytuganova, Kyrgyzstan-Turkey Manas University, Kyrgyzstan

Роль Интернет-технологий в повышении эффективности администрирования налогов

- Dr. Valentina Orlova, Donetsk National University of Economics and Trade, Ukraine

Меры социальной поддержки молодых специалистов аграрного профиля в Казахстане

- Ph.D. Candidate Timur Taipov, Kazakh National Agrarian University, Kazakhstan 
SESSION 6A: Tourism \& IT

Session Chair: Prof. Dr. Gültekin Yıldız

Strategies for Tourism Industry under the Global Economic Crisis: A Swot Analysis of Turkish Tourism ......382

- Asst. Prof. Dr. Orhan Akova, Istanbul University, Turkey

- Assoc. Prof. Dr. Mehmet Sarışık, Sakarya University, Turkey

- Asst. Prof. Dr. Dilek Dönmez, Çanakkale Onsekiz Mart University, Turkey

An Analysis of Cultural Tourism Cluster: The Case of Aksaray Province

- Ph.D. Candidate Muhammet Saygın, Aksaray University, Turkey

- Assoc. Prof. Dr. Himmet Karadal, Aksaray University, Turkey

The Effect of Information Technology on Innovation Abilities: A Research on SMEs

- Assoc. Prof. Dr. Himmet Karadal, Aksaray University, Turkey

- Ph.D. Candidate Muhammet Saygın, Aksaray University, Turkey

Software Production in Kyrgyzstan: Potential Source of Economic Growth 400

- Ph.D. Candidate Rahat Sabyrbekov, American University of Central Asia, Kyrgyzstan

SESSION 6B: Büyüme ve Gelişme II

Session Chair: Prof. Dr. Rldvan Karluk

Avrupa Birliği Bölgesel Kalkınma Politikaları: Yapısal Fonlar ve Diğer Mali Araçlar Çerçevesinde Bir

Değerlendirme

- Prof. Dr. Ahmet Incekara, Istanbul University, Turkey

- Mrs. Burcu Kılınç Savrul, Istanbul University, Turkey

Bağımsız Devletler Topluluğu Ülkelerinde Yakınsama: Satınalma Gücü Paritesine Göre Analiz

- Prof. Dr. Hüseyin Avni Egeli, Dokuz Eylül University, Turkey

- Asst. Prof. Dr. Hakan Kahyaoglu, Dokuz Eylül University, Turkey

- Mrs. Pinar Egeli, Celal Bayar, Turkey

Demiryolu Ulaşım Sistemlerinde Verimlilik

- Asst. Prof. Dr. Ali Kabasakal, Sakarya University, Turkey

- Mr. Ali Osman Solak, Ministry of Transportation, Turkey

Kurumların Ekonomik Büyüme Üzerindeki Etkisi

- Ph.D. Candidate Bekir Aşık, Beykent University, Turkey

SESSION 6C: Orta Asya Ekonomileri III

Session Chair: Asst. Prof. Dr. Cipar Aytuganova

Girdi-Çıktı Analizi Yaklaşımıyla Kazakistan Ekonomisinin Dışa Bağımlılı̆̆ının İncelenmesi (2006-2009)

- Asst. Prof. Dr. Tuncer Özdil, Kyrgyzstan-Turkey Manas University, Kyrgyzstan

- Ph.D. Candidate Zamira Oskonbaeva, Kyrgyzstan-Turkey Manas University, Kyrgyzstan

- Ph.D. Candidate Aynura Turdalieva, Kyrgyzstan-Turkey Manas University, Kyrgyzstan

Orta Asya Ülkelerinin İnsani Gelişmişlik Endeksleri Açısından Değerlendirilmesi

- Asst. Prof. Dr. Volkan Öngel, Beykent University, Turkey

- Asst. Prof. Dr. İlyas Sözen, Beykent University, Turkey

- Asst. Prof. Dr. Ahmet Alkan Çelik, Beykent University, Turkey

Ekonomik Büyüme ve Gelir Dağılımı İlişkileri: Geçiş Ekonomileri Deneyimi

- Ph.D. Candidate Dilek Özdemir, Atatürk University, Turkey

- Prof. Dr. Ömer Selçuk Emsen, Erzurum Atatürk University, Turkey

- Asst. Prof. Dr. Ayşen Hiç Gencer, Istanbul Aydın University, Turkey

- Dr. Cemil Hakan Kılıç, İstanbul Chamber of Commerce, Turkey

Kazakistan'da Yerleşik Türk Firmalarının Yapısı ve Geleceğe İlişskin Öngörü ve Öneriler

- Asst. Prof. Dr. Osman Barak, Çankırı Karatekin University, Turkey 
SESSION 6D: Finansal Hukuk

Session Chair: Prof. Dr. Faruk Andaç

Türkiye'de Mortgage Sistemi ve Ekonomik Kriz Açısından Değerlendirilmesi 456

- Prof. Dr. Mustafa Topaloğlu, Beykent University, Turkey

Sermaye Şirketlerinde Mali Durumun Bozulmasının Nedenleri

- Mr. Ahmet Tuncay, Turkish Supreme Court, Turkey

Türk Hukukunda Mali Yapısı Bozulan Sermaye Şirketleri ve Kooperatiflerde İflasın Ertelemesi

- Mr. Uğur Sayın, Turkish Supreme Court, Turkey

Sermaye Şirketlerinde Mali Durumun İyileştirilmesi Yolu Olarak Yeniden Yapılandırma 472

- Assoc. Prof. Dr. Adnan Deynekli, Turkish Supreme Court, Turkey 


\title{
Recent Monetary Policy in Turkey: Capital Flow, Reserves and Exchange Rate
}

\author{
Şaziye Gazioğlu (Hatay M. Kemal University \& Middle Eastern Technical University, \\ Turkey)
}

\begin{abstract}
In this paper, we investigate the recent monetary policies and development of Turkish banking system during the post 2001 financial and banking crisis. We explore the effects of capital inflows and outflows to real exchange rates and the real stock market prices, before and after the financial crisis. We investigate the relationship between real exchange rate, real stock prices and capital flows. We decompose the foreign flows into real assets and liabilities, in order to investigate the possible long-term effect of inflows and outflows. Reversal of capital flow seems to create a possibility of exchange rate crisis. The Turkish Central Bank by taking lessons from this experience they formulate their recent policies accordingly.

Recent Monetary Policy mix in Turkey aims to have financial stability by increasing the reserve ratio in each component of capital flows in Turkey. The ratio increases shorter the period of the asset. The Central Bank work claims to have an effect similar to inflation targeting.
\end{abstract}

JEL Codes: G1, F3, F4

\section{Introduction}

Indonesia and South Korea recently adopted instrument to manage money flows, therefore debate about capital controls has been revisited. While regulation of capital flows was seen as a legitimate policy tool during postwar economic restructuring, since 1980s, it has been frowned upon by advanced industrialized countries. Contribution of capital flows to International financial crisis has been recognized since the Asian crisis in 1997.

Despite the IMF's advise Malaysia had managed to restructure her foreign debt and they used capital control in order to recover from 1997 Asian financial Crisis. Recent policy practices and academic positions indicate that the image of capital controls might have changed again in the wake of the global financial crisis. While provoking fear of protectionism for some, others welcome the potential for enhancing global financial stability and development prospects. Gazioglu (2008) introduced a theoretical Model to justify the theoretical background and justification for some control. The question is thus how best to handle surges in inflows that may pose both prudential and macroeconomic policy challenges, such as appreciation of currency, which can harm exports. This paper reviews the theoretical background and present monetary policies of the Turkish Central Bank.

A decade has passed since the 2001 Financial Crisis \& Banking Crisis in Turkey. During the analysis of this paper many people were asking when the next crisis will be hitting Turkey. 2008-9 Mortgage Crisis (Banking Crisis) in the West has some similarities to the Turkish Banking crisis. The similarity is the effect of capital inflow and reversal of capital. The Financial crisis of 90's had the direction of capital towards partly to the US and partly to China via Hong Kong. In the Mortgage Crisis of 2008-9 the direction of flow seems to be out of the US, towards China as well. Though Turkey has been affected negatively via their trade, Banks in Turkey had their highest profitability, as the major Banks in the West suffered. This indicates that it is important to investigate the post 2001 Financial and Banking Crisis in Turkey. The strengths of the Banking sector in Turkey indicate the other side of the coin in the Global Banking Sector. Furthermore, Turkey has produced double figure growth rate along with improved trade balance due to her increased trade with Arab countries and Africa.

The debate over capital flows, especially in developing countries, has been one of the most popular topics in economics. Those in favor of unrestricted capital flows argue that the restrictions cause inefficiency and higher costs so they must be eliminated in order to secure markets. On the contrary, those in favor of restrictions argue that the capital movement has to be regulated since studies such as Eichengreen (1996) and Cohen (1998) show that capital mobility has not affected all countries in the same manner. Financial markets can include risk in case of reversal of capital inflow if there does not exist sufficient regulations. Alfaro et al (2003) states that there can be significant gains from foreign direct investment in cases of well-developed financial markets, otherwise foreign direct investment alone has an ambiguous effect on development.

In Turkey, after the 1980's, the market has been liberalized almost completely. Lukauskas and Minushkin (2000) suggest that this type of financial market opening in Turkey is a consequence of the need to finance persistent current account deficits, to service existing foreign debt, and to finance huge budget deficits. Furthermore, Turkey has to borrow to complement from abroad to obtain capital in order to finance economic development due to low domestic saving rates. The urgent liberalization of markets in Turkey can be linked to the little bargaining power of Turkey in attracting foreign investors because of her twin deficits, high inflation and political instability (Lukauskas and Minushkin (2000)). However, more recently, inflation has not been a 
problem. Considering urgent and quick liberalization of markets in Turkey, the restrictions on capital flows were eliminated prior to a regulatory framework. Hence, the economic nature of Turkey forces the economy to be more volatile depending on external shocks and more open to crises. The performance of Turkey in the context of the EU enlargement has been evaluated in Loewendahl and Ertugal-Loewendahl (2001) and has emphasized the importance of FDI for Turkey and comparatively higher dependence to capital flow for technological and innovation activities. However, during the sudden reversal of capital inflow in 2001, there has been a potential risk on the banking sector. Furthermore, inflation and exchange rate caused macroeconomic instability (Çulha (2006)). However, as we mentioned before Turkey's economic performance has been greatly improved.

There is an upward trend in direct foreign investment (FDI), since 1989 and especially after the 2001 financial crisis. FDI by sector shows that nearly $40 \%$ of the total FDI is in financial intermediation. This figure shows us the great importance of the banking sector within the FDI. Kaminsky and Reinhart (1999) claim that the banking and currency crises deepen via feeding back each other. The analysis over many industrial and developing countries, including Turkey, shows that after a boom sourced by capital inflow and credit the crises occur when a country plunges into a recession. Levine and Zervos (1998) underline the significant effect of financial factors on future rates of economic growth, capital accumulation and productivity growth.

The aim of this paper is to revisit foreign capital flows and recent Turkish Monetary policy. The rest of the paper is organized in the following manner. Section 2 we review foreign direct investment in Turkey and determinants of capital flow. In section 3 we investigate Turkish Banking system and role of the foreign shares. In section 4, we report the Policy mix of the Turkish Central Bank.

\section{Foreign direct Investment in Turkey and Determinants of Capital Flows}

The foreign direct investment (FDI) to Turkey follows an upward trend starting from the 1980's and makes a peak in 2006. The decomposition of foreign direct investment in the latest years indicates that there is a high concentration on financial intermediation and transport, storage and communications. Other sectors, including manufacturing, play only a minor role to affect the foreign direct investment. Though flows of investment to Turkey are a small percentage of the FDI in the world, its share in the Turkish industry is quite high. Foreign investors place pressures to buy the national industry. Such a structure of the economy directs the focus of the economy on service industry including the Banking sector and tourism, rather than manufacturing or production Gazioglu \&Basbas (2009).

Çulha (2006) revisits the effects of pull-push factors for Turkey from 1992:01 to 2005:12. Over the whole period, the pull factors have a greater contribution than the push factors. Furthermore, the stock exchange index positively affects capital inflows. The issue is the growing importance of the effect of foreign interest rates (as a push factor) proving the dependence on capital flow and desperate policies in the face of sudden capital outflows.

Considering the specific determinants of capital flow to the banking sector, there are only a few studies investigating this question. Sabi (1988) investigates parameters the expansion of the U.S. multinational banking (MNB) sector to developing and less-developing countries, including Turkey. He finds out that market size, presence of multinational corporations from the U.S., extent of economic development, and balance of payments are important selection criteria for MNBs. The variable for regulation seemed to be insignificant, which means that once a MNB is established, regulations will not affect further growth. Moreover, the time span is 1975-82, which has to be handled with updated data.

\section{Turkish Banking System and the Role of the Foreign Shares}

In Turkey, the main aim of internalization of the banking sector was to open the foreign competition to increase diversification, efficiency and quality of banking services (Pehlivan and Kirkpatrick, 1992). 1980-89 demonstrated an increase in the number of foreign-owned banks and a decrease of restrictions to the entry of foreign banks. Pehlivan and Kirkpatrick (1992) claims that entrance of foreign banks forced domestic banks to improve their cost-efficiency performance, but the benefits had not been realized immediately. Lukauskas and Minushkin (2000) suggest that in the 1990's "focus of banking activity shifted from deposit taking and lending in domestic currency to the buying and selling of foreign exchange and government debt".

Starting from the 1980's, the number of banks significantly rose. Until the 2001 crisis, the number of banks grew rapidly accompanied with the overexpansion of branches. The financial crisis of 2001 was also the crisis of the Banking sector, where Banking regulations were lagging behind the international regulation. After the crisis, restructuring in the banking sector has taken place causing a reduction both in number of banks and branches. Instead of re-structuring nationally to reduce the number of banks, the banks were sold to foreign Banks. Foreign share in the banking sector shows an upward trend over the period between 1980 and 2007 with the exception of crises (Figure 1). Especially, the rising trend of foreign banks' share reaches the highest level with 45.7 per cent at the beginning of 2007. 


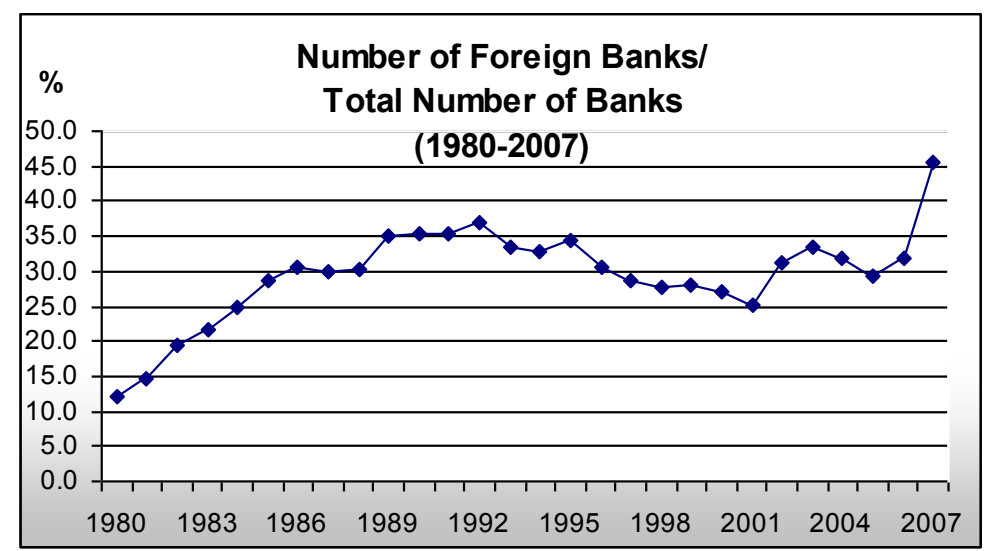

Figure 1. The Share of Foreign Banks in Turkey: 1980-2007. Source: Calculation from appendix 3 (Number of Foreign Banks/ Total Number of Banks)

Considering the performance of the banking sector, Steinherr et al (2004) analyze the financial intermediation, measured by ratio of assets and loans to gross national product, and show the upward trend of financial intermediation during the 1990's but a significant drop in the 2001 crisis. During the crisis, value added in financial services even drops below the level in 1990 (Steinherr et al. (2004). Özatay and Sak (2003), and Gazioglu $(2003,2005)$ underline the characteristics of the banking sector as one of the main causes of the crisis. Indeed, the fragility of the banking sector accompanied with other triggering factors led to the crisis Özatay and Sak (2003) emphasize the currency, interest and foreign exchange risk accumulation on the banks' balance sheets, heavy reliance of private banks on foreign exchange deposits and thereby on the capital flows, and differences between state and private banks. At the end, the cost of 2001 banking crisis to the Treasury was $\$ 43.7$ billion (29.5\% of GDP) and the cost to the private sector was $\$ 9.5$ billion (6.4\% of GDP), totaling about $35.9 \%$ of GDP in 2001 (Steinherr er al., 2004).

Following Steinherr et al (2004), selected efficiency parameters, reported by the Banks Association of Turkey, such as deposits-assets, deposits-branch, deposits-employee, assets-employee and assets-branch ratios draw attention to the productivity improvement in the banking sector.

Table 1 shows the net foreign asset that falls between 2000-2002 to -20 million increased to 80 million between 2002-2008. The main consequences of the 2000 Financial crisis is accompanied by banking sector crisis which lead to increase of foreign capital flows to the banking sector and the foreign ownership ratio has increased from 25 percent to 45 percent. The fall from 80 million to 40 million between $2008-2010$ is the result of Mortgage crisis in the West.

Moreover, operating cost-income ratio for the largest Turkish banks indicates a close average ratio to the EU level. In 2008 Mortgage crisis also hit the European financial sector. The southern EU members face financial crisis.

However, Turkish financial system showed no negative effect from EU crisis. Banking sector has shown that it has not been affected by the 2008 Mortgage crisis, due to the restructuring took place after the 2001 Turkish Financial Crisis. Though drop of the Turkish exports to Europe increase the balance of payment deficit, the government policy of "zero problems with the neighbors" lead Turkey to improve trade and economic growth increased to double figures.

\section{Empirical Evidence for Capital Flows to Banking Sector and Exchange Rate in Turkey}

In this section we investigate the post-2001 Turkish financial crisis. We investigate foreign capital inflow to banking sector ant its effect on the real exchange rate in Turkey.

The real effective exchange rate index, stock market price indices, foreign assets/ liabilities of the banking sector are used for $\mathrm{E}, \mathrm{V}$ and $\mathrm{H}$ respectively. The real effective exchange rate, foreign assets/ liabilities of the banking sector are acquired from the Central Bank of the Republic of Turkey for the period from 1994:01 to 2006:12. The consumer price index and the stock market price indices are obtained from the Turkish Treasury and Istanbul Stock Exchange, respectively Gazioglu \& Basdas (2008). Following, Gazioğlu (2005, 2008) we argue that invested real foreign assets in the stock market causes a rise in the stock market returns and appreciates the foreign currency (Model 1). A change in real foreign liabilities has a greater impact on real exchange rate than real foreign assets; asymmetric effect (Model 2). Gazioglu \& Basdas (2009). However, the post crisis period capital inflows is into banking sector. 


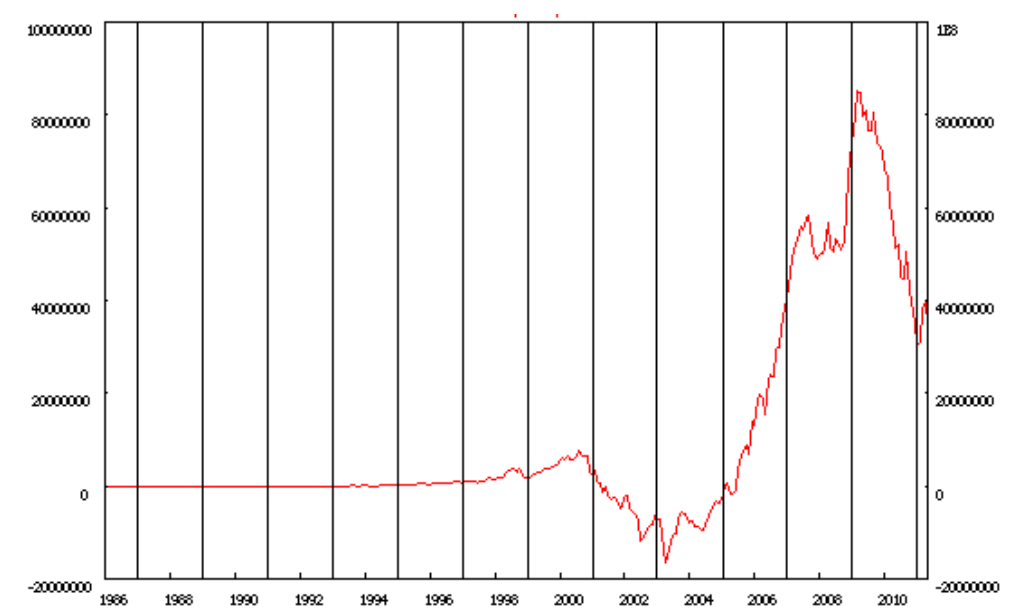

Table 1. Monetary Condition (Monthly, 000 TL) Source: Turkish Central Bank

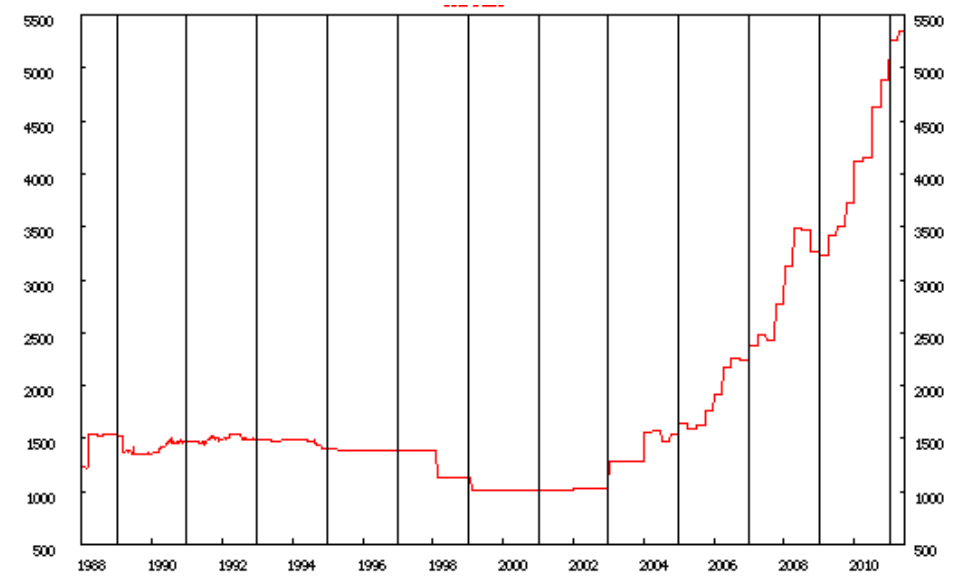

Table 2. The Central Bank Gold. Source: Turkish Central Bank

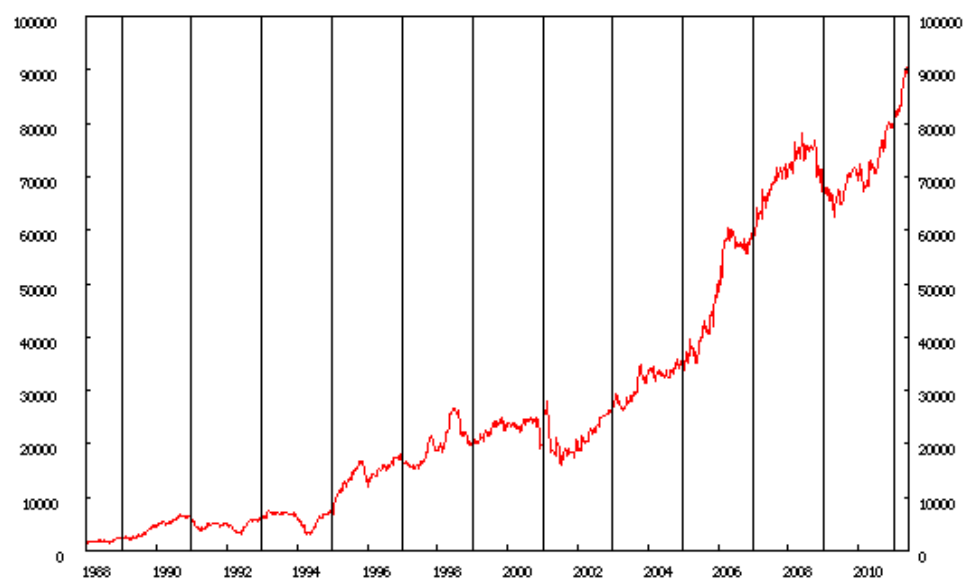

Table 3. The Central Bank Gold - fixed. Source: Turkish Central Bank 


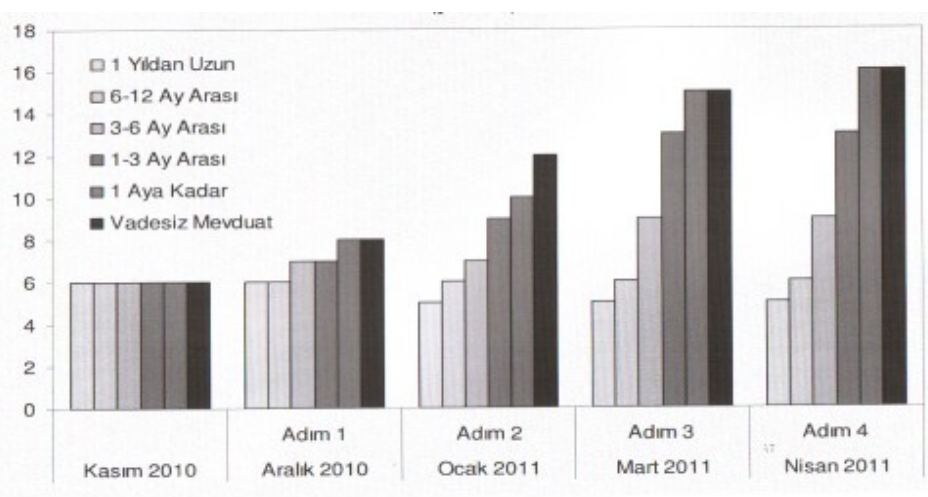

Table 4. The changes in the reserve ratio requirement. Source: Turkish Central Bank

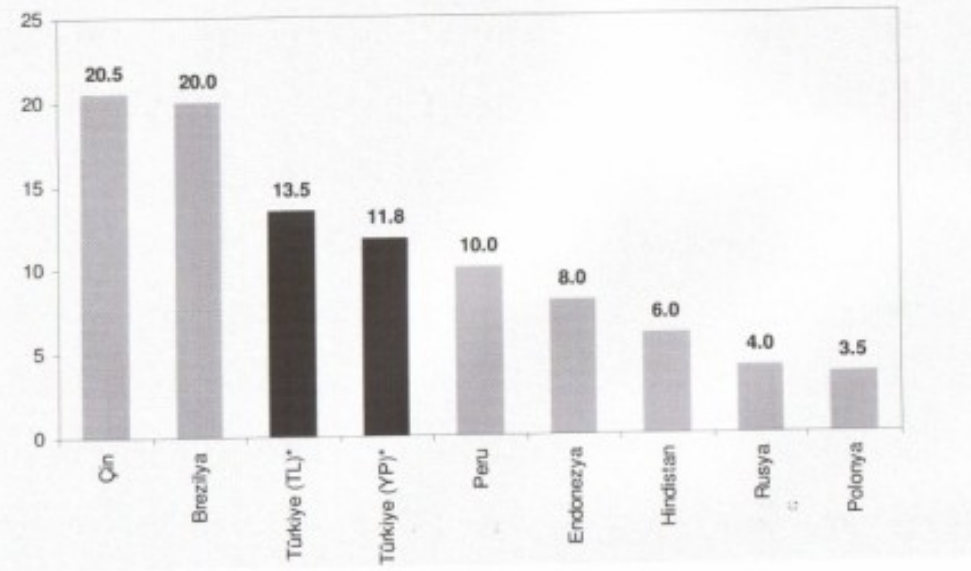

Table 5. Reserve ratio requirement in Turkey in comparison to other countries. Source: Turkish Central Bank

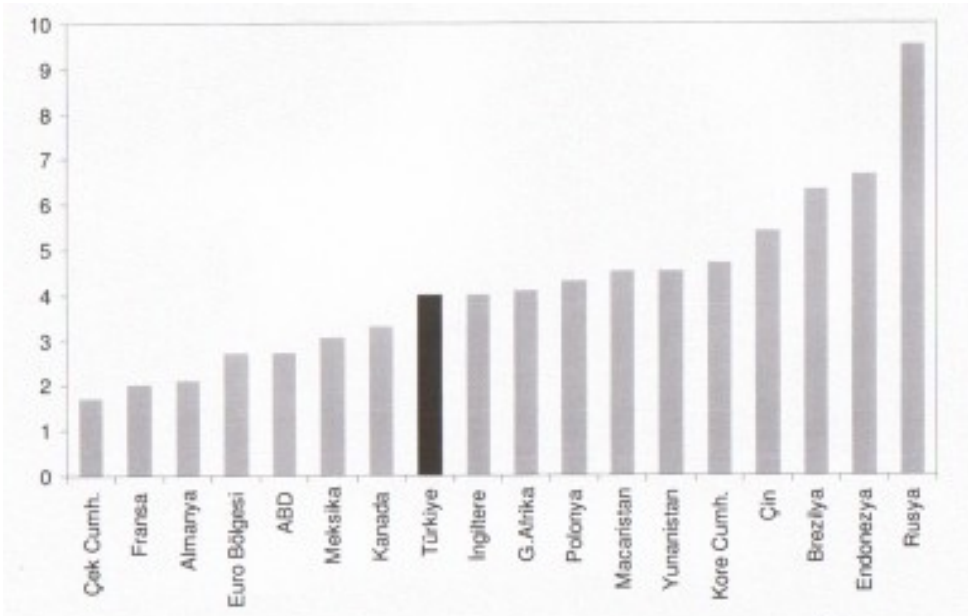

Table 6. Inflation rate in Turkey in comparison to other countries. Source: Turkish Central Bank

\section{Monetary Policy in Turkey}

Monetary Policy and capital flows goes and to and together. In Turkey pull-up theories are applicable. Since 2000 financial crisis had lot to do with reversal of capital flows in Turkey, similar to Asian crisis. Malaysia applied capital control in order to avoid borrowing from the IMF (Tan and Law (2000) and Ghosh (2000). Turkey has chosen to follow the second approach, as described below.

Quantitative pressures started for the period April-November 2010 as a start and continued after November in terms of increased percentage of existing assets (Basci 2011)

Approach 1: Monetary contraction via increasing interest rates, to stop capital inflows (Korea, Brazil)

Approach 2: Difference between domestic and foreign short term interest rate is kept close to each other. In order to control internal market, deal with the problem via other than interest rate. This methodology is not so 
different than inflation targeting. Only difference is that the instrument used is mixed rate rather than a single one. They aimed to overcome the macro-financial risks by obtaining the right policy mix. Therefore, the monetary policy is determined by all policy instruments rather than single interest rate movements.

\subsection{Financial Stability: Targets}

There have been various targets in order to obtain financial stability

i. Debt percentages. Main usage of internal fund

ii. Debt period: Both for internal and external debt, increasing the debt periods

iii. Improve the currency positions of public and private sector

iv. Risk Management Processes and Management. All kinds of risk management in all aspects of economic New Policy Mix.

Table 2, 3 report gold reserves and the gross US dollar reserves, respectively. Gold reserves had been constant around 1000 million until 2002 and increased steadily until 2008 to 3500 million \$. Since 2008 until 2011(April) it has increased to 5500 million \$. It seems it has been the Central Bank policy to increase the reserves as a responds to the Mortgage Crisis, in order to avoid risk of being affected. Table 3 also shows continues increase in gross US \$ reserves until 2011. In 2008, there was some decrease of reserves due to a responds to the Mortgage crisis.

In Table 4, we show the low interest rate policies and high ratio of reserve requirement. In November 2010, the ratio of reserve equipment was $6 \%$ for all funds regardless of their maturity. In December 6-12 month maturity stayed the same. 1-6 month maturity the rate became $7 \%$ and up to 1 month maturity rate increased to $8 \%$ f. In April 2011 one month or current accounts required the highest reserve requirement rate, which is $15 \%$. The lowest reserve requirement is for a year or more, which is $5 \%$.

Table 5 reports that Turkey is in the third place, after China \& Brazil, which requires 20.5 and $20.0 \%$ reserves respectively. The Table 6 indicates how quantity squeeze reduced inflation rate to $4 \%$ and Turkey's inflation is same level as Britain.

\subsection{Targets for the Financial Stability}

i. Debt ratios: More home sources for borrowing

ii. Debt periods: Through internal and foreign borrowing in order to increase debt period.

iii. Foreign Exchange Possession. Strengthen the public and private sectors foreign exchange conditions.

iv. Processes of Risk Management and Methods. All economic units deal with all kind of risk more effectively.

\subsection{Instruments other than Interest rate}

It might not be possible to obtain price and financial stability only by using interest rate policies. Solution is to use other instruments might be necessary. The possible instruments might be the followings:

i. Required reserve ratio

ii. Liquidity management in the Central Bank

iii. Capital requirement ratio

iv. Liquidity requirement ratio

v. Taxes

vi. Government expenditure except interest repayments

\section{Conclusion}

Rising share of foreign ownership in the stock market was an issue of concern in Gazioglu (2000, 2008), The foreigners bought the shares when the prices were low and as demand increased the price increased and as the prices were in the highest, reversal of capital flows took place. The 2001 Financial Crisis occurred with the reversal of capital inflows. The exchange rate crisis was accompanied by the Banking crisis in Turkey. The 2001 Crisis, which-resulted in the restructuring and privatization of the Banking sector, by attracting foreign capital. The foreign share of stock market ownership also increased from 30 to $70 \%$. In another word consequence of the crisis was cheep accusation of the Banks by foreign sector (Gazioglu (2008). Since the exchange rate was not fixed, no financial crisis occurred when stock market return was the highest in Jan06. However, a small crisis arrived as a foreign shock in 2008. The prime mortgage crisis in the US had minimum affect on Turkey, not through the capital outflows, but rather through a fall in demand Turkish export demand, from the Europe.

The recent policy mix by the Turkish Central Bank increased the reserve ratios for liquid funds and aims to increase the liquidity requirement ratio, in order to avoid over expansion of debt in both public and private sector. 


\section{References}

- Basci, E. (2011), “Turkish monetary policy” TCMB presentation, April 2011

- CCulha, A. (2006), "A Structural VAR Analysis of the Determinants of Capital Flows into Turkey”, the Central Bank of the Republic of Turkey Research and Monetary Policy Department Working Paper, No.06/05, October.

- Gazioğlu, Ş. (2001), “An Emerging Market, Volatility of Real Exchange Rate: The Turkish Case’ Middle East and North African Economies", Online Journal of MMEA.

- Gazioğlu, Ş. and D. McCausland (2002), "A Non-linear Currency Substitution Model of Hysteresis in Debt and Competitiveness", METU Studies in Development, Vol. 29, No. 3-4.

- Gazioğlu, Ş. (2003), "Capital Flows to an Emerging Market: Turkish Case Study”, International Advances in Economic Research, Vol. 9, No. 3.

- Gazioğlu, Ş. (2005), "Stock Market, Financial Crisis and Capital Flows in an Emerging Market: Turkish Case Study" in Gazioğlu, S. (eds): Emerging Markets in Financial Crisis: Capital Flow, Saving, Debt and Banking Reform, J-Net Publications, pp. 62-95, 2005.

- Gazioğlu, Ş. (2008), Stock Market Returns in an Emerging Financial Market Turkish Case Study, Applied Economics, 40(11), pp.1363-1372.

- Gazioglu, Ş \&Basdas (2009), "Investment Opportunities for Foreign Capital and Economic Fragility in Turkey" mimeograph

- Ghosh, D. (2000), "From Turbulence to Tranquility: Reform and Restructuring in Malaysia", in Regional Financial Markets: Issues and Policies, Dilip K. Ghosh (ed.) and Mohamed Ariff (ed.) Praeger Publishers.

- Kaminsky, G. L. and C. M. Reinhart (1999), "The Twin Crises: The Causes of Banking and Balance-ofPayments Problems", The American Economic Review, Vol. 89, No.3, pp. 473-500.

- Levine, R. and S. Zervos (1998), "Stock Markets, Banks, and Economic Growth”, The American Economic Review, Vol. 88, No.3, pp.537-558.

- Loewendahl, H. and E. Ertugal-Loewendahl (2001), “Turkey's Performance in Attracting Foreign Direct Investment: Implications of EU Enlargement”, ENEPRI Working Paper, No.3, November.

- Lukaushas, A. and S. Minushkin (2000), "Explaining Styles of Financial Market Opening in Chile, Mexico, South Korea and Turkey", International Studies Quarterly, Vol. 44, No. 4, pp. 695-723.

- Özatay, F. and Güven S. (2003), "Banking Sector Fragility and Turkey's 2000-01 Financial Crisis”, The Central Bank of the Republic of Turkey Research Department Discussion Paper, December.

- Sabi, M. (1988), "An Application of the Theory of Foreign Direct Investment to Multinational Banking in LDCS", Journal of International Business Studies, Vol. 19, No.3, pp. 433-447.

- Steinherr, A., A. Tukel and M. Ucer (2004), "The Turkish Banking Sector Challenges and Outlook in Transition to EU Membership", Bruges European Economic Policy Briefings, December.

- Tan, H. B. and Law, S. H. (2000), "Financial Volatility and Stock Prices: The Malaysian Experience Before and During the Asian Crisis", ${ }^{\text {st }}$ International Conference on Banking and Finance, University of Utara, Malaysia, August. 1. 


\title{
The Development and Interregional Integration Processes of Afghanistan
}

\author{
Nuriddin Kayumov (Tajikistan Academy of Sciences, Tajikistan)
}

\begin{abstract}
The given report considers the integration processes within the Central Asian Region and EAEC region space and their influence on economic situation of Afghanistan. It is emphasized, that the globalization of the world economy, new challenges and threats, especially intraregional integration becomes the predominant tendency of the world economy. Today practically the whole world is considered as a complex regional coalition, union or federation. By integrating between each other these countries protect their corporative interests.

Central Asian sub-region has all prerequisites and possibilities of becoming the new zone for the world development. However, during the years of sovereignty and independence the integration processes even aggravated. Integration processes in the framework of EAEC region are also not effective. All these do not allow rendering assistance and support to the neighboring country Afghanistan. The situation in this country, especially in the sphere of economy constitutes a threat not only to the Central Asian countries, but also for USA, Russia, China and the whole world. The ways of solving Afghan problems lie in the sphere of economy. The author considers possibilities and ways of achieving peace and stability in this country.
\end{abstract}

JEL Codes: O19, F15, I15

\section{Introduction}

Today Afghanistan is the main crisis spot in the world. Here is the threat of not only the internal and external instability, but also threat of developing international terrorism and contraband of heroin. The problems of afghan society, drug production and traffic have become one of the most serious problems not only for Afghanistan itself, but for many countries of the world, whose policy is interrelated with this region.

In the recent years, activation of "Taliban" in the North of Afghanistan, in the province of Kunduz has taken place. The Kunduz province borders on Tajikistan and this may lead to escalation of tension in the Central Asia and possibility of attacks to the territory of Tajikistan. Such attacks have already taken place.

Tajikistan has a common border with Afghanistan, its length is $1400 \mathrm{~km}$. Afghanistan as well has a common border with Uzbekistan and hence the stability and safety of the whole Region depends on the situation in this country. Therefore, it is clear why the world community is anxious about the situation in Afghanistan. The International Conference on the issues of cooperation concerning Afghanistan is the evidence of it.

\section{Historical Developments}

As far as July 10-12, 2008 in Issik-kul (Kyrgyzstan) the International Conference «Afghanistan, the Shanghai Organization for Cooperation, Security and geopolitics of the Central Eurasia» took place, where a number of conclusions were formulated, as well some recommendations made regarding activation of entrepreneurial activities and attraction of foreign investments in order to restore the economy of Afghanistan.

According to the initiative of the Republic of Tajikistan on October 21-22, 2008 the International Conference on Afghanistan has been conducted in the Dushanbe. It was proposed at the conference to create a multi-level system of international cooperation, which is the essential condition for effective counteraction and counter measure against terrorism, drug production and drug traffic. According to the results of conference a joint Declaration on partnership was made that was intended for strengthening the regional cooperation for struggle against the international drugs contraband. The participants of the conference supported the OSCE project on training of border specialists and establishment of the specialized learning center for training and retraining of law-enforcement agencies of Tajikistan and Afghanistan.

At the London International Conference a decision was proposed to donor countries render financial assistance to Afghanistan in the amount of 10,5 billion USD for realization of program aimed to the country's economic development. Heretofore at international conferences in Berlin and Tokyo the world community has promised 9,0 billion USD for this purpose. However, according to some sources the mentioned financial means had no a considerable influence on the social and economic life of the country.

In Moscow (Russia), on June 9-10, 2010 an International Forum "Afghan drug production - challenge for the world community" was conducted, where the issues of security threat due to the growth of drug production and drug use not only for the Central Asian Region, but also for other countries of Asia and Europe were discussed.

These International Conferences and Forums considered the problems of Afghan society from the position of struggle against terrorism and drug traffic. Undoubtedly, the issues of struggle against terrorism, distribution of 
drugs, border protection and fortification are the most important problems. But without solution of social and economic problems, development of real sector of economy, creation of new jobs, aimed for reduction of unemployment in Afghanistan are impossible. The volume of drug turnover grows day by day just like in previous years.

\section{Economic Development of Afghanistan}

The principal stabilizing factor can be only the development of those branches of economy, which form the natural competitive advantage of Afghanistan.

Though, the economy of Afghanistan in the recent years is growing with the high rates - up to 12-13\% annually, absolute volumes of GDP are not so large, approximately 11,0 billion USD that makes up 460 USD per capita. Foreign trade turnover do not exceed even 4,0 billion USD. Donors' aid makes up 13-14 billion USD.

At the same time, according to some data the annual volumes of financial means generated by drug mafia make up more than 300 billion USD. For the last 10 years the income from drug traffic has grown 40 times, besides approximately

$30-35 \%$ of drug producers' and drug runners' income goes to the budget of "Taliban" movement that are used for the purchase of armaments, for struggle against opposition within the country and for expansion of international terrorist activities in other countries. Out of 65 billion USD that is annually yielded from the opium production, approximately 5 billion remain within the Afghanistan. This comparison shows that the income from drug business dozens of times exceeds the volumes of donor assistance and country's budget altogether. Therefore, under the current situation not only the international drug lords, but also the common farmers are not interested in curbing of drug production and drug business.

\subsection{Economic Integration}

The situation in the economy of Afghanistan can be cardinally changed first of all on the basis of intra-regional integration of the Central Asian countries, Eurasian community, EAEC region and other interested countries.

Strengthening of regional integration based on the creation of various economic blocs and unions becomes the predominant tendency of modern geopolitical and geo-economic processes. Integration has no alternative, and incorporation of economic lives of the Central Asian states would give an opportunity to the Central Asian countries to realize their corporate interests and withstand all new challenges and threats, which are mainly conditioned by globalization process in the world economy.

The world energy crisis, which happened due to increase in production and growth of population, exhaustion of once rich deposits of hydrocarbon raw materials, availability of large reserves in the zones of pioneering development as the Central Asia is, all of these may result in competition between the great powers, which are the center of world policy and economy, as well will lead to tensions and instability in the Region. The given circumstances assume joining of efforts for protection of one's own national interests, development of effective approaches and mutually beneficial cooperation based on the close intraregional integration. This, first of all will provide a reliable system of high complementarities for region's economic potential, and secondly, the Region may be of interest for foreign investors only as the entity and as a great outlet. Under such approach in the longer term the Central Asian Region might become a new zone of the world economic growth. However the current condition of integration relations in the Region are far from the civilization and do not satisfy the requirements of our time.

About 20 years has passed, but the countries of region failed to become integrated, and on the contrary the situation worsens from year to year. It is as if the countries are trying to do everything in order to escape from integration. In fact instead of integration the disintegration process is increasing. There are all necessary conditions and factors for the deep and effective intraregional integration: all the Central Asian Republics were the members of integrated country and related to one common economy. The countries of region inherited from the USSR great many of plants and factories, which are combined in a single technological and transport network, as well as experience of creating and exploiting the unified electric power system, long distance oil and gas pipe lines. Besides, we are united by the territorial proximity, commonness of history, cultural heritage, traditions, mentality of region's population, availability of richest natural, mineral resources, considerable human potential, input complementarities and cooperation ties, communication and transport infrastructures, presence of common economic problems, and common interest in the safety of the whole region.

\subsection{Relations with Tajikistan}

Within the last years trade and economic relations of Tajikistan and Afghanistan speed up. From 2000 up to 2009 it has grown in 26.3 times, including export - in 10.4 times. Though this relations are far from the normal level: export makes up 26.9 and import - 44.2 million USD. There is no doubt that in perspective, after new HPPs will be put into operation, railway, automobile and communication networks will be developed, the level of economic relations between the Tajikistan and Afghanistan achieves a new quality. 
Upon availability of favorable integration conditions Tajikistan could render a serious support to Afghanistan in developing its economy. Tajikistan possesses huge potential for development of hydropower industry - about 527 billion $\mathrm{kWh}$. Out of this volume only 3.0-3.5\% are used in fact. At present there are a lot of disputes regarding the Rogun HPP (Hydro Power Plant), which is one of the largest in the Region. As soon as this HPP will be put into operation, Afghanistan becomes one of the principal power consumers, only through territories of this country the electric power can be transferred up to Pakistan and Iran. Afghanistan has already developed its own program for transit of electric power from Tajikistan. At present the Indian Company has started the construction of power transmission lines on the territories of both countries in order to join them. Sometimes ago the Ministry of energy and Industry of Tajikistan and the Department of Energy of Afghanistan has concluded agreements on construction of power transmission lines, with the capacity of $220 \mathrm{kV}$ in Kunduz city. With the lapse of time these power transmission lines will reach the Takhor province through the territory of Puli Khumri city. Today $10 \mathrm{MW}$ (megawatt) of electric power is being transferred from Tajikistan to Kunduz. There is an agreement between the both parties to increase this quantity up to 40 megawatt. The Afghan party purchases electric power from Tajik company "Pamir energy", which is established within the framework of the Agha Khan Project.

With relation to development of productive powers of Afghanistan in perspective, ensuring energy security for Tajikistan and Afghanistan, development of huge land areas and solution of other social and economic problems of the Afghan society, the construction of Dashtijumsky HPP, which was one of the largest plants in the postSoviet area, is of enormous importance. Construction of the mentioned HPP will solve not only the problems of energy saving, but also the problem of developing hundred thousand ha of lands.

\subsection{Infrastructure projects}

Afghanistan is interested in construction of railways in the Central Asia. A railway form Uzbekistan up to Afghan city Mazori Sharif has already been constructed, and now it is planned to drive a railway up to Tajik city Nizhniy Pyanj, and from Nizhniy Pyanj up to Afghan port Sherkhon Bandar, where this line will be divided into two parts. One of the ways will be driven to Kabul and further up to the Ainak copper deposit on the border with Pakistan, and the other up to Mazori Sharif, where it will be connected with the Uzbek part of the railway. The railway line from Mazori Sharif will be driven to the Farab province, then to Gerat and from Gerat to Iran. The Iranian side has already driven a railway line up to Gerat. The Uzbek party has also completed its own part of railway up to Mazori Sharif city. The financial means are already available for construction of railway from Gerat up to Mazori Sharif. And as a result all these parts will be connected to each other, and then this railway system will be connected with the Pakistan. All of this will promote more fruitful development of economic cooperation between the Afghanistan and the Central Asian countries.

Bridges are of great importance in relations between the Tajikistan and Afghanistan, the bridges that are built in Ishkashim, Khorog, Nizhniy Pyanj and Darvaz. These bridges play the important role in transport network and development of trade. In Ishkashim and Nizhniy Pyanj a frontier trade is organized. These areas are considered as free economic zones. All this will serve as a serious factor for development of Afghanistan's economy.

\section{Conclusion and Recommendations}

In conclusion of my report, I would like to propose a number of recommendations and measures on rehabilitation of Afghanistan's economy.

Most probably the recovery period may be prolonged for many years, if the world community does not take cardinal measures on recovery of Afghanistan's economy. Development of Afghanistan is complicated by the presence of serious inhibitive factors. The country is less-developed and poor historically, it has no productive and non-productive infrastructure, with the low level of education and health care, lack of relevant sectors of industry, unskilled level of specialists, the landlocked situation, with no outlets to the sea, poor material and technical base of agrarian and other sectors of economy, financial dependence on external donors and lastly political instability.

Solution of these complex problems should be through development of effective measures not only by the Government of Afghanistan, but also jointly with the interested countries, measures on the state economic policy. In order to realize this goal it is necessary to develop a long-term program for economic development of Afghanistan in perspective for the period of 20 years, with the precise definition of realization stages, objectives and financial support. The most important priorities should be determined.

As it is known Afghanistan - is a typical agricultural country with the backward material and technical base, low crop yield and productivity. Up to $38-40 \%$ of country's GDP falls to the portion of agriculture. More than $50 \%$ of population is the poor/vulnerable people, who live in rural areas. About the half of plough-lands are being irrigated artificially, the water in this country is the tight resource. Despite all these limitations the condition of agriculture is determinative for country's economy and should be considered as the issue of higherpriority. Specialization of this branch should be orientated to the development of those productions, which can 
serve as the basis for development of light, food and process industries. The production should be focused on the final output.

It is necessary for the Government of Afghanistan to develop and realize the program of shifting the agricultural sector to the industrial basis, according to the principal of "green revolution", with the view to provide its food safety.

Nevertheless, the agrarian model of developing economy is the dead-locked one. Therefore with the view of employing labor resources and increasing the economic efficiency, it is necessary to develop higher-priority branches of industry. The Government of Afghanistan should be focused on industrial and agrarian model of development. It is possible also in addition to the light and food industries develop processing and mining industries and natural gas extraction.

In the 80 s of the last century a considerable part of Tajikistan's demand in natural gas was provided through delivery from Afghanistan. Activation of geological exploration works, prospecting of new raw hydrocarbon deposits, will substantially lower the dependence of country on import of oil and gas from the Arabic countries.

The country can gain a huge profit from cotton production with its complete processing within the country. Afghanistan possesses sufficient potential for development of export industries and import substitution. In due time, the USSR had built 142 objects within the framework of program on rendering the technical assistance to Afghanistan. At present they are almost totally destroyed. Now it is necessary to think of their reconstruction. Certainly reformations in the sphere of economy are not possible without the well-considered reforms.

The world community renders the actual financial assistance to Afghanistan, but it is not sufficient. Investment activity of donor countries, who has undertaken the economic recovery of Afghanistan do not satisfy the needed requirements. For instance, out of the promised in 2002-2006 years amount of 30 billion USD only 13 billion USD was allotted, including through the Ministry of Finance 3,7 billion Such approach also took place in subsequent years.

The major contributions should be done first of all by USA, European Union and other interested countries. Afghanistan should enter the orbit of integration processes of countries-members of the Eurasian community. Many member nations of these unions, in particular China, Russia, Kazakhstan and some other countries possess a powerful economic and financial potential, which under effective integration can provide not only their own development, but as well the economic growth in Afghanistan.

All mentioned steps/measures should be aimed at creation of healthy economic system, which is a good chance for stabilizing the economic and political situation in the country, and the way out of systemic crisis. There is no other way.

On the other hand, the Government of Afghanistan, donor countries have to tighten control over the utilization of financial means. The facts of inefficient use of investments, intended for the recovery of economy, more than $50 \%$ of technical aid is totally inadmissible. According to the data of the Government of Afghanistan out of 9 billion USD, only $22 \%$ are spent for development of economy, and $50 \%$ are in hands of various NGOs, which have received the financial assistance bypassing the Government. Out of 2355 NGOs existing in the country 1950 are busy with money-laundering. As a result of conducted re-registration 1620 NGOs have disappeared, out of them 333 - are foreign NGOs.

Financial resources allotted by the world community for economic recovery of Afghanistan, in fact, are not used according to the intended purposes and squandered by mafia structures.

Thus, the solution of Afghan systemic crisis requires not only multilateral military and political, diplomatic, but also mainly the social and economic strategy. I believe that Afghanistan has serious preconditions for solving its geopolitical and geo-economic problems.

\section{References}

- Bulassa B. The Theory of Economic Integration. - London, 1962. - P. 2;

- The projects of cooperation and integration for CA countries, Comparative analysis, capabilities and perspectives, Bishkek 2007, pp. 28;

- Morris Shiff, L. Alan Winters., "Regional integration and development”, Moscow, "Ves mir", 2005, pp. 199;

- Tajikistan and CIS countries Goscomstat of RT, Dushanbe, 2009. p.p. 26.27.28.29. 


\title{
Kyrgyzstan's Relations with International Financial Organizations: Curse or Curve?
}

\author{
Yaşar Sarı (Kyrgyzstan-Turkey Manas University, Kyrgyzstan)
}

\begin{abstract}
Kyrgyzstan since the collapse of Soviet Union went to the transition path and while it is argued that it succeeded at some points, levels or degree. It is certainly that major obstacles to the successful transition are not overcome. First of all it was necessary to get out of Russian dominated economy since it was itself declining. Kyrgyzstan was the first former Soviet republics left Russian ruble zone and accepted its own currency, som in 1993. Moreover, it is also the first former Soviet republics entered to World Trade Organization (WTO) in 1998.

Second, finding new trade partners and external markets was a challenge. Kyrgyz governments wanted to go outside for two reasons: trading with outsiders at time of economic downturn in CIS was rise profitable and trading with outsiders would be a manifestation of their independence and sovereignty.

It is obvious that since the independence Kyrgyzstan still serves as supply of raw material such as Kyrgyzstan's primary budget income is still composed from natural resources (gold export). The Kyrgyz Republic is also classified as a low-income country with high debt vulnerability, due to these characteristics it is eligible to receive a significant level of grant from international financial organization, like World Bank.

In this paper, Kyrgyzstan's relations with the International Financial Organizations will divide three stages: Romantic years in 1990s, Debate on Heavily Indebted Poor Countries (HIPC) Initiative in 2000s, and the last one, after HIPC and Revolution in 2010.
\end{abstract}

JEL Codes: F59, F50, F33

\section{Introduction}

The breakup of the USSR was accompanied by skyrocketing inflation rates, drastically increased unemployment and dropped national/industrial/economical output. When the initial shocks were tamed down, leaders started thinking about prospective. The midterm plans included: the build up of independent fiscal and monetary policies, finding new trade partners, markets, suppliers and commodities.

Kyrgyzstan since the collapse of Soviet Union went to the transition path and while it is argued that it succeeded at some points, levels or degree. It is certainly that major obstacle to the successful transition is not overcome. This obstacle is in the economic nature and represented by lack of entrepreneurship.

First of all it was necessary to get out of Russian dominated economy since it was itself declining. Leaving a ruble zone was a crucial step in that respect which disattached Kyrgyzstan from Russian economic influence a certain point. Kyrgyzstan was the first former Soviet republics left Russian ruble zone and accepted its own currency, som in 1993. Moreover, it is also the first former Soviet republics entered to World Trade Organization (WTO) in 1998.

Second, finding new trade partners and external markets was a challenge. Kyrgyz governments wanted to go outside for two reasons: trading with outsiders at time of economic downturn in CIS was rise profitable and trading with outsiders would be a manifestation of their independence and sovereignty.

It is obvious that since the independence Kyrgyzstan still serves as supply of raw material such as Kyrgyzstan's primary budget income is still composed from natural resources (gold export). The Kyrgyz Republic is also classified as a low-income country with high debt vulnerability, due to these characteristics it is eligible to receive a significant level of grant from international financial organization, like World Bank.

In this paper, Kyrgyzstan's relations with the International Financial Organizations will divide three stages: Romantic years in 1990s, Debate on Heavily Indebted Poor Countries (HIPC) Initiative in 2000s, and the last one, after HIPC and Revolution in 2010.

As the international community moves from the superpower realpolitik structure of the Cold War era into the new millenium, the world order and its economic order are changing. No longer based on a structure of dependency but rather a structure of interdendepency, the New World Order seeks to create globalization through democratic ideologies and more importantly through an economic structure. By creating the International Monetary Fund, the World Bank, and the World Trade Organization, the international community sought to bring this independent structure to fruition. However, the World Bank, the IMF and the Wto are not successful in helping states become interdependent. Instead of helping create newly independent post-Soviet states through loans, these institutions have created dependent, underdeveloped nations. Not only has the IMF, the World Bank and the WTO created underdeveloped nations, but both continue to perpetuate the first and third world structure of the Old World Order. Since these nations are underdeveloped and not producing to their full capacity, they are 
stuck in a cycle of borrowing from which they can never full break free from and develop. Thus, this cycle of borrowing places these nations in a state of imperialism.

\section{International Financial Organizations: International Monetary Fund, World Bank, World Trade Organization}

Entering into a new era, the international community realized the importance of economics when they gathered together in 1944. Having the League of Nations fail at preventing World War II, the international community decided to reconvene and build another international organization. Meeting at Dumbarton Oaks, these nations began to from the infrastructure of the United Nations. Although the structure was similar to that of the League of Nations, the conference at Dumbarton Oaks introduced the idea of the importance of economics in international organizations. When the nations met again in San Francisco they discussed the importance of economics in the UN further. During this conference the Economic and Social Counsel was officially formed and its role was expanded so that it would be an integral part of the UN Charter.

Before the onset of the UN, 44 nations gathered together in Bretton Woods, New Hampshire to discuss global financial policies. Dealing with world depression after World War II, these 44 nations developed two financial institutions-International Monetary Fund and International Bank for Reconstruction and Development (IBRD) or World Bank to deter further global recession. Established in 1944, the IMF original purpose was to regulate the fixed exchange rate (dollar pegged to gold), to appropriate funds to member countries with balance-of-payment deficits (Bennett, 1995, 290). Today, the IMF has added to its role and its members (originally 39, today 187) in the international market. Because there were so many problems with the fixed exchange rate system, the IMF has moved to a more diverse rating system. Today, countries are allowed to determine the value of their currencies. Countries can take one of two measures. The first possibility is to peg their currency to that of another. For example, Kyrgyzstan may set its currency value to that of the US, so when the US dollar goes up, so will the Kyrgyz som too. The other measure is valuing their currency at what the market says their currency is worth; this is called floating. Because of this new freedom that countries have, the IMF had to increase its regulation measures. The IMF now surveys members' exchange policies. Another newly found responsibility of the IMF is to determine whether a country is acting open and reasonably when they set the value of its currency.

Thus, the purpose of the IMF is to promote international monetary cooperation, exchange rate stability, and the expansion of international trade by acting as a lender of last resort when a member country faced an economic crisis. A member country facing a financial crisis has access to the fund's resources and advice. As a country's drawings become larger relative its quotas, it must meet more exacting standards or so called "conditionalities", which typically mean significant changes in economic policies to ensure that the country's domestic and external deficits are drastically lowered or even eliminated. Failure to meet those conditions result in suspension, renegotiation or even cancellation of the program. Quota is a member country's contributions to the IMF, which is usually based on the country's weight in the global economy. Quotas are usually called "Special Drawing Rights" (SDR), which determines country's voting power and borrowing capacity.

Also, created during the Bretton Woods conference, the World Bank (IBRD) was designed handle cases concerning lending funds to members who could not pay their debts. Throughout its operation, the World Bank has created two affiliates to better facilitate its programs of development. These programs are International Finance Corporation (IFC) which 'stimulates private investments in developing nations' and International Development Association (IDA) which is "provide(s) for the special needs of the least-developed countries" (Bennett, 1995, 313). Through these programs the IMF and the World Bank sought to bring economic stability and order into the international community.

\section{The Kyrgyz Case}

Since their independence, Central Asian countries have experienced problems with their economic structure. As they moved from the imperial controls of Soviet Union, Central Asian countries experience political, economic and psychological traumas within their borders; thus causing a stagnation in their human and collective capital. Furthermore, the international and domestic trading markets were at a standstill, making their agricultural goods hard to export and sell. The combination of crises and stagnation placed these Central Asian countries in severe economic hardships. With very little production of capital within these countries, these nations looked externally to help aid in the rebuilding of their economic structures. The primary source of their aid came from loans from the International Financial Organizations. These loans sparked an opening of commercial trade and trade of ideologies. International financial organizations introduced the idea of open and free markets which lead to an increase in imports of foreign goods to especially Kyrgyzstan. Thus, last twenty years, Kyrgyzstan is importing more foreign goods than exporting and selling their own. Kyrgyzstan was being pulled further into the international economy in such a way that strongly condition its economic development. This development was based on dependency on external benefactors to provide the necessary means to continue the nation's economic structure. 
Kyrgyzstan's poverty was not caused by the country's inability to modernize but by the country's inability to handle economic situations since its independence. After its independence, for restructuring its economy and adopting market economy in the early 1990s Kyrgyzstan turned to the international financial organizations, i.e. the IMF and the World Bank, for help. As a result, Kyrgyzstan became dependent upon funds provided by these organizations out of necessity.

After the collapse of the Soviet Union Kyrgyz economy was severely affected resulting loss of its vast market, because around $91 \%$ of Kyrgyz export with the other union republics of the Soviet Union (Trushin and Trushin, 2000, 99). The collapse of factories and state farms, and the disappearance of Kyrgyz's traditional markets in the former Soviet Union, made Kyrgyzstan worse than any other former Soviet Union republics, except war-torn states Tajikistan, Armenia and Azerbaijan in the early 1990s (Gleason, 2003, 65-66).

Kyrgyzstan joined the IMF ON May 8, 1992 and its quota was 64.5 million SDR then became 88.80 million (about $\$ 140$ million, where \$1 approximately equals to 0.62 SDR). Kyrgyzstan has been implementing economic reforms under financial support from the IMF since 1993. From 1993 till 1998 IMF has implemented different Structural Adjustment programs in the country, which were designed to assist the country to adjust and weather crisis. Then in September 1999, the IMF introduced the Poverty Reduction and Growth Trust (PRGT), formerly Poverty Reduction and Growth Facility (PRGF) program for poorest member states, which faced difficulties in economics. Since 1993 IMF has conducted 7 lending arrangements with Kyrgyzstan:

\begin{tabular}{|c|c|c|c|c|c|}
\hline Facility & $\begin{array}{c}\text { Date of } \\
\text { Arrangement }\end{array}$ & $\begin{array}{c}\text { Date of } \\
\text { Expiration or } \\
\text { Cancellation }\end{array}$ & $\begin{array}{c}\text { Amount } \\
\text { Agreed }\end{array}$ & $\begin{array}{c}\text { Amount } \\
\text { Drawn }\end{array}$ & $\begin{array}{c}\text { Amount } \\
\text { Outstanding }\end{array}$ \\
\hline $\begin{array}{c}\text { Extended } \\
\text { Credit Facility }\end{array}$ & Jun 20, 2011 & Jun 19, 2014 & 66,600 & 9,514 & 9,514 \\
\hline $\begin{array}{c}\text { Exogenous } \\
\text { Shock Facility }\end{array}$ & Dec 10, 2008 & Jun 09, 2010 & 66,600 & 33,300 & 33,300 \\
\hline $\begin{array}{c}\text { Extended } \\
\text { Credit Facility }\end{array}$ & Mar 15, 2005 & May 31, 2008 & 17,760 & 17,760 & 17,381 \\
\hline $\begin{array}{c}\text { Extended } \\
\text { Credit Facility }\end{array}$ & Dec 06, 2001 & Mar 14, 2005 & 73,400 & 73,400 & 30,192 \\
\hline $\begin{array}{c}\text { Extended } \\
\text { Credit Facility }\end{array}$ & Jun 26, 1998 & Jul 25, 2001 & 73,380 & 44,690 & 0 \\
\hline $\begin{array}{c}\text { Extended } \\
\text { Credit Facility }\end{array}$ & Jul 20, 1994 & Mar 31, 1998 & 88,150 & 88,150 & 0 \\
\hline $\begin{array}{c}\text { Standby } \\
\text { Arrangement }\end{array}$ & May 12, 1993 & Apr 11, 1994 & 27,090 & 11,610 & 0 \\
\hline \multicolumn{3}{|c|}{ Total } & 412,980 & 278,424 & 90,387 \\
\hline
\end{tabular}

Table 1. Lending Agreements Conducted by the IMF with Kyrgyzstan

The programs are conducted in Kyrgyzstan by the IMF since 1993 include in five spheres. Those five spheres are: fiscal policy (taxes and governmental subsidies), monetary and exchange rate policy (inflation), external sector policies (foreign trade, taxes on imports and exports), debt strategy (balance of payment), structural reforms (banking sector, privatization, energy sector). It is obvious that developing countries, like Kyrgyzstan, might have little choice against "conditionalities" of the IMF. The IMF has expanded its role as "Lender of Last Resort" (Broome, 2010, 50). For that reason, it is understandable then why the IMF and its strategies foist on countries, communities and people to hostile the institution. By providing billions of dollars, or as it is calledlend assistance, the IMF has taken interventions. As the IMF claims that it can improve matter in those countries, which are facing crises, by putting pressure on countries to accept its conditions. In essence, the Fund argues that it must intervene, and quickly, if it determines that an ongoing crisis in one country will spill over to others, that is, the crisis will spread like an infectious disease.

Therefore, the countries, like Kyrgyzstan, who need financial assistance, ask assistance from the international financial institutions. Because the main tool to stabilize economy in these countries, facing economic difficulties, is lends. IMF provides money to adjust balance of payment, reduce poverty, and to overcome other economic problems (Broome, 2010, 125-127). However, money is given under certain conditions, as IMF calls themrecommendations. At a minimum, a loan agreement says the loan goes out on the condition that it will be rapid, usually with the schedule attached. Many loans impose conditions designed to increase the likelihood that they will be repaid. "Conditionality" refers to more forceful conditions, ones that often turn the loan into a policy tool. And often, the IMF keeps up the pretense that the letter of intent comes from the country's government. The IMF, of course, claims that it never dictates but always negotiates the terms of any loan agreement with the borrowing country. But these are one-sided negotiations in which all the power is in the hands of the IMF, largely because many countries seeking IMF help are in desperate need of funds (Stiglitz, 2002, 40). Thus, the 
imbalance of power between the IMF and the "client" country inevitably creates the "client" dependent on the IMF's policies.

The IMF has provided lends and technical assistance by imposing some conditions on Kyrgyzstan. These conditions require Kyrgyzstan to make structural reforms, such as privatization of state-run enterprises, decreasing social programs, and recommendation for political reforms. Some of these conditions violate a recipient country's sovereignty. These "attached conditions" makes the IMF to hold virtual neo-colonial control over developing countries, such as Kyrgyzstan.

Kyrgyzstan's adoption of shock therapy policies in 1990s as well as political crises sparked economic crises that the Kyrgyz government could not handle (Trushin and Trushin, 2000, 91). Another cause of Kyrgyzstan's economic struggles stemmed from the bad judgment on the government's part. As the market declined, the Kyrgyz government began to implement more policies prescribed by the IMF and World Bank, such as opening domestic market to the foreign competitors without any preparation. At the same time, social and political unrests began to permeate in Kyrgyzstan. The government policies also increased corruption in the country.

Seeing that the government had changed its role in the economic realm it did not want to give up this newfound power. Instead of competing corruption in the government and bureaucracy or trying to encourage investments, Kyrgyzstan turned to the IMF for help. This decision would prove to be detrimental to the Kyrgyz economy, as the effects would last well into the $21^{\text {st }}$ century. Including the IMF in economic policies, lead to an increased dependency by the Kyrgyz government to increase their loans form the IMF to fund their social and economic programs. As a result, the IMF and World Bank, as well as EBRD and Asian Development Bank loans and credits became the imprudence of the government and the source of many of the economic problems of Kyrgyzstan. With the already high inflation rate, the low rate of the som, and the now raising foreign deficit, the loans and credits from the international financial institutions only increased the amount of money Kyrgyzstan owed.

Following the IMF prescriptions did not solve the Kyrgyz economic decline. In spite of recovering, Kyrgyzstan continued to get deeper in debt and foreign deficit rose. As a result, to compensate the lowering price of their main export, the Kyrgyz government continued to borrow heavily in the foreign market. This created more problems because it put Kyrgyzstan into deeper debt. Since the government assumed a role that it could not fully facilitate well, hurt the Kyrgyz people and their economy more.

By the 2000s Kyrgyzstan began a frenetic cycle of borrowing. Promising relief from debt burdens, the IMF imposed reforms on borrowers. Much like the Soviet imposed ideologies, these reforms included opening up economies to foreign trade and investment, reducing the role of government, promoting exports, and taking steps against inflation. Through these reforms, the IMF is imposing a new form of imperialism. No longer based on gaining territory, the new imperialism wishes to dominate a country through economic means. By enslaving a country's economic structure, an imperial power can manipulate the country into a state of neo-colonialism. Meaning, these external forces can manipulate countries such as Kyrgyzstan into unequal trading agreements and unfair stipulations to loans. These unequal trading agreements such as a creating a system where only one crash crop may be exported by a country guarantees these nations will continue to be impoverished. Thus, continuing the cycle of borrowing more money.

Not only does this neo-colonialism structure of economic development hinder nations like Kyrgyzstan to form a stable and productive economic structure but it also divides the world again into the haves and the have-nots. The new world order is not based on the first world and third world system anymore, yet with resurgence of imperialism brought upon by the creation of the IMF and the World Bank, this system of division appears to be intact. As mentioned before, nations like Kyrgyzstan are unable to break the cycle of dependence on foreign loans because of historical dependence and governmental decisions. Moreover, they are dependent on these funds because it is the only source of capital entering the country. Therefore, because these nations are unable to grow and develop because of their economic development, they are considered the have-nots. By creating a system of dependence, the world order is still based on the first and third world structure.

The Kyrgyz government took out more and more foreign loans in the 20 years that Askar Akayev and Kurmanbek Bakiyev were in power-selling itself as the "Switzerland of Central Asia" and participating "War on Terror". But those years hadn't produced sustained economic development, and the new government headed by President Roza Otunbayeva has to deal with more sober realities. Total foreign debt is currently put at just over 2 billion 700 million dollars-equivalent to 60 per cent of the country's annual gross national product. Kyrgyzstan has most of debts to the international financial institutions. The largest lenders of Kyrgyzstan are the World Bank, the Asian Development Bank, and the International Monetary Fund that Kyrgyzstan respectively owes 684 million, 608 million, and 175 million dollars. The question as how Kyrgyzstan with its poor economy will pay off its debt arises. This is a serious concern not only of the top officials in the government, but of ordinary people as well; since they are the vulnerable part of the population which is directly or indirectly effected by the decisions of the Kyrgyz government.

There was a chance for Kyrgyzstan to get rid of its debts by joining Highly Indebt Poor Countries (HIPC) 
initiative proposed by the Bretton Wood Institutions (IMF and World Bank). As expected, there was a debate between different political actors whether to join this initiative or not. First group of people said that joining HIPC initiative will mean the loss of face of Kyrgyzstan in front of the international community, since Kyrgyzstan will put on a par with Africa's poorest countries. As a result, it will damage the image of Kyrgyzstan. The second group of people said that there is no chance for Kyrgyzstan to pay off its debts without the aid and support of international financial organizations. At the beginning of this debate both President Kurmanbek Bakiyev and Prime Minister Felik Kulov and Finance Minister Akylbek Japarov agreed to join HIPC Initiative. On March 23, 2006, Prime Minister formally requested a letter to the IMF and the World Bank. In that letter, "we will be happy to welcome any debt reliefs as part of the HIPC, which will help us to solve the problem of debt stability." However, after a long debate on the HIPC initiative in Jonorku Kenesh and Russia's involvement, the Kyrgyz government changed its policy and rejected to participate the initiative on February 20, 2007.

\section{Conclusion}

The IMF and World Bank do not offer assistance but rather they offer dependence and an imperialistic structure. Through the reforms and stipulations placed on these nations, the IMF and World Bank cause states to further indebt themselves. Kyrgyzstan is currently well over 2 billion 700 million dollars in debt. Not only does this debt stem from loans from the Paris Club members but debts from the international financial organizations. The IMF and World Bank were intended to bring economic structure into the international community, but seen by the Kyrgyzstan case, they have only brought economic hardship. The old world order of first and third world nations was to fade with the collapse of communism; however, it is continued with the aid of IMF and World Bank. Through their reforms, the IMF and World Bank have not created economic structure and interdependence but rather economic deterioration and dependence.

\section{References}

- $\quad$ LeRoy A. Bennett, International Organizations: Principles and Issues, Englewood Cliffs: Prentice Hall, 1995.

- Eskender Trushin and Eshref Trushin, "Basic Problems of Market Transition in Central Asia," in Central Asia and the New Global Economy, ed. Boris Rumer, Armonk: M. E. Sharpe, 2000.

- Gregory Gleason, Markets and Politics in Central Asia: Structural Reform and Political Change, London: Routledge, 2003.

- Andre Broome, The Currency of Power: The IMF and Monetary Reform in Central Asia, London: Palgrave Macmillian, 2010.

- Joseph Stiglitz, Globalization and Its Discontents, New York: Norton, 2002.

- IMF, http://www.imf.org/external/about.htm.

- IMF, http://www.imf.org/external/np/exr/facts/sdr.htm.

- IMF, http://www.imf.org/external/pubs/ft/sd/index.asp?decision=11436-(97/10).

- IMF, http://www.imf.org/external/np/fin/tad/extarr2 aspx?memberKey1=565\&date1 key=2011-07-31.

- $\quad 24 . \mathrm{kg}, \mathrm{http}: / / \mathrm{eng} .24 . \mathrm{kg} /$ business/2011/07/29/19459.html.

- IWPR, http://iwpr.net/report-news/kyrgyzstan-grapples-huge-debt.

- $\quad$ Eurasianet.org, http://www.eurasianet.org/departments/insight/articles/eav022307a.shtml. 


\title{
Multilateralism versus Regionalism in Eurasia: Theoretical Reasons of Choosing Sides for Kyrgyzstan
}

\author{
Zamirbek Manasov (Middle East Technical University, Turkey)
}

\begin{abstract}
This paper asks whether Kyrgyzstan should take part in the newly established Customs Union among Belarus, Kazakhstan and Russia or in the World Trade Organization (WTO). From the start of the foundation of the new Customs Union there have been deep discussions among the proponents and opponents of organization. This issue attracted extra attention and interest because the new Customs Union includes non-members of the World Trade Organization such as Russia, Belarus, and Kazakhstan. In Addition, the new Customs Union, unlike previous regional trade agreements, has formed a supranational body -the Custom Union Commission - which will decide on Common External Tariffs. Kyrgyzstan is already a member country of WTO and is going to join the new Customs Union. How will this membership work for Kyrgyzstan in short and long-term period? Will the new Customs Union be substitutive or complementary to the WTO in the development of international trade of Kyrgyzstan? Which side would be more beneficial for Kyrgyzstan: membership to a regional Customs Union or to a multilateral WTO? This paper hopes to answer these main questions. This paper will have five sections. Section one will provide a brief introduction. Section two will analyze the development of regionalism and multilateralism in the region. In section three, theoretical compatibility of regionalism and multilateralism will be discussed. Section four will determine what can be proposed for the current situation of Kyrgyzstan according to selected theoretical literature. Concluding remarks will be given in last section.
\end{abstract}

JEL Code: F13

\section{Introduction}

With the collapse of the Soviet Union in 1990, intra-trade among post-Soviet states suffered due to the breakdown in traditional market structures and a lack of alternative trade framework. Therefore, the concerned states immediately set the agenda to solve the Soviet-type economic interdependency among the republics and the infrastructure set in accordance with this model. The lack of experience in governance, both in the public and private sectors, further complicated the situation. The needed solutions were therefore more complex than expected. These countries must not only decide whether or not to cooperate and integrate and with whom, but also how deep should the cooperation be since there are political, social and economic costs. In this respect, within the short period of time, they established diplomatic relations with most countries of the world. They became members of the United Nations and other international organizations, such as the International Monetary Fund and the World Bank. They also signed hundreds of interstate treaties and trade agreements and entered into highly complex trade and economic relations with over 140 countries. However, during the entire independence period, trade relations in the post-Soviet area have also become more complicated. It seemed like the trade relations among these states have developed under the simultaneous influence of two directions: regionalism and multilateralism.

\section{Regionalism}

Post-Soviet States have undertaken to establish or re-establish different region-based organizations within the two decades after the independence. These organizations consist of either exclusively Former Soviet Union countries (Commonwealth of Independent States, Eurasian Economic Community, Central Asian Cooperation Organization), or also include other countries (Economic Cooperation Organization, Shanghai Cooperation Organization). The importance of these organizations for analysis is that they best represent the efforts of the Central Asian states to create a case for regionalism (Esengul, 2009).

The lack of effectiveness of all these organizations in terms of fostering trade and economic cooperation, which were urgently needed for every participating country, has been mentioned in many literatures. This paper does not aim to discuss the effectiveness or success, the cooperation potential, and the plans or their (non)implementation by these region-based organizations. However, as a part of this paper, it is necessary to show the impact of these organizations on regional trade rules and patterns.

In the early 1990s the Commonwealth of Independent States (CIS) countries adopted a Free Trade Agreement (FTA) with zero import tariffs for all goods originating from all the countries that signed up to it. This multilateral free trade arrangement was also reinforced by bilateral agreements between CIS countries (Jonson, 2004; 60). However, it is necessary to note that such bilateral free trade agreements allowed parties to introduce import duties on a limited number of commodities, either to protect sensitive domestic industries or as antidumping measures. 
Furthermore, several CIS members started to use temporary import bans against selected neighbors as a weapon in a variety of bilateral trade disputes or as an emergency measure, even if they have signed multilateral and bilateral trade agreements. For example, Russia and Ukraine have engaged in a number of bilateral disputes involving mutual bans of trade in certain commodities; Uzbekistan has cut off imports from the Kyrgyz Republic in retaliation for non delivery of electricity; and Kazakhstan has imposed prohibitive duties on trade with neighboring countries to deal with its balance of payments problems (Broadman 2005; 129). In other words using trade as a weapon in settling disputes has become an ordinary issue that decreased the workability of the CIS.

Relating or depending on their new independent economic, political and social policies, the leaders of some post-Soviet republics started to organize new regionalism processes within the CIS. These sort of new organizations were the result of internal policies of the initiating countries. For example, Kazakhstan President Nazarbayev put forward the idea of creating a new integration structure on the basis of the CIS, the Eurasian Union (Kulchik, 1996; 44). Nazarbeyev's Eurasian Union aimed at introducing common borders and creating super national currency. According to Nazarbayev, this would not mean the destruction of the CIS. On the contrary, the Eurasian Union (EurasEC) would act as a strong nucleus for region.

In 2000, the countries of the Customs Union (EurasEC) concluded an agreement on a Common Customs Tariff (Gürer, 2005). This agreement provides a five-year period (which can be further expanded) for the formation of a Common Customs Tariff with a special permission for Kyrgyzstan and Tajikistan to establish their own time schedules for the adoption of the tariff. The EurasEC strategy focused on a customs union and an eventual single currency for the region (Gleason, 2001). It emphasized economy-based issues more than the CIS and was designed to sponsor cooperation in five broad categories: free trade, customs; common market or products; services and labor; and a currency or monetary union. However, in terms of efficiency it was not different from the CIS.

The Central Asian Cooperation Organization (CACO) (and its predecessor, the Central Asian Economic Community) provides a forum for discussing and developing coordinated policy with regards to water and energy exchange issues that would require regional participation. Central Asian leaders have attempted to distinguish $\mathrm{CACO}$ from its predecessor by emphasizing improved effectiveness. Agreements and multilateral treaties were signed under CACO, sort of following the EU model. Examples include the coordination of tax collection methodology, indirect taxes, simplification and harmonization of customs rules (EurasEC), information exchange in different areas (CIS, EurasEC, CACO), and the rather unsuccessful attempt to establish the Central Asian Cooperation and Development Bank. However, enforceable agreements have been achieved so far mainly on a bilateral basis. Very few other practical results from regional organization activities have been achieved. According to President Karimov of Uzbekistan, the CACO had in many ways repeated the experience of the CIS. More than 250 CACO decisions were adopted but were not implemented. Many of the CACO's documents have proven to be as totally redundant as those of the CIS, Karimov concluded (Karasar, 2009). For Uzbekistan, CACO was considered as a tool for control over the region by a potential hegemonic power (Swanstrom, 2004; 44). In addition, as was mentioned by Esengul (2009; 128), fear of Russian neo-imperialism was considered as one of the sources of ineffectiveness of the CIS. Being sub-regional structures of the CIS, the $\mathrm{CACO}$ and EurasEC faced the same problems, fears and expectations.

In fact, there has not been any regional trade regulation with practical implications that has ever fully entered into force; only framework documents and declarations have been adopted in all regional organizations. Of course, trade and economic cooperation in the region did take place, but it was regulated by bilateral agreements or by the authority of leaders. In other words, besides bilateral agreements, the leaders of Central Asian states played a key role in shaping the emerging polities and institutions. Similarly, Moscow will play leading role in the new Customs Union. In all these states, a small group of authoritarian ruling elites has played the key role in shaping the emerging political and economic orders. These ruling elites have been unwilling to create regional organizations which would adversely affect their newly won sovereignty (Bohr, 2004; 501). It is difficult to say that the concept of regionalism can be used in all sense in the region (Chinara Esengul 2009).

\section{Multilateralism}

In pursuit of multilateralism, all these countries in question have applied for GATT and its successor, the WTO. For example, Russia and Belarus applied in 1993 and Kazakhstan applied in 1996. WTO accession never received strong support from President Boris Yeltsin. But soon after President Vladimir Putin came to office, Russia made WTO accession a priority. He created the massive Ministry of Economic Development and Trade and appointed a reformer, German Gref, as its head (Tarr, 2007). The Working Party on the accession of Belarus to the WTO was established on 27 October 1993 and held its first meeting in June 1997. Bilateral market access negotiations are ongoing on the basis of revised offers on goods and services. A revised Factual Summary of Points Raised was prepared by the Secretariat in June 2007. Comparing to other post-Soviet states accession process, Belarus has moved slowly. 
Kazakhstan's WTO Working Party was established on 6 February 1996. Bilateral market access negotiations are ongoing. The latest revision of the draft Report of the Working Party was circulated in June 2008. The Working Party held its tenth meeting in July 2008 (Khatibi, 2008). Among the other countries in the group, Kazakhstan has a relatively more developed market-oriented economy, but since the mid-1990s, its elite have been cautious about ceding discretionary economic power. This is reflected in the difficulties of the WTO negotiations regarding the administration of border controls by customs, quarantine, veterinary and other agencies (Pomfret, 2007; 40).

The WTO is the last major international organization of which Russia is not a member. More than 95 percent of world trade is carried out by the 153 WTO members, and Belarus, Kazakhstan and Russia remain outside of the WTO. They are still in the negotiation process. A prospective country has to go through a long application process that takes six years on average to complete, but these countries have been trying for seventeen years, which is much longer than any other applicant. This seems to buttress the notion that it is better for big countries to enter in most international negotiations, but when entering the WTO, the opposite is true. The bigger a trading partner country is, the more the other countries will be concerned about the effects of foreign trade will have on them. Every applicant must make a bilateral agreement on market access with every member who cares to make such a claim. Usually, 10-20 countries would be interested. For Russia, more than 60 member countries have demanded a bilateral protocol on market access (Aslund, 2010). Moreover, because the WTO decides on everything by consensus, each individual member can veto the entry of a new applicant. Russian officials are immensely irritated to see discrimination against their country because of its large size and they claim that it is inappropriate for Russia to be treated in such a way.

The main reason for Russia's slow approach to the WTO was that Russia's political leaders ignored the importance of the organization. Additionally, under the leadership of Putin in 2006, Russia's new policy of import substitution, extensive state intervention, industrial policy, and protectionism were reasons why Russia postponed joining the WTO. Russia undertook multiple protectionist measures in the following years. In May, 2008, when Medvedev took office, there was new reason to be optimistic about Russia's accession to the WTO. The new president repeatedly voiced his approval of the WTO in virtually all his major speeches, while Putin had ignored it during his last term as a president. However, in June 2009, Putin announced that Belarus, Kazakhstan, and Russia were abandoning their individual talks to join the WTO. Instead, they would enter as a single Customs Union. Putin's explanation was that the Customs Union was more important and could no longer be delayed for WTO accession (Aslund, 2010; 59-60). The end result however, was that Russia's almost complete accession to the WTO was jeopardized since after 16 years of negotiations, Russia was nearly ready to join the WTO.

Putin's novel proposal was the first application in the WTO history where countries wanted to access to the WTO as a group. No country has ever entered WTO collectively, which is not legally possible. Reacting to Putin's proposal, the General Secretary of the WTO declared that a Customs Union could not join the WTO. The Russian officials involved in the WTO negotiations then revised the meaning of its Customs Union joining the WTO to mean that the three countries will coordinate their accession to the WTO. In Kazakhstan, there is a common belief that, because of the close trade links with the Russian Federation, Kazakhstan's WTO accession should be coordinated with that of the Russian Federation. Yet, any coordination will necessarily slow down Russia, because Kazakhstan has not concluded its major bilateral protocols with the EU or the United States. Belarus on the other hand is still at an early stage of negotiations (Aslund, 2010; 60-62).

It would seem then that by declaring the intent to accede as a Custom Union, Putin simply delayed Russia's accession to the WTO for the foreseeable future. The reason is that Russia has less need for the WTO as compared to a manufacturing country like China. A series of World Bank and Russian studies has estimated that Russia can gain 0.5-1 percentage points in higher economic growth for a half decade if it joins the WTO. In other words, as was analyzed by Aslund (2010), rather than being a matter of trade policy, Russia's WTO accession has become political instrument of leaders in Moscow since there is little reason beyond political symbolism to synchronize accession dates. But there are good reasons for not delaying accession once substantive negotiations are complete.

In contrast to other Central Asian countries and Russia, Kyrgyzstan has pursued a two track policy of simultaneous regional and multilateral trade liberalization. It has become member of all the above-mentioned regional Organizations. As for the multilateral level, Kyrgyzstan began its accession process to the WTO in February 1996 and became a WTO member on 20 December 1998 (Rahmanova, 2000). Kyrgyz Republic remains the only WTO member among its Central Asian neighbors.

In order to boost economic growth, Kyrgyzstan has implemented a large-scale program aimed at political and macro-economic stabilization and structural reforms. The Government of Kyrgyzstan considered the complete integration of the country into the world trading system as a key to the long-term success of economic reforms and development. Kyrgyzstan recognized the necessity and importance of foreign investment since the country was without any significant industrial sector. In this context, Kyrgyzstan looked forward to have access to a great number of suppliers on the most favorable terms. Access to new foreign markets was indispensable for both 
balance of payment stabilization and for attracting foreign and domestic investors to industries. The first steps towards this goal were made in 1995 when experts of the relevant ministries and organizations of the country were sent to participate in the training seminars of the WTO (Quigley, 2004). In turn, Kyrgyzstan would access to major export markets, cheaper imports and the WTO's trade dispute settlement mechanism.

The Kyrgyz WTO experience indicates the importance of coherence between trade policy and domestic policy reform. Without domestic policy reform, WTO accession would be difficult. Kyrgyzstan would have benefited from its neighbors' concurrent accession. However, the lack of willingness on the part of the other Central Asian countries' and Russia's postponement to complete its WTO accession negotiations created contemporary disadvantages to Kyrgyzstan.

The Economic and fiscal costs of the WTO Membership are not negligible. Membership requires fairly large investments into the modernization and harmonization of various institutions directly involved in the conduct of foreign trade and investment (Drabek and Baccheta, 2010; 130). Accession is subject to a complex negotiation process, which is costly and which involves demands from existing member countries that the applicant countries do not necessarily consider to be in their own immediate interest. Accession commitments relate to market access, as well as policy rules not directly related to trade. Perhaps inevitably, bilateral or regional arrangements may often seem more attractive than WTO membership for some countries. As mentioned by Felbermayr and Kohler (2010), there is a "price" for WTO membership. Although the price is negotiable, the negotiating process is somewhat biased in favor of the existing members. Moreover, there is evidence that the price has risen through time (Evenett and Primo Braga, 2010). But, if countries are willing to pay this "price", so there must be some benefit from it.

What is important to point here is that the cost of membership for Kyrgyzstan is high and might not be negligible. In the studies of Drabek and Woo (2010) these costs are divided into separate groups: costs of accession, costs of implementation, costs of lost government revenues, and reduced scope for countries to conduct independent national policies. As indicated in their work, it is seems that it is not easy to switchover from central planning to market-based policy instruments. It might painful, but it is also highly valuable. Since joining the WTO strengthened the capacity of its market-based institutions and those specifically trade related, such as the financial sector, customs and trade facilitation, Kyrgyzstan is now better able to enjoy the benefits and meet the responsibilities of participation in multilateral trading system (Michalopoulos, 1999).

The Kyrgyzstan's experience indicates that WTO membership does not guarantee the provision of immediate benefits. It supports, but does not guarantee the expansion of export, fast industrialization, and development or the high levels of economic growth and unconditional growth of direct investments. The membership of countries in the WTO will allow resolving trade disputes between states based on WTO DSU (Dispute Settlement Understanding) rules and procedures. In view of these, therefore, it is important for Kyrgyzstan to promote the accession process of its neighbouring and main trading country-partners in the WTO, while using the advantage of its membership for providing market access for its goods.

\section{Regionalism versus Multilateralism in the Literature}

Many scholars cite the large number of Regional Trade Agreements (RTAs) notified to the WTO as evidence of the growth and significance of regionalism. From this perspective, because the number of RTAs notified to the WTO reached an all time high in early 2000s, regionalism appears more prevalent than ever. The main problem with using counts of RTAs as measures of the increasing importance of regionalism is that, while some agreements are important, many RTAs are inconsequential (Pomfret, 2006). For example, political and security considerations have been the main concern in the formation of all kinds of regional agreements, especially in the post-Soviet area.

There is another reason why non-member countries prefer Custom Union or RTAs rather than WTO. Free Trade Agreement (FTA) negotiations proceed more rapidly than WTO accessions and are completed more quickly. The average time for completing an FTA negotiation from the beginning of the negotiation to final entry into force is about 3 years. The average time for completing the task of a WTO working party is 6.9 years. Moreover, changes in economic conditions are much more in WTO accession than in an FTA negotiation. The process of FTA negotiations is simpler, while there may be a dozen or more members in a WTO accession party, each one representing separate agendas that may need bilateral and multilateral agreement (Ferrantino, 2010;143). A Customs Union among non-members might be a rescue vehicle in the short term. But in long term it is difficult to say if this same vehicle would be of help since there is an ongoing process among member countries of WTO to form or shape future multilateral trade rules and disciplines. There is no clear evidence of RTAs having superiority over WTO membership.

It should be noted that despite the fact that regionalism seems to function as a substitute, as Heydon mentioned, regional agreements can be a complement to the multilateral trading system, but they can never be a complete substitute for it (Heydon, 2008: 248). Regional agreements may in certain areas advance more quickly than is possible multilaterally, but they can never substitute for multilateral rulemaking. The issue of regionalism 
vs. multilateralism has generated a vast debate on whether the immediate consequences of regionalism for the economic welfare of the integrating partners encourage or discourage evolution towards a freer global trade. However, most analysts, including the WTO Secretariat, have concluded that on the whole, regional agreements have made a positive contribution to the liberalization of world trade.

Bhagwati (1999) expresses strong concerns about the negative effects of growing regionalism and worries that RTAs divert attention from the multilateral trading system. Bhagwati, in particular, stresses the benefits of free trade and rejects arguments about the need for an alternative to the GATT (WTO) for countries which wish to liberalize faster, for regionalism as a supplement to GATT (WTO), or for regionalism to accelerate the GATT processes.

Bagwell and Staiger (1999) questioned whether RTAs are "building blocks" or "stumbling blocks" for multilateral trade. They outlined a framework of effects with which to better understand the possible impact of regional agreements on multilateral trade. According to their analytical framework of effects, there are effects, under which regional agreements complement multilateral trade, and effects also exist under which regional agreements undermine the multilateralism. They concluded that RTAs are the building blocks for multilarelism. But when multilateralism system is working poorly, RTAs can have undesirable effects on multilateralism.

It is desirable then to analyze RTAs within the framework of WTO system. However, examination of specific RTAs within the framework of WTO has been troubled by disagreement about the interpretation of certain elements of the rules relating to RTAs as well as by certain procedural aspects. To solve this problem on the procedural side, the General Council of WTO replaced the previous system of separate working parties with the establishment of the Committee of Regional Trade Agreements (CRTA) in Febrary 1996 (Crawford and Laird, $2000 ; 5)$. The mandate of the CRTA is to carry out the examination of agreements referred to it by the Council for Trade in Services (agreements under Article V of the GATT) and the Committee on Trade and Development (agreements between developing countries). The CRTA is also charged to make recommendations on the reporting requirements for each type of agreement and to develop procedures to facilitate and improve the examination process. However, as analyzed in detail by Crawford and Laird (2000), in practice, the CRTA has not been able to resolve many of the systemic issues in the WTO. According to them, this certainly does the system little credit, but it is also a consequence of fundamental consensus process of the WTO.

\section{Theoretical Reasons of Choosing Side}

This section asks whether Kyrgyzstan should join the new Customs Union or stay in the WTO. During the WTO membership Kyrgyzstan initiated many reforms leading to the modernization of trade policy and entrance to the world market. RTAs have generally proved to be poorly suited to promoting trade liberalization and have created restrictions rather than supports. In addition, RTAs in general have become a vehicle for promoting political views or policies rather than a vehicle for development of regional trade. Therefore, in this section we will mainly discuss the reasons why Kyrgyzstan should stay within the WTO. As this paper seeks to analyze just the theoretical side of developments about RTAs and the WTO in the Kyrgyzstan, the reasons that will be put forward here will reflect essentially the theoretical analysis from relevant literature.

In the literature, (Drabek and Baccheta,2010) the reasons can be grouped under two categories: theoretical arguments and practical considerations. In this section the theoretical side of reasoning will be emphasized since, the practical side would need more empirical studies and field research in the region. In addition there are no common points among those states about the practical benefits of multilateralism.

The attractiveness of the WTO has several dimensions. One of the attractive sides of WTO is that governments are able to obtain an improved access to markets for their exports. By staying outside the WTO, the countries' trade partners would be in a position to apply discriminatory tariffs against non-members. In addition, non-member countries would have to negotiate border measures with their partners bilaterally or regionally. The WTO is, therefore, particularly important for small countries that have a limited power to exploit their size to improve their terms of trade.

Another reason why countries may be interested in joining the WTO is the beneficial effect of the WTO lending credibility to government policies. Governments often face a credibility gap in trying to convince foreign and domestic investors and the rest of the business community about their commitments to particular policies. Unlike the Customs Union policy reforms, policy reforms of the WTO are more credible because of the strategic interaction among the members and between the government and the private sector that makes the agreement interactive (Drabek and Baccheta, 2010; 98).

In addition, as Pomfret (2010) argued, the Regional Trade Agreements, including the Customs Union, have proved to be poorly suited to promoting trade liberalization and have created rather than resolved trade disputes. He tried to answer why countries are keen to join the WTO and why are they often disappointed after accession? According to him, applicants often have false expectation of benefits while new members find that they have underestimated the costs of accession, which make many countries disappointed. The benefits of WTO membership are real, but the most important ones are indirect and general. To a significant degree, the benefits 
from a rules-based international trading system are network benefits (Pomfret, 2010; 184). Being part of the common trading system rules and network benefits of WTO is preferable to the regional Customs Union.

Another point that is generally underestimated is the potential benefits from the WTO dispute settlement mechanism. During the GATT era (1947-1994) the system was biased in favor of the major trading nations, both in coverage trade liberalization and in effective recourse against countries breaking GATT rules. For example, multilateral trade negotiations were dominated by the U.S., EEC, Japan, and Canada during the GATT period. However, after the WTO establishment, a Dispute Settlement Mechanism was formed that has provided much greater involvement of middle and low income countries either individually or as the G20. In other words, in terms of negotiation process, WTO members have equal rights. There are few effective vehicles to resolve international trading disputes outside commercial arbitration, and those that exist can disfavor small trading nations against big ones. The WTO Dispute Settlement Mechanism provides a uniquely fair, accessible, and effective opportunity to each WTO member-irrespective of its size and level of income (Davey, 2010).

A set of norms and institutions that support the liberalization of markets, increase transparency and promote the rule of law, and that tighten the enforcement and the evolution of an independent judicial system are other beneficial effects of WTO membership on domestic policies and institutions. The role of WTO in this process is to facilitate the introduction of effective reforms not only by reinforcing the credibility of the government's trade policies but also by helping introduce polices that are based on best practices and policies that must be harmonized. The WTO is also considered to play an important and positive role in the development of predictability, security and transparency of market access. This should help to reduce incentives for corruption by providing countries with powerful institutional checks and balances in the international economic sphere. According to Drabek (2010), theory and evidence suggest that openness reduces corruption. Increased transparency and market-based institutions should further reduce rent-seeking behavior and corruption. The adherence to internationally acceptable rules governing international trade and foreign direct investment imposes stricter disciplines on governments and indirectly on firms. In other words, as summarized by Pomfret (2010), WTO accession deserves greater credit as a policy anchor.

As shown above, WTO membership is commonly regarded as a key vehicle to integrate less developed countries into the world trading system and thus to enhance their growth and development perspectives. Did the WTO deliver on this account? This question might have many dimensions and there is no easy answer. According to literature, the WTO should at least have had trade-promoting influence. However, empirical studies show that WTO is not perfect for promoting international trade. For example, the widely recognized study of Rose establishes that, "literature currently do not have strong empirical evidence that GATT/WTO has systematically played a strong role in encouraging trade" (Felmermayr and Kohler, 2010; 218). In other words, this paper argues that the WTO may not be the unique instrument for the promotion and development of trade among nations, but it is more qualified in the forming trade rules than other forms of RTAs.

\section{Conclusion}

This paper asks whether Kyrgyzstan should take part in the newly established Customs Union among Belarus, Kazakhstan and Russia or in the World Trade Organization. According to the analysis from theoretical literature it is concluded that Kyrgyzstan needs to say in the WTO. Joining to the new Customs Union is the short term solution to cope with the current situation in Kyrgyzstan as experienced during the past two decades. Past experiences show that FTAs among those states or trade related organizations in the region did not work properly. FTAs tend to keep contemporary policy rather than to solve the long term problems of international trade. In addition, the main member of the new Customs Union, Russia, is almost finished with its negotiation process to enter the WTO. It seems that by declaring the intent to accede as a Custom Union, Russia just delayed its accession to the WTO for the foreseeable future. There is little reason beyond political symbolism to synchronize accession dates among Russia, Kazakhstan and Belarus. Moreover, the new Customs Union could not be substituted for the WTO according to what have been discussed in the literature. This does not mean that the WTO system is perfect. Admittedly, there are lacking aspects of the WTO as in specifying the rules of the game in the dispute settlement mechanism. But it is far better than a world trading system without the rule of law. It is especially beneficial for developing countries, which may otherwise be subject to undesirable actions by larger trading countries. When we consider the contributions of the Customs Union and WTO to the development of international trade, the WTO membership is undeniably not only for Kyrgyzstan but also other countries.

\section{References}

- Aslund, Anders., 2010, “Why Doesn't Russia Join the WTO?”, Center for Strategic and International Studies, The Washington Quarterly, No 33:2 pp. 49-63

- Bagwell, Kyle, and Robert W. Staiger,1999, Regionalism and Multilateral Tariff Cooperation, in International Trade Policy and the Pacific Rim, ed.by John Piggott and Alan Woodland, New York: St. Martin's Press.

- Bhagwati, Jagdish, and Arvind Panagariya, 1999, Preferential Trading Areas and Multilateralism: Strangers, Friends or 
Foes?," in Regionalism in Trade Policy: Essays on Preferential Trading, ed. by Arvind Panagariya, River Edge, N.J. and London: World Scientific.

- Bohr, Annette., 2004, "Regionalism in Central Asia: New Geopolitics, Old Regional Order", International Affairs, Volume 80, Issue 3, pages 485-502.

- Broadman, H, G., 2005, From Disintegration to Reintegration, Eastern Europe and the Former Soviet Union in International Trade, The International Bank for Reconstruction and Development and The World Bank, Washington DC 20433.

- Crawford, Jo-Ann., Laird, Sam., 2000, "Regional Trade Agreements and the WTO”, Centre for Research in Economic Development and International Trade, University of Nottingham, No. 00/3.

- Davey, W. J., 2010, The WTO Dispute Settlement System: How Have Developing Countries Fared? in Is the World Trade Organization Attractive Enough for Emerging Economies? Critical Essays on the Multilateral Trading System, ed. by Zdenek Drabek. Palgrave Macmilan.

- $\quad$ Drabek, Z., Bacchetta, M., 2010, Effects of WTO Accession on Policymaking in Sovereign States: Lessons from Transition Countries, in Is the World Trade Organization Attractive Enough for Emerging Economies? Critical Essays on the Multilateral Trading System, ed. by Zdenek Drabek. Palgrave Macmilan.

- $\quad$ Drabek, Z., Woo, W. T., 2010, Who Should Join the WTO and Why?: A Cost-benefit Analysis of WTO Membership, in Is the World Trade Organization Attractive Enough for Emerging Economies? Critical Essays on the Multilateral Trading System, ed. by Zdenek Drabek. Palgrave Macmilan.

- Esengul, Chinara., 2009, The Politics of Regionalism in Central Asian, Ministry of Education and Science of the Kyrgyz Republic, The Jusup Balasagyn Kyrgyz National University, Institute for Integration of International Educational Programs.

- $\quad$ Evennet, S, J., Braga, C. A. Primo., 2005, "WTO Accession: Lessons From Experience”, World Bank Trade Note, No 22.

- Felbermayr, G., Kohler, W., 2010, Does WTO Membership Make a Difference at the Extensive Margin of World Trade, in Is the World Trade Organization Attractive Enough for Emerging Economies? Critical Essays on the Multilateral Trading System, ed. by Zdenek Drabek. Palgrave Macmilan.

- Ferrantino, M.J., 2010, Policy Anchors: Do Free Trade Agreements and WTO Accessions Serve as Vehicles for Developing- country Policy Reforn?, in Is the World Trade Organization Attractive Enough for Emerging Economies? Critical Essays on the Multilateral Trading System, ed. by Zdenek Drabek. Palgrave Macmilan

- Gürer, Heidemaria., 2005, Forms of Regional Cooperation in Central Asia, in Facing the Terrorist Challenge -Central Asia's Role in Regional and International Co-operation, Study Groups Regional Stability in Central Asia Security Sector Reform, Vienna and Geneva.

- Gleason, Gregory, 2001, "Inter-State Cooperation in Central Asia from the CIS to the Shanghai Forum", Europe-Asia Studies, Vol. 53, No. 7, pp. 1077-1095

- Heydon, Ken., 2008, Asymmetric Integration: The Role of Regionalism, in Developing Countries and the WTO: Policy Approaches, ed. by Gary P. Sampson and W. Bradnee Chambers, United Nation University Press, pp. 229-251.

- Jonson, L., 2004, Vladimir Putin and Central Asia, the Shaping of Russian Foreign Policy, St Martins Press, New York.

- Quigley, John., 2004, Kyrgyzstan's accession to the WTO, EurAsia Bulletin Volume 8 Number $1 \& 2$ Jan-February.

- Karasar, H.A., Kuşkumbayev, K., 2009, Türkistan bütünleşmesi : merkezi Asya'da birlik arayışları, Otuken Press, Istanbul.

- Khatibi, Arastou., 2008, “Kazakhstan's Accession to the WTO: A Quantitive Assessment”, ECIPE Working Paper, no. 02

- $\quad$ Kulchik, Y., Fadin, A., and Sergeev, V., 1999, Central Asia after the Empire, Pluto Press, London and Chicago.

- Michalopoulos, Constantine., 1999, "The Integration of Transition Economies into the World Trading System”, Fifth Dubrovnik Conference on Transition Economies, Dubrovnik Croatia, June 23-25.

- $\quad$ Pomfret, R., 2007, Lessons from Kyrgyzstan's WTO Experience for Kazakhstan, Tajikistan and Uzbekistan, AsiaPacific Trade and Investment Review Vol. 3, No. 2.

- $\quad$ Pomfret, R., 2010, Regional Trading Aggrements and WTO membership: Substitutes or Complements, Is the World Trade Organization Attractive Enough for Emerging Economies? Critical Essays on the Multilateral Trading System, ed. by Zdenek Drabek. Palgrave Macmilan.

- $\quad$ Rahmanova, Anarkan., 2000 , Kyrgyzstan, Country papers on accession to the WTO, Ministry of External Trade and Industry, Kyrgyzstan.

- Tarr, D., 2007, "Russian Accession to the WTO: An Assessment," Eurasian Geography and Economics, Vol. 48, No. 3, May-June, pp. 306-319. 


\title{
Türkiye’deki Gençliğin Şangay İşbirliği Örgütüne Yönelik Tutumuna Pazarlama Perspektifiyle Bakış
}

\author{
Burak Kartal (Celal Bayar Üniversitesi) \\ Çiğdem Sofyalıŏglu (Celal Bayar Üniversitesi)
}

\section{A Look at the Perceptions of the Turkish Youth towards Shangai Cooperation Organization from a Marketing Perspective}

\begin{abstract}
In search of new markets and trade partners after its thrill for European Union has faded, Turkey began to look at its east recently. Having strong ties with many countries in Central Asia due to its cultural and historical ties, Turkey is a bridge between Europe and Asia. Due to its importance and successful historical development, Shanghai Cooperation Organization (SCO) is Turkey's one of few options. In order to build closer trade relations between Turkey and members of the SCO, it's better to know what Turkish people, especially youth know and think about the Organization. This pioneer empirical study, by examining a sample of Turkish university students' knowledge and attitude towards SCO, is a first step of building the relations between the Organization and Turkish people and Turkish youth. Findings indicate that Turkish youth examined have positive attitude towards SCO compared to other alternative integrations and organizations. Besides, they think that a stronger SCO will be in favor of Turkey both economically and politically. Also, gender differences seem to exist like women's tendency towards North American and South American integrations.
\end{abstract}

JEL Codes: M16, F15

\section{Giriş}

Asya ve Avrupa kıtalarının kesişim noktasındaki Türkiye, yüzyıldan daha uzun süredir siyasi ve ekonomik gelişmesini Batıya yönelerek sağlamakta ve 1959 yılından bu yana da şimdiki ismiyle Avrupa Birliği'nin (AB) üyesi olmaya çalışmaktadır. AB ile ilişkisinin son yıllarda durağan bir şekilde devam etmesi, Avrupalı bazı yetkililerin aleyhte açıklamaları ve bu ilişkinin geleceğine yönelik belirsizlikler, Türkiye'nin alternatif entegrasyonlar, teşkilatlar veya işbirlikleri üzerinde durması ve bu konuda araştırmalar yapmasını gerektirmektedir.

Kotler vd. (1997) siyaset ve planlama yapan kamu yetkililerinin de işletme yöneticileri gibi stratejik bir bakış açısıyla dünya pazarlarında ekonomik gelişmeyi en iyi şekilde sağlayacak yolları belirlemesi gerektiğini öne sürmektedir. Bu kapsamda ülkelerin güçlü ve zayıf yanlarını değerlendirerek, en iyi firsatları belirleyerek, rekabetçi küresel politika ve stratejileri tasarlayıp uygulayarak uluslarına uzun dönemli refah sağlayabileceklerini iddia etmektedir.

Her ne kadar ekonomik ve siyasi olarak Türkiye için en önemli ortak hala AB olsa da, Kotler vd. (1997)'nin düşüncesi paralelinde yeni dış politika ve strateji seçeneklerinin de değerlendirilmesi doğru olacaktır. Yakın tarihteki gelişimiyle söz konusu seçenekler içinde en çok öne çıkanlardan birisi Şangay İşbirliği Örgütü (ŞiÖ) olmuştur. ŞîÖ ve Türkiye ilişkisinin her iki kesim için, hatta üçüncü taraflar açısından faydalı olabileceğine ilişkin literatürde çeşitli düşünce ve iddialara (Weitz, 2006; Karla ve Saxena, 2007) rastlanmaktadır. Bu düşüncelerin ne kadar doğru olduğu siyaset bilimcilerin, ekonomistlerin ve uluslararası ilişkiler uzmanlarının alanına girer. Bu çalışmanın hedefi ise pazarlama perspektifiyle böylesi olası bir ilişkide en önemli paydaşlardan birisi olan Türkiye'deki gençliğin, ŞİÖ ve benzeri örgüt ve entegrasyon alternatiflerine bakış açısını araştırmaktır. Buradan elde edilecek sonuçlar hem Türkiye'deki politika belirleyici ve uygulayıcılarına yol gösterecek, hem de ŞiÖ ve üye ülkelerine, gelecekte daha çok ilişkide bulunmaları muhtemel bir ülkedeki gençliğin kendilerine nasıl baktığı konusunda fikir verecektir.

\section{2 Şangay İşbirliği Örgütü ve Türkiye İlişkisine Bir Bakış}

Çin, Kazakistan, Kırgızistan, Rusya ve Tacikistan tarafından 1996 yılında Şangay Beşlisi olarak kurulan ve 2001 yılında Özbekistan'ın da katılımıyla Şangay İşbirliği Örgütü (Shangai Cooperation Organization) adını alan ŞiÖ, zengin doğal kaynaklara (uranyum, altın, doğalgaz, vb.) ve dünya nüfusunun yaklaşık yarısına sahiptir (Çoğal, 2011). Gözlemci statüsündeki Pakistan, Hindistan, İran ve Moğolistan gibi ülkelerin hepsinin veya bir kısmının gelecekte tam üye olmasıyla örgütün dünyadaki ağırlığı daha fazla artacaktır.

ŞİÖ’nün ne tür bir birliktelik olduğu konusunda belirsizlikler olduğu iddia edilse de (Kucera, 2010) en fazla ilerleme göstereceği alanlardan birisi ekonomi ve ticaret olarak gözükmektedir. Interbank, Şangay Kalkınma Fonu ve Şangay İş Kurulu'nun oluşturulması ile Merkezi Asya Ortak Pazarı gibi ekonomik hedefler (Ergenç, 
2006; Akçadağ, 2010), mevcut ve olası üye ülkelerin farklılaşan kaynak ve becerilerinin kaynaşmasını sağladı̆̆ı ölçüde sinerjik bir etkiyle ekonomi ve ticaret alanında önemli gelişmelere neden olacaktır. Bunun dışında ŞïÖ’nün kültür ve güvenlik alanında faaliyetleri bulunmaktadır. ŞïÖ yetkilileri zaman zaman askeri amaçlı bir birlik olmadıklarını söylese de (Hidayet Ekrem, 2011) uçaklarla gerçekleştirilen anti-terör tatbikatlarının işaret ettiği gibi, ŞiÖ bu alanda da gelecekte adım atma potansiyeline sahiptir.

Türkiye'nin Şiö ile daha yakın ilişkiye girmesinin hem kendisine hem de Şiö ve diğer ülkelere faydalı olacağını savunanların öne sürdükleri bazı savlar şunlardır:

Türkiye'nin olası ŞiöÖ üyeliği Türki cumhuriyetlerle ekonomik, sosyal ve kültürel yakınlaşmaya katkıda bulunacaktır. (Çoğal, 2011) Örgütün şimdiki üç üyesi ile Türkiye'nin derin tarihi ve kültürel bağları bulunmaktadır. Ayrıca petrol ve doğalgaz kaynaklarının dünyaya açılmasında önemli bir enerji koridoru olmak isteyen Türkiye (Çoğal, 2011) hem bu amacı doğrultusunda hem de sanayisinde ağırlıklı olarak kullandığı doğalgaza erişimde daha avantajlı bir konumda olacaktır. Dünyada pazarlama açısından en önemli gelişmelerden birisi Çin ve Hindistan gibi ülkelerdeki, gelirleri ve ihtiyaçları hızla artan orta kesimdir. Türkiye ŞiÖ ile yakınlaşarak hem nüfus olarak hem de artan gelir gücüyle büyük bir pazarla daha yakın ilişkiye geçmiş olacaktır.

Türkiye'nin Şi̇Ö’ne olası faydalarıyla ilgili olarak şu hususlar ele alınmaktadır: Öncelikle, kendi içinde hassas dengeler ve ilişkiler ağı içinde gelişimine devam eden örgütün Batı ile ilişkilerinde de benzer bir dengeleme unsuru olarak Türkiye'den yararlanabileceği öne sürülmektedir (Çoğal, 2011; Weitz, 2006). İkinci olarak ŞİÖ içindeki Türki cumhuriyetler için Türkiye daha fazla ekonomik ve sosyal katkı sağlama imkanı bulacak ve çeşitli alanlarda rol model olabilecektir. Son olarak, Türkiye ŞïÖ’nün başta Rusya ve Çin olmak üzere tüm üyeleriyle sorunsuz ve olumlu ilişkiler yürütmeye çalışmakta ve Örgütün finansal ve stratejik açıdan kilit bir müttefiki olma potansiyeline sahip gözükmektedir (Karla ve Saxena, 2007).

Türkiye'nin ŞiÖ’ne gerek gözlemci gerekse tam üye olarak katılmasının zor olduğunu düşünenler (Marat, 2008) olduğu gibi bunun örgüt genelinde olumlu karşılanacağını söyleyenler de (Kucera, 2011; http://energeopolitics.com, 2011) bulunmaktadır.

Türkiye üye olma yolunda çekimser kalsa ve Şiö de Türkiye’nin olası üyelik çabalarına sıcak bakmasa bile iki tarafın da kaçınamayacağı gerçek şudur: ŞiöÖ güçlendiği ve genişlediği sürece sınırlarına komşu olduğu ve Avrupa ile arasında bir köprü gibi uzanan Türkiye ile daha yakın ilişkilere girmek durumundadır.

\section{Türkiye’deki Gençliğin Şangay İşbirliği Örgütü ve Alternatif Entegrasyon ve Teşkilatlara Yönelik Tutumunun İncelenmesine Yönelik Bir Araştırma}

Türkiye, AB’nin yanı sıra başka entegrasyon ve teşkilatlarla işbirliği seçeneklerini değerlendirirken kendi vatandaşlarının ve özellikle gençliğinin düşüncelerini de bilmelidir. Bu araştırma ile bu amaca yönelik ilk adımlardan birisi atılmış olmaktadır. Bu kısımda öncelikle gerçekleştirilen ampirik araştırmanın amacı ve soruları verilip, daha sonra metodolojisi hakkında bilgi verilmektedir. Son olarak bulgular açıklanıp, değerlendirmesi yapılmaktadır.

\subsection{Araştırmanın Amacı ve Soruları}

Geleceğin kamu ve özel sektördeki yöneticilerine ve girişimcilerine yönelik bu ampirik araştırmanın temel soruları şunlardır:

1) Avrupa Birliği ile ilişkiler koptuğu takdirde Türkiye Şangay İşbirliği Örgütü’ne yaklaşmalı mıdır?

2) Avrupa Birliği ile ilişkiler koptuğu takdirde Türkiye İslam Konferansı Teşkilatı üyesi ülkelere yaklaşmalı midır?

3) Avrupa Birliği ile ilişkiler koptuğu takdirde Türkiye Kuzey Amerika’daki entegrasyona (NAFTA) yaklaşmalı midır?

4) Avrupa Birliği ile ilişkiler koptuğu takdirde Türkiye Güney Amerika'daki entegrasyonlara (Mercosur gibi) yaklaşmalı mıdır?

5) Şangay İşbirliği Örgütü'nün güçlenmesi ekonomik olarak Türkiye’nin lehine midir?

6) Şangay İşbirliği Örgütü'nün güçlenmesi siyasi olarak Türkiye'nin lehine midir?

7) Şangay İşbirliği Örgütü hakkındaki bilgi düzeyi ile bu teşkilata yönelik tutum arasında bir ilişki var midir?

8) İncelenen entegrasyon ve teşkilatlara yönelik tutum cinsiyete göre farklılaşmakta mıdır?

9) İncelenen entegrasyon ve teşkilatlara yönelik tutum yaşa göre farklılaşmakta mıdır?

\subsection{Araştırmanın Metodolojisi}

Araştırmada gözatım yöntemi kullanılmış ve anketler yüzyüze uygulanmıştır. Anket 3 bölümden oluşmaktadır. Birinci bölümde yaş ve cinsiyeti belirleyen demografik sorular bulunmaktadır. İkinci bölümde ise cevaplayıcıların incelenen entegrasyon ve teşkilatlara yönelik tutumlarının ölçüldüğü 5'li likert ölçeğinde hazırlanmış 6 ifade yer almaktadır. Bu ifadelerde AB ile ilişkiler koptuğunda ilgili entegrasyon veya teşkilata Türkiye'nin yaklaşması gerekliliği ve Şi̇̈’nün güçlenmesinin ekonomik ve siyasi olarak Türkiye'nin lehine olup olmadığı ölçülmeye çalışılmıştır. Anketin üçüncü bölümünde ise cevaplayıcıların ŞiöÖ hakkındaki bilgisini 
ölçmeye yönelik beş soru bulunmaktadır.

Araştırmada Türkiye'deki gençliğin araştırılan konudaki tutum ve düşünceleri ele alınmaktadır. Ancak söz konusu entegrasyon ve teşkilatlara yönelik bilgi sahibi olmak böylesi bir araştırma için gerekliliktir. Bu tür durumlarda örneği kasıtlı bir şekilde belirlemek gerekebilir (Nakip, 2003:186). Bu nedenle bu konuda eğitim almış olan bir işletme bölümünün mezuniyet aşamasındaki son sınıf öğrencilerine yargısal örnekleme ile tamsayım uygulanmıştır. Eğitim yılı sonunda gerçekleştirilen uygulama ile 146 adet kullanılabilir anket elde edilmiştir. Dolayısıyla bir ihtimalsiz örnekleme yöntemi seçilmesine rağmen araştırmanın işletme bölümü mezunlarına genellenebilirliğinin yüksek olduğu düşünülebilir. Bununla beraber seçilen okulun Ege Bölgesi’nde olması, genel seçimlerdeki farklılığa bağlı olarak Türkiye'nin geneliyle siyasi etkiye açık sorulardaki bulguların değerlendirilmesinde dikkatli olunmasını gerektirmektedir.

Araştırmada verilerin analizinde SPSS 17.0 istatistiksel paket programı kullanılmış ve tanımlayıcı istatistiklerin yanı sıra verilere çeşitli parametrik ve parametrik olmayan testler uygulanmıştır.

\subsection{Araştırma Bulguları ve Değerlendirmesi}

Anketlerde öncelikle veri denetimi gerçekleştirilmiş ve 146 anket analizler için uygun görülmüştür. Örnek hacmi pek çok analiz yöntemi için yeterli büyüklükte olmasına rağmen, çarpıklık ve basıklık değerleriyle grafiksel inceleme sonucu parametrik testler için gereken normallik varsayımı incelenmiştir. Bu incelemeler sonucu analiz edilen değişkenlere göre hem parametrik (t testi) hem de parametrik olmayan (ki-kare) testlerden yararlanılmıştır. Araştırmanın temel bulgu ve değerlendirmeleri şunlardır:

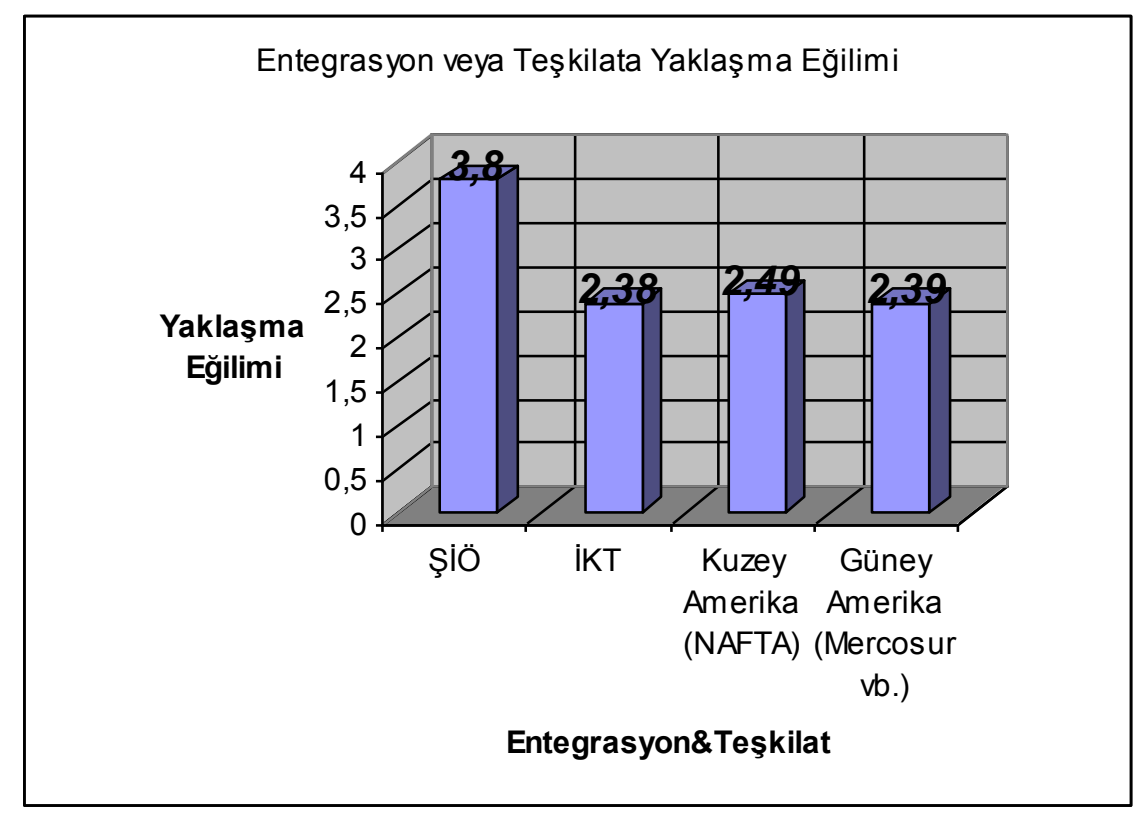

Şekil 1: AB dişındaki teşkilat veya entegrasyonlara yaklaşma eğilimi ortalaması

Araştırmanın en önemli bulgularından birisi, cevaplayıcıların AB'nin alternatifi olarak başlıca ŞïÖ’nü görmesidir. (Şekil 1 ve Tablo 1) AB ile ilişkiler koptuğu takdirde diğer entegrasyon ve teşkilatlara kıyasla ŞİÖ’ne daha fazla yaklaşılması gerektiği düşünülmektedir. $(\overline{\mathrm{X}}=3,8 ; \mathrm{S}=0,98)$ Kuzey Amerika ise ikinci sırada gelmektedir. Gençlerin Amerika ve Kanada ile daha fazla yakınlaşmasına yönelik tercihi $(\bar{X}=2,49 ; S=1,21)$, gerek bu ülkelerin mevcut durumu gerekse tarihi ilişkiler nedeniyle beklenen bir bulgudur. İslam Konferansı Teşkilatı ülkelerine yönelik yakınlaşma tercihinin $(\bar{X}=2,38 ; S=1,27)$ Mercosur gibi entegrasyonlara sahip Güney Amerika ile yaklaşık olarak eşit çıkması ise $(\bar{X}=2,39 ; S=1,17)$ ilk bakışta şaşırtıcı gibi görünse de örnekleme kısmında belirtilen hususa dayalı olarak olası görülebilir. Tablo 1'de görüldüğü gibi İslam Konferansı Teşkilatına yönelik tercihler diğer entegrasyon ve teşkilatlara kıyasla daha fazla kutuplaşma göstermektedir. Araştırmanın Türkiye'nin diğer bölgelerini de kapsayacak biçimde genişletilmesi belki de Türk gençliğinin AB dişındaki teşkilat ve entegrasyonlara yönelik bakış açısı ve tutumlarıyla ilgili elde edilen sonuçlarda bir değişikliğe neden olabilecektir.

ŞİÖ bilgisi ile ŞIÖ’ne yaklaşma eğilimi arasında istatistiksel bir ilişki belirlenememiştir. Benzer şekilde ŞİÖ bilgisi ile ŞiÖ’nün ekonomik veya siyasi olarak Türkiye'nin lehine olacağı görüşü arasında da ilişki gözükmemektedir. Bu durum Şi̇Ö’ne yaklaşımın bilgiden daha çok siyasi eğilim gibi başka faktörlerle ilişkili olabileceğine işaret etmektedir. Ancak Şi̇Ö konusunda daha bilgili olanların Mercosur gibi Güney Amerika'daki entegrasyonlardan daha uzak durma eğilimi gözlenmektedir. (Ki-Kare $p=0,05$ ) ŞïÖ ile ilgili olarak daha bilgili olanların ülkenin doğusundaki ülke ve entegrasyonlarla daha ilgili oldukları, buna karşın coğrafi olarak batıda ve 
oldukça uzak konumdaki Güney Amerika'daki entegrasyonlara daha ilgisiz kaldığı söylenebilir.

\begin{tabular}{|l|c|c|c|c|c|c|c|c|}
\hline Avrupa Birliği ile ilişkiler koparsa söz konusu teşkilat veya entegrasyona yaklaşmalıyız. \\
\hline & $\begin{array}{c}\text { Şangay İşbirliği } \\
\text { Orrgütü }\end{array}$ & \multicolumn{2}{|c|}{$\begin{array}{c}\text { İslam } \\
\text { Konferansı } \\
\text { Teşkilatı Üyeleri }\end{array}$} & \multicolumn{2}{|c|}{$\begin{array}{c}\text { Kuzey Amerika } \\
\text { (NAFTA) }\end{array}$} & \multicolumn{2}{|c|}{$\begin{array}{c}\text { Güney Amerika } \\
\text { (Mercosur vb.) }\end{array}$} \\
\hline & Sıklık & $\%$ & Sıklık & $\%$ & Sıklık & $\%$ & Sıklık & $\%$ \\
\hline $\begin{array}{l}\text { Kesinlikle } \\
\text { Katılmyorum }\end{array}$ & 3 & 2,1 & 47 & 32,2 & 39 & 26,7 & 42 & 28,8 \\
\hline Katılmıyorum & 12 & 8,2 & 38 & 26,0 & 38 & 26,0 & 40 & 27,4 \\
\hline $\begin{array}{l}\text { Ne Katılıyorum } \\
\text { Ne Katılmıorum }\end{array}$ & 33 & 22,6 & 30 & 20,5 & 36 & 24,7 & 34 & 23,3 \\
\hline Katıllyorum & 61 & 41,8 & 20 & 13,7 & 25 & 17,1 & 25 & 17,1 \\
\hline Tamamen Katıllyorum & 37 & 25,3 & 11 & 7,5 & 8 & 5,5 & 5 & 3,4 \\
\hline Toplam & 146 & 100,0 & 146 & 100,0 & 146 & 100,0 & 146 & 100,0 \\
\hline
\end{tabular}

Tablo 1: AB dışındaki teşkilat veya entegrasyonlara yaklaşma ĕ̆ilimi

\begin{tabular}{|l|c|c|c|c|}
\hline \multicolumn{2}{|c|}{ Şangay İşbirliği Örgütü'nün güçlenmesi Türkiye'nin ekonomik / siyasi } \\
olarak lehinedir \\
\hline \multicolumn{2}{|c|}{ Ekonomik } & \multicolumn{2}{c|}{ Siyasi } \\
\hline \multicolumn{2}{|c|}{ Aritmetik Ortalama } & \multicolumn{2}{|c|}{3,62} & \multicolumn{2}{c|}{3,47} \\
\hline & Sıklık & \% & Sıklık & \% \\
\hline Kesinlikle Katılmıorum & 4 & 2,7 & 7 & 4,8 \\
\hline Katılmiyorum & 19 & 13,0 & 20 & 13,7 \\
\hline Ne Katılıyorum Ne Katılmiyorum & 28 & 19,2 & 38 & 26,0 \\
\hline Katılıyorum & 73 & 50,0 & 60 & 41,1 \\
\hline Tamamen Kat1lıyorum & 22 & 15,1 & 21 & 14,4 \\
\hline Toplam & 146 & 100,0 & 146 & 100,0 \\
\hline
\end{tabular}

Tablo 2: Şangay İşbirliği Örgütü ve Türkiye’ye Etkisi

Şi̇Ö’nün güçlenmesi hem ekonomik hem de siyasi açıdan cevaplayıcılar tarafından olumlu karşılanmakta ve Türkiye'nin lehine olacağı düşünülmektedir. Özellikle ekonomik etkisinin daha fazla olacağı düşünülmektedir. Bu durum gençlerin ŞiOÖ ile ticari ilişkilerin geliştirilmesine daha sıcak bakmasına ama siyasi açıdan henüz ŞïÖ hakkında tereddüt etmesine ve AB konusunda hala umutlu olmasına bağlanabilir. ŞïÖ’nün Türkiye ile ilişkileri geliştirmesinin iki tarafa da faydalı olabileceğine giriş kısmında değinilmişti. Buradaki sonuç ise cevaplayıcıların da benzer bir algıya sahip olduğunu ve özellikle ekonomik açıdan Türkiye'ye katkısının fazla olacağını düşündüklerini göstermektedir. Ekonomik etki kadar olmasa da siyasi olarak etkinin olumlu olacağını düşünenlerin sayısı da fazladır. Bu durum, cevaplayıcıların geçmişte çekinilen soğuk savaş dönemindeki Sovyet Rusya ve insan hakları sorunlarına sahip Çin algısından büyük ölçüde arınmış olduklarına işaret etmektedir.

\begin{tabular}{|c|c|c|c|c|c|}
\hline \multicolumn{7}{|c|}{ Bă̆ımsız örneklemler için t- testi } \\
\hline & $\mathbf{2}$ Levene's Test & \multicolumn{2}{|c|}{} \\
\hline & $\mathbf{F}$ & Anlamlılık & $\mathbf{t}$ & $\mathbf{p}$ & $\begin{array}{c}\text { Fark } \\
\text { (Erkek-Bayan) }\end{array}$ \\
\hline Kuzey Amerika (NAFTA) & 1,332 & 0,25 & $-3,476$ & 0,001 & $-0,671$ \\
\hline Güney Amerika (Mercosur vb.) & 0,156 & 0,694 & $-2,073$ & 0,04 & $-0,397$ \\
\hline $\begin{array}{c}\text { ŞİÖ’nün güçlenmesi Türkiye'nin } \\
\text { ekonomik olarak lehinedir }\end{array}$ & 7,076 & 0,009 & 2,04 & 0,043 & 0,329 \\
\hline
\end{tabular}

Tablo 3: Cinsiyete Dayalı Yaklaşım Farklılıkları

Araştırmada incelenen entegrasyon ve teşkilatlara yönelik tercihin cinsiyete göre farklılaşıp farklılaşmadığ incelendiğinde iki husus öne çıkmaktadır. Öncelikle bayanların Kuzey Amerika $\left(\mathrm{p}_{\mathrm{t}}=0,001\right)$ ve Güney Amerika'daki entegrasyonlara $\left(\mathrm{p}_{\mathrm{t}}=0,04\right)$ erkeklere kıyasla daha sıcak baktığı tespit edilmiştir. Buna karşılık erkekler Şı̈Ö’nün güçlenmesinin ekonomik olarak Türkiye'ye olumlu etkisinin daha fazla olacağını $\left(p_{t}=0,043\right)$ düşünmekteler. Erkeklerin bir kısmının bu örgütün üyesi ülkelerde çalışma veya onlarla ticari ilişkiye girme düşüncesinde olması buna gerekçe olarak sunulabilir. Cinsiyete dayalı farklılaşmalar birlikte değerlendirildiğinde, bayanların Doğu ile ilgili kaygıları olduğu ve erkeklere kıyasla Batıya yönelme isteğinde 
bulundukları anlaşılmaktadır. Bu bakımdan olası bir işbirliğinde bayanların hangi konularda kaygı duyduğu tespit edilip, giderilmeye çalışılmalıdır.

Yaşa dayalı istatistiksel olarak anlamlı bir farklılık gözlenmemiştir. Örneklem grubunda yaş farkının az olması bunun muhtemel sebebi olabilir. Bununla beraber yaş arttıkça Şiốnün güçlenmesinin Türkiye'nin ekonomik ve siyasi olarak lehine olacağı düşüncesinin zayıfladığı gözlenmektedir.

\section{Sonuç}

Türkiye'nin $\mathrm{AB}$ ile uzun süreli yolculuğu her iki tarafa da önemli faydalar sağlamış olsa da giderek zorlaşmakta ve özellikle Avrupa'daki halkların geçmişten gelen önyargılarına takılmaktadır. Son yıllarda izlediği barışçıl ve dışa açık politika paralelinde Türkiye dış ekonomik ilişkilerinde de çeşitlilik aramaktadır. Bu arayış ülkenin dış ticaret verilerinde ve yöneticilerinin sözlerinde kendisini göstermektedir.

$\mathrm{AB}$ dışında dünyadaki başlıca entegrasyon ve örgüt seçenekleri arasında Türkiye için yakınlaşma olasılığı bulunanlar birkaç tanedir. Bunlar içinde dünyayı birden fazla kutuplu hale getirme potansiyeli olan tek örgüt de Şiö olarak göze çarpmaktadır.

ŞiÖ, NAFTA ve Mercosur gibi söz konusu entegrasyon ve örgütlere yönelik Türkiye'deki gençliğin tutumlarını ölçmeyi amaçlayan bu araştırmada ilginç bulgular elde edilmiş̧ir.

İlk olarak cevaplayıcılar ŞiÖ'ne daha fazla yaklaşılmasına sıcak bakmaktadır. İkinci sırada sıcak bakılan ise NAFTA'dır. Güney Amerika ve İslam Konferansı Teşkilatı ise bunları takip etmektedir. Ayrıca, ŞiÖ'nün güçlenmesi hem ekonomik hem de siyasi açıdan cevaplayıcılar tarafından olumlu karşılanmakta ve Türkiye'nin lehine olacağı düşünülmektedir. Şiö'nün özellikle ekonomik etkisinin daha fazla olacağı düşünülmektedir. Daha güçlü bir ŞïÖ’nün hem ekonomik hem de siyasi açıdan avantajları olacağını düşünmeleri, cevaplayıcıların geçmişte çekinilen soğuk savaş dönemindeki Sovyet Rusya ve insan hakları sorunlarına sahip Çin algısına artık sahip olmadıklarını ve ŞïÖ'nün gençlerce benimsenmesinde fazla sorun yaşanmayacağını göstermektedir.

Cevaplayıcıların Şiö hakkındaki bilgi düzeyinin artmasının tutumlarına etkisi incelendiğinde iki değişken arasında anlamlı bir ilişki bulunamamıştır. Benzer şekilde ŞïÖ bilgisi ile Şiö’nün ekonomik veya siyasi olarak Türkiye'nin lehine olacağı görüşü arasında da ilişki gözükmemektedir. Bu durum ŞiÖ'ne yaklaşımın bilgiden daha çok siyasi eğilim gibi başka faktörlerle ilişkili olabileceğine işaret etmektedir.

Cinsiyete dayalı farklılaşmalar incelendiğinde bayanların erkeklere kıyasla Batıya daha fazla ilgi duyduğu ve ŞïÖ'den ekonomik beklentilerinin erkekler kadar yüksek olmadığı tespit edilmiştir. Dolayısıyla ŞiÖ ile olası bir işbirliğinde bayanların kaygı duyduğu hususlar tespit edilip, giderilmeye çalışılmalıdır.

Sonuç olarak bütün bu bulgular, Türkiye'de dış politika konusunda karar verici ve uygulayıcılarına yol gösterebileceği gibi bu ülkelerde yatırım yapmayı düşünen işadamlarına da yardımcı olabilir. En azından bu örgüt ve üyelerine yönelik tespit edilen olumlu yaklaşım, yatırım kararlarını kolaylaştırabilir. Diğer yandan Şiö ve üye ülkeleri, gelecekte daha çok ilişkide bulunmaları muhtemel bir ülkedeki gençliğin kendilerine nasıl baktığı konusunda fikir sahibi olmaktadır.

Araştırmanın örnek hacmi az olmamasına karşın, daha büyük örneklemlerle gerçekleştirilmesi halinde başka ilişkilerin de tespit edilmesi olasıdır. Bunun yanında Türkiye'nin farklı bölgelerinde ve daha geniş bir yaş grubunda gerçekleştirilmesi de bu iki değişkene dayalı farklılıkları ortaya çıkaracaktır. Hassas bir konu olmasına karşın siyasi eğilimlerin etkisinin gelecek araştırmalarda ele alınması da düşünülebilir.

\section{Kaynakça}

- Akçadağ, Emine, 2010. “Şanghay İşbirliği Örgütü: Rusya-Çin Ortaklığı mı, Rekabeti mi?”, $\mathrm{http} / / / \mathrm{www}$.bilgesam.org/tr/index.php?option=com_content\&view=article\&id=640:anghay-birlii-oerguetuerusya-cin-ortakl-m-rekabeti-mi\&catid=122:analizler-guvenlik\&Itemid=147.

- Çoğal, Nejat, 2011. "Çok Kutuplu Dünya Projesi: Şangay İşbirliği Örgütü”, http://www.nejatcogal.com.

- Ergenç, Sedat, 2006. "Şangay İşbirliği Teşkilatı AB’ye Alternatif Olabilir mi?", http://sedatergenc.blogcu.com/sangay-isbirligi-teskilati-ab-ye-alternatif-olabilir-mi/1819145.

- Hidayet Ekrem, Nuraniye, 2011. http://www.turksam.org/tr/a614.html.

- http://energeopolitics.com/2011/06/15/the-turkey-domino-energy-geopolitics/, The Turkey Domino.

- Kalra, Prajakti and Siddharth S. Saxena, 2007. Shanghai Cooperation Organisation And Prospects Of Development In The Eurasia Region Turkish Policy Quarterly, Vol. 6, No. 2, pp.95-99.

- Kotler, Philip, Somkid Jatusripitak and Suvit Maesincee, 1997. The Marketing Of Nations: A Strategic Approach To Building National Wealth, The Free Press, New York, USA.

- Kucera, Joshua, 2010. "Pakistan and the SCO", http://www.eurasianet.org/node/33003.

- Kucera, Joshua, 2011. "Turkey, China and the Shangai Cooperation Organization", http://www.eurasianet.org/node/63650. 
- Marat, Erica, 2008. "The SCO And Foreign Powers In Central Asia: Sino-Russian Differences", http://www.cacianalyst.org/?q=node/4867.

- $\quad$ Nakip, Mahir, 2003. Pazarlama Araştırmaları, Teknikler ve Uygulamalar, Seçkin Yayınevi, Ankara.

- Weitz, Richard, 2006. “Towards A New Turkey-Nato Partnership In Central Asia”, Turkish Policy Quarterly, Vol. 5, No. 2. 


\title{
Orta Asya ve Güney Kafkasya'daki Türk Cumhuriyetlerinin Küresel Dünyaya Entegrasyonunun Ekonomi Politiği
}

\author{
Özlem Arzu Azer (Istanbul University, Turkey)
}

\section{Political and Economic Integration of the Central Asian and South Caucasian Turkish Republics into the Global World}

\begin{abstract}
With the dissolution of Soviet Union, former Soviet Republics' central planned economy transformed into free market economy and structural reforms were made as parallel of this development. These former socialist countries have some diffficulties to adopt capitalism due to absence of some fundamental feautures of capitalism and inheritance of Soviet Union.

Ending big threat of communism, the jeo-strategical importance of the region increased for the West because these countries own the oil and gas resources besides they are starting point or transit country of the energy pipelines. However, these transition countries could not develop economically and poverty became the major problem for most of Central Asian and South Caucasian Turkic Republics. As economic problems lead weakness of governance, ethnical conflicts and border conflicts threat these new independent countries. The region seems in the center of war for power due to rich natural resources and pipelines as well as the connection point to Afghanistan and being the exit to the Black Sea.

This paper seeks economic situations of Central Asian and South Caucasian Turkic Republics which jeostrategical importance increased due to natural resources and geographic location during Post Cold-War era. This work is based on statistical data provided by United Nations Commodity Trade Statistics Database (COMTRADE), United Nations Conference on Trade and Development (UNCTAD) and International Monetary Fund (IMF), covering the period of 1990-2008 and contains Azerbaijan, Kyrgyzstan, Kazakhstan, Turkmenistan, Uzbekistan, Tajikistan.
\end{abstract}

JEL Codes: D74, F59, P20

\section{Sovyetler Birliğii’nin Çöküşü ve Bağımsız Devletler Topluluğu'nun Oluşumu}

Sovyetler Birliği'nin dağılması anlamına gelen 15 Bağımsız Devletler Topluluğu'nun kurulması, 8 Aralık 1991 tarihinde 'Belovesjk Anlaşması' ile gerçekleşmiştir. Belovesjk Anlaşması, SSCB'nin dağılması ve Bağımsız Devletler Toğluluğu'nun (BDT) kurucu anlaşması olmasıyla birlikte ekonomi ve politika tarihinde bir dönemin sonu anlamına gelmektedir. Soğuk Savaş'ın sona ermesiyle, batılı uluslarüstü kurumların varlık nedenleri sorgulanırken, bu kurumların yeniden yapılandırılma gerekliliği de zuhur etmiş̧tir. İki kutuplu denge, yerini tek kutuplu bir dünyaya bırakırken, ilerleyen zamanlarda Rusya'nın dünya dengelerinde yeni bir rol alma çabaları, Kafkasya topraklarının güç savaşlarının odağında olmasına sebep olmuştur. Dünya tarihinde yeni bir sayfa açan 11 Eylül terör saldırısı ve artan kimlik kökenli iç çatışmalar paradigma değişikliğine sebep olurken, ABD ve uluslarüstü kurumlar 'teröre karşı küresel savaş' şemsiyesi altında yeni stratejiler oluşturmuş ve bu stratejiler kapsamında Kafkasya’nın jeostratejik önemi artmıştır.

\section{Soğuk Savaş Sonrasında NATO’nun Dönüşümü ve Ajandadaki Kafkasya}

Soğuk Savaş'ın bitişiyle komünizm tehdidinin sona ermesi sonucunda fonksiyonunu yitiren NATO sorgulanmaya başlamış, ancak artan etnik ve dini kökenli iç çatışmalar/savaşlar ve 2001 yılında ABD'de yaşanan terör saldırısı sonucunda yeni tehditler odağında yeniden yapılandırılmıştır. 1999 Washington Zirvesi'nde, halen yürürlükte olan Stratejik Konsept kabul edilmiş ve NATO'nun hareket alanını genişletilmiştir. NATO'ya küresel düzeyde güvenlik misyonu yüklenmesini sağlayan Stratejik Konsept'in esaslarına göre, 5.maddenin içeriği NATO'nun alan dışı operasyon yapmasına imkan veren yasal dayanak kazanmıştır.

SSCB'nin çöküşüyle NATO'nun tehdit algılamalarında değişiklik oluşmuş, yeni dönemin tehditleri ise savaşın değişen formu ekseninde artan kimlik çıkış noktalı iç çatı̧̧malar ve artan milliyetçilik akımları başta olmak üzere göç, uyuşturucu ve silah ticareti, küresel terörizm, kitle imha silahlarının yayılması olmuştur. Bir başka tehdit algılaması ise, batı değerlerini benimsememiş, demokrasinin yerleşmediği devletlerdir. Bu çerçevede, Güvenlik Konseyi tarafindan Batı değerlerini benimsememiş toplumlar ve devletlere yapılacak müdahalelerde ortak hareket mümkündür (Arr,1996:s.185). Böylece, NATO yeni bir savunma konseptiyle yapısal dönüşümünü gerçekleştirmiş̧tir. NATO’nun yeni tehdit algılamalarını; uyuşturucu ve insan kaçakçılığı, organize suçlar, uluslararası terörizmle mücadele, etnik ve bölgesel çatışmalar, göç, kitle imha silahlarının yayılması oluşturmaktadır. 
NATO’ya yeni bir anlam yükleyerek yapısal dönüşümünü tamamlaması için iç çatışmalarda yüklendiği görevlerden ziyade 11 Eylül 2001 tarihinde ABD'de Dünya Ticaret Merkezi ve Pentagon'a yapılan terör saldırıları rol oynamıştır. 11/9 terör saldırıları, dünya'da hem iktisadi anlamda, hem politik anlamda dönüm noktası olmuştur. Dünyanın ekonomik ve politik dönüm noktası sayılan 11/9 sonrasında Afganistan'a yapılan müdahale sayesinde ABD, eski Sovyet sahasındaki ülkelerle askeri bağlar kurmuş ve bu ülkelerde konuşlandırılan askeri üsler sayesinde güvenlik zemininde gelecekte de devam edecek bir ilişki inşaa etmiştir (Khagani,2007:224). Bölgesel stratejiler ve güvenlik konuları kapsamında, bölgede askeri üs sayısı hıla artmıştır. NATO ile gelişen ilişkiler paralelinde, askeri üslerin konuşlanmasıyla NATO'nun ve ABD'nin etkinlik alanının da Karadeniz Bölgesinden Kafkasya'ya, Kafkasya'dan da Afganistan'a uzanan bir coğrafyaya yayılması sözkonusudur. Buna paralel, Rusya'da 25 askeri üs (Ermenistan, Azerbeycan, Belarus, Gürcistan, Kazakistan,Kırgızistan, Ukrayna, Tacikistan, Moldovya) ile eski Sovyet alanında etkisini sürdürmektedir (Lackowski,2007:53). Aslında bölgede hem Rusya, hem ABD-NATO askeri üslerinin inşaası 21.yüzyıldaki güç savaşının göstergesidir.

Batı'nın enerji güvenliği bağlamında, bölgedeki yeni bağımsız devletlerin Batı ittifakına dahil edilmesi gündeme gelmiştir. NATO, İttifak'ın genişletilerek yeni tehdit algılamaları paralelinde ortak hareket etme kabiliyetinin artması için bazı programlar geliştirmiştir.

Bunlardan en önemli olanlardan bir tanesi, NATO üyesi olmayan eski sosyalist ülkelerle askeri işbirliğini amaçlayan, barış koruma operasyonları, kriz yönetimi, hava savunması, lojistik, istihbarat gibi faaliyet alanlarını kapsayan 'Barış için Ortaklık' oluşumudur (Peksarı,2007: s.56). 'Barış İçin Ortaklık' (Partnership for Peace-PfP) projesi 10-11 Ocak 1994 Brüksel Zirvesi’nde işlemeye başlamış ve bu bağlamda NATO’ya uyum çerçevesinde, Kafkasya, Orta ve Doğu Avrupa'daki eski sosyalist ülkelere askeri eğitimler verilerek askeri ve güvenlik birliği sağlanmakta, NATO stratejik ilkeleri ve temel değerleri benimsetilmektedir. Bu programa dahil olan NATO üyesi olmayan ülkelerden Hazar Havzası ve Kafkasya Bölgesi'ndekiler, yani eski Sovyet Cumhuriyetleri Kazakistan, Gürcistan, Kırgızistan, Tacikistan, Ermenistan, Ukrayna, Azerbeycan, Beyaz Rusya, Özbekistan, Moldova, Rusya, Türkmenistan'dır.

\section{Kaos Ortamında Kafkasya'nın Artan Jeostratejik Önemi}

Soğuk Savaş döneminde Kafkasya Bölgesi'nin, SSCB’nin hakimiyetinde olması, Batı'nın bu bölgede bir strateji geliştirmesinin önünü kesmiştir. SSCB'nin çöküşü ve yeni bağımsız devletler kurulmasıyla yeni bir dönem başlamış ve böylece Batı'nın Bölgeye bakışı da değişmiştir.

Kafkasya Bölgesi'nin, petrol ve doğalgaz kaynaklarına yakınlığı ve enerji kanallarının can damarında olması nedeniyle jeostratejik önemi büyük olup SSCB'nin dağılması sonrasında Batı'nın hakimiyet hedefinde hızla üst sıralara gelmiştir.

\begin{tabular}{|c|c|c|c|c|c|}
\hline & $\begin{array}{c}\text { Görünür } \\
\text { Petrol } \\
\text { Rezervleri } \\
\text { (milyar,varil) }\end{array}$ & $\begin{array}{c}\text { Dünyadaki } \\
\text { Payı \% }\end{array}$ & $\begin{array}{l}\text { Petrol Üretimi } \\
\text { (milyon,ton) }\end{array}$ & $\begin{array}{c}2008 \text { yılına } \\
\text { göre } \\
\text { değişim, } \\
2009 \\
\end{array}$ & $\begin{array}{c}2009 \text { Yılında } \\
\text { Dünyadaki } \\
\text { Payı \% }\end{array}$ \\
\hline AB & 6,3 & $0,5 \%$ & 50,6 & $-6,1 \%$ & $2,6 \%$ \\
\hline OECD & 90,8 & $6,8 \%$ & 860,1 & $-0,2 \%$ & $22,5 \%$ \\
\hline OPEC & 1029,4 & $77,2 \%$ & 1574,4 & $-7,3 \%$ & $41,2 \%$ \\
\hline Non-OPEC & 180,9 & $13,6 \%$ & 1602,0 & $0,1 \%$ & $41,9 \%$ \\
\hline $\begin{array}{c}\text { Eski } \\
\text { Sovyetler } \\
\text { Birliği } \\
\end{array}$ & 122,9 & $9,2 \%$ & 643,9 & $3,0 \%$ & $16,9 \%$ \\
\hline \multirow[t]{2}{*}{$\begin{array}{l}\text { Toplam } \\
\text { Dünya }\end{array}$} & 1331,1 & $100,0 \%$ & 3820,5 & $-2,6 \%$ & $100,0 \%$ \\
\hline & $\begin{array}{c}\text { Görünür Gaz } \\
\text { Rezervleri } \\
\text { (trilyon, kubik } \\
\text { metre) }\end{array}$ & $\begin{array}{c}2009 \\
\text { Dünyadaki } \\
\text { Payı \% }\end{array}$ & $\begin{array}{c}\text { Gaz Üretimi } \\
\text { (milyar, kubik } \\
\text { metre) }\end{array}$ & $\begin{array}{l}2008 \text { yılına } \\
\text { göre } \\
\text { değişim, } \\
2009\end{array}$ & $\begin{array}{c}2009 \text { Yılında } \\
\text { Dünyadaki } \\
\text { Payı \% }\end{array}$ \\
\hline $\mathbf{A B}$ & 2,42 & $1,3 \%$ & 171,2 & $-9,3 \%$ & $5,7 \%$ \\
\hline OECD & 16,18 & $8,6 \%$ & 1127,2 & $0,4 \%$ & $37,9 \%$ \\
\hline $\begin{array}{c}\text { Eski } \\
\text { Sovyetler } \\
\text { Birliği }\end{array}$ & 58,53 & $84,2 \%$ & 694,9 & $-12,2 \%$ & $23,2 \%$ \\
\hline Diğer EMEs & & & 1164,9 & $2,3 \%$ & $38,9 \%$ \\
\hline $\begin{array}{l}\text { Toplam } \\
\text { Dünya }\end{array}$ & 187,49 & $100,0 \%$ & 2987 & $-2,1 \%$ & $100,0 \%$ \\
\hline
\end{tabular}

Tablo 1: 2009 yll sonunda Kafkasya'daki Görünür Rezervler. Kaynak: BP Statistical Review of World Energy, June 2010, www.bp.com 
Batı gözünde, Hazar Havzası ve Kafkasya’nın jeopolitik öneminin artışının başlıca sebebi enerji güvenliğidir. Doğalgaz ve petrol kaynaklarına sahip bölge, aynı zamanda Avrupa'ya taşınan enerji kanalları açısından da güvenlik konularının başında gelmektedir. Doğalgaz kaynakları zengin olan bölgenin hem 'enerji kaynağı,' hem 'enerji kanalı' olma özeliği onu vazgeçilmez kılarken, gelecekte de Batı'nın ilgi alanında olacağı aşikardır.

Enerji kaynakları analizinde, aşağıdaki tablodan da görüleceği gibi, 2009 yılı sonunda bölgenin petrol üretiminde dünyadaki payı \% 16,9 iken doğalgaz üretimi \% 23,2 olarak gerçekleşmiştir. Bölgede petrol üretimi avantajına sahip ülkeler başta Kazakistan olmak üzere sırasıyla Azerbeycan, Türkmenistan ve Özbekistan iken doğalgaz üretimi açısından bu avantaja Türkmenistan ve Kazakistan sahiptir. Enerji üretiminde Ortadoğu'ya alternatif oluşturması ve enerji hatlarının geçiş yolu olması, Soğuk Savaş sonrası koşullarında bölgeye Batı ilgisinin artmasını açıklamaktadır.

Dünya'daki enerji tüketim dağılımına bakıldığında, halen başta petrol (2009:\%35) olmak üzere, kömür (2009:\%29) ve doğalgaz kaynaklarının (2009:\%24) en büyük paya sahip oldukları görülmektedir.

SSCB'nin çöküşü sonrasında yeni Karadeniz kıyı ülkelerinden olan Gürcistan'ın, petrol ve doğalgaz kaynaklarına sahip olmadığı halde Hazar petrol ve doğalgaz kaynaklarının transit noktası olması nedeniyle jeostratejik önemi artmıştır. Bakü-Supsa petrol boru hattı; Bakü-Tiflis-Ceyhan petrol boru hattı ve Bakü-TiflisErzurum doğalgaz boru hatlarının geçiş noktasında olması (Yevseyev) yanında yeni Karadeniz kıyı devleti olması da jeostratejik öneminin artmasına yol açmıştır. Bölgede çeşitli boru hattı projeleri geliştirilmektedir. Gürcistan'ın bir yandan transit ülke olmasından dolayı önemi artarken, diğer yandan Güney Osetya ve Abhazya ile yaşadığı sorunlar gündeminini meşgul etmektedir.

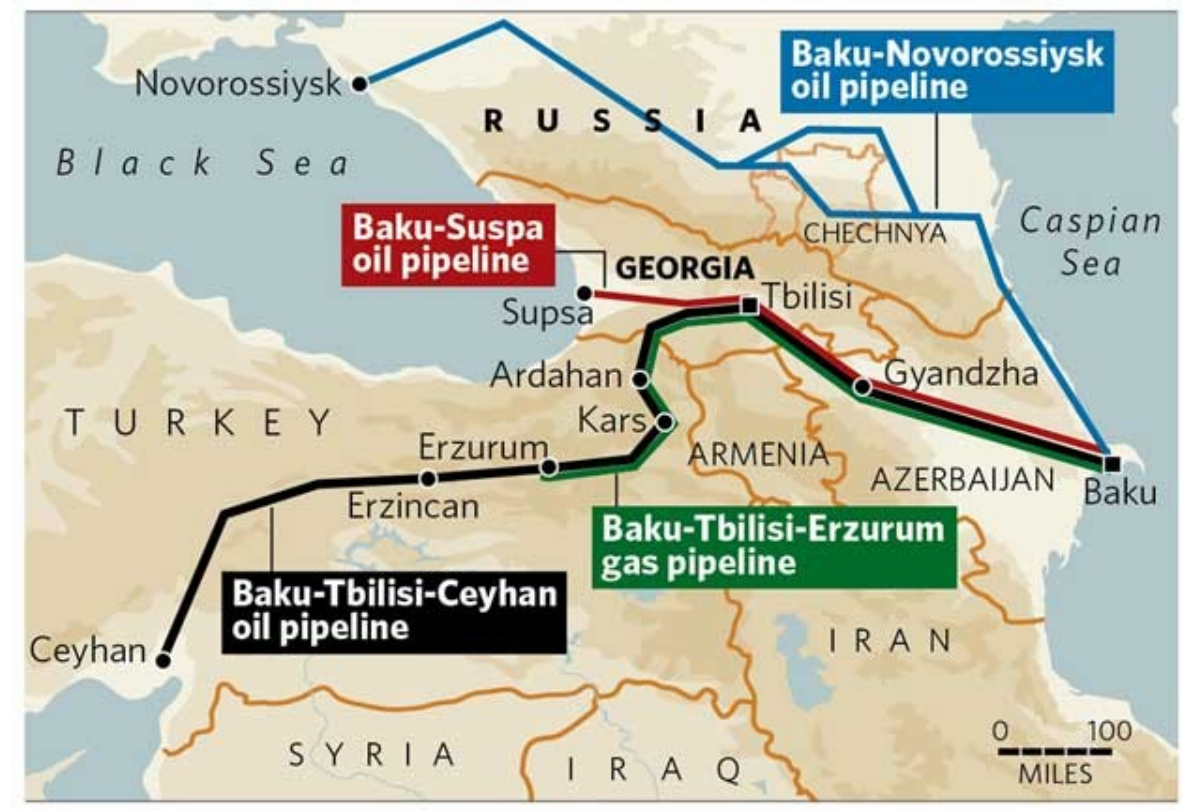

Şekil 1: Hazar Bölgesi Doğalgaz Boruhatları Haritası. Kaynak: European Dialogue.

Batı açısından enerji güvenliği bakımından Kafkasya özel bir öneme sahipken, Rusya açısından da Soğuk Savaş sonrası dönemde yeni bir güç dengesi oluşturma politikasının bir parçası ve daha da önemlisi güvenlik stratejileri kapsamında Batı güdümünde Kafkasya'nın şekillenmesi düşünülemez. Soğuk Savaş sonrasında, Rusya, eski Sovyet Cumhuriyetlerinden oluşan BDT ile yeni bir askeri ve güvenlik sorunsalıyla karşı karşıya kalmıştır (Garnett, 1997a). Bu yeni güvenlik sorunsalını oluşturan temel konular ise başta yeni ulusların ve yeni ulusal orduların oluşması olmak üzere, çatışmaların ve istikrarsızlığın yayılması, bu topraklardaki dışsal hegemonik isteklerdir (Garnett, 1997b).

Bölge'nin petrol ve doğalgaz kaynaklarına sahip olması sebebiyle, hegemonya savaşının sahasında olmasından dolayı Kafkasya'daki ülkelerin etnik kökenli çatışmaların ve sınır çatışmalarının ilerde de gündemde olacağı, özerk ve bağımsız yeni devletlerin oluşma ihtimalinin yüksek oluşu ve bu kaotik ortamda uluslar-üstü kurumlar tarafından siyasi ve ekonomik olarak yönlendirileceği düşünülmektedir.

Eski Rusya Başbakanı Yevgeniy Primakov, eski Sovyet Cumhuriyetlerinin istikrara kavuşmasına Rusya'nın katılımını ve Rusya ve BDT’nun yakınlaşmasını engellemek adına ‘bir dizi Batılı ülke yöneticisinin' çabaladığı yönünde bir analizi bulunmaktadır (Primakov, 2007:s.150).

İç çatışmalar ve sınır savaşları Bölgede istikrarsızlık yaratırken, bu durum NATO'nun üyelik hususunda çekimser davranmasına yol açmakta, bıçağın öteki yüzümde ise bazı Sivil Toplum Kuruluşları'nın desteğiyle yönetim değişikliği için eylem başlatabilecek kadar zayıf halkalar yaratmaktadır. Bu tür eylemlerin örnekleri, Doğu Avrupa ve Kafkasya'da görülmüştür. Kafkasya Bölgesi, Soğuk Savaş sonrasında iktidar değişikliği ile 
sonuçlanan bazı renkli devrimlere sahne olmuştur: Gürcistan (Kasım 2003/Gül Devrimi), Ukrayna (Kasım 2004/Turuncu Devrim), Kirgizistan (Mart 2005/Lale Devrimi).

$\mathrm{Bu}$ renkli devrimlerinde gösterdiği gibi, Hazar Havzası ve Kafkasya gerek sahip olduğu petrol ve doğalgaz kaynakları ile, gerek boru hatlarının başladığı/geçtiği yer olmasıyla, gerek Ortadoğu’ya uzanan coğrafyasıyla ve gerek yeni kıyı ülkelerinin Karadeniz’e çıkışıyla, 21.yüzyılda güç savaşlarının tam ortasında yer almaktadır. Bu güç savaşlarının yansımaları, kimi zaman sivil toplum kuruluşlarının örgütlediği isyanlarda, yönetim değişikliklerinde, kimi zaman askeri üslerin konuşlandığ ülkelerde artan iç karışıklıklar ve sınır çatışmalarıyla görülmektedir.

\section{Orta Asya Cumhuriyetlerine Makro Ekonomik Bakış}

Soğuk Savaş sonrasında jeostratejik önemi artan Hazar Havzası ve Kafkasya Bölgesi’nde, artan bu öneme paralel ekonomik gelişmeler yaşanmamış, yoksulluk çoğu Bölge ülkesinde gündemin başında yer almıştır.

Yaşanılan iç çatışmalar yanısıra sınır çatışmaları, bu ülkelerde ekonomik anlamda zayıflamaya yol açmış, böylesine önemi artan bir bölgede 'istikrarsızlık' hegemonik güçler için bölgeye açılan kapının anahtarı olmuştur.

Bölgedeki istikrarsızlık, sadece iç çatışmaların yol açtığı politik istikrarsızlığı kapsamayıp, aynı zamanda gelir dağılımı dengesizliğinden kaynaklanan ekonomik istikrarsızlığı da kapsamaktadır. Bu eski sosyalist geçiş ekonomilerinde, demokrasinin yerleşmesinin ve kapitalist piyasa sistemine uyumdan kaynaklanan sıkıntılar yanında altyapısal yetersizlikleri nedeniyle küresel ticaret'e entegrasyon sorunları yaşanmaktadır.

BM ticaret verilerine göre; Güney Kafkasya ve Orta Asya Türk Cumhuriyetleri’nin dünya mal ticaretindeki payı 2000 yılından beri çok fazla değişiklik gösterememiş ve 2010 yılında toplam ticaret haddi, dünya ticaretinin \% 0,47'si olarak gerçekleşmiştir. Bu durum, dünya ticaretine entegre olamadıklarını göstermektedir.

\begin{tabular}{|c|c|c|c|c|c|c|c|c|}
\hline & \multicolumn{4}{|c|}{2000} & \multicolumn{4}{|c|}{2010} \\
\hline milyon, USD & İthalat & \multicolumn{3}{|c|}{ İhracat } & İthalat & \multicolumn{3}{|c|}{ İhracat } \\
\hline Dünya & 6530032 & & 6526644 & -3388 & 15020635 & \multicolumn{3}{|c|}{$14879177-141458$} \\
\hline Azerbeycan & 1172 & & 1745 & 573 & 6599 & & 21325 & 14726 \\
\hline Kazakistan & 5040 & & 8812 & 3772 & 24024 & & 57244 & 33220 \\
\hline Kirgizistan & 558 & & 511 & -47 & 3228 & & 1489 & -1739 \\
\hline Tacikistan & 675 & & 784 & 109 & 4900 & & 2306 & -2594 \\
\hline Özbekistan & 2697 & & 2817 & 120 & 8386 & & 11587 & 3201 \\
\hline \multirow[t]{2}{*}{ Türkmenistan } & $\mathrm{v} / \mathrm{y}$ & & $\mathrm{v} / \mathrm{y}$ & & $\mathrm{v} / \mathrm{y}$ & & $\mathrm{v} / \mathrm{y}$ & \\
\hline & 10142 & $0,16 \%$ & 14669 & $0,22 \%$ & 47137 & $0,31 \%$ & 93951 & $0,63 \%$ \\
\hline
\end{tabular}

Tablo 2: Güney Kafkasya ve Orta Asya daki Türk Cumhuriyetlerinin Dünya Mal Ticaretindeki Yeri. Kaynak: BM Uluslar arası Ticaret verilerinden yararlanarak hazırlanmıştır.

Dünya mal ticaretinde sözkonusu ülkeler analiz edildiğinde;

Azerbeycan'ın 2010 yılında mal ihracatının \% 87'sinin petrol ve petrol ürünleri olduğu ve ihracatlarının yarısını İtalya, Fransa ve İsrail'e yaptığı görülmektedir.

Kazakistan'ın 2010 yılında mal ihracatının \% 65'ini ham petrol oluştururken, petrol ürünleri hesaba alındığında bu oran \% 71'e çıkmaktadır, ihracatının \% 42,2'sini Çin, İtalya ve Fransa'ya yapmaktadır.

Kırgızistan'ın 2010 yılında mal ihracatının \% 45'inin altından olduğu ve ağırlıklı olarak İsviçre, Birleşik Arap Emirlikleri ve Rusya Federasyonu'na ihrcat yaptığı görülmektedir. Bu değerlendirme yapılırken dikkate alınması gereken bir diğer nokta, bu ülkelerin ihracatlarının dünya mal ticaretinde paylarının yok denecek kadar az olmalarıdır, en yüksek ihracat rakamı USD 57.244 milyon ile Kazakistan (\%0,38), daha sonra da USD 21.325 milyon ile Azerbeycan'a $(\% 0,14)$ aittir. Dünya mal ticaretindeki yerleri analiz edildiğinde, dünya ticaretiyle entegre olamadıkları, ihracatlarının ise sahip oldukları doğal kaynaklardan oluştuğu görülmektedir. Bu durum, bu ülkelerin sadece dünya ticaretine entegre olamadığını değil, aynı zamanda gelişemediğini de göstermektedir.

Bununla birlikte, doğal kaynaklara sahip olan ülkeler yabancı yatırım için temel hedef olduğundan, bu tür bölgelerde yabancı yatırım çekmek için yapısal reformlar yapılması büyümeyle eşdeğer tutulmaktadır.

Bölgedeki Çin yatırımları dikkat çekicidir. Nisan 1996 tarihinde Kırgızistan, Tacikistan ve Kazakistanla ekonomi ve güvenlik anlaşmaları imzalayan Çin, Bölgedeki yatırımlarına hız vermiştir (UNCTAD, World Investment Report 2011, s.66).

- Kazakistan (2006) ve Türkmenistan'dan (2009) Çin’e iki petrol ve doğalgaz boruhattı inşaa edilmiş,

- Türkmenistan'da, Çin Ulusal Petrol Şirketi (China National Petrolium Corporation) için petrol ve 
doğalgaz bulma anlaşması yürürlüğe girmiş,

- 2009 yılında Kazakistan'da China Investment Corporation, KazMunaiGaz'ın \% 14,5 senedini, CNPC Mangistaumunaigaz'ın \% 49 hissesini almıştır.

- Çin’in Tebian Electric Apparatus firması, Kırgızistan ve Tacikistan'da elektrik nakil hattı inşaa etmiş, aynı zamanda Tacikistan’ın Pamir Dağlarında altın, gümüş, bakır ve tunsten çıkarma hakkı elde etmmiştir,

- XD Grup (Çin), Özbekistan'ın başkenti Taşkent’te elektrik sistemini modernize etmektedir,

- CNPS, devlet'e ait Kazatomprom şirketinin Kazakistan'da uranyum üretim yatırımına ortak olmuştur,

- China Guangdong Nuclear Power Corporation, Özbekistan, Navoi’de uranyum geliştirme işine ortak olmuştur.

Görüldüğü gibi, dünya ticaretine entegre olmayan söz konusu geçiş ekonomilerindeki doğal kaynaklar ve doğal kaynakların işlenmesi, yabancı yatırım için cazip bir alan oluşturmaktadır. Kona'nın belirttiği gibi, Rusya'nın etkisinin azalması sayesinde Bölge'de hem Batı, hem Japonya, Çin, hem Türkiye, İran, Pakistan, Hindistan gibi bölge devletleri bu yeni oyunda yerlerini almışlardır (Kona, 2002a: s.113).

Geçiş ekonomilerindeki bir diğer gerçek ise ekonominin gizli yüzü ile ilgilidir. 1990 sonrasında güçlü olmayan ekonomik yapıları, gelir dağılımı dengesizlikleri ve politik sorunlardan da kaynaklanan istikrarsız görünümleriyle Güney Kafkasya ve Orta Asya Bölgesi’ndeki geçiş ekonomileri bu istikrarsızlık ile ters orantılı olarak kayıtdışı ekonominin bir çıkış yolu olarak benimsendiği ülkeler olmuşlardır.

\begin{tabular}{|ccccccc|}
\hline & Azerbeycan & Kazakistan & Taciskistan & Özbekistan & $\begin{array}{c}\text { Türkmenist } \\
\text { an }\end{array}$ & Kurgzistan \\
\hline Nüfus, 000, 2009 & 8.977 & 15.568 & 7.469 & 27.911 & 5.353 & 5.317 \\
GSYH, mi \$, 2009 & 43.076 & 113.620 & 4.982 & 33.461 & $\mathrm{v} / \mathrm{y}$ & 4.683 \\
Büyüme Oran1, & $9,68 \%$ & $5,20 \%$ & $3,70 \%$ & $4,82 \%$ & $4,57 \%$ & $3,06 \%$ \\
1992-2010 & & & & & & \\
GSYH kb,USD & 4,798 & 7.298 & 667 & 1.199 & 3.451 & 881 \\
Gini endeksi & 16,8 & 30,9 & $\mathrm{v} / \mathrm{y}$ & $\mathrm{v} / \mathrm{y}$ & $\mathrm{v} / \mathrm{y}$ & 33,5 \\
İşsizlik & $6,5 \%$ & $12,8 \%$ & $\mathrm{v} / \mathrm{y}$ & $\mathrm{v} / \mathrm{y}$ & $\mathrm{v} / \mathrm{y}$ & $8,3 \%$ \\
\hline
\end{tabular}

Tablo 3: Güney Kafkasya ve Orta Asya Türk Cumhuriyetlerinin seçilmiş ekonomik verileri. Kaynak: UNDP, Human Development Reports Statistics ve IMF, World Economic Outlook Database.

Başta uyuşturucu ve silah kaçakçılığı, kadın ticareti olmak üzere geniş bir yelpazaye yayılan 'kayıtdışı ekonomi' bu geçiş ekonomilerinin dinamiği haline gelmiştir.

SSCB'nin çöküşünün en önemli sonuçlarından biri, Balkanlardan Kafkasya'ya kadar istikrarsızlık dalgasının oluşmuş olması ve sınırları Afganistan'a kadar uzanan 'çok rotalı suç otoban’ı sayılan 'yeni İpekyolu'nun oluşumudur (Glenny,2008:s.5).

Hazar ve Karadeniz'e çıkış kapısı olmaları, Afganistan çıkışlı uyuşturucu ticaretinde transit ülke olmaları Güney Kafkasya ülkelerinde sadece taşımacılığı değil, aynı zamanda uyuşturucu kullanımını da artırmıştır (INCB, 2010a: s.92).

Uluslararası Uyuşturucu Denetim Kurulu'nun Y1llık Raporu'na göre; 2009 y1lında Afgan uyuşturucusunun tahmini \% 25’i Orta Asya'dan geçmiştir. Kazakistan, Kırgızistan, Tacikistan ve Azerbeycan'da 2009 yılında ele geçirilen uyuşturucu oranı \% 13,4 gerileyerek 49,9 tondan (2008) 43,2 ton'a düşmüştür (INBC, 2010B: s.97). Rapora göre; bazı ülkelerde yaşanan iç ve sınır çatışmalarının şiddetlendirdiği politik istikrarsızlık, yetersiz sınır kontrolleri, dağlık coğrafya, yasadışı göç, kaçakçılık, kara para aklama, uyuşturucu yetiştirme ve ticaretini de kapsayan her türlü suç dalgasının artmasına yol açmıştır. Raporda işaret edilen suç türlerine hiç kuşkusuz silah ticaretini de eklemek doğru olacaktır. Aynı zamanda, Bölge'de ve aslında çoğu geçiş ekonomisinde kadın ticaretinin de gölge ekonominin önemli bir unsuru olduğu gözden kaçmamalıdır. Yargı sistemindeki eksiklikler de, bu tür yasadışı faaliyetlerin artmasına yol açmaktadır (Kona, 2002b: s.106).

\section{Sonuç}

Soğuk Savaş sonrasında, Rusya etkisinin azaldığı eski Sovyet Cumhuriyeterine Batı'nın bakışı değişmiştir. Batı'nın değişen bakış açısının en önemli göstergelerinden biri NATO’nun genişleme politikalarında en önemli yeri Kafkasya ve Orta Asy’nın almasıdır. Rusya’nın enerji politikaları yönünden kritik öneme sahip olan Bölgedeki etkinliği azaltılmak istenirken, buna paralel Bölgedeki ülkelerin ittifaka dahil olması veya dahil olma ümitleri enerji güvenliğinin sağlanması ve stratejik üstünlük sağlanması için hayati rol oynamaktadır. Bununla birlikte, Bölgedeki ülkeler etnik sorunlar ve sınır çatışmaları nedeniyle henüz İttifak'a dahil olamamakta, bununla birlikte Bölgede avantajı konuma gelmek isteyen Batı yanısıra Çin de Bölgedeki çıkarlarını makzimize etmeye çalışmaktadır.

Bölge'de ekonomik ve politik istikrarsızlık yaratan çatışmalar ve çatışma potansiyeli, NATO'nun yeni stratejik 
konsepti paralelinde düşünüldüğünde herhangi bir etnik veya dini çatışma nedeniyle alan dışı müdahale olasılığ ve sonrasında ise çatışma sonrası toplumlarda oluşan uluslar-üstü kurumların denetim ve hakimiyetinde bir yapı mümkün gözükmektedir.

Post-modern dünyanın çatışma ortamlarında, ulus-devletin parçalanması ile sonuçlanması kuvvetle muhtemel iç çatışmaların en önemli sonuçlarından bir başkası ise politik istikrarsızlığın oluştuğu veya arttığı, güvenlik açıklarının oluştuğu bir ortamda gölge ekonominin işlerliğidir. Gölge ekonomi, sadece çatışma döneminde değil, çatışma sonrasında da o ülkenin dinamiği haline gelmektedir. Soğuk Savaş sonrası süreçte, merkezi planlama sisteminden kapitalist sisteme uyarlanmaya çalışan ve bu yolda reformlar yapan geçiş ekonomilerinin büyük bir kısmında gölge ekonomi işlerlik kazanmıştır. Çatışma ortamında ortaya çıkan istikrarsızlık, gölge ekonominin o ülkenin dinamiği haline gelmesine yol açmakta, suç dalgasının yayılmasına zemin hazırlamaktadır.

Makroekonomik sorunlar, politik belirsizlik ve istikrarsızlığın süreklilik kazanması, jeostratejik önemi artan bu coğrafya'nın küresel dünyaya entegrasyonunda zorluklar yaratmaktadır. Küresel dünyaya entegrasyon, sahip olunan doğal kaynaklar veya boru hatları geçiş yollarının bu coğrafya'da başlaması veya transit ülke olmalarına paralel aslında ekonomik anlamda gelişmeleri gerekirken, güç savaşının ortasında bulunan bu ülkelerdeki iç çatışmalar veya sınır savaşları nedeniyle artan bölgesel istikrarsızlık bütünleşmeyi engelleyici bir unsur olarak belirmektedir. Öte yandan, bu ortam gölge ekonomisinin yerleşmesini ve ivme kazanmasını sağlarken; bu kapsamda yer alan uyuşturucu ve silah ticareti, kadın ticareti yanısıra iç çatışmaların NATO'nun yeni tehdit algılamaları içinde tanımlanması bölgedeki risk potansiyelini artırmaktadır.

Bu bağlamda, NATO’nun genişleme politikasında öncelikli bölge olmasına rağmen, bölge ülkelerinin istikrarsız ortamları nedeniyle İttifak'a üyelikten ziyade 'Barış İçin Ortaklık (PfP)' kapsamındaki projelere dahil edilmesi, bu ülkelerdeki kargaşanın artma potansiyeline işaret etmektedir.

Geçiş ekonomisi olarak adlandırılan bu ülkeler, liberal düzene uyum sürecinde yapısal zorluklar yaşamakta, sahip oldukları doğal kaynaklar ve petrol-doğalgaz boru hatlarının geçiş ülkesi olmalarından kaynaklı hakimiyet politikalarının hedefi olduklarından ekonomik anlamda gelişme gösterememekte, politik istikrarsızlık ekseninde dünyanın gerisinde kalmaktadırlar. Bölgenin jeostratejik önemi, coğrafi sınırların bir yanda Afganistan’a, diğer yanda Karadeniz'in öteki kıyısında Balkanlara komşu olması, bu ülkelerdeki istikrarsızlık ve kaos ortamının yayılma riskini taşımakla beraber hedef bölge konumunda olması sebebiyle de bugün olduğu gibi yarın da güç savaşlarının hedefinde olacağını göstermektedir.

\section{Kaynakça}

- Arı, 1996. Uluslararası İlişskiler ve Dış Politika. Marmara Kitap Merkezi, 7.Baskı, İstanbul.

- BP. BP Statistical Data, 22.05.2011, www.investis.com

- European Dialogue. Caspian Pipelines Map, http://www.eurodialogue.org/International-Security-Influence-Fuel-EnergyComplex-Caspian-Region

- IMF, World Economic Outlook Database, http://www.imf.org/external/pubs/ft/weo/2011/01/weodata/weoselgr.aspx

- $\quad$ INBC, 2010. Report of the International Narcotics Control Board for 2010.

- Garnett, 1997. "Russia and Its Borderlands: A Geography of Violence," US Army War College Quarterly, Spring 1997, Vol XXVII, pp 4-21.

- Glenny, 2008. McMafia, Crime Without Frontiers. The Bodley Head, London

- Khagani, 2007. "Geopolitics and Energy Security in the Caspian Region," The Journal of the Study of Modern Society and Culture, $\mathbf{N}: 38$.

- Kona, 2002. Türkiye-Orta Asya İşbirliği: Stratejiler ve Gelecek Senaryoları. IQ Kültür Sanat Yayıncılık, İstanbul.

- $\quad$ Lackowski, 2007. "Foreign Military Bases in Eurasia," SIPRI Policy Paper, No:18.

- Maidan news, http://maidan.org.ua/news/list.php3?bn=\&site=agora

- Msn news, http://news.in.msn.com

- Peksarı, 2007. NATO’nun Değişen Konsepti. Asil Yayın, Ankara.

- Primakov, 2007. Politikanın Mayınlı Tarlası. Selis Kitaplar, İstanbul.

- Radio Free Europe, http://www.rferl.org/content/article/1075768.html

- UN. Uluslararas1 Ticaret veritaban1, http://comtrade.un.org/pb/

- UNDP, Human Development Reports Statistics, http://hdrstats.undp.org/en/countries/profiles/UZB.html

- $\quad$ UNCTAD. World Investment Report 2011.

- Yevseyev. "International Security and its Influence on Fuel and Energy Complex of Caspian Region," http://vestikavkaza.ru/

- Wikipedia. Colour Revolution, http://en.wikipedia.org/wiki/Colour_revolution 


\title{
Devi Bağlayan Bağlar: Çin'in Orta Asya Enerji Kaynaklarındaki Çıkarı
}

\author{
Hasan Duran (Dumlupınar University, Turkey) \\ Kadir Kürşat Yılmaz (Dumlupınar University, Turkey)
}

\section{The Ties That Binds the Giant: China's Interests in Energy Sources of Central Asia}

\begin{abstract}
Following the collapse of Soviet Union, the interest of China towards the Central Asia first revolved around the security and border issues. Then the fast growing economy of China since 2000 needs energy more she can produce. Becoming one of the biggest energy users, China has become more and more dependent on other countries to fill her energy deficit. Thus China has identified Central Asia as her prime area to built cooperative relations. In this respect, China started new relationships with Turkmenistan and Kazakistan in order to secure and sustain the procurement of oil and natural gas.

Thanks to its rich oil and natural gas reserves, Central Asia has become a region in which the great powers compete; with the years 2000s China joined to the rush. The rivalry in the region has a potential to change the balance of power in the World. This study evaluates this rivalry in terms of political and economic effects on China.
\end{abstract}

JEL Codes: F50, F59

\section{Giriş}

Dünya petrol ve doğalgaz tüketiminde ön plana çıkan ülkeler olarak 2000'li yıllara kadar ABD-AB hâkimiyetinden bahsedilirken, 2000'li yıllarla birlikte bunlara üçüncü bir ülkenin de eklendiğini görüyoruz; Çin. Çin'in büyüyen ekonomisiyle birlikte enerji talebi ve tüketiminde de artışlar olmuş ve günümüz enerji piyasasında önemli bir aktör konumuna yükselmiştir. Çin, 2010 yılı enerji tüketiminde ABD'yi geride bırakarak dünyanın başlıca enerji tüketicisi olmuş - kullanılan her tür enerjide artışlar gerçekleşmiş- ve ülkenin dünya çapındaki tüketim payı \%20’nin üzerine çıkmıştır. (Dünya Devi Çin Enerji Tüketiminde de Lider, 2011).

Çin, 2004 yılına kadar enerji tüketimini \%245 oranında arttırırken, aynı süredeki enerji üretimi ancak \%194 oranında artmıştır. Devam eden sanayileşme ve kentleşme ise bir taraftan enerji talebini arttırırken, diğer taraftan da ulusal kaynakları giderek daha yetersiz hale getirmektedir. (Bayraç, 2010). Yani Çin enerji ihtiyacı bakımından (petrol ve doğalgaz) giderek artan bir oranda dış kaynaklara bağımlı hale gelmektedir. (Alkın ve Atman, 2006).

Çin, büyük miktarlarda doğalgaz-petrol alım anlaşmalarının bulunduğu İran ve Orta Doğu petrolüne bağımlı durumdadır. Son yıllarda Sudan ve Angola olmak üzere Afrika'da ve dünyanın birçok bölgesinde enerji yatırımlarında bulunmaktadır. Ancak Orta Doğu'dan sağladığı petrolün kontrolünün ABD'de olması, İran'dan sağlamak istediği petrol ve doğalgaz'ın yine ABD tarafından engellenmesi Çin'i alternatif arayışlara yönlendirmektedir. Çin (Hindistan'la birlikte) petrol tüketiminde artan dişa bağımlılığı nedeniyle Petro-politik açıdan yeni belirleyici ülke(ler) haline gelirken, enerji arz güvenliği de hayati bir önem taşıyacaktır. (Üretici Ülkelerin Petro-Politiği 2010-2025) Bu noktada akla ilk olarak Orta Asya ve buradaki Türk Cumhuriyetleri gelmektedir. (Yavuz, 2011) Özellikle petrol zengini Kazakistan ve doğalgaz zengini Türkmenistan dikkatleri üzerine çekmektedir.

\section{2 Çin'in Türk Cumhuriyetleri İle Diplomatik İlişkiler Kurması}

1950'lerde Çin-SSCB gerginliğinin başlamasıyla, uzun yıllar Çin’in belirgin bir Orta Asya politikası olmamış, bölgeye yönelik sadece sınır güvenliği sağlama amaçlı politikalar izlemiştir. Ancak 1980'lerin başında ÇinSovyet ilişkilerinin normalleşmesiyle Sovyet Orta Asyası ile Çin arasında özellikle ekonomik ilişkiler hızla gelişmeye başlamıştır. (Bekar, 1995). SSCB’nin dağılmasıyla beraber Çin, Orta Asya’yı Batıya açılmanın eşiği olarak görmeye başlamıştır. Çin, Türk Cumhuriyetleri'nin tamamını 1992 yılının ilk haftasında tanıyarak, bu ülkelerle diplomatik ilişkiler kurarak özellikle sınır sorunlarının çözümü, bölgedeki etnik ve dini çatışmaların önüne geçilmesi ve ülkelerarası işbirliğinin geliştirilmesi sorunlarına odaklanmıştır. Çin'in bu şekilde hareket etmesi, Rusya'yı ürkütmekten kaçındığını ve ekonomik kalkınmasına katkı sağlayacak hamlelere öncelik verdiğini göstermesi açısından önemlidir.

1994'e kadar ikili ilişkilerde önemli bir gelişme olmamıştır. Ancak 1994 yılında tüm bölge ülkelerine Çin üst düzey yetkililerince karşılıklı, önemli ziyaretler gerçekleştirilmiştir. İlk resmi ve yoğun ilişkileri başlatan Çin 
Başbakanı Li Peng, 1994 ziyareti esnasında bölge ülkelerini ziyaret etmiştir. Peng, bu ziyaretler esnasında Yeni İpek Yolu'nun canlandırılmasıyla, (Bekar, 1995) Çin'in bu yoldan Avrupa'ya, bölge ülkelerinin de Pasifik’e ulaşmasının mümkün olacağı ifade etmiştir. 1996 yılına kadar yapılan görüşmelerde ele alınan temel konular; Suçluların yargılanmasında ve iadesinde karşılıklı destek, radikal ve ayrılıkçı sorunlarda işbirliği ve sınır belirsizliklerinin çözümü olmuştur.

1996 yılına gelindiğinde ise Çin ile Orta Asya Türk Cumhuriyetleri arasında ilişkiler yeni bir ivme kazanmıştır. RF Devlet Başkanı Yeltsin'in 24-26 Nisan 1996 yılında yaptığı Çin ziyaretine, Çin’e komşu Kırgızistan, Kazakistan ve Tacikistan devlet başkanları da eşlik etmişlerdir. Bu ziyaret esnasında öncelikle RF ve Çin aralarında çeşitli işbirliği anlaşmalarına imza atmışlardır. Daha sonra beş ülke devlet başkanları bir araya gelmiş ve sınır bölgelerinde askeri güvenceye ilişkin bir anlaşma -Şanghay kentinde- imzalanmıştır. Böylece Şanghay Beşlisi adı verilen bir oluşum ortaya çıkmıştır. (Ekrem, 2003). Şanghay Örgütünün ön plana çıkardığı konular: Eşit düzeyde karşılıklı menfaat sağlama ve birbirilerinin iç işlerine karışmama, her türlü zarar vereci faaliyetlere karşı işbirliğinin yapmasının önemi, çok kutuplu bir dünya isteğine vurgu yapılmıştır. 2000 yılındaki 5. toplantının yapıldığı Duşanbe'de genişleme kararı alınmış ve bölgesel ve küresel sorunlarla ilgilenen diğer ülkelerinde katılmasına ortam yaratılmıştır.

Şanghay Beşlisi, 15 Haziran 2001 yılında -Özbekistan'ın da katılımıyla (İşyar, 2010)- genişleyerek Şanghay İşbirliği Örgütü’ne dönüşmüştür. Örgüt Çin, Rusya, Kazakistan, Kırgızistan, Tacikistan ve Özbekistan üyeler arasında politik, ekonomik, askeri ve enerji alanlarında bir işbirliği zemini oluşturmayı hedeflemektedir. (Bayraç, 2010) Şanghay İşbirliği Örgütü ile Çin, Uygur nüfusu olan Kazakistan ve Kırgızistan’ı da bu şekilde daha kolay kontrol edebilmenin yanında, Uygur ve Çeçen konularında ve bölgede ABD etkinliğini azaltmak için Rus-Çin işbirliğini sağlamıştır. Böylece Çin, rahatsızlık duyduğu konularda bölge ülkeleriyle ilişki kurmuş ve sınır sorunları çözmenin yanında Şanghay Örgütü sayesinde bölge ülkelerindeki nüfuzunu artırmıştır. Taraflar arasında sorunlar kısmen de olsa çözülmüş ve endişe veren güvensizlikler ortadan kaldırılmıştır

Çin, sınır güvenliği açısından ilgilendiği Orta Asya’ya son dönemde enerji konusunda da ilgisini yoğunlaştırarak sürekli artan enerji ihtiyacı ve tüketiminin bir kısmını bu bölgeden sağlamak istemektedir. Bunun için Çin, son yıllarda Orta Asya ülkelerinde önemli enerji yatırımları gerçekleştirmekte ve enerji alanında kullanılmak üzere bölge ülkelerine krediler vermektedir. Şanghay Beşlisi'nin ilk görüşmesinden kısa bir süre sonra 1997'de Kazakistan ile petrol kuyusu açma ve taşıma anlaşması yapılmıştır. (Ekrem, 2003). Türkmenistan ile 6 Temmuz 2000 yılında Çin devlet başkanı Jiang Zemin Türkmenistan ziyaretinde, indirimli kredi ve petroldoğalgaz alanlarında işbirliği anlaşması imzalanmıştır. (Ekrem, 2003). Çin artık bölge de ekonomik olarakta büyük bir güce kavuşmak istemektedir.

\section{3 Çin'in Orta Asya Stratejisi}

Çin’in yeni dönem ulusal çıkarlarında Orta Asya ve Hazar bölgesinin ayrı bir yeri vardır. (Adıbelli, 2008) Çin'in uzun zamandır var olan bölgeye ilgisinin önemli birkaç parametresi vardır: bunların başında güvenlik, ticaret ve enerji konuları gelmektedir. (Dikkaya, 2010) Orta Asya'nın jeopolitik ve jeostratejik açıdan önemi ve enerji kaynakları Çin için vazgeçilmez bir değere sahiptir. Bu bağlamda öncelikle Kazakistan'la petrol, Türkmenistan ile doğalgaz ticaretine başlamıştır. Çin'in Hazar kaynaklarına yönelmesi ise bölge ülkelerinin pazarlık payı artmıştır. (Yavuz, 2009) Çin bölgenin enerji kaynaklarını doğuya çevirme konusunda ısrarcılığı ve kararlı politikaları sayesinde oldukça etkin bir ülke haline gelmiştir. (Özertem, 2008) Ancak, Çin'in insan kaynağı fazlası ile Orta Asya doğal kaynaklarının fazlalığı arasındaki denge problemi (Davutoğlu, 2004) gelecekte önemli bir sorun olarak karşımıza çıkma olasılığı vardır. Aynı durum Rus Uzak Doğusu'nda da kendini göstermektedir. 10 milyonu bulmayan vasıfsız Rus nüfusuna karşılık bölgede 120 milyondan fazla Çinli bulunmaktadır. (İşyar, 2010)

Orta Doğu kaynaklı petrol alımlarında üretim alanları ve taşıma yollarının kontrolünün ABD'nde olması nedeniyle Çin, Orta Asya'dan yapılacak alımlar için Rusya ve Orta Asya ülkeleri (Kazakistan, Türkmenistan vb.) ile çeşitli projeler geliştirmektedir. Çin sadece Orta Asya'ya değil, Ermenistan üzerinden Güney Kafkasya bölgesine girmek ve bu bölgede faal olmak için de Ermenistan'a küçük yardımlarda bulunmaktadır. (Laçiner, 2005) Türkiye ile Azerbaycan arasında coğrafi engel oluşturan Ermenistan'ı destekleyerek, Türkiye'nin ve Batılı devletlerin Azerbaycan üzerinden doğuya açılmalarını önlemek istemektedir. (İşyar, 2010)

Orta Asya Türk Cumhuriyetleri, enerji kaynaklarından en iyi şekilde yararlanma çabası içersindedirler. Rusya muhalefetinin yanında Hazar'ın statüsündeki çözümsüzlük batıya doğalgaz satmayı zorlaştırmaktadır. Bu yüzden yeni projeler engellemekte, İran güzergâhı söz konusu olduğunda ise ABD bu duruma karşı çıkmaktadır. Sovyet döneminden kalma boru hatları, Rusya'ya ve diğer Orta Asya cumhuriyetlerine ulaşmaktadır. Bu nedenle, sadece Rusya üzerinden Avrupa'ya çıkmak çeşitli sorunları da beraberinde getirmektedir. Bunun için de mineral kaynakların çıkarılması, işletilmesi ve pazara götürülmesi için yabancı şirketlerin yatırımlarına ihtiyaç duymaktadırlar. Bu durumda Çin'in önemi ortaya çıkmakta ve sunduğu ekonomik avantajları kullanmak ve Çin'e doğalgaz satmak daha avantajlı ve sorunsuz olmaktadır.

Orta Asya ülkeleri, Çin'le aralarındaki ekonomik işbirliğine yeni güç katan boru hatlarının, halklarının 
çıkarlarına ve mutluluğuna hizmet edeceğini ve hattın bölgenin istikrarına ve gelişmesine de katkı yaptı̆̆ını ve bu nedenle uluslararası enerji işbirliğinin pekiştirilmesi ve enerji alanında ortaklık ilişkilerinin oluşturulması için büyük önem taşıdığı düşünmektedir. Petrol ve doğalgazda Rus etkisini dengelemek isteyen Kazakistan, Özbekistan ve Türkmenistan, Çin'i ekonomik ve siyasi boyutta Rusya'yı dengeleyecek en önemli aktör olarak da görmektedirler. (Bilgin, 2010) Çin'in Hazar Havzası ülkelerinin yönetim biçimleri ya da demokrasi arayışlarında olmayışı, sınır için çok fazla ülke işbirliğinin gerekmemesi Çin seçeneğini her zaman düşünmelerine yol açmaktadır.

Çin de kendi bölgesinde elini güçlendirebilmek ve küresel rekabette ön plana çıkabilmek için Orta Asya'ya olan ilgisini arttırmaktadır. (Tüysüzoğlu, 2010) Çin'in Orta Asya ülkeleriyle ile ekonomik ilişkilerinin artırmak istemesinin bir diğer sebebi, Doğu Türkistan bölgesinin de gelişmiş bölgeler kadar kalkınmasını sağlamaktır.

Çin ekonomik büyümesini küresel güce çevirmek isterken, her geçen gün daha fazla enerjiye ihtiyaç duymaktadır. Bu yüzden, Çin'in dış politika açılımlarında enerji jeopolitiği adeta eksen haline gelmiştir. Şı̈Ö ile işbirliği zemini oluşturulmuştur. Öncelikle sınır sorunlarının çözülmesi ve bölgesel güvenliğin pekişmesini hedefleyerek kurulan Şiö, Çin'in Uygur Bölgesi'nin yarattı̆̆ 1 ve yaratabileceği güvenlik endişelerini bertaraf edebilmiştir. Orta Asya'daki terörizmin ve radikal hareketlerin kontrol altında tutulmasını kolaylaştırarak işbirliği imkânlarını çoğaltmıştır. Çin, ŞïÖ ile Uygur unsurlarını bulunduran Kazakistan ve Kırgızistan'ı kontrol altında tutmaktadır. (Dikkaya, 2009) Sorunların çözülmeye başlanmasıyla beraber enerji projeleri devreye girmiştir. Enerjiden hareketle Orta Asya güvenliği ile ilgili de ortak bir yaklaşımlarının olduğunu söylemek mümkündür. Ayrıca Çin, Orta Asya devletlerini terörizm ve radikal dini hareketlerle mücadele konusunda desteklemektedir. Böylece bölge ülkeleri ile Doğu Türkistan Bölgesi’ni birbirine bağlayan Kazakistan-Çin petrol hattıyla, Türkmenistan-Kazakistan-Özbekistan-Çin doğal doğalgaz boru hatlarının tamamlanıp işler kılınmasının zemini oluşturulmuştur.

Atasu-Alashankou petrol boru hattı ile Çin-Merkez Asya doğalgaz boru hattı, merkez Asya ülkeleri ile Çin ekonomisi arasındaki stratejik "bağlantının" aracılığını yapmaktadır. Tüm dünya küresel krizle boğuşurken Türkmen doğalgazının Özbekistan, Kazakistan ve Kırgızistan üzerinden Çin'e ulaşmasını sağlayan Türkmenistan-Çin doğalgaz boru hattı hayata geçirilmiştir. Türkmenistan, Özbekistan, Kazakistan ve Çin Devlet Başkanlarının katılımı ile Türkmenistan'dan Çin'e uzanan Çin-Orta Asya Doğalgaz Boru Hattı'nın açılışı 14 Aralık 2009'da gerçekleşmiştir. (Türkmenistan-İran doğalgaz boru hattı açıldı, 2010) Ayrıca açılış sırasında Türkmenistan'ın Güney Yolöten sahasındaki doğalgaz yataklarının işletilmesi için 4 milyar dolarlık kredi anlaşması da imzalandı. (Çin'den Türkmenistan'a 4.1 Milyar \$Kredi, 2011)

$\mathrm{Bu}$ hat sayesinde Türkmenistan, doğalgazının \%70'ini sattığı Rusya'ya olan bağımlılı̆̆ını azaltmış ve talep güvenliğini pekiştirmiş olacaktır. Çin ise Orta Asya ile başladığı doğalgaz ticaretini ilerde Özbekistan ve Kazakistan'dan da doğalgaz alacak ş̧ekilde geliştirmek imkânına ulaşarak enerji arz güvenliğiyle, Doğu Türkistan Bölgesi'nin sınır güvenliğini sağlamlaştırmış olmaktadır. Hattın tam kapasite ile çalışmaya başlamasının ardından Türkmen doğalgaz rezervlerinin işletilmesinde Çinli firmaların büyük bir etkinlik kazanması beklenmektedir. (Dikkaya, 2010)

Türkmenistan-Çin boru hattı, Türkiye açısından da önem taşımaktadır. Çünkü Çin'in Kazak petrolünün yanı sıra ilk etapta Türkmen, ikinci etapta Kazak ve Özbek doğalgazını satın alacak olması, Orta Asya’nın Kafkasya üzerinden Türkiye'ye ve Avrupa'ya ulaşma gereksinimini en azından enerji bağlamında azaltmaktadır. Bu ülkelerin Kafkasya üzerinden batıya ulaşmaları, kendileri nezdinde artık elzem bir ihtiyaç değil; koşullar iyi olmak kaydıyla düşünebilecekleri yollardan birisi olacaktır. (Bilgin, 2010)

Zengin petrol yatakları olan Kazakistan'da iki yüz bin Uygur yaşamaktadır. (Çolakoğlu, 2010) Bir milyona yakın Kazak nüfusu da Çin'in Uygur Özerk Bölgesi'nde yaşamaktadır. (Dikkaya ve Bora, 2006) Bu durum Kazakistan'ın Çin'e karşı önemini artırmaktadır. 2009 yılında, Kazakistan Çin'den petrol ve doğalgaz sektöründe kullanılmak üzere 13 milyar dolarlık büyük bir kredi almıştır.(Çin'den Kazakistan’a 13 Milyar \$ Kredi, 2010) Çin'in Kazakistan'a verdiği önem her geçen gün arttırmaktadır. Çin, enerji alanında önemli alım antlaşmaları, enerji yatırımları ve enerji sektöründe kullanılmak üzere verilen kredilerle Kazakistan'da etkin bir konuma gelmiştir.

Kazakistan-Çin Petrol Boru Hattı: 3 aşamalı (Pamir, 2008) olan proje 625 km uzunluğundadır. Çin petrol şirketi CNPC ile Kazakistan'dan KazMunayGaz arasında \% 50-50 ortaklık ile işletilecektir. Hazar kıyısından Çin'in Alashankou kentine kadar olan hattı takip ederek boylu boyunca Kazakistan'1 geçmektedir. Kapasitesi 20 milyon ton hattın, 2004'te yapımına başlanan Atasu-Alashankou hattından ilk ham petrol 2006 Temmuz sonunda Çin'e ulaşmıştır. (Kazakistan-Çin Petrol Boru Hattından Çin'e 12 Milyon Ton Petrol Sevk Edildi, 2009) Aslında bu hat Hazar Denizi'nden Alashankou'ya yani Kazakistan'ı bir uçtan bir uca kat edecek bir hattın ikinci safhasıdır. Atırau-Kenkiyak hattı ile Atasu-Alashankou hattını birleştirecek olan 3. safhanın 2011'de bitmesi planlanmaktadır. Proje tamamlandığında Çin'in enerji talebinin \%5'ini karşılaması beklenmektedir. Çin ilerleyen zamanlarda, enerji tedarik ettiği ülkeleri çeşitlendirmiş, Orta Asya'da etkisini arttırmış, büyük bir ekonomik ve siyasi ağırlığa sahip bir devlet konumuna yükselecektir. Ayrıca Çin, Hazar denizine stratejik bir erişim yolu de elde etmiş olacaktır. (Sincan, Pekin için ne kadar değerli, 2009) Kazakistan ise, müşterilerinin sayısını arttırarak 
büyük bir ekonomik kazanç sağlamıştır. Üstelik Rusya'nın da Çin'e petrol satmak için bu hattı kullanması söz konusudur.

Kazakistan Ulusal Petrol ve Gaz Şirketi KazMunayGaz ile Çin'in Ulusal Petrol ve Gaz Şirketi CNPC, Çin'in Beyneu şehri ile Kazakistan'ın Çimkent şehri arasında doğalgaz boru hattı kurulması için anlaşmaya varmışlardır. Boru hattının inşası için ortak işletme kurulacak ve projenin uygulanmasına hemen başlanacaktır. Batı Kazakistan'da çıkarılan doğalgaz Çin'e ulaştırılacak ve proje yaklaşık 3.6 milyar \$'a mal olacaktır. (Kazakistan'dan Çin'e Yeni Doğalgaz Hattı, 2010)

Batılı şirketlerin bölgedeki yatırımları Kazakistan’ın bağımsızlı̆̆ı ve istikrarı için önemli bir güvencedir. Kazakistan, Batılı şirketleri ve Rusya'yı Çin ile dengelemeye çalışmaktadır. Çin ile Kazakistan arasındaki ticaret hacmi her geçen gün artarak 2010 yılında ikili ticaretin hacmi, 2009 yılına oranla \% 44.5 oranında artarak 20 milyar 410 milyon \$'a ulaşmıştır. (Çin-Kazakistan ortak bildirisi: İlişkiler "kapsamlı stratejik ortaklık" düzeyine çıkarıld1, 2011)

Kırgızistan'da 2005 yılında halk ayaklanmasıyla yaşanan iktidar değişikliğinden tedirgin olan Kazakistan devlet başkanı Nursultan Nazarbayev, kadife devrimin destekçileri olan ABD ve AB'ye karşı elini güçlendirmek ve Rusya'nın dikkatini üstüne çekebilmek için Orta Asya Birliği düşüncesini güçlü bir şekilde dile getirmiştir.

Kazak petrolü ve Türkmen doğalgazı dışında Özbekistan'ın siyasi-stratejik önemi, Çin'i bu ülkede etkili olmaya itmektedir. Andican olayları sonrasında ABD ile ilişkileri gerginleşen ve ABD üssünü kapatan Özbekistan Yönetimi de Çin'i dengeleyici alternatif olarak görmüştür. Kerimov, Andican olaylarının hemen sonrasında Çin'i “güvenilir dost” olarak tanımlamıştır. (Laçiner, 2006a) Kerimov'un 2005 yılındaki Çin ziyaretinde, petrol işbirliği anlaşması imzalanmış ve ikili ilişkileri geliştirme taahhüdünde bulunmuştur. Ancak Çin, Özbekistan ile yakınlaşmasını ABD’ye bir tür meydan okuma olarak yansıtmamaya çalışmıştır.

Çin menşeli ürünler Orta Asya pazarlarında gün geçtikçe daha fazla yer bulmaktadır. Çin'in Orta Asya'da artan etkinliğinin uzun dönemde Rusya'nın bölgedeki ekonomik ve politik etkinliğini azaltma potansiyeli de bulunmaktadır. 2009'da Kazakistan'ın Çin'e ihracatının (13.6 milyar \$) Rusya'ya olan (8.2 milyar \$) ihracatını aştı̆ğ, Kazakistan'ın ithalat ortakları arasında Çin'in (12.6 milyar \$) Rusya'nın (31.3 milyar \$) ardından ikinci sırayı aldığı görülmektedir.(Trade Profiles Kazakhstan, 2009) Çin'in 2010 yılı itibariyle hem ithalatta hem de ihracatta Türkmenistan'ın en önemli ortaklarından birisi haline gelmesi, Rusya'yı bölgesel ticaret açısından dengeleyebilecek bir ülke konumuna da getirmiştir. (Türkmenistan'ın En Fazla İthalat Yaptığı Ülke Türkiye, 2011)

Petrol ve doğalgaz boru hatlarının hayata geçirilmesi Çin açısından hayati derecede önemlidir. Bölge enerji kaynaklarını doğu'ya çeviren Çin böylece, hem SSCB'nin bir zamanlar egemen olduğu bölgelerdeki etkinliğini artırmış olacak hem de sürekli artan petrol ve doğalgaz ihtiyacının önemli bir bölümünü karşılayabilecektir. Çoğunluğu enerji alanında olmak üzere Türkmenistan'da Çin sermayeli 37, Kazak sermayeli 30 ve Özbek sermayeli 13 şirket faaliyet göstermektedir.

Çin'in enerji üzerinden Orta Asya'da izlediği stratejiler ise; Doğu Türkistan Bölgesi’nin yarattığı güvenlik endişelerini gidermek için işbirliği, enerji talebi için bölge petrol ve doğalgazından yararlanmak, Orta Asya üzerinde Kafkasya, Türkiye ve Avrupa ile yakınlaşmak olarak gösterilebilir. Bu stratejilerin gerçekleşmesi için Çin, Orta Asya'daki milliyetçilik ve İslami akımların yükselmesini istememekte ve enerji projelerini belli aşamalarda devreye sokmasına izin veren mevcut statükonun istikrar içerisinde devamını arzulamaktadır. (Bilgin, 2010)

\section{Cin-ABD Rekabeti}

Büyük bir jeopolitik öneme sahip Orta Asya; Rusya ve Batı Avrupa açısından Çin tehdidine karsı bir tampon bölgedir. Çin içinde Batı'dan gelebilecek tehditlere karşı tampon görevi görmektedir. Ancak ABD, Rusya ve Çin ilişkilerine enerji bağlamında bakıldığında, son yıllardaki mücadelenin enerji temeline kaymakta olduğu rahatça anlaşılmaktadır. (Ekşi, 2009)

ABD’nin Hazar Havzası'na bakışında enerji kaynaklarının özel bir önemi vardır. Daha önce çıkar sahası olarak tanımladığı Hazar bölgesini ise 1997'den itibaren sorumluluk sahası” olarak ilan eden ABD, 11 Eylül öncesi bölgeye yönelik politikalarını diplomatik ve ticari kanallardan yürütürken, 11 Eylül sonrası tutumunu kökten değiştirmiştir. Afganistan müdahalesiyle Çin'i batıdan çevreleyip, Çin'in Hint Okyanusu aracılığıyla bölge enerji kaynaklarına ulaşmasını engellemeyi hedeflemiştir. Bu yüzden Orta Asya, ABD için sadece yatırım olanakları ve ABD'ye petrol ve doğalgaz satışı olarak değil, ABD'nin rakiplerine doğalgaz ve petrol açısından sağlayacağı üstünlük bakımından bölge stratejik bir öneme taşımaktadır.

Türk Cumhuriyetleri ve İran'ın Rusya ve Çin ile yakınlaşması, Rusya’nın Avrupa'da aşırı güçlenmesi, İran'ın bölgesel varlığını pekiştirmesi ve Çin'in enerji ihtiyacını Rusya, Orta Asya ve İran'dan gidermesi ABD çıkarları için tehlikelidir. (Çin ve İran Arasında Dev Ortaklık, 2010) Azerbaycan dışında Orta Asya ve Kafkasya'nın enerji kaynaklarının Rusya'nın tekelinde kalıp Çin'e doğru yönelmesi yerine ABD, Azerbaycan'la beraber Türkmenistan'ın Türkiye üzerinden geçen hatlarla Avrupa'ya ve dünya piyasalarına bağlanmasını istemektedir. 
Böylece Rusya, Çin ve İran'ın mümkün olduğunca bölgedeki enerji kaynaklarının dışında tutulmasını sağlamaktır. (Bilgin, 2010)

ABD, İran Körfezinden Çin Denizine uzanan bölgedeki stratejik enerji geçiş boğazlarının denetimini elinde tutarak Çin'i enerji bakımından kendine bağımlı kılmayı ve enerji denetimini elinde tutmayı amaçlamaktadır. $\mathrm{ABD}$ ile Çin arasında denize ve enerjiye bağlı anlaşmazlıklar Hürmüz, Babülmendep ve Malacca Boğazı'nda düğümlenmektedir. Çin'in ihtiyaç duyduğu petrol ve doğalgazın ülkeye, deniz yoluyla taşınması sırasında kullanmak zorunda olduğu boğazların kritik durumu ile boru hatlarının geçiş bölgelerinin güvensizliği enerji sağlanmasında önemli tehditler oluşturmaktadır. Bu deniz yollarının güvenliği halen, büyük oranda $\mathrm{ABD}$ donanması tarafindan sağlanmakta bu açıdan da Çin'in ABD'ye olan bağımlılığı artmaktadır. (Bayraç, 2010)

Çin'in İran'la gerçekleştirdiği enerji ve askeri işbirliği de ABD'yi huzurluk etmektedir. Çin, petrol ithalatının \%12-15'lik kısmını İran'dan sağlamaktadır. İki devlet arasındaki çeşitli enerji anlaşmaları da mevcuttur. Ocak 2000'de Çin petrol şirketi olan SINOPEC ile Ulusal İran Petrol Şirketi (NIOC) arasında Zavareh ve Kaşhan'da arama yapılması için de değeri 13 milyar doları bulan bir anlaşma imzalanmıştır. Yine 2004'ün başında Çin, İran'dan 25 yılı aşan bir süreliğine toplam 20 milyar doları bulan sıvı doğalgaz alım anlaşması imzalamıştır. (İşyar, 2010) 2004 Sonbaharı'nda iki ülke 70-100 milyar dolarlık bir petrol ve gaz alım anlaşması imzalamışlardır. Yine iki ülke İran'ın Yadavaran petrol sahasını geliştirme konusunda anlaşmaya varmışlardır. Yadavaran'ın geliştirilmesinden sonra Çin, İran'dan 150.000 varil ham petrol de alacaktır. (Laçiner, 2006b) Çin'in İran'daki Yadavaran petrol rezevleri için 100 milyarlık yatırım yapması da beklenmektedir. (Alkın ve Atman, 2006)

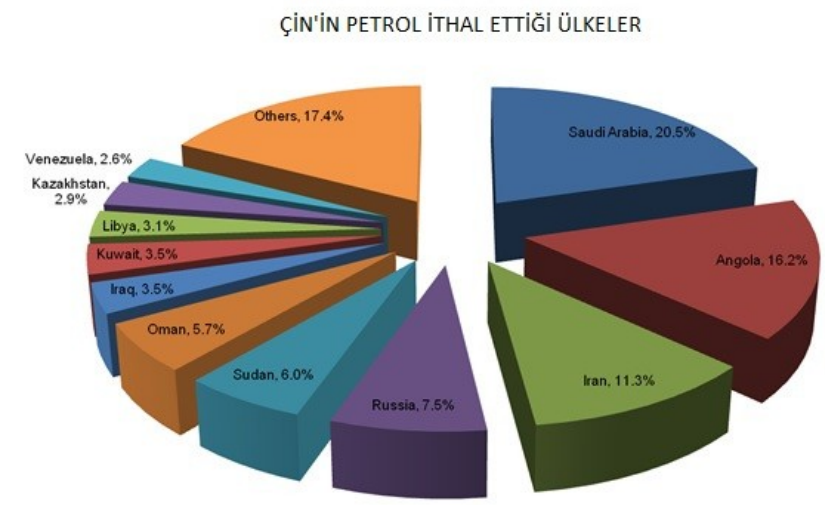

Tablo 1: Çin'in petrol İthal Ettiği Ülkeler. Kaynak: http://www.uzmanforex.com/

Çin, İran'a yaptırımlara uzun süre direnmesine rağmen, daha sonra hafifletilmesi koşuluyla, uranyum zenginleştirme faaliyetleri nedeniyle son Birleşmiş Milletler Güvenlik Konseyi'nde İran'a yaptırım kararlarını gönülsüzce de olsa desteklemiştir. (Hogg, 2010) Çin'in BM yaptırımlarına destek vermesine rağmen petrol ihtiyacının \%11'ünü karşılayan İran'ı gözden çıkarması oldukça zordur. Çin, Ortadoğu'ya olan bağımlılığını azaltarak, ABD'nin deniz egemenliği stratejisine ve ABD'nin Ortadoğu'da ki enerji hâkimiyetine karşı kendini güvene almaya çalışmaktadır. Bu anlamda Orta Asya kaynakları Çin için büyük bir öneme sahiptir.

\section{5 Çin- Rusya Rekabeti}

Komünist ideoloji konusunda görüş ayrılığına düşen iki ülke, son yıllarda ortak çıkarları doğrultusunda işbirliğini hızla artırmaktadır. Özellikle, Şanghay İşbirliği Örgütü ile son zamanlarda gelişen ilişkileri dikkat çekicidir. (Akçadăg, 2009) Çin, ABD'nin tek kutuplu dünya düzenine tepkiyi artırmak ve Orta Asya'da etkinliğini artırmak için Rusya'yı kendi saflarında tutup işbirliğini artırmak istemektedir. Rusya açısından Çin, siyasi olarak etkinliğini artırmasına katkı sağlayacak, enerji, silah satışı ve güvenlik konularında yararlanabileceği bir ülkedir. (Denker, 2000) Rusya, 2005-2009 dönemindeki silah ihracatının \%69'unu Asya ve Pasifik ülkelerine yapmıştır. Rusya, Çin'e en çok silah ihraç eden ülkedir. (Çınar, 2010)

Rusya ile Çin arasında özellik tek kutuplu sisteme karşı çok kutupluluğu savunma anlamında önemli birliktelikleri vardı. Sınır sorunlarına çözüm bulmak için oluşturulan daha sonra askeri tatbikatlar yapma kararı da alan Şangay İşbirliği Örgütü Rusya ile Çin’i birbirine yaklaştırmıştır. Şangay İşbirliği Örgütü çerçevesinde Rusya ve Çin bölgede güvenliği sağlama konusunda önemli adımlar atmışlardır. Aynı zaman da İran konusunda da ambargo kararlarına iki ülke uzun süre karşı çıkmışlardır. Sınır sorunları çözmek ve tek kutuplu dünya düzenine tepki vermekle başlayan dialog süreci, Çin'in artan enerji talebinin Rusya nezdinde de yarattığı imkânlar ikili ilişkileri sistematik bir işbirliği modeline dönüştürmektedir. (Alkın ve Atman, 2006). Çin'in artan enerji talebi, Rusya ile olan ilişkilerini daha üst boyuta taşımakla kalmayıp, bir yandan geçmişten süre gelen, 
diğer yandan yeni ortaya çıkan sorunların çözülmesini de teşvik etmektedir.

Rusya Avrupa pazarından yeterince ekonomik kazanç sağlamakta ve bu şekilde doğu-batı enerji koridorunu elinde tutmaktadır. Ayrıca, enerji talebi artan Doğu Pazarı'na da doğalgaz-petrol satmak istemektedir. Rusya'nın doğu pazarına yönelmek istemesi, Rus-Çin enerji işbirliğini daha kolay hale gelmektedir. Çin, Orta Asya'da etkin bir güç olan Rusya'ya enerji güvenliği için ihtiyaç duymaktadır. Orta Asya ülkeleriyle yapılan ikili anlaşmalar Rusya'yı enerji güvenliği konusunda by-pas etmeye yetmez. Çin, Orta Asya doğal kaynaklarından daha fazla yararlanmak isterken, Rusya bu süreçte önemli bir tedarikçi olduğu kadar aracı görevi de görmektedir.

Rusya'nın enerji kaynakları, artan enerji ihtiyacı karşılama da Çin için oldukça önemlidir. Aralık 2009 itibariyle 2 bin 757 km'si kullanıma sokulan Doğu Sibirya-Pasifik Okyanusu Petrol Boru Hattı (ESPO), 2013 yılında tamamlandığında $4070 \mathrm{~km}$. ile dünyanın en uzun petrol boru hattı olacaktır. Rusya'nın petrol yataklarını, Çin'in kuzeydoğusundaki petrol üretim merkezi Daqing'e bağlayacak olan ESPO'nun Çin bölümü enerji alanında iki ülkenin işbirliğini artıracaktır. (Çolakoğlu, 2010) Rusya, 2010'da CCin'den gelecekte yapacağı petrol sevkiyatı için 25 milyar dolarlık kredi almıştır. (Russia Opens China Pipeline For Siberian Oil, 2010)

Bölge enerji kaynaklarının ulaşımını sağlamak hususunda her ne kadar Rusya ile işbirliği yapsa da Çin, Rusya'nın nakil hatları üzerindeki etkisini kırmaya çalışmaktadır. Bu sebeple Çin, Altay DBH projesini askıya almış, Orta Asya Doğalgaz Boru Hattı Projesi’ni geliştirmiştir. Özbekistan, Türkmenistan ve Kazakistan’ın doğalgaz vereceği hattın kapasitesi 40 milyar $\mathrm{m}^{3}$ 'ü bulurken, Rusya'nın Rusya - Altay Doğalgaz Boru Hattı projesi askıya alınmıştır. Bu projenin gerçekleşmemesinde etkili olan unsur ise Rusya ve Çin'in doğalgaz fiyatında anlaşamaması olurken, Orta Asya Doğalgaz Boru Hattı Projesi ile Çin, Orta Asya doğalgazına Rusya'ya ihtiyaç duymadan ulaşabilme şansını yakalamıştır. (Okur, 2009)

Medvedev'in 27 Eylül 2010'daki Çin ziyareti, Mayıs 2008'de göreve gelmesinin ardından Çin'e yaptığı ikinci resmi ziyarettir. Ziyaret esnasında iki ülke, petrol, doğalgaz, kömür, enerji kaynaklarının etkili kullanımı, yenilebilir enerji kaynakları, nükleer enerjinin barışçıl amaçla kullanılması ve elektrik şebekesi gibi alanlarda bir dizi işbirliği belgesi imzalamıştır. Ayrıca terörizm, bölücülük ve köktendincilikle mücadeleyle ilgili bir işbirliği protokolü de imzalanmıştır. Rusya'nın devlet doğalgaz şirketi Gazprom, anlaşma ile 30 yıl süreyle yılda 30 milyar $\mathrm{m}^{3}$ doğalgaz sağlanmasının hedeflendiğini bildirmiştir. (Rusya-Çin arasında yeni enerji koridorları, 2010)

Kazak petrolü ve Türkmen doğalgazı alıcısı olan Çin, uzun zamandır bu ülkelerin doğal kaynaklarının dünyaya pazarlama tekelini elinde bulunduran Rusya'nın stratejik çıkarlarını zayıflatacaktır. Orta Asya enerji kaynakları konusunda Çin'in yaptığı hamleler sonucu ortaya çıkmakta olan rekabet Rusya'yı oldukça tedirgin etmektedir. (İşyar, 2010) Çin, Rusya'nın istikrarıyla ilgilenmesine rağmen Rusya'nın bölgede güçlenmesini istememektedir. $\mathrm{Bu}$ durum iki ülkenin gelecekte büyük bir rekabete girmesine yol açma ihtimali bulunmaktadır. Rusya ve Çin için Orta Asya'nın önemine değinmek gerekirse; Orta Asya, Rusya için hayati bir bölge olup, adeta bir arabanın motoru değerindedir. Çin için ise, arka bahçe bir tampon niteliğindedir. (İşyar, 2009) Bölgede ekonomik olarak güçlenmekte olan Çin, yakın gelecekte Rusya'nın en etkin ve birincil siyasi nüfusa sahip olduğu Orta Asya'da Rusya'nın yerini alabilecek konuma sahiptir. (Gürbüz, 2010)

\section{Sonuç}

Çin son yıllarda Rusya'yla kurduğu işbirliğiyle bölgeye girerek bölgede doğal kaynaklar olmak üzere ekonomik olarak büyük konuma sahip olmuştur. Çin günden güne Türk Cumhuriyetleri'nde yaptığı yatırımlar ve kurduğu ortaklıklarla daha etkili olmaktadır. Doğal kaynakların keşfi ve çıkarılma çalışmaları başta olmak üzere birçok sektör için bölge ülkelerine krediler vermektedir. Yine, alt yapı çalışmaları olmak üzere bölge de her alan da çalışmalar yürütme ve sürekli güçlenmektedir. Türkmenistan ve Kazakistan'a bu konu da daha çok önem verdiğini görmekteyiz. ABD ve Rusya ile çatışmaktan kaçınmakta ancak milli menfaatlerini konusunda da dikkatli davranıp stratejik hamleler yapmaktadır.

Çin'in ekonomik olarak Türk Cumhuriyetleri’yle iş birliğini geliştirmektedir. Rusya'yı ekonomik ve siyasi olarak dengeleyerek, Türk Cumhuriyetleri'nin Rusya’ya alternatif olarak aradığı bir güç olarak ortaya çıkmaktadır. Ancak ilerleyen zamanlarda bu gücün altında kalmaları ve güçlü devletlerin arasında seçim yapma durumuna düşmeleri takdirde Türk Cumhuriyetleri için seçimi zor bir durumun ortaya çıkması mümkündür. Ayrıca Çin'in insan kaynağı fazlası ile Orta Asya doğal kaynak fazlalığı ve nüfuz yoğunluğunun az olması gelecekte Türk Cumhuriyetlerine önemli bir baskı oluşturmaya müsaittir. Uygur bölgesinden geçen boru hatları ile Çin, bu bölgeyi yumuşak karnı haline getirerek bölgeyi tamamen içselleştirmiş olmaktadır.

Rusya, ABD, Türkiye ve İran arasında Orta Asya petrol-doğalgazı üzerinde yaşanan rekabete Çin'in de yatırımcı ve petrol-doğalgaz müşterisi olarak katılması, yeni büyük oyunu alevlendirerek, rekabeti hızlandıracaktır. Türk Cumhuriyetleri’nin petrol ve doğalgazının doğuya yönelişi, Türkiye üzerinden geçen hatlara daha az doğal kaynağın akmasına yol açacaktır. 


\section{Kaynakça}

- $\quad$ British Petrolium, Dünya Devi Çin Enerji Tüketiminde de Lider, 2011.

http://www.bp.com/genericarticle.do?categoryId=9018433\&contentId=7069637, (15.07. 2011), Enerji Enstitüsü, http://enerjienstitusu.com/2011/05/22/dunya-devi-cin-enerji-tuketiminde-de-lider/, (22.05.2011) ve detaylı bilgi için bkz; British Petrolium, www.bp.com/statisticalreview" target="_blank" (12.08.2011)

- H. Naci Bayraç, 2010. "Küresel Enerji Politikaları ve Türkiye”, http://www.turksam.org/tr/a1909.html. (12.03.2011).

- Kerem Alkın ve Sabit Atman, 2006. Küresel Petrol Stratejilerinin Jeopolitik Açıdan Dünya ve Türkiye Üzerindeki Etkileri, (Haz.), İTO Yayınları, Yayın No:2006-48, İstanbul.

- $\quad$ Stratejik Araştırmalar Enstitüsü, Üretici Ülkelerin Petro-Politiği 2010-2025, http://www.turksae.com/sq1_file/366.pdf, (15.07.2011)

- Olgan Bekar, 1995, “Çin ve Batı Türkistan”, Avrasya Dosyası Çin Özel, C.2., S.2., s.48.

- Celaleddin Yavuz, "Türkiye ve Asrın "Stratejik”Enerji Hatlarına Gelinen Aşama”, http://www.enerji2023.org/index.php?option=com_content\&view=article\&id=275:tuerkye-ve-asrin-qstratejkq-enerjhatlarina-gelnen-aama\&catid $=15$ : stratej\&Itemid $=\overline{1} 26,(10.07 .2011)$

- $\quad$ Nuriye Hidayet Ekrem, 2003. Çin Halk Cumhuriyeti Dış Politikası (1950-2000), Uzakdoğu-Pasifik Araştırmalar Dizisi:4, ASAM Yayınları, Ankara.

- Ömer Göksel İşyar, 2010. Avrasya ve Avrasyacılık, Dora Yayıncılık, Bursa.

- Barış Adıbelli, 2008. Avrasya Jeopolitiğinde Büyük Oyun, IQ Kültür Sanat Yayıncılık, İstanbul.

- Mehmet Dikkaya, 2010. "Çin-Orta Asya İlişkilerinde Doğal Gaz Faktörü ve Muhtemel Bölgesel Sonuçları”, http://www.usak.org.tr/makale.asp?id=1321. (22.03.2011)

- Celalettin Yavuz, 2009. "Rusya-Türkiye Yakınlaşması: Jeopolitik Bir Değerlendirme”, Jeopolitik, Yı1: 8, Sayı:65, İstanbul.

- Hasan Selim Özertem, 2008. “Kazakistan: Ekonomik Kalkınma ve Boru Hatları Siyaseti”, http://www.usak.org.tr/makale.asp?id=789. (09.01.2011)

- Ahmet Davutoğlu, 2004. Stratejik Derinlik Türkiye’nin Uluslararası Konumu, 17. Baskı, Küre Yayınları, İstanbul.

- Sedat Laçiner, 2005. Ermeniler Bir Uluslararası İlişskiler Çalışması, USAK Yayınları, Genişletilmiş 2.Baskı, Ankara.

- Mert Bilgin, 2010. "Yeni Asya’nın Enerji Paradigmasında Orta Asya ve Kafkaslar: Rusya, AB, ABD, Çin, İran ve Türkiye Arasındaki Açmazlar ve Stratejik Aç1lımlar”, http://www.stratejikongoru.org/makaleler/103-yeni-asyann-enerji paradigmasnda-orta-asya-ve-kafkaslar.html. (08.02.2011).

- Göktürk Tüysüzoğlu, 2010. “Orta Asya'da Çin Etkinliği ve Küresel Oyun”, http://www.stratejikboyut.com/haber/ortaasyada-cin-etkinligi-ve-kuresel-oyun--29654.html. (11.05.2011)

- Mehmet Dikkaya, 2009. Orta Asya ve Kafkasya Dönüşüm Süreci ve Uluslararası Ekonomi Politik, Beta Yayınları, İstanbul.

- CNNTürk, Türkmenistan-İran doğalgaz boru hattı açıld1, 2010. http://www.cnnturk.com/2010/ ekonomi/dunya/01/06/turkmenistan.iran.dogalgaz.boru.hatti.acildi/558167.0/index.html. (01.08.2011)

- Haber 7, Çin'den Türkmenistan'a 4.1 Milyar \$Kredi, http://www.haber7.com/haber/20110426/Cinden-Turkmenistana41-milyar-kredi.php, (14.07.2011)

- Selçuk Çolakoğlu, 2010. "Çin'in Orta Asya ve Kafkasya Politikası”, Orta Asya ve Kafkasya Rekabetten İşbirliğine, Tayyar Arı, (Der.), MKM Yayıncılık, Bursa.

- Mehmet Dikkaya ve Ali Bora, 2006. "Çağdaş Kazakistan'ın Ekonomi Politiği ve Türkiye'nin Yeri”, OAKA., C.I., S.2., Ankara, ss.110-127., http://www.usak.org.tr/dosyalar/dergi/2UY4CqNBcpY6XBe5SlCleeqEcVIOUp.pdf. (12.08.2011)

- Zaman, Çin'den Kazakistan'a 13 Milyar \$ Kredi, 2010, http://www.zaman.com.tr/haber.do?haberno=995249, (15.07.2011)

- $\quad$ Necdet Pamir, 2008. “Küresel Enerji Görünümü Karadeniz ve Hazar Denizleri Arasında Konumlanan Türkiye'nin Rolü”, http://www.tankstorageinternational.compdf08Pamir.pdf, (12.08.2011)

- Haberler,Kazakistan-Çin Petrol Boru Hattından Çin'e 12 Milyon Ton Petrol Sevk Edildi, 2009 http://www.haberler.com/kazakistan-cin-petrol-boru-hattindan-cin-e-12-haberi/. (12.08.2011)

- Açık İstihbarat, Sincan, Pekin için ne kadar değerli, 2009. http://www.acikistihbarat.com/Haberler.asp?haber=8028. (12.08.2011)

- $\quad$ TRT, Kazakistan'dan Çin'e Yeni Doğalgaz Hattı, 2010 http://www.trt.net.tr/haber/HaberDetay.aspx?HaberKodu=6cbafcc1-35c2-4e4e-a1a6-39ddbe9d1ba0. (12.07.2011).

- China Embassy, Çin-Kazakistan ortak bildirisi: İlişkiler "kapsamlı stratejik ortaklık" düzeyine çıkarıldı, 2011, http://www.chinaembassy.org.tr/tur/xwdt/t830392.htm, (10 Temmuz 2011)

- Sedat Laçiner, 2006a. "Hazar Enerji Kaynakları ve Enerji-Siyaset İlişkisi”, OAKA, C.1., S.1., Ankara, ss. 36-66. , http://www.usakgundem. com/ makale/61/enerjide-bat\%C4\%B1-tekeli-kalkarken-yeni-bir-akt\%C3\%B6r-olarak\%C3\%A7in-hindistan-ve-japonya.html. (18.07.2011).

- World Trade Organization, Trade Profiles Kazakhstan, 2009, http://stat.wto.org/CountryProfile/WSDBCountryPFView.aspx?Language=E\&Country=KZ, (15.07.2011) 
- Türkiye-Türkmenistan, Türkmenistan'1n En Fazla İthalat Yaptığı Ülke Türkiye, 2011, http://turkiyeturkmenistan.com/News.aspx?id=202, (12 .07.2011)

- $\quad$ Muharrem Ekşi, 2009. “Enerjinin Önemi ve Büyük Güçlerin Enerji Politikaları”, Mostar, Y11:5, Sayı:50, ss. 51-53.

- Stratejik Boyut, Çin ve İran Arasında Dev Ortaklık, 2010, http://www.stratejikboyut.com/haber/cin-ve-iran-arasindadev-yakinlasma--40746.html, (18.07.2011)

- Sedat Laçiner, 2006b. "Enerjide Batı Tekeli Kalkarken: Yeni Bir Aktör Olarak Çin, Hindistan ve Japonya”, http://www.usakgundem.com/makale/61/enerjide-bat\%C4\%B1-tekeli-kalkarken-yeni-bir-akt\%C3\%B6r-olarak\%C3\%A7in-hindistan-ve-japonya.html. (20.07.2011).

- BBC, Chris Hogg, 2010. "Çin'in İran’a Yaptırım Çelişkisi”, http://www.bbc.co.uk/turkce/haberler/2010/07/100730_china iran_sanctions.shtml. (12.08.2011)

- Emine Akçadağ, 2009. "Yükselen Güç Hindistan", http://www.bilgesam.org/tr/index.php?option=com_content\&view=article\&id=506:yuekselen-guechindistan\&catid=110:analizler-hindistan\&Itemid=138. (01.02.2011).

- Mehmet Sami Denker, 2000. 2000’li Yıllarda Asya Pasifik Güvenliği, Asam Yayınları, Uzakdoğu-Pasifik Araştırmaları Dizisi:1, Ankara.

- Burak Çınar, 2010. "Rus-Hint Askeri İşbirliğinin Stratejik Etkileri”, http://www.21yyte.org/tr/yazi.aspx?ID=3891\&kat1=1. (01.02.2011).

- CRİ Online, Çin-Rusya Petrol Boru Hattı projesi tamamland1, 2010. http://turkish.cri.cn/781/2010/09/27/1s128527.htm. (12.08.2011)

- $\quad$ Radikal, Rusya'dan Çin'e ilk petrol akmaya başladı, 2011.

http://www.radikal.com.tr/Radikal.aspx?aType=RadikalDetayV3\&ArticleID=1034894\&Date=02.01.2011\&CategoryID $=81$. (08.06.2011).

- $\quad$ Financial Times, Russia Opens China Pipeline For Siberian Oil, 2010. http://www.ft.com/intl/cms/s/0/dd89374a-b38c11df-81aa-00144feabdc0.html?ftcamp=rss\#axzz1STKuVVZl, (18 Temmuz 2011)

- Hürriyet, Rusya Çin'e uzanan kritik boru hattını açt1, 2010. http://www.hurriyet.com.tr/ekonet/15669318.asp. (07.06.2011).

- Eren Okur, 2009. "Enerji Kaynakları ve Orta Asya'nın Geleceği”, http://www.bilgesam.org/tr/index.php?option=com_content\&view=article\&id=433:enerji-kaynaklar-ve-orta-asyanngelecei\&catid=83:analizler-ortaasya\&Itemid=149. $(12.08 .2011)$

- $\quad$ BBC, Rusya-Çin arasında yeni enerji koridorları, 2010. http://www.bbc.co.uk/turkce/haberler/2010/09/100927_china_russia.shtml. (27.09. 2010)

- Ömer Göksel İşyar, 2009. Karşılaştırmalı Dış Politikalar Yöntemler Modeller Örnekler ve Karşılaştırmalı Türk Dış Politikası, Dora Yayınları, Bursa.

- Vedat Gürbüz, (2010), Rekabetten İşbirliğini Türk-Rus İlişkileri, Zaman, 12.01.2010. 


\title{
Orta Asya'da Büyük Oyun: Kırgızistan
}

\author{
Tevfik Orçun Özgün (Hacettepe University, Turkey) \\ Meral Uçmaz (Hacettepe University, Turkey)
}

\section{The Great Game in Asia: Kyrgyzstan}

\begin{abstract}
Marked the 19th Century, "The Great Game" which took place between Great Britain and Imperial Russia, has determined the fates of many other nations. In practical sense, the term is expired in the first quarter of the 20th Century. States of Central and Southern Asia, involved in the strategic plans of Great Powers focused their interest to Central Asia in the 20th Century. Especially, after the collapse of the Soviet Union the strategicially important Kyrgyzstan has become an area of struggle between the United States, Russia, and strategically rising China in order to hold economic concessions. This paper tries to handle the strategic games played internationally on Kyrgyzstan addressing the reference frame of "The Great Game".
\end{abstract}

JEL Code: F59

\section{Giriş}

Kırgız kelimesi ilk olarak M.S. VIII. yüzyılda yazılmış olan Orhon yazıtlarında geçmektedir. Çin kaynaklarına göre Kırgızların anavatanı Güney Sibirya'da Yukarı Yenisey havzasıdır. M.Ö. II-I. yüzyıllarda Tanrı Dağları ile Tannu-Ola arasındaki bölgede Kien-ku adında bağımsız bir devlet kuran Kırgızlar bu devletin yıkılmasıyla siyasi hâkimiyetlerini kaybetmişlerdir. Yüzyıllarca göçebe bir yaşam süren Kırgızlar bugün Issık Göl havalisinde, Tekes, Talas ve Çu ırmaklarının yukarı taraflarında, Altay, Pamir, Tanrı Dağlarında yaşamaktadırlar (Gömeç, 1999).

Kırgızlar, VI. yüzyılın sonlarından itibaren Çinliler tarafından Hakas ismi ile anılmıștır. 1700'lü yıllarda Kalmuk, Cungar, Oyrat baskılarından dolayı Altayların kuzeyindeki yerlerini terk ederek Tanrı Dağlarına göç etmişlerdir. XVIII. yüzyılın başında Hokand Hanlığı'nın yönetimine giren Kırgızlar, bu hanlıkta nüfusun önemli bir kısmını teşkil ettikleri için, başta ordu olmak üzere, devletin çeşitli kurumlarında söz sahibi olmuşlar, 1876'da Hokand Hanlığı ortadan kaldırılmış ve Kırgızlar Rus hâkimiyetine girmişlerdir. Ruslar Kırgızları hâkimiyetleri altına alınca onları Kırgız adını verdikleri Kazaklardan ayırt etmek için Kara-Kırgız olarak adlandırmışlardır (Barthold, 1986).

Uzun süre Çarlık Rusyasının hâkimiyetinde yaşayan Kırgızlar için 1985 yılında Gorbaçov'un SSCB'nin başına geçmesiyle birlikte bağımsızlık için, bütün Orta Asya Halklarında olduğu gibi bir umut ışı̆̆ı doğmuştur. 31 Ağustos 1991 yılında Askar Akayeviç Akajev başkanlığında Kırgızistan bağımsızlığını ilan etmiştir. Akayev yeni kurulan bağımsız Cumhuriyetin başına geçtikten sonra 21 Aralık 1991'de diğer dört Orta Asya Cumhuriyeti ile birlikte Bağımsız Devletler Topluluğu'na resmen katılmıştır. 1992'de Kırgızistan, Birleşmiş Milletler ve Avrupa Güvenlik ve İşbirliği Teşkilatı'na katılmıştır.

\section{Büyük Oyun}

Klasik anlamda Orta Asya üzerinde Büyük Britanya ve Rusya arasında cereyan eden mücadelenin adı olan Büyük Oyun 1813 yılındaki Rus-İran Antlaşması ve takiben 1907 yılındaki İngiliz-Rus Antlaşmasıyla ikinci aşamasına girmiş, II. Dünya Savaşı sırasında gerçekleşen Rus-İngiliz ittifakıyla son bulmuştur. İngiliz Doğu Hint Kumpanyası'nda görevli bir subay olan Arthur Conolly'e ithafen kullanılan bu kavram halen Orta Asya üzerinde yapılan mücadeleleri tanımlayabilmektedir (Hopkirk, 1992).

İran ve Türkistan sahası üzerindeki mücadeleler birçok çalışmanın nesnesidir. Orta ve Güney Asya devletleri aynı kıtada dahi bulunmamasına rağmen diplomatik ve askeri mücadele veren Büyük Britanya gibi bir gücün başka bir güç Rusya ile rekabetine sahne olmuşlardır. Büyük Britanya'nın Hindistan Yolunu güvence altına alma kaygısı ile Rusya'ya karşı gerçekleştirdiği Asya siyaseti günümüzde yerini başka bir siyasi aktörün Amerika Birleşik Devletlerinin Asya politikasına bırakmıştır. Rusya ve Amerika Birleşik Devletleri arasında cereyan eden Soğuk Savaş ve Büyük Oyun hattının aynı hizada olması da bu durumu özel hale getirmektedir.

Kırgızistan'ın siyaset sahnesindeki önemi sahip olduğu jeopolitik konumunun Orta Asya'da yarattığı birtakım durumlardır. Kırgızistan komşuları Özbekistan ve Kazakistan'ı sıkıntıya sokabilecek su kaynaklarına sahiptir. Kırgızistan coğrafi konumu itibariyle Kazakistan, Özbekistan, Tacikistan gibi zengin doğal kaynaklara sahip ülkeleri ve Çin Halk Cumhuriyeti arasında bir köprü konumundadır.

\section{Amerika Birleşik Devletleri Açısından Kırgız Jeopolitiği}

Kırgızistan toprakları Amerika Birleşik Devletleri’nin Afgan savaşında kullandığı stratejik bir üs 
konumundadır. Amerika Birleşik Devletleri'nin 2011 yılının Ekim ayında Afganistan'ı işgal ettiğinde Kırgızistan Manas Hava Üssü ABD ve Koalisyon güçleri için bir geçiş bölgesi haline gelmiştir. Bu durum aynı zamanda Amerika'nın genel Orta Asya politikaları arasında sayılabilir. Askeri ve enerji alanlarında amaçladığı çıkarlara ulaşabilmek için bölge ve Kırgızistan üzerindeki Rus ve Çin etkilerini bertaraf etmek gibi stratejiler de ABD'nin uyguladığı politikalardır. ABD’nin bağımsızlıklarını kazanan Türk devletlerine yukarıda bahsedilen nedenlerden ötürü yaklaşımı Özbekistan ve Kırgızistan'da askeri hava üssü açmasıyla sonuçlanmıştır.

Amerika Birleşik Devletleri'nin 11 Eylül saldırılarından sonra Kırgızistan'da askeri üs kurmasına karşılık olarak Rusya da Kırgız topraklarında yeni askeri üssü tesis etmiştir. Bununla beraber Çin de Kırgızistan ile askeri işbirliği kurmuştur. Bu bağlamda Kırgızistan, ABD ve AB'nin bölge üzerindeki mevcut dengeyi kendi tarafına çekmesi ihtimaline karşı Çin ve özellikle Rusya yanlısı bir politika gütmüştür. Kırgızistan Cumhurbaşkanı Askar Akayev'in Rusya yanlısı bir politika izlemesi Kırgızistan Dışişleri Bakanı Cengiz Aitmatov’un ABD’nin Kırgızistan'da AWACS sistemini kurmasını kabul etmemesi gibi sonuçlar doğurmuştur. Bu durum ABD'nin Kırgızistan politikasını etkilemiştir. Bunu ABD’nin E-3 Keşif Uçağını konuşlandırmasına karşı duruş ve Rusya'nın 2005'te Kant üssünü askeri olarak güçlendirmesi izlemiştir. Sınırları dâhilinde iki büyük gücün sahip olduğu üsler Kırgızistan üzerindeki mücadelenin en bariz göstergesidir. ABD’nin ve NATO'nun Afganistan'da Taliban ve El Kaide'ye karşı yürüttüğü politika Rusya açısından da önem arz etmektedir keza bu politikada olası bir başarısızlık durumunda İslamî radikallerin Orta Asya sınırına yaklaşma ihtimali bulunmaktadır (Ekrem, 2005).

\section{4 Çin'in Orta Asya Politikaları Kapsamında Kırgızistan}

ABD ve Rusya’nın üs kurmasına izin veren Kırgızistan, mevcut dengelerin bozulmasına zemin hazırlamıştır. Güç dengelerinin bozulması Büyük güçlerin mevcut çıkarlarının Kırgız iç siyasetine yön veren iç dinamiklere etki etmesi ülke içi çatışmalara sebep olmaktadır. Bu durum, ABD ve Rusya'nın Kırgızistan üzerindeki etkisi Çin’i de Orta Asya politikası ve çıkarları gereği Kırgızistan'a müdahale etmesi sonucunu doğurmuştur.

Rusya ve ABD’nin Orta Asya ve Kırgızistan mücadelesi, ABD’yi Orta Asya'da en büyük rakibi olarak gören Rusya'yı Çin'e karşı yakınlaşmaya itmiştir. Şangay İşbirliği Örgütü ve AEİÖ zemininde gerçekleşen bu yakınlaşma Orta Asya ülkeleri ve Kırgızistan ilişkileri açısından önem arz etmektedir. Çin'in Orta Asya ülkeleriyle gerçekleştirmeye gayret ettiği ekonomik ilişkiler enerji kaynakları, tekstil malzemeleri ve ucuz Çin mallarını içermektedir. Kazakistan ve Türkmenistan ile kurulmaya çalışılan ekonomik ilişkiler Kırgızistan ve Tacikistan ise Çin malları için pazar konumundadır. Bu cihetle sınır bölgelerine pazarlar oluşturulmaktadır.

Kırgızistan'ın en büyük ve en güçlü komşusu olan Çin Halk Cumhuriyeti Orta Asya'da bazı güvenlik politikaları göz etmektedir. Bu durum Kazakistan, Özbekistan gibi devletlerle Çin ile arasında köprü olan Kırgızistan'ı da etkilemektedir. Çin ekonomik gelişimini sağlaması hususunu güvenli bir bölgesel ortam koşuluna bağlı olduğunu kabul etmiştir. $\mathrm{Bu}$ nedenle bölgenin istikrarının sağlanması ve güvenliğinin oluşturulması ve korunması, ekonomik anlamda işbirliği ve ikili ilişkilerin kurulmasını gerektirmektedir. Bu nedenle 1997 yılında ilk kez Asya-Pasifik ülkelerinin güvenliğini koruma altına alma fikrini ortaya atan ASEAN Bölgesel Forumu Güven Artırıcı Önlemler Konferansı düzenlenmiştir. Aynı dönemde Rusya ve Çin arasında imzalanan "Çok Kutuplu bir Dünyanın ve Yeni bir Uluslararası Düzenin Kurulmasına İlişkin Ortak Deklarasyon" yukarıda bahsedilen içerikte başka bir örnek anlaşmadır. Ülkeler arasındaki meselelerin kuvvet ya da güç tehdidine başvurulmadan barışçıl yollardan çözümü, karşılıklılık temelinde güven, yarar, eşitlik ve işbirliği Çin'in güvenlik anlayışının temelini oluşturmaktadır. Çin'in 1996-2001 yılları arasında oluşturduğu, güvenlik anlayışı Şangay İşbirliği Örgütü gibi toplantılarda da arz edilmiş ve Orta Asya, Güneydoğu Asya ülkeleri tarafından kabul görmüştür. Bu güvenlik anlayışının temelinde askerî kuvvet devletlerarası meselelerin çözümünde meşru bir araç olmaktan kalkmakta, nükleer silahların caydırıcılığına karşı durulmakta ve işbirliğine dayalı güvenlik kavramı yer almaktadır (Ekrem, 2005).

Şangay İşbirliği Örgütü ise yukarıda bahsedilen güvenlik anlayışının olgunluk sürecinin henüz başında 1996 yılında Çin sınırlarının güvenlik meselelerine çözüm getirmek amacıyla Rusya, Kazakistan, Kırgızistan ve Tacikistan'ın oluşturduğu Şanghay Beşlisi adı verilen oluşumdur. Süreç içinde 1999 yılına gelindiğinde örgüt Orta Asya'da güvenlik ve ekonomi temelinde kurulu bir içeriğe sahip bir yapıya sahip olmuştur. Bunu takip eden dönemde 2002 yılında Çin ilk yurtdışı askeri tatbikatı Kırgızistan ile yapmıştır. 2003 yılında ise Rusya, Kazakistan, Kırgızistan ve Tacikistan ile birlikte Kazakistan ve Doğu Türkistan'da gerçekleştirdiği tatbikatları 2005 ve 2007 'de Rusya, 2006 yılında Tacikistan ile yaptığı tatbikatlar izlemiştir. Şangay İşbirliği Örgütü Orta Asya'da ABD'ye karşı bir tutum sergilemeye başlamış bunu 2005 yılında Astana'da gerçekleştirilen toplantıda ABD’nin Orta Asya'daki güçlerini geri çekmesi gerektiği belirtilmiştir.

Tüm bu güvenlik oluşturma ve bunu muhafaza etme çabalarına rağmen dini radikalizm, terörizm ve etnik ayrım son bulmamıştır. Bunun çok çarpıcı örneği Kırgızistan'da yaşanan toplumsal olaylar, çatışmalar olarak karşımıza çıkmaktadır. 


\section{Rusya'nın Orta Asya Politikası ve Kırgızistan}

Kırgızistan komşuları aksine önemli yer altı zenginliklerine ve sanayiye sahip değildir, bu durum bağımsızlığını elde etmesinden bu yana Rusya ile yakın ilişkiler kurma zorunluluğunu getirmiştir. Kırgızistan'ın Rusya ile mevcut organik bağı haricinde her hangi bir Batılı ülke ile geliştirdiği ilişkilerden söz etmek pek mümkün değildir. Bu durum Kırgızistan'ı Rusya'ya meyletmekten başka çare bırakmamaktadır.

ABD'nin Kırgızistan'daki varlığı Rusya'yı da tedirgin etmeye yetmiştir. 1941 yılında Kant'ta kurulan askeri okulun önemini kaybetmesi, Rusya'nın 2002 yılında bu bölgedeki hava alanının askeri üsse çevrilmesi aynı zamanda bölgeye yönelik ilgisinin de arttığını göstermektedir. Bu üs muhtemel hava ve terör saldırılarını savuşturmak, kontrol altına alabilmek adına kurulmuş, insan ve teçhizat yatırımı yapılmıştır. Bunun yanında Kırgızistan'da açtığı sismik, radyo sismik laboratuvarlarla Rusya bölgede etkinliğini arttırmıştır (Kamalov, 2011).

Rusya ekonomik anlamda en az münasebeti Kırgızistan ve Tacikistan ile kurmaktadır. Mevcut durumdaki dengesizliği anlatan en açık yön Kırgızistan'ın en büyük ekonomik işbirliği yaptığı ülke Rusya iken Rusya'nın ticari ilişkisi en az ülkelerden biri Kırgızistan'dır. Bu durum kaçınılmaz bağımlılığı getirmektedir. Kırgızistan ise Rus yatırımlarını askeri üslerin Kırgızistan’a devri, değişim ve dönüşüm süreçlerine katılım ile mukabele etme gayretindedir. Enerji alanında yapılan ikili anlaşmalara Gazpromneft-Aero Kırgızistan örnek verilebilir. Dastan şirketinin Rusya tarafında satın alınması da gösterir ki Kırgızistan stratejik kuruluşları Rusya’ya devri devam etmektedir (Kamalov, 2011).

\section{Sonuç}

Orta Asya ve Kırgızistan üzerinde oynanan oyunlar Büyük Devletlerin genel Asya stratejilerinin büyük çerçeveyi oluşturan küçük bir parçasıdır. ABD’nin Afganistan ve Asya politikası, Çin'in komşularıyla kurduğu siyasi ve ekonomik ilişkileri de içine alan kalkınma ve büyüme siyaseti, Rusya'nın Orta Asya devletleriyle mevcut ekonomik ve siyasi organik bağı bu çerçevede değerlendirilmesi gereken durumdur.

Kırgızistan'ın çevresindeki devletlere nazaran yeterince yer altı zenginliklerine sahip olmayışı coğrafi ve siyasi konumunu özellikle ön plana çıkartmaktadır. Bu durum ABD gibi devletler için stratejik hamleler yapmayı beraberinde getirmektedir. Kırgızistan'da kurulan üs, ABD’nin Afganistan savaşı için gerekli desteği sağlarken bölge üzerindeki hâkimiyetini de kuvvetlendirme adına önemlidir. Rusya ise Kırgızistan'dan elde edemediği kaynaklar sebebiyle ilgisiz kaldığı bu ülkeye ABD’nin yaklaşımından sonra daha fazla kayıtsız kalmamıştır. Bu da ikinci üssün Rusya tarafından Kırgızistan üzerinde kurulması manasına gelmektedir. ABD ve Rusya'nın bölge ve Kırgızistan üzerindeki faaliyetleri ikili mücadele ve çekişmelere meydan vermektedir. Çin ise bölgede yükselen bir güç olarak varlığını çevresiyle güven ortamı içinde olma ve bunu korumaya dayandırmıştır.

Kırgızistan'da meydana gelen isyanlar ve iç çekişmeler, iktidar değişimleri, Darbeler, Devrimler, çalışmamamızın haricinde bırakılmıştır. Kırgızistan'ın içinde bulunduğu buhranlı günlerden çıkışı siyasi elitlerin başarısına bağlıdır, bu hem Orta Asya ülkeleri hem Türkiye için önem arz etmektedir.

\section{Kaynakça}

- $\quad$ Barthol, W., “Khokand”, El, vol: 5, Leiden, 1986, s.29

- Gömeç, Saadettin, Türk Cumhuriyetleri ve Toplulukları Tarihi, Ankara, 1992.

- Hopkirk, Peter, The Great Game: The Struggle for Empire in Central Asia, Kodansha International, 1992 , S.1.

- Kamalov,İlyas, Rusya'nın Orta Asya Politikaları, edit: Murat Yılmaz, (Hoca Ahmet Yesevi Uluslararası Türk-Kazak Üniversitesi, İnceleme-Araştırma dizisi; yayın no: 02), Ankara 2011.

- http://www.sde.org.tr/tr/kose-yazilari/290/kirgizistanda-yeni-sivil-darbe.aspx

- $\quad$ http://www.sde.org.tr/tr/kose-yazilari/436/kirgizistan-olaylari-ve-tarihsel-dusunceler.aspx

- http://www.sde.org.tr/tr/haberler/1465/atambayev-turkiye-rusya-ve-kirgizistan-birlik-kursun.aspx 


\title{
Küresel Krizin Kırgızistan Ekonomisine Etkisi ve Türkiye Kırgızistan Ekonomik İlişskilerindeki Gelişmeler
}

\author{
S. Ridvan Karluk (Anadolu University, Turkey)
}

\section{Effects of Global Economic Crisis on Kyrgyzstan Economy and Developments in Economic Relations between Turkey and Kyrgyzstan}

\begin{abstract}
The global crisis which started in September 2008 adversely affected many global economies and also Kyrgyzstan economy. Kyrgyzstan economy which declined and experienced a severe recession in 2009 due to the crisis started recovering from the adverse effects of the crisis after 2010. What lie beneath this positive development is increased foreign exchange revenues abroad and vigor experienced in construction industry and industrial production. The recovery experienced in economies of Russia and neighbor Kazakhstan resulted in increased exports and thus increased revenues in foreign currencies obtained from foreign countries. The political disturbances experienced in Bishkek in April 2011 and ethnic conflicts experienced in southern Kyrgyzstan in June 2011, created an adverse effect on the economy. The crisis resulted in degradation of investment environment, adversely influenced the foreign investments and increased the current account deficit. These developments adversely influenced the banking sector too. The government attempted to diminish effects of the crisis through financial incentives. The budget deficit emerged as a result of crisis was attempted to be closed through support secured from International Monetary Fund (IMF). IMF, World Bank and Asian Development Bank lent great support to invigorating Kyrgyzstan economy after events of April and July. According to IMF, if political instability goes on in Kyrgyzstan in medium and long term, economic problems shall continue. Uncertainties in banking sector are amongst the main factors which increase the economic risks. Recovery of Kyrgyzstan economy is dependent on medium term financial policy measures to be applied to the economy and balancing the foreign trade.
\end{abstract}

JEL Code: F15

\section{Kırgızistan Cumhuriyeti’nin Kısa Tarihi ve Orta Asya İçin Önemi}

Kırgızistan, Kırgız ülkesi anlamına gelir. Kırgız isminin kökeni hakkında birkaç teori vardır. Bunlardan birincisi -iz eki (iki - iz=ikiz vb.) almış kırktır. Yani Kırk-ız, Kırklar'dır. Nadir Devlet’e göre ise Çağdaş Kırgız adı Türkçe'de kır - gez'mekten gelmektedir. (Nadir Devlet, s.5)

M.Ö. 2. yüzyıldan 1. yüzyıla kadar Hun egemenliğinden ayrılan Kırgız kabileleri Orta Asya'da Yenisey ve Baykal bölgelerine göçmüşlerdir. Bu bölgede M.S. 6. yüzyıldan 13. yüzyıla kadar hüküm süren ilk Kırgız Devleti olan Kaganat'1, 840 yllında ise Uygur Devletini yıkarak kendi devletlerini kurmuşlardır. Daha sonra bugün yaşadıkları topraklara gelen Kırgızlar, Karahanlılar döneminde Müslümanlığı kabul etmişlerdir. 1862'den itibaren Rusya'nın, 1919-1920 yıllarında ise Sovyet hakimiyetine girmişlerdir.

SSCB döneminde Kırgızistan 1924 anayasasıyla Rus Sovyet Federe Sosyalist Cumhuriyeti içinde Kara Kırgız Özerk Bölgesi olarak yer almış, 1925 yılında adı Kırgız Özerk Bölgesi olarak değiş̧tirilmiş, 1936 yılında Cumhuriyet ilan edilmiştir. Kırgızistan, Sovyetler Birliği’nin dağılma süreci içine girmesi üzerine 15 Aralık 1990'da egemenliğini, 31 Ağustos 1991'de bağımsızlığını ilan etmiş, 21 Aralık 1991'de diğer dört Orta Asya cumhuriyeti ile birlikte Bağımsız Devletler Topluluğu'na katılmıştır. (Yeniçeri, s.13)

Bağımsızlıktan 2005 yılına kadar Cumhurbaşkanlığı görevini Askar Akayev yerine getirmiştir. Kırgızistan'ın güneyinde Oş şehrinde başlayan ayaklanma hareketi sonucunda 24 Mart 2005 tarihinde Başkent Bişkek’te meydana gelen karışıklıklar sonunda Cumhurbaşkanı Akayev ülkeyi terk etmiş, Devlet Başkanlığı ve Başbakanlığa muhalefet lideri Kurmanbek Bakiyev getirilmiştir. (Değirmenci, s.5)

10 Temmuz 2005 tarihinde gerçekleştirilen Cumhurbaşkanlığı seçimi sonucunda Kurmanbek Bakiyev Cumhurbaşkanı seçilmiş, Cumhurbaşkanlığı adaylı̆̆ından kendisi lehine çekilen Feliks Kulov'u Başbakan olarak atamıştır. 19 Aralık 2006 da Başbakan Feliks Kulov ve Bakanlar Kurulu istifa etmiştir. Yeni Anayasa 29 Aralık 2006 da kabul edilmiş, 16 Ocak 2007 tarihinde de yürürlüğe girmiştir.

Yeni anayasanın kabul edilmesi sonrası Cumhurbaşkanı tarafından Başbakanlığa iki defa Feliks Kulov teklif edilmesine rağmen Parlamento bu teklifi uygun bulmamıştır. Aynı kişinin üçüncü kez aday gösterilmesi halinde Parlamento'nun kabul zorunluluğu bulunmasına rağmen Cumhurbaşkanı Başbakanlığa Tarım, Su ve İş̧leme Endüstrisi Bakan Vekili Azimbek İsabekov'u aday göstermiş, Parlamento'nun onaylamasından sonra İsabekov 29 Ocak 2007 tarihinde görevine başlamıştır. (Karaağaçlı, s.11) 
Bunun üzerine muhalefet, eski başbakan Feliks Kulov öncülüğünde 2007'nin ilkbaharında mitinglere başlanacağını açıklamıştır. Cumhurbaşkan Mart ayı sonunda siyasi durumun yumuşatılması amacıyla Başbakan Azimbek İsabekov'un istifasını kabul etmiş ve muhalefetin öncülerinden olan Almaz Atambaev’i Başbakanlığa aday göstererek Parlamento'dan onay almıştır.

Milletvekillerinin talebi üzerine 14 Eylül 2007 tarihinde toplanan Anayasa Mahkemesi, Kırgızistan halkına anayasa ile verilmiş hakların çiğnendiği gerekçesi ile halk oylamasına sunulmayan 29 Aralık 2006 tarihli anayasanın geçersiz olduğuna karar vermiştir. Cumhurbaşkanı tarafindan 19 Eylül 2007 tarihinde alınan karar ile anayasa değişikliğinin 21 Ekim 2007 tarihinde halk oylamasına sunulmasına karar verilmiştir.

21 Ekim 2007 tarihinde gerçekleşen halk oylamasında halkın \%76'sının oyu ile Anayasa değişikliği kabul edilmiştir. Anayasa gereği Cumhurbaşkanı görevinin sona ermesi gerekçesi ile Almazbek Atambaev’i görevden almıştır. Yeni anayasaya uygun olarak 16 Aralık 2007 tarihinde Parlamento seçimleri yapılmıştır. Seçimlere 12 parti katılmış, $\% 5$ ülke geneli ve $\% 0,5$ bölge barajını aşanlar \%47 oyla Cumhurbaşkanı öncülügünde kurulan Akyol, \%5'lik oranla Kırgızistan Komünist Partisi ve \%5'lik oyla Kırgızistan Sosyal Demokrat Partisi olmuştur. Partiler sırasıyla 71, 11 ve 8 koltuğa sahip olmuşlardır.

Parlamento'da büyük çoğunluğu elde eden Akyol Partisi eski hükümette Sanayi, Enerji ve Yakıt Kaynakları Bakanı İgor Çudinov’u Başbakanlığa aday göstermiş, Çudinov 24 Aralık 2007 tarihinde görevine başlamıştır. 2007-2009 yıllarında görev yapan Çudinov'un yerine daha sonra Daniyar Usenov atanmıştır.

$\mathrm{Bu}$ dönemde alınan kararlardan ve yolsuzlukların artmasından dolayı halkta hoşnutsuzluklar başlamıştır. 6 Nisan 2010 tarihinde Talas’ta karşı gruplar vilayet binasını basıp valiyi rehin almışlardır. 7 Nisan 2010 tarihinde Cumhurbaşkanlığı hizmet binasının (Beyaz Ev) önündeki meydanda 50 bin kişi toplanmış, protestuculara açılan ateş sonucunda100’e yakın kişi ölmüştür.

Aynı gün Beyaz Ev protestocular tarafından işgal edilmiş, Cumhurbaşkanı Bakiyev Beyaz Rusya'ya kaçmıştır. Geçici Hükümet Başkanlığına gelen Roza Otunbaeva 7 Nisan akşamı iktidarı ele geçirdiklerini duyurmuştur. 11 Nisan 2010'da ülkenin güneyinde yüzlerce kişinin ölümüne sebep olan Kırgızlar ile Özbekler arasında çatışmalar meydana gelmiştir.

27 Haziran 2010 tarihinde yapılan anayasaya halk oyuna sunulmuş ve halkın \%90,57'si anayasayı onaylamıştır. Bunun sonucunda Kırgızistan'da Parlamenter Cumhuriyet kurulmuştur. Geçici Hükümet Başkanı Roza Otunbaeva tekrar seçilmemek şartıyla 31 Aralık 2011 tarihine kadar Geçiş Dönemi Cumhurbaşkanı olarak görevde kalmıştır. Parlamento seçimlerinin tarihi 10 Ekim 2011 olarak belirlenmiştir.

Bağımsız Devletler Topluluğu (BDT) içindeki Kırgızların \%88,5’i Kırgızistan'da yaşamaktadır. Geri kalan Kırgızlar başta Özbekistan ve Tacikistan olmak üzere BDT'deki diğer ülkeler dağılmıştır. Kırgızistan'da 1999 sayımına göre nüfusun \%69,9'u Kırgız, \%13,8'i Özbek, \%12,5'i Rus, \%1,1'i Dungan, \%1,1'i Uygur, \%5,7'i diğer etnik gruplardan oluşmaktadır. Nüfusun \%75‘i Müslüman, \%20’i Rus ortodokstur.

Kırgızistan'ın resmi dilleri Kırgızca (\% 64,7) ve Rusçadır. (\% 12,5) Daha sonra Özbekçe $(13,6)$ gelmektedir.

Ülkede yerleşik Türk nüfusu (Ahıska ve Kırım Türkleri) 35.700 civarındadır. Kırgızistan’da yaşayan Türkiye Cumhuriyeti vatandaşı sayısı 6 bindir. Bağımsızlı̆̆ı izleyen dönemde Rus ve Alman kökenli Kırgız vatandaşlarının ülkeyi terk etmeye başlamışlardır.

\section{Kırgızistan Türkiye İlişskileri}

Türkiye, 16 Aralık 1991 tarihinde Kırgız Cumhuriyeti’nin bağımsızlığını tanıyan ilk ülke olmuş ve iki ülke arasında 29 Ocak 1992 tarihinde diplomatik ilişki kurulmuştur. 29 Ocak 1992 tarihli protokol uyarınca karşılıklı olarak büyükelçilikler açılmıştır. 23 Aralık 1991'de Kırgızistan devlet başkanı Askar Akayev ilk resmi ziyaretini Türkiye'ye yapmış ve bu ziyarette çok sayıda işbirliği anlaşması imzalanmıştır.

Kırgızistan ile Türkiye arasında 29 Mayıs 1991 tarihinde Ankara'da imzalanan Ekonomik ve Ticari İşbirliğine Dair Protokol ile başlayan ekonomik ve ticari ilişkiler hızla gelişmiş, 25 Aralık 1991'de Türk-Kırgız İş Konseyi oluşturulmuştur. Kırgızistan'da faaliyet gösteren sanayici ve işadamlarını bir araya getirmek amacıyla Bişkek’te Kırgızistan-Türkiye İşadamları ve Sanayiciler Birliği (KITİAD) kurulmuş, TİKA Bişkek Ofisi açılmıştır.

Bağımsızıı̆ın kazanılmasından sonra ekonomik ilişkilerdeki gelişme sonucunda Kırgızistan'da yatırım yapan Türk firmaları sayısı hızla artmıştır. Türk firmaları ağırlıklı olarak küçük ve orta ölçekli işletmelerdir. Bu işletmeler otel, firın, deri, taahhüt ve telekomünikasyon alanlarında faaliyet göstermektedir. Ülkede üstlendikleri yatırımlar arasında Coca-Cola fabrikası ve dağıtım şirketleri, Bişkek-Oş karayolu ıslah projesi, Narın ve Talas şehirlerinde 3.500 abonelik sayısal santrallerin kurulması, TV montaj ve üretimi, deri ve kürk işleme ile yağ üretim tesisleri gelmektedir.

1-2 Şubat 2011 tarihlerinde Başbakan Recep Tayyip Erdoğan ve Devlet Bakanı Zafer Çağlayan Kırgızistan’a resmi bir ziyaret gerçekleştirmişlerdir. Bu ziyaret esnasında Türkiye-Kırgızistan İş Forumu düzenlenmiştir. Kırgızistan Başbakanı Almazbek Atambayev, 28 Nisan 2011 tarihinde Ankara'da temaslarda bulunmuş ve Türkiye-Kırgızistan Ticaret ve Yatırım Forumu'na katılmıştır. Bu ziyaret sonucunda Türkiye Kırgızistan'ın 50 
milyon dolarlık borcunu silmiştir.

Atambayev, Başbakan Erdoğan ile yaptığı görüşmeyi şöyle anlatmıştır: "Tayyip Ağabeyi para vermesi için slkıştırdık. 'Beni niye sıkıştırlyorsun?' dedi. Ben de 'Başka bir ağabeyimiz yok' dedim. Tayyip Bey 50 milyon dolar borcumuzu sildi. "'(Milliyet, 28 Nisan 2011)

Atambayev, Ankara ziyaretinin ardından ülkesinde başkanlık sisteminden parlamenter sisteme geçildiğini belirterek şunları söylemiştir: "Bizim başkanlar 20 senede bir bina yapmamış, hep çalmış, çalmış. Bunun için bu sistemden vazgeçtik. Gelecekte Avrupa Birliği Türkiye'yi alır $m$ i bilmiyorum ama dileğim Ankara'dan Moskova'ya kadar bir birlik olmasıdır." Devlet Bakanı Ali Babacan ise iki ülke arasında 100 anlaşma imzalandığını, karşılıklı vizelerin kaldırılması anlaşmasının büyük önem taşıdığını açıklamıştır.

\section{Kurgızistan Ekonomisinin Genel Durumu}

Orta Asya Cumhuriyetleri'nden Kırgızistan, 5.3 milyon nüfusu ile küçük bir ülkedir. Yıllık nüfus artış hızı yüzde 1,3'tür. Okuma yazma oranı çok yüksektir. $(98,7)$ Halkın \%23'ü yüksek öğrenim kurumlarından, \%75,3'ü orta öğrenim okullarından mezundur. Ülkede Manas, Atatürk Ala-Too, İktisat ve Girişimcilik Üniversitesi, Türk Dünyası Kırgız-Türk Sosyal Bilimler Enstitüsü olmak üzere dört Türk üniversitesi, Türkiye'den işadamlarının desteklediği Araşan İlahiyat Fakültesi, Anadolu Kız Meslek Lisesi, Anadolu Lisesi ve Sebat Eğitim Kurumlarına ait 14 lise bulunmaktadır.

Kırgızistan bağımsızlığını kazandıktan sonra dış ticaret politikalarını liberalleştirmeye başlamış, 1998 yılında BDT ülkeleri arasında Dünya Ticaret Örgütü (WTO) üyesi olan ilk ülke olmuştur. Ülke küresel dünyanın tüm önemli uluslararası ekonomik kuruluşlarına üyedir: BM, AGIT, Avrupa Atlantik Ortaklık Konseyi (AAOK), ECO, İKÖ, Dünya Bankası, IMF, ILO, Avrupa Kalkınma ve İmar Bankası (EBRD), Uluslararası Sivil Havacılık Teşkilatı (ICAO), UNIDO, WHO, UNESCO, Uluslararası Finans Kuruluşu (IFC), İslam Kalkınma Bankası, Uluslararası Enerji Ajansı, Asya Kalkınma Bankası, BM Asya Pasifik Ekonomik ve Sosyal Komisyonu (ESCAP), Dünya Ticaret Örgütü, Bağlantısızlar Örgütü (gözlemci). (Karluk, s.355)

2010 yılındaki ulusal geliri 4,6 milyon, kişi başına düşen geliri ise 846 dolardır. Dünya ticareti içindeki payı 0,02 'dir. Kırgızistan'da sınırlı miktarda petrol ve doğal gaz rezervi bulunmakta ve iç talebin ancak \%12'sini karşılamaktadır. Kömür kaynakları yetersizdir. Elektrik enerjisi üretimi Kırgızistan'daki temel endüstrilerden biridir. Elektrik hidroelektrik santrallerinde üretilmekte ve düşük fiyattan tüketiciye sunulmaktadır.

2009 yılında elektrik fiyatlarının iki kat artmasına halk büyük tepki göstermiş, 2010 yılında halk ayaklanmasının nedenlerinin biri olmuştur. Ülke hidroelektrik kaynakların genişliği bakımından Rusya ve Tacikistan'ın ardından BDT ülkeleri arasında üçüncü sıradadır. Tien Şan dağlarındaki buzulların erimesiyle yıllık 55.000 Gigawatt saatlik bir potansiyel oluştuğu tahmin edilmektedir.

Uluslararası Para Fonu'nun verilerine göre Kırgızistan ekonomisi 2010 yılı dışında makul bir büyüme hızına ulaşmıştır. 2000- 2011 döneminde sadece 2010 yılında büyüme hızı negatif $(-1,4)$ olmuştur. Kırgızistan'ın 2007 yılından sonra büyüme hızının düşmesi, küresel krizin sonucudur. IMF'nin 2011 yılı için $\% 5$ öngörüsü, krizin etkilerinin ortadan kalkmaya başlamasının bir göstergesidir. (IMF, Regional Economic Outlook)

Kırgızistan'da fiyatlar son yıllarda artış eğilimine girmiştir. Bu artışta, küresel krizin etkisi büyük olmuştur. 2008 yılında, 1998 Rusya krizinden sonraki en hızlı fiyat artışı yaşanmıştır. Bunda en büyük etken \%40'lara ulaşan gıda fiyatlarındaki sıçramadır. Kırgızistan'da yiyecek fiyatlarının enflasyon sepeti içindeki payı \%58 civarındadır.

Ülkede ekmek ve unlu ürünlerde yıllık enflasyon oranı \%62,6, hayvansal ve bitkisel yağlarda $\% 49,3$ civarındadır. Fiyat artışları 2009 ve 2010 da tek haneye düşmüştür.

Ekonominin sağlıklı bir yapıya kavuşması için enflasyonla mücadele birinci önceliktir. IMF petrol ve gıda fiyatlarında bu yıl \%15 ile \%18 oranında bir artış öngörmektedir. IMF'nin bu yılki enflasyon beklentisi ise \%10 civarındadır. (IMF, Public Information Notice)

GSMH'nın yüzdesi olarak kamu mali dengesi 2008 yılı dışında devamlı eksi değerdedir. Bu durum Kırgızistan ekonomisinin kırılgan bir yapıda olduğunu göstermektedir. GSMH'nın yüzdesi olarak kamu brüt borcundaki azalma olumlu bir gelişmedir.

GSMH'nın yüzdesi olarak cari işlemler dengesinin giderek artması, Kırgızistan'ın önemle üzerinde durması gereken bir sorundur. Avrupa Birliği'nin bazı ülkelerinde ortaya çıkan krizin tüm dünyaya yayılması durumunda dış denge sorunu ülkeler bu muhtemel krizden çok daha çabuk etkilenebilirler. GSMH'nın yüzdesi olarak toplam brüt dış borcun azalma eğiliminde olması ise olumlu bir gelişmedir. 


\begin{tabular}{|c|c|c|c|c|c|c|c|}
\hline & $\mathbf{2 0 0 0 - 0 5}$ & $\mathbf{2 0 0 6}$ & $\mathbf{2 0 0 7}$ & $\mathbf{2 0 0 8}$ & $\mathbf{2 0 0 9}$ & $\mathbf{2 0 1 0}$ & $\mathbf{2 0 1 1}$ \\
\hline GSMH Büyüme Hızı (\%) & 4.1 & 3.1 & 8.5 & 7.6 & 2.9 & -1.4 & 5.0 \\
\hline Tüketici Fiyatları (\%) & 6.5 & 5.6 & 10.2 & 24.5 & 6.8 & 7.8 & 18.8 \\
\hline $\begin{array}{c}\text { Kamu Mali Genel Dengesi } \\
\text { (GSMH'nın Yüzdesi) }\end{array}$ & -5.6 & -2.1 & -0.3 & 0.0 & -3.6 & -6.5 & -8.9 \\
\hline $\begin{array}{c}\text { Toplam Kamu Brüt Borcu } \\
\text { (GSMH'nın Yüzdesi) }\end{array}$ & 103.7 & 72.5 & 56.8 & 48.5 & 58.0 & 62.6 & 59.5 \\
\hline İhracat (Milyar dolar) & 0.8 & 1.5 & 2.2 & 3.0 & 2.8 & 2.6 & 3.4 \\
\hline İthalat (Milyar dolar & 0.9 & 2.3 & 3.2 & 4.7 & 3.7 & 4.1 & 5.2 \\
\hline $\begin{array}{c}\text { Cari İşlemler Dengesi } \\
\text { (Milyar dolar) }\end{array}$ & 0.0 & -0.1 & 0.0 & -0.4 & 0.1 & -0.3 & -0.4 \\
\hline $\begin{array}{c}\text { Cari İşlemler Dengesi } \\
\text { (GSMH'nın Yüzdesi) }\end{array}$ & -0.1 & -3.1 & -0.2 & -8.1 & 2.0 & -7.4 & -8.7 \\
\hline $\begin{array}{c}\text { Toplam Brüt Dış Borç } \\
\text { (GSMH'nın Yüzdesi) }\end{array}$ & 107.1 & 77.7 & 60.2 & 45.1 & 58.2 & 68.3 & 63.6 \\
\hline $\begin{array}{c}\text { Brüt Resmi Rezervler } \\
\text { (Milyar dolar) }\end{array}$ & 0.4 & 0.8 & 1.2 & 1.2 & 1.6 & 1.7 & 1.8 \\
\hline
\end{tabular}

Tablo 1. Kirgızistan'in yıllara göre makro ekonomik dengeleri.

Kaynak: IMF, Regional Economic Outlook, May 2011

\begin{tabular}{|c|c|c|c|}
\hline & 2008 & 2009 & 2010 \\
\hline GSYİH (Milyon Som) & $185.013,6$ & $196.423,1$ & $212.177,4$ \\
\hline GSYİH (Milyon dolar, piyasa fiyatlarıyla) & $5.059,2$ & $4.579,7$ & $4.616,6$ \\
\hline Reel GSYİH Artış Oranı (\%) & 7,6 & 2,9 & $-1,4$ \\
\hline Kişi Başına (GSYİH, dolar) & 968,4 & 888 & 864 \\
\hline \multicolumn{4}{|l|}{ Enflasyon Oranı, $(\%)$} \\
\hline Tüketici Fiyat İndeksindeki Yıllık Artışı (\%) & 24,5 & 6,8 & 7,8 \\
\hline İşgücü (faal nüfus) & 2.343 .800 & 2.184 .300 & 2.216 .400 \\
\hline İşsizlik oranı $(\%)$ & 11,2 & 10,3 & 8,4 \\
\hline Yurt Dışında Çalışan İşçi Sayısı & 490.000 & 420.000 & 460.000 \\
\hline \multicolumn{4}{|l|}{ GSYİH Sektörel Büyüme Hızları (\%) } \\
\hline Tarım & 0,7 & 7,4 & $-2,8$ \\
\hline Sanayi & 14,9 & $-6,4$ & 9,8 \\
\hline Hizmet & 8,8 & 1,4 & $-4,7$ \\
\hline Diş Ticaret (Bin dolar) & 5.699 .000 & 4.475 .900 & 5.265 .500 \\
\hline İhracat & 1.641 .500 & 1.439 .000 & 2.027 .800 \\
\hline İthalat & 4.057 .000 & 3.036 .900 & 3.237 .700 \\
\hline Denge & -2.415 .500 & -1.597 .900 & -1.209 .900 \\
\hline Dünya Ticareti İçindeki Payı (\%) & 0,02 & 0,02 & 0,02 \\
\hline \multicolumn{4}{|l|}{ Ülke Toplamı İçinde Türkiye’nin Payı (\%) } \\
\hline İhracat & 2,7 & 2,5 & 1,83 \\
\hline İthalat & 2,2 & 2,4 & 2,61 \\
\hline Kamu Dış Borç Stoku (Milyon dolar) & $2.127,9$ & $2.475,6$ & $2.615,7$ \\
\hline Sabit Yabancı Sermaye Yatırımları (Bin dolar) & $653.223,2$ & $556.741,1$ & $445.962,8$ \\
\hline Emisyon Hacmi (Milyon som) & $30.559,8$ & $35.738,7$ & \\
\hline \multicolumn{4}{|l|}{ Seçilmiş Oranlar (\%) } \\
\hline İhracat/Itthalat & 40,4 & 47,4 & 62,0 \\
\hline İhracat/GSYİH & 32,4 & 31,4 & 43,0 \\
\hline İthalat/GSYİH & 80,2 & 66,3 & 70,0 \\
\hline
\end{tabular}

Tablo 2. Kırgızistan ekonomisine ilişkin ekonomik göstergeler.

Kaynak: Kırgızistan Milli İstatistik Kurumu ve Kırgız Merkez Bankası (T.C.Bişkek Büyükelçiliği) 


\begin{tabular}{|c|c|c|c|}
\hline $\begin{array}{c}\text { Kafkaslar ve Orta Asya Ülkelerinin } \\
\text { Büyüme Hıları }\end{array}$ & $\mathbf{2 0 0 9}$ & $\mathbf{2 0 1 0}$ & $\begin{array}{c}\mathbf{2 0 1 1} \\
\text { (Projeksiyon) }\end{array}$ \\
\hline Kafkaslar ve Orta Asya & 3.7 & 6.6 & 5.7 \\
\hline Petrol ve Doğalgaz İhracatçısı Ülkeler & 4.9 & 7.1 & 5.8 \\
\hline Azerbaycan & 9.3 & 5.0 & 2.8 \\
\hline Kazakistan & 1.2 & 7.0 & 5.9 \\
\hline Türkmenistan & 6.1 & 9.2 & 9.0 \\
\hline Özbekistan & 8.1 & 8.5 & 7.0 \\
\hline Ermenistan & -3.5 & 4.0 & 5.2 \\
\hline Gürcistan & -14.2 & 2.6 & 4.6 \\
\hline Kırgızistan & -3.8 & 6.4 & 5.5 \\
\hline Tacikistan & 2.9 & -1.4 & 5.0 \\
\hline Retrol ve Doğalgaz İthalatçısı Ülkeler & 3.9 & 6.5 & 5.8 \\
\hline Çin & -6.4 & 4.6 & 5.0 \\
\hline
\end{tabular}

Tablo 3. Kafkasya ve Orta Asya ekonomileri için büyüme hızları.

Kaynak: IMF, World Economic Outlook, ülke ve IMF tahminleri

Kırgızistan, $198.500 \mathrm{~km}^{2}$ yüzölçümü ile Türkiye'nin yaklaşık dörtte biri büyüklüğündedir. Ülkenin \% 6’s1 ormanlardan ve \% 4,2'si buzullardan oluşmakta, Tanrı ve Altay sıradağları ülkeyi birbirinden ayıran vadilere bölmektedir. Yüksek dağlardan çıkan düzensiz ve yüksek akış hızına sahip nehirler ulaşıma elverişli değildir. Elektrik enerjisi üretimi için kullanılan Narın, Tar, Kurşab, Talas, Alay, Çuy ve Kızılsu başlıca nehirleridir.

Kırgısiztan su kaynağı bakından zengin bir ülkedir. Bu kaynağın \%90’1 tarıma, \%7'si sanayi sektörüne, geri kalan \%3'ü ise içme suyu dahil diğer alanlara aktarılmaktadır. Ülkedeki 3.000'e yakın gölün en büyüğü 6202 km² genişliği ile dünyanın 2'nci en büyük dağ gölü olan Issık Göl'dür.

Kırgızistan'da 2,2 milyon civarındaki işgücünün \%32,4'ü tarım, \%39,5'i hizmetler, \%12,5'i sanayi sektöründe çalışmaktadır. İşsizlik oranı 2010 yılında \%8,4’tür. Kayıtlı işsizlerin \%52,7’si kadındır. Kırsal kesimde uzun dönemli işsizlik oranı \%70 civarındadır. Asgari ücret 600 Som’dur. Bişkek ve çevresi için asgari ücret 150-200 dolar arasındadır.

Küresel krize bağlı olarak artan işsizlik ve reel gelirde düşüş ülkede yoksulluğu yaygınlaştırmıştır. Ekonomik istikrarsızlığın artması sonucu 1994 yılında IMF'den ilk almıştır. 20 Aralık1998'de WTO üyesi olduğu için Orta Asya ülkeleri arasında liberal dış ticaret politikaları benimseyen ilk ülkedir.

1993 yılında ulusal para tedavüle girmiş, fiyatlar serbest bırakılmış, tarım sektöründe reform yapılmış, kamu varlıkları özelleştirilme kapsamına alınmıştır. Bu önlemler sonucunda ekonomide 1996 yılından sonra düzelme başlamıştır.

2008 ve sonrasında kriz Kırgızistan ekonomisini de olumsuz etkilemiștir. (Günal, s.29) Büyüme hızı 2009'da \%2,9'a gerilemiş ve 2010 yılında ise -\%1,4 olmuştur. IMF”ye göre 2011 yılı için büyüme hızı tahmini \%5'tir. $\mathrm{Bu}$ tahmin, küresel krizin olumsuz etkisinin giderek ortadan kalkacağının bir göstergesidir.

2010 yılında Kumtor altın madeni üretimi dışarıda tutulduğunda ulusal gelir -\%2,1 oranında gerilemiştir. Maden üretimi ile beraber değerlendirildiğinde ulusal gelirdeki düşüş -\%1,4'tür. Dünya finans krizinin ülke ekonomisine yansıması sonucunda 2010 yılında kişi başına düşen ulusal gelir önceki yıla göre \%2,7 oranında azalmıştır.

Kırgızistan ekonomisinde tarım sektörü ağırlıklı bir yere sahiptir. 2010 yılında ülkede üretilen gelirin \%18,5'i bu sektör kaynaklıdır. Ekilebilir alanların toplam yüz ölçüme oranı \%7'dir. Bu sebeple hayvancılık sektörde önemli bir yere sahiptir. Tarımsal üretimin \%55'i ev işletmelerinde gerçekleştirilmektedir.

İmalat sanayinin ulusal gelir içindeki payı \%15,97'dur. Sanayi üretiminin en önemli alt sektörü gıda işleme sanayiidir. Gıda işleme, aynı zamanda en çekici yabancı yatırım alanıdır. Sanayi üretiminin \%80’i imalat sektörü kaynaklıdır. 2010 yılında ulusal gelirin \%45,9’u hizmet üretiminden kaynaklanmıştır. Ticaret, otomobil ve özel kullanım eşyalarının tamiri $(\% 16,1)$ ile ulaştırma ve iletişim $(\% 9,1)$ diğer önemli alt hizmet sektörleridir.

Kırgızistan'da sektörde özel işletmelerin ağırlığı vardır. Ülkede 1 Ocak 2010 tarihi itibariyle 24.500 şirket faaliyet göstermektedir. Bunların \%13,1'i devlet şirketleri olup, özel şirketlerin toplamdaki payı \%69,4'tür. Şirketler Bişkek’te yoğunlaşmıştır. Şirketlerin büyük çoğunluğu küçük işletmelerdir. Orta ve büyük işletmelerin payı sirasiyla \%14,4 ve \%6,8'dir.

2009 yılında 2,48 milyar dolar olan dış borç, 2010 yılında da 2,62 milyar dolara ulaşmıştır. Bu sebeple Kırgızistan, "Çok Borçlu ve Yoksul" (Heavily Indebted Poor Countries: HIPC) gelişme yolunda olan 40 ülke arasındadır. (Alma Lucía Romero-Barrutieta, vd, s.6) 1999 yılında Dünya Bankası’na katılan Kırgızistan'ın 
yüksek dış borç yükü Paris Kulübü çerçevesinde yeniden yapılandırılmıştır. (Paris Club, s.6)

Kırgızistan, yüksek dış borcu dikkate alarak, yeni borçların mali yapısının reformuna yönelik olarak 2001 yılında uluslararası kreditör kuruluşlar tarafindan oluşturulan BDT-7 girişimine dahil olmuştur. Kırgızistan için Dünya Bankası, IMF ve Asya Kalkınma Bankası tarafından 2003-2010 dönemini kapsayan 2 milyar dolarlık Yoksulluğu Azaltma Programı geliştirilmiştir.

Bağımsızlık sonrasında Kırgızistan’da bankacılık sistemi yeniden düzenlenmiştir. Ülkedeki 22 ticari bankanın 15'i yabancı sermayelidir. Sermayesinin yarısından fazlası yabancı sermayeye ait olan 10 banka olmasına rağmen bankacılık hizmetleri gelişmemiştir. Bu sebeple nakde dayalı ekonomi ağırlıktadır.

Kırgızistan'a 1995 yılından sonra giren doğrudan yabancı sermaye miktarı 3.818 milyon dolardır. Bunun \%32,3'ü BDT ülkelerine aittir. 2010 yılında ülkeye 446 milyon dolar doğrudan yabancı sermaye girmiştir. Bu sermayenin \%32,3’ü BDT ülkeleri kaynaklıdır. 2009 yılına göre BDT ülkelerinden gelen doğrudan yatırımlar \%20'lik azalmıştır. Bunun sebebi 2010 yılında Kırgızistan'da meydana siyasi ve sosyal istikrarsızlıktır.

7 Nisan 2010 ve 10 Haziran 2010 olaylarının ekonomiye olumsuz etkisi büyük olmuştur. Uzun süre siyasi istikrarın sağlanamaması, komşu ülkeler Kazakistan ve Özbekistan kapılarının kapalı olması gibi nedenlerden dolayı ekonomide resesyon başlamış, planlanan yatırımlardan vazgeçilmiş veya ertelenmiştir. (Dikambaev, s.17)

Kırgızistan büyük ölçüde bölge ülkeleriyle ticaret yapmaktadır. Dünya ticareti içindeki payı çok azdır. İhracatı komşularının ithalat performansına bağlıdır. 1998 Rusya krizinde rublenin değerinin düşmesi sonucunda Rusya'nın ithalatındaki azalma ile Kazakistan'ın Rusya'dan ithalatı kısmak için \%200 oranında gümrük vergilerini arttırması, Kırgızistan'ın ihracatını olumsuz etkilemiştir.

Kırgızistan'ın ithalatında ilk sıradaki ülkeler Rusya $(\% 33,8)$, Çin Halk Cumhuriyeti $(\% 21,9)$, Kazakistan $(\% 12,5)$, ABD $(\% 5,9)$ ve Özbekistan'dır $(\% 3,2)$. Ülkenin ithalatında BDT ülkelerinin pay1 \%56,5 civarındadır. BDT ülkeleri, \%36'lık oranla Kırgızistan'ın en önemli ihracat yaptığ 1 bölgedir. İhracatında İsviçre \%19,1, Birleşik Arap Emirlikleri \%14,9, Rusya \%12,7, Kazakistan \%9 ilk sıralarda yer alan ülkelerdir.

Altın, 1997 yılında Kumtor madeninde üretimin başlamasından sonra ülkenin en büyük ihracat kalemi olmuştur. Altın, ülkenin ihracat gelirlerinin ortalama \%37'ni oluşturmakta, BDT ülkeleri dışına yapılan ihracatın \%32’ne denk gelmektedir. Tekstil ihracatı ağırlıklı olarak Rusya’ya gönderilen hazır giyim ürünlerinden oluşmaktadır.

Önemli ihraç ürünleri arasında kıymetli metaller (altın), organik olmayan kimyasal maddeler, tekstil ve hazır giyim, sebzeler, süt ve süt ürünleri, elektrik, meyveler, pamuk lifi sayılabilir.

Ithalatında ilk sıralarda kerosin ve benzin gibi mineral ürünler bulunmaktadır. Daha sonra giyim ve aksesuarları, ilaçlar, et ve et ürünleri (kanatlı), buğday, doğalgaz gelmektedir.

Kırgızistan, Gümrük Tarifeleri ve Ticareti Genel Anlaşması (GATT) ve Birleşmiş Milletler Ticaret ve Kalkınma Konferansı (UNCTAD) çerçevesinde oluşturulan Genel Tercihler Sistemine (GTS) dahil olduğu için GTS kapsamında tek taraflı tercihlerden yararlanmaktadır.

BDT bölgesi ülkeleriyle gerçekleştirdiği serbest ticaret anlaşmalarından sonra Rusya Federasyonu (Mart 1993), Ermenistan (Ekim 1995), Moldova (Kasım 1996), Ukrayna (Aralık 1997), Kazakistan (Kasım 1995), Özbekistan (Mart 1997), Beyaz Rusya (17 Mart 2000), Tacikistan (Aralık 2001) ve Azerbaycan (Ocak 2004) ile serbest ticaret anlaşmaları imzalamıştır.

Türkmenistan dışında tüm BDT ülkeleri Kırgızistan’ın ihracatına, Kırgızistan ise BDT ülkelerinden gelen tüm ürünlere serbest ticaret rejimi uygulamaktadır. Gürcistan ile 1997'de yapılan Ticaret ve Ekonomik İşbirliği Anlaşması 6 Ocak 2006 tarihinde yürürlüğe girmiştir. Bu anlaşma tercihli rejim içermemektedir.

\begin{tabular}{|c|c|c|c|c|}
\hline (Bin dolar) & 2008 & 2009 & 2010 & $\begin{array}{c}\text { Değişim } \\
(\%)\end{array}$ \\
\hline İhracat & 1641500,00 & 1439000,00 & 2027800 & 21,2 \\
\hline İthalat & 4057500,00 & 3036900,00 & 3237700 & 6,5 \\
\hline Hacim & 5699000,00 & 4475900,00 & 5265500 & 11,7 \\
\hline Denge & $-2416000,00$ & $-1597900,00$ & -1209900 & $-25,0$ \\
\hline
\end{tabular}

Tablo 4. Kırgızistan İstatistik Kurumu verilerine göre Kırgızistan ’ın yıllara göre dış ticareti.

Kaynak: Kırgızistan Milli İstatistik Kurumu (T.C.Bişkek Büyükelçiliği) Kırgızistan İstatistik Kurumu Temmuz ayında tarım ürünleri ihracatı kayıt dışı tahmini düzeltmeleri yapmaktadır.

\section{Türkiye ile Ekonomik ve Ticari İlişsiler}

Türkiye, Kırgızistan’ın bağımsızlığını tanıyan ilk ülkedir. Türkiye ve Kırgızistan arasında ekonomik ilişkilerinin geliştirilmesine yönelik olarak 29 Mayıs 1991 tarihinde Ankara'da Ekonomik ve Ticari İşbirliğine Dair Protokol imzalanmıştır.

Kırgızistan'da 1 milyon dolarını aşan yatırıma sahip Türk girişimci sayısı 25'tir. Kırgızistan'da 200 civarında 
KOBİ niteliğinde Türk firması ticari faaliyet göstermektedir. Türkiye'de ise 78 adet Kırgız sermayeli şirket bulunmaktadır.

Türkiye'nin Kırgızistan'da 400 milyon doları aşan yatırımı vardır. Türkiye'nin Kırgızistan'daki yabancı yatırımlar içinde payı \%12 civarındadır. Türkiye'yi ABD, İngiltere, Almanya, Güney Kore, Çin Halk Cumhuriyeti gibi diğer önemli yabanc1 yatırımcılar izlemektedir.

Ülkedeki Türk sermayeli yatırımlar içecek, bisküvi, şekerleme, çikolata gibi çeşitli gıda ürünleri yanında, mobilya, temizlik maddeleri, çay, un, tuz, şeker, boya, pvc ve plastik boru, yapı malzemeleri üretimi ile alışveriş merkezi işletmeciliği, marketçilik, bankacılık, tekstil üretimi, matbaa, turizm acenteliği, eğitim işletmeciliği ve inşaat alanlarındadır.

Bağımsızlık sonrasında ticari ilişkiler hızla artarken, 1998 ve 1999 yıllarında düşüş görülmüştür. Bu düşüşün temel sebebi, Uzakdoğu Asya'da başlayan ve daha sonra Rusya Federasyonu'nu derinden etkileyen ekonomik krizdir.

Kırgızistan Türkiye’nin diş ticaretinde \%0,05 paya sahiptir. İkili ticarette Türkiye'nin dış ticareti gerek TÜİK ve gerekse Kırgızistan Milli İstatistik Kurumu verilerine göre fazla vermiştir.

Kırgızistan Milli İstatistik Kurumu verilerine göre Türkiye, Kırgızistan’ın ithalatında Rusya, Çin Halk Cumhuriyeti, Kazakistan, ABD, Özbekistan, Beyaz Rusya, Almanya ve Japonya'dan sonra 9'ncu, buna karşılık Türkiye Kırgızistan'ın ihracatında İsviçre, Birleşik Arap Emirlikleri, Rusya, Kazakistan, ABD, Özbekistan ve Fransa'dan sonra 8'nci siradadır.

Kırgızistan ile Türkiye arasında dış ticaret 1992 yılında başlamıştır. 1994 yılında 18 milyon dolar olan dış ticaret hacmi, 1995'te 41 milyon dolar olmuş, 1996'da 52 milyon dolara ulaşmıştır. 1997 yılından sonra diş ticaret hacmi artış hızını kaybetmiştir.

1998 Rusya krizinin Kırgızistan ekonomisi üzerinde yaptığı olumsuzluk sebebiyle 1998 yılında ticaret hacmi 44 milyon dolara, 1999 yılında ise 27 milyon dolara gerilemiştir. Sonraki yıllarda ticaret hacmi artmış ve 2008 yılında en yüksek hacim olan 239 milyon dolara ulaşmıştır.

TÜİK'in 2010 yılı verilerine göre Kırgızistan ve Türkiye arasındaki ticaret hacmi 160,125 milyon dolar olmuştur. Bu yılda Türkiye'nin ihracatında \%7,7 oranında, Kırgızistan'ın ihracatında \%1,7 oranında düşüş yaşanmıştır.

Bunun sebebi, Kırgızistan'da 2010 yılı Nisan ve Haziran aylarında yaşanan halk ayaklanmasının sonucunda iş yerlerinin yağmalanması, küresel finansal kriz, ülkeden yabancı sermayenin çıkışı, sosyal ve ekonomik istikrarsızlık sebebiyle toplam talebin azalması ve petrol ürünleri fiyatlarındaki artıştır.

\begin{tabular}{|c|c|c|c|}
\hline Dış Ticaret & $\mathbf{2 0 0 8}$ & $\mathbf{2 0 0 9}$ & $\mathbf{2 0 1 0}$ \\
\hline Türkiye ile Ticaret & 136.072 & 109.374 & 121.908 \\
(Bin dolar, Milli İstatistik Kurumu *) $^{*}$ & & & \\
\hline Türkiye'nin ithalatı & 45.001 & 36.654 & 37.209 \\
\hline Türkiye'nin ihracatı & 91.071 & 72.720 & 84.699 \\
\hline Denge & 46.070 & 36.066 & 47.490 \\
\hline
\end{tabular}

Tablo 5. Kırgızistan Milli İstatistik Kurumu'na göre Türkiye Kırgızistan dış ticareti.

Kaynak: Kırgızistan Milli İstatistik Kurumu. Kırgızistan Milli İstatistik Kurumu verilerine göre Türkiye Kırgızistan dış ticaret hacmi 2010 yılında 122 milyon dolar olmuştur. Türkiye'nin Kırgızistan'a yönelik 2010 yılı ihracatı 84,6 milyon dolar, ithalat ise 37,2 milyon dolardır.

\begin{tabular}{|c|c|c|c|c|c|c|}
\hline Yıllar & $\begin{array}{c}\text { İhracat } \\
(\text { FOB) }\end{array}$ & $\begin{array}{c}\text { Değişim } \\
\mathbf{( \% )}\end{array}$ & $\begin{array}{c}\text { İthalat } \\
(\mathbf{C I F})\end{array}$ & $\begin{array}{c}\text { Değişim } \\
\mathbf{( \% )}\end{array}$ & Hacim & Denge \\
\hline 2000 & 20.572 & $-11,3$ & 2.350 & $-15,5$ & 22.922 & 18.222 \\
\hline 2001 & 17.350 & $-15,7$ & 6.350 & 168,4 & 23.657 & 11.043 \\
\hline 2002 & 24.005 & 38,4 & 17.623 & 179,4 & 41.628 & 6.382 \\
\hline 2003 & 40.862 & 70,2 & 10.906 & 38,1 & 51.768 & 29.956 \\
\hline 2004 & 74.702 & 82,8 & 13.384 & 22,7 & 88.086 & 61.317 \\
\hline 2005 & 89.530 & 19,8 & 14.113 & 5,4 & 103.643 & 75.417 \\
\hline 2006 & 132.172 & 47,6 & 27.455 & 94,5 & 159.627 & 104.717 \\
\hline 2007 & 181.311 & 37,2 & 45.020 & 64 & 226.331 & 136.291 \\
\hline 2008 & 191.351 & 5,5 & 47.974 & 6,6 & 239.325 & 143.377 \\
\hline 2009 & 140.002 & $-26,83$ & 31.446 & $-34,45$ & 171.448 & 108.556 \\
\hline 2010 & 129.227 & $-7,7$ & 30.899 & $-1,74$ & 160.126 & 98.328 \\
\hline
\end{tabular}

Tablo 6. TÜIK verilerine göre Türkiye Kırgızistan dış ticareti. Kaynak: TUIK ve Başbakanlık Kamu Diplomasisi Koordinatörülüğü 
Türkiye'nin Kırgızistan'dan ithalatı dalgalı bir seyir göstermektedir. 1994 yılında 3 milyon 940 bin dolar olan ithalat 1997'de 7 milyon 900 bin dolara çıkmış, 1998 yılından itibaren azalarak 1999'da 4 milyon 606 bin dolar ve 2000 yılında 2 milyon 350 bin dolar olarak gerçekleşmiştir. Sonraki yıllarda ithalat hızla artmaya başlamış ve 2008 yılında en yüksek seviye olan 47,9 milyon dolara yükselmiştir.

Türkiye'nin Kırgızistan'a ihracatında da benzer bir eğilim söz konusudur. 1994 yılında 15 milyon dolar olan ihracat, 1995'te 38 milyon dolara, 1996'da 47 milyon dolara ulaşmıştır. 1997'de azalış göstererek 43 milyon, 1999'da 23 milyon, 2005 yılında 14 milyon ve 2008 yılında en yüksek seviye olan 191 milyon dolara çıkmıştır.

Kırgızistan'ın Türkiye'den ithal ettiği başlıca ürünler makine, telekomünikasyon ürünleri, hazır gıdalar, motorlu taşıtlar, tekstil ve giyim eşyalarıdır. Türkiye'ye ihraç ettiği ürünler arasında ise deri, kürk mamulleri, dokumacılık hammaddeleri, hurda bakır, canlı hayvan ve hayvansal ürünler yer almaktadır.

DTM Bilgi Merkezi verilerine göre Kırgızistan'a yönelik ihracatımızda sanayi ürünleri \% $\% 99,2$ oranında yer tutarken, ithalatımızda tarım ürünleri $\% 84,1$, sanayi ürünleri ise $\% 15,8$ paya sahiptir.

Kırgızistan'ın 2010 yılında Türkiye'ye ihracatında en önemli kalem 25 milyon dolara ulaşan tarım ve hayvancılık ürünleridir. Özellikle ceviz ve kuru fasulye Kırgızistan için önemli ihraç kalemleridir. 2010 yılında pamuk talebi çok arttı̆ğ için 2009 y1lında 4'ncü sırada iken 2010 yılı 2'inci sıraya yükselmiştir. Bunun sebebi, pamuğun temel ihracaţ̧ıları olan Hindistan, Avustralya ve Pakistan'da sel ve olumsuz üretim şartları sebebiyle pamuk üretiminin azalmasıdır.

\section{Sonuç}

1991 yılında Sovyetler Birliği’nin dağılmasıyla birlikte ülke Sovyet desteğinden mahrum kalmış, özel tüketimde düşüş görülmüş ve kamu harcamaları artmıştır. Bunun sonucunda 1991-1995 döneminde ulusal gelir 1990'daki seviyesinin yarısına inmiştir. 1998 Rusya krizi ve 2007 yılında dünya piyasalarında yaşanan ekonomik kriz Kırgızistan ekonomisini büyük ölçüde etkilemiş̧tir.

Kırgızistan bağımsızlığını kazandıktan sonra piyasa ekonomisine geçiş çabaları açısından, en liberal kararları uygulayan ülkedir. Orta Asya ülkeleri içinde Dünya Ticaret Örgütü’ne (WTO) üye olan tek ülkedir. WTO üyeliği Kırgızistan'ın dış ticaret ve yatırım konularında uluslararası standartları uygulamaya başlamasını sağlamıştır.

Büyümenin yakın komşulardan gelen talebe bağlılığı, ekonominin ve dış şoklara açıklılığı, gida ve petrol fiyatlarındaki artışın tetiklediği yüksek enflasyon, kuraklıkla bağlantılı gıda ve elektrik üretiminde azalış, enerji kısıtlamaları, krizin ülke ekonomisi üzerindeki olumsuz etkilerini arttırmıştır.

Buna rağmen Kırgızistan, uluslararası piyasalarla tam olarak bütünleşmediği için krizin etkileri diğer ülkelere göre daha az hissedilmiştir.

2008'de başlayan küresel kriz, Kazakistan'ın inşaat sektöründeki hızlı büyümeyi yavaşlattığı için Kazak sermayesini itici güç olarak kullanan Kırgızistan'da durgunluğa yol açmıştır.

Kırgızistan ekonomisinde önemli yer tutan Kazak bankalarının küresel krizden etkilenmeleri Kırgızistan'a doğrudan yansımıştır. Bankacılık sisteminin yarısından fazlasını elinde tutan Kazak bankalarının sıkıntıya girmeleri Kırgızistan ekonomisini üzerinde olumsuz etki yaratmıştır.

Buna rağmen Kırgızistan bankalarının dünya bankalarıyla bütünleşme seviyesi yüksek olmadığından diğer ülkelere göre kriz ekonomi üzerinde yıkıcı olmamıştır. Kriz, 2009 yılında Kırgızistan sanayisine \%6,4'lük, dış ticaretine $\% 25,4^{\prime}$ lük azalma şeklinde yansımıştır.

Kırgızistan krize rağmen konvertibilite ve faiz oranlarında liberalizasyonu gerçekleştirmiştir ama işsizlik ülkenin temel bir sorun olmaya devam etmiştir.

Krizin olumsuz etkilerinin dışında ekonomide yapısal sorunların çözülememesi, kayıt dışı ekonominin büyüklüğü, kamunun yeterli gelir sağlamada karşılaştığı sorunlar, vergi kontrolünün sıklığı, sosyal güvenlik sisteminin iyi çalışmaması ve sosyal huzursuzluk, ülkede yoksulluğun artmasında önemli rol oynamıştır. Kırgızistan'da yoksulluk oranı \%43 olup, yoksul kesim daha çok Bişkek ve Oş şehirleri dışındaki bölgelerde geçimini hayvancılık ve çiftçilik ile sağlayanlar arasındadır.

Krizden etkilenen Kazakistan ve Rusya'da çalışan işçilerin ülkeye gönderdikleri dövizlerdeki azalma, krizin etkilerini arttırmıştır. Yurt dışından gönderilen dövizlerde 2009 yılından sonra bir artış olmasına rağmen 2008 y1lı seviyesine ulaşamamıştır.

Kırgızistan 1993 yılından bu yana IMF’ye üye bir ülkedir. Geçen süre içinde Fon Kırgızistan'a çeşitli araçlarla destek olmuştur. Uzun Dönem Taahhüt Programı (EPA) Kasım 2004 tarihinde tamamlanmış, yeni EPA Programı 2005-2010 döneminde geçerli olmuştur. IMF bu dönemde izlenen politikalardan ve ülkenin makro ekonomik performansinı olumlu bulmuştur.

Buna rağmen Kırgızistan'ın bankacılık sistemini yeniden yapılandırması ve iyi bir yönetişimi sağlaması IMF için öncellik olarak görmektedir.

Krize rağmen gelir hedefleri kısmen tutturulmuş, dış borçlar azaltılmıştır. Küresel kriz esnasında izlenen para 
ve esnek kur politikaları krizin dış şoklarının hafif atlatılmasını sağlamıştır. Fakat yapısal refomlar ve hükümetin icraatlarında saydamlığın sağlanamaması, IMF tarafından eleştirilmiştir.

IMF’nin Yoksulluğun Azaltılması ve Ekonomik Büyüme Planı (PRGF) kapsamında Kırgızistan'ın temel politika öncelikleri; makro ekonomik istikrarın sağlanması, makul bir dış borç stratejisinin oluşturulması, yeterli bir büyüme ve yapısal reformların gerçekleştirilmesi olarak belirlenmiştir.

IMF Yönetim Kurulu 20 Temmuz 2011 tarihinde üç yıl için Kırgızistan’a 66,6 milyon SDR (106 milyon dolar) tutarında Genişletilmiş Fon Kolaylığı (Extended Credit Facility: ECF) kapsamında kaynak tahsis etmiş ve bu miktarın 9,514 milyon SDR'lik kısmının (15,2 milyon dolar) kullanımını serbest bırakmıştır.

Fon'un Kırgızistan'a sağladığı bu destek programı, 2010 yılında meydana gelen iç kargaşanın ortaya çıkardığ istikrarsızlığı giderecek ve makro ekonomik istikrarı sağlayacaktır.

Kırgızistan sınırlı bir iç pazara sahiptir. Orta Asya bölgesinde merkezi konumu, bölge ülkelerine göre serbest piyasa koşullarına daha hızlı ayak uydurması, serbest bölgelerin varlığı, ülkeyi bölgeye yönelik pazara giriş stratejilerinde ayrıcalıklı bir konuma getirmektedir.

Kırgızistan, Kazakistan ve Çin Halk Cumhuriyeti gibi dünyanın en hızlı büyüyen iki ekonomisi ile komşudur. $\mathrm{Bu}$ sebeple yatırımcı için çekici bir ortam oluşturmaktadır. Ülkede ekonomik ve siyasi istikrarın sağlanması durumunda iki komşusu ile birlikte hızlı bir büyüme trendi sağlayabilir ve krizin olumsuz etkilerini daha çabuk giderebilir.

\section{Kaynakça}

- Abbas Karaağaçlı, 22.06.2010. “Kırgızistan’da İstikrarsızlık”, Bilge Adamlar Stratejik Araştırmalar Merkezi.

- Alma Lucía Romero-Barrutieta, 1 July 2011. Aleš Bulíř and José Daniel Rodríguez-Delgado, The Dynamic Implications of Debt Relief for Low-Income Countries, IMF Working Paper.

- Azamat Dikambaev, Yaz 2009. "Küresel Ekonomik Krizin Kırgız Ekonomisine Etkisi,” Turkish Policy Quarterly.

- BBC Türkçe, "Medvedev Kırgızistan'ın Talibanlaşmasından korkuyor," http://www.bbc.co.uk/turkce/haberler/2010/06/100618_medvedev_kyrgiz.shtml

- Bilge Adamlar Stratejik Araştırmalar Merkezi, Kırgızistan'da İstikrarsızlık, http://www.bilgesam.org/tr/index.php?option=com_content\&view=article\&id=715:krgzistandastikrarszlk\&catid=83:analizler-ortaasya\&Itemid $=1 \overline{4} 9$

- Bilge Adamlar Stratejik Araştırmalar Merkezi, Kırgızistan'daki Çatışmaların İç ve

- Diş Dinamikleri, http://www.bilgesam.org/tr/index.php?option=com_content\&view=article\&id=739:krgzistandaki-catmalarnc-ve-d-dinamikleri\&catid=83:analizler-ortaasya\&Itemid=149,

- Bişkek Büyükelçiliği Ticaret Müşavirliği, Kırgızistan'ın Genel Ekonomik Durumu ve Türkiye ile Ekonomik -Ticari İlişkileri, 2010, http://www.musavirlikler.gov.tr/upload/kır/rapor2010son.doc

- Central Intelligence Agency, The World Factbook: Central Asia: Kyrgyzstan, https://www.cia.gov/library/publications/the-world-factbook/geos/kg.html

- Doing Business, Ease of Doing Business In Kyrgyz Republic, http://www.doingbusiness.org/data/exploreeconomies/kyrgyz-republic

- International Monetary Fund, 20 June 2011. Press Release No. 11/245.

- International Monetary Fund, 23 May 2011. Executive Board of the International Monetary Fund, "Discussed the Ex Post Assessment of Longer-Term Program Engagement (EPA) with the Republic of Kyrgyzstan".

- International Monetary Fund, Caucasus, Central Asia Rebound, But Inflation Poses Risk, IMF Survey online, http://www.imf.org/external/pubs/ft/survey/so/2011/car042711b.htm

- International Monetary Fund, IMF Executive Board Discusses Ex Post Assessment of Longer-Term Program Engagement in the Kyrgyz Republic, http://www.imf.org/external/np/sec/pn/2011/pn1164.htm

- International Monetary Fund, IMF Executive Board Approves US\$106 Million Extended Credit Facility Arrangement for the Kyrgyz Republic, http://www.imf.org/external/np/sec/pr/2011/pr11245.htm

- International Monetary Fund, Regional Economic Outlook Middle East and Central Asia, April 11, http://www.imf.org/external/pubs/ft/reo/2011/mcd/eng/pdf/mreo0411.pdf

- International Monetary Fund, IMF Working Paper, The Dynamic Implications of Debt Relief for LowIncome Countries, http://www.imf.org/external/pubs/ft/wp/2011/wp11157.pdf

- Kırgız Cumhuriyeti Milli İstatistik Komitesi, Ocak-Şubat 2009. Kırgız Cumhuriyeti Sosyal Ekonomik 
Durumu.

- Kyrgyz National News Agency, www.kabar.kg/eng/

- Library of Congress - Federal Research Division, Country Profile: Kyrgyzstan, January 2007, http://lcweb2.loc.gov/frd/cs/profiles/Kyrgyzstan.pdf

- Mehmet Günal, 15.05.2010. “Kırgızistan Ekonomisi ve Küresel Krizin Etkileri”, İkibinyirmiüç, Sayı 109.

- $\quad$ Milliyet, 28.04.2011

- Milliyet, “Atambayev 'Tayyip Ağabey para ver' dedi Erdoğan 50 milyon dolarlık borcu sildi," http://ekonomi.milliyet.com.tr/atambayev-tayyip-agabey-para-ver-dedi-erdogan-50-milyon-dolarlik-borcusildi/ekonomi/ekonomidetay/28.04.2011/1383380/default.htm

- Nadir Devlet, 1993. Çağdaş Türkiler: Doğuştan Günümüze Büyük İslâm Tarihi, Çağ Yayınları, İstanbul.

- National Bank of The Kyrgyz Republic, www.nbkr.kg

- National Statistical Committee of Kyrgyz Republic, www.stat.kg

- Özcan Yeniçeri, 15.05.2010. "Kırgızistan'da Devrimden Devrime Giden Süreç”, İkibinyirmiüç, Sayı 109.

- $\quad$ Paris Club (2010), Annual Report 2009.

- Sébastien Peyrouse, 2007. The Economic Aspects of the Chinese-Central Asia Rapprochement, Central Asia-Caucasus Institute \& Silk Road Studies Program, A Joint Transatlantic Research and Policy Center, Johns Hopkins University, Washington.

- S. Rıdvan Karluk, 2007. Uluslararası Kuruluşlar, 6. Baskı, Beta Basım Yayın A.Ş., İstanbul.

- Silk Road Paper, Economic Aspects of the Chines - Central Asia Rapprochement, http://www.silkroadstudies.org/new/docs/Silkroadpapers/2007/0709China-Central_Asia.pdf

- T.C. Başbakanlık Dış Ticaret Müsteşarlığı, www.dtm.gov.tr

- T.C. Başbakanlık Dış Ticaret Müsteşarlığı, Kırgızistan Temel Ekonomik Özellikler Raporu, http:/www.foreigntrade.gov.tr/dtmadmin/upload/ANL/YurtDisiMuteahhitDb/tmh/program/kirgizistan/EK2.pdf

- T.C. Başbakanlık Kamu Diplomasisi Koordinatörülüğü, 2010. Türkiye Geniş Türk Coğrafyasına Yüzlerce Projeyle Destek Oluyor, Ankara.

- The World Bank, Heavily Indebted Poor Countries (40 countries), http://web.worldbank.org/WBSITE/EXTERNAL/TOPICS/EXTDEBTDEPT/0,,contentMDK:20260049 me nuPK:528655 pagePK:64166689 piPK:64166646 theSitePK:469043,00.html

- Turkish Policy Quarterly, http://www.turkishpolicy.com/

- Türk Bilimi, 2005: Kırgızistan'da Lale Devrimi, http://turkbilimi.com/?p=4038

- Türk Cumhuriyetleri Birliği, Uluslararası İşbirliği Platformu, $\mathrm{http} / /$ www.turkcumhuriyetleribirligi.com/index.php?option=com_content\&task=view\&id=12\&Itemid=26

- World Bank (çeşitli sayılar), World Development Indicators. 


\title{
Kırgızistan'ın Dıș Ticaret Sorunları
}

\author{
Cunus Ganiev (Kyrgyzstan-Turkey Manas University, Kyrgyzstan) \\ Damira Baigonushova (Kyrgyzstan-Turkey Manas University, Kyrgyzstan)
}

\section{Foreign Trade Problems of Kyrgyzstan}

\begin{abstract}
This paper aims to explore export potentials of Kyrgyzstan and proposes possible measures to increase it. Comparative factor endowment estimations show that export production of Kyrgyzstan is labor-intensive. Therefore, promotion of labor-intensive sectors of the economy is important for growth of the export. Thus, determination and promotion of relatively advantageous sectors of the economy are most important measures. In particularly promotion of textile and processing industries are characterized as significant among other sectors of the economy. Development of export potentials necessitates special state support and advisory agencies. Further acceleration of integration process with other Eurasian economies is expected to positively contribute to growth of the export. However, recent socio-political developments in Kyrgyzstan have shown that stability and provision with security are fundamental factors for development of export potentials.
\end{abstract}

JEL Codes: F11, F13, F15

\section{Giriş}

Kırgızistan'da uzun süredir dış ticaret açığı devam etmektedir. Bu gösterge, ülkenin büyüme hızına bağlı olarak ülke ekonomisi hızlı büyüdüğü dönemde çok yüksek düzeylere çıkmaktadır. Ödemeler bilançosunu göz önünde bulundurduğumuzda bildiğimiz gibi dış ticaret açı̆̆ı ya sermaye hesabı fazlasıyla karşılanır ya da dış borçlanma yoluyla. Maalesef ülkemizde siyasi ve iktisadi istikrarın süreklilik kazanamaması ve yüksek yolsuzluk nedeniyle yabancı sermaye girişi düşük düzeyde kalmakta, dolayısıyla dış borcumuz artmaktadır. Burada şunu da belirtmek gerekir ki, ülkemizin dış ticaret açığının önemli bir kısmı yabancı ülkelerde (özellikle Rusya'da) çalışmakta olan vatandaşlarımızın gönderdiği özel transferler tarafından karşılanmakta. Yani ülkemizin temel iktisadi sorunu ülke içinde istihdamı, üretimi ve dolayısıyla ihracatı istenilen düzeyde artıramamak olmaktadır.

Söz konusu iktisadi koşullarda Kırgızistan Hükümeti; Rusya, Kazakistan ve Belarus tarafından oluşturulmuş olan gümrük birliğine girmeyi planlamaktadır. Bu bağlamda sözkonusu çalışmada ülkenin dış ticaret açığı sorunu incelenerek ihracatı artırma yolları üzerinde durulacaktır.

\section{Dış Ticaret Açı̆̆ı Sorunu}

Kırgızistan 20 yıldır siyasi bağımsızlıkta yaşamaktadır. Fakat iktisadi açıdan hem üretim hem de tüketimde belli düzeyde ithalata bağımlılık devam etmektedir. Şekil 1'den görüldüğü gibi, ülkemizde ithalatın ihracattan çok büyüktür ve ülke ekonomisinin ithalattan bağımlılık sorunu önemli düzeydedir. Özellikle ekonomide önemli canlanma yaşandığı yani GSYİH senede \%8'ler civarında büyüdüğü 2007 ve 2008 yıllarında dış açık ani artarak 2 milyar dolara ulaşmıştır. 2008'de ithalat ihracatın 2 katına ulaşmıştır. Küresel krizin başlaması ve siyasi istikrarsızlıklar nedeniyle büyüme hızı çok yavaşladığı son yıllarda ise ithalatın azalması sonucunda dış açıkta düşme meydana gelmiştir. Bu durum Kırgızistan'da büyüme hızıyla ithalat arasında güçlü pozitif ilişkinin olduğunu yani büyümenin önemli ölçüde ithalattan bağımlı olduğunu tasdik etmektedir.

Bildiğimiz gibi, dış ticaret açı̆̆ı, dış ticaretin ülkede döviz kıtlı̆̆ı yarattığını gösterir. Özellikle yabancı sermaye girişinin düşük olması durumunda dış borçlanmanın artarak uzun dönemde ülke ekonomisini ciddi sorunlara karşı karşıya bırakmaması için dış ticaret açığı sorununun çözülmesi hayatidir.

Dış açık sorununu çözmede elimizde iki seçeneğimiz mevcuttur: ithalatı kısmak veya ihracatı artırmak. İthalatı kısmak; günümüz küreselleşme koşulları, DTÖ’ne üye olmamız, bazı zorunlu tüketim mallarında da iç üretim yetersizliği gibi nedenlerden dolayı hem çok zor, hem de ülke ekonomisini geri çekebileceği için çok risklidir. Bu yüzden dış rekabete ayak uydurabilecek iç üretimi artırmak ve böylece ihracatı geliştirmek ülkemizin temel iktisadi stratejisi olarak belirlenmeli ve bu konuda ciddi politikalar yürütülmelidir.

Diğer taraftan, ihracatın ekonomide sağladığı bir başka olumlu etki de, ekonomik kalkınmanın finansmanıyla ilgili bulunmaktadır. Bilindiği gibi, kalkınmanın finansmanı iki yönlü bir sorundur. Sorunun bir yönü, kalkınmanın iç finansmanı olup bu yurtiçi tasarrufların arttırılmasıyla ilgili bulunmaktadır. Sorunun bir başka yönü ise, ekonomik kalkınmanın dış finansmanıyla ilgili bulunmaktadır. Dış finansman konusunda ihracat artışından sağlanan döviz gelirleri, belirli bir kalkınma hızının gerektirdiği ithalatın finansmanında önemli bir kaynak olmaktadır (İsmail, 1970). 


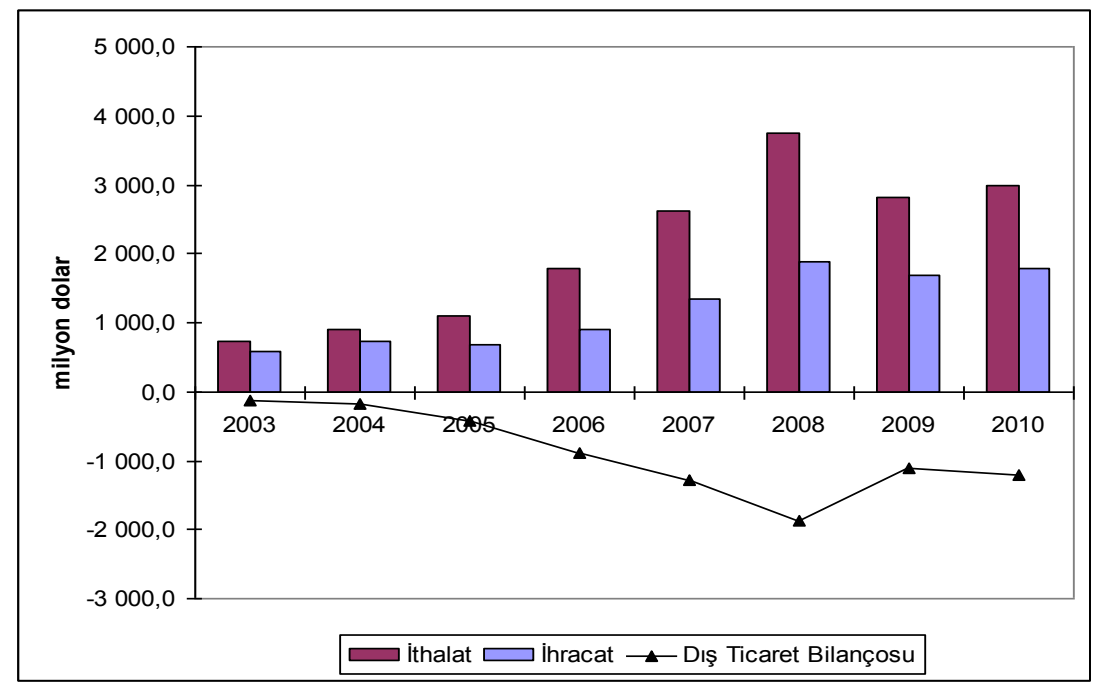

Şekil 1. Kırgızistan'da Dış Ticaret Açı̆̆ Trendi.

Kaynak: Kırgızistan Cumhuriyeti Merkez Bankası verilerinden faydalanarak çizilmiştir.

Fakat burada önemli bir noktaya değinmek gerekir. Günümüzde Kırgızistan’ın ihracatının önemli kısmını işletilmemiş tarımsal hammadde ürünleri (pamuk, fasulye, altın gibi) oluşturmaktadır. Singer-Prebish tezine göre, dış ticaret hadleri uzun dönemde tarım ürünleri, yani az gelişmiş ülkelerin aleyhine; sanayi ürünleri, yani gelişmiş ülkelerin lehine değişmektedir. Nitekim Bağımsız Devletler Topluluğu üyesi ülkelerine yapılan bir empirik çalışma da Kırgızistan dahil çoğu ülkeler için bu görüşü desteklemiştir. Milli gelir ile ihracat arasındaki ilişkiyi test eden bu çalışma sonuçlarına göre, "Moldova, Rusya Federasyonu ve Azerbaycan dışındaki tüm ülkelerin ihracat artışının milli gelir artışı üzerinde negatif etkisi olmaktadır” (Egeli, 2008). Dolayısıyla ülkede sanayileşmenin hızlandırılması gerekmektedir. İç piyasanın küçük olması nedeniyle ihracatın sanayileşmede önemi büyüktür.

\section{3 İhracatı Geliştirme Yolları}

İhracatı geliştirmek için öncelikle gelecek vaad eden sektörlerin belirlenmesi lazım. İhracatta güçlü sektörlerin belirlenmesinde; ülke içi üretimin yetersizliği, bazı kaynakların (örneğin petrol) ülkede bulunmaması, kalifiye işgücünün yetersizliği, Ar-Ge yetersizliği gibi diğer koşullar dikkate alınmadığında, temel teorik yaklaşım, yani karşılaştırmalı üstünlükler ve faktör donatımı teorisi, ülkenin faktör yoğunluğunu incelemeyi önerir. Yani, emekyoğun ülkede mukayeseli emek maliyeti düşük olduğu için emek-yoğun mallar daha ucuza üretilecek ve dolayısıyla ülkenin emek-yoğun sektörlerde rekabet gücü yüksek olacaktır. Diğer taraftan, sermaye-yoğun sektörlerde ise üretim maliyeti mukayeseli yüksek olacağı için bu tür malları ithal etmek daha rasyonel olacaktır.

Faktör yoğunluğu da mukayeseli olarak belirlendiğinden öncelikle Kırgızistan'ın temel dış ticaret ortaklarının incelenmesi gerekir. Yani ülkenin faktör yoğunluğunu tüm ticaret ortakları ile mukayese etmek yerine önemli ticaret ortaklarıyla mukayese etmek daha net sonuçlar verir kanaatindeyiz. Ülkenin dış ticaret ortaklarına baktığımızda ise, Rusya ve Kazakistan’ın, Kırgızistan'ın bağımsızlık dönemi boyunca temel dış ticaret ortakları konumunda devam ettiğini görürüz.
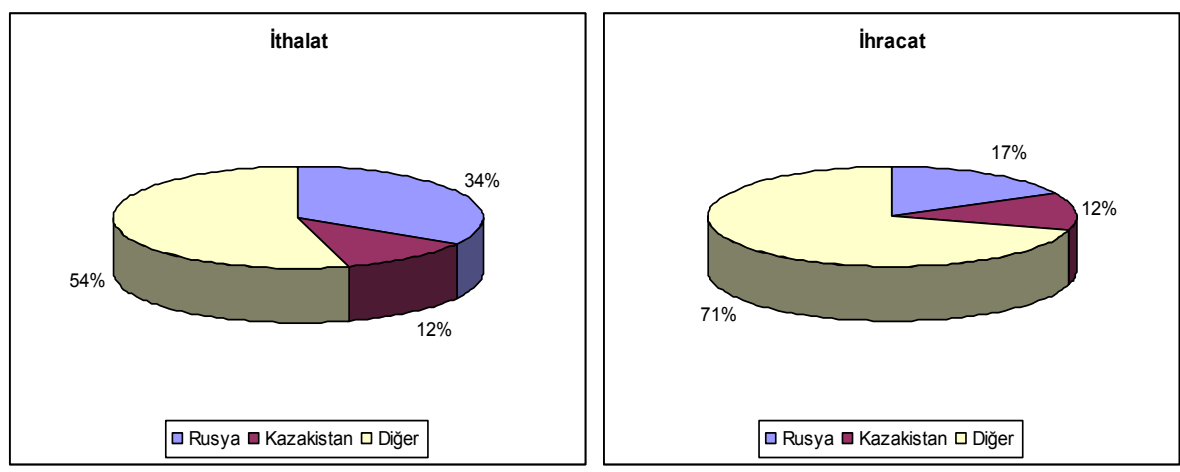

Şekil 2. 2010'da Kırgızistan 'in İthalat ve İhracatında Rusya ve Kazakistan'ın Payl, \%. Kaynak: Kırgızistan Cumhuriyeti Merkez Bankası verilerinden faydalanarak çizilmiştir.

Şekil 2'de 2010'da Kırgızistan'ın ithalat ve ihracatındaki Rusya ile Kazakistan'ın payları verilmiştir. Ülke ithalatının yaklaşık \%50'si söz konusu iki ülkeden yapılırken, ihracattaki bu ülkelerin payı \%30 civarındadır. 
Fakat burada şunu da belirtmek gerekir ki bu veriler resmi verilerdir ve bavul ticareti hariçtir. Özellikle son yıllarda Kırgızistan'da tekstil sektörünün üretiminin ve Rusya'ya ihracatının çok hızlı büyüdüğü ve önemli orana ulaştığı gözlenmektedir. Ama bu verilerin önemli kısmı kayıt dışı kalmaktadır. Yani Rusya ve Kazakistan, Kırgızistan'ın ihracatta da önemli ortaklarındandır ve ihracatı artırmadaki temel hedef piyasası durumundadır denilebilir.

Aynı zamanda söz konusu ülkeler Kırgızistan’ın girmeyi planladığı gümrük birliğinin temel üyeleridir.

Dolayısıyla Kırgızistan'ın mukayeseli faktör yoğunluğunu tespit etmede Rusya, Kazakistan ve Belarus'la karş1laştırmak uygun görülmüştür.

Faktör donatımı iki ayrı şekilde tanımlanabilir: fiziki ve ekonomik tanımlama.

Birinci yaklaşımda faktör bolluğu kavramı arz yönüyle ele alınır. Diğer bir değişle, faktör donatımı, üretim faktörlerinin fiziki miktarları ya da faktör stoku ile açıklanır. Bu yaklaşım açısından faktör donatımını belirlemek için ülkelerin sermaye stoku/ emek stoku oranlarını karşılaştırmak gerekir.

Ekonomik yaklaşımda faktör donatımı faktör fiyatları ile tanımlanır. Bu kıstas hem arz hem talep güçlerine dayanır (Seyidoğlu, 2007: 81-82). Bu yaklaşımda faktör donatımını belirlemek için sermayenin bedeli (yani faiz)/ emeğin bedeli (yani ücret) oranları karşılaştırılır.

Ekonomik yaklaşım daha güvenilir sonuçlar verir, çünkü bir ülkede örneğin sermaye bol miktarda olabilir, fakat talepten veya başka bir etkenden kaynaklanan çeşitli faktörlerden dolayı o ülkede sermaye fiyatı mukayeseli yüksek de olabilmektedir. Bu nedenle faiz/ ücret oranlarının karşılaştırılması daha uygundur.

Sonucun daha net görülmesi için faiz/ ücret oranı yerine ücret/ faiz oranı hesaplanmıştır.

Tablodaki verilere baktığımızda (tablo 1) Kırgızistan'ın diğer ülkelere göre emek-yoğun ülke konumunda olduğu apaçık görünmektedir. Yani önemli dış ticaret ortaklarımızla emek-yoğun mallarda rekabet gücümüz yüksek olacaktır. Ücret/faiz oranı, Rusya, Kazakistan ve Belarus'ta 40-55 civarında iken, Kırgızistan'da yaklaşık 10 bulunmuştur. Yani emek-yoğun sektörlerde diğer koşullar sabit varsayıldığında söz konusu ülkelere göre 4-5 katı daha fazla avantaja sahip konumdayız. Dolar cinsinden hesaplanmış ortalama ücretleri oranladığımızda da Kırgızistan'da ücretlerin diğer ülkelere göre yaklaşık 3-4 katı düşük olduğu tespit edilmiştir.

Nitekim günümüzde Kırgızistan'da tekstil sektörünün çok hızlı gelişmekte olması ve özellikle Rusya’ya yurt içinde üretilmiş tekstil mallarının önemli miktarlarda ihraç edilmekte olması bu durumun açık bir göstergesidir.

\begin{tabular}{|c|c|c|c|c|c|}
\hline & $\begin{array}{c}\text { Ortalama Kredi } \\
\text { Faiz Oranı* }\end{array}$ & $\begin{array}{c}\text { Ulusal Para } \\
\text { Cinsinden } \\
\text { Ortalama Aylık } \\
\text { Ücret }\end{array}$ & $\begin{array}{c}\text { Döviz } \\
\text { Kuru }\end{array}$ & $\begin{array}{c}\text { Ortalama } \\
\text { Aylık } \\
\text { Ücret, } \\
\text { dolar }\end{array}$ & $\begin{array}{c}\text { Ücret/ } \\
\text { Faiz } \\
\text { Oranı** }\end{array}$ \\
\hline Rusya & 14,5 & 22778,5 ruble & 28,07 & 811,5 & 55,96 \\
\hline Kazakistan & 14,9 & 84116 tenge & 145,3 & 578,9 & 38,85 \\
\hline Belarus & 11,9 & $\begin{array}{c}1648669 \\
\text { Belarus rublesi }\end{array}$ & 3013 & 547,2 & 45,98 \\
\hline Kirgizistan & 20,42 & 9233,5 som & 45,4 & 203,4 & 9,96 \\
\hline
\end{tabular}

Tablo 1. Rusya, Kazakistan, Belarus ve Kirgızistan'da Ücret/Faiz Oranları.

Kaynak: www.cisstat.com, BDT ülkelerinin resmi veri sitesi. * Illgili ülkelerin Merkez Bankaları sitelerinden alınmıştır. ** Yazarlar tarafindan hesaplanmıştır.

Demek ki, ihracatımızın gelişmesi için tekstil gibi emek-yoğun sektörlerimizin üretim ve ihracatını her taraftan desteklemek ülke ekonomisinin kalkınmasında önemli bir adım olacaktır.

Günümüz koşullarında kısa dönemde tekstil sanayi ve hafif sanayinin Kırgızistan'ın lokomotif sektörü olabilecek konumda olduğu söylenebilir.

Bu doğrultuda aşağıdaki gibi önemli durumların dikkate alınması lazım.

a) Ülkemizde tekstil sektörünün belki de en önemli zayıf taraflarının biri, girdilerin ithal malları olmasıdır. Yani ülkede dokumacılık sanayi hiç çalışmamaktadır. Bu ise bir taraftan ülkemizde yaratılan katma değeri düşürmekte, diğer taraftan ise girdi fiyatlarında artış, döviz kuru istikrarsızlığı gibi nedenlerle tekstil sektörünü risk altında tutmaktadır. Tarım sektörünü geliştirmek, dokuma sanayi gibi destek sektörlerin gelişmesini teşvik etmek amaca uygun olur.

b) Diğer bir sorun da eğitimli işgücü yetersizliği sorunudur. Firmalar işgücünü kendileri yetiştirmekte ve verimli, tecrübeli işçilerin kıt olması nedeniyle onların ücretleri yüksek olmaktadır. İşgücünün kalifiye olmaması nedeniyle ülkede hem işsizlik yüksektir, hem de işgücü bulmak zor olmaktadır. Bu çelişkili durumun aşılmasında devletin desteği hayatidir.

Öncelikle bu yönde gerekli çarelerin alınması gerekmektedir. Ayrıca, diğer ülke tecrübelerinden yararlanmakta da fayda var.

İhracat destekleri pek çok ülke tarafından çok çeşitli yollarla yapılmaktadır. Türkiye'de bu görevi yürütmede 
İGEME (İhracatı Geliştirme Etüd Merkezi)'nin rolü büyüktür.

Dünyadaki son gelişmelere bakacak olursak, kriz başladıktan sonra dünya ticaretinde hızlı bir daralma başlanmıştır. Dünya ticaretinin hızlı bir şekilde daralmasıyla pek çok ülkede ihracat destekleri gündeme gelmiştir. İhracat destekleri genel olarak dört farklı türde ortaya çıkmıştır (Kalkan ve Başdaş, 2009):

a) Mevcut kredilerin artırılması (veya yeni fonların yaratılması);

b) İhracat sigorta mekanizmalarına yönelik tedbirler;

c) İhracatta vergi iadelerinin artırılmasi;

d) Ticaret engellerinin artırılmasi.

Kırgızistan'da da bunun gibi destekler yapılabilir. Ayrıca aşağıdaki gibi öneriler sunulmaktadır:

- Emek-yoğun sektörlere finansman imkanlarının sağlanması (devlet bütçesinden kaynak ayrılarak destek amaçlı kredi kuruluşlarının kurulması),

- İşgücü yetiştirilmesinde destekçi olmak,

- Türkiye'nin tecrübelerinden yararlanmak ve gerekirse İGEME gibi devlet kuruluşu oluşturmak,

- Gelecek vaad eden sektörleri 5-10 seneye tüm vergilerden muaf tutmak,

- Yurt içi üretimin uluslararası pazarlaması ve tanıtımında destek sağlamak.

Bunun gibi çarelerin görülmesinin Kırgızistan'ın pek çok sosyal, ekonomik ve siyasi sorunlarının çözülmesine, ülkenin ekonomik güç kazanmasına yardımcı olacağını umuyoruz.

\section{Kaynakça}

- Seyidoğlu, 2007. Uluslararası İktisat. 16. Baskı. Güzem Can Yayınları No: 22, İstanbul.

- İsmail, 1970. Türkiye'de Devalüasyon Sorunu. A.Ü. Siyasal Bilgiler Fakültesi Dergisi, Cilt 25, s. 153.

- Kalkan ve Başdaş, 2009. İhracatın desteklenmesine yönelik Türkiye'nin rakiplerinin uyguladıkları kamu politikaları. TEPAV Politika Notu.

- Egeli, 2008. Bağımsız Devletler Topluluğu Ülkelerinde Milli Gelir İhracat İlişkisi. Proceedings of the International Congress 'Integration and Economic Development in Transition Economies'. Kyrgyz-Turkish 'Manas' University Publication: 106, Conference Series: 14. Bishkek-Kyrgyzstan. ss. 271-278. 


\title{
Kırgizistan ile Türkiye Arasındaki İlişsilerin Ekonomik ve Ticari Açıdan İncelenmesi
}

\author{
Semih Çetin (Hitit University, Turkey) \\ Burak Sertkaya (Hitit University, Turkey)
}

\section{An Analysis of Links between Turkey and Kyrgyzstan from Economic and Commercial Perspectives}

\begin{abstract}
Kyrgyzstan has become an attractive market because the country has a central location in Central Asia and kept pace with the free market faster than other countries in the region. Since Kyrgyzstan is a member of the World Trade Organization country become more important than the other countries in the region. In this study the recent history and the development of foreign trade relation between Turkey and Kyrgyzstan and the problems encountered in this relation are considered. Despite the growing trend of bilateral trade and economic relations since the early 90s, contraction experienced in the trade volume in 1998 and 1999 depending on the Russian crisis. Since the early 2000s, again the increasing trend of economic relations was observed. In this context by examining the trade relations between the two countries, the trade relations between the two countries are discussed and problems that encountered in the development process of the relations are investigated and solutions suggested.
\end{abstract}

JEL Codes: F10, F15

\section{Giriş}

Sovyetler Birliği’nin dağılmasıyla birlikte 1991 yılının ikinci yarısından sonra Avrasya ülkelerinin bağımsızlıklarını kazanmaları bölgenin jeopolitik ve ekonomik önemini artırmış, bu coğrafyada siyasi ve ekonomik yönden hangi devletlerin hakim güç olacağı tartışılmaya başlanmıştır. Literatürde geçiş ekonomileri olarak adlandırılan bu ülkeler hem ekonomik hem de siyasi anlamda yeniden yapılanma sürecine girmişlerdir. Bir geçiş ekonomisi olan Kırgızistan bölgenin önemli ülkelerinden biri olmak ve kalkınmayı sağlamak adına çeşitli adımlar atarak, 1998 yılında Dünya Ticaret Örgütüne üye olmuş ve bu adımla birlikte Dünya Ticaret Örgütü’ne üye olan ilk Avrasya ülkesi olarak bölge için önemli bir cazibe merkezi olma yoluna girmiştir.

Diğer yandan bu süreçte Türkiye ile Kırgızistan arasındaki ilişkiler de gelişmiştir. Türkiye, Kırgızistan'1 tanıyan ilk ülke olmuş ve 1992 yılında diplomatik ilişkiler kurulmuştur. Bu güçlü bağların kurulmasıyla 20002010 yılları arasında Kırgızistan ve Türkiye arasındaki ticaret hacmi yaklaşık \% 630 artmıştır. Türkiye'nin Kırgızistan'a olan ilgisi yatırımlarla da devam etmiş, Türkiye Kırgızistan'a yatırım yapan önemli ülkeler arasına girmiştir.

Kırgızistan ve Türkiye arasındaki ticaret hacminin daha yüksek bir potansiyel taşıdığı düşünüldüğünde, her iki ülkenin de ticaret hacmini artırması için çeşitli uygulamaları hayata geçirmesi gerekmektedir. Bu noktada her iki ülkenin de yapması gerekenler olduğunu söylemek yanlış olmaz. Fakat piyasa ekonomisine daha iyi adapte olan Türkiye'ye göre yeni ekonomik sisteme uyum sağlamaya çalışan Kırgızistan'ın yapısal sorunlarını çözmesi gerekmektedir.

Çalışmada öncelikle Kırgızistan ekonomisinin içerisinde bulunduğu ekonomik ve ticari durum ele alınmıştır. Daha sonra Türkiye ile Kırgızistan arasındaki ekonomik ve ticari ilişkiler raporlar çerçevesinde incelenerek, Kırgızistan ve Türkiye'nin ticari ve ekonomik ilişkilerinin güçlendirilmesi için yapılması gerekenler değerlendirilmiştir.

\section{Kırgizistan'ın Durumu}

Kırgızistan, 1936 yılında Sovyet yönetimi altındaki Cumhuriyetlerden biri olmuş, Sovyetler Birliği’nin 1991 yılında dağılmasından hemen sonra ise bağımsızlığını ilan etmiştir. Bu gelişmelere paralel olarak birlik altındaki ülkeler, merkeziyetçi ekonomik modelden serbest piyasa ekonomisine dayalı modele geçmiştir. Geçiş ekonomisi olarak adlandırılan bu ülkelerden birisi olan Kırgızistan da piyasa ekonomisine geçiş sürecinde diğer ülkeler gibi sorunlar yaşamıştır. Kırgızistan'ın piyasa ekonomisine geçişte uyum sorunları yaşaması mali ve ekonomik sorunları da beraberinde getirmiştir.

Temel alt yapıyı oluşturmadan hızlı bir şekilde piyasa sistemine geçmeye çalışan Kırgızistan'da bağımsızlığın ilk döneminde GSMH'da yarı yarıya bir düşüş yaşanmıştır. Bu geçiş sürecinde özelleştirmeler yapılmış, devlet ekonomi üzerindeki kontrolden kısmen de olsa vazgeçmiştir. Buna karşın güçlü ve sistemli bir iktisadi mekanizma kurulamamış ve ekonomik düşünce tam olarak piyasa ekonomisine adapte olamamıştır. Eski üretim 
yapısının ve merkezi sisteme ilişkin kurumların devam etmesi 70 yılı aşkın sosyal, kültürel ve siyasal bağların bulunması Rusya eksenli dış ticaret politikası izlenmesine sebep olmuştur (Sarsılmaz, 2003, s. 16) .

Ekonomide meydana gelen istikrarsızlıklardan sonra, Kırgızistan makro ekonomik istikrarı ve ekonomik büyümeyi sağlamak için önemli adımlar atmıştır. Buna bağlı olarak 1996'da makroekonomik durum kontrol altına alınarak, büyüme sağlanmıştır. GSMH 1996 yılında \%7, 1997 yılında ise \%9,9 $\operatorname{artmıştır(WB,~2001,~s.1).~}$ Şekil-1'de de görülebileceği gibi daha sonraki yıllarda ise GSMH artış göstermiştir. 2008 yılı itibariyle düşmeye başlayan GSMH, 2010 yılında 1996 yılından sonraki en büyük düşüşünü -\%1,3 ile yaşamıştır. Kırgızistan ekonomisi 1996 ile 2010 yılları arasında ortalama olarak \%4,6 büyüyerek aynı dönem dünya GSMH’sının ortalama büyüme hızından daha yüksek bir büyüme göstermiştir (World Bank Database).

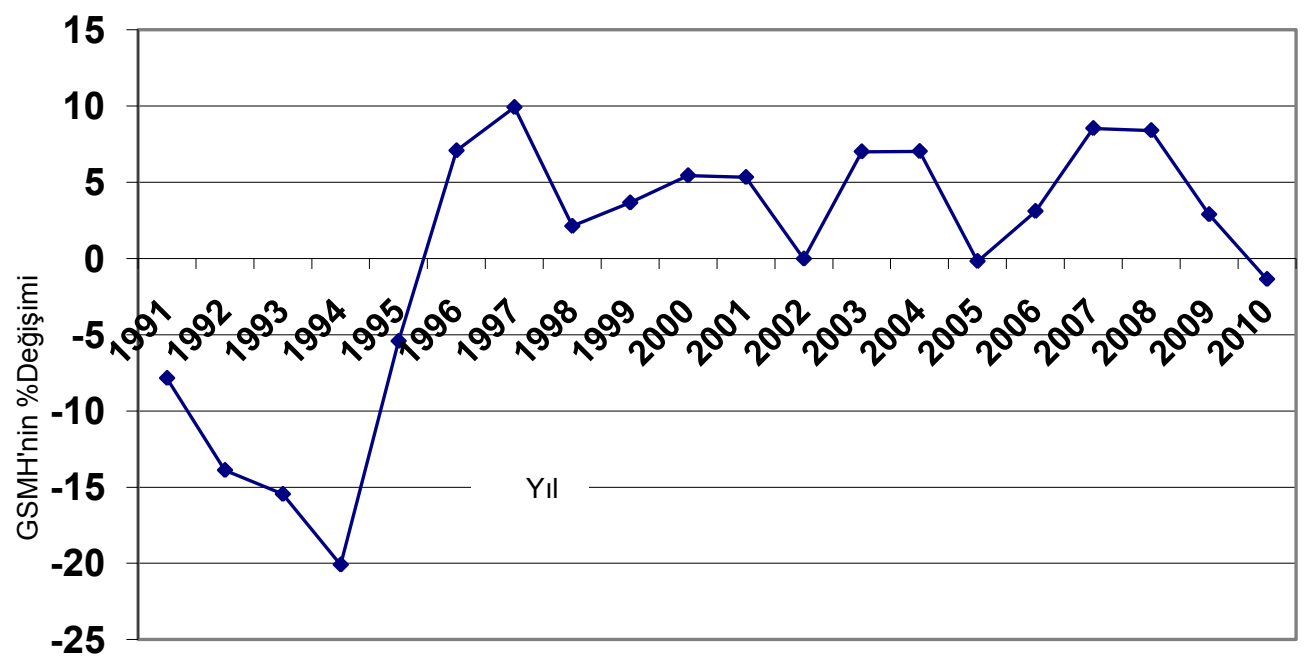

Şekil 1: Kırgızistan GSMH'sının Gelişimi (1991-2010). Kaynak: World Bank Database

Kırgızistan geçiş süreci sırasında yaşadığı sorunları aşmak ve ekonominin yeniden yapılandırılmasını sağlamak üzere IMF gibi uluslar arası kuruluşlarla birlikte destek programları oluşturmuştur. Bu kuruluşlarla birlikte yapılan reform çalışmalarının, ekonominin yeniden yapılandırılması, enflasyonun düşürülmesi, ekonomik büyüme ve piyasa ekonomisine adaptasyon gibi hedeflerin sağlanması açısından önemli katkıları olmuştur. Diğer yandan Kırgızistan'ın ekonomik yapıda gerçekleştirdiği reformlar diğer bölge ülkelerinden daha önce Dünya Ticaret Örgütü’ne üye olmasını (1998) sağlamıştır. Bu gelişme Kırgızistan’ın dışa açık kalkınma stratejisini benimsediğini gösteren diğer bir adım olarak yorumlanabilir (Egeli - Özen, 2008, s.14).

Yapılan bu çalışmalar ile birlikte ülkenin yapısal sorunlarını ortadan kaldırabilmek için mali, idari ve ekonomik sorunların da ortadan kaldırılması gerekmektedir. Bu sorunlara, düşük yatırım seviyesi, tarım ve hayvancılığın ekonomideki ağırlıklı yeri, yüksek dış borçluluk, yasadışı faaliyetlerin denetimindeki yetersizlikler örnek verilebilir.

\begin{tabular}{|c|c|c|c|c|c|c|c|}
\hline Yıllar & $\begin{array}{c}\text { Enflasyon } \\
\text { TÜFE }\end{array}$ & $\begin{array}{c}\text { İhracat } \\
\text { GSMH \% }\end{array}$ & $\begin{array}{c}\text { Ithalat } \\
\text { GSMH \% }\end{array}$ & $\begin{array}{c}\text { GSMH } \\
\text { Yllık \% }\end{array}$ & $\begin{array}{c}\text { Kişi Başı } \\
\text { GSMH } \\
\mathbf{( \$ )}\end{array}$ & $\begin{array}{c}\text { Sanayi } \\
\text { Üretimi } \\
\text { GSMH\% }\end{array}$ & $\begin{array}{c}\text { Tarım } \\
\text { Üretimi } \\
\text { GSMH\% }\end{array}$ \\
\hline 1996 & 31,95 & 30,74 & 56,56 & 7,08 & 392,44 & 18,29 & 49,75 \\
\hline 1997 & 23,44 & 38,29 & 46,19 & 9,92 & 374,15 & 22,81 & 44,61 \\
\hline 1998 & 10,46 & 36,48 & 58,03 & 2,12 & 343,12 & 22,76 & 39,53 \\
\hline 1999 & 37,03 & 42,20 & 57,00 & 3,66 & 256,77 & 24,98 & 37,68 \\
\hline 2000 & 18,70 & 41,85 & 47,58 & 5,44 & 278,66 & 31,39 & 36,75 \\
\hline 2001 & 6,92 & 36,72 & 37,02 & 5,33 & 307,81 & 28,93 & 37,29 \\
\hline 2002 & 2,13 & 39,58 & 43,34 & $-0,02$ & 321,57 & 23,34 & 37,68 \\
\hline 2003 & 2,97 & 38,68 & 45,25 & 7,01 & 380,86 & 22,32 & 37,06 \\
\hline 2004 & 4,11 & 42,56 & 51,26 & 7,03 & 434,25 & 24,13 & 33,27 \\
\hline 2005 & 4,35 & 38,73 & 57,71 & $-0,18$ & 478,25 & 22,39 & 31,95 \\
\hline 2006 & 5,56 & 41,72 & 79,03 & 3,10 & 545,86 & 20,06 & 32,77 \\
\hline 2007 & 10,18 & 44,01 & 88,53 & 8,54 & 726,40 & 19,29 & 31,08 \\
\hline 2008 & 24,52 & 55,62 & 92,10 & 8,40 & 973,86 & 19,32 & 29,23 \\
\hline 2009 & 6,86 & 49,87 & 80,76 & 2,89 & 881,36 & - & - \\
\hline 2010 & - & - & - & $-1,36$ & 860,39 & - & - \\
\hline
\end{tabular}

Tablo 1: Kırglzistan'ın Temel Ekonomik Göstergeleri (1996- 2010). Kaynak: World Bank Database 
Kırgızistan ekonomisinin 21. yüzyıldaki makro ekonomik performansı incelendiğinde, ekonomik koşulların dalgalı bir seyir izlediği söylenebilir. 1998 yılında yaşanan Rusya krizinin Kırgızistan ekonomisi üzerinde yarattığı daralmanın etkileri tam olarak geçmemişken, 2007 yılında ABD konut piyasasında baş gösteren ve sonrasında küresel çapta kendini hissettiren küresel iktisadi kriz birçok ülkede üretim ve refah kaybına neden olmuştur. Kırgızistan ekonomisi de küresel iktisadi krizden ciddi ölçüde etkilenmiştir. Bunun birlikte, 2010 yılında Kırgızistan'da görülen siyasi istikrarsızlık ve sivil kargaşa Kırgızistan ekonomisini olumsuz yönde etkilemiştir. Tablo-1'de Kırgızistan ekonomisine ait temel ekonomik göstergeler verilmiştir. Bu veriler incelendiğinde Kırgızistan ekonomisinin 2009 yılında GSMH'nın \%2,9 dolayında küçüldügüü görülmüştür. Aynı şekilde siyasi ve sosyal istikrarsızlık nedeniyle 2010 yılındaki büyüme \%-1,36 dolayında gerçekleşmiştir. Kişi başı GSMH'da ise 2009 yılında yaklaşık yüzde 10 düşüş yaşanmıştır. Bunun yanında 2009 yılında ihracatta görülen düşüş yaklaşık \%10 civarındadır. Dolayısıyla küresel iktisadi krizin Kırgızistan ekonomisi üzerine olan etkisi göz ardı edilemeyecek ölçüdedir.

\section{Türkiye İle Kırgızistan Arasındaki Ticari ve Ekonomik İlişkilerin Genel Seyri}

Orta Asya Türk Cumhuriyetleri ile Türkiye arasındaki kültür bağları bu ülkelerle ilişkilerin geliştirilmesi için uygun bir ortam sağlamıştır. Türkiye'nin teknik bilgi birikimi ve sanayileşme yolunda sahip olduğu deneyimler bu ülkeler ile Türkiye arasında işbirliğini artırmıştır. Türkiye, bağımsızlıklarını kazanmalarından sonra Orta Asya Türk Cumhuriyetleri ile çok yönlü ve özel ekonomik ilişkiler kurmaya çalışmıştır (Seyidoğlu, 1999, s.284-285).

Kırgızistan'nın ise Orta Asya Bölgesinde merkezi konuma sahip olması ve serbest bölgelerinin varlığı, Kırgızistan'ı diğer Orta Asya ülkeleri içinde farklı bir konuma getirmiştir (KTO, 2008, s.25).

\begin{tabular}{|c|c|c|}
\hline Anlaşmanın Adı & İmza Tarihi & İmza Yeri \\
\hline Ekonomik ve Ticari İşbirliğine Dair Protokol & 29.05 .1991 & Ankara \\
\hline Yatıımların Karşlıklı Korunması ve Teşviki Anlaşması & 28.04 .1992 & Bişkek \\
\hline Karma Ekonomik Komisyon Kurulmasına Yönelik Anlaşma & 16.08 .1995 & Bişkek \\
\hline Ticaret ve Ekonomik İşbirliği Anlaşması & 24.10 .1997 & Ankara \\
\hline Çifte Vergilenmeyi Önleme Anlaşması & 02.07 .1999 & Ankara \\
\hline Uzun Vadeli Ticari ve Ekonomik İşbirliği Anlaşması & 20.02 .2002 & Ankara \\
\hline Karma Ekonomik Komisyon VI. Dönem Protokolü & 05.08 .2006 & Bişkek \\
\hline
\end{tabular}

Tablo 2: Türkiye ile Kırgızistan Arasında Yürürlükte Bulunan Anlaşma ve Protokoller.

Kaynak: Bişkek Müşavirliği

\begin{tabular}{|c|c|c|c|c|}
\hline Yıllar & $\begin{array}{c}\text { Türkiye'nin } \\
\text { Kirgızistan'a İhracatı } \\
\text { (bin dolar) }\end{array}$ & $\begin{array}{c}\text { Türkiye'nin } \\
\text { Ihracatında } \\
\text { Kırgızistan'ın } \\
\text { Payı (\%) }\end{array}$ & $\begin{array}{c}\text { Türkiye'nin } \\
\text { Kirgızistan'dan } \\
\text { Ithalatı } \\
\text { (bin dolar) }\end{array}$ & $\begin{array}{c}\text { Türkiye'nin } \\
\text { İthalatında } \\
\text { Kırgızistan'ın } \\
\text { Payı (\%) }\end{array}$ \\
\hline 1994 & 16972 & 0,09 & 4294 & 0,02 \\
\hline 1995 & 38156 & 0,18 & 5512 & 0,02 \\
\hline 1996 & 47100 & 0,20 & 5878 & 0,01 \\
\hline 1997 & 49432 & 0,19 & 7555 & 0,02 \\
\hline 1998 & 41515 & 0,15 & 6772 & 0,01 \\
\hline 1999 & 23198 & 0,09 & 2779 & 0,01 \\
\hline 2000 & 20572 & 0,07 & 2349 & 0,00 \\
\hline 2001 & 17350 & 0,06 & 6307 & 0,02 \\
\hline 2002 & 24004 & 0,07 & 17622 & 0,03 \\
\hline 2003 & 40861 & 0,09 & 10905 & 0,02 \\
\hline 2004 & 74701 & 0,12 & 13383 & 0,01 \\
\hline 2005 & 89529 & 0,12 & 14112 & 0,01 \\
\hline 2006 & 132172 & 0,15 & 27454 & 0,02 \\
\hline 2007 & 181310 & 0,17 & 45019 & 0,03 \\
\hline 2008 & 191350 & 0,14 & 47974 & 0,02 \\
\hline 2009 & 140002 & 0,14 & 31446 & 0,02 \\
\hline 2010 & 129201 & 0,11 & 30899 & 0,02 \\
\hline
\end{tabular}

Tablo 3: Türkiye'nin Kırgızistan ile olan Ticari İlişkileri (1994-2010). Kaynak: Dünya Bankası, TÜIK, Kırgızistan Milli İstatistik Komitesi verileri kullanılarak hesaplanmıştır.

Türkiye ve Kırgızistan arasında ticari ve ekonomik ilişkilerin geliştirilmesine yönelik çeşitli anlaşma ve protokoller imzalanmıştır. Bunların ilki 1991 yılında Ankara’da imzalanan Ekonomik ve Ticari İşbirliğine dair protokol olmuştur. Son olarak imzalanan Karma Ekonomik Komisyon VI. Dönem Protokolü, iki ülkenin ticari potansiyellerinin ortaya çıkarılması ve sanayi, enerji, madencilik gibi alanlarda işbirliği imkanlarının 
araştırılmasına yönelik başlıklar içermektedir (Bişkek Müşavirliğii, 2008, s.44-45).

Türkiye ile Kırgızistan arasındaki ticari ilişkiler 1992 yılında başlamasından sonra 1997 yıllına kadar artan bir seyir izlemiştir. Türkiye’nin Kırgızistan'a olan ihracatı 1995-1997 yılları arasında artış eğilimi göstermesine karşın 1998 yılında düşüş trendine girmiştir. Bu dönemde iki ülke arasındaki dış ticaret hacmi önemli ölçüde azalmıştır. Bu düşüşün ana nedeni olarak 1998 yılında yaşanan ve sonrasında Orta Asya Ülkelerini de etkileyen Rusya krizi olarak gösterilebilir.

Tablo-4'den de görülebileceği gibi, Türkiye'nin Kırgızistan'ın ihracatı içerisindeki payı 1994'ten bu yana inişli çıkışlı bir seyir izlemiştir. 2007 yılında \%3,97 ile en yüksek seviyesine ulaşmış olan bu pay 2008 küresel krizi ile birlikte azalmaya başlamış ve 2010 yılında \%1,76’ya kadar düşmüştür. Kırgızistan'ın ithalatı içerisinde Türkiye'nin payı ise nispeten yüksek seyretmiştir. Türkiye'nin ithalattaki payı 2005 yılında \%8,12 ile en yüksek seviyesine ulaşmıştır. Son yıllarda bu pay \%4 civarında seyretmektedir. Diğer yandan, Türkiye'nin ihracat ve ithalatının içerisinde Kırgızistan'ın payı oldukça düşüktür.

Türkiye'nin Kırgızistan'dan ithalatının 2005-2010 dönemi arasındaki sektörel dağılımı incelenirse, Türkiye'nin ithalatında tarım ürünlerinin payının oldukça yüksek, sanayi ürünlerinin payının ise düşük olduğu görülmektedir (TÜİK, 2010).

\begin{tabular}{|c|c|c|c|c|}
\hline Yıllar & $\begin{array}{c}\text { Kırgızistan'ın } \\
\text { Türkiye'ye } \\
\text { İhracatı } \\
\text { (bin dolar) }\end{array}$ & $\begin{array}{c}\text { Kırgızistan'ın } \\
\text { İhacatında } \\
\text { Türkiye'nin Payı } \\
\text { (\%) }\end{array}$ & $\begin{array}{c}\text { Kırgızistan'ın } \\
\text { Türkiye'den } \\
\text { İthalatı } \\
\text { (bin dolar) }\end{array}$ & $\begin{array}{c}\text { Kırgızistan'ın } \\
\text { İthalatında } \\
\text { Türkiye'nin Payı } \\
\text { (\%) }\end{array}$ \\
\hline 1994 & 4294 & 1,26 & 16972 & 5,37 \\
\hline 1995 & 5512 & 1,35 & 38156 & 7,31 \\
\hline 1996 & 5878 & 1,16 & 47100 & 5,62 \\
\hline 1997 & 7555 & 1,25 & 49432 & 6,97 \\
\hline 1998 & 6772 & 1,32 & 41515 & 4,93 \\
\hline 1999 & 2779 & 0,61 & 23198 & 3,87 \\
\hline 2000 & 2349 & 0,47 & 20572 & 3,71 \\
\hline 2001 & 6307 & 1,33 & 17350 & 3,72 \\
\hline 2002 & 17622 & 3,63 & 24004 & 4,09 \\
\hline 2003 & 10905 & 1,87 & 40861 & 5,70 \\
\hline 2004 & 13383 & 1,86 & 74701 & 7,94 \\
\hline 2005 & 14112 & 2,10 & 89529 & 8,12 \\
\hline 2006 & 27454 & 3,46 & 132172 & 7,69 \\
\hline 2007 & 45019 & 3,97 & 181310 & 7,52 \\
\hline 2008 & 47974 & 2,92 & 191350 & 4,70 \\
\hline 2009 & 31446 & 2,19 & 140002 & 4,61 \\
\hline 2010 & 30899 & 1,76 & 129201 & 4,01 \\
\hline
\end{tabular}

Tablo 4: Kırgızistan'ın Türkiye ile olan Ticari İlişkileri (1994-2010). Kaynak: Dünya Bankası, TÜÍK ve Kırgızistan Milli İstatistik Komitesi verileri kullanılarak hesaplanmıştır.

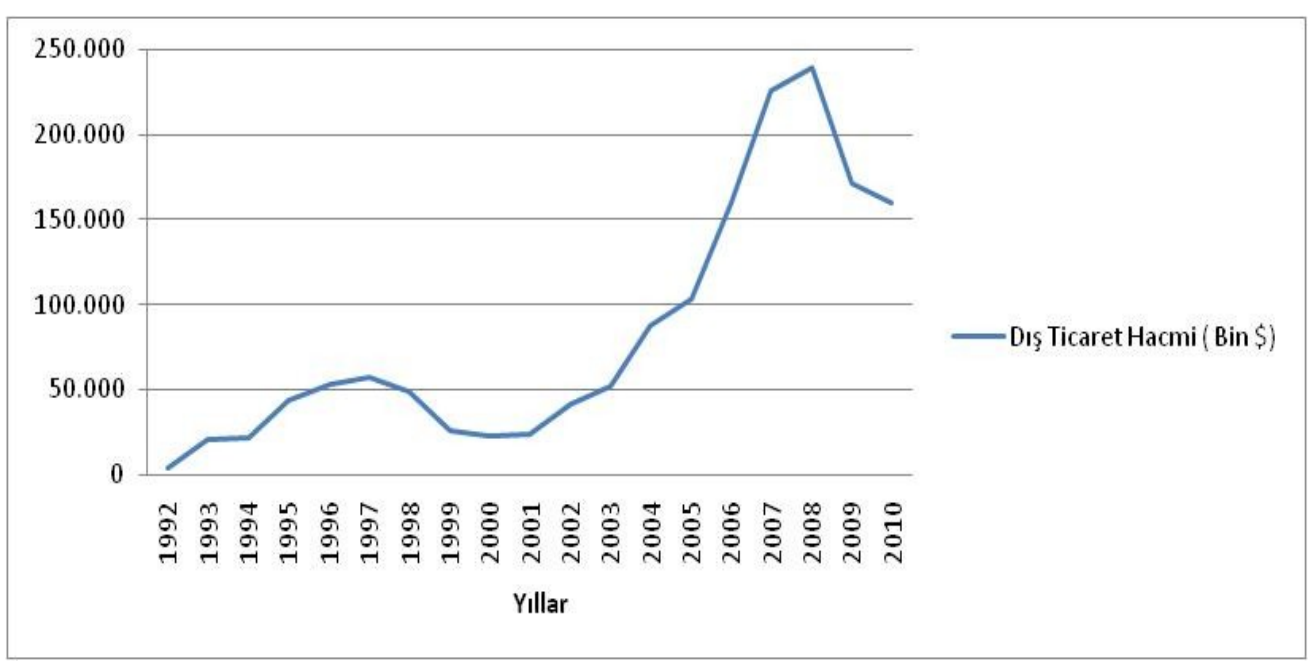

Şekil 2: Türkiye-Kırgızistan Dış Ticaret Hacmi (1992-2010). Kaynak: TÜIK

1992 yılında başlayan Türkiye ile Kırgızistan arasındaki ticaret ilişkisi sonraki yıllarda giderek artış göstermiştir. 1992 yılında 3,273 milyon dolar olan ticari hacmi 1997 yılında 56,988 milyon dolara ulaşmıştır 
(TÜİK, 2010). Fakat 1997 yılından sonra dış ticaret hacmi artış hızını kaybetmiştir. 1998 yılında 48,288 milyon dolar olan ticaret hacmi, 2000 yılında 22,921 milyon dolar seviyesine kadar gerilemiştir. Şüphesiz ki 1998 yılında yaşanan Rusya Krizi'nin hem Kırgızistan hem de Türkiye ekonomisine olumsuz etkileri olmuştur. Söz konusu gerileme 2001 yılında sona ermiş ve 2002 yılından itibaren Kırgızistan ile olan ticaret hacmi hızla yükselmeye başlamıştır. 2003 yılında ise ihracattaki artış hız kazanırken ithalatta yavaşlama görülmüştür. 2005 yılında ikili ticaret hacmi 100 milyon dolar seviyesini aşmış ve aynı şekilde 2006 yılında 159 milyon dolar olan ticaret hacmi, 2007 yılında 226 milyon dolara yükselmiştir. 2008 yılından itibaren ise küresel krizinde etkisiyle dış ticaret hacmi daralmış ve 2010 yılı itibariyle 160 milyon dolar seviyesine kadar gerilemiştir.

İki ülke arasında 1992 yılında imzalanan mutabakat zaptı kapsamında Kırgızistan Merkez Bankası'na, Türk Eximbank tarafından 75 milyon ABD doları tutarında mal ve proje kredisi açılmıştır. Toplamda 48,13 milyon dolarlık kullandırım gerçekleşmiştir. Geri ödemede yaşanan sorunlar nedeniyle Kırgızistan'nın Türkiye'ye olan yaklaşık 47 milyon dolarlık borç stoku 2005 tarihinde varılan mutabakat çerçevesinde yeniden yapılandırılmıştır. Bu kapsamda Kırgızistan kredi stoğunun \%50 oranında azaltılması kararlaştırılmıştır. Bu çerçevede Türkiye'nin Kırgızistan'a sağladığı Eximbank kredilerine ilişkin borcun ertelenmesi, Kırgızistan'ın IMF ile yürüttüğü programın uygulanması açısından önem taşımaktadır. Kırgızistan'a sağlanan mal ve proje kredileri kapsamında zirai ilaç, mobilya fabrikası makineleri, radyo-TV fabrikası makinaları, ekmek firını üretim tesisi makinaları, telekomünikasyon sistemleri ve otobüs ihracatı ile otel inşaatı projesi finanse edilmiştir (KTO, 2008, s.25).

\begin{tabular}{|c|c|c|c|c|c|c|}
\hline & \multicolumn{2}{|c|}{ Türkiye } & \multicolumn{2}{|c|}{ Kirgızistan } & \multicolumn{2}{|c|}{ Kirgizistan \% olarak } \\
\hline İhracat & $\begin{array}{l}\text { Süre } \\
\text { (Gün) }\end{array}$ & $\begin{array}{l}\text { Maliyet } \\
(\$)\end{array}$ & $\begin{array}{l}\text { Süre } \\
\text { (Gün) }\end{array}$ & $\begin{array}{l}\text { Maliyet } \\
(\$)\end{array}$ & $\begin{array}{c}\text { Süre } \\
\text { (Türkiye'nin \%'si) }\end{array}$ & $\begin{array}{c}\text { Maliyet } \\
\text { (Türkiye'nin\%'si) }\end{array}$ \\
\hline Belge Hazırlama & 6 & 220 & 23 & 210 & 383 & 95 \\
\hline $\begin{array}{l}\text { Gümrükleme ve } \\
\text { Teknik Kontrol }\end{array}$ & 3 & 200 & 3 & 200 & 100 & 100 \\
\hline $\begin{array}{c}\text { Liman ve Terminal } \\
\text { Yönetimi }\end{array}$ & 3 & 270 & 3 & 100 & 100 & 37 \\
\hline $\begin{array}{l}\text { Yurtiçi Taşımacılık } \\
\text { ve Yönetim }\end{array}$ & 2 & 300 & 34 & 2500 & 1700 & 833 \\
\hline Toplam & 14 & 990 & 63 & 3010 & 450 & 304 \\
\hline Ithalat & & & & & & \\
\hline Belge Hazırlama & 8 & 280 & 25 & 310 & 313 & 111 \\
\hline $\begin{array}{l}\text { Gümrükleme ve } \\
\text { Teknik Kontrol }\end{array}$ & 3 & 200 & 11 & 370 & 367 & 185 \\
\hline $\begin{array}{c}\text { Liman ve Terminal } \\
\text { Yönetimi }\end{array}$ & 3 & 183 & 3 & 100 & 100 & 55 \\
\hline $\begin{array}{c}\text { Yurtiçi Taşımacılık } \\
\text { ve Yönetim }\end{array}$ & 1 & 400 & 33 & 2500 & 3300 & 625 \\
\hline Toplam & 15 & 1063 & 72 & 3280 & 480 & 309 \\
\hline
\end{tabular}

Tablo 5: 2010 yılında Türkiye ve Kırgızistan'ın Karşılaştırmalı Olarak Sınırlararası Ticaret Düzenlemeleri. *Kırgızistan'ın daha iyi olduğu alanlar koyu olarak gösterilmiştir. Kaynak: Doing Bussines 2011 Turkey, Doing Bussines 2011 Kyrgyz Republic ülke raporları kullanılarak hesaplanmıştır.

Kırgızistan ve Türkiye'nin ithalat ve ihracat üzerindeki idari düzenlemeleri süre ve maliyet yönünden kıyaslandığında, Tablo 5'den izlenebileceği gibi Kırgızistan'ın belirgin biçimde Türkiye'nin gerisinde kaldığı gözlenmiştir. Özellikle yurtiçi taşımacılık alanında hem ithalatta hem de ihracatta önemli süre ve maliyet kayıpları söz konusudur. Türkiye'de ihracat yapmanın maliyeti 990\$, ihracat yapabilmek için geçen süre ise 14 gün iken, Kırgızistan'da ihracatın maliyeti Türkiye'nin \%304'ü, geçen süre ise \%450'si olarak hesaplanmıştır. Aynı durum ithalat için de geçerli olmakta Kırgızistan'da ithalatın maliyeti Türkiye'nin \%309'u, geçen süre ise \%480'idir. Yani İthalat ve ihracatta Kırgızistan’ın idari düzenlemeler noktasında aşması gereken önemli eşikler olduğunu söylemek yerinde olacaktır.

\begin{tabular}{|l|r|r|r|r|}
\hline \multicolumn{1}{|c|}{ Yatırımcı Ülkeler } & \multicolumn{1}{c|}{$\mathbf{2 0 0 6}$} & \multicolumn{1}{c|}{$\mathbf{2 0 0 7}$} & \multicolumn{1}{c|}{$\mathbf{2 0 0 8}$} & \multicolumn{1}{c|}{$\mathbf{2 0 0 9}$} \\
\hline Kazakistan & 136.387 & 182.712 & 360.966 & 213.046 \\
\hline İngiltere & 37.972 & 60.095 & 73.927 & 110.555 \\
\hline Kanada & 8,793 & 6.303 & 95.856 & 80.916 \\
\hline Çin & 7.316 & 2.909 & 57.530 & 51.467 \\
\hline Rusya & 19.786 & 13.352 & 36.178 & 44.910 \\
\hline Türkiye & 12.814 & 16.557 & 12.761 & 37.776 \\
\hline Avustralya & 3.451 & 5.524 & 18.119 & 23.492 \\
\hline Amerika & 6.357 & 13.029 & 6.286 & 23.148 \\
\hline
\end{tabular}

Tablo 6: Doğrudan Yabancı Yatırımcılar (2006-2009) Bin dolar. Kaynak: Kırgızistan Ulusal İstatistik Komitesi 
Türkiye'den Kırgızistan'a yapılan doğrudan yabancı yatırımlarda son yıllarda artış yaşanmıştır. Türkiye'den Kırgızistan'a yapılan doğrudan yabancı yatırım, 2006 yılında 12 milyon dolar civarında iken, 2009 yılında 37 milyon dolara yükselmiştir.

Diğer yandan, doğrudan yabancı sermaye girişini hızlandıracak nitelikte yabancı sermayeyi teşvik mevzuatının bulunmaması, söz konusu yatırımları gerçekleştirecek olan girişimcilerin çekingen davranmalarına yol açmaktadır. Ayrıca ülkenin ekonomik anlamda yaşadığı sorunların yanında siyasi açıdan yaşanan belirsizlikler ve iç karışıklıklar bu süreci olumsuz etkilemektedir (Egeli, Özen, 2008, s.18).

Yabancı yatırımcıların Kırgızistan'a çekilmesi noktasında; gerekli yatıım ikliminin yaratılması, tüm yabancı şirketlere ve onların yatırımlarına devlet garantisinin verilmesi ve ülkenin bununla ilgili gerekli altyapı, kanun ve kuralları oluşturması, yabancı yatırımcıların risklerinin sigortalanması ve nitelikli işgücünün ve işgücü arzının artırılması yatırımcıların Kırgızistan'a olan ilgisini artıracaktır. (Ramazanoğlu, Acar, 2007,s.393-394). Bu bağlamda Kırgızistan ile Türkiye'nin ekonomik ilişkilerinin geliştirilmesinde bu sorunların aşılmasının önemli olacağı düşünülmektedir.

\section{4 Öneriler ve Sonuç}

Sovyetler Birliğinin dağılması ve Kırgızistan'da yaşanan ekonomik sistem değişikliği geçiş yaşayan pek çok ülkede olduğu gibi Kırgızistan'da da serbest piyasaya uyum bakımından pek çok sorunu beraberinde getirerek ekonomik sorunların çıkmasına yol açmıştır. Fakat Kırgızistan, bölgenin önemli ülkelerinden biri olmak ve ekonomik gelişmeyi sağlamak adına önemli adımlar atmıştır. Bunun yanında serbest piyasa ekonomisine geçmesiyle birlikte Kırgızistan, ekonomideki istikrarsızlıklarını aşma yönünde çalışmalar yapmıştır. Buna bağlamda 1996 yılında makroekonomik durum kontrol altına alınarak büyüme sağlanmıştır. Kırgızistan ekonomisi 1996-2010 yılları arasında ortalama olarak \%4,6 büyüme kaydederek önemli bir gelişme göstermiştir.

Türkiye ile Kırgızistan arasındaki siyasi ve ekonomik ilişkilerin gelişmesi 1991 yılında Kırgızistan'ın bağımsızlığını kazanmasıyla başlamıştır. Bu dönemden sonra geliştirilen ekonomik ve ticari ilişkiler artan bir seyir izlemiştir. 1998 yılında yaşanan Rusya Krizi, Türkiye ile Kırgızistan arasındaki ekonomik ilişkileri kısa bir süreliğine de olsa sekteye uğratmasına rağmen 2000'li yıllardan sonra dış ticaret hacminde yeniden artış yaşanmışıır.

Kırgızistan'ın içinde bulunduğu durum genel olarak değerlendirildiğinde, Kırgızistan'ın serbest piyasa ekonomisine geçmesinin doğru bir adım olduğu; ancak bu adımın tek başına ekonomik büyüme ve kalkınma için yeterli olmadığı söylenebilir. Bu noktada Kırgızistan'ın Türkiye ile olan ekonomik ve ticari ilişkilerinin geliştirilmesi için Kırgızistan'ın serbest piyasa ekonomisine yeni geçmesi nedeniyle ortaya çıkan yapısal sorunlarını çözmesi ve belli başlı reformları hayata geçirmesi gerekmektedir. Kırgızistan ekonomisinin ağırlıklı olarak tarım ve hayvancıllğa dayalı olması, yatırım seviyesinin düşüklüğü, siyasi sorunlar, yabancı yatıımcıları çekme noktasında nitelikli işgücü yetersizliği gibi problemler iki ülke arasındaki ekonomik ve ticari ilişkilerin gelişmesini kısıtlamaktadır. Öte yandan Kırgızistan'da yabancı sermayeyi teşvik edecek mevzuatın yetersiz oluşu, girişimcilerin yatırımları gerçekleştirme hususunda çekingen davranmalarına yol açmaktadır.

İhracat ve ithalatta önemli eksikliği duyulan idari düzenlemelerin sebep olduğu maliyetlerin fazlalılı̆̆ Kırgızistan dış ticareti için sorun teşkil etmektedir. Yavaş işleyen bu yapının hızlandırılıp yatırımcı açısından daha düşük maliyetle çalışır hale getirilmesi, genelde ülkenin uluslararası ticaretinin iyileşmesine özelde ise Türkiye ile olan ticari ilişkilerinin geliştirilmesine yardımcı olacaktır.

$\mathrm{Bu}$ öneriler ışığında, gerek siyasi, gerekse ekonomik ve ticari ilişkiler bakımından temelleri farklı fakat kültürel olarak benzerlik gösteren bu iki ülkenin gelecekte ticari ve ekonomik ilişkilerinin daha da güçleneceği öngörülebilir.

\section{Kaynakça}

- Bişkek Büyükelçiliği Ticaret Müşavirliği, 2008, Kırgızistan'ın Genel Durumu ve Türkiye ile EkonomikTicari İlişkileri, Bişkek. Erişim: http://www.musavirlikler.gov.tr/detay.cfm?AlanID=3\&dil=TR\&ulke=KIR, 15.07.2011

- Egeli H. , Özen A., "Kırgızistan'da Mali Sistemin Yeniden Yapılandırılması Çerçevesinde Bütçede Reform Arayışları" Manas Üniversitesi Sosyal Bilimler Dergisi,sayı 1, s.14-31.

- Kırgızistan Ulusal İstatistik Komitesi, 2010 İstatistikleri, Erişim: www.stat.kg, 27.08.2011.

- KTO (Konya Ticaret Odası), 2008, Kırgızistan Ülke Raporu, Etüd Araştırma Servisi.

- Ramazanoğlu G., Acar İ.,”Bir Geçiş Ekonomisi Örneği Olarak Kırgızistan: Siyasi, Ekonomik ve Toplumsal Yanışımlar", Review of Social, Economic \& Business Studies, Vol. 7/8, 385-402.

- Sarsılmaz Filiz, 2003,Kırgızistan'ın Makro Ekonomik Analizi, Yayınlanmamış Yüksek Lisans Tezi, Bişkek.

- Seyidoğlu H.,1999, Uluslararası İktisat: Teori Politik ve Uygulama, İstanbul

- T.C. Bişkek Büyükelçiliği Ticaret Müşavirliği, Erişim: 
http://www.musavirlikler.gov.tr/detay.cfm?AlanID=3\&dil=TR\&ulke=KIR, 15.07.2011.

- TÜİK İstatistikleri 2010, Erişim: http://www.tuik.gov.tr, 25.07.2011.

- World Bank, 2001, Kyrgyz Republic: Fiscal Sustainability Study, Worldbank Publications.

- World Bank Statistics, 2010, Economic Indicators. 


\title{
Küreselleşmenin Ekonomik Entegrasyon Üzerine Etkileri
}

\author{
C. Erdem Hepaktan (Celal Bayar University, Turkey) \\ Serkan Çınar (Celal Bayar University, Turkey)
}

\section{The Effect of Globalization on Economic Integration}

\begin{abstract}
In this study integrations which are becoming important worldwide will be focused on and the trade between the member countries will be analysed.

The most important integrations of the world economy EU, NAFTA and APEC at the same time constitutes the financial areas of euro, dolar and yen. These three integrations have great importance among the trade between the member countries and the world's trade. For instance the proportion of the APEC countries in world's trade is $45 \%$, EU countries $38 \%$ and NAFTA countries $16 \%$. The said high percentage of proportions shows that globalisation speeds up the formation of integration and increases the trade between the member countries.
\end{abstract}

JEL Codes: F15, F01, A10

\section{Giriș}

Küreselleşme, dünya ülkeleri arasında ekonomik, siyasal ve sosyo-kültürel ilişsilerin yaygınlaştığı, maddi ve manevi değerlerin bölgesel veya ulusal sınırları aşarak uluslararası bir süreç olarak tanımlanabilmektedir (Yüksel, 2001: 13). Ancak, bu genel eğilimin yanı sıra, ülkeler aynı zamanda, ekonomik çıkarlarını koruyabilmek amacıyla kendi aralarında da bir takım ekonomik anlaşmalar yaparak bölgesel bir ekonomik entegrasyon süreci içine girmişlerdir. Bu sebeple, küreselleşme ve bölgesel ekonomik entegrasyonlar eş zamanlı bir gelişme sürecinin iki farklı görüntüsünü oluşturmaktadır (Paksoy, 2000: 20).

Uluslararası ekonomik bütünleşme girişimleri, içinde bulunduğumuz yüzyılda özellikle İkinci Dünya Savaşı sonrası hız kazanmıştır. Hiçbir ülkenin etrafına yapay duvarlar örüp tek başına yaşamasının mümkün görünmediği bu süreçte, ülkeler ikili ve çok taraflı işbirliği arayışları içerisinde bulunmakla, bir uluslararası ekonomik bütünleşme ya da bölgesel nitelikli bir ekonomik işbirliği içerisinde yer almaktadırlar.

\section{Bölgesel Entegrasyonlar}

Ekonomik bütünleşme ilişkileri ve çok amaçlı bölgesel karakterli uluslararası oluşumlar, 20. yüzyıl dünya ekonomisinde oldukça önem kazanmıştır. Bölgesel ekonomik entegrasyon, ulus devletin çizdiği sınırları, kişiler, mallar ve üretim faktörleri üzerine getirdiği kısıtlamaları kaldırarak bölgesel olarak piyasaların bütünleştirilmesi süreci olarak tanımlanabilir. Bölgesel ekonomik entegrasyon, dış ticareti artırarak ve kaynak dağılımını etkinleştirerek, üye ülkelerde refah artışına katkıda bulunabilir.

Bölgesel ekonomik entegrasyonlar uygulamada değişik derecelerde (şekillerde) ortaya çıkmaktadır: Serbest ticaret bölgesi, gümrük birliği, ortak pazar, ekonomik (ve parasal) birlik ve tam ekonomik bütünleşme şeklinde entegrasyonlar derecelendirilebilirler (Ertürk, 1991). Serbest ticaret bölgesi, en sı̆̆ entegrasyonu ve siyasal birlik ise, en derin halini oluşturmaktadır. Serbest ticaret bölgesinde, ülkeler arasında mal hareketliliğinin önündeki engeller karşılıklı olarak elimine edilmekte ve dolayısıyla üye ülkeler arasında gümrük vergileri kaldırılmaktadır.

Teoride ekonomik entegrasyonun başarı koşulları genel olarak şu şekilde sıralanabilir (Küçükahmetoğlu, 2006:51):

- Ekonomik alanın büyük olması ve çok sayıda ülkeden oluşmasıdır.

- Ülkelerin rakip ekonomiler olması durumunda elde edecekleri kazanç daha yüksek düzeyde olur. Bir ürünü yakın maliyetlerle üreten ülkeler arasında gümrük birliğinin oluşması sonucunda, o malı daha ucuza üreten ülkeler piyasaya hakim olur ve daha maliyetli üreten ülkeler ithalata başlarlar.

- Birlik öncesi uygulanan tarifeler ne kadar yüksekse, entegrasyon durumunda ticaret yaratma etkisi o kadar yüksek olur.

- Ülkelerin arz ve talep esnekliklerinin yüksek olması, yüksek düzeyde ticaret yaratma etkisinin ortaya çıkmasını sağlar.

- Ülkelerin coğrafi olarak birbirlerine yakın olması, taşıma maliyetlerini azaltarak dış ticareti arttırıcı etkide bulunur.

- Ülkelerin birbirlerinin ürünlerine yönelik talebin şiddetinin yüksek olması, entegrasyonu hızlandırır.

Entegrasyonun geleneksel olmayan etkilerinin başında, ülkelerin yapacakları reformlar için önemli bir güvence oluşturması gelmektedir. Ayrıca, pazarlık gücünün artması ve gelecekte oluşacak risklere karşı güvence 
oluşturması, entegrasyonun geleneksel olmayan faydaları arasında sayılabilir. Son olarak, bölgesel entegrasyonlar güvenlik kaygısıyla da yapılabilir (Fernandes, 1998; 204).

Dünya ekonomisinde, bölgesel nitelikli ekonomik bütünleşmelerden en önemli üç bloklaşmayı şu şekilde gruplandirabiliriz:

Birinci grupta, merkezini Avrupa Topluluğu'nun oluşturduğu Avrupa Entegrasyonu (Avrupa Birliği E.C) yer almaktadır. Bu kapsamda, A.T ile EFTA üyesi ülkeler arasında Avrupa Ekonomik Alanı oluşturulmuş ve Doğu Avrupa ülkeleri arasındaki ilişkiler de yoğunlaşmıştır.

İkinci grup bölgesel entegrasyon oluşumu, ABD, Kanada ve Meksika'nın 7 Ekim 1992'de imzaladıkları Kuzey Amerika Serbest Ticaret Bölgesi NAFTA'dır.

Üçüncü grup bölgesel entegrasyon girişimi ise, Japonya'nın 12 Pasifik ülkesi ile oluşturdukları Pasifik Ticaret Bölgesidir. Bu bütünleşme içerisinde, Japonya ile birlikte, Güney Doğu Kaplanları olarak adlandırılan; G.Kore, Hong-Kong, Tayvan, Singapur da bulunmaktadır.

\section{3 Ülkeleri Entegrasyona İten Nedenler}

Birlikte hareket etmenin sağlayacağı avantajlardan yararlanmak isteyen ülkeler, üçüncü ülke ekonomilerine karşı bir güç elde etmek amacıyla ekonomik bütünleşmeye yönelmişlerdir. Ülkeleri ekonomik bütünleşmeye yönelten nedenler;

-Genişleyen piyasa: Genişleyen piyasa sonucunda firmalar, ileri üretim teknikleri kullanmak üzere araştırmageliştirme faaliyetlerini arttırırlar. Araştırma-geliştirme faaliyetlerine bağlı olarak üretim gücünde sağlanan artışa etki eden unsurlardan en önemlisi, ortaya çıkan ekonominin teknolojik kapasitesindeki gelişmedir. Teknolojik gelişme, bir yandan ölçek büyümelerine yol açarken, öte yandan birim ürün maliyetlerini azaltıp ölçek ekonomilerine olanak sağlar.

- Içsel ve dişsal ekonomiler: Birim maliyetlerdeki değişiklikler, içsel ve dişsal etkenlerden meydana gelebilir. İçsel ve dışsal ekonomiler, eksik kapasite ile çalışan sanayinin, tam kapasite ile çalışması ortamını yaratmış ve üretim ölçeğinin artışını zorunlu kılmıştır.

-Üretim faktörlerinin dă̆ılımı: Ekonomik bütünleşmelerin ortak pazar ve daha ileri aşamalarında, üye ülkeler arasında üretim faktörlerinin serbestçe dolaşımı söz konusudur. Ulusal ekonomiden entegrasyona geçilmesiyle, entegrasyon sahası içinde üretim faktörlerinin coğrafi olarak dağılımı da değişmeye uğrayacaktır. Entegrasyon kurulduktan sonra, entegrasyon sahası içinde üretim güçlerinin coğrafi olarak alacakları durum konusunda, iki ayrı görüş bulunmaktadır. Birinci görüş; üretim faktörlerinin entegrasyonda toplanma etkisidir. Üretim faktörlerinin serbestçe dolaşımı sonucu, teknolojik değişimin daha hızlı olduğu, sermaye ve emeğin daha verimli kullanıldığ 1 gelişmiş ülkelerde ve nispi üstünlüğe sahip bölgelerde toplanması, üretim faktörlerinin toplanma etkisini oluşturmaktadır. İkinci görüş ise, üretim faktörlerinin entegrasyonda yayılma etkisidir. Ekonomik bütünleşmelerde toplanma etkisi olduğu kadar, yayılma etkisi de mümkündür. Bütünleşme sonucu ülkeler, mobil üretim faktörlerinden yararlanma yoluna gideceklerdir.

-Rekabet artışı: Büyük piyasada (entegrasyonda) sınırlayıcı şartlar, küçük piyasaya oranla azaldığı için firmaların daha etkin çalışması imkanı oluşacaktır. Küçük piyasa, firmaların optimum ölçekte çalışmasına olanak vermezken, büyük piyasada optimum ölçeğe ulaşılmaktadır.

-Politik nedenler: Genelde ekonomik bütünleşmeler, zamanla politik bütünleşmelere dönüşmektedir. Ekonomik bütünleşmenin ileri aşamalarında, ülkeler arası ekonomik ve sosyal politikaların uyumlaştırılması, ülkeler arası politik yakınlaşmayı içermektedir.

-Diğer nedenler: Doğrudan doğruya ekonomik bütünleşmenin gerçekleşme nedeni olmakla birlikte, ülkelerin ekonomik bütünleşmesine ortam hazırlayan başlıca faktörler bulunmaktadır. Söz konusu faktörler; ekonomik gelişme düzeylerinin yakın olması, coğrafi yakınlık, siyasi ve askeri konularda yakınlık, tarihi, dini ve kültürel bağların bulunması ve uluslararası anlaşmalardan doğan zorunluluklardır.

\section{Bölgesel Ekonomik Entegrasyon Örnekleri}

Dünya'daki küresel eğilimler, iki doğrultuda gerçekleşmektedir. Birincisi, uluslararası ticaretin tüm ülkeleri kapsayacak şekilde yani küresel bir ölçekte liberalleştirilmesi, “evrensel yaklaşım” olan GATT'1 ifade etmektedir. İkincisi ise, değişik ülkelerin bölgesel bir blok içinde ticareti serbestleştirici politikalar izleyerek ekonomik birlikler oluşturmaları olarak tanımlanan "ekonomik entegrasyon" kavramıdır.

Ekonomik entegrasyonlar, genel bir kanıya göre siyasi açıdan bağımsız ülkeleri ekonomik açıdan birbirine bağımlı hale getirir (Seyidoğlu, 1993: 415; İncekara, 1995: 60). Ekonomik entegrasyon için daha açık bir tanım yapmak gerekirse; B.Balassa'ya göre, en basitinden en ileri aşamasına kadar entegrasyonlar; ticareti engelleyici unsurların ortadan kaldırıldığı ticaret entegrasyonu, ülkeler arası faktör hareketlerine serbestlik kazandırıldığ faktör entegrasyonu, ulusal ekonomi politikalarının uluslararası ilişkileri güçlendirecek şekilde uyumlu hale 
getirildiği politika entegrasyonu ve son olarak da bunların birleştirilmesi sonucu gerçekleşen tam ekonomik entegrasyondur (Ertürk, 1997: 5).

\subsection{Avrupa Birliği (AB)}

Batı Avrupa'da ilk Avrupa Topluluğu, Avrupa Kömür ve Çelik Topluluğu olarak altı Avrupa ülkesi (Belçika, Almanya, Fransa, İtalya, Lüksemburg ve Hollanda) tarafından 18 Nisan 1951 tarihli Paris Antlaşması ile kurulmuş ve 25 Eylül 1952 tarihinde resmen faaliyete geçmiştir (Karluk, 2002: 397).

Ekonomik amaçla Avrupa Kömür ve Çelik Topluluğuna dört elle sarılan kurucu ülkeler, kömür ve çelik gibi endüstrilerle sınırlı kalmayıp ekonominin tüm sektörlerini kapsayacak bir bütünleşme aşamasına geçilmesi gerektiğine karar vermişlerdir. 25 Mart 1957 tarihinde Roma'da imzalanan ve 1 Ocak 1958 tarihinde yürürlüğe giren Roma Antlaşması ile Avrupa Ekonomik Topluluğu ve Avrupa Atom Enerjisi Topluluğu (EURATOM) kurulmuştur (Balkır-Demirci, 1989: 29). Böylece Avrupa'da birbirini tamamlayan üç kuruluş ortaya çıkmıştır. Her üç kuruluş da, aynı altı kurucu üye ülke arasında oluşturulmuştur: Almanya, Fransa, İtalya, Belçika, Hollanda ve Lüksemburg. Bu üç kuruluşla birlikte, bugünkü Avrupa Birliği'nin öncüsü durumunda olan Avrupa Ekonomik Topluluğu (AET) oluşturulmuştur (Seyidoğlu, 2001: 222).

Almanya, Belçika, Fransa, Hollanda, İtalya ve Lüksemburg'un kurucu üyesi bulunduğu Avrupa Topluluğu, 1 Ocak 1973 tarihinde İngiltere, İrlanda ve Danimarka'nın katılımıyla (Kuzeye Genişleme) üye ülke sayısı dokuza yükselmiştir. 1 Ocak 1981 tarihinde Yunanistan'ın, 1 Ocak 1986 tarihinde ise İspanya ve Portekiz'in topluluğa katılımı ile (Güneye Genişleme) üye ülke sayısı onikiye yükselmiştir. 1995 yılında Avusturya, Finlandiya ve İsveç'in katılımıyla üye sayısı onbeşe yükselmiştir. 2004 yılında Estonya, Litvanya, Letonya, Çek Cumhuriyeti, Polonya, Güney Kıbrıs Rum Yönetimi, Slovakya, Slovenya, Malta ve Macaristan'ın katıldığı Avrupa Birliği genişleme süreci, 2007 yılında Bulgarisan ve Romanya'nın katılımıyla üye ülke sayısı, yirmiyediye yükselmiştir. Halen Avrupa Birliği'ne üyelik sürecindeki aday ülkeler, Hırvatistan, İzlanda, Makedonya, Türkiye ve Karadağ'dır. Günümüzde 27 üye ülkesiyle Avrupa Birliği'nin temel hedefi; topluluğa üye ülkeler arasında tam bir ekonomik bütünleşmeyi gerçekleştirmektir.

\subsection{Güney Doğu Asya Ülkeleri Birliği (ASEAN)}

8 Ağustos 1967 tarihinde Bangkok Deklarasyonu ile Endonezya, Filipinler, Malezya, Singapur ve Tayland arasında kurulmuştur. 1975 yılına kadar önemli bir gelişme göstermeyen ASEAN, Vietnam'ın birleşmesinin üye ülkeler açısından doğurduğu tehdit karşısında, birliğe işlerlik kazandırmak ve bölge ülkelerinin ekonomik, sosyal ve kültürel gelişmesine yardımcı olmak amacıyla 1976 yılı Şubat ayında Bali'de gerçekleşen, Güney Doğu Asya Dostluk ve İşbirliği Anlaşması ile yeniden işlerlik kazanmıştır.

1967 Bangkok Deklarasyonu ile birlikte, ekonomik işbirliği daha başlangıç sürecinde ASEAN'ın temel amaçlarından biri olmuştur. 1976 yılında ikinci kez faaliyete geçirildikten sonra ise, tarımsal ve sınai mal üretiminin sağlanması amacıyla bölgede büyük-ölçekli sanayi tesisleri kurmak, ticarete konan engellerin kaldırılmasıyla ticareti serbestleştirmek, birlik olarak üçüncü piyasalara açılmak ve diğer uluslararası ekonomik ve mali konularda işbirliği sağlamak amaçlanmaktadır.

Bali Anlaşması ile ASEAN çerçevesinde üyeler arasında politik, ekonomik ve sosyal işbirliğinin geliştirilmesi ve bir bölgesel tercihli ticaret alanının yaratılması hedeflenmiştir.

\subsection{Kuzey Amerika Serbest Ticaret Bölgesi (NAFTA)}

2 Ocak 1988 tarihinde, ABD ile Kanada arasında ticari engellerin kaldırılması amacıyla imzalanan ABDKanada Serbest Ticaret Anlaşması, Meksika'nın da katılımıyla yeni bir serbest ticaret anlaşmasına dönüşerek, ülke parlamentolarından onay alındıktan sonra, 1 Ocak 1994 tarihinde yürürlüğe girmiştir. NAFTA anlaşması, üç üye ülke (ABD, Kanada ve Meksika) arasında ticari engel ve kısıtlamaların kaldırılmasını amaçlarken, üçüncü ülkelere karşı yapacakları ticarette kendi ulusal tarifelerini uygulamalarına da olanak sağlamaktadır.

\subsection{Avrupa Serbest Ticaret Bölgesi (EFTA)}

Avrupa'daki ekonomik bütünleşme hareketinin gümrük birliği şeklinde değil, bir serbest ticaret bölgesi şeklinde oluşturulmasını amaçlayan İngiltere'nin bu görüşü, Kurucu Altılar tarafından reddedilince, A.E.T dışında kalan İngiltere, Norveç, Danimarka, Avusturya, Portekiz, İsveç, İsviçre ve ortak üye statüsündeki Finlandiya ile birlikte EFTA'yı oluşturmuştur. İlgili anlaşma, 4 Ocak 1960 tarihinde Stockholm'de imzalanmış, 3 Mayıs 1960 tarihinde yürürlüğe girmiştir. Finlandiya, oluşuma 1961 yılında ortak üye statüsü ile, 1986 yılında da tam üye olarak katılmıştır. 1972 yılında Danimarka ve İngiltere, 1985 yılında ise Portekiz, Avrupa Topluluğu'na katılmak üzere EFTA'dan ayrılmışlardır. Buna karşılık, İzlanda 1970 yılında ve İsviçre ile arasındaki gümrük birliği ilişkisi nedeniyle başlangıçtan beri EFTA'ya özel protokolle bağlı olan Liechtenstein, 1991 yılında birliğe katılmışlardır. Günümüzde serbest ticaret bölgesi aşamasında olan EFTA’ya üye ülkeler, İsviçre, Norveç, İzlanda, Liechtenstein'dır.

\subsection{And Ülkeleri Paktı (ANDEAN)}

Bölgesel gümrük birliği anlaşmasıdır. 26 Mayıs 1969 tarihinde Bolivya, Ekvador, Şili ve Kolombiya’nın aralarında Cartagena Antlaşması'nı imzalamaları ile kurulmuştur. And Ülkeleri Paktı adını da alan bu kuruluş, 
üye ülkeler arası ticaret serbestisini ve üçüncü ülkelere karşı ortak gümrük tarifesi uygulamalarını öngörmektedir.

\subsection{Güney Amerika Ortak Pazarı (MERCOSUR)}

Latin Amerika ülkeleri arasında bölgesel ekonomik entegrasyon kurulmasına yönelik girişimler, 1950'li yıllara kadar uzanmaktadır. Bu amaçla 1957 yılında Amerikan Devletleri Ekonomik Konferansı düzenlenmiş ve bu konferans sonucunda Monteviedo Anlaşması imzalanarak Arjantin, Brezilya, Şili, Uruguay, Meksika, Paraguay ve Peru arasında serbest ticaret bölgesi (LAFTA) kurulmuştur. Ancak, LAFTA başarıya ulaşamamış ve iç ticarette tam bir serbestleşme sağlanamamıştır. 1980 yılında çok daha esnek bir sistem olan LAIA (veya ALADI), LAFTA'nın yerini almıştır. Üyelerine karşılıklı ticaret, tarife ve teknolojik anlaşma yapabilmeleri konusunda hareket serbestisi tanıyan yeni örgüt, amacının üye ülkeler arasında tercihli bir ekonomik bölge yaratmak olduğunu açıklamıştır (Karluk, 1995: 335). LAIA sistemi altında öncelikle Brezilya ve Arjantin, 1986 yılında ticari yakınlaşma sağlamaya yönelik bir protokol imzalamışlardır. 1991 yılında Paraguay ve Uruguay'ın da katılımıyla, bu dört devlet arasında Güney Ortak Pazarı (MERCOSUR) örgütü kurulmuştur.

Şili ve Bolivya da, 1996 yılında MERCOSUR örgütü ile serbest ticaret anlaşması imzalamış ve ortak üye statüsüne girmişlerdir. Böylece örgüt tüm Güney Amerika kıtasında ortak bir pazar yaratma hedefi doğrultusunda önemli bir adım atmıştır. Gümrük tarifelerinin sıfırlanmasını ve üyeler arasında mal, hizmet ve sermayenin serbest dolaşımını amaçlayan MERCOSUR, Latin Amerika kıtasının yüzölçümünün \% 59'unu, nüfusunun \%44'ünü, GSMH'sının \% 51'ini kapsayan önemli bir entegrasyon hareketidir. Ocak 1995 itibariyle Gümrük Birliğini de gerçekleştiren MERCOSUR, AB örneğini izleyerek, her alanda entegrasyona doğru ilerlemektedir (Seyidoğlu, 2001: 253). AB benzeri, rekabet politikalarının uyumlaştırılması, parasal entegrasyon ve ortak ekonomik kurumlar gibi konular MERCOSUR'un da gündemindedir.

\section{Entegrasyonların Üye Ülkelerarası Ticaret Analizleri}

Dünya ekonomisinde entegrasyon sürecinin bölgesel kapsamda artış gösterdiği görülmektedir. Dünya Ticaret Örgütü'nün 2009 yılında yayınlanan dünya ticaretinin gelişmesine dair raporunda da coğrafi bölgeler, yedi bölgede değerlendirilmektedir. Söz konusu coğrafi bölgeler; Kuzey Amerika, Güney ve Orta Amerika, Avrupa, Bağımsız Devletler Topluluğu, Afrika, Orta Doğu ve Asya bölgeleridir. Yedi coğrafi bölgenin dünya mal ihracatı içerisindeki payları, Tablo-1'de görülmektedir.

\begin{tabular}{|c|c|c|c|c|c|c|c|c|}
\hline & $\begin{array}{c}\text { Dünya } \\
\text { Geneli }\end{array}$ & $\begin{array}{c}\text { Kuzey } \\
\text { Amerika }\end{array}$ & $\begin{array}{c}\text { Güney } \\
\text { ve Orta } \\
\text { Amerika }\end{array}$ & Avrupa & BDT & Afrika & $\begin{array}{c}\text { Orta } \\
\text { Doğu }\end{array}$ & Asya \\
\hline Dünya Geneli & 100,0 & 100,0 & 100,0 & 100,0 & 100,0 & 100,0 & 100,0 & 100,0 \\
\hline Kuzey Amerika & 13,2 & 37,9 & 29,3 & 5,7 & 3,0 & 7,2 & 9,7 & 10,1 \\
\hline Güney ve Orta Amerika & 3,8 & 5,7 & 27,4 & 1,8 & 1,9 & 3,3 & 2,2 & 3,0 \\
\hline Avrupa & 41,2 & 18,1 & 17,1 & 70,9 & 47,1 & 41,5 & 30,1 & 13,3 \\
\hline BDT & 3,7 & 1,2 & 1,2 & 4,7 & 27,9 & 1,8 & 2,8 & 2,0 \\
\hline Afrika & 3,2 & 3,2 & 2,1 & 2,9 & 0,4 & 11,5 & 2,3 & 2,7 \\
\hline Orta Doğu & 5,7 & 3,0 & 1,1 & 1,5 & 1,2 & 8,6 & 20,9 & 11,2 \\
\hline Asya & 29,4 & 31,0 & 21,8 & 12,5 & 18,5 & 26,0 & 32,0 & 57,8 \\
\hline
\end{tabular}

Tablo 1: Dünya Mal İhracatında Bölgelerarası Ticaret (\%). Kaynak: Kaynak: WTO, World Trade Developments in 2009

Tablo-1'e göre, dünya mal ihracatında Avrupa'nın bölgesel payı \%41,2 ile ilk sıradadır. Dünya mal ihracatında \%29,4 pay ile Asya bölgesi ikinci sıradadır. Daha sonra sırasıyla K.Amerika $(\% 13,2)$, Orta Doğu (\%5,7), Güney ve Orta Amerika $(\% 3,8)$, BDT $(\% 3,7)$ ve son sirada Afrika $(\% 3,2)$ gelmektedir. 
Tablo-2'de, dünya genelinde seçilmiş beş bölgesel entegrasyona ait mal ticareti görülmektedir.

\begin{tabular}{|c|c|c|c|c|c|c|c|c|}
\hline $\begin{array}{l}\text { Seçilmiş Bölgesel } \\
\text { Entegrasyonlar }\end{array}$ & 2002 & 2003 & 2004 & 2005 & 2006 & 2007 & 2008 & 2009 \\
\hline \multicolumn{9}{|l|}{$\mathrm{AB}(27)$} \\
\hline Toplam İhracat & 2.638 & 3.149 & 3.762 & 4.065 & 4.591 & 5.347 & 5.921 & 4.588 \\
\hline Entegrasyon içi ihracat & 1.794 & 2.166 & 2.577 & 2.756 & 3.136 & 3.646 & 3.993 & 3.059 \\
\hline Entegrasyon dişı ihracat & 843 & 983 & 1.185 & 1.310 & 1.456 & 1.701 & 1.928 & 1.528 \\
\hline Toplam ithalat & 2.672 & 3.214 & 3.855 & 4.222 & 4.830 & 5.611 & 6.295 & 4.733 \\
\hline Entegrasyon içi ithalat & 1.786 & 2.156 & 2.576 & 2.754 & 3.133 & 3.646 & 3.993 & 3.059 \\
\hline Entegrasyon dişı ithalat & 886 & 1.058 & 1.278 & 1.468 & 1.697 & 1.965 & 2.302 & 1.673 \\
\hline \multicolumn{9}{|l|}{ NAFTA } \\
\hline Toplam İhracat & 1.106 & 1.163 & 1.320 & 1.476 & 1.664 & 1.841 & 2.035 & 1.602 \\
\hline Entegrasyon içi ihracat & 621 & 650 & 739 & 824 & 901 & 950 & 1.012 & 768 \\
\hline Entegrasyon dişı ihracat & 486 & 513 & 581 & 651 & 763 & 891 & 1.023 & 835 \\
\hline Toplam ithalat & 1.601 & 1.723 & 2.008 & 2.283 & 2.541 & 2.701 & 2.907 & 2.177 \\
\hline Entegrasyon içi ithalat & 618 & 640 & 715 & 791 & 864 & 914 & 964 & 717 \\
\hline Entegrasyon dişı ithalat & 983 & 1.083 & 1.292 & 1.492 & 1.676 & 1.786 & 1.942 & 1.460 \\
\hline \multicolumn{9}{|l|}{ ASEAN } \\
\hline Toplam İhracat & 407 & 475 & 569 & 656 & 770 & 865 & 990 & 814 \\
\hline Entegrasyon içi ihracat & 92 & 117 & 142 & 165 & 192 & 218 & 252 & 202 \\
\hline Entegrasyon dişı ihracat & 315 & 358 & 427 & 491 & 578 & 647 & 737 & 612 \\
\hline Toplam ithalat & 367 & 412 & 514 & 603 & 688 & 775 & 938 & 725 \\
\hline Entegrasyon içi ithalat & 84 & 101 & 125 & 151 & 174 & 195 & 229 & 179 \\
\hline Entegrasyon diş1 ithalat & 283 & 311 & 389 & 452 & 514 & 581 & 709 & 546 \\
\hline \multicolumn{9}{|l|}{ MERCOSUR } \\
\hline Toplam İhracat & 89 & 106 & 136 & 164 & 190 & 224 & 278 & 217 \\
\hline Entegrasyon içi ihracat & 10 & 13 & 17 & 21 & 26 & 32 & 42 & 33 \\
\hline Entegrasyon dişı ihracat & 79 & 93 & 119 & 143 & 164 & 191 & 237 & 185 \\
\hline Toplam ithalat & 62 & 69 & 95 & 114 & 140 & 183 & 258 & 186 \\
\hline Entegrasyon içi ithalat & 11 & 13 & 18 & 22 & 26 & 33 & 44 & 32 \\
\hline Entegrasyon diş1 ithalat & 52 & 56 & 77 & 91 & 114 & 149 & 214 & 154 \\
\hline \multicolumn{9}{|l|}{ ANDEAN } \\
\hline Toplam İhracat & 26 & 30 & 39 & 51 & 65 & 77 & 94 & 78 \\
\hline Entegrasyon içi ihracat & 3 & 3 & 3 & 5 & 5 & 6 & 7 & 6 \\
\hline Entegrasyon dişı ihracat & 23 & 27 & 36 & 47 & 60 & 71 & 87 & 73 \\
\hline Toplam ithalat & 28 & 31 & 37 & 46 & 56 & 71 & 93 & 74 \\
\hline Entegrasyon içi ithalat & 3 & 3 & 4 & 5 & 6 & 7 & 9 & 7 \\
\hline Entegrasyon diş1 ithalat & 25 & 27 & 33 & 41 & 50 & 64 & 85 & 67 \\
\hline
\end{tabular}

Tablo 2: Seçilmiş Bölgesel Entegrasyonların Mal Ticareti Analizi 2002-2009 (Milyon \$). Kaynak: WTO, Internatiaonal Trade Statistics 2010

Tablo-2'de, dünya genelindeki bölgesel entegrasyonlardan, AB, NAFTA, ASEAN, MERCOSUR ve ANDEAN'ın 2002-2009 yılları arasındaki mal ticareti incelendiğinde, tüm entegrasyonların dünya ticaretindeki paylarında hızlı bir yükseliş dikkat çekmektedir. Söz konusu entegrasyonların gerek ihracatlarında gerekse ithalatlarında sürekli bir artış trendi görülmektedir. Dünya ticaretinde bölgesel entegrasyonların ağırlık taşıdığı, bölgesel entegrasyonların dışında gerçekleşen ticarette ise, yine coğrafi yakınlığın önemli olduğu görülmektedir. Diğer bir ifade ile, dünya ticaretinin önemli bir kısmını bölgesel entegrasyonlar oluştururken, daha sonra ise, coğrafi olarak yakın olan ülkeler arasındaki ticaretin büyüklüğü dikkat çekmektedir. 
Tablo-3’te ise, dünya genelindeki tüm ekonomik entegrasyonların 2002-2009 döneminde gerçekleştirdikleri mal ticareti görülmektedir.

\begin{tabular}{|c|c|c|c|c|c|c|c|c|}
\hline İHRACAT & 2002 & 2003 & 2004 & 2005 & 2006 & 2007 & 2008 & 2009 \\
\hline Dünya Geneli & 6492.3 & 7585.6 & 9217.9 & 10488.6 & 12112.4 & 14001.4 & 16116.6 & 12490.2 \\
\hline \multicolumn{9}{|l|}{$\begin{array}{c}\text { Kuzey Amerika ve } \\
\text { Avrupa }\end{array}$} \\
\hline EFTA & 153.6 & 175.5 & 208.2 & 237.8 & 273.5 & 313.2 & 378.3 & 297.8 \\
\hline $\mathrm{AB}(27)$ & 2637.6 & 3148.9 & 3762.4 & 4065.3 & 4591.0 & 5346.8 & 5920.9 & 4587.6 \\
\hline NAFTA & 1106.2 & 1162.9 & 1319.6 & 1475.8 & 1664.1 & 1840.7 & 2035.2 & 1602.4 \\
\hline \multicolumn{9}{|l|}{$\begin{array}{c}\text { Güney ve Orta } \\
\text { Amerika }\end{array}$} \\
\hline ANDEAN & 26.0 & 30.0 & 38.9 & 51.4 & 64.8 & 76.7 & 94.1 & 78.4 \\
\hline CACM & 16.7 & 18.0 & 19.9 & 21.7 & 24.3 & 27.2 & 29.7 & 26.4 \\
\hline CARICOM & 7.3 & 9.0 & 11.0 & 14.9 & 20.2 & 20.1 & 26.3 & 14.9 \\
\hline MERCOSUR & 88.8 & 106.1 & 135.8 & 164.0 & 190.1 & 223.7 & 278.3 & 217.2 \\
\hline \multicolumn{9}{|l|}{ Afrika } \\
\hline CEMAC & 8.9 & 11.6 & 16.6 & 22.9 & 26.8 & 29.9 & 41.3 & 25.7 \\
\hline COMESA & 28.6 & 37.5 & 49.2 & 66.1 & 82.8 & 99.0 & 128.6 & 91.0 \\
\hline ECCAS & 18.5 & 22.5 & 32.0 & 49.4 & 61.2 & 77.2 & 109.5 & 69.2 \\
\hline ECOWAS & 29.5 & 37.0 & 53.7 & 67.1 & 78.1 & 85.5 & 107.0 & 76.3 \\
\hline SADC & 51.5 & 61.7 & 79.4 & 97.5 & 115.9 & 143.6 & 176.8 & 130.9 \\
\hline WAEMU & 8.7 & 9.8 & 11.6 & 12.7 & 14.2 & 15.0 & 18.1 & 16.8 \\
\hline \multicolumn{9}{|l|}{ Orta Doğu ve Asya } \\
\hline ASEAN & 407.4 & 474.8 & 568.9 & 656.0 & 769.8 & 865.4 & 989.8 & 813.5 \\
\hline GCC & 167.9 & 212.7 & 285.2 & 397.6 & 480.7 & 556.6 & 751.6 & 497.6 \\
\hline SAPTA & 70.8 & 84.0 & 105.2 & 132.6 & 158.9 & 190.0 & 240.8 & 204.2 \\
\hline \multicolumn{9}{|l|}{ İTHALAT } \\
\hline Dünya Geneli & 6741.2 & 7861.0 & 9567.1 & 10853.1 & 12435.3 & 14296.6 & 16513.1 & 12682.4 \\
\hline \multicolumn{9}{|l|}{$\begin{array}{c}\text { Kuzey Amerika ve } \\
\text { Avrupa }\end{array}$} \\
\hline EFTA & 124.3 & 143.1 & 168.0 & 187.0 & 211.8 & 248.2 & 279.7 & 228.6 \\
\hline $\mathrm{AB}(27)$ & 2672.1 & 3214.2 & 3854.5 & 4221.7 & 4830.6 & 5610.7 & 6295.3 & 4732.7 \\
\hline NAFTA & 1600.8 & 1723.1 & 2007.9 & 2283.4 & 2540.6 & 2700.8 & 2906.8 & 2176.7 \\
\hline \multicolumn{9}{|l|}{$\begin{array}{c}\text { Güney ve Orta } \\
\text { Amerika }\end{array}$} \\
\hline ANDEAN & 28.4 & 30.6 & 36.9 & 46.3 & 56.4 & 70.7 & 93.3 & 74.1 \\
\hline CACM & 26.2 & 28.2 & 32.1 & 36.2 & 41.5 & 47.7 & 54.5 & 41.4 \\
\hline CARICOM & 14.1 & 15.1 & 17.0 & 20.2 & 23.0 & 26.3 & 31.7 & 23.4 \\
\hline MERCOSUR & 62.3 & 69.1 & 95.1 & 113.9 & 139.5 & 182.8 & 257.8 & 186.3 \\
\hline \multicolumn{9}{|l|}{ Afrika } \\
\hline CEMAC & 5.9 & 6.0 & 6.9 & 7.9 & 10.5 & 12.6 & 16.2 & 16.8 \\
\hline COMESA & 35.6 & 39.8 & 51.2 & 64.7 & 75.4 & 93.5 & 118.6 & 111.4 \\
\hline ECCAS & 11.2 & 13.5 & 15.2 & 19.3 & 23.0 & 30.7 & 43.1 & 39.1 \\
\hline ECOWAS & 19.7 & 25.9 & 32.7 & 43.1 & 51.6 & 65.6 & 88.0 & 71.4 \\
\hline SADC & 48.9 & 65.5 & 84.8 & 98.6 & 118.7 & 139.4 & 168.4 & 132.7 \\
\hline WAEMU & 7.9 & 10.2 & 12.4 & 14.8 & 15.7 & 19.4 & 23.7 & 20.8 \\
\hline \multicolumn{9}{|l|}{ Orta Doğu ve Asya } \\
\hline ASEAN & 366.8 & 411.8 & 513.8 & 602.9 & 688.1 & 775.5 & 938.3 & 725.3 \\
\hline GCC & 99.3 & 117.3 & 154.3 & 188.3 & 225.1 & 295.0 & 378.8 & 301.8 \\
\hline SAPTA & 84.5 & 105.2 & 140.7 & 194.4 & 238.4 & 296.6 & 406.7 & 319.2 \\
\hline
\end{tabular}

Tablo 3: Bölgesel Entegrasyonların Mal Ticareti Analizi 2002-2009 (Milyar \$). Kaynak: WTO, International Trade Statistics 2010

Tablo-3’te dikkat çeken nokta, dünya ticareti içerisinde Kuzey Amerika ve Avrupa ülkeleri ile Orta Doğu ve Asya ülkelerinin gerçekleştirdikleri ticaret payının oldukça yüksek olduğudur. 
Tablo-4’te, 27 AB ülkesinin seçilmiş bölgelere ve ekonomilere ticareti görülmektedir.

\begin{tabular}{|c|c|c|c|c|c|c|c|c|}
\hline & \multicolumn{4}{|c|}{ Ticaret Hacmi (Milyar \$) } & \multicolumn{4}{|c|}{$\begin{array}{l}\text { Yıllık Yüzdesel Değişim } \\
(\%)\end{array}$} \\
\hline IHHRACAT & 2006 & 2007 & 2008 & 2009 & 2006 & 2007 & 2008 & 2009 \\
\hline Dünya Geneli & 4591.0 & 5346.8 & 5920.9 & 4587.6 & 13 & 16 & 11 & -23 \\
\hline Kuzey Amerika & 393.0 & 419.6 & 434.8 & 332.4 & 8 & 7 & 4 & -24 \\
\hline $\mathrm{ABD}$ & 334.4 & 354.5 & 363.0 & 279.7 & 7 & 6 & 2 & -23 \\
\hline Diğer Kuzey Amerika Ülkeleri & 58.7 & 65.0 & 71.8 & 52.7 & 14 & 11 & 10 & -27 \\
\hline Güney ve Orta Amerika & 61.5 & 74.1 & 89.5 & 68.6 & 15 & 21 & 21 & -23 \\
\hline Brezilya & 21.9 & 28.5 & 38.2 & 29.4 & 11 & 30 & 34 & -23 \\
\hline Diğer Güney ve Orta Amerika Ülkeleri & 39.6 & 45.6 & 51.3 & 39.2 & 17 & 15 & 12 & -23 \\
\hline Avrupa & 3394.4 & 3951.7 & 4335.6 & 3335.7 & 14 & 16 & 10 & -23 \\
\hline Avrupa Birliği (27) & 3135.6 & 3645.7 & 3993.1 & 3059.3 & 14 & 16 & 10 & -23 \\
\hline Diğer Avrupa Ülkeleri & 258.8 & 305.9 & 342.5 & 276.4 & 11 & 18 & 12 & -19 \\
\hline BDT & 131.7 & 174.5 & 218.2 & 132.4 & 31 & 33 & 25 & -39 \\
\hline Rusya Federasy & 89.9 & 120.9 & 153.0 & 90.2 & 28 & 34 & 27 & -41 \\
\hline Diğer BDT Ülkeleri & 41.8 & 53.7 & 65.2 & 42.2 & 36 & 29 & 21 & -35 \\
\hline Afrika & 113.3 & 138.5 & 171.9 & 147.0 & 7 & 22 & 24 & -14 \\
\hline Güney Afrika & 24.6 & 27.7 & 29.1 & 21.8 & 10 & 12 & 5 & -25 \\
\hline Diğer Afrika Ülkeleri & 88.7 & 110.8 & 142.9 & 125.2 & 6 & 25 & 29 & -12 \\
\hline Orta Doğu & 113.2 & 132.3 & 156.2 & 127.8 & 4 & 17 & 18 & -18 \\
\hline Asya & 337.6 & 396.0 & 443.3 & 383.2 & 11 & 17 & 12 & -14 \\
\hline Çin & 79.1 & 97.4 & 114.6 & 112.6 & 24 & 23 & 18 & -2 \\
\hline Japony & 55.2 & 58.4 & 60.8 & 49.0 & 3 & 6 & 4 & -19 \\
\hline $\begin{array}{l}6 \text { Doğu Asya Ülkesi (Çin, Singap } \\
\text { Kong, Güney Kore, Tayvan, Ts }\end{array}$ & 117.7 & 133.5 & 146.5 & 122.5 & 8 & 13 & 10 & -16 \\
\hline Diğer Asya Ülkeleri & 85.6 & 106.7 & 121.4 & 99.1 & 7 & 25 & 14 & -18 \\
\hline \multicolumn{9}{|l|}{ İTHALAT } \\
\hline Dünya Geneli & 4830.4 & 5610.7 & 6295.3 & 4732.7 & 14 & 16 & 12 & -25 \\
\hline Kuzey Ame & 257.3 & 296.8 & 324.7 & 255.0 & 8 & 15 & 9 & -21 \\
\hline $\mathrm{ABD}$ & 219.0 & 248.3 & 269.3 & 216.5 & 8 & 13 & 8 & -20 \\
\hline Diğer Kuzey Amer & 38.3 & 48.4 & 55.3 & 38.6 & 10 & 26 & 14 & -30 \\
\hline Güney ve Orta An & 93.7 & 109.5 & 129.8 & 90.8 & 22 & 17 & 19 & -30 \\
\hline Brezilya & 34.1 & 44.9 & 52.6 & 35.7 & 14 & 32 & 17 & -32 \\
\hline Diğer Güney ve Orta Amerika Ülkeleri & 59.7 & 64.6 & 77.2 & 55.2 & 28 & 8 & 20 & -29 \\
\hline Avrupa & 3377.6 & 3928.3 & 4319.9 & 3309.5 & 14 & 16 & 10 & -23 \\
\hline Avrupa Bir & 3133.2 & 3645.7 & 3993.1 & 3059.3 & 14 & 16 & 10 & -23 \\
\hline Diğer Avrupa Ülkeleri & 244.4 & 282.5 & 326.7 & 250.2 & 13 & 16 & 16 & -23 \\
\hline BDT & 224.6 & 252.3 & 337.8 & 203.4 & 27 & 12 & 34 & -40 \\
\hline Rusya Federa & 178.5 & 197.8 & 261.8 & 161.7 & 25 & 11 & 32 & -38 \\
\hline Diğer BDT Ülkeleri & 46.1 & 54.5 & 76.0 & 41.7 & 35 & 18 & 39 & -45 \\
\hline Afrika & 146.5 & 164.3 & 216.4 & 147.1 & 14 & 12 & 32 & -32 \\
\hline Güney Afrika & 23.0 & 28.4 & 32.5 & 20.7 & 11 & 23 & 15 & -36 \\
\hline Diğer Afrika Ülkeleri & 123.5 & 135.9 & 183.9 & 126.4 & 14 & 10 & 35 & -31 \\
\hline Orta Doğu & 87.0 & 93.0 & 114.1 & 66.6 & 5 & 7 & 23 & -42 \\
\hline Asya & 602.3 & 717.5 & 786.2 & 620.8 & 16 & 19 & 10 & -21 \\
\hline Çin & 244.4 & 317.7 & 364.1 & 299.1 & 23 & 30 & 15 & -18 \\
\hline Japonya & 96.9 & 107.4 & 110.3 & 77.8 & 5 & 11 & 3 & -29 \\
\hline $\begin{array}{l}6 \text { Doğu Asya Ülkesi (Çin, Singapur, Hong- } \\
\text { Kong, Güney Kore, Tayvan, Tayland) }\end{array}$ & 165.1 & 179.8 & 185.6 & 142.3 & 14 & 9 & 3 & -23 \\
\hline Diğer Asya Ülkeleri & 95.9 & 112.6 & 126.3 & 101.7 & 15 & 17 & 12 & -19 \\
\hline
\end{tabular}

Tablo 4: AB-27 Ülkelerinin Seçilmiş Bölgelere ve Ekonomilere 2006-2009 Dönemi Ticareti.

Kaynak: WTO, International Trade Statistics 2010

Tablo-4'te küresel ekonomilerdeki gelişmelere bağlı olarak en önemli nokta, 2008 krizi sonrasında ticaretteki yüzdesel daralmadır. 2009 yılında tüm ekonomik bütünleşmelerde ticaret hacmi, bir önceki yıla göre \%10’ları aşan bir azalma göstermektedir. 
Tablo-5'te NAFTA üyesi ülkelerin, NAFTA üyesi ülkeler arasındaki ve NAFTA üyesi olmayan ülkelerle ticareti görülmektedir. NAFTA üyesi ülkelerin gerek entegrasyon içi ticaret hacmi gerekse entegrasyon diş1 ticaret hacmi hemen hemen aynı düzeydedir.

\begin{tabular}{|c|c|c|c|c|c|c|c|c|c|}
\hline \multirow{2}{*}{$\begin{array}{c}\text { NAFTA } \\
\text { Ülkeleri }\end{array}$} & \multicolumn{3}{|c|}{ Dünya Geneli } & \multicolumn{3}{c|}{ NAFTA } & \multicolumn{3}{c|}{ Diğer Bölgeler } \\
\cline { 2 - 10 } & 2007 & 2008 & 2009 & 2007 & 2008 & 2009 & 2007 & 2008 & 2009 \\
\hline $\begin{array}{c}\text { Toplam Mal } \\
\text { İhracatı }\end{array}$ & 1840.7 & 2035.1 & 1602.3 & 950.0 & 1012.0 & 767.5 & 890.7 & 1023.1 & 834.9 \\
\hline $\begin{array}{c}\text { Toplam Mal } \\
\text { İthalat1 }\end{array}$ & 2700.8 & 2906.8 & 2176.7 & 914.4 & 964.5 & 716.9 & 1786.3 & 1942.3 & 1459.7 \\
\hline
\end{tabular}

Tablo 5: NAFTA Ülkelerinin 2007-2009 Dönemi Mal Ticareti Analizi (Milyon \$).

Kaynak: WTO, International Trade Statistics 2010

Tablo-6'da MERCOSUR üyesi ülkelerin dünya ticaretinde, toplam mal ihracatı ile toplam mal ithalatı görülmektedir. MERCOSUR üyesi ülkelerin dünya ticaretinde, sadece \%20'lik bir pay entegrasyon içi ticareti oluşturmaktadır. MERCOSUR üyesi ülkelerin dünya ticaretinde entegrasyon dışı ülkelerle ticareti \%80'lere yakın ağırlıklı bir payı oluşturmaktadır.

\begin{tabular}{|c|c|c|c|c|c|c|c|c|c|}
\hline MERCOSUR & \multicolumn{3}{|c|}{ Dünya Geneli } & \multicolumn{3}{c|}{ MERCOSUR } & \multicolumn{3}{c|}{ Diğer Bölgeler } \\
\cline { 2 - 10 } Ülkeleri & 2007 & 2008 & 2009 & 2007 & 2008 & 2009 & 2007 & 2008 & 2009 \\
\hline Toplam Mal İhracatı & 223.7 & 278.3 & 217.2 & 32.4 & 41.6 & 32.7 & 191.4 & 236.7 & 184.5 \\
\hline Toplam Mal İthalatı & 182.8 & 257.8 & 186.3 & 33.4 & 43.7 & 32.0 & 149.4 & 214.2 & 154.3 \\
\hline
\end{tabular}

Tablo 6: MERCOSUR Ülkelerinin 2007-2009 Dönemi Mal Ticareti Analizi (Milyon \$).

Kaynak: WTO, International Trade Statistics 2010

Tablo-7'de ANDEAN üyesi ülkelerin dünya ticaretinde, entegrasyon içi ticaretinin payı \%10 seviyesinin de altındadır. ANDEAN üyesi ülkeler, dünya ticaretinde yaklaşık \%90'lık bir pay ile entegrasyon dışı ülkelerle ağırlıklı bir ticaret içerisindedir.

\begin{tabular}{|c|c|c|c|c|c|c|c|c|c|}
\hline & \multicolumn{3}{|c|}{ Dünya Geneli } & \multicolumn{3}{c|}{ ANDEAN } & \multicolumn{3}{c|}{ Diğer Bölgeler } \\
\cline { 2 - 10 } ANDEAN Ülkeleri & 2007 & 2008 & 2009 & 2007 & 2008 & 2009 & 2007 & 2008 & 2009 \\
\hline Toplam Mal İhracatı & 76.7 & 94.1 & 78.4 & 5.9 & 7.0 & 5.9 & 70.7 & 87.1 & 72.5 \\
\hline Toplam Mal İthalatı & 70.7 & 93.3 & 74.1 & 7.2 & 8.6 & 6.9 & 63.5 & 84.7 & 67.2 \\
\hline
\end{tabular}

Tablo 7: ANDEAN Ülkelerinin 2007-2009 Dönemi Mal Ticareti Analizi (Milyon \$).

Kaynak: WTO, International Trade Statistics 2010

Tablo-8'de ASEAN üyesi ülkelerin dünya ticaretinde, toplam mal ihracatı ile toplam mal ithalatı görülmektedir. ASEAN üyesi ülkelerin dünya ticaretinde, yaklaşık olarak \%30'luk bir pay entegrasyon içi ticareti oluşturmaktadır. ASEAN üyesi ülkelerin dünya ticaretinde entegrasyon dışı ülkelerle ticareti \%70'lere yakın bir payı oluşturmaktadır.

\begin{tabular}{|c|c|c|c|c|c|c|c|c|c|}
\hline \multirow{2}{*}{ ASEAN Ülkeleri } & \multicolumn{3}{|c|}{ Dünya Geneli } & \multicolumn{3}{c|}{ ASEAN } & \multicolumn{3}{c|}{ Diğer Bölgeler } \\
\cline { 2 - 10 } & 2007 & 2008 & 2009 & 2007 & 2008 & 2009 & 2007 & 2008 & 2009 \\
\hline Toplam Mal İhracatı & 865.4 & 989.8 & 813.5 & 218.5 & 252.3 & 201.9 & 646.9 & 737.5 & 611.6 \\
\hline Toplam Mal İthalatı & 775.5 & 938.3 & 725.3 & 194.8 & 228.8 & 179.2 & 580.7 & 709.5 & 546.1 \\
\hline
\end{tabular}

Tablo 8: ASEAN Ülkelerinin 2007-2009 Dönemi Mal Ticareti Analizi (Milyon \$).

Kaynak: WTO, International Trade Statistics 2010

Yirminci yüzyılın ikinci yarısından sonra başlayan bölgesel ticaret anlaşmaları, 1990'lı yıllarda dünya çapında yürürlükte 50'nin altında olan bölgesel ticaret anlaşmalarında büyük artış kaydedilmiştir. Bölgesel ticaret anlaşmalarının zirve yaptığı yıl ise 2004 yılı olmuştur.

Tablo-9'da dünya genelinde gerçekleştirilen bölgesel ticaret anlaşmalarının hangi entegrasyon aşamasına karşılık geldiği görülmektedir. Dünya genelindeki 302 bölgesel ticaret anlaşmasının; 176 tanesi serbest ticaret anlaşması, 84 tanesi ekonomik entegrasyon anlaşması, 17 tanesi gümrük birliği anlaşması ve 14 tanesi de tercihli ticaret anlaşması kapsamındadır.

\begin{tabular}{|c|c|}
\hline & Bölgesel Ticaret Anlaşması Sayıs 1 \\
\hline Gümrük Birliği & 17 \\
\hline Ekonomik Entegrasyon Anlaşmaları & 84 \\
\hline Serbest Ticaret Anlaşmaları & 176 \\
\hline Tercihli Ticaret Anlaşmaları & 14 \\
\hline Toplam & 302 \\
\hline
\end{tabular}

Tablo 9: Dünya'daki Bölgesel Ticaret Anlaşmalarl. Kaynak: WTO, RTA Database 
Ekonomik bütünleşme aşamalarından tam ekonomik bütünleşme aşamasında olan Avrupa Birliği'nin toplam ithalatının dünya ülkeleri ithalatı içindeki payı, Tablo-11'de görülmektedir. 27 üyeli Avrupa Birliği'nin ithalatının 2010 yllı itibariyle \%62,1'i entegrasyon içinde yapılmaktadır. Toplam ithalat payında, entegrasyon dışındaki ülkelerden ön plana çıkanlar ise sırasıyla, ABD $(\% 16,6)$, Çin $(\% 13,0)$, Kanada $(\% 11,9)$ ve Japonya $(\% 9,6)$ 'dır.

\section{Sonuç ve Değerlendirme}

Küreselleşen dünya, ülkeler arasındaki ekonomik bütünleşmelerin artmasına yol açmıştır. Özellikle 1950'li yıllardan itibaren bölgesel ticaret anlaşmaları oluşmaya başlamış, 1990'lı yıllardan itibaren ise, söz konusu oluşumlar büyük ölçüde artış göstermiştir. Dünya Ticaret Örgütü verilerine göre, 2010 y1lında 302 tane gerçekleşmiş bölgesel ticaret anlaşması bulunmaktadır.

Uluslararası ekonomik bütünleşmeler, genel olarak, bağımsız ulusal ekonomiler arasında ticareti kısıtlayıcı engellerin kaldırıldığı, ticari ilişkilerin önem kazandığı süreçte, ülkeler arasında kurulan bölgesel gruplar ya da bloklar şeklinde tanımlanmaktadır. Ülkeleri ekonomik bütünleşmelere iten temel nedenler arasında, genişleyen piyasa ölçeğinden yararlanmak, içsel ve dışsal ekonomiler yaratmak, üretim faktörlerinin mobilitesini sağlamak, rekabeti arttırmak ve ekonomik-sosyal politikaların uyumlaştırılmasını sağlamak, sayılabilir. Söz konusu nedenlere ek olarak, ülkelerin benzer gelişmişlik düzeyinde olması, coğrafi açıdan yakınlık, tarihi, dini, kültürel bağların bulunması, siyasi, politik alanlardaki birliktelik ve uluslararası anlaşmalardan doğan zorunluluklar da, ülkelerin entegrasyon içerisinde yer almalarını hızlandıran faktörlerdir. Uluslararası ekonomik bütünleşmeler, genel olarak, serbest ticaret bölgesi, gümrük birliği, ortak pazar, ekonomik birlik ve tam ekonomik bütünleşmeler şeklinde beş aşamada sınıflandırılmaktadır.

Günümüzde kurulmuş bulunan ekonomik entegrasyonlar çok ve çeşitlidir. Hem gelişmiş ülkeler, hem de gelişmekte olan ülkeler, entegrasyon oluşturmaktadırlar. Entegrasyonlara göre küreselleşme, belli bir bölge ve ideolojiyi paylaşan ülkeler arasında olabileceği gibi, her bölgeyi ve ekonomik yapıyı kendisine yaklaştırarak belirli bir sistem ve düzen dahilinde işbirliklerini sağlamaya yönelik de olabilmektedir. Ekonomik entegrasyonlarla ülkeler, küreselleşme ile artan rekabet şartlarıyla başa çıkmakta tek başına yetersiz kaldıklarından bölgesel entegrasyon kurma yoluna gitmişlerdir. Ülkeler, ekonomik entegrasyon hareketleri içinde yer alarak, rekabet güçlerini arttırmaya çalışmaktadırlar.

Ülkeler, bugün kendilerinden geri olan ülkelere karşı küreselleşmeyi kullanırken, kendilerine ekonomik, teknolojik bakımdan rakip olan kutuplara karşı birleşerek entegrasyonlar oluşturmaktadırlar. Küreselleşme yolunda da bu kutuplar arasında çeşitli temas ve anlaşmalar gerçekleşmektedir. Birbirine zıt gibi gözüken bu iki gelişim, küreselleşme ve bölgeselleşme; genel görüş itibarıyla aslında birbirinin zıttı değil tamamlayıcısıdır. Bölgesel bir entegrasyona dahil olmak küreselleşme yolunda atılan ilk adımdır. Yukarıda yapılan ülkelerarası ticaret analizleriyle, bölgesel entegrasyonlar oluşturarak ülkelerin, küreselleşen Dünya'da daha geniş bir ihracat potansiyeline, rakip ülkelere karşı daha iyi bir rekabet gücüne ve daha güçlü bir politik erke sahip oldukları sonucuna ulaşılabilir.

\section{Referanslar}

- Balkır, Canan ve Muzaffer Demirci. 1989. Uluslararası Ekonomik Bütünleşme ve Avrupa Topluluğu. Filiz Kitabevi, İstanbul.

- Devlet Planlama Teşkilatı. 1995. Dünyada Küreselleşme ve Bölgesel Bütünleşmeler. Dünyada Küreselleşme ve Bölgesel Entegrasyonlar ve Türkiye İlişkileri Özel İhtisas Komisyonu Raporu (Kitap:2), T.C Başbakanlık DPT Müsteşarlığı Yayın No: 2375-Ö.İ.K:440, Ocak 1995, Ankara.

- Ertürk, Emin. 1991. Ekonomik Entegrasyon Teorisi. Ezgi Kitabevi Yayınları, Bursa.

- Ertürk, Emin. 1997. Ekonomik Entegrasyon Teorisi ve Türkiye'nin İçinde Bulunduğu Entegrasyonlar. 1.Bask1, Ezgi Kitabevi, Bursa.

- Fernandes R.-Portes J. 1998. Returns to Regionalism: An Analysis of Nontraditional Gains from Regional Trade Agreements, The World Bank Economic Review, Vol. 12, No. 2: 197-220.

- Güran, Nevzat ve İsmail Aktürk. Uluslararası İktisadi Kuruluşlar. İzmir, 1992.

- İncekara, Ahmet. 1995. Globalleşme ve Bölgeselleşme Sürecinde NAFTA ve Etkileri. İTO Yayınları, Yay. No:1995-14, İstanbul.

- Kahnert, F. ve diğerleri. 1969. Economic Integration Among Developing Countries. OECD, Paris.

- Karluk, Rıdvan. 1995. Küreselleşen Dünyada Uluslararası Ekonomik Kuruluşlar ve Entegrasyonlar. 2.Baskı. Anadolu Üniversitesi Basımevi, Eskişehir.

- Karluk, Rıdvan. 2002. Uluslararası Ekonomik Mali ve Siyasal Kuruluşlar. Turhan Kitabevi, Ankara.

- Korkmaz, Tülay. 1993. Avrupa Topluluğu, Karadeniz Ekonomik İşbirliği Projesi ve Türk Cumhuriyetleri, Maliye Bakanlığı Araştırma, Planlama Koordinasyon Kurulu Baş̧kanlığı Araştırmalar Cilt: XIII, Yayın No: 1993/322, ss.83-110. 
- Küçükahmetoğlu, Osman. 2006. Reel Entegrasyon Teorisi, Ekonomik Entegrasyon Küresel ve Bölgesel Yaklaşım içinde, ed. Küçükahmetoğlu, O. Ekin Yayınları

- Manisalı, Erol. 1971. Uluslararası Ekonomi: Gümrük Birlikleri ve Dinamik Entegrasyon Teorisi. İstanbul Üniversitesi Yayınları No:1694, İktisat Fakültesi Yay. No: 299, İstanbul.

- Paksoy, H. Mustafa ve Sadettin Paksoy. 2000. Ekonomik Bütünleşmeler ve Avrupa Birliği. Özdal Matbaacılık, Şanlıurfa.

- Seyidoğlu, Halil. 2001. Uluslararası İktisat. Güzem Yayınları, İstanbul.

- Yüksel, Mehmet. 2001. Küreselleşme Ulusal Hukuk ve Türkiye. Siyasal Kitabevi, Ankara. 


\title{
Совершенствование финансово - кредитных механизмов регулирования развития АПК
}

\author{
Dzhumabek Dzhailov (Ministry of Agriculture, Kyrgyzstan) \\ Farkhad Sariev (Zh. Alyshbaev Cooperation Institute of Issykkul, Kyrgyzstan) \\ Elmira Kupsuralieva (Kyrgyzstan-Turkey Manas University, Kyrgyzstan)
}

\section{Improvement of Financial and Credit Regulation Mechanisms in Agroindustrial Complex Development}

\begin{abstract}
Agroindustrial complex is a strategically important sector of the national economy. However, its unsustainable development within recent years strongly reduced its share in GDP of the country and aggravated the problems of food security. The factors of the sector situation aggravation are low investment attractiveness, poor development of financial and credit sphere. It is necessary to increase considerably not only volumes of assigned financial and credit resources but also to change significantly their assignment (financial support of priority sectors of agro industrial complex, subsidy assistance of farmers' expenses and percents on credits etc.)
\end{abstract}

JEL code: Q13

Сельское хозяйство производит около $1 / 3$ ВВП республики, в этой отрасли занято подавляющая часть активного населения страны (около 40\%). Продукция отрасли занимает весомое место в экспортном потенциале экономики. Занятость сельскохозяйственным производством является единственным источником дохода $60 \%$ населения, проживающего в сельской местности. С 2000 года сельскохозяйственное производство демонстрирует положительную динамику развития. Однако темпы его роста неадекватны имеющемуся потенциалу, имеют тенденцию к снижению, недостаточны для успешного развития отрасли и значительно отстают от роста экономики страны. За исключением 2009 г. среднегодовые объемы производства зерновых в 2006-2010 гг., были ниже, чем в среднем за 2001-2005 гг. Резко снизилось производство сахарной свеклы и табака. Практически не изменилось производство мяса и шерсти (Кыргызстан в цифрах, 2010.c.91-93). В результате за период 2005-2009 гг. удельный вес сельского хозяйства в структуре производства ВВП страны значительно снизился (с 30,5 до 22,1\%) (Бюллетень Национального Банка КР, с.21).

Во многом это обуславливается неустойчивостью развития отраслей растениеводства и животноводства, мелкокрестьянской структурой производства и еe низкотоварностью, крайне неэффективным использованием производственного потенциала отрасли в виду слабого финансового состояния отрасли.

Финансовое состояние преобладающего большинства хозяйствующих субъектов сельского хозяйства удручающе, многие находятся на грани банкротства. Растет убыточность сельхозформирований, кредиторская задолженность. В 2009 году балансовая прибыль предприятий сельского хозяйства, охоты и лесного хозяйства составила 36,0 млн. сомов. Кредиторская задолженность 558,8 млн. сомов. Дебиторская задолженность 341,2 млн. сомов (коэффициент ликвидности текущей задолженности составляет 0,61). Убыточные предприятия в процентах от общего их количества в сельском хозяйстве составляет $36,0 \%$. Инвестиции в основной канал в сельском хозяйстве составляет чуть более $2,0 \%$, а иностранных инвестиций - 0,1\%, что ограничивают возможности технического перевооружения и модернизации отрасли (Кыргызстан в цифрах, 2010, с.121, 209, 212). Совершенно недостаточен объем государственной поддержки отрасли, что также сказывается на ее доходности.

Предоставляемые ОАО «Айыл Банк» и другими кредитными учреждениями кредиты, из-за высоких процентных ставок (не ниже коммерческих кредитов), недоступны большинству фермерам и в целом не обеспечивают потребность в кредитных ресурсах сельхозтоваропроизводителей. Существующая система кредитования сельхозтоваропроизводителей по линии «Айыл Банка» слабо увязана с государственными программами по развитию сельского хозяйства, не направлена на модернизацию отрасли, стимулированию развития высокоэффективного товаропроизводителя.

Несмотря на то, что в республике обеспечен рост потребления продовольственных товаров наблюдается ее отставание по основным продовольственным товарам от потребления: по установленным физиологическим нормам потребления, уровень потребления мяса и мясопродуктов составляет 67,4\%, сахара - 44,2\%, масла растительного - 69\%, яиц - 36\%. Растет импортозависимость по основным продовольственным ресурсам. За последние 5 лет импорт вырос: пшеницы - на 91,9\%, муки - свыше 2,0 раз, сахар - на 10\%, животных и растительных масел - в 2,1 раза мяса - почти в 4,9 раза, т.е. темпы роста 
импорта отдельных видов продовольствия оказались выше темпов роста собственного производства (Концепция модернизации социально-экономического развития КР на период до 2015 года, с.54).

Достаточность финансовых средств является одним из аспектов функционирования экономической системы и определяет уровень технической оснащенности, эффективности материального производства, ее устойчивости. Рост в финансовой сфере не поддерживается аналогичной тенденцией в производственной. Так, по данным Национального банка КР сумма предоставленных кредитов в 2009 г. по сравнению с 2005 г. выросла в 3 раза и составляет 9993,4 млрд. сомов. В общем объеме доля долгосрочных вложений (свыше одного года) составила 64,7\%, или 6415,0 млрд. сом и выросла по сравнению с 2005 годом в почти в 9.3 раза. Основная часть предоставляемых кредитов идет в сферу торговли (около $30.0 \%$ ) и только $-18,0 \%$ в сферу сельскохозяйственного производства (Бюллетень Национального Банка КР, с.55). Таким образом, налицо определенное обособление финансового сектора от производственного. В связи с этим возникает необходимость проведения мероприятий по дополнительному привлечению средств в аграрный сектор из различных источников.

В последние годы наметилась серьезная тенденция роста мировых цен на продовольствие. Если в среднем за период 2000-2010 годы мировые цены на продовольствие выросли в 2 раза, то только за 2010 год и за первое полугодие 2011 года в среднем выросли на 33,0 \%. Наряду с общеизвестными факторами, обусловливающими рост цен на продовольствие (рост спроса, снижение ее предложения и др.) резкий скачок цен на продовольствие во многом определяется тенденцией роста себестоимости ее производства в связи с повышением соответствующих затрат. По оценкам экспертов подобная динамика роста цен на продовольствие сохранится и на ближайший период (до 2020 года) (Котликов Я.).

Динамика цен на продовольственные ресурсы во многом зависит от проводимой аграрной политики государства и от условий субсидирования сельскохозяйственного производства. В развитых государствах данный компонент аграрной политики играет решающую роль в деле поддержания стабильности розничных цен на сельхозпродукцию и в росте доходов сельхозтоваропроизводителей. Обьём субсидий составляет порядка 40,0\% стоимости затрат сельхозтоваропроизводителя (Аграрный сектор Казахстана: экономическая и социальная модернизация, с.223). Практически большая часть затрат фермеров в развитых странах компенсируется государством, что позволяет стабильно развивать производство и экспорт продовольствия, поддерживать высокий уровень конкурентоспособности отрасли.

Динамика роста цен на продовольствие намечается и в Кыргызстане. Причем растут цены на социально значимые виды продовольствия (сахар, мясо, хлеб и др.) и темпы роста довольно внушительные и даже выше мировых ее значений. На наш взгляд подобные тенденции изменения цен на продовольствие во многом объясняется недостаточностью инвестиций в сельское хозяйство, хронической нехваткой доступных финансовых средств, слабой государственной поддержкой сельскохозяйственного производства, технико-технологической отсталостью отрасли, неразвитостью аграрных отношений, характером и преобладанием мелкого землепользования. Данные особенности развития аграрного сектора страны вкупе с повсеместным ростом затрат фермеров на приобретение техники, ГСМ, семян и удобрений обусловливают указанный рост цен на продовольствие на рынке.

В этих условиях, а также принимая во внимание сложившийся уровень платежеспособного спроса населения страны субсидирование сельского хозяйства является одной из наиболее важных направлений повышения государственной финансовой поддержки аграрного сектора. К этим мерам следует отнести дальнейшее развитие и совершенствование интервенционных закупок государством сельхозпродукции с целью поддержания стабильных цен, гарантирующих определенную рентабельность и конкурентоспособность на внутреннем рынке, субсидирование элементов себестоимости сельхозпродукции (удешевление стоимости минеральных удобрений, выплата компенсации для снижения цены реализации продукции, списание или отсрочка долгов и т.д.)

Как показывают расчеты и возможности государственного бюджета Кыргызстана, целесообразно удельный вес субсидий довести в структуре себестоимости в 2015 г. в следующих размерах: по зерну до 9,2\% , кукурузе на зерно до 9,3\%, масличным культурам до 18,4\%, картофелю до 5,5\%, овощам до 6,7\%, хлопку-сырцу до 9,8\%, сахарной свекле до $12,3 \%$, мясу крупного рогатого скота до 7,7\%, баранине до $8,7 \%$ и молоку до $4,5 \%$.

Внедрение механизма субсидирования производства важнейших видов сельхозпродукции в Кыргызской Республике с учетом утвержденного среднесрочного прогноза бюджета на 2010-2012 годы предлагается ввести постепенно по нарастающему темпу с 2013 года. На наш взгляд предлагаемые расчеты субсидий вполне реальны и не создадут особой нагрузки на республиканский бюджет.

По нашим расчетам, объемы субсидирования сельскохозяйственной продукции для достижения прогнозируемых показателей будет равняться 3,0 млрд. сомов, что составит 2,5 \% прогнозируемой стоимости валовой продукции сельского хозяйства или $1,25 \%$ ВВП страны. В расчете на 1 га пашни объем предоставляемых субсидий составит 2500 сомов. Уровень рентабельности возрастает до 26,6\% и прибыли в 2 раза. 
Предлагается внедрить обязательное страхование по основным сельскохозяйственным культурам и категориям хозяйств, включая хозяйства населения. Для этого необходимо учитывать фактическую сложившуюся урожайность за несколько лет и расчетные прогнозируемые цены, установленные Министерством сельского хозяйства КР. Размер страховых платежей сельскохозяйственным товаропроизводителям устанавливается в размере $10 \%$ застрахованной стоимости урожая, в том числе $5 \%$ за счет республиканского бюджета, формирующих страховой фонд.

Для развития системы страхования сельского хозяйства предлагается создать Департамент по регулированию страхования в сельском хозяйстве, подведомственный Министерству сельского хозяйства КР, который будет выполнять роль агента в сельскохозяйственном страховании и решать следующие задачи: организация мероприятий по государственному регулированию страхования в сфере агропромышленного производства; информационное обеспечение деятельности по страхованию в аграрном секторе; обобщение опыта страхования в сельскохозяйственной сфере, разработка предложений по совершенствованию этой деятельности, использованию новых механизмов и форм государственной поддержки страхования в сфере агропромышленного производства.

Из прогнозных расчетов необходимых объемов инвестиций в АПК и их распределения по источникам инвестирования потребуют ежегодного инвестирования около 15 млрд. сомов и обеспечат ее потребность до 2015 год на 60\%. В международной практике основным источником инвестиций являются собственные средства (прибыль и амортизационные отчисления). Учитывая тенденции последних лет в сельском хозяйстве Кыргызстана, предполагаем, что доля собственных средств (прибыли) в структуре инвестирования основного капитала увеличится на 1,5 пункта к 2015 г., заемных (кредитных) средств на 6,5 пункта, а иностранных инвестиций снизится на 9,0 пункта.

В структуре источников финансирования будут и дальше преобладать кредитные средства. Значительную часть собственных средств целесообразно направлять на ежегодное погашение полученных долгосрочных кредитов, чем напрямую направлять на капитальные вложения. В этом случае сельхозформирования могут получить гарантированные платежами (возвратами) долгосрочные кредиты на 5-7 лет.

Одним из важнейших источников привлечения инвестиций в сельское хозяйство являются банковские кредиты, доля которых в настоящее время мала и не позволяет удовлетворить даже минимальные потребности в кредитных вложениях сельских товаропроизводителей.

В общем объёме выданных кредитов на сельхозпродукции больше половины занимают краткосрочные кредиты, доля которых в 2009 году составила около 60\% (Бюллетень Национального Банка КР, с.54). В тоже время проблема доступа сельхозтоваропроизводителей, особенно мелких, к финансовым ресурсам остается нерешенной. Ограничителями выступают высокие процентные ставки, короткие сроки кредитования, а также отсутствие у сельхозформирований ликвидного, с точки зрения банков, залогового обеспечения. Банки не желают вкладывать средства в сельскохозяйственное производство, которое не приносит высокий и стабильный доход и во многом зависит от природно-климатических факторов. Поэтому размеры получаемых сейчас сельхозтоваропроизводителями кредитных ресурсов в банках далеко не удовлетворяет их потребность в заемных средствах, особенно долгосрочных для инвестиции в основной капитал.

О недостаточности выделяемых кредитов для сельского хозяйства свидетельствует и тот факт, что в объеме произведенной валовой продукции сельского хозяйства за 2009 г. - (112,5 млрд. сомов), доля кредитов выданных банками второго уровня составляет всего около 5,3\%. В нашей республике практически недоступен банковский кредит мелким крестьянским (фермерским) и домашним хозяйствам, которые производят вместе до 98,0\% всей валовой продукции сельского хозяйства республики.

В республике не действует механизм ипотечного кредитования села, земельные ресурсы села не включены в рыночный оборот, которые являются главным средством производства. Поскольку многие хозяйства имеют землю, но не имеют другого имущественного обеспечения, то формирование и развитие земельного ипотечного кредитование в настоящее время является составной частью государственной кредитной системы.

Главное препятствие в развитии ипотеки заключается в том, что сельское хозяйство не является конкурентоспособной отраслью по сравнению с другими, высокодоходными секторами экономики. Аграрный сектор по-прежнему остается малопривлекательной отраслью для частного инвестора. Отсутствие кадастровой и имеющиеся недостатки в оценке рыночной стоимости земли и в целом несовершенство экономических механизмов развития вторичного земельного рынка заведомо обусловливают низкую ликвидность земель сельскохозяйственного назначения, что является основным сдерживающим фактором привлечения банковского капитала и частных инвестиций.

Инвестиционная политика в сельском хозяйстве должна быть направлена на стимулирование восстановления кредитного механизма как одного из элементов финансовой базы для осуществления 
инвестиционной деятельности в отрасли. Для этого следует планировать потребность в кредитах и кредитование с учетом совокупного норматива собственных оборотных средств предприятий, введение в практику среднесрочного кредита (до 3-х лет) для покрытия недостатка собственных оборотных средств, применение единого порядка сельскохозяйственного страхования производственных и коммерческих рисков.

Учитывая высокие процентные ставки и краткосрочность кредитов коммерческих банков, не заинтересованных в кредитовании сельского хозяйства как отрасли с длительным оборотом капитала, необходимо аккумулировать бюджетные средства, направленные на финансовую поддержку сельхозтоваропроизводителей в ОАО «Айылбанке».

Выделение дотационных и льготных инвестиционных и кредитных средств через данный банк позволит создать единую базу получателей кредита и развить механизм кредитного бюро. В результате, будет предоставлен доступ сельхозтоваропроизводителям к бюджетным средствам на льготной основе, повысится эффективность реализации государственных программ в АПК, привлечение инвестиционных ресурсов из различных источников и их размещение среди товаропроизводителей через ОАО «Айылбанк» и станет возможным рефинансирование капитала в сельской местности.

В рамках государственной поддержки сельхозтоваропроизводителей Правительством республики впервые начиная с 2011 года будет осуществляется ежегодная выдача кредитов в размере 1000 млрд. сомов рамках проекта «Доступные кредиты фермерам» под низкие процентные ставки $(9,0 \%)$ через коммерческие банки Кыргызской Республики (Постановление ПКР КР от 12 января 2011 года, №12 « Об утверждение проекта «Доступные кредиты фермерам»).

С учетом этого и прогнозируемых ростов объема предоставляемых кредитов, а также в целях эффективного распределения кредитов по областям и в разрезе сельскохозяйственных культур нами разработаны рекомендации о порядке выдачи кредитов сельскохозяйственным товаропроизводителям через коммерческие банки Кыргызской Республики на основе следующих принципов:

1. Справедливое распределение по регионам в зависимости от:

-сложившейся структуры посевных площадей в растениеводстве;

-структуры хозяйствующих субъектов;

-необходимости поддержки депрессивных и отдаленных районов.

2. Распределение кредитов по сельскохозяйственным культурам с учетом:

-обеспечения продовольственной безопасности;

-дальнейшего увеличения агроэкспортного потенциала отрасли.

3. Градация выдаваемых кредитов в зависимости от затрат на производство сельскохозяйственных культур.

Приведенный анализ структуры посевных площадей сельскохозяйственных культур показывает следующее распределение посевных площадей по областям и культурам: Чуйская область- 34,3\% посевных площадей, в т.ч. 36\% пшеницы, 54\% ячменя, 35,7\% кукурузы, 93\% сахарной свеклы, 24\% масличных культур, 11,8\% картофеля, 42,1\% овощей; Ыссыккульская область - 15,5\% посевных площадей, в т.ч пшеницы $19,9 \%$, ячменя $18,2 \%$, картофеля $37,3 \%$, овощей $6,3 \%$; Нарынская область $8,66 \%$ посевных площадей, в т.ч пшеницы 4\%, ячменя $12,7 \%$, картофеля 8,3\%, овощей $1,6 \%$; Таласская область - 8,7\% посевных площадей, в т.ч пшеницы 5,3\%, ячменя 1,1\%, кукурузы 7,8\%, зернобобовых (фасоль) 89,3\%, масличных 2,7\%, картофеля 18,8\%, овощей 8,8\%; Баткенская область- 5,3\% посевных площадей, в т.ч пшеницы 5,8\%, ячменя 7,0\%, кукурузы 8,1\%, зернобобовых 5\%, табака 10,2\%, масличных 4,1\%, картофеля 2,6\%, овощей 5,3\%; Жалал-Абадская область- 12,6\% посевных площадей, в т.ч $10,5 \%$ пшеницы, 1,5\% ячменя, 29,7\% кукурузы, 2,5\% зернобобовые, 54,1\% хлопчатника, 8,1\% табака, 36,2\% масличных, 9,0\% картофеля, 21,3\% овощей и Ошская область - 15,0\% посевных площадей, в т.ч пшеницы $18,3 \%$, ячменя $5,1 \%$, кукурузы $18,5 \%$, хлопчатника $45,0 \%$, табака $81,6 \%$, масличных $32,6 \%$, картофеля $12,0 \%$, овощей $14,5 \%$.

Количество крестьянских (фермерских) хозяйств в разрезе областей республики составляет: Чуйская область - 15,0\%, Иссыккульская - 9,0\%, Нарынская - 11,7\% .Таласская -5,6\% .Баткенская $-8,5 \%$ ,Жалалабадская - 28,4\% и Ошская область - 21,0\%.

В целях поддержки депрессивных и отдаленных районов Нарынской, Таласской и Баткенской областей при распределении кредитов рекомендуется ввести корректировку на коэффициент 1,2 в сторону увеличения объемов кредитования этих областей, что отразит высокие расходы сельхозтоваропроизводителей этих областей по сравнению со средними республиканскими.

Ежегодная льготная выдача предложенных объемов кредитов в сумме около 1000,0 млн. сомов, хозяйствующим субъектам сельского хозяйства Кыргызской Республики согласно разработанной рекомендации, позволит: 
- довести ежегодные темпы роста продукции сельского хозяйства до $4.0-4.5$ \%

- обеспечить ежегодный рост среднего дохода крестьянских (фермерских) хозяйств ежегодно на $12,0 \%$ к достигнутому среднему республиканскому реальному доходу в сумме 41200 сомов;

- своевременно и в полном объеме проводить необходимые агротехнические работы по посеву сельскохозяйственных культур, что скажется на росте урожайности и увеличении валового сбора урожая сельскохозяйственных культур;

- стабилизировать цены на основные продукты питания: хлебобулочные изделия, сахар, масло растительное;

- увеличить объемы налоговых поступлений от хозяйствующих субъектов сельского хозяйства в бюджет республики всех уровней;

- увеличить экспортный потенциал сельскохозяйственной продукции в 2,1 раза.

Для дальнейшей эффективной реализации проекта «Доступные кредиты фермерам» целесообразно : коммерческим банкам выдавать кредиты в комиссионном порядке с привлечением органов местной государственной администрации и местного самоуправления, районных управлений аграрного развития и представителей общественности (ассоциаций сельхозтоваропроизводителей); Министерству юстиции Кыргызской Республики и Государственной регистрационной службе при Правительстве Кыргызской Республики совместно с представителями коммерческих банков и органов местной государственной администрации и местного самоуправления организовать выездные регистрации залогового имущества сельхозтоваропроизводителей

Потенциальный инвестор заинтересован в получении прибыли, поэтому в качестве объекта вложения финансовых ресурсов предпочтет либо крупное предприятие, характеризующееся устойчивым финансовым состоянием, либо объединение предприятий. Международный опыт показывает, что обязательное участие сельхозпроизводителя в отраслевом союзе - это объективная особенность сельскохозяйственной экономики. Только через ассоциации и союзы, возможно, обеспечить сбалансированность интересов сельхозпроизводителей, перерабатывающих предприятий, розничной торговли, включая согласование ценовой политики на всех уровнях, поддерживать высокое качество продукции, вовлечь сельхозтоваропроизводителей в формирование аграрной политики.

Следовательно, необходимо создание мощных вертикально интегрированных агропромышленных формирований. Участниками этой интеграции должны быть и крупные сельскохозяйственные предприятия, и фермерские хозяйства. В целом, при активной организационно-правовой поддержке государства, приоритетными направлениями для инвестиций должны стать формирование и развитие региональных сельскохозяйственных агрокластеров. На основе анализа сложившихся тенденций развития основных отраслей АПК и с учетом необходимости более полного и эффективного использования ее ресурсного потенциала, направленного на расширение внутреннего производства и переработки продукции отрасли, повышения ее экспортного потенциала, эффективности

взаимодействия в единой технологической цепи» производство-хранение-переработка-реализация» обоснована необходимость организации в республике следующих агрокластеров: «Зерно», «Сахар», «Растительное масло», «Мясо», «Хлопок», «Табак», плодоовощной кластер по производству концентрированного «сока», «Картофель», «Фасоль» и кластер по разливу «бутилированной минеральной и столовой воды»

Эффективной формой организации агрокластеров на первоночальном этапе является акционерная форма управления. В группе кластеров по обеспечению продовольственной безопасности акционерная форма управления агрокластерами предусматривает совместное участие государства и бизнеса. Группа кластеров по развитию агроэкспортного потенциала организуется в основном бизнес-сообществами. Формы участия государства в управлении агрокластерами: выпуск государственных ценных бумаг; предоставление земель ФПС в долгосрочную аренду; либерализация земельного законодательства, снятие существующих ограничений полноценного функционирования земельного рынка; предоставление налоговых льгот или полное освобождение от уплаты налога на период вступления агрокластера на полную производственную мощность; предоставление льготных целевых долгосрочных кредитов под строительство агроперерабатывающих предприятий. В дальнейшем, с развитием агрокластерного производства возможен переход на корпоративные методы управления агрокластерами и формирование на базе указанных агрокластеров крупных отраслевых корпораций, которые обеспечат конкурентоспособность агропромышленной продукции на внутреннем и региональных рынках.

Для организации и реализации 13 агрокластерных проектов всего потребуется инвестиционных и кредитных ресурсов на сумму 85164 тыс. долларов США. Средний срок окупаемости агрокластерных проектов 3-3,5года, рентабельность агрокластеров составит в среднем 18-25\%. Вступление на полную производственную мощность функционирования агрокластеров позволит ежегодно: производить валовую продукцию на сумму 212475 тыс. долларов США; получить чистую прибыль на сумму 60392 
тыс. долларов США. Общая распределенная прибыль с учетом цепочки добавленной стоимости по каждому агрокластеру составит; сельским товаропроизводителям в сумме 31951 тыс.долларов США ( 52,9 \%); предприятиям перерабатывающей промышленности в сумме 19112 тыс. долларов США (31,6\%); предприятиям торговли и хранения в сумме 2676 тыс. долларов США (4,4\% ) и платежи в бюджет в сумме 6389 тыс. долларов США (10.5\%).

Организация агрокластеров приведет к устойчивому и динамичному развитию агропромышленного производства в республике. Будут сформированы крупные агропромышленные формирования по схеме ЦДС (цепочка добавленных стоимостей), что даст возможность значительно увеличить уровень глубокой переработки сельскохозяйственной продукции и сырья. В целом будет решена проблема обеспечения продовольственной безопасности страны. Внутренний рынок продовольствия по основным ее позициям (по хлебу и хлебопродуктам, мясу, сахару, растительному маслу) будет в основном обеспечиваться за счет собственного производства. Значительно увеличится экспортный потенциал страны, в частности минеральной воды, соков, картофеля мясомолочной продукции, хлопчатобумажной пряжи, фасоли. Поставки экспортной продукции вырастут не только в страны Ближнего, но и в страны Дальнего зарубежья.

\section{Литература}

- Кыргызстан в цифрах, 2010 /Статсборник.- Бишкек, Нацстатком, 2010.-С.336.

- Бюллетень Национального Банка КР. - Бишкек, №12,2009.- С.137.

- . .Концепция модернизации социально-экономического развития КР на период до 2015 года. -Бишкек, ЦЭС при МЭР и Т КР, 2008.- С.129.

- Котликов Я. Рост цен на продовольствие в мире. http://webcache.googlesertontent . com. /search?g $=$ cache

- Аграрный сектор Казахстана: экономическая и социальная модернизация.- Алматы, НИИ экономики АПК и развития сельских территорий. - С.563.

- Постановление ПКР КР от 12 января 2011 года, №12 « Об утверждение проекта «Доступные кредиты фермерам». 


\title{
Современное состояние аудиторских услуг в Кыргызской Республике
}

\author{
Kylychbek Supataev (Kyrgyz Academy of Law, Kyrgyzstan)
}

\section{The Current State of Audit Services in the Kyrgyz Republic}

\begin{abstract}
Studied the organizational aspects of the formation and current state of audit services for the whole country, as well as by region. Problems of the quantitative growth of skill-certified auditors and its impact on improving the quality of the audit. Explored public knowledge about the necessity and usefulness of the audit, and its influence on the formation of national capital in total capital of real sector of the economy. The role of audit in the development of financial and economic activities of businesses. Determined the influence of audit on the transition economy, reviewed its present contradictions, acute legal problems and prospects of development.
\end{abstract}

JEL Codes: M42, P20

Современный этап развития рыночных отношений привело к отделению прав собственности на капитал от фактического распоряжения капиталом, и такая экономическая взаимоотношения породила института аудита. Из-за недобросовестностью и злоупотреблениями теми лицами, которые фактически распорядились инвестированными капиталом, происходило банкротство акционерных обществ и массовый обман доверчивых акционеров, в результате акционеры частично или полностью теряли свои капиталы. Отсюда появилась объективная необходимость защита прав собственников, они нуждались достоверной информации о состоянии финансовых дел хозяйствующего субъекта, куда они вложили свои капиталы. Такой же достоверной информации нуждается потенциальные инвесторы и кредиторы, а также партнеры желающие иметь хозяйственные связи с экономическим субъектом. Поэтому аудит необходимо рассматривать как неотъемлемой инфраструктурой рыночной экономики.

Как известно, по мере становления и укрепления основ мировых рыночных отношений, аудиторская деятельность получила безусловное теоретическое и практическое признание, постепенно приобрела современную форму и достаточное развитие. Ведущие страны рыночной экономики имеют вековой опыт проведения аудита. Международная теория и практика аудита формировался в условиях жесткой конкуренции, и сопровождалось соответствующими исследованиями и широкими публичными обсуждениями материалов этих исследований. В результате к настоящему времени создана прочная правовая основа аудита, подробно разработаны формы его организации, методические материалы и стандарты аудита. В связи с этим наши задачи и основные направления исследования аудита должна быть направлена на разработку методику применения международных опытов с учетом конкретных социально-экономических, культурных, нравственных и правовых условий нашей республики.

Переход к рыночным отношениям, развитие предпринимательства, возникновения новых организационно-правовых форм организаций (акционерных обществ, обществ с различной ответственностью, кооперативов и др.) и многообразных форм собственности обусловил объективной необходимости введение в нашей стране нового экономического института - аудиторства. Его главная цель - обеспечить контроль за достоверностью информации, отражаемой в финансовой (бухгалтерской) отчетности хозяйствующего субъекта.

В Кыргызской Республике за последние годы проведена определенная работа по внедрению и развитию аудиторской деятельности в экономической жизни республики. Дважды приняты Закон Кыргызской Республики «Об аудиторской деятельности» 3 июля 1998 года и 30 июля 2002 года, приняты ряд правительственных постановлений по государственному регулированию аудиторской деятельности.

В соответствии со статьи 4 и 5 Закона Кыргызской Республики «Об аудиторской деятельности» аудитом имеют право заниматься физические лица, отвечающее квалификационным требованиям, установленным уполномоченным органом, и имеющее квалификационный сертификат аудитора.

Аудиторы, прошедшие аттестацию и желающие работать самостоятельно, а также аудиторские фирмы начинают свою деятельность после государственной регистрации в качестве субъекта предпринимательской деятельности, получения лицензии на осуществление аудиторской деятельности и включения в государственный реестр аудиторов и аудиторских фирм.

По мере развития рыночных отношений и рост потребности в достоверной экономической информации об имущественном и финансовом состоянии хозяйствующих субъектов, обеспечивающей интересы собственников, акционеров, инвесторов, кредиторов, других заинтересованных внешних контрагентов и дающей им определенные гарантии, увеличивается потребность в аудиторских услугах и прочих 
хозяйствующих субъектов.

В настоящее время нельзя сказать о том, что в Кыргызской Республике сформировался рынок аудиторов и аудиторских фирм. По данным Служба надзора и регулирования финансового рынка Кыргызской Республики, на сегодняшний день всего лишь 196 аудиторов получили квалификационные сертификаты на право осуществления аудиторской деятельности. По нашим расчетам, для своевременного обеспечения аудиторской проверки финансовой отчетности хозяйствующих субъектов подлежащих к обязательному аудиту и создания нормальной конкуренции в нашей республике необходимо $1000-1100$ сертифицированных аудиторов. Ниже этого уровня количеством сертифицированных аудиторов невозможно создать здоровую конкуренцию между аудиторами и аудиторскими фирмами. Без такой конкуренции не может быть речи о саморегулировании аудиторской деятельности и повышении качества аудиторской проверки.

В территориальном разрезе (по областям республики) предложение на рынке аудиторских услуг распределяется весьма неравномерно. По состоянию на 1 июля 2011 года более 87,9 \% аудиторов получивших квалификационные сертификаты являются жителями г. Бишкека, а также здесь же расположены аудиторские организации и аудиторы, занимающиеся индивидуальной трудовой деятельности. Аудиторские фирмы и аудиторы, получившие лицензии на осуществления аудиторской деятельности расположенных в Ошской, Джалал-Абадской, и Чуйской областях, составляет около 12,1% от общего количества. А в Баткенской, Иссык-Кульской, Нарынской и Таласской областях пока не имеют аудиторов.

Работающие на рынке Кыргызской Республики аудиторские фирмы можно разделит на три группы.

1) аудиторские фирмы «большой пятерки»;

2) несколько десятков ведущих национальных аудиторских фирм;

3) аудиторы, занимающиеся индивидуальной трудовой деятельности.

Фирмы «большой пятерки» занимают лидирующие позиции. Это связано и с их мощным экономическим потенциалом, и с создаваемой десятилетиями деловой репутацией, которая в сфере оказания аудиторских услуг имеет первостепенное значение. Присутствие на рынке Кыргызской Республики ведущих аудиторских фирм играет большую роль в практическом распространении международных стандартов аудита и передовых методов работы.

По мере расширения рынка аудиторских услуг серьезную конкуренцию ведущим мировым фирмам стали составлять ведущие национальные аудиторские фирмы. Некоторые из них вошли в международные организации аудиторско - консультационных фирм, что повысило статус национального аудита.

Аудиторские фирмы, действующие на рынке Кыргызской Республики, по своим характеристикам весьма разнородны, различен и качественный уровень оказываемых ими услуг. Однако можно с уверенностью сказать, что с 2002 года, когда были приняты Закон Кыргызской Республики «Об аудиторской деятельности» качественно изменилось мнение аудиторов и заинтересованных экономических субъектов относительно целей и задач аудита.

В настоящее время в Кыргызской Республике в основном создаются малые аудиторские фирмы. С развитием института аудита в нашей стране аудиторские фирмы будут объединяться в ассоциации, союзы и др. Цель такого объединения: развитие аудиторской деятельности, обмен опытом, разделение сфер влияния.

Однако следует учитывать экономические условия Кыргызской Республики, в которых работают аудиторские фирмы.

Во-первых, нельзя говорить о том, что заинтересованные в информации об экономическом субъекте пользователи (собственники, инвесторы, кредиторы, покупатели, поставщики) в полной мере воспринимают бухгалтерскую отчетность как информационную базу для принятия управленческих решений.

Класс реальных собственников еще только начинает формироваться. Многочисленных мелких акционеров эффективность управления предприятием интересует зачастую только в краткосрочной перспективе (в связи с выплатами дивидендов за отчетный год), а невысокий уровень экономических знаний не позволяет им объективно оценивать состояние и тенденции развития данного предприятия.

Во-вторых, в настоящее время основное содержание управленческой деятельности во многих организациях Кыргызской Республики - это не расширение поля деятельности, а борьба за выживание. Причины этого явления различны, аудитор же видит повышенный интерес организаций к налоговым вопросам и равнодушное отношение к содержанию бухгалтерской отчетности как методу привлечения внешних инвесторов (несмотря на важность их привлечения в долгосрочной перспективе).

Кроме объективных причин бедственного положения многих организаций существуют субъективные причины: нередко управленцы разных уровней считают, что в современных условиях организации выгоднее выглядеть убыточной, нежели преуспевающей. 
В-третьих, система нормативного регулирования бухгалтерского учета в Кыргызской Республики долгое время была подчинена интересам одного основного пользователя бухгалтерской отчетности налоговых органов. Процесс формирования отчетности, ориентированной на внешних пользователей, заинтересованных в достоверной информации о финансовом и имущественном положении организации, только начинается.

В-четвертых, аудитору часто приходится сталкиваться с работниками бухгалтерских и экономических служб организации, знания и навыки которых не всегда соответствуют современным требованиям, предъявляемым к экономическим отношениям, и, следовательно, к уровню развития бухгалтерского учета. Поэтому часто и руководство организации, и работники бухгалтерии расценивают суммы вознаграждений, выплаченных аудиторами, и как плату за минимизацию налоговых рисков, и как плату за обучение и консультирование сотрудников бухгалтерии, и как гарантию того, что вообще все будет хорошо, но только не как плату за формирование объективного мнения аудитора о достоверности бухгалтерской отчетности.

В-пятых, практически во всех организациях аудит проводится при самой высокой степени риска, что обусловлено сложностью законодательной системы Кыргызской Республики, нестабильностью экономической обстановки почти во всех секторах экономики, низким уровнем внутреннего контроля в организациях, а также отсутствием хорошо работающей системы нормативного регулирования аудиторской деятельности. Поэтому на данном этапе развития аудита в нашей стране необходимо внедрять в практику деятельности аудиторских фирм методики проверок, позволяющие повысить эффективность работ за счет применения прогрессивных методов, апробированных в международной практике.

По вопросу осведомленности общественности о роли, значения, задачи и необходимости аудита, нами проведены опрос жителей города Бишкек в количестве 300 человек. Они были разного возраста, различной занятости, то есть, охвачены различные социальные слои населения. По результатам опроса определены, из всех опрошенных 2 человека имеет полное и 3 человека имеет смутное представление, остальные ни каких сведений об аудите не имеет. Низкий уровень знаний об аудите среди общественности, не позволяет воспользоваться результатами аудиторской проверки при вложении капитала в той или иной компании, они не учитывает о том, что компании прошел аудиторской проверки или нет, и каков их результаты. До сих пор многие собственники, вложившие свои капиталы в различных компаниях, считает государство должно гарантировать сохранности их капитала.

В условия рынка государство не вправе вмешиваться в дела частных предприятий, то есть оно не может прямым образом контролировать деятельность компаний. Однако, действующий законодательство позволяет государству косвенным образом повиляет на этот процесс. В Законе Кыргызской Республики «О бухгалтерском учете» в статьи 14 указаны, субъекты, подлежащие обязательному аудиту, публикуют годовую финансовую отчетность не позднее 1 июня текущего года, после подтверждения независимыми аудиторами достоверности представленных в ней сведений и утверждения годового баланса и отчета о прибылях и убытках ежегодным общим собранием акционеров. Выполнение требований этого законодательства не с кем не контролируются, этот вопрос оставлено на самотек. В настоящее время в основном свои финансовую отчетность публикуют коммерческие банки и считанные компании, занимающиеся другими видом деятельности. Таким образом, многие компании остаются без контрольными, особенно компании находящихся на территории в тех областей, где отсутствуют аудиторские организации и сертифицированных аудиторов. Это позволяет нам сделать вывод о том, что в эти компаниях не проводится ежегодный аудиторская проверка финансовой отчетности.

Ф. Л. Дефлиз и другие в книге «Аудит Монтгомери» (Аудит Монтгомери / Ф. Л. Дефлиз, Г. Р. Дженник, В. М. О Рейлли, М. Б. Хирщ; Пер. с англ. - М.: Аудит, ЮНИТИ, 1997) отмечают, что потребителями финансовой информации, прошедший аудит, часто являются фактические или потенциальные инвесторы и кредиторы. Однако общественность, как правило, также заинтересована в получении финансовой информации, подвергнутой аудиту, так как их настоящие и будущие доходы, благосостояние также могут зависеть от достоверности финансовой информации.

Пользуясь бесконтрольности, в отдельных компаниях допускается разного рода финансовых нарушений и злоупотреблений, типа присвоение чужого капитала. Например, финансовая компания «Рентон групп», обманным путем не слишком зажиточного, но неискушенного, слишком доверчивого населения принудили вложит свои средства в эту компанию, обещав высокие проценты на вложенные средства, после чего объявили банкротом, организаторы присвоили чужого капитала и сбежали, а собственники остались без средств, они до сих пор не может обратно получить основную сумму вложенных средств, не говоря обещанных процентах. Эти люди из-за незнания аудиторского дела, своевременно не требовали проведение аудиторской проверки. Они до настоящего времени ходят в Правительство с жалобами, чтобы оно приняло меры по возмещению их капитала. Таких примеров можно привести десятки. 
Такое положение дел в аудиторской деятельности подрывало доверие общественности, в результате участие граждан нашей республики в формировании национального капитала, по мнению ученых и специалистов составляет всего лишь 40-45 процентов. Однако, возможности населения увеличения вложения капитала имеются, об этом подтверждает сами вложившие свои капиталы в «Рентон групп», вложенные средства некоторыми лицами в эту компанию достигало 200 тыс. сомов, в этом приняли участие даже пенсионеры. Это свидетельствуют о том, что у населения имеются достаточные средства для инвестирования экономики страны. Поскольку доверия общественности сорваны, они предпочитают сохранить свои средства в «чулках». Исследование показало, что 100 человек взрослого населения, 1-2 человека являются акционерами, а в сельских местностях еще ниже. В связи с этим, нашему Правительству и общественности необходимо провести целенаправленную работу по возврату доверие общественности и привлечение средства населения в экономику в виде инвестиции. Например, А. А. Терехов в своей монографии (Аудит. - М.: Финансы и статистика, 1999) отмечает, что западные аудиторы заслужили такое доверие общественности, что они после священников доверяет аудиторам.

Поступательное развитие рыночной экономики будет требовать все более широкого спектра услуг. Рынок станет более зрелым и требовательным. Уже сейчас заметно преобладание аудиторских фирм Кыргызской Республики в консалтинге, особенно в тех видах услуг, которые связаны с внутренними проблемами организаций.

Полезность управленческого консалтинга уже осознают наиболее грамотные бизнесмены Кыргызской Республики (хотя спрос на аудиторские услуги, бухгалтерские и налоговые консультации пока преобладает), и ситуация начинает меняться.

Необходимо отметит, что аудит и консалтинг соответствуют национальному характеру Кыргызской Республики. Граждане Кыргызской Республики не склонны к методичной рутинной работе, и культура массового производства приживается с трудом. Но нам свойственны глубокое проникновение в суть вещей и творческий подход к решению любых проблем.

Безусловно, отечественный рынок профессиональных услуг будет развиваться и цивилизоваться только вместе с обществом Кыргызской Республики. В этой связи трудно переоценить необходимость принятого закона Кыргызской Республики «Об аудиторской деятельности».

Определяя тенденции развития рынка аудиторских услуг, систему регулирования аудиторской деятельности в Кыргызской Республике, следует учитывать правовые традиции, существующие в нашей стране, а также специфику экономики, которая долгие годы находились под жестким контролем государства.

Уважение к праву, судебным решениям, пожалуй, никогда не было непременным элементом нашей хозяйственной и предпринимательской деятельности. Во многом причиной тому служило слепое копирование западных вариантов правового регулирования экономических отношений, отсутствие ясного представления о роли государства в воздействии на становление и развитие предпринимательства. Как показывает практика, законодательство об аудите Кыргызской Республики еще не способно органично воспринять те институты аудиторского права, которые существуют на Западе.

Одним из препятствий развития аудита является сторонники старой системы, которые оказывают скрытное сопротивление к нововведениям. Они по-другому трактуют правовые основы аудиторской деятельности сложившиеся в международной практике. Такое положение дел и в бухгалтерском учете, в результате переход на международные стандарты бухгалтерского учета и аудита находятся в шатком положении. Нами пока еще толком не изучены и не освоены в полном объеме теории и практики этих стандартов, а начали как-либо иначе интерпретировать, то есть отдельные ученые предлагают старый план счетов бухгалтерского учета финансово-хозяйственной деятельности предприятий совместить с международным стандартом. Международные стандарты бухгалтерского учета и аудита с трудом пробивает себе дороги в нашей стране. Задача наших исследований состоит в том, что разработать методических рекомендаций по успешному применению указанных стандартов на благо экономики нашей страны.

Определенные круги властных структур государства до сего времени относится к проблеме создания аудита весьма осторожно и противоречиво. Отдельные государственные чиновники и в настоящее время направляют своих контролеров и ревизоров в акционерные общества для проведения контроля и ревизии, ссылаясь на то, что определенная доля акции этих обществ принадлежит государству, не принимая в учет права других акционеров и собственников. Например, Э. А. Аренс и Дж. К. Лоббек (Аудит: Пер. с англ. М.: Финансы и статистика, 2005) отмечают, что в западных странах не допускают государственных служащих на финансовую проверку компании, если даже государство владеет более 50 процентами акций, что они будут ущемлять права остальных акционеров. Это свидетельствует, что правовые основы аудиторской деятельности пока еще должным образом не разработаны, т.е. они требуют дальнейшего совершенствования.

Гражданское общество с правовой экономикой строится на принципах самоуправляемости и 
самоконтроля. Это весьма важные принципы, их должны отстаивать аудиторы, их клиенты, профессиональные объединения бухгалтеров и аудиторов, научные работники и преподаватели бухгалтерского учета и аудита высших учебных заведений. Понятно, что достижение такой цели в Кыргызской Республике не так просто, как в бывшей авторитарной стране, но тем не менее представителям наших профессий необходимо активно участвовать в разработке законопроектов, а также разработать проект предложений о внесении изменений и дополнений законов «О бухгалтерском учете» и «Об аудиторской деятельности» отстаивающей и защищающей корпоративные интересы бухгалтеров и аудиторов.

На волне преобразования и экономических реформ некоторые государственные учреждения переименовали своих ревизоров аудиторами, например, сотрудников Счетной Палаты Кыргызской Республики также называют аудиторами. В этой связи, у большинства членов общества нет четкое представление о независимом аудите. Большинство бухгалтеров имеют смутное представление об аудите, не говоря о простых акционеров, инвесторов и владельцев капитала.

По результатам исследований рекомендуются следующее:

Во-первых, предстоит задача доведение до сведения широких масс населения о сути, сущности, значение, задачи и объективной необходимости независимого аудита в условиях рыночных отношений. Для радикального избавления от нынешнего правового нигилизма и неграмотности требуют от ученых, специалистов, государственных чиновников и аудиторов по чаще выступать через средств массовой информации по данной проблеме. Приучить население, что при решении вопроса вложении своего капитала в той или иной компании, они учитывали результаты аудиторских проверок, и своевременно требовали проведение аудиторской проверки, при случае банкротства, они предъявили иск к аудиторам. На наш взгляд, это является немаловажным фактором дающий толчок дальнейшего развития аудиторской деятельности и возврата доверия народа.

Во-вторых, Правительству необходимо принять меры по подготовке и аттестации аудиторов профессионалов, особенно заботиться о количественном росте сертифицированных аудиторов в периферийных регионах, для того, чтобы довести количество аудиторов до необходимого уровня в ближайшее время.

В-третьих, для обеспечение прозрачности и объективности финансовой деятельности хозяйствующих субъектов, Правительству вести целенаправленную работу по организации и регулированию аудиторской деятельности, осуществлять контроль в тех компаниях, подлежащие обязательному аудиту, что они выполняли требования законодательства о ежегодном проведении независимой аудиторской проверки и своевременной публикации свои финансовой отчетности, а также ускорить сроки перехода хозяйствующих субъектов к международным стандартам финансовой отчетности.

\section{Литература:}

- Аудит Монтгомери / Ф. Л. Дефлиз, Г.Р. Дженик, В. М.О Рейлли, М. Б. Хирш; Пер. с англ.

- Э. А. Аренс и Дж. К. Лоббек, Аудит: Пер. с англ. - М.: Финансы и статистика, 2005.

- $\quad$ Аудит: Учебник для вузов / В. И. Подольский, Г. Б. Поляк, А. А. Савин, Л. В. Сотникова; Под ред. проф. В. И. Подольского / - М.: Аудит, ЮНИТИ, 2005.

- $\quad$ А. А. Терехов. Аудит. - М.: Финансы и статистика, 1999.

- Булгакова Л.И. Аудит в России: механизм правового регулирования. - M.: WoltersKluwer, 2005.

- Бычкова С.М., Растамханова Л.Н. Риски в аудиторской деятельности. - М.: Финансы и статистика, 2003.

- Галузина С.М., Пупшис Т.Ф. Международный учет и аудит. - Санкт-Петербург.: ЗАО ИД «Питер», 2005.

- Суглобов А.Е. Международные стандарты аудита в регулировании аудиторской деятельности. - М.: Издательство «Экономистъ), 2005.

- Шешунова Т.Г., Городилов М.А. Аудит теория и практика применения международных стандартов. - М.: Финансы и статистика, 2005.

- Закон Кыргызской Республики «О бухгалтерском учете» г. Бишкек, Дом Правительства 29 апреля 2002 года № 76

- Закон Кыргызской Республики «Об аудиторской деятельности» г. Бишкек, Дом Правительства 30 ибля 2002 года № 134

- Рогуленко Т.М. Аудит: учебник / - М.: КНОРУС, 2010.

- Материалы Национального статистического Комитета Кыргызской Республики www.stat.kg

- Материалы Службы надзора и регулирования финансового рынка при Правительстве Кыргызской Республики www.fsa.kg. 


\title{
Проблемы применения налога на прибыль в Кыргызской Республике
}

\author{
Larisa Makarenko (Kyrgyz-Russian Slavic University, Kyrgyzstan)
}

\section{Problematic Issues in the Application of Corporate Income Tax in the Kyrgyz Republic}

\begin{abstract}
Corporate income tax is one of the national taxes in Kyrgyzstan. In the past few years the share of income tax revenue has been falling down. It should be noted that, apart from the economic reasons, the number of income tax payers is decreasing due to the widely using of special tax regimes in Kyrgyzstan. This paper aims to analyze the issues of corporate income taxation in Kyrgyzstan and offers their solution.

The main issues of corporate income tax application in Kyrgyz Republic are: the existence of problems caused by the economic situation in the country and financial policy; problems in tax administration; the solution of present problems requires a comprehensive approach; these problems cannot be solved only by improving the Tax Code; restoration of accounting and accountability in all economy sectors, the development of non-cash payments.
\end{abstract}

JEL Code: H30

Рассматривая роль, которую играет налог на прибыль с составе налоговых поступлений Кыргызской Республики, мы можем отметить, что хотя основная доля налогов поступает в бюджет от косвенных налогов, доля налога на прибыль в составе доходов, администрируемых налоговой службой достаточно велика. Также мы должны отметить тот факт, что налог на прибыль в последние годы имеет для доходной части бюджета все меньшее и меньшее значение.

\begin{tabular}{|c|c|c|c|}
\hline Годы & Налоговые поступления & Налог на прибыль & $\begin{array}{c}\text { в \% к налоговым } \\
\text { поступлениям }\end{array}$ \\
\hline 1997 & 3847,2 & 349,6 & 9 \\
\hline 1998 & 4866,5 & 452,4 & 9,3 \\
\hline 1999 & 5972,5 & 567,6 & 9,5 \\
\hline 2000 & 7675,5 & 572,8 & 7,5 \\
\hline 2001 & 9187,9 & 993,7 & 9,8 \\
\hline 2002 & 10474,7 & 967,6 & 7,7 \\
\hline 2003 & 11912 & 912,4 & 6,6 \\
\hline 2004 & 13986,6 & 918,6 & 7,8 \\
\hline 2005 & 16361,4 & 1283,2 & 5,3 \\
\hline 2006 & 19981,2 & 1191,6 & 7,2 \\
\hline 2007 & 26530,1 & 1411,0 & 4,8 \\
\hline 2008 & 31005,1 & 1752,0 & 4,0 \\
\hline 2009 & 30150,3 & 1720,8 & 2085,0 \\
\hline 2010 & 34616,1 & 2 & \\
\hline
\end{tabular}

Таблица. Доля налога на прибыль в налоговых поступлениях за 1997-2010гz. (Отчеты Государственной налоговой службы при Правительстве Кыргызской Республики 1997-2010)

Как налогоплательщики, так и работники налоговой службы зачастую являются сторонниками полной отмены данного налога. Если перечислить причины возникшей ситуации то, в первую очередь, к ним можно отнести следующие моменты:

- понижение образовательного уровня налогоплательщиков. Заполнение деклараций и ведение учета требует специальных знаний, либо дополнительных средств на привлечение специалистов;

- непроработанность и нечеткость отдельных положений Налогового кодекса;

- необходимость документально подтверждать вычеты из совокупного годового дохода. Это вызывает особенные проблемы у налогоплательщиков, приобретающих товары, работы и услуги у субъектов, применяющих специальные налоговые режимы, у субъектов, работающих без налоговой регистрации, а также при приобретении ворованных, нелегально произведенных и контрабандно ввезенных на территорию страны материальных ресурсов. 
По нашему мнению, сужение круга плательщиков налога на прибыль, уменьшение удельного веса налога на прибыль в доходах бюджета играет крайне негативную роль для экономики Кыргызской Республики.

Дело в том, что фискальная функция налога на прибыль, как бы важна она не была, не является единственной. Налог на прибыль, как встроенный стабилизатор, является мощным регулятором экономики.

Как встроенный стабилизатор, налог на прибыль действует следующим образом: при спаде уровень деловой активности сокращается, а поскольку налоговая функция имеет вид: $\boldsymbol{T}=\boldsymbol{t} \boldsymbol{Y}$ (где Т - величина налоговых поступлений, $\mathrm{t}$ - ставка налога, а Y - величина совокупного дохода), то величина налоговых поступлений уменьшается, а при «перегреве» экономики, когда величина фактического выпуска максимальна, налоговые поступления увеличиваются. Заметим, что ставка налога остается неизменной. Однако налоги - это изъятия из экономики, сокращающие поток расходов и, следовательно, доходов. Получается, что при спаде изъятия минимальны, а при перегреве максимальны. Таким образом, из-за наличия в налоговой системе страны налога на прибыль экономика как бы автоматически «остужается» при перегреве и «подогревается» при рецессии.

В качестве примера мы можем привести июньские события прошлого года, когда в результате беспорядков были закрыты таможенные границы. Ограничилось движение товаров, снизились продажи, упали цены на некоторые промышленные товары и, как следствие, упала прибыль. Плательщики налога на прибыль, не получив прибыли, просто перестали платить налог. Для субъектов, работающих по патенту, налоговые платежи не изменились, так как фиксированный налог не может оперативно реагировать на изменение экономической ситуации.

Таким образом, налог на прибыль является весьма эффективным инструментом воздействия на финансовое положение предприятий, повышающим (либо наоборот снижающим) их заинтересованность в развитии производства.

Контрольная функция налога на прибыль также очень важна, так как необходимость документального подтверждения расходов заставляет налогоплательщиков работать с добросовестными партнерами, которые могут подтвердить стоимость и происхождение товара. Проблемы налогообложения прибыли можно рассматривать в разных аспектах: с точки зрения теории налогообложения, с точки зрения экономической и, в том числе, налоговой политики. Также необходимо обратить на конкретные проблемы налогообложения прибыли, причиной которых является несовершенство налогового законодательства и налогового администрирования.

Рассмотрим теоретический аспект. Учитывая, что налог на прибыль относится к прямым налогам, а именно к прямым подоходным, необходимо помнить, что это налоги, которыми облагаются действительное получение доходов (прибыли). Они отражают фактическую платежеспособность плательщиков. К ним относятся налог на доходы физических лиц и на прибыль организаций.

Налог на прибыль, как и другие прямые налоги, имеет определенные преимущества, которые отмечались многими экономистами.

Во-первых, прямые налоги обеспечивают известный заранее и гарантированный доход государственному бюджету.

И.Х. Озеров писал: «прямые налоги, являясь оценочными, дают доход, по общему правилу, более верный и определенный, чем косвенные, являются твердым и постоянным источником для государственного хозяйства» (Озеров 2004а).

Во-вторых, они более справедливы, так как измеряются с платежеспособностью плательщиков, к тому же позволяют применять освобождение малых доходов имуществ и, что особенно важно, прогрессию для перераспределения налогового бремени на имущие слои населения. В-третьих, менее дестимулируют рост экономики, более нейтральны к результатам производства. В частности, бремя уплаты поимущественных налогов падает на владельцев собственности, потому что их не на кого переложить.

В-четвертых, требуют значительно меньших административных расходов по их взиманию. По словам И.А. Озерова: «Для прямых налогов требуется предварительный кадастр, который хотя и сопровождается значительными расходами, но, будучи раз произведен, может служить довольно продолжительное время» (Озеров 2004в).

Для объективного исследования данной проблемы, справедливо будет остановиться также на недостатках прямых налогов, которые свойственны, в том числе налогу на прибыль.

Во-первых, они не оставляют плательщикам права выбора: платить или не платить налоги. Для того, чтобы их не платить нужно не иметь ни дохода , ни имущества.

Во-вторых, прямые налоги психологически более заметны и обременительны для плательщиков, поскольку уплачиваются одномоментными отдельными платежами и существенными суммами. 
В-третьих, процесс их сбора характеризуется большой недоимкой, поскольку значительно труднее администрировать множество физических лиц налогоплательщиков, нежели юридических.

Кроме общетеоретических проблем необходимо обратить внимание на существование проблем, обусловленных экономической ситуацией в государстве, проводимой финансовой политикой.

Во-первых, в Кыргызской Республике налог на прибыль сегодня фактически уплачивают только крупные предприятия и в тех отраслях экономики, где нет возможности укрыть прибыль от налогообложения. Предприятия малого и среднего бизнеса чаще всего находят легальные и нелегальные способы уклонения. К числу других проблем данного налога относятся нечеткие определения совокупного годового дохода и основного дохода для сельскохозяйственных производителей.

Во-вторых, Налоговый кодекс Кыргызской Республики сегодня предлагает налогоплательщикам обширный перечень специальных режимов налогообложения, заменяющих уплату других налогов и, в первую очередь, налога на прибыль. Это, добровольный патент, обязательный патент, упрощенная система налогообложения, налоговый контракт

В-третьих, производители сельскохозяйственной продукции освобождаются от уплаты всех налогов, кроме земельного, НДС и местных налогов при получении доходов от реализации сельскохозяйственной продукции собственного производства и продуктов ее переработки в том случае, если доходы от данного вида деятельности составляют не менее $75 \%$ от общего объема доходов. Реально процентное соотношение различных видов доходов оценить практически не возможно. Особенно это трудно, когда субъект перерабатывает собственную продукцию и давальческую (например, мелет муку из собственной пшеницы и пшеницы других субъектов). То есть норма в налоговом законодательстве существует, однако механизма ее администрирования не существует.

В-четвертых, существующая налоговая система практически не стимулирует привлечение инвестиций, как отечественных, так и зарубежных. Хотя необходимо отметить, что такая попытка предпринималась. До сентября 1997 года Закон «Об иностранных инвестициях» предполагал освобождение хозяйствующих субъектов от налога на прибыль в том случае, если не менее $30 \%$ уставного капитала юридического лица внесено в иностранной валюте. Срок освобождения варьировался от 2 до 5 лет с момента получения прибыли, в зависимости от вида деятельности. Величина уставного капитала в законе не оговаривалась, поэтому любое совместное предприятие за 30 долларов США на валютном счете могло в течение 2-5 лет не платить налог не прибыль. Кроме того, выяснилось, что после истечения льготного периода, учредители ликвидируют данное предприятие и образуют новое, снова получая льготы. В конце концов, данная норма была отменена.

В-пятых, существующее законодательство практически никак не стимулирует реинвестицию полученной прибыли, использование отечественного сырья и материалов, использование местной рабочей силы.

В-шестых, существующая налоговая система не стимулирует легальный бизнес. Огромный объем законно или незаконно необлагаемых налогами оборотов делает законопослушных налогоплательщиков абсолютно неконкурентоспособными на отечественном рынке. Ведомственная коррупция в ряде случаев позволяет уклониться от налогового аудита.

К числу основных проблем налога на прибыль связанных с несовершенством законодательства можно отнести следующие:

- плательщиками налога на прибыль с 2009 года стали не только юридические лица, но и индивидуальные предприниматели ( далее ИП). Это привело к следующим негативным последствиям. ИП потеряли право на получение социальных и имущественных, а также стандартных вычетов, которыми пользуются физические лица при уплате подоходного налога;

- в Налоговом кодексе не описан подробно способ расчета налогового обязательства, указано, что выручка исчисляется в соответствии с Законом «О бухгалтерском учете». Однако ИП, как физические лица, имеют право не вести бухгалтерского учета. Для них перечень доходов и расходов должен быть отражен в Кодексе максимально подробно. Именно из-за трудностей изложения ИП вместо налога на прибыль используют специальные налоговые режимы.

- в новом Кодексе с 20 до 25\% уменьшены вычеты на ремонт основных средств, что, несомненно, продлевает срок амортизации;

- исключены вычеты на приобретение основных средств в виде 15 \% от стоимости, что также продлевает срок амортизации и тормозит процесс модернизации основных средств;

- усложнен расчет амортизационных отчислений. Если ранее стоимость группы рассчитывалась как стоимость основных средств на начало года плюс стоимость приобретенных основных средств и минус стоимость убывших основных средств, то сейчас прибытие и убытие основных средств пересчитывается пропорционально количеству месяцев, в течение которых налогоплательщик данными средствами владел. 
- введены необоснованные льготы по налогу на прибыль предприятий пищевой и перерабатывающей промышленности, осуществляющих промышленную переработку сельскохозяйственной продукции (кроме используемой для производства подакцизной группы товаров), сроком на 3 года. Перечень предприятий и критерии их отбора для включения в него утверждаются Правительством Кыргызской Республики.

- налогоплательщикам отказано в праве самостоятельно определять метод определения выручки, как это было ранее;

- в Кодексе не учтена специфика налогообложения страховых компаний.

К проблемам администрирования налога на прибыль мы можем отнести следующие:

- общеизвестно, что налогоплательщик обязан в течение года вносить предварительные платежи по налогу на прибыль не позднее 20 числа второго месяца текущего квартала налогового периода. Данная норма распространяется не только на предприятия и организации, но и на ИП, для которых уплата предварительных платежей и сдача промежуточной отчетности является еще большей проблемой, чем для предприятий. Это также дает ответ на вопрос, почему налогоплательщики выбирают не налог на прибыль, а специальные режимы налогообложения.

- $\quad$ форма декларации по налогу на прибыль также требует совершенствования, так как вычеты из СГД расписаны не достаточно подробно. Кроме того, происходит смешение понятий «Облагаемый доход» и «Облагаемая прибыль», что ведет к трудностям расчета. Вычеты на благотворительности расположены в перечне основных вычетов, хотя это методически не верно, так как исчисляются они от суммы, которая получается после вычета из СГД затрат, связанных с получением дохода.

Рассматривая возможность совершенствования применения налога на прибыль в Кыргызской Республике, мы должны отметить, что недостатки, присущие налогу на прибыль, как любому прямому налогу, исправлению подлежать не могут, так как они являются одной из характеристик данного налога. Однако, строя и реформируя налоговую систему, их необходимо принимать в расчет.

Что же касается вопросов налоговой политики, то последовательными действиями при реформировании налоговой системы, которые могут оказать положительное влияние на налогообложение прибыли, мы считаем следующие меры:

Последовательное создание единого налогового пространства на территории Кыргызской Республики путем максимального поэтапного сокращения применения специальных режимов налогообложения. Установление жестких критериев применения данных режимов.

Полная отмена таких специальных налоговых режимов как налоговый контракт и упрощенная система налогообложения.

Взаимоувязка специальных режимов налогообложения с классической системой, предусматривающей уплату налога на прибыль с целью исключения искусственного увеличения налогового бремени для крупных налогоплательщиков.

Восстановление системы налогового учета и отчетности для всех категорий налогоплательщиков.

Целенаправленное проведение мероприятий по развитию налоговой культуры у участников налогового процесса.

При предоставлении налоговых льгот, стимулирующих привлечение инвестиций, стимулировать только привлечение реальных инвестиций. Особенно стимулировать использование инвесторами отечественного сырья и других материальных ресурсов, использование национальных трудовых ресурсов, реинвестиции в экономику Кыргызской Республики.

Что же касается конкретных изменений, касающихся налогового законодательства и практики администрирования налога на прибыль, то мы можем предложить следующее.

Во-первых, разделить налог на прибыль на два платежа: «налог на прибыль юридических лиц» и «налог на прибыль индивидуальных предпринимателей». Это необходимо по следующим причинам. Индивидуальные предприниматели должны иметь более простую систему налогового учета. В Кодексе должны быть перечислены все основные виды вычетов из СГД, а не только те, размеры которых ограничиваются Налоговым кодексом. К ним относятся коммунальные услуги, заработная плата наемных работников, сырье материалы и т.д. То есть налогоплательщик, имеющий среднее образование должен получить возможность, прочитав Кодекс, самостоятельно рассчитать налог на прибыль.

- Во-вторых, применять для ИП социальные и имущественные вычеты, на которые имеют право плательщики подоходного налога. Кроме того, освободить ИП от уплаты предварительных платежей по налогу на прибыль, так как на современном этапе налоговые органы не в состоянии эффективно администрировать данную норму.

- В-третьих, изменить критерии отнесения налогоплательщиков к сельхозпроизводителям. Например, сделать критерием объем посевных площадей на одного работающего или поголовья скота. 
- В-четвертых, отменить льготы по налогу на прибыль для переработчиков сельхозпродукции, которая предоставляется сроком на три года по перечню, утвержденному Правительством Кыргызской Республики.

- В-четвертых, восстановить вычеты из совокупного годового дохода на приобретение основных средств, так как это будет стимулировать, обновление оборудования.

- B-пятых, увеличить вычеты на ремонт с 10 до 25\% от стоимости группы на конец года, что также приведет к ускорению амортизации.

- $\quad$ В-шестых, упростить систему исчисления амортизации, вернувшись к порядку, применяемому до 2009 года.

- $\quad$ В-седьмых, увеличить ставку налога на прибыль для финансовых организаций с 10 до 20\%. Сделать это необходимо с целью выравнивания налогового бремени, так как других налогов данные организации практически не платят.

- В-восьмых, увеличить вычеты на благотворительность до 15-20\%, что приведет к увеличению заинтересованности предпринимателей в расширении благотворительной деятельности.

- $\quad$ В-девятых, усовершенствовать форму декларации по налогу на прибыль, подробно перечислив основные вычеты из совокупного годового дохода. Кроме того, обеспечить налогоплательщиков бесплатными формами деклараций, а также бесплатными консультациями по их заполнению.

Конечно, необходимо также отметить, что на поступление налога на прибыль благоприятно повлияет изменение экономической ситуации в стране, а именно:

- $\quad$ открытие новых предприятий;

- повышение прибыльности предприятий;

- приток инвестиций в реальный сектор экономики;

- сокращение уровня теневой экономики.

Однако решение этих проблем требует комплексного подхода, данные проблемы не возможно решить только путем совершенствования положений Налогового кодекса. Это достаточно трудный путь, так как трансформационный период в экономике сопряжен с ослаблением финансовой и налоговой дисциплины. Необходимость применения специальных режимов налогообложения привела к достаточно негативным последствиям. Налогоплательщики, а также работники фискальных служб, не обладающие достаточно высокой налоговой грамотностью, либо склонные к совершению налоговых правонарушений, не заинтересованы в создании прозрачной налоговой системы, в полном отражении в учете всех доходов, расходов и оборотов физических и юридических лиц. Восстановление учета и отчетности во всех отраслях экономики, развитие системы безналичных расчетов - это и есть основное условие эффективного налогообложения прибыли.

\section{Литература}

- Налоговый кодекс Кыргызской Республики, 2010. Бишкек

- Озеров И.Х., 2004 Основы финансовой науки, Статут, Москва.

- Отчеты Государственной налоговой службы при Правительстве Кыргызской Республики, 1997-2010г. 


\title{
Сфера защиты депозитов: Евразийский опыт и его адаптация в Кыргызстане
}

Ruslan Gaidarov (Kyrgyz-Russian Slavic University, Kyrgyzstan)

\section{Deposit Protection in Eurasia and its Adaptation in Kyrgyzstan}

\begin{abstract}
In article the author describes the deposit protection system in Eurasia. Systems are compared with each other. It is also proposed to apply and improve the system of the Kyrgyz security deposits in a future perspective. Over the past 10 years in the scientific community and international financial institutions there was a notable rethinking of attitudes towards the protection of deposits, the role and place of the respective systems. If previously it was more neutral and cautious attitude, now at the international level has clearly proved the importance and effectiveness of this instrument of state policy. There is describes the principles of effective systems of deposit protection in article. There is proposed increase in the threshold compensation of the sum insured in those countries where it is not too large. There is justified by the transition from a single system of contributions to fund the deposit protection system to the differentiated contributions to the countries in which today the law contributions made by a simple calculation. The author asks: Should, in the light of international experience, to extend insurance coverage to the means of legal persons? The author believes that this successful experience, the acquisition of which countries should aspire to. But it is necessary to aware that the program deposit protection of legal persons requires completely different conditions, such as from banks, and by the Fund, acting as a deposit guarantee.
\end{abstract}

JEL Codes: G21, G22, G24

\section{1 Введение}

За последнее десятилетие системы защиты депозитов (СЗД) введены в бывших государствах социализма, в их число входят страны СНГ и Балтии: на сегодняшний день они действуют во всех странах Европейского Союза, в России, Армении, Казахстане, Белоруссии, на Украине, в Узбекистане, Таджикистане, Молдове и Кыргызстане.

Огромный вклад в разработке финансово-правовых основ кыргызской системы защиты депозитов внес исполнительный директор Агентства по защите депозитов Ж.Касымов, который посвятил данной теме длительное время и благодаря ему был принят Закон «О защите банковских вкладов (депозитов)». Также данной тематике уделяли большое внимание отечественные (кыргызские) ученные такие, как академик Т.К.Койчуев, профессора В.И.Кумсков, Н.Х. Кумскова, Д.Ч. Бектенова, М.Т. Койчуева, доктор экономических наук 3.И.Кудабаев, кандидат экономических наук Ч.Б. Аламанова.

В Европе работает Директива парламента с 1994 года. Согласно этого документа каждое государство член ЕС сам контролирует создание и развитие на своей территории 1-й или нескольких систем защиты депозитов. Тем самым ни одно кредитно-финансовое учреждение, которое получило разрешение на введение банковской деятельности, не может принимать банковские депозиты, не являясь членом 1-й из таких систем. Директива определяет уровень защиты депозитов в размере не меньше 20 тыс. евро на 1-го вкладчика.

Вся банковская система очень сильно подвергается кризисам, которые затрагивают не только устойчивые банки, а также клиентов этих банков. Существенную угрозу стабильной работе кредитнофинансовым учреждениям может дать изъятие банковских депозитов, причем это может иметь плачевный характер и захватить огромное число коммерческих банков, вызвать приостановление проведения ими расчетно-кассовых операций, а также привести к понижению экономической активности.

Последствия этих шоков наносят большой вред всей экономике страны, причем затраты на стабилизацию платежеспособности не так велики, как понижение доверия клиентов к банкам. Поэтому правительства многих государств создавали условия и вырабатывали способы борьбы, которые были связанны с массовым изъятием депозитов и кризисных ситуаций во всей банковской системе и экономике страны.

В последние года большое количество стран мира часто имели кризис банковской системы, что подвигло их ввести СЗД для нормализации финансовой системы и прекращения потенциальных банкротств отдельных банков на перспективу. Банковские кризисы затрагивали как развитые страны Евразии (Испанию, Швецию, Норвегию, Японию, Финляндию), так и развивающиеся.

Эффективность работы СЗД зависит от многих факторов и специфик. Как показывает евразийский 
опыт, функционирование институтов защиты депозитов и ее дальнейшее совершенствование осуществляется с учетом реформирования определенных институтов надзора и реструктуризации всей банковской системы, а также усовершенствования аудита банковской деятельности. Благодаря сплоченной координации всех этих институтов поддерживается стабильность всей банковской системы (Дж. Гарсия (Gillian Garcia), 2005).

Одним из обязательных условий хорошей работы банков - это наличие систем, которые поддерживают их функционирование. Эти системы есть практически во всех странах с исторически сформировавшейся рыночной экономикой и имеют две неразделимые функции:

1. обеспечивают финансовую стабильность банков, которые оказались в нелегких финансовых ситуациях, находящиеся на грани неплатежеспособности;

2. оберегают клиентов от полной потери их вкладов путем выплаты гарантированного возмещения по депозитам.

Тем самым, удается предотвратить массового изъятия банковских счетов населением. На данный момент практически во всех развитых и большей части развивающихся стран существуют системы защиты депозитов. В каждой стране они называются по-разному. В своей работе я буду их называть системами защиты депозитов (СЗД).

\section{2 Способы организации систем защиты депозитов (СЗД)}

Все способы защиты депозитов Международный Валютный Фонд (МВФ) условно делит на систему отрицательно выраженных сумм защиты депозитов и систему положительно выраженных сумм защиты депозитов. Если в стране функционирует первая система, то в этой стране нет какого-либо законодательного регулирования защиты депозитов, каждый независимый друг от друга случай рассматривается в суде, что в свою очередь затрудняет получение компенсации и в некоторых случаях возможность ее получения сводится к минимуму. Это было в Кыргызстане до принятия Закона «О защите банковских вкладов (депозитов)». Система положительно выраженных сумм защиты депозитов характеризуется наличием законодательства, который рассматривает вопрос о защите депозитов. В этих законах четко указываются участники СЗД и основные процедуры и инструменты. Организуется специальный фонд, который имеется в основании финансового механизма СЗД. Эта модель работает почти во всех развитых стран, а также в странах СНГ, в числе которых и Кыргызстан.

Способы организации СЗД можно примерно разделить на некоторые группы:

- выраженный отказ от защиты депозитов (как в Новой Зеландии);

- определенным законом приоритет вкладчиков перед другими финансовыми запросами при ликвидации банка (как в Австралии) за место гарантированной суммы по депозитам;

- некая неопределенность по возмещению;

- неформализованное возмещение;

- частичное возмещение;

- полное возмещение.

1-й и 2-й подходы имеют законность, но они редко применяются на практике. Их проблема в том, что в каждом случае тяжело оценить качество банковских активов. Поэтому эта трудность ослабляет рыночную дисциплину, уверенность первого и применяемость второго вариантов. Ко всему этому, несовершенны правила и процедуры закрытия (реструктуризации) неплатежеспособных банков. Очень часто они дают несостоятельным, но в то же время еще ликвидным, банкам продолжать свою работу. Изза того, что банковская система иногда подвергается отрицательному воздействию изъятия банковских вкладов, полное основание на рыночную дисциплину станет губительным для авторитета властей, при этом кредитор последней инстанции ощутит чрезмерное давление в плане поддержки банковской системе.

При 4-м и 6-м вариантах органы власти государства на свой выбор может неявно или явно защищать все вклады. Есть одно но, такие варианты иногда могут создавать проблемы некоторого нарушения моральных принципов для всей системы (предоставление защиты поощряет защищенные финансовые институты к увеличению доли высоко рисковых операций) и неверного ориентира (СЗД с единой ставкой взносов более ценна для коммерческих банков, которые имеют проблемы). Все перечисленные проблемы со стимулами также могут оказаться чересчур затратными или могут требовать вмешательства от правительства, например национализации банков.

Тем самым, национализированная банковская система имеет проблему неэффективного функционирования, в основном, за счет того, что, осуществляя в условиях полной защиты, коммерческие банки не стремятся к конкурентному поведению, а только за исключением, когда осуществляется чересчур эффективный банковский надзор и жестких правил исключения банков из СЗД. В противоположном случае такая система имеет цель присвоить полученную прибыль и списать понесенные убытки на государство. 
Можно сделать вывод, что проблема стимулов при полной защите депозитов, которая также может потребовать некой фискальной нагрузки, выступает мощным аргументом против такой альтернативы. Можно сказать, что 6-й подход обычно является запасным - в случае системного кризиса.

Практика дает понять, что в основном большое количество государств используют другую модель поведения. 5-й вариант, выбранный наибольшим количеством стран, а также одобренный Международным Валютным Фондом (МВФ), находится между уже проанализированными выше крайними вариантами. Этот вариант предполагает защиту банковских депозитов, которое имеет ограничение по размеру страховой суммы и поддерживает стабильность системы. Также является частью мер, работающих при помощи хорошо спланированных систем внутреннего контроля, надзорной и конкурентной дисциплины. Они оказывают влияние на стабильность банков и ликвидируют кризисы. Государственные власти защищают определенные категории владельцев банковских вкладов - обычно это мелкие вклады - или все вклады, но только в определенной части. Защита депозитов отражается в законах и/или в правительственных инструкциях для защиты от повального изъятия банковских депозитов (Международный Валютный Фонд, 2010). Такой способ и в Кыргызстане. Под гарантию попадает 100 тыс. сом на одного вкладчика (Закон КР «О защите банковских вкладов (депозитов)», в редакции 2009).

\section{3 Основные тенденции в построении СЗД}

Анализ информации о деятельности СЗД показывает, что сейчас нет единой и универсальной модели их разработки и дальнейшего функционирования. Особенности построения СЗД во многом зависят от скелета банковской системы, какой в стране банковский надзор, какая степень государственного регулирования деятельности финансово-кредитных организаций (Ranjana Sahajwala, Paul Van den Bergh., 2000).

Процесс унификации всего банковского законодательства и глобализации всей мировой экономики выявляет основные моменты в построении таких систем. Любая СЗД в банках складывается из различных характеристик, самыми главными являются:

- принципы охват финансово-кредитных организаций и видов банковских вкладов;

- принципы определения размеров гарантированного возмещения;

- роль государства, центрального (национального) банка и коммерческих банков в создании и функционировании агентства или фонда защиты депозитов (ФЗД);

- $\quad$ распределение затрат, связанных с защитой банковских вкладов (источники формирования ФЗД);

- $\quad$ роль (функции) СЗД в работе с проблемными банками, являющими участниками.

Какие варианты определенны для решения выше рассмотренных вопросов, зависит и модель построения СЗД.

\section{1 Охват кредитно-финансовых организаций и видов банковских вкладов}

Во многих странах (в том числе в Болгарии, Японии) системы ЗД созданы государством, а также участие в этих системах для всех банков является обязательным. В Европейском Союзе (ЕС) создание СЗД предусматривается специальной Директивой Парламента и законодательного Совета «О системах гарантирования депозитов».

СЗД, которые создаются по такому варианту, рассматриваются странами как важность в поддержании постоянной надежности всего банковского сектора и платежной системы в целом, а также для стабилизации моментной паники среди вкладчиков, если вдруг возникнут непредвиденные экономические события. Создание обязательной СЗД происходит на основании специального закона, который определяет ее основные характерные черты, принципы участия коммерческих банков и государства в ее функционировании, размеры страховых выплат клиентам, определенные моменты в образовании резервов системы и иные необходимые условия.

Создание такой СЗД рассматривается как создание финансового инструмента для возмещения ущерба вкладчикам банков и возложение на государство ответственности за его функционирование и развитие, которые оказывает многочисленное влияние на рост доверия вкладчиков к коммерческим банкам. Из-за того, что цели создания СЗД, носят публично значимый характер, то в принятых нормативных актах нацелено оговариваются меры общественного контроля, подотчетности, прозрачности ее функционирования. На таких принципах в Болгарии работает Фонд гарантий банковских вкладов, а в Финляндии функционирует Фонд гарантирования депозитов.

Разработанные законодательно СЗД являются действенным двигателем для реализации государственной политики, в регулировании банковской деятельности, которое позволяет свести баланс интересов владельцев и руководителей банков, клиентов, надзорных органов и политиков.

Обязательное участие банков в СЗД является самым главным для обеспечения ее стабильности и финансовой устойчивости, в дополнении и параллельно уменьшая финансовую тягу на какой-либо финансово-кредитный институт при формировании резервов СЗД (Дж. Гарсия (Gillian Garcia), 2005). В 
Кыргызстане все банки являются обязательными участниками системы защиты депозитов. В некоторых странах применяется добровольная система защиты депозитов, участвовать или не участвовать принимается финансово-кредитной организацией самостоятельно по добровольной воле. По мнению некоторых экспертов, в добровольной системе защиты депозитов заложены большие риски финансовой неустойчивости. Такие системы защиты депозитов действуют в таких странах, как Микронезия, Швейцария, Тайвань, Филиппины, Шри-Ланка.

В добровольной системе защиты депозитов государство не вмешивается в их работу, но и не дает им финансовую поддержку. Фонды защиты депозитов пополняются за счет взносов банков, которые являются участниками такой системы.

Однако часто такая система защиты депозитов имеет скрытое обязательное участие. При отказе от членства в такой системе защиты депозитов, финансово-кредитная организация вынуждена предоставлять дополнительную защиту по депозитам. Все это является определенным условием для выдачи лицензии на организацию депозитных операций. На опыте некоторых стран с добровольным участием в системе, в основном все банки предпочитают входить в СЗД. Это является как мотивом для конкурентной борьбы, так и хорошо устоявшимися «правилами игры».

Совет Европы согласно принятой в 1994 году директивы о системе защиты депозитов посоветовал всем странам применять обязательный принцип участия финансово-кредитных институтов, которые занимаются привлечением вкладов и осуществляют кредитную деятельность. По этим директивам ведущие страны Западной Европы - Германия, Франция и Италия создали систему с обязательным участием в системе защиты депозитов для финансово-кредитных институтов, хотя в начале 90-х годов эти СЗД в описываемых странах изначально были основаны на добровольном участии. Стоит отметить, что в некоторых странах система защиты депозитов охватывает не только коммерческие банки, но и другие финансово-кредитные институты. В Германии все финансово-кредитные учреждения, которые осуществляют деятельность по депозитным операциям, делятся на 3 специализированные группы, в каждой из них есть свой специализированный фонд по защите депозитов. Тем самым, в разных странах идут процессы сближения по характеру функционирования деятельности коммерческих банков с другими кредитно-финансовыми учреждениями. Всех их консолидирует создание одной конкурентной среды, рвение к защите депозитов более объемных групп мелких вкладчиков и т.д. Следовательно, и СЗД является здесь все более простой, чему способствует объединению систем защиты депозитов в рамках EC. Считают за правило, что системы защиты депозитов направлены на равную защиту депозитов всех владельцев разной категории, имеющих банковские вклады, населения и юридических лиц. Но при этом каждая система защиты депозитов имеет свои специфические особенности, которые уточняют виды вкладов, на которые распространяется защита. Все эти уточнения зависят от специфик государственной, в том числе денежно-кредитной политики, определенное развитие банковской системы и диапазон иных факторов.

Вот отечественный пример: Агентство по защите депозитов Кыргызской Республики в рамках Стратегии развития микрофинансирования на 2011-2015 годы выступит основным партнером Нацбанка в разработке Концепции системы защиты депозитов МФО. Целью Концепции является улучшение инфраструктуры микрофинансового сектора в целях стимулирования внутренних сбережений населения (Официальный сайт Агентства по защите депозитов, 2011).

Другой пример, в 16 странах защищаются депозиты исключительно физических лиц (Швейцария, Болгария, Латвия, Литва, Македония, Бангладеш). В некоторых странах защита депозитов распространяется и на вклады юридических лиц. В других странах из СЗД убираются депозиты в банках - нерезидентах (Япония), или в филиальных сетях национальных банков, действующие на территории иностранных государств. В некоторых системах под защиту не попадают средства в иностранной валюте. Обычно в большинстве стран под защиту попадают вклады в национальной и иностранной валютах. Согласно Директиве ЕС о гарантировании компенсации не защищаются все денежные средства, которые попадают под термин «собственные средства», а также депозиты между банками (IADI, 2008).

При создании кыргызской СЗД, в прочем также как и в России и других странах СНГ, внимание было акцентировано, прежде всего, на владельцах мелких и средних депозитов в целях охвата массового владельца депозитов. Не исключая финансовые возможности страны на этапе развития СЗД, сферу ее функционирования следует ограничить средствами только физических лиц. В основе почти в каждой СЗД есть принцип выплаты частичной или полной компенсации, вкладчикам при банкротстве банка.

Важно странам, где под защиту попадают только депозиты физических лиц, осуществлять защиту и юридических лиц. Это успешный опыт, к приобретению которого страны должны идти. Но необходимо также учесть, что программы защиты депозитов юридических лиц предполагают совершенно другие условия, как со стороны банков, так и со стороны фонда, выполняющего функцию гарантирования вкладов. Но нужно хорошо проанализировать, готовы ли страны сейчас к таким программам, не повлечет ли эта инициатива ряд негативных последствий, которые перевесит все положительные моменты. 


\section{2 Определение размеров страхового возмещения}

Как правило, размер выплат определяется исходя из суммы всех требований к банку. Противоположность между СЗД с полной и частичной суммой покрытия страхового возмещения заключается в том, что в 1-м случае защите подлежит весь депозит, а во 2-м - только его частичность по определенной шкале, которая имеет верхний предел. Мировая практика показывает, что существует распространение защиты как на один вклад, так и на все вклады каждого вкладчика в конкретном банке (Ranjana Sahajwala, Paul Van den Bergh., 2000).

Полная гарантия депозитов функционирует в нескольких странах, но и они постепенно от нее отказываются (Турция).

Некоторые СЗД включали полную защиту вкладов лишь в ситуации банковского кризиса (Япония, Южная Корея) с последующим переходом к частичной системе выплат.

Частичная защита вкладов используется в большинстве стран, в этот список входят и страны Европейского Союза. Размеры защиты определяются уровнем экономического развития страны.

В странах с развивающейся и переходной экономикой уровень сумм, которые защищаются, находится примерно в пределах от 380 долларов (Танзания) до 12000 долларов (Чехия). В странах Европейского Союза уровень сумм защиты 20000 евро.

В некоторых странах (Чехия, Оман) порог по выплатам в рамках СЗД носят различный характер. Как правило, используются два подхода. По первому подходу устанавливается порог защищенных средств в процентах от суммы вклада, а также пороговая сумма защищенного вклада. Данная методика используется, в частности, в странах ЕС. Например, в Люксембурге порог защиты составляет 90\% от суммы вклада, но не более 20000 евро (IADI, 2009).

Второй метод предполагает, что в диапазоне определенной суммы вклада защищается полная сумма, а свыше этой суммы применяются частичные расчеты с установлением лимита выплат.

Например, в Польше СЗД гарантирует полную защиту по депозиту в пределах 1000 евро, по депозитам от 1000 до 3000 евро - 90\%. Одинаковая схема функционирует в Португалии (тут полная гарантия депозитов в диапазоне 15000 евро, а далее - частичная гарантия депозитов до 45000 евро).

Опыт функционирования систем защиты депозитов в зарубежных странах свидетельствует, что подходяще правильным методом их разработки является пороговое ограничение выплачиваемых сумм. Порог размера выплат отражает необходимость честного перераспределения рисков между государством и кредиторами банков, к осмыслению владельцев депозитов к разумному и правильному поведению. Позволяя всем лицам, находящимся на территории страны, ввести предпринимательскую и другую не запрещенную законодательством финансово-экономическую деятельность государство не обязано гарантировать каждому получение дохода от этой деятельности (в рассматриваемом случае - это вложение своих денежных средств в кредитно-финансовые учреждения с целью дополнительного дохода в виде \% от размещения во вклады). Элемент общественного риска имеется в любом вложении средств, в том числе и при составлении договора о банковском вкладе. Так как банковская деятельность, которая функционирует в частных интересах, носит вместе с тем и общественное значение - обеспечение экономики инвестициями, государство поддерживает минимизацию названных рисков. Поэтому действует система четкого надзора за банковской деятельностью и создается СЗД.

В евразийской практике при выявлении максимальной суммы возмещения по депозитам, как правило, используют 2 подхода.

Первый подход. Рекомендуется Международным валютным фондом. Максимальное гарантийное возмещение устанавливается в пределах одного-двух ВВП на душу населения. В европейских странах Запада этот показатель варьируется: от 0,4 до 1,5. В нашей стране - от 1,5 до 2,0 (Международный валютный фонд, 2010).

Второй подход. Рекомендуется Международной ассоциацией систем защиты депозитов. Оптимальный размер гарантийного возмещения достигается при таком уровне, при котором порядка 70-80\% счетов депозитов покрываются в полном объеме сумой возмещения, а совокупная сумма возмещения по банкамучастникам составляет порядка 40\% от общей суммы гарантируемых депозитов (IADI, 2009).

Кыргызстану нужно поднять сумму возмещения с 100 тыс. сом до 300-400 тыс. сом, так как 100 тыс. не так большая сумма, хоть и соответствует рекомендациям МВФ. Если в перспективе сумма возрастет, то большая часть денежных средств, вращающих вне банков привлечется на депозиты, что улучшит экономическое состояние страны в целом, так как депозиты хорошие инвестиции в реальный сектор страны.

\section{3 Формирование и использование средств системы защиты депозитов}

Большое внимание уделяется формированию фонда по защите депозитов. По мнению некоторых международных экспертов: управляющий орган необходимо наделять независимым статусом, но также 
его правление не должно иметь сильно много штата в целях исключения неактивности и размывания ответственности. Члены управляющего органа должны назначаться правительством страны, а также нести ответственность за эффективность и обеспечивать отчет перед населением (Ranjana Sahajwala, Paul Van den Bergh., 2000).

Создание слаженного фундамента СЗД в качестве ни от кого независимого государственного органа дает решить еще одну главную задачу - проведение четко скоординированных действий с министерством финансов, национальным банком или определенным надзорным органом, который поддерживает финансовую надежность банковской системы.

Слаженность всех названных институтов во многих странах зависит от разделения между ними обязанностей и задач по регулированию банковской системы страны. При создании СЗД необходимо, чтобы его управляющий орган был наделен доступом к информации, нужной для того, чтобы заранее оценить риски, которые ей угрожают, предпринимать меры, к их ликвидации и, обеспечивать свою готовность к решению проблем, которые возникают на начальной стадии их выявления.

Все это позволяет оптимально управлять фондом по защите депозитов. Обеспечение рабочего взаимодействия между защитником депозитов и другими финансовыми организациями государства, координация их действий при хорошем разделении сфер полномочий и ответственности способствуют слаженности мер и позиций по обеспечению надежности финансовой системы.

Из обобщения материалов о деятельности СЗД можно сказать, что проектирование и создание хорошей и надежной системы невозможно без финансового вложения государства. В свою очередь государство, принимая во внимание общественные задачи системы, оказывает необходимую поддержку не только на момент ее создания и становления, но также и в режиме функционирования восполняя недостаток ее резервов. Необходимость участия государства определяется суммой рисков, которые за собой несут клиенты банков - участники СЗД.

Формирование государством части фонда по защите депозитов имеет следующие главные формы: предоставление фонду по защите депозитов всего или частичного начального капитала для старта функционирования СЗД. В Японии государство вложило в фонд две трети начального капитала. В Филиппинах, Индии и Греции государство вложило весь сформированный капитал. В Испании ежеквартальные взносы государства в фонд по защите депозитов имеет равные части с банкамиучастниками. А в Индии государство пополняет фонд по защите депозитов по мере необходимости (IADI, 2008).

Как уже отмечалось, следует считать, что фондовые резервы, которыми располагает система защиты депозитов, обязаны покрывать до 5\% защищенных вкладов. На этапе становления системы разовое вложение средств в этом объеме только за счет взносов коммерческих банков затруднительно без ущерба для их устойчивости и ликвидности. Поэтому финансовые вложения государства, являются единственным правдоподобным способом формирования фондов по защите депозитов.

Предполагается, что в последующем СЗД обязана обеспечивать свое формирование за счет ежеквартальных взносов коммерческих банков. Следует подчеркнуть, что инструмент самофинансирования СЗД является ведущим и самостоятельным. Предоставление страной начального капитала системы может быть как за счет правительства, так и за счет национального банка. Параллельно с начальным вложением средств в фонд в зарубежной практике имеются инструменты государственной защиты системы в момент кризиса. Задачей этого является приостановление банкротства, во-первых, системы защиты депозитов, сохранение к ней доверия и экономия ее ресурсов, потеря которого окажет очень неблагоприятное воздействие на экономическое положение и общество.

Возможность оказать прямую финансовую поддержку СЗД со стороны государственных властей есть в большинстве стран, которые имеют такие системы (около 60 государствах).

В момент кризиса в банковской системе со многой вероятностью может появиться ограничение финансовых ресурсов в пользовании системой. Чтобы его преодолеть зарубежный опыт предполагает разные методы экстренных бюджетных средств.

Кроме этого, в зависимости от различных ситуаций в большинстве стран агентству, как управляющему органу СЗД, можно занимать денежные средства на финансовом рынке либо у национального банка. Правительство страны поддерживает любое заимствование. Но выбор конкретных инструментов, в конце концов, имеет зависимость от финансовых возможностей страны.

В Швеции, Норвегии, Финляндии, Южной Кореи, Японии на цели выплат с клиентами системам защиты депозитов выделялись огромные бюджетные: средства и предоставлены гарантии государства по возврату средств. В Австрии, когда есть вероятность полного исчерпания финансирования в рамках СЗД, предполагается выпуск облигаций, которые обеспеченны государством. В Дании Минэкономики выступает гарантом финансирования СЗД необходимыми дополнительными средствами. В Великобритании СЗД имеет право брать кредит в Банке Англии в сумме до 175 миллионов фунтов. В 
Испании, Ирландии, Исландии, Финляндии, Нидерландах, в экстренных случаях тоже возможно брать кредит у Центробанка. В Венгрии правительством гарантируются пополнения фонда защиты депозитов у Нацбанка и на финансово-кредитном рынке (IADI, 2009).

В ряде стран Евразии государство в равных долях с коммерческими банками зачисляет в Фонд ежеквартальные взносы.

От выше изложенного следует, что развитые страны уже поняли необходимость участия государства в СЗД и приняли политический выбор, который подтверждает правильность такого шага. Но определенные инструменты финансовой поддержки зависят от многих факторов, в их числе финансовые реалии государства и широты банковского кризиса.

Для задач разработки гибкой системы финансовой поддержки имеется верный вариативный подход, который учитывает различные формы такой поддержки, при оказании ее государством.

СЗД при моменте страхового случая должна иметь соответствующие средства, которых достаточно для того, что осуществлять выплаты вкладчикам. Из евразийского опыта можно подчеркнуть 2 варианта их формирования.

1-й вариант заключается в формировании средств «по факту». Он подразумевает, что при моменте банкротства банка иные участники системы формируют средства, которые необходимы для расчетов с клиентами банка-банкрота. Этот вариант размещения резервов используется часто (но не всегда). Он используется частными СЗД, которые управляются их участниками (Италия, Австрия, Люксембург, Бахрейн, Швейцария, Франция, Голландия, Гибралтар, Германия).

Самым главным недостатком этого варианта является неимение конкретных гарантий полноты средств для расчетов с вкладчиками. При моменте страхового случая в один момент в нескольких банках может быть, что у других членов системы нет всех средств для критического формирования фонда по защите депозитов. Система, которая строится по такому варианту, также имеет трудности при определении размера ежеквартальных взносов, поскольку не имеет достаточной информации о финансовом положении и имеющимися рисками в банках.

2-й вариант предусматривает образование специального фонда, который находится в распоряжении управляющего органа СЗД за счет ежеквартальных взносов коммерческими банками. Финансирование системы за счет ежеквартальных взносов с ее участников в фонд защиты депозитов позволяет накапливать ликвидные средства для моментальной выплаты застрахованных сумм, гарантировать участие в покрытии расходов всей системы и ее участников, разделить по времени нагрузку на членов системы, которая связанна с выплатами застрахованных депозитов при ликвидации несостоятельных банков.

Наличие фонда защиты депозитов усиливает доверие клиентов в способности системы защитить их вклады. По этим причинам этот вариант поддерживается международными кредитно-финансовыми организациями и экспертами в области защиты депозитов. Он функционирует во многих странах и зафиксирован законодательно.

Для определения рационального размера фонда требуется реалистичная оценка положения банковской системы, суммы финансовых обязательств, возможности банков вносить требуемые взносы без влияния на прибыльность, платежеспособность и ликвидность.

Размер ежеквартальных взносов, который необходим для стабильности накопления фонда имеет зависимость от положения банковской системы и ее дальнейших перспектив. Процентная ставка взносов варьируется по странам в различно широких пределах, по данным МВФ на 2009 г., от 0,015 процента суммы защищенных депозитов в год в Тайване до 1,5 процента в Литве. Зачастую, ее размер выше в странах с развивающейся экономикой. Основные процентные ставки могут изменяться с различными целями и различными способами. В Аргентине для коммерческих банков с отличной репутацией предоставляется скидка в 10 процентов.

Первоначальная задача в развитых системах это защита средств фонда. Ресурсы фонда во многих странах можно инвестировать только в высокодоходные активы. В Польше, Венгрии, Чехии фонду по защите депозитов предоставляется счет в Центробанке (Международный Валютный Фонд, 2010).

Также большое внимание уделяется дифференцированным взносам в СЗД. Кыргызстану и другим странам нужно осуществить переход от единой системы взносов к дифференцированным взносам, так как это справедливая форма отчисления, хотя и сложна в разработке.

\section{4 Заключение}

Анализ зарубежной практики позволяет сделать следующее заключение:- «Чтобы СЗД была хорошо разработанной и соответствовала ключевым принципам, она должна быть частью хорошо продуманной системы обеспечения финансовой надежности государства, подкрепляющейся сильным и стабильным 
законодательным регулированием и надзором, а также эффективными законами и системой обеспечения за их исполнением, раскрытием информации и правильным введением бухгалтерского учета».

Исполнение всех этих условий может быть при наделении органа, управляющего СЗД соответствующими публично-правовыми полномочиями. Главное значение этот вопрос имеет в странах, где население традиционно в большей части доверяет государственным методам защиты их интересов (IADI , 2008). Этот подход определен и в рекомендациях по созданию эффективных СЗД.

Следуя из анализа тенденций развития и опыта СЗД в других странах, можно сделать следующее заключение о принципах создания и основных характеристиках кыргызской СЗД, которые следует принять при дальнейшем развитие кыргызского законодательства о защите депозитов.

Также по опыту нашей страны СЗД нужно организовывать по принципу обязательного вхождения в нее всех банков. Это обеспечит ее стабильность, повышение доверия населения к банкам и разработки общей системы надежности.

Участие государства в создании СЗД представляется необходимым и обязательным в финансовой форме, но также наделения Агентства необходимыми полномочиями на утвержденном законодательном уровне.

\section{Литература}

- Закон КР «О защите банковских вкладов (депозитов)» от 7 мая 2008 года N 78 (В редакции Закона КР от 29 апреля 2009 года N 139), г. Бишкек.

- Международный Валютный Фонд, 2010. Новости и публикации, http:/www.imf.org/external/news/

- Ranjana Sahajwala, Paul Van den Bergh. (2000) Supervisory risk assessment and early warning systems. BIS Working Paper No.4, Basel, December 2000

- Gillian Garcia. (2005), Deposit Insurance: Risk-Adjusted Pricing, Basel, Switzerland

- $\quad$ IADI (2008), Ключевые принципы для эффективных систем страхования депозитов (русскоязычная версия), [www.document] http://www.iadi.org (29 февраля, 2008).

- $\quad$ IADI (2009), Рекомендации по созданию систем защиты депозитов с дифференцированными взносами, принципы IADI, [www.document] http://www.iadi.org

- Официальный сайт НБКР - http://www.nbkr.kg.

- Официальный сайт Агентства защиты депозитов - http://www.azdkr.kg. 


\title{
Depleting Water Resources of Indian Punjab Agriculture: Lessons for High Potential Areas and Policy Options
}

\author{
Joginder Singh (Centre for Agricultural Research \& Rural Development, India)
}

\begin{abstract}
During the past half century, the Punjab State achieved exemplary growth in food-grain production. The fast shift in area from traditional diversified crops to monoculture of rice-wheat system was driven by forces such as price policy, technological change, market infrastructure and low cost of irrigation. But due to over exploitation of water resource, the sustainability of existing crop systems is becoming doubtful, creating critical second generation problem. This requires separate treatments in three distinct agro-climatic regions of the state. The semi-hilly tracts, comprising about $10 \%$ area, requires check dams against fast water run-off, cultivation across the slope and crops using less water such as maize, groundnut, pulses etc. The potential cotton belt, forming onefourth area, has brackish groundwater which needs to be used in conjunction with canal water; and the paddy crop in the area should be strictly discouraged. The fast receding water table in the central food security belt of the country is attributed to spreading rice cultivation. This demands policies of suitable water pricing; setting up tension-meters to monitor water requirements; laser leveling fields; keeping plot size smaller; genetic improvement of rice by developing short duration and late sown varieties; direct seeding of rice; encouraging sprinkler and drip irrigation; mulching with abundant quantities of crop residues and various other such agronomic practices. Therefore, collaborative efforts of researchers, policy makers, farmers and extension services can help in tackling the situation.
\end{abstract}

JEL Codes: Q01, Q18, Q25

\section{Introduction}

Water is the most essential ingredient of human, animal and plant life but as a public good, the use of it not being made judiciously. Both inadequate and excessive use of this resource may restrict the crop yields due to severe abiotic stresses. Due to increase in population of the country the per capita surface water availability was $5410 \mathrm{~m}^{3}$ in 1951 but has slid down to $1902 \mathrm{~m}^{3}$. The availability projected for 2050 is $1451 \mathrm{~m}^{3}$ and $1235 \mathrm{~m}^{3}$ with low growth and high growth respectively (Kumar et al, 2005). The availability of water is also has high spatial variability. Thus alarming rate of depletion of such precious resource calls for appropriate measures in terms of creating general awareness of users, processes, innovations and policies to enhance its use efficiency are required to normalize the inter-regional and overtime water use for different purposes.

Punjab is a small state of India occupying only $1.5 \%$ of the geographical area of the country. The state, popularly known as the "Granary of India" is contributing $21 \%$ of wheat, $11 \%$ rice and $10 \%$ cotton of the country's total output apart from sizable share in the production of various other crops. Thus, by exploiting high potential agriculture of the state, the country which was in the grip of serious food shortage till sixties has now been able to generate even surpluses apart from meeting the needs of its rapidly growing population. The technology encompassing intensive cultivation making high use of agro-chemicals, water and mechanical power has resulted in manifestation of several adverse effects on ecological balance such as fall in water table, developing pest resistance, degrading soil fertility, eroding bio-diversity etc. The underground water is a has been being used indiscriminately. This paper, therefore, is an attempt to examine the water related issues emerging from inter-temporal developments in Punjab agriculture. Specific objectives of the study are;

1. To study the quantum of water use due to increase in cropping intensity and cropping pattern

2. To analyze the rationale and consequences of overuse of water.

3. To suggest measures to minimize the ill-effects of over-exploitation of the natural resource.

\section{Data sources}

The study makes use of primary and secondary sources of data. The secondary data available on land use, cropping pattern, average yield of different crops in the state, area irrigated by different sources etc were collected to provide background of emerging problem concerning water resource. A few studies on this aspect already carried out were also reviewed. The analysis based on data collected from various sources such as Hydrology section of State Department of Agriculture, primary farm level data, secondary data on crop pattern and productivity and rainfall data of the state was done which has been used here too (Singh, 2004). It was supported by some other empirical evidences having association with the problem. The water requirements of different crops and other technical parameters were estimated with the help of soil and water engineers of Punjab Agricultural University. 


\begin{tabular}{|c|c|c|c|c|c|c|c|c|}
\hline Crop & $1960-61$ & $\%$ & 1980-81 & $\%$ & $2000-01$ & $\%$ & 2008-09 & $\%$ \\
\hline Rice & 227 & 4.8 & 1183 & 17.49 & 2612 & 32.92 & 2802 & 35.41 \\
\hline Maize & 327 & 6.91 & 382 & 5.65 & 164 & 2.07 & 139 & 1.76 \\
\hline Bajra \& Jowar & 140 & 2.96 & 70 & 1.04 & 6 & 0.08 & 3 & 0.04 \\
\hline Groundnut & 67 & 1.42 & 83 & 1.23 & 4 & 0.05 & 3 & 0.04 \\
\hline Cotton & 446 & 9.43 & 648 & 9.58 & 474 & 5.97 & 511 & 6.46 \\
\hline Sugarcane & 133 & 2.81 & 71 & 1.05 & 121 & 1.52 & 60 & 0.76 \\
\hline Kharif Pulses & 32 & 0.68 & 61 & 0.9 & 42 & 0.53 & 16 & 0.20 \\
\hline Sesamum & 8 & 0.17 & 17 & 0.25 & 19 & 0.24 & 7 & 0.09 \\
\hline Wheat & 1400 & 29.59 & 2812 & 41.58 & 3408 & 42.95 & 3522 & 44.51 \\
\hline Barley & 66 & 1.39 & 65 & 0.96 & 32 & 0.40 & 14 & 0.18 \\
\hline Gram & 838 & 17.71 & 258 & 3.81 & 8 & 0.10 & 3 & 0.04 \\
\hline Rapeseed\&mustard & 106 & 2.24 & 146 & 2.16 & 55 & 0.69 & 30 & 0.38 \\
\hline Lentil & 30 & 0.7 & 20 & 0.33 & 5 & 0.06 & 0 & 0.00 \\
\hline Potato & 9 & 0.19 & 40 & 0.59 & 70 & 0.88 & 83 & 1.05 \\
\hline Other vegetables & 23 & 0.49 & 24 & 0.35 & 46 & 0.58 & 34 & 0.43 \\
\hline Fruits & 42 & 0.89 & 29 & 0.43 & 34 & 0.43 & 68 & 0.86 \\
\hline Fodder \& others & 859 & 18.15 & 959 & 14.18 & 657 & 8.28 & 617 & 7.80 \\
\hline Total cultivated area & 3757 & & 4191 & & 4264 & & 4171 & 52.72 \\
\hline Total crop area & 4732 & 100 & 6763 & 100 & 7935 & 100 & 7912 & 100 \\
\hline Water requirement index & & 100.00 & & 173.4 & & 259.1 & & 270.1 \\
\hline
\end{tabular}

Table 1: Shift in Cropping Pattern of Punjab and Water Requirements (Area in 000 ha). \% means the area under the crop as per cent of Total cropped area. Area under vegetables, fodder and other crops is not shown crop-wise due to paucity of split up of such data. Fruits are perennial and the figures pertaining to area under fruits are also not much reliable. Water requirement index was worked out on the basis of number of irrigations applied by farmers to different crops.

\section{Land use and Production Pattern}

Out of the total geographical area of 5 million hectares of the state, about 4.2 million hectare is the net area sown. The unculturable land has been reclaimed and fallow land has been brought under cultivation. The cropping intensity also went up from $126 \%$ to $190 \%$ during this period. The coverage of land by more crop area has created higher demand for use of water resource. The area under forests has also increased though at a slow pace yet it is much less than the requirement for maintaining ecological balance.

As may be seen from Table 1, rice occupied merely 4.80\% of the total cropped area in 1960-61 but registered a steep rise up to $35.41 \%$ in $2008-09$. It did not confine only to traditional paddy belt but spread over to all the districts wherever adequate irrigation facilities were made available. Similarly, the area under wheat increased from only $27.32 \%$ in $1960-61$ to $44.51 \%$ of total cropped area in 2008-09 but the stage has now reached beyond which increase appears to rather impossible. On the other hand, area under maize, millets, sorghum, groundnut, gram, barley and lentil has fallen rapidly. However, cotton, sugarcane, pulses, rapeseed and mustard, potato and other vegetables have shown wide fluctuations from year to year.

Thus the production pattern in the Punjab State has become predominantly a monoculture of rice-wheat rotation because of higher profitability of these crops resulting from faster increase and higher stability in the productivity and effective price support by the government in comparison to other competing crops. The economic considerations in the choice of crops with higher requirement of water have thus overruled the exploitation of the natural resource endowments, particularly water. The index of water use on the basis of average number of irrigations applied to various crops by the farmers was worked out. Due to increase in area under cultivation, cropping intensity and shift in crop pattern, the water requirement during the past five decades has gone up by about 170 per cent. On the other hand, there is ample evidence to indicate that the Total Factor Productivity of these crops has gone down mainly due to ecological problems pertaining to depletion of soil fertility, water availability and pest resistance (Singh \& Hossain, 2002).

\begin{tabular}{|c|c|c|c|c|}
\hline Crop & $\begin{array}{c}\text { Period I } \\
\mathbf{1 9 7 0 - 7 1} \text { to } \\
\mathbf{1 9 8 0 - 8 1}\end{array}$ & $\begin{array}{c}\text { Period II } \\
\mathbf{1 9 8 0 - 8 1} \text { to } \\
\mathbf{1 9 9 0 - 9 1}\end{array}$ & $\begin{array}{c}\text { Period III } \\
\mathbf{1 9 9 0 - 9 1} \text { to } \\
\mathbf{2 0 0 0 - 0 1}\end{array}$ & $\begin{array}{c}\text { Period IV } \\
\mathbf{2 0 0 1 - 0 2} \text { to } \\
\mathbf{2 0 0 9 - 1 0}\end{array}$ \\
\hline Rice & 4.67 & 1.17 & 0.43 & 1.77 \\
Wheat & 2.27 & 2.92 & 1.99 & 0.19 \\
Sugarcane & 3.09 & 0.37 & 0.26 & -0.08 \\
Cotton & -1.82 & 7.24 & -5.83 & 7.95 \\
\hline
\end{tabular}

Table 2: CGR of Average Yield of major crops in Punjab (\%) 


\section{Intensity of Water Scarcity Problem}

\subsection{A Review}

Prihar et. al. (1993) estimated that good quality water was available to the extent of 3.12 million hectare meters or 25.34 million acre feet (MAF), whereas the normative requirement amounted to 39.75 MAF. The net deficit, therefore, comes out to 14.41 MAF. They warned that unless a very serious view was taken of the matter and immediate corrective policy measures adopted, the state would head towards a critical water famine situation. Singla, (1992) observed that water table in the sweet water region of the state during 1979-1991 was receding annually on an average by 0.2 meters. A situation might arise when the water table would go down to such an extent that lifting water would require heavy capital investment in the form of high power electric motors or submersible pumps and also increased energy consumption and ultimately, it may even become technically and economically an unfeasible proposition.

Batta Nidhi (2007) discussed the problems related to water use in Punjab emerging from faulty water and crop management practices, rapid urbanization and industrialization. The water resources should be used rationally so that it can is saved for our next generations by following various techniques such as canal water management, improving on-farm water use efficiency, conjunctive use of water, artificial recharge of ground water etc.

According to National Academy of Agricultural Sciences (2011) water-table in 82 per cent area of Punjab and 63 per cent of that in Haryana has gone down substantially. The study revealed that in Punjab groundwater at a depth of above 10 metre was only on 4 per cent of the area in 1973 and on 75 per cent area in 2002. The net annual groundwater draft in Punjab exceeds availability by 45 per cent. The study suggested that more watersaving options need to be introduced and promoted for managing groundwater judiciously and efficiently in Punjab described as "granary of the country."

Based on the water table data collected regularly, it was brought out that in 9,058 sq $\mathrm{km}$ of central Punjab it has gone down by more than 20 metres in the past one decade and the trend is continuing with some districts registering a fall despite a good monsoon of 2010 (Sidhu, 2011). Further, for both the pre- and post-monsoon periods collected by the Agriculture Department painted a grim picture The water table has gone down all over the state in the one-year period from June 2009 to June 2010. What is even more alarming is that areas in central Punjab have witnessed a dip in the water table even post- monsoon last year. This is the time when the water table invariably goes up. Experts claim that the state needs 52 MAF of water to sustain its present intensive cultivation. It has only 14.54 MAF of canal water leading to over exploitation of ground water. With farmers reluctant to reduce area under paddy cultivation, this over exploitation is likely to continue. The area under hybrid maize, which is being looked as an alternative to paddy, is stagnating at 1.50 lakh hectares.

\subsection{Water Resource in different Agro-climatic Regions}

The spectacular increase in agricultural production in Punjab has been made possible due to expansion of irrigation network covering $97 \%$ area in 2008-09 as compared to only 54\% in 1960-61 (Table 3). The area covered by canals in absolute is almost same. But in terms of percentage area irrigated, it is declining. The canals used to irrigate $58.4 \%$ of the total irrigated area in 1960-61, the share of which has declined to about $27.5 \%$ due to almost constant availability of water in the reservoir, continued seepage of water from canals and above all the shift in area towards higher water using enterprises. On the other hand, the underground water was being exhausted through tubewells at a faster rate which covered $73 \%$ of the total irrigated area in $2008-09$ as against only $41 \%$ in 1960-61. The fact of over-exploitation of water is further authenticated by the increase in the number of tubewells from 192 thousand in 1970-71 to 1276 thousand in 2008-09.

\begin{tabular}{|c|c|c|c|c|c|}
\hline Year & Canal & $\begin{array}{c}\text { Well and } \\
\text { Tubewell }\end{array}$ & Other sources & Total irrigated & $\begin{array}{c}\text { Net area irrigated } \\
(\%)\end{array}$ \\
\hline \multirow{2}{*}{$1960-61$} & $\begin{array}{c}1180 \\
(58.4)\end{array}$ & $\begin{array}{c}829 \\
(41.0)\end{array}$ & $\begin{array}{c}11 \\
(0.2)\end{array}$ & $\begin{array}{c}2020 \\
(100.0)\end{array}$ & 54 \\
\hline \multirow{2}{*}{$1970-71$} & $\begin{array}{c}1292 \\
(44.7)\end{array}$ & $\begin{array}{c}1591 \\
(55.1)\end{array}$ & $\begin{array}{c}5 \\
(0.2)\end{array}$ & $\begin{array}{c}2888 \\
(100.0)\end{array}$ & 71 \\
\hline $1980-81$ & 1430 & $\begin{array}{c}1939 \\
(57.3)\end{array}$ & $\begin{array}{c}13 \\
(0.4)\end{array}$ & $\begin{array}{c}3382 \\
(100.0)\end{array}$ & 81 \\
\hline \multirow{2}{*}{$1990-91$} & $(42.3)$ & $\begin{array}{c}2233 \\
(57.1)\end{array}$ & $\begin{array}{c}3909 \\
(100.0)\end{array}$ & 93 \\
\hline $2000-01$ & $(42.7)$ & $\begin{array}{c}3074 \\
(76.1)\end{array}$ & $\begin{array}{c}4038 \\
(100.0)\end{array}$ & 95 \\
\hline $2008-09$ & $(23.8)$ & $(72.6)$ & 1 & $\begin{array}{c}4064 \\
(100.0)\end{array}$ & 97 \\
\hline
\end{tabular}

Table 3: Area (000ha) irrigated by different sources in Punjab. Figures in parentheses indicate percentages. Source: Statistical Abstract of Punjab 2001 
The analysis across the agro-climatic regions showed that the coverage of canals declined in all the regions, while the tubewells registered faster coverage, more so in the South-Western (cotton) belt over the last two decades. During the last decade the average fall of water table in the central Punjab was $0.55 \mathrm{~m} / \mathrm{year}$. At some places the ground water level declined at the rate of even 0.75 to $1 \mathrm{~m} /$ year. On the other hand, the water table is rising in south- western districts. Kandi area has its own problems of shortage of irrigation water in spite of heavy rainfall (Hira et. al 2004).

\begin{tabular}{|c|c|c|c|c|c|c|}
\hline Zone & \multicolumn{3}{|c|}{ Canal } & \multicolumn{3}{c|}{ Tubewell and Well } \\
\hline & $\mathbf{1 9 7 5 - 7 6}$ & $\mathbf{2 0 0 0 - 0 1}$ & $\mathbf{2 0 0 8 - 0 9}$ & $\mathbf{1 9 7 5 - 7 6}$ & $\mathbf{2 0 0 0 - 0 1}$ & $\mathbf{2 0 0 8 - 0 9}$ \\
\hline Sub-mountainous & 87 & 45 & 81 & 238 & 553 & 409 \\
belt & $(26.7)$ & $(7.6)$ & $(16.5)$ & $(73.3)$ & $(92.4)$ & $(83.5)$ \\
\hline \multirow{2}{*}{ Central plains belt } & 430 & 312 & 149 & 1246 & 1601 & 1350 \\
& $(25.7)$ & $(16.3)$ & $(9.9)$ & $(74.3)$ & $(83.7)$ & $(90.1)$ \\
\hline South-West cotton & 816 & 645 & 883 & 329 & 863 & 1113 \\
belt & $(71.3)$ & $(42.8)$ & $(44.2)$ & $(28.7)$ & $(57.2)$ & $(55.8)$ \\
\hline \multirow{2}{*}{ State } & 1332 & 1002 & 1113 & 1813 & 3017 & 2950 \\
& $(42.4)$ & $(24.9)$ & $(27.4)$ & $(57.6)$ & $(75.0)$ & $(72.6)$ \\
\hline
\end{tabular}

Table 4: Area (000 ha) irrigated in different zones of Punjab. Figures in parentheses indicate percentages. Source: Statistical Abstracts of Punjab

The problems relating to macro-level water management require separate focus in the three different agroclimatic regions of Punjab.

The sub-mountainous (Kandi) region has undulating topography. The annual rainfall is more than $1000 \mathrm{~mm}$. Due to denudation of upper hills resulting from over-grazing and deforestation, there is high run-off of water resulting from flash floods and heavy soil erosion. During the last 2 decades, the number of tubewells almost doubled, providing irrigation to $84 \%$ of the total irrigated area while the surface water have not been well channelized (Table 4). Since water table is deep and soil is rocky, pumping out water is relatively uneconomical. Therefore, although there is problem of increasing use of water in this area but decline in water table is not severely aggravated.

Central (sweet water) region comprising the major part of the state is highly productive and has well knit system of irrigation, mainly in terms of tube-wells. The paddy-wheat is the major crop rotation followed in this belt. The water table in this zone has been falling with an average rate of 0.23 meter per year for the last 15 years (Gupta et. al., 1995). This belt had 5-6 meters of water table in 1981 and showed a fall of 24-25 cm per annum. This is a matter of serious concern and the trend needs to be arrested since it would need additional power requirement. If the decline in water table is continued at the existing rate, most of the centrifugal pumps would have to be replaced by submersible pumps, which would amount to tremendous cost on the farm sector. The state government's design to make electricity for irrigation completely free of cost since 1997 further contributed to the problem of declining water table resulting in indiscriminate use of water. Therefore, the prevalent production pattern seems to be unsustainable in the long run.

The south-western region comprising almost one-forth of the cultivated area of the state, popularly known as cotton belt has deep and brackish underground water. The area under irrigation has increased tremendously in this belt recently. The network of canal water supply in the area improved but could not cater to the requirements of increasing cultivated area, cropping intensity and area under water intensive crops. Thus the use of underground poor quality water through tubewells has been increasingly overexploited. With about 11-12 meter water depth in 1981, it is continuously showing a rise of $20-22 \mathrm{~cm}$ per year motivating the farmers to shift from cotton to rice cultivation. This has been largely responsible for the fast declining productivity of cotton due to the fact that:

a) The use of underground water has increased accumulation of salts on the soil surface deteriorating its health.

b) The higher inflow of canal water in some area has caused rise in water table and even water-logging in some pockets of this zone.

c) The high humidity resulting from paddy cultivation and water-logging of soil has encouraged the built-up of insect-pests, threatening the cultivation of cotton in this belt.

Therefore, in brief, water harvesting in semi-hilly areas, recharging the underground water in the central belt, encouraging water saving practices and shift in crop pattern in the south-western areas of the state can ease the situation significantly. The rainfall helped to improve the situation significantly but drawl due to paddy area alone equalized the recharge. The net deterioration of water balance situation was owing to parameters other than this including increase in cropping intensity, higher water use by other crops, non-agricultural uses (Singh, 2004)

\subsection{Energy Requirements}

Due to fall in water table, particularly in the central belt; 
a) The cost of pumping out water has increased. The power required for lifting water from deeper surface is much higher than the shallow one.

b) The centrifugal pumps are being replaced by submersible pumps.

c) More number of electric tubewells is being installed. The electricity is thus getting in short supply, as a result of which the diesel pumps are being increasingly used to supplement the electric tubewells.

The impact were substantiated (Singh 2004) with the help of overtime primary data collected from a sample of farmers and inferred that with the passage of time, the water crisis is aggravating by additional energy requirement and cost of exploring deeper water aquifers.

\subsection{Farmers' Practices and Water Requirement:}

It is not only increase in rice area and government policies that the water use has gone up, but the farmers, by way of their faulty practices are also responsible for aggravating the problem of water scarcity as discussed under:

\subsubsection{Early Transplanting of Rice}

Against the recommended time of transplanting of second week of June, about $25 \%$ rice area in the state is transplanted in the month of May. The reasons advocated by the farmers were that the early rice crop escapes pests and diseases and gets longer growing period resulting in higher yield. Similarly, the low opportunity cost of family and permanently engaged labour and farm machinery lowers the cost of cultivation if the crop is transplanted early. The estimated evapo-transpiration of rice crop has been averaged to $780 \mathrm{~mm}$ in the month of May as compared to $605 \mathrm{~mm}$ in case of timely transplanted (Hira \& Khaira, 2000). Thus the early transplanted rice crop has about $29 \%$ higher water requirements and over-exhausts the annual water resources in the state by $7.3 \%$ every year. The policy of late procurement of paddy by the state agencies has recently helped to restrict the early transplanting to some extent.

\subsubsection{Long Duration Varieties}

The varietal picture of rice crop in Punjab indicates that some varieties which are of long duration and are not recommended by the experts but still the farmers have adopted on a large area. For example, PUSA 44 variety has been cultivated on $30 \%$ area and thus the water requirement of the crop increased tremendously. Conversely, basmati, a superior strain of rice having lesser water requirement has almost doubled from about $5 \%$ to about $10 \%$ of total area under rice crop during the last 4-5 years. However, the global demand for basmati has pushed up basmati production recently, helping in water saving.

\subsubsection{Ignorance about ill-effects of water use in paddy}

The water use by the farmers is in excess of the requirement of the paddy crop. Higher intensity and more number of irrigations were, largely due to ignorance of the majority of farmers that good crop requires standing water throughout (Chatha et al. 1994) and also due to low price of water.

\subsubsection{Lack of suitable water management practices}

There are a number of agronomic practices through which enormous saving of water can be made possible. For example in place of open flooding system, ground pipe line furrow irrigation/ raised beds, drip and sprinkler irrigation, in-situ retention of rain water, mulching could improve the water use efficiency. Apart from timely transplanting with suitable varieties avoiding early and long duration varieties, conjunctive use of water, renovation of village ponds for irrigation, encouraging crop diversification (substituting high water requiring crops/ cultivars) are some other ways to solve the problem through various policy measures.

Therefore, to curb the over exploitation of water, policy legislation and extension, education of farmers in this respect are required for which in place of providing free electricity for the tubewells, subsidies on water saving technologies should be provided.

\subsection{Water pricing and productivity}

The average productivity of water was estimated on the basis of state average yield of crops and post-harvest prices. The value of by-product was also taken into account in the estimation process. The total quantity of water used was worked out on the basis of number of irrigations applied and $7.5 \mathrm{~cm}$ as an effective irrigation. It is evident from Table 5 that per cubic meter of water, the gross return varied from crop to crop viz. Rs 2.43 in case of paddy, Rs6.75 for rapeseed \& mustard crop, Wheat crop yielded Rs12.36, while the cotton crop promised Rs11.40/cu.m of water. Viewing it from another angle, to produce one $\mathrm{kg}$ of paddy grain required 4334 liters and wheat as 1080 liters. The cotton crop needed as much as 2394 liters of water for one $\mathrm{kg}$ output of seed cotton. Therefore, production and even export-import policy of agriculture sector, apart from economic parameters should take a serious view of requirements of natural resources especially water. 


\begin{tabular}{|cccccc|c|c|}
\hline Crop & $\begin{array}{c}\text { Av. Yield } \\
\text { (Kg/ha) }\end{array}$ & $\begin{array}{c}\text { Price } \\
\text { (Rs/q) }\end{array}$ & $\begin{array}{c}\text { Gross } \\
\text { return** } \\
\text { (Rs/ha) }\end{array}$ & $\begin{array}{c}\text { No of } \\
\text { irrigations }\end{array}$ & $\begin{array}{c}\text { Water } \\
\text { (cu.m./ha) }\end{array}$ & $\begin{array}{c}\text { Gross } \\
\text { return } \\
\text { (Rs/cu meter) }\end{array}$ & $\begin{array}{c}\text { Water use** } \\
\text { Lit/kg } \\
\text { of output }\end{array}$ \\
\hline Paddy & 6015 & 980 & 58947 & 22 & 24264 & 2.43 & 4034 \\
Maize & 3964 & 900 & 35676 & 5 & 5512 & 6.47 & 1391 \\
Millets & 1495 & 910 & 13605 & 2 & 2269 & 6.00 & 1518 \\
Groundnut & 1240 & 2850 & 35340 & 2 & 1985 & 17.80 & 1601 \\
Cotton* & 2303 & 2730 & 62872 & 5 & 5514 & 11.40 & 2394 \\
Sugarcane* & 6672 & 2200 & 146784 & 15 & 16539 & 8.88 & 2479 \\
Kharif Pulses & 840 & 5000 & 42000 & 2 & 2198 & 19.11 & 2617 \\
Sesamum & 356 & 6000 & 21360 & 2 & 2219 & 9.63 & 6233 \\
Wheat & 5107 & 1335 & 68178 & 5 & 5515 & 12.36 & 1080 \\
Barley & 3537 & 875 & 30949 & 4 & 4400 & 7.03 & 1244 \\
Gram & 1129 & 5000 & 56450 & 2 & 2233 & 25.28 & 1978 \\
Rapeseed\&Mustard & 984 & 3022 & 29736 & 4 & 4405 & 6.75 & 4477 \\
Rabi pulses & 1284 & 5000 & 64200 & 2 & 2200 & 29.18 & 1713 \\
Potato & 25464 & 800 & 203712 & 5 & 5508 & 36.98 & 216 \\
\hline
\end{tabular}

Table 5: Return/ cubic m use of water for different crops in Punjab, 2008-09. *Cotton yield in terms of seed cotton and Sugarcane in terms of gur with $10 \%$ recovery. ${ }^{* *}$ The quantity of water use is based on average number and intensity of irrigations applied by farmers and thus does not account for its percolation in the soil. IUS\$ = Indian Rs45 approximately

\section{Policy Prescriptions:}

- Diversification of agriculture through alternative crop systems such as cotton, basmati, maize, oilseeds and pulses, fruits and vegetables, dairy etc need to be encouraged in different agro-climatic conditions with the help of effective support price, processing and export infrastructure.

- Agronomic practices such as timely transplanting of rice, furrow irrigation, avoiding excessive flooding of fields, smaller fields, sprinkler and drip irrigation wherever possible could reduce the water requirements sizably.

- Suitable water pricing especially through metered system of electricity supply is essential.

- It has been estimated that about 60 per cent of irrigation water is lost in the form of seepage losses. Therefore, lining of canals, water courses and field channels, use of underground pipeline for conveyance of irrigation water should be practiced.

- A package of measures to increase the artificial recharge to augment the groundwater reservoir has to be taken. It has been estimated that the total unutilized water works out to be 0.433 million hectare meters, out of which 0.372 million hectare meters is through rivers and the rest comes through drains, nullahs, etc. This water is a potential source which can be utilized for artificial recharge to groundwater.

- The conjunctive use of surface and groundwater will help in developing strategy of irrigation for optimal agricultural development. The studies have revealed that an integrated approach for conjunctive use of surface water and poor quality groundwater supplemented with application of gypsum amendment and proper facilities for drainage on sodic soils could also reduce pressure on fresh water use.

- Export-import policy must take into account the use of water resource apart from comparative economic advantage of different crops.

\section{Summary}

A dramatic change with storming of rice in crop pattern was witnessed in high potential Punjab agriculture. This was a consequence of technological transformation and support price policy of government from food security angle. It led to fast overexploitation of water resources of the state and the water requirements of farm sector have gone up by about $170 \%$ during the past one and a half century. However, groundwater recharging through network of canals was not matching. The ruthless pumping out of groundwater in the central food grain belt and drifting away of surface water in the distantly located cotton belt which has brackish groundwater was at a heavy social cost through frequently deepening of tubewells and higher energy input for drawing water. It is essential to rationalize the farmers' practices through education and policy measures. It also lacks rationality to produce for the market without visualizing the future scenario. For instance, to produce one $\mathrm{kg}$ of paddy, more than four thousand liters of water is applied. In other words, to produce paddy worth Rs 2.43 , a cubic meter of water is applied. With liberalization of trade, more profitable crops in terms of water use efficiency have to be viewed and policies need to be reframed accordingly. 


\section{References}

- Batta Nidhi, 2007 “Judicious Use of water Resources”, Compiled in http://www.dswcpunjab.gov.in/contents/data_folder/Nidhi_Batta_Paper.htm

- Gupta, R.D et al 1995. “Availability and quality of Ground water in Punjab State”. In: Water Management, Punjab Agricultural University, Ludhiana, pp 18-42.

- Prihar, S.S et al. 1993. "Water Resources of Punjab”, Punjab Agricultural University, Research Bulletin, p 60 .

- Hira, G.S. and Khaira, K.L. 2000. "Water Resource Management in Punjab under Rice-Wheat Production System”, Research Bulletin, Punjab Agricultural University, Ludhiana, p 84.

- Kumar et al 2005. "Water resources of India”, Current Science, 89 (5)

- NAAS 2011 “Groundwater level falls in Punjab, Haryana due to over-use” New Delhi http://news.in.msn.com/business/article.aspx?cp-documentid=5160966

- Economic \& Statistical Organization, Punjab, "Statistical Abstract of Punjab", Chandigarh, India. Various issues.

- Singh, Joginder et al. 1997. "Changing Scenario of Punjab Agriculture- An Ecological Perspective", Bulletin by Centre for Research in Rural \& Industrial Development, Chandigarh, India.

- Singh, Joginder, 2004. "An Analysis of Depleting Water Resources of Indian Punjab and Policy Options” in Workshop proceedings on Groundwater Use in North-West India, Centre for Sustainable Agriculture, New Delhi, P. 166-177.

- Joginder Singh and Hossain M. 2002. "Total factor productivity analysis and its components in a highpotential rice-wheat system: a case study of the Indian Punjab". P. 409-417 in Sombilla M, Hossain M and Hardy B, editors.Developments in the Asian rice economy, 3-5 December 2001, Los Baños, Philippines: International Rice Research Institute. 436 p.

- Singla, T.L., 1992. “Groundwater Recharge Programme - Present status and scope”. Water Resources Day, Vol. I, Punjab Agricultural University, p 1169-73. 


\title{
Parental Perception of School Education and Human Capital Formation: A Case Study in Selected Villages of Pakistan
}

\author{
Abdul Salam Lodhi (University of Bonn, Germany)
}

\begin{abstract}
In countries where sending their children to school for basic education is not obligatory parental perception on schooling can be a key element in view that this will drive up their demand for school education. This paper includes parental perception as factor for education demand and investigating the issues that upsetting parental perception for school education. For this purpose, it is assumed that parental perception is combination of his or her perception of the impact of school education on the future income of their child and compatibility of school education with religious values. A field survey was conducted in 43 villages of Pakistan in months of Aug-Dec. 2009 and 963 households were interviewed from all four provinces of Pakistan. Ordered logistic and stereotype ordered regression models were used for the analyzing. The study results show that the probability of agreeing that school education will increase future income of a child; increase from .1 to .5 when school education of a farmer increases from 0 to 10 years of schooling. The perception becomes more in favor, in the areas where initial expected future income reaches at level of Rs.10,000 (about 124\$) per month. Beliefs in tribal norms and degree of religiousness have a negative impact on compatibility perception while degree of religiousness shows positive impact on same perception with increase in years of schooling of parents.
\end{abstract}

JEL Code: J01

\section{Introduction}

In countries where sending children to schools for basic education is not obligatory, the formation of human capital is mainly dependent on the decisions of the parents. Their perceptions regarding the existing type of school education and other available alternate activities to school education for their children might affects their decisions regarding whether or not to send their children to schools.

The relationship among poverty, child schooling, child labor, and other possible alternative activities are extensively searched in the last decades. But still there is a strong need for careful investigations, to separate out the different directions and types of causations of the correlations of poverty and child activities including schooling, in a particular area. To find out the facts and to suggest effective policy measures for eradication of low literacy rates and child labor. Since the previous work of Basu and Van (1998) proposed the "luxury axiom" that children only work when their families are unable to meet their basic needs. This axiom proposes a strong linkage between child labor and poverty, and the same idea also been got support by the studies $\{($ e.g, Maitra and Ray (2002), and Edmonds (2005)\}. Glewwe and Jacoby (2004) found a positive and significant relationship between changes in wealth and changes in the demand for education. They also explains that the wealth effect persists even after controlling for locality-specific factors such as changes in education returns, supply, quality of school, and for the opportunity cost of schooling.

However, some other studies have showed some contradictions on these sayings by suggesting a more nonlinear relationship between poverty, child labor and schooling decisions. Such as, in their work Bhalotra and Heady (2003) found a "wealth paradox"- children in land-rich households are more likely to work and less likely to go to school than the children in land-poor households. Ray (2000) the results of his study have rejected both 'Luxury' and 'Substitution' hypotheses in the context of child labor in Pakistan and suggest that income and related variables do not have the expected negative effect on children's work input and child schooling.

Some related studies on the issue of schooling and child labor emphasis on the importance of parental education and other community variables. Duryea and Kuenning (2003) enumerate that increasing in schooling level of household head by two additional years is found to have a much larger effect on schooling and employment outcomes of the children than a $20 \%$ change in state wages or family income. Rosati and Rossi (2007) documented that at a community level expansion of the quality and availability of education has served to reduced rates of child labor.

Alderman et al. (2001) suggest that among other variables, household decisions are also sensitive to the school quality. Findings of Barro (2001) suggest that at national level, quality and quantity of schooling both matter for economic growth but quality is much more important. Schooling quality has significant impact on the productivity of a child and in the payoffs in the adult labor market in the long run. While in short term, it may have profound effects on the decisions for poor households as to whether or not to send their child to school when they have other alternatives such as child labor and free religious education. This assumption gets some support from the previous literature on the issue of schooling and child labor such as Fasih (2008), reports that no doubt education has high returns in low and middle-income countries but evidence show that these returns are lower for the poor compared to the rich because poor only can afford poor-quality schools. There is a large body 
of empirical evidences presenting the causes of differences in returns to school education due to the differences in schooling quality. For example Bedi and Edwards (2002), Psacharopoulos and Velez (1993), Barro (2001), Behrman and Birdsall (1983) and Card and Krueger (1992) find that quality of schooling varies significantly with in the developing countries and schooling quality has strong positive effects on adult earrings. Therefore lower quality of schooling could result in a lower return to education for given investment of time and money. But these previous literature is wanting of the information if one wants to know about the motivations of the parents behind the decisions of choosing activities other than school education, such as religious education, child labor, and staying in-active.

Labor market demands can vary in different regions of a country and this variation can be significant in development countries. For example, studies conducted by Behrman (1999), Squire (1981), and Rosenzweig (1978), show an overview of the regional differences of the labor markets in development countries and note the evidence of segmented labor markets. Van de Walle and Gunewrdena (2001) and (Aslam, 2009) report empirical evidences, that there are differences in returns to schooling across the individuals in same country due to ethnicity and gender discrimination.

The Parental perception of school education is a key element as positive perception can drive their desire for sending their children for school education. Along with other factors, a high desire from parents for school education would widely endorsed a higher literacy rate in future; this assumption is an important policy issue and would also constitute remarkable progress towards the achievement of universal primary education with gender parity in a country like Pakistan. This paper will contribute to this debate by including household head's perception of school education as a factor of demand for school education and investigate the influences that are affecting it. For investigating of household head's perception of the available type of education, it is assumed that this perception is a combination of impact of school education on the future income of their child and its compatibility with religious values. Thus it is also assumed that parents have different perceptions toward the future returns for their children from school education and have dissimilar thinking on the compatibility of school education with religious values.

To achieve these objectives, a field survey was conducted in about 43 villages, in all four provinces of Pakistan during August to December, 2009. During this survey, 963 households were interviewed and information on a total of 2,494 children was collected. The rest of the paper is organized as follows. Section 2 briefly discusses the model used for the study. Section 3 describes and presents the results on parental perception of school education and child productivity. Section 4 presents and describes the results on parental perception of school education and its compatibility with religious values. Concluding comments are presented in the section 5 .

\section{The Model}

Bacold and Ranjan (2008) model, with some modification according to the research area, was used in the current study. It was assumed that each household consist of one parent and one child and the income of parent is $(y)$. Each child has one unit of time that can be used either for school education $\left(S_{e}\right)$, religious education, $\left(R_{e}\right)$, child labor $\left(C_{l}\right)$, working and going to school $\left(W_{s}\right)$, and staying in-active $\left(N_{a}\right)$. Parents have to decide how much time child will allocate to these activities. The amount of human capital $(H)$, and wages $(\mathrm{W})$, earned by a child will depend on the time allocation to school/religious education and work/ staying in-active. When a child goes to school or madrassah (religious educational institutions locally called madrassah) for religious education, there is direct cost to education and an opportunity cost of child wages that child could earn while going for work. The direct cost of education will depend on the type of educational institution (public or private) and the opportunity cost depends on the wages of child labor. The total cost of education, combination of direct and opportunity cost, is denoted by $\left(E_{c}\right)$. Staying in-active child condition is because of the reason that parents could not afford education cost and child is not able to find a job in child labor market. So the child has enough leisure time, denoted by $(i)$, with lower human capital formation.

Household utility maximization functions with given level of consumption and human capital formation and leisure time of the child is given by:

$$
U(C, f(H), i)
$$

This utility function is restricted with time constraint for the any of given child activity resulting different level of human capital formation. With the assumption that in the fourth child activity that is working and going to school $\left(W_{s}\right)$ leisure time $(i)$ is almost equal to 0 whereas in the fifth child activity that is staying in-active $\left(N_{a}\right.$ ), leisure time is $(i)$, is almost equal to 1 . With this assumption the time constraint can be written as:

With budget constraint: $C=y+W-E c$

$$
S_{e}, i+R_{e}, i+C_{l}, i+W_{s}, i+N_{a}, i=1
$$

Based on the marginal returns to the child actives, mentioned above, any of the following five possible outcomes can be selected by the parents. 
1) $\mathrm{S}_{\mathrm{e}}>0, i>0, \mathrm{R}_{\mathrm{e}}=0$, and $\left.\mathrm{C}_{\mathrm{l}}=02\right), \mathrm{S}_{\mathrm{e}}=0, i>0, \mathrm{R}_{\mathrm{e}}>0$, and $\left.\mathrm{C}_{\mathrm{l}}=0,3\right) \mathrm{S}_{\mathrm{e}}=0, i>0, \mathrm{R}_{\mathrm{e}}=0$, and $\left.\mathrm{C}_{1}>0,4\right) \mathrm{S}_{\mathrm{e}}>$ $0, i \equiv 0, \mathrm{R}_{\mathrm{e}}=0$, and $\mathrm{C}_{1}>0$, and 5) $\mathrm{S}_{\mathrm{e}}=0, i \equiv 1, \mathrm{R}_{\mathrm{e}}=0$, and $\mathrm{C}_{1}=0$

\section{Modeling the perception regarding impact of schooling on future earnings}

Ravallion and Quentin (1999) concluded that schooling increases future earning of a child. In the context of low and middle income countries, Fasih (2008) reports that returns to school education is high only for those who can afford good quality education. This situation may affect the perception of poor and lower middle class of the economy toward the returns on schooling. who couldn't able to send their children to highly quality private and public schools, because of high cost of education, may conclude that sending their children to school will not increase their future income. So they might think schooling as a useless activity. To check this surmise, in this section parental perception on future returns to school education is modeled by knowing their opinion. This perception is measured by asking a closed ended question such as "do you agree that schooling will ensure greater future income for your child as compare to all other available alternatives". The options for this close ended question was 0 ) agree, 1) ambivalent, and 2) disagree. The functional form of the equation will be:

$$
\pi_{r}=f(\text { hhedu, sedu, expfure, dagr })
$$

where $\pi_{r}$ stands for perception on the future returns from schooling whereas hhhedu measure the years of schooling successfully completed by the head of household, sedu quantify the years of schooling successfully passed by the mother of the child, expfure enumerate the average expected wage for secondary school passed individuals, and dagr captures the situation if head of house hold has occupation of agriculture farming. A dummy variable of dagr is used and, dagr $=1$ if head of household' occupation is agriculture and $=0$ if otherwise. For future expected wage for each region was calculated by using secondary data on initial wage rate for a secondary school passed individual in private and public sector, and unemployment rate of the each region.

Based on the nature of the problem and statistical tests for the selection of the model, ordered logistic regression is used to analyze the perception of the head of household regarding the impact of school education on the future income of his/her child. The general statistical structural of the model is as under:

$$
y_{i}^{*}=X_{i} \beta+\varepsilon_{i}
$$

Where $y^{*}$ can be divided into $J$ ordinal categories, and

$y_{i}=j$ if $\tau_{j-1} \leq y_{i}^{*}<\tau_{j}, \mathrm{j}=1, \ldots, m$

Where the probability of being in the lowest category $\left(y_{i}=1\right)$ is "disagree" and highest category $\left(y_{i}^{*}=m\right)$ is "agree"

After using data of the perception of the head of household regarding the impact of school education on future income of a child, the predicted probabilities in the ordered logistic Regression are obtained by the standard formula, given as under:

$$
\begin{aligned}
& \operatorname{Pr}\left(\text { edufinperc }=\mathrm{j} \mid \mathrm{x}_{\mathrm{i}}\right)=F\left(\tau_{j}-X \beta\right)-F\left(\tau_{j-1}-X \beta\right) \\
& \text { whereas } X \beta=\beta_{1} \text { hhhedu }+\beta_{2} \text { medu }+\beta_{3} \text { expfure }+\beta_{4} \text { dagr }
\end{aligned}
$$

Ordered logistic Regression (OLR) model simultaneously estimates multiple equations. The numbers of equations estimated for this problem are the number of categories of independent variable 3 minus 1 , so for this problem 2 equations are estimated. As Ordered Logistic Regression OLR provides one set of coefficients for each response variable. That is why this model needs an assumption of parallel regression. The results of the tests for this model shows that, parallel regression assumption, is not violated. So the odds ratio is assumed to be constant for all categories.

\subsection{Results and Discussion}

Form the results given in (Table 1) of future income perception, I find that school education of the head of household and mother of the child, expected average future income and occupation of the head of household are statistically significant. The positive signs for hhhedu, medu, and expfure indicate that an increase in any of these variables necessarily decreases the probability of, dependent variable (Perception regarding the future income of a child), being in the lowest category $\left(y_{i}=\right.$ disagree) and increases the probability of being in the highest category $\left(y_{i}=\right.$ agree $)$. While for dagr the probability of being in lower category is higher compared to nonfarming occupation of the head of household. Study results show that, keeping all other variables of the model constant, one unit increase in the years of schooling of the head of household causes 1.248 factor change odds of being in higher category of future income expectation of a child after getting school education. In the case of exfure, increase in odds of higher level will increase by 1.143 factors, when exfure increases by Rs. 500. For dagr we have interesting results that can be interpreted as one unit increase in dagr (i.e., 0 to 1), meaning from farming to non-farming occupation, one can anticipate 0.628 factors in the odds of being in a lower category, keeping all other variables constant. The results suggest that one std. deviation increase in schooling of the head of household, i.e., 5.72, the odds of agreeing will be 3.557 times greater than the odds of middle and lower 
categories, keeping other variables constant. Study results also revealed that one unit and one standard deviation increase in the school education of mother of the child will increase the odds of higher category by 27.8 and 205.1 percent respectively, compared to the middle and lower categories, keeping other variables constant.

\begin{tabular}{|c|c|c|c|c|c|}
\hline Explanatory Variables & $\mathbf{b}$ & $\mathbf{e}^{\wedge} \mathbf{b}$ & $\mathbf{e}^{\wedge} \mathbf{b S t d X}$ & $\mathbf{\%}$ & $\mathbf{S D o f X}$ \\
\hline $\begin{array}{c}\text { Years of schooling successfully } \\
\text { completed by head of Household }\end{array}$ & $\begin{array}{c}0.222^{* * *} \\
(0.017)\end{array}$ & 1.248 & 3.557 & 24.8 & 5.720 \\
\hline $\begin{array}{c}\text { Years of schooling successfully } \\
\text { completed by mother of the } \\
\text { children }\end{array}$ & $\begin{array}{c}0.246^{* * *} \\
(0.037)\end{array}$ & 1.278 & 3.051 & 27.8 & 4.543 \\
\hline $\begin{array}{c}\text { Expected average future income } \\
\text { for a secondary pass individual }\end{array}$ & $\begin{array}{c}0.133^{* * *} \\
(0.023)\end{array}$ & 1.143 & 1.553 & 14.3 & 3.303 \\
\hline $\begin{array}{c}\text { Occupation of the head of } \\
\text { household }\end{array}$ & $\begin{array}{c}-0.466^{* *} \\
(0.163)\end{array}$ & 0.628 & 0.819 & -37.2 & 0.429 \\
\hline
\end{tabular}

Table 1. Empirical Results of the Ordered Logistic Regression

- $\quad \mathrm{b}=$ raw coefficient

- $\quad$ SDofX $=$ standard deviation of $X$

- $\mathrm{e}^{\wedge} \mathrm{b}=$ factor change in odds for unit increase in $\mathrm{X}$

- $\mathrm{e}^{\wedge} \mathrm{bStdX}=$ change in odds for standard deviation increase in $\mathrm{X}$

- $\%=$ percent change in odds for unit increase in $\mathrm{X}$

\subsection{Predicted Probabilities}

Table 2 shows a summary of predicted probability for a hypothetical head of household perception's regarding the effect of education on future income of his/her child. From the above results it is obvious that probability of agreeing that school education will increase future income of a child increases from 0.1 to 0.5 , when schooling of a farmer increases from 0 to 10 years of education. While keeping average expected future income of secondary passed individual at average and mother's school education at 0 . The perception becomes more in favor, that schooling education has positive impacts on the future earnings of a child, in the areas where the initial expected future income reaches at the level of Rs. 10,000 (about 124\$). In a situation, when household head has 10 years of successful school education and mother of a child with 5 years of successful school education, with an average future income for secondary pass individual of Rs.10, 000 in the area, the probability of agreeing is about 0.9 with a miner difference for farming and non-forming households.

\begin{tabular}{|r|r|r|r|l|l|l|}
\hline \multicolumn{5}{|c|}{ Household characteristics } & \multicolumn{3}{c|}{ Probability for outcome category } \\
\hline hhhedu & medu & expfure & \multicolumn{1}{|c|}{ dagr } & disagree & ambivalent & agree \\
\hline $\mathbf{0}$ & 0 & 5,705 & 1 & 0.672 & 0.223 & 0.105 \\
\hline $\mathbf{1 0}$ & 0 & 5,705 & 1 & 0.182 & 0.298 & 0.520 \\
\hline $\mathbf{5}$ & 5 & 5,000 & 1 & 0.193 & 0.305 & 0.502 \\
\hline $\mathbf{1 0}$ & 5 & 8,000 & 1 & 0.034 & 0.094 & 0.872 \\
\hline $\mathbf{1 0}$ & 5 & 8,000 & 0 & 0.022 & 0.063 & 0.915 \\
\hline $\mathbf{1 0}$ & 5 & 10,000 & 1 & 0.020 & 0.059 & 0.921 \\
\hline $\mathbf{1 0}$ & 5 & 10,000 & 0 & 0.013 & 0.038 & 0.949 \\
\hline
\end{tabular}

Table 2. Predicted Probabilities for Hypothetical Head of Household Perception's on the Effect of School Education on Future Income of His/Her Child

\section{Modeling perception on compatibility of school education with religious values}

There is general support for the hypothesis that poorer and more religious people will send their children to madrassa (local name for religious schools) for religious education, but Andrabi et al (2006) found a weak evidence that the poorer and less-educated families are more likely send their children to madrassa (religious educational institutions locally called Madrassa) and also found somewhat strong support for the hypothesis that poor children in settlements without a school use madrassa education more often. Singer (2001) reports that the reason for the madrassas new centrality stems from the weakening of the Pakistani state educational institutions, the madrassas having become immensely popular by targeting the lower classes and refugee populations, whom the Pakistani state has failed to provide with proper access to quality education. These study results are also inline with the findings of Stern (2000), who reports that Pakistan's endemic poverty, widespread corruption and often ineffective and poor educational institutions create an opportunity for Islamic recruitment and other undesirable child activities, such child labor, staying in-active etc., among poor and lower middle class people. The aim of study in this section is to estimate the perception of household head regarding the extent to which schooling education is discordant or compatible with religious values. To guesstimate the perception of household heads, they were asked if they think that schooling is dissonant or compatible with religious values. For this varying purpose their responses were categorized as; "dissonant", "ambivalent", and "compatible". In this section the perception of household is modeled as; 


$$
\gamma=f(\text { hhhedu, sedu, degreg, betri, degreg) }
$$

whereas $\gamma$ stands for the perception of the head of household regarding the compatibility of school education with religious values, hhhedu is to capture the years of school education successfully completed by head of household, sedu to measure the years of school education successfully completed by spouse of head of household, degreg is to gauge the degree of religiosity of head of household, and btn a dummy variable to distinguish house heads, who believe on tribal norms and otherwise. degreg is an index number used to measure the degree of religiosity of head of household. The index numbers for degree of religiosity were constructed by asking the question regarding religious practices and from 0 to 5 numbers was given to them respectively. Household heads who, pray daily regular with jamath, pray daily regular but not with jamath, pray daily but not regular, pray only on Fridays and Eids, pray only on Eids, and never pray, were give 5,4,3,2,1, and 0 number, respectively. The effect of tribal norms were captured by adding a dummy variable, $b t n=1$ if he/she believe on the tribal norms and 0 if otherwise.

Statistically significant results for Approximate Likelihood-ratio and Wald test confirmed that the parallel regression assumption will be violated if we use ordered logit regression model. The stereotype ordered regression (SOR) model, was proposed by Anderson (1984) reported by (Long and Freese 2006), in response to the restrictive assumption of parallel regression in the ordered regression model. Formally SLM for this section can be written as

$$
\operatorname{Pr}(\mathrm{y}=\mathrm{m} \mid \mathrm{x})=\frac{\exp \left(\theta_{m}-\emptyset_{m} x \beta\right)}{\sum_{\mathrm{j}=1}^{J} \exp \left(\theta_{\mathrm{j}}-\emptyset_{\mathrm{j}} \mathrm{x} \beta\right)}
$$

Where the distinguishing features for the model are as $\theta_{j}=0, \emptyset_{\mathrm{j}}=0$ and $\emptyset_{1}=1$

From the equation given above one can compute predictions for each case in the sample. In the give case we have three outcome categories (dissonant, neither dissonant nor compatible, and compatible) and four independent variables, whereas $X \beta$ is a vector of independent variables is equal to:

$$
X \beta=\beta_{1} \text { hhhedu }+\beta_{2} \text { sedu }+\beta_{3} \text { btri }+\beta_{4} \text { degreg }
$$

\subsection{Results and Discussion}

Results of (Table 3) divulged that years of schooling of head of household and his spouse effecting positively while believe on tribal norms, degree of religiosity are effecting negatively the religious compatibility perception. Study results revealed that one unit increase in the years of schooling of the head of household's school education, the odds of compatibility versus dissonant increased by a factor of 1.218 or one unit change in the years of schooling of the head of household head changes the odds of compatibility versus dissonant by 21.8 percent, holding all other variables constant. For a standard deviation increase in school education of the head of household, roughly 6 years, the odds of compatibility versus dissonant increased by a factor of 3.095, holding all other variables constant.

\begin{tabular}{|c|c|c|c|c|c|}
\hline Explanatory Variables & $\mathbf{b}$ & $\mathbf{e}^{\wedge} \mathbf{b}$ & $\mathbf{e}^{\wedge} \mathbf{b S t d X}$ & $\mathbf{\%}$ & SDofX \\
\hline $\begin{array}{c}\text { Years of schooling successfully } \\
\text { completed by head of Household }\end{array}$ & $\begin{array}{c}0.198^{* * *} \\
(0.029)\end{array}$ & 1.218 & 3.095 & 21.8 & 5.720 \\
\hline $\begin{array}{c}\text { Years of schooling successfully } \\
\text { completed by spouse of by head } \\
\text { of Household }\end{array}$ & $\begin{array}{c}0.178^{* * *} \\
(0.049)\end{array}$ & 1.194 & 2.240 & 19.4 & 4.543 \\
\hline Believes on tribal norms & $\begin{array}{c}-1.649^{* * *} \\
(0.294)\end{array}$ & 0.192 & 0.438 & -80.8 & 0.500 \\
\hline Degree of religiousness & $\begin{array}{c}-0.459^{* * *} \\
(0.102)\end{array}$ & 0.632 & 0.561 & -36.8 & 1.260 \\
\hline
\end{tabular}

Table 3. Results of Stereotype ordered logit model

- $\quad \mathrm{b}=$ raw coefficient

- $\quad$ SDofX $=$ standard deviation of $X$

- $\mathrm{e}^{\wedge} \mathrm{b}=$ factor change in odds for unit increase in $\mathrm{X}$

- $\mathrm{e}^{\wedge} \mathrm{bStdX}=$ change in odds for standard deviation increase in $\mathrm{X}$

- $\%=$ percent change in odds for unit increase in $\mathrm{X}$

While for one standard deviation increase in school education of spouse of the head of household, roughly 4.5 years, the odds of compatibility versus dissonant increased by a factor of 2.240, keeping other variables constant. For believes on tribal norms, to capture this effect a dummy variable is used, study results revealed that the odds of compatibility versus dissonant decreased by factor of 0.192 for those who has believe on the tribal norms compared to their counterparts who does not believe on such norms, holding all other variables constant. The study results suggest that degree of religiosity also has statistically significant effects on the perception of household. One degree increase in religiosity of head of household decrease the odds of compatibility versus dissonant by factor of 0.632 , keeping other variables constant. 


\subsection{Predicted Probabilities}

Table 4 showing a summary of predicted probability for a hypothetical individual head of household perception's regarding the compatibility of school education with the religious values. In a household where the household head and his spouse are uneducated, household had believe in tribal norms and is highly religious, the probability of having a perception that school education is dissonant with religious values is 0.468 . In the same situation the probability of having the perception that school education is compatible with religious values is 0.104 . The probability of having the perception that school education is dissonant with the religious values decreases with increase in the school education of head of household and his spouse. Even with the high degree of religiousness, i-e 5, with 10 years of successful school education for head of household and his spouse and no believe in tribal norms, the probability of having perception that school education is dissonant with religious values is on 0.015 . On the other hand the probability of having the perception that school education is compatible with religious values in the same situation is 0.754 . The study results exposed that household head's and his spouse years of successfully completed school education has positive impact while his believe on tribal norms and degree of religiousness has negative impacts on his perception that school education is compatible with the religious values. In the families where father and mother of children are not educated most likely have an opinion that schooling education is dissonant with the religious values. These are the potential target groups who send their child for religious education or prefer activities other than school education. Study results also elucidate that head of household, who has strong believe on tribal norms most likely has perception that school education is dissonant with religious values. Household's heads who has such perception will never allow their female family members for school education, even in some cases they will stand firm and resist on such steps. Evidences from the study and general trend show that, believes on tribal norms, gets weaken with the increase of education in the household members. So highly religious, uneducated, and having strong believer of tribal norms most likely prefer child activities other than school education. The change in probability of the perceptions that school education is dissonant with religious values is only 0.076 of the literate households' heads from average to high degree of religiousness.

\begin{tabular}{|r|r|r|r|r|r|r|}
\hline \multicolumn{4}{|c|}{ Household Characteristics } & \multicolumn{2}{c|}{ Probability of the outcome category } \\
\hline hhhedu $u$ & \multicolumn{1}{|c|}{ sedu } & \multicolumn{1}{|c|}{ bth } & degreg & Dissonant & Ambivalent & Compatible \\
\hline 0 & 0 & 1 & 5 & 0.468 & 0.428 & 0.104 \\
\hline 0 & 0 & 1 & 1 & 0.210 & 0.498 & 0.292 \\
\hline 10 & 0 & 1 & 5 & 0.194 & 0.495 & 0.311 \\
\hline 10 & 5 & 0 & 5 & 0.033 & 0.310 & 0.657 \\
\hline 10 & 10 & 0 & 3 & 0.007 & 0.163 & 0.830 \\
\hline 10 & 10 & 0 & 4 & 0.010 & 0.196 & 0.794 \\
\hline 10 & 10 & 0 & 5 & 0.015 & 0.231 & 0.754 \\
\hline
\end{tabular}

Table 4. Predicted Probabilities for Hypothetical Head of Household Perception's Regarding Compatibility of School Education with Religious Values

\section{Conclusion}

Whole study can be distinguished in to two parts such as parental perception of impact of schooling on child productivity and parental perception of compatibility of school education with religious values. From the study results one can conclude that parental perception of that schooling will enhance the future income of their child gets better with the increase in years of schooling of head of household and his spouse. Parental perception regarding the impacts of school on the future income of a child grows positively with the increase in the level of expected future income for the secondary-pass individuals. This perception gets worse for the household engaged in agriculture formation with low levels of school education.

Findings of the study on the compatibility of school education with the religious values indicate that religious compatibility perception increase with each years of schooling completed by the parents of child. Beliefs in tribal norms have a negative impact on the perception of compatibility of school education with the religious values. The degree of religiousness has a negative impact on the "compatibility" perception with 0 years of schooling for the parents. The degree of religiousness has positive impacts with increase in year of schoolings of parents.

\section{References}

- Andrabi, T., J. Das, A. I. Khwaja, and T. Zajonc (2006). "Religious school enrollment in Pakistan: A look at the data" Comparative Education Review, 50 (3) 446 - 477.

- Anderson, J. A. (1984). "Regression and Ordered Categorical Variables", Journal of the Royal statistical Society Series B 46: 1-30.

- Alderman, H., P. F. Orazem, and E. M. Paterno (2001). "School quality, school cost, and the public/ private school choices of low-income households in Pakistan", The Journal of Human Resources, 36 (2) 304 - 336.

- Aslam, M. (2009). “Education Gender Gaps in Pakistan: Is the Labor Market to Blame?”, Economic 
Development and Cultural Change, 57 (4).

- Bacolod, Marigee P. and Paiya Ranjan (2008). "Why child work, attend school, or stay idle: The role of ability and household wealth", Economic Development and Culture change, 56 (4), 791-828.

- Bhalotra, S. and Heady C., (2003). "Child farm labor: the wealth paradox”, World Bank Economic Review, 17, 197-227.

- $\quad$ Basu, K. and P. Van (1998). "The Economics of child labor”, American Economic Review, 88 (3) 412 - 427.

- Barro, R. J. (2001). "Human capital and growth", American Economic Review, 91(2), 12-17.

- Bedi, A.S. and John H. Y. Edwards (2002). "The impact of schooling quality on earnings and education returns-evidence from a low-income country", Journal of Development Economics, 68 (2002) 157-185.

- Behrman, J.R., (1999). Labour markets in developing countries. In O. Ashenfelter and D. Card (eds.), Handbook of Labour Economics, Vol. 3B, Amsterdam: Elsevier, pp. 2859-2939.

- Behrman, J.R. and Birdsall, N. (1983). "The quality of schooling: quantity alone is misleading”, American Economic review, 73, 928-46.

- Card, D. and Krueger, A. B. (1992). "Does schooling quality matter? Returns to education and the characteristics of public schools in the United States", Journal of Political Economy, 100, 1-40.

- $\quad$ Duryea, S. and M. A. Kuenning. (2003). School attendance, child labor and local labor market fluctuations in urban Brazil. World Development, 31 (7) : 1165-1178.

- Edmonds, E.,(2005). Does Child Labor Decline With Improving Economic Status? The Journal of Human Resource, 40(1) 77-99.

- $\quad$ Fasih, T. (2008). Linking Education Policy to Labor Market Outcomes, Washinton DC: World Bank Publication.

- $\quad$ Long, J. S. and J. Freese (2006). Regression Model for Categorical Dependent variables using Stata, Second Edition.

- Maitra, P. and R. Ray (2002). "The Joint Estimation of Child Participation in Schooling and Employment: Comparative Evidence from Three Continents", Oxford development Studies, 30 (1): 41-62.

- $\quad$ Psacharopoulos, G. and Velez, E. (1993). "Education quality and labor market outcomes: evidence from Bogota, Colombia", Sociology of Education, 66, 130-45.

- $\quad$ Ravallion, M. and Q. Wodon. (1999). "Does child labor displace schooling? Evidence on behavioral responses to and enrollment subsidy". World Bank Policy Research Working Paper No. 2116.

- Ray, R., (2000). "Analysis of Child Labor in Peru and Pakistan: A comparative study", Journal of Population Economics, (2000)13: 3-19.

- $\quad$ Rosenzweig, M. R. (1978). "Rural wages, labor supply and land reform: a theoretical and emprical analysis", American Economic Review, 68, 847-61.

- Rosati, F.C., and M. Rossi, (2007). "Impect of School Quality on Child Labor and School attendance: The case of Conafe Compensatory education Program in Mexico". Understanding Children's Work Working Paper. Rome: UCW.

- $\quad$ Singer, P.W. (2001). Pakistan's Madrassahs: Ensuring a system of education not jihad. Brookings Institutions Analysis Paper 41. Washington D.C.

- $\quad$ Stern, Jessica. 2000." Pakistan's Jihad Culture." Foreign Affairs 79 (6): 115-126.

- Squire, L. (1981). Employment Policy in Developing Countries: A Survey of Issues and Evidence. Oxford: Oxford University Press.

- Van de Walle, D. and Gunewardena, D. (2001). "Sources of ethnic inequality in Vietnam", Journal of Development economics, 65, 177-207. 


\title{
Agriculture Cooperatives of Russia: Present State and Perspectives under the Contemporary Conditions*
}

\author{
Igor Tonkoshkurov (Khakassia State University, Russia)
}

\begin{abstract}
The article considers the analysis of agriculture cooperatives in Russia. Special attention is paid to absence of the strategy for developing modern cooperative system in Russia. Cooperatives are going to become one of the most attractive forms of businesses in many countries. However, in Russia is not enough developed the low level of the cooperatives regulation. After the 20 years of their functioning we try to have a good look at their current situation. Special attention is paid to the influence of globalization on development of farming cooperatives. Main results of the study are definition of modern position and structure of farming cooperatives in Russia and estimation of their perspectives in the near future.
\end{abstract}

\section{JEL Codes: Q13}

\section{Introduction}

There is the third sector of economics in all countries of the world, which enjoys its full authority in the cooperative sector. It has been developing very successfully and has proved to be very optimal even under the circumstances of the economical crisis. Moreover, the cooperatives also play a very important social role.

The agro-industrial sector is a big part of the national economy of Russia. Nevertheless, none of its subsectors are able to cope with the economical crisis by themselves. This is why the consolidation and integration of the agro-industrial companies based on cooperatives, is an important condition for activating this sector and stabilising the economy.

The main social and economical task of the agricultural cooperation is to create the organisational-legal system for protecting the interests of agricultural producers in the market society environment. This can be reached by creating self-directed business entities under democratic conditions.

The agricultural cooperatives have made an important contribution in socioeconomical development all over the world. According to UN, almost 3 billion people (half of the global population) are supplied to by cooperatives (Kutlijarova, 2007, p. 67).

In spite of the fact that agricultural cooperation plays an important role in strengthening the economic potential, competitive ability and social status of agricultural companies, and also improving business conditions and creating stimuli for production growth, its development in Russia is however still at the very beginning.

\section{Agricultural cooperatives in Russia: present situation}

Cooperative motion in Russia has undergone very many changes in the last decade. There is going to be a change in the internal structure of the agricultural cooperatives. The actual situation on the Russian market with high prices on machinery, fuel, equipment and replacement components, fertilisers and seeds doesn't allow an advance in the farming industry.

Many problems arise as well by the sale of products. Wholesale dealers buy up agricultural products for a lower cost and farmers don't have a chance to enter the market independently.

These problems require a consolidation and joining of efforts of the small and medium producers. This process has begun in many of Russian's regions in the last decade. In this respect it promotes the official law «About agricultural cooperation» (federal statute from 1995). In sixty regions of the Russian Federation in 2009 there were about 12000 agricultural producers' cooperatives (Cooperative sector in Russia, 2009, p. 14).

At the present stage all forms of agricultural consumer cooperatives are developing:

- agro-processing cooperatives;

- cooperative marketing associations;

- service cooperatives;

- buying cooperatives;

- insurance cooperatives;

- rural credit cooperatives.

The growth of the rural cooperative motion is developing in different ways and in diverse rates in the regions of Russia (table 1).

\footnotetext{
* Supported by Alexander von Humboldt Foundation (German Chancellor Fellowship Programme 2010/2011).
} 


\begin{tabular}{|l|c|c|c|c|}
\hline \multirow{2}{*}{ Federal district } & \multirow{2}{*}{ Total } & \multicolumn{3}{c|}{ Agricultural consumer cooperatives } \\
\cline { 3 - 5 } & & processing & service & marketing \\
\hline Central Federal District & 155 & 104 & 32 & 19 \\
\hline Southern Federal District & 51 & 41 & 3 & 7 \\
\hline Northwestern Federal District & 27 & 16 & 10 & 1 \\
\hline Far Eastern Federal District & 48 & 42 & 2 & 4 \\
\hline Siberian Federal District & 124 & 95 & 9 & 20 \\
\hline Urals Federal District & 67 & 40 & 16 & 11 \\
\hline Volga Federal District & 230 & 117 & 84 & 29 \\
\hline Russian Federation & 702 & 455 & 156 & 91 \\
\hline
\end{tabular}

Table 1: Allocation of agricultural consumer cooperatives in Russia, 01.01.2005. Source: Conception of development of agricultural consumer cooperatives, 2006

\begin{tabular}{|l|c|c|c|c|}
\hline \multirow{2}{*}{ Federal district } & \multirow{2}{*}{ Total } & \multicolumn{3}{c|}{ Agricultural consumer cooperatives } \\
\cline { 3 - 5 } & & processing & service & Marketing \\
\hline Voronezh Region & 15 & 14 & - & 1 \\
\hline Kaluga Region & 19 & 8 & 7 & 4 \\
\hline Moscow Region & 11 & 2 & 4 & 5 \\
\hline Orel Region & 24 & 17 & 3 & 4 \\
\hline Ryazan Region & 10 & 7 & 2 & 1 \\
\hline Tver Region & 23 & 19 & 4 & - \\
\hline Altai & 26 & 21 & 2 & 3 \\
\hline Krasnoyarsk Territory & 13 & 8 & - & 5 \\
\hline Novosibirsk Region & 30 & 23 & 4 & 3 \\
\hline Omsk Region & 13 & 8 & - & 5 \\
\hline Republic of Sakha & 33 & 30 & 1 & 2 \\
\hline Krasnodar Territory & 8 & 6 & 1 & 1 \\
\hline Volgograd Region & 26 & 20 & 2 & 4 \\
\hline Republic of Bashkortostan & 41 & 28 & 3 & 10 \\
\hline Republic of Tatarstan & 44 & 23 & 15 & 6 \\
\hline Udmurt Republic & 38 & 22 & 14 & 2 \\
\hline Sverdlovsk Region & 24 & 13 & 7 & 4 \\
\hline
\end{tabular}

Table 2: Agricultural consumer cooperatives in leading regions of Russia (selective), 01.01.2005 Source: Conception of development of agricultural consumer cooperatives, 2006

Agricultural consumer cooperatives in Russia are gaining ground in such regions as Rostov, Tyumen, Astrakhan, Buryatia, Bashkiria, Tatarstan, Saratov, Volgograd, Orel, Udmurt (table 2).

The inadequately developed systems of agricultural consumer cooperatives are in the North Caucasian Federal District and Far Eastern Federal District (with the exception of Republic of Sakha). In such republics of North Caucasian as Dagestan, Ingushetia, Kabardino-Balkaria, Karachai-Cherkess, North Ossetian and Chechnya, they haven't made any agricultural consumer cooperatives.

In the Conception of Development of Agricultural Consumer Cooperatives (Ministry of Agriculture of Russia, 2006), the support of agricultural consumer cooperatives is put into effect in the following ways: 1) improvement of legislative regulations of the cooperative motion; 2) financial and credit support of agricultural consumer cooperatives; 3) information, consulting and methodological support of cooperatives activities; 4) personnel training.

According to the Ministry of Agriculture of Russia, 5100 agricultural cooperatives were created by the $1^{\text {st }}$ of January 2009 (Janbjh, 2010). The most successful cooperative development was in the Volgograd and Tumen regions as well as in Mordovian and Yakutskaya Republic (Saha). The Foundation of the Development of Agricultural Credit Cooperation in Russia reveals that there had been 1793 agricultural credit cooperatives by the $1^{\text {st }}$ of January 2011 (www.ruralcredit.ru).

Particular development demonstrates dacha and horticultural cooperatives. As is reported by the International Labour Organization, at present the Union of Horticulturists of Russia unites 67 regional organisations which represent interests of 27 million Russian horticulturists, gardeners and dacha households (Cooperative Sector in Russia, p. 22).

Small businesses have started receiving support in terms of the national project "Agro-industrial development" (2006-2007). Some of the project measures have developed into the State Program for Agricultural Development and Regulation of Agricultural Products, Resources and Foods Market in 2008-2012 (State Program), which was 
adopted on the $14^{\text {th }}$ of July 2007 . Small agricultural businesses received only $7,9 \%$ of all programme funds (48,3 billion RUB from 551,3 billion RUB), which was even less after the adoption of anti-crisis measures (particularly after the extensions of the statutory fund of "Rosselhozbank") - 5\% (Janbjh, 2010).

The main tasks of the State Programme supporting small agricultural businesses are:

- credits ensuring private farms, farming businesses and agricultural consumer cooperatives;

- development of the agricultural credit cooperation;

- creation and development of agricultural consumer cooperatives for supply, sales and processing of agricultural products.

It is important to say that this programme does not use the potential of agricultural credit consumer cooperatives enough. Nowadays the credit cooperatives provide only $6,3 \%$ of their funds for credits that are transferred to small agricultural businesses (Janbjh, 2010). Table 1 shows the provided credits for small agricultural businesses in 2008 .

\begin{tabular}{|c|c|c|c|c|c|}
\hline \multirow[b]{2}{*}{ Credits } & \multirow{2}{*}{$\begin{array}{l}\text { Received } \\
\text { credits in } \\
2008\end{array}$} & \multicolumn{4}{|c|}{ Credit organizations } \\
\hline & & $\begin{array}{l}\text { Rosselhoz } \\
\text { bank }\end{array}$ & $\begin{array}{c}\text { Sberbank } \\
\text { Rossii }\end{array}$ & $\begin{array}{l}\text { Other } \\
\text { banks }\end{array}$ & $\begin{array}{c}\text { Credit } \\
\text { cooperatives }\end{array}$ \\
\hline $\begin{array}{l}\text { Credits received for } \\
\text { development of small } \\
\text { businesses, mln. RUB }\end{array}$ & 48256 & 33553 & 9945 & 1721 & 3036 \\
\hline$\%$ & 100 & 69,5 & 20,6 & 3,6 & 6,3 \\
\hline
\end{tabular}

Table 3: Credits, received by small businesses in 2008. Source: Janbjh, 2010

The table shows that the main share of credits is granted by "Rosselhozbank" (up to 70\%). The share of commercial banks in crediting small agricultural businesses is very small. Nowadays the support of small businesses is mostly done by "Rosselhozbank", but there is a limit of the "Rosselhozbank" subsidiaries, whereas it has limited access to distant regions of the country. In our opinion, the network of agricultural credit cooperatives, which are mostly located very close to the homes and workplaces, could cope with this task and provide rural population with credit resources more effectively.

\section{Problems of the cooperative's segment in the agricultural sector}

The main reasons for the insufficient development of agricultural cooperation includes the following:

- $\quad$ low level of state support of agriculture;

- $\quad$ absence of effective legal basis and clear guidelines;

- $\quad$ weak protection of the binary market from the subsidised foods and raw materials imports;

- $\quad$ big price disparity concerning agricultural products and resources for agricultural production;

- $\quad$ insufficient development of market infrastructure.

According to Professor A.P. Koshkin, there is still no concept or strategy for developing a modern cooperative system in Russian Federation (Koshkin, 2009).

The modernisation process is not moving forward very effectively, but extremely unprofitable. First of all it influences the economic state of socially unprotected population in a negative way. This process is extreme in the rural areas.

The main problems result from the dynamic and constant change of Russian cooperative legislation. It is important to say that there have been several federal laws adopted in Russia lately that are aimed at the improvement of legal status of cooperatives and their consolidation. These laws include federal laws "About agricultural cooperation", "About production cooperatives", "About credit consumer cooperatives of citizens", "About farms", "About garden, vegetable gardens and summer cottage non-commercial associations of citizens". Besides there have been adopted federal laws considering the changes and amendments to the Law of Russian Federation "About consumers cooperation (consumers organizations and their associations) in Russian Federation" and other laws.

The above mentioned laws reflect the economical and social role of cooperatives. They define the necessity to use the potential of cooperatives for raising the effectiveness of national economy, reaching the goals of social development, fighting poverty and creating full and effective employment and social protection for the population.

Besides all if this, there is still no full legislative basis that could ensure competitiveness and stable development of the cooperative system in market conditions. The tax legislation does not fully consider the specificity of some cooperatives types and it does not stimulate the creation of new cooperatives on sales, supply, joint machines usage or the involvement of private farms in these cooperatives. There is no effective coordination of ministries and departments in developing programmes and laws that are aimed at the 
development of cooperation of state companies or private businesses, especially small businesses.

In Russia there are still no legislative mechanisms of state support for the successful development of cooperative system. That is why the development of the cooperation especially in agriculture fully reflects the socioeconomical, political, technical and legislative conditions in the country.

\section{Conclusion}

The cooperative economy sector has to become the object of state governance and has to become a task of federal executive authorities. Nowadays there is no such unit in the government of Russia. It is also very important to organise and monitor the development and state of the cooperative sector. The special role in this integration process has to be played by cooperation and integration based on the consolidation of industrial, processing and agroservice companies with agricultural producers. It should take the raise of economics of weak companies into account, which have not received any credits in the last couple of years (Suetov, 2009).

Currently the Ministry of Agriculture of the Russian Federation has prepared the Concept of the Development of Agricultural Consumer Cooperation which is aimed at effective cooperation of agricultural consumer cooperatives and consumer organisations that unite 4 million people in a Central Union (and these are not only agricultural producers) (Itkulov, 2011). Such documents allow a long-term strategy of agricultural cooperation to develop and build a stable basis for its development.

The change of socioeconomical conditions for agricultural companies and private farms in Russia is connected with the oligopoly on the agricultural foods markets and growing individualisation of agricultural production. This means the necessity of detailed coordination in providing resources and products as well as consolidation among all participants of the agricultural sector.

This unusual theory, in terms of history and cooperation, and the creation of agricultural cooperatives initiated by the government, can bring positive results only when the organisational conditions correspond with the market conditions, when they consider the specificity of formal and non-formal institutes on the domestic agricultural market.

\section{References}

- $\quad$ Kutlijarova, R., 2007. Legal Regime of Share and Indivisible Funds of Agricultural Cooperative, Pravo $i$ politica, 10 (94).

- Janbjh, R., 2010. Potential of Agricultural Cooperation in Development of Small Forms of Managing on Rural, Agro-Inform, 1/2 (140).

- http://www.ruralcredit.ru.

- Koshkin, A., 2009. The Cooperative Policy in Modern Russia // http://portal.rea.ru/portal/Main.nsf/0/A2A3A3AB7CE863A1C32575FF0033EABA!OpenDocument.

- Suetov, A., 2009. The Theory and Practice of Agricultural Cooperation in Russia, Agroprogress, Moskow.

- Itkulov, S., 2011. Cooperation is Simply Joint Work, Selskaja Zhizn, the 5. January.

- Cooperative Sector in Russia and the Implementation of the ILO No. 193 in the development of different Russian cooperative trends / International Labour Organization. - Moscow: ILO, 2009.

- Conception of development of agricultural consumer cooperatives, Ministry of agricultural of Russia, 2006. 


\title{
Economic Growth and Democracy in Moldova
}

\author{
Tatiana V. Pîschina (Academy of Economic Studies, Moldova)
}

\begin{abstract}
Using the experience from previous studies and applying it to the evolving realities this article supports the idea of the existing links between economic growth and democracy. The paper reviews economic growth of the Republic of Moldova since 1991, the year which also signifies Moldova's entry to the path towards a sovereign nation state based on the principles of democracy. Central focus of the analysis is the quality of economic growth and its link to democracy in the long term perspective. In other words, this is the long-term indirect effect of democracy on the quality of economic growth. This quality, or at least some aspects of it, in its turn, is herein understood as accumulation of social capital and more stable political situation that constitutes the core of the national welfare state - a state associated with growth simultaneous with development and maintenance of the economic and social well-being of its citizens. For almost 20 years Moldova's economic growth has not been supported by development. This research suggests that democracy is the missing link between a healthy society and a healthy economy. Democracy facilitates economic growth with development. This implies that economic reform in transition countries should be supported by the structural transformation of the state and social institutions towards basic principles of democracy. This will aid curbing such acute challenges as social unrest, inequality in access to welfare, as well as corruption. Finally, only through democracy can the Republic of Moldova succeed on the way towards European integration.
\end{abstract}

JEL Codes: O11, I38, P29

\section{Introduction}

This short study is an introduction to the analysis of democracy and its relationship to economic growth with development in context of the transition economies in a long-term perspective. It presents the case study of the Republic of Moldova as well as uses major theoretical considerations about democracy and economic growth to make assumptions about where the link between the two should be drawn, how and why. This topic is acute especially for the post-Communist transition states, where democracy has long been a sought for virtue. In Moldova, on the level of the national economy, democracy may be an answer to weakening of the evils of corruption and social dissatisfaction due to inaccessible welfare. It is also a path to increased economic partnership with the West, the European Union in particular.

In the following part of the paper, a brief overview of Moldova's economic and political stance since the 1990s to date will be given. Secondly, the analysis will put together major theoretical considerations on democracy and economic growth to subsequently make assumptions about where and why there should be a link between the two. The emphasis will be made on the link between economic and social well-being in context of a transition state like Moldova. Finally, the concluding part will summarise the main assumptions of the research and will put forward the argument of democratisation of state institutions as a catalyst of long- term economic growth with development. It is crucial to note that the opinions are subjective, open to scrutiny, and this paper is intended as an introduction to future projects and research in the field of transition and developing economies and their long-term growth.

\section{Background to Moldova's Economic Growth without Development}

For the purpose of this brief account, the following will commence by considering two major issues: the effectiveness of Moldova's economy 1991 through 2008, and the assessment of Moldova's democracy. So, is Moldovan economy effective?

The Republic of Moldova gained its independence in 1991, which also signified the continuation of a downscale persistence of its real GDP levels, the trend that lasted for almost a decade and was reversed to slow growth again in 2000-2001. However, even in 2008 the GDP levels have only reached the benchmark of the early 1990s. Today, Moldova is the poorest country in Europe, a supplier of cheap labor to the global market. The GDP per capita per year equals US\$1,503 (current prices, 2010). The real GDP in 2008 compared with the base year (1991) is only 56\% (Pîschina, 2009).

There is one major problem in Moldova's economy - reduction of the key factors of economic growth - labor and capital - lead to a reduction in potential output volume, that is, a narrowing of the boundaries of production possibilities. As a result, Moldova is on the path to economic growth without development. We will come back again later to how this problem may be addresses through more democracy in the governing apparatus. Thus, the question about the effectiveness of Moldova's economy cannot, unfortunately, be answered positively. 


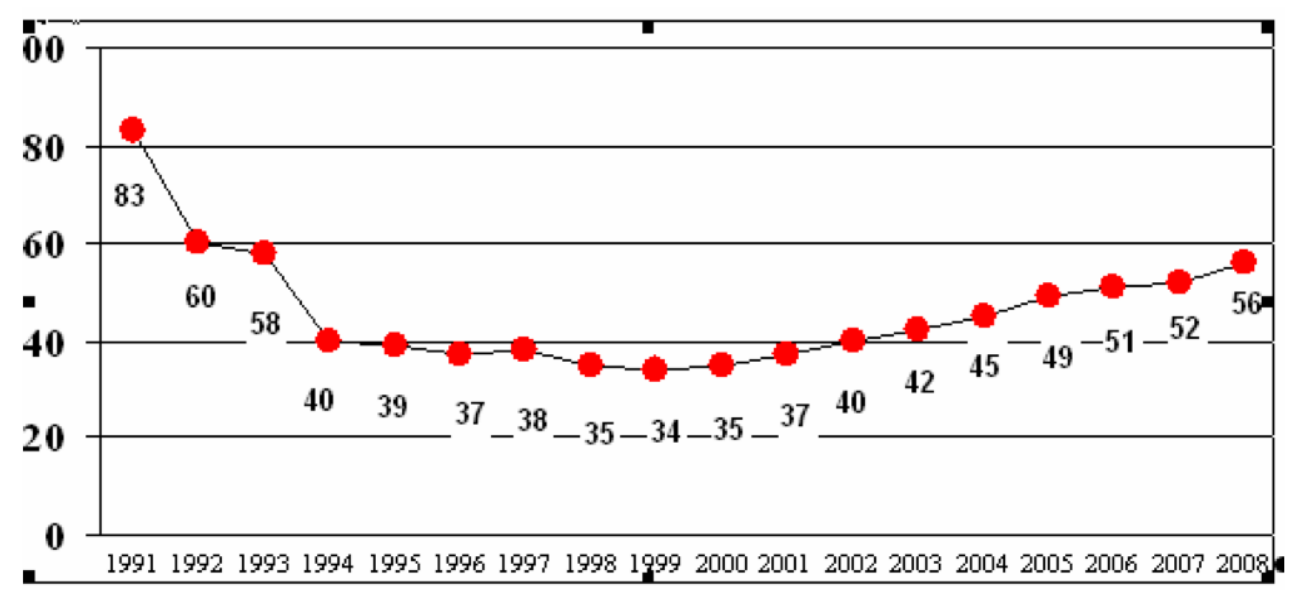

Figure 1: Dymanics of the Real GDP in Moldova, \%, 1990=100\% Source: Pîschina, 2009.

In this context, what is Moldova's political situation? Subjectively, Moldova's current development is a battle for power between the communists and the various sorts of democrats, all failing to live up to the expectations of the voters. It involves shuffling and reshuffling of the votes, supported by an ambiguous stance of all sorts of partnerships promised by the parties, from Russia to the United States to Romania and the European integration. So far, the output from the US aid is limited, trade with Russia is turbulent and the European integration project seems to be a rather far-fetched goal. All of this instability is rather transparent and hits badly both the internal economic growth and external economic support from Moldova's sponsors.

Yet, since its independence in 1991 Moldova has made progress towards democratisation coupled with the slow economic recovery. This progress was noted in the report for USAID in 2005 that examined Moldova since its independence in 1991, particularly with regards to privatisation, reduced governmental regulation of business as well as manageable levels of inflation (see www.moldova.usaid.gov for extended reports) . More recently, economic and social dissatisfaction resulted in the social upheaval in response to another series of elections with the communist win in April 2009. The CEPS report of 2009 rightfully referred to the situation as an impasse, which goes on to date resulting in the fact that the country does not have a president, but basically a ruling representative. This, of course, challenges the crucial for Moldova economic and social integration policy with the European Union. Particularly hopeful for Moldova remains the European Neighbourhood Policy (ENP) and Eastern Partnership (EaP) for free trade, among other aspects, in which the country remains a frontrunner due to its democratisation discourse, as also noted in the CEPS report.

So why can democratisation be considered particularly important for the long-term economic growth with development in Moldova? If we recall the major identified problems in Moldova's economy, reduced factors of labor and capital, it becomes clear that for some reason people leave Moldova, and businesses are reluctant to invest in Moldova, which is one of the sources of the draining juices of Moldova's economy. This reason could very well rest in the fact that Moldova is plagued by corruption and general sense of instability both in the government and on behalf of its citizens that only recently have demonstrated more or less pronounced interest in the faith of their country.

Democracy as such is not automatically a remedy for social dissatisfaction, political instability or elimination of corruption. After all, the best way to implement order in the pure sense of the word would be through democracy's antipode - in a form of authoritarianism. However, this study holds that for a European economy like Moldova any sort of autocracy is no longer a solution, and only democracy is. At this point in time, Moldova's economic openness trend should necessarily be supported by the social freedom discourse, and by the main features of democracy - freedom to chose political and economic paths for the country, the ability to alter its course and the following sense of responsibility of each individual to be accountable for their own decisions and the consequences in the broader context. This, if you please, means tackling such challenges as corruption from within, from the social bottom, rather than imposing a regime top-down.

\section{Democracy and Economic Growth: Why, Where and How}

To explain the point of view on Moldova expressed earlier, we may consider some basic definitions to then assume about why, where and how the link between democracy and economic growth should be drawn in this particular case. Causal relationship between democracy and economic growth can deservedly be considered as one of the most debated topics on the verge of economics and political sciences. There is no consensus as to whether democracy leads to economic growth, or, on the contrary whether economic growth leads to the establishment of a democratic society. Moreover, the extent to which democracy is related to economic growth at all is in practice very difficult to measure. And, it is not only because of the structural complexity of this 
causation. It is also because of the instinctive and subjective understanding of the concept of democracy.

\section{Definitions}

Democracy is responsive to evolutionary sentiments of different societies that discuss and understand democracy from the point of view of their own historically determined reality. The definition of democracy results in the outcome of a discussion about democracy, which is why the more reflections and criticisms current point of view main entail, the closer one might get to understanding what democracy in context of economic growth actually constitutes as a concept.

Democracy can be simply understood as the rule of the people. In the framework of a nation state, it occurs when the people are capable to openly and equally influence fairly elected government. In an ideal democratic situation, the government would act as facilitator of the needs of the society. For countries like Moldova, democracy could also be symbolic to some sort of liberation from the past, prosperity and closeness to Europe. On the other hand, older generations willing to preserve that link with the past see it as detrimental to the society. With this complexity in mind, democracy in Moldova should be viewed as a qualitative change towards people deciding their own political and economic faith and thus towards them being responsible for their choices and actions. A democratic government like that would lead Moldova long and prosperous way. Democracy, thus can be understood as an indirect condition of long-term economic growth with development.

So, what about the economic growth with development? As an economist, I most often refer to economic growth in terms of, for instance, various GDP indicators, production and consumption, inflation levels etc. These are all indicators of economic growth, however, for the purpose of this study I would like to suggest a specific focus to economic growth - occurring with or without development. Growth with development, in this sense, refers primarily to the wellbeing of the individuals, their equal access to welfare - to the products of economic growth, as well as through such indicators as corruption levels. Social satisfaction in economic terms leads to the most important constituent of every nation state - accumulation of human capital, brain consolidation instead of brain drain, the development of patriotism instead of hostile nationalism and unification and further growth of the nation in both political and economic sense. If that were achieved, factors such as labor and capital would accumulate in Moldova, which has all geographic and geopolitical preconditions for healthy economic growth.

Why?

Starting from the counterfactual, one of the strongest democracies in the world, the United States, has been in and out of the system-induced crisis for the past several years. China, on the other hand, is one of the contemporary economic miracles built on the remarkably well-managed synergy of communist government with the market liberalisation reforms. China's growth has not been achieved through democracy at all. Speaking to my Chinese colleagues, however, it seems China's growth is shallow to China's common man, and there is little about it he can do. The political future in China is increasingly unclear. Rising living standards of the population cause growing protests against the Party. In the long run, the question arises: is economic growth, even if it does happen, sustainable without a civil society based on the democratic principles?

The richest countries in the world, with the exception of Singapore, are democracies. Democratisation led to increased growth rate by $1 \%$ compared with similar non-democratised economies. The transition process from democracy to dictatorship led to a decrease in growth rate by $2 \%$ (Persson, Tabellini 2008). There are almost no rich non-democracies in the world. Democracy and non-democrats, on average grow to nearly the same rate, yet, democracy is slightly faster. Although, taking into account other factors, the effect can however be rendered as statistically insignificant. Nevertheless, evidence suggests that the growth rate of non-democracies is much less stable. China under Mao - an economic disaster; Castro's Cuba - no growth; Pinochet was both growth and recession. The trick is probably, when you reach a certain level of per capita income democracy consolidates further growth.

Ultimately, democratic institutions in principle better fight corruption because they are by definition designed by people and to serve the interests of the people, and help constrain theft, bribery, corruption or the rule of law (Dixit 2004). For democratic leadership to hold on to power, it is necessary to demonstrate economic results. So, at a low level of social development - especially during the transition from agrarian society to an industrial one, the Chinese model works just fine. At a higher level of social consciousness, it is difficult to find proof that an authoritarian regime can lead to sustainable growth. Hence, democracy is a factor in economic growth with development - a long term, sustainable economic growth.

Where?

So, there is something about democracy in context of economic growth worth discussing more profoundly, preferably through not only purely quantitative lens, but also through a more complex qualitative toolbox than assesses social consequences of non-democratic choices. This social aspect of economic growth is important because it is decisive for, among many, such crucial factors as elimination of corruption or equal access to welfare. It, in it's turn, affects whether people - crucial intangible resource of any economy - would in fact stay and develop this economy, or go abroad to escape black holes such as corruption and social disorder, as it happens in Moldova. This is as to where the link between democracy and economic growth should be drawn - 
democracy makes people accountable for their economic choices as well as political. Democracy, through elections, also allows to influence various decisions, be it on taxes, salaries, social benefits, etc. Therefore, on the level of society, democracy is a crucial long-term keeper of economic growth supported by social development.

How?

Obviously, the change should start from democratization of the governing apparatus and through sociopolitical establishments and practices, such as elections, to start with. In conditions of the transition economy, democratisation must take place somewhere between the top-down and bottom-up forms of governance. For instance, besides elections and social education through media channels, democratic civil society must be supported by adequately paid work that would override corruption. Economic well-being that is supported by the people, or from within, will be sustainable in the long-run.

Finally, closeness to the EU plays a crucial role. The EU has its own normative role in pressuring Moldova towards democratisation, to stop power violation and social crackdown as well as to put special emphasis on the violations of human rights. This makes cooperation more attractive and likely, and for Moldova's citizens this could serve as more or less an incentive to achieve more economic freedoms without having to abandon their households.

Thus, national economy and democracy are two systems with a positive feedback: an effective competitive economy can only be sustained in a democratic civil society. The state should participate in economic activity both indirectly and directly, implementing social and structural transformations facilitating economic growth with development.

\section{Conclusion}

No matter how we treat democracy as a political system in various social contexts, democracy, unlike any other political system, has one ultimate privilege - it does not impede growth, even if it may not always support in depending on the social context. Democracy, in its essence, means freedom, independence and choice. This is why economics and democracy will always follow a circular pattern: Democracy entails prosperity, just as prosperity entails democracy. To grow we need social and economic freedom that we must respect. The richer we get, the more free we want to be in our choices and expressions. This brief account was intended to ignite further interest to investigate transition countries like Moldova on the way towards their economic growth and social development. The link between economics and democracy is in people, and in the extent that they are happy to support that economy, given it offers them basic democratic freedoms. Finally, democracy can aid curbing such challenges as corruption and unequal access to welfare.

\section{References}

- Dixit, A. K. 2004. Economics of Lawlessness. Alternative Modes of Governance. Princeton University Press.

- Persson, T. and Tabellini, G. 2008. "The growth effect of democracy: Is it heterogeneous and how can it be estimated?", in: Helpman, E. (ed.), Institutions and Economic Performance, Harvard, Harvard University Press.

- Pîschina, T. V. 2009. National Scientific Project: "Economic Growth and Structural Priorities - theoretical and practical aspects" under the State Program "Development of mechanisms and methods for stimulating economic growth, reducing poverty and improving the quality of life".

- CEPS 2009. "Moldova's 'wannabe democracy' is worth rescuing" by George Dura and Elena Gnedina for CEPS (Center for European Pilicy Studies). 


\title{
Geçiş Ekonomilerinde Dış Borçlulukta Değişmeler
}

\author{
Ahmet UZUN (Cumhuriyet University, Turkey) \\ Çağatay KARAKÖY (Cumhuriyet University, Turkey) \\ Selçuk EMSEN (Atatürk University, Turkey)
}

\section{The Changes in Foreign Debt for the Transition Economies}

\begin{abstract}
1989 and the years following 1991 were the times in which many important economic and political turnovers had taken place in the world. That was the time when Berlin Wall fall down with scattering the Eastern block and many politically and economically independent states came into being, at the same time, ongoing about 70 years socialist system also started to spin into liberal system. The constituted 27 states in 1991 were tended to liberal economic system instead of socialist economy, and these stated were called as transition economies. With the transition period, there has have been significant decreases in the level of affluence, hyperinflation and some common properties seen at the beginning. It became inevitable to get foreign debt for reorganization and configuration of these economies. Nevertheless these foreign debts caused many serious problems in some of these economies. In the present work we tried to understand the economic structure and external loans of the transition economies, which are different with respect to their natural resources and are similar to each other in term of social, political and cultural aspects. It was under debated to investigate the relationship between indicated foreign debts and indicated domestic income and external trade so foreign trade financing problematic which thought to be the source of going into debt and economical development relations are searched.
\end{abstract}

JEL Codes: F21, F34, H63

\section{Giriş}

Gelişmekte olan ülkelerde karşılaşılan temel sorunlardan birisi tasarruf açığıdır. Bilindiği gibi gelirin tüketimden arta kalan kısmı tasarruf olarak adlandırılmakta ve bunlar da yatırımlara kanalize edilmektedir. Böylece yatırımlar ekonomide daha yüksek gelir ve istihdam olgusunu yaratmaktadır. Diğer taraftan ülkelerin iç kaynakları, yani tasarruf düzeyleri de düşük gelir ve düşük tasarruf eğilimleri nedeniyle ekonomik kalkınmanın finansmanında yetersiz kalmaktadır. Dolayısıyla gelişmekte olan ülkelerde ekonomik büyümenin hızlandırılması için gerekli yatırımların yurtiçi kaynaklardan karşılanamaması, dış borçlara olan ihtiyacı giderek artırmaktadır (Bilginoğlu ve Aysu, 2008: 2). Ayrıca yurtiçi tasarruf düzeyi yeterli derecede yüksek olsa bile, özellikle bir kısım yatırım mallarının ithal edilmesi gereği de ithalatı ve dolayısıyla döviz gereksinimini kaçınılmaz kılmaktadır. Bu çerçevede yurtiçi tasarruf yetersizliğini kapama ve döviz açı̆̆ konusu olmaktadır ki, bu da dış borçlanmayı kaçınılmaz hale getirmektedir.

Ayrıca dış borçlanmaya gidilirken, temelde borçlanma ile elde edilecek yarar ilişkisi araştırılır. Özellikle sermayenin kıt kaynak olmasına paralel olarak sermayenin marjinal verimliliğinin göreceli olarak yüksek olduğu ülkelerde dış borçlanmanın yararlarına vurgu yapılır. Ancak, burada dış borcun ülkenin kendi potansiyellerini kullanmasına yardımcı olduğu ve buna karşılık onu artırmadığı da ileri sürülmektedir (Ogunmuyiwa, 2011: 29). Dış borç maliyetinin yararını aşması ve dış borcun ödeme gücünü zorlaması söz konusu olduğunda, bu durum ülkelerin dış borçlanma üzerine sınırlama getirmelerini gerekli hale getirebilmektedir. Kalkınmanın finansmanı için alınan dıs borçların ekonomiye yük olușturmadan sürdürülebilirliğinin sağlanmasında ekonominin massetme kapasitesi (kullanma gücü), ödemeler bilançosu dengesi, dış borcun vadesi ve dış borç oranları gibi borçlanmanın sınırını belirleyen ölçütler dikkate alınır. Bu noktada massetme kapasitesi ölçütüne göre, dış borçlanmaya reel üretimi arttırdığı ölçüde gidilmelidir (Kozalı, 2007: 62).

Dış borçlanmada sınırın aşılmasıyla literatürdeki tanımlamaya göre yüksek borçlu fakir ülkeler (HIPC; Heavily Indebted Poor Countries) kategorisine girilmesi söz konusu olabilir. Böyle bir durum ise genel tanımlanmayla üç tür sorunun varlığını gündeme taşır (Presbitero, 2005: 6-8):

i. Borç fazlası-tehdidi (debt overhang). Krugman (1988) ile Sachs (1989)'ın belirttiği şekliyle yüksek borcun ekonomik performansı bozması borç tehdidi olarak tanımlanır. Zira yüksek borç yükü, getirilerin yabancılar tarafından bir tür vergilendirilmesi anlamına gelerek yatırımları sıkıştırma etkisi yaratır.

ii. Dişlama etkisi (crowding out effect): Borç akımları ekonomik performansı etkilemektedir. Chowdhury (2004), Clements ve diğ. (2003) ile Elbadawi ve diğ. (1997)'in çalışmalarında HIPC konumundaki ülkelerin net pozitif kaynak transferlerine maruz kalmaları nedeniyle, büyük borç yükünün caydırıcı etkisinin ortaya çıkabileceği ve borç servisi ekonomik büyümede kritik bir kısıtlayıcı olabileceği ifade edilmiştir.

iii. Belirsizlik (uncertainty): Borç ödeyemezlik riski borç yükünün büyüklüğüne borç servisi yeteneğinin azalmasına bağlı olarak gerek yerli, gerekse yabancı yatırımcılar açısından olumsuz koşulların varlığına 
sinyal teşkil eder. Özellikle borcun boyutuna bağlı olarak ortaya çıkacak yüksek ve istikrarsız enflasyon süreçleri ve paralelinde faiz oranları makroekonomik yapıda bozucular anlamına gelecektir.

Diğer taraftan çalışmada inceleme konusu yapılan geçiş ekonomilerinin de sosyalist planlamacılık gereği her şeyin devlete ait olduğu bir yapıdan piyasa ekonomisine geçişte kurumsal yapıları inşa edebilmek amacıyla dış kaynak teminine gitmeleri zorunluluk arz etmiştir. Özellikle özelleştirme uygulamalarının paralelinde kamu kaynaklarının kısıtlanmasına karşılık yeniden yapılanmayı sağlama ve dışa açılmayla birlikte tüketim kalıplarının kırılmasının yarattığı ithalat patlamaları döviz açığı sorununu gündeme taşımıştır. Dolayısıyla geçiş ekonomilerinden bağımsızlığını 1991 yılında elde eden eski Sovyetler bünyesindeki ekonomilerde başlangıçta sıfır olan borç yükünün zamana bağlı olarak oluşmaya ve artmaya başladığı gözlenmektedir. Başta eski Sovyet ülkeleri olmak üzere Doğu Bloğunu oluşturan ülkelerde borç yükünün giderek artış göstermesinde, genel literatürdeki bakış açısına paralel olarak, daha çok büyümeyi artırma ve fakirliği azaltma eğilimlerini amaçlayan yapısal reformların etkinliği belirleyici unsur olmuştur (Presbitero, 2005: 5).

Ayrıca girdi-üretim-pazar ağının kopması sonucu geçiş ekonomilerinde üretim yetersizlikleri kendini gösterirken; düşük üretim ve düşük ihracat sarmalına karşılık ithalatta patlamalar da ortaya çıkmıştır. Bu durumun yansımaları ise cari işlemler bilançosunda giderek derinleşen açıklar olmuştur. Cari açıkların yıldan yıla artış göstermesi de gereksinim duyulan sermaye girişlerinin sürdürülebilirliğini ve piyasa ekonomisinde geçiş için istikrar programlarının uygulanabilirliğini sorgulatır nitelik taşımıştır (Wachtel, 1998: 2-3).

$\mathrm{Bu}$ çalışma dış borçlanma ile ekonomik büyüme ilişkilerinin araştırmasını geçiş ekonomileri özelinde yapmayı amaçlamaktadır. Bu doğrultuda geçiş ekonomilerinde dış borçlanmanın ekonomik büyüme üzerine etkileri araştırılırken; aynı zamanda geçiş öncesinde önemli ölçüde dışa kapalı olan bu ekonomilerin dışa açıklığının da ekonomik büyüme ve borçlanma etkileri inceleme konusu yapılmıştır.

\section{Literatür Araștırması}

Literatür araştırmasında 152 gelişmekte olan ülke üzerine 1977-2002 dönemini kapsayan araştırmada kişi başına gelir artış hızı ile dış borç arasındaki ilişkilerin araştırıldığı çalışmada ilaveten gecikmeli gelir ile makroekonomik, kurumsal ve sosyal değişkenler kullanılmıştır. Araştırmadan elde edilen bulgularda, borçluluk ile ekonomik büyüme arasında ters yönlü ilişkinin olduğunu; borç servisinin de dışlama etkileri yaratarak büyümeyi sekteye uğrattığını ortaya koymuştur. Özellikle borç nispetindeki \%10’luk bir artışın büyümeyi \%0.12 azalttığı ve bu durumun HIPC konumunda ise borç servisinde \%1'lik azalışın büyümeyi \%0.1 arttırdığ tespit edilmiştir (Presbitero, 2005: 9-23).

Türkiye üzerine yapılan çalışmada dış borçların ekonomik büyüme üzerindeki etkisi 1965-2007 dönemi için zaman serisi analizleriyle inceleme konusu yapılmıştır. Bu çalışmada dış borçlar ile ekonomik büyüme analize tabi tutulurken, elde edilen bulgularda kısa ve uzun dönemde dış borçların ulusal çıktı düzeyini olumsuz yönde etkilediği tespit edilmiştir. Dolayısıyla dışarıdan transfer edilen kaynakların bütünüyle üretken yatırımlar için kullanılmadığı; yani borçların verimsiz alanlarda yapılan harcamaları karşılamak üzere de kullanıldığı ifade edilmiştir (Uysal ve diğ., 2009: 166-176).

1970-2007 arası dönem için Nijerya üzerine yapılan araştırmada zaman serisi analizlerine gidilmiştir. Dış borçlanmanın büyümeyi teşvik ettiğine dair hipotezin sınandığı çalışmada, dış borçların büyümeyi teşvik etmediği; aksine hafif de olsa düşürücü etkilerinin olduğu tespit edilmiştir. Bu durum Nijerya'da savurganlığın ve mali disiplinsizliğin yansıması olarak kendini gösteren büyümede durağanlık sonucu anlamına gelmektedir. Büyüme reçetesi olarak borcu azaltıcı bir mali disiplin uygulaması ve kamu fonlarının verimli alanlarda kullanılmasını gerekli kılmaktadır (Ogunmuyiwa, 2011: 31-33).

Dış borçların GSYİH'ya ve ihracata oranı ile kişi başına gelir reel ekonomik büyümesi ilişkilerinin araştırıldı ğı çalışma 1980-2004 dönemini ve 114 ülkeyi kapsamaktadır. Dış borç ve büyüme verilerinin yanı sıra yatırımlar, nüfus artışı, ilköğretime kayıt oranı, ekonominin dışa açıklığı, enflasyon oranı ile dış ticaret hadleri de kullanılmıştır. Düşük büyüme oranı ile borcun GSYİH'ya oranının yüksekliği arasında ters yönlü korelasyonun varlığı tespit edilirken; borç yönetimini disipline edici politikalar uygulayan HIPC grubunun güven aşılayarak daha fazla kaynak girişi ve yabancı yatırım çekebildikleri tespit edilmiştir (Presbitero, 2008: 5-20).

1976-2003 arası dönem için 24 gelişmekte olan ülke üzerine yapılan çalışmada kişi başına gelir ile borç yükünün GSYİH'ya oranı arasındaki ilişkiler araştırılırken; aynı zamanda borç servisinin ihracata oranı, dışa açıklık ve yurtiçi yatırımlar gibi değişkenler de kullanılmıştır. Elde edilen bulgularda gelir ile borç yükü arasında negatif yönlü ilişkiler bulunurken; bunun dış borcun sürdürülemez noktada olması halinde daha derinden ortaya çıktığ1 tespit edilmiştir. Diğer taraftan borç yükünün yurtiçi yatırımlar üzerinde sıkıştırma etkileri yarattığı ve dışa açıklığın da yatırım iklimini pozitif etkileyerek büyümeye dolaylı yansımalarının olduğu belirtilmiştir (Safia, 2008: 10-16).

Türkiye üzerine 1970-2005 yıllarını kapsayan çalışmada reel değerlerle GSMH, dış borç stoku, dış borç servisi, kamu ve özel sektör yatırımları değişkenleri kullanılmıştır. Yapısal kırılmanın dikkate alındığı eşbütünleşme testleri sonucunda hem dış borç stokunun hem dış borç servisinin büyümeyi olumsuz etkilediği 
belirlenmiştir. Türkiye'de dış borçların verimli kullanılmadığı ve büyümeyi olumsuz etkilediği belirlenirken; aynı zamanda Türkiye'nin borç fazlası sorunu ile karşı karşıya olduğu ifade edilmişstir. Türkiye'nin dış borç sorununun temelinde yurtiçi tasarrufların yetersizliği yatarken, dış borç gereksiniminin azaltılması için yurtiçi tasarrufları arttırıcı yönde politikaların ve kamu kesimi tasarruf açığını kapatabilmesi için de etkin bir vergi sisteminin uygulamaya geçirilmesi gerekliliğine vurgu yapılmıştır (Kozalı, 2007: 92-116).

93 gelişmekte olan ülke üzerine 1969-1998 arası dönemi kapsayan çalışmada büyüme üzerine dış borcun (doğrusal olmayan) etkilerini araştırmıştır. Elde edilen bulgularda borçluluk oranının iki katına çıktığı ülkelerde kişi başına gelir büyüme oranlarında $\% 0.5-\% 1$ arasında azalışların olduğu ortaya konulmuştur. Diğer taraftan ihracatının \%100’ünün altında ve \%300’ün üzerindeki dış borçlu ülkeler arasındaki kişi başına gelir farklılığı, yıllık \%2'yi aştığı tespit edilmiştir. HIPC başlangıcı konumundakiler için de borç düzeyindeki azalışlar, kişi başına gelir artışını \%1 artırıcı etkisi olduğu gözlenmiştir (Partillo ve diğ., 2002: 7-20).

\section{Dış Borç ve Büyüme İlişskileri Üzerine Analizler}

Dış borç ve ekonomik büyüme ilişkilerini ele alan literatür dikkate alındığında, dış borçlanmanın belirli bir düzeye kadar büyümeyi olumlu yönde etkilediği; bu düzeyin aşılması halinde aşırı borçluluk olgusunun ortaya çıkmasına paralel olarak büyüme üzerine yansımalarının negatif yönde olacağı kabulü vardır. Bu durumun aynı zamanda dışlama etkileri yaratarak, hem özel sektörün yatırıma kanalize edeceği kaynakların kısılması hem de yurtdışına net kaynak transferinin gerçekleşeceği söylenebilir. Dış borçların optimizasyonu sorunu olarak nitelendirilecek noktanın ilerisinde borçluluğun ortaya çıkması literatürde "Borç Laffer Eğrisi" olarak da tanımlanır (Presbitero, 2008: 3). Diğer taraftan borçlanmanın getirisi olarak doğrudan yatırım olgusu ile izah edilemeyen; daha doğrusu dolaylı etkilerle, özellikle kurumsal yapılar inşa ederek, pozitif dışsallıklar yapmak amacıyla kullanımı daha çok geçiş ekonomilerine özgüdür. Geçiş ekonomilerinde yurtiçi tasarruf yetersizliği ya da döviz açığı sorununa bağlı kalınmaksızın, piyasa ekonomisi kurumlarının ithali için dış kaynak gereksinimi söz konusu olmuştur. Bu noktada ikiz açık olgusunun yanında kurumsallaşma adına dış borçlanma gereksiniminin geçişin karakteristiği olduğu söylenebilir. Çalışmada borçlanma ve büyüme ilişkilerinin eşik değer boyutu ya da Borç Laffer Eğrisi yapısı dikkate alınmaksızın cari ilişkinin aşağıdaki şekilde forma dönüştürülmesi mümkündür:

$$
\mathrm{g}=\mathrm{F}(\mathrm{DEBT})+\varepsilon_{\mathrm{i}}
$$

(1) nolu modelde büyüme-borç ilişkileri araştırılırken, dolar bazında GSYİH büyüme rakamları (g) ile borcun GSMH'ya oranı (DEBT) değerleri alınmıştır. Çoğu ülkenin 1991'de bağımsızlığı kazanması nedeniyle geçiş ekonomilerinin büyümesinde olumlu etkilerinin ortaya çıkması beklenen borçlanma olgusunu aynı zamanda dışa açıklığın da hem borçlanma gereksinimi düşürmesi hem de ülkenin dinamizme ulaşarak büyümesini tetiklemesi açısından olumlu yönde etkilediğine dair görüşler söz konusudur. Özellikle Neo-klasik iktisat ekolünde CobbDouglas üretim fonksiyonuna ihracat değişkeninin eklenmesi, üretimi etkileyen üçüncü bir girdi gibi toplam faktör verimliliğindeki artışlara sebebiyet vereceği kabul edilir (Medına-Smith, 2001: 1). Büyümede ihracat boyutunun yanı sıra ithalatın da girdi temini kolaylığı sağlaması ve pazara girişin getirdiği olumlu yansımalar büyüme dinamikleri arasında kabul edilir (Safia, 2008: 15-16). Bu açıdan dişa açıklık boyutu (1) nolu modele aşağıdaki şekilde eklenebilir:

$$
\mathrm{g}_{\mathrm{ti}}=\mathrm{F}\left(\mathrm{DEBT}_{\mathrm{ti}} ; \mathrm{OPEN}_{\mathrm{ti}}\right)+\mathrm{v}_{\mathrm{i}}
$$

(2) nolu model (1) nolu modele OPEN değişkenini eklenmiş halidir. OPEN değişkeni de ekonominin dişa açıklığını temsil eder ve bu da ihracat ile ithalat toplamının GSYİH'ya oranlanması ile elde edilir. (1) ve (2) nolu modellerde $\varepsilon$ ve $u$ ise hata terimlerini ifade eder. Çalışma geçiş ekonomierinden verisine sağlıklı bir şekilde ulaşılabilen ülkeler grubunu kapsadığından, burada t, zaman dilimini ve i de ülkeleri temsil eder.

\begin{tabular}{|c|c|c|c|c|c|c|}
\hline \multirow{2}{*}{} & \multicolumn{2}{|c|}{$\mathrm{g}$} & \multicolumn{2}{c|}{ debt } & \multicolumn{2}{c|}{ open } \\
\cline { 2 - 7 } & \multicolumn{2}{|c|}{ Seviye } & \multicolumn{2}{c|}{ Seviye } & \multicolumn{2}{c|}{ Seviye } \\
\cline { 2 - 7 } & İstatistik & Olas1l1k & İstatistik & Olas1l1k & İstatistik & Olas1lik \\
\hline Levin, Lin \& Chu t* & -4.63273 & 0.0000 & -4.79882 & 0.0000 & -5.01533 & 0.0000 \\
\hline Breitung t-stat & 1.96322 & 0.9752 & -0.02887 & 0.4885 & -1.02002 & 0.1539 \\
\hline $\begin{array}{c}\text { Im, Pesaran and Shin } \\
\text { W-stat }\end{array}$ & -2.39923 & 0.0082 & -1.57957 & 0.0571 & -3.32853 & 0.0004 \\
\hline $\begin{array}{c}\text { ADF - Fisher Chi- } \\
\text { square }\end{array}$ & 74.8803 & 0.0007 & 64.1478 & 0.0090 & 82.2873 & 0.0001 \\
\hline $\begin{array}{c}\text { PP - Fisher Chi- } \\
\text { square }\end{array}$ & 71.6955 & 0.0015 & 76.4122 & 0.0005 & 96.4773 & 0.0000 \\
\hline Hadri Z-stat & 8.32532 & 0.0000 & 9.45833 & 0.0000 & 8.63945 & 0.0000 \\
\hline
\end{tabular}

Tablo 1. Birim Kök Sınama Sonuçları 
(2) nolu model çerçevesinde dış borç ile ekonomik büyüme ilişkilerinin araştırması 1993-2008 yılları arası dönemi kapsamaktadır. Analize konu olan ülkeler de Arnavutluk, Azerbaycan, Beyaz Rusya, Bulgaristan, Ermenistan, Gürcistan, Kazakistan, Kırgızistan, Letonya, Litvanya, Makedonya, Moldova, Moğolistan, Özbekistan, Polonya, Romanya, Rusya Federasyonu, Tacikistan, Türkmenistan ve Ukrayna olmak üzere 20 ülkeden oluşmaktadır. Veri seti Dünya Bankası CD rom'dan derlenmiştir. Serilerin durağan olup olmadığında dair araştırma sonuçları Tablo 1'de verilmiştir. Birim kök sınama sonuçlarına göre kullanılan üç değişkenin de seviye değerleri cinsinden durağan olduğu görülmektedir.

Bu değişkenlere ilişkin tanımlayıcı istatistikler de Tablo 2'de verilmiştir.

\begin{tabular}{|l|l|l|l|}
\hline & $\mathrm{g}$ & DEBT & OPEN \\
\hline Ortalama & 3.753750 & 46.54406 & 94.55562 \\
\hline Medyan & 5.250000 & 41.35000 & 91.45000 \\
\hline Maksimum & 34.50000 & 147.7000 & 199.7000 \\
\hline Minimum & -30.90000 & 0.900000 & 36.50000 \\
\hline Std. Sapma. & 8.093121 & 30.04363 & 31.44153 \\
\hline Gözlem Sayıs1 & 320 & 320 & 320 \\
\hline
\end{tabular}

Tablo 2. Tanımlayıcı İstatistikler

Tanımlayıcı istatistiklere göre bu 20 geçiş ekonomisinde ele alınan dönemde ortalama büyümenin $\% 3.75$ düzeyinde gerçekleştiği ve en yüksek büyüme \%34.5 ile 2006 yılında Azerbaycan'da ve en yüksek küçülme de \%30.9 ile 1994'de Moldova'da ortaya çıkmıştır. Büyüme rakamlarının ortalama değerinin oldukça üzerinde standart sapma değerlerinin varlığı gözlenirken; bu ekonomilerde büyümede önemli boyutta istikrarsızlığın olduğu söylenebilir. Borç stokunun milli gelire oranı değerleri açısından ortalama \%46.54'lük bir borçluluk nispeti vardır. Ekonominin dışa açıklığı açısından da ortalamanın \%94.56 olduğu gözlenmektedir.

Ekonomik büyüme ile diş borçluluk ve dışa açıklık arasındaki ilişkilerin kaba bir boyutu korelasyon katsayılarından görülebilir.

\begin{tabular}{|c|c|c|c|}
\hline & $\mathrm{G}$ & DEBT & OPEN \\
\hline $\mathrm{G}$ & 1.0000 & & \\
\hline DEBT & 0.1653 & 1.0000 & \\
\hline OPEN & 0.0084 & 0.3083 & 1.0000 \\
\hline
\end{tabular}

Tablo 3. Değişkenlere İlişkin Korelasyon Katsayıları

Korelasyon katsayıları açısından değerlendirildiğinde, büyümenin borç yükünden pozitif yönde etkilendiği, ancak ilişkinin boyutunun zayıf olduğu dikkati çekmektedir. Aşağıdaki şekilde de birikimli GSYİH değerleri ile kümülatif dış borç rakamları arasındaki ilişkiler resmedilmiştir.

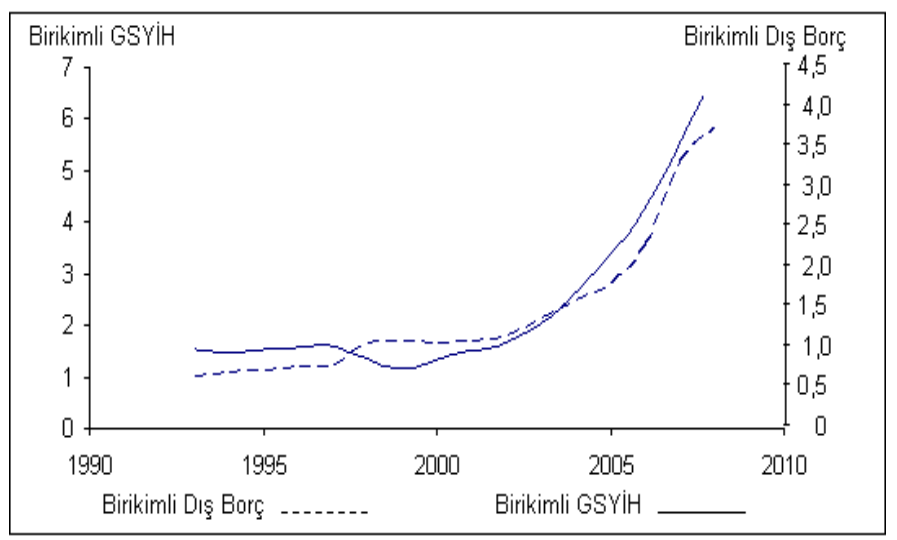

Şekil 1. Birikimli GSYİH ve Dış Borç İlişkileri

Geçiş ekonomilerinde resesyonist sürecin tamamlanmasıyla birlikte, alınan dış borç ile büyüme arasında bir bağ oluşmuşken; bunun Borcun Laffer Eğrisi olarak tanımlanan boyutunun sol kısmında olduğu (Borç Laffer Eğrisi ile ilişkin şekli boyut için bkz. Ek 1), yani ekonomilerin genel olarak borç sarmalı içerisine düşmedikleri ileri sürülebilir. Dış borç ile ekonomik büyüme ilişkilerinin yönünü veren nedensellik test sonuçları da aşağıdaki tabloda gösterilmiştir. 


\begin{tabular}{|c|c|c|c|}
\hline \multirow[b]{2}{*}{$\mathrm{H}_{0}$ Hipotezi } & \multicolumn{3}{|c|}{ Gecikme Uzunluğu: 2} \\
\hline & Gözlem & F-İstatistiği & Olasılik \\
\hline DEBT, g'nin nedeni değildir. & \multirow[b]{2}{*}{280} & 0.2916 & 0.7472 \\
\hline g, DEBT'in nedeni değildir. & & 5.2455 & 0.0058 \\
\hline OPEN, g’nin nedeni değildir. & \multirow[b]{2}{*}{280} & 0.7480 & 0.4742 \\
\hline g, OPEN'ın nedeni değildir. & & 1.9590 & 0.1429 \\
\hline OPEN, DEBT'in nedeni değildir. & \multirow[b]{2}{*}{280} & 0.8898 & 0.4119 \\
\hline DEBT, OPEN'ın nedeni değildir. & & 1.2634 & 0.2843 \\
\hline
\end{tabular}

Tablo 4. Granger Nedensellik Testi

Nedensellik sınamalarında büyüme-borç-dışa açıklık ilişkileri araştırılmıştır. Nedensellik test sonuçlarına göre büyüme ve borç arasında tek yönlü nedensel ilişki saptanmışken; borç-büyüme arasında ilişki yakalanamadığı gibi, büyüme ile açıklık ve borç ile açıklık arasında da nedensellik ilişkileri tespit edilememiştir. Benzeri olgu büyümenin belirleyicileri olarak borç ve açıklık değişkenlerinin regresyon analizine koşturulduğu (bkz. Ek 2) durumla da paralellik arz etmektedir.

\begin{tabular}{|c|c|c|c|c|c|c|c|}
\hline & $\begin{array}{c}\text { Panel } \\
\text { v-İst. }\end{array}$ & $\begin{array}{c}\text { Panel } \\
\text { rho-İst }\end{array}$ & $\begin{array}{c}\text { Panel } \\
\text { PP-İst }\end{array}$ & $\begin{array}{c}\text { Panel } \\
\text { ADF-İst }\end{array}$ & $\begin{array}{c}\text { Grup } \\
\text { rho-İst. }\end{array}$ & $\begin{array}{c}\text { Grup } \\
\text { PP-İst. }\end{array}$ & $\begin{array}{c}\text { Grup } \\
\text { ADF-İst. }\end{array}$ \\
\hline g DEBT & 0.556 & $-2.217^{(\mathrm{a})}$ & $-4.809^{(\mathrm{a})}$ & $-6.829^{(\mathrm{a})}$ & -0.622 & $-5.848^{(\mathrm{a})}$ & $-6.892^{(\mathrm{a})}$ \\
\hline DEBT g & 0.593 & -0.598 & $-2.144^{(\mathrm{b})}$ & $-1.379^{(\mathrm{c})}$ & 0.783 & $-1.890^{(\mathrm{b})}$ & $-2.731^{(\mathrm{a})}$ \\
\hline g OPEN & 0.228 & $-2.537^{(\mathrm{a})}$ & $-6.699^{(\mathrm{a})}$ & $-4.779^{(\mathrm{a})}$ & -0.661 & $-6.799^{(\mathrm{a})}$ & $-4.915^{(\mathrm{a})}$ \\
\hline OPEN g & 0.933 & $-3.481^{(\mathrm{c})}$ & $-5.231^{(\mathrm{a})}$ & $-2.332^{(\mathrm{b})}$ & -0.154 & $-3.272^{(\mathrm{a})}$ & -0.153 \\
\hline DEBT OPEN & -0.409 & 0.449 & -0.686 & -1.014 & 1.586 & -0.857 & -1.258 \\
\hline OPEN DEBT & 1.369 & -1.643 & $-2.873^{(\mathrm{c})}$ & $-4.594^{(\mathrm{b})}$ & 0.801 & -0.707 & $-1.975^{(\mathrm{b})}$ \\
\hline
\end{tabular}

Tablo 5. Pedroni Eş-bütünleşme Test Sonuçları. Not: Parantez içerisindeki değerler test istatistiğine ilişkin olasılık değerlerini vermektedir. (a) \%1, (b) \%5 ve (c) \%10 önem düzeyinde anlamlılı̆̆ yansıtır.

Söz konusu ilişkilerin uzun dönemli boyutunun araştırıldığı Pedroni eş-bütünleşme test sonuçları da büyümeborç ilişkilerinin uzun vadede de devam edeceği ve buna ilaveten ekonomik büyümenin dişa açıklığ1 besleyeceği; dışa açıklığın da borçluluğun sürdürülmesi anlamına geleceğine dair bulgulara rastlanmıştır.

\section{Değerlendirme ve Sonuç}

1993-2008 arası dönem için geçiş ekonomilerinde büyüme ve dış borç ilişkilerinin araştırıldığı çalışmada, dışa açıklık ve borçlanma olgularını 1993'den itibaren tecrübe etmeye başlayan bu ülkelerin genel olarak yeniden yapılanmanın finansmanı başta olmak üzere üretim-pazar ve gelir-tasarruf bağlarının kopmasının bir yansıması olarak dış borçlanmaya yöneldikleri gözlenmektedir. Ancak, dışarıdan alınan borcun ekonomik büyüme üzerine henüz olumsuz yansımalarının olmadığı tespit edilmiştir. Özellikle borçluluk sürecine giren ülkelerin borçlanmada fayda-maliyet analizi olarak ifade edilen borcun getirisi ile anapara ve faiz ödemelerinden oluşan götürülerinin getiri boyutu açısından yüksek olduğu izlenimi söz konusudur. Literatürde Borç Laffer Eğrisi ile tanımlanan getiri-götürü ilişkilerinde geçiş ekonomilerinin eğrinin olumlu boyutunda yer aldığı gözlenmektedir. Dolayısıyla büyümeyi pozitif etkileyen borçlanma sürecinin dengeli bir şekilde sürdürülebilirliğine dikkat edildikçe, geçiş ekonomilerinin borç sarmalına düşmeksizin büyümelerini devam ettirmeleri mümkündür.

Burada borçlanmanın maliyetlerini dikkate alan politikalar olarak uzun dönemde dişa açıklığın borçlanmayı etkilediğine dair sonuçlar, özellikle geçiş ekonomilerinin dışa açık, fakat dış ödemeler dengesini gözeten politikalar uygulaması gerektiği söylenebilir. Aksi takdirde, ithalata dayalı bir büyüme olgusunun borçlanma ile finansmanı söz konusu olacaktır ki, uzun vadede bunun sürdürülebilir bir büyüme modeli olmadığg HIPC deneyiminden açıktır. Yüksek borçluluğun kaynakların etkinsizliğini beslediği bir yapının ortaya çıkmaması adına, parasal ve mali disiplin uygulamaları ile birlikte dış dengeyi gözetici politika uygulamalarının geçiş ekonomilerinde büyümenin sürdürülebilirliğine katkıda bulunacağ ileri sürülebilir.

\section{Kaynakça}

- Bilginoğlu, M. Ali ve Ahmet Aysu (2008), "Dış Borçların Ekonomik Büyüme Üzerindeki Etkisi: Türkiye Örneği”, Erciyes Üniversitesi İktisadi ve İdari Bilimler Fakültesi Dergisi, 31: 1-23.

- Kozalı, Jale, Dış Borç Sorunu ve Dış Borçların Ekonomik Büyüme Üzerine Etkisi: Türkiye Örneği, (Yayınlanmamış Yüksek Lisans Tezi), Dokuz Eylül Üniversitesi Sosyal Bilimler Enstitüsü, İzmir, 2007.

- Medina-Smith, Emilio J. (2001), "Is the Export-Led Growth Hypothesis Valid for Developing Countries? A Case Study of Costa Rica”, United Nations Conference on Trade and Development, Policy Issues in International Trade and Commodities Study Series No. 7. 
- Ogunmuyiwa, M. S. (2011), “Does External Debt Promote Economic Growth in Nigeria?”, Current Research Journal of Economic Theory, 3(1): 29-35.

- Partillo, Catherine, Hélène Poirson and Luca Ricci, External Debt and Growth, IMF Working Paper, $\mathrm{WP} / 02 / 69,2002$.

- Presbitero, Andrea F. (2005), “The Debt-Growth Nexus: a Dynamic Panel Data Estimation”, Economic Policy and Open Economy Macro, Quaderno Di Ricerca, n. 243, Milan, May 21st-22nd.

- Presbitero, Andrea F. (2008), “The Debt-Growth Nexus in Poor Countries: A Reassessment", Economics: The Open-Access, Open-Assessment E-Journal, 2: 1-28.

- Safia, Shabbir (2008), Does External Debt Affect Economic Growth: Evidence from Developing Countries. International Research Journal of Finance and Economics, pp. 1450-2887. (http://aysps.gsu.edu/ECON_MA_ShabbirS.pdf) (Haziran 2011).

- Uysal, Doğan, Hüseyin Özer ve Mehmet Mucuk (2009), “Dış Borçlanma ve Ekonomik Büyüme İlişkisi: Türkiye Örneği (1965-2007)”, Atatürk Üniversitesi İktisadi ve İdari Bilimler Dergisi, 23(4): 161-178.

- Wachtel, Paul (1998), "Current Account Balances and External Debt in Transition Economies: Lessons for Central Asia", Challenges to Economies in Transition: Stabilization, Growth and Governance, Bishkek, Kyrgyz Republic, May 27-28.

\section{EKLER}

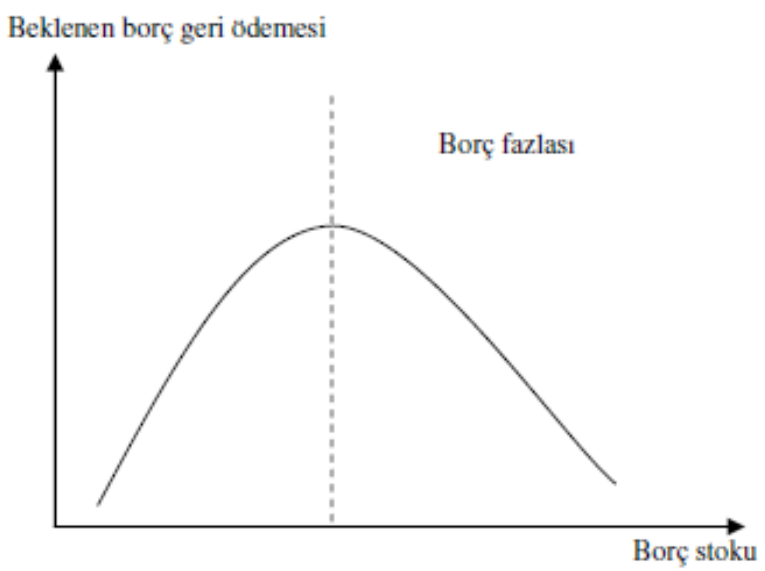

Ek 1. Borç Laffer Ĕgrisi Kaynak: Bilginoğlu ve Aysu, 2008: 9.

\begin{tabular}{|c|c|c|c|c|c|c|}
\hline & \multicolumn{2}{|c|}{ Ortak Sabitli } & \multicolumn{2}{|c|}{ Sabit Etkili } & \multicolumn{2}{|c|}{ Tesadüfi Etkili } \\
\hline & Parametre & Olasılık & Parametre & Olasılık & Parametre & Olasılık \\
\hline $\mathrm{C}$ & 2.642830 & 0.0691 & $\begin{array}{c}- \\
1.431520\end{array}$ & 0.4962 & 2.183070 & 0.1402 \\
\hline DEBT & 0.048434 & 0.0022 & 0.120978 & 0.0000 & 0.058693 & 0.0002 \\
\hline OPEN & $\begin{array}{c}- \\
0.012092\end{array}$ & 0.4199 & $\begin{array}{c}- \\
0.004712\end{array}$ & 0.8312 & $\begin{array}{c}- \\
0.012280\end{array}$ & 0.4181 \\
\hline $\mathrm{R}^{2}$ & \multicolumn{2}{|c|}{0.029} & \multicolumn{2}{|c|}{0.187} & \multicolumn{2}{|c|}{0.039} \\
\hline $\mathrm{F}$ istatistiği & 4.788 & 0.008 & 3.268 & 0.000 & 6.599 & 0.001 \\
\hline D.W. istatistiği & \multicolumn{2}{|c|}{0.519} & \multicolumn{2}{|c|}{0.632} & \multicolumn{2}{|c|}{0.534} \\
\hline F testi & & & 3.046 & 0.000 & & \\
\hline Hausman testi & & & & & 31.080 & 0.000 \\
\hline
\end{tabular}

Ek 2. Panel Regresyon Analiz Sonuçlarl.

Not: Ortak, sabit ve tesadüfi etkili modeller çerçevesinde yapılan F ve Hausman testleri sabit etkili modeli işaret etmiştir ve dolayısıyla sabit etkili modelle parametreler yorumlamaya esas alınmıştır. 


\title{
Likidite Azlığı Priminin Menkul Kıymet Getirileri Üzerinde Etkileri ve Avrasya İçin Önemi
}

\author{
Serdar Kuzu (Istanbul University, Turkey)
}

\section{The Effects of the Illiquidity Premium on Security Returns and its Importantance for Eurasia}

\begin{abstract}
This study investigates the illiquidity premium, which has major impact on Eurasian economies, and its term structure. For this aim, Germany which is very important for Europa and Asia countries is investigated. In this study, the effects of the term structure of the illiquidity premium on government and corporate bonds and "the return of securities - illiquidity premium - expectation theory relationship" are investigated through various parameters and formulations. Consequently, the study is used to Kempf, Korn and Uhrig-Homburg' study, which aims to investigate relations between German public sector's bonds and private sector's bonds and it was realized 2009. It is found that illiquidity premium varies in short, medium and long terms depending upon different factors and the curve that connects illiquidity premiums with different terms is a $U$ shaped curve.

Studies that use traditional methods in asset pricing evaluate the illiquidity premium as a systematic risk criteria. But, illiquidity is a risk factor that should be investigated alone instead of be investigated with all of the risk factors.

Financial market makers aim to make arrangements that remove the problems arising from the level of liquidity, in other words increase the level of liquidity, and contribute to the formation of efficient price.Further studies in this field will be very important in the development process of corporate bonds market with the decrease of interest rates in international markets and the issue of new corporate bonds in developing countries recently.
\end{abstract}

JEL Codes: E43, G12, G10

\section{Literatürel Analiz}

Son yıllarda Çin, Türkiye ve Türki Cumhuriyetlerin ekonomik alanda gösterdikleri büyük atılım, söz konusu ülkelerdeki işletmelerin likidite konusunda daha detaylı düşünmelerini gerekli kılmaktadır. Likidite, varlıkların istenildiği zaman kolaylıkla ve en az maliyetle nakde dönüştürülmesini ifade etmektedir. Bu bakımdan likidite tasarruflarını çeşitli yatırım araçlarında değerlendirmek isteyen tüm yatırımcılarda olduğu gibi özellikle de Avrasya ülkelerindeki yatırımcılar açısından da oldukça önemli bir kavramdır. Likidite kavramı ülke ekonomileri yönüyle önemli olmakla birlikte, çoğu zaman likidite ve likidite primi kavramları bir biri yerine kullanılmakta likidite azlığı primi ise literatürde pek yer bulmamaktadır. Bununla birlikte bu çalışma Avrasya ülkeleri çerçevesinde likidite azlığı kavramını dikkate alan ve bunun için bilimsel bir tartışmayı bünyesinde barındıran öncü çalışmalardan birisi olması nedeniyle büyük öneme haizdir.

Amihud (2000)'de likidite azlığı priminin hisse senedi getirilerini olumlu yönde etkilediği, Dimkon ve Hanke (2004)'te ise, likidite azlığının varlık fiyatlarını etkilediği ve beklenen getiriyi arttırarak ülke ekonomilerini etkilediği sonucuna ulaşılmıştır, Amihud ve Mendelson (2006)'da gerçekleştirilen çalışmada likiditenin stok getirilerini açıklamaya yardımcı olduğu, likidite azlığının hisse senedi fiyatlarını düşürdüğü ve beklenen getiride artışa yol açtı̆̆ı ve varlık fiyatlarını açıklamada önemli olduğu bununda ülke ekonomilerinin özellikle de gelişmekte olan ülke ekonomilerinin (Kırgızistan, Azerbaycan, Türkmenistan...) gelişmesine direkt etkisi olacağ1 sonucu elde edilmiştir. Buna benzer bir sonuç Khandani ve Lo (2009)'da, Likidite azlığı ve varlık getirileri arasında pozitif bir korelasyon olduğu sonucuyla görülmektedir; Jong ve Driessen tarafından 2005 yılında yapılan Liquidity Risk Premia In Corporate Bond Markets adlı çalışmada likidite riskinin varlık fiyatlarını ve getirilerini açıklama gücü olduğunu tespit etmişlerdir.

Literatür taramasını takip eden kısımda, finansal varlıkların fiyatlarını ve getirilerini etkileyen faktörlerden, üçüncü bölümde, likidite, likidite primi, likidite azlığ 1 ve likidite azlığ primi kavramlarından bahsedilmiş, dördüncü bölümde menkul kıymet getirileri ve likidite azlığı primi arasındaki ilişki üzerinde durulmuş, beşinci bölümde beklentiler teorisi, getiri eğrileri ve likidite azlığı primi arasındaki ilişki açıklanmış, son bölümde ise likidite azlığı priminin ölçülmesinde kullanılan yöntemlerden bahsedilerek, Alexander Kempf, Olaf Korn, Marliese Uhrig-Homburg tarafından yapılan çalışma referans alınarak likidite azlığı priminin vade yapısı açıklanmaya çalışılmıştır. 


\section{Kavramsal Çerçeve ve Araştırma Değişkenleri}

\subsection{Likidite Riski}

Likidite oldukça karmaşık bir konseptir. Basitçe likidite bir menkul kıymetin kolayca alınıp satılabilmesidir (Amihud vd,2005). Likit bir varlık istenildiğinde, piyasanın çalışma saatlerinde satıcının satmak istediği fiyattaki minimum kayıpla hızlı bir şekilde nakde dönüştürülebilir. Likit piyasaların en önemli özelliği her zaman satıcı ve alıcıların piyasada hazır bulunmasıdır (Xavier ve Timmermans, 2009). Likidite riski, menkul kıymetin gerçek fiyatının üzerinde veya gerçek fiyatına yakın bir değerde kolayca satılmasını gerektirir. Almış olduğu tahvili vade sonuna kadar elinde tutmayı düşünen bir yatırımcı için likidite riski daha az önemli iken, vade sonunu beklemeden tahvili elinden çıkarmak isteyen biri için likidite önem arz etmekte yani likidite riski önem kazanmaktadır. Likidite, finansal piyasalarda oldukça önemli etkiye sahiptir

\subsection{Likidite Azlığı Kavramı}

Likidite azlığı likiditenin zıddıdır, normal şartlarda likit olan bir piyasadaki alıcı ve satıcıların aniden piyasadan çekilmesi ya da herhangi bir menkul kıymete yapılan yatırımda menkul kıymete ait ikincil piyasanın olmaması durumunda bu yatırımdan vade sonuna kadar çıkılamaması gibi sebeplerle likidite azlığı ortaya çıkabilir (Timmermans ve Xavier, 2009).

Likiditenin azalmasına yol açan başlıca faktörler ise broker ücretleri, alım-satım emirlerine ilişkin işlem maliyetleri, işlem vergileri, talep yetersizliği, yatırım riski, özel bilgi şeklindedir (Amihud vd., 2005). Sayılan nedenlere bağlı olarak bazı menkul kıymetlere yatırım yapan yatırımcılar likiditeden kaynaklanan faktörlere katlanmanın karşıllı̆ı olarak bu riski telafi etmek isteyeceklerdir. Bunun için de bu tarz riskleri taşımayan menkul kıymetlerden farklı olarak ilave bir getiri arzulayacaklardır. Bu sebeple likidite azlığından kaynaklanan riski yatırımcılar varlık değerlemesinde iskonto faktörü olarak dikkate alacaklardır.

\subsection{Likidite Riski-Likidite Primi-Likidite Azlığı Primi İlişkisi}

Likidite riski, yatırımcılara göre piyasa ile ilgili geniş çaplı makroekonomik değişkenleri içeren sistematik bileşenler bütünüdür. Risk göreceli bir kavramdır dolayısıyla farklı faktörlere göre riskin derecesi değişebilir, likiditeden kaynaklanan riskin ölçüsü likidite azlığı primi ile ifade edilebilir (Emektar ve,Morris ,2010). Likidite primi likidite dışında diğer koşullar bakımından bir birine benzeyen likit ve likit olmayan varlıklar arasındaki fiyat farklılığının bir ölçütüdür. Başka bir ifadeyle bir varlık ya da varlık grubunu satmak için bir takım maliyetlere katlanmak gerekirken diğer bir varlık alım-satım maliyetine katlanmadan ya da önemsiz denilebilecek bir düzeydeki maliyetle nakde dönüştürülebilir (Hibber, 2010).

Likiditesi az olan varlıklara yatırım yapanlar bu varlıkları ellerinde tutmak için daha yüksek bir getiriye ihtiyaç duymaktadırlar. Genel olarak finansal piyasalarda likidite yatırımcılar tarafından sevilen bir özellik olduğu için yatırımcı ikinci el piyasası derin olmayan tahvillerden daha fazla getiri ister (Emektar veMorris, 2010). Bu fazla getiri isteği de likidite azlı̆̆ primi ile açıklanır.

Likidite primi zamana ve varlık türlerine göre farklılaşmaktadır. Çünkü farklı varlıklar farklı likidite düzeylerine sahiptir (Hibber, 2010). Zamanla piyasalardaki likidite sorunu varlıkların getirilerini olumlu yönde etkilemektedir. Yatıım enstrümanlarının likit olup olmaması getirilerini etkilemektedir (Duarte ve Young, 2007).

Yatırım araçlarında risksiz faiz oranını aşan getiri bu varlıklara ilave bir risk getirmektedir. Fazla getiriyi temsil eden bu risk primi yani likidite azlığı primi olarak adlandırılmaktadır. (Amihud vd, 2005)

Likidite azlığı pirimi, Likidite dışında bütün özellikleri benzer olan iki varlığın getirileri arasındaki farktır (Xavier ve Timmermans, 2009). Amihud'a göre hisse senetleri riskli yatırım araçları olmasının yanında kısa vadeli hazine menkul kıymetlerine nazaran daha az likittirler. Hisse senetleri taşı1ıkları yüksek riske karşılık hazine menkul kıymetlerinin getirisini aşan kısmı likidite azlığı getirisinin de dahil olduğu risk bileşenlerini içermektedir

Brennan ve Subrahmanyam'a göre, likit olmama ve getiri arasında pozitif bir ilişki bulunmaktadırlar. Likit olmama ölçüsünü, kalıcı ve geçici bileşenlerine ayırarak, her iki bileşenin de finansal varlıklardan beklenen getiriyi artırdığını göstermişlerdir. (Kayalı ve Ünal,2010) 


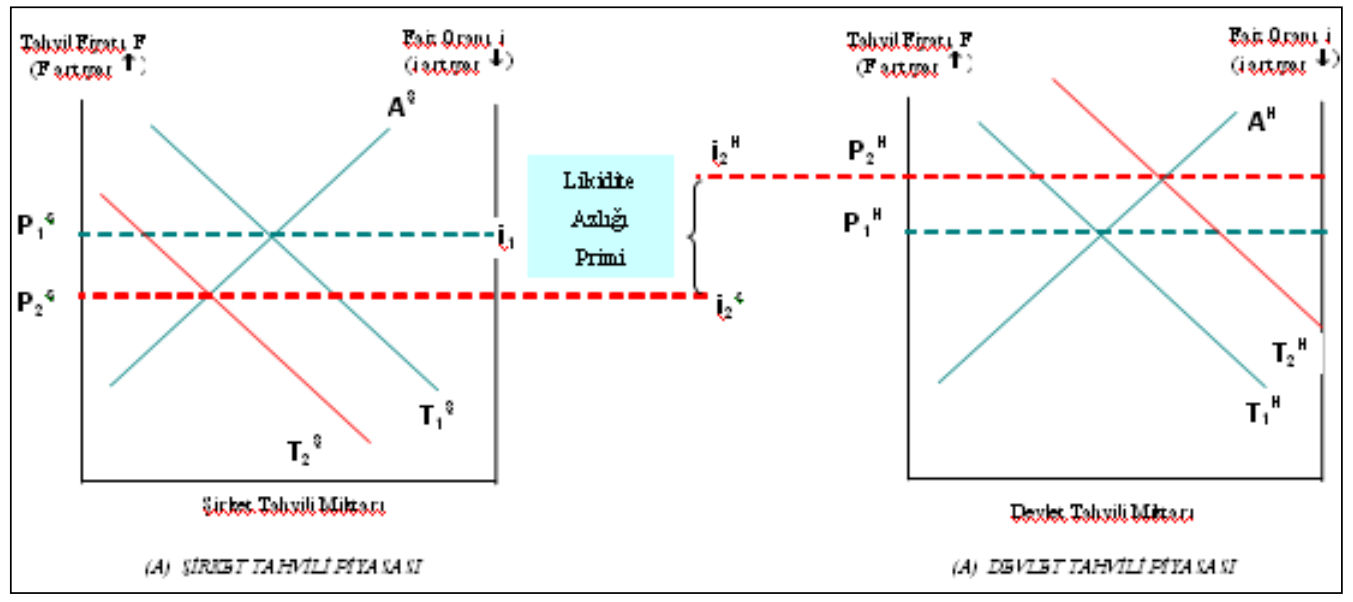

Şekil 1: Likidite Azlı̆̆ Primi. Kaynak: http://www3.dogus.edu.tr/amuslumov, (05.03.2010).

Şekil 1'de İki piyasalı bir ekonomi gösterilmektedir. Birinci piyasa şirket tahvili piyasası, ikinci piyasa ise devlet tahvili piyasasıdır.

- Devlet tahvili piyasası geniş ve derin olduğu için alıcı ve satıcı sayısı daha fazladır ve bu da devlet tahvili piyasasının daha likit olmasına yol açmaktadır.

- Bu durumda, aynı denge faiz oranı söz konusu ise (diğer koşulların aynı olması koşuluyla) tahvil talep edenler devlet tahvili piyasasına daha fazla talep gösterecek, sonuçta tahvil talep eğrisi $\mathrm{T}_{1}{ }^{\mathrm{H}}$ sağa kayacak, devlet tahvilinin fiyatı yükselecek, getirisi (faiz oranı) ise azalacaktır.

- Benzer olarak, likiditesi göreceli olarak düşük olan şirket tahviline talep azalacak ve talep eğrisi $T_{1}{ }^{S}$ sola kayacak, şirket tahvilinin fiyatı düşecek, getirisi (faiz oranı) ise yükselecektir.

- Talep eğrilerinin kayması ile ortaya çıkan getiri farkı ise likidite azlığı primi olarak adlandırılmaktadır.

Likidite primi ile likidite azlığı primi sıklıkla bir biri yerine kullanılmaktadır fakat, bu kavramlar yakın ilişkide olmasına rağmen farklı anlamları ifade etmektedir. Likidite primi, varlıkların likit olması durumunda varlık fiyatlarını etkileyen bir unsur olmakta iken, likidite azlığı primi; likit olmayan varlıkların likit varlıklarla kıyaslandığında daha yüksek getiri sağlamaları halindeki getiri farkını ifade etmektedir (Novy-Marx, 2006). Yani likidite primi düzeyi farklı olan varlık fiyatlarını ifade etmekte iken, varlıklar arasındaki getiri farkını likidite azlığı primi ile açıklanmaktadır.

Avrasya ekonomileri açısından incelendiğinde ise özellikle temel ekonomik geliri petrol ve petrol türevleri olan ülkelerin likidite azlığından ziyade likidite bolluğu içerisinde oldukları teorik olarak öngörülebilir. Ancak bu teorik yaklaşım çoğu zaman doğru değildir. Özellikle Orta Asyalı devletlerde, petrol ve petrol türevlerinden elde edilen gelirlerin büyük bölümünün devlet teşebbüsleriyle veya büyük ailelerin ortaklığında faaliyet gösteren çok uluslu şirketlerle paylaşıldığı görülmektedir. Dolayısıyla Orta Asyalı şirketlerde likidite bolluğu yerine likidite azlığından bahsetmek daha doğru olacaktır. Bu durumda Asyalı şirketler için likidite azlığı priminin bir varlık unsuru olduğunu ifade etmek mümkün olacaktır.

\section{Avrasya Ekonomilerinde Menkul Kıymet Getirileri ve Likidite Azlı̆̆ı Primi İlişkisi}

Likidite azlığı primi yatııım yapılan varlıkların vadesinde önce elden çıkarılması halinde önem kazanmaktadır. Çünkü vade sonunun beklenmesi halinde yatırımcı elde edeceği getiriyi bilmektedir. Varlıkların vadesinde önce elden çıkarılmak istenmesi halinde varlığın satışında yatırımcı ikinci el piyasanın sı̆̆ olması ya da olmaması gibi sebeplerle, sahip olduğu varlığı beklediğinden daha düşük bir fiyata satmak zorunda kalacaktır. İkincil piyasaları yeterli gelişmişlik düzeyinde olmayan Asya ülkeleri için özellikle de Orta Asya ülkeleri için menkul kıymet getirileri ile likidite azlığı arasındaki ilişkiyi net olarak ortaya koymak mümkün olmamaktadır. Bununla birlikte petrolü ve petrol türevi ürünleri baz alan menkul kıymetlerin (devlet tahvilleri, bonolar...) ihracının, bir finansal yöntem olarak kabulü suretiyle Asya ekonomileri bağlamında, menkul kıymet getirileri ile likidite azlığ primi arası ilişkiyi tespit etmek kolaylaşacaktır. Türev ürünlerin yaygınlaşması da Orta Asya ekonomilerinde menkul kıymet getirileri ile likidite azlığı arasında var olduğu düşünülen ilişkinin daha somut bir düzlemde gerçekleşeceği düşüncesini güçlendirmektedir.

Satış fiyatı dışında varlığın satışına ilişkin ilave maliyetlerin de ortaya çıkma ihtimali yatırımcının elde edeceği nakit miktarını daha da azalmasına yol açabilir. Bu sebeple likidite azlığı varlık fiyatları üzerinde baskı oluşturmakta ve getiri beklentisini artırmaktadır. (Dimson ve Hanke,2004). Likiditesi düşük varlıklara yatırım yapan yatırımcılar, kabul ettikleri riske karşılık daha yüksek getiri elde etmek isteyeceklerdir. Bu sebeple bu varlıkların değerlenmesinde kullanacakları iskonto oranını belirlerken likiditesi düşük olan bu varlıkların değerlemesine likidite primini iskonto oranına ilave etmelidirler (Watsonwyatt, 2004). 


\subsection{Beklentiler Teorisi, Getiri Ĕgrileri ve Likidite Azlığı Primi}

Beklentiler teorisi faiz oranlarının vade yapısının açıklamayı amaçlamaktadır. Beklentiler teorisine göre çizilen getiri eğrisi ile gerçek getiri eğrisi arasındaki fark, likidite azlığı primi olarak ifade edilebilir. Likiditesi düşük olan varlıkların da yatırımcılar tarafından talep görmesi için, yatırımcıları uzun vadeli borç vermeye teşvik edecek bir likidite primi ödenmelidir. Likidite primi, aşağıdaki formülasyon ile gösterilebilir (Teker ve Gümüşsoy, 2006).

$$
0=\mathrm{L}_{1}<\mathrm{L}_{2}<\mathrm{L}_{3}<\ldots \mathrm{L}_{\mathrm{n}} \text { ve }\left(\mathrm{L}_{2}-\mathrm{L}_{1}\right)>\left(\mathrm{L}_{3}-\mathrm{L}_{2}\right)>\left(\mathrm{L}_{4}-\mathrm{L}_{3}\right) \ldots>\left(\mathrm{L}_{\mathrm{N}}-\mathrm{L}_{\mathrm{N}-1}\right)(2)
$$

$\mathrm{L}_{i}$, vadelere göre likidite primlerini ifade eder ve vadeler arttıkça likidite azlığı primi azalan bir oranda artar. Likidite primi dahil edilmiş Beklentiler Teorisi, şöylece ifade edilebilir (Teker ve Gümüşsoy, 2006),

$$
\left(\left(1+\mathrm{R}_{\mathrm{N}}\right)\right)^{\mathrm{N}}=\left(\left(1+\mathrm{R}_{1}\right)\left(1+\mathrm{t}_{\mathrm{t}+1} \mathrm{f}_{1}+\mathrm{L}_{2}\right) \ldots\left(1+{ }_{\mathrm{t}+\mathrm{N}-1} \mathrm{f}_{1}+\mathrm{L}_{\mathrm{N}}\right)\right)(3)
$$

Beklentiler teorisine göre, yatırımcılar vade tercihi olmayan varlıkları ellerinde bulundurdukları sürece kar maksimizasyonu hedefleyen kişilerdir. Belirli bir risk sınıfına ait, vadesi önemsiz tüm varlıklar birbirine tam ikame olarak kabul edilir. Yatırımcıların getiri oranı aynı olduğu sürece, 10 yıl vadeli bir varlık almaktansa, iki tane 5'er y1llk birbirini takip eden varlıklar almak veya periyodik olarak birbirini takip eden 1'er yıl vadeli varlıklar almak arasında bir fark yoktur. Beklentiler hipotezi, faiz oranlarının gelecekteki değerini, bono sahiplerinin beklentilerinin belirlediği varsayımına dayanır (Teker ve Gümüşsoy, 2006).

\section{Likidite Azlığı Priminin Ölçülmesi}

Likidite oldukça karmaşık bir kavramdır. Likidite düzeyinin belirlenmesi direkt olarak mümkün değildir. Bir varlığın likiditesinin direkt olarak tespit edilmesi tek bir faktöre bağlı olmadığından belirlenmesi oldukça karmaşıktır. Amihud tarafından geliştirilen ILLIQ yöntemine göre bir hisse senedinin likiditesi aşağıdaki formülle ölçülebilir (Jong ve Driessen ,2005).

$$
\text { ILLIQi, } t=\frac{1}{D t} \sum_{d=1}^{D t} \frac{\left|r_{i t}^{d}\right|}{V_{i t}^{d}}
$$

- ILLIQ i,t: $\mathrm{t}$ ayındaki i hisse senedi için likidite azlığı primi

- Dt bir ay içerisindeki işlem günü sayısı

- $\left|r_{i}^{d} t^{d}\right|$ t ayında d gününde i hisse senedi getirisi

- $\quad V_{i t}^{d}$ hisse senedinin piyasa değerinin yüzdesi olarak t ayındaki t günündeki i hisse senedinin işlem miktarını ifade etmektedir.

\section{Likidite Azlı̆̆ı Priminin Vade Yapısı}

Likidite azlığı primi likidite dışında benzer özelliklere sahip olan varlıkların getirileri arasındaki getiri farkıdır. Avrasya ekonomileri, özellikle de gelişmekte olan Orta Asya ekonomilerinde artan öneme sahip şirketler için önem taşıyan likidite azlığı primi konusunda büyük önem taşıyan Kempf, Korn ve Uhrig-Homburg, tarafından yapılan çalışma da, Alman finans piyasasındaki özel sektör tahvilleri ile devlet tahvillerinin getirileri karşılaştırılmak suretiyle likidite azlığ $\breve{g}_{1}$ primi tespit edilmiş ve getiri farklılıklarına ilişkin likidite azlığ kullanılarak likidite azlığı priminin vade yapısı ortaya çıkarılmaya çalışılmıştır. Devlet tahvilleri (BUNDS) ve Pfandbriefe Alman tahvil piyasasının en önemli 2 enstrümanıdır. 2007 yılı verilerine göre devlet tahvilleri tahvil piyasasının \%33' ünü, Prandbirefe ise \% 25 ini oluşturmakta idi. Amerikan hazinesinin, Amerikan tahvil piyasasındaki rolüne benzer bir şekilde ikincil piyasadaki BUNDS olarak adlandırılan devlet tahvilleri yüksek likidite seviyesi ile Euro bazlı sabit getirili menkul kıymetler için karşılaştırma olanağı sağlamaktadır ( Kempf vd., 2009).

\subsection{Likidite Azlığı Priminin Vade Yapısını Biçimlendiren Kısa ve Uzun Dönem Faktörler}

Çalışmada söz konusu menkul kıymetlere ait likidite azlığı priminin dönem yapısını ortaya koymak amacıyla Nelson ve Siegel yaklaşımı kullanılmıştır. Yaklaşım 4 parametre ile $\left(\beta_{o t}, \beta_{1 t}, \beta_{2 t} \tau_{t}\right)$ zaman yapısının karakterini ortaya koymaya izin vermektedir. Nelson-Siegel yöntemi çerçevesinde t zamanındaki vadesi T'de dolacak olan sıfır kuponlu bir tahvil getirisi aşağıdaki gibidir.

$$
y(T)=\beta_{o t,}+\beta_{1 t,}\left[\frac{1-e^{-T / \tau_{t}}}{T / \tau_{t}}\right]+\beta_{2 t}\left[\frac{1-e^{-T / \tau_{t}}}{T / \tau_{t}}-e^{-T / \tau_{t}}\right]
$$


Devlet tahvili ve Pfandbrief piyasası parametrelerini tahmin etmek için vadesine 3 ay, 6 ay 1,2,3,4,5,6,7,8,9,10,11,12,13,14 ve 15 yıl kalanların ay sonu getirileri, Bundesbank verilerinden seçilmiştir.

Faktörler dönem yapısının farklı segmentleri ile yakın ilişkilidir.

- $\quad \beta_{o t}$, Uzun vade dönem yapısının düzeyini belirlemektedir. Bu sebeple $\beta_{o t}$, uzun dönemli faktör olarak tanımlanmaktadır.

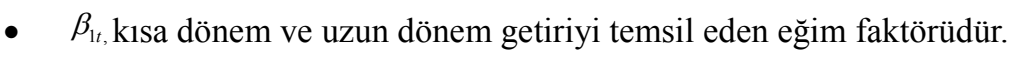

- $\quad \beta_{o t+} \beta_{1 t}$ kisa vadenin dönem yapısını ifade etmektedir. Bu sebeple $\beta_{o t+} \beta_{1 t}$ kısa dönem faktör olarak adlandirılmaktadır.

- $\quad \beta_{2 t}$ orta vadeli getiriyi yönlendiren biçimlendirme faktörüdür.

\subsection{Vade Yapısının Biçimi}

Verilen parametreler iki piyasa segmentini tahmin etmektedir. Parametreler $\beta_{o t}^{S P} \equiv \beta_{o t}^{P F}-\beta_{o t}^{B U}, \beta_{o t}^{S P}+\beta_{1 t}^{S P} \equiv \beta_{o t}^{P F}-\beta_{o t}^{B U}+\beta_{1 t}^{B U} \beta_{o t}^{S P}$, ve $\beta_{o t}^{S P} \equiv \beta_{o t}^{S P}-\beta_{o t}^{S P}$ uzun dönem faktör, kısa dönem faktör ve likidite azlığının zaman yapısının şekillendirme faktörleridir. Uzun dönem faktör dönem yapısının uzun dönemde likidite azlığı primini ölçmekte ve şekil faktörü orta dönemde likidite azlığ̣ primini baskın bir şekilde etkilemektedir. Likidite azlığı priminin vade yapısının biçiminde ilk izlenimi edinmek için veri periyodunda bütün ayların ortalamasını hesaplanmıştır. Ortalama dönem yapısı sonucu grafik 1'de gösterilmektedir.

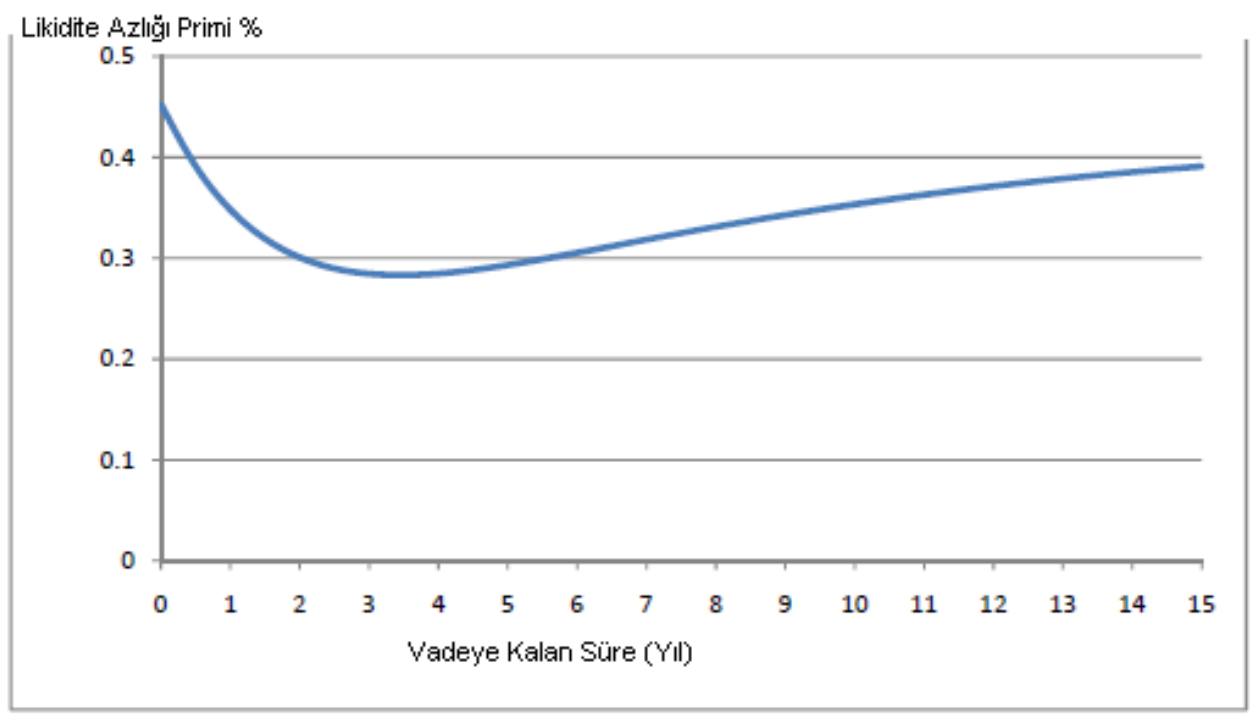

Grafik 1 : Likidite Azlı̆̆ Priminin Ortalama Vade Yapısı. Veri Aralığı Ocak 2000-Ağustos 2008

Grafik 1 bütün vadeler için ortalama pozitif likidite azlığı olduğunu göstermektedir. Bununla birlikte farklı vadeler için prim farklılaşmaktadır. Likidite azlığı priminin dönem yapısı ortalamada açıkça U şeklini almaktadır. Prim kısa ve uzun vadede oldukça yüksektir, fakat orta vadeli tahvillerde daha düşüktür. Likidite fiyatı kısa ve uzun vadeli tahviller için orta vadelilerle kıyaslandığında daha yüksektir.

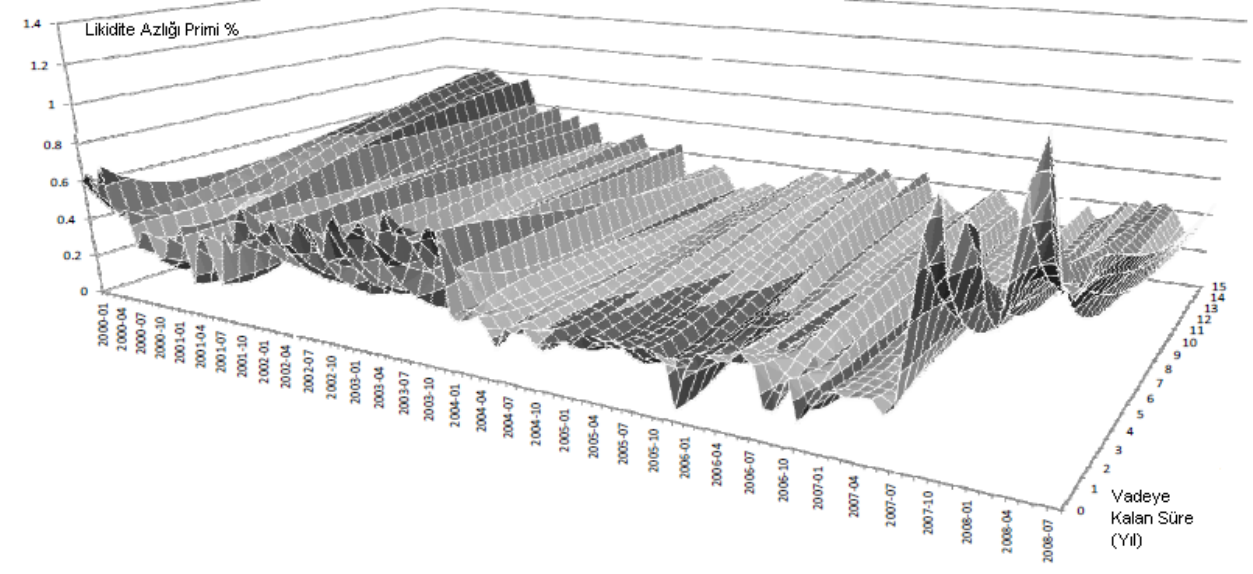

Grafik 2: Likidite Azlı̆̆ı Priminin Vade Yapısı 
Grafik 2 zamana göre likidite azlığı priminin dönem yapısının gelişimini göstermektedir. Grafik her ay için dönem yapılarını göstermektedir. Grafiğe göre zaman yapısının biçiminde değişimler olduğunu görülmektedir. Grafikte, genellikle likidite azlığının priminin U biçimindeki eğrileri, aynı zamanda artan vade yapıları, eğrilerdeki bazen sert düşüşler ve çıkışlardan bazen kambur şekilli eğrileri görülmektedir. Likidite azlığı pirimi bütün vadelerde daima pozitiftir fakat, düzeyi değişmektedir. Örneğin 2004 başlarında kısa dönem için likidite fiyatı oldukça düşüktür, fakat 2007'nin ortasında ve daha sonra oldukça yüksektir. Bu durum finansal kriz döneminde likiditeyi arttırıcı bir olgudur. Kriz döneminde yatırımcılar yüksek likiditeyi tercih ederek, devlet tahvillerinde likidite için daha yüksek fiyat ödemeye razı olmuşlardır. Sonuç, özellikle piyasa ağırlığının kesin olmadığ ekonomik krizin likidite fiyatındaki etkileri kısa vadeli tahvillerde uzun vadelilere göre daha çok telaffuz edilmiştir. Böylelikle likidite azlığı pirimi farklı yollarla zamanla farklılaştığı görülmektedir. Bu durum grafik 3 te görülmektedir.

A: Kısa Ve Uzun Dönem Faktörler

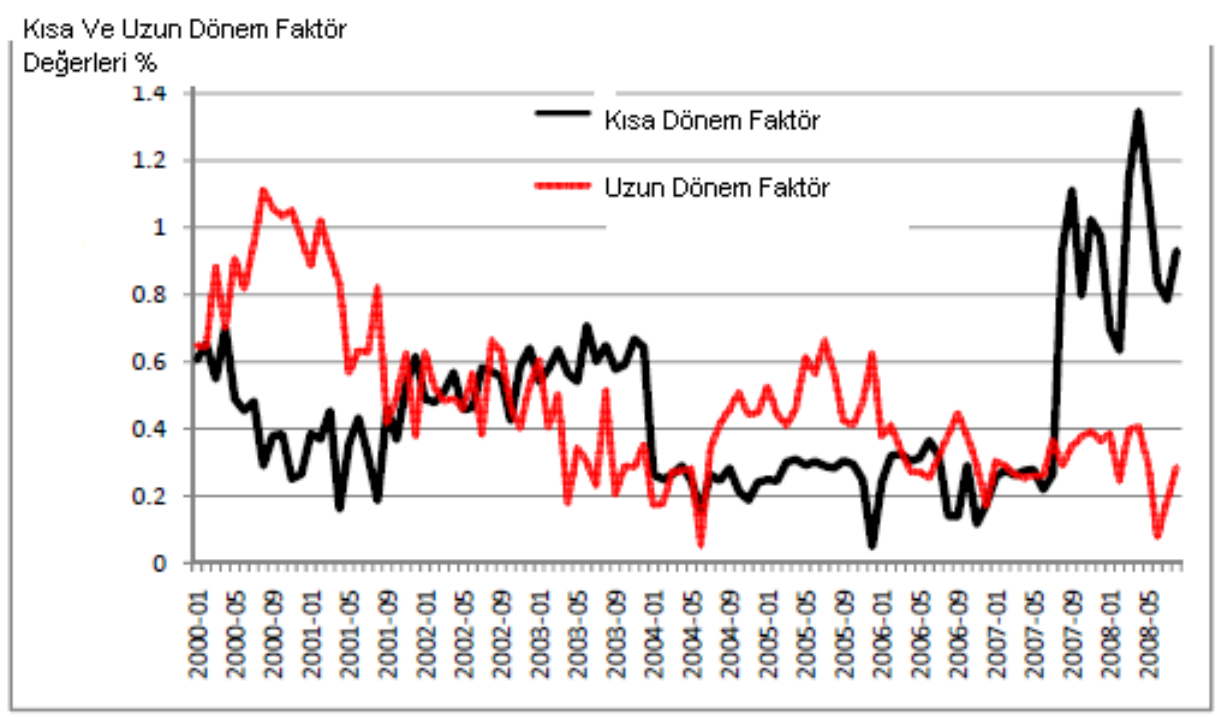

Grafik 3: Likidite Azlı̆̆l Primi Vade Yapısı Faktörlerinin Zamana Bă̆lı Değişsimi

Grafik 3 te uzun dönemli likidite azlığı priminin kısa dönemli likidite azlığı priminin üzerinde olduğu dönemler mevcuttur, örneğin, Ağustos 2004'ten Şubat 2006'ya kadar olduğu gibi likidite uzun vadede daha fazla fiyatlanmıştır. Aksine Ağustos 2007 den Ağustos 2008 e kadar yatırımcılar kısa vadede yüksek likidite arzulamışlardır. Kısa dönem ve uzun dönem arasındaki likidite azlığı primi korelasyonu negatiftir ve anlamlı bir şekilde sıfırdan farklıdır. Bu bulgular farklı ekonomik etkilerin uzun ve kısa vade dönem yapısında etkili olabileceğini ortaya koymaktadır.

\subsection{3. Vade Yapısını Yönlendiren Ekonomik Faktörler}

Çalışmada, likidite azlığı primi farklı vadelerdeki likidite fiyatını ölçme imkanı vermektedir. Bu fiyat 2 ekonomik faktörü yansıtmaktadır.

i) Kurumsal düzenlemeler ve piyasa karakterinden kaynaklanan 2 piyasa arasındaki likidite farklılığı,

ii) Yatırımcının likidite beklentisi.

$\mathrm{Bu}$ sebeplerle likidite fiyatı yatırımcının gelecekteki sahip olduğu menkul kıymetleri alım satım konusundaki zorunluluklarına dayanmaktadır. Likidite fiyatını etkileyen ekonomik faktörler farklı değişkenler kullanılarak elde edilmiştir. Yatırım kararları uzun dönemli risklerden etkilenmektedir. Finansal piyasalardaki uzun dönemli görünüm ve ekonomi pozitif görünüme sahipse gelecek yatırımcılar için daha az risk taşımakta ve yatırımcılar sahip oldukları menkul kıymetlere ait yatırımları daha uzun süre ellerinde tutabilmektedirler. Çalışmada, ekonomik görünüm ve uzun vadeli gelecekteki alım satım kararları ile ilgili risk göstergesi olarak, IFO iş dünyası endeks'i Ifoinder kullanılmıştır. Ifoinder endeksi, Almanya'da iş dünyasının en önemli göstergesidir. Ifo endeksi, IFO Enstitüsü tarafından aylık bazda yayınlanan 7000 civarında firmaya yönelik araştırmalara dayanmaktadir.

Çalışmada çeşitli kontrol değişkenleri kullanılmıştır. Illk olarak Alman tahvil piyasasındaki yabancı yatırımcılar için net yatırım kontrolü yapılmıştır. Íkinci olarak, kredi riski kontrol edilmiştir. Devlet tahvilleri ve Pfandbrief tahvillerinde ödememe riski olmamasına rağmen Pfandbrief tahvillerinin kredi riski taşıdığına dair algılar olabilir. Kredi riskini temsil etmesi açısından Bloomberg Euro bölgesi Endüstriyel endeksi AA+\AA tahvil getirileri ve Bloomberg Euro bölgesi endüstriyel endeksi BBB tahvil getirileri kullanılmıştır. Ay sonu 
değerleri vadesine bir yıl kalan tahviller için kullanılmıştır. Son olarak modelde dinamik etkileşimleri ortaya koymak için kontrol değiş̧enleri olarak likidite azlı̆ğ faktörlerinin gecikmeli değiş̧enleri ayrılmıştır

Likidite azlığı priminin vade yapısına ilişkin her faktör için bir eşitlik tahmin edilmiştir.

$$
\begin{aligned}
& \text { Short }_{t}=\gamma_{0}^{8}+\gamma_{1}^{8} \text { Volume }_{t}^{8}+\gamma_{2}^{8} \text { Volatility }_{t}+\gamma_{3}^{8} \text { VDA } X_{t}+\gamma_{4}^{8} \text { Ifoinde }_{t}+\gamma_{5}^{8} \text { Foreign }_{t}+\gamma_{6}^{8} \text { Credit }_{t} \\
& +\sum_{i=1}^{2}\left(\alpha_{i, 8}^{8} \text { Short }_{t-i}+\alpha_{i, 8 h}^{8} \text { Shape }_{t-i}+\alpha_{i, l}^{8} \text { Long }_{t-i}\right)+\varepsilon_{t}^{8} \\
& \text { Shape }_{t}=\gamma_{0}^{8 h}+\gamma_{1}^{s h} \text { Volume }_{t}^{s h}+\gamma_{2}^{s h} \text { Volatility }_{t}+\gamma_{3}^{s h} V D A X_{t}+\gamma_{4}^{s h} \text { Ifoindex }_{t}+\gamma_{5}^{s h} \text { Foreign }_{t}+\gamma_{6}^{s h} \text { Credit }_{t} \\
& +\sum_{i=1}^{2}\left(\alpha_{i, 8}^{s h} \text { Short }_{t-i}+\alpha_{i, 8 s h}^{s h} \text { Shape }_{t-i}+\alpha_{i, l}^{s h} \text { Long }_{t-i}\right)+\varepsilon_{t}^{s h} \\
& \text { Long }_{t}=\gamma_{0}^{l}+\gamma_{1}^{l} \text { Volume }_{t}^{l}+\gamma_{2}^{l} \text { Volatility }_{t}+\gamma_{3}^{l} \text { VDAX } X_{t}+\gamma_{4}^{l} \text { Ifoindex }_{t}+\gamma_{5}^{l} \text { Foreign }_{t}+\gamma_{6}^{l} \text { Credit }_{t}
\end{aligned}
$$

t zaman endeksi Ağustos 2001'den Mayıs 2007 ye kadar olan zamanı ifade etmektedir.

Vade yapısını yönlendiren ekonomik faktörlere ilişkin analiz, açıklayıcı değişkenlerin kısa ve uzun vade yapısında likidite azlığı priminde önemli etkiye sahip olduğu fakat bu sonuçların vade yapısının şekli hakkında bilgi vermediğini, ikinci olarak, likidite azlığı pirimi yatıımcının karşılaşacağı belirsizlikler tarafından yönlendirilmekte olduğunu, en yüksek düzeydeki belirsizliğin en yüksek likidite azlığı primine işaret ettiğini ve yatırımcıların belirsizliğin yüksek olduğu zamanlarda likiditeye önem verdiğini göstermektedir.

Yukarıdaki bulgulara ilave olarak, kısa ve uzun vade likidite azlığını etkileyen farklı türde belirsizlikler mevcuttur. Buna göre;

Kısa vadeli likidite azlığı primi varlık piyasalarındaki kısa vadeli dalgalanmalardan etkilenmekteyken, uzun vadeli likidite azlığı pirimi IFO endeksi ile ölçülen ekonomik görünümdeki uzun vadeli belirsizlik tarafından şekillendirilmektedir. Bundan dolayı farklı değişkenler zaman yapısının farklı kısımlarını yönlendirmektedir.

Kısa vadeli pirim regresyon eşitliğinde, sermaye piyasası ve tahvil piyasasındaki dalgalanmalardan kaynaklanan önemli bir etki olduğu görülmüştür. Sermaye piyasası ve tahvil piyasasındaki eş hareketlilik tahvil ve sermaye piyasasındaki daha yüksek riski ifade etmekte bu da daha yüksek likidite azlığı primine yol açmaktadır. Tartı̧̧ma doğrultusunda daha yüksek düzeydeki bir dalgalanma, bir varlığın likiditesini daha değerli ve devlet tahvili piyasasını daha cazip hale getiren alım satım işlemlerinin daha fazla olması ihtimalini ortaya çıkarmaktadır. VDAX etkisi sadece kısa vadelidir ve hisse senedi piyasası yatıımcılarının da fiyatlardaki dalgalanma dönemlerinde devlet tahvilleri aracilığ ile tahvil piyasasına girdiklerine işaret etmektedir. Fiyatlarda dalgalanma etkisinin önemini açıklamak için hisse senedi ve tahvil piyasasında eş zamanlı pozitif bir standart sapma şoku dikkate alınmıştır. Sonuç olarak bu tarz bir şok durumunda likidite azlığı pirimi yaklaşık $6 \mathrm{bp}$ artmaktadır. Bu artış kısa vadeli marj eğrisinde ortalama marjın yaklaşık altıda biridir.

Likidite azlığı primi uzun vadede IFO endeksi tarafindan şekillendirilmektedir. Olumlu bir ekonomik ortamda daha yüksek bir endeks değeri daha düşük bir likidite azlığı primini ortaya çıkarmaktadır. Olumsuz bir durum ise bu durumun tersine likidite azlığı primini arttırmaktadır. IFO endeksinin bir standart sapma artı̧̧ı halinde uzun vade likidite azlığı pirimi 4 bp den daha fazla düşüş göstermektedir, bu da ortalama uzun vade pirimin \% $10^{\prime}$ u kadardır.

Sonuçlar, likidite azlığı priminin vade yapısının farklı eğiminin kısa ve uzun vade risklerin farklı rejimleri yansıttığını ortaya çıkarmaktadır. Çalışmadaki ilginç bir tespite son dönemlerde ihraç edilen tahvillerin işlem hacmi bu 3 faktör içinde önemsiz olmasıdır. Bu da piyasa katılımcılarının Prandbrief ve devlet tahvili piyasasındaki likidite farklılığının yatırım kararlarının yeniden değerlendirmemeleri ile açıklanabilir.

Kontrol değişkenlerine bakıldığında yabancı yatırımcıların net talebinin ve kredi değişkeninin önemli olmadığı görülmektedir. Bu sebeple Prandbrief ve devlet tahvilleri arasındaki marjın şekillendirilmesinde Prandbrief ve devlet tahvili piyasasının kredi riski ya da yabancı yatırımcıların sadece devlet tahvili piyasası hakkında bilgi sahibi olmalarından kaynaklandığına dair bir kanıt yoktur. Bir tahvilin kısa vade likidite azlığı pirimi için kısa dönemli dalgalanma daha önemli olmaktadır. Bununla birlikte daha uzun vadeyi kapsayan ekonomik görünüm daha uzun vadeli tahviller için önem kazanmaktadır.

\section{Sonuç ve Değerlendirme}

Kempf, Korn, Uhrig-Homburg tarafından yapılan çalışmada, likidite azlığı primi vade yapısına ait grafikteki vade yapısını temsil eden eğrinin düz olmadığı, U şeklinde biçimlendiği ve ekonomik çevredeki değişimlerin etkisini yansıtarak U şeklinde biçimlenen yapının da sürekli aynı seyretmediği tespit edilmiştir. Likidite azlı̆ğ 
primi vade yapısı incelendiğinde kısa ve uzun vade de birbirinden farklılaşmakta fakat genel anlamda yayılma etkisi göstermemektedir. Kısa vade de vade yapısı hisse senedi ve tahvil piyasasındaki dalgalanma tarafından şekillendirilmektedir. Uzun vadeli likidite azlığı pirimi uzun vadeli ekonomik görünüm tarafından şekillendirilmektedir. Bulgular likiditeye geçme konusunda artan bir riskle karşı karşıya kalan uzun vadeli yatırımcıların ekonominin gerilediği dönemlerde uzun vadeli tahviller için daha fazla fiyat ödemeye razı olduklarını göstermektedir. Orta vadeli tahviller için likidite azlığı pirimi kısa ve uzun vadeli risk faktörlerinden etkilenmektedir.

Yatırımcılar açısından likiditesi düşük olan bir varlığa yatırım yapılması karşılığında istenilen ek getirinin şüphesiz bu menkul kıymetleri ihraç edenlerin sermaye maliyetlerini etkileyecektir. Varlık fiyatlamasına yönelik geleneksel yöntemlerle yapılan çalışmalar likidite azlığı primini sistematik risk ölçütü olarak değerlendirmektedir. Oysa likidite azlığı, topyekun diğer risk unsurları içerisinde değerlendirilmek yerine, kendi başına incelenmesi gereken bir risk unsudur.

Finansal piyasa yönetimlerinin amacı, likiditeden kaynaklanan olumsuzlukları giderecek, yani likiditeyi yükseltecek ve fiyatların etkin oluşumuna katkıda bulunacak düzenlemeleri yapmaktır. Konu hakkında yapılacak çalışmalar finansal piyasa aktörlerine de bu bakımdan önemli kaynak teşkil edecektir. Ayrıca faiz oranlarının düşmesi ile birlikte yeni tahvil ihraçlarının başladığı şu günlerde ülkemizde olsun Avrasya ülkelerinde olsun özel sektör tahvil piyasasının gelişmesi açısından da bu alanda yapılacak çalışmalar, son derece önem arz etmektedir.

$\mathrm{Bu}$ açıdan, Avrasya ekonomileri açısından araştırmanın bulguları büyük önem taşımaktadır. Avrasya ekonomilerinin çoğunlukla gelişmekte olan ekonomiler olarak tanımlandığı kabul edilerek, aşağıdaki değerlendirmelerin ortaya konulması işletme finansı açısından da değer taşımaktadır.

Elde edilen bulgulara göre, menkul kıymet getirisi ile likidite azlığı arasında regresyonel ve korelatif pozitif bir ilişki mevcuttur. Bu bağlamda Avrasyalı şirketlerin bu ilişki çerçevesinde yatırım stratejisi seçmeleri rasyonel bir tutum olacaktır.

Likidite azlığı priminin, likidite riskinin bir dengeleyicisi ve öteleyicisi olduğu görülmektedir. Alman merkezli çalışmada da görüleceği üzere işletmeler, likidite azlığı primini bir risk yönetim mekanizması ve aracı olarak kullanabilirler. $\mathrm{Bu}$ mekanizmanın varlığı, Avrasyalı işletmelerin risk yönetimi konusundaki opsiyonlarını artırmaktadır.

Likidite azlığı primini, menkul kıymet piyasalarının gelişmişlik düzeyinden ve ikinci piyasaların varlığından bağımsız düşünmek mümkün değildir. Bu bağlamda gelişen Asya borsalarının performans durumu likidite azlığı primini gelecekte de gündemde tutacak ve yeni birçok çalışmanın yapılması için öncü rolü üstelenecektir.

\section{Kaynakça}

- Amihud, Mendelson, Pedersen ve Lass, 2005, Liquidity And Asset, Foundations and Trends in Finance.,2005. p.269-304

- Amihud, Y. 2000. "Illiquidity and Stock Returns: Cross-Section and Time-Series Effects”,Journal of Financial Markets 5, p.31-56.

- Dimson ve Hanke, 2004, “The Expected Illiquidity Premium: Evidence From Equity Index-Linked Bonds, Rewiev Of Finance, 8, p.19-47.

- Duarte ve Young, 2007, “Why is PIN Priced?”, Journal Of Financial Economics, 91(2), p.119-138.

- Emektar, 2010, “ Robert Morris ile Likidite Primi ve Likidite Azlığı Primi” konulu görüşme, 12.03.2010.

- $\quad$ http://www.wise.xmu.edu.cn/seta2006/download/ORAL\%20PRESENTATION/\%E5\%AD\%99\%E8\%B0\%A 6/IlliquidityandStockReturn7.pdf (01.07.2011) p 1-15,

- http://www3.dogus.edu.tr/amuslumov, (05.03.2010).

- Jong ve Driessen 2005, , "Liquidity Risk Premia In Corporate Bond Markets", Tilburg University, 2005,p.13. http://papers.ssrn.com/sol3/papers.cfm?abstract_id=686681, (20.03.2010).

- Hibber ve John,2010, "Liquidity Premium: Myth Or Reality?", http://www.barrhibb.com/documents/downloads/Liquidity_Premium_Literature_Review.PDF (10.03.2010).

- Kayalı ve Ünal. 2010. “Piyasa Mikro Yapısı, Finansal Varlıkların Likiditesi Ve Fiyatların Oluşumu”, Dumlupınar Üniversitesi Sosyal Bilimler Dergisi, 12,.p.8

- Kempf, Korn ve Homburg, 2009.“The Term Structure Of Illiquidity Premia”, Center For Financial Research,

- $\quad$ Novy-Marx, 2006, "Excess returns to illiquidity". Working Paper. University of Chicago, February 2006, s.1.Watsonwyatt 2010,Latest Thinking On Liquidity Premia, Watsonwyatt.com, (01.03.2010).

- $\quad$ Teker ve Gümüşsoy 2006, "Faiz Oranı Eğrisi Tahmini : TC. Hazine Bonosu Ve Eurobond Üzerine Bir Uygulama", 8. Finans Sempozyumu, İzmir, 1-4 Kasım 2006 p.4.

- Timmermans ve Xavier,2009 “Investing In Illiquidity Assets”, Risk And Rewards”. 53, p.12. 


\title{
Türkiye Sigorta Sektörü ve Analizi
}

\author{
Sinan Kuşçu (Prime Ministry Maritime Undersecretary, Turkey) \\ Galip Afşin Revanoğlu (Kyrgysztan-Turkey Manas University, Kyrgystan)
}

\section{An Analysis of Insurance Industry in Turkey}

\begin{abstract}
Today, insurance is related with every kind of trade, industry and an important part of the social structure. Insurance, in conjunction with securement qualifications, is also an element of trust. In addition, the creator of funds as of the part of economic activities, capital accumulation has become a yardstick to ensure and increase prosperity. Accumulated funds (especially in life insurance), banking and capital markets banker at a leading activities of insurance created. For this reason, insurance one of the most important activities that developed countries dealt with. In other words, there is a strong correlation between insurance activities and economic activities of developed countries with high social level.
\end{abstract}

JEL Codes: G22, E02, E44

\section{Giriş}

Sigortacılık, uzun vadeli fon oluşturması nedeni ile ekonomide sermaye birikimine ve kredi kapasitesinin genişlemesine katkıda bulunmaktadır. Ayrıca ekonomik faaliyette bulunan rol alan ajanlara (aktörlere) teminat vererek faaliyetlerin kesintisiz devam etmesini sağlamaktadır. Bu özellikleri nedeni ile sigortacılık, ülke kalkınmasına doğrudan destek sağlayan önemli bir finansal sektördür. Yine benzer bir şekilde, ticaret hacmindeki genişleme ve ekonomik büyüme de, teminat verilebilecek yeni alanlar ortaya çıkararak ve mevcut kapasitesini artırmak sureti ile sigortacılığın gelişmesine katkı sağlamaktadır. Bu sebeple, ekonomik gelişme ile sigorta sektörünün gelişmesi arasında doğrusal bir ilişki olduğu söylenebilir. (Kuşçu, 1996), çalışmasında, gerek fertlerin gelirlerindeki artışın, gerekse ülke milli gelirindeki artışın, sigorta talebini artırdığını ortaya koymuştu.

2008 yılında gelişmiş ülkelerde başlayan ve daha sonra tüm dünyayı etkisi altına alan ekonomik kriz, yukarıda açıklanan ilişki nedeni ile sigortacılık sektörünü de olumsuz yönde etkilemiştir. Bunun sonucu olarak dünyada sigorta prim üretimi 2008 ve 2009 yıllarında gerilemiştir. Ülkemizde ise, hayat dışı dallarda prim üretimi artışı son iki yıldada enflasyon oranının altında kalmış ve sektör prim üretimi küçülmüştür.

2009 yılı sonu itibarı ile Türkiye'de, sigortacılık ve bireysel emeklilik sektörlerinde toplam 57 şirket faaliyet göstermektedir. Bu şirketlerin 33 tanesi hayat dışı (elementer) branşlarda, 10 tanesi hayat sigortası branşında, 13 tanesi ise, hem hayat hem de hayat dışı branşlarda faaliyet göstermektedir. Sadece bir adet şirket reasürans alanında faaliyet göstermektedir. Ayrıca ruhsat sahibi olmakla birlikte, faaliyet göstermeyen ya da faaliyeti kamu otoritesi tarafından durdurulan 4 tane hayat dışı ve bir tane de hayat sigortası şirketi bulunmaktadır.

$\mathrm{Bu}$ çalışmamızda, sigortacılığın tarihine kısa bir gezinti yaptıktan sonra, Türkiye de ve dünyada sigorta sektörünün durumuna bir göz atacağız.

\section{Sigortanın Tanımı ve Anlamı}

Sigorta Latince kökenli bir kelime olup, tam Türkçe karşılı̆̆ “emniyet ve güven” anlamındadır. Bu tanımdan da anlaşılacağı gibi, ileride meydana gelebilecek tehlikelerin insanın kendi canına, malına, çıkarlarına veya sorumlu olduğu hallerde üçüncü şahıslara zarar verebilecek olaylar karşısında önceden güven sağlayabilmesi için bir sisteme gerek duyulmuştur. Bu sisteme sigorta veya sigortacılık denmiştir. Bu sistem sayesinde, aynı tehlikelere maruz kalan insanlar, tehlikelere de birlikte karşı koymuşlardır (Baran, 1982: 11).

İnsanlar yaşantıları boyunca doğadan veya insanların davranışlarından kaynaklanan kendilerine çeşitli maddi zararlar veren olaylarla karşılaşırlar. Bu olayların bazıları özellikle doğadan kaynaklananlar tesadüfi olaylardır. Bazen hiç umulmadık bir olay çok tehlikeli sonuçlar doğurur ve kişiye zarar verir. Bu zarar, can ve mal kaybı şeklinde olabilir. İşte insan hayatının giderek hareketlendiği ve teknolojinin her geçen gün hayatımızı yönlendirdiği günümüzde, bu tehlikeler her geçen gün artmaktadır. Bu nedenle insan ve toplum için çeşitli potansiyel zararlar doğurabilecek bu tarz tehlikeli olaylara karşı bir önlem alma fikri sigorta kavramını ve sigortacılı̆̆ doğurmuştur.

$\mathrm{Bu}$ çerçevede en geniş anlamı ile sigortacılık; "ortaya çıkması beklenen rizikolar sonucunda oluşacak hasarlara karşı tedbir almaktır" şeklinde tanımlayabiliriz. Yine bir başka tanımda da; "sigorta, herhangi bir yangın, kaza, ölüm, vs. gibi doğal afetler sonucunda hasara uğrayan bina, eşya, mal ve can kaybından dolayı zarar gören sigortalının, sigortacı tarafından zararının ödenmesini amaçlayan bir sözleşmedir" şeklinde tanımlayabiliriz. Bu tanımdan da sigortanın yeni bir anlamı ve yönü karşımıza çıkıyor ki o da, sigortanın bir sözleşme olduğudur. Yani taraflar arasında yapılan bir ticari akittir (Çaldağ, 1979: 8). 
Sigortanın tanımını kısaca yaptıktan sonra, sigortanın konusu olan riski yani sigortacı ağzı ile rizikoyuda tanımlamak gerekir. Risk veya riziko; "gerçekleşme ihtimali ve süresi açısından, geleceğe yönelik şüpheli bir olay" şeklinde tanımlanabilir. Yine bir başka tanımda da; " zarar ihtimali veya arzu edilmeyen bir olayın meydana gelme ihtimali" şeklinde tanımlanmıştır (Pekiner, 1974: 3).

\section{Tarihte Sigorta Benzeri Faaliyetler}

Tarihte ilk sigorta benzeri faaliyetler, M.Ö. 4500 yıllarında aşă̆ Mısır'da rastlanmaktadır. Burada yaşayan taş yontucuların aralarında bir yardımlaşma sandığı kurduğu ve birinin ölümü halinde bu sandıktan ölenin yakınlarına yardım yaptıkları bir papürüsten anlaşılmaktadır (Çaldağ, 1979: 5).

Talmud'un Babil'de bulunan yazılarında (M.Ö. 2500 senelerinde), sigortanın İbraniler tarafindan ticari muamele olarak yapıldığını görmekteyiz. İnsanların günlük hayattaki zararları, mala mal şeklinde tanzim ediliyordu. Babil'deki kervancıların bir hayvanının kaybolması durumunda, kervancıların verdiği aidatlarla oluşturulan sandıktan zarar tanzim ediliyordu.

Yine M.Ö. 650-558 yıllarında Atina Kanunlarına göre, birbirleri ile yakın kan bağı bulunan topluluklar, kendi aralarında oluşturdukları bir örgüte belirli bir meblağ öderdi ve üyelerinin ölümü halinde yakınlarına yardım yaparlard1.

M.S. 200 yılında ise, Roma İmparatorluğu'nda dini, mesleki ve askeri kuruluşlara karşılık, ölen üyelerin birinci derece yakınlarına belli miktarlar üzerinden para ödendiği de kaydedilmektedir (Külçür, 1946: 1-3).

Sigorta benzeri faaliyetlere bütün eski uygarlıklarda rastlanabileceğini daha önce belirtmiştik. Olayı bu çerçevede incelediğimiz zaman, Eski Türk Devletlerinde de bu tür faaliyetlerin olduğu söylenebilir.

Masao Mori (1987)'nin belirttiğine göre; Büyük Hun İmparatorluğu devrinde Sogd'lu tüccarlar Çin ile yaptıkları ticaretin güvenliğini sağlamak için, Hunlarla sıkı bir ilişki kurmuşlardı ve ticaret yollarının güvenliğinin sağlanması karşılığında, elde ettikleri gelirin bir kısmını onlara bir nevi "koruma vergisi" adı altında veriyorlard. Sogd'lular bu vergiyi daha sonra Göktürklere ödemişlerdir (Mori, 1987: 340-347).

Daha sonraki Türk devletleri'nde (Hazarlar, İlhanlılar, Selçuklular ve Anadolu Beylikleri) ise, alınan bu koruma vergisi, kervanların yol boyunca güvenliklerinin sağlanması karşılığında muhafızlara verilmek üzere, "gümrük vergisi" ne ek bir vergi olarak alınmıştır (Atan, 1990: 25).

Alaaddin Keykubat'ın ticari maksatlarla ve kervan yollarının güvenliğini sağlamak için açtı̆̆ seferler sonucunda, kazandığı zaferleri müteakip, tecavüz ve yağmaya uğrayan kervanların sahiplerine, aldığı ganimetlerden ve devlet hazinesinden bütün zararları tanzim ettiğine dair bilgilere sahibiz. Bu olay bize Selçukluların ister yazılı taahhüt neticesinde olsun, isterse yazılı bir taahhüt olmasın, devletin itibarı ve iktisadi siyaseti için, yabancı bir devlet veya eşkıyanın tecavüzleri karşısında ticari emtiayı tazmin ettiklerini göstermektedir (Akpınar, 1990: 36).

Bu çerçevede, Selçukluların iktisadi siyaseti gereği ve teamül neticesi olarak, bir tür devlet sigortası uygulaması içerisinde olduklarından bahsetmek hatalı olmayacaktır (Turan, 1971: 285).

Lonca Teşkilatı, Osmanlı İmparatorluğu'nda modern sigortacılı̆̆ı̆ başlamasından önce, batı ülkelerinin lonca teşkilatlarında olduğu gibi, sadece teşkilat üyelerinin zararlarını karşılamakla kalmamış, yeni iş kuracaklara, çalışamaz durumda olanlara yardım için, üyeler arasında birlikler oluşturmuştur. Ortak fonlardan üyelerinin hastalık ve ölüm gibi beklenmeyen hallerde, bu hallere karşı karşıya kalacakları zararlarını karşılamak için sistemler oluşturmuşlardır. (Erdoğan, 1993: 26).

\section{Türkiye'de Sigorta Sektörünün Yapısal Durumu}

Şirket Sayısı: Türkiye'de sigortacılık sektöründe 2007 yılında faaliyet gösteren şirket sayısı 61 iken, 2008 y1lında 62'ye, 2009 yllında ise, sektöre 4 yeni şirket katılmış, buna karşın 2 şirket piyasadan çekilmiş ve 2 şirketinde başka şirketlerle birleşmesi sonucunda, piyasadaki şirket sayısında bir değişiklik olmamıştır.

31.12. 2009 tarihi itibari ile mevcut 62 şirketin dağılımı şöyledir: 37 adedi hayat dışı branşlar, 10 adedi hayat, 14 adeti hayat ve emeklilik, bir tanesi ise, reasürans şirketidir. Ancak, hayat dışındaki 37 şirketin 4 tanesi, 10 tane hayat şirketinden ise, bir tanesi piyasada faaliyet göstermemektedir. Yani mevcut 62 şirketin, fiilen 57 tanesi faaliyette bulunmaktadır (SDK, 2009: 9).

$\mathrm{Bu}$ şirketler tarafından 2009 yılı sonu itibarı ile hayat dışı dallarda 33.281 .456 adet ve hayat branşında da 7.893.579 adet olmak üzere toplam; 41.175 .035 adet poliçe düzenlenmiştir. 2008 yıllna göre yıllık artış1 $\% 14,51$ 'dir.

Yıl içinde düzenlenen poliçelerden iptal ve fesih olanlar ile birikimli hayat sigortası poliçelerinden iştira, vefat ve vade gelimi gibi nedenlerden dolayı ayrılmalar da dikkate alındığında, 2009 yılı sonu itibarı ile 9.938 .683 adet hayat sigortası poliçenin yürürlükte olduğunu görüyoruz. Bu poliçelerin 2.988.647'si birikimli hayat sigortalarına ait iken, 2.203.491 adeti ise, bireysel emeklilik poliçesidir (SDK, 2009: 12).

Sigorta Sektörünün Sermaye Yapısı: Türkiye'de sigorta potansiyelinin yüksek olması ve sektörün son 
yıllarda gösterdiği hızlı gelişme yabancı yatırımcıların Türk sigortacılık piyasasına olan ilgisini artırmıştır. 31.12. 2009 tarihi itibariyle mevcut 37 hayat dışı şirketin, 24'ü ve 24 hayat ve emeklilik şirketinden 19'u doğrudan veya dolaylı olarak yabancı ortaklıdır. Bu şirketlerden 35 tanesinin, yabancı ortaklık payı \%50'nin üzerindedir. 31.12.2009 tarihi itibarı ile piyasada yabancı ortaklı firma sayısı 43'tür (SDK, 2009: 13).

Sigortacılık ve BES Sektörünün Türkiye Finans Piyasasındaki Durumu: Türk finans sektörü, bankacılık ağırlıklı bir yapıya sahiptir. Finans sektörünün aktif büyüklüğü 2009 y1lı itibari ile, 1.047,7 Milyar TL'ye yükselmiştir. Bu miktarın 834 Milyar TL'lik kısmı bankacılık sektörüne (TCMB hariç) ait iken, sigortacılık ve bireysel emeklilik sektörünün aktif toplamı 33,4 Milyar TL.'dir. Yani bankacılık sektörünün pay1 \%79,6 iken, sigorta sektörünün payı sadece \%3,19'dur. Daha açık bir ifade ile bankacılık sektörü lider durumda iken, sigorta sektörü ve menkul kıymetler yatırım fonları takip eder (SDK, 2009: 15).

Sigorta Sektöründe İstihdam Durumu: Sigorta piyasasında faaliyet gösteren 62 adet şirkette toplam çalışan sayısı, 15.602 kişidir. 2009 yılı sonu itibarıyla, sigorta hizmetlerini pazarlamak için kurulan ve TOBB nezdinde tutulan levha'ya kayıt yaptırmış acente sayısı 15.579'a ulaşmıştır. Bireysel emeklilik aracısı sayısı 15.666'dır. Piyasada 72 adet broker hizmet vermektedir. Bunların 57'si sigorta ve reasürans, 13'ü sigorta, 2'si ise, sadece reasürans brokerliği yapmaktadır. 2009 yılı sonu itibarı ile, sektörde 908 adet gerçek ve 431 adet tüzel kişi sigorta eksperi, 1.154 kişi ise tarım sigorta eksperi olarak faaliyet göstermektedir. Sigorta şirketleri ile anlaşmalı olarak faaliyet gösteren aktüer sayısı, 36'dır. Sigorta sektörünün 2009 yılı sonu itibarı ile 60 binden fazla kişiye istihdam imkanı sağladığını söyleyebiliriz (SDK, 2009: 11).

\section{Türkiye Sigorta Sektörünün Temel Göstergeleri}

Sigorta sektörü, ekonomideki gelişmelerden çok hızlı ve yüksek oranda etkilenen finansal sektörlerden biridir. Gayri Safi Yurt İçi Hasıla (GSYİH)'nın arttığı dönemlerde sigortacılık sektörü, GSYİH'dan daha yüksek oranda büyümekte, GSYİH’nın küçüldüğü dönemlerde ise daha fazla küçülmektedir (Kuşçu, 1996: 1).

Türkiye'nin 2008 yılı GSYİH'sı cari fiyatlarla 950.144 milyon TL iken, 2009 yılında, 953.974 milyon TL. olarak gerçekleşmiştir. Başka bir deyişle, dünyada ki ekonomik krize rağmen, Türkiye GSYİH'sını azda olsa yükseltmeyi başarmıştır. Bu sonuç sigorta sektörüne olumlu yönde yansıyarak krize rağmen büyümeyi getirmiştir.

GSYİH'deki artışa paralel bir şekilde aynı dönemde sigorta sektöründe de prim üretiminin, 2008 yılında 11.780 milyon TL iken, 2009 yılında 12.436 Milyon TL 'ye yükseldiği görülmüştür. 2009 yılında sektörün sigortalılara 24.938.878 Milyon TL. teminat verdiği görülmüştür. Yani bir başka ifade ile sektörde GSYİH’nın \% 1,30’u kadar prim üretilip, bunun karşılığında sigortalılara GSYİH'nın 26 katı kadar teminat verilmiştir. Bunun yanında, bireysel emeklilik sisteminde biriken fon tutarının, GSYİH’ya oranı \% 0,96 ' ya ulaşmıştır (SDK, 2009: $5)$.

\begin{tabular}{|c|c|c|c|c|c|}
\hline (Milyon TL) & 2005 & 2006 & 2007 & 2008 & 2009 \\
\hline Prim Üretimi & 7.817 & 9.670 & 10.931 & 11.780 & 12.436 \\
\hline Teminat Tutarı & 7.500 .780 & 9.472 .643 & 11.910 .814 & 22.676 .538 & 24.937 .878 \\
\hline Birikim Tutarı & 1.219 & 2.836 & 4.603 & 6.400 & 9.125 \\
\hline GSYİH & 648.932 & 758.391 & 843.158 & 950.144 & 953.974 \\
\hline Prim/GSYİH (\%) & 1,20 & 1,28 & 1,30 & 1,24 & 1,30 \\
\hline Teminat/GSYİH (\%) & 1155,87 & 1249,04 & 1412,64 & 2386,64 & 2614,10 \\
\hline Birikim Tut./GSYİH (\%) & 0,19 & 0,37 & 0,55 & 0,67 & 0,96 \\
\hline
\end{tabular}

Tablo 1. Prim Teminat ve Biriken Fon Tutarlarının Seyri ve GSYİH.

Kaynak: T.C. Başbakanlık Hazine Müsteşarlı̆̆l, SDK 2009 Raporu, s: 5.

\begin{tabular}{|l|r|r|r|r|r|}
\hline \multicolumn{7}{|c|}{ (Milyon TL) } & \multicolumn{1}{c|}{$\mathbf{2 0 0 5}$} & $\mathbf{2 0 0 6}$ & \multicolumn{1}{c|}{$\mathbf{2 0 0 7}$} & \multicolumn{1}{c|}{$\mathbf{2 0 0 8}$} & \multicolumn{1}{c|}{2009} \\
\hline \multicolumn{7}{|c|}{ Prim Üretimi } \\
\hline Hayat D1ş1 Prim & 6.575 & 8.284 & 9.600 & 10.204 & 10.614 \\
\hline Hayat Prim Üretimi & 1.242 & 1.386 & 1.331 & 1.576 & 1.822 \\
\hline Toplam Prim Üretimi & 7.817 & 9.670 & 10.931 & 11.780 & 12.436 \\
\hline Hayat Pay1 (\%) & 15,89 & 14,33 & 12,18 & 13,38 & 14,65 \\
\hline \multicolumn{7}{|c|}{ Teminat Tutarı } \\
\hline Hayat D1ş1 Teminat & 7.410 .652 & 9.358 .669 & 11.756 .248 & 22.452 .225 & 24.722 .284 \\
\hline Hayat Teminatı & 90.128 & 113.974 & 154.566 & 224.314 & 215.594 \\
\hline Toplam Teminat & 7.500 .780 & 9.472 .643 & 11.910 .814 & 22.676 .538 & 24.937 .878 \\
\hline
\end{tabular}

Tablo 2. Brüt Prim Üretimi ve Teminat Tutarlarının Seyri

Kaynak: T.C. Başbakanlık Hazine Müsteşarlı̆̆l, SDK 2009 Raporu, s: 1.

Türkiye sigorta sektörü 2009 yılında, hayat dışı dallarda 10.614 Milyon TL ve hayat branşında 1.822 Milyon 
TL olmak üzere toplam 12.436 Milyon TL brüt prim üretimi gerçekleştirmiştir.

Bu prim üretiminden reasürans yolu ile alınan miktar düşüldüğü zaman, direkt prim üretimi 12.193 Milyon TL olarak gerçekleştiği görülmektedir. Burada hayat dışı prim üretimi 10.371 Milyon TL, hayat branşında reasürans yolu ile prim üretimi mümkün olmadığı için, brüt ve direkt prim üretim tutarları arasında fark bulunmamaktadır.

Türkiye'de hayat dıșı sigorta branşlarında prim üretimi, hayat branşından daha yüksektir. Bu durum yıllar itibari ile küçük dalgalanmalar göstermekle birlikte, toplam prim üretiminde hayat dişı sigorta dallarının payı ortalama \% 85 düzeyindedir. Ancak 2005-2007 yılları arasında BES’ne hayat sigortalarının aktarılması nedeni ile hayat branşının toplam prim üretimi içindeki payı bir miktar gerilemiş ve 2007 yılında devirlerin sona ermesi sonucunda tekrar artmaya başlamıştır (SDK, 2009: 2).

\begin{tabular}{|l|r|r|r|r|r|}
\hline \multicolumn{1}{|c|}{ (Milyon TL) } & $\mathbf{2 0 0 5}$ & $\mathbf{2 0 0 6}$ & $\mathbf{2 0 0 7}$ & \multicolumn{1}{c|}{$\mathbf{2 0 0 8}$} & \multicolumn{1}{c|}{$\mathbf{2 0 0 9}$} \\
\hline HD Direkt Prim & 6.575 & 8.090 & 9.370 & 9.995 & 10.371 \\
\hline Hayat Direkt Prim & 1.242 & 1.385 & 1.331 & 1.564 & 1.822 \\
\hline Direkt Prim Toplamı & 7.817 & 9.475 & 10.701 & 11.560 & 12.193 \\
\hline Nominal Değişim (\%) & 18,18 & 21,21 & 12,95 & 8,02 & 5,48 \\
\hline Reel Değişim (\%) & 9,71 & 10,54 & 4,2 & $-1,85$ & -0.98 \\
\hline
\end{tabular}

Tablo 3. Direkt Prim Üretiminin Seyri. Kaynak: T.C. Başbakanlık Hazine Müsteşarlı̆̆l, SDK 2009 Raporu, s: 2.

Bireysel emeklilik şirketleri tarafindan 2009 yılında katılımcılardan net 1.672 milyon TL. katkı payı tahsil edilmiştir. Bu miktarın 655 Milyon TL'lik kısmı yeni sözleşmelere, kalan 1.017 Milyon TL'lik kısmı ise 2009 yılı sözleşmelerine aittir.

2009 y1lı sonu itibari ile, yürürlükte bulunan sözleşmeler için tahsil edilen toplam katkı payı tutarı 7.034 Milyon TL'ye ulaşmıştır. Yıl içindeki 2.735 Milyon TL'lik artış ile birlikte BES'nde biriken fon tutarı 9.125 Milyon TL'ye ulaşmıştır.

Hayat sigortası ile bireysel emeklilik sisteminde (BES) tahsil edilen prim ve katkı payları ile yatırıma yönlendirilen birikim ve fon tutarları karşılaştırıldığında, bireysel emeklilik sisteminde toplanan fonlar hayat sigortasına göre daha hızlı artmıştır. Hayat sigortasında biriken fonlar 2005 yılında, bireysel emeklilik sisteminde biriken fonların yaklaşık üç katı iken, 2009 yılı sonu itibarıyla, BES'de biriken fonlar, hayat sigortasında biriken fonların iki katına yaklaştığı görülmektedir.

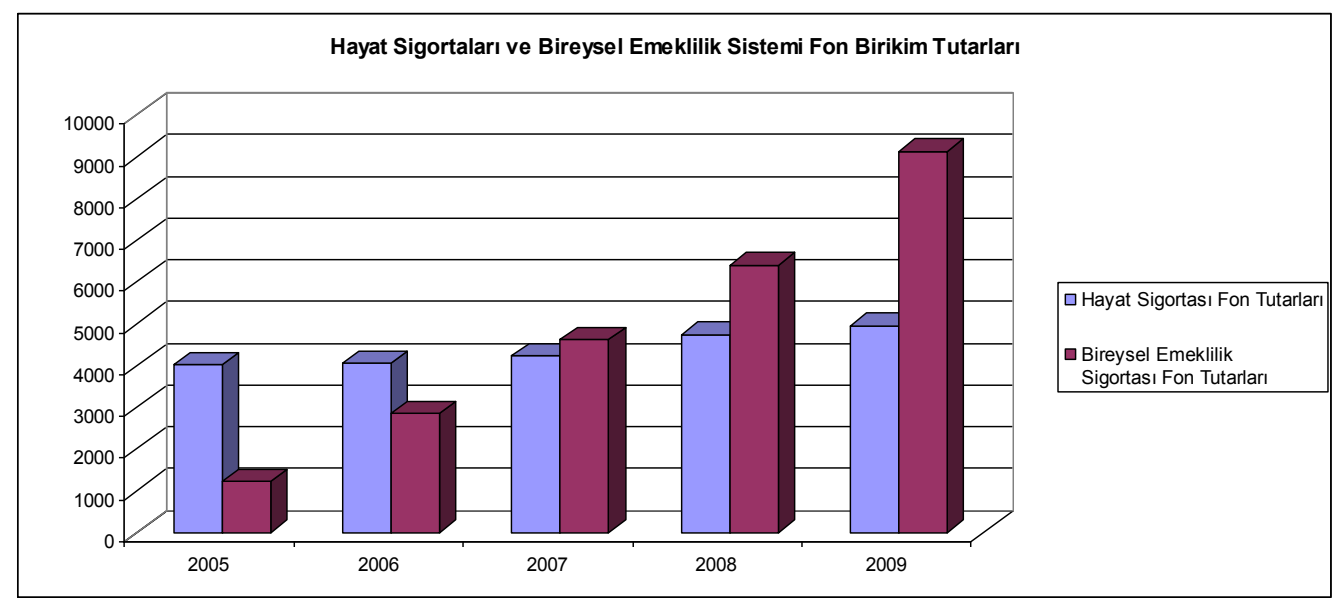

Grafik 1. Hayat Sigortalart ve Bireysel Emeklilik Sistemi Birikim Miktarlart.

Kaynak: T.C. Başbakanlık Hazine Müsteşarliğı, SDK 2009 Raporu, s: 6.

\section{Sonuç}

Dünya sigorta prim üretiminde sanayileşmiş ülkeler 2009 yılı itibari ile \% 87, gelişmekte olan ülkeler ise \% 13 paya sahiptir. Son yıllarda gelişmiş ülkelerde prim üretimi düşerken, bunun tam aksine gelişmekte olan ülkelerde prim üretimi, Türkiye örneğinde de olduğu gibi krize rağmen artmıştır.

Türkiye, \% 0,21 pay ile dünya sıralamasında 36'ncı sıradadır. 2008 yılında kişi başına 106,2 ABD doları prim üretirken, bu oran 2009 yılında 113 dolara çıkmıştır (SDK, 2009: 8).

2009 yılında, Dünya sigorta sektörü \% 4,77 oranında bir düşüş yaşamış ve 4.066 Milyar ABD doları prim üretmiştir. Hayat branşında \% 6,36, hayat dışı branşlarda ise \% 3,16 küçülme meydana gelmiştir. Ancak prim üretimindeki reel küçülme oranı, kriz nedeni ile nominalden daha az gerçekleşmiştir (SDK, 2009: 7).

Türkiye sigorta sektörü genelde, gelişmekte olan piyasalara paralel hareket etmektedir. 
Gelişmekte olan piyasalar 2008 ve 2009 yılında da krize rağmen büyümeye devam etmişlerdir (hayat: \% 4,2, hayat dış1: \% 2,9). Ancak Türkiye 2008 yılında hayat branşında büyürken, hayat dışı branşlarda reel olarak düşüş yaşamıştır. Dünyanın ve Türkiye'nin krizden çıkması ile birlikte, prim üretimi de artmaya başlamıştır.

\section{Kaynakça}

- Akpınar, Turgut (1990). Tarihte Sigorta ve Yurdumuzda Sigortaya Dair İlk Fetvalar, Tarih ve Toplum Dergisi, cilt: 13, say1: 75, s: 34-39.

- Atan, Turhan (1990). Türk Gümrük Tarihi: Başlangıçtan Osmanlı Devletine Kadar, TTK yayını, 1. Cilt, Ankara.

- $\quad$ Baran, T. Fikret (1982). Sigorta ve Reasüransa Bir Yaklaşım, Milli Rea. T.A.Ş. yay., Ank.

- Çaldağ, Yurdakul (1979). Sigorta İşletmeleri ve Muhasebesinin İnc., A.İ.T.İ.A yay, Ankara.

- Erdoğan, İlhan (1993). İsteğe Bağlı Sigorta Hizmetine karşı Tutum, Beta yayınları, İstanbul.

- Kuşçu, Sinan (1996). Sigorta Talep Teorisi ve Türkiye Uygulaması, Erzurum.

- Külçür, F. Kamil (1946). Sigorta Muameleleri Matematiği ve Prensipleri, İstanbul.

- Mori, Masao (1987). Sogdluların Orta Asya'daki Faaliyetleri, Belleten C:XLVII, say1:185, s: 340-347, Ankara

- Pekiner, Kamuran (1974). Sigorta İşletmeciliği, Adana İ.T.A. yayını, Adana.

- Turan, Osman (1971). Selçuklular Zamanında Türkiye, İstanbul.

- T.C. Başbakanlık Hazine Müsteşarlığı Sigorta Denetleme Kurulu (2010), Türkiye’de Sigortacılık ve Bireysel Emeklilik Faaliyetleri hakkında Rapor, Ankara. 


\title{
Çevre Hakkı ve Uygulaması
}

\author{
Faruk Bilir (Selcuk University, Turkey) \\ Berkan Hamdemir (Selcuk University, Turkey)
}

\section{Environmental Right and its Practice}

\begin{abstract}
All the great natural disasters of the twentieth century are the products of human activities. The main reason for this is the people misuse the nature. Because of industrial activity, population growth and consumption, humankind is facing serious environmental problems today. Moreover in the globalizing world, this problem is not only a country's problem but also it is all country's problem, all over the world.

Increase in environmental problems is only increases the economic costs, today. But, in case of take precautions the economic activities will stop because of shortage of source. Even worse, depending on environmental problems as a result of natural disasters, the needs of people may not supply and the vibrant life may end. For this reason, the environment right is the necessity of existence and validity for all of the other rights and freedoms.
\end{abstract}

JEL Code: Q5

\section{Giriş}

İnsanlar ancak kendilerine yaşam desteği sunan bir çevrede yaşayabilirler. Bu nedenledir ki insanoğlu Güneş Sistemi içindeki gezegenlerden sadece Dünya'da yaşamını sürdürmektedirler. İnsanoğlunun Dünya 'daki hava, su, toprak, doğal kaynaklar, flora ve faunayı kirletmesi, bilinçsizce tüketmesi ve yok etmesi sadece bir çevre sorunu olrak kalmaz; bu aynı zamanda Dünyanın insanoğluna sunduğu yaşam destek sistemlerinin de ortadan kalkmasına ve doğal olarak insan neslinin yok olmasına kadar gidecek tehlikeli bir sürecin başlamasına neden olur. Dolayısıyla çevre hakkı, üzerinde önemle durulması gereken bir haktır. Çünkü sağlıklı bir çevre bütün insani faaliyetlerin ve hakların ön koşuludur.

Çevre hakkının önemine binaen bu çalışmada öncelikle çevre ve çevre hakkının kavramsal çerçevesi ve tarihsel süreci üzerinde durulduktan sonra; çevre hakkını ihlal eden çevre sorunlarının nedenleri ve etkilerinden bahsedilecektir. Daha sonra çevre sorunları karşısındaki yaklaşımlar ve izlenmesi gereken politikalar bağlamında insanoğlunun çözüm arayışlarından bahsedilecek ve sonuç olarak insanoğlunun hem ekonomik hem sosyal hem de kültürel faaliyetlerde bulunabilmesi ve hepsinden önemlisi neslini sürdürebilmesi için çevre hakkının ne kadar önemli olduğu üzerinde durulacaktır.

\section{2 Çevre Hakkı}

\subsection{Kavram}

Çevre kavramı, çok çeşitli öğeleri içinde barındırması dolayısıyla farklı şekillerde tanımlanan bir kavramdır (Güneş ve Coşkun, 2004, s. 4). Kavramın bu özeliğine rağmen yine de bir çevre tanımı yapacak olursak, en genel hatlarıyla çevre; insanların ve diğer tüm canlıların içinde yaşadığı, birbirleriyle iletişim kurduğu, sosyal, kültürel, ekonomik, fiziksel ortam olarak tanımlanabilir. Ancak kavram bu çalışmada çok yönlü anlamıyla değil; insanlar ve diğer tüm canlıların içinde yaşadığı fiziksel mekân anlamında kullanılacaktır. Fiziksel çevre bu anlamıyla insan ve diğer tüm canlıların içinde yaşadığı somut mekânı temsil etmektedir (Güneş ve Coşkun, 2004, s. 6). Bu fiziksel mekânın genel olarak su, hava, toprak, doğal kaynaklar ile flora ve faunadan oluştuğunu söyleyebiliriz.

Çevre hakkı ise esas olarak insanı referans alarak tanımlanan bir haktır (Tekeli, 2005, s. 6). Böyle bir referansla çevre hakkı, insanların sağlıklı bir çevrede yaşama yetkisi olarak tanımlanabilir. Bu hak tüm insanları için mutlaktır. $\mathrm{Bu}$ basit tanımdan hareketle çevre hakkının konusunun; çevrenin (hava, su, toprak, doğal kaynaklar, flora ve faunanın) korunması ve korunamamış olan çevrenin olması gereken (doğal) haline kavuşturulması için gerekli önlemlerin alınması olduğunu söyleyebiliriz. Çevre hakkının yararlanıcıları ise insanlar ve insanların oluşturduğu organizasyonlardır (devlet, kamu kurumları, özel kuruluşlar v.s.) Bunlar aynı zamanda çevre hakkının muhataplarıdır (sorumlularıdır). Gelecek kuşaklar henüz var olmadıkları için bu hakkın sorumlusu olmamalarına rağmen; yararlanıcıları arasında kabul edilmelidir.

Çevre hakkı her ne kadar insan referanslı tanımlansa da kanaatimce yaşanılan küre sadece insanların değil, diğer tüm canlıların da yaşamını sürdürmesi için kullandığı ortak bir mekân olduğu için bu hakkın yararlanıcıları arasında insan dışındaki tüm canlıları da saymak gerekir. Ancak, insan dışındaki canlıları, çevre hakkının sorumluları arasında saymak kanaatimizce doğru değildir. Çünkü çevreye verilen zarar, esas olarak insan eliyle verilmektedir. Böylece, çevreyi sadece insan referanslı değil de diğer canlıları da referans alarak yeniden tanımlayacak olursak; çevre hakkı, tüm canlıların sağlıklı bir çevrede yaşama yetkisidir diyebiliriz. 


\subsection{Tarihsel Sürec}

İnsan hakları mücadelesi, insanlığın yaşadığı değişim ve egelişime bağlı olarak duyduğu gereksinimler paraleleinde sürekli çeşitlenerek çoğalan hak taleplerini içeren dinamik bir süreci ifade etmektedir. (Anar, 2000, s. 24). Bu hak mücadelesi sürecinde elde edilen hakları, Fransız hukukçu Karel Vasek tarihsel evrimine göre üç kuşağa ayırarak sınıflandırmaktadır (Torunoğlu, 2005, www.sendika.org.) Buna göre; tarihsel süreçte ilk olarak ortaya çıkan ve başlangıcı XVII. yüzyıla dayanan birinci kuşak haklar, "insan kişiliğinin korunmasına ilişkin medeni ve siyasal hakları"; tarihsel süreçte birinci kuşak haklardan sonra sanayi devriminin yarattığı ekonomik ve sosyal sorunlara karşı ortaya çıkan ikinci kuşak haklar, insan onuruna yaraşır bir şekilde yaşamanın gereği olarak kabul edilen "ekonomik, sosyal ve kültürel hakları" ve üçüncü kuşak haklar ise insanın sağlıklı bir çevrede ve barış içerisinde yaşamasını öngören “dayanışma hakları”nı kapsamaktadır (Atar, 2007, s. 111).

Üçüncü kuşak haklar, küreselleşme sürecinde, dünyada yaşanan uluslararası eşitsizlikçi ve çatışmacı ortama bir tepki olarak doğmuş haklardır. İşte çevre hakkı da böyle bir tepkinin neticesi ortaya çıkan üçüncü kuşak haklardandır (Erdoğan, 1999, s. 181). Ekonomik saiklere endekslenen sanayileşme, hızlı kentleşme, toplumsal faydayı bireyciliğe kurban eden anlayış, olaylara tek boyutlu olarak sadece üretim, kâr ve sermaye birikimi olarak bakmış; çevreyi göz ardı ederek bugün dünyayı çok ağır çevre sorunlarıyla yüz yüze bırakmıştır. Böylece, doğal üretim kaynaklarının tüketilmesi, yok edilmesi, bozulması ve kirlenmesiyle ortaya çıkan bu sorunlar karşısında bir tepki ve aynı zamanda da önlem olarak çevre hakkı, uluslar arası toplumun gündemine girmeye başlamıştır.

Çevre hakkı, uluslararası alanda ciddi bir şekilde ilk defa 1972'de Stockholm'de yapılan Birleşmiş Milletler Çevre ve İnsan Konferansı'nda ciddi şekildde gündeme gelmiştir. 100'den fazla ülke temsilcisinin katıldığı bu Konferans, çevre sorunlarına yönelik politika arayışlarında bir milat olarak kabul edilmektedir (Ürkmez, www.cekud.org). Bu konferans sonucunda yayınlanan Stockholm Bildirisi (1972) nin birinci maddesinde; insanın, onurlu ve iyi bir yaşam sürdürebilmesi için sağlıklı/elverişli bir çevrede yaşama hakkına sahip olduğu, bu hakka sahip olan insanların aynı zamanda hem bugünkü hem de gelecek kuşaklar için çevreyi koruma sorumluluklarının olduğu açık bir şekilde vurgulanmıştır (Güneş ve Coşkun, 2004, s. 56). Konferansın önemi, farklı siyasal bloklardan ve farklı kalkınma düzeyine sahip ülkeleri ortak ilkeler etrafinda bir araya getirip; tüm ülkelerin evrensel bir nitelik kazanan çevre sorunları karşısında ortak sorumluluklarını kabul eden bir yaklaşımı benimsemesidir (Egeli, 1996, s. 15). Bu Konferans sonunda yayınlanan "İnsan ve Çevresi Deklarasyonu" doğrultusunda, Birleşmiş Milletler (BM) bünyesinde, çevre ile ilgili çalışmaları sürdürmek ve koordinasyonu sağlamak üzere Birleşmiş Milletler Çevre Programı (UNEP: United Nations Environmental Program) nın kurulması ve doğal kaynakları ve tabîi varlıkları tahrip etmeden, çevreyi ön plana çıkararak kalkınmayı hedefleyen bir anlayış olan "sürdürülebilir kalkınma" anlayışının ilk kez gündeme getirilmiş olması (Egeli, 1996, s. 16) bu konferansı önemli kılan diğer nedenler olmuştur.

Çevre hakkı konusunda bir diğer önemli adım, 1992’de Brezilya'nın Rio kentinde 178 ülkeden 1200 delegenin katıldığı BM Çevre Kalkınma Konferansı'dır. Bu Konferans neticesinde Biyolojik Çeşitlilik Sözleşmesi, İklim Değişikliği Sözleşmesi, Rio Deklarasyonu, Gündem 21 ve Ormanların Kullanılması Sözleşmesi gibi beş önemli metin ortaya çıkmıştır. Ancak bağlayıcılığı olmayan metinler ve gelişmiş ülkelerin özellikle atmosfere salınan karbondioksidin \%30'unun sorumluluğunu taşıyan Amerika Birleşik Devletleri'nin üretim faaliyetlerine hız vermeden devam edeceklerini açık veya zımni olarak beyan etmeleri, bu Konferansa bağlanan umutları kırmıştır (Egeli, 1996, s. 21-24).

Çevre hakkı konusunda uluslar arası alanda atılan bir diğer önemli adım 1997'de Japonya 'enın Kyoto kentinde gerçekleştirilen konferans sonunda kabul edilen ve 2005 y1lında yürürlüğe giren, özellikle gelişmiş ülkelere seragazı azaltımı konusunda yükümlülükler getiren Kyoto Protokolü'dür. Çevre ile ilgili uluslararası alanda atılan adımlar bu sayılanlarla sınırlı değildir. Bunların dışında Avrupa Birliği’nin çevre ile ilgili uygulamaya soktuğu eylem programları ve habitat toplantıları başta olmak üzere çevre hakkı ile ilgili çeşitli uluslararası konferanslar yapılmış ve bildiriler ilan edilmiştir ve bu çalışmaların, dünyanın içinde bulunduğu çevre sorunları nedeniyle sıklaşarak devem edeceği de kuvvetle muhtemeldir.

Bütün uluslar arası çabalara rağmen çevre hakkına yönelik uluslararası bir koruma mekanizması hâlen mevcut değildir. Ancak Avrupa Konseyi bünyesinde 1950'de kabul edilen İnsan Haklarını ve Temel Özgürlükleri Koruma Sözleşmesi'nde (AİHS) ve Ek protokollerde, çevre hakkı, özgün bir insan hakkı olarak tanınmamış ve güvenceye bağlanmamış olmasına rağmen; Sözleşmee nin yargı organı olan Avrupa İnsan Hakları Mahkemesi (AİHM) içtihatlarında çevre hakkının, Sözleşme "enin yaşam hakkı (m. 2), özel yaşam ve aile yaşamına saygı hakkı (m. 8), aşağılayıcı muamele yasağı (m. 3) ve mülkiyet hakkı (1 no.lu Ek Protokol, m.1) gibi diğer haklar aracılığıyla dolaylı olarak korunduğu görülmektedir (Kaboğlu, 1998, s. 301).

Çevre hakkının uluslararası belgelerde yaşam hakkını besleyen bir insan hakkı olarak yer almaya başlaması etkisini ulusal yasa metinlerinde de göstermiştir. Stockholm Bildirgesiyle başlayan süreçte artık pek çok devlet, sağlıklı ve düzenli bir çevrede yaşam hakkına, bir insan hakkı olarak anayasalarında ve diğer hukuk metinlerinde yer vermektedirler (Keleş ve Ertan, 2002, s. 78). Ancak gelinen noktada tüm bu girişimlerin yetersiz olduğu görülmektedir. 


\section{3 Çevre Sorunlarının Nedenleri ve Etkileri}

Ekosistemde yer alan bileşenler arasında karşılıklı etkileşim sonucu oluşan bir doğal denge mevcuttur. Bu doğal denge, çevre bileşenlerinin kendi varlıklarını devam ettirebilmek için yaptıkları mücadelenin sonucu olarak bozulabilmektedir. Bu bozulma çevre sorunu olarak karşımıza çıkmakta ve etkisini yerel veya evrensel düzeyde hissettirebilmektedir (Güneş ve Coşkun, 2004, s. 13). Çevre sorunlarının oluşması doğal kaynaklı (volkan patlaması, yangın, deprem gibi doğal afetlerden kaynaklı) olabileceği gibi; insan faaliyetleri sonucu yapay kaynaklı da olabilir (Gökdayı, 1997, s. 71). Eğer doğal kaynaklı çevre sorunlarını bir kenara bırakacak olursak, günümüzde çevre sorunlarının ortaya çıkmasında en büyük etki insanoğlunundur. Başka bir ifadeyle yaşanan çevre sorunları temelde insan kökenlidir.

Çevre sorunlarının temelinde esasen insanoğlunun doğaya hâkim olma ve birbirine üstünlük sağlama çabasının yattı söylenebilir. Bu bağlamda çevre sorunlarının nedenleri; şehirleşme, endüstriyel gelişme, nüfus artışı ve yaşam tarzı (Güneş ve Coşkun, 2004, s. 21), insanların bilinçsizliği ve buna bağlı olarak kalkınma için gerçekleştirilen birçok faaliyetin ekosistemin kendisini yenilemesine izin verecek biçimde olmaması, yoksulluk gibi nedenler olarak sıralanabilir (Gökdayı, 1997, s. 70).

Şehirleşme, kent alalarının tarım alanları aleyhine genişlemesine, bu da genişleme oranında o bölgedeki flora ve faunanın yok olmasına sebep olmaktadır. Ayrıca şehirleşmenin getirdiği nüfus artışı, o bölgedeki su vs. doğal kaynakların aşırı kullanımından kaynaklı çevre sorunlarına da neden olmaktadır (Gökdayı, 1997, s. 23).

Endüstriyel gelişme, doğal kaynakları hammadde olarak talep eden daha sonra da bu hammaddeyi ara ürün veya nihai ürün haline getirip insanoğlunun kullanımına süren bir süreçtir. İşte hem hammadde talebi sürecinde doğanın dengesi bozulmakta -örneğin hammadde olarak odun talep eden bir sektör ağaç kesilmesine ve oradaki doğal dengenin bozulmasına sebep olmaktadır- hem de bu hammaddelerin işlenmesi sonucunda ortaya çıkan kimyasal atıkların çevreye verdiği zararlar sonucunda bir çevre sorunu ortaya çıkmaktadır (Gökdayı, 1997, s. 24).

Nüfus artışı da çevre sorunlarının önemli bir nedenidir. XX. yüzyılın ikinci yarınsından sonra nüfus artışında hatırı sayılır bir hız gözlenmiştir. 1900 yılında 1.6 milyar olan Dünya nüfusu, 1950 yılında 2.5 milyara, 2000 yılında 6 milyara ve 2010 yılı itibariyle de 6.8 milyara ulaşmıştır. 2083 yılında bu rakamın 10 milyar olacağ1 tahmin edilmektedir (www.geograpy.about.com). İşte bu nüfus artışı temel yaşam ihtiyaçlarını karşılamak için beraberinde çevresel değerlerin daha çok tüketilmesine de yol açmaktadır. Bu nüfus artışının ortaya çıkardığı en büyük çevresel sorun ormansızlaşmadır. Ormansızlaşma da beraberinde, yağmurların azalması ve buna bağlı olarak su kaynaklarının fakirleşmesi, erozyon, çölleşme gibi sorunları getirmektedir (Güneş ve Coşkun, 2004, s. 26-27).

Mevcut dünya nüfusunun 1 milyarını gelişmiş ülkede yaşayan insanlar oluştururken geri kalanını gelişmekte olan ülkelerde yaşayan insanlar oluşturmaktadır (Çamurcu, www.balikesir.edu.tr, s. 87-88). Buna rağmen gelişmiş ülkeler dünya kaynaklarının 3/4’ünü kullanmakta ve dünyada yaşanan çevre sorunlarının da 3/4’üne sebep olmaktadır (Güneş ve Coşkun, 2004, s. 26). Bu da bu ülkelerdeki yaşam tarzının bir sonucudur. Bu ülkelerdeki lüks yaşam tarzları beraberin aşırı tüketimi de getirdiği için bu tüketim ihtiyacını karşılamak üzere doğal kaynaklar aşırı derecede tüketilmektedir.

Aslında çevre sorunlarının temelinde yukarıda bahsedilen nedenlerinin hepsini de kapsayacak şekilde tüketim olgusunun olduğunu söyleyebiliriz. Tüketim olgusu, ihtiyaç duyulan mal ve hizmetlerin üretimi için daha fazla kaynağın tüketilmesini ve bu üretim sürecinde ortaya çıkan birçok atığın doğaya bırakılmasını içeren bir süreç olduğu için çevre sorunlarının ortaya çıkmasında temel sebeptir (Gökdayı, 1997, s. 70-71).

Yukarıda değinilen nedenlere bağlı olarak ortaya çok ciddi çevre sorunları çıkmaktadır. Bunların başında havanın, suyun ve toprağın kirlenmesi gelmektedir ki bu unsurlar insanlara yaşam destek koşullarını sunan temel unsurlardır. Dolayısıyla bunların kirlenmesi insan yaşamını tehlikeye atmaktadır. Bu kirlilikler bağlamında nükleer kirlenmeler, manyetik kirlenmeler, karbon monoksit gazını salınımından kaynaklanan kirlenmeler, seragazı salınımından kaynaklı ozon tabakasının tahribi gibi durumlar insanoğlu açısından önemli çevre sorunları yaratmaktadır. Yine yukarıda izah edilen sebeplerden kaynaklı ormansızlaşma ve buna bağlı olarak yağış rejiminin değişmesi, su kaynaklarının azalması, erozyon, çölleşme ve nihayetinde iklim değişikliği; özellikle küresel ısınma gibi çevre sorunları, artık yüz yüze olduğumuz sorunlardır. Bütün bu çevre sorunları, doğal kaynak ve enerji darboğazını yaratacağından, besin ihtiyacının karşılanamaması, sağlık sorunları, biyolojik çeşitliliğin azalması, toplu ölümler gibi vakıalarla sonuçlanabilecek süreçlere gebedirler. Nitekim bıugün Somali‘de yaşanan insanlık dramı (açlık kaynaklı) bu söylenilenleri doğrulamaycak örneklerden ilk akla gelen ve en güncel olanıdır.

Endüstriyel büyümenin, sürekli nüfus artışının ve daha fazla tüketimin, kaynakları ne zaman bitireceği ve insanlığı ekolojik bir felaketle karşı karşıya bırakacağı her bir yaşam destek unsuru için (su için, tork için, enerji kaynakları için) farklıdır. Muhakkak bunların birçoğu da aniden ve bir anda tükenmeyecektir. Fakat bunların birçoğu kendilerini yükselen maliyet ve azalan gelir şeklinde kendisini belli edecektir ve hatta etmektedir (Dünya Çevre ve Kalkınma Komisyonu, 1991, s. 73). 


\section{4 Çevre Sorunları Karşısında İnsanoğlunun Çözüm Arayışları}

Bir önceki başlık altında çevre sorunlarının neler olduğunu ve bu sorunların sebeplerini ortaya koyan genel bir fotoğraf çekmeye çalıştık. Peki, insanoğlunun yukarıdaki fotoğraf karşısında yapması gereken şey nedir? İnsanoğlu, hiçbir şey yapmadan yaşam destek sistemlerinin her geçen gün yok olmasına; dolaysısıyla insanlığın sonunun gelmesine, gelecek kuşaklara yaşam hakkı kalmamasına seyirci mi kalacaktır? Bu soruya "evet" cevabını vermek, insanlık tarihiyle ve insanoğlunun yaşama ve neslini sürdürme içgüdüsüyle uyumlu ve gerçekçi bir cevap değildir. Peki insanoğlu, mevcut fotoğraf karşısında bir şey yapacaksa bu ne olmalıdır. Çevre sorunlarına sebep olan kentleşme ve endüstriyel faaliyetleri bırakıp, teknolojinin sunduğu modern yaşam tarzlarından tamamen vaz $\mathrm{m} ı$ geçmelidir? Ya da nüfus artışının önüne geçmek için sert yasal tedbirler mi almalıdır? Tahmin edileceği üzere insanoğlu bugün sahip olduğu pek çok şeyden vazgeçmeyi kabul etmeyecektir? Hatta doğaya hakim olma, daha rahat yaşama ve diğerlerine üstünlük kurma çabalarını teknolojik gelişmelere daha da hız vererek sürdürecektir. Tarihsel süreç bunu göstermektedir. O zaman cevabı aranması gereken soru şu olmalıdır: Bu olgu karşısında nasıl bir yol izlenebilir? Yani insanoğlu mevcut yaşam tarzından ödün vermeden ama çevre sorunlarını da kendileri başta olmak üzere doğadaki diğer canlılar ve gelecek nesiller için nasıl tehditkar omaktan çıkarabilir? Bu soruya hem çevrenin geleceği üzerine öne sürülen yaklaşımlar dikkate alınarak cevap verilebilir hem de bu konuda alınması gereken somut önlemler dikkate alınarak cevap verilebilir.

\section{1 Çevrenin Geleceği Üzerine Yaklaşımlar}

Çevrenin geleceği üzerine üç temel yaklaşım söz konusudur. Bunlar, sürdürülebilir kalkınma, derin ekoloji ve yetinme yaklaşımlarıdır.

\subsubsection{Sürdürülebilir Kalkınma Yaklaşımı}

Sürdürülebilir kalkınma yaklaşımının özünde, çevre politikalarıyla kalkınma stratejilerinin bütünleştirilmesini sağlayacak bir çerçeve çizmek; bugünün ihtiyaçlarını ve beklentilerini, geleceğin ihtiyaçlarından ödün vermeksizin tedarik etmenin yöntemlerini ortaya koymak düşüncesi yatmaktadır (Dünya Çevre ve Kalkınma Komisyonu, 1991, s. 73). Bu yaklaşım, ekonomik ve sosyal gelişme gerçekleştirilirken, doğal dengenin de gözetilmesini esas almaktadır. Bu nedenle sürdürülebilir kalkınmayı dengeli kalkınma ile eş anlamlı olarak şu şekilde tanımlanabilir: Sürdürülebilir kalkınma, "şimdiki kuşakların gereksinimlerinin gelecek kuşakların kaynaklarını tehlikeye atmadan karşılanmasına imkân veren ekonomik büyüme politikalarıdır.” (Güler, 1994, s. 362).

$\mathrm{Bu}$ yaklaşım çerçevesinde gerçekleştirilmesi gereken hedefler olarak şunlar gösterilmektedir (Dünya Çevre ve Kalkınma Komisyonu, 1991, s. 78):

- Büyümeyi canlandırmak; büyümenin kalitesini değiştirmek;

- $\quad$ iş bulma, yiyecek, enerji, su ve sağlık konularındaki temel ihtiyaçları karşılamak;

- $\quad$ sürdürülebilir bir nüfus düzeyini garantiye almak;

- $\quad$ kaynak tabanını korumak ve zenginleştirmek; teknolojiyi yeniden yönlendirmek;

- riski yönetmek ve karar vermede çevre ile ekonomiyi birleştirmek.

Bahsedilen hedefleri gerçekleştirmek ve dolayısıyla sürdürülebilir kalkınmayı sağlamak için de şunların gereklidir (Dünya Çevre ve Kalkınma Komisyonu, 1991, s. 96):

- Karar alınmasında vatandaşların etkin katılımını sağlayan bir siyasal sistem;

- $\quad$ kendi çabasıyla ve sürdürülebilir biçimde üretim fazlası ve teknik bilgi sağlayabilecek bir ekonomik sistem;

- $\quad$ uyumsuz kalkınmadan doğan gerilimlere çözüm bulabilen bir sosyal sistem;

- $\quad$ kalkınma için gerekli ekolojik tabanı korumaya saygı gösteren bir üretim sistemi;

- durmadan yeni çözümler arayabilecek bir teknolojik sistem;

- ticaret ve finansmanda sürdürülebilir düzenleri destekleyen bir uluslar arası sistem;

- $\quad$ esnekliğe, kendini düzeltme yeteneğine sahip bir yönetim sistemi.

\subsubsection{Yetinme Seviyesi Yaklaşımı}

Kalkınmanın sürdürülebilir olması için her şeyden önce kaynakların da sürdürülebilir olması gerekmektedir. Bu bağlamda kaynakları: Ormanlar ve deniz ürünleri gibi canlı doğal kaynaklar; madenlerden oluşan cansız doğal kaynaklar ve enerji kaynakları olmak üzere kabaca üç kategoriye ayırmak mümkündür. Canlı doğal kaynaklar her ne kadar kendini yenileyebiliyorsa da bunları tüketme hızı, kendilerini yenileme hızıyla orantılı olmalıdır. Aksi halde tamamen tükenmeleri söz konusu olacaktır. Cansız doğal kaynaklara gelince, bunların kendilerini yenilemeleri mümkün olmadığı için ne kadar yavaş tüketilirse tüketilsinler bir gün muhakkak tamamen tükeneceklerdir. Dolayısıyla cansız doğal kaynaklar konusunda bunları çok kıskanç kullanmaktan başka yapılabilecek bir şey gözükmemektedir. Günümüzde kullanılan fosil yakıtlardan oluşan enerji kaynakları da bir gün muhakkak tükenecektir. Bu noktada yenilenebilir enerji kaynaklarına yönelmek, enerji konusunda uzun vadede sorunu çözecek tek yol gibi gözükmektedir (Gökdayı, 1997, s. 175). 
Kaynaklarla ilgili bu durum, sürdürülebilir kalkınmanın, mevcut şartların aynen devam etmesi durumunda bile deyim yerindeyse "kötü sonu geciktirmek"ten başka bir işe yaramayacağı yönünde bir düşüncenin ortaya atılmasına sebep olmuştur. Bu düşünceye göre aslolan gelişmiş ülkelerdeki tüketim düzeyinin yetinme seviyesine çekilmesidir (Gökdayı, 1997, s. 175). İşte yetinme seviyesi yaklaşımı olarak da adlandırılan bu yaklaşımın özünde yatan düşünce, kalkınmanın ve canlı yaşamının sürdürülebilmesi için sürdürülebilir kalkınma yaklaşımının yetersiz ve aldatıcı olduğu, bunun yerine insanların temel ihtiyaçlarını gidermeye yönelik bir tüketim anlayışının benimsenmesinin daha gerçekçi ve kalıcı bir çözüm olduğu fikri yatmaktadır (Gökdayı, 1997, s. 179).

Yetinme seviyesi yaklaşımını benimseyenlere göre, bir zamanlar kapitalizmin üzerinde yükseldiği ve burjuvazinin epeyce bir sermaye biriktirdiği; "hep daha fazla tüket” ideolojisi, artık dünyamızın ve gelecek kuşakların haklarını korumak için artık yeterli değildir. Kendimiz, dünya ve gelecek kuşaklar için doğru olanı yapmak adına bir an evvel "gerçek ihtiyaçlar" (beslenme, barınma gibi temel ihtiyaçlar) ile "yapay ihtiyaçlar"1 (lüx tüketim) birbirinden ayılmalı ve kaynaklar sadece gerçek ihtiyaçlarımıza tahsis edilmelidir (Porritt, 1989, s. 124-125; aktaran, Gökdayı, 1997, s. 180).

\subsubsection{Derin Ekoloji Yaklaşımı}

Çevrenin geleceği üzerine yaklaşımlardan sürdürülebilir kalkınma ve yetinme seviyesi yaklaşımları esas olarak insanı merkez alır iken derin ekoloji anlayışı, doğayı merkez olarak almaktadır. Biyosantrik düşünüş yerine ekosantrik düşünüşün hakim olduğu bu yaklaşım, Norveçli felsefeci Arne Neass'a göre şu temel ilkeler üzerinde yükselmektedir: Yeryüzünde değerli olan tek şey insan değildir; ekosistemin tümü değerlidir ve türlerin sürdürülmesi gereklidir. İnsanlar yaşamak için çevreyi yok etmeden ihtiyaçları kadar olanı doğadan almalı; ekosistemdeki tüm yaşam dengeli bir şekilde muhafaza edilmelidir. (Yaren, 1995, s. 99-101).

İnsanların, mevcut yaşam standartlarından vazgeçmeye pek yanaşmayacaklarından hareketle derin ekoloji yaklaşımının çok gerçekçi olmadığı ileri sürülmüş ve alternatif olarak da yine biyosantrik bir anlayışı esas alan yüzeysel ekoloji yaklaşımına ilişkin çeşitli ilkeler ortaya atılmıştır. Bu yüzeysel ekolojik yaklaşım, doğanın değerli olduğunu kabul etmekle birlikte özünde doğadaki bütün değerlerin insanlar için olduğu, insan için olmayan bir değerden söz edilemeyeceği düşüncesini barındırmaktadır. Bu yaklaşım, çevrenin bozulmasının kalkınmayı engellediği durumda ancak çevre sorunlarıyla ilgili önlem alınması gerektiği savunmaktadır (Yaren, 1995, s. 101).

\section{2 Çevre Sorunları Konusunda İzlenebilecek Politikalar}

Çevrenin korunmasına dair alınabilecek önlemler doğrultusunda geliştirilen çevrecilik söylemlerinin, ağırlıklı olarak, dünya ekosisteminde bozulan dengelerinin tüm insanlığı nasıl tehlikelerle karşı karşıya bırakacağ üzerinden geliştirildiği görülmektedir. Başka bir ifade ile "cennetin çekiciliğinden çok cehennemin ikna ediciliğine" güvenilerek politikalar geliştirilmeye çalışılmaktadır. Böyle bir söylemden yola çıkan politikalar da genellikle tepeden aşağıya kurulmakta ve bu yaklaşım içinde, yerele de çoğunlukla tepeden gelerek saptanan sorumluluklar ve görevler kalmaktadır. Başka bir ifadeyle yerelden yaratıcı bir işlev beklenmemektedir. Oysa iki farklı çıkış noktasından (yerelden ya da dünya ekosisteminden) hareketle kurulacak çevre söylemleri her zaman örtüşmeyebilir (Tekeli, 2005, s. 2). Bu nedenle çevre sorunları konusunda küresel ölçekli politikalar kadar yerel ölçekte izlenecek politikalarda büyük önem arz etmektedir.

Çevrenin geleceği konusunda dünya ölçeğinde izlenebilecek politikalara bakacak olursak, bunları: Büyümenin sınırlanması ve/veya sıfırlanması, kültürel çeşitliliğin korunması, üretim ve tüketimde küçülmeye gidilmesi, güneş enerjisi ve rüzgar enerjisi başta olmak üzere alternatif enerji kaynaklarına yönelinmesi, ülkeler arasındaki gelişmişlik düzeyinden kaynaklı ekonomik dengesizliklerin giderilmesi, canlıların yaşama ortamlarının iyileştirilmesi, kirletenlerin bu kirlenmeyi ortadan kaldıracak oranda bedel ödemesi, kirliliğe sebep olan teknolojilerin en çok kirleteninden başlanarak kademeli olarak alternatiflerinin bulunup terk edilmesi, çevre sorunlarının birbirini tetikleyici nitelikte olduğu unutulmadan bu sorunlara karşı bütüncül bir yaklaşım sergilenmesi ve çevre güvenlik sistemlerinin kurulması olarak sayabiliriz (Gökdayı, 1997, s. 183-217).

Çevrenin geleceği konusunda dünya ölçekli politikalar revaçta ve önemli olmasına rağmen; bu soruna yerelden yola çıkarak, çeşitli çözümler üretmek de önem arz etmektedir. Ĕ̆er insanların korumaya çalıştı̆̆ çevre, kafalarında bir yer ile somutlaştırılabilirse örneğin onların yaşadıkları, gezdikleri, eğlendikleri yerler olarak kodlanırsa insanlar, çevreyi korumak konusunda daha duyarlı davranacaklardır (Tekeli, 2005, s. 7). Böylece yerelden ulusala oradan da küresele doğru önemli bir duyarlılık ve çaba oluşmuş olacaktır. Yerel ölçekli politikalar ayrıca, o yerde çevreyi korumak için yapılması gerekenin ne olduğunu saptamak konusunda da daha sağlıklı tespitlerin bire bir yapılmasına ve uygulanmasına sebep olacağı için daha gerçekçi ve faydalı olacaktır.

Çevre sorunlarına yönelik dünya ölçeğinde izlenmesi gereken politikalar ve yerele yüklenmesi gereken sorumluluktan bahsederken bütün bunları kapsayıcı ve anlamlı kılıcı bir konuya daha değinmeye gerek vardır ki o da insan unsuru. Günümüzde yaşanan çevre sorunları nasıl ki insan kökenli ise bu sorunların çözümü de yine insan kökenlidir. İnsanların çevre konusunda uyması gereken kuarllardan bahsetmek, tek başına yeterli değildir. Aslolan insanlarda bunları hayata getirecek istek ve bilinci oluşturmaktır. Bu istek ve bilinci oluşturmak için de 
yapılması gereken şey çevre eğitimidir. Bu hem okullarda önem verilmesi gereken bir eğitimdir hem de devlet ve sivil toplum kuruluşlarının ortaklaşa yapacağı toplumun bütün kesimlerine ve bütün zamana yayılması gereken bir eğitimdir.

\section{Sonuç}

Sanayi devrimini müteakiben yaşanan endüstriyelleşme, nüfus artışı ve tüketim alışkanlıkları, beraberinde doğal kaynakların aşırı tüketimini getirmiş; bu da ortaya ciddi çevre sorunlarının çıkmasına sebep olmuştur. Bu sorunlar artık üretimi daha maliyetli hale getirme şeklinde kendini hissettirse de önlem alınmaması durumunda, kendisini sadece üretim maliyetlerinin artmasında hissettirmekle kalmayacak; üretimin durmasına ve dolayısıyla insanların temel ihtiyaçlarını bile karşılamayacak bir duruma gelmesine sebep olacaktır.

Artık insanoğlu, "Daha fazla nasıl üretebiliriz?" "Ekonomilerimizi daha ne kadar büyütebiliriz?” gibi sorular üzerine kafa yormadan önce bu isteklerimizi çevre hakkına riayet ederek (sağlıklı bir çevreyi riske atmadan) nasıl gerçekleştirebiliriz üzerinde durmalıdırlar. Deyim yerindeyse insanoğlu, çevre dostu üretim modelleri geliştirmek, üretirken çevreye verilen zararı giderecek bedeli ödemek zorundadır. Bu çerçevede öncelikle sürdürülebilir bir kalkınma modeli izlenmeli; alternatif enerji kaynakları ve çevreyi daha az kirleten teknolojiler geliştirmelidir. Bunlar yapılırken aynı zamanda aşırı lüks tüketime giren tüketim alışkanlıklarını törpülemek, insanların çevreyi kirletmeme ve koruma konusunda duyarlılığını artırmak için de bu yönde bir bilinç oluşturmak adına çevre eğitimi faaliyetlerine kesintisiz devam etmek gerekmektedir.

Çevre hakkının gerçekleşmesi için alınması gerek önlemlerin maliyetinin, çevre felaketleri yaşandıktan sonra onu eski haline getirmek için yapılması gerekenlerin maliyetinden daha fazla olması zor görünmektedir. Hele ki yaşam destek sistemleri tamamen çöktükten sonra bunu hiçbir mali bedel karşılığında tekrar tesis etmek mümkün değildir. Bu nedenle ekonomik faaliyetler başta olmak üzere, insanların tüm davranışlarında bunu dikkate alarak hareket etmeleri gerekmektedir.

Gelinen noktada, ekonomik faaliyetler başta olmak üzere bütün faaliyetlerin yapılabilmensin koşulu; buna müsaade eden, bunun için yaşam destek sistemleri sunan bir çevrenin varlığıdır. Bu durum diğer her şey için adeta bir ön koşuldur. Bu nedenle insanoğlunun, yaşanabilir bir dünya için çevre sorunları konusunda yapması gerekenler vardır. $\mathrm{Bu}$ insanoğlunun kendisine karşı olduğu kadar, yeryüzündeki diğer canlılara ve gelecek nesillere de olan bir borcudur. Bir Kızılderili atasözünün dediği gibi : "Bu dünya bize atalarımızdan miras kalmadı, biz onu torunlarımızdan ödünç aldık”.

\section{Kaynakça}

- Anar, Erol, 2000. Insan Hakları Tarihi, 2. Baskı, Çiviyazıları, İstanbul.

- Atar, Yavuz, 2007. Türk Anayasa Hukuku, 4. Bask1, Mimoza, Konya.

- Çamurcu, Hayri, Dünya Nüfus Artışı ve Getirdiği Sorunlar, Balıkesir Üniversitesi Sosyal Bilimler Dergisi, s. 86-105, http://sbe.balikesir.edu.tr/dergi/edergi/c8s13/makale/c8s13m9.pdf, Erişim Tarihi: 05.07.2011.

- Çeçen, Anı1. 2000. Günümüz Koşullarında İnsan Haklarının Genel Görünümü, Türkiye'de İnsan Haklarl, TODAİE Yayınları, Yayın No:301, Anakara, s. 3-6.

- Çepel, Necmettin, 1983. Genel Ekoloji, İstanbul Üniversitesi Orman Fakültesi Yayınları, Matbaa Teknisyenleri Basımevi, İstanbul.

- Çevre Hukuku ve Tarihçesi, http://www.cevreonline.com/hukuk/cevhukuk_tarihce.htm, Erişim Tarihi: 02.07.2011.

- Dünya Çevre ve Kalkınma Komisyonu, 1991. Ortak Geleceğimiz, 3. Baskı, (Çeviren: Belkıs Çorakçı), Türkiye Çevre Sorunları Vakfı Yayını.

- Egeli, Gülün, 1996. Avrupa Birliği ve Türkiye'de Çevre Politikaları, Türkiye Çevre Vakfı Yayını, Ankara.

- $\quad$ Erdoğan, Mustafa, 1999. Anayasal Demokrasi, 3. Bask1, Siyasal Kitabevi, Ankara.

- Gökdayı, İsmail, 1997. Çevrenin Geleceği (Yaklaşımlar ve Politikalar), Türkiye Çevre Vakfı Yayını, Ankara.

- Güler, Çağatay, 1994. Çevre Sözlüğü, Saypa Yayınları, Ankara.

- Güneş, Yusuf/A. Aydın Coşkun, 2004. Çevre Hukuku, Kazancı Hukuk Yayınları, İstanbul.

- Kaboğlu, İbrahim Ö., 1996. Çevre Hakkl, İmge Kitabevi, İstanbul.

- Kaboğlu, İbrahim Ö., 1998. Özgürlükler Hukuku (İnsan Haklarının Hukuksal Yapısı), Alfa Yayınları, İstanbul

- Keleş, Ruşen/Can Hamamcı, 1993. Çevrebilim, İmge Kitabevi, Ankara.

- Keleş, Ruşen/ Birol Ertan, 2002. Çevre Hukukuna Giriş, İmge Yayınevi, Ankara.

- Kuzu, Burhan, 1997. Sağlıklı ve Dengeli Bir Çevrede Yaşama Hakkı, Fakülteler Matbaası, İstanbul. 
- Milattan itibaren çeşitli yıllardaki nüfus miktarı ve gelecek yıllardaki tahmini nüfus miktarı, http://geography.about.com/od/obtainpopulationdata/a/worldpopulation.htm, Erişim Tarihi: 05.07.2011.

- Porritt, Jonathan, 1989. Yeşil Politika, (Çev. Alev Türker), Ayrıntı Yayınları, İstanbul.

- Tekeli, İlhan, 2005. Çevre Hakkına Yerelden Yaklaşmak, Sivil Toplumu Geliştirme Merkezi, Ankara, http://www.stgm.org.tr/tr/icerik/detay/cevre-hakkina-yerelden-yaklasmak, Erişim Tarihi: 10.07.2011.

- Torunoğlu, "Ethem, 2005. Çevre Hakkı Insan Hakkıdır, http://www.sendika.org/yazi.php?yazi_no=1791.17.02.2009, Erişim Tarihi: 17.02.2009.

- $\quad$ Turgut, Nükhet, 1998. Çevre Hukuku, Ankara.

- Ürkmez, Taner, Çevre Hakkının Tarihsel Gelişimi, http://cekud.org/site/page.asp?dsy_id=904, Erişim Tarihi, 17.02.2009.

- Yaren, F. Bülent, 1995. Yaşamı Kavrayış Üzerine Yapılanan Sorun: Çevre Sorunu, Değişen Dünya Görüşü Ekonomi-Ekoloji İlişkileri Bağlamında ekolojik Kalkınma, Yeni Türkiye Dergisi-Çevre Özel Sayısı, Temmuz-Ağustos, s. 90-102. 


\title{
Azgelişmiş Ülkelerde İşsizlik Sigortası'nın Önemi
}

\author{
Faruk Andaç (Çağ University, Turkey)
}

\section{The Importance of Unemployment Insurance in Underdeveloped Countries}

\begin{abstract}
In the absence of unemployment insurance, unemployment descends over like a nightmare on the personnel in business life and constitutes his/her utmost anxiety. Particularly in underdeveloped countries where population increase is rapid whereas speed of industrialization is back, unemployment introduces with itself a good number of adverse effects as well.

On accounts of these reasons there is a substantial need for Unemployment Insurance which is a state-enforced social security in order to meet maintenance and living expenses of the dependant personnel whose active business life has been, due to socio-economic accounts, terminated against their will. Indeed, Unemployment Insurance not only provides fiscal support to the worker but it also guarantees future employment and gains collective bargaining power to the person. By means of an effective job-oriented training and effective operating job-placement system the insurance system also offers a chance of obtaining a new job to the unemployed In other terms "it provides the power and opportunity to acquire in better conditions a new job with appropriate payment answering to the competency and skill of the unemployed".

Unemployment insurance that is desperately needed to make people live happy under the security of job must be, as it is the case for the rest of other countries as well, established in underdeveloped states as well.
\end{abstract}

JEL Code: J65

\section{Giriş}

"İşsizlik Sigortasının mevcut olmadığı bir ülkede işsizlik, bir kabus gibi çalışma hayatındaki ferdin üzerine çökmekte ve onun en başta gelen endişesini teşkil etmektedir’(Ekin, 1971). Özellikle nüfus artışı fazla, sanayileşme hızı yetersiz azgelişmiş ülkelerde işsizlik, pek çok olumsuz etkilerini de beraberinde getirmektedir (Andaç, 2010).

İşsizlik, üretici insan gücü kaynağının israf edilmesine, işgücünün iş göremez veya işe yaramaz duruma gelmesine, dolayısıyla da milli gelir ve üretimin düşmesine, böylece sosyal barışı temelinden sarsmasına neden olmaktadır.

Şüphesiz işsizliği önlemenin en etkin çözüm yolu istihdam kapasitesini artıracak yatırımların artırılmasıdır. Ancak, görülmüştür ki her ülkede hatta gelişmiş ülkelerde bile tam istihdamı sağlamak, işsizliği ortadan kaldırmak mümkün değildir. Buna göre çalışma istek ve yeteneğinde olup da günün çalışma ve ücret koşullarına göre emeğini sunmasına karşın ekonomik nedenlerle uygun bir iş bulamayan işsizin yaşamını devam ettirmesine imkan sağlamak toplumun görevidir (Andaç, 2010).

Bu nedenle kazancı sosyo-ekonomik nedenlerle isteği dışında kesilmiş, çalışma istek ve yeteneğinde olan bağımlı çalışanların geçinme ve yaşama ihtiyaçlarını karşılamak üzere, devletçe zorunlu olarak kurulmuş sigortacılık tekniği ile faaliyet gösteren bir sosyal güvenlik kuruluşu olan İşsizlik Sigortası'na büyük bir ihtiyaç vardır. Zira İşsizlik Sigortası, işçiye parasal destek sağlamakla beraber gelecekte çalışma güvencesi vermekte, ferdi iş pazarlığı gücü kazandırmaktadır. İşe dönük etkin bir eğitim ve iyi işleyen işe yerleştirme sistemi ile işsize yeni bir iş bulma imkanını da vermektedir (Andaç, 2010). Diğer bir ifade ile "işsize nitelik ve yeteneğine göre, daha iyi koşullarda uygun ücretle yeni iş elde etme güç ve fırsatını vermektedir” (Maruflu, vd, 1978).

\section{2 İşsizlik Sigortasının Doğuş Nedeni}

"İnsan tabiat kanunları gereği doğar yaşar ve ölür. Yaşam süreci içinde yaşamını devam ettirebilmesi için birçok mal ve hizmete ihtiyacı vardır. Bu mal mal ve hizmetler tabiatta hazır vaziyette değillerdir. Bunları belli bazı teknik ve ekonomik usullerle kullanılabilir bir duruma getirmek zorundadır. İnsanların yaşamlarını devam ettirebilmeleri için ihtiyaç duydukları bu mal ve hizmetlerin meydana getirilmesine 'Üretim' diyoruz. Üretimin meydana getirilebilmesi için yapılan faaliyetlere, çabalara, gayretlere ise kısaca 'Çalışma' diyoruz. Diğer bir ifadeyle çalışma, insan gücünün katılımı ile yapılan mal ve hizmet üretimidir.” (Andaç, 2008).

Buna göre insanın yaşamını devam ettirebilmesi için mal ve hizmet üretmesi dolayısıyla çalışması gerekir. Eğer bir insan mal ve hizmet üretemiyorsa dolayısıyla çalışamıyor veya çalışmıyorsa yaşamını devam ettirebilmesi zordur, hatta mümkün değildir. 
Bu durumda olan kimselere yani mal ve hizmet üretemeyen, çalışamayan kimselere 'İşsiz' denilmektedir. İşsiz olan bir kimse, kendini hem faydasız, arzu edilmeyen insan olduğu hissine kaptırır hem de kişiyi korkuya sevkeder ve bu korkudan da nefret doğar. Bu konuda William H. Beveridge "İşsizlikten doğan iki kötülük vardır. İlk olarak işsizlik, işsiz kalan kişide faydasız, arzu edilmeyen insan olduğu hissini yaratır. İkinci olarak ise işsizlik, insanların hayatına korkuyu getirir ve bu korkudan da nefret doğar" ifadesini kullanmıştır (Beveridge, 1945).

Diğer taraftan işsizlik, üretici insan gücü kaynağının israf edilmesine, işgücünün iş göremez veya işe yaramaz duruma gelmesine, dolayısıyla da milli gelir ve üretimin düşmesine, böylece sosyal barışı temelinden sarsmasına neden olmaktadir.

Şüphesiz işsizliği önlemenin en etkin çözüm yolu istihdam kapasitesini artıracak yatırımların artırılmasıdır. Ancak, görülmüştür ki her ülkede hatta gelişmiş ülkelerde bile tam istihdamı sağlamak, işsizliği ortadan kaldırmak mümkün değildir. Buna göre çalışma istek ve yeteneğinde olup da günün çalışma ve ücret koşullarına göre emeğini sunmasına karşın ekonomik nedenlerle uygun bir iş bulamayan işsizin yaşamını devam ettirmesine imkan sağlamak toplumun görevidir (Andaç, 2010).

$\mathrm{Bu}$ nedenle kazancı sosyo-ekonomik nedenlerle isteği dışında kesilmiş, çalışma istek ve yeteneğinde olan bağımlı çalışanların geçinme ve yaşama ihtiyaçlarını karşılamak üzere, devletçe zorunlu olarak kurulmuş sigortacılık tekniği ile faaliyet gösteren bir sosyal güvenlik kuruluşu olan İşsizlik Sigortası'na büyük bir ihtiyaç vardır. Zira İşsizlik Sigortası, işçiye parasal destek sağlamakla beraber gelecekte çalışma güvencesi vermekte, ferdi iş pazarlığı gücü kazandırmaktadır. İşe dönük etkin bir eğitim ve iyi işleyen işe yerleştirme sistemi ile işsize yeni bir iş bulma imkanını da vermektedir (Andaç, 2010). Diğer bir ifade ile işsizlik sigortası, "işsize nitelik ve yeteneğine göre, daha iyi koşullarda uygun ücretle yeni iş elde etme güç ve fursatını vermektedir" (Maruflu, vd, 1978).

\section{3 İşsizlik Sigortası Kavramı}

“İşsizlik sigortası, hemen herkesin hem fikir olduğu bir kavram özelliğini henüz taşımamaktadır. Zira, işsizlik sigortasının günümüzde gerçek fonksiyonunu yerine getiren bir kuruluş olduğunu söylemek kanımızca biraz iyimserlik olur. Ancak, gerçek fonksiyonun nelerden oluştuğunu belirtmek de oldukça güç bir sorundur. Çeşitli görüşlerle beraber çeşitli uygulamalara rastlamaktayız. Yalnız hemen şunu belirtelim ki, işsizliği önleyen bir faktör olarak anlaşılmamalı, aksine işsizlik olayı ortaya çıktıktan sonra, fonksiyonunu yerine getiren sosyal güvenlik aracı olarak düşünülmelidir. Kavram olarak açıklığa kavuşabilmesi için işsizlik sigortasının tanımında bir birliğe kavuşmak ve özelliklerini ortaya koymak gerekecektir.” (Andaç, 1999).

Yapılmış olan bazı tanımlara ve işsizlik sigortasının yerini belirlerken elde ettiğimiz sonuçlara dayanarak kesin olmamakla birlikte bize göre tanımını şu şekilde yapabiliriz: "İşsizlik sigortası, kazancı sosyo-ekonomik nedenlerle isteği dışında kesilmiş olup da çalışma istek ve yeteneğinde olan bağımlı çalışanların geçinme ve yaşama ihtiyaçlarını karşılamak üzere, katılma zorunluluğu olan ve sigortacılık tekniği ile faaliyet gösteren sosyal güvenlik sistemi içinde devletçe kurulmuş bir sosyal sigorta koludur” (Andaç, 1999).

1999 tarih ve 4447 sayılı Türk İşsizlik Sigortası Kanununun 47. maddesine göre ise "İşsizlik sigortası: Bir işyerinde çalışırken, çalışma istek, yetenek, sağlık ve yeterliliğinde olmasına rağmen, herhangi bir kasıt ve kusuru olmaksızın işini kaybeden sigortalılara işsiz kalmaları nedeniyle uğradıkları gelir kaybını belli süre ve ölçüde karşılayan, sigortacılık tekniği ile faaliyet gösteren zorunlu sigorta"dır (Andaç, 2010).

\section{4 İşsizlik Sigortasının Özellikleri}

Sosyal sigortaların tüm özelliklerini taşımakla beraber işsizlik sigortasının kendine özgü, sosyal güvenlik kuruluşlarından farklı bazı özellikleri vardır. Bu özelliklerini şöyle sıralayabiliriz:

\section{1 İşsizlik Riskini Tazmin Özelliği}

"İşsizlik sigortasının konusu işsizlerdir. Sosyo-ekonomik nedenlerle isteği dışında geçici bir süre için işsiz kalmış çalışanları kapsamına alır. Bu gibi kişilerin tek gelir kaynağı ücret olduğuna göre bunların işsizlik halinde yaşamlarını devam ettirebilmeleri olanaksızdır. Öte yandan bu gibi kişilerin düşeceği zaruretler toplumda çok büyük bir sosyal, ekonomik ve politik sorunlar yaratmaktadır. Gerek insancıl ve gerekse toplumsal düşünceyle bu gibi kimseleri korumak zarurettir. Kendilerine yaşamlarını devam ettirebilmeleri için iş temin edilemiyorsa bunun tazmini gerekir. İşsizlik sigortası bunu sağlar.

Sosyo-ekonomik risk olan işsizlik, sosyal güvenliğin konusu olan diğer mesleki, fizyolojik ve sosyal risklerden farklıdır. Zira işsiz, kendi elinde olmadan çalışma arzu ve yeteneğinde olmasına rağmen sosyal ve ekonomik bir nedenle işsiz kalmış ve geliri kesilmiştir. Tekrar iş bulup çalışma ihtimali, işsizlik süresi uzadıkça zayıflamaktadır. Halbuki, mesleki ve fizyolojik risklerde tekrar aynı işine dönme hakkı saklıdır. Ancak eklemek gerekir ki her işsize de işsizlik sigortası uygulanması mümkün değildir. Kapsamına girecek işsizlerde bazı koşullar aranmaktadır” (Andaç, 2010). 


\subsection{Zorunluluk Özelliği}

"İşsizlik sigortasına katılmak zorunludur. Bu özelliği diğer özel sigortalardan ve yardım kuruluşlarından ayrılan en önemlisidir. Özel sigortalarda katılmalar ihtiyaridir. Halbuki sosyal, ekonomik ve politik sorun yaratan işsizlik riski için toplumsal ve insancıl açıdan konunun tazmini zorunluluk arzeder. Gerçi, trafik sigortası da zorunludur. Fakat mahiyeti değişiktir.

Yardım sandıklarından da bu özelliğinden dolayı ayrılır. Zira, bu ve buna benzer yardım sandıklarında da katılma ihtiyaridir.

İşsizlik sigortasında zorunluluk olmazsa, işsizlik riskini tazmin etmek sosyal yardım kuruluşlarına düşer. Bu da devlete büyük yük yükler. Zarurete düşmeden bir kimse bunun faydasını anlayamayacağından zorunluluk esası getirilmiştir. İşsizlik sigortasının bu özelliği sayesinde asıl yararı, işsizlik tehlikesinden habersiz olanların da yararlanması sağlanmaktadır. Asıl yardıma muhtaç olan zümre, düşük gelirle çalışan geniş işçi kitleleridir. Bunlar kendi menfaatlerini önceden bilemedikleri için zorunluluk ilkesi getirilmiştir. İşçi çalışmaya başladığ andan itibaren sigortalanır. Hiç bir işçi buna itiraz edemez" (Andaç, 2010).

\subsection{Prim Ödeme Özelliği}

"Sigortacılık tekniği gereği işsizlik sigortası işçinin prim ödeme esasına dayanır. Bu özelliğinden dolayı işsizlik halinde alacağı ödenek bir haktır. İane olarak değerlendirilmemelidir. Primler genel ilke olarak sadece sigortalılar tarafindan ödenmekle beraber sosyal politika ilkelerine dayalı olarak sosyal adaletin gerçekleştirilmesi amacıyla buna işverenler ve gerekirse devlet özel veya genel vergilerle katkıda bulunur.

Devletin katkısı ancak bütün işsizlerin işsizlik sigortası kapsamına alınması halinde görülmektedir. Eğer daha önce bir işte çalışmış, yetersiz prim ödemiş veya hiç prim ödememiş ya da hiç çalışmamış bütün işsizlerin işsizlik sigortası kapsamına alınması gibi bir uygulama yapılacaksa, devlet bu sırada prim ödeme zorunda kalabilir. Fakat bugün için böyle bir uygulamaya rastlanmamıştır. Ancak, Hindistan'da böyle bir uygulamaya gidilmesi düşünülmüş ise de devlete büyük maddi külfet yükleme yanında diğer bir takım sorunları da beraberinde getireceği anlaşılınca bu düşünceden vazgeçilmiştir (Şahin, 1979).

Primlerin miktarı ve işçi-işverene düşecek nispetler aktüaryal hesaplarla tespit edilir. Sigortacılık tekniğine göre hesaplanır. Bu hesaplamada muhtemel işsizlik süresi içinde geçimini sağlayacak asgari ücreti karşılayacak prim miktarı belirli bir süre ödenmek koşuluyla ilgililerden kesilir. Ancak işçinin çalışırken geçimini tehlikeye sokmayacak bir miktar olması da gerekir.

İşçinin prim ödemesi ona bu sigortadan yararlanma hakkını verir. İşsizlik halinde alacağı ödenekler bir haktır. İane, sadaka, yardım değildir. Sosyal yardım kuruluşlarından bu yönü ile ayrılır” (Andaç, 2010).

\subsection{Devletçe Kurulma Özelliği}

"Günümüzde, işsizlik sigortası diğer sosyal sigorta kuruluşları gibi devlet tarafından özel yasalarla kurulmaktadırlar. Daha önceleri tarihsel gelişim seyrine baktığımızda, sendikalar tarafından, işverenler tarafindan, mahalli idareler tarafından kurulmaktaydılar. Fakat, gelişen sosyal olaylar karşısında devlet bizzat sosyal önlemler almaya başlamıştır. Hatta, devletin yapısında da değişme olmuş, Mutlak Liberalist Devlet yapısı, Müdahaleci Sosyal Hukuk Devleti şekline dönüşmüştür. Bugün bütün uygulamalarda sosyal sigortalar gibi işsizlik sigortası da devlet tarafından özel yasayla kurulmakta ve yönlendirilmektedir.

İnsan Hakları Evrensel Beyannamesi ilkelerini benimsemiş her devlet gibi sosyal güvenlikle ilgili hükümler (İnsan Hakları Beyannamesinin 22. ve 25. Maddeleri hükümlerinde olduğu gibi) 1982 Anayasamızın 60. maddesinde yer almıştır. Sosyal devlet kavramının doğal bir neticesi olan bu madde aynen şöyledir: "Herkes, sosyal güvenlik hakkına sahiptir. Devlet, bu güvenliği sağlayacak gerekli tedbirleri alır ve teşkilatı kurar”.Şu halde sosyal güvenlik hakkını sağlamak için sosyal sigorta ve sosyal yardım kuruluşları kurmak ve kurdurmak devletin ödevlerindendir" (Andaç, 2010).

\subsection{Yeniden İşe Yerleştirme Özelliği}

"İşsizlik sigortaları genellikle işsize gelir kaybını telafi etmek için parasal destek olması yanında, kendisine en kısa bir zaman içinde iş bulmak zorundadır da. Zira, uzun süre işsize yardımcı olması kurumun masraflarının artmasına neden olacaktır.

Uzun süreli işsizlik, işsizin vasfinı yitirmesine neden olmakta, psikolojik ve sosyolojik bunalımlara düşmesine, adi suçlar işlemesine sebep olmakta, çalışmaya karşı isteksizliği artırmakta, kişiliğini yitirmesini, sorumluluk duygusunun azalmasını oluşturmaktadır. Bu nedenle işsizlik sigortası eğitim programları düzenlemekte, işsizi yeniden çalışma hayatına katılmaya hazır vaziyette tutmak zorunda kalmaktadır.

$\mathrm{Bu}$ nedenlerle işsizlik sigortası işsizin kendi gayreti yanında işsize en kısa süre içinde iş bulup, yeniden işe yerleştirmek zorunda kalmaktadır. Bunun için işsizlik sigortası kuruluşları, iş ve işçi bulma kurumları ile işbirliği içinde faaliyetlerini sürdürmek zorundadır. Yine mesleki eğitim kuruluşlarıyla da ilişki içinde bulunmak gereğini hissetmektedir" (Andaç, 2010). 


\section{5 İşsizlik Sigortasının Kapsamı}

İşsizlik sigortasının kapsamını şüphesiz bir iş yerinde bağımlı çalışıp da, sosyo-ekonomik nedenlerle isteği dışında işsiz kalanlar oluşturur. Genellikle bağımlı çalışanlar işçilerdir. Bağımsız çalışanlar da (veya çalıştıran) işverenlerdir.

İşçi, üretime genellikle bedeni iş gücü ile katkıda bulunan kimselerdir Bu günkü anlayışla işçi, kapitalist sanayi düzeninin bir sonucu olup üretim araçları ile çalışan ve hür bir anlaşma ile sermaye sahibine emeğini satarak yaşayan kişidir (Sencer, 1969).

Bağımsız çalışanlar ise, üretim faaliyetini kendi hesabına yürüten sermaye sahibi olanlardır. Kendi mülkiyetinde bulunan üretim araçlarını yöneten, kullanan ve serbestçe kullanma olanağına sahip kimselerdir. Diğer bir tanımla üretime genellikle sermayeleri ile katkıda bulunan kimselerdir. Bunlar kendi iş güçleriyle birlikte yardımcı iş gücü kullanarak ya da kendileri bizzat üretim faaliyetinin içinde olmayıp iş gücü kiralayarak başka kimselere üretim yaptırırlar. Bağımsız çalışanlar işsizlik sigortası kapsamına girmezler.

İşsizlik sigortası, tanımında da belirtilmiş olduğu gibi işsize hizmet eden bir kuruluştur. Ancak, şunu da belirtmek gerekir ki, her işsize hizmet eden bir kuruluş değildir. Kapsama girecek işsiz, çalışma istek ve yeteneğinde olup da günün çalışma ve ücret koşullarına göre emeğini sunmasına karşın sosyo-ekonomik nedenlerle isteği dışında (gayri iradi) çalışma olanağı bulamayan kişidir. Buna göre, iradi işsizlik kapsam dışı bırakılmış olup, gayri iradi işsizlik de belirli bir süre prim ödeme firsatı buluncaya kadar çalışabilmiş kimseler bu sigortadan yararlanabileceklerdir.

\section{Sonuç}

İnsanların iş güvencesi içinde daha mutlu yaşaması için en çok ihtiyaç duyulan İşsizlik Sigortası her ülkede olduğu gibi özellikle azgelişmiş ülkelerde de kurulmalıdır (Andaç, 1988).

\section{Kaynakça}

- $\quad$ ANDAÇ, 1988. Milliyet Gazetesi. 8 Nisan 1988.

- ANDAÇ, 1988. İş Hukuku, Adalet yayınevi, Ankara.

- $\quad$ ANDAÇ, 1999. İşsizlik Sigortası, TÜHİS yayını, Ankara.

- $\quad$ ANDAÇ, 2010. İşsizlik Sigortası, TÜHİS Yayını, 2. Baskı, Ankara.

- $\quad$ BEVERIDGE, 1945. Full Employment in a Free Society, W.W. Norton and Co.Inc. New York.

- $\quad$ EKİN, 1971. İşsizlik, İstanbul.

- MARUFLU, vd, 1978. “Türkiye'de İşsizlik Sigortası Uygulamasına Dönük Model Araştırması”, DPT yayını, 1630 (304), p. 15.

- SENCER, 1969. Türkiye’de İşçi Sınıfi Doğuşu ve Yapısı, İstanbul.

- ŞAHIN, 1979. “İşsizlik Sigortası Üzerine bir araştırma”, İşgücü Dergisi, 3, p. 14. 


\title{
Türkiye'de Yeşil Yakalı Mesleklerin Gelişiminde Güncel Eğilimler
}

\author{
Zerrin Sungur (Anadolu University, Turkey)
}

\section{Current Trends in the Development of Green Jobs in Turkey}

\begin{abstract}
A sustainable green economy simultaneously values the importance of natural resources and inclusive, equitable, and healthy opportunities for all communities. A green job, also called a green-collar job is, according to the United Nations Environment Program, "work in agricultural, manufacturing, research and development, administrative, and service activities that contribute(s) substantially to preserving or restoring environmental quality. Specifically, but not exclusively, this includes jobs that help to protect ecosystems and biodiversity; reduce energy, materials, and water consumption through high efficiency strategies; de-carbonize the economy; and minimize or altogether avoid generation of all forms of waste and pollution." Turkey, an OECD country, also has some green jobs and employment. The main purpose of this study is to explore the trends in the emergence of green jobs sector and also to investigate the reflections of these developments on the employment rates in Turkey. The potential for green jobs exist in countries at all levels of economic development. Investments and programs to promote green jobs can be targeted at those who tend to need them most; young people, women and poor in Turkey.
\end{abstract}

JEL Codes: Q56, O13

\section{Giriş}

Günümüzde çözüm aranan temel ekonomik ve sosyal sorunlar artık hem ulusal hem de küresel düzeyde çevre sorunlarından ayrı düşünülemez hale gelmiştir. Yoksulluk, işsizlik, kentleşme ve nüfus artışı gibi sorunlar bir taraftan kalkınma, istihdamın artırılması ve yeni işlerin yaratılması gibi çıkış yollarına doğru ilerlerken, bu süreçte sürdürülebilirlik ve yenilenebilirlik kavramları ön plana çıkmıştır.

Tarım ve sanayi toplumlarında doğal kaynaklar ve çevre hoyratça kullanılmıştır. Özellikle geçtiğimiz yüzyılın son çeyreğinden itibaren "gelecek nesillerin kendi ihtiyaçlarını karşılayabilmelerini tehlikeye sokmaksızın bugünkü nesillerin ihtiyaçlarını karşılayabilen kalkınma” yani sürdürülebilir kalkınma anlayışı giderek hâkim olmaktadır. (Fisunoğlu, 1990; Tosunoğlu, 1998) Bu bağlamda sürdürülebilirlik ve yenilenebilirlik kavramları doğal kaynakların daha etkin kullanılması gereğini beraberinde getirirken, çalışma yaşamına yeni ufuklar ve meslekler kazandırmıştır. Sanayi toplumu ve sonrasında mavi ve beyaz yakalı meslekler ağırlıkta iken, bugün bu mesleklerin yanında artık yeşil yakalı olarak ifade edilen meslekler de istihdam yapısında önem kazanmaktadır.

Bu bildiride öncelikle yeşil yakalı mesleklerin tanımı ve kapsamı, daha sonra ise bu mesleklerin gelişim seyri ve istihdam kapasiteleri ele alınacaktır. Son olarak da, dünyada ve Türkiye'de yeşil yakalı mesleklere ilişkin istihdam ve eğitim olanaklarının gelişme seyri değerlendirilmeye çalışılacaktır.

\section{Yeşil Yakalı Mesleklerin Tanımı ve Kapsamı}

Birleşmiş Milletler Çevre Programı'nda yer alan tanıma göre “yeşil işler” ya da bir başka deyişle yeşil yakalı meslekler imalat, tarım, hizmet ve Ar-Ge sektörlerinde insanlığın karşı karşıya olduğu çevresel tehditleri gidermeyi amaçlayan işler/ mesleklerdir. (UNEP, 2008) Mavi yakalılar sanayideki, fabrikalardaki, üretim bantlarındaki emek yoğun işçi kesimini, beyaz yakalılar ise kurumsal alanda, ofislerde çalışanları tanımlamakta iken, son dönemlerde yukarıda tanımlanan "yeşil yakalı" meslekler ön plana çıkmaktadır. Ancak, yeşil yakalı meslekler sadece çevre dostu işlerle sınırlı olmayıp, toplumun yararına çalışan tüm sivil toplum kuruluşlarından sürdürülebilirliğe öncelik veren mesleklere kadar oldukça geniş bir alana uzanmaktadır.

Çevre dostu meslekler olarak tanımlanan yeşil işler büyümenin, sürdürülebilir kalkınmanın ve işsizlikle mücadelenin öncüsü olarak görülmektedir. ILO’nun tanımına göre; bir iş sürdürülebilir üretime katkı sağlıyorsa, enerji ve doğal kaynaklardan tasarruf ediyorsa, yenilenebilir enerji kullanıyorsa, çevre ve hava kirliliğine yol açmıyorsa, biyo-çeşitliliği koruyorsa o iş yeşil bir iştir; inşaattan tarıma, hizmetten metalürjiye kadar. Yeşil işler sadece çevre koruma sektörleriyle de ilgili değildir. (http://tr.euronews.net)

Yeşil yakalı meslekler arasında; yenilenebilir enerji danışmanlığı, yenilenebilir enerji mühendisliği, rüzgar enerjisi uzmanlığı, rüzgar enerjisi teknikerliği, yeşil pazarlama danışmanlığı, karbon satış uzmanlığı, yeşil insan kaynakları yöneticiliği, çevre ve enerji hukuku uzmanlığı, organik tarım mühendisliği, doğal yaşam koçluğu, ekolojik turizm danışmanlığı, 1sı yalıtım uzmanlığı, çevre mühendisliği, ekolojik bina tasarımcılığı, şehir planlama mühendisliği, atık su uzmanlığı ve içilebilir su uzmanlığı sayılabilir. Hatta yeşil kozmetik veya organik kozmetik gibi ileride yeni alanlar da ortaya çıkabilecektir. 


\section{Yeşil Yakalı Mesleklerin Gelişimi}

Yeşil yakalı meslekler yelpazesinin dünyada ve özellikle gelişmiş ülkelerde genişlemesi üç temel nedenle ilişkilendirilebilir. Bunlar; teknolojik gelişmeler, ekonomik koşullar ve enerji politikalarıdır.

Teknolojik gelişmeler. Birçok verimli ve yenilenebilir enerji teknolojileri geleneksel fosil yakıt teknolojilerinden daha maliyetli ve pahalıdır. Fakat yenilenebilir teknolojiler ucuzladıkça piyasa buna hızla uyumlu hale gelmektedir. Rüzgâr, güneş ve hidrojen gibi kaynakların ve bunlarla ilgili teknolojilerin geleceğin piyasasında baskın olacağı tahmin edilmektedir. Diğer taraftan bu kaynaklardan hangisinin önde olacağ 1 konusu henüz net değilken, ülkelerin enerji politikalarının farklı birçok temiz enerji kaynağının bir araya geldiği bir doku ile oluşacağı beklenmektedir.

Ekonomik koşullar. Ekonomik açıdan bakıldığında ise, verimli ve yenilenebilir enerji teknolojisinin sermaye yoğun olduğu görülmektedir. Bu durumda enerji fiyatları ve ekonomi, işletmelerin ve tüketicilerin eğilimlerini ve yatırım özelliklerini etkileyecektir. Fosil yakıt fiyatlarının son yıllarda giderek yükselmesi, verimli enerji ve yenilenebilir teknolojilerin ekonomik açıdan bir seçenek olmalarını ve güçlenmelerini etkilemiştir.

Enerji politikaları. Bu yönde bir değerlendirme yapıldığında ise, genellikle uzun dönemli hedefleri olan enerji politikalarının işletmelerde yeşil enerji ve teknolojilere yatırım yapma ihtiyacını doğurduğu söylenebilir. (Cleary and Kopicki, 2009)

\section{Dünyada Yeșil Yakalı Meslekler}

Dünyada en çok yeşil yakalı sırasıyla Çin, A.B.D., Brezilya ve Almanya'da çalışmaktadır. Dünyada 2030 yılına kadar yeşil iş yaratmada liderliği biyolojik yakıt sektörünün alması ve 12 milyon yeni işin ortaya çıkması beklenmektedir. Bunu 6.3 milyon işle güneş enerjisinden elektrik üretimi izlerken, rüzgar enerjisinden elektrik üretiminin de 2.1 milyon iş yaratması tahmin edilmektedir. Yeşil yakalı mesleklerin bilinen gelişme seyri genellikle gelişmiş ülkelerde gerçekleşirken, Brezilya ve Çin gibi hızlı gelişen ülkelerde de bazı gelişmeler dikkat çekmektedir. Bunların yanında yeşil yakalı meslekler gelişmekte olan diğer ekonomilerde de görülmeye başlanmıştır. Örneğin; Bangladeş’te yürütülen bir projede yerli gençler ve kadınlar gerekli eğitimi alarak sertifikalı güneş teknisyenleri, bakım ve onarım uzmanları olarak yetiştirilirken, böylelikle 100000 kişiye istihdam olanağı yaratılacaktır. Hindistan'da ise 9 milyon hanenin verimsiz çalışan eski tip ocaklarının gelişmiş olanlarla değiştirilmesi sayesinde 150000 kişiye istihdam sağlanabilecektir. (ILO, 2008)

\begin{tabular}{|c|c|c|c|}
\hline Yenilenebilir enerji kaynağg & Dünya * & \multicolumn{2}{|c|}{ Seçilmiş ülkeler } \\
\hline Rüzgar & 300,000 & $\begin{array}{c}\text { Almanya } \\
\text { ABD } \\
\text { İspanya } \\
\text { Çin } \\
\text { Danimarka } \\
\text { Hindistan }\end{array}$ & $\begin{array}{l}82,100 \\
36,800 \\
35,000 \\
22,200 \\
21,000 \\
10,000\end{array}$ \\
\hline Güneş (fotovoltaik) & $170,000 * *$ & $\begin{array}{c}\text { Çin } \\
\text { Almanya } \\
\text { İspanya } \\
\text { ABD }\end{array}$ & $\begin{array}{l}55,000 \\
35,000 \\
26,449 \\
15,700 \\
\end{array}$ \\
\hline Güneş (Termal) & 624,000 ve üstü & $\begin{array}{c}\text { Çin } \\
\text { Almanya } \\
\text { İspanya } \\
\text { ABD }\end{array}$ & $\begin{array}{c}600,000 \\
13,300 \\
9,142 \\
1,900 \\
\end{array}$ \\
\hline Biyokütle & $1,174,000$ & $\begin{array}{c}\text { Brezilya } \\
\text { ABD } \\
\text { Çin } \\
\text { Almanya } \\
\text { İspanya }\end{array}$ & $\begin{array}{c}500,000 \\
312,200 \\
266,000 \\
95,400 \\
10,349\end{array}$ \\
\hline Hidroelektrik & 39,000 ve üstü & $\begin{array}{c}\text { Avrupa } \\
\text { ABD }\end{array}$ & $\begin{array}{l}20,000 \\
19,000\end{array}$ \\
\hline Jeotermal & 25,000 & $\begin{array}{c}\text { ABD } \\
\text { Almanya }\end{array}$ & $\begin{array}{c}21,000 \\
4,200\end{array}$ \\
\hline Yenilenebilirler, Toplam & $\begin{array}{c}2,332,000 \mathrm{ve} \\
\text { üstü }\end{array}$ & & \\
\hline
\end{tabular}

Tablo 1. Seçilmiş Ülkelerde ve Dünyada Yenilenebilir Enerji Sektöründe Tahmini İstihdam Rakamları. Kaynak: http://www.ilo.org *Verilerin mevcut olduğu ülkeler için geçerlidir. ** Japonya'nın PV endüstrisinde Almanya'nın PV endüstrisi kadar istihdam sağlandı̆̆ varsayılmaktadır. 
Dünya çapında halihazırda yenilenebilir enerjide yeşil işlerin dağılımı 2010 yılı itibariyle incelenirse; sırasıyla biyokütle enerjisi ( $\% 50)$, güneş enerjisi ( $\%$ 27), rüzgar enerjisi (\% 13), fotovoltaik güneş enerjisi (\% 7), hidroelektrik enerji (\% 2) ve jeotermal enerji (\%1) gelmektedir. Bu dağılım tablosunun 2030 yılında üç ana kaynakta yoğunlaşarak biyoyakıtın \% 59, fotovoltaik güneş enerjisinin $\% 31$ ve rüzgarın $\% 10$ pay aldığı bir tabloya dönüşeceği kestirilmektedir.(Basmac1, 2011)

Dünyada, rüzgar enerjisi sektöründe 300000 kişiye istihdam sağlanmaktadır. Güneş enerjisinde ise (fotovoltaik ve termal) büyük çoğunluğu Çin'de olmak üzere yaklaşık 800 bin kişi çalışmaktadır. Yaklaşık 1,2 milyon kişi biyokütle alanında çalışırken, bunun da çevresel etkileri tartışmalı olan biyoyakıt alanında önde gelen dört ülkede (Brezilya, ABD, Almanya, Çin) yoğunlaştı̆̆ı görülmektedir. (Tablo 1)

Dünyada, geri dönüşüm, enerji verimliliği, su arıtımı ve sürdürülebilir ulaşımı içeren çevresel ürünlerin ve hizmetlerin toplam hacmi bugün 1000 milyar Avro olarak hesaplanırken, bu rakamın 2020 yilında 2200 milyar avroya ulaşması beklenmektedir. Avrupa Komisyonu'nun tahminlerine göre Avrupa Birliği'nin eko-endüstrisi, y1llık 227 milyar Avro'luk hacmi ve AB'nin toplam GSMH'sinin \% 2,2'si ile Avrupa'nın en büyük sektörlerinden biri durumundadır. Bu endüstri geniş bir şekilde tanımlanmıştır: kirlilik kontrolü (çoğunlukla hava kirliliği kontrolü, atık yönetimi ve çevre yönetimi) ve kaynak yönetimi (yenilenebilir enerji tesisleri ve su tedariki) başlıca alanlar arasındadır. Komisyona göre eko-endüstri 3,4 milyon tam zamanlı istihdam oluşturmaktadır ki, bu hem otomotiv imalat sanayindeki, hem de ilaç sanayindeki istihdamdan daha fazladır.

Son yıllarda bu alanda çeşitli politikalar geliştirilmiş ve seçim kampanyalarında işlenen bir konu haline gelmiştir. İngiltere'de faaliyet gösteren New Economics Foundation, ABD eski başkanlarından Roosevelt'in 1930ların ekonomik bunalımından çıkmak için önerdiği "Yeni Düzen" politikalarını dönüştürüp iklim değişikliği, işsizlik ve finansal kriz ile başa çıkmak için "Yeni Yeşil Düzen" adı altında 100 ayda uygulanacak bir program önermiştir. Hemen ardından, Birleşmiş Milletler Çevre Programı "Küresel Yeşil Yeni Düzen" raporunu açıklamıştır. Raporun amaçları arasında dünya ekonomisini canlandırmak, istihdam oluşturmak ve korumak; sürdürülebilir ve kapsayıcı bir büyümeyi teşvik etmek, "Milenyum Gelişim Hedeflerine" ulaşmak, özellikle 2015'e kadar aşırı yoksulluğu ortadan kaldırmak ve karbona bağımlılığını ve ekosistemin bozulmasını engellemek yer almaktadır. ABD Başkanı Obama, seçim kampanyası sırasında açıkladığı "Amerika için Yeni Enerji" planı çerçevesinde gelecek 10 yıl içinde 5 milyon "yeşil yakalı" istihdamı için 150 milyar dolarlık yatırım yapacağını belirtmiş̧ir. İngiliz Yeşil Partisi de bir milyon yeşil iş vaat etmektedir. (http://www.ekolojimagazin.com) Hillary Clinton 2008 yılında A.B.D. başkanlık seçimi kampanyalarında yaptığı konuşmalarda daha fazla yeşil yakalı iş olanağı sağlanması yolunda seçmenlere özellikle vaatlerde bulunmuştur. Diğer adaylar da konuşmalarında A.B.D.'nin enerji politikalarına ilişkin olarak milyonlarca kişiye yeşil yakalı istihdam sağlayabilecek olan sürdürülebilir ve yenilenebilir gelişmeye benzer vurgular yapmışlardır. (Pappu, 2008; Chozick, 2008)

Bir çevre kuruluşu olan Greenpeace'ın yaptığı bir araştırma sonucuna göre dünyada sadece yenilenebilir enerji sektöründe en az 8 milyonluk bir istihdam olanağı bulunmaktadır. Bu alanda özellikle temiz enerjide lider olan Almanya'nın 250 bin kişilik yeşil istihdamı 2020'de 450 bine çıkarmayı hedeflemektedir. Almanya örneğindeki başarının güçlü siyasi bir kararlılığa dayandığı ifade edilmektedir. Hükümet destekli krediler, yenilenebilir enerji hakkında çıkarılan yasa, yatırımcılara sağlanan imkânlar kararlııklar arasında yer almaktadır. Aynı zamanda 2020 yılı Avrupa Birliği’nin 3 milyon kişilik yeşil istihdama ulaşmayı hedeflediği bir tarihtir. (http://tr.euronews.net) Almanya, 2001'de aşamalı olarak nükleerden vazgeçme kararı verdiğinde yenilenebilir enerjileri destekleyen bir dünya lideri konumuna gelmiştir, fakat daha sonra bu eski teknolojilere bağlı kalma kararının yeşil enerjide bugüne kadar çeyrek milyon yeni iş alanı yaratan Almanya'yı lider konumundan indireceği ifade edilmektedir. Greenpeace, Almanya Başbakanı Angela Merkel'in Almanya'da bulunan nükleer santrallerin çalışma sürelerini 8-14 yıl arasında uzatma açıklamasını kınarken, bu kararı Alman halkının geleceğini tehlikeye atan ekonomik ve ekolojik bir çılgınlık olarak tanımlamaktadır. (http://www.greenpeace.org)

Yeşil yakalı mesleklerin iyi ücretlerle çalışlan, iş güvencesi, güvenli çalışma koşulları olan, işyerinde şerefe, itibara, çalışanların haklarına önem verilen yani düzgün işler olması da gerekmektedir. Maalesef, günümüzde bu her zaman geçerli bir durum değildir. Geri dönüşüm işi bazen ciddi sağlık sorunlarına, meslek hastalıklarına yol açabilecek, düşük ücretli bir iştir. Brezilya, Kolombiya, Malezya ve Endonezya gibi biyoyakıt ürünlerinin yetiştirildiği ülkelerde çalışanlar genellikle aşırı iş yükü, düşük ücretler, tarım ilaçlarına ve baskıya maruz kalma gibi güçlüklerle baş etmek zorundadırlar. Bu dikkat çekici nokta, sürdürülebilir kalkınmanın sadece çevre için değil, yeşil yakalılar için de geçerli olması gereğini ortaya çıkarmaktadır. (http://www.worldwatch.org)

Dünya Çalışma Örgütü'nün Yeşil Yakalı Meslekler Programı'nda Kasım 2010 tarihi itibariyle ülke düzeyinde verilen destekler üç temel başlıkta yer almaktadır. Bangladeş, Brezilya, Şili, Çin, Kosta Rika, Hırvatistan, Fiji, Guyana, Haiti, Hindistan, Endonezya, Kenya, Tanzanya, Uganda, Lübnan, Nepal, Filipinler, Sri Lanka, Güney Afrika ve Tayland yeşil yakalı meslekler konusunda aktif olarak desteklenmekte ve finanse edilmektedir. El Salvador, Honduras, Sırbistan ve Güney Afrika'nın alt bölgelerinde yeşil yakalı işler henüz küçük bir pay almakta iken finanse edilmeye ihtiyaç duymaktadır. Üçüncü grupta yer alan Hırvatistan, Dominik Cumhuriyeti, Laos, Liberya, Malavi, Senegal ve Vietnam ise yeşil yakalı işler konusunda destek talebinde bulunan ülkeler olarak sıralanmaktadır. (http://www.ilo.org) $\mathrm{Bu}$ üç grupta yer alan ülkelerin kıtalara göre yoğunluğu 
incelendiğinde ağırlıklı olarak özellikle Doğu Asya'nın, Güney Amerika'nın doğusunun ve Güney ve Doğu Afrika’nın ön plana çıktığı görülmektedir. Bu tablo içerisinde gelişmekte olan ülkelerden biri olarak Türkiye'nin de yerini alması ve tabi ki desteklenmesi gerekmektedir.

\section{Türkiye'de Yeşil Yakalı Meslekler}

Türkiye, enerji ihtiyacının büyük bir kısmını geleneksel enerji kaynaklarından sağlamaktadır. Örneğin; enerji ihtiyacının \% 85'i petrol, taşkömürü, doğalgaz ve linyit gibi fosil yakıtlardan oluşmaktadır. Ayrıca Türkiye enerjisinin \% 70 veya daha fazlasını da ithal kaynaklardan temin eden bir ülke konumundadır. Genel enerji tüketiminde \% 38 ile petrol, \% 27 ile kömür, \% 23 ile doğal gaz ilk sıraları alırken, geriye kalan \% 12'lik pay hidrolik dâhil olmak üzere yenilenebilir enerji kaynaklarından elde edilmektedir. (Tutar ve Eren: 2011)

Özellikle son dönemlerde yapılan yenilenebilir enerji yatırımları ve AB ile başlayan çevre müzakereleriyle beraber Türkiye'de yeşil yakalı mesleklerde bir artış görülmektedir. Türkiye'de kamu sektöründe çevresel faaliyetlerde istihdam edilenler ve özel sektörde rüzgâr endüstrisinde, organik tarımda, ekolojik pazarlarda çalışanlar ve çevre mühendislerinin sayıları incelendiğinde, 50000 kişilik bir istihdam olduğu varsayılmaktadır. Sadece hidroelektrik santrali, rüzgâr santralleri ve jeotermal projelerin hayata geçmesiyle bu sayının 100000 'in üzerine çıkması tahmin edilmektedir. Türkiye'de ulaşım, inşaat, enerji, tarım gibi sektörlerde yeşil işlerin gelişmesi çok daha kolay görünmektedir. Bu alanda kamu ve özel sektörün işbirliğine bağlı olarak karbon salımının azaltılması yönündeki çabalar karşılığını bulabilir. Yenilenebilir enerji sektöründe rüzgâr ve güneş enerjisine yapılacak yatırımlar kısa sürede yüz binlerce yeni istihdam yaratabilir özelliktedir. Yine yenilenebilir enerji sektöründe bulunan jeotermal, hidroelektrik, biyokütle alanlarında da yüksek seviyede istihdam potansiyeli bulunmaktadir.

AB'nin çevre müktesebatı içerisinde en kapsamlı düzenlemelerden biri sanayi kirliliğinin önlenmesine yönelik atık yönetimidir. Bu doğrultuda Türkiye'de de sanayi işletmeleri, lisans ve emisyon limit değerleri temelinde sıkı koşullara tabi tutulacaktır. İşletme izin prosedürlerini yürüten farklı kamu kurumları arasında etkin bir eşgüdüm mekanizması oluşturulacaktır. Ayrıca, atık oluşumu ve bertaraf edilmesi, enerji verimliliği, hammadde kullanımı, gürültü ve kazaların önlenmesi gibi hususlar bütünsel bir yaklaşımla ele alınacaktır. Kirliliğin kaynakta kontrolü, azaltılması, yeniden kazanımı ve geri dönüşümü gibi önlemler yoğunlaşacaktır.

Türkiye'de yeşil yakalıların toplam sayısı henüz bilinmemekle beraber, Avrupa Rüzgar Enerjisi Birliği verilerine göre Avrupa Birliğgi'nde yeni kurulacak her bir MW'lık güç için 15 kişi istihdam edilebilmektedir. Ülkemizde hâlihazırda işletmede olan 433 MW gücünde rüzgâr santrali dikkate alındığında, rüzgar endüstrisinde yaklaşık 6500 kişilik istihdam yaratıldığı söylenebilir, fakat bu rakamın tamamının sürekli iş olduğu varsayılamaz. Yeşil yakalıların yenilenebilir enerji sektörünün ötesinde tarımda da kendine çalışma sahası bulduğu dikkate alınmalıdır. Örneğin; organik tarımda çalışan 14000 üretici bulunmaktadır; ekolojik pazarlarda, ekolojik ürün dağıtımı ve satışında çalışanlar da eklendiğinde bu rakam daha da artacaktır. Yalıtım sektöründe 15 000 kişinin çalıştığı tahmin edilmektedir. Çevre Mühendisleri Odası'na kayıtlı 6000 çevre mühendisi bulunmaktadır. Güneş enerjisi sektöründe 2001 rakamlarına göre 2000 kişi istihdam edilmiştir. Kamu kurum ve kuruluşlarında 2007 yılı itibariyle çalışan 8 500'e yakın yeşil yakalı kişi de dâhil edildiğinde, günümüzde Türkiye'de yaklaşık 50000 yeşil yakalının çalıştığı söylenebilir.

Rüzgâr enerjisi konusunda Elektrik İşleri Etüt İdaresi Genel Müdürlüğünün (EİE) hesaplamalarına göre Türkiye'nin rüzgâr potansiyeli 48000 MW civarındadır. Enerji Bakanlığı'na göre kurulu güç 2020 yılına kadar 20 bin MW`a çıkarılacak. Avrupa Rüzgâr Enerjisi Birliği’nin verdiği yukarıdaki orana göre rüzgâr enerjisi sektöründe 2020’ye kadar 20 bin MW'a ulaşılırsa 300 bin kişilik istihdam sağlanabilecektir. Bu sektörde özellikle rüzgar tribünlerinin yurtiçinde imal edilmesiyle daha fazla iş alanı yaratılabilecektir. Ayrıca EİE'nin verilerine göre Türkiye' de şu anda güneş enerjisi kapasitesinden ancak binde 1 oranında yararlanılabilmektedir. $\mathrm{Bu}$ alanda da önemli bir istihdam yaratılması mümkün görünmektedir. Aynı şekilde yenilenebilir enerji endüstrisinin diğer alanlarında-jeotermal, hidroelektrik, biyokütle - çalışan ve ileride çalışabilecek yeşil yakalıların bir envanteri de çıkarılabilir.

Türkiye'de güneş enerjisi araştırma ve geliştirme konularında Elektrik İşleri Etüt İdaresi Genel Müdürlüğü (EIE)’nin yanında TÜBİTAK, Marmara Araştırma Merkezi (MAM) ve çeşitli üniversitelerde (Ege Üniversitesi Güneş Enerjisi Araştırma Enstitüsü, Muğla Üniversitesi, ODTÜ, Kocaeli Üniversitesi, Fırat Üniversitesi, Anadolu Üniversitesi vb.) çalışmalar yapılmaktadır. Güneş enerjisi verilerinin ölçülmesi konusunda Devlet Meteoroloji İşleri Genel Müdürlüğü faaliyet göstermektedir. Türkiye’nin en fazla güneş enerjisi alan bölgesi Güney Doğu Anadolu Bölgesi’dir, bunu Akdeniz Bölgesi izlemektedir. (Yörükoğulları: 2010)

Türkiye'nin jeotermal enerji potansiyeli değerlendirildiğinde ise; halen 85 MWe kurulu güç ile üç ayrı jeotermal santralden elektrik enerjisi üretildiği ve büyük çoğunluğu Batı Anadolu'da yer alan yerleşim alanlarında konut ve sera ısıtmacılığı uygulamalarının mevcut olduğu görülmektedir. (Parlaktuna: 2010)

Türkiye'nin yıllık benzin tüketimi 4.5 milyon m 3tür. \% 2'lik karışım oranında 90 bin ton, 5 5'lik karışımda 225 bin ton biyoetanol ihtiyacı söz konusudur. Yıllık motorin tüketiminin yaklaşık 10 milyon ton olduğu ülkemizde \% 2'lik karıştırma oranı için biyodizel ihtiyacı 200 bin m 3 tür. Biyoetanol üretiminin artırılabilmesi 
için üretim miktarlarının artırılması gerekmektedir, bunlar içinde en uygun hammaddeler mısır ve buğdaydır. Mısır üretiminin 5 yıl içerisinde 8 milyon tona, buğday üretiminin de 23 milyon tona çıkarılması mümkündür. Yağ bitkileri tarımının yaygınlaştırılması ile ekonomiye olan katkılar yanında ham yağ ve ham petrol bazında yaklaşık 11 milyon dolarlık bir döviz tasarrufu söz konusudur. (Koçkar: 2010)

Türkiye, dünya hidroelektrik potansiyeli içinde \% 1 paya sahiptir. 129,9 milyar kWh ekonomik yapılabilir potansiyeli ile Avrupa ekonomik potansiyeli içinde yaklaşık \% 15 hidroelektrik potansiyeline sahip bulunmaktadır. Hidroelektrik santrallerinin üretimi, yağış koşullarına bağımlı olduğundan her yıl toplam üretim içindeki payı değişim göstermekle beraber, Türkiye'de elektrik enerjisinin yaklaşık \% 20-30’u su gücünden üretilmektedir. (Tanışli: 2010).

Türkiye'de hidrojen ve hidrojen teknolojileri konusunda dikkat çekici çalışmalar yapılmaktadır. Bu anlamda Türkiye'de yürütülen hidrojen tabanlı projeler şöyle sıralanabilir:

Atatürk Hava Meydanı otobüs projesi, rüzgar-hidrojen projesi, hastane projesi, Ambarlı Santrali hidrojen projesi, hidroelektrik-hidrojen projesi, biokütle-hidrojen projesi, hidrojenli ev projesi, traktör projesi, forklift projesi, deniz taksi projesi, güneş-hidrojen projesi, İzmit Belediyesi otobüs projesi, Türkiye'de hidrojenle çalışan otobüs projesi, Bozcaada'da hidrojen üretimi projesi. (Tutar ve Eren: 2011)

\subsection{Türkiye’de Kamu Sektöründe Çalışan Yeşil Yakalılar}

TÜİK'in 2002 yılı Çevresel İstihdam ve Harcamalar Envanteri’nde kamu kurum ve kuruluşlarının çevresel faaliyet konuları şöyle sıralanmaktadır: Dış ortam havasını ve iklimi koruma, İçme ve kullanma suyu, Atıksu yönetimi, Atık yönetimi, Toprağın yeraltı ve yüzey sularının korunması ve iyileştirilmesi, Gürültü ve vibrasyonun azaltılması, Biyolojik çeşitliliğin ve peyzajın korunması, Radyasyona karşı koruma (dış güvenlik hariç), Enerji, Araştırma ve geliştirme ve diğer çevre koruma faaliyetleri.

Kamu kurum ve kuruluşlarında 2007 yılında 8485 personel istihdam edilmiştir. 2007 yılında bunların \% 78'i, 2008 yılında ise çevresel faaliyetlerde istihdam edilen 7557 personelin \% 67'si sadece çevresel faaliyetlerle ilgili işlerde çalışırken, \% 33'ü diğer faaliyetlerin yanısıra çevresel faaliyetleri de yürütmektedir. 2007 yılında kamudaki yeşil yakalıların \% 75'i erkek iken \% 25'i kadındır. 2008'de çevresel faaliyetlerde çalışan personelin \% 65'i yüksekokul ve üzeri eğitime sahipken, \% 22'si lise ve dengi okul mezunudur. (http://www.tuik.gov.tr)

2007'de kamuda çevre istihdam rakamı neredeyse 1997 rakamına eşittir. 1997'den beri sürekli artan personel, 2005 yılında 14500 kişiye ulaşmış ama son yıllarda önemli oranda azalmıştır. Bu azalış 2005 yılında Köy Hizmetleri Genel Müdürlüğ̈̈’nün İl Özel İdareleri’ne devrinden ve 2007 yılında Tarım Bakanlığı İl Müdürlüklerinde çalışanların sayılmamasından kaynaklanıyor. Açıklanan son istihdam paketi çerçevesinde 120 bin kişinin, ağaçlandırma, erozyon kontrolü çevre düzenlemesi gibi işlerde istihdamını hedeflenmektedir. Bu durum kamuda geçici de olsa çevresel istihdamı artıracaktır. (http://www.ekotrent.com)

\section{Değerlendirmeler ve Sonuç}

Tanımlamadaki zorluklar, özel sektörde yeşil yakalıların istihdamını ortaya koyabilecek standartlaşmış ve güncel veri yokluğu, Türkiye'deki yeşil yakalı istihdamının boyutlarını tam anlamıyla izlememize olanak vermemektedir. $\mathrm{Bu}$ alanda farkındalığın ve araştırmaların artması yeşil yakalıların daha sağlıklı ve detaylı incelemesine yardımcı olacaktır. Kurumlar arası işbirliğinin sağlanması, teşvikler ve düzenlemeler yeşil yakalıların önünü açabilir.

Türkiye enerji konusunda dışa bağımlı bir ülke olduğu için yenilenebilir enerji kaynaklarına ve yeşil yakalı mesleklere gereken önem verilmelidir. Enerji, inşaat, tarım ve ulaşım gibi yeşil işlerin kolaylıkla gelişebileceği sektörlerde özel-kamu işbirliği, düşük karbon ekonomisi yaratmada önemli roller oynayabilir.

Türkiye'nin, AB çevre müktesebatına uyumu ve Kyoto Protokolü sonrasında ortaya çıkacak anlaşma çerçevesinde düşük karbon ekonomisi için teknoloji transferinden ve uluslararası yardım mekanizmalarından faydalanmanın yolları aranabilir.

Gelişmiş ülkelerin yeşil iş̧leri ve temiz enerji teknolojilerini geliştirmelerinde en önemli faktörlerden biri ArGe’ye verdikleri önemdir. Türkiye’de devlet ve özel sektör, çok düşük olan Ar-Ge harcamalarını arttırmalı ve önceliklerini gelişen yeşil teknolojiler doğrultusunda gözden geçirmelidir.

Türkiye'de önümüzdeki dönemlerde yapılacak yatırımlar ve yapılacak programlarda yeşil yakalı mesleklerin gelişimine katkıda bulunabilecek adımlar atılmalıdır. Böylelikle bu mesleklerin yaratacağı istihdama en fazla ihtiyaç duyan kesimlere yani gençlere, kadınlara ve işsizlere yönelinmelidir.

Ayrıca mesleki eğitim düzenlemeleri gelecekte öne çıkabilecek çevresel sektörlerin ihtiyaçlarıyla uyumlu hale getirilmelidir. Yeşil işlerin gereksinim duyduğu teknolojilerin, politikaların ve düzenlemelerin oluşturulması, kamu ve özel sektörün, sendikaların etkin işbirliğinden geçmektedir.

Yeşil yakalı meslekler, farklı disiplinlerin buluştuğu ve işbirliğine gidebileceği, yaratıcılık ve hayat boyu eğitim ve gelişim gerektiren mesleklerdir. Bu yüzden yeşil işlerde çalışmak isteyen kişilerin kendilerini sürekli yetiştirmeleri, alanları dışında pazarlama, iletişim, reklam, psikoloji, sosyoloji gibi disiplinler hakkında da bilgi 
sahibi olmaları yararlı olacaktır.

\section{Kaynakça}

- Basmacı (çev.), 2011. "Yeşil İşler- Rakamlar ve Gerçekler” Türk-iş, Sayı: 394, sy: 108-110.

- Cleary and Kopicki, 2009. Preparing the Workforce for a 'Green Jobs' Economy- Research Brief. John J. Heldrich Center for Workforce Development.

- Chozick, 2008. "Clinton Pushes 'Green Collar' Jobs in Md. Factory Tour". The Wall Street Journal, http://blogs.wsj.com/washwire/2008/02/11/clinton-pushes-green-collar-jobs-in-md-factory-tour/. (11-072008)

- Fisunoğlu, 1990. “Sürdürülebilir Kalkınma ve Ekonomi”, Sürdürülebilir Kalkınma Konferansl, Türkiye Çevre Sorunları Vakfı Yayını, Ankara.

- Forstater, 2006. "Green Jobs- Public Service Employment and Environmental Sustainability", Challenge, Vol. 49, No. 4, pp. 58-72.

- Koçkar, 2010. "Biyoenerji” Yenilenebilir Enerji Kaynakları, Anadolu Üniversitesi Yayını No: 2116, sy: 74- 103.

- Pappu, 2008. "Politicians Power Up With 'Green-Collar' Workers", The Washington Post. http://www.washingtonpost.com/wp-dyn/content/article/2008/01/22/AR2008012203784.html. (11-07-2008)

- Parlaktuna, 2010. “Jeotermal Enerji” Yenilenebilir Enerji Kaynakları, Anadolu Üniversitesi Yayını No: 2116, sy: 46-73.

- Renner, 2008. Worldwatch Report: Green Jobs: Working for People and the Environment http://www.worldwatch.org/node/5925 (12.08.2010)

- Tanışl1, 2010. "Hidroelektrik Enerji” Yenilenebilir Enerji Kaynakları, Anadolu Üniversitesi Yayını No: 2116, sy: 104-123.

- Tosunoğlu, 1998. Sürdürülebilir Kalkınmada Japonya Örneği ve Türkiye Açısından Bir Değerlendirme, Yüksek Lisans Tezi, Anadolu Üniversitesi Sosyal Bilimler Enstitüsü.

- Tutar ve Eren, 2011. "Geleceğin Enerjisi: Hidrojen Ekonomisi ve Türkiye”, Uluslar-arası İktisadi ve İdari Incelemeler Dergisi, Y11: 3, Sayı:6, sy: 1-25.

- United Nations Environment Program 2008. “Green Jobs: Towards Decent Work in a Sustainable, LowCarbon World" (12.08.2010)

- United Nations Environment Program 2007; 2008. The UNEP-ILO- IEO-ITUC Green Jobs Initiative.

- United Nations Environment Program (http://www.unep.org) (13.08. 2010)

- Yörükoğulları, 2010. "Güneş Enerjisi”, Yenilenebilir Enerji Kaynakları, Anadolu Üniversitesi Yayını No: 2116, sy: 2-25.

- http://www.ilo.org/wcmsp5/groups/public/---dgreports/dcomm/documents/publication/wcms_098503.pdf (17.08.2010)

- "Hillary's Plan to Create a Green Jobs Revolution: Creating New, High-Wage Jobs of the Future". $\mathrm{http}: / / \mathrm{www} \cdot$ hillaryclinton.com/news/release/view/?id=5909. (11.07.2008)

- $\quad$ "5 Million Green Collar Jobs". Barack Obama's presidential campaign website. http://my.barackobama.com/page/content/newenergy. (11.07.2008)

- http://www.ekotrent.com/ (14.08. 2010)

- http://www.greenpeace.org/turkey/(22.09.2010)

- http://www.greenpeace.org/turkey/news/almanya-temiz-enerjide-liderligini-kaybedebilir-070910 $(10.09 .2010)$

- http://www.ilo.org/global/topics/green-jobs/lang--en/index.htm

- http://www.ilo.org/greenjobs

- http://www.ilo.org/wcmsp5/groups/public/@dgreports/@dcomm/documents/presentation/wcms_149921.pdf

- http://www.unep.org/newscentre/default.asp?ct=shortfilms (13.08. 2010)

- http://tr.euronews.net/2010/09/20/yesil-is-sektorunde-istihdam/ (22.09.2010)http://www.tuik.gov.tr/PreHaberBultenleri.do?id=6205 


\title{
Türkiye'de "Değere Bağlı Sağlık Sistemi" Temelinde Kamu ve Özel Sektör Açısından Algılanan Hizmet Kalitesi
}

\author{
Müjgan Hacıoğlu Deniz (Istanbul University, Turkey) \\ Elif Haykır Hobikoğlu (Istanbul University, Turkey)
}

\section{Perceived Service Quality in Public and Private Health Sector in Turkey in the Context of "Value-Based Health System"}

\begin{abstract}
As a result of the fast and radical changes in Turkish health sector during the last ten years, a dual structure has emerged in Turkey. In this study we have tried to point out basic variables on which patient preferences towards getting health care from public or private sector depends, and also by what percentage these variables provide satisfaction to patients in the context of value-based health care system. By taking a poll we have measured the magnitude of health expenditures goes to public and private hospitals and in return of these expenditures, the level of satisfaction people get in the context of value-based health system. Also we try to compare these two different kinds of hospitals by considering service quality and different prices. aasure and was also asked. In health sector which is one of the biggest and basic sectors of Turkey, in order to achieve efficiency in using resources, we can benefit from the "value-based health system" which will pave the way for optimum allocation of resources. When we take considere the main examples relating with this issue all over the world we can easily recognize that in developed and rich countries like UK and USA, the "value-based health system" is getting more and more importance and having a crucial role in optimising resources in health industry. Considering the dual structure of health sector, people's satisfaction level in comparison with their health expenditures was searched and end up with a conclusion about the satisfaction level according to prices charged by different hospitals. Public survey also show which part of patients prefer what kind of health care system and price level that patients choose to pay for their health care. Finally, it is seen that behavioral intention is mostly taking the first place in this matter.
\end{abstract}

JEL Code: I11

\section{GíRiş}

Ülkemizde sağlık hizmetleri sektörü son yıllarda önemli değişikliklere maruz kalmaktadır. Bir taraftan sayısı hızla artan özel sağlık kurumları nedeniyle rekabet yoğunlaşmakta; diğer taraftan son yıllarda yapılan düzenlemeler sonucunda, hastaların gerek özel hastanelerden gerekse kamuya ait diğer sağlık kurumlarından sağlık hizmetleri almalarının yolu açılmaktadır. Ayrıca, aile hekimliği sistemine geçilmiştir. Böylesi bir ortamda, rekabetçi üstünlük yaratabilmek ve sürdürebilmek için, sağlık hizmetleri sağlayıcıları, konuya hizmet sağlayıcı bakış açısından yaklaşan ve sağlık hizmetlerinin etkin bir şekilde sunulmasına önem veren geleneksel sağlık hizmetleri sunumu yaklaşımını hastaların tatminini dikkate alan hasta memnuniyeti odaklılık ilkesiyle bütünleşik hale getirmeye çalışmaktadırlar. Bunun bir sonucu olarak da, sağlık hizmeti sağlayıcıları için hizmet kalitesi ve hasta tatmini konuları kritik öneme sahip konular haline gelmektedir. (Dursun ve Çerçi, Aralık 2004)

Günümüzde sağlık hizmetlerinin kalitesinin hasta tatminini ortaya çıkaracağı; hasta tatmininin de hastaların benzer rahatsılıklarında aynı hizmet sağlayıcıyı tercih etmeleri ve/veya başkalarına tavsiye etmeleri yoluyla süreklilik kazanacağı ve hastalar tarafindan algılanan hizmet kalitesinin bir göstergesi olacağı açıktır. Sağlık hizmetlerinin kalitesi, sadece sağlık hizmetleri sağlayıcıları ve hastalar açısından değil, hükümetler açısından da önemli bir konudur. Kaliteli sağlık hizmetleri, insanların daha sağlıklı ve daha mutlu olmalarına katkıda bulunacaktır. Dolayısıyla, sağlıklı ve mutlu insanlar da hükümetlerin hem seçimlerde oy alabilmelerine, hem de sağlık harcamalarını azaltabilmelerine imkan sağlayacaktır. (Varinli vd., 1999)

Sağlık hizmeti sunumunda geleneksel tedavi yaklaşımı, mevcut bilgi ve teknolojiyle, sağlık hizmetleri çıktısını artırmayı hedeflemektedir. Genellikle sağlık hizmetlerinin verilmesiyle hizmet çıtılarının ölçülmesi arasında önemli sayılabilecek bir zaman aralığı vardır. Bazı durumlarda, çıktının ne olduğunun değerlendirilmesi ya çok zordur ya da neredeyse imkansızdır. Şöyle ki, sağlık hizmetini alan bir çok hasta, sağlık hizmetinin uygun bir şekilde verilip verilmediği; hatta, gerekli olup olmadığı konusunda yeterli bilgi ve beceriye sahip değildir. Tüm bunların bir sonucu olarak da, hasta, konunun teknik boyutunun dışında kalan hasta-doktor ilişkisi ve/veya hastane ortamı gibi dolaylı nitelikteki kriterleri kullanarak hizmet kalitesini değerlendirme yoluna gitmektedir (Bowers vd., 1994). Bu açıdan, sunulan sağlık hizmetinin kalitesini sağlık hizmetini alan hastanın bakış açısıyla sorgulayan, muayene ve tedavi yöntemlerinin yanı sıra ödediği para karşılığında algıladığı hizmetin kalitesini de ölçen yöntemler geliştirilmeye başlanmıştır.

Yukarıda sözü edilen nedenlerle, sağlık hizmetlerinin kalitesi, hasta tatmini ve sağlık hizmetleri tüketicilerinin 
davranışının incelenmesi önemli bir konu haline gelmiştir. Türk Sağlık sisteminde bu konuda yapılan araştırmaların da henüz sınırlı sayılabilecek bir sayıda bulunması bize sağlık hizmetleri kalitesi ve hasta tatmini konularının incelenmesine ihtiyaç olduğunu göstermektedir. Bu ihtiyaç göz önünde bulundurularak, bu çalışmada Sağlık Bakanlığı'nca "aile hekimleri üzerinde" yaptırılan ve yeni sağlık sisteminden memnuniyet düzeyini yansıtan anket ile birlikte aynı zamanda; "özel hastanelerde sunulan sağlık hizmeti kalitesi ile hasta memnuniyeti ve değer-sağlık-ilişkisinin tespit için" İstanbul'da hizmet veren tam teşekküllü özel bir hastane'de tedavi olan hastalara anket uygulanarak sonuçları analiz edilmiştir.

\section{Sağlık Hizmetlerinde Kalite, Algılanan Değer ve Hasta Tatmini İlişkisi}

Gerçek şu ki, herkes için paha biçilmez bir değer olan "sağl1k" için bir değer biçmek ve bu değere dayanan bir sistem kurmak, başta batılı ve gelişmiş ülkeler olmak üzere tüm ülkelerin güncel problemi olarak gözükmektedir. Amerika Birleşik Devletleri'nde ise halen aktif olarak devam eden sağlik reformu çerçevesinde karşılaştırmalı etkililik (comparative effectiveness) ve maliyet-etkililik gibi eskiden pek konuşulmayan kavramlar gündemde öne çıkmaktadır. Bu da sağlık ekonomisi yöntemlerinin dünyanın en büyük ekonomisine sahip bu ülkede çok daha yaygın bir şekilde kullanılacağının kaçınılmaz olduğunun habercisi gibi görünmektedir. (Fidan, 2010)

Tüm bu gelişmeler, kaynakların eşitlikçi ve etkin kullanılması tartışmalarını alevlendirip, sağlık ekonomisinin temel kavram ve yöntemlerinin ve bunların sağlık sistemlerine uygulanmasının önemini daha da artırmıştır. Bu çerçevede hem ilaçların hem de diğer sağlık hizmetlerinin "değere dayalı olarak fiyatlandırılması" eğilimi giderek hız kazanmaktadır. (Varol \& Saka, 2011) Ekonomi bilimi, sınırlı kaynaklarla sınırsız insan ihtiyaçlarını karşılamayı hedefler. En genel bakış açısı ile ekonomi, insanların sınırsız ihtiyaçlarını tatmin etmek için kıt kaynakların en etkin bir şekilde kullanımını incelemektedir; ancak ekonomi sadece mal ve hizmetlerin üretimi ile değil üretilen mal ve hizmetlerin nasıl dağıtıldığı ile de ilgilidir. (Mankiw, 2007) Ekonomik teori, kavram ve teknikler bu süreci açıklamayı, hem mal ve hizmetleri üretenlerin hem de tüketenlerin değişik durumlara karşı gösterdikleri tepkiyi değerlendirmeyi, elde edilen veriler ışığında önceliklendirme kararlarında yol göstermeyi ve bu kararların olası sonuçlarını politika belirleyicilere sunmayı amaçlamaktadır. Bu nedenle ekonomik modellemelerin "değ ere bă̆lı" bir sistem kurmada yeri kaçınılmazdır.

Tüm dünyada olduğu gibi Türkiye'de de sağlık harcamaları son on yıllarda hızlı bir şekilde arttı. Türkiye'nin sağlık harcamalarının gayri safi milli hasıla içindeki payı, 1980-2005 yılları arasında toplam 2,3 kat ile tüm Ekonomik Kalkınma ve İşbirliği Örgütü (Organisation for Economic Co-operation and Development - OECD) ülkeleri içinde en büyük artışa sahiptir (ortalama OECD artışı 1,35 kat). 1980 yılında Türkiye'de kişi başına harcanan sağlık harcaması \$62 iken bu rakam 2005 yılında $\$ 592$ olmuştur.

"Eğer bugün Türkiye'deki herkese 1980’lerdeki tıbbi teknolojiye geri dönülmek kaydıyla \$530 olan aradaki farkın ödenmesi önerilse, bunu kaç kişi kabul eder? Öyleyse sorun, harcanan miktarda değildir. Harcanan paranın yeterince yarar sağlayıp sağlamadığını değerlendirmede, değere bağlı sağlık sistemi reformu, kısıtlı kaynaklar (sağlık bütçesi) içerisinde değeri artırmaya, yani sağlık hizmetlerine ulaşımı, kaliteyi, dengeli dağılımı artırmaya yönelik olmalıdır".(Başer, 2009)

\subsection{Hizmet Kalitesi}

Değere bağlı sağlık sisteminde esas amaç, halkın vergilerinden oluşturulan sınırlı sağlık bütçesiyle, sağlık hizmetinin en etkin şekilde sunulmasıdır. Bu sistemde değere karar verme mekanizmaları şu şekilde özetlenebilir:

"(a) Sağlık Hizmetine Ulaşım, (b) Kalite, (c) Kaynak Kullanımı ve (d) Eşitlik olmak üzere dört başlıkta toplanabilir. Bu dört mekanizma birbirinden bağımsız değildir. Örneğin, sağlık hizmetine ulaşılamazsa doğal olarak kaliteli hizmet de alınamayacaktır." (Başer, 2009)

Konu ile ilgili yapılan araştırmalar hizmet kalitesinin firmanın performansıyla, müşteri tatminiyle (Cronin ve Taylor, 1992) ve satın alma niyetiyle ( Boulding vd., 1993) ilişkili olduğunu ortaya koymaktadır. Son dönemde Türkiye'de yapılan çalışmalarda "hastaların hizmet kalitesiyle ilgili algılamalarının", hastaların tatmin elde etmelerinde ve hastane kârlılığındaki rolü incelenmiş ve bir sağlık kurumunun başarısında kilit öneme sahip bir değişken özelliği taşıdığ 1 tespit edilmiştir. (Dursun ve Çerçi, Aralık 2004)

Öte yandan hastanın sağlık bakımındaki koordinasyon yoksunluğu, sağlık harcamalarının artmasının ve bakım kalitesinin düşmesinin bir başka sebebi olarak görülmektedir. Bundan dolayı olsa gerek ABD'de birçok sigorta şirketi, aile hekimliğini zorunlu tutarak, hem sağlık kalitesini artırmakta hem de maliyetleri düşürmeyi hedeflemektedir. Yapılan çalışmalar, hastanın bakımının aile hekimi tarafindan koordine edilmesinin hem maliyeti düşürdüğünü hem de bakım kalitesini artırdığını göstermektedir. (Medpac, 2008)

Hedeflenen ideal sağlık sisteminde, sağlık hizmetini sağlayan kuruluşlar, devlet ve özel hastaneler, sağlık ocakları, hem sağlık hizmetinin kalitesinden hem de devletin kendi hastaları için sağladığı sağlık kaynaklarının (ödemelerin) doğru kullanılmasından sorumlu olmalıdır. Şöyle ki, Sağlık Bakanlığı veya geri ödeme kurumları, bu kuruluşlara kalitelerini artırmak için teşvikler sunmakta ve gerekli bilgileri sağlamaktadır. "Hastaneler arasındaki sağlık bakımı kalitesindeki farklıı̆̆ın giderilmesi, sağlık harcamalarının azaltılması 
konusunda en önemli şartlardan birisidir". 2008'de "Health Affairs" dergisinde yayınlanan grafik de bunu açıç̧a göstermektedir. Hastanelere yapılan beklenenden fazla ödemeler (outlier payment) ile hastaneye yatan kişilerin hastalık derecesi arasında bir ilişki olmadığı grafikte görülmektedir. Esas farklılaşma hastane kalitesi üzerinedir. Düşük kaliteli (bir yıldız) hastanelerin aldığı gereğinden fazla ödemeler, yüksek kaliteli (beş yıldız) hastanelerin aldığı miktarın neredeyse iki katıdır.

\subsection{Hasta Tatmini}

Tüketicinin satın alma niyeti ve müşteri bağlılığı üzerindeki potansiyel etkileri nedeniyle, tüketici tatmini konusu da pazarlama literatüründe hem de ekonomi biliminde geniş uygulama alanı bulan konulardan birisidir. Sağlık hizmetleri sağlayıcıları açısından hasta tatmini, yüksek oranda hastaların elde tutulması, olumlu kulaktan kulağa iletişim ve yüksek kârlılık; ayrıca hastanın doktor tarafından kendisine verilen tavsiyelere ve isteklere uyma eğilimini artırması gibi olumlu sonuçlar doğurmaktadır.(Dursun \& Çerçi, 2004) Bu nedenlerden dolayı, hasta tatmininin bilinmesinin sağlık kurumları açısından büyük yararları bulunmaktadır.

Konuyla ilgili literatür incelendiğinde, hizmet kalitesi ve hasta tatmini arasındaki nedensellik ilişkisi konusunda bir fikir birliğinin olmadığı ve nedensellik ilişkisi konusunda başlıca üç farklı görüşün bulunduğu görülmektedir. (Dursun ve Çerçi, Aralık 2004) Birinci görüş,hizmet kalitesinin tatminden önce ortaya çıktığını (Brady vd., 2002; Parasuraman vd., 1994; Cronin ve Taylor, 1992); ikinci görüş,tatminin, hizmet kalitesinden önce ortaya çıktığını (Bitner ve Hubbert, 1994; Bolton ve Drew,1994) ve son görüş de, hizmet kalitesi ile tatmin arasında her zaman aynı şekilde tekrarlanan, diğer değişkenden önce ortaya çıkma durumunun olmadığını, yani, ilişkinin yönünün değişebildiğini (Dabholkar, 1995 ve McAlexander vd., 1994) savunmaktadır. Özetle, hizmet kalitesi ve tatmin arasındaki nedensellik ilişkisi konusunda bir fikir birliği olmamakla birlikte, hizmet kalitesinin tatminden önce ortaya çıktığı, yani tatmin düzeyini belirlediği görüşünün daha yaygın kabul gördüğü anlaşılmaktadır. Yaygın kabul gören bu görüş doğrultusunda, aşağıdaki hipotez ortaya konulmuştur.

- H1: Algılanan hizmet kalitesi, hasta tatminini etkilemektedir. (Dursun\&Çerçi, Aralık 2004)

Yapılan bazı çalışmaların sonuçları, algılanan hizmet kalitesinin tüketicilerin sonraki satın alma ve/veya başkalarına tavsiye etme davranışlarını, başka bir deyişle, davranışsal niyetlerini etkilediğini benzer şekilde, tatmininde tüketicinin davranışsal niyetleri üzerinde etkisinin bulunduğunu göstermektedir. Bu nedenle, aşağıdaki iki hipotez belirlenmiştir.

- H2: Algılanan hizmet kalitesi, hastanın davranışsal niyetini etkilemektedir.

- H3: Alınan hizmetle ilgili hasta tatmini, hastanın davranışsal niyetini etkilemektedir. (Dursun\&Çerçi, Aralık 2004)

\subsection{Algılanan Değer}

İşletmeler, ürünlerinin/hizmetlerinin tüketicilere sundukları yararları geliştirerek, verimlilik artışı yoluyla maliyetlerini düşürerek veya her ikisini birden gerçekleştirerek, ürünlerinin/hizmetlerinin değerini artırmaya çalışmaktadırlar. Bir ürünün/hizmetin sahip olduğu yüksek değer, kâr elde etmede ve tüketici tatmini yaratmada işletmeye rekabetçi bir üstünlük sağlamaktadır.

Bir ürün/hizmet ile ilgili olarak, tüketicinin algıladığı yararları ve algıladığı maliyetleri değerlendirmesinin sonucunda, tüketicinin zihninde o ürün/hizmet ile ilgili algılanan değer oluşmaktadır. Şüphesiz, algılanan yararların, algılanan maliyetlerden daha çok olması, algılanan değerin yüksek olması anlamına gelmektedir.

Anderson and Frogner'ın 2008 aralık ayında Health Affairs'de yayınlanan makalelerinde Dünya ülkelerinin sağlık harcamaları ve beklenen yaşam sürelerini gösteren grafikte dört bölge görülmektedir. Birinci bölge Japonya (JP) ve İtalya (IT) gibi ülkelerin bulunduğu bölge, ikinci bölge Fransa (FR) ve Almanya (GE) gibi ülkelerin bulunduğu bölge, üçüncü bölge de Danimarka (DK) ve Norveç (NO) gibi ülkelerin olduğu bölgedir. Dördüncü bölgede ise (en kötü bölge) sağlık harcamaları beklenenin üzerinde ve yaşam süreleri beklenenin altında ülkeler olan BE (Belçika), TR (Türkiye) ve ABD (Amerika Birleşik Devletleri) bulunmaktadır. Diğer ülkelere bakarak, Türkiye'de kişi başına sağlık harcamaları beklenenden $\$ 300$ fazlayken, yaşam süreleri ise beklenenin 2,5 yıl altındadır. ABD'de ise sağlık harcamaları beklenenden $\$ 2.000$ fazla ve yaşam süreleri de beklenenin 3,1 yıl altındadır. Diğer taraftan Japonya'da hem sağlık harcamaları beklenenden daha azdır hem de yaşam süreleri beklenenden 3,5 yıl daha fazladır.

ABD sağlık harcamalarına 2005 yılında kişi başına yaklaşık \$6.401 harcamıştır. Yani ABD’de 2005 yılında bir kişinin yaptığı sağlık harcaması Türkiye'deki bir kişinin yalnız sağlığa yaptığı harcamanın 10 katından daha fazladır. Ancak, iki ülkenin diğer hiçbir OECD ülkesinde olmayan (Belçika hariç) ortak yanları harcadıkları paranın karşılığını alamıyor olmalarıdır. (Health Affairs, 2008 December) ABD'de sağlık harcamalarındaki önlenemez artış ve bu artışın sağlık kalitesine yansımaması yüzünden hükümet bir takım önlemler alınmaya karar verilmiştir. Her iki ülkede de mevcut sorunlar benzerlikler gösterdiğinden, özellikle sosyal sigorta çerçevesinde Değgere-Bă̆lı Să̆lık Sisteminin kurulmasında Türkiye, ABD'de yapılan çalışmalardan yararlanabilir.

Bir hasta açısından, algılanan yarar, hastanın hangi ölçüde sağlı̆̆ını yeniden kazandığı ile ilgilidir. Sağlık hizmetini almak için ödediği ücret, harcadığı zaman ve yaşadığı zihinsel ve bedeni stres ise, hastanın katlandığı 
maliyetlerdir. Choi vd. (2004), Cronin vd. (1997), Fornell vd. (1996) ve Gooding (1995) tarafindan yapilan araştırmaların bulguları, algılanan değerin algılanan hizmet kalitesinden etkilendiğini, algılanan değer ile tatmin ve davranışsal niyet arasında anlamlı ilişkiler bulunduğunu göstermektedir. Bu bulguların ışığında, aşağıdaki üç hipotez belirlenmiştir:

- H4: Algılanan sağlık hizmeti kalitesi, algılanan hizmet değerini etkilemektedir.

- H5: Algilanan değer, hasta tatminini etkilemektedir.

- H6: Algılanan değer, hastanın davranışsal niyetlerini etkilemektedir. (Dursun\&Çerçi, Aralık 2004)

Yukarıda bahsi geçen hipotezlerle ortaya konulan sağlık hizmetlerinde hasta tatmini modeli Şekill'de verilmiştir. Modeldeki dört değişken arasındaki ilişkiler, yukarıda sözünü ettiğimiz hastaneye gelen hastalardan toplanan birinci el veriler kullanılarak test edilmiştir.

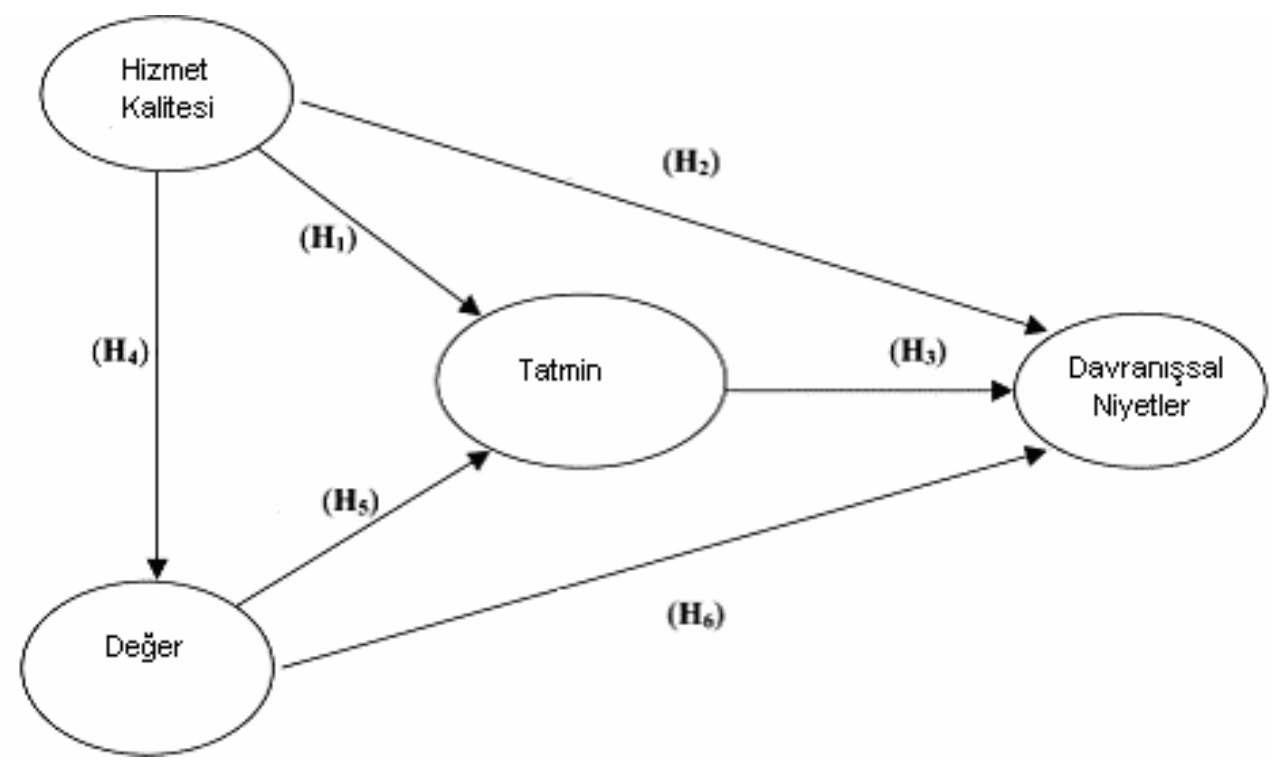

Şekil 1: Sağlık Hizmetlerinde Hasta Tatmini Modeli. Kaynak: Dursun ve Çerçi, 2004.

\section{Araştırmanın Yöntemi}

Sağlık hizmetlerinde algılanan kalite, algılanan değer, hasta tatmini ve davranışsal niyet arasındaki ilişkileri ortaya koymayı amaçlayan bu çalışmada, tanımlayıcı araştırma modeli (yüz yüze anket metodu) kullanılmıştır. Çalışmada birinci el veriler kullanılmış ve veriler İstanbul'daki Özel bir Hastaneye muayene ve tedavi için başvuran hastalar arasından seçilen kişilere bizzat uyguladığımız anket formu aracılığıyla ve Kocaeli'de Aile Hekimliği'ne tabi sağlık ocaklarında tedavi olan hastalara kurum tarafindan uygulanan anket aracılığı ile toplanmıştır. Başka bir deyişle, çalışmanın ana kütlesini özel hastaneye ve aile hekimlerine/kamu doktoruna muayene ve tedavi için başvuran hastalar oluşturmuştur.

Verilerin toplanmasında kullanılan anket formu iki bölümden oluşmuştur. Birinci bölümde, cevaplayanın cinsiyeti, mesleği, yaşı, eğitim durumu ve sahip olduğu sosyal güvence ile ilgili sorular yer almıştır. İkinci bölümde ise, hastaların hastanede kaldıkları süre içerisinde almış oldukları hizmetlerin kalitesiyle ilgili düşüncelerinin belirlenmesi amacıyla, Parasuraman vd. (1985 ve1988) tarafından geliştirilen ve daha sonra diğer bir çok araştırmacı tarafından da kullanılan "Servqual Ölçeği"nden yararlanılmış ve konuya göre uyarlanmıştır.

Anketteki son 3 ifade hizmet kalitesini ölçmek için kullanılmış ve bu ifadeler beşli ölçek ( $1=$ çok kötü, ..., 5= çok iyi) ile ölçülmüştür. Hastaların davranışsal niyetlerini belirlemek amacıyla, "tekrar hastaneye yatması gerekirse bu hastaneyi tercih edip etmeyeceği" ve "gerektiği durumlarda bu hastaneyi eş, dost ve akrabalarına tavsiye edip etmeyeceği" ifadelerine yer verilmiş ve bu ifadeler de beşli ölçek (ilk ifadede $1=$ kesinlikle tercih etmem, ..., $5=$ kesinlikle tercih ederim ve ikinci ifadede $1=$ kesinlikle tavsiye etmem, ..., $5=$ kesinlikle tavsiye ederim) ile ölçülmüştür. Ayrıca, Zeithaml (1988) tarafindan yapılan öneri doğrultusunda, hastanın kendisine sunulan sağlık "hizmetinin fiyatını nasıl bulduğu" beşli ölçekli (1= çok pahalı, .., 5= çok ucuz) bir soru ile ölçülmüştür. İkinci bölümde, son olarak, hastaya "genel olarak hastaneden almış olduğu hizmetlerden memnun olup olmadiğg”" sorulmuş ve bu ifade de yine beşli ölçek $(1=$ hiç memnun değilim, ..., $5=$ çok memnunum) ile ölçülmüştür. Son olarak da, Hizmet kalitesi ile ilgili 15 ifadenin ve davranışsal niyet ile ilgili 3 ifadenin ortalamaları alınarak SPSS programı ile analize sokulmuştur.

Kocaeli'de yapılan ankette "aile hekimine" başvurarak, sağlık hizmeti alan hastaların büyük bölümünü 25-35 yaşları arasında, ev hanımı, ilköğretim-lise mezunu, öğrenci ve düşük gelirli hastaların oluşturduğu anlaşılmaktadır. Cevaplayıcıların yaklaşık yüzde 15 'inin herhangi bir sosyal güvenceye sahip olmadığı ve sosyal 
güvenceye sahip olanlar içerisinde ise, "Yeşil Kartlı" hastaların çoğunlukta olduğu görülmektedir. Aile hekimliğinden faydalanan hastaların genelde bu hizmetten memnun olsalar da aldıkları hizmeti ölçecek herhangi bir değer algısı olmadığından ve çoğunlukla gidebilecekleri başka alternatifleri olmadığından objektif karar verememektedirler.

\section{Araştırmada Elde Edilen Bulgular}

Algılanan hizmet kalitesi, algılanan değer, hasta tatmini ve hastanın davranışsal niyeti arasındaki ilişkiyi belirlemek amacıyla yapılan regresyon analizi sonuçları ve değişkenlerin regresyon değerleri incelendiğinde, algılanan hizmet kalitesi, hasta tatmini ve davranışsal niyet arasındaki korelasyon katsayılarının istatistiksel olarak anlamlı olduğu görülmektedir. Buna karşılık, algılanan değer ile diğer değişkenler arasında pozitif korelasyonlar bulunmakla birlikte, korelasyon katsayılarının istatistiksel olarak anlamlı olmadığı anlaşılmaktadır. Anlamlı çıkan korelasyon katsayıları incelendiğinde, algılanan hizmet kalitesi ile hasta tatmini arasında yüksek ve pozitif bir korelasyon bulunduğu görülmektedir. Başka bir deyişle, kendilerine sunulan sağlık hizmetini kaliteli olarak algılayan hastaların elde edecekleri tatminin düzeyi de artış göstermektedir.

Yukarıda söz edilene benzer ilişki algılanan hizmet kalitesi ile hastanın davranışsal niyeti arasında da mevcuttur. Sunulan hizmeti kaliteli olarak algılayan hastalar, benzer bir sağlık hizmetine ihtiyaç duyduklarında aynı sağlık kurumunu seçme ve sağlık kurumunu eşe ve dosta tavsiye etme niyetini taşımaktadırlar. Aynı zamanda, hasta tatmini ile hastanın davranışsal niyeti arasında da yüksek sayılabilecek anlamlı ve pozitif bir korelasyonun bulunduğu görülmektedir. $\mathrm{Bu}$ sonuç da, tatmin olan hastaların, aynı sağlık kurumunu yeniden tercih etme ve başkalarına tavsiye etme niyetini taşıdıklarını göstermektedir.

Diğer taraftan, kamudan hizmet alanlar üzerinde yapılan ve hasta memnuniyeti ölçülmeye çalışılan anket sonucunda hizmet değeri, hasta tatmini ve davranışsal niyet arasında ilişki anlamlı bulunamamıştır. Sağlık hizmetinin algılanan değeri ile hizmet kalitesi, hasta tatmini ve davranışsal niyeti arasındaki regresyon sonuçları anlamlı değildir. Ancak, korelasyon katsayılarının anlamlı çıkmamasının belki de en önemli nedeni olarak, ülkemizde sağlık hizmetlerinin bedelinin bir sosyal güvenlik kurumu tarafından ödeniyor olması gösterilebilir. Çalışmaya katılan hastalar açısından da bakıldığında, bir sosyal güvenceye sahip hastaların oranının yüzde 86 civarında olduğu görülmektedir. Başka bir deyişle, hastaların çok büyük bir bölümü, aldıkları sağlık hizmeti için ne kadar bir bedel ödendiğini bilmemektedir.

Bu çalışmada daha önce bahsedildiği gibi algılanan sağlık hizmeti kalitesi, değer, hasta tatmini ve davranışsal niyet arasındaki ilişki Kamu (Kocaeli’ndeki aile hekimleri bazında) ve Özel Kesim (İstanbul'da Özel bir hastane bazında) karşılaştırılması yapılarak elde edilen bulgular yorumlanmıştır. Şöyle ki; İstanbul'daki özel bir hastenede tedavi olan hastalardan toplanan verilerin analiz sonuçları, algılanan sağlık hizmeti kalitesi, hasta tatmini ve davranışsal niyet arasında anlamlı ilişkilerin bulunduğunu ve hizmet kalitesinin hasta tatmini ve davranışsal niyeti etkileyen en önemli değişken olduğunu göstermiştir. Ayrıca, bulgular, hasta tatmininin davranışsal niyet üzerinde önemli bir etkiye sahip olduğunu ortaya koymuştur.

\section{Sonuç}

Sağlık hizmetlerinde algılanan kalite, algılanan değer, hasta tatmini ve davranışsal niyet arasındaki ilişkileri belirlemek amacıyla özel kesimin sunduğu sağlık hizmetine yönelik yapılan anketin SPSS ve regresyon analizlerinin sonuçları, Şekil 1'de ortaya konulan modeldeki algılanan değer dışındaki diğer değişkenler arasında anlamlı pozitif ilişkilerin bulunduğunu, diğer bir ifadeyle "algılanan hizmet kalitesinin hasta tatmini ile davranışsal niyeti ve hasta tatminin de davranışsal niyeti olumlu yönde etkilediklerini ortaya koymuştur." Hastanın almış olduğu hizmetin kalitesi ile ilgili algılamaları daha olumluya doğru arttıkça, hastanın tatmin elde etme düzeyi de bu artıştan olumlu bir şekilde etkilenmektedir yani, almış olduğu hizmet ile ilgili memnuniyeti de paralel olarak artmaktadır.

Benzer şekilde, hizmet kalitesi ile ilgili olumlu algılamalar ve tatmin olma düzeyindeki artışlar, hastanın davranışsal niyetine de olumlu yönde yansımaktadır. Hizmet kalitesi ile ilgili olumlu algılamalar ve tatmin düzeyindeki artışlar, hastaların hizmet aldıkları sağlı kurumunu, benzer bir rahatsızlık durumunda yeniden tercih etme ve/veya eşe dosta tavsiye etme niyetlerini, tatmin düzeyi düşük hastalara göre, daha olumlu bir şekilde etkilemektedir.

Diğer taraftan, Aile Hekimliği (Kamu'dan) hizmeti alan hastalara uygulanan anket çalışmasında ortaya çıkan bulgular ise algılanan hizmet değeri ile hasta tatmini ve davranışsal niyet arasındaki ilişkiyi anlamlı kılmamıştır. Bunun sebebi olarak; Türkiye'de daha aile hekimliği sistemine yeni geçilmiş olması dolayısıyla toplumun her kesimi tarafından tam olarak benimsenmemiş olması ve aile hekiminden beklenen sağlık hizmetinin de nasıl ve ne şekilde olması gerektiği hakkında net bir fikir oluşmamış olması gösterilebilir.

Ancak, ilişkinin anlamlı çıkmaması, bizleri ilişkinin olmadığı sonucuna götürmemelidir. Bu çalışma Sağlık Bakanlığı'na bağlı aile hekimliği sisteminden sağlık hizmeti alan farklı yaş gruplarındaki hastalara uygulanmıştır ve hastaların küçük bir bölümü aldıkları hizmetin bedelini kendilerinin ödediğini; çok büyük bir bölümü ise, 
hizmet bedelinin ait oldukları sosyal güvenlik kurumu tarafından ödendiğini belirmişlerdir. Dolayısıyla, cevaplayıcı hastaların çok büyük bir bölümü gerçekte hizmet için ne kadar bedel ödendiğini bilmemekte; bu nedenle de büyük bir olasılıkla, hizmetin değeriyle ilgili sağlıklı bir değerlendirme de yapamamaktadırlar.

$\mathrm{Bu}$ çalışmanın bulguları, sağlık hizmetleri sunan kurumlar için dikkate alınmaya değer mesajlar içermektedir. Hizmet kalitesinin hem hasta tatminini hem de hastanın davranışsal niyetini olumlu yönde etkilemesi, hizmet kalitesinin artırılmasına yönelik ciddi adımların atılmasının gerekliliğine işaret etmektedir. Her geçen gün daha da şiddetlenen rekabet ortamında, hizmet kalitesinde iyileşmeler gerçekleştirebilen sağlık kurumları önemli bir rekabetçi üstünlük kazanabilecekler; yüksek oranda hastaların elde tutulmasına, olumlu kulaktan kulağa iletişime, yüksek kârlılığa, hastanın doktor tarafından kendisine verilen tavsiyelere ve isteklere uyma eğiliminin artırmasına olumlu bir şekilde yansıyacaktır.

Özetle denilebilir ki, "Sağlıkta Dönüşüm Projesi" kapsamında faaliyet gösteren sayı ve nitelikleri günden güne artan "Kamu" (aile hekimliği, üniversite) ve "Özel" tüm sağlık kurum ve kuruluşlarının özverili ve uyumlu çalışmasının bir sonucu olarak Türkiye'de hastaların hizmet kalite algısı daha da gelişecek ve ödedikleri ücret

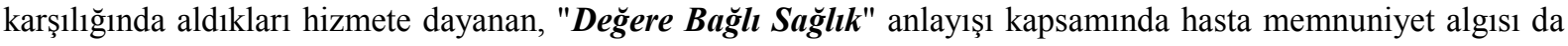
şekillenecektir.

\section{Kaynakça}

- Anderson and Frogner, 2008. "Health Spending in OECD Countries: Obtaining Value Per Dollar", Health Affairs (Millwood), 27(6), pp. 1718-27.

- $\quad$ Argan, M.T. ve M. Argan, 2002. "Sağlık Hizmetleri Pazarlamasında Kaliteve Osmangazi Üniversitesi Tıp Fakültesi Hastanesindeki Servislerde Yatan Hastalara Yönelik Bir Araştırma", 7. Ulusal Pazarlama Kongresi: 21.Yüzyllın Pazarlama Paradigmasl, Afyon: Kocatepe Üniversitesi, s. 133-150.

- Baser, Dimick, Staiger, Birkmeyer, 2009. "Outlier Payments for Cardiac Surgery and Hospital Quality", Health Aff (Millwood), 28(4), pp.1154-60.

- Baser, 2009. http://www.saglik-ekonomisi.com/sed/index.php/dergi-arsivi/say- 2/pdf. (Son erişim tarihi: 26 Temmuz 2011).

- Başkent Üniversitesi, 2004. Ulusal Hastalık Yükü ve Maliyet Etkililik Çalışması, Sağlık Bakanlığı, Ankara, www.hm.saglik.gov.tr (Son erişim: 29 Temmuz 2011).

- Berman ve Tatar, 2004. Türkiye Ulusal Sağlık Hesapları 1999-2000, Sağlık Bakanlığı, Ankara, www.hm.saglik.gov.tr, (Son erişim: 31 Temmuz 2011).

- $\quad$ Bitner and Hubbert, 1994. "Encounter Satisfaction Versus Overall Service Satisfaction Versus Quality", in Rust, R. T. and Oliver, R.L. (Ed.), Services Quality: New Directions in Theory and Practice, Sage Publications, Thousand Oaks CA, pp. 72-92.

- Bolton and Drew, 1994. "Linking Customer Satisfaction to Service Operations and Outcomes", in Rust, R. T. and Oliver, R. L. (Ed.), Services Quality: New Directions in Theory and Practice, Sage Publications, Thousand Oaks CA, pp. 173-200.

- $\quad$ Boulding, W., A. Karla, R. Staelin, and V.A. Zeithaml,1993. "A Dynamic Process Model of Service Quality: from Expectations to Behavioral Intentions", Journal of Marketing Research, 30 (February), pp. 7-27.

- Bowers, Swan and Koehler, 1994. "What AttributesDetermine Quality and Satisfaction With Health Care Delivery", Health Care Management Review, 19 (4), pp. 49-55.

- $\quad$ Brady, M. K., J. J. Cronin and R. R. Brand, 2002. "Performance-OnlyMeasurement of Service Quality: A Replication and Extension", Journalof Business Research, 55 (1), pp. 17-31.

- Choi, CHO, Lee and Kim, 2004. "The Relationships Among Quality, Value, Satisfaction and Behavioral Intention in Health Care Provider Choice: A South Korean Study", Journal of Business Research, 57 (8), pp. 913-921.

- Cronin and Taylor, 1992. "Measuring Service Quality: A Re-Examination and Extension", Journal of Marketing, 56 (July), pp.55-68.

- Dabholkar, 1995. "A Contingency Framework for Predicting Casuality Between Customer Satisfaction and

- Service Quality", in Advances in Consumer Research, Volume 22, eds. Frank R. Kardes and Mita Sujan, Provo, UT : Association for Consumer Research, pp. 101-108.

- Dabholkar, Shepherde, Thorpe 2000." A Comprehensive Framework for Service Quality: An Investigation of Critical Conceptual and Measurement Issues", Journal of Retailing, Vol.76, No.2, pp. 139-173.

- Dursun ve Çerçi, 2004. "Algılanan Sağlık Hizmeti Kalitesi, Algılanan Değer, Hasta Tatmini ve Davranışsal Niyet İlişkileri Üzerine Bir Araştırma", Erciyes Üniversitesi İktisadi ve İdari Bilimler Fakültesi Dergisi, Sayı: 23 (Temmuz-Aralık), ss. 1-16. 
- Fidan, 2010. http://www.saglik-ekonomisi.com/sed/index.php/dergi-arsivi/say- 3,editörden:s.1.

- $\quad$ Fornell and Lehmann, 1996. "Customer Satisfaction, Market Share, and Profitability: Findings from Sweden", Journal of Marketing, 58, pp. 53-66.

- Gooding, 1995. " Quality, Sacrifice, and Value in Hospital Choice ", Journal of Health Care Marketing, 15 (4), pp. 24-31.

- Headly and Miller, 1993. "Measuring Service Quality and its Relationship to Future Consumer Behavior", Journal of Health Care Marketing, 13 (4), pp. 32-41.

- $\quad$ McAlexander, Kaldenberg, Koenig (1994)."Service Quality Measurement", Journal of Health Care Marketing", Vol.14, Issue3, pp.34-39.

- $\quad$ Medpac (Medicare and the Health Care Delivery System), 2008. http://www.medpac.gov/documents/Jun08_EntireReport.pdf, (Son erişim tarihi: 28 Temmuz 2011).

- Medpac (Medicare and the Health Care Delivery System), 2011. "Report To The Congress, June 2011", http://www.medpac.gov/documents/Jun11Entire Report.pdf, (Son erişim tarihi: 30 Temmuz 2011).

- Parasuraman, Zeithaml and Berry, (1985), "A Conceptual Model of Service Quality and its Implications for Future Research", Journal of Marketing, 49, pp. 41-50.

- Parasuraman, Zeithaml and Berry (1988),"SERVQUAL: A Multiple Item Scale for Measuring Consumer Perceptions of Service Quality", Journal of Retailing, 64 (Spring), pp. 12- 37.

- Parasuraman, Berry and Zeithaml, (1991). "Refinement and Reassessment of the SERVQUAL SCALE", Journal of Retailing, vol.67, No.4, pp. 420-450.

- $\quad$ Parasuraman, Zeithaml and Berry, (1994). "Reassessment of Expectations as a Comparison Standard in Measuring Service Quality: Implications for Further Research", Journal of Marketing, 58 (January), pp. $111-124$.

- Varol ve Saka, 2011. "İngiltere'de Yeni PPRS Reformu ve Değere-Dayalı Fiyatlandırma Sistemi", Sağllk Ekonomisi Dergisi, Sayı 3,

- Varinli, İlkay and Erdem, 1999. "Patient Perceptions about Service Quality of a Hospital in Turkey", in Young, J.A., R.D. Green and F.W. Gilbert (Ed.), Advances in Marketing: Theory, Practice, and Education, Society for Marketing Advances 1999 Proceedings, Atlanta-Georgia, October 26-30, ss. 272276. 


\title{
Büyüme ve İstihdam Arasindaki İlişki: Türkiye Örneği
}

\author{
Yusuf Muratoğlu (Hitit University, Turkey)
}

\section{The Relationship between Growth and Employment: The Case of Turkey}

\begin{abstract}
One of the main problems of the Turkish economy in many years is unemployment. Policy makers apply many policies to increase employment. One of the most important of these policies is increasing economic growth by both ensure economic growth and increase employment in this way. This study analyzes relationship of economic growth and employment by using quarterly data of TUIK for Turkey. The variables used are GDP as a economic growth and employment rate as a employment. First types of employment are explained then growth models are discussed. In empirical application integration levels of the variables are investigated with the using DF, PP and KPSS tests. After this applications long run relationship is investigated by using Engle-Granger Analysis. Then the relation between growth and employment rate is tested by using Granger causality.
\end{abstract}

JEL Codes: O40, E24, C50

\section{Giriș}

Günümüzde ülkelerin karşılaştığı en büyük sorunlarından biri istihdam artışını sağlayamamaktır. Emeğin atıl kalmasının birçok nedeni vardır. İktisat yazınında emeğe olan talebi artırmanın yollarından biri ekonomik büyümeyi arttırmaktır. Bu bağlamda büyümeyi sağlayan faktörler önem kazanmıştır. Fakat dünya ekonomisi incelendiğinde yüksek büyüme rakamlarına rağmen istihdamın artmaması büyüme ile istihdam arasındaki ilişki üzerinde tartışmalara yol açmaktadır. Yeni bir boyut kazanan büyüme ile istihdam ilişkisi Türkiye ekonomisi içinde son derece önem taşımaktadır. Türkiye'de dönem dönem görülen yüksek oranlı büyümeye rağmen istihdam artmamış ve hatta bazı dönemlerde büyümeye karşılık işsizlik artmıştır. İstihdamın azalması sonucunda işsiz sayısında meydana gelen artışlar sosyal dengeleri alt üst etmekte ve kaosa yol açmaktadır. Çalışmanın amac1 Türkiye ekonomisinde 2000-2011 döneminde ekonomik büyüme ile istihdam arasındaki ilişkiyi ortaya koymaktır.

\section{2 İstihdam ve Ekonomik Büyüme}

Mal ve hizmet üretmek için şüphesiz emeğe ihtiyaç vardır. İstihdamın temel belirleyicisi yurtiçi mal ve hizmet talebidir. İstihdamı belirleyen diğer faktörler ise ihracat ve ithalat seviyeleridir. Bu faktörler birlikte ele alındığında; yurtiçi talebe ihracat ithalat farkı eklendiğinde GSYİH elde edilir. İstihdamın ilk belirleyicisi GSYİH'dir. Fakat üretimde kullanılan teknikler, işgücü maliyetleri ve kapasite kullanım oranları da istihdamın diğer belirleyicileridir (Akyıldız, 2006).

Ekonomik büyümeyi, bir ülkede, belli bir dönemde üretilen tüm mal ve hizmetlerin parasal ifadesi olan GSYİH'de meydana gelen artış olarak tanımlayabiliriz. Bir ülkede ekonomik büyüme tam istihdam altında kullanılan iktisadi kaynakların daha etkin kullanılması veya kullanılan kaynaklara yenilerinin eklenmesiyle gerçekleşir (Kaynak, 2005). Temel olarak, tüketim harcamaları, yatırım harcamaları, stok atışları ve ihracat ithalat farkı GSYIH'yi oluşturan harcamalardır (Akyıldız, 2006).

İstihdam kavramını tam istihdam ve eksik istihdam olarak ikiye ayırabiliriz. Tam istihdam; cari ücret seviyesinde, çalı̧̧mak isteyen herkesin iş bulabildiği istihdam düzeyidir. Eğer işsizleri istihdam edecek kadar iş mevcut ise gerçek hayatta bir miktar insanın işsiz kalması ekonominin tam istihdamda olmaması anlamına gelmez(Aren, 2008). Hane halkı işgücü anketinde eksik istihdam iki ayrı grupta ölçülmekte ve bu iki grubun toplamı eksik istihdamı oluşturmaktadır. Görülebilir eksik istihdam; Referans döneminde ekonomik nedenlerle kırk saatten daha az süre çalışıp mevcut işinde ya da ikinci bir işte daha fazla süre çalışmaya müsait olan kişilerdir. Diğer nedenlerle eksik istihdam; görülebilir eksik istihdam dışında kalanlardan mevcut işinden elde ettiği gelirin azlığ ya da kendi mesleğinde istihdam edilemediği gibi nedenlerle mevcut işini değiş̧tirmek istediği ya da ikinci bir iş aradığını bildiren kişilerdir (İstatistik Göstergeler Statistical Indicators 1923-2009, 2010).

İktisat yazınında birçok büyüme teorisi vardır. Teoride ilk kabul gören büyüme modeli klasik büyüme modelidir. Klasik büyüme modeli çok sayıda düşünürün fikirlerinin bir araya gelmesiyle oluşmuştur. Fakat teoriye en büyük katkı Ricardo tarafından yapılmıştır. Adam Smith'de büyüme ile ilgili görüşlerini, yazdığı Milletlerin Zenginliği adlı eserde belirtmiş̧tir. Klasiklere göre büyüme sermaye birikimi ile sağlanır. Sermaye birikiminin kaynağı tasarruflardır. Tasarruflar yatırıma dönüşür ve ekonomik büyümeyi sağlar. Ricardo'ya göre kapitalistlerin tek amacı kar elde etmektir ve kapitalistler sürekli üretimi arttırmaya yönelik çabalar içersindedirler. Üretimi arttırmak için daha çok işgücü istihdam edilecek buna bağlı olarak işgücü talebi ücreti 
arttıracak ücretlerdeki artış nüfus artışına sebep olacaktır. Böylece tarımsal ürünlere olan talep artacaktır ve ekonomide büyüme meydana gelecektir.

İkinci büyüme modeli de Harrod- Domar büyüme modelidir. Harrod ve Domar Keynesyen iktisatçılardır. Ekonominin büyümesi sonucu meydana gelen hareketlere karşı Harrod'un tutumu Keynes'in ki gibi eksik istihdamdan tam istihdama varma durumunu araştırmaktır. Fakat Harrod Keynes'den farklı olarak Keynes'in kısa dönemde makrostatik olarak incelediği problemi makrodinamik bir gözle incelemiştir (Ülgener, 1980). Harrod-Domar büyüme modeli toplam talep, üretim ve istihdam arasındaki ilişkiden yola çıkmaktadır ve büyüme hızını marjinal tasarruf oranı (s) ile sermaye-hasıla katsayısıyla (k) açıklamıştır. Ekonomik büyüme sermaye hasıla katsayısının değeriyle ters orantılıken, marjinal tasarruf oranıyla doğru orantılıdır. Yani ekonomide marjinal tasarruf oranı arttıkça ve sermaye hasıla katsayısı düştükçe ekonominin büyüme hızı artacaktır (Özsağır, 2008).

Üçüncü büyüme modeli Neo-Klasik Büyüme modelidir. 1956 yılında Solow tarafından ortaya çıkarılan büyüme modeli neo-klasiklerin düşünce yapısını yansıtmakta olup ekonomistler tarafindan kabul gören en temel modeldir. Modelin temel konuları; tasarruf, yatırım ve ekonomik büyümenin dışsal değişken olan nüfus artışı ve teknolojik gelişme ile ilişkisidir. Solow makalesinde sonuç olarak Keynesyen ilişkileri ve yapışkanlıkları dikkate almıştır (Solow, 1956). Solow modelinde piyasa ekonomisinde istikrarlılık vardır. Uzun dönemde ekonomi kararlı ve dengeli büyüme sürecine girecektir. Dengeli büyüme süreci sermaye birikimi, nüfus artışı ve teknolojik gelişmenin birbirleriyle ilişkileri göz önünde bulundurularak açıklanmaktadır. İlişkileri açıklayacak olursak; nüfusun artışı büyüme oranını etkiler fakat büyüme oranı nüfus artışını etkilemez. Bir başka ilişki de teknolojik gelişme büyüme oranını etkilerken büyüme oranı teknolojik gelişmeyi etkilemez. Yani büyüme oranı ile nüfus artışı ve teknolojik gelişme arasında tek yönlü nedensellik ilişkisi vardır.

Son büyüme modeli içsel büyüme teorisidir. Ölçeğe göre artan ya da sabit verime dayalı bir üretim fonksiyonunu temel alan içsel büyüme kuramı Neo-klasik kuramın varsayımının tersine, dışsal olarak belirlenen teknolojiyi, Ar-Ge ve beşeri sermaye ile içselleştirmiştir. Böylece büyümeyi sistem içindeki içsel faktörlere bağlamıştır. Neo-klasik büyüme kuramı özellikle büyüme oranını etkileyen faktörlerin belirlenmesinde yetersiz kalmıştır. İlk defa Romer (Romer, 1986) çalışmasında içsel büyüme modelleri ele alınmıştır (Atamtürk, 2007). İçsel büyüme teorilerinin ortaya çıkış aşamasında teknolojik bilgi üretimi hakkında bilginin gizli bir kamusal mal niteliğinde olması, teknolojik gelişmelerle ortaya çıkan bilgiden diğer ekonomik birimlerin sağladığı faydanın çok önemli olması, eğer bir dişsallık varsa bilgi üretiminde özel kesim yanaşmak istemeyecek ve piyasa aksayacak olması, teknolojik gelişme ile fiziki ve beşeri sermaye yatırımları arasında bir bağlantı bulunması noktaları üzerinde durulmuştur (Kibritçioğlu, 1998). Büyümenin başat faktörü olarak farklı yaklaşımlar öne sürülmekle birlikte bu yaklaşımlar, AK modeli, Arrow-Romer modeli, Lucas modeli, Ar-Ge modeli, Kamu Politikası modeli olarak beş ana başlıkta toplanabilir.

İktisat yazını tarandığında; Yılmaz(2005) çalışmasında yaptığı nedensellik testine göre Türkiye ekonomisinde büyüme oranı ile işsizlik oranı arasında nedensellik ilişkisi olmadığını bulmuştur. Okun(1962) çalışmasında işsizlik ile büyüme arasında asimetrik bir ilişkinin olduğunu belirtmiştir. Fagerberg vd.(1997) çalışmasında büyüme ve işsizlik arasında negatif bir korelasyon bulmuştur. Al-Ghamam(2003) çalışmasında yaptığı nedensellik testine göre büyümeden istihdama çok yönlü ilişki olduğunu bulmuştur.

\section{Yöntem ve Ampirik Sonuçlar}

\subsection{Verilerin İncelenmesi}

Bu çalışmada veri olarak Türkiye 2000-2011 dönemi üç aylık istihdam ve GSYİH rakamları kullanılmıştır. Veriler TUIKK resmi sitesinden alınmıştır. Kullanılan veriler IST ve BUY olarak adlandırılmıştır. Şekil 1'de kullanılan serilerin grafikleri görülmektedir.
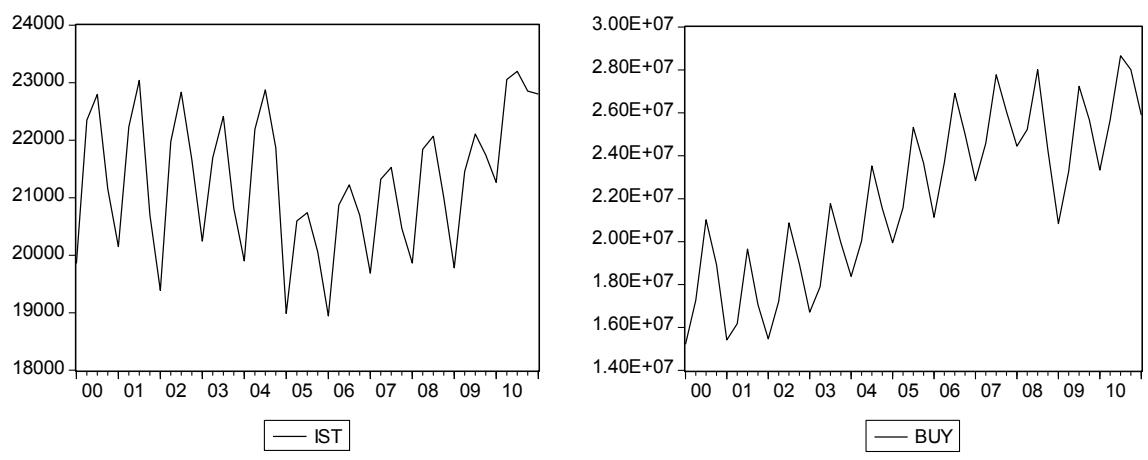

Şekil 1. 2000-2011 Yılları Arası Türkiye İstihdam ve GSYİH Rakamları. Kaynak: TUIK

Serilerin öncelikle mevsimsellik içerip içermediklerinin araştırılması gerekmektedir. Şekil 2'de serilerin 
mevsimsel istiflenmiş grafikleri görülmektedir ve iki seri de mevsimsellik içermektedir.
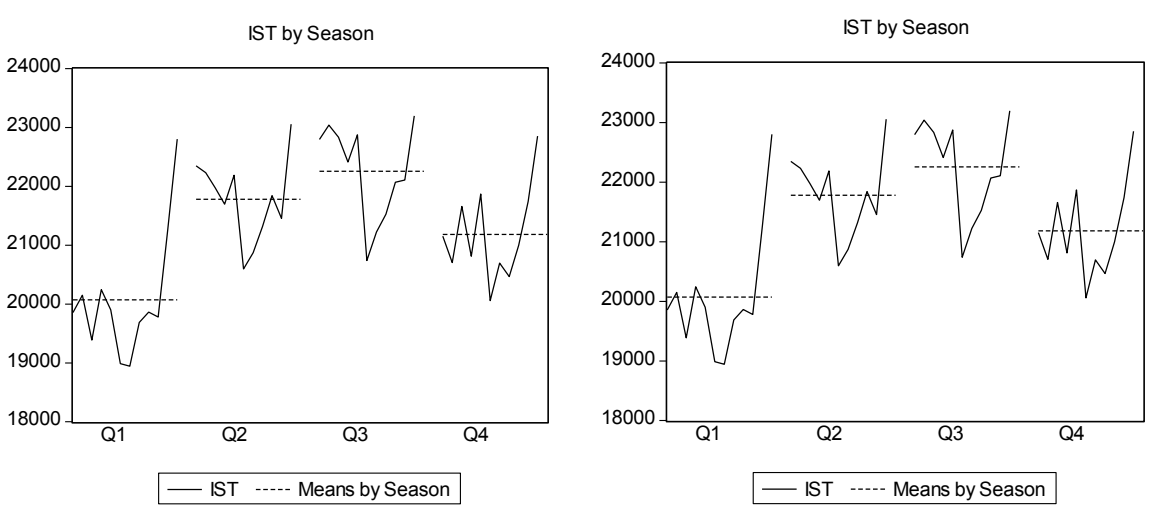

Şekil 2. 2000-2011 Yılları Arası Türkiye İstihdam ve GSYIH Rakamları Mevsimsel İstiflenmiş Seriler

Mevsimsellik içeren seriler mevsimsellikten arındırılmış ve serilerin sonuna mevsimsellikten ayrıştırıldığını göstermek amaciyla SA harfleri eklenmiştir.
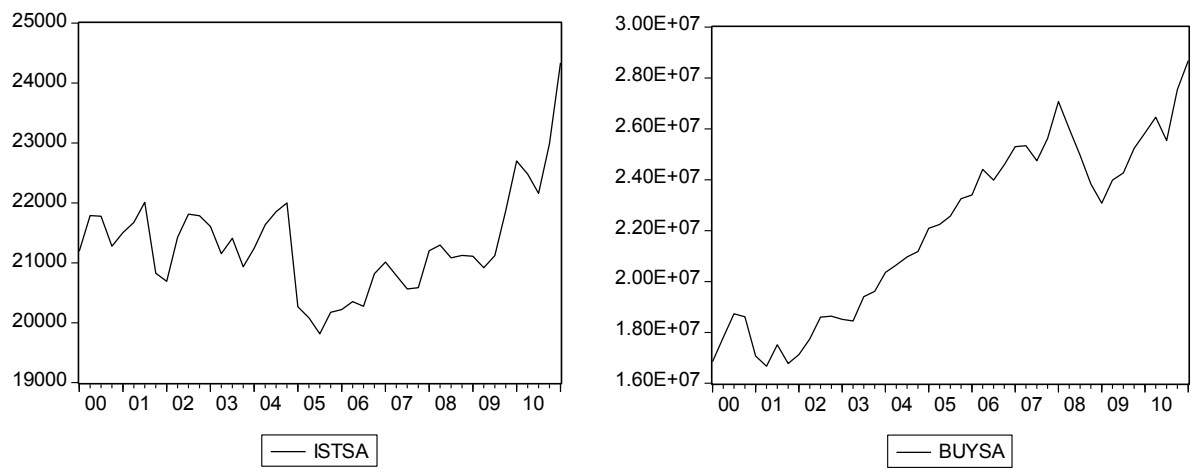

Şekil 3. 2000-2011 Yılları Arası Türkiye İstihdam ve GSYIH Rakamları Mevsimsellikten Arındırılmış Seriler

Son olarak serilerin değişkenliklerinin giderilmesi için serilerin logaritması alınmıştır. Çalışmada kullanılacak iki seri LBUYSA ve LİSTSA' dır.

\subsection{Durağanlığın Saptanması}

Ekonometri uygulamalarında kullanılan iki önemli veri türünden biri zaman serisi verileridir. Zaman serisi uygulamaları varsayımlardan biri kullanılan verilerin durağan olduğu varsayımıdır.

Durağan sürecin en basit tanımı; herhangi bir trend etkisi taşımayan, varyansı ve ortalaması sabit olan (zaman içerisinde değişmeyen), kovaryansı hesaplandığı döneme değil, dönem arasındaki farka bağlı olan süreçtir. Zayıf Durağanlık koşulları olarak tanımlanan bu koşullar, bir zaman serisi $Y_{t}$ için denklem (3.1), (3.2) ve (3.3)' deki gibi gösterilir.

$$
\begin{aligned}
& E\left[Y_{t}\right]=\mu \\
& \operatorname{Var}\left[Y_{t}\right]=\sigma^{2} \\
& \operatorname{Cov}\left[Y_{t}, Y_{t+n}\right]=\operatorname{Cov}\left[Y_{t}, Y_{t+m}\right]
\end{aligned}
$$

Yukarıda sayılan koşullara ek olarak; incelenilen zaman serisinin herhangi bir $n$ gözlemin, $\mathrm{Y}\left(\mathrm{t}_{1}\right), \mathrm{Y}\left(\mathrm{t}_{2}\right), \ldots, \mathrm{Y}\left(\mathrm{t}_{\mathrm{n}}\right)$ her $n$ ve $k$ için, $Y\left(t_{1}+k\right), Y\left(t_{2}+k\right), \ldots, Y\left(t_{n}+k\right)$ setinin ortak dağılımı ile aynı dağılıma sahipse bu süreç güçlü durağan olasılıklı süreç olarak bilinir. Bu çalışmada serilerin durağan olup olmadıkları ADF ve PP birim kök testleri ve KPSS durağanlık testi ile belirlenmeye çalışılmıştır. ADF test istatistiği ile DF test istatistikleri büyük örneklemde aynı dağılımı sergilediğinden, kullanılacak tablolar aynıdır. Önsav ve test istatistiklerinin kurulması Dickey-Fuller (Dickey ve Fuller, 1979) makalesinden farklılık göstermemektedir. Eklenecek gecikmeli değer sayısı seçilirken ardışı bağımlılı̆̆ın ortadan kalkması önemlidir. Denklem (3.4), (3.5) ve (3.6) kullanılan üç modeli genel olarak göstermektedir.

$$
\Delta \mathrm{Y}_{\mathrm{t}}=\rho \mathrm{Y}_{\mathrm{t}-1}+\sum_{\mathrm{i}=1}^{\mathrm{k}} \beta_{\mathrm{i}} \Delta \mathrm{Y}_{\mathrm{t}-\mathrm{i}}+\varepsilon_{\mathrm{t}}
$$




$$
\begin{aligned}
& \Delta \mathrm{Y}_{\mathrm{t}}=\alpha_{0}+\rho \mathrm{Y}_{\mathrm{t}-1}+\sum_{\mathrm{i}=1}^{\mathrm{k}} \beta_{\mathrm{i}} \Delta \mathrm{Y}_{\mathrm{t}-\mathrm{i}}+\varepsilon_{\mathrm{t}} \\
& \Delta \mathrm{Y}_{\mathrm{t}}=\alpha_{0}+\beta \mathrm{t}+\rho \mathrm{Y}_{\mathrm{t}-1}+\sum_{\mathrm{i}=1}^{\mathrm{k}} \beta_{\mathrm{i}} \Delta \mathrm{Y}_{\mathrm{t}-\mathrm{i}}+\varepsilon_{\mathrm{t}}
\end{aligned}
$$

Elde edilen bu denklemden sonra sıfır önsavı katsayının bire değil sıfıra eşitliği ile sınanır ve kullanılan test istatistiği $\tau$ (tau) olarak adlandırılır.

Test önsavı ve test istatistiği:

$\mathrm{H}_{0}: \rho=0$ Seri durağan değildir. Serinin birim kökü vardır.

$\mathrm{H}_{\mathrm{a}}: \rho<0$ Seri durağandır. Serinin birim kökü yoktur.

$$
\tau=\frac{\hat{\rho}}{\mathrm{S}_{\hat{\rho}}} \sim \operatorname{DF}(79)
$$

\begin{tabular}{|c|c|c|c|c|c|}
\hline \multirow{2}{*}{ Değişkenler } & Model & Test istatistiği & $\begin{array}{c}\text { \%1 kritik } \\
\text { değer }\end{array}$ & $\begin{array}{c}\text { \%5 kritik } \\
\text { değer }\end{array}$ & $\begin{array}{c}\text { \%10 kritik } \\
\text { değer }\end{array}$ \\
\hline \multirow{3}{*}{ LiSTSA } & Sabit+trend & -0.7077 & -4.1809 & -3.5155 & -3.1882 \\
\cline { 2 - 6 } & Sabit & -0.6257 & -3.5885 & -2.9297 & -2.6030 \\
\cline { 2 - 6 } & Sabit ve trend yok & 0.8655 & -2.6185 & -1.9485 & -1.6121 \\
\hline \multirow{3}{*}{ LBUYSA } & Sabit+trend & -2.0659 & -4.1809 & -3.5155 & -3.1882 \\
\cline { 2 - 6 } & Sabit & -0.5469 & -3.5885 & -2.9297 & -2.6030 \\
\cline { 2 - 6 } & Sabit ve trend yok & 2.3321 & -2.6185 & -1.9485 & -1.6121 \\
\hline \multirow{3}{*}{$\Delta$ LISTSA } & Sabit+trend & $-5.6694 * * *$ & -4.1864 & -3.5180 & -3.1897 \\
\cline { 2 - 6 } & Sabit & $-5.3623^{* * *}$ & -3.5924 & -2.9314 & -2.6039 \\
\cline { 2 - 6 } & Sabit ve trend yok & $-5.3665 * * *$ & -2.6198 & -1.9486 & -1.6120 \\
\hline \multirow{3}{*}{$\Delta$ LBUYSA } & Sabit+trend & $-5.7336^{* * *}$ & -4.1864 & -3.5180 & -3.1897 \\
\cline { 2 - 6 } & Sabit & $-5.7906 * * *$ & -3.5924 & -2.9314 & -2.6039 \\
\cline { 2 - 6 } & Sabit ve trend yok & $-5.3717 * * *$ & -2.6198 & -1.9486 & -1.6120 \\
\hline
\end{tabular}

Tablo 1. ADF Testi Sonuçlarl. $\quad \Delta$ serinin farkı alınarak elde edilen seriyi göstermektedir. $\quad$ *, **, *** sırasılla; \%10, \%5, \%1 boş hipotezin reddedildiğini göstermektedir. Gecikme kriteri olarak SIC kullanılmıştır.

Tablo 1'de ADF birim kök sınamaları özetlenmiştir test sonucunda iki seri içinde birim kök olduğunu söyleyen önsav red edilememiş yani seriler I(1) çıkmıştır. Bir sonraki aşamada serilere PP testi uygulanmıştır.

Phillips ve Perron (Phillips ve Perron, 1988) makalelerinde daha çok finansal zaman serilerinde popüler olan birim kök testlerini geliştirmiş̧lerdir. Bu test hatalarda meydana gelen serisel korelasyon ve değişen varyans sorunu ile baş etme konusunda ADF ile farklılaşmaktadır. ADF denkleminde otokorelasyonu engellemek amacıyla gecikmeli değerlerin eklenmesi yerine yazarlar DF denklemini tahmin ederek t istatistiklerini de yeniden düzenlemişlerdir. Dickey - Fuller yaklaşımı ile kırılma olan bir seriyi kırılmadan önceki ve sonraki dönemlere bölmek gerekmektedir. Ama bu alt dönemler yeterince gözlem içermiyorsa serbestlik derecesi kaybından dolayı sapmaya yol açacaktır. Böyle durumlarda PP testi ile serbestlik derecesi kaybı önlenmektedir. Bu test yanlış bir $\mathrm{H}_{0}$ önsavını reddetmek için daha güçlüdür. Denklem (3.8) ve (3.9) bu testin kullandığı önsav testlerini ve istatistiklerini göstermektedir.

$$
\begin{gathered}
\Delta \mathrm{Y}_{\mathrm{t}}=\beta^{\prime} \mathrm{D}_{\mathrm{t}}+\pi \mathrm{Y}_{\mathrm{t}-1}+\mathrm{u}_{\mathrm{t}}, \mathrm{u}_{\mathrm{t}} \sim \mathrm{I}(0) \\
\mathrm{t}_{\alpha}=\mathrm{t}_{\alpha}\left(\frac{\gamma_{0}}{\mathrm{f}_{0}}\right)^{\frac{1}{2}}-\frac{\mathrm{T}\left(\mathrm{f}_{0}-\gamma_{0}\right)(\operatorname{se}(\hat{\alpha}))}{2 \mathrm{f}_{0}^{\frac{1}{2}} \mathrm{~s}}
\end{gathered}
$$

Formülde kullanılan $\alpha$ tahmin edilen katsay1; s denklemin standart hatası; $\gamma_{0}$ hata varyansı ve $f_{0}$ sifir frekansındaki artık spektrumu tahmincisidir. Bu testte de; sabitin olduğu, hem sabit hem trendin olduğu modeller için test uygulandı. Önsavlar ve karar kriteri DF testi ile aynıdır. 


\begin{tabular}{|c|c|c|c|c|c|}
\hline Değişkenler & Model & Test istatistiği & \%1 kritik değer & \%5 kritik değer & \%10 kritik değer \\
\hline \multirow{3}{*}{ LiSTSA } & Sabit+trend & -0.2662 & -4.1809 & -3.5155 & -3.1882 \\
\cline { 2 - 6 } & Sabit & -0.7317 & -3.5885 & -2.9297 & -2.6030 \\
\cline { 2 - 6 } & Sabit ve trend yok & 0.9258 & -2.6185 & -1.9485 & -1.6121 \\
\hline \multirow{3}{*}{ LBUYSA } & Sabit+trend & -2.2273 & -4.1809 & -3.5155 & -3.1882 \\
\cline { 2 - 6 } & Sabit & -0.5217 & -3.5885 & -2.9297 & -2.6030 \\
\cline { 2 - 6 } & Sabit ve trend yok & 2.5331 & -2.6185 & -1.9485 & -1.6121 \\
\hline \multirow{4}{*}{$\Delta$ LiSTSA } & Sabit+trend & $-7.8194 * * *$ & -4.1864 & -3.5180 & -3.1897 \\
\cline { 2 - 6 } & Sabit & $-5.2581 * * *$ & -3.5924 & -2.9314 & -2.6039 \\
\cline { 2 - 6 } & Sabit ve trend yok & $-5.2933 * * *$ & -2.6198 & -1.9486 & -1.6120 \\
\hline \multirow{3}{*}{$\Delta$ LBUYSA } & Sabit+trend & $-5.6923 * * *$ & -4.1864 & -3.5180 & -3.1897 \\
\cline { 2 - 6 } & Sabit & $-5.7537 * * *$ & -3.5924 & -2.9314 & -2.6039 \\
\cline { 2 - 6 } & Sabit ve trend yok & $-5.3717 * * *$ & -2.6198 & -1.9486 & -1.6120 \\
\hline
\end{tabular}

Tablo 2. PP Testi Sonuçları. A serinin farkı alınarak elde edilen seriyi göstermektedir.

*, **, *** sırasiyla; \%10, \%5, \%1 boş hipotezin reddedildiğini göstermektedir. Gecikme kriteri olarak SIC kullanılmıştır.

Tablo 2 PP testi sonuçlarını özetlemektedir. Bu test sonucunda da serileri I(1) bulunmuştur. Son olarak daha güçlü bir test olan ve durağanlığın sınandığı KPSS testi uygulanmıştır.

Kwiatkowski, Phillips, Schmidt ve Shin (Kwiatkowski, vd, 1992) testlerini serinin durağan olduğunu söyleyen boş önsavı kullanarak test istatistiği Lagrange Çarpanı üzerine kurulmuştur. Bu test ekonometri yazınında durağanlık testi olarak ele alınmaktadır. Diğer testlerin önsavları hem birim kök hem durağanlığa göre yorumlanırken, KPSS testi sadece durağanlığı söyleyen önsav üzerine kurulur.

Test önsavları :

$$
\begin{aligned}
& \mathrm{H}_{0}: \sigma_{\varepsilon}^{2}=0 \Rightarrow \mathrm{Y}_{\mathrm{t}} \sim \mathrm{I}(0) \\
& \mathrm{H}_{\mathrm{a}}: \sigma_{\varepsilon}^{2}>0 \Rightarrow \mathrm{Y}_{\mathrm{t}} \sim \mathrm{I}(1)
\end{aligned}
$$

Önsavlarda dikkat edilmesi gereken nokta, sıfır önsavının serinin durağan olduğunu söyleyen önsav olmasıdır. Önceki bölümlerde incelenilen tüm testlerde sıfır önsavının reddi serinin durağan olduğuna karar verilmesi anlamına gelirken bu test de tam tersi söz konusudur.

\begin{tabular}{|c|c|c|c|c|c|}
\hline \multirow{2}{*}{ Değişkenler } & Model & Test istatistiği & $\begin{array}{c}\text { \%1 kritik } \\
\text { değer }\end{array}$ & $\begin{array}{c}\text { \%5 kritik } \\
\text { değer }\end{array}$ & $\begin{array}{c}\text { \%10 kritik } \\
\text { değer }\end{array}$ \\
\hline \multirow{2}{*}{ LİSTSA } & Sabit+trend & 0.2040 & 0.2160 & 0.1460 & 0.1190 \\
\cline { 2 - 6 } & Sabit & 0.2219 & 0.7390 & 0.4630 & 0.3470 \\
\hline \multirow{2}{*}{ LBUYSA } & Sabit+trend & 0.1171 & 0.2160 & 0.1460 & 0.1190 \\
\cline { 2 - 6 } & Sabit & 0.8063 & 0.7390 & 0.4630 & 0.3470 \\
\hline
\end{tabular}

Tablo 3. KPSS Testi Sonuçları

Yapılan KPSS testi sonucunda da seriler birinci farkta durağan olduğu saptanmıştır. Bu durumda serilerin birinci farkta durağan olan seriler olduğu sonucuna varılır. Bu nedenle yapılacak olan analizlerde ilk fark serileriyle çalışılacaktır.

\subsection{Eşbütünleşme testi}

Serilerin eşbütünleşik olup olmadıklaırnın araştırılması için Engle ve Granger İki Aşamalı Yöntemi kullanılacaktır. Eşbütünleşmenin varlığını sınamak için Engle ve Granger (Engle ve Granger, 1987) belirli bir süreç önermektedir. Bu sürece göre; değişkenlerin bütünlenme derecesi belirlenir. Bu amaçla Dickey-Fuller, ADF, Phillips-Perron vb. testleri kullanılabilir. Her iki değişken de durağansa eşbütünleşme analizi yapmaya gerek yoktur. Değişkenler farklı sıradan bütünleşmişse eşbütünleşik olmadıklarına karar verilir.

$$
\mathrm{Y}_{\mathrm{t}}=\beta_{0}+\beta_{1} \mathrm{X}_{\mathrm{t}}+\mathrm{u}_{\mathrm{t}}
$$

(3.10) numaralı denklemin parametreleri tahmin edilir. Değişkenlerin bütünleşik olup olmadığını belirlemek için (3.10) numaralı modelin artıklarına durağanlık testlerini uygulanır. Ancak bu artıklara Dickey-Fuller ya da ADF testleri yapılırken klasik tablo değerleri kullanılamaz. Bunun nedeni elimizde hata terimleri $\mathrm{e}_{\mathrm{t}}{ }^{\prime} l e r$ değil, bunların tahminleri olan $\hat{e}_{t}$ 'ların olmasıdır. Kritik değerler için Engle ve Yoo (Engle ve Yoo, 1987)'ya bakılabilir. Durağanlık testi sonucunda $\hat{e}_{t}$ serisi durağan bulunursa değişkenlerin bütünleşik oldukları sonucuna varilır. 


\begin{tabular}{|c|c|c|}
\hline $\begin{array}{ll}\text { Değişkenler } & \text { Regresyon Denklemleri } \\
\end{array}$ & LBUYSA & LISTSA \\
\hline \multirow{2}{*}{ Sabit } & 13,7661 & 9,6612 \\
\hline & 2,1778 & 15,6830 \\
\hline \multirow{2}{*}{ LİSTSA } & 0.3139 & \\
\hline & 0.4950 & \\
\hline \multirow{2}{*}{ LBUYSA } & & 0.0180 \\
\hline & & 0.4950 \\
\hline ADF İstatistiği & $-0,8452$ & $-0,7798$ \\
\hline
\end{tabular}

Tablo 4. Engle Granger Eş Bütünleşme Testi Sonuçlarl

Elde edilen istatistik değerleri Engle-Yoo tablo değerinden mutlak değer olarak küçük olduğundan hata teriminin durağan olmadığ böylece iki modelde de serilerin eşbütünleşik olmadığı sonucuna varılır.

\subsection{Granger Nedensellik Analizi}

Granger nedensellik testi (Granger, 1969) ile değişkenlerin arasındaki ilişkinin yönü belirlenmektedir. Granger testinin gerçekleştirilmesi için gereken aşamalar özetlenecek olursa; Y'nin tüm gecikmeli değerleri ve diğer değişkenlerle regresyona tabi tutulacaktır (ancak bu regresyonda X'in hiçbir gecikmeli değeri yer almamalıdır). Aynı regresyonu bu kez X'in gecikmeli değerlerini ekleyerek gerçekleştirilecektir. Bu bir kısıtlanmamış regresyon olacaktır ve bu regresyondan kısıtlanmamış hata kareleri toplamı (RSSur) elde edilecektir. Buradaki boş (red) önsavı Ho : $\sum \alpha_{i}=0$ 'dir (gecikmeli X değerleri regresyonda yer almamalıdır) Bu önsavı test etmek için verilen $\mathrm{F}$ testi uygulanmalıdır.

$$
\mathrm{F}=\frac{\left(\mathrm{RSS}_{\mathrm{R}}-\mathrm{RSS}_{\mathrm{UR}}\right) / \mathrm{m}}{\mathrm{RSS}_{\mathrm{UR}} /(\mathrm{n}-\mathrm{k})}
$$

Burada m ve (n-k) serbestlik derecelerindeki F dağılımına bakılacaktır. Buradaki örnekte m, X'in gecikmeli değerlerinin sayısını (kaç tane gecikmeli $\mathrm{M}$ değeri olduğunu), k ise kısıtlanmamış regresyondaki tahmin edilen parametre sayısını göstermektedir.

Eğer seçilen anlamlılık düzeyine göre hesaplanan F değeri kritik (tablo) F değerinden daha büyükse, boş (red) önsavı reddederek, $\mathrm{X}$ terimlerinin regresyonda yer alması gerektiğine karar verilmiş olur.

Granger Nedensellik Testi'nde kullanılacak olan gecikme sayısı önemlidir. Bu amaçla VAR modeli kurularak gecikme sayısı belirlenecektir. Kurulan VAR modelinde gecikme belirleme kriterlerine göre gecikmesiz model kullanılması uygun olduğu saptanmıştır. Fakat kurulan bu modelde yapılan otokorelasyon testi sonucu otokorelasyon olduğu saptanmıştır. Otokorelasyondan arındırılması amacıyla üç gecikmeli model kurulmuş, otokorelasyon olmadığı saptanmıştır ve Granger Nedensellik Testi’nde de üç gecikmeli model kurulmuştur.

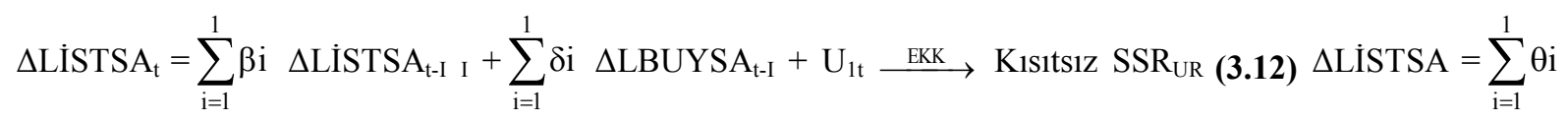
$\Delta$ LISTSA $_{t-\mathrm{I}}+\mathrm{U}_{2 \mathrm{t}} \stackrel{\mathrm{EKK}}{\longrightarrow} \mathrm{K}_{1} 1 \mathrm{t} 11 \mathrm{SSR}_{\mathrm{R}}$

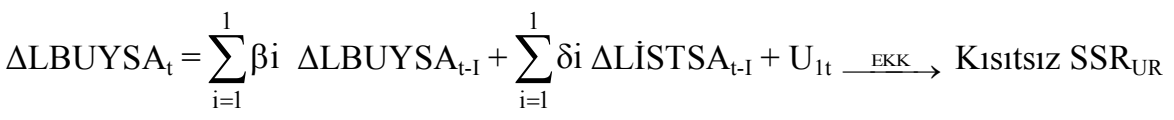

$\Delta$ LBUYSA $_{t}=\sum_{\mathrm{i}=1}^{1} \theta \mathrm{i} \Delta \mathrm{LBUYSA}_{\mathrm{t}-\mathrm{I}}+\mathrm{U}_{2 \mathrm{t}} \stackrel{\mathrm{EKK}}{\longrightarrow} \mathrm{K}_{1 \mathrm{~S} 1 \mathrm{tl}} \mathrm{SSR}_{\mathrm{R}}$

\begin{tabular}{|c|c|c|}
\hline \multicolumn{3}{|c|}{ Gecikme Sayısı: 3 } \\
\hline Boş Önsav: & F-İstatistiği & Olasılık \\
\hline$\Delta$ LBUYSA, $\Delta$ LİSTSA'nın Granger Nedeni değildir & 1.1855 & 0.3297 \\
\hline$\Delta$ LİSTSA, $\Delta$ LBUYSA'nın Granger Nedeni değildir & 1.7403 & 0.1772 \\
\hline
\end{tabular}

Tablo 5. Granger Nedensellik Testi Sonuçları

Yapılan Granger Nedensellik testi sonucunda iki seri içinde Ho hipotezi red edilememiş ve serilerin birbirinin nedeni olmadiğı sonucuna varılmıştır.

\section{Sonuç}

Araştırmanın uygulama kısmında Türkiye istihdam rakamları ve GSYİH rakamları verileri arasındaki ilişki ekonometrik yöntemler kullanılarak araştırıldı. Yapılan üç durağanlık testi de aynı sonucu verdi ve iki serinin de 
birinci farkta durağan olduğu saptandı. Bu iki seri arasında uzun dönemli ilişki olup olmadığı Engle Granger eş bütünleşme yöntemi kullanılarak araştırıldı. Yöntem sonucunda serilerin eş bütünleşik olmadığı yani uzun dönemli ilişkiye sahip olmadıkları saptandı. Bu durum seriler arasında kısa dönemli ilişkinin varlığı anlamına gelmektedir ve bu ilişkinin incelenmesi amacıyla VAR modeli kuruldu. Değişkenler arasındaki nedenselliğin incelenmesi amaciyla uygulanan Granger Nedensellik testi sonucunda iki serininde birbirinin Granger nedeni olmadı̆̆ 1 sonucuna varıldı.

Okun(1962) makalesinde işsizlikteki azalıştan kat kat daha fazla çıktı artışını pozitif yönlü kapasite kullanım oranı ve çalışma sürelerinin artışına dayandırmaktadır. Bu da Türkiye ekonomisindeki yüksek oranlı büyüme artışlarının istihdamı aynı oranda arttırmamasının nedeni olabilir. Yani istihdamsız büyümeyi kapasite kullanım oranlarındaki ve çalışma sürelerindeki artışla açıklayabiliriz.

Emek, sermaye ve teknoloji büyüme modellerinin en önemli değişkenleridir. Türkiye ekonomisine bakıldığında sermaye yoğun bir büyüme gerçekleşmektedir. Türkiye'de emek yoğun üretimin yerini sermaye yoğun üretim tarzı almaya başladığından beri işsizlik gittikçe artmıştır. Özellikle tarım sektöründe makinalaşmayla kırsal işsizlik artmış ve köyden kente göç yaşanmış buna bağlı olarak da kent işsizliği artmıştır. Köyden kente göç ile birlikte tarım sektöründeki işgücü diğer sektörlere kaymıştır. Fakat işgücü yüksek verimliliğe sahip sanayi sektörü yerine hizmetler sektörüne kaymıştır. Bu durumun ekonomik büyümeye katkısı olmamıştır.

Teknolojik gelişmelerle birlikte nitelikli işgücüne talep artarken niteliksiz işgücüne talep azalmıştır. Türkiye'de üretim teknolojisine uygun nitelikli işgücünün yetiştirilemesi gerekmektedir.

Sermaye piyasalarında yapılacak yeni düzenlemelerle spekülatif finansal hareketler önlenmeli uzun süreli yabancı sermayenin yeni yatırımlar yapması özendirilmelidir.

\section{Kaynakça}

- Akyıldız, Hüseyin. 2006, Türkiye’de İstihdamın Analitik Dinamiği, Ankara: Asil Yayın Dağıtım.

- Al-Ghannam Hamad A.(2003). The Relationship Between Economic Growth And Employment In Saudi Private Firms. Economic Studies Vol.:5-9.

- $\quad$ Aren, Sadun. 2008, İstihdam Para ve İktisadi Politika, Ankara: imge kitabevi.

- $\quad$ Atamtürk, Burak. 2007, "Büyüme Teorileri ve IMF Politikaları”, Marmara Üniversitesi İI.B.F. Dergisi, S.1, ss. 89-103.

- Dickey, D. A. and W. A. Fuller. 1979, "Distribution of the estimators for autoregressive time series with a unit root," Journal of the American Statistical Association, Vol. 74, No. 366, pp. 427-431.

- $\quad$ Engle, R. F. Granger, C.W.J. 1987, "Cointegration and error correction: representation, estimation and Testing”, Econometrica, Vol. 55, No. 2, pp. 251-276.

- Engle, R. F. Yoo, B.S. 1987, "Forecasting and Testing in Cointegrated systems", Journal of Econometrics, Vol. 35, pp. 143-159.

- Fagerberg J., Verspagen B. ve Caniels M. (1997). Technology, Growth andUnemployment Across European Regions. Reg. Studies 31, 457-466.

- Granger, C.W.J. 1969, Investigating Causal Relations By Econometric Models and Cross-Spectral Methods, Econometrica, 37.

- İstatistik Göstergeler Statistical Indicators 1923-2009, 2010, Ankara: Türkiye İstatistik Kurumu Matbaas1.

- Kaynak, Muhteşem. 2005, Kalkınma İktisadı, Ankara: Gazi Kitapevi.

- Kwiatkowski, Denis. Peter Philips. Peter Schmidt. Yongcheol Shin. 1992, "Testing the null hypothesis of stationarity against the alternative of a unit root", Journal of Econometrics, Vol. 54, pp. 159-178.

- Okun, Arthur. M. 1962, "Potential Gnp: Its Measurement and Significance", Proceedings of the Business and Economic Statistics Section of the American Statistical Association.

- Özsağır, Arif. 2008, “Dünden Bugüne Büyümenin Dinamiği”, 2008, KMU İ.I.B.F Dergisi, S.14, ss. 332-347.

- Peter C. B. Phillips. Pierre Perron. 1988 “Testing for a Unit Root in Time Series Regression”, Biometrika, Vol. 75, No. 2, pp. 335-346.

- Romer, Paul M. (1986): “Increasing Returns and Long Run Growth,” Journal of Political Economy, 94, 1002-37.

- Solow, Robert M. 1956, “A Contribution to the Theory of Economic Growth", The Quarterly Journal of Economics, Vol. 70, No. 1, pp. 65-94.

- Ülgener, F. Sabri. 1980, Milli Gelir İstihdam ve İktisadi Büyüme, İstanbul: Der Yayınevi.

- Yılmaz, Göktaş Özlem. 2005, “Türkiye Ekonomisinde Büyüme ile İşsizlik Oranları Arasındaki Nedensellik İlişkisi”, IÜ İktisat Fakültesi Ekonometri ve İstatistik Dergisi, S. 2, ss. 11-29. 


\title{
Макроэкономическая оценка постсоветского развития в Таджикистане
}

\author{
Khodjamakhmad Umarov (Institute of Economics, Tajikistan)
}

\section{Macroeconomic Assessment of post-Soviet Development in Tajikistan}

\begin{abstract}
Official statistic data show a very optimistic picture of the post-Soviet economic growth in Tajikistan. In fact, over the period 1999 to 2008 these rates are overestimated. It is well known that between growth rate of gross savings there is a close correlation, that proves not only the world's economic history, but also by current trends and proportions of macro-economic relations. Base on well-founded arguments, the author proves the need for significant adjustments in economic growth and a number of indicators of socio-economic development. Recommendations will summarize the issues related with mobilizing domestic savings, gross savings closer regulations and gross savings on the way stop capital flight to offshore zones.
\end{abstract}

JEL Codes: A10

Таджикистан обладает экономикой, которая нуждается в догоняющем развитии. Она не только должна преодолеть бедность подавляющего большинства населения, но и выйти из среды сельских бедных стран мира и найти свое место в ряду стран со средним уровнем экономического развития. Для этого страна нуждается в высоких темпах экономического роста. Согласно расчетам ученых из Института экономических исследований при Министерстве экономического развития и торговли РТ если с 2005 по 2007 г. среднегодовые темпы роста ВВП будут находиться на уровне 11-13\%, то к 2015 году страна по производству ВВП на душу населения может выйти к уровню, который был достигнут Таджикистаном в 1990 году.

Однако для достижения высоких темпов экономического роста нужно обеспечить высокую норму валового накопления. Между последними имеет место корреляционная связь. Япония и «азиатские драконы», вышедшие на высокий уровень экономического развития в течении продолжительного времени отличались высокой нормой валового накопления. Последняя в те годы не опускалась ниже $30 \%$. КНР в течении 80-90-х годов XX веков. И первые два десятилетия XXI века показывали, что можно добиться весьма высоких темпов роста ВВП путем сохранения нормы валового накопления между 35 и $40 \%$. В Индии для того, чтобы обеспечить ежегодные темпы экономического роста на уровне $6 \%$ за последние 20 лет пришлось поддержать норму валового накопления на уровне почти $25 \%$.

Опыт среднеразвитых и слаборазвитых стран доказывает, что низкой норме валового накопления с неизбежностью сопутствуют низкие темпы экономического роста. Так, в странах Африки за две последние десятилетия норма валового накопления и темпы экономического роста составляли соответственно около $20 \%$ и приблизительно $2 \%$ соответственно. В странах Латинской Америки отмеченные показатели не указанные периоды времени составили $20-21 \%$ и $2 \%$. Такая ситуация присуща и многим азиатским странам.

Нужно особо отметить, что такая закономерность не чужда Таджикистану. Однако здесь проявляют себя совершенно другие, взаимоисключающие тенденции, что следует из нижеследующей таблицы.

\begin{tabular}{|c|c|c|c|c|c|c|c|}
\hline & $\mathbf{1 9 9 1}$ & $\mathbf{1 9 9 5}$ & $\mathbf{1 9 9 7}$ & $\mathbf{1 9 9 9}$ & $\mathbf{2 0 0 0}$ & $\mathbf{2 0 0 1}$ & $\mathbf{2 0 0 2}$ \\
\hline Темпы роста ВВП- годовые & $-5,4$ & $-12,4$ & 1,7 & 3,7 & 8,3 & 9,6 & 10,8 \\
\hline Валовые накопления (в \% к ВВП) & 12,3 & 28,7 & 19,7 & 17,3 & 9,4 & 9,7 & 9,4 \\
\hline & $\mathbf{2 0 0 3}$ & $\mathbf{2 0 0 4}$ & $\mathbf{2 0 0 5}$ & $\mathbf{2 0 0 6}$ & $\mathbf{2 0 0 7}$ & $\mathbf{2 0 0 8}$ & \\
\hline Темпы роста ВВП- годовые & 11,0 & 10,3 & 6,7 & 7,0 & 7,8 & 7,8 & \\
\hline Валовые накопления (в \% к ВВП) & 10,0 & 12,2 & 11,6 & 16,0 & 24,6 & $\ldots$ & \\
\hline
\end{tabular}

Таблица 1. Динамика темпов экономического роста и валового накопления. (в \%)

Источник: Таджикистан: 15 лет государственной независимости. Ст.сб. Душанбе, 2006, стр.207.

Статистический ежегодник Республики Таджикистан. Душанбе, 2009, стр. 206. И расчеты автора по ст.сб. «Основные показатели национальных счетов» за соответствующие годы.

Эти данные показывают, что в Таджикистане такая связь не придерживается. Странным представляется, что в годы с самими высокими уровнями валового накопления имеют место либо минусовые, либо очень низкие темпы роста ВВП $(1991,1995,1997,1999,2007)$. И наоборот в годы с 
низким уровнем валового накопления имело место очень высокие темпы экономического роста (2000, 2001, 2002, 2003, 2004 г.г.). Если даже учесть фактор лага в 3-4 года, то опять не получается с нахождением какой-либо связи. Отсюда можно придти к выводу о том, что данные о темпах экономического роста не представляются достоверными.

Однако, не вызывают сомнения объективность отмеченных выше связей применительно к среднеразвитым и слаборазвитым странам, где стратегии экономического развития основываются на использование экономических факторов экономического роста. Что касается высокоразвитых стран, то там действуют закономерности несколько иного типа. Здесь корреляция между нормой валового накопления и темпами экономического роста выражается слабее (Более подробно см.: Булатов А. Россия в мировом инвестиционном процессе. «Вопросы экономики». 2004, №1, стр. 76,77). Это можно объяснить господством преимущественно интенсивного типа экономического роста и постоянным нарастанием масштабов «экономики знаний». К тому же в развитых странах «исправно» работает амортизационный фонд, формирование и использование которого гарантируется законодательством этих стран, хорошо наложенным учетом в предприятиях и банках. Устойчивая ориентация на эффективное использование инноваций позволяет использовать средства амортизационного фонда в качестве источника наращивания объемов производства, поскольку быстрая смена поколений машин и механизмов и рост производительности труда позволяет на одну и ту же сумму амортизационных отчислений ввести в действие новое технологическое оборудование с более высокими показателями производительности.

Профессор Булатов А. верно подчеркивает, что за счет внедрения инноваций (быстрого использования в экономике новых знаний) и формировании «новой экономики» США удалось сохранить высокие для развитых стран темпы экономического роста в 80-е и 90-е годы прошлого века. Он обратил особое внимание на то, что именно твердая ориентация на внедрение инноваций в экономики позволило добиться обеспечения таких темпов при норме валового накопления которое для развитых стран является сравнительно низким (около 20,5\% в 80 -е годы и $21 \%$ в 90-е годы). С этих позиций остается загадкой как можно добиться столь высоких темпов экономического роста в Таджикистане при крайне низкой норме валовых накоплений в условиях, когда ресурсы расширенного воспроизводства использовались на низком уровне эффективности («Вопросы экономики». 2004, №1, стр. 76.).

В любом случае, в перспективе Таджикистану неизбежно приходится повысить норму валового накопления до 28-32\%, когда полностью будут исчерпаны резервы недоиспользованных мощностей и выяснится, что без модернизации экономики дальнейшее ее развитие становится невозможным. И такие нормы могут обеспечить высокие темпы экономического роста, когда развитие экономики станет не только экономически, но и социально эффективной, т.е. если любой процент годового прироста ВВП найдет соответствующее положительное отношение на уровне жизни людей.

Известно, что главным источником финансирования инвестиций являются валовые сбережения. Выполненные обследования показали, что в общемировом масштабе норма валовых сбережений которая рассчитывается как отношение валовых сбережений к ВВП находится на том же уровне, что и норма валового накопления, т.е. на уровне 23-24\%. Как и норма валового накопления норма валовых сбережений в развитых странах находится ниже по сравнению с развивающимися странами, поскольку первые не нуждаются в высоких темпах экономического роста. Данные мировой статистики показывают, что в Африке в 2000-е годы норма валовых сбережений составила от 19 до 20\%, в Латинской Америке- от 17 до 19\%, в Японии- 27-30\%, в КНР- почти 40\%, в новых промышленно развитых азиатских странах 28$30 \%$ (World Economic Outlook, 2008.)

Что касается бывшего Советского Союза, то там в течении всей послевоенной истории имело место высокий уровень валовых сбережений, которые превышали 30\% по отношению к национальному доходу. Кстати, в первом десятилетии XXI века Россия показывает высокую норму валовых сбережений, составляющих от 32 до $35 \%$.

В Таджикистане ситуация в этом плане остается неопределенной. Это объясняется резкими различиями официальных данных, которые касаются норм валовых накоплений и норм валовых сбережений. К тому же данные статистических сборников, выпущенные в отдельные годы оказывался по одним и тем же годам разными. Так, если в одном статистическом справочнике рассчитанная норма валового сбережения за 2000 год составляет 0,6 то по другому справочнику получается 21,0\%, за 2001 год- соответственно $1,8 \%$ и 23,7\%, за 2002 год- 6,4 и 23,8\% (Основные показатели национальных счетов. Ст.сб. Душанбе, 2004, стр. 110 и Основные показатели национальных счетов. Ст.сб. Душанбе, 2008, стр. 27. ). Если же брать 2000-е годы то можно наблюдать следующую картину.

\begin{tabular}{|c|c|c|c|c|c|c|c|c|}
\hline & $\mathbf{2 0 0 0}$ & $\mathbf{2 0 0 1}$ & $\mathbf{2 0 0 2}$ & $\mathbf{2 0 0 3}$ & $\mathbf{2 0 0 4}$ & $\mathbf{2 0 0 5}$ & $\mathbf{2 0 0 6}$ & $\mathbf{2 0 0 7}$ \\
\hline Норма валовых накоплений & 9,4 & 9,7 & 9,4 & 10,0 & 12,2 & 11,6 & 16,0 & 24,6 \\
\hline Норма валовых сбережений & 21,0 & 23,7 & 23,8 & 27,7 & 34,7 & 26,7 & 32,6 & 30,7 \\
\hline
\end{tabular}

Таблица 2. Динамика нормы валовых накоплений и валовых сбережений. (в \%).

Источник: Основные показатели начиональных счетов. Ст.сб. Душанбе, 2008, стр.110, 129 и 15 и 27. 
Ни в одной стране мира невозможно найти такого разброса в соотношении между вышеприведенными показателями. Они по своей экономической природе очень близки друг к другу и их отделяет лишь временной лаг, т.е. со временем валовые сбережения превращаются в валовые накопления. Промежуточным звеном в этом временном лаге выступают инвестиции.

В Таджикистане, сбережения не только не полностью превращаются в валовые накопления, но и ориентируются на реализацию неинвестиционных задач. В условиях Таджикистана значительная часть сбережений направляются на выполнение всякого рода обрядов и обычаев- свадеб, похорон, поминок, религиозных процедур и т.д. Согласно выполненным в 2010 году страновым офисом МОМ обследованиям, $6 \%$ вернувшихся из миграции вследствие финансового кризиса мигрантов заработанные и направленные на Родину деньги использовали на проведение свадеб и торжеств по случаю обрезания детей. 4,5\% мигрантов свои заработки использовали для выполнения религиозных обычаев.

Поэтому, в отличии от многих стран в Таджикистане соотношение между сбережениями и инвестициями остается нерациональным. Несмотря на то, что в последние годы в стране реализуется программа упорядочивания традиций, обрядов и обычаев нерациональные, неинвестиционные затраты в структуре валовых сбережений остаются высокими.

В мире преобладает совершенно иная, даже противоположная, нежели в Таджикистане ситуация. В мировом масштабе объемы инвестиций незначительно превышают объемы сбережений. Если к этому вопросу придти с позиции странового разреза, то можно наблюдать определенные различия. Например, в США уже в течении длительного промежутка времени сбережения оказываются меньше инвестиций на 3-5\%. В Японии имеет место обратная ситуация. Здесь в течении продолжительного времени сбережения превышают объемы инвестиций на 1,5-3\%. В остальных развитых азиатских странах такое превышение доходит до $6,5 \%$. В отличии от Таджикистана в подавляющем большинстве развивающихся стран объемы инвестиций заметно превышают объемы сбережений.

Профессор Булатов А. верно отмечает, что в любой стране разница между сбережениями и инвестициями покрываются международными нетто-движениями капитала, то есть чистой разницей между ввозом и вывозом капитала. В странах с отставанием нормы сбережений от нормы валового накопления это обычно ведет к нетто-ввозу капитала извне (например, в США, Китае и большинства развивающихся стран). В других странах это обуславливается нетто- вывозом капитала (например, в развитых странах Азии и Европы, а также в некоторых развивающихся странах) («Вопросы экономики». 2004, №1, стр. 79.).

В условиях Таджикистана превышение сбережений над валовым накоплением и следовательно над инвестициями объясняются следующими обстоятельствами: а) значительная часть сбережений превращаются в мимолетные затраты с целью выполнения обрядов, обычаев и других традиций и религиозных процедур;

б) ощутимая часть сбережений расходуется на обслуживание накопленного государственного долга, а также восстановление золотовалютных запасов страны;

в) вся растущая по объемам часть сбережений направляются за границу, главным образов, в оффшорные зоны. Согласно Платежному балансу НБТ только в 2007 году 372 млн. долларов составила утечка из страны. Естественно полагать, что такая утечка состояла главным образом из живых денег. Именно этими моментами объясняется то, что при относительно высокой норме валовых сбережений экономика страны испытывает инвестиционный голод.

Другими словами, в Таджикистане валовые сбережения подвергаются растранжириванию. Это приводит к замедлению процессов социально-экономического развития. В данном случае, как верно отметил профессор Николаев М. «инвестиционная деятельность призвана создать материальные условия для социально-экономического развития государства.

С позиций социального результата- это улучшение качества жизни, которое характеризуется показателями денежных доходов на душу населения, развитие медицинского и культурно-бытового обслуживания граждан, сохранение природной среды и т.д. При этом от таких отраслей, как здравоохранение, образование, жилищное и коммунальное хозяйство, существенно зависит качество жизни населения. С точки зрения социального результата, инвестиционные процессы, имеющие место в условиях экономического роста, далеко не в полной мере содействуют социально-экономическому развитию государства («Экономист», 2007, №3, стр. 19.).

Это означает, что из-за низкой инвестиционной активности, вызванной низкой нормы валового накопления не достигается главная социальная цель развития экономики - повышение уровня материального и духовного благосостояния населения. Это выражается в целом ряде отрицательных явлений, которые имеют место в развитии социальной сферы.

Численность населения в 2007 году возросло по сравнению с 1984 годом на 65,3\%. Однако по всем важнейшим отраслям социальной сферы наблюдается ухудшение показателей ввода в действие объектов 
социально-культурного развития в абсолютном отношении. По сути дела инвестирование на основные фонды детских дошкольных учреждений прекратился- ввод в действие ДДУ сократился более чем в 10 раз, а в расчете не душу населения почти в 17 раз. За последние две пятилетия ввод в действие больничных коек в абсолютном отношении уменьшился на 32,4\%, общеобразовательных школ- на 5,9\%, жилых домов- в 2,1 раза. С учетом ввода в действие одноименных объектов колхозами и ростом населения падение ввода в действие объектов социальной сферы получается не просто быстрым, а катастрофичным. И в этом воочию можно убедиться, если учесть, что и источники финансирования инвестиций на развитие социальной сферы значительным образом снизились из-за растущих масштабов различий между нормой валового накопления и нормой валовых накоплений, взятые в динамике.

Приоритеты сферы вложения инвестиций определяются критериями экономической и социальной эффективности. В частности, для Таджикистана весьма важными представляется развитие трудоемких производств, с целью решения проблемы занятости и безработицы, развитие материалоемких производств, которые опирались бы на местные дешевые сырьевые ресурсы. Речь в частности, идет о быстром развитии туризма и народных художественных промыслов, предприятий по переработке хлопкаволокна, овощей, фруктов, винограда и производства из них готовых продуктов, которые оказались бы конкурентоспособными не только во внутреннем, но и во внешних рынках.

Естественно полагать, что Таджикистан нуждается в быстром инвестиционном развитии и последние обеспечивается приоритетной ролью науки и наукоемких отраслей экономики. Структурные сдвиги в инвестировании экономики призваны также обеспечить технологический прорыв в масштабе страны, как в центре, так и в периферийных районах. Вместе с тем в современных условиях инновационные прорывы представляются возможными, если будет уделено внимание модернизации не отдельных технологических процессов, а внедрению макротехнологий по выпуску высокотехнологичной и наукоемкой продукции.

Пока в Таджикистане в рамках экономической и политической политики внедрения макротехнологий не уделяется никакого внимания. Между тем, целые отрасли в стране нуждается в макротехнологиях и запаздывание с решением этого вопроса может снизить конкурентоспособность экономики страны на мировом рынке. В Таджикистане есть целые отрасли, которые нуждаются в ускоренном инвестиционном развитии и рост их эффективности возможен на путях применения макротехнологий. К последним относится химическая и горнодобывающая отрасль, а так же сельское хозяйство. Таджикистан располагает конкурентными преимуществами в отношении развития этих отраслей, однако реализация таких преимуществ не возможен без технологического прорыва путем внедрения соответствующих макротехнологий.

\section{Литература}

- Таджикистан: 15 лет государственной независимости. Ст.сб. Душанбе, 2006.

- Статистический ежегодник Республики Таджикистан. Душанбе, 2009.

- Булатов А. Россия в мировом инвестиционном процессе. «Вопросы экономики». 2004, №1.

- Булатов А. Россия в мировом инвестиционном процессе. «Вопросы экономики». 2004, №1.

- World Economic Outlook. IMF. September 2008, p. 231-234.

- Основные показатели национальных счетов. Ст.сб. Душанбе, 2004.

- Основные показатели национальных счетов. Ст.сб. Душанбе, 2008.

- Основные показатели национальных счетов. Ст.сб. Душанбе, 2008.

- Булатов А. Россия в мировом инвестиционном процессе. «Вопросы экономики». 2004, №1.

- Николаев М. Условия инвестиционного воспроизводства. «Экономист», 2007, №3. 


\title{
Проблемы продовольственной безопасности Казахстана
}

\author{
Gani Kaliev (Academy of Agricultural Sciences, Kazakhstan)
}

\section{The Problem of Food Security in Kazakhstan}

\begin{abstract}
The growing actuality of food security problem in the world economy, emphasises on foundations of agricultural policy such as food production, distribution and trade. Considering this, Kazakhstan developed national food reserves for taking measures to stabilize demand and prices.

The purpose of the paper is to analyse the key issues of food security in Kazakhstan, performance of the agrarian sector, product consumption, export and import, factors of productivity, competitiveness of agricultural sector.

Statistical data analysis results shows, that the stable tendency of the technological gap and unattractiveness of agrarian sector for investment, caused the low level of competitiveness of agricultural enterprises in Custom Union.
\end{abstract}

JEL Code: Q18

Проблема продовольственной безопасности носит глобальный характер, поэтому производство, распределение и торговля продуктами питания является основой агропродовольственной политики каждой страны, тем более что в настоящий период мировая продовольственная проблема обострилась. Любая страна принимает собственные меры, направленные, в первую очередь, на стабильность развития внутреннего производства, создание национальных запасов продуктов питания для стабилизации спроса и цен.

В Республике Казахстан с целью обеспечения продовольственной безопасности были введены поправки в законодательную базу, основой которых является создание страховых запасов, регулирование ценообразования на социально-значимые продукты и др.

В настоящее время социально-экономическое положение казахстанского аграрного сектора проявляет тенденцию роста. Объем валовой продукции сельского хозяйства за последние восемь лет вырос в 3,6 раза. При этом цены за этот период выросли почти в 3 раза.

Валовой сбор зерновых культур в 2009 г. достиг 20,8 млн, но в 2010 г.снизился до 12,6 млн тонн. Тем не менее данные объемы позволяют обеспечить внутренние потребности страны и экспортный потенциал порядка 5-6 млн. тонн (включая муку).

В русле диверсификации производства в последние годы расширяются площади крупяных и масличных культур (рисунок 1).

Вместе с тем в структуре посевов все еще не достаточно зернофуражных и крупяных культур, сахарной свеклы и кормовых культур, сокращаются их площади и производство фруктов.

Наметился устойчивый рост поголовья скота, птицы и продукции животноводства. Среднегодовые темпы прироста численности скота и птицы во всех категориях хозяйств составили 4-6\%, а производства продукции животноводства 3-4 \%, что говорит о недостаточном росте продуктивности животных, вследствие слабого племенного ядра в стаде и проблемами с обеспечением кормами мелкотоварных хозяйств (рисунок 2).

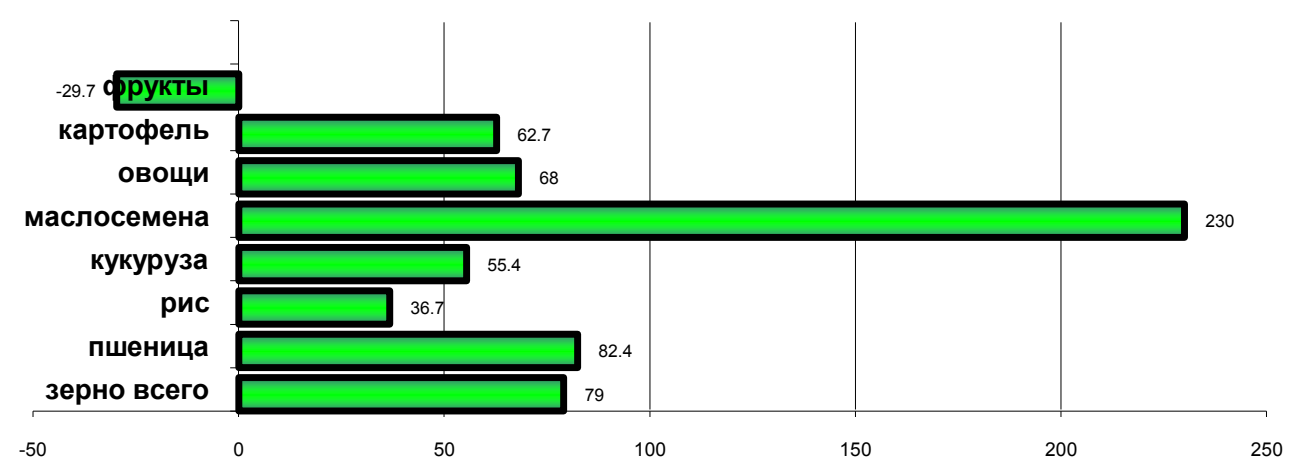

Рисунок 1. Темпь прироста производства продукции растениеводства в Казахстане (2009 г. в \% к 2000 


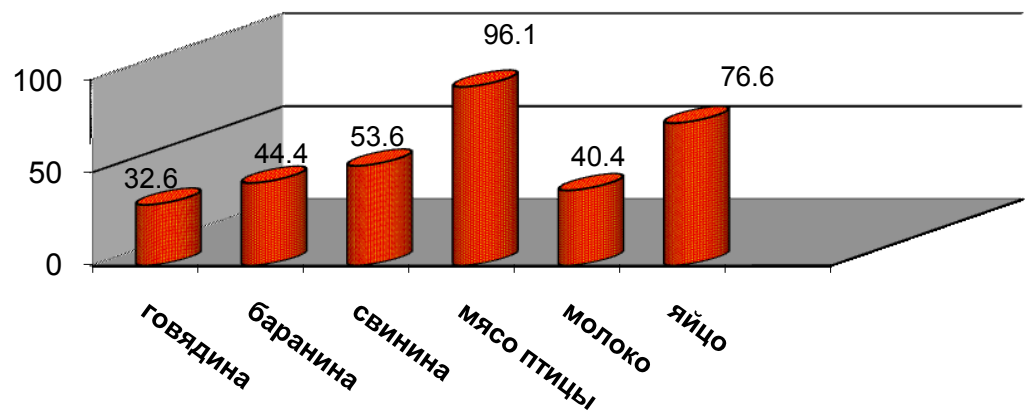

Рисунок 2. Темпы прироста производства продукиии животноводства в Казахстане (2009 г. в \% к 2000 г.)

Наблюдается рост и в производстве продукции перерабатывающей промышленности. В последние годы стоимость произведенной перерабатывающими предприятиями продукции увеличивается в среднем на $10-13 \%$ в год.

Однако, несмотря на вышеуказанные позитивные процессы в развитии АПК республики, уровень потребления по основным видам продуктов не достаточно высокий, хотя и по многим продуктам превысил действующие нормы национального стандарта потребления (таблица 1).

\begin{tabular}{|c|c|c|c|c|}
\hline \multirow[t]{2}{*}{ Продукты } & \multicolumn{3}{|c|}{ Год } & \multirow{2}{*}{$\begin{array}{c}2009 \text { г. в \% } \\
\text { К } 2000 \text { г. }\end{array}$} \\
\hline & 2000 & 2005 & 2009 & \\
\hline Хлебопродукты & 123 & 114 & 121,2 & 98,5 \\
\hline Картофель & 66 & 47 & 43,2 & 65,5 \\
\hline Овощи и бахчевые & 85 & 71 & 75,6 & 88,9 \\
\hline Фрукты & 14 & 13 & 17 & 121,4 \\
\hline Caxap & 20,5 & 28,4 & 30 & 146,3 \\
\hline Растительное масло & 8,5 & 10,8 & 13,2 & 155,3 \\
\hline Мясо & 44 & 40 & 50,4 & 114,5 \\
\hline Молоко & 235 & 189 & 210 & 89,4 \\
\hline Яйцо, штук & 102 & 108 & 128,4 & 125,9 \\
\hline Рыба & 3,5 & 8,4 & 9,4 & 268,6 \\
\hline
\end{tabular}

Таблица 1. Динамика потребительского спроса населения Казахстана на основные виды продуктов питания кг на душу населения

Как видим, в последний период спрос на продовольствие со стороны населения республики стал снижаться, что вызвано чрезмерным ростом цен на продовольствие, которые приблизились к пределу покупательной способности, и потребление отдельных видов продукции стало снижаться (картофель, овощи, сахар, молоко, яйцо).

При этом структура потребления практически не изменяется. Несколько повысилась доля хлебопродуктов (до 46\%), сахара (до 13\%), снизилась - молока (до14\%), мяса (до 8\%). Структура не соответствует научно обоснованным нормативам - в рационе питания населения республики отмечается повышенное содержание углеводов и жиров, что отрицательно влияет на здоровье человека.

Поэтому несмотря на увеличение расходов населения на продовольствие (с 39 до 44\%) потребление еще далеко от нормативов, диктуемыми научно обоснованными нормами потребления (рисунок 3 ).

Для республики проблемным остается низкая экономическая доступность населения к продуктам питания, что определяет сложившийся уровень спроса продовольствия в стране, не смотря на высокую физическую насыщенность рынка.

Величина прожиточного минимума в среднем на душу населения в стране в 2010 году составляла около 100 долл. в месяц. В России прожиточный минимум на 20-30\% выше. Это снижает экономическую доступность продовольствия даже при использовании на продовольствие до 70-80\% доходов, и ставит под угрозу продовольственное обеспечение значительной части населения.

В итоге производство отдельных видов продовольствия превышает необходимый уровень для удовлетворения современного спроса населения страны на продовольствие. К ним относятся зерно, картофель, овощи, молоко и яйцо, остальных продуктов производиться недостаточно (рисунок 4).

Поэтому существует и другая сторона, сохранение высокой импортной зависимости страны по отдельным видам сельскохозяйственной продукции и продовольствия, что вызывает серьезные опасения за состояние продовольственной безопасности страны. Значительная часть продовольствия поступает из 
стран СНГ, и в первую очередь, из Таможенного союза (таблица 2).

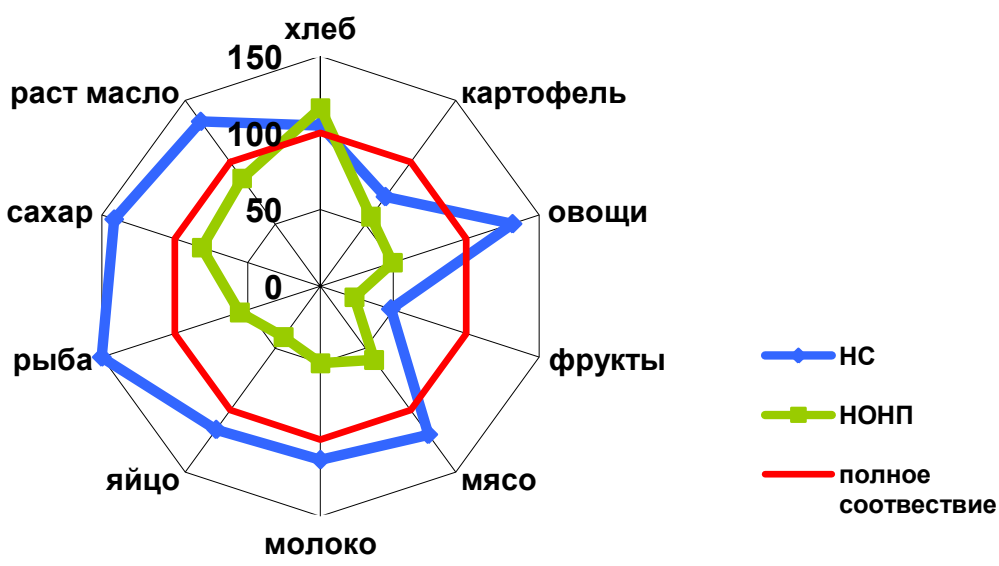

Рисунок 3. Потребление продовольствия в Казахстане (в \% к научно обоснованным нормативам (НОНП) и национальному стандарту (HC)

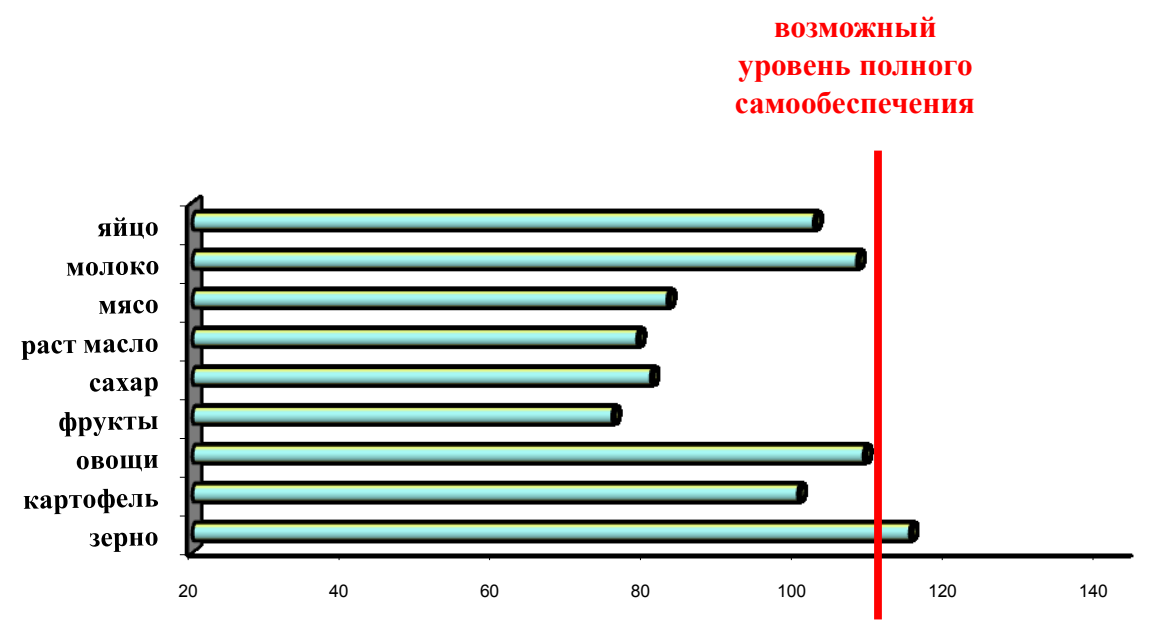

Рисунок 4. Уровень современного производства продовольствия в Казахстане, в \% к необходимым для полного самообеспечения объемам

\begin{tabular}{|c|c|c|c|c|c|c|c|}
\hline \multirow{2}{*}{$\begin{array}{c}\text { Вид } \\
\text { Продукции }\end{array}$} & \multirow[t]{2}{*}{ Всего } & \multicolumn{2}{|c|}{ В том числе из } & \multirow{2}{*}{$\begin{array}{c}\text { Вид } \\
\text { Продукции }\end{array}$} & \multirow[t]{2}{*}{ Всего } & \multicolumn{2}{|c|}{ В том числе в } \\
\hline & & CHГ & TC & & & СНГ & TC \\
\hline \multicolumn{4}{|c|}{ Импорт } & \multicolumn{4}{|c|}{ Экспорт } \\
\hline Сливки различн. & 75,6 & 69,8 & 27,5 & Зерно & 5492,2 & 2584,8 & 73,5 \\
\hline Сливоч. Масло & 5,1 & 4,2 & 2,0 & - пшеница & 5066,4 & 2430,5 & 60,4 \\
\hline Сыры & 19,8 & 17,1 & 4,2 & Мука пшенич. & 2296,8 & 1494,6 & 0,8 \\
\hline Растит. Масло & 74,0 & 66,5 & 41,5 & Овощи & 124,0 & 114,8 & 101,6 \\
\hline -подсолнечное & 64,4 & 64,3 & 41,5 & Бахчевые & 14,3 & 12,9 & 12,8 \\
\hline Caxap & 411,0 & 96,6 & 63,0 & Фрукты & 0,4 & 0,4 & 0,4 \\
\hline Колбасные изд. & 12,4 & 12,3 & 12,3 & Растит. Масло & 34,5 & 34,3 & 0,04 \\
\hline Мясные консервы & 1,7 & 1,5 & 1,5 & -подсолнечное & 33,4 & 33,2 & 0,04 \\
\hline $\begin{array}{l}\text { Плодоовощные } \\
\text { консервы }\end{array}$ & 81,9 & 29,5 & 9,6 & Caxap & 13,2 & 13,2 & 5,3 \\
\hline Мясо птицы & 124,9 & 17,3 & 1,7 & Молочные продукты & 7,1 & 6,9 & 3,5 \\
\hline
\end{tabular}

Таблица 2. Объемы импорта и экспорта аграрной продукции в 2010 г. тыс. тонн

В целях обеспечения продовольственной безопасности многие страны организуют различные интеграционные объединения. 
Одна из форм интеграции стран СНГ - создание Таможенного союза трех государств. Это закономерный результат многолетнего развития отношений России, Беларуси и Казахстана. Однако следует отметить, что уровень продовольственной безопасности в этих странах различный, что подтверждается данными таблиц 3.

\begin{tabular}{|c|c|c|c|c|c|}
\hline \multirow[t]{2}{*}{ Показатель } & \multirow[t]{2}{*}{ Казахстан } & \multirow[t]{2}{*}{ Беларусь } & \multirow[t]{2}{*}{ Россия } & \multicolumn{2}{|c|}{ Казахстан в \% к } \\
\hline & & & & Беларуси & России \\
\hline Зерно & 1313 & 881 & 684 & 149,0 & 19,2 \\
\hline Овощи & 155 & 230 & 95 & 64,8 & 163,2 \\
\hline Фрукты & 11 & 72 & 19 & 15,2 & 57,9 \\
\hline Картофель & 174 & 737 & 219 & 23,6 & 79,5 \\
\hline Мясо (уб. Вес) & 56 & 96 & 47 & 58,3 & 119,1 \\
\hline Молоко & 332 & 681 & 230 & 48,8 & 144,3 \\
\hline Яйцо (шт.) & 207 & 352 & 277 & 58,8 & 74,7 \\
\hline
\end{tabular}

Таблица 3. Производство на душу населения в странах Таможенного союза, 2009 г. кг/душу

В расчете на душу населения в Казахстане только объемы производства зерна превышают аналогичные показатели Беларуси и России; мяса и молока производится больше, чем в России.

Это сказывается и на потреблении продовольствия населением (таблица 4).

\begin{tabular}{|c|c|c|c|c|c|}
\hline Продовольствие & Казахстан & Беларусь & \multirow{2}{*}{ Россия } & \multicolumn{2}{|c|}{ Казахстан в \% к } \\
\cline { 4 - 6 } & & & & Беларуси & России \\
\hline Хлебопродукты & 121,2 & 90,0 & 121,0 & 134,7 & 100,2 \\
\hline Картофель & 43,2 & 190,0 & 135,0 & 22,7 & 32,0 \\
\hline Овощи и бахчевые & 75,6 & 144,0 & 115,0 & 52,5 & 65,7 \\
\hline Фрукты & 17,0 & 59,0 & 57,0 & 28,8 & 30,0 \\
\hline Сахар & 30,0 & 39,0 & 40,0 & 76,9 & 75,0 \\
\hline Растительное масло & 13,2 & 15,8 & 12,8 & 83,5 & 103,1 \\
\hline Мясо & 50,4 & 75,0 & 62,0 & 67,2 & 81,3 \\
\hline Молоко & 210,0 & 234,0 & 242,0 & 89,7 & 86,8 \\
\hline Яйцо (шт.) & 128,4 & 275,0 & 254,0 & 46,6 & 50,5 \\
\hline
\end{tabular}

Таблица 4. Потребление продовольствия в 2009 г. населением стран Таможенного союза. кг на душу 6 год

Аналитики и эксперты по проблеме формирования Таможенного союза выделяют следующие сдерживающие факторы, снижающие рост конкурентоспособности АПК Казахстана: низкий уровень конкурентоспособности предприятий АПК объясняется сохранением устойчивой тенденции их технологического отставания; аграрная отрасль остается непривлекательной для инвестиций. В Казахстане на 1 га посевов вкладывается инвестиций в 3 раза меньше, чем в России и в 20 раз, чем в Беларуси; сохраняется мелкотоварность аграрного сектора, особенно в животноводстве, где 80-85\% его продукции производится в личных подворьях; производительность труда в сельском хозяйстве составляет около 5 тыс. долл. на одного занятого в год, в развитых странах $-50-70$ тыс. долл.; низкий уровень развития кооперативных отношений сельского хозяйства с перерабатывающей промышленностью и торговлей при недостаточном развитии обслуживающих структур; неразвитая система сбыта приводит к удорожанию сельхозпродукции и продовольствия; значительно усилился рост цен на российские товары: на 10-20\%; рост уровня внешнего таможенного тарифа: с 10\% до 15-20\%.

Такая ситуация негативно скажется на отечественном товаропроизводителе и может привести к ликвидации и банкротству многих предприятий АПК. Тем более, что основой ведения сельскохозяйственного производства в Беларуси и России является высокая урожайность посевов и продуктивность животных, которая во многом превышает показатели нашего сельского хозяйства (таблица 5).

\begin{tabular}{|c|c|c|c|c|c|}
\hline \multirow{2}{*}{} & Казахстан & Беларусь & Россия & \multicolumn{2}{|c|}{ Казахстан в \% к } \\
\cline { 4 - 6 } & & & & Беларуси & России \\
\hline \multicolumn{7}{|c|}{ Урожайность, ц/га } \\
\hline Зерно & 12,6 & 333 & 22,7 & 37,8 & 55,5 \\
\hline Сахарная свекла & 183 & 450 & 322 & 40,7 & 56,8 \\
\hline Картофель & 260 & 186 & 142 & 86,0 & 112,7 \\
\hline Овощи & 219 & 242 & 200 & 90,4 & 109,5 \\
\hline \multicolumn{7}{|c|}{ Продуктивность, кг/гол. } \\
\hline Надои молока & 2255 & 4355 & 3590 & 51,7 & 62,8 \\
\hline Яйценоскость, шт. & 215 & нет данных & 313 & нет данных & 68,7 \\
\hline
\end{tabular}

Таблица 5. Показатели урожайности сельхозкультур и продуктивности скота и птицы за 2009 ح. 
Это говорит о более высокой интенсивности ведения сельского хозяйства и преимуществах участия в межгосударственной торговле. Поэтому урожайность основной культуры - пшеницы за последние годы в России колебалась в 1,3 раза, в то время как в Казахстане в 2 раза. Это вызвано еще и более жесткими условиями ведения производства, так как в России уровень естественной продуктивности климата составляет порядка 100 балов, в Казахстане же только 40. Более радикально изменились торговые взаимоотношения с другими странами СНГ. Казахстан стал больше экспортировать зерна, муки, овощей, макаронных изделий, но и больше стал импортировать картофеля, фруктов, растительного масла, сахара.

Вероятно, влияние на торговые отношения оказал низкий уровень производства прошлого года, введение запретов на экспорт отдельными странами, но в большей степени это влияние следующих факторов: нарушение специализации национальных АПК и межгосударственного разделения труда, которое опиралось на максимальное соответствие природно-климатическим условиям; деградация крупных перерабатывающих предприятий и отраслей сельского хозяйства, ориентированных ранее на межгосударственные поставки; рост себестоимости продовольствия, определенной удорожанием используемых ресурсов. Частичное влияние на рост цен оказывают и открытость экономики и диспропорции мирового рынка. Например, в Казахстане цена импортного мяса птицы за год выросла с 684 до 905 долл./т (+32\%), сухого молока и сливок - с 1995 до 3100 долл.(+55\%), сливочного масла - с 2650 до 3800 (+43\%), подсолнечного масла - с 883 до у1003 долл./т (+14\%) и т.д.; низкий уровень промышленной переработки и недозагруженность мощностей перерабатывающих предприятий. В республике мощности перерабатывающих предприятий используются по мукомольным заводам на 42,5\%, крупяным - 29,6, молочным и мясным предприятиям - 36-42\%; потребление продовольствия на национальных рынках обеспечивается в большой мере за счет импорта из государств дальнего зарубежья. В Казахстане доля импорта сельскохозяйственной продукции и продовольствия в емкости рынка превышает $30 \%$ (более 2 млрд. долл.).

В условиях Таможенного союза Казахстану необходимо принять меры по укреплению производства экспортоориентированной продукции и усилив свое присутствие на рынках стран ТС и других стран СНГ, увеличив поставки зерна, овощей, отдельных видов фруктов.

Таким образом, формирование Таможенного союза создает большие возможности для свободного движения товаров, капитала, активизации инвестиционного сотрудничества между странами, развития экспортного потенциала государств-участников. Вместе с тем, следует подчеркнуть, что в условиях Таможенного союза Казахстану следует проводить адекватную экономическую политику. 


\title{
Роль животноводства в обеспечении продовольственной безопасности Казахстана
}

\author{
Altynbek Moldashev (Research Institute of Agricultural Economics and Rural Development, \\ Kazakhstan)
}

\section{The Role of Livestock in Ensuring Food Security in Kazakhstan}

\begin{abstract}
Agriculture is the main economic activity of rural area population in Kazakhstan. The growing actuality of food security problem increases importance of livestock sector. Given paper aims to study current problems of livestock production, conditions and forecast expected growth of livestock. The analysis shows, that concentration of livestock production in small commodity production, natural households holding back the process of intensification of livestock industry and competitive production of meat and milk and limits the effectiveness of the processing industry.
\end{abstract}

JEL Code: Q10, Q18

В Казахстане животноводство одно из важных видов экономической деятельности сельского населения. В валовой продукции сельского хозяйства отрасль занимает 44 (2007 г.) - 50\% (2010 г.). В последнее десятилетие наблюдается рост поголовья скота и птицы, при этом их продуктивность остается на низком уровне (таблица 1).

Средний удой молока на 1 корову составляет - 2233 кг, реализованный живой вес 1 головы КРС - 305 кг, овцы - 38 кг, свиней - 95 кг, что значительно ниже соответствующих показателей продуктивности животных стран ТС.

Это следствие преобладания беспородного, низко продуктивного скота в хозяйствах населения, низкой кормообеспеченности, не совершенного организационно-экономического механизма регулирования рынка кормового зерна и земельных отношений.

В республике сложилась парадоксальная ситуация. Основное поголовье скота (82-85\%) размещено преимущественно в мелких хозяйствах населения, не имеющих достаточно кормовых угодий, в то время как значительный потенциал пастбищ и сенокосов сосредоточен в фермерских хозяйствах (55\%), и сельхозпредприятиях (33\%), однако они производят лишь $18 \%$ мяса и 10 \% молока, поскольку специализируются на производстве продукции растениеводства. Около 93 млн.га. пастбищ не используются, переведены в государственные земли запаса.

Сосредоточение производства животноводческой продукции в мелкотоварных, натуральных хозяйствах населения сдерживает процесс интенсификации животноводческой отрасли и производство конкурентоспособного мяса и молока, что в свою очередь, ограничивает возможности эффективного функционирования перерабатывающей промышленности.

Уровень переработки мяса в настоящее время составляет лишь 25\%, а молока - 35\% имеющихся ресурсов. При этом отмечается опережающий рост потребительских цен на мясомолочную продукцию вследствие разобщенности действий и интересов партнеров рынка, отсутствия нацеленности их на конечный результат. Это негативно отражается на уровне платежеспособного спроса населения. В 2009 году потребление мяса и мясопродуктов составляло лишь 51 кг, а молока и молочных продуктов - 210кг на душу населения, или ниже российского уровня на $18 \%$ и 14\%, белорусского на - 32\% и $10 \%$.

При этом доля импорта в потреблении сохраняется высокой (мясо птицы - 58\%, консервированные мясные продукты - 93\%, колбасы - 37,3\%, молоко и молочные продукты - 36\%, сыры - 64,4\% .

Сейчас в республике принимаются меры для развития животноводства, особенно мясного и молочного направлений. Определены меры государственной поддержки отрасли. Однако, они еще не дают должной отдачи.

В перспективе развитие отраслей животноводства должно осуществляется на основе действия интенсивных факторов расширенного воспроизводства.

С учетом ограниченности финансовых ресурсов в ближайшей перспективе приоритет в развитии животноводческой отрасли будут иметь отрасли, базирующиеся на использовании естественных кормовых угодий, на интенсивных технологий выращивания. Поэтому в условиях Казахстана более высокими темпами получит развитие мясное скотоводство, овцеводство и бройлерное, птицеводство (таблица 1).

Используя пофакторный метод рассчитан прогноз численности поголовья скота и птицы (таблица 1). 


\begin{tabular}{|c|c|c|c|}
\hline \multirow[t]{2}{*}{ Наименование } & \multicolumn{2}{|c|}{ Год ы } & \multirow{2}{*}{$\begin{array}{c}2020 \text { г. в \% } \\
\text { к } 2009 \text { г. }\end{array}$} \\
\hline & 2009 & 2020 & \\
\hline KPC & 6095,2 & 7160 & 117,5 \\
\hline овцы и козы & 17369,7 & 21500 & 123,8 \\
\hline свиньи & 1326,3 & 1520 & 114,6 \\
\hline птица & 32686,5 & 41380 & 126,6 \\
\hline лошади & 1438,7 & 1600 & 111,2 \\
\hline верблюды & 155,5 & 170 & 109,3 \\
\hline Всего, усл. поголовье КРС & 10118,4 & 11583 & 114,5 \\
\hline
\end{tabular}

Таблица 1. Прогноз численности поголовья скота и птищьы в Казахстане. тыс. го л

В развитии отрасли скотоводства рекомендуется формирование товарных зон выращивания скота мясного и молочного направлений, что позволит более эффективно использовать конкурентные преимущества регионов и генетический потенциал пород крупного рогатого скота в целях развития специализированных зон производства конкурентоспособных товаров (говядины, сливочного масла и твердых сыров).

Для интенсивного развития мясного скотоводства целесообразно отдать приоритет формированию семейных фермерских хозяйств, обеспеченных высокопродуктивным скотом и прочной кормовой базой. Они станут основой выращивания молодняка крупного рогатого скота поставляемого затем на откормочные площадки. Такая система производства говядины позволит интенсивно развивать отрасль мясного скотоводства и экспортировать на рынок России не менее 60 тыс. тонн мяса к 2010 г. в последующем - 180 тыс. тонн. Средний вес одной головы КРС, реализуемой на убой, составит 400-450 кг. В перспективе на откормочные площадки требуется поставлять в год не менее 280-300 тыс. гол. КРС мясного направления.

Приоритетом развития овцеводства должно стать комплексное использование полипродуктивной особенности отрасли, широкий ассортимент продукции, шерсти, баранины, овчины, кожевенного сырья и молока.

В настоящее время например, в России растет спрос на шерсть, в странах СНГ и ЕС - на охлажденную баранину. Кроме того, на внутреннем рынке также отмечается неудовлетворенный спрос на мясо и шерсть.

Поэтому, изучив опыт развитых стран и свой отечественный предлагаем комплексное развитие отрасли овцеводства. Прежде всего, необходимо создание средних и крупных специализированных хозяйств в республике, которое должно сопровождаться формированием эффективной инфраструктурой. Например, в Австралии, весь сервис фермера - овцевода (поголовьем от 5 до 40 тыс. овец) осуществляют две федеральные фирмы с региональными звеньями. В их функции входит создание пастбищ, изгородей, стрижка овец, подготовка шерсти, снабжение спецкомбикормами и обеспечение жизнедеятельности семьи фермера.

Необходимо внедрять подобный сервис и в Казахстане, начиная с регионального уровня.

В условиях складывающейся жесткой конкуренции за рынок сбыта в ближайшей перспективе предлагается создавать овцеводческие хозяйства, развивая в них породную специализацию. Это обеспечит высокое качество продукции, относительно дешевой по затратам энергии, кормов и труда. Только тогда она сможет иметь конкурентные преимущества на внутреннем и внешних рынках. Индикаторами конкурентоспособности овец должны быть следующие показатели - получение с одной головы не менее 3 кг шерсти в мытом виде и ягнят к отъему в 3,5-4 месяца весом не менее 30 кг.

Интенсивное развитие бройлерного птицеводства позволит максимально использовать существующие производственные мощности птицефабрик, получая не менее 100-110 тыс.т. мяса. В целях снижения стоимости отечественного мяса птицы необходимо совершенствовать механизм взаимоотношений с товаропроизводителями кормового зерна, используя долговременные договорные отношения. Кроме того, целесообразно применять новые ресурсосберегающие технологии выращивания бройлеров, при производстве охлажденного мяса. При этом, как показывает опыт России, значительно повышаются, вкусовые качества мяса, снижаются издержки обращения, увеличивается потребительский спрос.

В целях защиты внутреннего рынка от импорта мяса птицы рекомендуется введение квоты, что позволит более эффективно проводить политику импортозамещения и государственной поддержки отечественных товаропроизводителей. По нашему мнению, целесообразно импортируемое мясо птицы (окорочка) как более дешевый продукт направлять в продажу социально незащищенным слоям населения через специализированные магазины. Это обеспечит им экономическую доступность данного продукта питания, так как стоимость импортного мяса птицы, с учетом растаможения, не более 110-120 тенге за 1 кг, или ниже рыночной цены в 3,5 раза. Кроме того, произойдет переливание капитала из торговой сферы 
в производственную, так как доходы оптовой торговли резко снизятся.

Методы динамических тенденций, оценки конкурентоспособности сельскохозяйственной продукции позволяют сделать следующие выводы.

В результате интенсивного развития приоритетных отраслей животноводства производство мяса в целом по республике увеличится до 1200 тыс. тонн. Средний годовой темп прироста мяса составит 2,7\%, в том числе по мясу птицы - 3,8\%, говядине - 3,4\% и баранине - 2,65\%, что позволит поднять уровень самообеспеченности мясом до оптимальной величины (98\%), снизить долю импорта мяса птицы до 40\%, повысить уровень потребления мяса и мясопродуктов на душу населения до 75 кг, кроме того, ежегодно экспортировать на рынок стран Таможенного союза, в частности в Россию, до 60 тыс. тонн говядины к 2020 г. и 180 тыс. тонн к 2030 г.

\section{Литература}

- $\quad$ Трксеитова Р. А., Молдашев А.Б., Тореханов А.А. и др. Размещение отраслей животноводства по природнохозяйственным зонам Республики Казахстан.-Алматы, 2008

- Коллективная монография «Аграрный сектор Казахстана: экономическая и социальная модернизация».-Алматы, 2010

- Омарханова Г.Г., Шалыгиа В.Г. Современное состояние отрасли животноводства в Республике Казахстан //Проблемы агрорынка.-2011.- N2 


\title{
Реформирование системы здравоохранения Кыргызстана: проблемы и перспективы
}

\author{
Damira Japarova, (Kyrgyzstan-Turkey Manas University, Kyrgyzstan)
}

\section{Health System Reform in Kyrgyzstan: Problems and Prospects}

\begin{abstract}
Today in all over the world costs of medical services are growing and alternative ways of effective financing of health care are being researched. During the reforms the Kyrgyz Republic introduced a system of compulsory medical insurance, the institution of family medicine and a "single payer" system. The main goal of reform programs is the orientation of the health care system to complex primary health care. Methods of payment for hospital services flush to an artificial increase in the number of hospitalizations and unnecessary assignment of diagnostic and therapeutic procedures. The main brake of health care reform is underfunding of sector. Improving health care is possible by limiting the free medical care. The replacement of free care by paid services occurs spontaneously, there are abuses and the shadow economy in health care. The Compulsory medical insurance doesn't have such terms as an accident, insurance risk, and the current model in Kyrgyzstan is not a real model of insurance and serves as a kind of state-funding health care. The most part of the population in rural areas is not involved in the payment of health insurance due to unemployment. Patients pay a fee in addition to medication, and also carry out informal payments to doctors, that is, patient with co-payments have to repeatedly pay for the same medical service without a guarantee of a cure. Taking into account the experience of other countries, the imposition of patient payment for their own care, in our opinion, is more just to bringing the patient for his treatment.
\end{abstract}

JEL Codes: I12, I18

В настоящее время серьезной проблемой во всем мире становится тенденция роста стоимости медицинского обслуживания. В связи с этим, почти во всех странах осуществляется поиск альтернативных путей более эффективного финансирования здравоохранения, что требует радикальных изменений в сфере медицины.

Следует отметить, что здравоохранение в условиях бывшей социалистической системы обеспечивало бесплатное предоставление медицинских услуг для всего населения, и было основано не на профилактики заболеваний, а главным образом на лечебной медицине. В связи с распадом Союза, система здравоохранения Кыргызстана испытала серьезные негативные изменения, связанные с сокращением финансирования расходов на здравоохранение, а также ухудшением инфраструктуры и качества предоставляемых медицинских услуг. И поэтому основная цель, программ по реформированию системы здравоохранения в республике заключалась в переориентации системы здравоохранения на качественное первичное медицинское обслуживание, путем сокращения обслуживания в клиниках и перевода основной нагрузки медицинского обслуживания на семейную медицину в поликлиниках. При этом большое внимание уделяется профилактике заболеваний и вовлечению населения в деятельность по охране здоровья.

В Кыргызстане завершилась 15-летняя реформа системы здравоохранения. Она началась в 1996 году в рамках национальных программ «Манас» и «Манас таалими». Основным направлением Национальной программы реформирования сектора здравоохранения на 2006-2010 годы являлось развитие первичного здравоохранения: ФАПов, ГСВ, службы скорой и специализированной помощи и общественного здравоохранения. Соответственно ставилась задача совершенствования методов их финансирования.

В ходе реформы здравоохранения внедрена система обязательного медицинского страхования и института семейной медицины, использованы новые принципы формирования бюджета. По Программе государственных гарантий создана система «Единого плательщика» в виде Фонда обязательного медицинского страхования, ответственного за покупку медицинских услуг. Определены «покупатели» и «поставщики» медицинских услуг. Наметилась тенденция к увеличению финансирования здравоохранения, рост которого в 2006 году составил 10,6 \% и в 2010 13\%, по сравнению с предыдущим годом, составив 2,4\% к ВВП. Общие расходы на здравоохранение на 2011 год были предусмотрены в сумме 9213,5 млн. сомов, в том числе за счет бюджетных средств 8451,9 млн. сомов, и за счет специальных средств 328,5 млн. сомов.

Однако этих средств оказалось недостаточно. В настоящее время на выполнение только Программы государственных гарантий необходимо свыше 6 миллиардов сомов, а дефицит расходов государственных гарантий на 2011 год составляет 1 миллиард 455 миллионов сомов (Ксения Толканева Бишкек, «report.kg»,. 26 Апреля 2011). В связи с этим главным тормозом реформ здравоохранения является резкое 
недофинансирование отрасли.

Таким образом, основная проблема здравоохранения - постоянно увеличивающийся разрыв между ростом расходов на здравоохранение и возможностями государства финансировать его на достаточном уровне. В связи с этим, система здравоохранения не в состоянии обеспечить доступ населения к качественной медицинской помощи, это касается особенно социально незащищенных слоев.

Надо отметить, что по доле личных расходов населения в совокупном объеме затрат на здравоохранение, Кыргызстан находится на уровне стран с низким доходом на душу населения, а по уровню государственных обязательств, согласно реформе здравоохранения, Кыргызстан впереди многих стран с развитой рыночной экономикой.

В последнее время в республике осуществляются ряд национальных, государственных, целевых программ по приоритетным направлениям охраны здоровья населения. Однако ни одна из них не получила необходимого финансирования, и программы реализуются в основном за счет средств международных доноров. Например, государство не финансировало Программу, принятую в 2008 году для улучшения перинатальной помощи, направленную на снижение материнской и младенческой смертности, для реализации которой было необходимо более 47 миллионов долларов.

В последние годы в области здравоохранения в республике было принято более 20 законов, осуществление которых, ежегодно требовало более 3-4 миллиардов сомов. Некоторые из них финансировались частично. Например, в рамках реализации Закона КР «О сахарном диабете» на бесплатное лечение (применение инсулина и других препаратов) ежегодно выделяется более 60 миллионов сомов, когда фактическая потребность составляет 177 миллионов сомов. На исполнение Закона КР «О защите населения от туберкулеза» ежегодно выделяется 334 миллиона сомов, что составляет 60 процентов от реальных потребностей. По Закону КР «Об онкологической помощи населению» финансовые средства практически не выделяются (Мира Ниязалиева: В Кыргызстане финансирование здравоохранения в 6 раз меньше потребностей. 28/03/11 09:15, Бишкек - ИА «24.kg», Айзада Кутуева.)

Из-за дефицита средств еще в 1999 году был принят закон «О внебюджетной деятельности государственных учреждений здравоохранения». Он позволяет получать специальные средства за оказание населению платных услуг. Однако их доля в бюджете здравоохранения не превысила 6 процентов. Таким образом, сейчас покрываются лишь 30 процентов потребности здравоохранения в финансах, т.е. защита прав пациента как потребителя в нашей стране не реализуется. Тем более выбор пациентом лечебного учреждения или врача на практике полностью зависит от воли и желания медицинского работника или администрации ЛПУ. В Кыргызстане существующие государственные обязательства носят декларированный характер, их мера не соответствует экономическим возможностям страны. В республике практически не исполняется программа государственных гарантий.

По данным Национального статистического комитета, цены на медикаменты и изделия медицинского назначения только за 2009 - 2010 годы выросли на 30\%, при этом расходы государственного бюджета по статье медикаменты увеличились лишь на 3\%. И поэтому, доля расходов на медикаменты в бюджете стационаров республики в прошлом году составила лишь 4,4 процента. По отчетам Минздрава КР, на лечение льготных пациентов используется 94 процента выделяемых государством средств. Соответственно, на остальных граждан приходится не более 6 процентов бюджетных денег. На практике это означает, что на лекарственное обеспечение одного пациента государство в среднем тратит 11 сомов в сутки, а на питание - 28 сомов. Естественно, при таком финансировании невозможно говорить об эффективном лечении. Итак, программа государственных гарантий по обеспечению граждан медикосанитарной помощью в Кыргызстане не работает. Льготы и бесплатные лекарства декларируются властями, а на деле каждый сам платит за свое лечение.

В таких условиях единственный способ повышения эффективности здравоохранения - ограничение бесплатной медицинской помощи. И для достижения реальной сбалансированности государственных гарантий медицинского обслуживания населения с их финансовым обеспечением и для сокращения размеров теневого рынка в здравоохранении необходимо легализовать платные услуги населению. Лучше обеспечивать реальной медицинской помощью лишь некоторые категории граждан, чем декларировать льготное лечение едва ли не для половины всех кыргызстанцев. Стратегия неявного замещения бесплатной медицинской помощи платной не формулируется в официальных документах и нормативных актах, тем не менее, она реально существует. Замена бесплатной помощи платными услугами происходит стихийно и бессистемно, платные услуги в государственных учреждениях оказывают те же медики и на том же оборудовании, что и в случае бесплатной помощи, - отсюда различные злоупотребления и рост теневой экономики в здравоохранении. Вероятно, оказание платных услуг должно быть перемещено в частные медицинские организации или в специально выделенные отделения и организации государственного здравоохранения.

В настоящее время, в год на медицинское обслуживание одного человека государство выделяет около 
20 долларов. В эту сумму входит и лечение в стационаре, и питание, и зарплата медикам, и оплата коммунальных услуг учреждениями здравоохранения. Между тем, в России этот показатель составляет 460 долларов. Ясно, что без всеобеего оздоровления экономики республики существенных изменений в системе здравоохранения не произойдет. Но экономический рост - это вопрос будущего, а люди нуждаются в медицинской помощи сейчас. Чтобы выйти из сложившейся ситуации, предлагается перевести некоторые категории лиц, имеющих право на бесплатное лечение, на сооплату. Например, ведение беременности будет бесплатным, но при родах необходимо ввести оплату в размере 300 сомов. Все равно женщины негласно платят больницам.

Итак, для достижения реальной сбалансированности государственных гарантий медицинского обслуживания населения с их финансовым обеспечением и для сокращения размеров теневого рынка в здравоохранении необходимо легализовать платные услуги населению.

Стратегия неявного замещения бесплатной медицинской помощи платной не формулируется в официальных документах и нормативных актах, тем не менее она реально существует. Замена бесплатной помощи платными услугами происходит стихийно и бессистемно, платные услуги в государственных учреждениях оказывают те же медики и на том же оборудовании, что и в случае бесплатной помощи, - отсюда различные злоупотребления и рост теневой экономики в здравоохранении. Вероятно, оказание платных услуг должно быть перемещено в частные медицинские организации или в специально выделенные отделения и организации государственного здравоохранения.

Правительства западных стран избегают необоснованных деклараций о полной бесплатности медицины. И обеспечение сбалансированности государственных обязательств с имеющимися финансовыми ресурсами диктует необходимость введения доплат населения за строго определенный набор видов услуг. В отличие от российского и белорусского здравоохранения, где действует разделение на бесплатные и платные услуги, в большинстве западноевропейских систем здравоохранения работает принцип соплатежей на основную часть видов медицинской помощи. Пациент вносит установленный процент от общей стоимости посещения врача или госпитализации.

Во многих странах используется жестко нормированная система государственных гарантий, вне которой медицинская помощь оказывается на платной основе, т.е. на основе соплатежей или добровольного медицинского страхования. В Дании, Исландии, Канаде, Норвегии, Финляндии доминирует государственное страхование - добровольное или обязательное. В США, Израиле, широко используется частное страхование. Во Франции и Японии медицинское страхование - компонент общей системы социального страхования. В Бельгии, Нидерландах, Люксембурге, Германии и Швейцарии правительство лишь регулирует деятельность различных независимых фондов. Впрочем, по мнению многих экспертов, различия между финансированием за счет налогообложений или за счет фондов социального страхования несущественны: страховые взносы составляют определенный фиксированный процент заработной платы, что равнозначно установленному налогу на нее.

Во многих странах, где обещают полностью бесплатную медицинскую помощь, используют соплатежи населения. В ряде бывших соцстран уже введена система соплатежей населения. В секторе первичной помощи они действуют в Эстонии, Чехии, Хорватии, Кыргызстане, Латвии, Литве. В секторе вторичной помощи в Венгрии и Латвии установлены небольшие доплаты за стационарную помощь; в Эстонии существуют доплаты за услуги специалистов; в Чехии планируют ввести соплатежи с установлением максимума выплат. Соплатежи используются и в Грузии, где всегда была сильно развита неформальная плата за любую медицинскую услугу.

Система соплатежей в разных вариантах используется практически во всех западных странах с развитыми системами общественного здравоохранения. Размер соплатежей варьирует от символической суммы (Швеция) до достаточно высокой (Франция). В РФ используются натуральные соплатежи (приобретение больными лекарств, питание за свой счет, использование личного постельного белья и посуды в стационаре), что, однако, не закреплено ни в одном нормативном документе (Шейман И.М. // Экономика здравоохранения. - 2000. - N 6. - с. 47-55)). Во многих странах соплатежи включены в систему ОМС, т.е. помимо взносов работодателя застрахованные также выплачивают определенные взносы.

В Швеции основное бремя расходов на медицинскую помощь несет государство, однако примерно $10 \%$ услуг в формате соплатежей оплачивает само население. Так, визит к врачу обходится пациенту в $100-$ 300 шведских крон, а день пребывания в стационаре - не более 80 крон. Лечение у стоматолога для людей моложе 20 лет бесплатное, затраты остального населения частично компенсируются: начав лечение, пациент вносит только первые 700 крон, а дальнейшие расходы на 35 - 70\% (в зависимости от общей стоимости лечения) ему возвращаются. Пациенты должны полностью оплачивать приобретенные лекарственные препараты до тех пор, пока затраченная сумма в течение одного года не превысит 100 долл. США. Далее, в зависимости от затраченной суммы, действует система дотаций (Ортендаль К. // Российский семейный врач. - 2000. - N 3. - с. 7-15) ). 
При покупке лекарств, выписанных врачом, медицинская страховка с учетом их общей стоимости возвращает больному от 50 до $100 \%$ расходов. В результате никому не приходится тратить на лекарства более 1300 крон в год.

Гонорарные системы оплаты предполагают соплатежи пациентов. Но и в странах с использованием принципа подушевой оплаты или твердой зарплаты также обычно имеются соплатежи населения. Например, в Швеции посещение врача сопряжено с доплатой суммы, эквивалентной 6 американским долларам, в Греции - менее доллара. Соплатежи при получении амбулаторных услуг в системе общественного здравоохранения не применяются лишь в Германии, Италии, Португалии, Испании, Дании. В некоторых странах (Ирландия, Нидерланды) соплатежи отсутствуют только при низком доходе пациента.

Возможны следующие варианты введения соплатежей населения при получении стационарной помощи

- доплаты вводятся только для работающего населения;

- лица, страдающие хроническими заболеваниями, освобождаются от доплат;

- $\quad$ доплаты вводятся за питание, гостиничные услуги;

- расчет доплат дифференцирован в зависимости от тяжести и длительности пребывания в стационаре;

- $\quad$ устанавливается лимит доплат по отношению к средней заработной плате на территории; пациент оплачивает установленный процент стоимости каждого дня госпитализации свыше установленного норматива срока стационарного лечения (в соответствии с медико-экономическими стандартами).

Итак, в настоящее время большинство стран в своих схемах финансирования переносят часть финансовой ответственности на потребителя, что известно как со-оплата. Важнейшим обоснованием для введения со-оплаты является ограничение пациента от его желания получить чрезмерное лечение за счет средств страхования. Индивидуальные схемы со-оплаты отличаются друг от друга по природе финансовых договоренностей. В основном существуют 3 типа таких схем: удержание; со-страхование (застрахованный должен определенную пропорцию в стоимости каждой единицы, употребляемой медицинской помощи); соучастие в оплате услуг по категориям населения.

- Удержание представляет собой оплату некоторой суммы неличностными деньгами до начала действия механизма страхования и предоставления медицинской помощи. Например, пациент уплачивает первые $\$ 50$ наличными в счет покрытия расходов на лечение в больнице или $\$ 200$ в счет покрытия расходов на амбулаторно-поликлинические услуги за год. Соучастие в оплате услуг - это единовременная выплата, которую потребитель должен уплатить за каждую предоставленную услугу. Например, 5 долларов за выписанный рецепт.

- Со-страхование предусматривает оплату определенного процента от общей суммы самим пациентом. Например, пациент оплачивает $20 \%$ от стоимости лечения. Со-оплата рассматривается как дополнительный источник финансирования для поставщиков разных уровней. $\mathrm{B}$ схемы со-оплаты входят медикаменты, оптика, в некоторых странах введены определенные ставки за посещения врача или пребывание в больнице.

- По категориям населения. Уровень со-оплаты зависит и от категорий населения. Это делается с целью защиты малоимущих или тех, кто страдает тяжелыми хроническими заболеваниями.

Учитывая опыт других стран, введение платы больного как части оплаты стоимости собственного лечения, на наш взгляд, является более справедливым путем привлечения пациента для его лечения.

Следует отметить, что в наших условиях пациенты дополнительно вносят плату за медикаменты, а также нередко осуществляют неофициальные платежи - «подарки» врачам, другому мед.персоналу и, непосредственно, денежные вознагрождения (особенно, плата за операции). Кроме того очень часто врач направляет больного в определенную аптеку или лабороторную клинику имея при этом долю от стоимости проданных пациенту лекарств, или платы за лабороторные исследования, в которых даже если нет необходимости. Все это свидетельствует о том, что больной с введением сооплаты вынужден теперь многократно оплачивать одну и ту же медицинскую услугу, в итоге не имея гарантию на полное выздоровление.

Реализованная в Кыргызстане модель, которую принято именовать «системой обязательного медицинского страхования», по сути, не является истинной моделью страхования. Она всего выглядит как разновидность государственной формы финансирования системы здравоохранения. У работодателей отсутствует прямая мотивация поддержки медицинского страхования, скорее наоборот - стремление сократить платежи на ОМС. Обязательный взнос на ОМС по существу не является страховым взносом, а представляет некую разновидность обязательного государственного налога, что особенно подтвердится при передаче функции сбора средств на обязательное медицинское страхование от фондов ОМС к налоговым структурам. (Министерство здравоохранения КР Отчет. Оценка реализации национальной 
программы реформы здравоохранения КР»Манас таалими» апрель 2011г).

Отмечается неполный охват населения республики обязательным медицинским страхованием. Основная часть, т.е. около $70 \%$ населения проживающая в сельской местности в связи с отсутствием основного места работы не принимает участия в оплате средств обязательного медицинского страхования. Однако в связи с низкой доходностью они подвержены риску заболевания больше, чем городское население. Средства ОМС не оказали серьезного влияния на финансовое положение здравоохранения, их доля в расходах сектора в 2010 году составила всего 14 процентов (Министерство здравоохранения КР Отчет. Оценка реализации национальной программы реформы здравоохранения КР «Манас таалими» апрель 2011г.)

Таким образом, структура финансовых ресурсов характеризует незначительную долю средств ОМС в финансовых источниках здравоохранения. Причиной этого заключается в том, что основными плательщиками взносов системы ОМС в Кыргызстане, являются работники бюджетной сферы, имеющие небольшие фиксированные доходы, обеспечивающие незначительный абсолютный размер поступлений по обязательному медицинскому страхованию.

Часть населения, представляющая коммерческую структуру и имеющая более высокие доходы, несмотря на принятие закона, обязывающего работодателей, независимо от форм собственности, платить страховые взносы, почти не охвачены системой страхования здоровья. Кроме того, иностранные граждане, проживающие продолжительное время в Кыргызстане не имеют возможности страховать собственное здоровье. Стоимость медицинских услуг, предоставляемых иностранным гражданам необоснованно высока, что способствует увеличению количества платежеспособных пациентов, вынужденных искать и обращаться к частнопрактикующим врачам, в обход государственных поликлиник. Такие условия характеризуют потенциальные дополнительные источники финансирования медицины в период острого дефицита денежных ресурсов.

Итак, существующая модель системы обязательного медицинского страхования в той форме, как она ныне представлена в Кыргызстане, не является структурой и механизмом, обеспечивающей повышение качества медицинской помощи. В действующей системе ОМС сохранены такие же методы распределения средств, как и при государственном бюджетном распределении.

Кроме того, одним их существенных недостатков отечественной системы обязательного медицинского страхования, является отсутствие экономически обусловленных форм и механизмов включения застрахованного пациента, потребителя медицинских услуг в системы отношений страхования. В отношениях потребителя медицинских услуг с системой предоставления этих услуг отсутствует прямая мотивация, ставящая потребителя на первое место в ряду приоритетов взаимоотношений. По сути, пациент (застрахованный) находится вне системы отношений субъектов системы ОМС и, более того, входит в параллельные внесистемные отношения с медицинскими работниками, как например, неофициальная плата за лечение. ОМС как система финансирования здравоохранения и управления качеством медицинской помощи в большей или меньшей степени используется практически во всех странах мира и СНГ, поскольку это единственная возможность вневедомственной независимой экспертизы качества медицинской помощи и дополнительный источник внебюджетного финансирования здравоохранения.

Изучение экономического содержания системы ОМС, позволяет убедиться в том, что в действующей системе ОМС отсутствуют такие понятия, как страховой случай, страховой риск, а финансовые компенсации осуществляются, как правило, по количественным параметрам: стоимостным характеристикам отдельно взятой услуги, амбулаторному посещению, койко-дням. Понятно, что эти единицы никакого отношения к научно обоснованному расчету или покрытию страхового риска не имеют. Не удаются реализовать в практической медицине и систему пролеченного случая. Несмотря на то, что финансы системы ОМС выведены из государственного сектора, сбор средств осуществляется государственными органами социального страхования, и поступают в государственные казначейства.

Имеющиеся в системе здравоохранения ресурсы используются неэффективно. Существующая система оказания медицинской помощи характеризуется избыточной сетью медицинских учреждений с низким материально-техническим оснащением; доминированием стационарной помощи, низкой приоритетностью первичной медико-санитарной помощи. Новые же методы оплаты стационарных услуг за «пролеченный случай» приводят к искусственному увеличению количества госпитализаций и необоснованному назначению диагностических и лечебных процедур. 


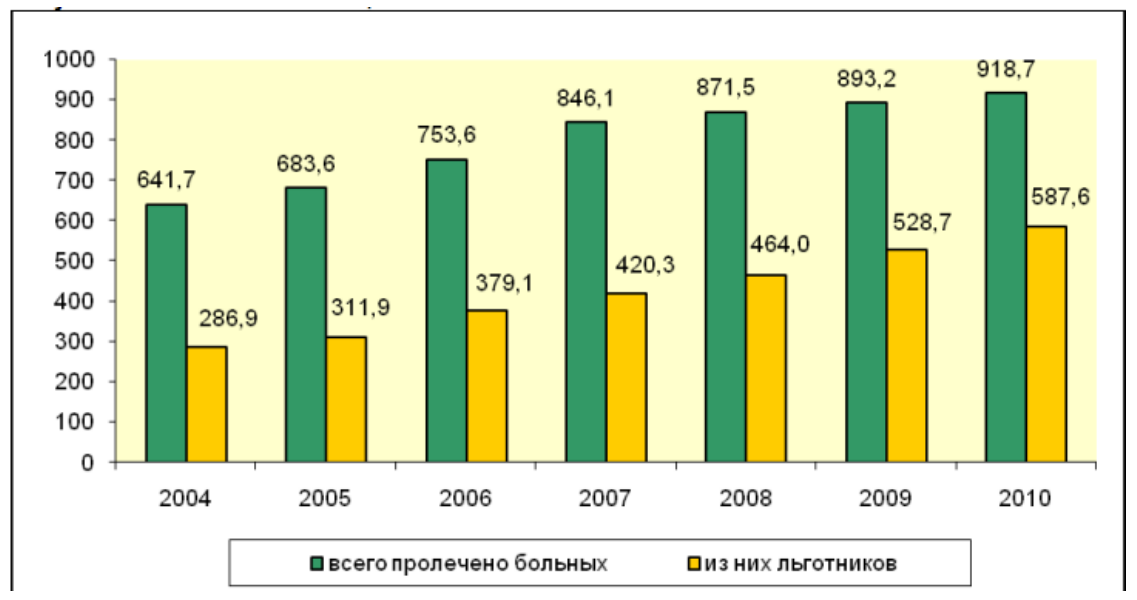

Рисунок 1. Рост госпитализаџии с 2004 по 2010 г2.

Источник: Министерство здравоохранения КР Отчет. Оценка реализации национальной программы реформы здравоохранения КР «Манас таалими» апрель 2011г.

Динамика роста госпитализаций характеризует тот факт, что лечение в стационарах не сокращается, а напротив, увеличивается, что противоречит целям реформы в здравоохранении. Это показывает, что ограниченные ресурсы в здравоохранении используются неэффективно.

Следует отметить, что в настоящее время правительство предлагает на первичном уровне, к введению бесстатейного финансирования, при котором управляющие больниц получат право распоряжаться отпущенными на учреждение средствами, самостоятельно распределяя их на питание, лекарства и другие нужды. (Организации здравоохранения г.Бишкек перейдут на новый метод финансирования/ 16 Июня 2011. http://www.med.kg/Zdravooxranenie/spravka08.shtml?m=119\&sm=119297) ).

Для развития негосударственного сектора здравоохранения и создания рынка медицинских услуг необходимо принятие закона «О частной медицинской деятельности», а профессиональные медицинские ассоциации должны обладать достаточными по объему контрольными полномочиями по отношению к системе негосударственного здравоохранения. Конкуренция среди организаций частного здравоохранения должна привести к существенному снижению стоимости медицинских услуг. В настоящее время стоимость медицинских услуг в частном секторе значительно выше, чем в учреждениях здравоохранения (ситуация прямо противоположная другим видам рынка).

\section{Литература}

- Ксения Толканева Бишкек, «report.kg»,. 26 Апреля 2011

- $\quad$ Мира Ниязалиева: В Кыргызстане финансирование здравоохранения в 6 раз меньше потребностей. 28/03/11 09:15, Бишкек - ИА «24.kg», Айзада КУТУЕВА

- Шейман И.М. // Экономика здравоохранения. - 2000. - N 6. - С. 47-55.

- Ортендаль К. // Российский семейный врач. - 2000. - N 3. - С. 7-15.

- $\quad$ Министерство здравоохранения КР Отчет. Оценка реализации национальной программы реформы здравоохранения КР» Манас таалими» апрель 2011г.

- Организации здравоохранения г. Бишкек перейдут на новый метод финансирования 16 Июня 2011. http://www.med.kg/Zdravooxranenie/spravka08.shtml?m=119\&sm=119297

- Бушуев В. В., Голубев В. С., Коробейников А. А., Селюков Ю. Г. Человеческий капитал для социогуманитарного развития. - М.: «ИАЦ Энергия», 2008. - 96 с.

- Программа государственных гарантий не исполняется. Бишкек, "report.kg", Елена Накимова, апрель 2011 год 


\title{
The Benefits and Problems of International Trade in the Context of Global Crisis
}

\author{
Ercan Ekmekcioglu (Kyrgyzstan-Turkey Manas University, Kyrgyzstan)
}

\begin{abstract}
The undertaking of this study is to analyze the different benefits and problems of international trade and how this industry is affected by the global crisis. The advancement of information technology in terms of communication has changed the business environment and trade industry. Numerous benefits can be obtained by participating in the international trade industry and the WTO extends their policies and implementation of the agreement to fairly accommodate all participating countries. This article intends to investigate the three major factors affecting the trend in the marketing and trade industry over the years due to the changes in business environment. These changes are mainly caused by the development of information technology, globalization and power concentration of power among countries. The problem however, arises when the top players in the trade industry control these policies and misunderstandings from critics give in to the argument of fairness in trade transactions. This article also discusses the prediction of global exchange rate in the following years and the cause of the global financial crisis. The different losses and bailouts for US and European countries is analyzed and its effect on the international trade industry and the author suggests possible solutions for the betterment of the trade industry in general.
\end{abstract}

JEL Codes: F10, O10, F50

\section{Introduction}

The exchange of goods, services, capital between countries and regions is referred to as International Trade and it has given rise to the global economy. There are different forms of trade and the advancement in technology has also changed the economic trend among various industries. In such a way that international trade, most especially in terms of supply and demand is directly related to the events happening all over the world (Heakal, 2003).

This article intends to analyze the different benefits and problems of International Trade in the aspects of information technology modernity and the global crisis that occurs nowadays.

\section{Information Technology}

Three major factors have affected the trend in the marketing and trade industry over the years due to the changes in business environment. These changes are mainly caused by the development of information technology, globalization and power concentration (Albercht \& Sack, 2000, p.6). The advancement in information technology has paved way to a faster and efficient world for international trade. Investors can communicate easily with just a click of a button and an investor can now process their business transactions online. They may also monitor the stock exchange, foreign exchanges, import and export through their mobile phones or through different accessible financial websites.

Due to the effect of information technology in the nature of international trade, many companies are interested in outsourcing their businesses as well. Larson (1996) states that,

"Today, technological innovation is required to satisfy customers' demands for lower prices, faster delivery, and higher quality products and services. These demands, coupled with a globally competitive environment, place a great deal of pressure on the profit margins of manufacturers, service providers, and export trading companies alike". To survive in this environment, businesses must effectively use technology to ensure that they can tap into the right information and act on it quickly".

It has been established that information technology is essential in doing business transactions internationally, most especially in trading goods and services. Therefore, countries participating in international trade also develop their system and technology to cope up with the environment. An example are financial websites such as Bloomberg that provide the most updated news, data, trade information and it can be viewed by people all over the well. According to the website of Bloomberg (2011), "bringing transparency to capital markets through access to information could increase capital flows, produce economic growth and jobs, and significantly reduce the cost of doing business." With this, investors all over the world participate in international trade online and can easily access vital information necessary in trade. 


\section{Developing Countries}

The state of international trade has a great impact on the economy of developing countries most especially for those who basically rely on international trade to increase their GDP. The rapid growth of industrialization together with the formation of numerous multinational corporations has lead to changes in the trade industry. Grossman and Rogoff (2007) explain that "governments set trade taxes simultaneously to maximize their individual objective functions." In this statement the international trade agreement between countries is given attention as it brings advantages and disadvantages.

Moreover, other developing countries on the other hand have a different regime that according to Grossman and Rogoff (2007) "governments set trade taxes jointly to maximize a weighted sum of their objective functions." The international trade agreements may vary among each developing country and modern production techniques have also affected the industry.

Since the industry have risen in half of the $20^{\text {th }}$ century, many countries are now engaging in international trade. It has been established that in engaging in international trade, the country would be able to benefit in terms of GDP however, another factor is the highly advanced transportation systems wherein developing countries need to cope with others (Shah, 2011).

In their participation to this form of trade, they will have to improve their system individually. Also, the growing transnational corporations may affect the system as it is rapidly evolving together with outsourcing of different products and services as well as a very rapid industrialization (Aswathappa, 2006).

\section{Benefits of International Trade}

The benefits of international trade can be depicted on the countries that have developed their income and those who have obtained trade power over the years. According to Stanley (2011) "nations with strong international trade have become prosperous and have the power to control the world economy. The global trade can become one of the major contributors to the reduction of poverty". This form of trade has flourished over the years due to the fact that countless of benefits can be derived from importing and exporting of goods to other countries most especially in terms of demand and supply and the efficiency of that it offers (Carr and Indira, 2010).

According to Hata (2008) "a country would consider trading internationally in an effort to give their GDP a big boost very quickly." This is true as some countries have better quality of products and they intend to market it to other countries for exposure and the transaction would be able to generate income (ITA, 2011). This will also be the case in return if a country intends to import goods from other countries that have the products and services they need.

Also, some products can only be found in a certain country such as agricultural products wherein each country has dissimilar weather thus the production of goods may vary in every country. Some agricultural products may be hard to produce in tropical countries while other countries on the other hand have an overflow of supply for that particular agricultural product. Stanley (2011) also listed the following benefits of international trade:

- Enhances the domestic competitiveness

- Takes advantage of international trade technology

- Increase sales and profits

- Extend sales potential of the existing products

- Maintain cost competitiveness in your domestic market

- Enhance potential for expansion of business

- Gains a global market share

- Reduce dependence on existing markets

- Stabilize seasonal market fluctuations

Among others, engaging in the international trade lead to the exceptional performance of a company to cope up with existing products and service all over the world. Once a country initiates international trade, the import and export of goods is maintained and enhanced to impress other countries or regions for customer satisfaction purposes.

\section{Problems encountered with International Trade}

Following the boost of industrialization and international trade suddenly the hindrance to the trade industry approached the world. The global crisis has greatly affected the market in the economy became at a loss affecting the whole world. Shah (2010) mentions that, "the extent of this problem has been so severe that some of the world's largest financial institutions have collapsed".

Also, it is at that time when some companies have financial issues that resorted to bankruptcy and eventually closed their businesses. The trade industry went down because the top players in the industry have suffered as well. 
Then, the World Trade Organization (WTO) implemented the rules for international trade. According to Anderson and Cavanagh (1997);

"The General Agreement on Tariffs and Trade (GATT) was an international organization created in 1947 to reduce trade barriers through multilateral negotiations. In January 1995, the GATT was replaced by a stronger World Trade Organization (WTO), the result of eight years of GATT negotiations. Today, member countries number 125 (nearly the whole world except China, some former communist countries, and a number of small nations) and WTO rules apply to over 90 percent of international trade".

This agreement gave rise different controversies and misunderstandings because of the wide range of its coverage compared to the GATT agreement that focuses only on the reduction of tariffs among manufactured goods. It has been argued if the Uruguay round would be more effective or the GATT agreement. Most of the businesses all over the world are encountering problems with the rules of these agreements.

Anderson and Cavanagh (1997) explains that the Uruguay round "is slated to result in average tariff reductions of 38 percent for developed economies, reducing average tariffs worldwide from 6.3 percent to 3.9 percent. In comparison, average tariff rates just after World War II were 40 percent. The most controversial outcome of the Uruguay Round was the establishment of much stronger enforcement mechanisms in the WTO". Their policy is deemed to be unfair because it only favors the powerful countries controlling the trade industry while developing countries need to cope up with them.

\section{Global Exchange Rate}

The powerful players in the trade industry has been expected to depreciate due to the global crisis and recession but surprisingly in 2008 there an appreciation in the US dollar occurred rather than depreciation. Then, it has been established that "the adjustment process has taken a very different path with a collapse in asset prices and a massive deleveraging process among financial institutions being at the core of the crisis". Since the United States is one of the powerful players and controls the international trade industry predictions have been made that after the recession in the near 2012 the global exchange rate would depreciate.

\section{Global Financial Crisis: Losses and Bailouts for US and European Countries in Context (\$ trillion)}

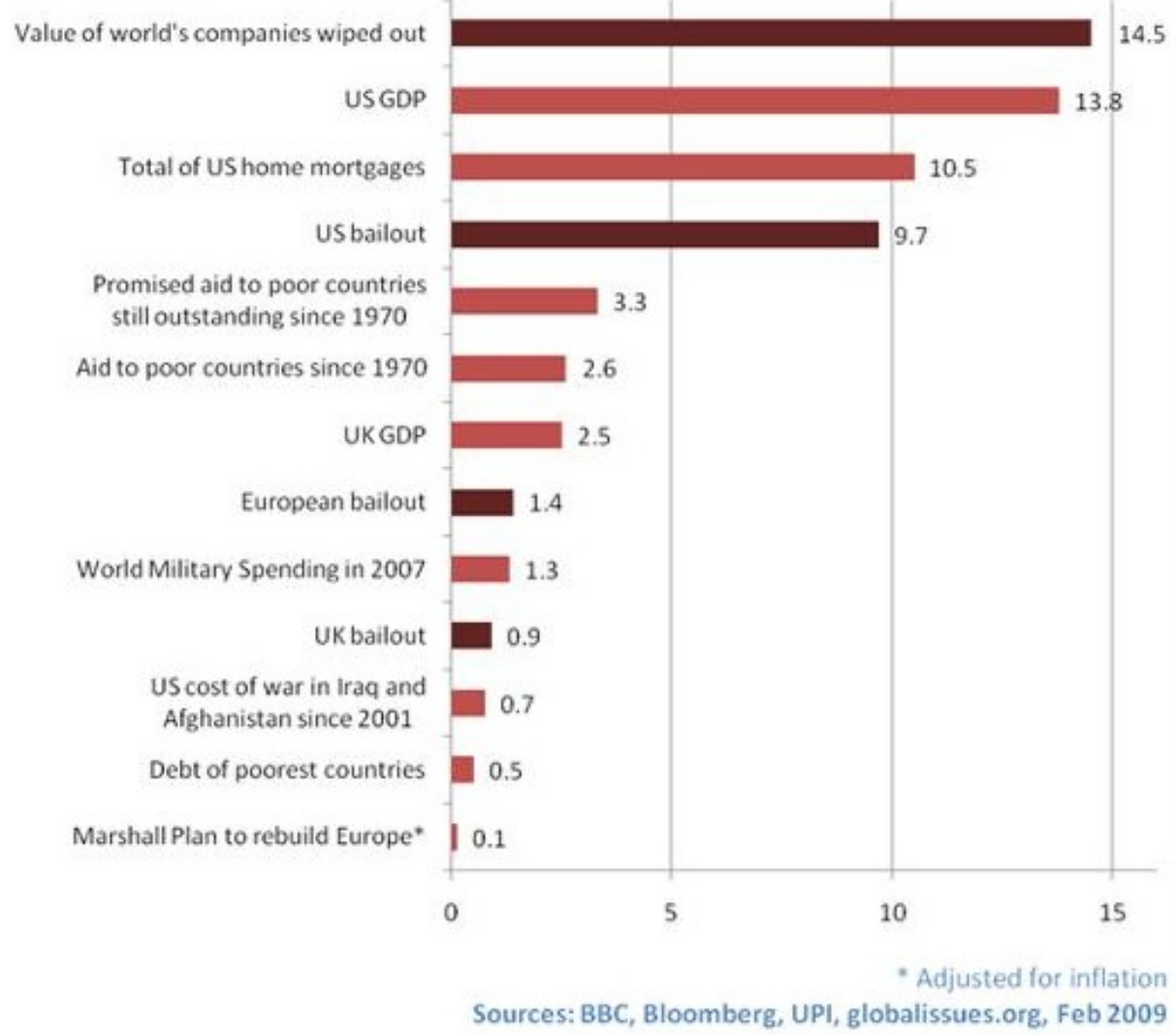

Figure 1. Global Financial Crisis: Losses and Bailouts for US and European Countries in Context (in Trillion Dollars, 2009). Source: BBC Bloomberg. 
This is because explains that "there was a fairly widespread expectation that a US dollar depreciation would play an important if not central role in the global adjustment process". The decline of US dollar would have a great impact to other countries involved with international trade for the competitiveness and a sustainable investment. Factors that are affecting international trade include pattern of global capital flows from US to elevate cash for redemptions and the foreign investors have changed their equities into a more stable income with countries like the United States. It is shown in the Figure 1 that all countries have been affected by the global financial crisis in 2009.

\section{Law of Supply and demand}

Also, developing countries believe they get a raw deal when it comes to international trade. They have certain problems which are first of all is "relying on only one or two primary goods as their main exports" (Cohen, 1997). Once the demand or the supply of this goods and services they would have no other option or a contingency source of products. Not only that, they would also need to consider the following factors such as that "they would not be able to control the price they get for these goods, price they pay for manufactured goods increases all the time, as the value of their exports changes so much long term planning is impossible and the increasing the amount of the primary good they produce would cause the world price to fall" (Feenstra, 2004).

Another problem arises when it comes to rights. The exchange of goods and services can easily be infringed or copied. A financial website Export.Gov (2011) suggests that, while trade barriers and unfair practices take many forms, the most common examples are listed below: Intellectual property infringement - including copyright, patent and trademarks; lack of competitive bidding for foreign government tenders; competition from unfairly traded imports; unfair and trade distortive subsidies provided by foreign governments to overseas competitors; foreign trade remedy investigations conducted inconsistent with international obligations; burdensome certification and testing requirements that are not required by domestic manufacturers and increasing imports and unfair competition (Streatfield and Lacey, 2008).

Together with the advancement in information technology come the problems along with it as well. Weeks (2006) explains that "the role of communication networks in economic activity has become more and more important". Business firms need to cope with other competing companies with the advancement and development of their communication technologies for international trade transactions. As a consequence of these changes, economic analysis of networks has proven that the relationship between trade and communication networks is highly significant. The barriers arise when the "communications costs which are largely fixed in nature, unlike specific transport costs" (Harrigan, 2004). Since the process of trading internationally deals with making transactions globally the communications cost is higher compared to local networks for international trade uses a worldwide common network services.

\section{Solutions}

The international trade policies are implemented in order to facilitate in a better trading industry. Since the top players in the globe are the ones who are controlling these policies it is only favorable for all countries involved in the international trade industry that fair policies should be implemented. This goes out to the countries that control the industry in terms of tariffs, economic policies, income, copyright policies and infringement, online transactions, advancements in technology, sustainability and the development of countries coping up with the trade industry.

It would only be fair to include the developing countries in making decisions most especially if involves them as well. It has been established earlier that some countries only rely on international trade to increase their GDP therefore it would only be fair to them to implement just policies. Different disagreements and misunderstandings have caused fall outs between existing countries in the industry and this can be minimized if WTO would be able to implement the agreement properly and not to be controlled by US and European countries only.

\section{Conclusion}

Therefore, the international trade paved the way for global transactions and increase in market profitability. With this, numerous benefits have been gained by different countries participating in the trade industry. The advancements in technology have also allowed efficiency and accessibility of information and in doing business transactions.

Benefits include increase in GDP sales and profits, development of quality products and services, market profitability and market size. International trade also extends potential of the existing products, gaining a global market share and reduces the dependence on existing markets. These benefits however, have problems along with it. 
As mentioned earlier, the international trade industry would be able to minimize certain misunderstandings and disagreements with the proper implementation and fair international trade policies. Moreover, a strict implementation in terms of copyright nad infringement policies would also help solve the different aspects of the country's property rights. The advancements of technology enhances the communication process in doing international business transactions thus different countries participating in the international trade has the need to cope up with the changes in the trade business environment.

\section{References}

- $\quad$ Albercht, M., \& Sack, S. (2011, August). International Trade Statistics 2010. Retrieved from World Trade Organization: http://www.wto.org/english/res_e/statis_e/its2010_e/its10_toc_e.htm

- Anderson, S., \& Cavanagh, J. (1997, January 1). World Trade Organization. Retrieved from Fpif.org: http://www.fpif.org/reports/world_trade_organization

- Bloomberg. (2009, Feb). Global Financial Crisis: Losses and Bailout for US and European Countries in Context. Retrieved from BBC Bloomberg: http://www.globalissues.org/issue/1/trade-economy-related-issues

- Bloomberg. (2011). Take a Closer Look at Bloomberg. Retrieved from bloomberg.com: http://www.bloomberg.com/about/

- Carr, I. (2010). International Trade Law. New York: Cavendish Publishing Limited.

- Cohen, B. (1997). International Trade and Finance: New Frontiers of Research. United Kingdom: Cambridge University Press.

- $\quad$ Export.gov. (2011, May 23). Help with Trade Problems. Retrieved 2011, from export.gov Helping US Companies Export: http://export.gov/tradeproblems/index.asp

- $\quad$ Feenstra, R. C. (2004). Advanced International Trade: Theory and Evidence. New Jersey: Princeton University Press.

- Grossman, G., \& Rogoff, K. (2007). Handbook of International Economics. Oxford: Elsevier Publications.

- Harrigan, J. (2004). Handbook of International Trade, Volume 1. United Kingdom: Blackwell Publishing Ltd.

- Hata, P. (2008, June 18). Benefits of International Trade. Retrieved 2011, from Ezine@rticles: http://ezinearticles.com/?Benefits-of-International-Trade\&id=1259699

- Heakal, R. (2003, November 25). What is International Trade? Retrieved 2011, from investopedia: http://www.investopedia.com/articles/03/112503.asp\#axzz1VKgk5ftE

- International Trade Administration. (2011, June 3). International Trade Administration Office of Industry Analysis. Retrieved from trade.gov: http:/www.trade.gov/mas/ian/index.asp

- Larson, B. (1996, May). Information Technology and International Trade: Resources for the Modern Exporter. Retrieved 2011, from The CBS interactive business network: http://findarticles.com/p/articles/mi_m1052/is_n5_v117/ai_18299930/

- Shah, A. (2011, June 5). Trade, Economy \& Related Issues. Retrieved 2011, from globalissues.org: http://www.globalissues.org/issue/1/trade-economy-related-issues

- Streatfeild, J., \& Lacey, S. (2008). New Reflections on International Trade. USA: Cameron.

- Weeks, R. (2006). International Trade Issues. New York: Nova Science Publishers, Inc. 


\title{
Developing Country Concerns on Multinational Trade: Problems of Kyrgyzstan's Trade Development
}

\author{
Aidai Budaichieva (International Ataturk-Alatoo University, Kyrgyzstan) \\ Kiyalbek Akmoldoev (International Ataturk-Alatoo University, Kyrgyzstan) \\ Jarkyn Junushbaeva (International Ataturk-Alatoo University, Kyrgyzstan)
}

\begin{abstract}
The essence of global economy lies in creation of multilateral trading system. However, in current world practice the multilateralism does not respond to its ideal concept: countries do not get equal gains from multilateral trading system. Dependence on import is the major concern of developing countries within WTO. As other developing countries Kyrgyzstan has a negative trade balance. Yet non-membership appears to be an even less viable option. The aim of this paper is to find out an appropriate trade policy for Kyrgyzstan.
\end{abstract}

JEL Codes: F10, F13

\section{Introduction}

Multilateralism, in the context of global trade, is defined as "an approach to the conduct of international trade based on cooperation, equal rights and obligations, non-discrimination and participation as equals of many countries regardless of their size or share of international trade" ( Dictionary of trade policy terms 2nd ed. 1998, 187). However, countries do not get equal gains from multilateral trading system.

The General Agreement on Tariffs and Trade (GATT) and its successor, the World Trade Organization (WTO), were set up to promote world trade which is based on multilateralism.

Opinions about WTO tent to differ sharply: opponents of globalization see in it a symbol and motor of globalization that has tightly come into for much criticism; for others the WTO is one of the essential building blocks of multilateral and cooperative world order, indeed an instrument of restraining the process of globalization. The widespread and sustained interest in joining it underlines the importance attached by many countries to WTO membership - even though, especially in developing countries liberalization has given way to growing disappointment, and very few such countries are able to sustain in increasingly competitive trading conditions. Yet non-membership appears to be an even less viable option.

As many developing countries Kyrgyzstan is experiencing positive and negative effects from membership in WTO. Kyrgyzstan entered the WTO in 1998. For thirteen years of experience in multilateral trading system Kyrgyzstan had faced such benefits like access to cheaper import, low prices for domestic consumers and comparative advantage to re-export in comparison to other regional trade partners. However, there are also negative effects of WTO membership. Huge flow of import goods had discouraged domestic production; low import tariffs on agricultural products restrain development of agriculture sector. Kyrgyzstan also has trade relationships with non-members of WTO, mainly with regional trade partners such asRussia and Kazakhstan. But creation of the Customs union (CU) between Russia, Kazakhstan and Belarus in 2010 had strong effects on Kyrgyz trade balance. This situation leads to the need to decide whether Kyrgyzstan's economic development and prosperity would be best served by closer integration with the relatively high-tariff system of the CU, which is based on the existing tariff system of Russia, or by continuing the low-tariff, essentially open and free-trade oriented system that it adopted upon WTO accession.

The aim of this paper is to:

- analyze the condition of developing countries in agriculture within WTO

-analyze the impact of WTO membership of Kyrgyzstan on its trade

-to find out whether to enter the CU or stay within WTO membership

As well as other developing WTO member countries Kyrgyzstan's expectations have not been met. The negative trade balance witnesses its consequences: enormous inflow of import prevents from domestic production growth. Moreover, during the accession process to the WTO, Kyrgyzstan being a developing country engaged into commitments of developed countries that also negatively affected the trade balance.

This paper is based on quantitative analysis by using statistics of Organization for Economic Co-operation and Development (OECD), World Resources Institute (WRI), Food and Agriculture Organization Statistics (FAOSTAT), National Statistics Committee of Kyrgyz Republic, Ministry of Economic Regulation and Trade of Kyrgyz Republic, Ministry of Agriculture of Kyrgyz Republic.

Books and websites also have been used in conducting the research. Empirical analysis has been conducted by Pearson Correlation Method (SPSS). 


\section{Biases in the Trading System Against Developing Countries}

As a large share of trade flows has been intraregional and intra-firm, efforts by developing countries to participate fully in an increasingly interdependent global economy have been hindered by biases in the trading system (Report of the Secretary-General of UN, 2001).

According to the principle of comparative advantage, a country gains from trade when it specializes in areas of production or processing where it is relatively more competitive.

Food and Agriculture Organization (FAO) studies show that this principle is severely violated by a number of obstacles that work mostly against the interests of developing countries. Agriculture remains one of the most highly protected arenas of international trade. Tariffs average around $4 \%$ for industrial goods but $62 \%$ on agricultural products. (Thomas C. Beierle 2002,5). Governments, particularly in rich developed countries, also continue to subsidize domestic farmers in ways that

substantially distort trade by favoring domestic production and exports over imports from abroad. Market distortions caused by subsidies, tariffs and technical barriers to trade, discourage farmers in developing countries from being competitive.

For a large number of developing countries, especially the 82 low-income food-deficit countries (LIFDCs) currently identified by FAO, the agricultural sector remains largely underdeveloped, in respect of production both for the domestic market and for export. At the same time, in most of these countries, the agricultural sector lies at the centre of their economies. It accounts for a large share of GDP, employs a large proportion of the labor force, represents a major source of foreign exchange earnings, supplies the bulk of basic food required by the population and provides subsistence and other income for large rural populations. It provides a living for more than $50 \%$ of developing countries' population, on average. In developed countries, only around $9 \%$ of the population lives off agriculture (FAO 2009, 12-14).

The WTO agreements, which were the outcome of the 1986-1994 Uruguay Round of trade negotiations, provide numerous opportunities for developing countries to make gains. Further liberalization through the Doha Development Agenda negotiations aims to improve the opportunities.

But a number of problems remain. The poorest group of developing countries, the G90 has placed on the Doha Agenda a number of problems they face in implementing the present agreements. And they complain that they still face exceptionally high tariffs on selected products ("tariff peaks") in important markets that continue to obstruct their important exports. A related issue is "tariff escalation", where an importing country protects its processing or manufacturing industry by setting lower duties on imports of raw materials and components, and higher duties on finished products.

Although some of the developing countries have increased their share in world exports of processed agricultural products, the developed countries captured the bulk of the rapidly growing trade in this sector. High dependence on exports of primary agricultural products continued to be a prominent feature in many developing countries, particularly the least developed countries (LDCs). The share of developing countries in world exports of processed agricultural products decreased from 27 percent in 1981-1990 to 25 percent in 1991-2000. For LDCs as a group, the share in processed agricultural exports fell sharply from 0.7 percent to 0.3 percent (FAOSTAT 2003).

\begin{tabular}{|c|c|c|c|c|c|c|}
\hline \multirow{2}{*}{ years } & \multicolumn{3}{|c|}{ Primary products } & \multicolumn{3}{c|}{ Processed products } \\
\cline { 2 - 7 } & Developed & Developing & LDCs & Developed & Developing & LDCs \\
\hline $1981-1990$ & 62.2 & 33.8 & 3.1 & 73.0 & 27 & 0.7 \\
\hline $1991-2000$ & 67.4 & 32.6 & 2.2 & 75.0 & 25 & 0.3 \\
\hline
\end{tabular}

Table 1. Share in world agricultural exports, all commodities (\%)

According to FAO today, the share of developing countries in world food trade adds up to about 27 percent of total - essentially the same level as 20 years ago.

\subsection{Global consequences of developed country domestic support}

Domestic support to farmers of developed countries leads to unequal outcomes at the expense of developing countries.

Although developed countries in Doha Development Round of the WTO have agreed to eliminate export subsidies by 2013, the EU and U.S. and Japan are unwilling to make significant concessions on domestic support ( EarthTrends 2007). 


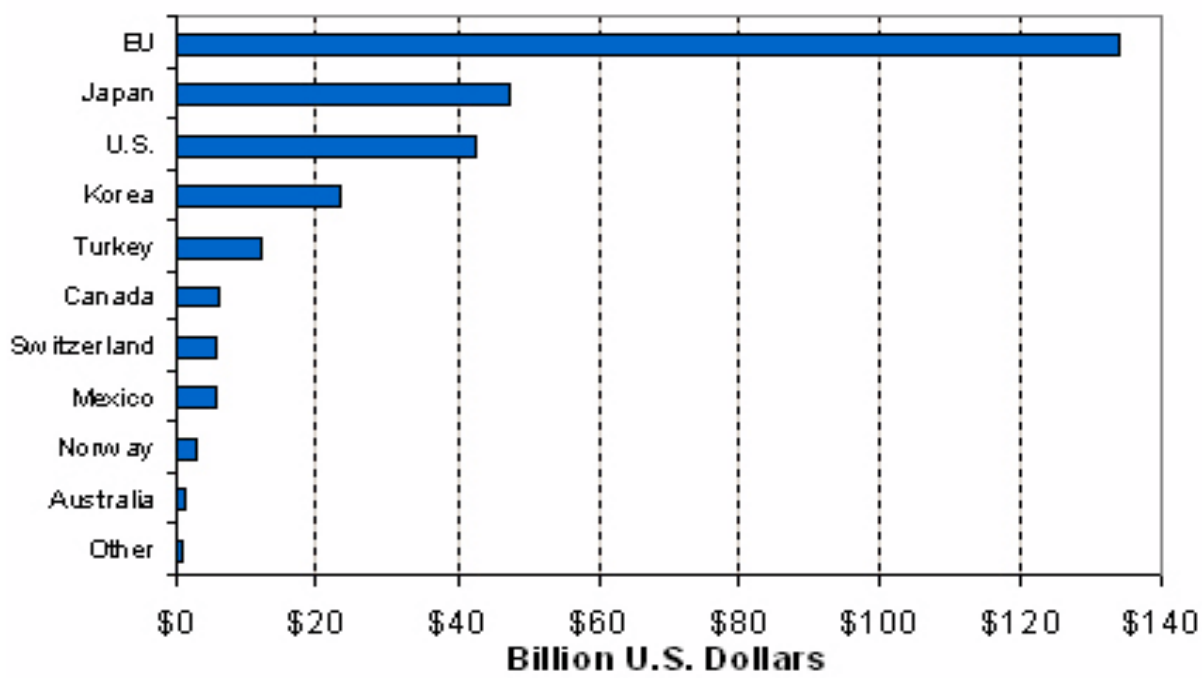

Figure 1: Domestic Support to Farmers

The agricultural subsidies and tariffs used by wealthy countries to support their farming sectors as having a serious, if not fatal, drag effect on the sustainable development of agriculture in the poor parts of the world. The U.S. Department of Agriculture (USDA) calculates that protectionist policies in developed countries are responsible for around $80 \%$ of global agricultural price distortions, with the European Union contributing 38\% and the United States around 16\%. These policies raise commodity prices domestically but depress them on world markets by about $12 \%$ on average (Thomas C. Beierle 2002,p9).

Domestic support to agriculture in developed countries encourages over-production, which in turn increases supplies on world markets (by reducing import demand or increasing export supply) and depresses world prices. Low prices make it harder for producers in developing countries to compete in their home markets, as well as in international markets, thus reducing incentives for production and retarding the development of the agricultural sector.

\subsection{Import surges in developing countries}

As a result of domestic support of developed countries many developing countries are vulnerable to import surges (temporary sharp rises in imports) and temporary low import prices that could damage agricultural production activities. Import surges and low import prices are of particular concern to developing countries striving to develop agricultural potential and diversify production to enhance food security and alleviate poverty. While lower import prices may benefit consumers, sudden and large temporary declines in commodity level prices disproportionately hurt producers.

\begin{tabular}{|c|c|c|}
\hline \multicolumn{2}{|c|}{ Developing countries(DC) } & Developed countries \\
\hline All DCs & LDCs & \\
\hline 5.6 & 5.2 & 1.9 \\
\hline
\end{tabular}

Table 2. Growth rate trend of food imports (percent per annum, 1990-2000)

Since the 1990s, food imports by developing countries have been rising sharply: 5.6 percent per annum for developing countries and by 6.9 percent for the LIFDCs (FAO 2003). Projections indicate that this trend will continue.

\subsection{Internal supply constraints}

Many developing countries, particularly LDCs, face internal supply constraints that limit their ability to respond to opportunities for trade in processed agricultural products. These include weak technology; insufficient transport, storage and marketing infrastructure; inadequate legal and regulatory arrangements; and policyinduced disadvantages resulting from trade and macroeconomic policies that are biased against agriculture and exports.

\section{Impact of WTO on Kyrgyzstan's trade}

\subsection{Kyrgyzstan's trade conditions before entering the WTO}

The major peculiarity of external economic integration of Kyrgyzstan lies in participation of Kyrgyzstan in many international and regional organizations. Before entering the WTO Kyrgyzstan became a member of Custom union (Russia, Kazakhstan, Belarus, Tadjikistan), in 2000 a member of Eurasian Economic Community. However a creation of CU wasn't effective. Very slow process of harmonization of tariffs and legislation 
influenced international trade. Adopted tariffs of CU members were different. Complexity of harmonization process was linked with ineffective work of regulative institutions which coordinated the sphere of external trade and production. Another problem of economic integration is that governmental trade agreements were directed to regulative trade that prevented development of market mechanism.

\begin{tabular}{|c|c|c|c|c|c|}
\hline (billionsUS dollars) & $\mathbf{1 9 9 4}$ & $\mathbf{1 9 9 5}$ & $\mathbf{1 9 9 6}$ & $\mathbf{1 9 9 7}$ & $\mathbf{1 9 9 8}$ \\
\hline Trade turnover & 657.1 & 9312 & 1343.1 & 1313.1 & 1355.1 \\
\hline Export & 340.1 & 408.9 & 505.4 & 603.8 & 513.6 \\
\hline Import & 317 & 522.3 & 837.7 & 709.3 & 841.5 \\
\hline Trade balance & +23.1 & -113.4 & -332.3 & -105.5 & -327.9 \\
\hline
\end{tabular}

Table 3. Dynamics of external trade of Kyrgyzstan in period proceeding entry in WTO

Despite the fact that in period from 1994 to 1998 years external trade turnover of the republic doubled, the balance of trade was negative and increased annually. From 1996 external trade turnover growth rate decreased substantially (National Statistic Committee of Kyrgyzstan 2010). The major problem of integration within CU countries was economic recession of all former Soviet states in that period. In such conditions any international activities objectively couldn't have neither political nor economical results.

Search for external factors that could positively affect the internal production process, and also willingness to declare itself as a new independent government contributed to the decision of Kyrgyzstan to enter the WTO.

The entrance of Kyrgyzstan the WTO assumed the establishment of stable tariff regimes that would give the government competitive advantage over other CU members.

Also there were many political and economical premises of entering the WTO. The major political reasons of entering the WTO are protection and support by more developed countries. In order to have equal relationships with foreign partners the republic should have to be under the protection of international law.

The primary economical premises of entering the WTO are a provision of privileges for export of goods and services in the market of WTO member countries. Also by entering the WTO Kyrgyzstan supposed to get more stable and predictable conditions for investments that could lead to increase of volume and improvement of quality of investments in all sectors of the economy.

\subsection{The major trade partners of Kyrgyzstan with WTO member countries}

The major trade partners of Kyrgyzstan in WTO are the countries of European Union (external trade with them amounts 23.1\%), China (23\%), USA (10\%), Turkey (6,3\%) (Brovko N.A 2010, p62).

However, Kyrgyzstan doesn't have stable trade relationships with most WTO member countries. In different years export and import indices increase or decrease sharply.

Only with one WTO member country- Switzerland, Kyrgyzstan has positive trade balance. In the last five years more than $90 \%$ of export to Switzerland was due to the export of gold. Dynamics of import goods from Switzerland increased by 1.8 times from 2002 to 2006, mainly because of medical and pharmaceutical products. Kyrgyzstan has relatively stable tendency in trade with China and Turkey (Brovko N.A 2010, p 62).

Kyrgyzstan exports to Turkey leather and wool materials. China is interested in import of scraps, copper, aluminum and aluminum withdrawals from Kyrgyzstan.

Despite the constant growth of total import volume from China there is no steady volume of imported goods that complicates specification of leading import goods from China.

In comparison with China import from Turkey for the last five years there is a stable specification of import groups such as equipment, plastic and plastic goods, finished food stuffs, alcoholic and non-alcoholic beverages and tobacco, clothes and construction materials.

\subsection{Trade condition of Kyrgyzstan with WTO countries and EurAsEC.}

From 2004 trade turnover with WTO countries is decreasing (National Statistic Committee of Kyrgyzstan 2010).

\begin{tabular}{|c|c|c|c|c|c|c|c|}
\hline & $\mathbf{2 0 0 2}$ & $\mathbf{2 0 0 3}$ & $\mathbf{2 0 0 4}$ & $\mathbf{2 0 0 5}$ & $\mathbf{2 0 0 6}$ & $\mathbf{2 0 0 7}$ & $\mathbf{2 0 0 8}$ \\
\hline Trade turnover & 100 & 100 & 100 & 100 & 100 & 100 & 100 \\
\hline WTO & 52.9 & 40.1 & 47.2 & 43.2 & 41.9 & 37.3 & 31.2 \\
\hline
\end{tabular}

Table 4. Kyrgyzstan's total external trade turnover ratio with WTO member countries(\%)

The major reasons of turnover decrease are:

1. weak internal market and low level of standard of life in Kyrgyzstan

2. territorial remoteness of Kyrgyzstan from major members of WTO

3. imperfection of export structure and it's raw material orientation 
From the table below it is clear that in comparison to trade with WTO member countries export and import with EurAsEC member countries is increasing steadily. Kyrgyzstan mainly trades with Russia and Kazakhstan. $44 \%$ of Kyrgyzstan's total trade turnover amounts only with those two countries (Russia 26, 9\%, Kazakhstan 16, 8\%) (National Statistic Committee of Kyrgyzstan 2010).

The increase of export volume is explained by the fact that Kyrgyzstan imports from WTO countries and then re-exports imported goods to EurAsEC. (mainly to Russia and Kazakhstan)

\begin{tabular}{|c|r|r|r|r|r|r|}
\hline & \multicolumn{1}{|c|}{$\mathbf{2 0 0 2}$} & \multicolumn{1}{|c|}{$\mathbf{2 0 0 3}$} & \multicolumn{1}{c|}{$\mathbf{2 0 0 4}$} & \multicolumn{1}{c|}{$\mathbf{2 0 0 5}$} & \multicolumn{1}{c|}{$\mathbf{2 0 0 6}$} & \multicolumn{1}{c|}{$\mathbf{2 0 0 7}$} \\
\hline EurAsEC & 377.6 & 530.5 & 752.2 & 837.2 & 1307.7 & 1987.7 \\
\hline Export & 128.4 & 174.5 & 249.1 & 274.8 & 369.1 & 554.4 \\
\hline Import & 249.2 & 356 & 503.1 & 562.4 & 938.6 & 1433.3 \\
\hline Trade balance & -120.8 & -181.5 & -254 & -287.6 & -569.5 & -879.9 \\
\hline WTO & 567.4 & 673.3 & 783.1 & 766.3 & 1052.5 & 1326.2 \\
\hline Export & 307.3 & 371.6 & 430.7 & 351.8 & 333.2 & 437.7 \\
\hline Import & 260.1 & 301.7 & 352.4 & 414.5 & 719.3 & 888.5 \\
\hline Trade balance & +47.2 & +69.9 & +78.3 & -62.7 & -386.1 & -450.8 \\
\hline
\end{tabular}

Table 5. Kyrgyzstan's trade with WTO countries and EurAsEC (millions of US \$)

\subsection{Empirical analysis of Kyrgyzstan's import dependence within WTO}

As well as other developing countries within WTO, Kyrgyzstan became strongly dependent on import. The results were that a correlation between GDP and import is $96 \%$, which means that interrelation between GDP and import is very significant. (Table6). Figure 2 illustrates that sharp rise of import since 2005 reflect a parallel growth of GDP. At the same time, export has been dependent on import (a correlation between export and import is $87 \%$ ). Export growth is explained by existence of re-export, as Kyrgyzstan imports goods at law tariff from WTO members (especially from China and Turkey) and re-exports them to its regional trade partners.

\begin{tabular}{|c|c|c|c|c|}
\hline & & import & export & GDP \\
\hline import & Pearson Correlation & 1 & $\mathbf{, 8 7 7 ^ { * * }}$ & $\mathbf{, 9 6 7}^{\text {*** }}$ \\
& Sig. (2-tailed) & &, 000 &, 000 \\
& $\mathrm{~N}$ & 14 & 14 & 14 \\
\hline \multirow{2}{*}{ export } & Pearson Correlation &, $877^{* *}$ & 1 & $\mathbf{, 8 8 2}^{* *}$ \\
& Sig. (2-tailed) &, 000 & &, 000 \\
& $\mathrm{~N}$ & 14 & 14 & 14 \\
\hline GDP & Pearson Correlation &, $967^{* *}$ &, $882^{* *}$ & 1 \\
& Sig. (2-tailed) &, 000 &, 000 & 14 \\
\hline
\end{tabular}

Table 6: Correlations between import, export and GDP. ${ }^{* \star}$ Correlation is significant at the 0.01 level (2-tailed).

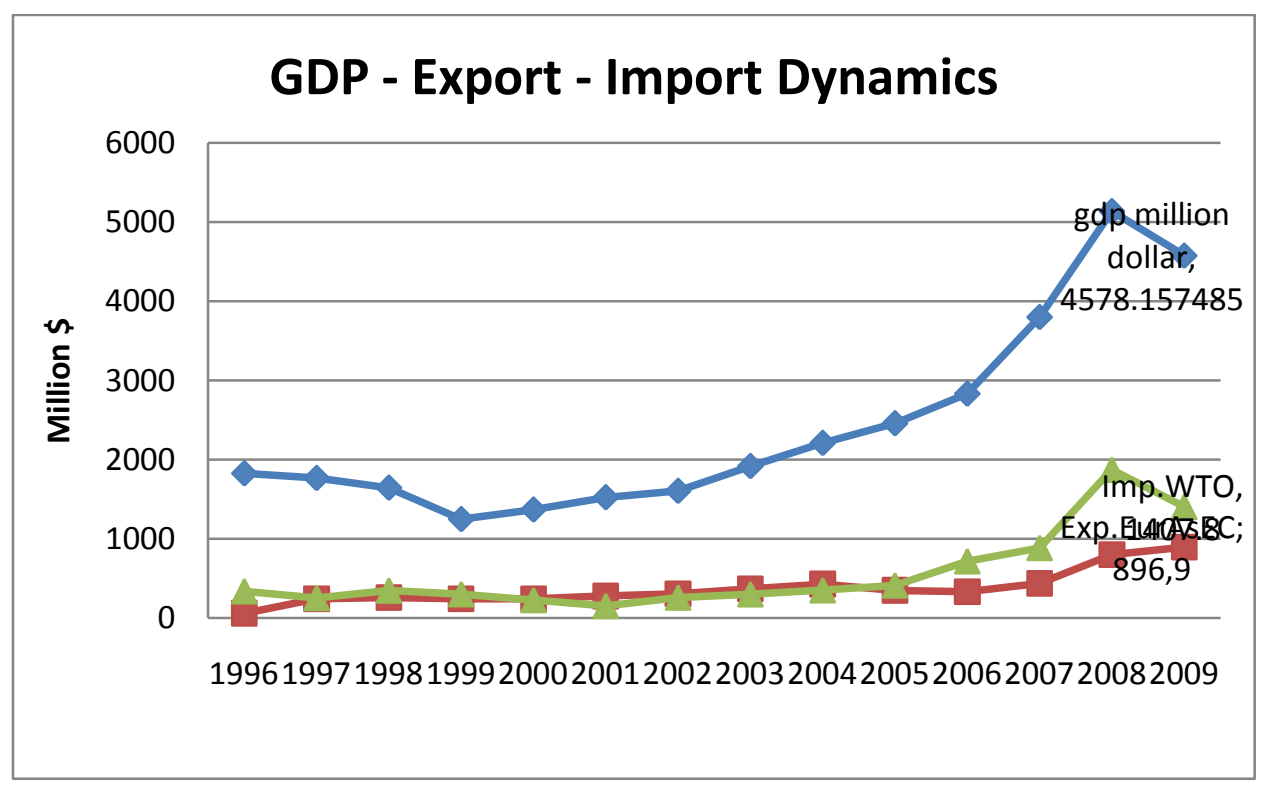

Figure 2: GDP - Export - Import Dynamics 


\section{Custom Union and Kyrgyzstan}

The formation of the Custom Union between Russia, Belarus and Kazakhstan influences economy of Kyrgyzstan mainly trade flows, revenues generated by imports, consumer price levels and employment. While most effects would result from Kyrgyzstan's joining the CU, the mere existence of the CU has some important effects even if Kyrgyzstan remains outside - in particular on the substantial transit trade in Chinese goods that has developed in recent years.

\subsection{Major Impacts from Joining the Custom Union.}

- Adopting the Common External Tariff (CET) in its present state would roughly double the average tariff applied by Kyrgyzstan, from an average of $5.1 \%$ to the CET average of $10.6 \%$.

- The accession of Kyrgyzstan to the Customs Union would be a remarkable step towards integrating economic relations with Russia and the other CU members and would significantly reduce trade relations with non- CIS states.

- Because budget revenues in Kyrgyzstan are heavily dependent on import duties and VAT collected on imports, reduced imports from non-CIS countries have the potential to significantly reduce state revenues, despite the fact that average tariff for non-CIS imports would be approximately doubled. Kyrgyzstan's reliance on revenues from imports contrasts with Russia's and Kazakhstan's reliance on export revenues.

- Adoption of the CU CET would be a major change. Approximately 92\% of the Common External Tariff (CET) is based on the Russian tariff, which is focused on protection of Russian producers from imports and encouragement of transition of consumers of other CU countries to Russian products. This is a tariff designed to benefit Russia.

- Adoption of the CU CET would result in an increase in consumer prices. Prices for goods imported from CU members would not change, but those for goods from non-CIS countries would increase markedly.

- The accession of Kyrgyz Republic to the CU will decrease GDP of Kyrgyzstan.

- The accession of Kyrgyzstan to the CU will result in huge inflow processed goods from Kazakhstan and Russia. Currently the presence of such goods is already at high level. Customs opening will influence to domestic producers. Exporting primary products producers will lose a revenue generation from value added.

- Kyrgyzstan under GATT Art. XXVIII have to offer a "compensatory adjustment" to WTO members if it enters to the CU. It can amount from 1, 5-7 billions of US dollars.

- The CU will broaden the market size which will attract the FDI inflow; investors are interested in investing not in one certain country but in a regional union.

- Kyrgyz agricultural goods and construction materials are more competitive than Chinese goods, as China is not a member of Custom Union and it is imposed with higher tariffs. Thus Kyrgyz goods have a potential to be exported in to the Custom Union members.

- The closure of customs will lead to the rise of prices to agricultural products giving the incentive for Kyrgyz farmers to produce more goods with higher quality and volume.

Moreover, the differences among the economic indices of the current CU members and Kyrgyzstan are enormous ( Allen M. Shinn, Askar Beshimov and Azamat Usubaliev 2010). So the gain of Kyrgyzstan in trading with CU members will be significantly less in comparison with other members.

\begin{tabular}{|c|c|c|c|c|}
\hline $\mathbf{2 0 0 8}$ & Kyrgyzstan & Belarus & Kazakhstan & Russia \\
\hline GDP, billion USD & 5.0 & 60.3 & 135.6 & 1676.6 \\
\hline Agriculture & $26 \%$ & $9 \%$ & $6 \%$ & $6 \%$ \\
\hline Industry & $17 \%$ & $39 \%$ & $42 \%$ & $39 \%$ \\
\hline Services & $57 \%$ & $53 \%$ & $52 \%$ & $54 \%$ \\
\hline GDP growth & $7.6 \%$ & $10.0 \%$ & $3.3 \%$ & $5.6 \%$ \\
\hline $\begin{array}{c}\text { GDP per capita, thousand } \\
\text { USD }\end{array}$ & 0.95 & 6.23 & 8.72 & 11.81 \\
\hline $\begin{array}{c}\text { Export, } \% \text { of GDP } \\
\text { Import, } \% \text { of GDP }\end{array}$ & $61 \%$ & $54 \%$ & $61 \%$ & $28 \%$ \\
\hline $\begin{array}{c}\text { Postal money transfers and } \\
\text { compensations, billion USD }\end{array}$ & 1.23 & 0.45 & 0.19 & $17 \%$ \\
\hline Inflation, GDP deflator & $26 \%$ & $16 \%$ & $21 \%$ & $18 \%$ \\
\hline Population, million people & 5.3 & 9.7 & 15.6 & 142 \\
\hline Population growth, $\%$ & $1.1 \%$ & $-0.2 \%$ & $0.1 \%$ & $-0.1 \%$ \\
\hline
\end{tabular}

Table 3: Data of the CU members and Kyrgyzstan 
These data demonstrate that the economy of Kyrgyzstan is a great deal smaller than the economies of the other members. GDP per capita is much lower, agriculture and international trade are much more important, and population growth is higher. The dominating position of Russia is obvious. These differences immediately suggest that CU conditions that favor the much more highly developed Russian economy may well not favor the very different situation in Kyrgyzstan. All three CU members have much higher levels of industrial development than

Kyrgyzstan, and all three have much less dependence on agriculture. Russia and Kazakhstan depend heavily on commodity exports. Russia and Belarus have large but relatively inefficient industrial sectors, which require protectionist tariffs in order to survive international competition. Russia and Kazakhstan are significant markets for Kyrgyz products and important sources of Kyrgyz imports, particularly fuel. Kyrgyz trade with Belarus, however, is insignificant.

Thus, it is clear that entering the CU is not economically beneficial for Kyrgyzstan. Even if Kyrgyzstan has a big trade turnover with Russia and Kazakhstan there is no proper trade policy with those countries. It is necessary to define all possible risks and expected outcomes of joining the CU.

\section{Conclusion}

Major focus of this paper is based on analysis of condition of developing countries in agriculture within WTO, impact of WTO membership on Kyrgyzstan's trade. After conducting the research certain consequences of developing countries membership in WTO became evident. The cost of agricultural protection falls particularly hard on developing countries, where agriculture typically accounts for a much higher share of economic output, exports, and employment than in developed countries. Agricultural sector growth is critical to many developing countries' overall economic growth, and reform of protectionist policies promises many billions of dollars of annual benefits to developing countries as a whole. The second issue of developing countries is that they became strongly dependent on import. Thus, building appropriate trade negotiations with WTO members is crucial for developing countries.

They should achieve fairness on tariff setting in agriculture and production sectors.

Despite the fact that Kyrgyzstan's experience in WTO has not been efficient, it should not consider the accession to the Custom Union as the best alternative because the research analysis show that entering the CU is not economically beneficial for Kyrgyzstan. Also, there is no appropriate trade policy, which could represent efficient and stable trade relations with CU countries. It is necessary to attract re-exporters into the production sector. Even if the time of re-export is used up, it is impossible abruptly to change the system. It is better for Kyrgyzstan to wait until CU members enter the WTO because last negotiations of Russia and Kazakhstan with WTO members show that their accession will be completed in near future. By that time Kyrgyzstan should develop its agriculture and production sector.

\section{References}

- Dictionary of trade policy terms 2nd ed. 1998,187

- Report of the Secretary-General of UN, 2001. "Finance and trade". "Trade and Development and the Department of Economic and Social Affairs of the United Nations", 30 April- 2 May 2001

- $\quad$ FAOSTAT (2003)

- $\quad$ EarthTrends 2007, using data from OECD 2006

- Agricultural Trade Reform and Poverty in the Developing World, April 2007.

- http://earthtrends.wri.org/updates/node/194

- Allen M. Shinn, Askar Beshimov, Azamat Usubaliev. April 19, 2010. Economic Consequences of the Customs Union for the Kyrgyz Republic

- National Statistic Committee of Kyrgyzstan 2010 


\title{
Budget Deficits and Trade Deficits in Turkey: An Empirical Investigation of Causality
}

\author{
H. Zeynep Budak (Bahcesehir University, Turkey)
}

\begin{abstract}
The problem of budget deficits and trade balances has been attracting attention of many academicians and policymakers. There are two main approaches regarding the relationship between budget and trade deficits. Keynesian theory argues that the budget deficit is the major cause of the trade deficit while Ricardian Equivalence Hypothesis denies the relationship between the two deficits. This study aims to test the validity of the Keynesian theory and the Ricardian equivalence hypothesis for Turkey by identifying the relationship between budget and trade deficits. Data used in this study are budget deficit and trade deficit as percentages of gross domestic product for the years 1975-2009. Cointegration analysis and error correction model are employed to examine the linkages between the two variables. Empirical results support the Keynesian view indicating a long term relationship between budget and trade deficits in Turkey. Results also show that the direction of causality is from budget deficit to trade deficit. It is concluded that, any policy attempting to reduce the budget deficit in Turkey would help improving the trade balance.
\end{abstract}

JEL Code: F30, H60, H62

\section{Introduction}

Current account and budget balances are considered to be important indicators of economic respectability and sustainability. Twin Deficits Hypothesis suggests that an increase in budget deficit will lead to an increase in current account deficit. Keynesian approach supports this hypothesis while the Ricardian Equivalence Hypothesis argues that there is no relationship between the budget deficit and current account deficit. The issue of whether these two balances are related is vital for both policymakers and practitioners as it may have different economic implications.

The relationship between budget and trade deficits has been discussed in considerable amount of empirical studies in recent years. A significant amount of the studies on twin deficits hypothesis were carried out for the United States of America (USA). Darrat (1988) tests the twin deficits with Granger Causality Test and finds that there is a two-way causality relation between two variables. According to this, current account deficit and budget deficit affect each other. Bachman (1992) uses VAR (Vector Auto-Regression) analysis in his study and suggests that a strong relationship exists between budget and trade deficits and budget deficit leads to external deficit. Similarly, Dibooğlu (1997), using VAR analysis, confirms the validity of twin deficit hypothesis for the USA. In their study Kim and Roubini (2007) argue that there is a significant relationship between the budget and trade deficits. Unlike other studies, they points out that there is an inverse relationship between the variables. Grier and Ye (2009) study the short and long term relationships between the two deficits by using VAR-GARCH model. The study provided evidence that there is no significant relationship between the two variables in the long term. However, budget deficit affects current account deficit in the short term.

There are also some other studies which analyze twin deficits for other countries. Winner (1993) concludes that twin deficit theorem is not valid for Australia. Vamvoukas (1990) aimed at defining the relationship between budget deficit and current account deficit in Greece. The researcher concludes that the budget deficit has a significant effect on the current account deficit in short and long term. In their study which was carried out for the member countries of the Association of Southeast Asian Nations (ASEAN) Baharrumshah et. al (2006) find that twin deficit theorem is valid for these countries and there is a significant relationship between budget deficit and current account deficit in the long term.

There is a limited number of studies carried out to explain the relationship between budget deficit and current account deficit in Turkey. Zengin (2000) observed the twin deficit hypothesis for Turkey. It was found out by using VAR analysis that long term budget deficits have a significant effect on foreign trade deficit. Akbostanc1 and Tunç (2002) argued that there is a long term linkage between twin deficits and a decrease in budget deficit leads to an increase in current account deficit. Utkulu (2003) finds evidence supporting thetwin deficits hypothesis, he also argues that the budget deficit and the current account deficit moves in the same direction in Turkey. Besides, it is concluded that the direction of causality is two-way. Sever and Demir (2007) by using Granger Causality Test finds that the existence of budget deficits, confirming the traditional hypothesis, has a significant impact on the current account deficit.

This study aims to test the validity of the Keynesian approach and the Ricardian Equivalence Hypothesis for Turkey by identifying the relationship between budget and trade deficits. Using annual data, the ratios of budget deficit/ gross domestic product (GDP) and foreign trade deficit/ GDP for 1975-2009 period were analyzed in the 
study.

The rest of the article is organized as follows: In Section 2 theoretical ground of Twin Deficits Hpothesis is demonstrated. In section 3 methodology employed in this study is described. Section 4 represents the empirical results of the study while section 5 concludes the paper.

\section{Theoretical framework}

Import and export, the biggest two components of current account balance significantly affect national income.

$$
\mathrm{Y}=\mathrm{C}+\mathrm{I}+\mathrm{G}+(\mathrm{X}-\mathrm{M})
$$

In the equation above, "Y" stands for gross national product, "C" stands for consumption; "I" stands for investment, "G" stands for expenditures of the government, "X-M" stands for net exports. One can define net exports as current account balance (CA), and by using the relation that after tax (T) income equals the sum of private savings $(\mathrm{Sp})$ and consumption obtain:

$$
\mathrm{Sp}+(\mathrm{T}-\mathrm{G})=\mathrm{I}+\mathrm{CA}
$$

As seen above, the sum of private and public savings is equal to investment plus current account balance. By rearranging the equation above, the current account balance is shown as:

$$
\mathrm{CA}=(\mathrm{Sp}-\mathrm{I})+(\mathrm{T}-\mathrm{G})
$$

This simply states that the current account balance is defined as public savings minus investments plus budget deficit. Supposing that the difference between private sector savings and investments (savings investment gap) is stable, an increase in budget deficit will lead to an increase in current account deficit. This is called as "twin deficit" relation.

There are two basic approaches to explain the effect of the increase in budget deficits on current account deficits. The first one is Keynesian Approach and the other one is Ricardian approach. According to Keynesian Approach (Keynesian income-expenditure approach) the increase in budget deficit will increase the total domestic spending $(\mathrm{C}+\mathrm{I}+\mathrm{G})$ and it refers to an increase in domestic income. The increase in income will lead to an increase in import and hence foreign trade surplus will decrease and/or foreign trade deficit will go up. Consequently, the increase in budget deficit will result in the increase in current account deficit. In other words, the increase in budget deficit due to public spending will result in the increase in national income by stimulating more consumption and production. The increase in national income leads to an increase in import. Supposing that export is constant, the increase in foreign trade deficit will equal to budget deficit.

In Keynesian open economy model, the cause of current account deficits in economies with high capital mobility is stated to be public deficit. According to this, an increase in public spending leads to a decrease in the amount of national savings. The decrease in saving acts as a warning for government authorities to raise interest rates. On the other hand, government goes into debt to finance the budget deficit and this leads to an increase in interest rates. The increase in interest rates takes the foreign investors' attention and causes the inflow of hot money into the country. Hot money inflow results in an increase in foreign exchange supply, and so domestic currency will rise in value. When domestic currency is more valuable than foreign exchange, imported goods would be cheaper and domestic goods would be more expensive. Hence, the cost of import will increase and the cost of export will decrease. As a consequence, foreign trade deficit and current account deficit will increase.

Taking all above mentioned points into consideration, Keynesian approach explains the relationship between current account deficit and budget deficit in two ways. It suggests that there is a positive relationship between budget deficit and current account deficit. It also makes an explanation about the causality relationship between them. According to Keynesian approach budget deficit leads to current account deficit. I other words, the direction of the causality is from budget deficit to current account deficit.

The idea that the increase in budget deficit due to public spending affects the current account deficit is not accepted by some economists who support Ricardian Equivalence Hypothesis (REH). According to Ricardian Equivalence Hypothesis, if budget deficit occurs because of a tax reduction, it will not affect the current account balance. According to Ricardian approach, when economic units decide on investments and savings, they take lifetime budget into consideration. Depending on it, in an economy where public spending is stable and there is no pressure of going into debt, even tax reduction takes place; it will not affect the saving level. Because economic units are aware that they will pay more taxes in the future, they economize today instead of consuming more. In other words, personal saving will take place at a level that will meet the public spending which is declining. Since saving level will be stable, this mechanism above will not process and it will not affect the current account level.

\section{Methodology}

In this study The Engle-Grenger Two-Step Cointegration Method was used to find out whether there is a longrun relationship between budget deficit and foreign trade deficit. Cointegration is one of the methods which can 
be conducted on non-stationary series. This analysis aims at determining the long term relationship between the variables. According to Engle and Granger (1987), the linear combination of the series which are non-stationary but integrated of the same order can be stationary. These series are said to be cointegrated series. Cointegrated variables may act separately and deviate from their relationship in the short run, but their association would return and they would move together in the long run.

The first step of the analysis involves estimation of cointegrating relationship for series which are confirmed to be integrated by using ordinary least squares method. Then the residuals of the estimation model are tested to see if they are stationary. If residuals, which are accepted to be the linear combination of the series, are found to be stationary the variables are said to be cointegrated. Series which are cointegrated are stated to be showing a long term equilibrium relation. There is an error correction mechanism linking the series in the long run. EngleGrenger (1987) explains this mechanism with Granger Representation Theorem. The error correction mechanism induces the series to move together over time.

According to Granger (1988) there is at least one-way causality relation between the cointegrated series. At the second step Error Correction Model (ECM) is conducted and the causality relationship is analyzed. ECM includes lagged residuals of the previous model which are called error correction terms and differenced series. By using stationary series this model eliminates the problem of spurious regressions. The error correction model can be represented as follows:

$$
\Delta\left(\mathrm{y}_{\mathrm{t}}\right)=\beta_{1} \Delta \mathrm{x}_{\mathrm{t}}+\beta_{2}\left(\mathrm{u}_{\mathrm{t}-1}\right)+\mathrm{e}_{\mathrm{t}}
$$

In the equation above, $\Delta$ indicates that the series is differenced. $\mathrm{u}_{\mathrm{t}-1}$ stands for lagged residual and is called error correction term. If the coefficient $\beta_{2}$ is negative and statistically significant this means that an error correction mechanism and causality exists.

\section{Empirical Results}

First of all, unit root test is conducted to determine whether the observed series are stationary or not. For that purpose, Augmented Dickey-Fuller (ADF) test is used. The null hypothesis $\left(\mathrm{H}_{0}\right)$ of ADF test indicates that series has a unit root. "tg" stands for foreign trade deficit/GDP ratio and "bg" stands for of budget deficit/GDP ratio. The results of stationarity tests are shown below. As it is seen, for both variables p values exceed $5 \%$. So the null hypothesis, which claims to contain a unit root, is accepted. Both series are found to be non-stationary.

\begin{tabular}{|c|c|c|c|}
\hline \multicolumn{4}{|c|}{$\begin{array}{l}\text { Null Hypothesis: TG has a unit root } \\
\text { Exogenous: None } \\
\text { Lag Length: } 1 \text { (Automatic - based on SIC, maxlag=8) }\end{array}$} \\
\hline & & t-Statistic & Prob.* \\
\hline Augmented Dickey & er test statistic & -0.226403 & 0.5970 \\
\hline Test critical values: & $\begin{array}{l}1 \% \text { level } \\
5 \% \text { level } \\
10 \% \text { level } \\
\end{array}$ & $\begin{array}{r}-2.636901 \\
-1.951332 \\
-1.610747 \\
\end{array}$ & \\
\hline
\end{tabular}

Table 1. ADF Test Results for Trade Deficit

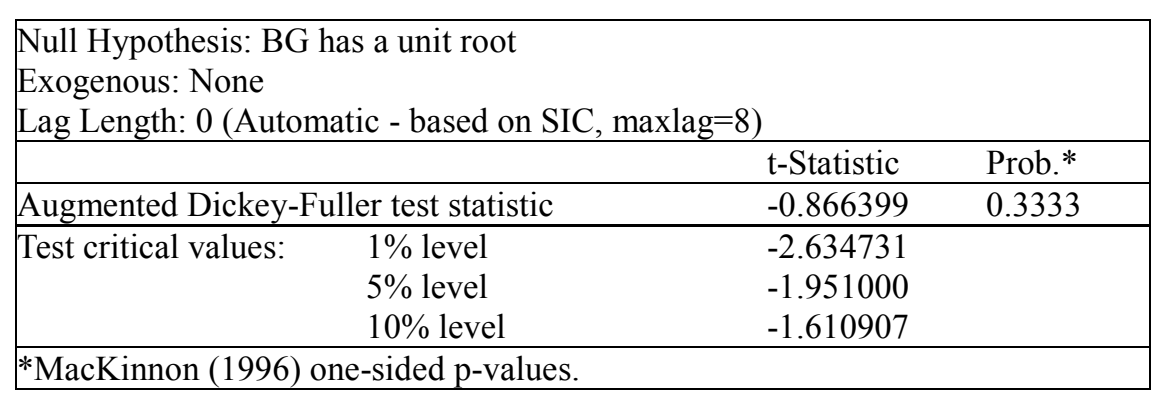

Table 2. ADF Test Results for Budget Deficit

After determining that the series are non-stationary, first differences of both series are taken, and first difference series (dtg and $\mathrm{dbg}$ ) were created. A unit root test was conducted for these series. Test results are indicated below: 


\begin{tabular}{|c|c|c|c|}
\hline \multicolumn{4}{|c|}{$\begin{array}{l}\text { Null Hypothesis: } \mathrm{D}(\mathrm{TG}) \text { has a unit root } \\
\text { Exogenous: None } \\
\text { Lag Length: } 0 \text { (Automatic - based on SIC, maxlag=8) }\end{array}$} \\
\hline & & t-Statistic & Prob.* \\
\hline Augmented Dickey & er test statistic & -8.235537 & 0.0000 \\
\hline Test critical values: & $\begin{array}{l}\% \text { level } \\
5 \% \text { level } \\
10 \% \text { level }\end{array}$ & $\begin{array}{l}-2.636901 \\
-1.951332 \\
-1.610747\end{array}$ & \\
\hline
\end{tabular}

Table 3. ADF Test Results for First Difference Series of Trade Balance

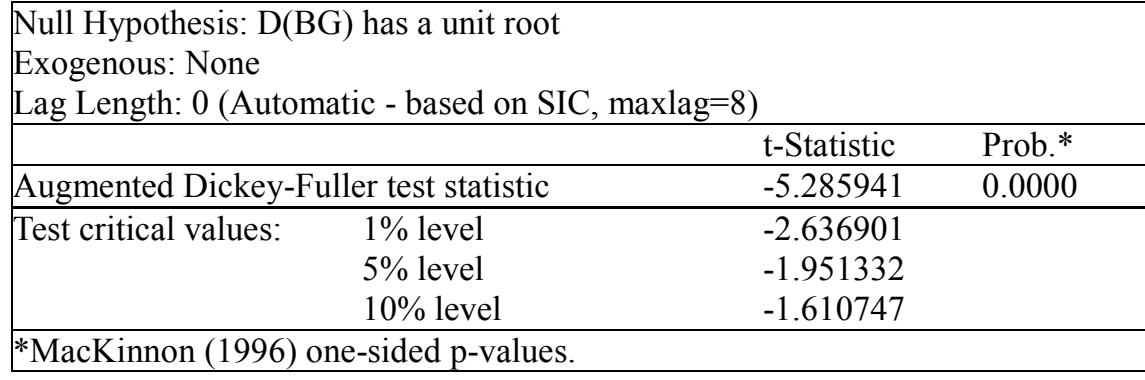

Table 4. ADF Test Results for First Difference Series of Budget Balance

As seen, almost both $\mathrm{p}$ values are zero. According to it, for both variables, the null hypothesis which claims that series contain a unit root is rejected. That is, non-stationary series become stationary by first differencing. This means that, both bg and tg are integrated of the first order, that is they are both I(1). Since both variables are integrated of the same order, they may be moving together in the long term. The Engle-Granger Two-Step Cointegration Analysis was conducted.

\section{The Engle-Granger Two-Step Cointegration Analysis}

At the first step of the analysis, the coefficients of a static relationship between tg and bg are estimated by ordinary least squares method and unit root test is applied to the residuals.

Note that commenting on the coefficients is impossible due to spurious regression problem, this analysis is just carried out in order to test the stationarity of residuals. Because two-way causality relations will be analyzed in this study, estimation equations are created considering both directions.

$$
\begin{aligned}
& \operatorname{tg}_{\mathrm{t}}=\mathrm{a}_{1} \mathrm{bg}_{\mathrm{t}}+\mathrm{c}_{1}+\mathrm{e}_{1} \\
& \mathrm{bg}_{\mathrm{t}}=\mathrm{a}_{2} \mathrm{tg}_{\mathrm{t}}+\mathrm{c}_{2}+\mathrm{e}_{2}
\end{aligned}
$$

In the equations, tg and bg stand for variables of foreign trade deficit/GDP ratio and budget deficit /GDP ratio, $\mathrm{a}_{1}$ and $\mathrm{a}_{2}$ stand for regression coefficients, $\mathrm{c}_{1}$ and $\mathrm{c}_{2}$ stand for invariables, $\mathrm{e}_{1}$ and $\mathrm{e}_{2}$ stand for residuals, and $\mathrm{t}$ stands for time. Residuals obtained from these equations are tested for stationarity. Results of unit root tests are represented below:

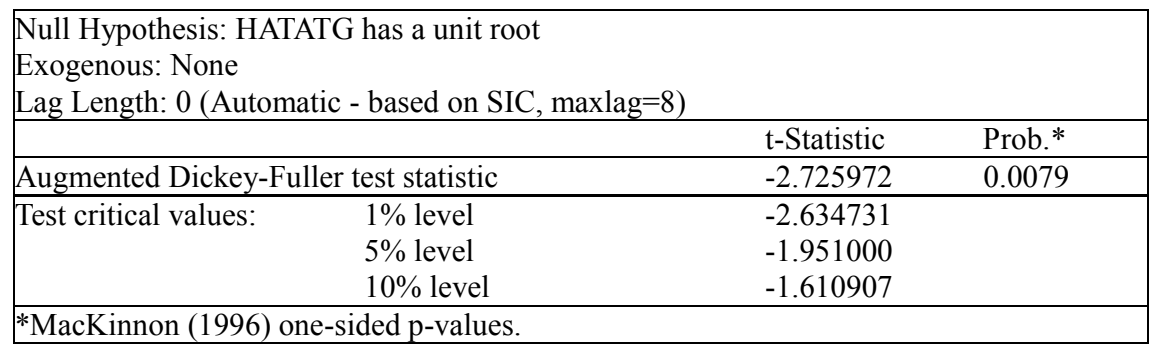

\begin{tabular}{|c|c|c|c|}
\hline \multicolumn{4}{|c|}{$\begin{array}{l}\text { Null Hypothesis: HATABG has a unit root } \\
\text { Exogenous: None } \\
\text { Lag Length: } 0 \text { (Automatic - based on SIC, maxlag=8) }\end{array}$} \\
\hline & & $\mathrm{t}$-Statistic & Prob.* \\
\hline Augmented Dickey & test statistic & -2.394391 & 0.0181 \\
\hline Test critical values: & $\begin{array}{l}1 \% \text { level } \\
5 \% \text { level } \\
10 \% \text { level }\end{array}$ & $\begin{array}{l}-2.634731 \\
-1.951000 \\
-1.610907\end{array}$ & \\
\hline
\end{tabular}

Table 5. ADF Test Results for Residuals

Table 6. ADF Test Results for Residuals

As seen in the tables, for both equations the null hypothesis which claims that residuals (hatabg and hatatg) 
contain unit root is rejected $(0.0079<0.05$ and $0.018<0.05)$. Based on this, error terms are said to be $\mathrm{I}(0)$, that is, stationary. As it is known, rejecting the null hypothesis of a unit root in this case is evidence in favor of cointegration, therefore implies the existence of a long run relationship between $\mathrm{tg}$ and $\mathrm{bg}$.

In the second ECM is used to determine the causality relationship and error correction mechanism is tried to be revealed. First differences of the series ( $\mathrm{dtg}$ and $\mathrm{dbg}$ ) and lagged residuals of the previous analysis are used in this model. Two error correction models are developed in order to analyze two-way causality relations. The estimation equations are as follows:

$$
\begin{aligned}
\Delta \operatorname{tg}_{\mathrm{t}} & =\alpha_{1} \mathrm{dbg}_{\mathrm{t}}+\beta_{1} \mathrm{u}_{\mathrm{t}-1}+\mathrm{c}_{1} \\
\Delta \mathrm{bg}_{\mathrm{t}} & =\alpha_{2} \mathrm{dtg}_{\mathrm{t}}+\beta_{2} \mathrm{u}_{\mathrm{t}-1}+\mathrm{c}_{2}
\end{aligned}
$$

$\Delta \operatorname{tg}$ and $\Delta$ bg stand for the first difference values of foreign trade deficit/ GDP and budget deficit/ GDP, $\alpha_{1}, \alpha_{2}$, $\beta_{1}$ and $\beta_{2}$ stand for regression coefficients, $c_{1}$ and $c_{2}$ stand for constant terms, $u$ and $u$ ' stand for lagged residuals.

\begin{tabular}{|c|c|c|c|c|}
\hline \multicolumn{5}{|c|}{$\begin{array}{l}\text { Dependent Variable: DTG } \\
\text { Method: Least Squares } \\
\text { Date: } 12 / 25 / 10 \text { Time: } 21: 03 \\
\text { Sample (adjusted): } 19762009 \\
\text { Included observations: } 34 \text { after adjustments }\end{array}$} \\
\hline Variable & Coefficient & Std. Error & t-Statistic & Prob. \\
\hline $\mathrm{DBG}$ & -0.154915 & 0.158406 & -0.977963 & 0.3357 \\
\hline HATATG(-1) & -0.325126 & 0.129720 & -2.506363 & 0.0177 \\
\hline $\mathrm{C}$ & 0.000480 & 0.002968 & 0.161824 & 0.8725 \\
\hline R-squared & 0.206964 & \multicolumn{2}{|c|}{ Mean dependent var } & 0.000282 \\
\hline Adjusted R-squared & 0.155801 & \multicolumn{2}{|c|}{ S.D. dependent var } & 0.018776 \\
\hline S.E. of regression & 0.017252 & \multicolumn{2}{|c|}{ Akaike info criterion } & -5.197719 \\
\hline Sum squared resid & 0.009226 & \multicolumn{2}{|c|}{ Schwarz criterion } & -5.063040 \\
\hline Log likelihood & 91.36122 & \multicolumn{2}{|c|}{ Hannan-Quinn criter. } & -5.151790 \\
\hline F-statistic & 4.045146 & \multicolumn{2}{|c|}{ Durbin-Watson stat } & 2.346230 \\
\hline Prob(F-statistic) & 0.027481 & & & \\
\hline
\end{tabular}
The results of ECM regression are as follows:

Table 7. ECM Results for Trade Balance

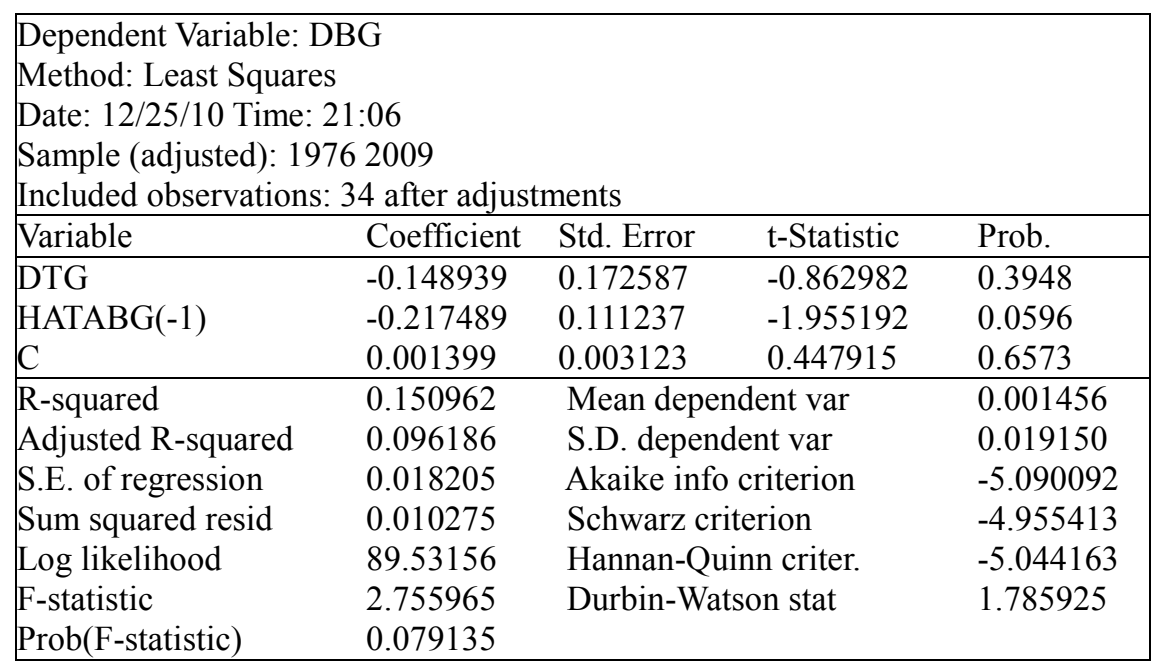

Table 8. ECM Results for Budget Balance

Taking dtg as dependent variable, error correction term (hatatg $(-1))$ is significant $(0.017<0.05)$ and takes a negative value that is larger than $-1(-0.325)$. These results indicate that there is a long term causality relationship between $\mathrm{tg}$ and $\mathrm{bg}$ and error correction mechanism is valid for these two variables. So, the budget deficit has a significant effect on the foreign trade deficit.

On the other side placing $\mathrm{dbg}$ as the dependent variable, the results does not imply a causality relationship. According to the second error correction model, budget deficits are not affected by foreign trade deficits. Although the coefficient of error correction model is negative and larger than $-1(-0.2174)$, it is not statistically significant $(0.0596>0.05)$. Depending on this, the foreign trade deficit does not have a significant impact on the budget deficit.

Results indicate that the relationship between the budget deficit and foreign trade deficit is a one way causality relationship. Both variables move together in the long run and an error correction mechanism exists. In addition 
to this, the direction of causality is from the budget deficit to the foreign trade deficit.

\section{Conclusion}

This study aimed at determining the relationship between budget deficit and foreign trade deficit in Turkey. Annual values of budget deficit / GDP and foreign trade deficit / GDP ratios for 1975 - 2009 period were analyzed in the study. Another purpose of the study is to determine whether Keynesian approach or Ricardian approachis valid for Turkey. Engle-Grenger Two-Step Cointegration Method were used in order to find out whether there is a long term equilibrium relationship between the two variables and to determine the direction of the causality relation between the variables.

According to the findings of the study, it was concluded that the budget deficit and foreign trade deficit move together in the long term and there is an error correction mechanism bounding these two variables. Based on this, it is possible to point out that the Ricardian Equivalence Hypothesis, which supports that budget deficit and foreign trade deficit are not related, is not valid for Turkey.

Moreover, the findings of the study indicate that a causality relation between foreign trade and budget deficit exists and the direction of this relation is from the budget deficit towards the foreign trade deficit. Namely, it was found that the budget deficit has a significant impact on the foreign trade deficit. According to this, an increase in the budget deficit leads to an increase in the foreign trade deficit and a decline in the budget deficit leads to a decline in the foreign trade deficit. This result proves the twin deficits hypothesis for Turkey for the study period.

It is concluded that two explanations of the Keynesian Approach are valid for Turkey. Thus, this study suggests that applied fiscal policies have a vital impact on the foreign trade deficit and thus the balance of current account. Reducing the foreign trade deficit and current account deficit depend on the policy measures for reducing the budget balance.

\section{References}

- Darrat, 1988. "Have Large Budget Deficits Caused Rising Trade Deficits", Southern Economic Journal, 54, p. 879-87.

- Bachman, 1992. "Why Is The Us Current Account Deficit So Large? Evidence From Vector Autoregressions", Southern Economic Journal, 59, p. 232-40.

- Dibooğlu, 1997. “Accounting for US Current Account Deficits: An Empirical Investigation,” Applied Economics, 29, p. 787-793.

- Kim and Roubini, 2007. "Twin Deficit or Twin Divergence? Fiscal Policy, Current Account and Real Exchange Rate in th U.S", Journal of International Economics, 74, p. 362-383.

- Grier and Ye, 2009. "Twin Sons of Different Mothers: The Long and The Short of the Twin Deficits Debate”, Economic Inquiry, 4, p. 625-638.

- Winner, 1993. "The Relationship of the Current Account Balance and the Budget Balance", American Economist, 37, p.78-84.

- Vamvoukas, 1990. “The Twin Deficits Phenomenon: Evidence From Greece”, Applied Economics, 9, p.1093-110.

- Baharumshah, et.al, 2006. "Testing Twin Deficits Hypothesis using VARs and Variance Decomposition", Journal of the Asia Pacific Economy, 3, p.331-354.

- Zengin, 2000. "The Twin Deficits Hypothesis (The Turkish Case)", http://www.opf.slu.cz/vvr/akce/turecko/.

- Akbostancı and Tunç, 2002. "Turkish Twin Deficits: An Error Correction Model of Trade Balance", ERC Working Papers, 6.

- Utkulu, 2003. "Türkiye'de Bütçe Açıkları ve Dış Ticaret Açıkları Gerçekten İkiz mi? Koentegrasyon ve Nedensellik Bulguları", D.E.Ü.İI.I.B.F. Dergisi, 1, p.45-61.

- Sever and Demir, 2007. "Türkye'de Bütçe Açıkları ve Cari Açık Arasındaki İlişkilerin VAR Analizi ile İncelenmesi”, Osmangazi Üniversitesi İ̈BF Dergisi, 1, p. 47-63.

- Uğur and Karatay, “ỉkiz Açıklar Hipotezi: Teorik Çerçeve ve Hipoteze Yönelik Yaklaşımlar”, Sosyoekonomi, 1, p. 102-122.

- Ataç, 2006. Beyhan Ataç, Maliye Politikası, Etam Matbaa A.Ş, Eskişehir.

- Engle and Granger, 1987. Co-Integration and Error Correction: Representation, Estimation, and Testing", Econometrica, 2, p. 251-276.

- Granger ,1988. “Some Recent Developments In A Concept Of Causality”, Journal of Econometrics, 39, p.199-211.

- Brooks, 2008. Econometrics for Finance, Cambridge University Press. 


\title{
Turizmin Türk Ekonomisine Etkilerinin Girdi-Çıktı Analizi ile Değerlendirilmesi
}

\author{
Mehmet Sarışık (Sakarya University, Turkey) \\ Orhan Akova (Istanbul University, Turkey) \\ Oğuz Türkay (Sakarya University, Turkey) \\ Didar Sarı (Sakarya University, Turkey)
}

\section{An Evaluation of the Impact of Tourism on Turkey's Economy by Input-Output Analysis}

\begin{abstract}
The main aim of this paper is to present an example of Input-Output analysis for estimating the economic impact of tourism in Turkey. IO analysis is frequently used tool to evaluate economic impacts from tourism (Briassoulis 1991; Fletcher 1989; Johnson and Moore 1993) and to determine the role and importance of different economic value added, incomes and employment and it analyses the existing connection in an economy (Camelia, 2009). An alternative tool for regional analysis is the CGE model, which incorporates general equilibrium links between production structures, incomes of various groups, and demand patterns. Use of the CGE framework in modelling tourism effects represents a new approach to impact modeling for this economic sector (Deying, et al. 1997).

Tourism has been one of the most dynamic and fastest developing industries in Turkey especially since 1985. Additionally, after 1985, Turkey has been seen and accepted as one of the most favourite destinations around the world by the European tourists even if it has been compared with its competitors as Greece, Italy, and Spain and so on. The number of tourists increased from 24.12 million in 2005 to 33.03 million, and tourism revenues increased to 20.8 billion USD dollars in 2010 from 18.2 billion in 2005 . It is estimated that 1.2 million people are employed in tourism directly in 2010 while another 1.3 million are employed indirectly. This paper examines the impact of tourism by using IO analysis and explains the CGE model.
\end{abstract}

JEL codes: A10, C67

\section{Giriş}

Küresel ekonomide önemi her geçen gün artan rekabet edebilirliğin temel ilkesi ekonomilerde endüstriler arası arz-talep ilişskisini doğru tanımlayabilmek ve bu doğrultuda yatırım ile üretim miktarlarını optimal boyutlarda belirleyebilmektir. Yapılan yatırımların beklenen getiri oranı ve bu yatırımın diğer sektörler arasındaki yerinin belirlenmesi de ayrı bir önem taşımaktadır.

Endüstriler arası ilişkilerin giderek daha karmaşık bir hal alması, bir sektöre yönelik talebin karşılanabilmesi için ilişkili birçok sektör veya endüstride üretim yapılması gerekliliğini ortaya çıkarmaktadır. Söz konusu ilişkilerin boyutunun, bu ilişkilerin ekonomi üzerinde yarattıkları etkilerinin, bir sektörde yapılan yatırımın diğerlerine yansımalarının ayrıntılı biçimde ortaya konulabilmesi ve bunların matematiksel/istatiksel analizler yardımıyla açıklanmasında sıklıkla kullanılan tekniklerden birisi de Girdi-Çıktı (GÇ) (Input-Output-IO) analizidir (Uyar, 2006:4; Surugiu, 2009; Kweka ve diğ.,2001). GÇ endüstriyel yapıyı analiz etmek için kullanılan ve endüstriler ve ilgili kesimler arası ilişkilerin basit bir şekilde analizinin ötesine geçerek istatistik rakamlar üzerinden ve karşılıklı doğrudan ve dolaylı etkileşimleri ortaya koyan bir yöntemdir (Dang ve dig., 2011:81). Ulusal veya bölgesel seviyede makro ekonomik düzeyde kurulan GÇ modeli, ilgili alanlarda temel ekonomik ve sosyal sorunlarını çözümlemede yardımcı olmakta ve planlama ya da bölgesel kalkınmada bir araç olarak kullanılmaktadır (Ersungur ve Kızıltan;2008; Öztürk, 1980: 29; Bocutoglu, 1990: 2-3).

Bir sektörün üretimde bulunurken diğer sektörlerden ne kadar girdi temin ettiği ve bu girdiler sonucunda ulaşılan toplam üretim miktarı; ürettiği çıktının ne kadarının diğer sektörler için girdi olarak kullanıldığını ve bunun sonucunda oluşan toplam tüketim miktarını analiz etme mantığına dayanmaktadır. Bu yönü ile de sektörün yarattığı ekonomiyi diğer sektörleri hesaba katarak değerlendirme imkânı vermektedir. Bu değerlendirmede bir sektörün diğer sektörlerle alım-satım ilişkisi, yarattığı katma değer (işgücü ödemeleri vb.) ve nihai tüketici ile ilişkisi ortaya çıkarılmaya çalışılır (Unur, 2004:131). Buna ek olarak, bir bölgede gerçekleşen sektörel üretim tüketim ilişkileri diğer bir bölge ile de yine GÇ tabloları üzerinden kıyaslanabilmektedir (Shinichi ve Shaowei, 2003:1-3).

Sektörler arası ilişkileri ve genel ekonomi üzerindeki etkileri inceleme imkânı tanıyan GÇ analizi, ilişkili olduğu alt sektörler ve diğer endüstrilerin çokluğu ile dikkat çeken turizm endüstrisine yönelik ekonomik çalışmalarda sıklıkla tercih edilen bir yöntem olarak dikkat çekmektedir. Turizmin ekonomik etkilerini GÇ 
analizi ile ortaya koymaya çalışan Surugiu (2009), söz konusu tekniği; bir endüstri ya da sektördeki ürünün nihai talebine iliş̧kin değişikliklerin yayılmacı etkilerini ölçmenin standart bir yöntemi olarak açıklamaktadır. Bir sektörde yapılan üretim diğer birçok sektörden elde edilen girdilerle gerçekleşmektedir. Bu girdilerin bir kısmı diğer sektörlerin ürettiği hammadde, yarı-mamul veya mamul (hizmetler dâhil) iken bir kısmı da hane halkından ve devletten elde edilen girdilerdir. Bu bileşenlerle üretilen ürünler de yine diğer sektörlere veya hane halkı ve devlete girdi olacak şekilde satılmaktadır (Kayacan, 2007). Bu durumda GÇ analizi bir sektörün ülke ekonomisine katkısını bu karşılıklı ilişkiyi sistematik şekilde açmak suretiyle incelemektedir. Bu analiz ekonominin farklı bölümlerinin karşılıklı ilişkilerini ürettikleri katma değeri de hesaba katarak ve yarattıkları toplam üretim ve tüketim üzerinden analiz etmektedir.

GÇ analizinin öncüsü olarak görülen Leontief (1986), 'Input Output Economics' adlı eserinde GÇ’yı karmaşık bir ekonomik sistem içinde yer alan çeşitli sektörler arasındaki ilişkileri sayısallaştıran bir ekonomik yöntem olarak tanımlamıştır. Leontief, analize konu olacak ekonomik sistemin bütün dünyayı içine alacak kadar geniş ya da sadece bir işletmeyi konu alacak kadar dar olabileceğinin altını çizmektedir. Tüm durumlarda sistemin temelde aynı olduğunu belirten yazar, her bir sektörün üretim süreci ve yapısının; kullanılan girdiler ve üretilen çıktılar arasındaki ilişkileri sayısallaştırarak ifade eden yapısal katsayıların uygun bir vektör ile temsil edilmesi şeklinde özetlemektedir. Sektörler arası karşılıklı bağımlılık; üretilen ve kullanılan her bir mal veya hizmete ilişkin toplam girdi ve çıktı için oluşturulan bir takım doğrusal denklemlerle tanımlanmaktadır. Sistemin bütününe ilişkin teknik yapı ise, bütün sektörlere ait girdi ve çıktıların katsayılarının yer aldığı bir matriste kısaca gösterilmektedir. Bu aynı zamanda denge denklemlerine dayanan parametre setlerini de içermektedir (Leontief, 1986:19).

\section{Türkiye Turizm Sektörünün GÇ Analizi İle Değerlendirilmesi}

GÇ analizi diğer tüm sektörler gibi turizmin de ekonomi içindeki yeri ve etkilerini anlamada sıklıkla kullanılmaktadır. Unur, çalışmasında (2004) GÇ analizini çarpan analizi ile birlikte turizmin ikincil ekonomik etkilerini ölçmede kullanılan bir analiz olarak ele almıştır. Araştırmacıya göre bu yöntem zaman ve para maliyetinin daha fazla olmasına karşın daha geniş veri kullanılarak sektörlerin karşılıklı ilişkisine odaklandığı için daha gerçekçi sonuçlar üretmekte ve esnek kullanım olanağı ile daha tercih edilir olmaktadır. Analizin kullanılmasında her ülke için sektörel girdi ve tüketimleri ortaya koyan arz ve kullanım tabloları ile bunlara dayanılarak hazırlanan GÇ tabloları temel alınmaktadır. Türkiye'de Türkiye İstatistik Kurumu (TÜIK) tarafindan belli yıllarda yayınlanan GÇ tabloları analizlerde temel alınmaktadır. En son 2002 yılında yapılan GÇ analiz tablosu ilgili yazında mevcuttur.

TUIKK sektörlerarası girdi-çıktı istatistiklerinin oluşturulmasında baz aldığı sektör yapıları/gruplarını belirlerken turizm adında tek bir yapıdan değil turizm kapsamında farklı işletmelerin yer aldığı farklı sektörler üzerinden değerlendirme yapmaktadır. Buna bağlı olarak turizm sektörü seyahat, konaklama ve yeme-içmeyle ilgili alanlar olarak üç boyutta GÇ tablolarında yer almaktadır. Turizmle ilgili yapılacak değerlendirmelerde TUIK tarafından 2002 yılı için hazırlanan veri setinde "oteller ve lokantalar", "destekleyici ve yardımcı ulaştırma faaliyetleri; seyahat acentelerinin faaliyetleri" ve "Eğlence, dinlenme, kültür ve sporla ilgili faaliyetler" alanları ele alınmaktadır.

\subsection{Ara Girdi Oranı (Geriye Bağlantı)}

Belli bir sektörde üretimde kullanılan ara girdilerin toplam girdi miktarına oranıdır. Diğer bir ifadeyle bir sektörün diğer sektörlerden ne oranda girdi temin ettiğini ve bu yolla diğer sektörlere ne katkı sağaldığını ifade eder. Özetle, sektörün toplam girdi miktarının sektörel üretim miktarına oranıdır ve aşağıdaki formülle ifade edilir;

$$
F_{j}=\frac{\sum_{i=1}^{n} x_{i j}}{\sum_{i=1}^{n} x_{i j}+D_{j}+N_{j}}(j=1,2, \ldots, n)
$$

Formülde; $F_{j}$ sektörün belli bir dönem içinde diğer sektörlerden elde ettiği ara girdileri miktarını $; D_{j}$ sektörel toplam aşınma payını; $N_{j}$ ise sektörün yarattığı katma değeri ifade etmektedir. Turizm sektörü için bu formül ele alındığında şu rakamsal sonuca ulaşılmaktadır:

$$
F_{j}=18575195 / 35594191=\mathbf{0 , 5 2 1}
$$

Bu rakam turizmde (1) birimlik üretim için yaklaşık $(0,52)$ birimlik girdi sağlanması gerektiğini ortaya koymaktadır. Geriye bağlantı katsayısı her bir sektörün turizm üretimine katkısını hesap etmeye de olanak sağlamaktadır. Üretilen bir teknik katsayı ile ekonomiye sektörel katkıyı ortaya koyabilmek adına her bir sektörün bir diğeri ile etkileşimini de belirlemek mümkündür. Her sütun için ayrıca hesaplanan bu teknik katsayılar belirli bir sektörde 1 birim üretim artışı sağlamak için diğer sektörlerden ne oranda girdi alınması gerektiğini ortaya koymaktadır (Dilber, 2007:215). Teknik katsayı formülü şu şekildedir: 


$$
r_{i j}=\frac{x_{i j}}{\sum_{i=1}^{n} x_{i j}}(i, j=1,2, \ldots, n)
$$

Yukarıdaki formülde $r_{i j} \mathrm{i}$ ve $\mathrm{j}$ sektörleri arasındaki karşılıklı ilişki oranını ifade etmektedir. Bu oranının büyüklüğü "j” sektörünün üretim sürecinde “i” sektöründen daha fazla oranda girdi temin ettiğini göstermektedir. Düşük bir ilişki oranı iki sektör arasında yüzeysel ilişkiyi ortaya koyabilir. Sektörün turizme girdi sağladığı miktarın turizmde toplam üretim girdisine oranı sektörün katkı katsayısını ortaya koymaktadır. Bu bakımdan Tablo 1'de (ilgili tabloya ilişkin açıklamalar Tablo 2'de verilmiştir) yer alan değerlerden hareketle en yüksek katkıların \%17 ile destekleyici ve yardımcı ulaştırma faaliyetleri; seyahat acenteleri faaliyetlerinden geldiği, bir sonraki en yüksek katkının ise \%13 ile gıda ürünleri ve içecek imalatı sektörünce sağlandığı görülmektedir. Geriye bağlantı katsayısı (+) katma değer = 1'dir (Dang vd., 2011:92). Bu yaklaşımla turizm sektörünün yarattığı katma değer $\% 48$ oranındadır.

\subsection{Ara Tüketim Talebinin Analizi (ileriye bağlantı)}

Ara talep turizmin diğer sektörlere yönelik sunumunu ifade eden ve diğer sektörlerin turizmden talebini ortaya koyan miktarın toplam çıktıya oranıdır. Bir sektörün diğer sektörlere katkı sunma düzeyini ortaya koymaktadır. Sektörel olarak üretilen ve sunulan ara ürünler toplamının üretim miktarına oranıdır ve aşağıdaki formülle açıklanır.

$$
G_{i}=\frac{\sum_{j=1}^{n} x_{i j}}{\sum_{j=1}^{n} x_{i j}+Y_{i}}(i=1,2, \ldots, n)
$$

$\mathrm{G}_{\mathrm{i}}$ turizme yönelik ara talep oranını, $X_{i j}$ turizme yönelik diğer sektörlerden gelen talebi, $X_{i j}+Y_{i}$ ise turizme yönelik nihai talebi ifade etmektedir. Bu kapsamda turizme yönelik ara talep oranı şu şekilde hesaplanabilir:

$$
G_{i}=14871050 / 35594191=0,41
$$

$\mathrm{Bu}$ sonuç bize turizm sektörü ürettiğinin \%41'lik kısmını diğer sektörlere girdi olarak sunduğunu göstermektedir. Başka bir ifadeyle turizmdeki 1 birimlik üretim artışının diğer sektörlerin üretimine 0,41 birimlik bir katkı sağlayacağını ortaya koymaktadır. Bunun yanında turizmin her bir sektöre sunduğu katkının turizmin toplam üretim miktarına oranı da sektörler bazında yarattığı katkının katsayısını sunmaktadır. Tablo 1 'de bu katkının en yüksek olarak \%25 oranında kara taşımacılığı alanına, \%23'lük oranla ikinci en yüksek katkının destekleyici ve yardımcı ulaştırma ve seyahat acentalarının faaliyetlerine ve \%6'lık bir oranda sigorta ve emekli fonları hariç, mali aracı kuruluş faaliyetlerine sağlandığı anlaşılmaktadır.

\begin{tabular}{|c|c|c|c|c|c|}
\hline I & Satırlar (milyar TL) & İB Kats. & GB Kats. & Sütunlar (milyar TL) & II \\
\hline 1 & 3775483 & 0,25 & 0,17 & 3234498 & $\mathrm{~A}$ \\
\hline 2 & 3511946 & 0,23 & 0,13 & 2549824 & $\mathrm{~B}$ \\
\hline 3 & 977386 & 0,06 & 0,09 & 1785563 & $\mathrm{C}$ \\
\hline 4 & 780855 & 0,05 & 0,06 & 1281788 & $\mathrm{D}$ \\
\hline 5 & 694521 & 0,04 & 0,04 & 839226 & $\mathrm{E}$ \\
\hline 6 & 607551 & 0,04 & 0,04 & 826527 & $\mathrm{~F}$ \\
\hline 7 & 497804 & 0,03 & 0,03 & 698095 & $\mathrm{G}$ \\
\hline 8 & 391250 & 0,02 & 0,03 & 599481 & $\mathrm{H}$ \\
\hline 9 & 368847 & 0,02 & 0,03 & 583167 & $\mathrm{I}$ \\
\hline 10 & 339943 & 0,02 & 0,02 & 548665 & $\mathrm{~J}$ \\
\hline 11 & 327152 & 0,02 & 0,02 & 527316 & $\mathrm{~K}$ \\
\hline 12 & 247311 & 0,01 & 0,02 & 476276 & $\mathrm{~L}$ \\
\hline 13 & 222959 & 0,01 & 0,02 & 385087 & $\mathrm{M}$ \\
\hline 14 & 205585 & 0,01 & 0,02 & 376055 & $\mathrm{~N}$ \\
\hline 15 & 178642 & 0,01 & 0,01 & 347329 & $\mathrm{O}$ \\
\hline 16 & 175085 & 0,01 & 0,01 & 331816 & $\mathrm{P}$ \\
\hline 17 & 1568720 & 0,10 & 0,13 & 2532532 & Top. ${ }^{*}$ \\
\hline Top & 14871049 & 0,41 & 0,52 & 18575195 & \\
\hline & & $* U ̈ r u ̈ n$ & & & \\
\hline
\end{tabular}

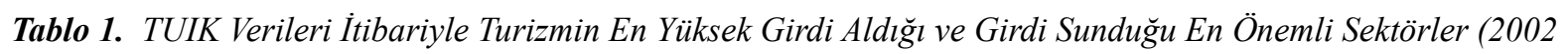
verileri ile)

$\mathrm{Bu}$ rakamlar turizmin ülke ekonomisine katkısının örneğin, \%25'lik kısmının kara taşımacığına girdi sunabildiğini açıklamaktadır. Bu oranın sıfıra eşit olması iki sektör arasında doğrudan bir ilişki olmadığını göstermektedir. Ara tüketim oranının yüksek olması sektörün ekonomi içerisindeki diğer sektörleri destekleme 
gücünü ortaya koyarken, ara girdi oranının düşük olması sektörce yaratılan katma değerin yüksekliğini ortaya koymaktadır.

\begin{tabular}{|c|c|c|c|}
\hline I & TURİZMİN GİRDİ SUNDUĞU SEKTÖRLER & II & TURİZME GİRDİ SUNAN SEKTÖRLER \\
\hline 1 & Kara taşımacılığı ve boru hattıyla taşımacılık & $\mathrm{A}$ & Destekleyici ve Yar. Ulaşt. F.; seyahat Acent. Faal. \\
\hline 2 & Destekleyici ve yar. Ulaşt. F.; seyahat Acent. Faal. & $\mathrm{B}$ & Gıda ürünleri ve içecek imalatı \\
\hline 3 & Sigorta ve emkli. Fon. hariç, mali aracı kur. Faal. & $\mathrm{C}$ & Kara taşımacılığı ve boru hattıyla taşımacılık \\
\hline 4 & Eğlence, Dinl., kültür ve sporla ilgili faaliyetler & $\mathrm{D}$ & Tarım, avcılık ve ilgili hizmet faaliyetleri \\
\hline 5 & Havayolu taşımacılığı & $\mathrm{E}$ & Diğer iş faaliyetleri \\
\hline 6 & $\begin{array}{l}\text { Motorlu taşı1lar ve motosikletler dişında kalan toptan } \\
\text { ticaret ve ticaret komisyonculuğu }\end{array}$ & $\mathrm{F}$ & Sigorta ve Emkli. Fon. hariç, mali aracı kur. Faal. \\
\hline 7 & Suyolu taşımacılı̆̆ & $\mathrm{G}$ & Eğlence, Dinl., kültür ve sporla ilgili faaliyetler \\
\hline 8 & Posta ve telekomünikasyon & $\mathrm{H}$ & Gayrimenkul faaliyetleri \\
\hline 9 & Gayrimenkul faaliyetleri & I & Oteller ve lokantalar \\
\hline 10 & Kamu yönetimi ve savunma, zorunlu sosyal güvenlik & $\mathrm{J}$ & Elektrik, gaz, buhar ve sıcak su üretimi ve dağıtımı \\
\hline 11 & Sağlık işleri ve sosyal hizmetler & $\mathrm{K}$ & $\begin{array}{l}\text { Motorlu taşıtlar ve motosikletler dışında kalan } \\
\text { perakende ticaret, kişisel ve ev eşyalarının tamiri }\end{array}$ \\
\hline 12 & $\begin{array}{l}\text { Motorlu taşıtlar ve motosikletler dışında kalan } \\
\text { perakende ticaret, kişisel ve ev eşyalarının tamiri }\end{array}$ & $\mathrm{L}$ & $\begin{array}{l}\text { Motorlu taşıtlar ve motosikletler dişında kalan toptan } \\
\text { ticaret ve ticaret komisyonculuğu }\end{array}$ \\
\hline 13 & Oteller ve lokantalar & $\mathrm{M}$ & Kimyasal madde ve ürünlerin imalatı \\
\hline 14 & $\begin{array}{l}\text { Motorlu taşıt. ve motosikletlerin satış, bakımı ve } \\
\text { onarımı; motorlu taşıt yakıtının perakende satış1 }\end{array}$ & $\mathrm{N}$ & $\begin{array}{l}\text { Kok kömürü, rafine edilmiş petrol ürünleri ve nükleer } \\
\text { yakıt imalatı }\end{array}$ \\
\hline 15 & Tekstil ürünleri imalatı & $\mathrm{O}$ & Posta ve telekomünikasyon \\
\hline 16 & Diğer iş faaliyetler & $\mathrm{P}$ & $\begin{array}{l}\text { Motorlu taşı1t. ve motosikletlerin satış, bakımı ve } \\
\text { onarımı; motorlu taşı1t yakıtının perakende satış1 }\end{array}$ \\
\hline 17 & Diğer Sektörler & $\mathrm{R}$ & Diğer Sektörler \\
\hline
\end{tabular}

Tablo 2. Tablo 1'de yer alan kısaltmalara ilişkin açıklamalar

GÇ analizlerinde kullanılan A matrisi, sektördeki bir birim çıktının üretimi için gerekli olan doğrudan girdileri vermektedir. "Leontief Ters Matrisi” olarak literatüre giren (I-A) ${ }^{\lrcorner}$; doğrudan ve dolaylı gereksinimleri vermektedir. Ters matrisin sütunlarının toplamı; GÇ analizine dahil olan her bir sektöre ait çıktı katsayılarının toplamını vermektedir. Çıktı katsayıları her bir sektörün karşılıklı yapısal bağımlılığını veya her sektörün ekonominin kalanına ilişskin geriye dönük bağlantılarını göstermektedir (UN, 1990:7). Diğer bir ifadeyle; belli bir mala ilişkin talebin bütün sektörler üzerindeki etkisini anlamak için, ters matristeki söz konusu malın üreticisi olan sektörün sütun toplamına bakılmalıdır. Nihai taleplerin bir sektör üzerindeki etkisini belirleyebilmek için de, ilgili sektörün ters matristeki satır toplamlarının değerleri dikkate alınmalıdır (Uyar, 2006, s.10).

Turizmde GÇ analizleri için Birleşmiş Milletler (UN) adına hazırlanılan kitapta, standart GÇ tekniği; uluslararası turizm harcamalarının ekonomik etkilerinin ölçümü için göreceli olarak basit ve kolay anlaşılır oluşu ve gereken verilerin çoğu ülkede ulaşılabilir olmasından dolayı önerilmektedir. Gerekli verilere ulaşılabilmesi halinde ise genişletilmiş GÇ modeli ile turizm endüstrisinin aşağıdaki değişkenler üzerinde yarattığı ekonomik etkilerin ölçülmesi önerilmektedir (UN, 1990:2-3):

a) Ödemeler dengesi

b) Gayri safi yurtiçi hâsıla (sektörel ve bölgesel bazda gelir dağılımını içeren)

c) İstihdam

d) Devlet bütçesi ve

e) İstikrar politikasıdır (Yatırım politikası, vergi politikası vs.).

Teoride GÇ analizlerinin dayandığı birkaç temel ilke bulunmaktadır ki bunların ilki, ekonominin " $N$ ” sayıda farklı mal üreten "N" sayıda içsel sektörden; buna karşın bir adet dışsal sektörden oluşmasıdır (nihai talep). İkincisi, her malın sadece bir üretim sektörü tarafından üretilmesidir. Üçüncü ilke, sektörün oluşturduğu çıtı seviyesi ile girdiler arasında sabit ve doğrusal bir ilişki olmasıdır. Dışsal bir ekonomi yada oransız maliyetleri göz ardı ederek, ölçeğe göre sabit getirinin olması ve ara girdiler için ikame olmaması ise diğer ilkelerdir (Kweka ve diğ.,2001:5). Hara (2008:84) ise; GÇ analizlerinde, arz kısıtı gibi bir varsayımın olmayışı, ölçeğe sabit getirinin olması, sabit bir girdi yapısının bulunması ve sektör çıtılarının homojen olmasını bu tekniğin yapısal kisitları olarak ifade etmektedir.

Leontief'in ardından yapılan çok sayıda çalışma ve getirilen eleştiriler, GÇ analiz tekniğini geliştirirken aynı zamanda genişletilmesini sağlamıştır. Öyle ki başlangıçta durağan ve kapalı bir model olan Leontief Modeli, ilerleyen yıllarda zaman boyutunu da dahil eden dinamik girdi çıktı modellerine ve hesaplanabilir genel denge modellerine (HGDM) (CGM) doğru gelişmiştir (Uyar, 2006:3). 


\section{Hesaplanabilir Genel Denge Modeli (HGDM) (Computable General Equilibrium- CGE): Yeni Bir Yaklaşım}

Kaynağını Girdi-Çıktı (GÇ) yönteminden alan Hesaplanabilir Genel Denge Modeli (HGDM); GÇ tekniğinin yapısındaki bazı kısıtlamalardan dolayı geliştirilerek ortaya çıkarılmıştır. Dwyer ve Spurr (2010:4) çalışmalarında, GÇ analizlerinin yerine HGDM'lerin kullanılmaya başlamasını bir paradigma değişimi olarak yorumlamaktadırlar. Bu teknik ekonomide yaşanabilecek olası değişikliklerin dolaylı veya dolaysız ilgili tüm sektörler üzerindeki etkilerini ele alır ve üreticinin kar, tüketicinin fayda maksimizasyonu yaptığını kabul eder. HGDM'lerin mal, hizmetler ve üretim faktörlerine ilişkin piyasa serilerinden oluştuğunu ifade eden Blake ve arkadaşları (2001), her piyasa, sektör ya da hanenin dışsal değişimlere karşı nasıl tepki vereceğini belirleyen kendi ekonomik kuralları olduğunu belirtmektedirler. Üretim, tüketim, ticaret ve kamu faaliyetlerini şekillendiren bazı denklem sistemlerinden oluşan HGDM; kaynak kısıtlarını ortaya koyarken yeniden dağılımına olanak sağlamakta; devlet politikaları ve ekonomideki yapısal değişikliklerden etkilenen fiyat ve gelir ile talebi de göz önünde bulundurarak GÇ modelindeki bazı sınırlamaları ortadan kaldırmaktadır (Dwyer ve Spurr, 2010:4, Dwyer ve diğ., 2005:9, Ennew, 2003:12). HGDM pek çok farklı alanda gerçek ekonomik sorunlara 1ş1k tutabilmekte ve ilgili politikaları (Markusen'in 2002) formüle edebilmektedir. Bu modern iktisat teorisi (Starr, 1997) ile reel ekonomiler ile başa çıkmak için yeni bir bakış açısı sunulmuş ve sağlam bir mikro ekonomik temele (Sugiyarto 2000) dayanan özelliğiyle karmaşık görünen ekonomik ilişkilerin analizi yapılabilmektedir.

GÇ Modelleri mal ve hizmetler için ara talepleri ortaya koyarken, bunların nihai talep olabilmesi için tüketiciler, devlet, yatırımlar ve ihracatlar tarafından karşılanması gerekmektedir. $\mathrm{Bu}$ nedenle girdi-çıktı modelleri nihai talep üzerindeki dolaylı etkileri hesaplamaktadırlar. HGD modelleri ise Şekil 1'de görüldüğü gibi faktör ve döviz piyasalarını da dahil etmekte; sadece dolaylı değil; uyarılmış etkileri de içererek daha kapsamlı ve objektif analiz olanakları sunmaktadır (Blake ve diğ., 2001:5). HGD modelleri doğrusal optimizasyona dayanan GÇ modelleri ve makro ekonometrik modeller için tamamlayıcı bir alternatif niteliğindedir. GÇ modelleriyle HGD modelleri arasındaki temel farklılık HGD modellerinde fiyat mekanizmasının içselleştirilmiş olmasıdır. GÇ modelleriyse fiyatların sabit varsayıldığı talep yönlü modellerdir.

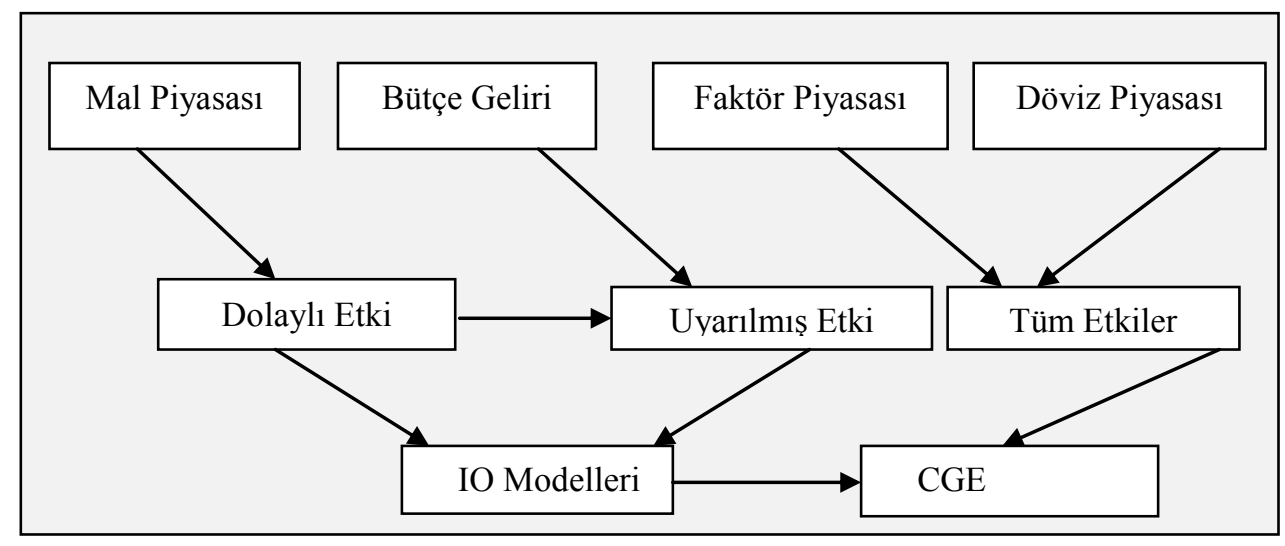

Şekil 1. Genel denge Modeli yapısı IO ve CGE Modelleri. Kaynak: Blake ve diğ. (2001:5)

Ekonometrik modellerle HGD modelleri arasındaki temel farklılık ise HGD modellerinin ekonomik yapıyı bir bütün olarak ele almasıdır (Erten, 2009:44). Ekonomideki bütün ilişkileri eş anlı olarak çözümleyebilen HGD, modellerin ihtiyaç duyduğu veri altyapısının oluşturulmasıdır (Erten, 2009; 33, Pyatt ve Round, 1985;17) Geleneksel olarak, bu tür ekonomik hesap ve hesaplamalara ilişkin analizler GÇ çarpanlarını kullanan uydu hesaplarına dayanmaktadır (Butcher ve diğ, 1998).

Turizm talebindeki değişimlerin devlet bütçesi, gayri safi yurtiçi hasıla, istihdam gibi makroekonomik değişkenler üzerindeki etkilerini inceleme imkanı sağlayan HGDM, akademik araştırmaların yanında Dünya Bankası, OECD, Dünya Ticaret Örgütü gibi kuruluşlarca analiz tekniği olarak kullanılmaktadır (Sinclair ve diğ., 2005:2). HGDM, Turizm Politikası ve Tahmin Modellerine (TPF); Turizm Uydu Hesapları (Tourism Satallite Accounts) verileri eklenerek oluşturulmuş ve turizm ekonomisi için alternatif bir model haline gelmiştir (Blake ve diğ, 2001:3). Leif Johansen (1960) tarafından geliştirildiği bilinen HGDM'ye, turizm ekonomisine yönelik çalışmalarda sıklıkla başvurulmaktadır. 1990'ların sonlarından itibaren, HGDM geliştirilmiş ve ilgili soruları yanıtlamak için özellikle Avustralya ve Hawaii turizm ile ilgili çalışmalarda kullanılmıştır (Zhou ve diğ., 1997; Adams ve Parmenter 1995). Ayrica model; turizmin makro ekonomik etkileri (Blake, 2000; Blake ve Sinclair, 2004; Sinclair ve diğ.2005; Dwyer ve diğ.2005; Slocum, 2006; Laffargue,2009 ); savaş, iklim değişiklikleri gibi sıra dışı olayları içeren turizm krizleri (Yang ve Chen, 2009; Currie ve diğ. 2004, Berrittella ve diğg.2004); turizm-büyüme ilişkisi (Brida ve diğ. 2008; Kweka, 2004) gibi farklı alanlarda kullanılabilmektedir. Ancak Türkiye'de özellikle bu alanda yapılmış yeterli inceleme yoktur. 


\section{Sonuç}

Turizm sektörünün ortaya çıkardığı gelir, ödemeler gücü üzerindeki etkisi ve dünya ticaretindeki önemli yeri gibi nedenler, bu sektör ile bağlantılı olduğu diğer sektörlerin ekonomik boyutunun incelenmesini, tartışılmasını ve yapılacak planlamalarda dikkate alınmasını zorunlu kılmaktadır. Bu zorunluluk başta küresel olmak üzere ulusal ve bölgesel katma değer hesaplamalarının yapılmasına da öncülük etmektedir.

Geliştirilen ilk modellerden birisi olan GÇ analizi, uluslararası turizm kuruluşları ile ülke ekonomistleri tarafından uzun yıllar kullanılagelmiştir. Modelde özellikle katsayılar üzerinden hareketle katma değer rakamlarının ele alınması ve bu rakamlarla sektörler arası ilişkilerin boyutunun tahmin edilmesi söz konusudur. Model, sektörlerin birbirlerinden sağladığı girdi ve çıktıyı ortaya koymaktadır. Türkiye'de de uzun yıllardır kullanılmasına rağmen Türkiye İstatistik Kurumu tarafindan en son yapılan değerlendirme 2002 yılına aittir. GÇ analizlerinde bir takım sınırlamalar söz konusudur. Örneğin genel ekonomi politikalarında olası değişiklikler, fiyat veya talepteki oynamalar sistem tarafindan ihmal edilmektedir. Döviz kurlarında ortaya çıkan dalgalanmalar da sistem tarafından hesaba alınmamaktadır. Dolayısıyla ithal ürünlere dayalı diğer bir sektördeki ilişki boyutu olası döviz kuru değişikliklerinde yeniden değerlendirilmek zorundadır. Bu durum GÇ analizi tarafından gerçekleştirilemez.

İlerleyen y1llarda alternatif bir yaklaşım olarak öne sürülen Hesaplanabilir Genel Denge Modelleri ortaya sürülmüştür. 1960'lı yıllarda başlayan bu akım özellikle son yıllarda uluslararası hesaplamalarda ve ilgili yazında önemli bir yer tutmaktadır. Bu model, GÇ’nin sınırlılıklarını ortadan kaldırmaya ve değişmelerin diğer sektörlerarası ilişkilerde ve genel ekonomideki yansımalarını da formüle etmeye çalışmaktadır. Gelir, fiyat ve talep gibi değişkenlerde meydana gelebilecek azalış veya artışların etkilerinin diğer bağımlı sektörler üzerindeki etkisini de hesaba almaktadır. Dolayısıyla elde edilen bilgilerin daha gerçekçi ve güncel durumu yansıtması söz konusudur. Türkiye'de ilgili resmi kurumlar açısından ve akademisyenler tarafından turizme yönelik bir analiz çalışmasına rastlanamamıştır. Bununla birlikte ilgili yerli yazında farklı sektörlere ilişkin yapılan araştırmalar bulunmaktadir.

Gelecekte yapılacak genel değerlendirmeler ve akademik çalışmalarda HGDM kullanılması, hem bu modelin kullanımının yaygınlaşmasını hem de yeni açılımlar ortaya koymasını kolaylaştıracaktır.

\section{Kaynaklar}

- Adams ve Parmenter, 1995. An Applied General Equilibrium analysis of the economic effects of tourism in a quite small, quite open economy, Applied Economics, 27, ss. 985-994.

- Berrittela, Bigano, Roson ve Tol, 2004. A General Equilibrium Analysis of Climate Change Impacts on Tourism, http://papers.ssrn.com/sol3/papers.cfm?abstract_id=609742, ET.”15.07.2011.

- $\quad$ Blake, 2000. The Economic Effects of Tourism in Spain, TTRI Discussion Paper, 2.

- Blake ve Sinclair, 2004. The Economic Impact of Tourism in Cyprus: Computable General Equilibrium Analysis, http://www.nottingham.ac.uk/ttri/industryreports/ CyprusReport. PDF, ET.

- Blake, Durbarry, Sinclair ve Sugiyarto, 2001. Modelling Tourism and Travel using Tourism Satellite Accounts and Tourism Policy and Forecasting Models,

http://fama2.us.es:8080/turismo/turismonet1/economia\%20del\%20turismo/economia\%20del\%20turismo/modelling\%20 tourism\%20using\%20satellite\%20account\%20tourism.pdf, ET.

- Bocutoglu, 1990. Endüstrilerarası İktisat, Teori ve Türkiye Uygulamaları, KTÜ, Trabzon.

- $\quad$ Brida, Pereyra, Devesa; ve Aguirre, 2008. An Evaluation of the Contribution of Tourism on Economic Growth: The Case of Spain, France, Italy, U.K. and USA, Cuadernos de Turismo, 22, s. 35-46.

- Briassoulis, 1991. Methodological Issues: Tourism Input-Output Analysis, Annals of Tourism Research, 18,485-494.

- Butcher, Fairweather veSimmons. 1998. The Economic Impact of Tourism on Kaikoura, Tourism Recreation Research and Education Centre (TRREC).

- Crompton, Lee veShuster. 2001. A guide for undertakingeconomic impact studies: The springfest example, Journal of Travel Research, 40, ss. 79-87.

- Dang, Sifeng ve Wang, 2011. Optimization of Regional Industrial Structures and Applications, CRC Press.

- Dilber, 2007. Turizm Sektörünün Türkiye Ekonomisi Üzerindeki Etkisinin Girdi-Çıktı Tablosu Yardımıyla Değerlendirilmesi, Celal Bayar Üniversitesi İ̈BF Yönetim ve Ekonomi Dergisi, 14, 205-220.

- Dwyer ve Spurr, 2010. Tourism Economics Summary, Sustainable Tourism Cooperative Research Centre, Gold Coast, Qld, Australia.

- Dwyer, Forsyth, Spurr ve Ho, .2005. Economic Impacts and Benefits of Tourism in Australia : A General Equilibrium Approach, Sustainable Tourism Cooperative Research Centre, Gold Coast, Qld, Australia.

- Ennew, 2003. Understanding the Economic Impact of Tourism, http://fama2.us.es:8080/turismo/turismonet1/economia\%20del\%20turismo/analisis\%20del\%20turismo/understanding $\% 2$ 0the\%20economic\%20impact\%20of\%20tourism.pdf

- Ersungur ve Kızıltan, 2008. Türk Ekonomisinde Sektörlerarası Yapısal Bağınlaşma: Girdi-Çıktı Yöntemiyle Bir 
Uygulama, İktisadi ve İdari Bilimler Dergisi, 22, 2, ss.17-31.

- $\quad$ Erten. 2009. Türkiye için sektörel sosyal hesaplar matrisi üretme yöntemi ve istihdam üzerine bir hesaplanabilir genel denge modeli uygulamas1, DPT uzmanlık tezleri, 2805, Ankara

- $\quad$ Fletcher, 1989. Input-Output Analysis and Tourism Impact Studies”, Annals of Tourism Research, 16, 514-529.

- Frechtling ve Horvath, 1999. Estimating the Multiplier Effects of Tourism Expenditures on a Local Economy through a Regional Input-Output Model, Journal of Travel Research 37(May):324-332.

- Hara, 2008. Quantitative Tourism Industry Analysis: Introduction to Input-Output, Social Accounting Matrix Modeling, and Tourism Satellite Accounts, Elsevier, Oxford.

- Johnson ve Moore. 1993. Tourism Impact Estimation, Annals of Tourism Research, 20, 279-288.

- Johansen, 1960. A Multi-Sector Study of Economic Growth, North-Holland Pub. Co., Amsterdam.

- Jones ve Munday, 1990. Evaluating the Economic Benefits from Tourism Spending through Input-Output Frameworks: Issues and Cases, Annals of Tourism Research, 17, ss. 249-269.

- Kayacan, 2007, Ulusal Ekonomide Ormancılık Sektörü: Tarımsal Girdi-Çıktı Analizinin Bulguları, Verimlilik Dergisi, 1.

- Kweka, 2004. Tourism and The Economy of Tanzania: A CGE Analysis, CSAE Conference on Growth, Poverty Reduction and Human Development in Africa, 21 - 22 March 2004, Oxford, UK.

- Kweka,. Morrisey, Blake, 2001. Is Tourism a Key Sector In Tanzania? Input-Output Analysis of Income, Output, Employment and Tax Revenue, http://www.nottingham.ac.uk/ttri/discussion/2001_1.pdf, ET.13.07.2011.

- Laffargue, 2009. The economic and social effects of tourism activities and tourism policies. A survey of the computable general equilibrium (CGE) models approach http://www.cepremap.ens.fr/depot/docweb/docweb0905.pdf, ET.15.07.2011.

- $\quad$ Leontief, 1986. Input-Output Economics, Oxford University Press, Oxford.

- Markusen, 2002. General-Equilibrium Modelling Using GAMS and MPS/GE: Some Basics.

- Mukhopadhyay, 1980. Estimating Impact of Tourism through Input-Output analysis, International Journal of Tourism Management, 1, ss.99-108.

- $\quad$ Öztürk,. 1980. Yönetici Kararlarında Leontief Modeli, Bursa .T..A. Yayını, No: 41, Ankara

- Ruíz. 2006. Small island tourism, Tourism and the economy of Puerto Rico: an input-output approach, Ecological Economics, 56, 1, ss. 28-48 Shinichi ve Shaowei. 2003. How to Construct the Interregional Input-Output Table, İçinde, Shinichi, Ichimura ve Wang, Hui-Jiong (Editor), Interregional Input-Output Analysis of the Chinese Economy, World Scientific Publication.

- Sinclair, Blake ve Gooroochurn, 2005 Modelling Tourism Impacts On Small Island Economies: Evidence From Cyprus, Malta and Mauritius, http:/www.irfd.org/events/wfsids/virtual/papers/sids_tsinclairetal.pdf, ET.15.11.2011.

- Slocum, 2006. The Impact of Tourism on the Economy of Nevada: A Tourism Satellite Account and Computable General Equilibrium Model, Yüksek Lisans Tezi, Nevada Üniversitesi, Reno.

- Starr, 1997. General Equilibrium Theory: An Introduction, Cambridge: Cambridge University Press.

- Sugiyarto, 2000. The Economic Effects and Distributional Implications of Economic Reform Policy on the Indonesian Economy: A CGE Approach, Thesis, Nottingham University.

- Surugio, 2009. The Economic Impact of Tourism. An Input-Output Analysis, Romanian Journal of Economics, 2009(XIX), 29, 2(38), s. 142-161.

- Pomeroy, Uysal ve Lamberte, 1988. An input-output analysis of South Carolina's economy: With special reference to coastal tourism and recreation, Leisure Sciences: An Interdisciplinary Journal, 4, ss. $281-288$.

- Tyrrell ve Johnston, 2001. A framework for assessing direct economic impacts of tourist events: Distinguishing origins, destinations, and causes of expenditures, Journal of Travel Research, 40, 94-100.

- Unur, 2004. Turizmin Ekonomik Etkilerinin Ölçülmesi”, Dokuz Eylül Üniversitesi Sosyal Bilimler Enstitüsü Dergisi, 6(4), 114-142.

- UN (United Nations), 1990. Guidelines on Input-Output Analysis of Tourism, Newyork.

- Uyar, 2006. Türkiye'de Hizmetler Sektörünün Input-Output Yaklaşımıyla (1996 Yı1ı Üretici Fiyatlarıyla) Değerlendirilmesi, Akademik Bakış, Mayıs, 9.

- Vozikis ve Mescon, 1985. The economic impact of tourism at the port of Miami, Annals of Tourism Research, 12, ss.515-528.

- West ve Gamage, 2001. "Macro Effects of Tourism in Victoria, Australia: A Nonlinear Input-Output Approach, Journal of Travel Research, 40, 101-109.

- Yang ve Chen, 2009. A General Equilibrium Analysis of the Economic Impact of a Tourism Crisis: A Case Study of the SARS Epidemic In Taiwan, Journal of Policy Research in Tourism, Leisure and Events, 1, 1, , s. 37-60.

- Zhou, Yanagida, Chakravorty ve Leung, 1997. Estimating economic impacts from Tourism, Annals of Tourism Research, 24, ss.76-89. 


\title{
Marmara Bölgesinde Turizm Lisans Öğrencilerinin Konaklama Sektöründe Cinsiyete Göre Kariyer Düşünceleriyle İlgili Bir Araştırma
}

\author{
Burhanettin ZENGİN (Sakarya University, Turkey) \\ Lütfi Mustafa ŞEN (Sakarya University, Turkey) \\ Osman TAŞAR (Sakarya University, Turkey)
}

\section{A Study on Career Planning of Tourism Bachelor Degree Students in the Marmara Region}

\begin{abstract}
The aim of this study is in common with revealing meaningful differences between gender and making career and determining meaningful differences to choose department according to gender in situation working in hospitality managements after graduation of tourism students, the aim is also being analyzed whether having meaningful differences when choosing department according to gender and career thoughts due to differences between gender in Marmara Region Universities Tourism Undergraduate Students. Related with study; the study population was formed 3.729 tourism undergraduate students from Sakarya University, Çanakkale University Istanbul University Study 'sample was composed of 543 tourism bachelor students who were chosen with simple random method which was equal to $15 \%$ of population. In the study, the questionnaire way was chosen as a method of data collection.

Questionnaires were examined Undergraduate Tourism Students of Marmara's region important universities; Accumulated Data were analyzed to SPSS 15 package program. As a result of study; it wasn't found meaningful differences on department preferences in accounting department of tourism managements according to gender groups of tourism students linked with Mann-Whitney U test it was found meaningful differences in front office, housekeeping, food\&beverage, accounting, sales\&marketing, technical services, Security and Human Resources in Hospitality Managements according to gender of tourism students. Hence, Students Gender is an effective element for department preferences in hospitality managements. When being examined to averages, it could be understood that more women would prefer human resources than men, and more men would prefer to security department than women.
\end{abstract}

JEL Codes: J 24, J23

\section{Giriş}

Günümüzün hızla gelişen rekabet koşullarında işletmeler yeni ve modern yönetim şekillerini tercih etmektedirler. Özellikle insan faktörünün büyük yer tuttuğu, misafir-çalışan etkileşiminin en üst derecede olduğu konaklama işletmelerinde, her açıdan hedeflere ulaşmak için işgücü verimliliğine büyük önem verilmesi gerektiği tartışılmaz bir konudur (Mankan, 2007:140).

Türkiye'de ve çeşitli ülkelerde yapılan araştırmalar, turizm ve otelcilik sektöründe işgücü devir oranının yüksek, çalışanların iş tatmininin düşük, ücretlerin düşük fakat çalışma saatlerinin fazla olduğunu ortaya koymaktadır. Turizm ve otelcilik sektörünün yapısal sorunları olarak değerlendirilebilecek bu sorunların, yönetici adayı olarak eğitim alan öğrencileri de olumsuz etkilemesi şaşırtıcı bulunmamalıdır (Birdir, 2002:496). Turizm sektöründe emek yoğun ve dinamik bir çalışma ortamının bulunması çalışan faktörünü daha da ön plana çıkardığı söylenebilir. Bununla beraber, turizm ve daha özelde otel işletmelerinde çalışan faktöründen en etkin ve verimli bir şekilde faydalanabilmek, kariyer planlamasını ve bu kapsamda çalışanların kariyer değerleri ile kariyer yolu tercihlerini dikkate almayı gerektirmektedir. Bu kavramların analizi, işletmelere çalışanlarını daha iyi anlama, onların işletme ile ilişkilerini belirleyen etkenleri kontrol edebilme olanağı sunabilir (Türkay ve Eryılmaz, 2010:180). Bu yoldan çıkılarak, bu çalışmada turizm eğitimi alan öğrencilerin cinsiyet unsuru dikkate alınarak kariyer düşünceleri üzerine yapılması uygun görülmüştür.

\section{Literatür Araștırması}

Kariyer bir çalışanın tüm çalışma yaşamı boyunca yaptığı işlerden oluşur (Özgen ve diğ., 2002:179). Bir diğer tanımlama ise bireyin yaşamı boyunca üstlendiği bir takım görevle ilgili rolleri üzerinedir. Bu roller, bireysel gelişim, kendini aşma, işsizlik dönemi, başarısızlık, stajyer, öğrenci veya gönüllü olarak çalışma gibi bireyin olumlu ve olumsuz tüm aşamalarını kapsayan bir süreçtir (Patton ve Mcmahon, 1999:4). Kariyer adımlarını doğru şekilde atabilmek, bu adımları belli bir süreç içerisinde hangi zaman dilimi içerisinde neyin yapılacağına karar vererek yapmak kariyer planlaması olarak tanımlanmaktadır (Schreuder ve Theron, 1999: 4). Kariyer 
Yönetimi, çalışanların işlerinde ilerlemek, üst düzeylere gelmek istemeleri, aldıkları eğitim, zihinsel yetenekleri, kişilik özellikleri, kendilerini geliştirme düzeyleriyle yakından ilişkilidir. İyi bir Kariyer Yönetimi uygulanan organizasyonlarda kişiler bir süre sonra hangi statüde olacaklarını bilebilir veya tahmin edebilirler. Kişinin bunu bilmesi, onu işine ve kuruma bağlar, motivasyonunu sağlar (Kozak, 2004:73).

Otel işletmelerinde işgörenlerin niteliğini artırmak, örgütün verimliliğini sağlayacak diğer unsurları gerçekleştirmek, personel devrini ve maliyetleri azaltmak, aidiyet duygusunu geliştirmek ve modern yönetim yaklaşımlarını uygulayabilmek için kariyer planlamasına ihtiyaç bulunmaktadır. Mullins ve Davies, otel yönetimindeki etkileyicilik unsuru üzerinde durarak bu farklılığın, sosyal ve beşeri özelliklerin kişisel özelliklerle dengelenmesi sonucu ortaya çıktığını ileri sürmektedir. Otel işletmelerinin çeşitli değişimler karşısında esnek bir yapısı bulunduğundan, yöneticilerin bu yapısal farklılığa uygun bir gelişim göstermesi gerekmektedir (Güzel, 2005:123).

Geçmişte iş hayatında kadınlar genellikle çok az oranlarda çalışmaktaydılar. Günümüzde ise kadınlar geçmişe göre iş hayatında daha fazla yer almakta, ancak örgütlerin üst yönetiminde çoğunlukla görev alamamaktadırlar. Günümüzde kadınlar hala cinsiyetten doğan problemlerle sıkça karşılaşmaktadırlar. Burada karşımıza "Cam Tavan" kavramı çıkmaktadır. Cam tavan; örgütlerde tepe yönetim pozisyonu için kadınlara konulan keyfi bir engel anlamına gelmektedir. Yönetimdeki kadınların ilerlemesi, cinsel kimliklerinden ve çalışan kadına olan tutumdan dolayı engellenmektedir. Kadın yöneticiler, erkek meslektaşları tarafından şirket içinde kabul edilememe handikabı ile karşı karşıyadırlar (Aytaç, 1997:220; Akgemci, 2004:197).

Demografik özelliklerden olan cinsiyet, atfedilmiş bir statüdür. Bir diğer anlatımla, cinsiyet toplumda bireye atfedilen bir konumdur. Bireyler, atfedilen statüleri üzerinde kontrole sahip değildirler. Bunun aksine, aldıkları eğitim ve/veya meslekleri aracıllğıyla kazanılmış statülerini belirleyebilirler. Bir atfedilmiş statü olan cinsiyeti ise, değiştiremezler. Cinsiyet aynı zamanda temel bir statüdür. Bunun nedeni, cinsiyetin bütün toplumlarda önemli bir sosyal anlama sahip olmasıdır. Bu bağlamda kadınlar, çoğunlukla annelik ve eşlik gibi toplumsal cinsiyetleri ile erkekler ise mesleki ünvan gibi statülerle tanımlanırlar. (Demirbilek, 2007: 13).

Günümüz Türkiye'sinde konaklama sektöründe çalışanların $\% 40$ gibi önemli bir kısmını kadınlar oluştururken, üst düzey yöneticilik ya da tepe yönetiminde bu durumun farkl gelişmesi dikkat çekmektedir. Konaklama sektöründeki kadınların genellikle, orta kademe yöneticilik pozisyonlarında yoğunlaşması, üst düzeyde (otel müdürü, genel müdür, $\mathrm{CEO}$ vb.) $\% 10$ oranında temsil edilmesi kariyer gelişiminde kadınların cinsiyete dayalı bir ayrımcılık nedeniyle engellendiğini göstermektedir (Kozak, 2001:137).

Uygulamaya bakıldığında cinsiyete dayalı ayrımcılık, personel sistemimizde çoğunlukla kadınlara yönelik gerçekleştiği ortaya çıkmaktadır. Geçmişte kadınlar ve davranışları hakkında ön yargılar, kadınların işe girmelerini ve yükselmelerini ister istemez kısıtlamıştır. Bunun yanında kadınların kariyerlerini sınırlayan çocuk doğurma ve yetiştirme rollerinin genellikle erkek yöneticiler, kocalar ve ekseri de kadınların kendileri bakımından kadınlara yönelik sınırlamalar getirdiğine de inanılmaktadır. Bununla beraber günümüzde yapılan araştırmalar göstermiştir ki bayanların bu tür sınırlamalara karşı işlerini erkekler gibi başarıyla gerçekleştirip hatta bazı alanlarda onlardan daha iyi oldukları bilinmektedir. Özellikle son yıllarda yönetim alanında birçok özel sektörde bayanların üst düzey yönetici konumunda çalışıp başarılı olduğu bilinen bir gerçektir (Col, 1991:714; Argon ve Eren, 2004:73). Pek çok çalışma, kadınların kariyerlerinin iş yaşamlarına başladıkları andan itibaren "çıkmaz" kariyer yollarına yönlendirildikleri, bu sebeple kadınların yöneticilik kademesine bile ulaşamayıp kariyerlerinin alt düzeyinde "plato" halinde yığınlaşma olduğu ve belirli pozisyonlardaki atama ve terfilerde erkeklerin tercih edildiğini özellikle üst yönetsel pozisyonların erkek hâkimiyetinde olduğuna dikkat çekerek kadınlara yöneticilik yapma firsatı verilmediğini belirtmiştir (Bayrak ve Yücel, 2000:128; Kök ve Halis, 2007:135).

Turizm eğitimi veren dört yıllık fakülte ve yüksekokulların turizm bölümlerinde yapılan geniş çaplı araştırmalarda hem öğrencilerin demografik özellikleri ve sektörde çalışma eğilimleri hem de sektörde çalışma konusundaki tavırlarını incelemişlerdir. Bu çalışmalarda; turizm öğrencilerinin yaklaşık yarısının sektörde çalışma koşulları hakkında yetersiz bilgiye sahip oldukları için turizm bölümünde okumak durumunda oldukları, stresli iş hayatı, özel hayatın yaşanamaması, uzun çalışma saatleri, düşük sosyal statü, tatmin etmeyen ve adil olmayan ikramiyeler, düşük ücretler kalifiye olmayan yöneticiler ve iş arkadaşları kötü fiziki çalışma koşulları yüzünden bu sektörde çalışmaya negatif baktıkları, karşılanmayan beklentileri ve sektördeki hayal kırıklıklarının kariyer tercihlerini etkilediği dikkat çeken sonuçlardır (Gürkan ve diğ., 2010:356).

Bireylerin beklentilerini karşılayacağı umuduyla belirli bir kariyere yönelmeleri "ön taahhüt" olarak nitelendirilmektedir. Ön taahhüt aşaması daha sonraki kariyer deneyimleriyle test edilecektir. Turizm eğitimi alanında eğitim almayı seçen öğrenciler, kariyerleriyle ilgili ön taahhüt aşamasını gerçekleştirmiş olmaktadırlar. Öğrenciler daha sonraki aşamada bu ön taahhütlerini aldıkları eğitim, staj ve iş deneyimleriyle test edeceklerdir. Sonuçta, öğrencilerin turizm alanında kariyer yapma ön taahhütleri ya güçlenecek, ya zayıflayacak ya da tamamıla ortadan kalkabilecektir (Unur vd., 2004;396; Buyruk, 2009:978). Ayrıca ülke ekonomilerinin gelişmesinde ve toplumların kalkınmalarında girişimcilik yadsınamaz bir öneme sahiptir. Genellikle insanların girişimcilik ruhu, doğuştan kişilik özellikleriyle ilgili olarak ve sonradan çevresel bir takım etkileşimler 
sonucunda ortaya çıkmakta ve kazanılmaktadır. Kişiler gelecekleriyle ilgili planlarını yaparlarken, özellikle üniversite çağında, kariyerlerine ilişskin önlerine net hedefler koyabilmektedirler. Buna göre, yeteneklerinin güçlü ve zayıf yönlerinin farkına varmakta ve kendi kişilik özelliklerini tanımaya çalışmakta, böylece girişimcilik eğiliminde olan öğrenciler mezuniyetleri sonrası için kendi iş yerlerini kurma planları yapabilmektedirler (Serinkan ve Barutçu, 2006:318).

Tablo 1'de (Ehtiyar ve Üngüren, 2008:162:163) turizm eğitimi almakta olanlar ve/veya turizm eğitimi almış olanlar üzerine yapılan araştırmaları özet halinde sunulmuşlardır. Literatürde turizm lisans eğitimi alan öğrencilerin demografik özelliklerinden cinsiyet itibariyle otel işletmelerinde departman seçimleriyle ilgili spesifik bir çalışmaya rastlanılmamıştır. Ancak literatürde turizm eğitimi alan öğrencilerin kariyer beklentileri, genel olarak turizm işletmelerinde kariyer gelişiminde cinsiyetten kaynaklanan sorunlarla çalışma bulunmaktadır. Çimen (2008) “Turizm Lisans Öğrencilerinin Mesleki Yönelimleri” başlıklı çalışmasında meslek tercihi ile cinsiyet arasında eğlence, marina, spor, demiryolları, karayolları, kat hizmetleri ve kurvaziyer gemilerde görev alma konularında kız öğrencilerin erkek öğrencilere göre daha isteksiz görüldüğü sonucuna varmıştır. Hızlı yaşam gerektiren, gezmeye olanak tanıyan ve fiziki çaba isteyen meslek gruplarını bayanların tercih etmemesini toplumsal cinsiyet ve fiziksel olanaklar açısından değerlendirilmesi farklılığın nedenini bulma konusunda fikir vermektedir. Diğer yandan bayanların meslekleri açısından tercih ettikleri meslek grupları; eğitmenlik, bankacılık, insan kaynakları ve halkla ilişkiler bölümleri olarak sıralanabilmektedir (Çimen, 2008:199). Çalışmamızda diğer çalışmalardan farklı olarak, turizm eğitimi gören öğrencilerin kariyer planları açısından cinsiyet ile konaklama işletmelerinde çalışmak istedikleri departmanlar ve aynı zamanda hedefledikleri kariyer düzeyleri arasında ilişki olup olmadığı analiz edilecektir.

\begin{tabular}{|c|c|}
\hline Yazar/ Yazarlar & Temel Bulgu \\
\hline $\begin{array}{l}\text { Kızılırmak (2000), Kuşluvan (2000), } \\
\text { Ağaoğlu (1991), Tüylüoğlu (2003), King } \\
\text { ve arkadaşları (2003), Altman ve } \\
\text { Brothers (1995) }\end{array}$ & $\begin{array}{l}\text { Turizm sektörünün işgücü ihtiyacını, turizm eğitimi almamış İs gücünü } \\
\text { istihdam ederek karşılamakta olduğu tespit edilmiştir. Ayrıca turizm } \\
\text { eğitimi almış mezunların büyük çoğunluğunun turizm sektörü dışında } \\
\text { istihdam edildiği saptanmıştır. }\end{array}$ \\
\hline $\begin{array}{l}\text { Ünlüönen (2004), Kuşluvan ve Kuşluvan } \\
\text { (2000) }\end{array}$ & $\begin{array}{l}\text { Öğrencilerin okumakta oldukları programa ve mezuniyet sonrası iş } \\
\text { imkanları ile ilgili değerlendirmelerinde zamanla olumsuz yönde } \\
\text { değişimler saptanmıştır. Ayrıca araştırmaya katılan öğrencilerin } \\
\text { çoğunluğunun seçtiği bölümden pişman oldukları ifade edilmiştir. }\end{array}$ \\
\hline Aksu ve Köksal (2005) & $\begin{array}{l}\text { Öğrencilerin sektöre karşı olumsuz bir tutum ve görüş içersinde } \\
\text { oldukları saptanmıştır. Çoğunlukla olumsuz tutum ve görüş içersinde } \\
\text { olan öğrencilerin yanında olumlu görüş̧ beyan eden öğrenciler de } \\
\text { bulunmuş, bu öğrencilerin üniversite giriş sınavında turizm bölümünü } \\
\text { ilk sırada ve istekli seçtikleri, stajlarını yurt dışında gerçekleştirdikleri } \\
\text { belirtilmiştir. }\end{array}$ \\
\hline Güzel (2006), Aktaş ve Boyacı (1992) & $\begin{array}{c}\text { Yükseköğretim kurumlarında sunulan turizm eğitimin hizmet kalitesi } \\
\text { bakımından öğrencilerin beklentilerini karşlamadıklarını ve tatmin } \\
\text { düzeylerinin oldukça düşük olduğunu tespit edilmiştir. }\end{array}$ \\
\hline $\begin{array}{l}\text { Kozak ve Kız1lirmak (2001), Pavesic ve } \\
\text { Brymer (1990), Baron ve Maxwell } \\
\text { (1993), Jenkis (2001), Pavesic ve } \\
\text { Brymer (1990), Getz (1994) }\end{array}$ & $\begin{array}{l}\text { Staj yapan öğrencilerin yapmayan öğrencilere göre daha olumsuz } \\
\text { tutum içinde olduklarını saptanmıştır. Turizm eğitimi almış mezunların } \\
\text { zamanla turizm sektöründe çalışmak istemediklerini ifade edilmiştir }\end{array}$ \\
\hline $\begin{array}{c}\text { Pelit ve Güçer (2006), Gökdeniz ve ark. } \\
\text { (2002), Çakır (1998), Kuşluvan ve } \\
\text { Kuşluvan (2000), Baron ve Maxwell } \\
\text { (1993) }\end{array}$ & $\begin{array}{l}\text { Öğrenciler, verilen eğitimin staj esnasında yarar sağlamadığını } \\
\text { belirtmiş ve staj yaptıkları kurumlarının kendilerini ucuz iş gücü olarak } \\
\text { gördükleri ifade edilmiştir. Ayrıca öğrencilerin stajlardan memnun } \\
\text { olmadıkları ve stajın öğrencileri meslekten uzaklaştırdığı saptanmıştır. }\end{array}$ \\
\hline Demirer (2000), Johnstone (1994) & $\begin{array}{l}\text { Turizm işletmeciliği öğrencilerinin, sektör temsilcilerinin beklentilerini } \\
\text { tam anlamıyla karşılamadıkları tespit edilmiştir. }\end{array}$ \\
\hline Koyuncu (2000) & $\begin{array}{c}\text { Turizm işletmeciliği öğrencilerinin beklentilerinin sektörle } \\
\text { uyuşmadığını saptamış ve çalışma koşullarının öğrencileri olumsuz } \\
\text { tutum içersine sürüklediği ifade edilmiştir. }\end{array}$ \\
\hline Üzümcü ve Bayraktar (2004) & $\begin{array}{c}\text { Turizm eğitmenlerinin verdiği mesleki eğitimi etik açısından } \\
\text { inceledikleri araştırmada, etik ilkelerin tam olarak uygulanmadığını ve } \\
\text { verilen eğitimin yetersiz olduğunu saptamışlardır. }\end{array}$ \\
\hline Cooper ve Shepherd (1997) & $\begin{array}{c}\text { Turizm eğitimiyle turizm sektörü arasındaki ilişkiyi inceledikleri } \\
\text { araştırmalarında, turizm endüstrisinin düš̈k statülü işimkanı } \\
\text { sunduğunu ve turizmin kariyer değeri yüksek bir sektör olarak } \\
\text { algılanmadığını ifade etmişlerdir. }\end{array}$ \\
\hline Purcell ve Quinn (1996) & $\begin{array}{l}\text { Turizm endüstrisinde çalışanların eğitim durumları diğer sektörlerde } \\
\text { çalışanlara göre düşük kaldığı tespit etmiştir. }\end{array}$ \\
\hline Koko ve Guerrier (1994) & $\begin{array}{l}\text { Turizm eğitimi almış mezunların çalışma koşulları ve katılım ve } \\
\text { gelişim firsatlarının sınırlılığı, motivasyon yetersizliği ve iş } \\
\text { tatminsizliğinden dolayı sektörü terk ettiklerini saptamışlardır. }\end{array}$ \\
\hline Casado (1992) & $\begin{array}{l}\text { Konaklama işletmeciliğine öğrencilerinin mezun olmadan önce } \\
\text { oldukça gerçekçi beklentilerinin olması ve işe alımlarında başarılı } \\
\text { olacaklarını umduklarını ifade etmelerine rağmen konaklama } \\
\text { işletmelerindeki sirkülasyonun yüksek olduğunu saptamıştır. }\end{array}$ \\
\hline
\end{tabular}

Tablo 1. Turizm Eğitimi Alan Öğrenciler Üzerine Yapılmış Çalışmalarla İlgili Literatür Taraması 


\section{Metodoloji}

Çalışmanın amacı; genel olarak turizm lisans eğitimi alan öğrencilerin mezun olduktan sonra konaklama işletmelerinde çalışmaları durumunda, cinsiyete göre departman seçiminde anlamlı bir farkın olup olmadığının belirlemek ve cinsiyet ile kariyer yapma düşünceleri arasında anlamlı bir ilişki olup olmadığının belirlemektir. Özelde ise Marmara bölgesindeki üniversitelerde okuyan turizm lisans öğrencileri arasında cinsiyet farkından kaynaklanan kariyer düşünceleri ile ilgili ve cinsiyete göre bölüm seçiminde anlamlı bir farkın olup olmadığının analiz edilmesidir. Çalışmada veri toplama yöntemi olarak anket tekniği seçilmiştir. Ankette kategorik ve beşli Likert olmak üzere iki tür ölçek kullanılmıştır. Öğrencilere ilişkin demografik verileri elde etmeye yönelik ölçek kategorik tarzda, çalışmanın ana problemini çözmeye yönelik olarak, öğrencilerin kariyer hedefleri açısından, konaklama işletmelerindeki departmanların önem derecelerini ölçmeye yönelik oluşturulmuş ölçek ise beşli Likert tarzında hazırlanmıştır.

Anket için ölçek geliştirilirken Baltacı ve Üngören (2010), Roney ve Öztin (2007), Buyruk (2009) ve Gürkan ve diğ.'nin (2010) çalışmalarından da yararlanılmıştır. Bu çalışmanın ideal evrenini Türkiye'nin önemli bir bölgesi olan Marmara bölgesinde eğitim gören turizm lisans öğrencileri oluşturmaktadır. Ancak süre kısıtı ve maddi olanaksızlıklar gibi nedenlerle ile bu çalışmanın gerçek evrenini, Marmara bölgesinin önemli üniversitelerinden olan ve turizm lisans eğitimi veren Sakarya Üniversitesi, Çanakkale Üniversitesi, İstanbul Üniversitesi, Düzce Üniversitesi ve Balıkesir Üniversitesi'ndeki 3.720 turizm lisans öğrencileri oluşturmaktadır. Araştırmanın örneklemini ise evrenin \%15'ine denk gelen Basit Tesadüfi Örnekleme yöntemiyle seçilmiş 543 turizm eğitimi gören turizm lisans öğrencileri oluşturmaktadır. Bu amaçla Marmara bölgesinin önemli üniversitelerinden olan bu 5 üniversiteye 900 anket dağıtılmış olup 590 adedi geri dönülmesi sağlanmıştır. Çeşitli veri eksiklikleri nedeniyle 47 anket değerlendirmeye alınmamıştır. Geri kalan 543 anket, Social Science SPSS 15.0 for Windows paket programında analize tabi tutulmuştur.

Öğrencilere ilişkin demografik veriler ve cinsiyete göre kariyer düşüncülerine verdikleri cevaplar frekans analizine tabi tutulmuştur. Frekans Analizi; her bir değişkenle ilgili olarak merkezi eğilimin ve deneklerin merkezi eğilime olan yakınlıklarını tespit etmek amacıyla kullanılır (Altunışık ve diğ., 2007:314). Çalışmada turizm eğitimi alan öğrencilerin cinsiyete göre konaklama işletmelerinde departman tercihleri hususundaki farklılıkları tespit edebilmek amacıyla öncelikle Bağımsız İki Grup Arası Farkların Testi (Independent - Samples t-Test) uygulanması düşünülmüştür. Ancak Kolmogorov-Smirnov (K-S) testi sonucunda verilerin normal dağılım göstermediği sonucu çıkmıştır. Bu nedenle, Bağımsız İki Grup Arası Farkları Testinin nonparametrik biçimi olan Mann-Whitney U Testinin uygulanmasına karar verilmiştir. Mann-Whitney U Testinde Sig. (2-tailed) değeri \% 5 'ten küçük olması durumunda, gruplar arasında anlamlı bir farklılık olduğu sonucuna varılmaktadır.

\section{Bulgular}

Tablo 2'de ankete katılan öğrencilere ait demografik verilerin frekans analizi sonuçları yer almaktadır. Anketimize katılan öğrencilerin \%49,9'u bayan, \%50,1'i ise erkeklerden oluşmaktadır. Yaş grubu bakımından öğrencilerin yaklaşık \%67,8'lik kısmı 21-23 yaş grubunda yer almaktadır. Öğrencilerin büyük bir kısmının $(\% 47,0)$ klasik lise mezunu olduğu, turizm lisesi mezun öğrenci oranının ise çok düşük olduğu $(\% 9,6)$ görülmektedir. Bunun turizm lisesi mezunlarının 4 yıllık turizm lisans eğitimine devam edenlerinin oranlarının düşük olduğu sonucu çıkarılabilir.

Öğrenciler, sınıfları açısından incelendiğinde ise ankete katılan 4. Sınıf öğrenci sayısının çok düşük olduğu dikkat çekmektedir. Bunun nedeni; turizm eğitimi alan 4. Sınıf öğrencilerinin, bir bölümünün iş başı eğitimi kapsamında sektörde staj yapmakta olmalarıdır. Bu öğrenicilerin tamamına e-posta yoluyla anketler gönderildiyse de gerek sürenin çok kısıtlı olması, gerekse öğrencilerin iş başı eğitimindeki yoğun çalışma temposundan dolayı geri dönüş oranı çok düşük olmuştur. Ankete katılan öğrencilerin çoğunluğu \%37,2 gibi bir oranla ikinci sınıf öğrencilerinin oluşturduğu görülmektedir. Bunlara ilaveten, öğrencilerin büyük bir kısmı $(\% 56,5)$ eğitim gördükleri bölümü isteyerek seçtiklerini belirtmişlerdir. Verilen eğitimin sektörde iş bulabilme ve kariyerlerinde başarılı olabilme konusundaki yeterliliği bakımından ise öğrencilerin \%28,0'i aldıkları eğitimi yeterli görürken, $\% 40,1$ 'i ise yeterli görmemektedir. Buna rağmen öğrencilerin büyük bir k1smı $(\% 57,8)$ gelecekte kariyerlerinin en üst noktasında, kendilerini genel müdür konumunda görebilmektedirler. Öğrencilerin yaklaşık \%44,4'ü ise sınavda almış olduğu puana göre tercih yaptığı ve turizm işletmeciliğinin günümüzde \%20,8'i geçerli bir meslek olduğunu düşündükleri için eğitim gördükleri bölümü tercih ettiklerini belirtmişlerdir.

Tablo 3'e bakıldığında turizm lisans öğrencilerinin mezun olduktan sonra bir konaklama işletmesinde çalışmak istedikleri departmanlara yönelik verdikleri cevaplar verilmektedir. Tablo 3'e göre Ön büro departmanı için \%21,8 gibi bir oran istemiyorum, \%55,6 gibi yüksek bir oran ise çalışmak istediğini belirtmiştir. Kat hizmetleri departmanı için \%72,9 gibi çok yüksek bir oran istemiyorum, \%9,6 gibi bir oran ise çalışmak istediğini belirtmiştir. Muhasebe departmanı için \%38,1 gibi bir oran istemiyorum,\%35,5 gibi bir oran ise çalışmak istediğini belirtmiştir. 


\begin{tabular}{|c|c|c|c|c|c|}
\hline ÖZELLÍKLER & \multicolumn{2}{|c|}{ ÖRNEKLEM } & \multirow{2}{*}{\begin{tabular}{|c|} 
ÖZELLÍKLER \\
Şu an eğitim gördüğünüz bölümü isteyerek mi seçtiniz?
\end{tabular}} & \multicolumn{2}{|c|}{ ÖRNEKLEM } \\
\hline Cinsiyet & $\mathbf{N}$ & $\%$ & & $\mathbf{N}$ & $\%$ \\
\hline Bay & 271 & 49,9 & Evet & 307 & 56,5 \\
\hline Bayan & 272 & 50,1 & Hayır & 163 & 30,0 \\
\hline Toplam & 543 & 100,0 & Kararsızım & 73 & 13,4 \\
\hline Yaş & $\mathbf{N}$ & $\%$ & Toplam & 543 & 100,0 \\
\hline 17 ve altı & 2 & 0,4 & $\begin{array}{l}\text { Sizce üniversitede aldığınız eğitim, turizm sektöründe } \\
\text { kariyer planınıza uygun bir iş bulabilmeniz ve } \\
\text { kariyerinizde başarılı olabilmeniz için yeterli mi? }\end{array}$ & $\mathbf{N}$ & $\%$ \\
\hline $18-20$ & 125 & 23,0 & Evet & 152 & 28,0 \\
\hline $21-23$ & 368 & 67,8 & Hayır & 218 & 40,1 \\
\hline 24 ve alt 1 & 48 & 8,8 & Kararsızım & 173 & 31,7 \\
\hline Toplam & 543 & 100,0 & Toplam & 543 & 100,0 \\
\hline $\begin{array}{l}\text { Mezun Olunan } \\
\text { Lise }\end{array}$ & $\mathbf{N}$ & $\%$ & $\begin{array}{l}\text { Gelecekte kariyerinizin en üst noktasında kendinizi } \\
\text { bulunduğunuz organizasyonun hangi kademesinde } \\
\text { görüyorsunuz? }\end{array}$ & $\mathbf{N}$ & $\%$ \\
\hline Düz Lise & 255 & 47,0 & Genel Müdür & 314 & 57,8 \\
\hline Turizm Lisesi & 52 & 9,6 & Genel Müdür Yardımcısı & 31 & 5,7 \\
\hline Anadolu Lisesi & 82 & 15,1 & Departman Müdürü & 147 & 27,1 \\
\hline Süper Lise & 110 & 20,3 & Departman Müdürü Yardımcısı & 14 & 2,6 \\
\hline Kolej & 14 & 2,6 & Alt Kademe Personel & 37 & 6,8 \\
\hline Meslek Lisesi & 21 & 3,9 & Toplam & 543 & 100,0 \\
\hline Diğer & 9 & 1,7 & $\begin{array}{l}\text { Şu anda eğitim gördüğünüz bölümü niçin tercih } \\
\text { ettiniz? }\end{array}$ & $\mathbf{N}$ & $\%$ \\
\hline Toplam & 543 & 100,0 & Sınavda almış olduğum puana göre tercih yaptığım için & 241 & 44,4 \\
\hline Sinif & $\mathbf{N}$ & $\%$ & Eğitimini almış olduğum mesleği sevdiğim için & 98 & 18,0 \\
\hline Hazırlık Sinıfi & 5 & 0,9 & Günümüzde geçerli bir meslek olduğu için & 113 & 20,8 \\
\hline 1. Sinif & 134 & 24,7 & Başka seçeneğim olmadığg için & 26 & 4,8 \\
\hline 2. Sinif & 202 & 37,2 & Çevremin (öğretmen, aile) tavsiyesi olduğu için & 29 & 5,3 \\
\hline 3. Sinif & 137 & 25,2 & Diğer & 36 & 6,6 \\
\hline 4. Sinif & 54 & 9,9 & Toplam & 543 & 100,0 \\
\hline Uzatmalı & 11 & 2,0 & & & \\
\hline Toplam & 543 & 100,0 & & & \\
\hline
\end{tabular}

Tablo 2. Demografik Veriler

\begin{tabular}{|c|c|c|c|c|c|}
\hline \multicolumn{6}{|c|}{$\begin{array}{l}\text { Mezun olduktan sonra bir konaklama işletmesinde hangi departmanda çalışmak istediğinizin önen } \\
\text { derecesini belirtiniz. }\end{array}$} \\
\hline Ön büro Departmanı & $\mathbf{N}$ & $\%$ & $\begin{array}{l}\text { İnsan Kaynakları Yönetimi } \\
\text { Departmanı }\end{array}$ & $\mathbf{N}$ & $\%$ \\
\hline Hiç istemiyorum & 59 & 10,9 & Hiç istemiyorum & 40 & 7,4 \\
\hline İstemiyorum & 59 & 10,9 & İstemiyorum & 27 & 5,0 \\
\hline Kararsızım & 123 & 22,7 & Kararsızım & 100 & 18,4 \\
\hline İstiyorum & 203 & 37,4 & İstiyorum & 199 & 36,6 \\
\hline Çok istiyorum & 99 & 18,2 & Çok istiyorum & 177 & 32,6 \\
\hline Toplam & 543 & 100,0 & Toplam & 543 & 100,0 \\
\hline Kat Hizmetleri & $\mathbf{N}$ & $\%$ & Satış ve Pazarlama Departmanı & $\mathbf{N}$ & $\%$ \\
\hline Hiç istemiyorum & 283 & 52,1 & Hiç istemiyorum & 47 & 8,7 \\
\hline İstemiyorum & 113 & 20,8 & İstemiyorum & 53 & 9,8 \\
\hline Kararsızım & 95 & 17,5 & Kararsızım & 100 & 18,4 \\
\hline İstiyorum & 44 & 8,1 & İstiyorum & 186 & 34,3 \\
\hline Çok istiyorum & 8 & 1,5 & Çok istiyorum & 157 & 28,9 \\
\hline Toplam & 543 & 100,0 & Toplam & 543 & 100,0 \\
\hline Muhasebe & $\mathbf{N}$ & $\%$ & Teknik Hizmetler & $\mathbf{N}$ & $\%$ \\
\hline Hiç istemiyorum & 133 & 24,5 & Hiç istemiyorum & 314 & 57,8 \\
\hline İstemiyorum & 74 & 13,6 & İstemiyorum & 99 & 18,2 \\
\hline Kararsızım & 143 & 26,3 & Kararsızım & 82 & 15,1 \\
\hline İstiyorum & 136 & 25,0 & İstiyorum & 37 & 6,8 \\
\hline Çok istiyorum & 57 & 10,5 & Çok istiyorum & 11 & 2,0 \\
\hline Toplam & 543 & 100,0 & Toplam & 543 & 100,0 \\
\hline Finansman & $\mathbf{N}$ & $\%$ & Güvenlik & $\mathbf{N}$ & $\%$ \\
\hline Hiç istemiyorum & 94 & 17,3 & Hiç istemiyorum & 353 & 65,0 \\
\hline İstemiyorum & 78 & 14,4 & İstemiyorum & 87 & 16,0 \\
\hline Kararsızım & 135 & 24,9 & Kararsızım & 60 & 11,1 \\
\hline İstiyorum & 159 & 29,3 & İstiyorum & 33 & 6,1 \\
\hline Çok istiyorum & 77 & 14,2 & Çok istiyorum & 10 & 1,8 \\
\hline Toplam & 543 & 100,0 & Toplam & 543 & 100,0 \\
\hline
\end{tabular}

Tablo 3. Turizm Lisans Öğrencilerinin Mezun Olduktan Sonra Bir Konaklama Isşletmesinde Çalışmak İstedikleri 


\begin{tabular}{|c|c|c|}
\hline $\begin{array}{l}\text { Konaklama işletmelerinde kariyer ilerleme açısından erkeklere yönelik cinsiyete dayalı ayrımcılık } \\
\text { yapılmaktadır. }\end{array}$ & $\mathbf{N}$ & $\%$ \\
\hline Kesinlikle Katılmiyorum & 117 & 21,5 \\
\hline Katılmiyorum & 119 & 21,9 \\
\hline Kararsızım & 134 & 24,7 \\
\hline Katıliyorum & 102 & 18,8 \\
\hline Kesinlikle Katıliyorum & 70 & 12,9 \\
\hline Toplam & 543 & 100,0 \\
\hline $\begin{array}{l}\text { Konaklama işletmelerinde kariyer ilerleme açısından kadınlara yönelik cinsiyete dayalı ayrımcılık } \\
\text { yapılmaktadır. }\end{array}$ & $\mathbf{N}$ & $\%$ \\
\hline Kesinlikle Katılmıyorum & 105 & 19,3 \\
\hline Katılmiyorum & 149 & 27,4 \\
\hline Kararsızım & 127 & 23,4 \\
\hline Katıliyorum & 94 & 17,3 \\
\hline Kesinlikle Katıliyorum & 68 & 12,5 \\
\hline Toplam & 543 & 100,0 \\
\hline $\begin{array}{l}\text { Cinsiyet, kariyer planlaması yaparken konaklama işletmelerine departman tercihinde önemli bir } \\
\text { faktördür. }\end{array}$ & $\mathbf{N}$ & $\%$ \\
\hline Kesinlikle Katılmıyorum & 44 & 8,1 \\
\hline Kat1lmiyorum & 82 & 15,1 \\
\hline Kararsızım & 119 & 21,9 \\
\hline Katıliyorum & 167 & 30,8 \\
\hline Kesinlikle Katıliyorum & 131 & 24,1 \\
\hline Toplam & 543 & 100,0 \\
\hline Konaklama İşletmelerinde kadınlar erkeklere göre kariyer hedeflerine daha kolay ulaşmaktadır. & $\mathbf{N}$ & $\%$ \\
\hline Kesinlikle Katılmiyorum & 99 & 18,2 \\
\hline Kat1lmiyorum & 147 & 27,1 \\
\hline Kararsizım & 140 & 25,8 \\
\hline Katıliyorum & 92 & 16,9 \\
\hline Kesinlikle Katıliyorum & 65 & 12,0 \\
\hline Toplam & 543 & 100,0 \\
\hline Konaklama İşletmelerinde erkekler, kadınlara göre kariyer hedeflerine daha kolay ulaşmaktadır. & $\mathbf{N}$ & $\%$ \\
\hline Kesinlikle Katılmiyorum & 88 & 16,2 \\
\hline Katılmiyorum & 127 & 23,4 \\
\hline Kararsızım & 152 & 28,0 \\
\hline Katıliyorum & 123 & 22,7 \\
\hline Kesinlikle Katıliyorum & 53 & 9,8 \\
\hline Toplam & 543 & 100,0 \\
\hline Cinsiyetim bu bölümü tercih etmemde önemli bir faktördü. & $\mathbf{N}$ & $\%$ \\
\hline Kesinlikle Katılmiyorum & 244 & 44,9 \\
\hline Katılmiyorum & 120 & 22,1 \\
\hline Kararsızım & 89 & 16,4 \\
\hline Katıliyorum & 57 & 10,5 \\
\hline Kesinlikle Katıliyorum & 33 & 6,1 \\
\hline Toplam & 543 & 100,0 \\
\hline $\begin{array}{l}\text { Konaklama İşletmelerinde verilen hizmetler göz önüne alındığında kariyer yapma açısından } \\
\text { kadınlar için daha uygundur. }\end{array}$ & $\mathbf{N}$ & $\%$ \\
\hline Kesinlikle Katılmıyorum & 107 & 19,7 \\
\hline Katılmiyorum & 156 & 28,7 \\
\hline Kararsızım & 164 & 30,2 \\
\hline Katıliyorum & 83 & 15,3 \\
\hline Kesinlikle Katıliyorum & 33 & 6,1 \\
\hline Toplam & 543 & 100,0 \\
\hline $\begin{array}{l}\text { Konaklama İşletmelerinde verilen hizmetler göz önüne alındığında kariyer yapma açısından } \\
\text { erkekler için daha uygundur. }\end{array}$ & $\mathbf{N}$ & $\%$ \\
\hline Kesinlikle Katılmıorum & 78 & 14,4 \\
\hline Kat1lmiyorum & 134 & 24,7 \\
\hline Kararsızım & 161 & 29,7 \\
\hline Katıliyorum & 114 & 21,0 \\
\hline Kesinlikle Katılıyorum & 56 & 10,3 \\
\hline Toplam & 543 & 100,0 \\
\hline Mezun olduktan sonra turizm sektöründe iş bulma konusunda kadınlar daha avantajlıdır. & $\mathbf{N}$ & $\%$ \\
\hline Kesinlikle Katılmıyorum & 86 & 15,8 \\
\hline Katılmiyorum & 146 & 26,9 \\
\hline Kararsızım & 159 & 29,3 \\
\hline Katıliyorum & 90 & 16,6 \\
\hline Kesinlikle Katıliyorum & 62 & 11,4 \\
\hline Toplam & 543 & 100,0 \\
\hline Mezun olduktan sonra turizm sektöründe iş bulma konusunda erkekler daha avantajlıdır. & $\mathbf{N}$ & $\%$ \\
\hline Kesinlikle Katılmıyorum & 84 & 15,5 \\
\hline Katılmiyorum & 115 & 21,2 \\
\hline Kararsizim & 157 & 28,9 \\
\hline Katıliyorum & 123 & 22,7 \\
\hline
\end{tabular}




\begin{tabular}{|l|c|c|}
\hline Kesinlikle Kat1liyorum & 64 & 11,8 \\
\hline Toplam & $\mathbf{5 4 3}$ & $\mathbf{1 0 0 , 0}$ \\
\hline
\end{tabular}

Tablo 4. Ankete Katılan Cinsiyet Açısından Kariyer Tercihiyle İlgili Faktörlere Katılım Düzeyi

Muhasebe departmanında çalışmak isteyenlerin ve istemeyenlerin oranı birbirine yakın çıktığı gözükmektedir. Finansman bölümü için \%31,7 gibi bir oran istemiyorum, \%43,5 gibi bir oran ise çalışmak istediğini belirtmiştir. Insan kaynakları yönetimi departmanı için \%12,4 gibi bir oran istemiyorum, \%69,2 gibi yüksek bir oran ise çalışmak istediğini belirtmiştir. Satış ve Pazarlama departmanı için \%18,5 gibi bir oran istemiyorum, \%63,2 gibi yüksek bir oran ise çalışmak istediğini belirtmiştir. Teknik hizmetler bölümü için \%76,0 gibi çok yüksek bir oran istemiyorum, \%8,8 gibi düşük bir oran ise çalışmak istediğini belirtmiştir.

Ankete katılan cinsiyet açısından kariyer tercihi ile ilgili faktörlere katılım düzeyi Tablo 4'de verilmiştir. Tablo 4' göre “konaklama işletmelerinde kariyer ilerleme açısından erkeklere yönelik cinsiyete dayalı ayrımcılık yapılmaktadır" ifadesine katılımcıların \%43,4'ü katılmıyorum derken \%21,1'i katılıyorum demiştir. "Katılımcılar konaklama işletmelerinde kariyer ilerleme açısından kadınlara yönelik cinsiyete dayalı ayrımcılık yapılmaktadır" ifadesine \%46,7'si katılmıyorum derken, \%29,8'i katıliyorum şeklinde ifade vermiştir. Katılımcılar, "cinsiyet, kariyer planlaması yaparken konaklama işletmelerine departman tercihinde önemli bir faktördür" ifadesine \%23,3'si katılmadıkları görülürken \%54,9'u katılıyorum şeklinde ifade etmişlerdir. "Konaklama Işletmelerinde kadınlar erkeklere göre kariyer hedeflerine daha kolay ulaşmaktadır" ifadesine ise katılımcıların 45,3'ü katılmıyorum derken, \%28,9’u katılıyorum diye cevaplamışlardır. "Konaklama Işletmelerinde erkekler kadınlara göre kariyer hedeflerine daha kolay ulaşmaktadır" ifadesine ise katılımcıların 39,6'sı katılmıyorum derken, \%39,5'i katılıyorum diye cevaplamışlardır. "Cinsiyetim bu bölümü tercih etmemde önemli bir faktördü" ifadesine ise katılımc1ların \%67'si katılmıyorum derken, \%16,6'sı katılıyorum şeklinde ifade bulunmuşlardır. Ankete katılan katılımcılar, "Konaklama İşletmelerinde verilen hizmetler göz önüne alındı ̆̆ında kariyer yapma açısından kadınlar için daha uygundur" ifadesine ise \%48,4'ü katılmıyorum şeklinde ifade ederken, 21,4'ü katılıyorum şeklinde ifade etmişlerdir. "Konaklama Işsletmelerinde verilen hizmetler göz önüne alındı̆̆ında kariyer yapma açısından erkekler için daha uygundur” ifadesine katılımcıların \%39,1'i katılmıyorum şeklinde ifade ederken, \%31,3'ü katılıyorum şeklinde ifade etmişlerdir. Ayrıca katılımcıların "Mezun olduktan sonra turizm sektöründe iş bulma konusunda kadınlar daha avantajlıdır" ifadesine \%42,7'si katılmıyorum yönünde cevaplarken \%28,0’1 katılıyorum yönünde cevaplar vermiştir. Son olarak "Mezun olduktan sonra turizm sektöründe iş bulma konusunda erkekler daha avantajlıdır" ifadesine ise katılımcıların \%36,7'si katılmıyorum yönünde cevap verirken, \%34,5'i katılıyorum yönünde cevap vermişlerdir.

\begin{tabular}{|c|c|c|c|c|}
\hline Departmanlar & Ortalama & $\begin{array}{l}\text { Standart } \\
\text { Sapma }\end{array}$ & $\begin{array}{l}\text { Kolmogorov- } \\
\text { Smirnov Z }\end{array}$ & $\begin{array}{l}\text { Asymp. Sig. } \\
\text { (2-tailed) }\end{array}$ \\
\hline Önbüro Departmanı & 3,42 & 1,222 & 5,620 & 0,000 \\
\hline Kat Hizmetleri Departmanı & 1,86 & 1,066 & 7,256 & 0,000 \\
\hline Yiyecek - İçecek Departmanı & 2,92 & 1,347 & 3,818 & 0,000 \\
\hline Muhasebe Departmanı & 2,83 & 1,327 & 3,926 & 0,000 \\
\hline Finansman Departmanı & 3,09 & 1,301 & 4,506 & 0,000 \\
\hline İnsan Kaynakları Yönetimi Departmanı & 3,82 & 1,159 & 5,912 & 0,000 \\
\hline Satış ve Pazarlama Departmanı & 3,65 & 1,234 & 5,669 & 0,000 \\
\hline Teknik Hizmetler Departmanı & 1,77 & 1,065 & 8,005 & 0,000 \\
\hline Güvenlik Departmanı & 1,63 & 1,019 & 8,954 & 0,000 \\
\hline $\begin{array}{l}\text { Konaklama işletmelerinde kariyerde ilerleme açısından } \\
\text { erkeklere yönelik cinsiyete dayalı ayrımcılık yapılmaktadır }\end{array}$ & 2,81 & 1,380 & 3,660 & 0,000 \\
\hline $\begin{array}{l}\text { Konaklama isletmelerinde kariyerde ilerleme açısından } \\
\text { kadınlara yönelik cinsiyete dayalı ayrımcılık yapılmaktadır }\end{array}$ & 2,76 & 1,292 & 4,433 & 0,000 \\
\hline $\begin{array}{l}\text { Cinsiyet, kariyer planlaması yaparken konaklama } \\
\text { isletmelerinde departman tercihinde önemli bir faktördür }\end{array}$ & 3,48 & 1,234 & 4,962 & 0,000 \\
\hline $\begin{array}{l}\text { Konaklama isletmelerinde kadınlar erkeklere göre kariyer } \\
\text { hedeflerine daha kolay ulaşmaktadır }\end{array}$ & 2,77 & 1,267 & 4,273 & 0,000 \\
\hline $\begin{array}{l}\text { Konaklama isletmelerinde erkekler kadınlara göre kariyer } \\
\text { hedeflerine daha kolay ulaşmaktadır }\end{array}$ & 2,86 & 1,218 & 3,655 & 0,000 \\
\hline Cinsiyetim bu bolumu tercih etmemde önemli bir faktördü & 2,11 & 1,254 & 6,075 & 0,000 \\
\hline $\begin{array}{l}\text { Konaklama isletmelerinde verilen hizmetler göz önüne } \\
\text { alındığında kariyer yapma açısından kadınlar için daha } \\
\text { uygundu }\end{array}$ & 2,59 & 1,144 & 4,248 & 0,000 \\
\hline $\begin{array}{l}\text { Konaklama isletmelerinde verilen hizmetler göz önüne } \\
\text { alındığında kariyer yapma açısından erkekler için daha } \\
\text { uygundur }\end{array}$ & 2,88 & 1,197 & 3,725 & 0,000 \\
\hline $\begin{array}{l}\text { Mezun olduktan sonra turizm sektöründe is bulma konusunda } \\
\text { kadınlar daha avantajlıdır }\end{array}$ & 2,81 & 1,221 & 4,039 & 0,000 \\
\hline $\begin{array}{l}\text { Mezun olduktan sonra turizm sektöründe iş bulma konusunda } \\
\text { erkekler daha avantajlıdır }\end{array}$ & 2,94 & 1,236 & 3,554 & 0,000 \\
\hline
\end{tabular}

Tablo 5. Kolmogorov-Smirnov (K-S) Test Sonucu 
Veriler güvenilirlik analizine tabi tutularak verilen cevapların güvenilirliği ölçülmeye çalışılmıştır. Soruların cevaplarına güvenirliliğini test etmek amacıyla yapılan güvenirlilik testinde Alpha katsayıs1 0,633 gibi bir oran çıkarak, güvenilir veriler olduğu söylenebilir. Tablo 5'de örneklemden elde edilen verilerin normal dağılım şartını taşıyıp taşımadıklarını ölçmek amacıyla kullanılabilen Kolmogorov-Smirnov (K-S) test sonucu yer almaktadir.

Tablo 5'de Kolmogorov-Smirnov (K-S) testi sonucunda Asymp. Sig. (2-tailed) değerinin 0,05'den küçük olması, verilerin normal dağılmadığı anlamına gelmektedir. Dolayısıyla çalışmada örneklemden toplanan verilerin normal dağılım sergilemediği anlaşılmaktadır. Bu nedenle, çalışmada araştırma problemini çözmek amacıyla, normal dağılım şartı aranmayan nanparametrik bir analiz tekniği olan Mann-Whitney U Testi kullanılmıştır. Tablo 6'da Mann-Whitney U testi sonuçları yer almaktadır. Burada, çalışmanın temel araştırma sorusu olan, turizm eğitimi alan öğrencilerin cinsiyete göre kariyer düşüncelerinde anlamlı bir farkın olup olmadığı test edilmiştir.

\begin{tabular}{|c|c|c|c|c|c|c|}
\hline \multirow{2}{*}{ Departmanlar } & \multirow{2}{*}{$\begin{array}{c}\text { Mann- } \\
\text { Whitney U }\end{array}$} & \multirow[b]{2}{*}{ Wilcoxon W } & \multirow[b]{2}{*}{$\mathbf{Z}$} & \multirow{2}{*}{$\begin{array}{c}\text { Asymp. } \\
\text { Sig. } \\
\text { (2-tailed) }\end{array}$} & \multicolumn{2}{|c|}{ Mean Rank } \\
\hline & & & & & Bay & Bayan \\
\hline Önbüro Departmanı & 35185,500 & 72313,500 & $-0,949$ & 0,343 & 278,16 & 265,86 \\
\hline $\begin{array}{ll}\text { Kat } & \text { Hizmetleri } \\
\text { Departmanı } & \end{array}$ & 34600,500 & 71728,500 & $-1,343$ & 0,179 & 280,32 & 263,71 \\
\hline $\begin{array}{l}\text { Yiyecek }- \\
\text { Departmanı }\end{array}$ & 33416,500 & 70544,500 & $-1,925$ & 0,054 & 284,69 & 259,35 \\
\hline Muhasebe Departmanı & 35852,500 & 72980,500 & $-0,564$ & 0,573 & 275,70 & 268,31 \\
\hline Finansman Departmanı & 33506,000 & 70634,000 & $-1,882$ & 0,060 & 284,36 & 259,68 \\
\hline $\begin{array}{l}\text { İnsan Kaynakları } \\
\text { Yönetimi Departmanı }\end{array}$ & 24685,000 & 61541,000 & $-6,982$ & $\mathbf{0 , 0 0 0}$ & 227,09 & 316,75 \\
\hline $\begin{array}{lcc}\text { Satış ve } & \text { Pazarlama } \\
\text { Departmanı } & \\
\end{array}$ & 31250,000 & 68106,000 & $-3,184$ & 0,001 & 251,31 & 292,61 \\
\hline $\begin{array}{ll}\text { Teknik } & \text { Hizmetler } \\
\text { Departmanı } & \end{array}$ & 31635,000 & 68763,000 & $-3,200$ & 0,001 & 291,27 & 252,81 \\
\hline Güvenlik Departmanı & 30780,000 & 67636,000 & $-3,846$ & $\mathbf{0 , 0 0 0}$ & 293,42 & 249,58 \\
\hline
\end{tabular}

Tablo 6. Mann-Whitney U Test Sonuçları

\section{Sonuç ve Öneriler}

Çalışma neticesinde, Mann-Whitney U testi sonuçları incelendiğinde turizm eğitimi alan öğrencilerin cinsiyet gruplarına göre konaklama işletmelerinde Muhasebe departmanında departman tercihlerinde anlamlı fark

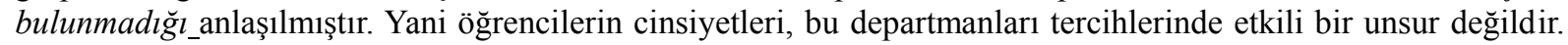
Buna karşılık Mann-Whitney U Sonuçları incelendiğinde turizm eğitimi alan öğrencilerin cinsiyet gruplarına göre konaklama işletmelerinde Ön büro, Kat Hizmetleri, Yiyecek-İçecek, Finansman, Satış ve Pazarlama, Teknik Hizmetler, Güvenlik ve İnsan Kaynakları Yönetimi Departman-larında, departman tercihlerinde anlamlı fark bulunmuştur. Yani öğrencilerin cinsiyetleri, konaklama işletmelerinde bu departmanları tercihlerinde etkili bir unsurdur.

Ortalamalar incelendiğinde, bayanların erkeklere göre İnsan Kaynakları Yönetimi Departmanını daha çok tercih ettikleri, erkeklerin ise bayanlara göre Güvenlik Departmanını daha çok tercih ettikleri anlaşılmaktadır. Öğrencilerin mezun olduktan sonra, kısa süre içerisinde iyi bir iş bulabilmeleri ve kariyerlerinde başarılı olabilmeleri için üniversitelerde öğrencilere verilen dersler kadar, öğrencilerin ilgi ve kişisel becerilerine uygun kariyer düşüncelerini belirlemeleri ve bu hedeflere ulaşmalarını sağlayacak etkili bir kariyer planı geliştirmeleri hayati bir önem taşımaktadır. Bu kapsamda çalışmanın, öğrencilerin kariyer planlarını yaparken cinsiyetin de bu konuda önemli bir faktör olduğunun bilinmesi ve kariyer hedeflerinin belirlenmesinde göz önüne alınması gerekliliğini irdelemesi açısından bu konuda yapılan çalışmalara katkı sağlayacağı düşünülmektedir.

Maliyet ve özelliklede süre kısıtı nedeniyle anket uygulama çalışması Marmara bölgesinin önemli üniversitelerinden olan ve turizm lisans eğitimi veren Sakarya Üniversitesi, Çanakkale Üniversitesi, İstanbul Üniversitesi, Düzce Üniversitesi ve Balıkesir Üniversitesi lisans öğrencileri ile sınırlı tutulmuştur. Çalışmadan elde edilen sonuçlar, söz konusu kısıtlar nedeniyle geneli temsil etmede yeterli olmasa da bu konuda yapılmış olan çalışmalara katkı sağlaması açısından yararlı olacağı düşünülmektedir. Bundan sonraki çalışmalarda, daha geniş örneklem kitlesinden alınacak verilerle ve daha etkin istatistiksel analizlerle bu konuda geneli kapsayan sonuçlara ulaşılabilir. $\mathrm{Bu}$ çalışmada, turizm eğitimi alan öğrencilerde cinsiyetin konaklama işletmelerinde departman tercihindeki etkisi analiz edilmiştir. Bundan sonraki çalışmalarda, yiyecek-içecek işletmeleri ve seyahat işletmelerinde cinsiyetin bölüm tercihleri üzerindeki etkisinin analiz edilmesinin yararlı olacağı düşünülmektedir. 


\section{Kaynakça}

- AKGEMCI, Tahir (2004), Gelecekte Kariyer Yönetimi ve Güncel Sorunlar, Editörler: ŞiMŞEK, M. Şerif ve Adnan Çelik, Kariyer Yönetimi, Gazi Kitapevi, Ankara.

- $\quad$ ALTUNIŞIK, R., R. Coşkun, S. Bayraktaroğlu, E. Yıldırım (2007), Sosyal Bilimlerde Araştırma Yöntemleri: SPSS Uygulamal1, Sakarya Yayıncılık, Sakarya.

- ARGON, Türkan ve Altay Eren (2004), İnsan Kaynakları Yönetimi, Nobel Yayın Dağıtım, Ankara.

- BALTACI, Furkan ve Engin Üngören (2010), “Turizm Eğitimi Alan Öğrencilerin Eğitim Memnuniyetlerinin ve Geleceğe Yönelik Bakış Açılarının Belirlenmesine Yönelik Bir Araştırma”, 11. Ulusal Turizm Kongresi, Kuşadas1, s.312-323.

- BİRDİR, Kemal (2003), “Turizm ve Otel İşletmeciliği Eğitimi Alan Lisans Öğrencilerinin Turizm Endüstrisinde Çalışmayı Tercih Etmemelerinin Temel Nedenleri: Bir Nominal Grup Tekniği Araştırması”, Turizm Eğitimi Konferans-Workshop, Ankara, s. 495-504.

- BUYRUK, Lütfi (2009), "Turizm Lisans Eğitimi Alan Öğrencilerin Kariyer Beklentileri Üzerine Bir Araştırma", 10. Ulusal Turizm Kongresi, Mersin, s. 977-990.

- ÇIMMEN, Hürriyet (2008), "Turizm Lisans Öğrencilerinin Mesleki Yönelimleri: Akçakoca Turizm İşletmeciliği ve Otelcilik Yüksekokulu Örneği”, Anatolia: Turizm Araştırmaları Dergisi, Cilt 19, Sayı 2, s. 194-202.

- DEMİRBİLEK, Sevda (2007), "Cinsiyet Ayrımcılığın Sosyolojik Açıdan İncelenmesi”, Finans Politik Ekonomik Yorumlar, Cilt:44, Say1:511, s.317-339.

- EHTIYAR, Rüya, Engin Üngören (2008), "Turizm Eğitimi Alan Öğrencilerin Umutsuzluk ve Kaygı Seviyeleri İle Eğitimi Yönelik Tutumları Arasındaki İlişkilerin Belirlenmesine Yönelik Bir Araştırma”, Uluslar arası Sosyal Araştırma Dergisi, Cilt:1, Sayı:4, s.159-181.

- Gürkan Güney Çetin, D. Dönmez, D. KÜÇÜKALTAN (2010), “Turizm Alanında Eğitim Gören Öğrencilerin Kariyer Hedefleri: Ön Lisans Öğrencileri Üzerine Bir Araştırma”, 11. Ulusal Turizm Kongresi, Kuşadas1, s.351-363.

- GÜZEL, Tülay (2005), "Eğitim ve Gelişme, Editör: DEMİ, Cengiz, Konaklama İşletmelerinde İnsan Kaynakları Yönetimi: İlkeler ve Uygulamalar”, Nobel Yayın Dağıtım, Ankara, s.99-128.

- KOZAK, Meryem Akoğlan (2001), Konaklama İşletmelerinde Kariyer Planlaması, Anadolu Üniversitesi Yayınları, No. 1326, Eskişehir.

- KOZAK, Meryem Akoğlan (2004), Otel İşletmelerinde İnsan Kaynakları Yönetimi \& Örnek Olaylar, Detay Yayıncılık, Ankara.

- KÖK, Sabahat ve Muhsin Halis (2007), Kariyer Yönetimi, Orion Yayınevi, Ankara.

- MANKAN, Esra (2007), Toplam Kalite Yönetimi ve İşgören Verimliliğine Etkisi, Editör: ŞENTURAN, Şermin, Yönetsel ve Örgütsel Açıdan İnsan Kaynakları, Beta, İstanbul, s. 105-147.

- ÖZGEN, Hüseyin, A. Öztürk, A. Yalçın (2002), İnsan Kaynakları Yönetimi, Nobel Kitapevi, Adana.

- PATTON, Wendy ve Mary McMahon (1999), Career Development and Systems Theory, A new Relationship, Brooks/Cole Publishing CO., Pasific Grove.

- RONEY, Sevgin Akış ve Perin Öztin (2007), "Career Perceptions of Undergraduate Tourism Students: A Case Study in Turkey", Journal of Hospitality, Leisure, Sport and Tourism Education Cilt:6, Sayı:1, s. 4 -17.

- SCHREUDER, Amg ve Al Theron (1999), Careers: An Organizational Perspective, Juta Akedemic, South Africa.

- SERİNKAN, Celalettin, Esin Barutçu (2006), "Pamukkale Üniversitesi İIBbf Öğrencilerinin Kariyer Planları ve Sosyotropi-Otonomi Kişilik Özelliklerine İlişkin Bir Araştırma", Afyon Kocatepe Üniversitesi, İIBBF Dergisi, Cilt:8, Say1:2, s. 317-339.

- TÜRKAY, Oğuz, Burak Eryılmaz (2010), "Kariyer Değerleri ve Kariyer Yolu Tercihleri İlişkisi: Türk Turizm Sektöründen Örnekler”, Muğla Üniversitesi Sosyal Bilimler Dergisi (ILLKE), Bahar, Sayı: 24, s.179199. 


\title{
Firmaların Bankalara İlişskin Algılarında Sektörel ve Aylık İşlem Sayısı Farklılıklarının İncelenmesi
}

\author{
İbrahim Halil Ekşi (Kilis 7 Aralık University, Turkey) \\ Yavuz Akçi (Gaziantep University, Turkey)
}

\section{An Analysis of Differences in Firms' Perception of Banks based on Sectors and Number of Monthly Transactions}

\begin{abstract}
In this study, it was aimed to put forward the perception differences of banks, one of the most important tool of the capital market which is a political tool to develop financial improvement on owners and managers of firms. The data was collected by means of face to face meetings with the managers of 520 companies from manufacturing, trading and service sectors, randomly selected from Adana, Mersin and Gaziantep provinces. The relationship between the perception of banking services and the number of monthly transactions and provinces with the banks with which their firms have business activities was studied by analyzing the collected data and doing the frequency, percentage and ANOVA tests. According to the results of the analysis, even though there was no difference in terms of sectors, there was seen an important difference in terms of the number of monthly transactions and provinces. The satisfaction of different products and services for the firms having relatively fewer number of monthly transactions is also crucial today, when the customer satisfaction is of great importance.
\end{abstract}

JEL Codes: G21, M21, G32

\section{Giriş}

Bir ekonomide fon fazlası olan taraflardan toplanan atıl ve kullanılabilir fonların, üretken ve verimli alanlarda kullanılmak üzere fon ihtiyacı olan taraflara uygun şartlarla aktarılması fonksiyonunu yerine getirmesi gereken bankacılık sektörünün, büyüklük ve önemi giderek artmaktadır. Özellikle 1980 sonrası uygulamaya konulan reform politikaları sonrasında, sektörün karşılaştığı başlıca temel sorunlar; ekonomik istikrarsızlık, mali riskler, yüksek kaynak maliyeti, haksız rekabet koşulları, teknolojideki hızlı gelişmeler, öz kaynakların yetersizliği ve yeniden yapılanma sorunları seklinde sıralanabilir (Tunçsiper ve diğerleri, 2007). Bu sorunlara ek olarak yabancı bankaların pazardaki payının artması da sektörün karşılaştığı diğer bir gerçektir. İşte sayılan tüm bu nedenlerden dolayı, günümüzde bankalar arasındaki rekabet çok üst seviyelere çıkmıştır. Bankalar bu rekabet ortamında ayakta kalabilmek için hem müşterilere daha kaliteli hizmet vermek hem de müşterilerin algılarını anlamak durumundadırlar. Türkiye gibi gelişmekte olan ülkelerde faaliyet gösteren özellikle de KOBİ ölçeğindeki firmaların en önemli sorunlarının finansman ihtiyacı olduğu da göz önüne alınacak olursa (Bougheas vd., 2004; Wang, 2004; Ongena, 1999), bankaların firmaların kendileri hakkındaki algılamalarının önemini bir kez daha ortaya koymaktadır. Bu algılamada literatürde de incelenen aylık işlem sayısı ve sektör farklılıklarının etkili olup olmadığı çalışmamızın amacını oluşturmaktadır.

\section{2 İlgili Literatür}

Finans literatüründe firma - banka ilişkileri konusunda yapılan çalışmalarda, genellikle ya banka ilişkileri ile firma performansı arasındaki ilişkinin (Degryse ve Ongena, 2002 - Tsuru, 2001) ya da banka ilişkilerinde ölçeğin ve mali yapının etkisi (Ogawa ve diğerleri, 2007 - Karamustafa ve Karakaya, 2003 - Castelli ve diğerleri, 2009) incelenmiştir. Bunların dışında literatürde banka ilişkileri ile ilgili ulaşılabilen çalışmalar şunlardır:

- Öncü ve diğerleri (2010) çalışmalarında, banka müşterileri üzerinde yaptıkları anket çalışmasında, banka tercihlerinde etkili olan en önemli değişkenlerin sırasıyla; bankaların güvenilir olması, bankaların müşteri ilişkilerine verdiği önem ve bankaların mevduat faizlerinin yüksek olması sayılmıştır,

- Pala ve Kartal (2010), internet bankacılığını kullanan banka müşterileri üzerine yaptıkları anket çalışmasında, banka müşterilerinin internet bankacılığına yönelik tercihleri erişim ve kullanım kolaylığı, öğrenme kolaylığı, işlem çeşitliliği, bankanın internet sayfasındaki yetersizlikler, güvenlik, ödeme ve finansal işlemler ve hayat tarzı olmak üzere yedi boyutta ele alınmıştır,

- Taşkın ve diğerleri (2010) ise, Bursa'daki tüketicilerin banka tercihlerini incelenmiş ve banka tercihini etkileyen faktörler tespit edilmiş ve önem dereceleri ortaya konmuştur,

- Durer ve diğerleri (2008) ise, banka çalışanlarının ve müşterilerinin görüşleri doğrultusunda bankacılık hizmetlerinin sunulmasında elektronik dağıtım kanallarının önemini araştırdığı çalışmalarında, internet bankacılığının gerek çalışanlar ve gerekse müşteriler açısından günümüzde ve gelecekte en önemli dağıtım kanalı olduğu gözlemlenmiştir, 
- Yılmaz ve diğerleri (2007), kamu ve özel sektör bankalarının hizmet kalitesini karşılaştırmış ve müşterilerin bankaların verdiği hizmetlerin hepsinde beklentilerinin altında hizmet algıladıkları ortaya çıkmıştır.

Literatürdeki çalışmalarda, kısıtlı da olsa, ilişki sayısı faktörünün kullanıldı̆̆ı gözlemlenirken; faaliyet gösterilen sektörün banka algılamalarında farklılığa neden olup olmayacağı konusunda herhangi bir çalışmaya rastlanılmamıştır.

\section{Uygulama}

Çalışmanın uygulama kısmında, Akdeniz ve Güney Doğu Anadolu'daki 3 ilde faaliyet gösteren firmalardan anket yöntemi ile veriler toplanıp analiz edilmiştir.

\section{1 Ölçek ve Örneklem}

Verilerin toplanmasında, 3 tane tanımlayıcı, 5 tane de açıklayıcı olmak üzere 8 sorudan oluşan anket formundan yararlanılmıştır. Araştırmada 5'li Likert Ölçeği (5; Kesinlikle katılıyorum,... 3;Kararsızım,... $1 ;$ Kesinlikle katılmıyorum) kullanılmış ve cevaplayıcılardan sorulan her bir yargıya hangi derecede katılıp/katılmadıklarını belirtmeleri istenmiştir. Cevaplandırıcının, belirsiz bir duruma da dikkate alınarak, kararsızlık tercihi de anket formuna eklenmiştir.

Çalışmamızda, veri toplama aracı olarak kullanılan anket tekniğinin güvenilir ve geçerli bir teknik olduğu ve firmaların anket sorularına verdikleri cevapların geçerli ve güvenilir oldukları varsayılmıştır.

Anket formunda yer alan soruların tamamı için, Cronbach's Alpha değeri hesaplanmış ve $\alpha=0,739$ olarak bulunmuştur. Söz konusu değer, soru kâğıdının firmaların memnuniyet düzeylerini ölçmede geçerli ve güvenilir bir araç olduğunu göstermektedir.

Söz konusu anket formu, 1'i Güneydoğu Anadolu'dan, 2'si de Akdeniz Bölgesinden olmak üzere 3 ilde faaliyet gösteren firmalara tesadüfi örnekleme yöntemiyle uygulanmıştır. Anketler 2010 yılı Temmuz-Ağustos aylarında toplam 535 firmaya yüz yüze görüşme yöntemi ile uygulanmıştır. Ancak 15 firmanın anket sorularına verdikleri cevaplar eksik veya hatalı olduğundan çıkartılmış ve netice itibariyle 520 anket üzerinden değerlendirme yapılmıştır. İllerin seçiminde ilin bölge ekonomisindeki payı - büyüklüğü göz önüne alınmıştır. Anket verilerinden toplanan veriler, SPSS 16.0 paket programındaki veri kütüklerine aktarılmıştır. İl bazında anket yapılan firma sayısı aşağıdaki tabloda verilmiştir:

\begin{tabular}{|c|c|c|c|}
\hline \multicolumn{2}{|c|}{ ILLER } & Frekans & $\%$ \\
\hline 1 & Adana & 202 & 38,8 \\
\hline 2 & Mersin & 115 & 22,1 \\
\hline 3 & Gaziantep & 203 & 39,0 \\
\hline \multicolumn{2}{|c|}{ Toplam } & 520 & 100 \\
\hline
\end{tabular}

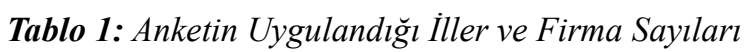

\subsection{Hipotezler ve Yöntem}

Çalışmanın amacı ve literatürdeki benzer çalışmalar doğrultusunda, test edilecek hipotezler aşağıdaki şekilde oluşturulmuştur:

- H1: Firmaların banka personelinin işlem süresine ilişkin algılarında sektörel bir farlılık vardır.

- H2: Firmaların banka personelinin davranışlarına ilişkin algılarında sektörel bir farlılık vardır.

- H3: Firmaların banka personelinin danışmanlık hizmetine ilişkin algılarında sektörel bir farlılık vardır.

- H4: Firmaların bankaların verdiği promosyonlara ilişkin algılarında sektörel bir farlılık vardır.

- H5: Firmaların bankaların sanal hizmetlerine ilişkin algılarında sektörel bir farlılık vardır.

- H6: Firmaların banka personelinin işlem süresine ilişkin algılarında işlem sayıları bakımından bir farlılık vardır.

- H7: Firmaların banka personelinin davranışlarına ilişkin algılarında işlem sayıları bakımından bir farlılık vardır.

- H8: Firmaların banka personelinin danışmanlık hizmetine ilişkin algılarında işlem sayıları bakımından bir farlılık vardır.

- H9: Firmaların bankaların verdiği promosyonlara ilişkin algılarında işlem sayıları bakımından bir farlılık vardır.

- H10: Firmaların bankaların sanal hizmetlerine ilişkin algılarında işlem sayıları bakımından bir farlılık vardır.

Oluşturulan hipotezlerin test edilmesi için tek yönlü varyans (ANOVA) analizi kullanılmıştır. Anova, iki veya daha fazla ortalama arasında fark olup olmadığını test etmekte kullanılır. Analiz, 1. tip hata oranını yükseltmeden ortalamaları karşılaştırmaktadır. Varyans analizlerinde eğer gruplar arasında anlamlı farklar bulunmuşsa, farklılıkların hangi gruplar arasında gerçekleştiğini tespit etmek amacıyla Post Hoc testleri kullanılmaktadır. Post Hoc testlerinde bir çok seçenek bulunmasına rağmen en sık kullanılan testler Tukey ve Benferronni testleridir. Bizim çalışmamızda da farklılıkların tespitinde Tukey testinden yararlanılmıştır. 


\section{Araştırmanın Bulguları}

\subsection{Frekanslar ve Ortalamalar}

Anketin uygulandığı firmaların karakteristik özelliklerinin toplu olarak gösterilmesi amacıyla, aşağıdaki tablo hazırlanmıştır:

\begin{tabular}{|c|c|c|c|c|c|c|c|c|c|c|}
\hline \multicolumn{4}{|c|}{ SEKTÖREL DAĞILIM } & \multicolumn{5}{|c|}{ IŞLEM SAYISI DAĞILIMI } \\
\hline SEKTÖR & Üretim & Ticaret & Hizmet & Toplam & iş̧LM & $1-25$ & $26-50$ & $51-100$ & $\begin{array}{c}101 \text { ve } \\
\text { üstü }\end{array}$ & Toplam \\
\hline Frekans & 99 & 256 & 165 & 520 & Frekans & 233 & 123 & 90 & 74 & 520 \\
\hline$\%$ & 19 & 49,2 & 31,7 & 100 & $\%$ & 44,8 & 23,7 & 17,3 & 14,2 & 100 \\
\hline
\end{tabular}

\section{Tablo 2. Firma Özellikleri}

Araştırma kapsamındaki firmaların karakteristik özelliklerine bakıldığında, genel itibariyle dengeli bir şekilde dağılım göstermektedir. Sektörel dağılım incelendiğinde firmaların yaklaşık yarısı ticaret sektöründe, \%19'u üretim ve \%31,7'si de hizmet sektöründe faaliyet göstermektedirler. Firmaların bankalarla yaptıkları aylık işlem sayıları incelendiğinde yaklaşık \%44,8'i ayda 25'ten defadan daha az işlem yaptıkları, \%23,7'si 25-50 arası işlem yaptıkları, \%17,3'ü 51-100 arası işlem yaptıkları ve \%14,2'sinin de aylık işlem sayısının 100'den fazla olduğu görülmüştür. Firmaların yaklaşık \%68,5'inin aylık işlem sayısı 50'nin altındadır.

Firmaların açıklayıcı anket sorularına verdikleri cevapların frekans dağılımları ve genel ortalamalarının incelenmesi amacıyla bağımlı değişkenlere ilişkin sorular 5'li skala şeklinde yapılmıştır. Ortalamaların yorumlanması için 5-1=4/5=0.80 formülüyle ortalamalar ve bunlar için kullanılacak katılma dereceleri belirlenmiştir. $1.00-1.80$ arası kesinlikle katılmıyorum, $1.81-2.60$ arası katılmıyorum, $2.61-3.40$ arası kararsızım, $3.41-4.20$ arası katılıyorum ve $4.21-5.00$ arası ise kesinlikle katılıyorum aralığına denk gelmektedir. Bulgular incelendiğinde bağımlı değişkenlere ilişkin cevapların ortalamalarının 2,88 ve 3,80 arasında dağıldığı görülmektedir. Ortalamalar incelendiğinde genel olarak firmaların bankaların hizmetleri ve personellerinden olan memnuniyet algıları "katılıyorum" derecesine denk geldiği görülmektedir. Bağımlı değişkenlere verilen cevapların ortalamaları ve bunlara karşılık gelen katılma dereceleri Tablo 3 'te verilmiştir.

\begin{tabular}{|c|c|c|c|c|c|}
\hline & Süre & Davranış & Danışmanlık & Promosyon & e-bankacılık \\
\hline $\mathrm{N}$ & 520 & 520 & 520 & 520 & 520 \\
\hline Ortalama & 3,52 & 3,73 & 3,61 & 2,96 & 3,70 \\
\hline Std. Hata & 1,269 & 1,146 & 1,154 & 1,394 & 1,203 \\
\hline $\begin{array}{c}\text { Katılma } \\
\text { Derecesi }\end{array}$ & Katıliyorum & Katılıyorum & Katılıyorum & Kararsızım & Katılıyorum \\
\hline
\end{tabular}

Tablo 3. Bă̆ımlı Değişkenlerin Ortalamaları ve Katılma Dereceleri

\begin{tabular}{|c|c|c|c|c|c|c|}
\hline Bağımlı değişken & Sektör & $\mathrm{N}$ & Ortalama & Std. Hata & $\mathrm{F}$ & Önem \\
\hline \multirow{4}{*}{ Personel Hizı } & Üretim & 99 & 3,707 & 1,127 & \multirow{4}{*}{2,071} & \multirow{4}{*}{0,127} \\
\hline & Ticaret & 256 & 3,531 & 1,243 & & \\
\hline & Hizmet & 165 & 3,382 & 1,377 & & \\
\hline & Toplam & 520 & 3,517 & 1,269 & & \\
\hline \multirow{4}{*}{ Personel Tutumu } & Üretim & 99 & 3,798 & 1,059 & \multirow{4}{*}{0,569} & \multirow{4}{*}{0,567} \\
\hline & Ticaret & 256 & 3,672 & 1,221 & & \\
\hline & Hizmet & 165 & 3,764 & 1,076 & & \\
\hline & Toplam & 520 & 3,725 & 1,146 & & \\
\hline \multirow{4}{*}{ Finansal Danışmanlık } & Üretim & 99 & 3,828 & 1,069 & \multirow{4}{*}{2,294} & \multirow{4}{*}{0,102} \\
\hline & Ticaret & 256 & 3,539 & 1,181 & & \\
\hline & Hizmet & 165 & 3,588 & 1,153 & & \\
\hline & Toplam & 520 & 3,610 & 1,154 & & \\
\hline \multirow{4}{*}{ Promosyonlar } & Üretim & 99 & 3,202 & 1,428 & \multirow{4}{*}{2,255} & \multirow{4}{*}{0,106} \\
\hline & Ticaret & 256 & 2,855 & 1,411 & & \\
\hline & Hizmet & 165 & 2,988 & 1,334 & & \\
\hline & Toplam & 520 & 2,963 & 1,394 & & \\
\hline \multirow{4}{*}{ Internet Bankacılığı } & Üretim & 99 & 3,869 & 1,131 & \multirow{4}{*}{1,766} & \multirow{4}{*}{0,172} \\
\hline & Ticaret & 256 & 3,609 & 1,193 & & \\
\hline & Hizmet & 165 & 3,733 & 1,255 & & \\
\hline & Toplam & 520 & 3,698 & 1,203 & & \\
\hline
\end{tabular}

Tablo 4: Sektör farklılıkları ile banka personeli ve hizmetleri arasındaki anlamlı farka ilişkin Anova Sonuçları 
Genel ortalamalar incelendiğinde anket sorularını cevaplayan firma sahipleri veya yöneticilerinin, Bankalarla yaptıkları işlemlerin süresinde, banka personellerinin tutum ve davranışlarında, finansal danışmanlık hizmetlerinde ve internet bankacılığı hizmetlerinde bankalarından memnun oldukları, bankaların verdiği promosyonlar konusunda ise ne memnun ne de memnun değil algısında oldukları görülmektedir.

\subsection{Hipotezlerin Test Edilmesi}

Firmaların faaliyette bulundukları sektörleri ve bankalarla yaptıkları aylık işlem sayıları arasındaki farklılıkların banka personeli ve hizmetlerine ilişkin algılarında etkili olup olmadığının anlaşılması için tek yönlü varyans (ANOVA) analizi uygulanarak hipotezler test edilmiştir. Öncelikle sektör farklılı̆̆ ile banka personeli ve hizmetlerine ilişkin farklılıkların analizi (diğer bir ifade ile, Ho1, Ho2, Ho3, Ho4 ve Ho5'in anova analizi) yapılarak Tablo 4'de verilmiştir. Daha sonra firmaların bankalarla yaptıkları aylık işlem sayıları ile banka personeli ve hizmetleri arasındaki farklılıkların analizi (diğer bir ifade ile, Ho6, Ho7, Ho8, Ho9 ve Ho9'un anova analizi ) yapılarak tablo 5 'te verilmiştir.

Firmaların faaliyette bulundukları sektörleri ile banka personeli ve hizmetlerine ilişkin algıları arasındaki anlamlı farkın belirlenmesi için yapılan Anova testinde; sektörlere bağlı algılamalar arasında anlamlı bir fark bulunamamıştır. Firmaların faaliyette bulundukları sektörleri farklı olsa bile banka personeli ve hizmetlerine ilişkin algıları benzerlik göstermektedir.

\begin{tabular}{|c|c|c|c|c|c|c|c|}
\hline $\begin{array}{l}\text { Bağımlı } \\
\text { değişken }\end{array}$ & İşlem sayısı & $\mathrm{N}$ & Ortalama & Std. Hata & $\mathrm{F}$ & Önem & Tukey \\
\hline \multirow{5}{*}{ Personel Hizı } & (I) $1-25$ & 233 & 3,330 & 1,296 & \multirow{5}{*}{3,759} & \multirow{5}{*}{, $011^{*}$} & \multirow{5}{*}{ I ve III } \\
\hline & (II) $26-50$ & 123 & 3,585 & 1,207 & & & \\
\hline & (III) 51-100 & 90 & 3,822 & 1,147 & & & \\
\hline & $\begin{array}{l}\text { (IV) } 101 \text { ve } \\
\text { üstü }\end{array}$ & 74 & 3,622 & 1,352 & & & \\
\hline & Toplam & 520 & 3,517 & 1,269 & & & \\
\hline \multirow{5}{*}{ Personel Tutumu } & (I) $1-25$ & 233 & 3,528 & 1,160 & \multirow{5}{*}{6,256} & \multirow{5}{*}{, $000 *$} & \multirow{5}{*}{ I ve III } \\
\hline & (II) $26-50$ & 123 & 3,732 & 1,222 & & & \\
\hline & (III) 51-100 & 90 & 4,111 & ,965 & & & \\
\hline & $\begin{array}{l}\text { (IV) } 101 \mathrm{ve} \\
\text { üstü }\end{array}$ & 74 & 3,865 & 1,051 & & & \\
\hline & Toplam & 520 & 3,725 & 1,146 & & & \\
\hline \multirow{5}{*}{$\begin{array}{c}\text { Finansal } \\
\text { Danışmanlık }\end{array}$} & (I) $1-25$ & 233 & 3,412 & 1,160 & \multirow{5}{*}{7,973} & \multirow{5}{*}{, $000 *$} & \multirow{5}{*}{$\begin{array}{l}\text { III ve I, } \\
\text { II, IV }\end{array}$} \\
\hline & (II) $26-50$ & 123 & 3,675 & 1,177 & & & \\
\hline & (III) 51-100 & 90 & 4,089 & ,979 & & & \\
\hline & $\begin{array}{l}\text { (IV) } 101 \text { ve } \\
\text { üstü }\end{array}$ & 74 & 3,541 & 1,137 & & & \\
\hline & Toplam & 520 & 3,610 & 1,154 & & & \\
\hline \multirow{5}{*}{ Promosyonlar } & (I) $1-25$ & 233 & 2,700 & 1,382 & \multirow{5}{*}{8,737} & \multirow{5}{*}{, $000 *$} & \multirow{5}{*}{$\begin{array}{l}\text { III ve I, } \\
\text { II, IV }\end{array}$} \\
\hline & (II) $26-50$ & 123 & 3,049 & 1,330 & & & \\
\hline & (III) 51-100 & 90 & 3,556 & 1,308 & & & \\
\hline & $\begin{array}{l}\text { (IV) } 101 \mathrm{ve} \\
\text { üstü }\end{array}$ & 74 & 2,932 & 1,427 & & & \\
\hline & Toplam & 520 & 2,963 & 1,394 & & & \\
\hline \multirow{5}{*}{$\begin{array}{c}\text { Internet } \\
\text { Bankacılığ } 1\end{array}$} & (I) $1-25$ & 233 & 3,438 & 1,282 & \multirow{5}{*}{9,189} & \multirow{5}{*}{, $000 *$} & \multirow{5}{*}{ I ve III } \\
\hline & (II) $26-50$ & 123 & 3,772 & 1,158 & & & \\
\hline & (III) 51-100 & 90 & 4,178 & ,978 & & & \\
\hline & $\begin{array}{l}\text { (IV) } 101 \text { ve } \\
\text { üstü }\end{array}$ & 74 & 3,811 & 1,069 & & & \\
\hline & Toplam & 520 & 3,698 & 1,203 & & & \\
\hline
\end{tabular}

Tablo 5: Aylık işlem sayıları ile banka personeli ve hizmetleri arasındaki anlamlı farka ilişkin Anova Sonuçları (*\%1 anlamlılık düzeyinde, grup ortalamaları arasında anlamlı farklılık olduğunu ortaya koymaktadır.)

Banka personelleri ve hizmetlerinden olan memnuniyet ile firmaların bankalarla yaptıkları aylık işlem sayıları arasındaki anlamlı farkın ölçülmesi için yapılan anova çözümlemesinde aşağıdaki durumlar gözlemlenmiştir;

- Firmaların bankalarla yaptıkları aylık işlem sayıları ile banka personellerinin işlem yapma hızları arasında anlamlı fark görülmüştür ( $\mathrm{p}=0,011)$. Farkın kaynağının belirlenmesi için yapılan Tukey testinde; aylık işlem sayısı 25'ten az olan firmalar ile işlem sayısı 51-100 arası olanlar arasında olduğu görülmüştür. Aylık işlem 
sayısı 25'ten az olan firmaların banka personellerinin işlem hızları sorusuna verdikleri cevapların ortalamaları 3,33 iken 51-100 arası olanların ortalamaları 3,82 olmuştur. Bu da işlem sayısı düşük olanların yüksek olanlara göre personelin daha yavaş işlem yaptıklarını göstermektedir.

- Firmaların bankalarla yaptıkları aylık işlem sayıları ile banka personellerinin tutumları arasında anlamlı fark görülmüştür ( $\mathrm{p}=0,000)$. Farkın kaynağının belirlenmesi için yapılan Tukey testinde; aylık işlem sayısı 25 'ten az olan firmalar ile işlem sayısı 51-100 arası olanlar arasında olduğu görülmüştür. Aylık işlem sayısı 25'ten az olan firmaların banka personellerinin tutumu sorusuna verdikleri cevapların ortalamaları 3,52 iken 51100 arası olanların ortalamaları 4,11 olmuştur. Bu da işlem sayısı düşük olanların yüksek olanlara göre personelin tutum ve davranışlarından daha az memnun olduklarını göstermektedir.

- Firmaların bankalarla yaptıkları aylık işlem sayıları ile bankaların finansal danışmanlık hizmetleri arasında anlamlı fark görülmüştür $(\mathrm{p}=0,000)$. Farkın kaynağının belirlenmesi için yapılan Tukey testinde; aylık işlem sayısı 51-100 arasında olanlar ile diğerleri arasında olduğu görülmüştür. Finansal danışmanlık hizmetlerine ilişkin sorulan soruya verilen cevapların ortalamaları incelendiğinde işlem sayısı 51-100 olanlar 4,09 olduğu diğerlerinin ise 4,00'dan düşük olduğu görülmektedir. Bu da işlem sayısı 51-100 arası olan firmaların bankaların finansal danışmanlık hizmetlerinden olan memnuniyetlerinin diğerlerine oranla daha fazla olduğunu göstermektedir

- Firmaların bankalarla yaptıkları aylık işlem sayıları ile bankaların verdikleri promosyonlar arasında anlamlı fark görülmüştür $(p=0,000)$. Farkın kaynağının belirlenmesi için yapılan Tukey testinde; aylık işlem sayısı 51-100 arasında olanlar ile diğerleri arasında olduğu görülmüştür. Finansal danışmanlık hizmetlerine ilişkin sorulan soruya verilen cevapların ortalamaları incelendiğinde işlem sayıs 51-100 olanlar 3,55 olduğu diğerlerinin ise 2,93 - 3,04 arasında olduğu görülmektedir. Bu da işlem sayısı 51-100 arası olan firmaların bankaların verdikleri promosyanlardan olan memnuniyetlerinin diğerlerine oranla daha fazla olduğunu göstermektedir

- Firmaların bankalarla yaptıkları aylık işlem sayıları ile internet bankacılığı hizmetleri arasında anlamlı fark görülmüştür ( $\mathrm{p}=0,000)$. Farkın kaynağının belirlenmesi için yapılan Tukey testinde; aylık işlem sayısı 25 'ten az olan firmalar ile işlem sayısı 51-100 arası olanlar arasında olduğu görülmüştür. Aylık işlem sayısı 25'ten az olan firmaların banka personellerinin işlem hızları sorusuna verdikleri cevapların ortalamaları 3,43 iken 51-100 arası olanların ortalamaları 4,17 olmuştur. Bu da işlem sayısı düşük olanların işlem sayısı 51-100 arasında olanlara göre daha az memnun olduklarını göstermektedir. Aylık işlem sayısı 1-25 arası olan firmaların internet bankacılığını kullanma oranlarının da bu sonuçta bir etkisi olabilir.

Anket uygulaması Adana, Gaziantep ve Mersin illerini kapsamaktadır. Banka personeli ve hizmetleri ile iller arasındaki anlamlı fark için yapılan anova testinde; Personel tutumu $(p=0,025)$ ve finansal danışmanlık hizmetleri arasında $(\mathrm{p}=0,042)$ anlamlı farklılıklar olduğu görülmüştür. Personelin işlem hızı, promosyonlar ve internet bankacılığında ise anlamlı farklar görülmemiştir. Farkların nedeni incelendiğinde farkın Gaziantep ve Mersin illeri arasında olduğu görülmüştür. Gaziantep firmalarının memnuniyet düzeyleri Mersin firmalarına göre daha düşük olduğu görülmüştür.

\section{Sonuç ve Politika Önerileri}

Finans piyasasının önemli oyuncularından biri olan bankaların kurumsal müşterilerin beklentilerini karşılayabilme, memnuniyet algılarını ölçebilmek amacıyla yapılan bu çalışma sonucunda; banka personellerinin sundukları hizmetler ile bankaların sunduğu hizmetlere ilişkin firma algılarında sektörlere göre anlamlı farklılıklar görülmemiştir. Farklı sektörlerdeki firmaların birbirine benzer algılara sahip oldukları görülmüştür. Aynı şekilde firmaların bankalarla yaptıkları işlem sayıları açısından değerlendirildiklerinde özellikle aylık işlem sayıları 50-100 arası olan firmaların genel itibariyle işlem sayısı 50'den az ve 100'den fazla olanlara göre daha pozitif bir algıya sahip oldukları görülmüştür. Ayrıca illere göre farklılıklar da incelendiğinde de Gaziantep'teki firmaların Mersin'deki firmalara göre daha negatif algıya sahip oldukları görülmüştür.

Sonuç olarak sektör farklılıklarının banka personeli ve hizmetlerine ilişkin algıda farklılık göstermediği, işlem sayısı farklılıkları ile il farklılıklarına ilişkin algıların ise anlamlı farklılıklar oluşturduğu görülmüştür. Bu araştırma sonuçlarından bankalar personel ve hizmet politikalarını belirlerken faydalanabilir. Özellikle işlem sayısı düşük firmaların memnuniyetlerinin düşük olması, bankaların dikkate alması gereken bir durumdur. $\mathrm{Bu}$ çalışma, gerek uygulama alanı ve gerekse banka mülkiyet yapılarına göre farklılaştırılarak, farklı açılardan test edilebilir.

\section{Kaynakça}

- $\quad$ Bougheas, S., Mizen, P. ve Yalçın, C.. (2004). Access To External Finance: Theory And Evidence On The Impact Of Firm-Specific Characteristics, Central Bank Of The Republic Of Turkey, Working Paper, Research Department No:04/06,

- Castelli, A., Dwyer, G. ve Hasan, I.. (2009). Bank Relationships And Firms' Financial Performance: The Italian Experience. Bank Of Finland Research Discussion Papers. 36, 
- $\quad$ Degryse, H. ve Ongena, S.. (2002). Bank-Firm Relationships And International Banking Markets. International Journal Of The Economics Of Business, 9(3): 401-417,

- Durer, S., Özsözgün, A. ve Akbaş, H. E. (2008). Bankacılıkta Elektronik Dağıtım Kanallarının Önemi: Banka Çalışanlarının Ve Müşterilerinin Görüşlerinin İncelenmesi, Öneri: Marmara Üniversitesi Sosyal Bilimler Enstitüsü Dergisi, 2008,8(30):9-17,

- Karamustafa, O. ve Karakaya, A.. (2003). Kobi-Banka İlişkileri Üzerine Ampirik Bir Çalışma - Araştırma. Muhasebe Ve Finansman Dergisi, 17: 85-93,

- Ogawa, K., Sterken, E. ve Tokutsu, I.. (2007). Why Do Japanese Firms Prefer Multiple Bank Relationship? Some Evidence From Firm-Level Data. Economic Systems, 31:49-70,

- Ongena, S.. (1999). Lending Relationships, Bank Default And Economic Activity. International Journal Of The Economics Of Business, 6(2): 257-280,

- OÖncü, M. A., Kutukız, D. ve Koçoğlu C. M. (2010). Hizmet Kalitesinin Ölçülmesi Ve Bankacılık Sektöründe Bir Uygulama, Muhasebe Ve Finansman Dergisi, 2010,(45):237-252,

- Pala E. ve Kartal B., (2010). Banka Müşterilerinin İnternet Bankacılığı İle İlgili Tutumlarına Yönelik Bir Pilot Araştırma, Yönetim Ve Ekonomi Yı1:2010 Cilt:17 Sayı:, 43-61

- Taşkın, Ç., Akat, ve Ö., Erol, Z., (2010). Tüketicilerin Banka Tercihini Etkileyen Faktörlerin Belirlenmesi: Bursa'da Bir Araştırma, Anadolu Üniversitesi Sosyal Bilimler Dergisi, 2010,10(3):11-22,

- Tsuru, K.. (2001). Bank Relationships And Firm Performance: Evidence From Selected Japanese Firms İn The Electrical Machinery İndustry. Rietı Discussion Paper Series 01-E-004-2001,

- Tunçsiper, B., Yılmaz G. ve İlban M. O., (2007). Türk Bankacılığı Sorunları Üzerine Bir Arastırma: Balıkesir Örneği, Dumlupınar Üniversitesi Sosyal Bilimler Dergisi, Say1: 17, 2007, Ss. 69-89.

- Yılmaz, V., Çelik H.E. ve Depren, B., (2007). Devlet Ve Özel Sektör Bankalardaki Hizmet Kalitesinin Karşılaştırılması: Eskişehir Örneği, Doğuş Üniversitesi Dergisi, 8 (2) 2007, 234-248

- Wang, Y.. (2004). Financing Difficulties And Structural Characteristics Of Smes İn China. China \& World Economy, 12(2):34-49 


\title{
Kümelenme Modeli ve Politikaları Çerçevesinde Bilgi Yapılanması ve Rekabet İlişsisi
}

\author{
Elif Haykır Hobikoğlu (Istanbul University, Turkey) \\ Müjgan Hacığlu Deniz (Istanbul University, Turkey)
}

\section{The Relationship between Innovation and Competition under the Framework of Clustering Model and Policies}

\begin{abstract}
Generally cluster aims to make all firms and corporates which belong to the same logistic chain to be professional about a specific area. Today Cluster Model which Michel Porter explain with the theory of Diamond is one of the main tools to be successful in international competition. Specifically cluster makes easier for corporates to be infront of their rivals by increasing efficiency, using advantages of geographical closeness and also with high specialization and providing important opportunities for high value-added products. Cluster policies have provided more efficient areas by means of highly competent regions for their firms. In this study, we have searched and analized the pre-requisite conditions for clusters and reasons behind them, the relationship between competition-venue and between innovation and clusters, also important actors in the process of cluster development. We have also explained the theorathical framework behind the concept of cluster and focus on the efficiency of clustering policies. In this framework, we try to put optimum sampes of cluster policies both in Turkey and the globe. Under the global competition and within the era of research and knowledge, it is so crucial for firms to pay attention for importance of clusters and their role in benefiting form advantages of cluster policies. As a result, we can say that nation states today need to develop a multi-dimensional and mutualinfluential national cluster policies in order to provide more appropriate manufacturing environment and innovative human capital for their national firms. Our study explains the reasons of this opinion by taking consideration of the realities of countries and some major industries with a number of real specific examples.
\end{abstract}

JEL Code: O31

\section{Giriș}

Michel Porter'ın elmas teorisi ile ortaya koyduğu kümelenme modeli uluslararası rekabette öne çıkmıştır. Kümelenme aynı tedarik zincirindeki kurum ve firmaların belli bir konuda uzmanlaşmalarını sağlayarak, yüksek uzmanlaşma ve coğrafi yakınlığın avantajlarından yararlanma yöntemi ile verimliliği arttırarak katma değer yaratma konusunda uygulama alanı sağlayarak rekabette önde olmayı kolaylaştırmıştır. Kümelenme politikaları rekabette üstün alanlar yaratarak verimli bölgelerin oluşmasına imkân sağlamıştır. Bilgi toplumunda rekabet avantajı sağlamak için kümelerin rolü ve önemi artmış. Bilginin oluşturulması, yayılması, kullanılması ekonomik büyümenin itici gücünü oluşturmaktadır. İnovasyon ile birlikte ele alınan kümelenme yaklaşımı bölgesel ekonomilerin gelişiminde önemli bir alternatif oluşturmuştur. Uzmanlaşmanın coğrafi boyutunun sağladığ1 avantajlar öne çıkmıştır. Sonuç olarak küresel rekabet şartları, ülkelerin etkileşimli ve çok yönlü bir ulusal kümelenme politikası geliştirilmelerini ülke gerçekleri ve uzmanlaşma becerileri doğrultusunda zorunlu kilmaktadir.

\section{Kavramsal Açıdan Kümelenme ve Kümelenme Modeli}

M. Porter uluslar arası rekabette önde olmak için avantaj sağlamanın aracını kümelenme olarak göstermektedir. Porter, kümelenmeyi “Aynı sektörde faaliyet gösteren, birbirleriyle işbirliği ve rekabet içinde olan firmaların (tedarikçiler, müşteriler, satıcılar) ilgili kurumlarla (üniversiteler, meslek kuruluşları, işkoluyla ilgili diğer kurumlar) aynı coğrafi alanda yoğunlaşmaları" olarak tanımlamaktadır. Kümelenme içinde işbölümü ve uzmanlaşmanın neden olduğu üretkenlik ve inovasyon Kobi’lere rekabet gücü kazandırmaktadır (Porter, 1990:1-9).

Storpe ise, bir ülkedeki spesifik bir ürünün dünya ihracatındaki payının o ülkenin toplam payından fazla olmasının o ülkenin o ürün konusunda bir uzmanlaşmaya sahip olduğunun göstergesi olduğunu ve küresel krizlerin çözümünün lokal işbirliklerinin sağlandığı kümelenme çözümünden geçtiğini savunmaktadır. (Storper,2003;60-90)

Kümelenmenin maliyet düşürücü etkisi firmalara küresel rekabet gücü kazandırmaktadır.

Küme ağı, öğrenmeyi hızlandırarak, işlem maliyetlerini azaltarak, işletme düzeyinde maliyetlerin düşmesine sebep olarak ortak bilgi havuzundan kombine yararlanmaya katkıda bulunmaktadır. (Hertog,1999;74-76)

Küme, firmalara küresel rekabet gücü kazandırarak ihracat ile döviz girdisiyle makro iktisadi etki yapmaktadır. 
Kümelenmenin maliyet minimizasyonu ile sağladığı mikro iktisadi avantaj, girişimcilik artısıyla istihdama pozitif katkı yapmaktadır. Ulusal kümelenme politikaları, kalkınmanın unsuru olarak iktisadi politikalar içinde yer almaktadır. (Khan and Ghani, 2009;220-239)

Smith ve Ricardo'nun belirttiği rekabet üstünlüğü sağlayan avantajların günümüzde ki karş1lığg olan kümelenme, ekonomik krizlere çare olabilecek bir yöntem sağlayabilir. Kümelenme sistemi Marx'ın iş bölümü ve uzmanlaşma teorisinin yanı sıra teknolojiyi de içine alan işbölümü süreçlerini de içermektedir. Nüfus artısı, teknolojik gelişmeler, bilgi gelişimi, iletişim hızı temel teorilerle bağlantısını "Kümelenme" ile kurmaktadır. Çünkü küme piyasası belirtilen unsurları kullanarak maliyetleri düşürüp istihdamı artırmakta, döviz girdisi ve reel gelirde artışa neden olmaktadır. Maliyet artışlarının, maliyet enflasyonu sonucu reel geliri azalttığı ve fiyatları arttırdığı bilinmektedir. Küme tablosunda kümelenme evrensel kümesi ve alt kümelerinin gösterimin formulize edilmesi su şekildedir; Kümelenme etkisi $=\{\{$ Mikro İktisat\} U \{Makro İktisat\} U \{ Uluslararası İktisat \} U \{ Kalkınma İktisadı\} \} şeklindedir. Kümelenmenin yukarıdaki formülde gösterilen iktisadi etkilerinden dolayı, ulusal iktisadi politikalarda "Kümelenme Etkisi” dikkate alınmalıdır. (İrhan, 2010, 87)

Brenner ve Mühlig kümelerin doğuşunu etkileyen unsurları ortaya çıkarmak için 2006 yılında önemli bir çalışma yapmıştır. Çalışmada altı kıtadan otuz iki ülkeden on yedi sektörden toplam 159 küme incelenmiştir. (Brenner ve Mühlig, 2007:20-22)

Araştırmada, uzmanlaşmış istihdam yapısına olan ihtiyaç, kümeninin doğuşunu hazırlayan en önemli unsur olarak karşımıza çıkarken, ücret, bölgesel özellikler, teknokent ve teknopark konuları önem sırasında alt bölümlerde yer almıştır.

Küme oluşumunu uyaran unsurlara baktığımızda geçmiş olayların etkisinin önemsiz olduğunu, çekici firma olma motivasyonunun da önemli bir uyaran olduğunu görmekteyiz.

\section{Kümelerde Bilgi Yapılanmasının Etkileri}

Kümelerde genişleyen bilgi tabanı bilginin yayılmacı özelliğini geliştirerek bilgiyi açık bir mal haline getirir. Kümeler bilgiyi kullanırken hem coğrafi yakınlık kavramını hem de organizasyonel bilgiyi kullanarak taşınabilir bilgiyi alabilme kabiliyetinin gelişmesine önem vermektedirler. Coğrafi yakınlık girdi maliyetlerini azaltarak işbirliği alanlarını güçlendirerek rekabet avantaji sağlar.Ayrıca coğrafi yakınlık ani değişimler karşısında esneklik geliştirmeyi sağlayarak dikey ilişkilerin güçlenmesini sağlar. İşletmeler en iyi yaptıkları işte uzmanlaşarak işbölümü dolaşımını geliştirirler. Parça bilgi ve mimari bilgi ayırımı kümelerde bilgi yapılanmasının iki temel unsurudur. Parça bilgi bütüne ait bir bilgi değil kaynak, özellik ve teknolojiye ait bir bilgidir. Parça bilgi dolaşabilir, bütünün bir parçasının özelliklerini taşır, dış koşullara bağlıdır, tekniktir, şeffaftır, benzer özellikteki işletmeler arasında dolaşımı daha kolaydır. Mimari bilgi ise işletmeyi diğer işletmelerden ayıran özellikler tarafından belirlenir. Mimari bilginin dolaşımında güven önemli bir unsurdur, dolaşımı kısıtlıdır, kapalıdır, belirgin özellikler taşımamaktadır, kuruma özgüdür, ait olduğu sisteme bağımlı bir yapı içerir. Mimari bilgi tren you iken, parça bilgi taşınan kargodur. (Tallman,2004;256-272)

\begin{tabular}{|c|c|c|c|c|}
\hline $\begin{array}{c}\text { Önem } \\
\text { Sırası }\end{array}$ & $\begin{array}{c}\text { Kümenin Doğuşunu Etkileyen } \\
\text { durumlar }\end{array}$ & Önemli & Önemsiz & Cevapsız \\
\hline 1 & Uzmanlaşmış İstihdam Yapısı & 105 & 10 & 44 \\
\hline 2 & Network & 78 & 37 & 44 \\
\hline 3 & Üniversite ve Eğitim Kurumları & 70 & 22 & 67 \\
\hline 4 & $\begin{array}{c}\text { Geçmişten Gelen Tarihsel } \\
\text { Gerekçeler }\end{array}$ & 66 & 0 & 83 \\
\hline 5 & Kurumsal Sistem & 61 & 2 & 96 \\
\hline 6 & Altyapı Unsurları & 52 & 10 & 97 \\
\hline 7 & Kültür Unsurları & 52 & 14 & 93 \\
\hline 8 & Coğrafi Unsurlar & 51 & 2 & 106 \\
\hline 9 & İç Talep & 49 & 20 & 90 \\
\hline 10 & İç Politikalar & 47 & 8 & 104 \\
\hline 11 & Lojistik unsurlar & 43 & 13 & 103 \\
\hline 12 & Yaşamsal Nitelik & 31 & 18 & 110 \\
\hline 13 & Sermaye Piyasası & 30 & 16 & 113 \\
\hline 14 & Ücret & 23 & 10 & 126 \\
\hline 15 & Bölgesel Özellikler & 21 & 0 & 138 \\
\hline 16 & Teknoparklar ve Teknokentler & 21 & 9 & 129 \\
\hline
\end{tabular}

Tablo1: Kümenin Doğuşunu Etkileyen Unsurlar. Kaynak: Brenner ve Mühlig 


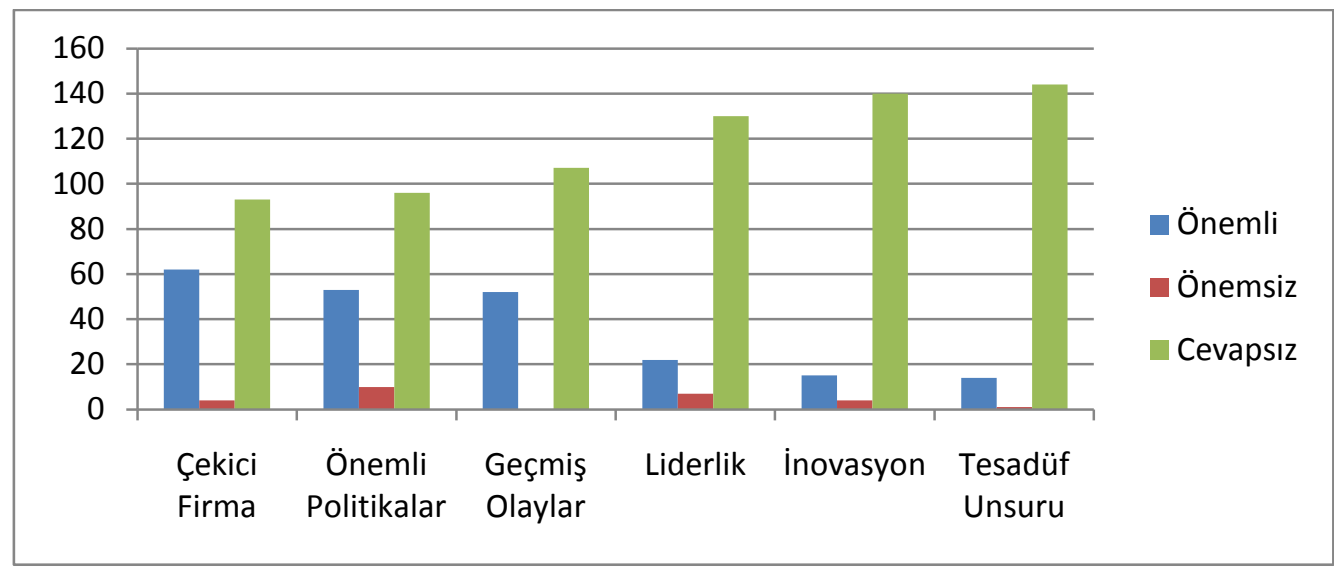

Şekil 1: Küme Oluşumunu Uyaran Unsurlarç Kaynak: Brenner ve Mühlig

\section{Kümelenme Politikaları}

Kümelenme politikaları kobilerin rekabet gücünün geliştirilmesi, bölgesel kalkınmanın sağlanması, kaliteli üretimin gerçekleşmesi, inovasyona dayal gelişimin oluşması rekabet gücü ve ihracatın artmasını sağlamak amaçlı arçlardan oluşmaktadır.Gelişmekte olan ülkeler küresel rekabette yer bulabilmekk için küme politikaları geliştirmektedir. Küme politikaları mikro ve makro ölçeklidir.Küme altyapı, finans ve eğitim yatırımları her kurumun yararlanabileceği yatırımlardandır, bu yatırımlardan bir grubun yararlanması başka bir grubun yararlanmasını engellemeyerek etkin bir alan oluşturmaktadır. (Türkkan, 2009)

Kümeler piyasa aktörlerini birbiriyle ilişkilendirir, ortak arge ve ticarileştirme çalışmaları gerçekleştirir, kollektif hizmetler sunarak iş bağlantıları gerçekleştirir. Kümelenme politikaları doğrudan yabancı yatırım ve ihracatın arttırılması, stratejik endüstrilerde kaliteli emek gücünün geliştirilmesi, arge işletme bağlantısının korunarak çıkan sonuçların üretime dönüştürülerek ticarileştirilmesi gibi amaçlar içermektedir.

\begin{tabular}{|l|}
\hline Risk sermayesi finansmanını destekleyen program ve yasaların hayata geçirilmesi \\
\hline Destek hizmetleri için teknoloji transferinin sağlanması \\
\hline Fikri ve Sınai mülkiyet haklarınınkorunması \\
\hline Sanayi -üniversite işbirliğinin desteklenmesi \\
\hline Uzmanlaşan mesleki eğitim desteğinin sağlanması \\
\hline İhracat ağlarının geliştirilip etkinleştirilmesi \\
\hline Küme haritalandırma çalışmalarını etkinliğinin sağlanması \\
\hline Şirketler arası ağ kurumunun gerçekleştirilmesi \\
\hline Piyasa istihbaratını gerçekleştirilmesini sağlayan sistemlerin kurulması \\
\hline Alıcı satıcı aracılık hizmeti sağlayan kurumların etkinleştirilmesi \\
\hline Teknik standartların belirlenmesi \\
\hline Uluslarası düzeyde piyasa bilgisine ulaşımı salyan sistemlerin kurulması \\
\hline Değerlendirme sisteminin kurulması \\
\hline Beraber çalışacak işletmelerin belirlenmesini sağlayan sistemlerin kurulması \\
\hline Kobiler için iş geliştirme desteğinin sağlanması \\
\hline Küme ve bölgenin pazarlanması \\
\hline Çalışma ortağı arayışlarının değerlendirileceği sistemin kurulması \\
\hline Tedarik zinciri için bağlantı yardımının sağlanması \\
\hline Etkileşimi sağlamak için farklı piyasa aktörlerinin aynı cŏrafi bölgeye yerleştirilmesi \\
\hline Emek piyasasına dair bilginin toplama ve kullanımını sağlayacak sistemler geliştirme \\
\hline
\end{tabular}

Tablo 2: Kümelenme Politikası Araçlart. Kaynak: OECD, Competitive Regional Clusters: National Policy Approches

\section{Dünyada Başarılı Küme Örnekleri}

Fransa Grenoble kümesi, entegre devre ve yarı iletkenler konusunda uzmanlaşarak 307 milyar Euroluk hacme, 153 patente, 97.000 çalışan ulaşmıştır. Her yıl 6000 öğrenci, 400 araştırmacı Grenoble bölgesinde uzmanlaşma imkanı yakalamaktadır. (Europe Innova, 2008, 23-25)

İrlanda bilişim hizmetleri kümesi,114 milyar dolarlık bir hacme ulaşmış ve 165 bin iş alanının açılmasına olanak tanımıştır. Kümelenme \% 40 oranında maliyet avantajı sağlayarak başarıya ulaşmıştır. Bu noktada RDA İlanda Bölgesel Kalkınma Ajansının önemli katkıları olmuş, IBM, Microsoft, Lotus yatırımlarını bölgeye 
taşımalarında etkili ollmuştur. (Europe Innova, 2008; 30-33)

Viyanada Best of Biotech(BOB) biyoteknoloji alanında girişimcilik teşviki vererek şirketlerin desteklenmesini sağlamaktadır.

Finlandiya bilgi ve iletişim teknolojileri konusunda telekominikasyon ekipman üretimi alanında başarılı bir küme örneği sergilemiştir. Finlandiya'da bilgi ve iletişim teknolojileri üretimindeki katma değer \%35 oranında büyümüş, 1998 de kümelenmenin GSYİH'daki payı ise \%6.6 olmuştur. (Paija, 2001;19)

İrlanda Galway şehrinde ve çevresindeki yazılım kümelenmesinin içinde bulundurduğu Nortel işletmesi ile ön plana çıkmıştır. İrlanda'da 2003 yılında yazılım sektöründeki istihdam iki katına çıkmıştır.

Danimarka elektronik, telekominikasyon, radyo-tv yayıncılığı ve bilgi eğlence alanlanlarında donanım, üretim, toptan satış, tamir, içerik uygulama aşamalarında yoğunlaşan bir kümelenme sisteminde başarı göstererek, ihracatının \% 55'ini elektronik, \%22'sini radyo- tv yayıncılığı, \%1'ini bilgi eğlence ve \% 9'unu da telekominukasyon sektöründe yoğunlaştırmıştır. (Dahl ve Dalum, 2001;87)

Uzakdoğu'da Tayvan Hsinchu Bilim Parkın'da ileri teknoloji kümesi bölgede güçlü bir yapı oluşturmuştur. Hindistan'da Bangalore Bölgesi Kümesi bioteknoloji, yazılım bilgi teknolojileri konusunda Biocon, Motorola, Hewlwtt Packard gibi şirketleri bünyesinde barındırarak önemli bir açılım sağlamıştır. Kore'de ise Gangham bilgi ve iletişim teknolojileri kümesi önemli başarılar sağlamıştır. (Park,2008:195-196)

Hollanda'da multimedya kümelenme çerçevesinde multimedya altyapısı oluşturan faaliyetler (Biligi ve iletişim teknolojileri donanım, yazılım, üretimi, tasarım, iş danışmanlığı), içerik dağıtımı (elektronik altyapısı yolu ile dağıtım sağlayıcılığı), içerik sağlama (radyo-tv yayıncılığı, eğlence yayıncılığı), e-pazarlama (medya edinme ve pazarlama iletişimi) gibi faaliyetlerde etkinlik gösteren genç bir kümelenmedir. Multimedya kümesinin bazı kısımları sosyal ve bölgesel ağlarla tanımlanmaktadır, eğitim ortamları, küme toplantıları gibi alanlarda çalışma alanları ortak olan kişiler karşılaşarak yakın bir platformda bilgi alışverişi yapma olanağına kavuşurlar. Bu konularda Amsterdam Yeni Medya Birliği, Eindhoven Multimedya Birliği, Tewente'de Teleport Vakfı kümelenme konusunda önemli görevler üstlenmiştir. Ayrıca Amsterdam, Enschede ve Eindhovenda Ekonomik İşler Bakanlığı tarafından finanse edilen kuluçkalık merkezleri bulunmaktadır. (Hertog ve Maltha, 2001,186-195)

Norveçte tarım-gıda kümelenmesi GSYİH'nın yaklaşık \% 10'unu temsil etmektedir. Norveç gıda kümelenmesi balık temelli deniz ürünleri, süt ürünleri, tahıl temelli gıdalar ve içecek ürünleri olmak üzere temellenmişti.Norveç gıda üretim sistemi ülkedeki en büyük ve en etkin kümedir. (Hauknes, 2001;217-233)

İsviçre'de inşaat sektörü kümelenmesi istihdam bakımından oldukça önemli bir orana sahip olmuştur. 1.1 milyar CHF cirosu ile Geberit grubu 4300 kişiyi istihdam etmektedir. Holderbank çimento, çakıl ve betonda 11 milyar CHF cirosuyla önemli bir küme kuruluşudur. (Vock;,2001,319-324)

Brezilya'da Sinos Vadisi ayakkabı ve deri ürünlerinin yoğunlaştuğı küme ile dünyanın en büyük üçüncü ayakkabı ihracatçısı olarak pazar payını 20 sene içerisinde \% 12'ye çıkartmıştır.

\section{Avrupadaki Kümeleşmiş ve Kümeleşmemiş Firmaların Karşılaştırılması}

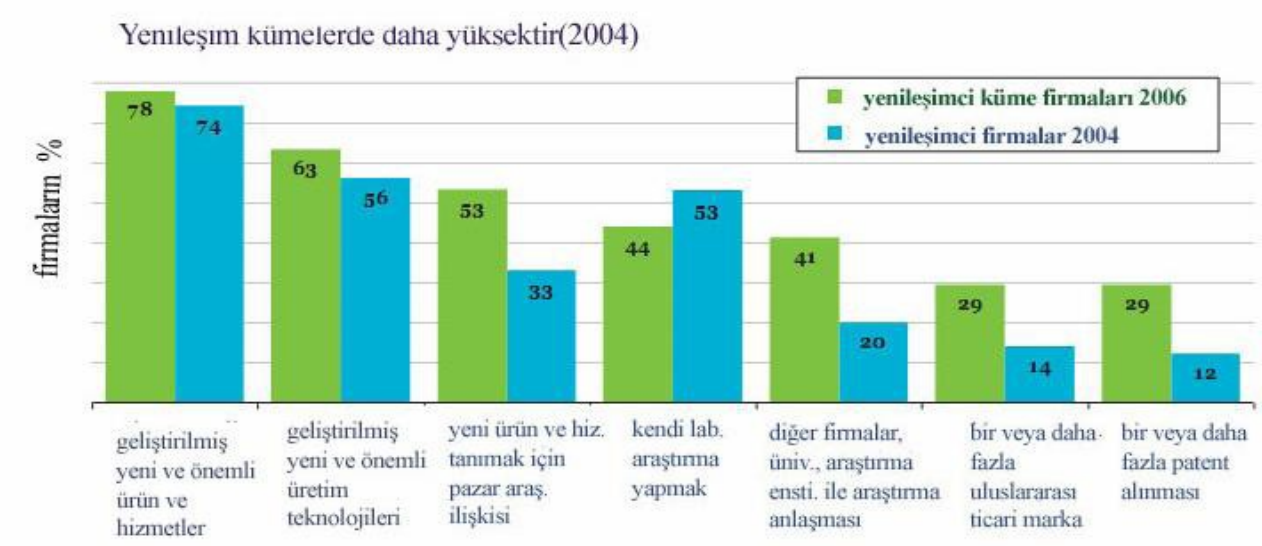

Şekil 2: Inovasyon Faaliyetleri Açısından Avrupa'daki Kümelenmiş ve Kümelenmemiş Firmaların Karşılaştırılması. Kaynak: www.inovasyon.org.

Avrupa'da faaliyet gösteren kümelenmiş ve kümelenmemiş firmaların karşılaştırmasına gösteren şekilde de görüldüğü gibi kümelenmiş firmalarda, geliştirilmiş yeni ve önemli ürün ve hizmetler, üretim teknolojileri bu ürünlerin tanıtılması için pazar araştırması, laboratuar araştırmaları, üniversite işbirliğinin sağlanması ve patent alım oranları daha yüksektir. $\mathrm{Bu}$ da göstermektedir ki inovatif faaliyetlerin varoluş alanları kümelenme faaliyetlerinin doğası ile daha uyumlu bir gidişat sergilemektedir. 


\section{Türkiye'de Kümelenme Politikalarının Çerçevesi}

Türkiye'de 2000 yılında Lizbon Stratejisi ile kümelenme alanındaki çalışmalar yoğunlaşmıştır. Devlet Planlama teşkilatının hazırladığı 9. Ulusal Kalkınma Planı bölgesel kalkınmanın teşviki ve inovasyon yolu ile katma değeri yüksek ürünlerin üretimine geçilmesi üzerinde durmaktadır.

Tükiye'de rekabet avantajı taşıyan sektörlerin geliştirilerek ulusal kümelenme politikasına temel teşkil etmesi ve sürdürülebilir ihracat artışını sağlayacak rekabetçi yapının geliştirilmesine katkı sağlaması amacıyla, 2 yıl süreli "Ulusal Kümelenme Politikasının Geliştirilmesi Projesi” hazırlanmış ve Avrupa Birliği (AB) Katılım Öncesi Mali Yardımları kapsamında 6 Milyon Euro finansman sağlanarak; Sanayi ve Ticaret Bakanlığı, Tarım ve Köyişleri Bakanlığı, Maliye Bakanlığı, Kültür ve Turizm Bakanlığı, Devlet Planlama Teşkilatı, Hazine Müsteşarlığı, Kosgep, Tubitak gibi kurumların işbirliğinde bir çalışma yapıllmıştır. (www.bodto.org.tr)

Kümelenme projesi ile kümelenme konusunda temel bir çerçeve oluşturulmuş, işbirliği konuları irdelenmiş ve desteklenmiştir. Türkiye'de kümelenme konusunda yapılan etkin çalışmalar Europen Cluster Allience üyeliği sağlanmıştır. Türkiye'de ulusal kümelenme politikasının geliştirilmesi ile temel olarak firmalar arası işbirliği imkanları geliştirmesi, yabancı sermayenin için çekici bir ortamın hazırlanması, inovatif faaliyetlerin arttırılması, ölçek ekonomilerinin yaratılması, bölgesel ve ulusal düzeyde rekabet gücünün arttırılmasına yönelik altyapının oluşturulması hedeflenmiştir.((www.bodto.org.tr)

\begin{tabular}{|c|c|}
\hline Pilot Kümeler İl & Sektör \\
\hline Kayseri & Mobilya \\
\hline Gaziantep & Makine Halısı, Ayakkab1 \\
\hline Kahramanmaraş & Tekstil \\
\hline Sivas & Doğal Taşlar \\
\hline Yozgat & Mobilya \\
\hline Trabzon & Dişlemeçiliğgi Ticat İşlemleri \\
\hline Samsun & Kayısı \\
\hline Malatya & Kış Turizmi \\
\hline Erzurum-Kars & Turizm \\
\hline Mardin & Makine \\
\hline Çorum & İşlenmiş Gida İş Kümesi \\
\hline Mersin & Yazılım İş Kümesi \\
\hline Ankara & Ev Tekstili İş Kümesi \\
\hline Denizli-Uşak & Otomotiv Yan Sanayii Kümesi \\
\hline Konya & Yat Üretimi ve Yat Turizmi İş Kümesi \\
\hline Muğla & Organik Gıda İş Kümesi \\
\hline İzmir & Otomotiv İş Kümesi \\
\hline Marmara & Slektrik Elektronik Aletler İş Kümesi \\
\hline Manisa & Seramik İş Kümesi \\
\hline Eskişehir-Bilecik-Kütahya &
\end{tabular}

Tablo 3: Türkiye'de Bölgesel Rekabet Edebilirlik Operasyonel Programı Kapsamında Öne Çıkan ve Yol Haritası Belirlenen ve Hazırlanan Kümeler. Kaynak: Ulusal Kümelenme Politikasının Geliştirilmesi Projesi Basın Bildiri Notu

Türkiye'nin rekabet gücü önceliklerinin yerel bazda belirlenmesi kümelenmenin etkinliğini artıracak politikalar oluşmasını sağlayacaktır. Şehirlerin rekabette üstün oldukları özelliklerin güçlendirilmesi sanayi politikalarının etkinliğini arttırarak bölgesel kalkınmanın önceliklerini belirleyerek temel kümelenme haritasının etkinleşmesinde rol oynayacaktır.

Kümelenme stratejisinin oluşturulması kapsamında Kayseri ve Yozgat mobilya sektöründe, Erzurum, Kars, Muğla turizm konusunda, Marmara Bölgesi ve Konya otomotiv sektörü konusunda, Mersin işlenmiş gıda konusunda temel kümelenme alanları oluşturulması açısından rekabette önceliklerin belirlenmesini sağlayarak potansiyel faydaların etkinleştirilmesi konusunda öncü pilot bölgeler oluşturmuştur.

\section{Sonuç}

Kümelenme, işletmelerin verimliliğini arttırır, yeniliklerin ortaya çıkmasını ve palazlanmasını sağlar ve ticarileşme sürecini hızlandırarak rekabette üstünlük sağlar. Küreselleşmenin etkisiyle yerel kaynakların sağladığı bilginin alternatif oluşturarak rekabette önde olmayı sağladığı bir yöntem olan kümelenme temel bir politika aracı olmuştur. Rekabette önde olmaya programlanmış günümüz ekonomisi küresel trendlerin takip edildiği, yerelden yararlanma sisteminin doğru politikalarla desteklenmesi önemli açılımlar sağlamaktadır. Aynı ve birbirini tamamlayan ürünleri üreten üreticilerin bir araya gelerek ortak bir paydada buluşmaları ortak 
etkinlikleri kolaylaştırarak dinamik ve etkileşimli bir yapının oluşmasını sağlayacaktır. Dünya'da ve Türkiye'de görülen başarılı küme örnekleri devlet, üniversite ve araştırma kurumları, girişimciler ve finansal kurumların işbirliği ile doğru sonuçları vermektedir. Kümenin bileşenleri arasında öğrenme ve etkileşim ortamının sağlanması, nitelikli işgücüne ulaşımın kolaylaşması, ortak ar-ge faaliyetleri sonucu araştırma faaliyeti maliyetlerinin düşmesi, sektörle ilgili tüm tedarikçilerin bir arada bulunmasını sağladığı zaman ve maliyet avantajı önemli faydalar sağlayarak zorlu küresel rekabet koşullarında bir açılım sağlamaktadır. Girişimcilerin önündeki yasal ve fiziki engellerin kaldırılmasına olanak sağlayacak bilgilendirme ofislerinin kurulması ve finansal zorlukların yeni iş fikirlerinin önünde zorluk teşkil etmesini önleyecek kuluçkalıların ve risk sermayesi kuruluşlarının kurularak işlerlik kazandırılması önemli bir rekabet destekleyicisi olarak kümelenme faaliyetinin ülkede gelişmesini sağlayacaktır.

\section{Kaynakça}

- Altan Akarsoy, Tülay(2011), 'Küme ve Kümeleşme”, Ankara

- Brenner ,Thomas ve Andre Mühlig(2007), "Factors and Mechanisms Causing the Emergence of Local Industrial Clusters", Papers on Economic and Evolution, Ed.Evolutionay Economics Group, No:0723, Germany.

- Dahl, Michael ve Dalum Bent,(2001) ‘'Danimarka'da BİT Kümelenmesi”, Yenilikçi Kümelenmeler, OECD Yayınları

- Europe Innova (2008), Case Studies of Clustering Efforts in Europe: Analysis of their Potential for Promoting Innovation and Competitiveness, Preliminary Draft, Stockholm, Cluster Publications

- European Commision(2006), Innobarometer on Cluster's Role in Facilitating Innovation in Europe 2006

- Hauknes, Johan (2001), 'Norveçte Tarım- Gıda Üretiminde Yenilikçilik” Tarzları, Yenilikçi Kümelenmeler, OECD Yayınları

- Hertog, Pim Den (1999), Cluster Analysisand Cluster Based Policy Making in OECD Countries: an Introduction to The Theme, BoostingInnovation: The Cluster Approach, OECD, Paris,p.74.

- Hertog, Pim, Maltha, Swen (2001), Hollanda MultimedyaKümelenmesi, Yenilikçi” Kümelenmeler, OECD Yayınları

- İrhan, Bayram. H(2010), Kümelenmenin Teorik Temelleri ve İktisadi Etkileri, Sosyal Bilimler Ddergisi(2),83-88, www.iudergi.com/tr/index.php/sosyalbilimler/article, Erişim Tarihi:23 Mayıs 2011

- Khan, Javed and J.A. Ghani; (2009), "Clusters and Entrepreneurship: Implications for Innovation in a Developing Economy” Journal of Development Entrepreneurship, 9(3), Manchester- UK, pp. 221-238.

- OECD(2007), Competitive Regional Clusters: National Policy Approches, Reviews of Regional Innovation, OECD Publishings, 2007, s92-93

- Paija, Laura(2001), BİT Kümelenmesi, Yenilikçi Kümelenmeler, OECD Yayınları

- Park Ork, Sam(2008),, "ICT Clusters and Industrial Restructuring of Korea: The Case of Soul”, Growing Industrial Clusters in Asia: Serendipity and Science, Edited by Shahid Yusuf, Washington, Word Bank

- Porter, Micheal; (1990), The Competitive Advantage of Nations, The Free Press, New York, pp.1-10.

- Storper, Michael(2003)The Limits to Globalization :Technology Districts and International Trade, Economic Geography, Vol.68, No:1, Oxford University pres, United Kingdom

- Tallman, Stephen(2004), Knowledge Clusters and Competitive Advantage, Academy of Management Review, CX:24, No:2, Nisan

- Thomas Brenner ve Andre Mühlig(2007)," Factors and Mechanisms Causing the Emergence of Local Industrial Clusters, Papers on Economic and Evolution, Ed.Evolutionay Economics Group, No:0723, Germany

- Türkkan, Erdal(2009), Sektörel ve Bölgesel Kümelerin Etkinlik Kazanmasındaki Rekabet Sürecinin Rolü, Rekabet günlüğü,www.rekabet.gov.tr

- Vock, Patrick(2001), İsviçre İnşaat sektörü kümelenmesi, Yenilikçi Kümelenmeler, OECD Yayınları

- "Ulusal Kümelenme Politikasının Geliştirilmesi projesi Basın Bildiri Notu" www.bodto.org.tr/images/other/kumelenme_kapanis_etkinligi_basin_\%20bilgi_\%20notu.pdf. Nisan 2011

- $\quad$ www.inovasyon.org, erişim tarihi: Nisan 2011 


\title{
2005-2009 Döneminde Kırgızistan Ekonomisindeki Yapısal Değişimin Girdi-Çıktı Analiziyle İncelenmesi
}

\author{
Tuncer Özdil (Kyrgyzstan-Turkey Manas University, Kyrgyzstan) \\ Ainura Turdalieva (Kyrgyzstan-Turkey Manas University, Kyrgyzstan)

\section{An Analysis of Structural Changes in Kyrgyz Economy using Input-Output Technique (2005-2009)}

\begin{abstract}
Structural changes in economy become the important goal of economic development in the developing countries. During the ongoing globalization process, the successful execution of special analysis and approaches caused the growing interest in macroeconomic planning and development policies. In this context, input-output analysis is emerging as an alternative research method among the other economic planning methods.

The purpose of the present paper is to describe the structural changes in production, compare the structural parameteres of production for the years 2005-2009, investigate the sources of differences and give recommendations that will bring solutions to the problems.

Research is based on input-output analysis and used input-output tables prepared for the years 2005 and 2009 by The National Statistical Committee Kyrgyz Republic. Industrial structure dependency, production techniques, efficiency of input usage, were calculated in this paper.

The results are as follows: there were found some sub-sectors in agriculture, manufacturing and service sector, on which economy depends on; equal efficiency of production techniques and input usage. It is notable that for achieving economic growth, economy needed investments to stimulate the production capacity, which strengthening inter-sectoral relationship and stable macro-economic planning.
\end{abstract}

JEL codes: C67, D57, O11

\section{Giriş}

Ulusal ekonomi, ülke genelinde belli bir kalıba oturmuş üretim süreci ve gelişme süreci içerisinde oluşmuş, birbiriyle karşılıklı bağımlılık ilişkilerde bulunan ekonomik sektörlerin oluşturduğu bütün bir sistemidir. Dolayısıyla, gelişmekte olan ülke ekonomilerinde uygulanan ekonomik politikaların temel amaçlarından biri, kalkınmayı hızlandıracak şekilde ekonomik yapı değişimini gerçekleştirmektir. Küreselleşme ise tüm dünyada olduğu gibi Kırgızistan'da da bu yapısal değişimi daha da hızlandırmıştır. Oldukça geniş kapsamlı olan ekonomik yapı kavramına bağlı olarak, yapısal değişimi açıklamaya yönelik farklı yaklaşımlarla yapılacak araştırmalar, ülkedeki ekonomik yapının farklı yönlerini yansıtabilmesi ve daha sağlıklı ekonomik plan ve politikaların belirlenmesi için daha da önemli olmaktadırlar. Bu durum ekonomik yapının incelenmesinin girdi çıtı analizi yaklaşımıyla yapılmasının temel nedenini oluşturmaktadır.

Bu amaç doğrultusunda, 2005-2009 yılları için Kırgızistan İstatistik Komitesi tarafından hazırlanan Girdi-Çıktı akım tabloları kullanılarak, ilgili dönemde, ekonomik üretim yapısındaki değişmenin, endüstriyel bağınlaşma, üretim tekniklerindeki değişme, aramalı kullanımındaki etkenlik ve toplam etkenlik katsayılarına göre incelenerek, ekonomideki yapısal değişim hakkında tarafları bilgilendirerek daha rasyonel plan ve politikaların hazırlanmasına katkıda bulunma hedeflenmektedir.

Araştırma girdi-çıktı çözümlemelerine dayanmakta ve temel veri kaynağı olarak Kırgızistan Milli İstatistik Komitesi tarafından 2005 ve 2009 yılları için hazırlanan 34 sektörlü girdi-çıktı tabloları kullanılmaktadır. Çalışmanın amacına uygun olarak yapısal değişim; endüstriyel bağınlaşma, üretim tekniklerinin karşılatırılması, sektörel ve makro düzeyde aramalı kullanımında toplam etkenlik katsayılarının hesaplanması suretiyle incelenmektedir. Böylece elde edilen teknik sonuçlarla Kırgızistan'ın sektörel bazda üretim yapısındaki değişimi olumlu ve olumsuz yönleriyle açıklanmakta, yapılabilecekler konusunda görüş ve öneriler getirilmektedir.

\section{Girdi-Çıktı Analizi Yaklaşımıyla Yapısal Değişme}

Endüstrilerarası mal ve hizmet akımı çok yönlü ve karmaşık bir yapıya sahiptir. Ulusal ekonominin planlanabilmesi için, her şeyden önce, ekonominin yapısını tanımak ve endüstriler arasındaki ilişkileri bilmek gerekir. Girdi- Çıktı Analizi, matematiksel ve istatistiksel teknikler yardımıyla, endüstrilerarası ilişkileri tutarlı olarak inceleyen bir modeldir. Bir ekonomik sistemin belirli yapısal özelliklerini tanımlayan bir veriler toplamı ve sistemin belirli bir zaman aralığı içinde belirli bir anındaki davranışını etkileyici ve açıklayıcı analitik bir teknik olarak tanımlanabilir (Todaro, 1987, s.17). Analizin temeli, herhangi bir ülke ekonomisinin kendi içerisinde homojen ya da birbirine benzer mallar üreten endüstrilere bölünebilmesi ve bu endüstrilerin 
birbirleriyle ve ekonomiyle olan etkileşimlerinin matematiksel ifadesine dayanır. Girdi Çıktı modelleri sektörel tutarlılık planlamasından dış ticaret teorilerinin sınanmasına, beşeri kaynak planlamasından bölgesel planlamaya yapısal değişim çözümlemelerinden endüstrilerarası bağınlaşma çözümlemelerine kadar çok çeşitli alanlarda yaygın olarak kullanılmaktadırlar. Ekonominin üretim, tüketim, dış ticaret v.b. gibi çeşitli birimleri arasındaki karşılıklı ilişkileri birarada ekonomi genelinde ve sektörel düzeyde inceleme olanağını oldukça basit ve uygulanabilirliği yüksek tekniklerle vermesi girdi-çıktı modellerinin uygulamadaki en önemli üstünlüğüdür.

Ekonomik yapının önemli bir unsurunu üretimde sektörler arasında ortaya çıkan karşılıklı bağımlılıklar oluşturur. Üretim sürecinde ekonomide hiçbir sektör biribirinden bağımsız, yalıtılmış durumda değildir. Ekonomik sektörler arasında mal ve hizmet alışverişlerinden kaynaklanan karşılıklı bağımlılıklar vardır. Bu karşılıklı mal ve hizmet alışverişi kısaca endüstriyel bağınlaşma olarak adlandırılmaktadır (Aydoğuş, 1999, s.93). Endüstriyel bağınlaşma iki şekilde ortaya çıkmaktadır. İlk olarak sektör kendi üretimini gerçekleştirmek için diğer sektörlerlerden kendi üretiminde kullanmak üzere aragirdi talep eder. Bu geriye bağlantı etkisi olarak bilinir. İkinci olarak sektör kendi çıktısını diğer üretim sektörlerine aragirdi olarak arzeder. Bu ise ileri bağlantı etkisi olarak tanımlanmaktadır. Bu kapsamda endüstrilerarası bağınlaşma çözümlemeleri sektörel ileri ve geri bağlantı etkilerine göre yapılarak bir yandan ekonomide kilit sektör ve yatırım önceliklerinin belirlenmesinde yaygın olarak kullanılırken, diğer yandan da, endüstrilerarası üretim yapısının hem dönemler arası hemde ülkelerarası karşılaştırılmasında vazgeçilmez bir teknik olarak ortaya çıkmaktadır.

Girdi-Çıktı modelleri kapsamında üretim yapılarının karşılaştırılması genellikle endüstrilerarası bağınlaşma, üretim teknikleri, aragirdi kullanımları ve temel girdi kullanımları gibi konuları kapsar. Özellikle ülkelerarası yapılan karşılaştırmalarda ülkelerin doğal, coğrafik, gelişmişlik düzeyi, sosyo-kültürel özelliklerinin farklı olması üretim yapılarının da farklılaştıracaktır. Ancak bu farklılıkların nedenlerinden birisi de tabloların hazırlandıkları dönemden ve hazırlanış ilkelerinden kaynaklanan farklılıklardır. Kuşkusuz Girdi-Çıktı analizinin teorik varsayımlarından kaynaklanan sektör sayısı ve içerikleri, toplulaştırma, ekonomi genelindeki enflasyonist etkiler gibi benzer farklılıkların etkilerinin dönemlerarası karşılaştırmalarda hiç ya da çok az olacağı düşünülmektedir (Aydoğuş, 1999, s.93).

Üretim yapısının önemli bir unsuru olarak endüstriyel bağınlaşma yapılarının karşılaştırılması sektörel bağlantı etkilerinin karşılaştırılmasına dayanır. Bu karşılaştırma doğrudan ve toplam ileri ve geri bağlantı etkilerine göre yapılabileceği gibi, sıkça kullanılan bir gösterge Santhanam ve Patil tarafından geliştirilen bağımlılık oranı katsayısıyla da yapılabilir. Herhangi bir “j”” sektörünün bağımlılık oranı $b_{j}$,

$$
b_{j}=\frac{\left[\frac{1}{2}\left(\sum_{i} x_{i j}+\sum_{j} x_{i j}\right)\right] / \sum_{j} x_{i j}}{x_{j} / \sum_{j} x_{j}}
$$

şeklinde tanımlanabilir. Bu tanımın paydasındaki terim, $\mathrm{j}$ sektörünün çıktısının ekonominin toplam çıktısına oranını, payındaki terim ise sektörün kullandığı toplam ara girdi ile sektörün ürettiği çıktıya olan toplam ara talebin ortalamasının sektörün çıktısına olan toplam aratalebe oranını göstermektedir (Aydoğduş, O. 1999, s. 105). Bu katsayı ne kadar büyükse ekonomi bu sektöre o kadar bağımlı demektir. Dönemsel karşılaştırmalarda sektörel bağımlılık katsayılarındaki artış ve azalışlara göre dönem içinde bağımlılığın değişimi incelenbilir.

Girdi-çıktı çözümlemesinde dar anlamda sektörel üretim tekniklerini, teknoloji (katsayı) matrisinin sütunları temsil eder. Ekonomide, r ve s gibi herhangi iki farklı dönemde "j”" sektöründeki üretim teknikleri aşağıdaki katsayı aracılığıyla karşılaştırılabilir;

$$
P T_{j}^{r s}=\frac{\sum_{i}\left|a_{i j}^{r}-a_{i j}^{s}\right|}{(1 / 2) \sum_{i}\left(a_{i j}^{r}+a_{i j}^{s}\right)}
$$

$\mathrm{Bu}$ iki dönemin “j” sektöründe karşılık gelen girdi katsayıları arasındaki farkların mutlak değerlerinin toplamının, karşılıklı katsayılarının aritmetik ortalamalarının toplamına oranı $\mathrm{PT}_{\mathrm{j}}^{\mathrm{rs}}$ şeklinde tanımlanmaktadır. $\mathrm{PT}_{\mathrm{j}}^{\mathrm{rs}}$ katsayısı, saf bir katsayı olup 0 ile 2 arasında değerler alabilir (Aydoğduş, O. 1999, s.106). Dönemler arasında teknik katsayılarda değişim yoksa yani üretim teknikleri aynıysa payda yeralan mutlak farklar sıfır olacağından katsayı 0’a eşit çıkacaktır. Bunun anlamı dönem içinde sektörde üretim teknolojisinde hiç farklılığın olmadığı anlamındadır. Eğer teknik katsayılar iyice değiştiyse, payda da yeralan 1/2 katsayısı nedeniyle bölüm sonucu en fazla iki çıkacaktır. Bunun anlamı da, değişimin çok fazla olduğu anlamındadır. Bu yönüyle katsayı ne kadar 0'a yakın çıkarsa değişim az, ne kadar 2'ye yakın çıkarsa değişim o kadar fazla demektir. Genel olarak 0.80 ’nin üzerindeki oranlar değişimin çok olduğu yönünde değerlendirilmektedirler.

Farklı dönemler arasında çeşitli aramalların kullanımındaki etkenlik dereceleri ise aşağıdaki gibi karşılaştırılabilir: 


$$
I U_{i}^{r s}=\frac{\sum_{j} a_{i j}^{r} x_{j}^{s}}{\sum_{j} a_{i j}^{s} X_{j}^{s}}
$$

Buradaki $I U_{{ }^{\prime}}^{r s}$ katsayısı $\mathrm{r}$ ve s dönemlerindeki $i$. malın aramal olarak kullanımındaki etkenliğin benzerlik derecesini, $X_{j}^{s}$ ise ikinci veya son dönem üretim vektörünü göstermektedir. Katsayının payındaki terim $r$ döneminde s dönemi üretimini (üretim vektörünü) gerçekleştirmek için ne kadar $i$ malının aramal olarak kullanılması gerektiğini, paydadaki terim ise s döneminde aynı üretimi (üretim vektörünü) gerçekleştirebilmek için aynı $i$ malının ne kadar aramal olarak kullanılması gerektiğini göstermektedir (Aydoğduş, O. 1999, s.107). Burada doğal olarak bir oran sözkonusudur. Oranın sonucu 1 ise bu dönem içerisinde sektörel bazda aramalı kullanımında farklılığın olmadığı aramalı kullanım etkenliğinin değişmediği anlamına gelmektedir. Katsayının 1 'den küçük çıkması dönem içerisinde aramalı kullanımın azaldığı anlamına gelecek ve olumlu olarak sektörde aramalı kullanımında etkenliğin, verimliliğin arttığı anlamında yorumlanacaktır. Tam tersi olarak katsayının 1'den büyük çıkması diğer şartlar veriyken ilgili sektörde üretimde aragirdi kullanımının arttı̆̆ı dolayısıyla etkenliğin, verimliliğin azaldığı anlamına gelecektir.

İki farklı döneme ait olan üretim tekniklerinin karşılaştırılmasında kullanılabilecek daha bütüncül ve anlamlı gösterge ters matris ve veri nihai talep vektörleri kullanılarak, $\mathrm{M}$ ve $\mathrm{N}$ gibi iki farklı dönem için toplam etkenlik katsayısıları aşağıdaki gibi hesaplanabilir.

$$
T_{i}^{M N}=\frac{\left(\sum_{j} r_{i j}^{M} F_{0 j}\right)}{\left(\sum_{j} r_{i j}^{N} F_{0 j}\right)}
$$

Burada payındaki terim, $\mathrm{F}_{0}$ gibi veri bir nihai talep vektörünün karşılanması için $\mathrm{M}$ döneminde gerekli toplam $i$ malı miktarını, paydası ise aynı nihai talebin $\mathrm{N}$ döneminde gerektirdiği toplam $i$ malı miktarını göstermektedir (Aydoğduş, O. 1999, s.110). Doğal olarak burada katsayı 1'e eşit çıkarsa ekonomi genelinde toplam aragirdi kullanımlarında değişme olmadığı yani herhangi bir teknik ilerlemenin bulunmadığı, katsayı 1'den küçük çıkarsa aynı üretimin daha az aragirdiyle kullanılmasıyla gerçekleştirilmesi nedeniyle ekonomi genelinde etkenliğin arttığı, katsayı 1'den büyük çıkarsa da, bu kez aynı talebin daha çok aragirdi kullanılarak üretildiği ortaya çıkacağından diğer şartlar veriyken dönem içinde etkenliğin azaldığı yönünde yorumlanmalıdır.

Gelişme sürecinde ülkenin ekonomik yapısını oluşturan öğelerinin değişmesi ile ekonomik yapıda değişimlerinin ortaya çıkması gayet doğal bir olgudur. Dolayısıyla, söz konusu unsurlarının değişiminin incelenmesi rasyonel iktisat politikalarının üretilmesi ve uygulanmasında da önemli olmaktadır.

\section{2005-2009 Döneminde Kırgızistan Ekonomisindeki Yapısal Değişim}

Kırgızistan ekonomisindeki yapısal değişimin Girdi-Çıktı analiziyle incelenmesi; Kırgızistan Milli İstatistik Komitesi tarafından hazırlanan 2005 ve 2009 yıllarına ait Girdi-Çıktı tabloları kullanılarak yapılmıştır. 1991 yılında bağımsızlığını elde ettikten sonra, ekonomide sektörlerarası çözümlemelere yönelik girdi-çıtı analizi çalışmaları 1994 yılında Milli İstatistik Komitesi tarafından başlatılmıştır. Dağılma öncesi dönemde de, eski Sovyetler Birliği'ne bağlı bir cumhuriyet iken, Kırgızistan için 1966 ve 1972 yıllarında girdi-çıktı tablolarının hazırlandığı, ve bu tablolardan elde edilen bilgilerin cumhuriyetin makroekonomik planlamasında kullanıldığı bilinmektedir (Koyçuyev, 1983, s.228.). Ancak dağılma sonrası finansal kaynakların yetersizliği, diğer cumhuriyetlerle olan ilişkilerin kopması, toplumda yaşanan sosyo-ekonomik yapıdaki büyük değişim gibi nedenlerle bu çalışmalarda aksamalar ortaya çıkmıştır. Ancak, milli muhasebe sistemine göre üretim kayıtlarının tutulmasıyla, mal ve hizmetlerin ekonomik birimler arasındaki kullanımını yansıtan girdi-çıktı çözümlemelerinin temelini oluşturan endüstrilerarası akım tablosu, 1998-2003 yılları arasında yapılan çalışmalarla ilk kez 2003 yılında yayınlanabilmiştir. Hazırlanan ilk tablo olan 2003 yılı tablosu 91 sektörlü bir tablodur. Ardından Dünya Bankasının desteklediği ortak bir projeyle çalışmalar daha da geliştirilmiştir. Bu proje kapsamında ekonomik sektörler kapsam bakımından ISIC ekonomik sektör ürün ve faaliyet sınıflamasına uygun hale getirilmiş, 2005 yılından başlanarak her yıl için düzenli olarak, aynı sektör sayısı ve kapsamda girdi-çıktı tabloları hazırlanmıştır. 2009 yılı tablosu hali hazırda son hazırlanan Girdi-Çıktı tablosudur.

Çalışmamız sektör sayısı ve kapsam bakımından birbiriyle aynı, ençok benzer, en geniş zaman aralıklı iki tablo olan 2005 ve 2009 yıllarına ilişkin girdi-çıktı tabloları kullanılarak yapılmıştır. Her iki tablo da, hazırlandıkları yılın cari fiyatlarıyla düzenlenmiş 34 sektörlü tablolardır. Tablolarda ihracat bir nihai talep unsuru olarak düşünülerek II. Bölmede kolon vektör olarak yer alırken, ithalatta da, rakip tamamlayıcı ithalat ayrıştırması yapılamadığından, ithalatın tamamen rakip ithalat olduğu varsayımı kabul edilmiş, sektörel ithalata bir arz kaynağı olarak nihai talep unsurları içerisinde eksi (-) değerli kolon vektör olarak yer verilmiştir. Çalışmamızda da hesaplamalar bu durum dikkate alınarak net değerler üzerinden yapılmıştır. 


\subsection{5 ve 2009 Yıllarında Kırgızistan Ekonomisinde Endüstriyel Bağınlaşma}

Kırgızistan ekonomisinde endüstriyel bağınlaşmanın ölçülebilmesi için 2005 ve 2009 yılı girdi-çıktı tabloları kullanılarak bağımlılık oranları $\left(b_{j}\right), 2005$ ve 2009 yıllarına ait teknik katsayıların mutlak farklarından yola çıkılarak üretim tekniklerinin karşılaştırılması (tablo 1), sektörel aramalı kullanımındaki değişimin incelenmesiyle ilgili olarak aramalı kullanımında toplam etkenlik; Leontief ters matrisi ve veri nihai talep vektörleri kullanılarak karşılaştırmalar (tablo 2) yapılmıştır.

\subsection{Kırgızistan Ekonomisinde Sektörel Bağımlıık Oranları ve Üretim Etkenliği}

Kırgızistan ekonomisi için 2005 ve 2009 yılı girdi çıktı tabloları kullanılarak sektörel bağımlılık oranları ve üretim etkenlik katsayıları hesaplanmıştır. Sonuçlar tablo 1'de görülmektedir. Sektörel bağımlılık katsayıları, sektörel doğrudan ileri ve geri bağlantı etkileri yardımıyla hesaplanan katsayılardır. Katsayı ne kadar çok küçük sıfıra yakın çıkarsa sektörün ekonomiye bağımlılığı o kadar az, katsayı ne kadar büyük çıkarsa sektörün ekonomiye bağımlılığı o kadar çok demektir. İki dönem için hesaplanan bağımlılık katsayıları ne kadar çok birbirine yakın ise dönem içinde bağımlılığın o kadar az olduğu anlaşılır. 2005 ve 2009 yıları için hesaplanan bağımlılık katsayıları ve aradaki değişimi tanımlayabilmek için bu katsayıların birbirlerine oranları tablo 1'de verilmektedir. Genel olarak tarım ve tarıma dayalı sanayiler dışında tüm sektörlerin bağımlılık katsayıları oldukça büyük çıkmıştır. Dönem içinde sektörel bağımlılıktaki değişimi daha iyi görebilmek için 2009 yılı katsayısı 2005 yılı katsayısına oranlanmıştır. Sözkonusu oranlar incelendiğinde, beş alt sektörden oluşan tarım sektöründe; 1. Tarım, avcılık ve ormancılık, 3.Kömür, petrol ve doğal gaz çıkarımı, 5.Diğer madencilik türleri olarak üç sektörde, bağımlılık katsayıları 1'den büyük çıkmıştır. Bu sektörlerde dönem içinde ekonomiye bağımlılığın arttığı görülmüştür. 19 tane altsektörden oluşan imalat sanayinde ise, 06.Besin ve tütün ürünleri üretimi, 09.Kağıt ve karton ürt. yayın ve basım, 10.Kok kömürü ür.; petrol rafine; kimya, 11.Diğer metal olmayan mineral üretimi, 14.Makine ve teçhizat üretimi, 16.Elektrik enerjisi üretimi ve dağıtımı, 17.Gaz yakıtların üretimi ve dağıtımı, 18. Buhar ve sıcak su sağlama (verme) 19. Suyun toplanması, tem. ve dağıtılması alt sektörlerinde oranlar birden büyük çıkmış sektörel bağımlılığın arttığı gözlenmiştir. Hizmet sektörlerinin önemli bir kısmında ise, sektörel bağımlılık azalmıştır (Tablo 1).

Girdi-Çıktı analizinde, sektörel aragirdi kullanımlarını gösteren herbir sütun ilgili sektör için kullanılan teknolojiyi, üretim ilişkilerini tanımlayan bir üretim fonksiyonu olarak düşünülebilir. Burada da, her bir sektör için hesaplanan tenik katsayıların her iki döneme denk gelen katsayıların mutlak farkları, katsayıların ortalamasına oranlanarak üretim teknikleri katsayıları hesaplanmıştır. Katsayı tanımı gereği, 0 ile 2 arasında değer almaktadır. Katsayının tamamen sıfıra eşit çıkması dönem içinde kullanılan teknolojide hiç değişme olmadığını, katsayının enyüksek değer 2'ye eşit çıkması teknolojinin çok fazla değiştiği anlamına gelir. Genel olarak 0,8 'in üzerindeki katsayılar değişimin önemli olduğu yönünde değerlendirilmektedir. Burada da, ekonomi genelinde ekonomik üretim sektörlerinden sadece, 2.Balık avlama ve yetiştirme, 11.Diğer metal olmayan mineral üretimi, 20.İnşaat, 23.Otomobil, teknik bakım ve onarım, 26.Posta ve iletişim (haberleşme) alt sektörlerinde katsayı 0.8 'e çok yakın veya üzerinde çıkmıştır (Tablo 1). Buradan genel olarak dönem içerisinde ekonomide; teknolojik anlamda değişimin olmadığı sonucu ortaya çıkmaktadır.

\subsection{Kırgızistan Ekonomisinde Aragirdi Kullanımında Toplam Etkenlik}

Girdi-Çıktı analizi yaklaşımıyla doğrudan aragirdi kullanımlarında etkenlik karşılaştırmaları birim üretimdeki aragirdi kullanımlarını gösteren teknik katsayı matrislerinin karşılaştırma yapılan yıl üretim vektörüyle çarpılarak elde edilen aragirdi kullanım değerlerinin birbirleriyle karşılaştırılmaları suretiyle yapılmaktadır. Aragirdi kullanımlarının hesaplanması doğrudan olabileceği gibi toplam etkileri yansıtabilmesi bakımından daha bütüncül ve makro düzeydeki bir karşılaştırma için Leontief ters matrisleri ve veri nihai talep vektörleri yardımıyla da yapılabilir. Her iki şekilde yapılacak karşılaştırmalarda birbiriyle tutarlı sonuçların elde edilmesi beklenir. Ancak ters matris yardımıyla hesaplanacak aragirdi kullanımları doğrudan ve dolaylı toplam etkileri yansıtması bakımından diğerine göre daha anlamlı ve önemlidir. Burada da makroekonomik çözümleme anlamında çalışmanın amacına da daha uygun olması nedeniyle toplam etkilere göre aragirdi kullanımları hesaplanmıştır. Elde edilen sonuçlar tablo 2'de verilmektedir.

Toplam etkenlik katsayılarının hesaplanması; bütüncül bir yaklaşımla karşılaştırma yapılan veri yıl nihai talep vektörü, -burada 2009 yılı nihai talep vektörü kullanılmıştır-, 2005 yılındaki teknolojiyle karşılansaydı sektörel üretimler ne olacaktı? sorusunun cevaplanmasına dayanır. Bu üretimler 2009 yılı üretimleriyle karşılaştırılarak, talebin aynı olması nedeniyle aradaki farkın tamamen aragirdi kullanımlarından kaynaklandığ değerlendirme yapılır. Sektörel üretimde azalma söz konusuysa kaynağı belli olmamakla birlikte bunun sektörel aragirdi kullanımlarındaki azalmadan kaynaklandığı yani aynı nihai talebin daha az girdiyle karşılandığı düşünülür. Üretimde değişme sözkonusu değilse aragirdi kullanımlarının değişmediği sonucu ortaya çıkar. Eğer üretim değeri öncekinden büyük çıkıyorsa bu kezde teknik olarak aragirdi kullanımının arttığı sonucu gündeme gelir. Ancak bu ekonomik rasyonalikle açıklanamayacak, teorik beklentilere uyumlu bir sonuç değildir. Eğer dönem içerisinde teknolojinin eskiyerek gerilemesi sözkonusu değilse, bunun nedenlerinin ayrıca araştırılması gerekir. Bu durumda ilk akla gelen Girdi-Çıktı analizinin teorik varsayımları, ve tabloların hazırlanışındaki farklılıklardır. Girdi-Çıktı tablolarının sağlıklı sonuçlar verebilmesi için ülkede düzgün, sağlıklı bir milli muhasebe, üretim kayıt sisteminin ayrıntılı olarak oluşturulması gerekmektedir. Bunun yanı sıra analizin 
varsayımlarından kaynaklanan bazı kısıtlayıcı unsurlar söz konusudur. Bunlar kısaca, dönem içerisindeki fiyat değişimlerinin tablolara yansıtılamaması, alt sektör bazında uygun deflatörlerin olmayışı, sektör kapsamları, ithalatın tamamlayıcı ve rakip ithalat olarak ayrıştırılamaması gibi sayılabilir. Kuşkusuz bu ve benzer sorunlar burada da geçerlidir. Ancak çalışmamızda gerek Girdi-Çıktı analizinin varsayımlarından, gerekse de genel ekonomik koşullardan kaynaklanan türlü kısıtların elde edilen sonuçlar üzerinde etkisi inceleme konusu yapılmamaktadır. Tablolardaki bilgilerin en doğru sonuçları yansıtan, güvenilir bilgiler olduğu varsayılmaktadır.

2005-09 dönemi toplam etkenlik yaklaşımıyla sektörel üretimler hesaplanmıştır. Bunun için 2009 yılı nihai talep vektörü, 2005 yılı ters matrisyle çarpılarak yeni üretim değerleri bulunmuş, bunlar eski 2009 yılı üretimlerine oranlanarak birbirleriyle karşılaştırılmıştır. Tüm sonuçlar tablo'2de görülmektedir.

Tablo 2'ye göre, bazı sektörlerde oran sonuçları 1'den büyük çıkmıştır. Yukarıda da belirtildiği gibi analiz tekniğinden ve fiyatlama sürecinden kaynaklanan olumsuzluklar bir yana bırakılırsa, oranın birden büyük çıktı̆̆ bu sektörler için dönem içinde aragirdi kullanımlarının arttığı, kullandıkları teknolojinin eskiyerek gerilediği yorumu yapılabilir. Oranın 1'den büyük çıktığı bu sektörler genelde tarım ve dayalı sanayiler olmuştur. Bunun dışında 5 tane alt sektörden oluşan tarım sektöründe; 03.Kömür, petrol ve doğal gaz çıkarımı, 04.Maden (metal) cevheri çıkarımı, 05.Diğer madencilik sanayi (türleri) sektörlerinde aragirdi kullanımlarının azalarak etkenliğin arttığ görülmektedir. 14 tane alt sektörden oluşan İmalat sanayiin'de, 06.Besin ve tütün ürünleri üretimi, 09.Kağıt ve karton ürt. yayın ve basım, 10.Kok kömürü ür.; petrol (rafine; kimya, 11.Diğer metal olmayan mineral üretimi, 14.Makine ve teçhizat üretimi, 16.Elektrik enerjisi üretimi ve dă̆ıtımı, 18. Buhar ve sıcak su sağlama (verme), 19.Suyun toplanması, tem. ve dağıtılması sektörleri olarak toplam 8 sektörde aragirdi kullanımları azalmıştır. Ekonomi genelinde tüm sektörler dikkate alındığında, 34 tane sektörden 19 tanesinde dönem içinde aragirdi kullanımlarının azaldığı görülmüştür.

Kuşkusuz burada elde edilen sonuçlara ihtiyatla yaklaşmak gerekir. Önceden de belirtildiği gibi, kullanılan analiz tekniğinden kaynaklanan, tabloların hazırlandığı dönemden kaynaklanan, sektör kapsamları, fiyat artışları, muhasebe ve kayıt sisteminin yetersizliği gibi bazı kısıtlar burada ulaşılan sonuçların güvenilirliğini etkilemektedir. Ancak Kırgızistan ekonomisi için üretim istatistiklerinden yararlanılarak yapılan ekonomik yapıyla ilgili benzer çalışmalarda elde edilen sonuçlar incelendiğinde, burada ulaşılan sonuçlara yakın sonuçların elde edildiği farkedilmiştir. Bu çalışmalarda, 2005-2009 dönemi için genel olarak imalat sanayinde kapasite kullanım oranlarının düştüğü, sektörel yapının verimliliği sağlamaktan uzak olduğu, sanayideki maliyet artışlarının Kırgızistan'ın en önemli sorunlarından olduğu belirtilmektedir (Экономическая политика социально-экономического развития Кыргызской республики на долгосрочный период до 2025 г.: Том I.Б.: ЦЭС при МЭРиТ КР, 2007, с.58-80.; Нацинальный Статистический Комитет КР. Промышленность КР за 2005-2009. Годовая публикация. Бишкек 2010.c. с.210.).

\section{Sonuç}

Kırgızistan Ekonomisinde Girdi Çıktı analiziyle yapısal değişimin incelemesinde tabloların hazırlandıkları dönemden ve teorik varsayımlardan kaynaklanan kısıtlar burada da ortaya çıkmıştır. Teorik beklentilerle uyumlu olmayan bazı sonuçlar karşımıza çıkmıştır. Aslında bu sonuçların her birisi ayrı birer araştırma konusu olarak da incelenebilir. Ancak konunun bu yönü, ve gerek analiz tekniğinden gerekse de genel ekonomik koşullardan kaynaklanan türlü kısıtların elde edilen sonuçlar üzerindeki etkileri burada inceleme konusu yapılmamaktadır. Tablolardaki bilgilerin en doğru sonuçları yansıtan geçerli, güvenilir bilgiler olduğu varsayılmaktadır.

Tüm bunlara rağmen, Ekonomik sistemde yer alan sektörlerin birbirileriyle olan ilişkilerini yansıtan matematiksel model Girdi-Çıktı analizi olmaktadır. Ancak hazırlanan Girdi-Çıktı tablolarının sağlıklı sonuçlar verebilmesi için ülkede düzgün, sağlıklı bir milli muhasebe, üretim kayıt sisteminin ayrıntılı olarak oluşturulması gerekmektedir. Bunun yanı sıra analizin varsayımlarından kaynaklanan bazı kısıtlayıcı unsurlar söz konusudur. Bunlar kısaca, dönem içerisindeki fiyat değişimlerinin tablolara yansıtılamaması, alt sektör bazında uygun deflatörlerin olmayışı, sektör kapsamları, ithalatın tamamlayıcı ve rakip ithalat olarak ayrıştırılamaması gibi sayılabilir. Tüm bunlar; Girdi-Çıktı çözümlemelerinden elde edilebilecek sonuçların güvenilirliğini etkilemekle birlikte yine de yöntemin kullanılmasıyla, bir ülke ekonomisine ilişkin makroekonomik planlamayla ilgili ilginç sonuçlar elde edilebilmektedir.

Burada da elde edilen sonuçlar genel olarak değerlendirildiğinde, aslında birbiriyle uyumlu sonuçlar elde edilmiştir. Farklı yaklaşımlarla yapısal değişimin tanımlanmaya çalışıldığı bu çalışmada, sektör bazında incelendiğinde, birçok sektörde tüm katsayılar birbiriyle tutarlı çıkmıştır. Yani ekonomide etkin olan veya olmayan sektörler tüm katsayılara göre tutarlı çıkmıştır. Örneğin; 05.Diğer madencilik sanayi (türleri), 07.Tekstil ve konf. San., deri ve ür. Ürt. 10.Kok kömürü ür.; petrol (rafine; kimya, 13.Hazır (işlenmiş) maden mamulleri, 11.Diğer metal olmayan mineral üretimi, 12.Maden (metal) sanayi, 21.Toptan ticaret, 23.Otomobil, teknik bakım ve onarım, 26.Posta ve iletişim (haberleşme), 30.Eğitim, 32.Çevre temizliğini koruma hizmetleri gibi sektörlerde tüm katsayılar birbirlerini destekler yönde çıkmışlardır. Diğer sektörlerde de katsayılar arası tutarsız farklılıklar çok fazla değildir.

Teknik katsayılara dayalı olarak yapılan üretim tekniklerinin iki dönem arasındaki karşılaştııılmasında, toplam 
19 tane alt sektörden oluşan tarım ve imalat sanayilerinde, 02.Balık avlama ve yetiştirme, 11.Diğer metal olmayan mineral üretimi, 17.Gaz yakıtların üretimi ve dağıtımı, 05.Diğer madencilik sanayi (türleri) alt sektörlerinin oluşturduğu 4 sektör dışındaki tüm sektörlerde üretim tekniklerindeki değişim çok az çıkmıştır. Yani hesaplanan katsayılar 0,8'in çok altında olup 0,314 ile 0,692 arasında değişmektedir. .

Dünyadaki diğer ülkeler gibi Kırgızistan da hızlı bir değişim geçiren ekonomiye sahip bir ülkedir. Yapılacak makroekonomik planlama da bu özelliğin mutlaka dikkate alınması gerekir. Bu nedenle, bundan sonrası için önceden de olduğu gibi, homojen girdi-çıktı tablolarının dönemsel karşılaştırmalara imkan verecek şekilde, belirli periyotlarla düzenli olarak aynı içerik ve kapsamda hazırlanmalarının Kırgızistan ekonomisinde makroekonomik planlama için oldukça önemli olduğunu düşünüyoruz.

\begin{tabular}{|c|c|c|c|c|c|}
\hline \multirow{2}{*}{$\begin{array}{c}\text { Sira } \\
\text { no }\end{array}$} & \multirow[b]{2}{*}{ Ekonomik Sektörler } & \multicolumn{2}{|c|}{ Endüstriyel Bağ.(bj) } & \multirow[t]{2}{*}{$\begin{array}{c}\text { Oran } \\
\left(\mathbf{b}_{09} / b_{05}\right) \\
\end{array}$} & \multirow[b]{2}{*}{ Ürt.tek. } \\
\hline & & 2005 & 2009 & & \\
\hline 01 & Tarım, avc1lık ve ormancılık & 3.49 & 3.54 & 1.01 & 0.680 \\
\hline 02 & Balık avlama ve yetiştirme & $115,480.68$ & $27,960.96$ & 0.24 & 1.219 \\
\hline 03 & Kömür, petrol ve doğal gaz çıkarımı & 142.39 & 214.29 & 1.50 & 0.543 \\
\hline 04 & Maden (metal) cevheri çıkarımı & $2,680.44$ & $1,714.33$ & 0.64 & 0.475 \\
\hline 05 & Diğer madencilik sanayi (türleri) & 706.69 & 995.93 & 1.41 & 0.764 \\
\hline 06 & Besin ve tütün ürünleri üretimi & 22.77 & 26.16 & 1.15 & 0.437 \\
\hline 07 & Tekstil ve konf. San., deri ve ür. Ürt. & 80.30 & 71.10 & 0.89 & 0.486 \\
\hline 08 & Kereste ve ahşap doğrama üretimi & $1,088.59$ & 703.26 & 0.65 & 0.533 \\
\hline 09 & Kağıt ve karton ürt. yayın ve basım & 177.94 & 233.38 & 1.31 & 0.498 \\
\hline 10 & Kok kömürü ür.; petrol (rafine; kimya & 44.16 & 58.45 & 1.32 & 0.645 \\
\hline 11 & Diğer metal olmayan mineral üretimi & 39.95 & 71.53 & 1.79 & 0.796 \\
\hline 12 & Maden (metal) sanayi & 13.51 & 9.65 & 0.71 & 0.570 \\
\hline 13 & Hazır (işlenmiş) maden mamulleri & 244.12 & 219.80 & 0.90 & 0.314 \\
\hline 14 & Makine ve teçhizat üretimi & 56.28 & 105.34 & 1.87 & 0.545 \\
\hline 15 & Diğer san. Sector. ve ikincil işlemeler & $85,243.50$ & 512.02 & 0.01 & 0.537 \\
\hline 16 & Elektrik enerjisi üretimi ve dağıtımı & 36.50 & 81.94 & 2.25 & 0.692 \\
\hline 17 & Gaz yakıtların üretimi ve dağıtımı & 86.63 & 281.36 & 3.25 & 0.942 \\
\hline 18 & Buhar ve sıcak su sağlama (verme) & 179.22 & 319.20 & 1.78 & 0.572 \\
\hline 19 & Suyun toplanması, tem. ve dağıtılmas1 & 503.31 & 593.29 & 1.18 & 0.605 \\
\hline 20 & İnşaat & 38.77 & 14.49 & 0.37 & 0.814 \\
\hline 21 & Toptan ticaret & 56.68 & 47.00 & 0.83 & 0.596 \\
\hline 22 & Perakende ticaret & 9.36 & 9.46 & 1.01 & 0.619 \\
\hline 23 & Otomobil, teknik bakım ve onarım & 57.23 & 120.85 & 2.11 & 0.819 \\
\hline 24 & Otel ve restoranlar & 94.28 & 71.67 & 0.76 & 0.569 \\
\hline 25 & Ulaştırma ve yardımcı hizmetler & 23.68 & 24.61 & 1.04 & 0.481 \\
\hline 26 & Posta ve iletişim (haberleşme) & 31.02 & 43.72 & 1.41 & 0.864 \\
\hline 27 & Mali faaliyetler (arac1lık, arbitraj) & 47.84 & 38.64 & 0.81 & 0.377 \\
\hline 28 & Gayri menkul mallar ile işlemler; kira. & 31.58 & 26.31 & 0.83 & 0.729 \\
\hline 29 & Devlet yönetimi & 81.57 & $29,051.82$ & 356.15 & 0.597 \\
\hline 30 & Eğitim & 889.47 & 297.86 & 0.33 & 0.627 \\
\hline 31 & Sağlık ve sosyal hizmetler & 692.09 & 355.73 & 0.51 & 0.744 \\
\hline 32 & Çevre temizliğini koruma hizmetleri & $1,093.04$ & $2,670.99$ & 2.44 & 1.066 \\
\hline 33 & Dernek ve birlik.; dinlen., kültür ve sp. & 327.25 & 230.50 & 0.70 & 1.130 \\
\hline 34 & Kişisel hizmetler (sunumu) & $10,524.41$ & 302.94 & 0.03 & 0.811 \\
\hline
\end{tabular}

Tablo 1. Kırgızistan Ekonomisinde Endüstriyel Bă̆ınlaşma ve Üretim Etkinliği (2005-2009) Kaynak: K.C. Milli Istatistik Komitesi. 2005, 2009 Yılı Girdi-Çıktı Sonuç Tabloları kullanılarak tarafımızca hesaplanmıştır. 


\begin{tabular}{|c|c|c|c|c|}
\hline \multirow{2}{*}{$\begin{array}{c}\text { Sira } \\
\text { no }\end{array}$} & \multirow[b]{2}{*}{ Ekonomik Sektörler } & \multicolumn{2}{|c|}{$\begin{array}{c}\text { Toplam Etkilere Göre } \\
\text { Etkinlik } \\
\end{array}$} & \multirow{2}{*}{$\begin{array}{c}\text { Oran } \\
\left(\mathbf{X}_{09} / \mathbf{X}_{05}\right)\end{array}$} \\
\hline & & $X_{2009-09}$ & $X_{2005-09}$ & \\
\hline 01 & Tarım, avcılik ve ormancılık & 233,347 & 121,521 & 1.92 \\
\hline 02 & Balık avlama ve yetiştirme & 26 & 17 & 1.55 \\
\hline 03 & Kömür, petrol ve doğal gaz çıkarımı & 6,503 & 34,596 & 0.19 \\
\hline 04 & Maden (metal) cevheri çıkarımı & 443 & 449 & 0.99 \\
\hline 05 & Diğer madencilik sanayi (türleri) & 834 & 4,370 & 0.19 \\
\hline 06 & Besin ve tütün ürünleri üretimi & 44,222 & 46,745 & 0.95 \\
\hline 07 & Tekstil ve konf. San., deri ve ür. Ürt. & 30,529 & 20,281 & 1.51 \\
\hline 08 & Kereste ve ahşap doğrama üretimi & 8,863 & 4,556 & 1.95 \\
\hline 09 & Kağıt ve karton ürt. yayın ve basım & 6,316 & 11,733 & 0.54 \\
\hline 10 & Kok kömürü ür.; petrol (rafine; kimya & 91,871 & 107,455 & 0.85 \\
\hline 11 & Diğer metal olmayan mineral üretimi & 11,481 & 23,865 & 0.48 \\
\hline 12 & Maden (metal) sanayi & 64,436 & 47,420 & 1.36 \\
\hline 13 & Hazır (işlenmiş) maden mamulleri & 9,093 & 8,733 & 1.04 \\
\hline 14 & Makine ve teçhizat üretimi & 21,860 & 40,493 & 0.54 \\
\hline 15 & Diğer san. Sectör. ve ikincil işlemeler & 2,581 & 1,407 & 1.83 \\
\hline 16 & Elektrik enerjisi üretimi ve dağıtımı & 9,702 & 20,997 & 0.46 \\
\hline 17 & Gaz yakıtların üretimi ve dağıtımı & 8,111 & 7,030 & 1.15 \\
\hline 18 & Buhar ve sıcak su sağlama (verme) & 2,232 & 3,353 & 0.67 \\
\hline 19 & Suyun toplanması, tem. ve dağıtılması & 856 & 1,116 & 0.77 \\
\hline 20 & İnşaat & 47,802 & 35,143 & 1.36 \\
\hline 21 & Toptan ticaret & 13,336 & 8,669 & 1.54 \\
\hline 22 & Perakende ticaret & 67,603 & 55,300 & 1.22 \\
\hline 23 & Otomobil, teknik bakım ve onarım & 5,296 & 8,875 & 0.60 \\
\hline 24 & Otel ve restoranlar & 9,784 & 7,604 & 1.29 \\
\hline 25 & Ulaştırma ve yardımcı hizmetler & 57,667 & 62,590 & 0.92 \\
\hline 26 & Posta ve iletişim (haberleşme) & 19,953 & 29,631 & 0.67 \\
\hline 27 & Mali faaliyetler (arac1lık, arbitraj) & 16,047 & 23,370 & 0.69 \\
\hline 28 & Gayri menkul mallar ile işlemler; kira. & 20,845 & 28,935 & 0.72 \\
\hline 29 & Devlet yönetimi & 22,058 & 24,365 & 0.91 \\
\hline 30 & Eğitim & 12,373 & 12,205 & 1.01 \\
\hline 31 & Sağlık ve sosyal hizmetler & 7,931 & 7,865 & 1.01 \\
\hline 32 & Çevre temizliğini koruma hizmetleri & 201 & 517 & 0.39 \\
\hline 33 & Dernek ve birlik.; dinlen., kültür ve sp. & 5,230 & 5,309 & 0.99 \\
\hline 34 & Kişisel hizmetler (sunumu) & 2,280 & 1,650 & 1.38 \\
\hline
\end{tabular}

Tablo 2: Kırgızistan Ekonomisinde Armalı Kullanımında Toplam Etkenlik (2005-2009) Kaynak: K.C. Milli Istatistik Komitesi. 2005, 2009 Yılı Girdi-Çıktı Sonuç Tabloları kullanılarak tarafımızca hesaplanmıştır.

\section{Kaynakça}

- $\quad$ Aydoğuş O., Girdi-Çıktı Modellerine Giriş, Gazi Kitabevi Ankara, 1999.

- Bocutoğlu, E., Girdi - Çıktı Analizine Giriş, Karadeniz Üniversitesi İktisadi ve İdari Bilimler Fakültesi Ders Notları, Yayın No:23, Trabzon, 1985

- $\quad$ Chenery H.B, Clark P.E, Endüstrilerarası İktisat, (Çev. Cemil Çınar), ODTÜ, Ankara, 1965.

- Kepenek Y. Türkiye İmalat Sanayiinin Üretim Yapısı (1963-1973), Ankara ODTÜ, 1977.

- Kepenek Y., Türk İmalat Sanayiinin Üretim Yapısı, Friedrich Ebert Vakfı Araştırma Sonuçları, İstanbul, 1991.

- $\quad$ Korum U., Input Output Analizi, Sevinç Matbaas1, Ankara, 1963.

- Korum U., Türk İmalat Sanayi ve İthal İkamesi : Bir Değerlendirme, Ankara Üniversitesi Siyasal 
Bilgiler Fakültesi Yayınları No:408, Ankara,1977.

- Koyçuyev T., SSCB Ülkerinde Dengeli Ekonomik Büyüme Özelliklerinin Analizi ve Teorik Problemler, Doktora Tezi, Moskova İktisat Enstitüsü, Moskova-1983.

- $\quad$ Miernyk W.H., The Elements of Input Output Analysis, Random House, West Virginia University, 2 Printing, 1966.

- $\quad$ Öney E. , İktisadi Planlama, 3. Bask1, A.Ü.S.B.F. Yayın No:526, Ankara, 1983.

- Todaro M.P., Kalkınma Planlaması (Modeller ve Yöntemler), (Çev. Orhan Sezgin), İstanbul, 1987.

- Национальный статистический комитет КР. Межоотраслевой баланс производства и использования товаров и услуг КР за 2005, 2009 гг.

- Экономическая политика социально-экономического развития Кыргызской республики на долгосрочный период до 2025 г.: Том І.-Б.: ЦЭС при МЭРиТ КР, 2007, -368 с.

- Нацинальный Статистический Комитет КР. Промышленность КР за 2005-2009. Годовая публикация. Бишкек 2010. 


\title{
Kamu-Özel İşbirliği Projeleri ve Kırgızistan Ekonomisi Açısından Önemi
}

\author{
Ahmet Burçin Yereli (Hacettepe University, Turkey) \\ Mustafa Kizıltan (Hacettepe University, Turkey)
}

\section{Public-Private Partnership and Its Importance for Kyrgyzstan Economy}

\begin{abstract}
Public-Private Partnership (PPP) means to join forces with public and private bodies. The supplementation to this process by public and private organizations and their gains are ab-initio subjected with an agreement. Thereby the government activate the market dynamics in order to supply some public goods without using budget resources. In this paper, the significance of public-private partnership will be emphasized and will discuss which projects are eligible and how will they be realized and what kind of co-operations will take place by PPP projects in Kyrgyzstan.
\end{abstract}

JEL Codes: H42, H44

\section{Giriş}

Gelişmekte olan ülkeler ve geçiş ekonomileri açısından en önemli sorunlardan bir tanesi alt yapı yatırımlarıdır. Gelişmekte olan ülkelerde alt yapının yetersizliği ve geçiş ekonomilerinde ise eskimiş alt yapının yenilenmesi ciddi bir kaynak sorunu olarak karşımıza çıkmaktadır. Altyapı yatırımları; elektrik üretimi ve dağııımı, içme suyu ve atık su hizmetleri, tarımsal amaçlı sulama, eğitim ve sağlık ile ulaşım ve haberleşme hizmetleri gibi çok geniş bir alana yayılan yatırımları kapsamaktadır. Bu tür yatırımlar genellikle yüksek maliyetli olduğu için daha çok kamu sektörü tarafından sunulmaktadır. Ancak son yıllarda dünya genelinde yaşanan kamu finansman sorunları ve küresel durgunluk nedeniyle bu tür yatırımlarda da azalma meydana gelmiş̧tir.

Gelişmiş ülkeler son 20-30 yıllık dönemde alt-yapı yatırımlarının finansmanında Kamu-Özel İşbirliği Projeleri'ne giderek daha fazla yer vermeye başlamışlardır. Genellikle yerel yönetimlerce görülmekte olan hizmetlerden, ekonomik büyümeye doğrudan katkı yapan genel yönetim hizmetlerine kadar pek çok yatırım projelerinde kamu-özel işbirliği teknikleri kullanılabilmektedir.

\section{Neden Kamu-Özel İşbirliği Projeleri?}

Kamu-Özel İşbirliği modellerinin geliştirilmesine yol açan temel etken olarak 1980'lere kadar gelinen süreçteki kamu başarısızlıkları gösterilebilir. Kamu tarafından başlatılan, ancak siyasi veya ödenek yetersizliği gibi nedenlerle bitirilemeyen projelerin ekonomiye yük olması sorununa çözüm arayışları ile birlikte bu tür işbirliği modelleri geliştirilmeye çalışılmıştır. Ayrıca kamunun bazı yatırım projelerinde etkinsizliklere ve verimsizliklere neden olduğu herkesçe bilinmektedir. Bu etkinsizlik ve verimsizlik, projelerin bitirilme sürelerinin en başta öngörülene göre daha uzun olması ve öngörülenden yüksek maliyetlere ulaşması gibi nedenlerle ortaya çıkmaktadır.

Özelleştirme uygulamaları yaygın olarak devletin finansman krizlerine çözüm yollarının arandığı 1980'li yıllardan itibaren yoğunluk kazanmış, bu dönemle birlikte devletin ekonomideki rolü azaltılarak düzenleyici rolüne ağırlık verilmiş ve özel sektörün ekonomideki rolünün artırılması için çeşitli modeller geliştirilmiştir (Eker, 2007, s. 59; Çal, 2008, s. 5). Ekonomide özel sektörün rolüne verilen önemle birlikte, özel sektör kuruluşlarının ekonominin her alanında olduğu gibi, altyapı yatıımlarında da aktif katılımcı olabilmelerine imkan sağlanmıştır. Özelleştirme uygulamalarındaki artışa bağlı olarak Kamu-Özel İşbirliği modelleri de bu süreçte görülmeye başlanmıştır.

Özelleştirme uygulamaları temel olarak kamunun ekonomideki rolünün azaltılmasını ve devletin zamanla regülatör durumuna getirilmesini amaçlamaktadır. Özellikle ekonomideki katma değer rolü ve özel sektörün maliyetlerini düşürücü etkisi ile altyapı yatırımlarına duyulan ihtiyaç çeşitli özelleştirme modellerin geliştirilmesine neden olmuştur. İşte bu modellerden bir tanesi Kamu-Özel İşbirliği modeli olarak karşımıza çıkmaktadır. Bu model kamunun tüm yatırımları üstlendiği klasik kamu yatırımları ile özel sektörün mülkiyeti üstlendiği özelleştirme modelleri arasında bir alternatif olarak gözükmektedir. Bu modelin seçilmesindeki en önemli faktör klasik özelleştirme yöntemlerine göre mülkiyetin kamuda kalması neticesinde toplumsal tepkiyi en aza indirmesi olarak ifade edilebilir. Ayrıca, klasik kamu yatırımlarına göre yatırım riskinin kamu ve özel sektör arasında paylaştırılması ve bütçe dışı kaynaklardan yatırımın finanse edilebilmesi de modelin bir diğer avantajlı yönüdür. Bu tarz bir finansman kaynağı kamunun borçlanma gereğini düşürerek kamu kaynaklarının daha etkin 
ve verimli kullanılabilmesine de imkan verebilmektedir.

İşsizliğin önemli bir sorun olduğu gelişmekte olan ülkelerde sınırlı kamu kaynaklarının verimli alanlarda kullanılması işsizlik başta olmak üzere bir çok yapısal sorunun çözümüne katkı sağlamaktadır. Bu nedenle özellikle gelişmekte olan ülkeler için önemli ve gerekli olan altyapı projeleri/yatırımları ertelenemez boyutlara ulaşmakta, bu projelerin gerçekleştirilebilmesi kamu kaynağı yanında alternatif kaynaklara başvurulmasını zorunlu hale getirmektedir. Farklı kaynakların kullanımını sağlayacak işbirliği modellerinin uygulanması ile özel sektör kaynakları harekete geçirilerek, kamunun borç yükü hafifletilebilmekte, ülkeye yabancı sermaye çekilebilmektedir. Böylece atıl kalmış yatırımlar bitirilerek ekonomik gelişmeye katkıda sağlanabilmektedir. Ayrıca altyapı yatırımlarının hızlı bir şekilde bitirilmesi, orta ve uzun vadede özel sektör maliyetlerini düşürerek, toplumun refahını artırmaktadır.

Kamu yatırımlarında özel sektörün katılımı uygulamaları daha önceleri imtiyaz sözleşmeleri yoluyla gerçekleştirilmiş olup, modern anlamda Kamu-Özel İşbirliği modellerinin kullanılmasına ise ilk olarak 1992 yılında İngiltere'de Özel Sektör Finans Girişimi - Private Finance Initative adıyla başlanmıştır. Başarılı olarak uygulanan bu model bir çok ülkeye örnek olmuş ve 1999 yılında modeli benimseyen ülke sayısı 10 civarında iken, 2008 yılında 100'ün üzerine çıkmıştır (Tekin, 2007, s. 10).

\section{Kamu-Özel İşbirliği Modelleri}

Dünya üzerinde geniş bir uygulama alanı bulan Kamu-Özel İşbirliği modelleri genel olarak üç başlık altında toplanmaktadır:

\section{Geleneksel Kamu İhalesi Yoluyla Özel Sektör Katılımının Sağlanması:}

$\mathrm{Bu}$ yöntemde kamu mülkiyetinde olan işletmelerin bazı işleri özel sektöre gördürülmektedir. Burada özel sektörün kazancı kendi becerilerine bağlı olarak değişmektedir. Kamunun amacı bu sayede özel sektörün uygulama beceresinden yararlanarak maliyetleri düşürmektir. Yapılan ihaleler yoluyla; "Hizmet Sözleşmeleri”, "İ̧̧letme ve Yönetim Sözleşmeleri” ve "Kiralama” gibi yöntemler kullanılmaktadır. Bu şekilde yapılan işler; çöplerin toplatılması, sayaçların okunması vs. gibi kısa dönemli olmaktadır.

\section{Bazı Kamu Yatırımlarına Özel Sektörün Katılımının Sağlanması:}

$\mathrm{Bu}$ yöntemlerde kamu tarafından finansmanı sağlanan projelere özel sektör hem uygulayıcı olarak hem de finansman sağlayarak katkıda bulunmaktadır. Bu yöntemlerde kamunun elektrik, su, doğalgaz gibi altyap1 sektörlerindeki bazı tekel konumları imtiyaz olarak 25-30 yıllık sürelerle özel sektöre devredilmektedir.

Sözleşme süreleri göreli olarak uzun vadeli olduğundan sözleşme yapılış aşamasında ortaya çıabilecek durumlar detaylı şekilde tanımlanmalı, sözleşmeler uzun süreli değişikliklere uyum sağlayacak şekilde esnek yapılmalıdır. Ancak bu esneklik uzun vadede siyasilerin müdahale aracı olacak şekilde kurgulanmamalıdır. Rekabetin tam olarak tesis edildiği ihaleler işi en düşük maliyetle yapacak firmaların seçilmesini sağlayabilecektir.

\section{Klasik Özelleștirme Yöntemleri:}

$\mathrm{Bu}$ yöntemlerde kamu mülkiyetinde olan işletmeler ihale yoluyla tamamen veya kısmen özel sektöre devredilmektedir. Bu yöntemin özel sektör katılımı yöntemlerinden farkı mülkiyetin belli süreli olarak değil tamamen veya kısmi olarak özel kesime geçmesidir (Devlet Planlama Teşkilatı [DPT], 2006, s. 2-6).

Avrupa Birliği ve uluslararası ekonomik kuruluşların bu alanlardaki desteği ve çalışmalarının katkısı da oldukça önemlidir. Avrupa Birliği, bu çalışmaları üye ülkelerde desteklemek ve modellerin yasal altyapısını güçlendirmek amacıyla kaynak niteliğinde önemli metinler yayınlamış olup, proje örneklerini ve bu örneklerden çıkarılacak dersleri belirterek, önemli ilkeler ortaya koymuştur. Bu ilkelerden en önemlisi genel olarak şeffaflığın ön plana çıkartılmasıdır. Şeffaflık hem kamu hem de özel sektör firmaları için bir güven ortamı sağlayarak projelerin başarı şansını artırmaktadır. Böylece projelerin devamlılı̆̆ı sağlanabilmektedir.

Kamu sektöründe yer alan Kamu-Özel İşbirliği uygulayıcıları için pratik bir araç olarak 2003 'te “Avrupa Komisyonu Bölgesel Politikalar Genel Müdürlüğü” tarafından yayınlanan "Başarılı Bir Kamu-Özel İşbirliği İçin Ana Esaslar - Guidelines for Succesful Public-Private Partnerships" raporuna göre bu ortaklık modellerinden beklenen faydalar şu şekilde sayılmaktadır (Europe Comission, 2003, s. 15):

- Altyapı tedarikinin hızlanması,

- Hizlı uygulama,

- Projelerin toplam yaşam maliyetlerinde düşme,

- Daha iyi risk dağılımı,

- Projelerin uygulanması sırasında ortaya çıkan daha iyi teşvikler,

- Hizmet kalitesinin iyileşmesi,

- Ek gelir yaratılması,

- Kamu yönetiminde iyileşme.

Modelden beklenen faydalar bu şekilde sayılmakla birlikte modelin uygulanması sırasında dikkat edilmesi 
gereken risk unsurlarının da bulunduğunun farkında olunmalıdır. Modelin başarıyla uygulanabilmesi için öncelikle yeterli bir özel sektör tecrübesi gerekmektedir. Projenin özel sektöre yaptırılması öncesinde yapılacak bir ihalede etkili bir rekabet ortamı oluşmaz ise projeden beklenen faydalar gerçekleşemeyecektir. Özel sektör gerekli deneyime sahip olmakla birlikte özel sektörün finansman imkanları, mali piyasaların derin olmaması sebebiyle kısıtlı ise, özel sektörün projeleri yürütebilmesi mümkün olmayacaktır.

Kamu-Özel İşbirliği modellerinin yaygınlaşması ve hızla gelişmesi sonucu Avrupa Komisyonu bu modellerle ilgili çalışmalar yaparak 30 Nisan 2004'te kamu sözleşmeleri ve imtiyazları ile ilgili ilkelerin belirlendiği “Yeşil Kitabl" (Green Paper on Public Private Partnerships and Community Law on Public Contracts and Concessions) ve Haziran 2004'te de Kamu-Özel İşbirliği örnek olayları ile ilgili “Kaynak Kitabı” (Resource Book on PPP Case Studies) yayınlamıştır. Ancak bu çalışmalarda Kamu-Özel İşbirliği kavramının tam olarak bir tanımı yapılmamıştır. Konu ile ilgili olarak Yeşil Kitap’ta yer alan 1. maddeye göre; genel olarak altyapı hizmetleri veya tedarik hizmetlerinin kamu otoriteleri ve iş alemi arasında finansmanını, yapımını, yönetimini ve bakımını garanti altına almayı amaçlamak şeklinde bir hedef tanımlanmaktadır. Bu modeller yoluyla özel sektör ortağı ile uzun vadeli ilişki kurularak projelerin finansmanı sağlanmakta ve kamu ile özel sektör tarafları arasında riskler paylaşılabilmektedir (Europe Comission, 2004a, s. 3).

Yeşil Kitap kamu tedariki ile ilgili birlik düzeyinde Kamu-Özel İşbirliklerinin uygulanmasını incelemekte olup, Yeşil Kitap’ta belirtilen bu ilkeler Kaynak Kitap vasıtasıyla örneklendirilmektedir. Özellikle Kaynak Kitap'ta birçok örnek olay sıralanmış olup, bu örnekler ve modelleri uygulamak isteyen ülkeler için kitap tam bir laboratuar niteliğindedir. Örneklerle, ortaya çıkan avantajlar ve dezavantajlar sayılmış olup, modeller ile ilgili ilkeler ve çıkarılan dersler ortaya konmuştur. Örneklerde gelişmekte olan ülkelerin karşılaşabilecekleri farklı durumlar sayılmış ve belli tanımlara ulaşılmıştır. Bu örneklerde yer alan durumları kısaca aşağıdaki şekilde sayabiliriz:

- Uluslararası işletme tecrübesi ve uzmanlıklardan faydalanılarak elde edilebilecek olan verimlilik artışı,

- Klasik kamu tedariki yöntemleri ile kamu-özel işbirliği yöntemlerinin karşılaştırılması,

- Kamu-özel işbirliği yöntemlerinin finansman sorunlarına çare olunması amacıyla seçilmesi,

- Kamu sektörü tarafından borç alınarak gerçekleştirilen proje örnekleri,

- Kamu-özel işbirliği projesinin özel sektör deneyimden faydalanmak amacı ile kullanılması,

- Kurulan işbirliği modellerindeki sözleşme yöntemlerinin incelenmesi,

- Verim artırmak ve maliyet etkinliği sağlamak amacıyla kamu-özel işbirliği projelerinin kullanımı.

Bütün bu proje örnekleri ele alınıp değerlendirildiğinde ortaya çıkan sonuç kamu-özel işbirliği modellerinin klasik kamu kuruluşlarından daha etkin bir şekilde çalıştı̆̆ 1 ve belirlenen standartlara daha rahat bir şekilde ulaştığı şeklindedir. Bu durumda kamu-özel işbirliği ile arzu edilen sonuçlara daha kısa sürede ve daha isabetli olarak varılabilmektedir.

Tüm proje örneklerinden çıkarılacak ortak dersler ise şu şekilde sayılabilir (Europe Comission, 2004b, s. 170):

- Kamu-özel işbirliği modellerinin başarısı için en temel ölçüt risklerin dengeli bir şekilde paylaşılmasıdır. Risklerin projeyi en başarılı şekilde gerçekleştirecek kesim tarafından üstlenilmesi projenin başarı şansını artıracaktır. Yasal kurallar tarafların üstlendikleri riskleri en iyi şekilde tanımlayacak şekilde belirlenmelidir. Riskli, ancak finansal olarak getirisi yüksek olan projeler özel sektör firmalarına projeye katılım yönünde teşvik sağlayacaktır.

- Seçilen işbirliği modelinin gerekçesinin kamuoyu ile paylaşılması projeye olan desteği artıracaktır. Projelerin maliyet, talep, süre değişkenlerinin başarılı bir şekilde tahmini de projelerin başarısı ve kamu desteği için önem taşımaktadır.

- İşbirlikleri uzun vadeli sözleşmelere dayalı olduğundan politik istikrara ihtiyaç duyulmaktadır. Sözleşme süresi boyunca her gelen siyasi iktidarın sözleşme şartları ile oynamak istemesi bu projelerin başarı şansını olumsuz yönde etkileyecektir.

- Projelerden beklenen temel faydalar ve projenin uygulanması sırasında ortaya çıkabilecek risklerde ve bu faydalardan hangi tarafların yararlanacağı ve risklere hangi tarafların katlanacağı da iyi tespit edilmelidir.

Yeşil Kitap’ta yer alan kamu-özel işbirliği modellerinin tanımından da görüleceği gibi bu işbirlikleri çeşitli alanlarda ve şekillerde kullanılabilmekte olup, kullanım şekillerine göre farklı isimler alabilmektedirler. İhtiyaca göre farklı amaçlarla kullanılabilen bu yöntemleri kısaca şu şekilde sayabiliriz (Sarısu, 2009, s. 156-162):

- İşletme - Bakım

- Tasarla - Yap

- Tasarla - Yap - Finanse Et - İşlet

- Kirala - Satın Al

- Yap - Kirala - Devret

- Yap - İşlet - Devret

- İşletme Hakkı Devri 
- Yap - Devret - İşlet

- Kirala - İşlet - Geliştir - İşlet

- Satın Al - Geliştir - İşlet

- Yap - Sahip Ol - İşlet

\section{Türkiye'de Kamu-Özel İşbirliği Uygulamalarının Yasal Çerçevesi}

Türkiye'de kamu ile özel sektörün işbirliğine yönelik uygulamalar Osmanlı İmparatorluğu dönemine kadar uzanmakta olup, çeşitli kamu hizmetlerinin yerine getirilmesinde ve bazı malların üretiminde özel sektörden yararlanılmıştır. Türkiye'nin ilk Kamu-Özel İşbirliği Projesi Fransız- İngiliz konsorsiyumu tarafından Yap-İşletDevret modeli ile 1874 yılında gerçekleştirilen ve 17 Ocak 1875'te Karaköy-Beyoğlu arasında çalışmaya başlayan dünyanın ikinci yer altı demiryolu tünelidir. Bu işletme 42 yıllık faaliyetinden sonra 1917 y1lında Osmanlı İmparatorluğu'nun mahalli idaresine devredilmiştir (Keşli, 2009, s. 35).

Bununla birlikte bazı kamu hizmetlerinin yerine getirilmesinde özel sektör kuruluşları ile farklı işbirliği modellerinin uygulandığı görülmektedir. İmtiyaz, İltizam, Yap-İşlet-Devret (YİD), Yap-İşlet (Yİ), İşletme Hakk1 Devri gibi yöntemlere Osmanlı döneminde de rastlanmaktadır. Kamu-Özel İşbirliği modellerinden imtiyaz sözleşmelerine dayanak teşkil eden kanun ise 10 Haziran 1326 (1910) tarihli "Menafiyi Umumiyeye Müteallik İmtiyazat Hakkında Kanun"dur.

Cumhuriyet dönemine genel olarak bakıldığında ise kamu hizmetleri daha çok devlet eliyle gerçekleştirilmeye çalışılmıştır. Ancak dünyadaki gelişmelere paralel olarak kamu hizmetlerine duyulan ihtiyacın artması, buna nazaran kamu kaynaklarının yetersiz kalması ve kamu başarısızlığı kavramının ön plana çıkması, 1980'li yıllarla birlikte piyasanın önünü açıcı politikaların uygulanmasına olanak sağlamıştır. Bu bağlamda 1980'li yıllarla birlikte Türkiye'de liberal anlamda birçok yasal düzenleme yapılmıştır. Yasal dayanakların temeli 1984 yılında çıkarılan 3096 Sayılı Kanun'dur. Daha sonra buna bağlı olarak başka düzenlemeler de gerçekleştirilmiştir. Ekonomide serbestleşme yolunda atılan bu yasal adımları şu şekilde sıralayabiliriz (D.P.T., 2007a, s. 1-3):

- 4.12.1984 tarih ve 3096 Sayılı "Türkiye Elektrik Kurumu Dışındaki Kuruluşların Elektrik Üretimi, İletimi, Dağıtımı ve Ticareti ile Görevlendirilmesi Hakkında Kanun”,

- 28.5.1988 tarih ve 3465 Sayılı "Karayolları Genel Müdürlüğü Dışındaki Kuruluşların Erişme Kontrollü Karayolu (Otoyol) Yapımı, Bakımı ve İşletilmesi İle Görevlendirilmesi Hakkında Kanun”,

- 13.6.1994 tarih ve 21959 Sayılı Resmi Gazetede yayımlanarak yürürlüğe giren 3996 Sayılı "Bazı Yatırım ve Hizmetlerin Yap-İşlet-Devret Modeli Çerçevesinde Gerçekleştirilmesi Hakkında Kanun”,

- 8.6.1996 tarih ve 22660 Sayılı Resmi Gazetede yayımlanan 96.8269 Say1lı "Elektrik Enerjisi Üretim Tesislerinin Kurulması Hakkında Bakanlar Kurulu Kararı",

- 21.4.2005 tarihli ve 5335 Sayılı "Bazı Kanun ve Kanun Hükmünde Kararnamelerde Değişiklik Yapılmasına Dair Kanunun 33 üncü maddesindeki düzenleme",

- 1.3.1994 tarih ve 21864 Sayılı Resmi Gazetede yayımlanarak yürürlüğe giren ve 3291 Sayılı Özelleştirme Kanununa 5 ek madde ekleyen 2.2.1994 tarih ve 3974 Sayılı Kanun,

- 24.11.1994 tarih ve 4046 Sayılı “Özelleştirme Uygulamaları Hakkında Kanun”,

- 1982 Anayasasında değişiklik yapan 13.8.1999 tarih ve 4446 Sayılı Kanun,

- Anayasaya uyum yasaları çerçevesinde 21.1.2001 tarih ve 4501 Sayılı "Kamu Hizmetleri İle İlgili İmtiyaz Şartlaşma ve Sözleşmelerinden Doğan Uyuşmazlıklarda Tahkim Yoluna Başvurulması Halinde Uyulması Gereken İlkelere Dair Kanun".

Türkiye'de 1980'lerden itibaren uygulama alanı bulan bu işbirliklerinin herkes tarafından kabul edilen tek bir tanımı veya modeli mevcut değildir. Ancak Devlet Planlama Teşkilatı tarafından 2007 yılı Kasım ayında hazırlanan "Bazı Yatırım ve Hizmetlerin Kamu Kesimi ile Özel Sektör İşbirliği Modelleri Çerçevesinde Gerçekleştirilmesine İlişkin Kanun Tasarısı Taslağı”na göre Kamu-Özel İşbirliği Modeli; merkezi yönetim kapsamındaki kamu idareleri, sosyal güvenlik kurumları, mahalli idareler ve kamu iktisadi teşebbüsleri tarafından yürütülen tarım, sulama, madencilik, imalat, enerji, ulaştırma, haberleşme, bilgi teknolojileri, turizm, konut, kültür, kentsel ve kırsal altyapı, belediye hizmetleri, kentsel dönüşüm, çevre, araştırma geliştirme hizmetleri ile eğitim, sağlık, adalet, güvenlik ve genel idare altyapısı yatırım ve hizmetlerinin bu Kanun'da tanımlanan Kamu-Özel İşbirliği modelleri çerçevesinde gerçekleştirilmesine ilişkin usul ve esasları kapsamaktadır.

Türkiye'de bu amaçla kullanılabilecek yöntemler ise, ilgili Kanun Tasarısı Taslağı'nın 5. maddesine göre şu şekilde sayılmaktadır (DPT, 2007b, s. 3):

i. Yap-İşlet-Devret Modeli: Kamu ve özel sektör firması arasında yapılan bir sözleşmeye dayalı olarak gerçekleştirilen ve özel sektör firmasının finansmanını sağlayarak yönettiği kamu işletmesini sözleşme sonunda kamu idaresine devrettiği bir kamu-özel işbirliği modelidir.

ii. Yap-İşlet Modeli: Kamu ve özel sektör firması arasında yapılan bir sözleşmeye dayalı olarak gerçekleştirilen ve özel sektör firmasının finansmanını sağlayarak yönettiği kamu işletmesinin 
mülkiyetinin sözleşme sonunda özel sektör üzerinde kaldığı bir kamu-özel işbirliği modelidir.

iii. Yap-Kirala Modeli: Kamu ve özel sektör firması arasında yapılan bir sözleşmeye dayalı olarak gerçekleştirilen ve özel sektör firmasının finansmanını sağlayarak ortaya çıkardığı işletmenin özel sektör firmasınca kamu idaresine kiralandığı ve yapının mülkiyetinin sözleşme sonunda kamu mülkiyetine geçtiği bir işbirliği şeklidir.

iv. İşletme Hakkı Devri Modeli: Kamu idarelerinin mülkiyetinde bulunan hizmetlerin tamamen veya kısmen işletilmek üzere özel sektör firmalarına devredilmesi şeklinde ortaya çıkan bir işbirliği şeklidir.

Kamu kaynaklarının kullanımında proje ve/veya uygulama bazında esneklik sağlanabilmesi açısından tanımlanmış genel ve tek bir modelin bulunmaması proje bazında değişik modellerin uygulanabilmesine olanak sağlayabilecektir. Bu son yıllarda gelişmekte olan ülkelerde benimsenmeye çalışılan "Yeni Kamu Yönetimi Anlayışına" da uygundur. Bu yaklaşıma göre girdi odaklılıktan sonuç odaklılığa ve mevzuata uyumdan performans esasına doğru bir geçiş söz konusudur. Böylece kamu kaynaklarının kullanılması bakımından hesap verilebilirlik, mali saydamlık ve performans esasına uyma ön plana çıkmaktadır.

Avrupa Birliği ile katılım müzakereleri yürütmekte olan Türkiye'nin Avrupa Birliği müktesebatı nezdinde yürütmekte olduğu kamu alımları ile ilgili 5. fasıla göre, kamu-özel işbirliği ihalelerinde saydamlığı sağlaması ve eşit ve serbest rekabet ile ilgili ortak kuralları benimsemesi gerekmektedir. $\quad \mathrm{Bu}$ fasıl uyarınca Türkiye'de, 2008 Ulusal Programı'na göre hedeflenen "Bazı Yatırım ve Hizmetlerin Kamu Kesimi ile Özel Sektör İşbirliği Modelleri Çerçevesinde Gerçekleştirilmesine İlişkin Kanunu"nun hala çıkarılamamış olması büyük bir eksikliktir.

\section{Kamu-Özel İşbirliği Modelleri ve Kırgızistan}

Kırgızistan ekonomisi diğer Orta Asya ülkelerine benzer olarak bir geçiş ekonomisi görünümündedir. Ulusal gelirin yetersizliği ölçüsünde kamu kaynakları kıt ve iç tasarruf düzeyi yetersizdir. Dolayısıyla ekonomik büyümenin en temel dinamiği olan alt yapı yatırımlarını kendi mali imkanları ile gerçekleştirebilmek açısından ciddi sıkıntılar içindedir. Sovyetler Birliği Dönemi'nde bir tarım ve hayvancılık üssü olarak görülen Kırgızistan, Birliğin dağılmasının ardından bağımsızlığını ilan etmiş ve piyasa ekonomisini hedefleyen bir geçiş ekonomisi olarak kendi yasal-kurumsal düzenlemelerini gerçekleştirmeye başlamıştır.

Kırgızistan, sahip olduğu ekonomik potansiyelini ve stratejik konumunu doğru kullanabildiği ölçüde zenginleşme kapasitesi olan bir ülkedir. Kaynakların doğru ve verimli kullanılabilmesi durumunda ciddi bir ekonomik büyüme yakalayabilecek güce sahiptir. Nitekim bu doğrultuda zaman zaman çeşitli uygulamalar gerçekleştirilmeye çalışılmaktadır.

Kamu yatırımlarının finansmanında ya olağan kamu gelirleri olan vergi gelirleri ya da olağanüstü kamu gelirleri olan devlet borçlanması kullanılmaktadır. Kamu yatırımları vergi gelirleri ile finanse edilemediğinde çoğu zaman borçlanma yöntemine başvurulmaktadır. Borçlanma iç piyasadan yapılabildiği gibi dış piyasalardan da yapılabilmektedir. Yatııımların bu şekilde finansmanının ekonomi üzerinde farklı etkilere yol açtığı herkesçe bilinmektedir.

Kırgızistan'da ulusal gelir düzeyinin düşüklüğü nedeniyle alt-yapı yatırımlarının vergiler ya da iç borçlanma marifetiyle karşılanabilmesi neredeyse imkansızdır. Yani, ekonomik büyümenin finansmanını iç kaynaklarla karşılayabilmek oldukça güçtür. Bu durumda dış kaynaklara yönelme gibi bir mecburiyet ortaya çıkmaktadır. Ancak, Kırgızistan ekonomisindeki ve siyasetindeki istikrarsızlıklar da dış kaynakların maliyetini yükseltmektedir.

İşte bu noktada Kamu-Özel İşbirliği modelleri alternatif bir çözüm önerisi olarak üzerinde durulması ve tartışılması gereken önemli konulardan biridir. Kırgızistan açısından bu modellerin uygulanabilirliği tartışmasında cevap aranacak sorular şunlardır:

1. Kırgizistan'ın mevcut hukuk düzeni Kamu-Özel İșbirliği modellerine uygun mudur?

Kırgızistan Anayasası bağımsızlık döneminde üç defa baştan kaleme alınmıştır. Zaman zaman küçük anayasa değişiklikleri ile Anayasa günün koşullarına uydurulmaya çalışılmaktadır. 1993 Anayasası 1994'ten itibaren 2003 yılının Şubat ayına kadar beş defa değiş̧ikliğe uğramıştır. Bunların tamamı referandumla yapılmıştır. 21 Ekim 2007 ve 27 Haziran 2010 tarihli Anayasalar da referandumla kabul edilmiş ve yürürlüğe girmiştir. Son Anayasa daha çok demokratik sistemi yerleştirmeye yönelik olarak hazırlanmış olduğu için ekonomik hükümler açısından yetersiz kalmıştır. Öncelikle 2010 Anayasası "Kamulaştırma", "Özelleştirme", "Devletleştirme", Uluslararası Tahkim" gibi konularda açık ve anlaşılır hükümlere yer vermelidir.

Anayasaya bağlı olarak Kamu-Özel İşbirliği modellerinin uygulanabilmesine imkan veren yasaların da yürürlüğe konulmasında büyük fayda bulunmaktadır. Bu yasalar çerçevesinde kamu otoritesinin sorumluluklarının sınırı ve tarafların hakları açık bir biçimde tanımlanmış olmalıdır.

2. Kırgızistan'da Kamu-Özel İşbirliği modellerinin uygulanabilmesinin önündeki en önemli bürokratik engeller nelerdir? 
Kırgızistan'da Kamu-Özel İşbirliği modellerinin uygulanabilmesinin önündeki en önemli engellerden biri bürokratik istikrarsızlıktır. Bürokraside görev alanlar bulundukları makama liyakat esasına göre değil, siyasi ya da ailevi bağlara dayalı olarak gelmektedir. Kamuda görev almak isteyenler açısından en önemli müşevvik kontrolsüz rüşvet mekanizmasıdır. Dolayısıyla bürokraside gerekli reformlar yapılmalı ve ekonomik kurumlarda görev alacak olanlar bu kurumlarda görev alabilecek düzede eğitim almış ehil kişiler arasından seçilmelidir. Her şeyden önemlisi rüşvet ile etkili bir mücadele stratejisi geliştirilmelidir.

Özel sektörün hareket alanını tanımlamak ve denetlemek açısından piyasada düzenleyici ve denetleyici kurumların görev sahasının da belirlenmesi gerekmektedir. Özellikle Rekabet Kurumu, İhale Kurumu, Özelleştirme Kurumu gibi kurum ve kuruluşlar bu noktada önemli hale gelmektedir.

3. Kırgızistan'da uygulanabilecek Kamu-Özel İșbirliği modelleri özel sektör açısından cazip olabilir mi?

Kırgızistan, geçiş sürecinde olan bir ekonomi olması sebebiyle özel sektör açısından pek çok engeli bünyesinde barındırmaktadır. Bu engellerin en önemlisi yolsuzluk ve rüşvet olarak belirtilebilir. Bir diğer engel ise siyasi ve bürokratik istikrarsızlıklardır. Siyasette rol alanların çok sık değişmesi ve hukuk düzeninin siyasi güce bağlı olarak aynı şekilde sık sık değişmesi özel sektör açısından hiç de cazip olmayan bir durumdur. Bürokratların de çok sık değişmesi bürokratik geleneğin oluşmasını engellemektedir. Yasal-kurumsal alt-yapı oluşturulmadan, bürokratik gelenek inşa edilmeden ve siyasi istikrar sağlanmadan Kamu-Özel İşbirliği modellerinin uygulanabilmesi oldukça güçtür.

Özel sektörün bu alandaki beklentilerini olumsuz yönde etkileyecek bir diğer husus ise ülke genelinde gelir düzeyinin düşük oluşu ve gelir dağılımının bozukluğudur. Kamu-Özel İşbirliği modelleri ile üretilecek olan mal ve hizmetlerin öncelikle iç piyasada satın alma gücü yeterli olan geniş bir tüketici kitlesi tarafından talep edilen mal ve hizmetler olması gerekir. Maalesef Kırgızistan bugün itibariyle böyle bir konumda değildir.

Kırgızistan'da iç tasarrufların yetersizliği nedeniyle dinamik ve yeterli sermayeye sahip bir girişimci profili henüz ortaya çıkmış değildir. Bu nedenle yabancı sermaye ihtiyacı ön plana çıkmaktadır. Ancak Kırgızistan benzeri pek çok ülke yabancı sermaye çekebilmek için cazip tedbirlere başvurmaktadır. Bu nedenle Kırgızistan da yabancı sermaye açısından cazip bir takım uygulamalara bir an önce başlamalıdır. Kamu-Özel İşbirliği modelleri açısından hangi alanlarda ortak yatırım potansiyeli varsa o alanlara yönelik destek uygulamalarına yer verilmelidir.

\section{Kamu-Özel İşbirliği modelleri Kırgızistan'da daha çok hangi sektörlerde uygulanabilir?}

Kamu-Özel İşbirliği modelleri açısından Kırgızistan çok geniş bir uygulama alanına sahip değildir. Öncelikle ekonomik faaliyetlerde ciddi bir dönüşüm gerekmektedir. Ekonomik faaliyetlerin artması ile birlikte bir takım mal ve hizmetlerin üretiminde Kamu-Özel İşbirliği modelleri tartışılmaya başlanacaktır. Örneğin, motorlu taşıt araçlarının sayısı kontrolsüz bir şekilde artmaktadır. Bu araçların kent içi ve şehirlerarası trafikte yol açtığı sorunlar önceden öngörülememekte ve tedbir alınamamaktadır. Alt yapı aşınmakta, park sorunu büyümekte ve ekonomik ilişkiler her açıdan bu süreçte olumsuz etkilenmektedir. Bu basit örnek bile Kırgızistan'a gelecek yabancı sermayenin kararlarını etkileyen önemli konulardan birisidir.

Kırgızistan'da öncelikle Kamu-Özel İşbirliği modellerinin kısa, orta ve uzun vadede hangi sektörlerde cazip olabileceği bir master plan ile ortaya konulmalıdır. Bu plan çerçevesinde sektörel kalkınmaya yönelik stratejik planlar hazırlanmalıdır. Sürecin planlı bir şekilde yönetilmesi olmazsa olmaz bir başarı koşuludur.

Kısa vadede turizm sektörü mukayeseli bir üstünlüğe sahiptir. Devletin sahip olduğu ve turistik potansiyeli olan alanlar önce turizm uygulama alanı olarak belirlenmelidir. Bu uygulama alanlarında uygulanacak olan destekler sayılmalı ve bedelsiz arazi tahsisi ile yap-işlet-devret uygulamalarına öncelik verilmelidir. Gerek kış turizmi ve gerekse akarsu ve göllerle dayalı mevsimlik turizm ile ören yerlerinin işletilmesine yönelik faaliyetler Kırgızistan ekonomisine para kazandıracak alanlardır. Ayrıca eğlence turizmi açısından da ciddi bir potansiyel bulunmaktadir.

Orta ve uzun vadede havalimanı ve raylı sistem ile birlikte Kamu-Özel İşbirliği uygulamalarında çeşitlilik artacaktır. Ekonomideki gelişmeye ve büyümeye bağlı olarak yeni ihtiyaçlar için farklı modeller uygulanacaktır.

\section{Sonuç}

Kırgızistan, bağımsızlığını izleyen son yirmi yıllık dönem göz önüne alındığında geçiş ekonomisi özelliğini devam ettiren bir görünüme sahiptir. Son altı yıl içinde yaşanan halk hareketleri ve köklü iktidar değişiklikleri nedeniyle siyasi istikrarı sağlamada da güçlükler yaşamaktadır. Ulusal gelir düzeyinin düşüklüğü, yaygın kayıt dışılık, gelir dağılımındaki aşırı bozukluk ve kamu bürokrasisindeki geniş çaplı yolsuzluk ve rüşvet uygulamaları ülke ekonomisinin iyiye gidişinin önündeki en önemli engellerdir.

Geçiş ekonomilerinde, piyasa ekonomisine uyum sürecinde yaşanan en önemli sorunlardan biri piyasa müşevviklerinin yetersiz oluşudur. Bu noktada yurtiçinde girişimci potansiyelinin eksikliği ya da yokluğu nedeniyle karşılaşılan sorunlar daha belirgin olarak karşımıza çıkmaktadır. Türkiye'de 1923-1933 arasında yaşanan benzeri bir piyasa ekonomisini hedefleyen süreç sonucunda ve 1929 Dünya Buhranı'nın da etkisiyle devletçilik yıllarının başladığı ve piyasa hedefinden giderek uzaklaşıldığı hatırlanacak olursa, Kırgızistan piyasa 
ekonomisi hedefinden hiç sapmadan ve yirmi yıldır büyük bir sabırla geçiş döneminin ağır koşullarına karşı azimle mücadelesine devam etmektedir. Halen yetersiz sermaye birikimi nedeniyle dinamik bir özel sektör potansiyelinden yoksundur. $\mathrm{O}$ nedenle kalkınmanın finansmanı için dış kaynaklara ihtiyaç duymaktadır. $\mathrm{Bu}$ kaynakların başında ise yabancı sermaye gelmektedir.

Kırgızistan'da Kamu-Özel İşbirliği modellerinin yasal-kurumsal alt yapısı en uygun biçimde oluşturulmalıdır. Özellikle bu modellere yabancı sermaye desteği sağlanabilmesi açısından uluslararası tahkimin önü açılmalıdır. Ülke genelinde öncelikle ele alınıp mücadele edilmesi gereken sorun ise yolsuzluk ve rüşvettir. Bu sorunun ortadan kaldırılması için ciddi tedbirler alınmalı ve kararlılıkla uygulanmalıdır.

Kamu-Özel İşbirliği modellerine yönelik olarak inşa edilecek yasal alt yapıda ortaklığın devam ettirilmesini sağlayacak esnekliklere yer verilmeli ve mevzuat her türlü yasal riski en aza indirecek şekilde tasarlanmalıdır. Kamunun yönetimdeki kontrolünün kaybı kamunun konuya müdahale yetkilerini sınırlandırabileceğinden kamu yararının göz ardı edilmesine yol açabilir. Böyle bir durumun ortaya çıkmaması ancak ve ancak iyi tanımlanmış bir yasal mevzuatla mümkün olur. Kamu-Özel İşbirliği modelleri genellikle uzun vadeli ve katı kurallara sahip olduklarından yasal mevzuat değişebilen taleplere cevap verebilecek şekilde esnek bir yapıda kurulmalıdır. Uzun vadeli ortaklıkta oluşabilecek bir anlaşmazlı̆̆ın hizmetin kesilmesine yol açabileceği unutulmamalıdır. Çünkü katı yapıya sahip sözleşmelerde hizmetin özel sektör ortağından kamu sektörüne geçişi belli bir süre alacak, böyle bir sürede hizmet sunumunda kesinti yaşanabilecektir (Sarısu, 2009, s. 183-190).

Kamu-Özel İşbirliği modelleri proje bazında, dünya örnekleri de göz önünde tutularak tüm olumlu ve olumsuz yönleri ile birlikte değerlendirilmelidir. Modelin, altyapı hizmetlerinin gerçekleştirilmesinde kullanılabilecek farklı alternatiflerden olduğu, faydaları olduğu kadar çeşitli riskleri de içerdiği akılda tutulmalıdır. Model tüm bu yönleri ile analiz edildiğinde diğer modellere göre üstünlükleri ortaya konabiliyorsa kullanılmalıdır. Aksi takdirde kamu kaynaklarının etkili, verimli ve ekonomik kullanımı gerçekleşmeyecek ve kamu kaynakları israf olabilecektir.

\section{Kaynaklar}

- Aktan, C.C., Dileyici, D. (2005). Altyapı Reformu: Altyapı Hizmetlerinin Sunumu ve Finansmanında Yeni TrendlerAlternatif Yöntemler. Aktan, C.C., Dileyici, D., Vural, İ.Y. (Ed.). Altyapı Ekonomisi Altyapı Hizmetlerinde Serbestleşme ve Özelleştirme (s. 43-63). Ankara: Seçkin Yayıncılık.

- Avrupa Birliği Bakanlığı (t.y.). Erişim: 27 Temmuz 2011, http://www.abgs.gov.tr/index.php?p=70\&l=1

- Çal, S. (2008). Türkiye'de Kamu Hizmeti ve İmtiyazın Dönüsüm Öyküsü [Elektronik Sürüm]. Ankara: TOBB Yayını.

- Devlet Planlama Teşkilatı. (Nisan 2006). 9. Kalkınma Planı (2007-2013) İnşaat, Mühendislik-Mimarlık, Teknik Müşavirlik ve Müteahhitlik Hizmetleri Özel İhtisas Komisyonu Nihai Raporu Ekler. Erişim: 27 Temmuz 2011, http://plan9.dpt.gov.tr/oik56_insaat/561insaatek.pdf

- Devlet Planlama Teşkilatı. (2007). Bazı Yatırım Ve Hizmetlerin Kamu Kesimi İle Özel Sektör İşbirliği Modelleri Çerçevesinde Gerçekleştirilmesine İlişkin Kanun Tasarısı Taslă̆ı. Ankara :Devlet Planlama Teşkilatı.

- Devlet Planlama Teşkilatı. (2007). Bazı Yatırım ve Hizmetlerin Kamu Kesimi İle Özel Sektör İşbirliği Modelleri Çerçevesinde Gerçekleştirilmesine İlişkin Kanun Tasarısı Taslağl Genel Gerekçesi. Ankara: Devlet Planlama Teşkilatı.

- $\quad$ Eker, A.Y. (Bahar 2007). Kamu Özel Sektör Ortaklıkları. Bütçe Dünyası, 2(25), 59-67. Erişim: 27 Temmuz 2011, http://www.butce.org/Html/dergi/25/aeker.pdf

- $\quad$ Europe Comission. (Mart 2003). Guidelines For Succesful Public- Private Partnerships. Erişim: 27 Temmuz 2011, http://ec.europa.eu/regional_policy/sources/docgener/guides/ppp_en.pdf

- $\quad$ Europe Comission. (Nisan 2004). Green Paper on Public- Private Partnerships and Community Law on Public Contracts and Concessions (Rapor No: COM(2004) 327 final). Erişim: 27 Temmuz 2011,

- http://eur-lex.europa.eu/LexUriServ/LexUriServ.do?uri=COM:2004:0327:FIN:EN:PDF

- $\quad$ Europe Comission. (Haziran 2004). Resource Book on PPP Case Studies. Erişim: 27 Temmuz 2011, http://ec.europa.eu/regional_policy/sources/docgener/guides/pppresourcebook.pdf

- Keşli, A. (2009). Yerel Yönetimler için AB Çevre Müktesebatı ve Çevre Yatırımlarının Planlanması. Erişim: 27 Temmuz 2011, Bölgesel Çevre Merkezi Rec Türkiye Ağ Sitesi: http://www.rec.org.tr/dyn_files/32/661-4-PresentationAhmetKesli.pdf

- $\quad$ Sarısu, A. (2009). Kamu\& Özel İşbirlikleri. Ankara: Yaklaşım Yayıncılık.

- $\quad$ T.C. Başbakanlık. (2008). 2008 Yılı Ulusal Programı. Erişim: 27 Temmuz 2011, http://www.abgs.gov.tr/index.php?p=42260\&l=1

- Tekin, A.G. (Mayıs-Haziran 2007). Kamu-Özel Sektör İşbirlikleri ve Ortaklıkları [Elektronik Sürüm]. İdarecinin Sesi, 21(122), 10 . 


\title{
Geçiş Ekonomilerinde Liberalizm ve Büyüme İlişkileri
}

\author{
Cevat GERNI (Beykent University, Turkey) \\ Selahattin SARI (Beykent University, Turkey) \\ M. Kemal DEĞER (Karadeniz Technical University, Turkey) \\ Selçuk EMSEN (Atatürk University, Turkey)
}

\section{Liberalism and Economic Growth in Transition Economies}

\begin{abstract}
In the world economy, since 1960s, countries, which are open and apply liberal policies succeeded higher economic growth and welfare. Therefore, liberal policies became more attractive. In that case, the transition, which has political, economic, and socio-cultural aspects, means moving from socialist-authoritarian structure to market based-liberal structures. In the literature, there are many studies which point out labor force and capital are not significant on the economic growth. In addition, the literature focuses on the importance of institutions on the economic growth. In this study, we compare the countries which were quickly away from the socialist structures with the countries which were slow on the reforms. Our analysis depends on their economic growth with cross section. However, we know the importance of institutional aspects on the growth research; therefore, we applied 2SLS regression analysis and to determine the economic liberalism indicators we used political rights, civil liberties, years that were under the socialism, openness, secondary school ratio, and public spending/GDP ratio. In the late phase, GDP per capita, as an indicator of economic growth, is explained with an independent variable which is predicted in the first phase via liberalism variable, and labor-population ratio and constant capital stock GDP ratio variables used in Neo-classical Solow-type growth model.
\end{abstract}

JEL Codes: C31, F44, P26.

\section{Giriş}

Eski Sovyet bloğu ekonomilerine özgü bir kavram olarak geçiş süreci tanımlaması, sosyalist sistemin sonlanmasıyla birlikte, karşılaşılan sorunlar açısından diğer ekonomilerden faklılık arz etmeleriyle kendini ayırt edici boyuta taşımıştır (Fischer ve Sahay, 2004: 2). Geçişten bahsedildiğinde, Sovyetlerin yanı sıra eski Yugoslavya, Küba, Vietnam ve Çin ile Angola, Etiyopya ve Mozambik’ten oluşan bir ülkeler demeti söz konusudur. Ancak, literatürde yaygın olarak inceleme konusu yapılan grup daha çok eski Sovyetleri ifade eder (Fischer ve diğ., 1996: 45). Bu anlamda geçiş olgusunun temelinde siyasal boyutun yanı sıra iktisadi ve sosyokültürel yapı da dahil edilir. Diğer taraftan geçişin 1989'da Polonya'da başladığı kabul edilirken; daha öncelerinde 1950'lerde Yugoslavya'da, 1968'de Macaristan'da ve hatta değişik tarihlerde yapılan teşebbüslerle Sovyetlerde ortaya çıktığı ileri sürülmektedir. Ancak, bu teşebbüsler, piyasa ekonomisine yönelim amacı taşımadığı (Fischer ve diğ., 1996: 45); daha çok sistemdeki tıkanıklıkları aşmaya yönelik 1slahatlar niteliğindeydi. Geçişin üç sacayağı üzerine inşa edildiği, yani siyasal anlamda otoriter-totaliter devlet anlayışından demokratik sisteme; ekonomik anlamda merkezi planlamacılıktan piyasa ekonomisine ve sosyokültürel anlamda da tek tip-homojen anlayıştan heterojen yapıya yönelimler söz konusudur. Bu sürecin ortaya çıkmasında liberal anlayışa sahip Batı Bloğunun Doğu Bloğuna üstünlüklerinin belirginleşmesi etkili olmuştur. Dolayısıyla başlangıçta Doğu Bloğunun mevcut yapıyı ıslah etme çabalarıyla kendini gösteren değişim anlayışının 1989'da Polonya'da başlayan ve yine aynı yıl Berlin Duvarının yıkılmasıyla devam eden arayışların sonucu olarak 1991'de eski Sovyetlerin çöküşüyle zirveye çıkan gelişmeler kümesi olduğu söylenebilir. Bu yönüyle iki kutuplu bir dünya anlayışından tek kutuplu bir dünya düzenine yönelim söz konusu olmuştur.

Ortaya çıkan yeni dünya düzeni de dünya ülkelerinin sınıflandırmasını yeniden oluşturarak, gelişmiş, gelişmekte olan-az gelişmiş, bağlantısızlar ve geçiş ekonomileri şeklinde teşekkül ettirmiştir. Yeni düzenin geçiş̧ boyutunu oluşturan eski merkezi planlı ekonomiler ise gösterdikleri ekonomik performanslar açısından farklılık arz etmişlerdir. Buna göre bir kısım ekonomiler geçiş resesyonu olarak adlandırılan ekonomik daralmaları daha kısa sürede deneyim ederek, kısa zamanda istikrarlı ve yüksek büyüme skorları elde etmiş̧lerdir. Diğer bir kısım geçiş ekonomilerinde ise iktisadi daralmalar uzun sürmüş ve büyümede de istikrarsızlıklar kendini göstermiştir. $\mathrm{Bu}$ farklılaşmanın temelini araştıran çalışmalarda daha çok başlangıç koşulları şeklinde nitelendirilen yapı olarak ekonomilerin 1989 yılı gelir düzeyi ve sosyalizm altında geçen yıl sayısı gibi unsurlar dikkate alınmıştır. Diğer bir kısım çalışmalarda da farklılığın temelinde ekonomilerin reformist olabilmelerinin yansımalarına atıflar söz konusudur. Reformist yapıyı temsilen de EBRD indeksi kullanılırken; EBRD belirleyicileri olarak reforma başlama yılı, sivil özgürlükler gibi değişkenler kullanılmaktadır.

$\mathrm{Bu}$ çalışmada sağlkklı veri setine sahip 24 geçiş ekonomisi için ekonomik büyümenin belirleyicileri araştırılmıştır. Bunun için literatürde kullanılan modellerden hareketle üç aşamalı regresyon tahminlerine gidilmiştir. Öncelikle başlangıç gelirini belirleyen unsurlar araştırılarak, bir başlangıç geliri tahmini değişkeni 
elde edilmiştir. Daha sonra aynı metodoloji takip edilerek EBRD liberalizasyon indeksinin belirleyicileri saptanmıştır. Son olarak tahmini başlangıç geliri ve liberalizasyon değişkenlerini de kapsayan Neo-klasik büyüme fonksiyonuna AB'ye uzaklık gölge değişkeni dahil edilerek 2008 yllı için yatay kesit analizlere gidilmiştir. Bu çerçevede, cari literatür özeti ve bu özetten hareketle üç regresyon eşitliği için değişken saptaması yapılmış ve daha sonra ekonometrik analizlerle büyümenin belirleyicileri incelenmiştir.

\section{Literatür Araştırması ve Model Seçimi}

Geçişle birlikte üretimdeki azalmaların yapısı incelendiğinde, eski Sovyetler (ES) ile Merkezi ve Doğu Avrupa (MDA)'daki ülkeler arasında üretim kayıplarında belirgin artışların varlı̆̆ı dikkati çekmektedir. Buna göre ES ülkelerindeki üretim düşüşleri ve daha sonra ekonominin kendini toparlaması MDA ile karşılaştırıldığında, ES ülkelerinde üretimdeki düşüşlerin daha dramatik gerçekleştiği ve buna karşılık üretimde düzelmelerin ise daha yavaş seyrettiği gözlenmiştir (Berg ve diğ., 1999: 4-5). Üretim kayıplarının temeli ise daha çok dört noktada ele alınmaktadır. Birincisi, yapısal değişim olarak ifade edilen olguda, geçiş süresince uygulanan politikalar ve başlangıç koşullarında kendini bulmuştur. Buna göre yapısal değişime gidilirken uygulanan politikalar ile sahip olunan mevcut yapının, yani başlangıç koşullarının "eski" ve "yeni”" sektörlerdeki yansımalarına dikkat çekilir. İkincisi, esnek dinamik yapının izin verdiği ölçüde ve zaman içerisinde başlangıç koşullarının sabit etkiler sergilememesinin yansımaları üretimdeki kayıpların temel etkeni olarak gösterilir. Üçüncüsü, ortaya çıkan kısıtların yarattığı gecikmeli etkilerin yansımalarına yoğunlaşır. Dördüncüsü, makroekonomik politikalar kadar, politik içsellik sorunlarının varlığını üretim kayıplarının sebebi olarak görür ki, bu açıdan mali dengeyi sağlamaya yönelik politikaların üretim ve büyüme üzerine yansımalarına atıf yapılır. Bu boyutları dikkate alındığında, iktisat teorisinin standart uzun dönem büyüme eşitlikleri (örneğin Levine ve Renelt, 1992; Sala-i Martin, 1997) ile geçiş sürecinde büyümenin belirleyicilerinin açıklanamadığına dikkat çekilmektedir. Bu yönüyle ekonomi dışı gibi gözüken, ancak ekonomiyi-üretimi-büyümeyi etkileyen unsurların varlı̆̆ı geçiş ekonomileri özelinde daha bir anlam ifade etmeye başlamıştır. Bunlar içerisinde politik değişimi ifade eden bir kısım liberalizasyon indekslerinin standart modellerden daha anlamlı sonuçlar verdiği gözlenmektedir (Berg ve diğ., 1999: 5-10).

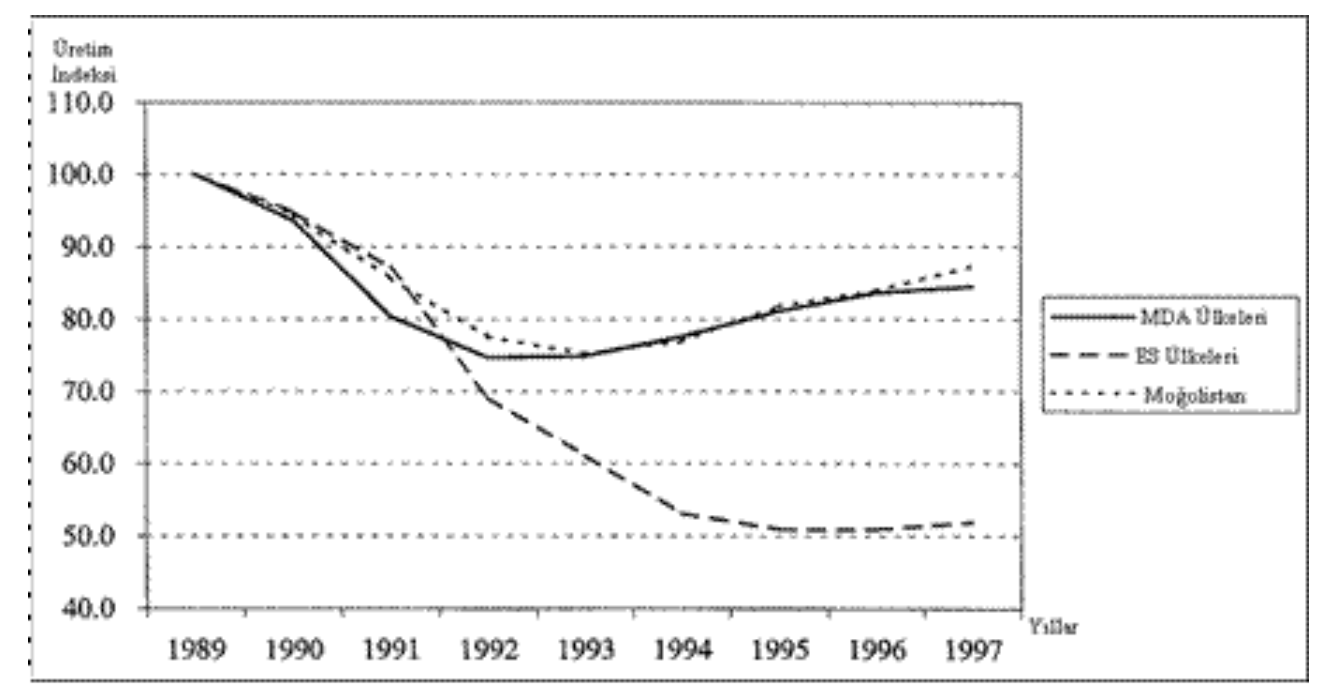

Şekil 1. Üretimdeki Gelişmeler (1989=100)

Geçiş ekonomilerine ilişkin literatür incelendiğinde, ekonomik performanstaki farklılığı açıklamada üç unsura vurgu göze çarpmaktadır. (i) Bir ülkenin başlangıç noktası en azından kısa dönemde sonraki gelişimi üzerinde etkili olmaktadır. (ii) Mali açıklar ve yüksek enflasyon olgusunun olumsuz yansımaları söz konusu iken, çok güvenilir bir makroekonomik istikrar programı büyüme için gerekli koşul konumundadır. (iii) Reformlar demetine sürdürülebilir büyüme için ihtiyaç duyulurken, reformlar da temelde fiyat ve ticari liberalizasyon ile küçük ölçekli özelleştirmeden başlayarak kurumsal yeniden yapılanma, rekabet politikası ve finansal sektör gelişimi gibi daha ileri kurumsal reformları ifade eder (Falcetti ve diğ., 2006: 422). Bu değişkenler açıldığında, başlangıç koşulları olarak planlamacılıkta geçen yıl sayısı, AB'ye uzaklık, ticari bağımlılık ve doğal kaynak zenginliği gibi faktörler ele alınır. Makroekonomik istikrar ölçütleri olarak mali açıkların GSYİH payı ve enflasyon oranı gibi değişkenler kullanılır. Yapısal reformları temsilen genellikle EBRD indeks değerleriliberalizasyon ve küçük ölçekli özelleştirme-alınırken; regresyon tahminleri için de başlangıç koşulları, büyüme ve sivil haklar indeksi üzerine yoğunlaşma söz konusudur (Falcetti ve diğ., 2002: 229, 238, 240).

Geçiş ekonomilerinde büyüme karakteristiği dikkate alındığında, geçişin ilk yıllarında başlangıç koşullarının önemli etkilerinin olduğu ve bu etkinin zamana bağlı olarak zayıfladığına dair yaygın bir literatür bulunmaktadır (bkz. De Melo ve diğ., 2001; Berg ve diğ., 1999; Havrylyshyn ve van Rodeon, 2003). Şöyle ki; coğrafi olarak 
batıdan uzakta bulunan ekonomilerde geçiş süreciyle birlikte üretim kayıplarının daha sert ve uzun süreli olduğu; doğudaki ülkelere özgü bu yapıda komünizm altında geçen yıl sayısının daha fazla olduğu dikkat çeker. Başlangıç koşulları için kullanılan değişkenler arasında başlangıçtaki fert başına gelir düzeyi ile EBRD indeks değerlerini alan çalışmalar bulunmaktadır. EBRD indeksi gelişmişlik düzeyinin bir ölçütü olarak alınırken; bunun yanı sıra ticari bağımlılık, makroekonomik dengesizlik (enflasyon ve karaborsa primi), AB'den mesafe olarak uzaklık, doğal kaynak donanımı, pazar belleği ve devlet kapasitesi gibi değişkenler de dahil edilir. EBRD ile ölçülen ekonomik bozucuların batıdakilere nazaran doğudakilerde daha yüksek olduğu gözlenir (Fischer ve Sahay, 2004: 4-5; De Mole ve diğ., 2001: 5). Diğer taraftan istikrar programına başlama y1lı, uygulanan kur rejimi (sabit kur rejiminin enflasyonla mücadelede ve dolayısıyla istikrarı sağlayarak büyümeyi gerçekleştirmede daha etkili olduğu düşüncesi), sistem içerisinde ticaretin GSYİH'ya oranı ve 1988 SGP fert başına milli gelirine de yer verilir (Fischer ve diğ., 1996: 49-51). Bir diğer çalışmada da başlangıç koşullarının ölçütü olarak; kentleşme oranları, telefon ağı ve AB'nin başkenti Bürüksele uzaklığı ya da enflasyon oranları ve karaborsa primi alınmaktadır. Ayrıca başlangıç GSYİH düzeyi, AB’ye uzaklık, emeğin tahsisindeki bozukluklar, merkezi planlamada geçen yıl sayısı ve makroekonomik dengesizlikler başlangıç koşulları olarak alınmaktadır (Falcetti ve diğ., 2006: 426).

Ancak, geçişin başlangıç noktasında ülkelerin sahip olduğu gelir ile büyüme arasındaki devam eden ilişkinin zamana bağlı olarak zayıfladığı gözlenmiştir. Bu duruma benzer şekilde reformlardan büyümeye doğru ortaya çıkan olumlu yansımaların da zamana bağlı olarak zayıfladığı dikkati çekmektedir. Büyüme üzerine makroekonomik politikaların etkinliği de enflasyon ve mali dengenin GSYİH'ya oranı göstergeleri ile takip edilir. Bu noktada Fischer ve Sahay (2004), Fischer ve diğ. (1996) ile Loungani ve Sheets (1997) tarafindan yapılan araştırmalarda enflasyon oranı ne kadar düşük ve bütçe açıkları ne kadar küçük ise, büyüme oranlarının o kadar yüksek olacağını ortaya koymuşlardır. Loungani ve Sheets (1997) yüksek enflasyonun, örneğin \%500'ü aşan enflasyon skorlarının ertesi yılda büyümede \%2'lik kayba ve takip eden yıllarda da \%4'lük düşüşlere neden olduğunu ortaya koymuşlardır. Araştırmalardan büyüme ve enflasyon ilişkilerinin olumlu seyredebilmesi için enflasyonun eşik değerinin \%10-20 aralığı olarak tespit edilmiştir. Buna göre Christoffersen ve Doyle (2000) eşik değeri \%13 olarak belirlerken; Ghosh ve Phillips (1998) bu değerin tek haneli olması gerektiğine dair bulgulara ulaşmışlardır (Falcetti ve diğ., 2006: 423).

Diğer taraftan reformlar açısından ilk etabı fiyat ve ticari liberalizasyon ile küçük ölçekli özelleştirme oluştururken; ikinci etap ise kurumsal yönetim, rekabet politikası ve finansal kurumlar gibi daha ileri kurumsal reformlardır. Bu açıdan Havrylyshyn ve van Rooden (2003) ekonomik liberalizasyonun kurumsal kaliteyi iyileştirerek büyüme performansına olumlu etkide bulunduğunu ifade ederken; Stiglitz (2001) kurumsal yapıdaki iyileşmeye bağlı olarak özelleştirmenin önemine vurgu yapmıştır. Geçiş sürecinde piyasa yönelimli reformlar ile kümülatif büyüme arasında pozitif bir korelasyonun varlığı dikkat çekmektedir. Dolayısıyla büyüme performansında reformist olabilme yeteneğine sahip olma, başlangıç milli gelir düzeyi ve mali bütçede fazla verebilme gibi unsurlar büyümeyi pozitif yönde etkilemektedir. Diğer taraftan üretimde telafi edici gelişmeler, petrol fiyatları ve dışa dönük büyüme de ekonomik büyümeyi etkileyen unsurlardandır; ancak bunlar reformların etkisini azaltmamaktadır. Reformist olabilme yeteneğinin AB üyeliği sürecine dahil olan ve üye olan ülkelerde daha yüksek olduğu görülmüştür ki, bu ülkelerde standartlar gelişmiş ülkeler düzeyine ulaşmıştır. $\mathrm{Bu}$ yeni $\mathrm{AB}$ üyesi ülkeler 1989'dan beri diğer geçiş ekonomilerine göre daha yüksek büyüme ve daha iyi yaşam standartlarına ulaşmışlardır. Bu açıdan bir diğer husus, en azından kısa dönemde diğer faktörler reformların önemini azaltabilirken; bunun uzun dönemde etkilerinin olduğu kabul edilmektedir. Diğer taraftan büyümeden de reformlara doğru geri besleme etkilerinin var olduğu da tespit edilmiştir (Falcetti ve diğ., 2006: 422-424).

Cari literatür dikkate alındığında, geçiş ekonomilerinin büyüme performansına bilinen Solow tipi modelde yer alan emek ve sermayeden ziyade başlangıç koşulları ile liberalizasyon-reformcu olabilme yeteneğinin etkili olduğu gözlenmektedir. Yine literatürde başlangıç koşulları için temsil kabiliyeti olan değişkenlerden birinin ele alınmasının yanında bir demetin oluşturduğu karma değişkenler de kullanılmaktadır. Benzeri durum liberalizasyon veya reform indeksleri içinde geçerlidir. Bu açıdan değerlendirildiğinde, geçiş süresince toplam üretim veya üretim artışına ilişkin yapısal ekonometrik modelin aşağıdaki gibi olduğu varsayılır (Berg ve diğg., 1999: 12):

$$
\begin{aligned}
& Y_{t, i}=F\left(Y_{t-1, i}, \ldots ; P_{t, i}, P_{t-1, i}, \ldots ; S_{t, i} ; X_{t} ; Z_{t}\right)+\varepsilon_{t, i} \\
& P_{t, i}=G\left(Y_{t, i}, Y_{t-1, i}, \ldots ; P_{t, i}, P_{t-1, i}, \ldots ; S_{t, i} ; X_{t} ; Z_{t}\right)+\mu_{t, i} \\
& S_{t, i}=H\left(Y_{t, i}, Y_{t-1, i}, \ldots ; P_{t, i}, P_{t-1, i}, \ldots ; S_{t, i} ; X_{t} ; Z_{t}\right)+\eta_{t, i}
\end{aligned}
$$

Burada $Y_{t, i}$ temel bağımlı (üretim düzeyi veya büyüme hızı) değişkendir; $P_{t, i}$ politik değişkenler vektörü dür (ki bu, makroekonomik politik değişkenleri ve yapısal reform indeksini içerir); $X_{t}$ başlangıç koşullarını da kapsayan gözlenebilir ülkeye özgü etkilerdir; Zt gözlenemeyen ülkeye özgü etkilerdir. St,i geçişin başlangıcından bu yana yapısal değişimin boyutunu ifade eder; yani bu değişken, büyüme üzerine politikaların veya başlangıç koşullarının geçiş sürecinde ne tür değişimin olduğuna dair olasılığı yakalamak için dahil edilir (Berg ve diğg., 1999: 12). Modelde panel tekniğine uygun olarak, t zaman aralığını ve i de ülkeleri ifade eder.

Yukarıdaki modeller ve cari literatürden hareketle bu çalışma için uygun modelin şu değişkenleri içereceği 
düşünülmüştür: geçiş ekonomilerinde büyüme hızını açıklamak üzere, sermaye ve işgücüne ilaveten başlangıç yılı, liberalizasyon indeksi ve gelişmiş en yakın piyasaya (AB) uzaklık değişkenleri alınmıştır. Dolayısıyla basit büyüme formunda söz konusu değişskenler aşağıdaki şekilde matematiksel forma dönüştürülmüştür:

$$
\mathrm{Y}_{\mathrm{i}}=\mathrm{F}\left(\mathrm{K}_{\mathrm{i}} ; \mathrm{L}_{\mathrm{i}} ; \mathrm{IC}_{\mathrm{i}} ; \mathrm{LI}_{\mathrm{i}} ; \mathrm{D}_{1 \mathrm{i}}\right)+\varepsilon_{\mathrm{i}}
$$

Çalışma 2008 yılına ilişkin büyüme eşitliğini araştırmayı amaçladığından, yani yatay kesit nitelik taşıdığından t unsuru dışlanarak, ülkeleri ifade eden i unsuruna yer verilmiştir. Dolayısıyla $Y_{i}$, büyüme oranını (bir diğer tahminde de cari GSYİH değerlerini); $\mathrm{K}_{\mathrm{i}}$, sermaye stokunun GSYİH içerisindeki payını; $\mathrm{L}_{\mathrm{i}}$, istihdam edilenlerin çalışma çağı nüfusa oranını; $\mathrm{IC}_{\mathrm{i}}$, başlangıç koşullarını; $\mathrm{LI}_{\mathrm{i}}$, liberalizasyon indeksini; $\mathrm{D}_{1 \mathrm{i}}, \mathrm{AB}$ 'ye uzaklık gölge değişkenini (Düsseldorf’a ortalama uzaklığın altında kalan ülkeler için 0, ortalama uzaklığın üzerinde kalan ülkeler için 1); $\varepsilon_{\mathrm{i}}$ de hata terimini sembolize eder. Bu değişken, Avrupa Para Birliği’ne üyelik unsuru olarak enflasyon, faiz ve kur kriterlerini taşıması nedeniyle üye ülkeleri diğer geçiş ekonomilerinden ayırt edici nitelik taşır (Cincibuch ve Podpiera, 2006: 548).

(4) nolu modelde yer alan $\mathrm{IC}_{\mathrm{i}}$ ile $\mathrm{LI}_{\mathrm{i}}$ değişkenlerinin literatürde birden fazla değişkenle ifade edilmesi nedeniyle bu çalışmada da söz konusu değişkenlerin bir kümesi alınmıştır. Bu kümeleme için gerek $\mathrm{IC}_{\mathrm{i}}$ değişkeninin, gerekse $\mathrm{LI}_{\mathrm{i}}$ değişkeninin bağımlı değişken olarak temsil edeceği düşünülen birer değişkeni alınmış ve bu bağımlı değişkenleri açıklayıcı nitelikte diğer değişkenler regresyon analizi ile tahmin edilerek,(4) nolu model için bağımsız bir veri setinin oluşturulması yoluna gidilmiştir. Dolayısıyla (4) nolu modeldeki $\mathrm{IC}_{\mathrm{i}}$ ve $\mathrm{LI}_{\mathrm{i}}$ değişkenleri için aşağıdaki şekilde modeller oluşturulmuştur:

$$
\begin{aligned}
& \mathrm{IC}_{\mathrm{i}}=\mathrm{F}\left(\mathrm{CMEA}_{\mathrm{i}} ; \text { PRIV }_{\mathrm{i}} ; \text { YEAR }_{\mathrm{i}} ; \mathrm{D}_{2 \mathrm{i}}\right)+\mathrm{v}_{\mathrm{i}} \\
& \mathrm{LI}_{\mathrm{i}}=\mathrm{F}\left(\mathrm{OPEN}_{\mathrm{i}} ; \mathrm{GOV}_{\mathrm{i}} ; \mathrm{CIV}_{\mathrm{i}} ; \mathrm{D}_{3 \mathrm{i}} ; \mathrm{D}_{4 \mathrm{i}}\right)+\varpi_{\mathrm{i}}
\end{aligned}
$$

\begin{tabular}{|c|c|c|c|c|c|c|c|c|c|}
\hline & \multirow{2}{*}{$\begin{array}{l}\text { Komünizm } \\
\text { Altında } \\
\text { Geçen Y11 }\end{array}$} & \multirow{2}{*}{$\begin{array}{c}1989 \\
\text { Fert } \\
\text { Başına } \\
\text { Geliri }\end{array}$} & \multirow[b]{2}{*}{$\begin{array}{c}\text { Doğal } \\
\text { Kaynak }\end{array}$} & \multirow{2}{*}{$\begin{array}{l}\text { İstikrar } \\
\text { Programı } \\
\text { Tarihi }\end{array}$} & \multirow{2}{*}{$\begin{array}{c}\text { Özel } \\
\text { GDP } \\
\text { Pay1 } \\
(1992)\end{array}$} & \multirow[b]{2}{*}{$\begin{array}{c}\text { AB'ye } \\
\text { Uzaklık }\end{array}$} & \multicolumn{2}{|c|}{$\begin{array}{c}\text { Özel Sektör } \\
\text { Payı }\end{array}$} & \multirow[b]{2}{*}{ Kur Rejimi } \\
\hline & & & & & & & 1990 & 1992 & \\
\hline Albania & 47 & 1400 & Fakir & Ağu.92 & 10,8 & 1494 & 5.0 & 60.0 & Esnek \\
\hline Armenia & 71 & 5530 & Fakir & Ara.94 & 31,5 & 3143 & 12.0 & 45.0 & Esnek \\
\hline Azerbaijan & 70 & 4620 & Zengin & Oca.95 & 12,6 & 3270 & 10.0 & 25.0 & Esnek \\
\hline Belarus & 72 & 7010 & Fakir & Kas.94 & 10,2 & 1435 & 6.0 & 15.0 & Esnek \\
\hline Bulgaria & 43 & 5000 & Fakir & Şub.91 & 26,2 & 1574 & 9,5 & 36.0 & Esnek \\
\hline Croatia & 46 & 6171 & Fakir & Eki.93 & 30 & 913 & 10.0 & 47.0 & Sabit \\
\hline Estonia & 51 & 8900 & Fakir & Haz.92 & 24,9 & 1449 & 10.0 & 62.0 & Sabit \\
\hline Georgia & 70 & 5590 & Orta & Eyl.94 & 18,1 & 3069 & 15.0 & 30.0 & Esnek \\
\hline Hungary & 42 & 6810 & Fakir & Mar.90 & 39 & 1002 & 19.0 & 60.0 & Sabit \\
\hline Kazakhstan & 71 & 5130 & Zengin & Oca.94 & 8,3 & 5180 & 7.0 & 25.0 & Esnek \\
\hline Kyrgyzistan & 71 & 3180 & Fakir & May.93 & 14,1 & 5047 & 7.0 & 40.0 & Esnek \\
\hline Latvia & 51 & 8590 & Fakir & Haz.92 & 26,9 & 1293 & 10.0 & 60.0 & Esnek/Sabit \\
\hline Lithuania & 51 & 6430 & Fakir & Haz.92 & 22,8 & 1299 & 11,5 & 55.0 & Esnek/Sabit \\
\hline Macedonia & 47 & 3394 & Fakir & Oca.94 & 14 & 1522 & 14.0 & 40.0 & Sabit \\
\hline Moldova & 51 & 4670 & Fakir & Eyl.93 & 12,1 & 1673 & 10.0 & 30.0 & Esnek \\
\hline Mongolia & 70 & 1613 & Fakir & Eki.92 & 55 & 6589 & 10.0 & 55.0 & Esnek \\
\hline Poland & 41 & 5150 & Orta & Oca.90 & 45,3 & 995 & 27.0 & 58.0 & Sabit \\
\hline Romania & 42 & 3470 & Orta & Eki.93 & 25,7 & 1637 & 16,5 & 40.0 & Esnek \\
\hline $\begin{array}{c}\text { Russian } \\
\text { Federation }\end{array}$ & 74 & 7720 & Zengin & Nis.95 & 23,5 & 2088 & 6.0 & 58.0 & Esnek \\
\hline $\begin{array}{c}\text { Slovak } \\
\text { Republic }\end{array}$ & 42 & 7600 & Fakir & Oca.91 & 32,4 & 824 & 6.0 & 60.0 & Sabit \\
\hline Slovenia & 46 & 9200 & Fakir & Şub.92 & 20 & 815 & 11.0 & 40.0 & Esnek \\
\hline Tajikistan & 71 & 3010 & Fakir & Şub.95 & 11,2 & 4938 & 10.0 & 15.0 & Esnek \\
\hline Ukraine & 74 & 5680 & Orta & Kas.94 & 25,5 & 1664 & 10.0 & 36,5 & Esnek \\
\hline Uzbekistan & 71 & 2740 & Orta & Kas.94 & 12,5 & 4788 & 10.0 & 30.0 & Esnek \\
\hline
\end{tabular}

Tablo 1. Geçiş Ekonomilerine Illişkin Temel Değişkenler. Kaynak: Fisher ve diğ., 1996: 50; Berg ve diğ., 1999 : 56; Fischer ve Sahay, 2000: 14; De Mole ve diğ., 2001: 4; IMF, Classification of Exchange Rate Arrangements and Monetary Policy Framework

(5) nolu modelde bağımlı değişken olarak alınan başlangıç koşulları ( $\left.\mathrm{IC}_{\mathrm{i}}\right)$ için 1989 yılı satın alma gücü paritesi (SGP) ile kişi başına gelir alınarak indekse dönüştürülmüştür. Bu indeks değeri her bir ülke gelirinin geçiş ortalaması gelire oranıdır. $\mathrm{IC}_{\mathrm{i}}$ değiş̧kenini açıklayıcı değişkenlerden $\mathrm{CMEA}_{\mathrm{i}}$ sosyalist blokla olan ticaretin

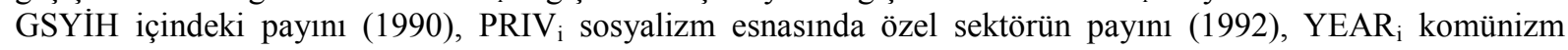
altında geçen yıl sayısının en uzun süre sosyalizm altında kalan Sovyetler Birliği’nin yıl sayısına oranını temsil 
etmektedir. $\mathrm{D}_{2 \mathrm{i}}$ ise doğal kaynak sahipliği gölge değişkenini (zengin olan ülkeler 1 ve olmayan ülkeler 0 ) ve $v_{i}$ de hata terimini gösterir. (6) nolu modelde ise bağımlı değişken olarak alınan liberalizasyon indeksi $L_{i}$ ile sembolize edilirken; bu değişken 2008 yılı EBRD ülke skorlarının gereken en üst değer olan 38.7'ye oranlanması ile elde edilmiştir. LI $_{i}$ değişkenini açıklamak üzere kullanılan değişkenler 2008 y1lı değerleri cinsinden alınmıştır. OPEN, ekonominin dışa açıklığını yansıtır ve ihracat ile ithalat değerlerinin toplamının GSYİH'ya oranı ile belirlenir. GOV , kamu harcamalarının GSYİH'ya oranını; CIV $_{\mathrm{i}}$, sivil özgürlükler indeks değerini gösterir. $\mathrm{D}_{3 \mathrm{i}}$, reforma başlangıç yılı kukla değerini (1992 ve öncesi için 1, sonrası için 0) ve $\mathrm{D}_{4 \mathrm{i}}$ de uygulanan kur sistemi kukla değerini (sabit kur sistemi için 1, esnek kur sistemi için 0) temsil eder. Çalışmada 2008 yılı ekonomik büyümesine etki edeceği düşünülen temel (4) nolu model ile yine (4) nolu modelde yer alan $\mathrm{IC}_{\mathrm{i}}$ değişkeni ile $\mathrm{LI}_{\mathrm{i}}$ değişkenleri sırasıyla (5) ve (6) nolu modellerde tahmin süreçlerini içerir. Bu üç modelde kullanılan gölge değişkenlere ilişkin değerleri kapsayan bilgiler Tablo 1'de verilmiştir.

\section{Uygulama Sonuçları}

Geçişle birlikte üretimdeki azalmalar ve hiper enflasyon olguları yaşanırken, bir süre sonra bu yapının doğal hale gelmesiyle göreceli istikrarın yakalandığı dikkat çekmektedir. Ancak, gelinen durum değerlendirildiğinde, geçiş ekonomilerinin bir kısmı dünya ortalamasını da aşarak AB'ye üyeliği dahi gerçekleştirebilirken; bir kısmı da göreceli olarak geri kalmış ülkeler düzeyinde yerini almışlardır. Bu çalışmada üç aşamalı yatay kesit regresyon tahminlerinde 2008 yılı ekonomik büyümesinin alınmasının gerekçesi, 2009 yılında ağırlığı hissedilen dünya krizinin etkilerinden arınmış büyüme belirleyicilerinin araştırılması bulunmaktadır. Bu bağlamda ES ile MDA ülkelerinde büyüme belirleyicileri araştırılırken, öncelikle (5) nolu modelle cari büyümeye başlangıç koşullarının etkisini belirleme amacı güdülmüştür. (5) nolu model tahmin sonuçları ile t istatistikleri aşağıdaki gibidir.

$$
\begin{aligned}
& \mathrm{IC}_{\mathrm{i}}=1.476+0.018 \mathrm{CMEA}+0.004 \mathrm{PRIV}-1.254 \mathrm{YEAR}+0.325 \mathrm{D}_{2} \\
& \text { (3.174) (2.105) (0.629) (-2.122) (1.213) } \\
& \mathrm{R}^{2}=0.257 \quad \mathrm{~F}=1.651
\end{aligned}
$$

Başlangıç gelirine etki eden faktörlerin araştırılmasında, 1989 yılı gelirini pozitif yönde etkileyen unsur bloğun kendi aralarındaki ticaretidir (CMEA) ve bu değişken \%5 önem düzeyinde anlamlı bulunmuştur. Buna karşılık komünizm altında geçen yılın (YEAR) da negatif ve \%5 önem düzeyinde etkili olduğu gözükmektedir. Dolayısıyla sosyalizm altında geçen yıl sayısının fazla olduğu ekonomilerde başlangıç geliri düşük düzeylerde iken; kendi aralarında ticareti fazla yapan ülkelerde ise kişi başına gelir daha yüksektir.

İkinci aşamada (6) nolu modelle liberalizasyon-reform indeksine etki eden unsurlar belirlenmiştir. Çalışmanın temel amacı da liberalizasyon ile ekonomik büyüme ilişkilerini araştırmaktır. Liberalizasyon indeksinin belirleyicilerine ilişkin (6) nolu model tahmin sonuçları ile t istatistikleri aşağıda verilmiştir.

$$
\begin{array}{cccc}
\mathrm{LI}_{\mathrm{i}}=99.61 & -0.031573 \mathrm{OPEN} & -0.0910 \mathrm{GOV} & -5.52439 \mathrm{CIV}+0.36774 \mathrm{D}_{3}-5.50754 \mathrm{D}_{4} \\
(1522.5)(-102.58) & (-38.90) & (-681.77) & (13.09) \\
\mathrm{R}^{2}=0.99 & \mathrm{~F}=320542.1 & (-231.92)
\end{array}
$$

Liberalizasyon indeksinin belirleyicilerini araştırmak üzere oluşturulan modelde kullanılan tüm değişkenler istatistiki açıdan \%1 önem düzeyinde anlamlı bulunmuştur. LI değişkenini sadece D3 değişkeni pozitif yönde etkilerken; OPEN, GOV, CIV ve D4 değişkenlerinin negatif etkilediği tespit edilmiştir.

(5) nolu modelde 1989 yılı fert başına başlangıç gelirinin belirleyicileri tahmin edilerek, tahmini IC serisi oluşturulmuştur. Diğer taraftan (6) nolu modelde de 2008 yılı liberalizasyon indeksinin belirleyicileri araştırılmış ve bu parametrelerden hareketle tahmini LI serisi elde edilmiştir. IC ve LI serileri de (4) nolu ana modeldeki büyüme eşitliğinin birer açıklayıcı değişkeni konumuna getirilmiştir. Böylece (4) nolu büyüme modelinde 2008 yılı büyümenin belirleyicileri araştırmasına gidilebilmiştir.

\begin{tabular}{|c|c|c|c|c|c|c|}
\hline & $\mathrm{Y}$ & $\mathrm{K}$ & $\mathrm{L}$ & $\mathrm{LI}$ & $\mathrm{IC}$ & $\mathrm{D} 1$ \\
\hline Ortalama & 8.475000 & 0.274333 & 0.483790 & 74.21094 & 0.999989 & 0.333333 \\
\hline Medyan & 7.850000 & 0.268500 & 0.480908 & 77.27964 & 0.957978 & 0.000000 \\
\hline Maksimum & 25.00000 & 0.400000 & 0.540412 & 90.05588 & 1.351691 & 1.000000 \\
\hline Minimum & 1.200000 & 0.193000 & 0.406609 & 51.52081 & 0.732736 & 0.000000 \\
\hline Std. Sap. & 4.441235 & 0.056198 & 0.040953 & 11.06947 & 0.207897 & 0.481543 \\
\hline Gözlem & 24 & 24 & 24 & 24 & 24 & 24 \\
\hline
\end{tabular}

Tablo 2. Büyüme Modeline İlişkin Değişkenlere Ait Tanımlayıcı İstatistikler

Büyümenin ortalama \%8.48 civarında gerçekleştiği görülürken; en düşük büyüme skorunun \%1.2 ile Macaristan'da; en yüksek büyüme skoru da \%25 ile Azerbaycan'da gerçekleşmiştir. Mutlak anlamda en yüksek sermaye birikiminin olduğu ülke Rusya Federasyonu ve Polonya iken; bunun 2008 yılı GSYİH içerisindeki payının en yüksek olduğu ülke ise Ermenistan; en düşük olduğu ülke de Tacikistan'dır. Geçiş ekonomileri 
içerisinde en düşük gelirli ülkeler grubu içerisinde bulunan bu iki ülkeden Ermenistan'da payın yüksekliğine karşılık üretime dönüşümde sıkıntıların olduğu söylenebilir. Tacikistan'da da yeterli birikime ulaşamamanın getirmiş olduğu büyüme kısıtının varlığından bahsedilebilir. Libarelleşme indeksi açısından ülkelerin homojen olmadığı bir yapının varlığı standart sapma değerinin göreceli yüksekliğinden anlaşılmaktadır. Başlangıç koşulları açısından da özellikle 1989 yılı SGP ile kişi başına milli gelirin Doğuda bulunan geçiş ekonomilerinde düşük olması, sosyalist sistemin teorik açıdan gelir dağılımında eşitlikçi yapıdan uzak olduğuna işaret ederken; aynı zamanda geçiş sürecinin startının verildiği 1991 yılı itibarıyla politik ve iktisadi unsurlar açısından da yarışa eşit koşullarda başlamadıklarının göstergesidir.

(4) nolu modelde kullanılan değişkenlere ait korelasyon katsayıları, regresyon tahmini öncesi 2008 yılı büyümesini açıklamada kaba bir öngörüde bulunma imkanı sunmaktadır.

\begin{tabular}{|c|c|c|c|c|c|c|}
\hline & $\mathrm{Y}$ & $\mathrm{K}$ & $\mathrm{L}$ & $\mathrm{LI}$ & $\mathrm{IC}$ & $\mathrm{D} 1$ \\
\hline $\mathrm{Y}$ & $\mathbf{1 . 0 0 0}$ & -0.078 & 0.355 & -0.316 & 0.104 & 0.573 \\
\hline $\mathrm{K}$ & -0.078 & $\mathbf{1 . 0 0 0}$ & 0.316 & 0.014 & -0.017 & -0.078 \\
\hline $\mathrm{L}$ & 0.355 & 0.316 & $\mathbf{1 . 0 0 0}$ & 0.016 & 0.084 & 0.139 \\
\hline $\mathrm{LI}$ & -0.316 & 0.014 & 0.016 & $\mathbf{1 . 0 0 0}$ & 0.372 & -0.587 \\
\hline $\mathrm{IC}$ & 0.104 & -0.017 & 0.084 & 0.372 & $\mathbf{1 . 0 0 0}$ & -0.456 \\
\hline $\mathrm{D} 1$ & 0.573 & -0.078 & 0.139 & -0.587 & -0.456 & $\mathbf{1 . 0 0 0}$ \\
\hline
\end{tabular}

Tablo 3. Büyüme Modeline İlişkin Değişkenlerin Korelasyon Katsayıları

24 geçiş ekonomisinin 2008 yılı ekonomik büyüme skorlarını açıklamada göreceli olarak en kuvvetli açıklama gücünün olduğu değişken AB'ye uzaklık gölge değişkeni, yani D1'dir. AB'den uzaklaştıkça, büyüme üzerine etkinin arttığına dair bir bulgu söz konusudur. Özellikle AB'ye mesafe olarak yakın ülkelerin ekonomik ilişkilerinde $A B$ 'nin payının çok yüksek düzeylere gelmiş olması ve $A B$ ülkelerinde gözlenen durgunluğun bu ülkelere de sirayet ettiğine dair bulguya ulaşılmıştır. Diğer bir ifadeyle, AB'ye üye olan geçiş ekonomilerinin büyüme kalıbının da birlik ortalaması büyüme trendine girerek, büyüme skorlarını hafifçe düşürdüğüne dair literatürle örtüşme söz konusudur (Mitrović ve Ivančev, 2010: 13). Diğer taraftan LI ile ifade edilen liberalizasyon indeksinin ise büyüme üzerine korelasyon katsayısının -0.316 çıkması da D1 gölge değişkeni benzeri etkilerden kaynaklanmaktadır. Büyüme skorlarında ortalamanın üzerine çıkan ülkelerin daha çok liberal politikalarda geri kalmış doğudaki ülkelerden oluşması, katsayının beklenen işaretinin dışında bir değer almasına yol açtığı düşünülebilir. Diğer taraftan Neo-klasik büyüme fonksiyonunun sermaye ve emek unsurlarından sermayenin çok zayıf ve negatif etkilerinin olmasına karşılık, emek unsurunun 0.355 gibi bir değerde olması da, yüksek büyüme yaşayan geçiş ekonomilerinin emek-yoğun yapıda olduklarına işaret eder.

Yatay kesit analizler çerçevesinde 24 geçiş ekonomisi için yapılan büyüme tahminine ilişkin sonuçlar da Tablo 4'de verilmiştir.

\begin{tabular}{|c|c|c|c|c|}
\hline \multicolumn{3}{|c|}{ Bağımlı Değişken: Y(büyüme) } & \multicolumn{2}{|c|}{ Y(cari GSYİH) } \\
\hline Değişken & Katsayı & Std. Hata & Katsayı & Std. Hata \\
\hline $\mathrm{C}$ & -11.56807 & 10.09160 & $1.83 \mathrm{E}+11$ & $9.04 \mathrm{E}+11$ \\
\hline $\mathrm{K}$ & -7.896096 & 13.35157 & $-2.83 \mathrm{E}+12^{(\mathrm{b})}$ & $1.20 \mathrm{E}+12$ \\
\hline $\mathrm{L}$ & 28.15842 & 18.76756 & $4.02 \mathrm{E}+12^{(\mathrm{b})}$ & $1.68 \mathrm{E}+12$ \\
\hline LI & -0.032262 & 0.079411 & $-1.25 \mathrm{E}+10^{(\mathrm{c})}$ & $7.11 \mathrm{E}+09$ \\
\hline $\mathrm{IC}$ & $8.913757^{(\mathrm{b})}$ & 3.887406 & $-1.35 \mathrm{E}+11$ & $3.48 \mathrm{E}+11$ \\
\hline D1 & $6.201110^{(a)}$ & 1.972024 & $-4.37 \mathrm{E}+11^{(\mathrm{a})}$ & $1.77 \mathrm{E}+11$ \\
\hline $\mathrm{R}^{2}$ & 0.554673 & F-statistic & 0.402081 & F-statistic \\
\hline Ayarlanmıș $\mathrm{R}^{2}$ & 0.430971 & $4.483952^{(\mathrm{a})}$ & 0.235993 & $2.420887^{(\mathrm{c})}$ \\
\hline
\end{tabular}

Tablo 4. Büyüme ve GSYIH Modeli Tahmin Sonuçlarl.

Not: (a) \%1, (b) \%5 ve c \%10 önem düzeyinde anlamllğl gösterir.

Tablo 4'deki sonuçlar Tablo 3'deki korelasyon katsayılarının işaretleriyle paraleldir. 2008 yılı büyümesinden istatistiki açıdan anlamlı etkileri olan değişkenler IC (\%5'de) ve D1 (\%1'de) değişkenleridir. Dolayısıyla geçiş ekonomilerinin cari büyümelerinde halen daha başlangıç koşullarının, yani IC değişkeninin etkisinin devam ettiği görülmektedir. Sosyalist sistemden alınan mirasın 17 yıllık süreç sonrasında büyüme etkilerinin devamı, sistemin bıraktığı yapının yansımalarının süregeldiğine işaret eder. Diğer taraftan AB'ye fiziki uzaklık gölge değişkeni D1 de anlamlı etkilere sahiptir. Bu değişkenin \%1 önem düzeyinde büyümeye etki etmesi, yukarıda da belirtildiği gibi, birlik ortalaması büyümenin durağanlaşmasının birliğe üye olan ve üye olmasa da birlikle yakın ilişkileri olan ülkelerin dış yansıma olgusu gereği büyümelerinin benzeşiklik göstermelerinin bir sonucudur. Bu ülkelerde emek ve sermaye unsurunun büyüme üzerinde istatistiki açıdan anlamlı etkileri yakalanamamıştır. Ancak, işaret açısından sermaye unsuru negatif; emek unsuru ise pozitif etkilere sahiptir. Diğer taraftan liberalizasyon indeksi değeri de istatistiki açıdan anlamsız ve buna karşılık negatif etkileri bulunmaktadır. Dolayısıyla 2008 yılı büyümesinde katsayıları ve işaretleri açısından sermaye ve liberalizasyon indeksinin 
beklenenden farklılık göstermesi, büyüme skorları açısından emek yoğun ve yeterince liberal politikalar uygulamamış ülkelerin daha yüksek performans sergilemelerinin büyüme literatürü için bir örnek teşkil etmeyen yansımaları olarak değerlendirilebilir. Özellikle sermaye zengini ve görece daha liberal politika uygulayan ülkelerde büyümenin ortalamanın altında kalması, hem uygulamanın etkinliğinin tartışılması gereğine hem de uyguladıkları politikalarda yeni açılımlar içersinde bulunmaları gereğine işaret eder.

\section{Sonuç}

24 geçiş ekonomisinde 2008 yılı ekonomik büyümesine etki eden faktörlerin araştırıldığ aşamalı regresyon tahminine gidilmiştir. Öncelikle literatürdeki büyüme eşitliklerinden hareketle, büyümeye etki eden faktörlerden bir büyüme eşitliğine ulaşılmıştır. Buna göre büyümeye etki edeceği düşünülen faktörler olarak emek, sermaye gibi klasik üretim fonksiyonu araçlarına ilaveten geçiş ekonomilerine özgü üç değişken daha modele dahil edilmiştir. Bunlar; liberalizasyon indeksi, başlangıç koşulları ve AB'ye uzaklık gölge değişkenidir. Bu büyüme formunda yer alan liberalizasyon indeksi ile başlangıç koşulları için de belirleyici unsurlar modellenmiştir. Liberalizasyon indeksinin belirleyicileri olarak ekonominin dişa açıklığı, kamu harcamalarının GSYİH'ya oranı, okullaşma oranı, sivil özgürlükler indeksi ile döviz kuru uygulamaları ve reforma başlama yılı gölge değişkenleri alınmıştır. Başlangıç koşulları için 1989 yılı fert başına gelirinin belirleyicileri olarak da kendi aralarındaki ticaret, milli gelirde özel sektörün payı ve sosyalizm altında geçen yıl sayısı ile doğal kaynak sahipliği gölge değişkenleri kullanılmıştır.

Birinci regresyonda başlangıç koşulları tahmin edilmiştir. Başlangıç koşullarını katsayı işaretleri ve istatistik açıdan anlamlı düzeyde etkileyen değişkenlerden sosyalizm altında geçen yıl sayısının negatif etkisi varken; kendi aralarındaki ticaretin ise pozitif etkileri bulunmuştur. İkinci regresyon eşitliğinde liberalizasyon indeksinin belirleyicileri araştırılmıştır. Bu modelde kullanılan tüm değişkenler istatistiki açıdan anlamlı çıkarken; liberalizasyon indeksine okullaşma oranları ile kur uygulamaları pozitif; diğer değişkenler ise negatif etkide bulunmuştur. $\mathrm{Bu}$ iki regresyon ile oluşturulan tahmin değerlerinden hareketle üçüncü bir regresyon tahminine gidilmiştir. Üçüncü regresyon tahmini büyümenin belirleyicilerini araştırırken; istatistiki açıdan anlamlı etkileri olan değişkenler, başlangıç geliri ve AB'ye uzaklıktır. Liberalizasyon ve ekonomik büyüme ilişkilerinin ise beklenenin aksine, negatif ve istatistiki açıdan anlamsız olduğu görülmüştür.

\section{Kaynakça}

- Berg, Andrew, Eduardo Borensztein, Ranta Sahay and Jeromin Zettelmeyer (1999), The Evolution of Output in Transition Economies: Explaining the Differences. Working Paper No. 99/73. IMF, Washington, D.C.

- Christoffersen, Peter and Peter Doyle (2000), "From Inflation to Growth: Eight Years of Transition”, Economics of Transition, 8(2): 421-451.

- $\quad$ Cincibuch, Martin and Jiri Podpiera (2006), "Beyond Balassa-Samuelson: Real Appreciation in Tradables in Transition Countries", Economics of Transition, 14(3): 547-573.

- De Melo, Martha, Cevdet Denizer, Alan Gelb and Stoyan Tenev (2000), "Circumstances and Choice: The role of Initial Conditions and Policies in Transition Economies", World Bank Economic Review, 15(1): 1-31.

- Falcetti, Elisabetta, Martin Raiser and Peter Sanfey (2002), "Defying the Odds: Initial Conditions, Reforms, and Growth in the First Decade of Transition", Journal of Comparative Economics, 30: 229-250.

- Fischer, Stanley and Ranta Sahay (2004), Transition Economies: The Role of Institutions and Initial Conditions, IMF mimeo. Washington D.C.

- $\quad$ Fischer, Stanley, Ratna Sahay and Carlos A. Vegh (1996), "Stabilization and Growth in Transition Economies: The Early Experience", Journal of Economic Perspectives, 10: 45-66.

- Ghosh, Atish R. and Steven Phillips (1998), Inflation, Disinflation and Growth, Working Paper No. 98/68. IMF, Washington, D.C.

- Havrylyshyn, Oleh, Ron van Rooden (2003), "Institutions Matter in Transition, but so do Policies", Comparative Economic Studies, 45: 2-24.

- Loungani, Prakash and Nathan Sheets (1997), "Central Bank Independence, Inflation and Growth in Transition Economies", Journal of Money, Credit and Banking, 29(3): 381-399.

- Merlevede, Bruno (2003), "Reform Reversals and Output Growth in Transition Economies", Economics of Transition, 11(4): 649-669.

- Mitrović, R. Dragutinović and Olgica Ivančev (2010), "Driving Forces of Economic Growth in the Second Decade of Transition”, Economic Annals, LV(185): 7-32.

- $\quad$ Stiglitz, Joseph E. (2001), “Whither reform? Ten years of the Transition”, In: Pleskovic, Boris, Stiglitz, Joseph E. (Eds.), Annual World Bank Conference on Development Economics, 1999, World Bank, Washington DC., pp. $27-56$. 


\title{
Orta Asya Türk Cumhuriyetleri’nde Sürdürülebilir İktisadi Büyümenin Belirleyicileri
}

\author{
Fahri Solak (Marmara University, Turkey) \\ Ercan Sarıdoğan (Marmara University, Turkey)
}

\section{The Determinants of Sustainable Economic Growth in the Central Asian Turkish Republics}

\begin{abstract}
Sustainable economic growth is very important for sustainable welfare of society. In this context, it is vital to determine the factors affecting sustainable economic growth and to design economic policies for affecting sustainable economic growth.

Main aim of this study is to investigate the determinants of sustainable economic growth and to recommend economic policies and strategies for selected Central Asian Turkish Republics, namely, Azerbaijan, Kazakhstan, Kyrgyzstan, Uzbekistan and Turkmenistan in order to achieve sustainable economic growth and development.

The main result of the study is that the main source of economic growth of Turkish Republics depends on the natural resources, which is not enough for sustainable economic growth in the long run. For this reason, Turkish Republics should transform their economic structures from natural sources based economic growth into sciencetechnology and innovation based and global competitiveness oriented economic growth path by designing economic policies for developing human capital, education, research and development, national industry strategy improving the business and investment environment for investors and eliminating structural and institutional problems.
\end{abstract}

JEL Codes: O11, O13, O32

\section{Giriş}

Türk Cumhuriyetleri ekonomileri genelde dışa açık ekonomiler olmalarına rağmen, dünya ekonomisiyle göreceli olarak düşük bir entegrasyona sahiptirler. Doğal kaynaklar ekonomik büyümenin temel tetikleyicisi konumundadır (Emerson ve Diğ., 2010). Bu bağlamda dünya ekonomisinde doğal kaynaklara yönelik talep ve bu malların fiyatları arttıkça ülke ekonomilerinin makro dengeleri ve büyüme hızları yüksek seyretmektedir. Ne var ki koşullar terse döndüğünde de ekonomiler sıkıntılara düşmektedirler.

Dünya ekonomisinde, küresel rekabet gücü koşullarındaki sürekli ve hızlı değişim, hem mikroekonomi hem de makroekonomi düzeyinde tüm iktisadi birimleri bu rekabete ayak uydurmayı zorunlu kılmaktadır. Bu rekabete ayak uyduramayan ülkeler ve firmalar piyasadan silinecektir. Bu bağlamda, küresel rekabetin değişen dinamiklerine baktığımızda rekabetin, geleneksel doğal kaynaklar üstünlüğünden, hızla bilim-teknolojiinovasyon temelli üstünlüğe kaydığını görüyoruz. Bu sebeple, gerek mikroekonomi düzeyinde, firmalar ve bireyler; gerekse de makroekonomi düzeyinde ülkeler, küresel rekabet güçlerini yükseltmek için bilim-teknolojiinovasyon temelli küresel rekabet stratejileri geliştirmek zorundadırlar. Dolayısıyla, girişimcilerin de artık, tekno-girişimciler olarak dünya ekonomisine entegre olmaları yüksek risklerin yanında yüksek kazanımları da birlikte getirmektedir (Solak ve Sarıdoğan, 2011b).

\section{Türk Cumhuriyetlerinde Ekonomik Büyümenin Belirleyicileri}

\subsection{Azerbaycan Ekonomisinde Ekonomik Büyümenin Belirleyicileri}

Tablo-1'de Azerbaycan ekonomisi için makroekonomik göstergeleri verilmiştir. Buna göre, reel GSYİH büyümesi 2008 küresel iktisadi krizinin baş göstermesi ile yavaşlama eğilimine girmiştir. Küresel iktisadi krizin daraltıcı etkisinin 2012 yılına doğru devam edeceği tahmin edilmektedir.

GSYİH harcama kalemlerinin 2006'dan itibaren değişimi hızına baktığımızda, özel tüketim harcaması başta olmak üzere, diğer tüm harcama kalemleri ortalama olarak 2008 yılına kadar artış göstermesine rağmen, küresel iktisadi krizle birlikte 2009 yılından itibaren daralam eğilimine girmiştir. Özellikle dış talepte daralma, ülkenin ihracatını devamında ise yurt içi üretim ve harcama kalemlerini daraltmıştır.

GSYİH'nin kaynaklarında baktığımızda ise, hizmetler ve sanayi sektörünün büyüme hızının kriz dönemine kadar oldukça yüksek olmasına karşın, küresel iktisadi kriz etkisiyle yavaşlama göstermiştir. Ancak sanayi sektöründe ise yavaşlama hızının daha yüksek olduğu görülmektedir. 


\begin{tabular}{|c|c|c|c|c|c|c|c|}
\hline & 2006 & 2007 & 2008 & 2009 & 2010 & 2011t & $2012 t$ \\
\hline \multicolumn{8}{|l|}{ GSYİH } \\
\hline Reel GSYİH (\%) & 34.5 & 25 & 10.8 & 9.3 & 5 & 2.9 & 2.7 \\
\hline \multicolumn{8}{|c|}{ GSYİH Harcama Kalemleri (\% Reel Değișim) } \\
\hline Özel Tüketim Harcaması & 26 & 17.9 & 38.5 & 0.1 & 3.6 & 2.8 & 2.6 \\
\hline Devlet Harcamas1 & 30.4 & 24.1 & 21.3 & 4.9 & 5.1 & 3 & 2.6 \\
\hline Brüt Sabit Sermaye Yatırımı & 2.6 & -5.9 & 11.1 & -8.4 & 5.6 & 2.5 & 2.5 \\
\hline Mal-Hizmet İhracı & 40.9 & 43.3 & 11 & 2.9 & 4.2 & 4.4 & 2.4 \\
\hline Mal-Hizmet İthalatı & 14.3 & 14 & 13.1 & -5.3 & 1.9 & 2.2 & 2 \\
\hline \multicolumn{8}{|c|}{ GSYİH Kaynakları (\% Reel Değişim) } \\
\hline Tarım & 0.9 & 4 & 6.1 & 3.5 & -2.2 & 5.5 & 3.2 \\
\hline Sanayi & 36.6 & 35 & 7 & 8.6 & 2.6 & -1 & 0.5 \\
\hline Hizmetler & 42.3 & 12.1 & 20.2 & 11.8 & 10.8 & 9.3 & 6 \\
\hline \multicolumn{8}{|l|}{ Nüfus ve Gelir } \\
\hline Nüfus (m) & 8.5 & 8.6 & 8.8 & 8.9 & 9 & 9.1 & 9.2 \\
\hline Kisi Başına GSYİH (US\$ PPP) & 8,030 & 10,216 & 11,370 & 12,376 & 12,967 & 13,368 & 13,887 \\
\hline \multicolumn{8}{|c|}{ Kamu Maliyesi Göstergeler ( GSYİH \%'si) } \\
\hline Genel Bütçe Dengesi & -2.7 & -2.3 & -9.5 & -14.5 & -15.1 & -21.6 & -19.6 \\
\hline Net Kamu Borcu & 9.5 & 7.4 & 5.9 & 8.9 & 5.3 & 4.7 & 4.3 \\
\hline \multicolumn{8}{|l|}{ Cari İşlemler Dengesi (US\$ m) } \\
\hline Dış Ticaret Dengesi & 7,745 & 15,224 & 23,012 & 14,583 & 19,730 & 20,055 & 19,902 \\
\hline Cari İşlemler Dengesi (US\$ m) & 3,708 & 9,019 & 16,453 & 10,178 & 14,725 & 14,622 & 14,412 \\
\hline
\end{tabular}

Tablo-1 Azerbaycan Makroekonomik Göstergeler. Kaynak: Economist Intelligence Unit (2011), IMF (2011a,b) t:tahmin

Kişi başına gelirdeki değişme, satın alma gücüne göre zamanda göre düşük hızda da olsa artış göstermektedir. Kamu maliyesinde, genel bütçe dengesindeki açık, küresel iktisadi krizin etkisiyle artış göstermiştir.

Dış ticaret ve cari işlemler dengesine baktığımızda, küresel iktisadi krizin etkisiyle dış talepte daralma, diş ticaret ve cari işlemler dengesindeki fazlalılığg 2009 yılında önemli ölçüde azaltmış, kriz sonrası dönemde tekrar iyileşme gözlemlenmektedir.

\subsection{Kazakistan Ekonomisinde Ekonomik Büyümenin Belirleyicileri}

Tablo-2'de Kazakistan ekonomisi için makroekonomik göstergeleri verilmiştir. Buna göre, reel GSYİH büyümesi 2008 küresel iktisadi krizinin baş göstermesi ile yavaşlama eğilimine girmiştir. Küresel iktisadi krizin daraltıcı etkisini 2010 yılı itibari ile geride bırakmaya başlamıştır.

\begin{tabular}{|c|c|c|c|c|c|c|c|}
\hline & 2006 & 2007 & 2008 & 2009 & 2010 & 2011t & $2012 t$ \\
\hline \multicolumn{8}{|l|}{ GSYIH } \\
\hline Nominal GSYİH (US\$ m) & 81 & 103.1 & 134.9 & 111.4 & 141.5 & 175.8 & 191.8 \\
\hline Reel GSYİH (\%) & 10.7 & 8.9 & 3.3 & 1.2 & 7 & 6.7 & 6.3 \\
\hline \multicolumn{8}{|c|}{ GSYİH Harcama Kalemleri (\% Reel Değişim) } \\
\hline Özel Tüketim Harcaması & 12.7 & 10.9 & 6.3 & 0.6 & 10.9 & 7.4 & 6.9 \\
\hline Devlet Harcaması & 7.8 & 14.6 & 3.5 & 1 & 2.6 & 3 & 3.3 \\
\hline Brüt Sabit Sermaye Yatırımı & 29.7 & 17.4 & 1 & -0.8 & 3.8 & 5.2 & 5.9 \\
\hline Mal-Hizmet İhrac1 & 6.5 & 9 & 0.7 & -11.6 & 1.9 & 3.6 & 3.5 \\
\hline Mal-Hizmet İthalatı & 12.2 & 25.9 & -11.5 & -16 & 0.9 & 2.3 & 3.4 \\
\hline \multicolumn{8}{|c|}{ GSYİH Kaynakları (\% Reel Değişim) } \\
\hline Tarım & 5.8 & 9.7 & -5.9 & 13.1 & -11.7 & 6 & 4.2 \\
\hline Sanayi & 7.2 & 5.7 & 2.1 & 2 & 11.8 & 8.1 & 6.8 \\
\hline Hizmetler & 10.1 & 12.7 & 4.7 & -0.3 & 6 & 5.5 & 6.2 \\
\hline \multicolumn{8}{|l|}{ Nüfus ve Gelir } \\
\hline Population (m) & 15.4 & 15.6 & 15.8 & 16 & 16.2 & 16.4 & 16.6 \\
\hline Kisi Başına GSYİH (US\$ PPP) & 9,784 & 10,854 & 11,303 & 11,381 & 12,138 & 12,980 & 13,997 \\
\hline \multicolumn{8}{|c|}{ Kamu Maliyesi Göstergeler ( GSYIH \%'si) } \\
\hline Genel Bütçe Dengesi & 0.8 & -1.7 & -2 & -3 & -2.5 & -2.3 & -2.1 \\
\hline Net Kamu Borcu & 11.9 & 7.8 & 8.6 & 13.5 & 15.5 & 15.9 & 18.4 \\
\hline \multicolumn{8}{|l|}{ Cari İșlemler Dengesi (US\$ m) } \\
\hline Diş Ticaret Dengesi & 14,642 & 15,091 & 33,519 & 14,969 & 28,881 & 33,471 & 33,041 \\
\hline Cari İşlemler Dengesi (US\$ m) & $-1,999$ & $-8,226$ & 6,596 & $-4,221$ & 4,319 & 8,205 & 7,184 \\
\hline
\end{tabular}

Tablo-2 Kazakistan Makroekonomik Göstergeler. Kaynak: Economist Intelligence Unit (2011), t:tahmin

GSYİH harcama kalemlerinin 2006'dan itibaren değişimi hızına baktığımızda, özel tüketim harcaması başta olmak üzere, diğer tüm harcama kalemleri ortalama olarak 2007 yılına kadar artış göstermesine rağmen, küresel iktisadi krizle birlikte 2008 yılından itibaren daralam eğilimine girmiştir. Özellikle 2008 ve 2009 y1llarında dış talepte daralma, ülkenin ihracatını devamında ise yurt içi üretim ve harcama kalemlerini daraltmıştır. 
Kazakistan ekonomisi için, GSYİH'nin kaynaklarına baktığımızda ise, tarım, hizmetler ve sanayi sektörünün büyüme hızının kriz dönemine kadar devam etmesine karşın, 2008 yılı itibariyle küresel iktisadi kriz etkisiyle yavaşlama göstermiştir. Sanayi ve hizmet sektörü 2010 yılı itibari ile iyileşme hızlanmıştır.

Kişi başına gelirdeki değişme, satın alma gücüne göre zamanda göre düşük hızda da olsa artış göstermektedir. Kamu maliyesinde, genel bütçe dengesindeki açık, küresel iktisadi krizin etkisiyle düşük düzeyde artış göstermiştir.

Dış ticaret ve cari işlemler dengesine baktığımızda, küresel iktisadi krizin etkisiyle dış talepte daralma, dış ticaret ve cari işlemler dengesi 2009 yılında olumsuz etkilenmiş, kriz sonrası dönemde tekrar iyileşme başlamıştır.

\subsection{Kırgızistan Ekonomisinde Ekonomik Büyümenin Belirleyicileri}

Tablo-3.'te Kırgızistan ekonomisi temel makroekonomik göstergeleri verilmiştir. Buna göre, reel GSYİH 2007 ve 2008 'de \%8 civarında iken küresel iktisadi krizle birlikte 2009 yılından itibaren GSYİH azalma göstermiştir.

\begin{tabular}{|l|c|c|c|c|c|}
\hline & $\mathbf{2 0 0 6}$ & $\mathbf{2 0 0 7}$ & $\mathbf{2 0 0 8}$ & $\mathbf{2 0 0 9}$ & $\mathbf{2 0 1 0}$ \\
\hline GSYİH (US\$ bn) & 2.8 & 3.8 & 5.1 & 4.7 & 4.5 \\
\hline Reel GSYİH (\%) & 3.1 & 8.5 & 8.4 & 2.9 & -1.4 \\
\hline TÜFE ( \%) & 5.6 & 10.2 & 24.5 & 6.9 & 8 \\
\hline Nüfus (m) & 5.2 & 5.3 & 5.3 & 5.4 & 5.5 \\
\hline İhracat(US\$ m, fob ) & 906 & 1,337 & 1,874 & 1,700 & 2,056 \\
\hline İthalat (US\$ m, fob) & $-1,792$ & $-2,614$ & $-3,754$ & $-2,814$ & $-3,283$ \\
\hline Cari İşlemler Dengesi (US\$ m) & -303 & -261 & -750 & -300 & -408 \\
\hline
\end{tabular}

Tablo-3 Kirgızistan Temel Makroeekonomik Göstergeler. Kaynak: Economist Intelligence Unit (2011)

Tablo-4'te Kırgızistan ekonomisi temel yapısı verilmiştir. Buna göre, 2009 yılı için GSYİH’nın kaynaklarını incelediğimizde tarımın payı \%24.8, sanayi \%23.1 ve hizmetler ise \%52 düzeyindedir. Tablo-3.2'de Kırgızistan ekonomisi temel yapısı çerçevesinde, GSYİH'nın bileşenleri verilmiştir. Buna göre, özel tüketim harcaması, $\% 88$, kamu tüketim harcamas1, \%18.8, brüt sabit sermaye harcamas1 \%27.2, diğer yandan, stok değişimi, -08.6 ve net ihracat ise, -\%23.8'dir. Bu sonuçlara göre, ülke harcamalarının önemli bir kısmını dış kaynak kullanarak gerçekleştirmektedir.

İhracatın temel bileşmini incelediğimizde, değerli metaller ve taşların \%37.1, kimyasalların \%18, mineral ürünlerin $\% 16.3$ ve tekstilin ise $\% 7.2$ olduğunu gözlemliyoruz. Diğer yandan, ithalatın temel bileşimini incelediğimizde, mineral ürünler \%27.5, makine ve ekipmanlar \%10.9, kimyasallar $\% 10.1$ ve yiyecek, içecek ve tütünün \%8.1 olduğunu gözlemliyoruz. Bu sonuçlara göre, Kırgızistan ekonomisi doğal kaynak temelli kalemleri ihracat ederken, ithalatında ise mineral ürünlerin ardından, makine ve ekipmanları \%11'lik bir paya sahiptir.

Özdil ve Turdalieva (2010), Kırgızistan'da sürekli ve kalıcı ekonomik kalkınma ve gelişmeyi sağlamak için üretim kapasitesini arttırıcı yatırımlara ihtiyaç olduğunu, öncelikle dışa bağımlılığı azaltıcı, ama ülkedeki üretim potansiyelini harekete geçirecek sektörlere ağırlık verilmesi gerektiğini vurgulamışlardır.

\begin{tabular}{|c|c|c|c|}
\hline GSYİH'nın Kaynakları (2009) & $\begin{array}{c}\text { Toplamın } \\
\text { \%'si }\end{array}$ & GSYİH'nın Bileşenleri (2009) & $\begin{array}{c}\text { Toplamın } \\
\text { \%'si }\end{array}$ \\
\hline Tarım \& Ormancılık & 24.8 & Özel Tüketim Harcaması & 88.8 \\
\hline Sanayi & 23.1 & Kamu Tüketim Harcaması & 18.8 \\
\hline Hizmetler & 52 & Brüt Sabit Sermaye Harcaması & 27.2 \\
\hline & & Stokta Değişim & -8.6 \\
\hline Temel İhracat Kalemleri (2009) & $\begin{array}{c}\text { Toplamın } \\
\text { \%'si }\end{array}$ & Temel İthalat Kalemleri (2009) & $\begin{array}{c}\text { Toplamın } \\
\text { \%'si }\end{array}$ \\
\hline Değerli Metaller ve Taşlar & 37.1 & Mineral Ürünler & 27.5 \\
\hline Kimyasallar & 18 & Makine ve Ekipmanları & 10.9 \\
\hline Mineral Ürünler & 16.3 & Kimyasallar & 10.1 \\
\hline Tekstil & 7.2 & Yiyecek\&İçecek ve Tütün & 8.1 \\
\hline
\end{tabular}

Tablo-4 Kırgızistan Ekonomisi Temel Yapı. Kaynak: Economist Intelligence Unit (2011)

\section{4 Özbekistan Ekonomisinde Ekonomik Büyümenin Belirleyicileri}

Tablo-5'te Özbekistan ekonomisi için makroekonomik göstergeleri verilmiştir. Buna göre, reel GSYİH büyümesi 2009 küresel iktisadi krizinin baş göstermesi ile düşük düzeyde yavaşlama eğilimine girmiştir.

Özbekistan ekonomisi için, GSYİH'nin kaynaklarına baktığımızda ise, hizmetler ve sanayi sektörünün büyüme hızının kriz dönemine kadar devam etmesine karşın, 2009 yılı itibariyle küresel iktisadi kriz etkisiyle yavaşlama göstermiştir. Tarım, sanayi ve hizmet sektörü 2010 yılı itibari ile iyileşme hızlanmıştır. 
Kişi başına gelirdeki değişme, satın alma gücüne göre zamanda göre düşük hızda da olsa artış göstermektedir. Kamu maliyesinde, genel bütçe dengesinde, küresel iktisadi krizin etkisiyle düşük düzeyde artış göstermiştir.

Dış ticaret ve cari işlemler dengesine baktığımızda, küresel iktisadi krizin etkisiyle dış talepte daralma, dış ticaret ve cari işlemler dengesi 2008-2009 yılında olumsuz etkilenmiş, kriz sonrası dönemde tekrar iyileşme başlamıştır.

\begin{tabular}{|c|c|c|c|c|c|c|c|}
\hline & 2006 & 2007 & 2008 & 2009 & 2010 & $2011 t$ & $2012 t$ \\
\hline \multicolumn{8}{|l|}{ GSYİH } \\
\hline Nominal GSYİH (US\$ m) & 17,022 & 22,298 & 27,899 & 32,792 & 38,956 & 45,378 & 52,377 \\
\hline Reel GSYİH (\%) & 7.3 & 9.5 & 9 & 8.1 & 8.5 & 8.6 & 8.7 \\
\hline \multicolumn{8}{|c|}{ GSYIH Kaynakları (\% Reel Değişim) } \\
\hline Tarım & 6.2 & 6.1 & 4.5 & 5.7 & 6.8 & 6.7 & 7 \\
\hline Sanayi & 10.8 & 12.1 & 12.7 & 9 & 8.3 & 6.9 & 7.5 \\
\hline Hizmetler & 6 & 11 & 10.5 & 9.6 & 10.1 & 11.3 & 11 \\
\hline \multicolumn{8}{|l|}{ Nüfus ve Gelir } \\
\hline Population (m) & 26.5 & 26.9 & 27.5 & 28 & 28.5 & 29 & 29.7 \\
\hline Kisi Başına GSYİH (US\$ PPP) & 2,156 & 2,396 & 2,604 & 2,794 & 3,009 & 3,266 & 3,556 \\
\hline \multicolumn{8}{|c|}{ KAMU MALIYYSİ GÖSTERGELER ( GSYİH \%'si) } \\
\hline Genel Bütçe Dengesi & 3.8 & 2.7 & 1.5 & 0.2 & 0.3 & -0.2 & -0.3 \\
\hline Net Kamu Borcu & 21.3 & 15.7 & 9.8 & 9.7 & 7.9 & 7.4 & 6.8 \\
\hline \multicolumn{8}{|l|}{ Cari İşlemler Dengesi (US\$ m) } \\
\hline Dış Ticaret Dengesi & 1,774 & 1,692 & 1,021 & 1,712 & 3,980 & 5,380 & 4,490 \\
\hline Cari İşlemler Dengesi (US\$ m) & 2,927 & 4,326 & 4,053 & 3,580 & 5,814 & 7,453 & 6,370 \\
\hline
\end{tabular}

Tablo-5 Özbekistan Seçilmiş Makroekonomik Göstergeler. Kaynak: Economist Intelligence Unit (2011), t:tahmin

\subsection{Türkmenistan Ekonomisinde Ekonomik Büyümenin Belirleyicileri}

Tablo-6.'da Türkmenistan ekonomisi temel makroekonomik göstergeleri verilmiştir. Buna göre, reel GSYİH 2009 yılında, iktisadi krizle birlikte -\%8 azalma göstermiştir.

\begin{tabular}{|c|c|c|c|c|c|}
\hline & $\mathbf{2 0 0 6}$ & $\mathbf{2 0 0 7}$ & $\mathbf{2 0 0 8}$ & $\mathbf{2 0 0 9}$ & $\mathbf{2 0 1 0}$ \\
\hline GSYİH (US\$ bn) & 10.3 & 12.7 & 17 & 14.7 & 17.1 \\
\hline Reel GSYİH (\%) & 11.4 & 11.6 & 9.8 & -8 & 6 \\
\hline TÜFE ( \%) & 8.2 & 6.3 & 14.5 & 4 & 10 \\
\hline İhracat(US\$ m, fob ) & 7,156 & 9,114 & 11,786 & 8,946 & 10,415 \\
\hline İthalat (US\$ m, fob) & $-2,558$ & $-3,780$ & $-5,363$ & $-8,071$ & $-8,672$ \\
\hline Cari İşlemler Dengesi (US\$ m) & 3,349 & 4,034 & 3,553 & $-1,905$ & $-1,105$ \\
\hline
\end{tabular}

Tablo-6 Türkmenistan Ekonomisi Temel Yapısı. Kaynak: Economist Intelligence Unit (2011)

Tablo-7'de Türkmenistan ekonomisi temel yapısı verilmiştir. Buna göre, 2008 yılı için GSYİH'nın kaynaklarını incelediğimizde tarım-ormancılığın payı \%53.7, sanayi \%12.3 ve hizmetler ise \%34 düzeyindedir.

Tablo-7'de Kırgızistan ekonomisi temel yapısı çerçevesinde, 2008 yılında GSYİH'nın bileşenleri verilmiştir. Buna göre, özel tüketim harcaması, \%55.5, kamu tüketim harcaması, \%8.3, brüt sabit sermaye harcaması $\% 6.5$ ve net ihracat ise, \%29.7'dir.

2001 yılı için ihracatın temel bileşmini incelediğimizde, gazın \%57, ham ve rafine petrol \%26, pamuk lifi \%3 ve tekstil \%2 olduğunu gözlemliyoruz. Diğer yandan, 1999 yılında, ithalatın temel bileşimini incelediğimizde, makine ve ekipmanlar \%60 ve yiyecek, içecek ve tütünün \%15 olduğunu gözlemliyoruz. Bu sonuçlara göre, Türkmenistan ekonomisi doğal kaynak temelli kalemleri ihracat ederken, ithalatında ise makine ve ekipmanları $\% 60$ 'lik bir paya sahiptir.

\begin{tabular}{|l|c|l|c|}
\hline GSYİH'nın Kaynakları (2008) & $\begin{array}{c}\text { Toplamın } \\
\text { \%'si }\end{array}$ & GSYİH'nın Bileşenleri (2008) & $\begin{array}{c}\text { Toplamın } \\
\text { \%'si }\end{array}$ \\
\hline Tarım \& Ormancılık & 53.7 & Özel Tüketim Harcaması & 55.5 \\
\hline Sanayi & 12.3 & Kamu Tüketim Harcaması & 8.3 \\
\hline Hizmetler & 34 & Brüt Sabit Sermaye Harcaması & 6.5 \\
\hline & & Net İhracat & 29.7 \\
\hline Temel İhracat Kalemleri (2001) & $\begin{array}{c}\text { Toplamın } \\
\text { \%'si }\end{array}$ & Temel İthalat Kalemleri (1999) & $\begin{array}{c}\text { Toplamın } \\
\text { \%'si }\end{array}$ \\
\hline Gaz & 57 & & 60 \\
\hline Ham ve Rafine Petrol & 26 & Makine ve Ekipmanları & \\
\hline Pamuk Lifi & 3 & & 15 \\
\hline Tekstil & 2 & Yiyecek\&İçecek ve Tütün & \\
\hline
\end{tabular}

Tablo-7 Türkmenistan Ekonomisi Seçilmiş Makroekonomik Göstergeler.

Kaynak: Economist Intelligence Unit (2011) 


\section{Sonuç}

Türk Cumhuriyetlerinde ekonomik büyümenin temel dinamikleri doğal kaynaklar temelinde gerçekleşmektedir. Ancak uzun dönemde Türk Cumhuriyetleri'nin ekonomik büyümesinin sürdürülebilir olabilmesi için bu doğal kaynak bağımlı büyüme patikasından, bilim-teknoloji-inovasyon temelli küresel rekabet gücü temelli ekonomik büyüme patikasına geçmesi hayati bir zorunluluktur.

Türk Cumhuriyetlerinin uzun dönemde sürdürülebilir ekonomik büyümeyi sağlayabilmeleri için, (Solak ve Sarıdoğan, 2011b), orta ve uzun vadede hammadde-ara malı, finansman, teknoloji açısından dışa bağımlılığ azaltacak, talep açısından, iç pazar hacmini güçlü kılacak, dış talep açısından ise küresel rekabet gücünü, ürünlerin reel katma değerini, ihracatta pazar ve ürün çeşitliliğini ve pazar hakimiyetini yükseltecek içsel büyüme modelleri temelli ekonomi politikalarının tasarlanması, sürdürülebilir ekonomik büyümeyi sağlayabilmek açısından son derece büyük önem arzetmektedir

\section{Kaynakça}

- Economist Intelligence Unit. 2011. Country Report: Azerbaijan, July

- Economist Intelligence Unit.. 2011. Country Report: Kazakhstan, July

- Economist Intelligence Unit.. 2011. Country Report: Kyrgyz Republic, July

- Economist Intelligence Unit.. 2011.Country Report: Turkmenistan, July

- Economist Intelligence Unit.. 2011. Country Report: Uzbekistan, July

- Emerson, M. ve diğ. 2010. "Into Eurasia Monitoring The EU's Central Asia Strategy Report Of The Eucam Project" Centre For European Policy Studies (CEPS), Brussels,

- IMF. 2011a. Regional Economic Outlook, Middle East And Central Asia, April,

- IMF. 2011b. World Economic Outlook, Washington, April,

- $\quad$ Özdil, T., ve Turdalieva, A. "Girdi-Çıktı Analizi Yaklaşımıyla Kırgızistan İmalat Sanayinin İncelenmesi (2005-2008)" International Conference On Eurasian Economies 2010, Turkey

- Solak, F. ve E. Sarıdoğan, 2001a. "Sürdürülebilir İktisadi Büyüme Ve Küresel Rekabet Gücü Bağlamında Tekno-Girişimciliğin Rolü Ve Önemi” 3.Uluslararası Girişimcilik Kongresi, Kırgızistan-Türkiye Manas Üniversitesi, Bişkek, Kırgızistan 16 - 17 Mayıs 2011

- Solak,F. ve E.Sarıdoğan, 2001b. “Küresel İktisadi Krizin Türk Cumhuriyetleri’ne Etkileri” Marmara Üniversitesi İ.I.B.F. Dergisi Y11 2011, Cilt XXX, Sayı I, S. 93-115 


\title{
Национальные особенности формирования экономической политики в условиях мирового кризиса и посткризисный период
}

\author{
Alisher Rasulev (Institute of Economics, Uzbekistan)
}

\section{National Features of Economic Policy in the Global Crisis and Post-Crisis Period}

\begin{abstract}
The main feature of present stage in global economic system development is the overcome of global financial crisis and global financial architecture reformation, which requires anti-crisis adjustment in monetary policy. There are two important issue related to realization of anti-crisis program: the relation of anti-crisis policy nature and purpose to national economic development strategy and final aim of economic policy. The second important issue is elimination of contradictions between national policy (interests) and global values.

The given article focuses on the features of national economy development on conditions of world economic crisis and the post crisis period, the role of government as the basic actor in economy management, the principal direction of the anti-crisis program and measures of Uzbekistan.
\end{abstract}

JEL Code: E20

Главной особенностью современного этапа развития мировой экономической системы является преодоление последствий глобального финансового кризиса и реформирование мировой финансовой архитектуры, что требует, в свою очередь, внесения антикризисных корректив в монетарную политику конкретных государств.

Эффективное осуществление программы антикризисных мер связано с решением ряда принципиальных вопросов. Первый вопрос связан с характером и целями антикризисной политики по отношению к стратегии развития национальной экономики и конечной цели экономической политики. Если антикризисная программа носит временный характер, то каким образом такая финансовая политика и ее риски отразятся на посткризисной экономике? Если эта политика носит долговременный характер и выступает в качестве «новой экономической политики», как ее задачи соотносятся с целями построения инновационной постиндустриальной экономики и задачами повышения качества жизни? Само возникновение этих вопросов в определенной степени указывает на неэффективность существующей системы методов государственного регулирования экономики. Сейчас, когда приняты экстренные меры по выходу из кризиса, самое время определить приоритеты макроэкономической политики.

Другой важной особенностью экономической политики становится устранение противоречия между национальной политикой (интересами) и глобальными ценностями. Решение этой задачи затрудняется сложившейся спецификой международного сотрудничества в сфере экономики.

Во-первых, стремление к глобальному партнерству еще не стало, но в условиях кризиса становится объективной необходимостью. В настоящее время в сфере международного сотрудничества сложилась такая ситуация: чем сильнее правительства отдельных государств, тем больше элемент добровольности в этом сотрудничестве.

Во-вторых, существуют разногласия по вопросам политических ценностей, интересов, стандартов жизни и экологических ограничений, которые еще более осложняют добровольное достижение компромисса.

В-третьих, отмечается неготовность национальных экономик брать на себя обязательства и ответственность по глобальным проблемам, например таким, как международная торговля, защита окружающей среды и т.п.

В-четвертых, за некоторым исключением, большинство стран не спешат с формированием наднациональных органов для регулирования их монетарной политики.

Меняется роль государства, как основного актора глобального управления. Если раньше можно было четко разделить формы участия государства в глобальном управлении на непосредственную и опосредованную, то в условиях формирования нового миропорядка и возрастания значения международных союзов и региональных интеграционных группировок превалирует опосредованная форма участия государства в глобальном управлении. В то же время государство расширяет свои полномочия, делегируя часть их транснациональным инстанциям. 
В борьбе с глобальным кризисом правительства большинства развитых стран прилагают усилия, фактически дискредитирующие частную собственность, подрывающие фундаментальную основу рыночной экономики - личную ответственность человека (и прежде всего предпринимателя) за принимаемые им решения. Частные риски государство (но также и общество) готово принять на себя, то есть политика национализации убытков делает на следующем шаге неизбежной национализацию рисков.

Происходит фактическая национализация попавших в тяжелое положение компаний посредством предоставления им финансовой помощи. Национализация осуществляется, по крайней мере, по трем каналам: через выкуп долгов отдельных фирм, через рекапитализацию в обмен на акции, а также путем инфляции накопленных обязательств. Государства склонны взять на себя все пассивы (обязательства) финансовых учреждений - как путем гарантий, так и посредством прямого вливания капитала. Естественно, что помощь финансовым институтам сопровождается формальным или фактическим размыванием пакетов, принадлежащих частным собственникам. Права частной собственности ставятся тем самым под сомнение.

Правда, у нынешней национализации есть одна существенная особенность - ее вынужденный характер. Помимо прямого огосударствления наблюдается общий рост дирижизма, то есть рост числа индивидуальных решений институтов власти, выбор ими (а не рынком) правых и виноватых, а также готовность государства указывать экономическим агентам, какие услуги они должны оказывать и какие товары производить.

В настоящее время большинство правительств полагает, что проблема «системообразующих предприятий» может быть решена путем лучшего регулирования их хозяйственной деятельности, более внимательного отношения к ним со стороны органов власти. Чаще всего такого рода предложения адресованы банковскому сектору, хотя и к производственным отраслям (особенно инфраструктурным) они тоже вполне применимы.

Эффективность подобного регулирования вызывает принципиальные сомнения: если раньше такой системы построить не удавалось, то почему вдруг она окажется эффективной теперь? Гораздо более продуктивным (хотя и более сложным) является путь преодоления однозначной увязки данной фирмы с оказываемой ей услугой, необходимой с национальной точки зрения. Государство должно обеспечить доступность активов и технологий для экономического агента, который может прийти на смену менеджменту и собственникам системообразующего банкрота, и именно в этом и состоит реальное искусство политика.

Экономический кризис поставил перед политиками и экспертами ряд фундаментальных вопросов функционирования современных хозяйственных систем. Это вопросы, которые требуют интеллектуального прорыва, осмысления новых реалий и нахождения решений задач, как правило, не имеющих однозначных решений.

Большинство обсуждаемых мер пока не получили достаточной политической поддержки на национальном уровне. Очевидно, спешка при принятии решений о дополнительных мерах по регулированию финансового сектора может привести к проявлению и реализации латентных рисков, а в будущем - к развитию арбитража между различными юрисдикциями и изменению расстановки сил на мировой карте финансовых центров.

По сути, регуляторы сейчас не могут принимать решения без оглядки на действия регулирующих органов других стран. В текущих условиях становится актуальным механизм наднационального мониторинга национальных финансовых секторов и учет их рисков участниками трансграничных сделок и регуляторами. Проблема в том, что ставшие глобальными рынки регулируются на национальном уровне. Однако это лишь смягчает указанное противоречие, но не устраняет его.

Рассматривая функции государства как регулятора экономики, нужно учитывать принципиально новую парадигму, с которой оно столкнулось. Его позиции во многих традиционных сферах существенно уступают наднациональным регуляторам. Ставка рефинансирования национальных банков, курс национальной валюты, импортные барьеры, экспортные субсидии, налогообложение, социальная политика, образование, профессиональная подготовка кадров - это те рычаги экономического регулирования, влияние государства на которые (и многие другие) смещается в пользу внешних регуляторов. По сути, речь идет о том, что впервые в истории правительство должно частично отказаться от своих суверенных прав контроля на собственной территории над экономикой и другими сферами общественной жизни.

Мировой опыт свидетельствует о наибольшей эффективности саморегулирующейся экономики на основе рыночных механизмов с определенной степенью вмешательства государства. Уроки кризиса свидетельствуют, что рынок, предоставленный самому себе, порождает множество непредсказуемых проблем, которые способны подорвать основы, как экономической системы, так и государства в целом. Это обусловлено тем, что рынок не способен создать и поддерживать сколько-нибудь устойчивую инфраструктуру. В этом плане на современном этапе во всех индустриально развитых странах 
государство играло и продолжает играть существенную роль.

Мировой финансово-экономический кризис, его глубина и динамика - продемонстрировали рост влияния глобальных процессов на национальные экономики. Нарастающая тенденция глобализации практически всех сфер жизнедеятельности, особенно экономической, укрупнила масштабы интеграции и кооперации, и в то же время усилила международную конкуренцию. За всем этим стоит жесткая конкурентная среда, представляющая собой серьезное испытание для реализации национальных интересов. Ситуация усугубляется тем, что многие зарубежные государства в посткризисный период будут предпринимать активные действия по защите собственных рынков и поддержке своих предприятий-экспортеров.

Все это показывает со всей очевидностью бесперспективность выстраивания различного рода барьеров и защитных механизмов, а равно и преодоления рецессии за счет вливания в экономику исключительно внутреннего капитала. Движущиеся в данном направлении государства утратят возможность влиять на формирование нового экономического порядка, что, в конечном счете, обречет их на периферийные позиции в мировой экономической иерархии.

В нынешней ситуации единственный путь для ускоренного развития национальных экономик - это расширение взаимодействия с мировыми рынками при активной политике по защите и продвижению интересов национальных производителей. В этих условиях развитие конкурентной среды приобретает первостепенное значение, поскольку обостряется борьба предприятий за финансовые ресурсы, за удовлетворение снижающегося спроса на товары и услуги.

Мировой финансово-экономический кризис выявил подготовленность институциональной структуры Узбекистана к адекватным ответам на внешние вызовы. Эффективное государственное регулирование социально-экономическими процессами явилось базисом для устойчивого роста экономики и ее высокой адаптации к условиям быстро изменяющейся внешней среды. Как отметил Президент РУз И.А. Каримов: «Важное значение для смягчения и нейтрализации воздействия кризиса имели продуманность и своевременность принятых правительством комплекса антикризисных решений, рассчитанных на 20092012 годы и обеспечивающих устойчивую и бесперебойную работу нашей финансово-экономической, бюджетной, банковско-кредитной системы, мер по оказанию помощи предприятиям, реальным секторам экономики и социальной поддержки населения страны» (Каримов И.А., 2010, с.30.).

Качественное изменение внешней среды ставит перед республикой новые задачи при неизменности базовых целей и приоритетов ее социально-экономического развития. Формирование конкурентоспособной экономики, преодоление внутренних дисбалансов является на сегодняшний день необходимым условием проведения успешной внешнеэкономической политики. В первую очередь это относится к таким субъектам хозяйствования, которые в условиях кризиса показали неэффективность и неспособность к адаптации и саморазвитию, поэтому подлежат модернизации, санации или ликвидации. И хотя в среднесрочной перспективе, безусловно, усилятся регулирующие и контролирующие функции государства, реализовываться они должны не столько в зарегулированной, сколько в конкурентной среде. Сохранение и развитие последней является залогом устойчивого развития - в условиях мирового финансово-экономического кризиса и дальнейшего прогресса - после его преодоления. Поэтому тенденция к усилению государственного регулирования и защитных государственных мер будет во многих случаях сопровождаться мерами по сохранению или даже активизации основных конкурентных механизмов.

Несмотря на затяжной спад в мировой экономике, в Узбекистане продолжаются масштабные структурные преобразования и укрепление рыночных механизмов, растет производство, повышаются показатели экспорта, в первую очередь за счет увеличения выпуска продукции с высокой добавленной стоимостью, расширяется его диверсификация и география поставок, динамичными темпами растет привлечение иностранных инвестиций.

Логическим продолжением политики глубоких последовательных преобразований стала Антикризисная программа мер на 2009 - 2012 годы, изложенная в книге Президента РУз И.А. Каримова «Мировой финансово-экономический кризис, пути и меры по его преодолению в условиях Узбекистана», которая получила высокое признание ведущих экономистов мира. Основными направлениями Антикризисной программы мер Узбекистана являются поддержка и укрепление бюджетной, финансовобанковской и кредитной системы, отраслей реального сектора экономики, модернизация, техническое и технологическое обновление производства с целью повышения его конкурентоспособности на внутреннем и внешнем рынках.

Осуществление этих мер позволило за последние два года в два раза увеличить совокупный капитал коммерческих банков, уровень достаточности которого почти в три раза превышает международные стандарты, установленные Базельским комитетом. Большое значение имело обеспечение финансовой устойчивости предприятий реального сектора за счет ускоренной модернизации производства, внедрения инновационных технологий, экономии ресурсов и снижения себестоимости продукции. Приняты меры 
по максимальному снижению налогового бремени для хозяйствующих субъектов. Беспрецедентная поддержка была оказана отечественным предприятиям-экспортерам, в результате их стабильной работы объем экспортных поставок в 2009 году вырос. Особое внимание было уделено стимулированию развития малого бизнеса и частного предпринимательства - сегодня в этой сфере производится более $50 \%$ ВВП страны. Успешная реализация Антикризисной программы мер, фактически начавшаяся еще в 2008 году, минимизировала отрицательные последствия мирового кризиса и позволила Узбекистану в числе немногих стран мира обеспечить устойчивые темпы роста экономики и повышения реальных доходов населения.

Ключом к высокой эффективности антикризисных мер явился правильный выбор важнейших приоритетов социально-экономической политики, базирующихся на пяти основополагающих принципах реформирования, предложенных Президентом И,А. Каримовым.

Другим важным моментом, отличающим Антикризисную Программу Узбекистана от программ других стран СНГ, явилось то, что она учитывала социальные факторы. Анализ антикризисных программ правительств ряда стран СНГ показал, что основной акцент был сделан на стабилизацию финансового сектора, развитию инфраструктуры, малого и среднего бизнеса. При этом социальная составляющая поддержания уровня жизни населения в кризисный период была выведена за рамки антикризисных программ. Создание рабочих мест в результате развития малого бизнеса и индивидуального предпринимательства, обеспечения надомного труда на базе кооперации с промышленными предприятиями, а также ввода новых объектов, реконструкции и расширения действующих производств, встало мощным заслоном на пути обвального роста безработицы и усилению пессимизма в социальных настроениях общества, наблюдавшегося в других странах СНГ. Четкая социальная направленность программных мер также выражена во всесторонней государственной поддержке науки, образования, здравоохранения и культуры. Особое внимание уделяется вопросам реализации мер по увеличению внутреннего спроса за счет мобилизации и дальнейшего стимулирования участия банковских структур, хозяйствующих субъектов и населения в инвестиционных процессах. Примером реализации подобных проектов может стать Программа по ускоренному развитию и строительству жилья и социальной инфраструктуры на селе, призванной коренным образом переустроить и обновить облик села на современной архитектурной и индустриальной основе, повысить уровень жизни населения на селе и приблизить ее к городским условиям. Для реализации этой крупнейшей программы, рассчитанной на длительную перспективу, создан мощный проектный, индустриально-строительный, инженернотехнический потенциал, созданы необходимые организационные структуры, стимулирующие меры и преференции. Через специально созданный банк и его филиалы на местах в 2010 году предусматривается выделить на эти цели свыше 390 миллионов долларов в эквиваленте, что более чем в 4 раза превышает показатели 2009 года. Намечается строительство во всех сельских районах свыше 7600 жилых домов с расчетной стоимостью около 400 млн. долл. в эквиваленте.

Данные мониторинга общественного мнения по итогам 2010 года, представленные Центром изучения общественного мнения «Ижтимоий фикр», свидетельствуют о том, что Антикризисная программа Президента Узбекистана находит полную поддержку у 96,4\% граждан.

Благодаря своевременным и адекватным решениям по смягчению последствий мирового финансовоэкономического кризиса, успешной реализации Антикризисной программы, принятой по инициативе И.А. Каримова, по оценке самих граждан, финансово-экономический кризис не повлиял на материальное положение их семей.

Мировой финансово - экономический кризис не оказал существенного негативного влияния также и на социальные настроения граждан Узбекистана в отношении их ожиданий на 2010 год. Подавляющее большинство населения считало, что в ближайшие 12 месяцев социально-экономическое положение в стране станет ещё лучше, а по мнению каждого пятого респондента оно останется таким же стабильным, как и в 2009 году.

Важнейшим направлением поддержки хозяйствующих структур явились дополнительные меры по стимулированию и облегчению налоговой нагрузки, упрощению и унификации системы налогообложения. В целом в рамках реализации Антикризисной программы за счет предоставления налоговых льгот и преференций в распоряжении хозяйствующих субъектов остались средства на сумму свыше 500 млрд. сум, которые были направлены на пополнение оборотных средств, техническое перевооружение производства, освоение новых видов продукции, материальное стимулирование работников.

Особое внимание было уделено усилению поддержки и стимулированию ускоренного развития малого бизнеса и частного предпринимательства, играющего все более значимую роль в обеспечении экономического роста, создании рабочих мест и решении проблем занятости, роста доходов и благосостояния населения. Сегодня субъектами малого бизнеса производится около 52,5\% ВВП против $31 \%$ в 2000 году. Это, в первую очередь, результат той поддержки, которая постоянно оказывается малому 
бизнесу и частному предпринимательству со стороны государства.

В 2010 году с 8 до 7\% был снижен единый налоговый платеж для малых промышленных предприятий, уменьшены в среднем в 1,3 раза и размеры фиксированного налога для индивидуальных предпринимателей. Значительно сокращены расходы предпринимателей по организации своего дела. Так, в 4 раза снижена стоимость получения архитектурно-планировочных заданий, в 2,5 раза - экспертизы проектно-сметной документации, в 2 раза - стоимость оформления кадастровых документов.

Субъектам малого предпринимательства в течение года передано в аренду около 2 тысяч свободных помещений, выявленных в результате инвентаризации, при этом тарифы на аренду помещений в зависимости от места расположения и вида деятельности снижены от 3 до 10 раз. Общий объем выделенных этому сектору кредитных ресурсов превысил 1,8 триллиона сум.

Говоря об эффективности и результативности мер, осуществленных в рамках Антикризисной программы в 2009 году, следует особо отметить их направленность на решение двух ключевых задач создание новых рабочих мест и дальнейшее повышение уровня жизни населения. Всего в 2010 году создано более 950 тысяч рабочих мест, из них свыше 604 тысяч мест, или 65\% от общего числа вновь введенных рабочих мест, создано в сфере малого бизнеса и фермерства, более 210 тысяч мест в сфере надомного труда.

Необходимо подчеркнуть, что изучению опыта республики по преодолению негативного влияния последствий мирового финансового кризиса и по дальнейшему динамичному реформированию экономики была посвящена Международная научно-практическая конференция «Эффективность антикризисных программ и приоритеты посткризисного развития (на примере Узбекистана)», которая состоялась в Ташкенте в апреле 2010 г. В ней приняли участие свыше 400 государственных и общественных деятелей, бизнесменов и экспертов из 46 стран, представители крупнейших международных организаций и финансовых институтов, в том числе таких, как Организация Объединенных Наций, Международный валютный фонд, Всемирный банк, Азиатский банк развития, Исламский банк развития, ЕврАзЭС.

Как отметил директор департамента Центральной Азии регионального бюро ПРООН по странам Европы и СНГ Махмуд Айуб, глобальный кризис крайне негативно отразился на социальном развитии в мировом масштабе. Около 240 миллионов человек лишились работы, более 170 миллионов - оказались в бедности. Один из важнейших позитивных результатов реализации Антикризисной программы Узбекистана - то, что население страны практически не ощутило негативного влияния глобального кризиса. Проведение сильной социальной политики, особенно в период мирового кризиса, - это мудрый подход. Глава представительства Всемирного банка в Узбекистане Лу Брефор остановился на макроэкономических последствиях глобального кризиса для государств Центральной Азии и подчеркнул, что реализация Антикризисной программы Узбекистана и мер в рамках определенных его руководством приоритетов на перспективу обеспечивает дальнейшее успешное социально-экономическое развитие страны.

\section{Литература}

- И.А. Каримов. «Мировой финансово-экономический кризис, пути и меры по его преодолению в условиях Узбекистана».- Т.: Узбекистан, 2009.

- Каримов И.А.Наша главная задача - дальнейшее развитие страны и повышение благосостояния народа. - Т.: Узбекистан, 2010. 


\title{
Евразийское экономическое сообщество: современное состояние и перспективы развития
}

Orazaly Sabden (Institute of Economics, Kazakhstan)

\section{Eurasian Economic Community: Current State and Development Prospects}

\begin{abstract}
The paper is devoted to development of integration processes in the Eurasian space in the context of post crisis development. The in-depth analysis of socio-economic development of the Eurasian Economic Association' member-countries, including foreign trade and investment policy of the countries is presented. The proposals are given on further co-operation in the framework of this Association.
\end{abstract}

JEL Code: R11

Происходящие сегодня мировые процессы, связанные с экономическим кризисом, приводят к необходимости оценки правильности избранной стратегии развития Казахстана, определения его места в глобальных и региональных процессах на Евразийском пространстве. В марте 1994 года Президентом РК Н.Назарбаевым была предложена концепция формирования Евразийского союза, базирующаяся на добровольной, равноправной интеграции, совместном политико-экономическом развитии постсоветских государств, выхода стран СНГ на ведущие позиции в глобальной экономике, которая в очередной раз подтверждает свою актуальность и сегодня.

Актуальность теории евразийства для мирового сообщества, связана с активизацией азиатского направления в международной экономике и политике; развитием идеи евразийства как новой философии региональной интеграции на постсоветском и евразийском пространствах; становлением евразийской экономики самостоятельным геоэкономическим объектом формирующегося многополярного мира.

В качестве стимулов к интеграции в рассматриваемом регионе можно выделить следующие: наращивание экономического потенциала региона; расширение экономического влияния в посткризисном периоде; экономическая безопасность общих границ; транзит энергоресурсов в европейском и азиатском направлениях; преодоление межрегиональной конкуренции путем неконкурентного участия в крупных ресурсоэнергетических и других проектах. Если говорить о Казахстане, то его участие в ЕврАзЭС было обусловлено потребностью перехода к более высокому уровню интеграции, более новому этапу экономического развития страны в рамках СНГ.

Значение Казахстана для ЕврАзЭС в настоящее время признается всеми государствами-участниками данной организации. В этой связи, целесообразным является разработка системы взаимоотношений Казахстана со своими региональными партнерами в более широком формате.

В состав ЕврАзЭС входит Беларусь, Казахстан, Кыргызстан, Россия и Таджикистан(ЕврАзЭС было создано 31 мая 2001 г. на базе Таможенного союза в соответствии с Договором об его учреждении, подписанным главами пяти государств. Узбекистан не является членом ЕврАзЭС, поэтому он не включен в анализ). Анализ динамики ежегодного изменения валового внутреннего продукта (ВВП) свидетельствует, что практически все страны ЕврАзЭС в период 2001-2008 гг. демонстрировали достаточно высокие темпы роста. В 2009 гг. вследствие воздействия мирового финансовоэкономического кризиса, практически во всех странах интеграционного объединения темпы роста ВВП замедлились, а в России отмечено его существенное падение.

\begin{tabular}{|c|c|c|c|c|c|c|c|c|c|c|}
\hline Страны ЕврАзЭС & 2001 & 2002 & 2003 & 2004 & 2005 & 2006 & 2007 & 2008 & 2009 & 2010 \\
\hline Беларусь & 4,7 & 5,0 & 7,0 & 11,4 & 9,4 & 10,0 & 8,6 & 10,0 & 0,2 & 7,6 \\
\hline Казахстан & 13,5 & 9,8 & 9,3 & 9,6 & 9,7 & 10,7 & 8,9 & 3,2 & 1,2 & 7,0 \\
\hline Кыргызстан & 5,3 & 0,0 & 7,0 & 7,0 & $-0,2$ & 3,1 & 8,5 & 8,4 & 2,3 & $-1,4$ \\
\hline Россия & 5,1 & 4,7 & 7,3 & 7,2 & 6,4 & 8,2 & 8,5 & 5,2 & $-7,9$ & 4,0 \\
\hline Таджикистан & 9,6 & 9,1 & 10,2 & 10,6 & 6,7 & 7,0 & 7,8 & 7,9 & 3,4 & 6,5 \\
\hline
\end{tabular}

Таблица 1 - Динамика изменения ВВП в странах-членах ЕврАзЭС, 2001-2010 г2. (в \% к предыдущему году). Источник: Межгосударственный Статистический комитет СНГ.

Страны-участницы ЕврАзЭС заметно разнятся по уровню социально-экономического развития. Об этом свидетельствует также показатель валового национального дохода (ВНД) на душу населения, рассчитанный по паритету покупательной способности (ВНД/ППС). Он представляет собой интегрированный показатель, характеризующий качество экономического роста и уровень жизни 
населения. Среди стран ЕврАзЭС наиболее высокий уровень этого показателя имеет Россия (41 место среди 208 стран мира), за ней следуют Казахстан (56-е), Беларусь (65-е), Кыргызстан (141-е) и Таджикистан (145-е). При этом ВНД/ППС на душу населения в Кыргызстане составляет всего 18,7\%, а Таджикистане - $15,1 \%$ от среднего уровня по Сообществу (см. рисунок).

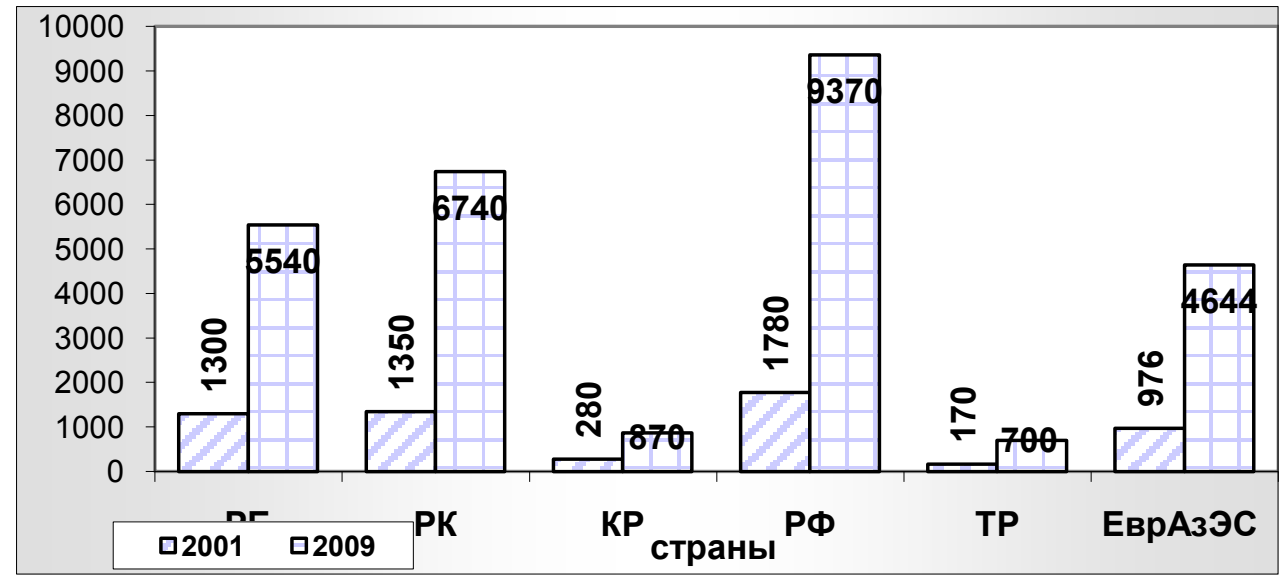

Рисунок - ВНД/ППС на душу населения в странах-членах ЕврАзЭС, 2001-2009 г2. Источник: World Bank, 2010.

В течение 2001-2010 гг. во всех странах ЕврАзЭС возрос объем промышленного производства. Наиболее высокие темпы прироста отмечаются в промышленности Беларуси - 223\% и Казахстана 202\%. Наиболее сложная ситуация характерна для промышленности Кыргызстана, где за последние 10 лет объем производства увеличился всего на 15\%. Причем за указанный период в этой стране трижды отмечалось падение производства промышленной продукции - от 3 до 9 процентов. Другим примечательным фактом является то, что в Кыргызстане, России и Таджикистане в 2009 г. отмечалось замедление (по сравнению с 2008 г.) темпов роста промышленного производства, тогда как в Беларуси и Казахстане отмечается неуклонный рост (табл. 3).

Росту экономики способствовала инвестиционная деятельность в странах Сообщества, активность которой по странам-участницам заметно отличается. Практически во всех странах ЕврАзЭС в период 2001-2010 гг. наблюдалось увеличение объема инвестиций в основной капитал. За эти годы в Беларуси этот показатель увеличился на 458\%, Казахстане - на 199\%, Кыргызстане - на 196\%, России - на 181\%. В Таджикистане течение 2005-2010 гг. объем инвестиций в основной капитал возрос на 325\% (ЕврАзЭС было создано 31 мая 2001 г. на базе Таможенного союза в соответствии с Договором об его учреждении, подписанным главами пяти государств. Узбекистан не является членом ЕврАзЭС, поэтому он не включен в анализ)

\begin{tabular}{|c|c|c|c|c|c|c|c|c|c|c|c|}
\hline Страны & $\mathbf{2 0 0 0}$ & $\mathbf{2 0 0 1}$ & $\mathbf{2 0 0 2}$ & $\mathbf{2 0 0 3}$ & $\mathbf{2 0 0 4}$ & $\mathbf{2 0 0 5}$ & $\mathbf{2 0 0 6}$ & $\mathbf{2 0 0 7}$ & $\mathbf{2 0 0 8}$ & $\mathbf{2 0 0 9}$ & $\mathbf{2 0 1 0}$ \\
\hline Беларусь & 100 & 106 & 111 & 119 & 138 & 153 & 170 & 186 & 206 & 200 & 223 \\
\hline Казахстан & 100 & 114 & 125 & 137 & 150 & 158 & 169 & 177 & 181 & 184 & 202 \\
\hline Кыргызстан & 100 & 105 & 93 & 109 & 115 & 101 & 91 & 97 & 112 & 105 & 115 \\
\hline Россия & 100 & 103 & 106 & 116 & 125 & 130 & 135 & 143 & 146 & 132 & 143 \\
\hline Таджикистан & 100 & 115 & 124 & 137 & 157 & 173 & 183 & 202 & 193 & 181 & 199 \\
\hline
\end{tabular}

Таблица 2 - Динамика изменения промышленного производства в странах-членах ЕврАзЭС, 2001-2010 г2. (базовый 2000 г., \%). Источник: Межгосударственный Статистический комитет СНГ.

Ситуация в инвестиционной сфере стран-членов Сообщества обусловлена двумя основными факторами. Во-первых, период трансформации экономической системы характеризовался резким сокращением использования внутренних инвестиционных ресурсов, что не позволяло предприятиям и организациям этих стран заниматься инвестиционной деятельностью, направленной на развитие национальной экономики. Во-вторых, инвестиционная активность и, соответственно, экономический рост во многих странах поддерживается и усиливается участием иностранного капитала. Однако, второй фактор в странах ЕврАзЭС имеет весьма неодинаковое проявление.

К примеру, для Казахстана это направление приобрело приоритетный характер. Одним из главных направлений экономических реформ в республике была и остается выработка привлекательной инвестиционной политики, что обусловило необходимость создания благоприятного инвестиционного климата для отечественных и иностранных инвесторов. Общепризнано, что инвестиционный климат Казахстана является одним из самых привлекательных среди развивающихся рынков. Это подтверждается тем, что республика первой среди стран СНГ получила кредитный рейтинг инвестиционного уровня (Россия получила после Казахстана). 
Благоприятный инвестиционный климат, как правило, со временем приводит к увеличению объема инвестиций, как внутренних, так и иностранных, что имеет решающее значение для поддержания высоких темпов экономического роста в стране. Проведенный анализ свидетельствует, что во всех странах Сообщества, динамика привлечения прямых иностранных инвестиций (ПИИ) достаточно высока. В 2009 г. по сравнению с 2001 г. рост ПИИ составил: в Беларуси - 605\%, Казахстане - 560\%, Таджикистане - 597\%, России - 477\% и Кыргызстане - 259\% (табл. 3).

\begin{tabular}{|c|c|c|c|c|c|c|c|c|c|}
\hline & $\mathbf{2 0 0 1}$ & $\mathbf{2 0 0 2}$ & $\mathbf{2 0 0 3}$ & $\mathbf{2 0 0 4}$ & $\mathbf{2 0 0 5}$ & $\mathbf{2 0 0 6}$ & $\mathbf{2 0 0 7}$ & $\mathbf{2 0 0 8}$ & $\mathbf{2 0 0 9}$ \\
\hline Беларусь & $\mathbf{1 0 0 , 0}$ & 117,8 & 135,9 & 147,2 & 170,5 & 195,7 & 320,9 & 474,3 & 605,3 \\
\hline Казахстан & $\mathbf{1 0 0 , 0}$ & 120,5 & 136,2 & 173,2 & 198,3 & 254,6 & 345,9 & 461,8 & 560,0 \\
\hline Кыргызстан & $\mathbf{1 0 0 , 0}$ & 113,4 & 126,3 & 171,9 & 124,9 & 149,6 & 197,5 & 245,0 & 259,4 \\
\hline Россия & $\mathbf{1 0 0 , 0}$ & 133,9 & 182,8 & 231,1 & 340,6 & 502,4 & 928,3 & 403,9 & 477,1 \\
\hline Таджикистан & $\mathbf{1 0 0 , 0}$ & 124,8 & 146,5 & 172,5 & 209,9 & 442,9 & 695,6 & 591,9 & 597,1 \\
\hline
\end{tabular}

Таблица 3: Динамика изменения притока ПИИ в странах-членах ЕврАзЭС, 2001-2010 г2. (базовый 2001,\%). Примечание: подсчитано и составлено на основании данных World Investment database.

В настоящее время удельный вес внешнеторговых показателей стран-членов ЕврАзЭС в мировой торговле незначителен, но имеет тенденцию к росту. Совокупная доля экспорта стран членов ЕврАзЭС в общемировом показателе в 2009 г. составила 2,98\% (в 2001 г. - 1,92\%), в мировом импорте - 1,84\% (в 2001 г. - 0,91\%). В течение 2001-2009 гг. Беларусь поднялась с 65-го места на 60-е, Казахстан - с 53-го на 45-е место, Россия с 17-го на 13-е место среди 227 стран мира. Кыргызстан, в 2001 г. занимал 131-е место, а к 2009 г. опустился на 140-е место, Таджикистан опустился со 138-го на 148-е место среди 227 стран мира (расчет по данным COMTRADE database).

За прошедшие девять лет удельный вес Беларуси, Казахстана и России в мировой торговле заметно увеличился. Так, в мировом экспорте доля Беларуси увеличилась с 0,12 до 0,17 процентов, Казахстана - с 0,14 до 0,35 процентов, России - с 1,65 до 2,44 процентов. Доля Кыргызстана и Таджикистана в мировом экспорте практически не изменилась и составляет $0,01 \%$.

Аналогичные тенденции характерны для долевых показателей этих стран в мировом импорте. В частности, удельный вес импорта Беларуси возрос с 0,13 до 0,23 процентов, Казахстана - с 0,10 до 0,22 процентов, России - с 0,67 до 1,35 процентов. Удельные показатели Кыргызстана и Таджикистана увеличились незначительно - на $0,01 \%$ (табл.4).

\begin{tabular}{|c|c|c|c|c|c|c|c|c|c|c|c|}
\hline Страны & $\mathbf{2 0 0 1}$ & $\mathbf{2 0 0 2}$ & $\mathbf{2 0 0 3}$ & $\mathbf{2 0 0 4}$ & $\mathbf{2 0 0 5}$ & $\mathbf{2 0 0 6}$ & $\mathbf{2 0 0 7}$ & $\mathbf{2 0 0 8}$ & $\mathbf{2 0 0 9}$ \\
\hline \multicolumn{10}{|c|}{ Экспорт } \\
\hline ЕврАзЭС - всего & 1,92 & 1,96 & 2,12 & 2,37 & 2,77 & 3,00 & 3,08 & 3,60 & 2,98 \\
\hline Беларусь & 0,12 & 0,13 & 0,13 & 0,15 & 0,15 & 0,16 & 0,18 & 0,21 & 0,17 \\
\hline Казахстан & 0,14 & 0,15 & 0,17 & 0,22 & 0,27 & 0,32 & 0,35 & 0,45 & 0,35 \\
\hline Кыргызстан & 0,01 & 0,01 & 0,01 & 0,01 & 0,01 & 0,01 & 0,01 & 0,01 & 0,01 \\
\hline Россия & 1,65 & 1,67 & 1,79 & 1,99 & 2,33 & 2,50 & 2,55 & 2,93 & 2,44 \\
\hline Таджикистан & 0,01 & 0,01 & 0,01 & 0,01 & 0,01 & 0,01 & 0,01 & 0,01 & 0,01 \\
\hline \multicolumn{10}{|c|}{ Импорт } \\
\hline ЕврАзЭС- всего & 0,91 & 0,96 & 1,03 & 1,13 & 1,27 & 1,53 & 1,89 & 2,15 & 1,84 \\
\hline Беларусь & 0,13 & 0,14 & 0,15 & 0,17 & 0,16 & 0,18 & 0,20 & 0,24 & 0,23 \\
\hline Казахстан & 0,10 & 0,10 & 0,11 & 0,13 & 0,16 & 0,19 & 0,23 & 0,23 & 0,22 \\
\hline Кыргызстан & 0,01 & 0,01 & 0,01 & 0,01 & 0,01 & 0,01 & 0,02 & 0,02 & 0,02 \\
\hline Россия & 0,67 & 0,70 & 0,75 & 0,80 & 0,93 & 1,12 & 1,42 & 1,63 & 1,35 \\
\hline Таджикистан & 0,01 & 0,01 & 0,01 & 0,01 & 0,01 & 0,01 & 0,01 & 0,02 & 0,02 \\
\hline
\end{tabular}

Таблица 4: Удельный вес стран-членов ЕврАзЭС в мировой торговле, 2001-2009 гг. (в процентах). Источник: расчет по данным COMTRADE database

Развитие внешнеторговых отношений стран-членов ЕврАзЭС свидетельствует об увеличение номинальных стоимостных объемов экспорта и импорта. В период 2001-2009 гг. совокупный внешнеторговый оборот интеграционного объединения увеличился в 3,2 раза, в том числе экспорт - в 2,9 раза, импорт - в 3,6 раза.

На протяжении всего анализируемого периода внешнеторговые показатели стран-членов ЕврАзЭС демонстрировали устойчивую положительную динамику роста. Однако, в 2009 г. эти показатели в абсолютном выражении снизились, что обусловлено влиянием глобального финансово-экономического кризиса. В частности, объем совокупного внешнеторгового оборота сократился на 40,9\%, в том числе экспорта - на 42,2\%, импорта - на 39,0\%. 
Анализ структуры экспортно-импортных поставок внутри ЕврАзЭС свидетельствует, что главным торговым партнером всех стран интеграционного образования выступает Россия. В тоже время ее удельный вес в экспорте из некоторых стран-членов ЕврАзЭС сокращается. Так, доля белорусского экспорта в Россию за эти годы снизилась с 99 до 94 процентов, доля казахстанского экспорта - с 92 до 84 процентов, доля таджикского экспорта - с 96 до 88 процентов. Удельный вес казахстанского экспорта в остальные страны ЕврАзЭС растет: в Беларусь - с 0,27 до 1,3 процентов, в Кыргызстан - с 4,6 до 9,2 процентов, в Таджикистан - с 3,2 до 5,7 процентов. Доля экспорта из Кыргызстана в страны ЕврАзЭС имеет неустойчивую тенденцию. Динамично растут экспортные поставки российских товаров на рынки стран-членов ЕврАзЭС, особенно в Кыргызстан и Таджикистан. Удельный вес экспорта России в Беларусь в 2001-2007 гг. снижался, но в 2008-2009 гг. вновь вырос. Аналогичный показатель по Казахстану имеет неустойчивую, волнообразную динамику. Заметно увеличился удельный вес поставок таджикских товаров на белорусский рынок - с 1,3 до 4,6 процентов.

Наиболее высокими темпами в страны ЕврАзЭС увеличивался экспорт из России (3,3\%). На втором месте Кыргызстан (2,8\%), на третьем Казахстан (2,2\%). Таджикистан и Беларусь увеличили свой экспорт равными темпами по $1,8 \%$.

\begin{tabular}{|c|c|c|c|c|c|c|}
\hline \multirow{2}{*}{$\begin{array}{c}\text { Страна- } \\
\text { экспортер }\end{array}$} & \multirow{2}{*}{ Год } & \multicolumn{5}{|c|}{ Удельный вес стран-членов ЕврАзЭС в общем объеме } \\
& & \multicolumn{5}{|c|}{ Экспорта в страны ЕврАзЭС } \\
\hline \multirow{3}{*}{ Беларусь } & 2001 & - & 0,71 & 0,18 & 99,05 & 0,06 \\
& 2005 & - & 3,10 & 0,15 & 96,60 & 0,15 \\
& 2009 & - & 4,40 & 0,92 & 94,20 & 0,48 \\
\hline \multirow{3}{*}{ Казахстан } & 2001 & 0,27 & - & 4,55 & 91,99 & 3,20 \\
& 2005 & 0,80 & - & 6,77 & 87,91 & 4,52 \\
& 2009 & 1,29 & - & 9,23 & 83,80 & 5,68 \\
\hline \multirow{3}{*}{ Кыргызстан } & 2001 & 2,82 & 34,40 & - & 56,86 & 5,92 \\
& 2005 & 0,51 & 42,25 & - & 48,90 & 8,33 \\
& 2009 & 1,01 & 36,93 & - & 57,48 & 4,58 \\
\hline \multirow{3}{*}{ Россия } & 2001 & 64,17 & 33,96 & 1,02 & - & 0,85 \\
& 2005 & 58,59 & 37,84 & 2,18 & - & 1,39 \\
& 2009 & 61,12 & 33,44 & 3,35 & - & 2,09 \\
\hline
\end{tabular}

Таблица 5: Удельный вес стран-членов ЕврАзЭС в общзем объеме экспорта в страны ЕврАзЭС, 20012009 гг. Источник: подсчитано на основе данных COMTRADE database. Примечание: по Таджикистану расчеты сделаны на основе зеркальной статистики.

\begin{tabular}{|c|c|c|c|c|c|c|}
\hline \multirow{2}{*}{$\begin{array}{c}\text { Страна- } \\
\text { импортер }\end{array}$} & \multirow{2}{*}{ Год } & \multicolumn{5}{|c|}{ Удельный вес стран-членов ЕврАзЭС в общем объеме } \\
\cline { 3 - 7 } & & Беларусь & Казахстан & Кыргызстан & Россия & Таджикистан \\
\hline \multirow{3}{*}{ Беларусь } & 2001 & - & 0,15 & 0,12 & 99,70 & 0,03 \\
& 2005 & - & 0,31 & 0,02 & 99,64 & 0,03 \\
& 2009 & - & 0,45 & 0,02 & 99,47 & 0,07 \\
\hline \multirow{3}{*}{ Казахстан } & 2001 & 1,56 & - & 1,12 & 97,24 & 0,08 \\
& 2005 & 3,00 & - & 1,71 & 95,04 & 0,24 \\
& 2009 & 3,91 & - & 1,24 & 94,70 & 0,16 \\
\hline \multirow{3}{*}{ Кыргызстан } & 2001 & 3,42 & 46,93 & - & 48,79 & 0,86 \\
& 2005 & 1,25 & 31,74 & - & 66,66 & 0,35 \\
& 2009 & 5,06 & 19,09 & - & 75,59 & 0,27 \\
\hline \multirow{3}{*}{ Россия } & 2001 & 64,08 & 32,81 & 1,01 & - & 2,11 \\
& 2005 & 62,26 & 35,12 & 1,59 & - & 1,03 \\
& 2009 & 61,15 & 33,56 & 3,34 & - & 1,95 \\
\hline \multirow{2}{*}{ Таджикистан } & 2001 & 1,82 & 43,76 & 4,80 & 49,62 & - \\
& 2005 & 2,04 & 35,68 & 5,43 & 56,85 & - \\
& 2009 & 4,01 & 27,88 & 1,72 & 66,39 & - \\
\hline
\end{tabular}

Таблица 6: Удельный вес стран-членов ЕврАзЭС в общем объеме импорта в страны ЕврАзЭС, 2001-2009 22. Источник: рассчитано на основе данных COMTRADE database. Примечание: по Таджикистану расчеты сделаны на основе зеркальной статистики.

Во взаимной торговле стран-членов ЕврАзЭС доминируют импортные поставки из России. При этом их доля в поставках в Беларусь на протяжении последних девяти лет остается низменной - на уровне почти 100\%. Вторым партнером Беларуси в импортных поставках внутри данного интеграционного объединения является Казахстан, доля которого увеличилась в три раза - с 0,15 до 0,45 процентов. Доля 
белорусского импорта на российский рынок, хотя и имеет тенденцию к снижению, остается самой высокой среди стран ЕврАзЭС. Вторым по значимости российским партнером по импорту является Казахстан (порядка 1/3 всего импорта из стран ЕврАзЭС). Казахстан также является важным поставщиком товаров на рынок Кыргызстана и Таджикистана. Добавим, что две третьих товаров, импортируемых Таджикистаном из стран данного объединения, поступают из России.

В динамике импортных поставок из стран ЕврАзЭС лидирует Кыргызстан - 8,3\%, на втором месте Таджикистан - 6,2\%, на третьем Казахстан - 3.2\%, на четвертом Беларусь - 3,1\%. Наименее низкие темпы роста импортных поставок из стран интеграционного объединения характерны для России $(1,8 \%)$.

Таким образом, среди интеграционных объединений, в которых участвует Казахстан, наиболее благоприятные перспективы раскрываются между государствами ЕврАзЭС. Однако, проведенный анализ показал, что не все страны имеют высокий темп развития. Существующая разница в уровне и качестве социально-экономического развития пяти государств обусловлена глубиной и скоростью реформ, проведенных в странах-членах Сообщества. Наиболее продвинуты экономические реформы в Казахстане и России.

В течение 2001-2009 гг. внешнеторговые показатели Беларуси, Казахстана и России, входящие в состав ЕврАзЭС с октября 2000 г., демонстрировали устойчивую позитивную динамику роста. В совокупности страны-члены ЕврАзЭС являются нетто-экспортерами. Анализ структуры внешнеторговых отношений убедительно показывает, что Россия была и остается главным торговым партнером всех стран интеграционного объединения. Динамично растут поставки российских товаров в Кыргызстан и Таджикистан. В тоже время удельный вес России во внешнеторговых показателях ряда стран ЕврАзЭС сокращается. Прежде всего, это относится к экспортным поставкам на российский рынок товаров из Казахстана и Таджикистана, (удельный вес снизился на 8\%), Беларуси (на 5\%). Во взаимных импортных поставках внутри ЕврАзЭС также продолжают доминировать российские товары, в особенности на рынки Беларуси (почти 100\% всех поставок из стран ЕврАзЭС) и Казахстана (95-97\%).

Направления сотрудничества по приоритету долгосрочной перспективы обусловливаются логикой развития глобальной экономики. В первую очередь это технологически перспективные отрасли, сотрудничество в которых позволит укрепить позиции стран-партнеров на мировых рынках высокотехнологичной продукции. Так же по некоторым позициям, в которых возможно доминирование стран-партнеров, целесообразна интеграция в форме неких организаций, типа ОПЕК, с целью олигопольного или монопольного контролирования ряда товарных рынков. Такими рынками могут быть газовый, редкоземельных металлов, хромитов, урана и ряда других.

Наконец, еще одним направлением перспективного сотрудничества могут быть совместные усилия по формированию и продвижению брендов интегрированных бизнес-структур на мировые рынки.

Обозначенные направления интеграции закономерно задают и набор основных механизмов реализации стратегии соседства. Именно механизмы во многом обусловливают эффективность интеграционных процессов, а их адекватность реальным потребностям интеграции будет предопределять взаимную заинтересованность стран и национальных хозяйствующих субъектов в укреплении этой интеграции. В системе необходимых механизмов можно выделить три основных уровня - механизмы межгосударственной интеграции, экономические механизмы государственного стимулирования корпоративной интеграции и организационные механизмы корпоративной интеграции.

Первый уровень - механизмы прямого государственного влияния на интеграцию - могут включать ряд мер, среди которых можно выделить создание межгосударственных институтов развития и координацию действий странами-партнерами на мировых рынках в целях повышения эффективности внешнеторговой политики. Следует отметить, что первый из указанных механизмов уже применяется - с целью содействия развитию рыночной экономики государств-участников, их устойчивому экономическому росту и расширению взаимных торгово-экономических связей, создан Евразийский банк развития (ЕАБР).

Значительно более перспективной представляется межгосударственная координация действий на мировых рынках, причем на различных секторах этих рынков. Наиболее перспективными секторами представляются глобальные сырьевые и фондовые рынки.

Трансферт технологий в условиях глобализации может быть более эффективным с использованием операций на мировых рынках капитала, на основе участия в капитале иностранных компаний. Это позволит решить несколько задач в области технологической модернизации национальных экономик странпартнеров:

- получить доступ к передовым технологиям;

- организовать обучение специалистов в зарубежных компаниях;

- получить возможность использования брендов хай-тек продукции;

- организовать размещение части производства в странах ЕврАзЭС . 
Помимо мировых рынков капиталов и технологий, приоритетным направлением интеграционных инициатив стран ЕврАзЭС должна быть координация действий на мировых товарных рынках, особенно на тех их сегментах, где страны-партнеры вместе могут занимать доминирующее положение. Это позволит укрепить позиции соответствующих бизнес-структур, базирующихся в ЕврАзЭС и выступающих проводниками экономических и иных интересов стран-партнеров. В этой области особенно перспективным представляется сотрудничество России и Казахстана, как стран с наиболее богатым в ЕврАзЭС ресурсным потенциалом.

Формирование межгосударственных компаний в рамках реализации интеграционного потенциала может быть особенно ускоренным и эффективным на основе использования инструментария государственного предпринимательства и государственно-частного партнерства. Эти механизмы, предполагающие участие государственных (или с участием государства) институтов и компаний, позволяют провести интеграцию на корпоративном уровне быстрее и миновать длительный период эволюционного «созревания условий» для объединения капиталов частных хозяйствующих субъектов.

Использование в процессе формирования межгосударственных компаний потенциала межгосударственной интеграции, по нашему мнению, позволит осуществлять этот процесс более быстрыми темпами и с большей эффективностью за счет роста масштаба международных операций в странах-партнерах, роста капитализации создаваемых структур путем объединения их активов, совместной экспансии на рынки третьих стран.

На государственном уровне стимулирование корпоративной интеграции может осуществляться (помимо рассмотренных методов прямого участия посредством госкомпаний и институтов развития) и косвенными мерами экономического стимулирования. В частности, целесообразно предоставление налоговых льгот для совместных предприятий, особенно действенно в данном случае может быть освобождение от налогообложения прибыли, направляемой на выплату дивидендов зарубежным стратегическим акционерам, что позволит создать стимулы для объединения на уровне компаний разных стран. Также целесообразно предоставлять льготные кредиты и инвестиции межгосударственных институтов развития для корпоративных международно-интегрированных компаний.

Использование всего спектра рассмотренных механизмов позволит, по нашему мнению, успешно реализовывать интеграционные стратегии соседства и партнерства между Казахстаном и странами ЕврАзЭС и укреплять социально-экономические взаимосвязи на всех уровнях сотрудничества.

\section{Литература}

- Н.А. Назарбаев Евразийский экономический союз: теория или реальность //Известия, 19.03.2009

- Колеров М. Геополитические риски Таможенного союза России, Казахстана и Беларуси //www.regnum.ru/news

- Головнин М. Многостороннее финансовое взаимодействие на постсоветском пространстве // Проблемы теории и практики управления, 2007, №4. - С.34

- Договор об учреждении Евразийского экономического сообщества от 10 октября 2000 года, ст. 2.

- Примбетов С.Д. ЕврАзЭС: итоги и перспективы. - Алматы, 2007. - С.С.144-152

- Информационно-аналитический бюллетень Центра проблем интеграции Института экономики РАН, 2008, № 4(8). - C. 9

- World Economic Outlook: Recovery, Risk, and Rebalancing. - International Monetary Fund, Washington. October 2010.

- Millennium Development Goals. - World Bank, 2010 // www.worldbank.org. 


\title{
О возможностях развития Кыргызско-Грузинского сотрудничества
}

\author{
Iuri Tsuladze (State Committee for Science and Technologies, Georgia) \\ Turar Koychuev (Kyrgyzstan-Turkey Manas University, Kyrgyzstan)
}

\section{The Possibilities for the Development of Kyrgyz-Georgian Cooperation}

\begin{abstract}
Since independence, post-soviet republics have formed own foreign policy in all directions. Both Georgia and Kyrgyzstan already have economic, trade and other relation with many countries, for example, relations with Turkey cover not only economy and trade, but also science, culture and other areas. Kyrgyzstan and Georgia have favorable conditions for revival of cooperation.

Given article analyzes the formation and development of economic and social cooperation, exchange of experience in post soviet reforming period.

There are promising possibilities for the deep, effective and mutually beneficial cooperation, establishment of political trust between the authorities, strengthening of friendship and of broad social contacts between our peoples.
\end{abstract}

JEL Code: P20

С приобретением независимости, бывшие союзные республики самостоятельно строят свою внешнюю политику во всех областях жизнедеятельности. Устанавливают связи в широком мировом пространстве, не забывая и о связях между собой. И Грузия, и Кыргызстан уже имеют доверительные экономические, торговые связи со многими странами, в частности, в качестве примера можно привести связь с Турцией, которая охватывает не только экономику и торговлю, но и науку, культуру и иные области. А для того, чтобы Кыргызстан и Грузия возродили на новой качественной основе свои связи между собой, есть благоприятные предпосылки...

Агропромышленный продовольственный комплекс по праву продолжит оставаться важным приоритетным производственным сектором в экономике Кыргызской Республики. Основой являются прекрасные условия для выращивания различных сельскохозяйственных культур. Все условия и возможности, данные природой, используются далеко недостаточно. При более широких и более полноценных освоениях ассортимент пищевых продуктов мог бы быть гораздо богаче.

В свое время в республике раньше гораздо больше, чем сегодня, разводили сады и плантации ягод, имеющих винодельческое значение. Производимые в республике вина неоднократно завоевывали почетные места и медали на международных выставках. Существовали «винсовхозы», которые представляли собой комплексное агропромышленное пищевое объединение: «выращивалось и собиралось» сырье, подвергалось промышленной переработке и выпускались вина: игристые, крепкие, сухие, белые и красные.

Мнимая антиалкогольная компания, начатая во второй половине 80-х годов XX века в СССР уничтожала винодельческие хозяйства в СССР, в том числе в Кыргызстане. Выкорчевывались и выравнивались сады и плантации ягод. Эти сады и ягоды могли использоваться не только для производства вин, но и производства компотов, варенья, джемов, соков и для потребления в естественном свежем виде.

В условиях рынка и расширения экономических и торговых связей возрождение в значимых масштабах виноделия могло бы стать важным продуктом экспорта. Можно было бы определить производственные, экономические совместные предприятия со странами, имеющими богатый и известный опыт в международном и крупном региональном масштабах, и найти широкий внешний рынок сбыта.

В этом плане привлекательным, на наш взгляд, является привлечение к сотрудничеству грузинских виноделов, имеющих богатый опыт, вина которых славятся далеко за пределами Грузии. В СССР всегда ценились грузинские вина. В настоящее время некоторые марки грузинских вин стали выпускаться малыми и средними хозяйствами в Кыргызстане, но незначительно и «не очень известны» на рынке. Более широкий подход к проблеме и расширение масштабов должны превратить виноделие в заметную отрасль республики в условиях рынка. Появились бы соответствующие, сопутствующие предприятия торговли, общественного питания, кафе-дегустаторы, клубы клиентов, сочетающие функции общественного, торговли, встреч для общения и дискуссий по интересам, музыкальных вечеров и т.д. 
В Кыргызстане, на юге республики, в определенной степени природно-климатические условия позволяют в определенных рамках и с определенными технологиями выращивать лимоны, очень сочные и прекрасные по вкусовым качествам. Сейчас «заглохло». Можно было возрождать и, более того, расширять ассортимент цитрусовых. И в этом случае полезным был бы опыт Грузии. Аджария, ведь, славится в этом плане.

На свое прошлое развитие подходить нужно объективно, справедливо отмечая и достоинства, и негативы. В советское время государством серьезное внимание уделялось развитию рыбного хозяйства: использовались естественные озера и горные речки, создавались искусственные пруды, строились и вводились в эксплуатацию рыбзаводы. Ныне утеряны бывшие достижения. В Грузии и Кыргызстане много горных речек. Каковы в них возможности наращивания речного рыболовства и создания соответствующих и сопутствующих предприятий. Опыт друг друга мог бы построить мостик сотрудничества. Может быть, исследование этого вопроса требует серьезного внимания?

В свое время для развития речного хозяйства в Кыргызстане и вообще для развития всей пищевой промышленности в республике большой вклад внес грузин - Леонид Цуладзе, который после окончания Астраханского института рыбного хозяйства вместе с супругой, тоже выпускницей этого же института, получил распределение как молодой специалист в Киргизию и многие годы трудовой деятельности отдал Кыргызстану. Руководил Министерством. После возвращения в Грузию работал в Батуми и создал дельфинарий, свое детище. Многие годы оставался его руководителем. Леонид Цуладзе - отец Юрия Цуладзе, одного из авторов данного доклада. Юрий родился в Кыргызстан, в Кемине, учился во Фрунзенской средней школе №6 им. И.В. Панфилова. Корни наши. После окончания Московского высшего технического училища им. Баумана поехал работать в Тбилиси. Это был 1961 год. К тому времени его родители вернулись на историческую родину - Грузию. Но семья Цуладзе не порвала связь с Кыргызстаном, ставшим для них вторым домом. Леонид Цуладзе приезжал на Всесоюзную конференцию во Фрунзе. Неоднократно приезжал Юрий. Вот и нынче он с нами. Продолжает дружить со своими друзьями и всегда встречает радостно их в Тбилиси. Наша человеческая дружба и творческое сотрудничество продолжается.

Да, кстати, возможно ли создание дельфинария на озере Иссык-Куль? Или размеры озера и объем воды недостаточен для дельфинов. Или климат холодный?

В Кыргызстане развивается золотодобыча и золотообрабатывающая промышленность, создаются возможности производства ювелирных, сувенирных и других потребительских изделий. Есть ресурсные возможности освоения и обработки других благородных металлов, тоже возможно производство самых различных потребительских товаров и украшений, предметов роскоши. Есть ценные породы деревьев для использования в соответствующих целях. Опыт Грузии по производству различных потребительских, ювелирных и сувенирных изделий из металлов, камней, дерева и костей известный. Требует внимание изучения этого опыта, установление производственного и делового сотрудничества, приносящего взаимный выигрыш.

Располагая уникальными биоресурсами, Кыргызстан и Грузия смогли бы найти возможности для реализации совместных проектов в области фармакологии, дополняя друг друга.

Безусловно, расширение и углубление экономических связей способствовало бы развитию сотрудничества в области науки, образования, культуры и здравоохранения, организации санаторнокурортных учреждений, физической культуры и спорта.

После распада Советского Союза бывшие союзные, ныне суверенные республики определяют свои идеологии, модели, стратегии, политики и программы развития с учетом национальных особенностей и своих возможностей. Но ориентир в принципе один - путь к политической демократии и рыночной экономической свободы и открытости, что открывает широкие возможности для развития сотрудничества между собой.

Страны за достаточно недолгий срок определенный опыт деятельности в новых общественнополитических и социально-экономических условиях. Есть положительные и негативные моменты. Поэтому взаимное знакомство опытами, перенятие положительного и освобождение от негативного актуально.

В этом плане опыт Грузии по созданию новой системы управления страной и ее искоренению заслуживает серьезного изучения и принятие положительных моментов. В Кыргызстане коррупция создает серьезные проблемы.

Если подвести итог доклада, то можно утверждать: у Кыргызстана и Грузии есть перспективные возможности для широкого и глубокого, эффективного и взаимовыгодного сотрудничества, установления политического доверия между властями, укрепления дружбы и установления широких социальных контактов между нашими народами, имея ввиду научные, культурные, образовательные и туристические связи. Земли Манаса и Шота Руставели всегда тянулись друг к другу по взаимной симпатии. В Кыргызстане народ читает и знает Шоту Руставели, его «Витязь в тигровой шкуре». Многие родители 
называют своих сыновей Тариэлем и Автандилом, дочерей - Тинатин и Нестан. Станут тесной наша дружба, надеемся, и в Грузии появятся грузинские юноши Манасы, Семетеи и девушки с именем Каныкей и Айчурек!...

Взаимное притяжение народов друг другу не преодолимо. На этом притяжении держится мир!..

\section{Литература:}

- Койчуев Т. Есть ли у Кыргызстана будущее ? - Б., 2010.-324 с.

- Койчуев Т. Мировая экономика и постсоветская Центральная Азия. - Б., 2011. - 122 с.

- Официальные материалы Национального Статистического комитета КР 


\title{
Rusça ve Türkçe’de Çokanlamlı Ekonomi Terimlerinin Analizi
}

\author{
Larisa Zakharova (Beykent University, Turkey)
}

\section{An Analysis of Polysemantic Economical Terms in Russian and Turkish}

\begin{abstract}
This article is about a comparative analysis of polysemanticism of economical terms in Russian and in Turkish. The theorical base of investigation is works of Russian linguists, such as P.V.Candoeva, S.P.Afanasyeva, A.D.Ugodchikova, etc., who have noted, that the polysemantics determines the depth of the object of nomination of such research. Polysemanticism is the way for effectiveness of language sources, reflection of the efforts in term-creation and the creative integration of different sciences. One of the most widespread ways of the development polysemanticism of terms in Russian is methonymy, narrowing of meaning of words in generel use, specification and change of term semantic. Extended materials were examined with respect to the ways of transfering of meaning of economical terms in Russian and their equivalents in Turkish were founded. Most of economical terms in Russian are adobted from English that is why, when we translate a polysemantic term to Turkish, it may have two equivalents for each of its meaning. For instance, double-meaned term 'aktiv' in Russian was translated in Turkish as 'varlık' for it first meaning and for the second we have used both 'varllk' and adobted term 'aktif'.
\end{abstract}

JEL Code: Z1

\section{Giris}

Sözlüksel bir birimin aynı anda birkaç anlam taşıma özelliği, yani çok anlamlılık, dil birimleri kullanma tasarruf kanunun bir parçasıdır, zira "hiçbir dil her belli düşünceyi ona has bir kelime ya da bir ögeyle ifade etme durumunda değildir. Tecrübenin kesinliği sınırsızdır, fakat en zengin dilin bile kaynakları kısıtlıdır" (Виноградов, s.15).

Makalenin amacı milli edebiyattaki terimlerin çok anlamlılı̆̆ına olan farklı bakış açılarını incelemek, var olan yazılı malzemenin analizini yapmak ve çok anlamlılığın bir dilin çerçevesinde ya da diller arası çerçevesinde Rusçadaki çok anlamlı ekonomi terimlerinin Türkçe eşdeğerleri ile karşılaştırmak.

\section{Kaynak Taraması}

K.Y.Averbuh, R.A.Budagov, L.S.Datsuk, L.A.Kapanadze, E.N.Tolikina, A.A.Reformatorskiy gibi bilim adamları genel dil ve terminoloji sistemleri arasında kesin farklılıklar görüyor ve terim işlevli dilsel göstergenin tek anlamlı bir kelime olduğunu savunmaktadırlar. Anlamların dakikliği ve betimleme bütünlüğü terimin doğru kullanımına bağlı olduğundan, çok anlamlılık sorunu, çok anlamlı terim birimlerin anlamsal (semantik) ayrılması büyük bir önem taşımaktadır.

Dil bilimi içerikli kaynaklardaki “çok anlamlılık” teriminin tanımına başvuralım. O.S.Ahmanova’ya göre: çok anlamlılık, "genellikle şekil değişimi ve kelimenin ilk anlamının gelişmesi sonucunda tek bir kelimenin birbirilerine bağlı birkaç anlam taşıma özelliğidir" (Ахманова, s.335). Fakat yukarıda da belirttiğimiz gibi terim sistemdeki çok anlamlılık özel bir olaydır ve makalenin amacı da çok anlamlı terimlerin yaşama haklarının olup olmadığını, bilimsel içerikli metinlerin anlaşılmasına engel olup olmadıklarını, çok anlamlı terimlerin hangi yollarla oluştuğunu ve ayrıca çok anlamlı terimlerin Türkçede karşılıklarının olup olmadığını meydana çıkarmaktır.

R.A.Budagov'un savına göre terim tek anlamlılığı ve ait olduğu dil sistemindeki kesin durumu ile tanımlamaktadır (Будагов, s.215). L.A.Kapanadze terimin tek anlamlılı̆̆ını onu edebi dilin diğer kelimelerinden önemli ölçüde ayırt eden esas özelliği olarak görmektedir (Капанадзе, s.41).

K.Y. Averbuh'a göre terimlerin gerçek işlevi hususunda yapılan analiz terimin işlevsel bir birim olduğunu ve bu terim sistemin çerçevesinde tek anlam eğilimde olduğunu ve belli bir bağlamda kendi iletişim görevine zarar vermeden bir anlamdan fazla anlam belirtemeyeceğinden terminoloji alanında çok anlamlılığın olmadığını göstermektedir. Yazar terimin tek anlamdan farklı olan tüm sapmalarını olabilecek bir özellik olarak görmeyerek, onun yanlış kullanma olayı olarak sınıflandırmaktadır (Авербух, s.39-40).

L.S.Datsuk kelimeyi dilin iletişimsel ve spesifik tanımların sistemini belirten terimlerin dil dışındaki iki farklı sistemin birimi olarak incelemektedir. Bu sistemlerin kelimeyi bu sistemlere özgü ve herhangi bir şekilde birbirilerine uymayan özelliklerle donatmaları bundandır. Tek istisna kelimenin esas özelliğidir, yani özel bir tanımı anlam sisteminin bir birimi olarak belirtmek için kullanılan ve bu tanımın bir birim niteliğinde terim sistemine giren bir genel işaret değeridir (Дацюк, s.6). Bu bakış açısının taraftarlarına göre, terim sistemce 
verilen özel niteliklerle donatılmış aktüel edilmiş bir kelimedir ve bu kelime yalnızca tek özel bir anlamı belirtmekte ve tanım sisteminin diğer anlamlarından ayırmaktadır. Dil sistemindeki kelimenin anlam genellemesi kelimeye sırasıyla bir sistemin çerçevesinde özdeş ayırma özelliğe sahip farklı hususi anlamları belirtme ve terim sistemlerine onların bir birimi olarak girme imkânı tanımaktadır. Her ayrı anlam sistemi terim-kelimeye tek bir nitelik yüklemektedir, belirtilen anlamın tek bir içeriği ile bağlantı nitelik, böylece de başka bir anlam taşıma özelliğinin potansiyel olabilirliğine bile yer vermemektedir. Bu potansiyelliğe ancak dil sistemin bir birimi olan kelime sahiptir. Buna bağlı olarak L.S.Datsuk'a göre, çok anlamlı kelimenin istisnai özelliğidir ve terime özgü değildir.

A.A.Reformatorskiy tek anlam taşıma özelliğini terimin belirleyici vasfi olarak ya da tek anlamlılı̆̆ (monosemiye eğilimi) terim alan çerçevesinde görmektedir (Реформатский, s.46-54). Reformatorskiy terimlerin izole olma durumunun, onların terim alana göre iç yerleşiminin ve bağlama göre dış yerleşiminin altını çizmektedir.

Fakat terminolojide birbirileriyle aynı içeriği ve anlamı taşıyan sapmalar da ortaya çıkmaktadır, bu da çok anlamlılığın ortaya çıkmasını sağlamaktadır. Bilimsel düşüncenin gelişimi hem yeni terimlerin hem de farklı nüansların ortaya çıkmasına neden olmaktadır. V.P.Danilenko, L.N.Zenkova, Y.A.Klimovitskiy, N.Z.Kotelova, L.L.Kutina gibi bilim adamları terim çok anlamlılığın varlığını kabul ederek bu durumu "esaslı eksiklik" olarak görüyorlar ve bilimsel teknik terimlerden beklenen farklı taleplerin arasında tek anlamlılığın bir terim sistemi çerçevesinde ilk plana çıktı̆̆ını belirtmektedir. Terim doğasına aykırı olan çok anlamlı terimin kesin belirtme özelliğini, sarihliğini yok etmekte ve bağlam dışındaki algılamaya engel olmaktadır.

Farklı bilim alanların terimleri üzerinde araştırmacılarca yapılan terim çok anlamlılık analizi bu meseleye farklı bir bakış açısı daha sunmaktadır. Bazı bilim adamları terim çok anlamlılı̆ı olağan bir olay olarak görmektedir ve eski anlamlar üzerinde yeni farklı anlamların gelişmesinin ağırlık kazandığını düşünmektedir, zira bu olay zaman ve çaba tasarrufu sağlamakta ve en uç noktalardaki bilim alanların kesişme noktasında yaratıcı düşüncenin doğmasına yardımcı olmaktadır. En az sayıda dilsel birimler kullanarak çok fazla bilgi verebilen dil işaretinin tasarruf prensibi faaliyeti tam burada ortaya çıkmaktadır (Джандоева, s.12). V.A.Tatarinov da aynı sonuca ulaşmaktadır. Ona göre "terimlerin anlam sınırlarının değişmesi, yeni anlamların ortaya çıkması devamlı gelişen gerçekliğin anlama sürecini aks ettiren gelişen terim sisteminin muntazam bir olayıdır. Bir terime sonsuza kadar belli bir içerik yüklenmekte ise bu terimin belirttiği anlam da korumaktadır. Terimin anlam netleşmesi onun "kemikleştiğì" anlamına gelmemekte, terimin taşıdığı anlam içeriğinin devamlı detaylaştırma gerektirdiği anlamına gelmektedir” (Татаринов, s.8). Örneğin pek çok araştırmanın sonucuna göre fiilden yapılmış isimlerden oluşan bir grup kelime anlamın düzenliliği anlam gelişimiyle nitelenmektedir (Афанасьева, s.15). Bu isimlerin tür anlamlarını belirtme özelliklerini ve yapıldıkları fiillerin birleşme özelliklerini kaybetmeleri süreç anlamlarla etkileşim içinde olan nesnel anlamların gelişmesine yol açmaktadır.

Terimin çok anlamlılığı bilim alanının kavram sistemi yapısını ve onun diğer terim sistemleriyle olan bağlılaşmayı yansıtmaktadır. Bunun delili olarak bilim adamları terim sistemindeki ad aktarma (mecaz) olgusunun olmadığını göstermektedirler. Mecaz edebi dilin kelimelerinden terim yaratmanın bir yoludur, fakat daha sonra bu terim tek anlamlı olarak var olmaktadır. Bu yaklaşımın taraftarları, terim çok anlamlılığı genel dildeki çok anlamlılık ile karşılaştırarak, terimin tek anlamlılığa olan yönelim düşüncesini reddetmektedir. Terimin çok anlamlılığı onun kesin olmadığının belirtisi değildir. Terminolojideki çok anlamlılık sistemi ne kadar çok gelişmişse konu o kadar çok incelenmiştir, ortak bilimsel tanımlar ile bir sahaya ait kavram bağlantıların aleti daha doğru kurulmuştur demektir. Bazı çalışmalarda terim çok anlamlılığın düzenliliği ispatlanmaktadır; düzenlilik terim çok anlamlılığın ayrılmaz bir parçasıdır. T.A.Alekseenko tanımların birbirilerine bağlı olma düzenliliğin esas kıstasını tipiklikte, anlamın benzer kombinasyonların tekrarlanmasında görmektedir (Алексеенко, s.2).

L.M.Noviçkova dildeki çok anlamlılık olgusunun yasallığını açıklarken anlamsal bir oluşum olarak dilsel isim verme (eşseslilik) birimlerin ve tek bir terimin (çok anlamlılık) yapısında dilsel iletişim araçların sözcükselanlamsal değişimi seviyesinde anlam değişim özelliğinin terimlere özgü olduğunu belirtmektedir (Новичкова, s.6). Bizim araştırmamız için özellikle önemli olan yazarın dilde gerekli ve yasal olarak nitelenen bu belirtilen eğilimlerin farklı milli dillerdeki terminolojilerde ortak olduğu iddiasıdır.

\section{Ekonomi Terimlerinin Analizi}

Araştırılan sistemdeki çok anlamlılık farklı nedenlerden kaynaklanabilir. Bu nedenleri araştırırken buna benzer olayların açığa çıkartılması için bu çok anlamlı kelimelere denk gelen Türkçe karşılıkları incelenmiştir. Toplumsal hayatın bir olayı olan ekonomi terimleri ortak kullanımlı kelimelere yakındır. Bu da herşeyden önce bazı terminoloji birimlerin ortak kullanımlı bir kelimenin anlam daraltılması ya da genişletilmesi sonucunda ortaya çıkmaktadır. Bununla birlikte bu kelime kendi terim işlevini söz öbeği şeklinde kullanmaya başlamaktadır. (Киршо, s.86). Örneğin zona kelimesi Küçük Akademik Sözlüğün verilerine göre Rusçaya Yunancadan alınmıştır ve iki anlam taşımaktadır: 1. Kuşak, iki çizgi arasındaki saha. Coğrafya kuşağı. Sıcak kuşak. Askeri harekât sahası. Erişilebilir alan. Radyo cihazlarının çekim sahası. 2. Paleontoloji ve jeolojide - katman, kat. 
Deniz altının kontinental katmanı. 3. Paralel kenarların kesişme yerinde kristal façetaların toplamı. (Словарь русского языка, II.c., s.47). 18. Yüzyılın başından itibaren saha kelimesi Rusça'da anlamca genişlemiş ve tabiat iklim koşullarına bağlı kalmaktan çıkmıştır. "Kuşak, saha, herhangi bir sınır ya da sınır boyunca uzanan alanın ve genel olarak da bölgenin terim anlamı, ortak koşullara, özelliklere, aynı zamanda iktisadi özelliklere sahip olan alan" birleşim ögeleri yardımıyla gerçekleşmektedir: serbest ticaret alanı, teknik uygulama alanları, sanayi üretim alanlarl, servis alanları, özel iktisat alanı, serbest iktisat alanı.

Aynı sistemin çerçevesinde terimin gelişmesi esnasında ortaya başka bir anlamı çıkması olayı ilginçtir. Terim genel kullanımdaki kelimenin bir anlamıysa ve diğer yandan da tek bir anlam taşımıyorsa, yani bir anlamdan fazla anlam içeriyorsa, ortaya ikili bir çok anlamlılık çıkmaktadır. Örneğin: komissiya - 1) birkaç kişiden oluşan grup, ya da herhangi bir işyerinde, kuruluşta ve özel yetkili kuruluşta özel yetkilerle donatılmış birkaç kişiden oluşan bir grup Komisyon atamak. Komisyon oluşturmak. Tıbbi uzman komisyonu. Silahsızlaştırma komisyonu; 2) bir ödül karşılığında verilen görev; 3) bir tarafın (komisyoncu) diğer tarafa (mal sahibi) bir kazanç (ödül) karşılığında mal sahibinin menfaatlerini koruyarak yaptığı satış akdi içeren özel anlaşma; 4) satış akdi sonunda alınan özel ücret. Rusça komissiya kelimesini Fransızcadan alınan komisyon kelimesiyle edebi dilde karşılaştırma onların birbirilerine neredeyse eşdeğer olduğunu göstermektedir. (1. Alt kurul. 2. tic. Bir işte aracılık yapan kimseye bırakılan yüzde, simsariye). Komissiya ve komisyon kelimeleri incelediğinde, bu terimin Osmanlıcada kullanıldığını, günümüz Türkçesinde de ona karşılık Rusça'da 3. anlamı içeren "Bir aracıyla bir satıcı arasında aracılık ederek alışverişi gerçekleştiren kişinin yüzde hesabıyla aldığı ücret” yüzdelik kelimenin kullanıldığı ortaya çıkmaktadır.

Çok anlamlılığın gelişmesine yol açan nedenlerden birisi terimin özelliğidir. Ülkenin ekonomi geliştikçe terimin anlamı detaylaşmakta ya da değişmekte, yani terim yeni özellikler sahip olmaktadır. Örneğin Rusça'da devalvatziya terimi önceleri "ulusal paranın değer kaybetmesi, devletin parasındaki altın değerinin düşmesi” anlamındaydı. 20. Yüzyılın ikinci yarısından itibaren "döviz piyasasının oldukça uzun bir süre içerisindeki düşmesi” ve bunun yanı sıra altın standart kaybolmuş ve "ulusal paranın dövize çevrilme oranının düşmesi" anlamını kazanmıştır. Fakat her iki anlamdaki düşme piyasada kendiliğinden oluşan bir faaliyetten kaynaklanmayıp ancak para sahibi olan hükümetin bilinçli, amaçlı faaliyetlerin sonucunda gerçekleşmektedir (devlet). Bu terime Türkç'ede devalüasyon kelimesi denk gelmektedir, ve Rusça'da kullanılan ilk anlamını içermektedir: Sabit kur rejiminde; resmi kurun yükseltilmesi, yani ulusal paranın diğer ulusal paralar karşısında değerinin düşürülmesi. Gerçekte bu işlem, satın alma değeri azalmış bir paranın yeni bir değer kazanması için yapılır ve ulusal para değerinin eşdeyişle resmi kurun yabancı paralar cinsinden düşürülmesi anlamındadır" (Hançerlioğlu, s.59).

Rusçadaki bazı terimlerin anlamları birbirilerine bağlıdır ve hiper-hiponimik ilişkiyi göstermektedir. Örneğin, obligatsiya: 1) tahvil, sahibine nominal değeri üzerinden sabit faiz sağlayan değerli kağıt ( buradaki kullanımın “değerli kağıt" türünden olduğunu görmekte); 2) Belli koşullar altında devlet ya da bir kuruluş tarafından verilen iç borçlanma senedidir. Terimin birinci anlamı geniştir, ikincisi ise belli bir evrakın çeşididir. Bu olayın aynısı Türkçe'de kullanılan tahvil teriminde de görülmektedir, fakat Türkçedeki iki anlam da birbirinin aynısıdır ve yalnızca belirtilen evrak sayısıyla birbirinden ayrılmaktadır: 1) Devletin veya özel bir kuruluşun ödünç para almak için çıkardığı, değişik dönemlerde belirli oranlarda faiz getiren yazılı senet; 2)Kamu ve özel kesim tarafından değişken veya sabit faizli, kupon ödemeli ya da iskontolu olarak çıkarılan bir yıldan uzun vadeli borç senedi.

Rusça ekonomi terimlerine dayanarak yapılan analizi çok anlamlılığın gelişmesini yol açan bu anlamların belli mecaz tiplerini belirlemeye imkân tanımıştır. Örneğin delo kelimesi bir ekonomi terimi olarak 4 anlam taşımaktadır: 1) iş, yetenek alanı, meslek; 2) işletme; 3) herhangi bir olayla ilgili açılan dava; 4) bir şahsa, meseleye, olaya ait bir evrak dosyası (Райзберг, s.17). İkinci ve dördüncü anlamda kullanılan tanımlar terimin birinci anlamdaki sürecin sonuca olan ad aktarımsal başkalaşımıdır. Bu kelimenin Türkçedeki eşdeğerini arama bizi Rusça'da çıkan sonuçların neredeyse aynılarına getirmiştir. $\dot{I}_{S ̧:}$ 1) Kullanma değeri yaratan çalışma; 2) Kazanç sağlayıcı ve gelir getirici çalışma; 3) Yapılacak şey, görev (Hançerlioğlu, s.182-183). Terimin Rusçadaki ve Türkçedeki anlamı üçüncü anlamdaki kullanımı dışında aynıdır, delo ve iş kelimelerinin anlam gelişme mantığı benzerlikler taşımaktadır.

Eylemin bir nesneye ad aktarımı bir başka örnekleri Rusçadaki sberejeniye terimi (1 para ve masraf tasarrufu; 2) günlük ihtiyaçlar için kullanılmayan biriken özel bir gelir) ve Türkçedeki birikim terimidir (1. Mal ve sermayenin toplanıp çoğalma süreci. 2. Tasarrufların yeni yatırımlar şeklinde sermaye stokuna eklenmesi. 3 . İşletme kârının kâr payı olarak dağıtılmayıp özkaynağa eklenmesi). İlişkiye dayanan ad aktarımı: parça - bütün örneğin, tovar terimidir: 1) iktisadi üretimsel faaliyetin maddi olan herhangi bir ürünü; 2) alım satım nesnesi, alıcı ve satıcı arasındaki pazar ilişkisi. Bunun Türkçedeki eşdeğeri mal'dır: 1) insan gereksinimlerini karşılayan özdeksel gereçler; 2) bir toplumun belli sayıdaki kişilerinin pazarda satmak için sürekli olarak ürettikleri ve her zaman üretebilecekleri toplumsal değiştirme değeri.

Rusça ve Türkçe'de çok anlamlı eşdeğerlerin arayışı tek anlamlı ve çok anlamlı terimlerin birçok yerde birbirilerine uymadığı sonucuna getirmiştir. Böylece borç kelimesinin anlamına (1) Yerine getirilmesi gereken yükümlülük. 2) Ödünç verilen para. 3) Borçlunun alacaklısına vermekle yükümlü olduğu para. 4) Tecimsel bir 
işletmenin ya da girişimin borçlarının tümü (Hançerlioğlu, 34)) Rusçada birkaç kelime denk gelmektedir. Borç terimin birinci anlamındaki tanımına Rusça obyazatelstvo kelimesi, ikinci anlamındaki tanıma - zayem, üçüncü tanıma - $d o l g($ geri verilmesi gereken kimi şartlar altında alınan borç para), dördüncü tanıma - debet kelimeleri denk gelmektedir.

\section{Sonuç}

Kusursuz terim sistemindeki her işaret yalnızca bir tek birime ait olmalıdır, ya da başka bir deyişle tek bir anlamı belirtmek için kullanılmalıdır. Fakat terimlerin işlevselliği devamlı olarak bir çok anlamlılık doğurmaktadır. Bu nedenle de terimin çok anlamlılı̆̆ını belli bir dilin anlam sisteminde aynı anda iki ya da daha fazla anlam için kullanılan bir özellik olarak tanımlayabilir ve bunu da dil ile düşüncenin bağlantısından kaynaklanan sürekli ve kanun çerçevesinde bir olay olarak sınıflandırabilmektedir.

Yapılan araştırmanın bilgileri bizlere iktisadi terminolojideki çok anlamının var olduğunu ve hem dil dışındaki hem de dilbilimsel sebeplerden kaynaklandığını göstermektedir.

Terim sistemindeki çok anlamlılık farklı nedenlerden kaynaklanabilir: bir terimin anlam daraltılmakta ya da genişletilmekte, terimin anlamı detaylaşmakta ya da değişmekte, hiper-hiponimik ilişkiyi göstermekte, ad aktarmaktadır.

Rusçada çok anlamlı Türkçede eşdeğerlerin arayışı tek anlamlı ve çok anlamlı terimlerin birçok yerde birbirilerine uymadığg sonucuna getirmektedir. Böylece bir Rusça'da çok anlamlı teriminin her annlam için birkaç Türkçe'de terimleri denk gelmektedir.

\section{Kaynakça}

- Виноградов В.В. Русский язык (Грамматическое учение о слове). М, 1986.

- Ахманова О.С. и др. О принципах и методах лингвистических исследований. М, 1966.

- Будагов Р.А. Человек и его язык. М, Изд-во МГУ, 1976.

- Капанадзе Л.А. О понятиях "термин" и "терминология"// Развитие лексики современного русского языка. М, 1965.

- Авербух К.Я. Терминография: традиционное и специфическое// Теория и практика научнотехнической лексикографии: Сб. статей. М, 1986.

- Дацюк Л.С. Системообразующие и системоприобретенные свойства термина (на материале английских терминов в области физики полупроводников): Автореф. дис....канд.филол. наук. Львов, 1989.

- Реформатский А.А. Что такое термин и терминология/ Вопросы терминологии. М, Изд-во АН СССР, 1961.

- Джандоева П.В. Полисемия в современной французской научно-технической терминологии (на материале терминологической системы электроники): Автореф. дис....канд.филол. наук. Киев, 1988.

- Татаринов В.А. Семантика и перевод эллиптических паратактических словосочетаний // Fremdsprachen. 1988, № 3.

- Афанасьева С.П. Регулярная полисемия абстрактных существительных со значением процесса (на материале английской строительной терминологии): Автореф. дис....канд.филол. наук. Л., 1984.

- Алексеенко Т.А. Регулярность полисемии в терминосистемах современного английского языка (на материале английской музыкальной, физической и математической терминосистем): Автореф. дис....канд.филол.. наук. М., 1986.

- Новичкова Л.М. Языковой статус термина и проблема разрешения его многозначности в процессе перевода: Автореф. дис....канд.филол.наук. М., 1992.

- Киршо С.М. Современная русская финансово-кредитная терминология как система (лингвистический анализ): Автореф. дис. канд. филол..наук. Одесса, 1989.

- Словарь русского языка: в 4 т. M, 1981-1984, Т.2.

- Hançerlioğlu O. Ekonomi Sözlüğü. İstanbul. Remzi Kitabevi. 1997.

- Райзберг Б.А., Лозовский Л.Ш., Стародубцева Е.Б. Современный экономический словарь. 2-е изд., испр. М, 1999. 


\title{
Stock Valuation: Dividend Discount Models
}

\author{
Syrgak Kydyraliev (American University of Central Asia, Kyrgyzstan) \\ Anarkul Urdaletova (Kyrgyzistan-Turkey Manas University, Kyrgyzstan)
}

\begin{abstract}
One of the most widespread problems on a securities market is the problem of definition of an estimated stock value. It is necessary to note, that the stock price as well as the price of any good in the market is defined as the result of supply and demand interaction. Our task is to offer the mechanism, which allows making decision on purchase or sale. For this purpose the method of asset estimation by future cash flows will be used - i.e. we believe that the estimated value of an asset is equal to present value of the future cash flows which are provided by the asset. In our paper we will introduce methods for the valuation of stocks with arithmetic and pseudoarithmetic growth of dividends.
\end{abstract}

JEL Code: G12

\section{Introduction}

The development of the real economy should be based on domestic investment. Therefore a chain of 3 elements should work: income, saving, and investment. The fact that this chain is not working in Kyrgyzstan makes us rely on foreign investors, while within the country hundred millions of dollars remain unused in the economy.

Many Kyrgyz economists consider the concentration of financial market in the banking sector as a problem. Private banks occupy more than $90 \%$ of the financial market, and only $10 \%$ is left for the market of securities. According to international data, the banking sector in the developed countries is not greater than $30 \%$ the financial market (Dobretsova, 2007).

As a result of lack of competition there is a big difference between interest rates on deposits and credits:

\begin{tabular}{|c|c|c|c|c|c|c|}
\hline & $\mathbf{2 0 0 3}$ & $\mathbf{2 0 0 4}$ & $\mathbf{2 0 0 5}$ & $\mathbf{2 0 0 6}$ & $\mathbf{2 0 0 7}$ & $\mathbf{2 0 0 8}$ \\
\hline Interest rate on credits, in \% & 26,06 & 24,56 & 25,41 & 25,59 & 28,7 & 30,1 \\
\hline Interest rate on deposits, in \% & 3,48 & 3,52 & 4,03 & 3,64 & 5,8 & 6,3 \\
\hline
\end{tabular}

Table 1: Interest rates on deposits and credits. Source: www.nbkr.kg

To overcome this disproportion it is necessary to develop the market for stocks and bonds. Therefore we should introduce the main concepts of this market to the potential market actors.

\section{Stable Dividends}

Stock valuation is an extremely challenging problem on the securities market. Supply and demand interaction determines the price of a stock as well as any other product. In order to make a proper decision to buy or sell the asset an investor needs to know its value.

For this purpose the presented paper uses the method of asset estimation by future cash flows, i.e. we consider the estimated value of an asset to be equal to the present value of the future cash flows provided by the asset. Future cash flows are dividends. They fluctuate according to different models through time.

For rough estimations it is enough to assume that the amount of dividends and the interest rate are stable (Ross, et. al, 1998). In this situation, assuming the unlimited number of dividends, the estimated stock value $(P)$, amount of dividend $(D)$, paid at the end of each period $(t)$, and cost of equity capital $(r)$ will be connected by a formula

$$
P=\frac{D}{1+k}+\frac{D}{(1+k)^{2}}+\frac{D}{(1+k)^{3}}+\ldots+\frac{D}{(1+k)^{n}}+\ldots . \quad k=r t
$$

Since the cost of equity capital is positive we deal with a decreasing geometric progression. Therefore, the stock value is defined by a formula:

$$
P=\frac{D}{k}, \quad k=r t
$$

\section{Constantly Growing Dividends}

The assumption that the amount of dividends is stable is too unrealistic. Therefore, a model in which dividends increase by the same percentage each period is offered - constant growth stocks valuation (Ross, et. al, 1998). 
In this situation the value of a stock $(P)$, amount of dividends $\left(D_{0}\right)$, paid before the stock valuation, a percentage growth of dividends $(g)$ and the interest rate $(r t=k)$ are connected by the following formula:

$$
\begin{aligned}
& P=\frac{D_{1}}{1+k}+\frac{D_{2}}{(1+k)^{2}}+\frac{D_{3}}{(1+k)^{3}}+\ldots+\frac{D_{n}}{(1+k)^{n}}+\ldots= \\
& \frac{D_{0}(1+g)}{1+k}+\frac{D_{0}(1+g)^{2}}{(1+k)^{2}}+\frac{D_{0}(1+g)^{3}}{(1+k)^{3}}+\ldots+\frac{D_{0}(1+g)^{n}}{(1+k)^{n}}+\ldots .
\end{aligned}
$$

When $g<k$ we have a decreasing geometric progression with ratio $\frac{1+g}{1+k}$. Therefore,

$$
P=\frac{D_{0}(1+g)}{k-g}
$$

In order to obtain (1) and (3) it is not necessary to use a formula for the sum of the decreasing geometric progression. It is sufficient to know, that the estimated stock value exists:

Let $P=\frac{D}{1+k}+\frac{D}{(1+k)^{2}}+\frac{D}{(1+k)^{3}}+\ldots+\frac{D}{(1+k)^{n}}+\ldots$.

Rewrite it as

$$
P=\frac{D}{1+k}+\frac{1}{1+k}\left[\frac{D}{1+k}+\frac{D}{(1+k)^{2}}+\frac{D}{(1+k)^{3}}+\ldots+\frac{D}{(1+k)^{n}}+\ldots\right]
$$

The expression within brackets is equal to $P$.

Therefore $P=\frac{D}{1+k}+\frac{1}{1+k} P$. Then, $\mathrm{P}(1+\mathrm{k})=\mathrm{D}+\mathrm{P}$ and $P=\frac{D}{k}$.

The same consideration allows us to get from

$$
P=\frac{D_{0}(1+g)}{1+k}+\frac{D_{0}(1+g)^{2}}{(1+k)^{2}}+\frac{D_{0}(1+g)^{3}}{(1+k)^{3}}+\ldots+\frac{D_{0}(1+g)^{n}}{(1+k)^{n}}+\ldots .
$$

formula (3). Rewrite (2) as

$$
P=\frac{D_{0}(1+g)}{1+k}+\frac{1+g}{1+k}\left[\frac{D_{0}(1+g)}{1+k}+\frac{D_{0}(1+g)^{2}}{(1+k)^{2}}+\ldots+\frac{D_{0}(1+g)^{n}}{(1+k)^{n}}+\ldots\right] \text {. }
$$

The expression within brackets is equal to $P$.

Therefore

$$
P=\frac{D_{0}(1+g)}{1+k}+\frac{1+g}{1+k} P \text {. }
$$

Then $P(1+k)=D_{0}(1+g)+(1+g) P$, and $P=\frac{D_{0}(1+g)}{k-g}$.

\section{Arithmetically Growing Dividends}

Now, we use the introduced method for the valuation of stocks with arithmetic growth of dividends.

Let $D_{0}$ be the amount of dividends paid recently. Assume that dividends at the end of each following period will be greater by some number $d$.

Valuing this stock by future cash flows, we get

$$
P=\frac{D_{0}+d}{1+k}+\frac{D_{0}+2 d}{(1+k)^{2}}+\frac{D_{0}+3 d}{(1+k)^{3}}+\ldots+\frac{D_{0}+n d}{(1+k)^{n}}+\ldots
$$

Rewrite (4) as $P=\frac{D_{0}+d}{1+k}+\frac{1}{1+k}\left[\frac{D_{0}+2 d}{1+k}+\frac{D_{0}+3 d}{(1+k)^{2}}+\ldots+\frac{D_{0}+n d}{(1+k)^{n-1}}+\ldots\right]$.

We split each ratio inside the brackets in two:

$[\ldots]=$ 
$=\left[\left(\frac{D_{0}+d}{1+k}+\frac{d}{1+k}\right)+\left(\frac{D_{0}+2 d}{(1+k)^{2}}+\frac{d}{(1+k)^{2}}\right)+\ldots+\left(\frac{D_{0}+(n-1) d}{(1+k)^{n-1}}+\frac{d}{(1+k)^{n-1}}\right)+\ldots\right]$.

The sum of the first terms equals $P$, and the sum of the second terms according to formula (1) equals $\frac{d}{k}$.

Therefore

$$
P=\frac{D_{0}+d}{1+k}+\frac{1}{1+k}\left[P+\frac{d}{k}\right]
$$

Then, $P(1+k)=D_{0}+d+P+\frac{d}{k}$, and $P k=D_{0}+d+\frac{d}{k}$.

As a result we obtain a formula for the valuation of stocks with arithmetic growth of dividends:

$$
P=\frac{D_{0}+d}{k}+\frac{d}{k^{2}} \text {. }
$$

\section{Pseudo-Arithmetically Growing Dividends}

We could ask: how realistic are these models?

Using other words: Are there any stocks with stable dividends; with arithmetic or geometric growth of dividends...?

Seems like there are no stocks with absolutely stable or geometrically growing dividends... At the same time you can find stocks which have stable dividends or approximately geometrically growing dividends during pretty long periods of time and so on.

Let's consider the data on Tiffany \& Co stocks.

\begin{tabular}{|c|c|c|c|c|c|c|c|c|c|c|c|}
\hline & $\mathbf{2 0 0 0}$ & $\mathbf{2 0 0 1}$ & $\mathbf{2 0 0 2}$ & $\mathbf{2 0 0 3}$ & $\mathbf{2 0 0 4}$ & $\mathbf{2 0 0 5}$ & $\mathbf{2 0 0 6}$ & $\mathbf{2 0 0 7}$ & $\mathbf{2 0 0 8}$ & $\mathbf{2 0 0 9}$ & $\mathbf{2 0 1 0}$ \\
\hline January & 0,03 & 0,04 & 0,04 & 0,04 & 0,05 & 0,06 & 0,08 & 0,1 & 0,15 & 0,17 & 0,17 \\
\hline April & 0,03 & 0,04 & 0,04 & 0,04 & 0,05 & 0,06 & 0,08 & 0,1 & 0,15 & 0,17 & 0,2 \\
\hline July & 0,04 & 0,04 & 0,04 & 0,05 & 0,06 & 0,08 & 0,1 & 0,12 & 0,17 & 0,17 & 0,25 \\
\hline October & 0,04 & 0,04 & 0,04 & 0,05 & 0,06 & 0,08 & 0,1 & 0,15 & 0,17 & 0,17 & 0,25 \\
\hline
\end{tabular}

Table 2: Dividends on Tiffany\&Co stocks. Source: www.tiffany.com

Dividends were paid 4 times a year, in one of the days, from $10^{\text {th }}$ to $12^{\text {th }}$, of the named months.

It can be noted, that quite long, from 2000 to 2003, dividends were stable.

We can observe even more interesting thing, if we remember, that the fiscal year in the U.S.A. starts in summer.

We rearrange the table and note two fragments:

\begin{tabular}{|c|c|c|c|c|c|c|c|c|}
\hline & $\mathbf{2 0 0 2 -}$ & $\mathbf{2 0 0 3 -}$ & $\mathbf{2 0 0 4 -}$ & & & $\begin{array}{c}\mathbf{2 0 0 4}- \\
\mathbf{2 0 0 3}\end{array}$ & $\mathbf{2 0 0 4}$ & $\mathbf{2 0 0 5}$ \\
& $\mathbf{2 0 0 5}$ & & $\begin{array}{c}\mathbf{2 0 0 5}- \\
\mathbf{2 0 0 6}\end{array}$ & $\begin{array}{c}\mathbf{2 0 0 6}- \\
\mathbf{2 0 0 7}\end{array}$ \\
\hline July & 0,04 & 0,05 & 0,06 & & July & 0,06 & 0,08 & 0,10 \\
\hline October & 0,04 & 0,05 & 0,06 & & October & 0,06 & 0,08 & 0,10 \\
\hline January & 0,04 & 0,05 & 0,06 & & January & 0,06 & 0,08 & 0,10 \\
\hline April & 0,04 & 0,05 & 0,06 & & April & 0,06 & 0,08 & 0,10 \\
\hline
\end{tabular}

Table 3: Dividends on Tiffany \& Co stocks throughout the fiscal year.

This observation allows us to generate a problem of the valuation of stocks with dividends stable within a fiscal year and growing by some number between years - the valuation of stocks with "pseudo-arithmetic" growth of dividends.

Suppose dividends $D_{0}$ are recently paid on a stock. At the end of each four following quarters they will be equal to $D_{1}=D_{0}+d$, then, in the next four quarters the amount of dividends will be $D_{2}=D_{1}+d=D_{0}+2 d$, and so on.

Then the estimated value of this stock will be:

$P=\frac{D_{1}}{1+k}+\frac{D_{1}}{(1+k)^{2}}+\frac{D_{1}}{(1+k)^{3}}+\frac{D_{1}}{(1+k)^{4}}+\frac{D_{1}+d}{(1+k)^{5}}+\ldots+\frac{D_{1}+d}{(1+k)^{8}}+\frac{D_{1}+2 d}{(1+k)^{9}}+\ldots$

Rewrite $\mathrm{P}$ as 


$$
\begin{aligned}
& P=\frac{D_{1}}{1+k}+\frac{D_{1}+d}{(1+k)^{5}}+\frac{D_{1}+2 d}{(1+k)^{9}}+\frac{D_{1}+3 d}{(1+k)^{13}}+\ldots \\
& +\frac{D_{1}}{(1+k)^{2}}+\frac{D_{1}+d}{(1+k)^{6}}+\frac{D_{1}+2 d}{(1+k)^{10}}+\frac{D_{1}+3 d}{(1+k)^{14}}+\ldots \\
& +\frac{D_{1}}{(1+k)^{3}}+\frac{D_{1}+d}{(1+k)^{7}}+\frac{D_{1}+2 d}{(1+k)^{11}}+\frac{D_{1}+3 d}{(1+k)^{15}}+\ldots \\
& +\frac{D_{1}}{(1+k)^{4}}+\frac{D_{1}+d}{(1+k)^{8}}+\frac{D_{1}+2 d}{(1+k)^{12}}+\frac{D_{1}+3 d}{(1+k)^{16}}+\ldots
\end{aligned}
$$

and introduce

$$
P_{4}=\frac{D_{1}}{(1+k)^{4}}+\frac{D_{1}+d}{(1+k)^{8}}+\frac{D_{1}+2 d}{(1+k)^{12}}+\frac{D_{1}+3 d}{(1+k)^{16}}+\ldots
$$

Then, $\mathrm{P}=(1+\mathrm{k})^{3} \mathrm{P}_{4}+(1+\mathrm{k})^{2} \mathrm{P}_{4}+(1+\mathrm{k}) \mathrm{P}_{4}+\mathrm{P}_{4}$.

Sum up the obtained geometric progression and obtain

$$
P=P_{4} \frac{(1+k)^{4}-1}{k} \text {. }
$$

Now transform $\mathrm{P}_{4}$ :

$$
\begin{aligned}
& P_{4}=\frac{D_{1}}{(1+k)^{4}}+\frac{1}{(1+k)^{4}}\left(\frac{D_{1}}{(1+k)^{4}}+\frac{d}{(1+k)^{4}}+\frac{D_{1}+d}{(1+k)^{8}}+\frac{d}{(1+k)^{8}}+\ldots\right)= \\
& =\frac{D_{1}}{(1+k)^{4}}+\frac{1}{(1+k)^{4}}\left(P_{4}+\frac{d}{(1+k)^{4}}+\frac{d}{(1+k)^{8}}+\frac{d}{(1+k)^{12}}+\ldots\right)= \\
& \frac{D_{1}}{(1+k)^{4}}+\frac{1}{(1+k)^{4}}\left(P_{4}+\frac{d}{(1+k)^{4}-1}\right) . \\
& \text { Then } \quad P_{4}\left[1-\frac{1}{(1+k)^{4}}\right]=\frac{1}{(1+k)^{4}}\left(D_{1}+\frac{d}{(1+k)^{4}-1}\right) \\
& \text { So } \quad P_{4}=\frac{D_{1}\left[(1+k)^{4}-1\right]+d}{\left[(1+k)^{4}-1\right]^{2}} .
\end{aligned}
$$

Replacing the expression for $P_{4}$ in formula (6), we get

$$
P=\frac{D_{1}\left[(1+k)^{4}-1\right]+d}{k\left[(1+k)^{4}-1\right]}=\frac{D_{1}}{k}+\frac{d}{k\left[(1+k)^{4}-1\right]} .
$$

Using this formula we have a possibility to evaluate stocks with "pseudo-arithmetic" growth of dividends.

\section{Conclusion}

Stock valuation can be a difficult task. In order to fulfill it various models can be used. In our paper we employed the method of asset estimation by future cash flows or dividends. We introduced the common models with stable and constantly growing dividends. Then we developed them to obtain new results, which can be applied for the assets on the real market.

This paper for the first time presents formulas for the valuation of stocks with dividends being members of an arithmetic progression and with dividends with pseudo-arithmetic growth. Such models make it possible to make investment decisions for different purposes.

We assume this paper to be useful for specialists working on stock market. Moreover, the content of the current paper can be a part of the variety of classes, such as Corporate Finance, Investments, etc.

\section{References}

- Dobretsova N.N., 2007. Romantic of Capital. CENTI, Bishkek, p. 112-121

- Ross, Westerfild and Jordan, 1998. Fundamentals of Corporate Finance. IRWIN, Chicago, p. 188-200 


\title{
Implications of the Global Financial Crisis on the Banking Sector in Eastern Europe and Baltic States
}

\author{
Eva Banincova (Kobe University, Japan)
}

\begin{abstract}
In 2008-09 the banking sectors of four Central and East European States and three Baltic States have experienced a large-scale financial crisis in the EU for the first time since becoming foreign-owned. Amongst the new EU member states Baltic States and Hungary were the worst affected economies.

The paper first explores why the extent of crisis varied among these seven states by distinguishing major differences in the pre-crisis bank lending practices which reflect different macroeconomic developments and exchange rate policies in these states. Based on the analysis of bank performance indicators since 2008 and my interviews with representatives of major banks active in the region, the important role of foreign banks in mitigating the risks of financial contagion is outlined. The implication from the crisis is examined mainly from the perspective of the financial supervision and regulation in the enlarged EU. By inspecting the concrete experience of financial supervision authorities in the Baltic States the paper shows why the host country supervisors were not able to curb excessive lending and risk-taking by large Scandinavian banks. Since it is expected that the new EU regulatory and supervisory framework will reinforce the financial stability in the case of large cross-border banking groups, the paper addresses the issues in the financial crisis prevention, management are resolution in the new EU member states which will improve based on the new EU regulatory and supervisory framework for credit institutions.
\end{abstract}

JEL Code: G01, G21, G28

\section{Introduction}

The 2008-09 financial crisis in the EU affected the new EU member states in Central and Eastern Europe. The banking sectors of these states have been experiencing a large-scale financial crisis for the first time since they became predominantly foreign-owned. However, it is important to distinguish among these states according to the extent to which they have been affected by the financial crisis. As Figure 1 shows, Baltic States and Hungary were the worst affected economies. This paper aims to specify those features of the pre-crisis developments in the banking sector that explain why certain countries were more affected than others by the 2008-09 financial crisis in the EU. We will focus on four Central and East European States (CEES) and three Baltic States. Next we address the issue of financial stability and demonstrate how the foreign banks in this region react to the worsening economic situation. Then we outline policy responses to the crisis, namely the financial supervision and regulation. Finally, we discuss the implications which can be drawn from the crisis.

\section{Pre-crisis Developments in Bank Credit to Private Sector}

Following the liberalization of financial sectors during the EU accession process, banks from EU member states of Western and Northern Europe participated in the bank privatization of CEES and Baltic States. As a result, the banking sectors of these states have a high degree of foreign ownership. However, while the claims on Baltic States are highly concentrated in Sweden, CEES have a more diversified structure of main lenders (Figure 2).

\begin{tabular}{|c|c|c|c|c|c|c|c|}
\hline & $\mathbf{2 0 0 5}$ & $\mathbf{2 0 0 6}$ & $\mathbf{2 0 0 7}$ & $\mathbf{2 0 0 8}$ & $\mathbf{2 0 0 9}$ & $\mathbf{2 0 1 0}$ & 2011* \\
\hline Estonia & 9.4 & 10.6 & 6.9 & -5.1 & -13.9 & 3.1 & 4.9 \\
\hline Latvia & 10.6 & 12.2 & 10.0 & -4.2 & -18.0 & -0.3 & 3.3 \\
\hline Lithuania & 7.8 & 7.8 & 9.8 & 2.9 & -14.7 & 1.3 & 5.0 \\
\hline Poland & 3.6 & 6.2 & 6.8 & 5.1 & 1.7 & 3.8 & 4.0 \\
\hline Czech Rep. & 6.3 & 6.8 & 6.1 & 2.5 & -4.1 & 2.3 & 2.0 \\
\hline Slovakia & 6.7 & 8.5 & 10.5 & 5.8 & -4.8 & 4.0 & 3.5 \\
\hline Hungary & 3.2 & 3.6 & 0.8 & 0.8 & -6.7 & 1.2 & 2.7 \\
\hline Slovenia & 4.5 & 5.9 & 6.9 & 3.7 & -8.1 & 1.2 & 1.9 \\
\hline Cyprus & 3.9 & 4.1 & 5.1 & 3.6 & -1.7 & 1.0 & 1.5 \\
\hline Malta & 4.2 & 1.9 & 4.6 & 5.4 & -3.3 & 3.2 & 2.0 \\
\hline Romania & 4.2 & 7.9 & 6.3 & 7.3 & -7.1 & -1.3 & 1.5 \\
\hline Bulgaria & 6.4 & 6.5 & 6.4 & 6.2 & -5.5 & 0.2 & 2.8 \\
\hline
\end{tabular}

Figure 1. Real GDP growth rate (as \% change on previous year) Source: Eurostat. (GDP growth rate for 2011 is a forecast.) 


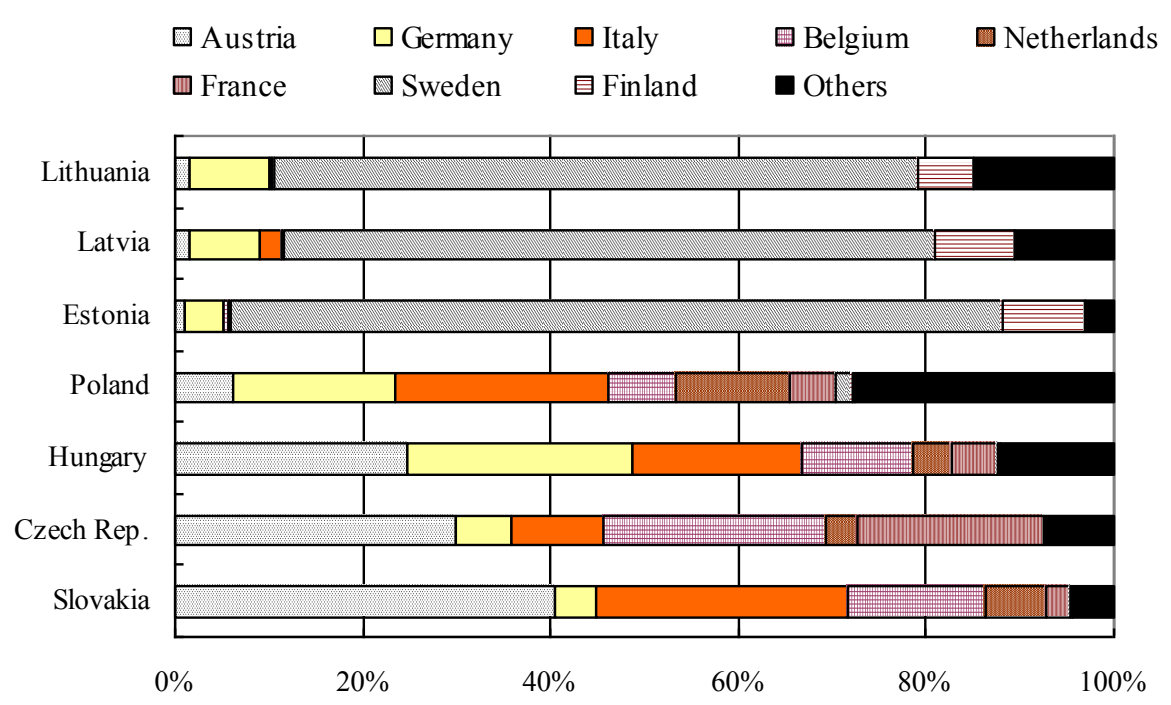

Figure 2. Consolidated Foreign Claims on individual states by nationality of reporting banks (immediate borrower basis) as of end-March 2007. Source: BIS, Consolidated Bank Statistics.

A very dynamic credit growth distinguished Baltic States from CEES since 2002. In terms of loan structure, Baltic States showed two distinctive features. Firstly, household loans for housing purchases expanded rapidly in Estonia and Latvia, followed by Lithuania, while all loan types increased on a much smaller scale in CEES (Figure 3). Secondly, foreign currency loans represented a much larger share of loans (especially household loans) in the Baltics than in CEES (except for Hungary) between 2003 and 2007. According to European Commission (2008), the share of foreign currency loans for all sectors was approximately $80 \%$ in Estonia and Latvia, around $50 \%$ in Lithuania and Hungary, around $25 \%$ in Poland, around $20 \%$ in Slovakia and approximately $10 \%$ in the Czech Republic in December 2006. In the states with a high share of foreign currency loans (Baltic States and Hungary) foreign currency loans expanded more rapidly than foreign currency deposits, which clearly indicates an increasing currency mismatch.

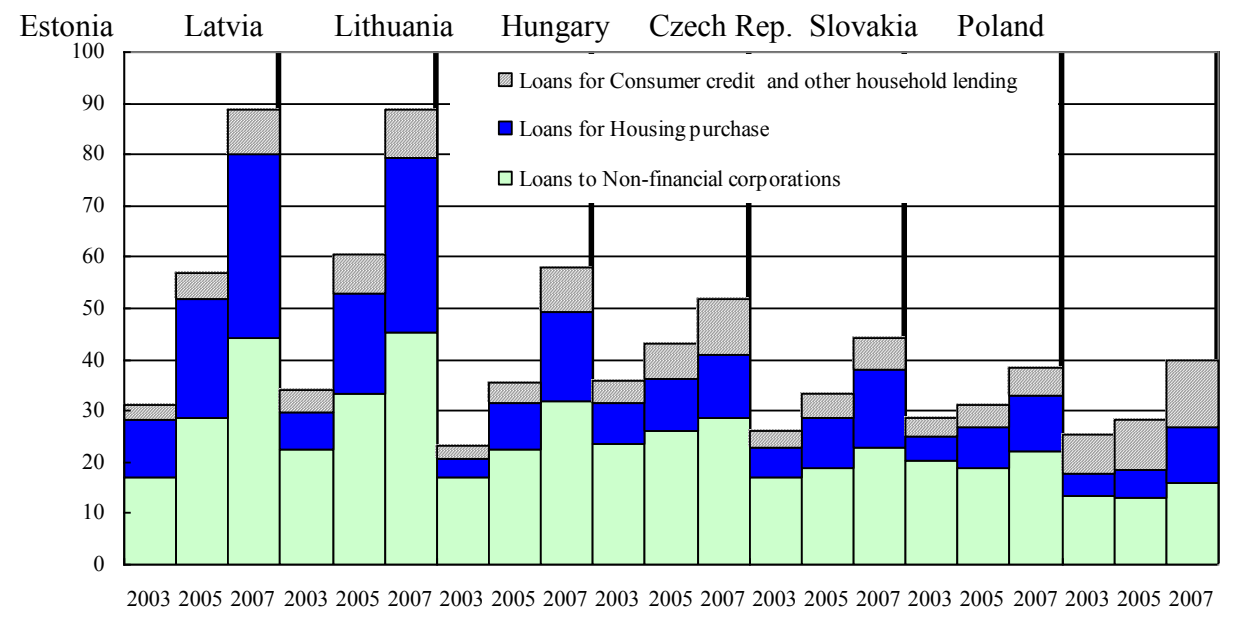

Figure 3. Structure of Bank Loans to the Private Sector (as \% of GDP). Source: ECB, EU Banking Structures, Years 2005 and 2008.

\section{Reasons for Different Pre-crisis Credit Developments}

Regarding the foreign currency loans, it has to be noted that while most foreign currency loans in the Baltics were Euro denominated, Swiss Franc-based loans were dominant in Hungary. Such a difference in foreign currency composition reflects different motives behind demand for foreign currency loans in these states. Lower interest rates of foreign currency loans were the main motivating factor in Hungary, whereas the Baltic States have had the tradition of foreign currency borrowing since the 1990s due to their fixed exchange rate regimes leading to a low perception of exchange rate risk.

Next, when we compare developments in Balance of Payment of these states, there are the following differences in the structure of foreign capital inflows that financed current account deficits of these states. FDI (Foreign Direct Investment) dominated capital inflows in CEES except for Hungary that relied mostly on 
portfolio investment between 2003 and 2006 (Figure 5), while other investments (investment which consists mainly of intra-group bank loans) dominated Baltic foreign capital inflows and clearly exceeded FDI after 2005 (Figure 4). As evident from this data, credit expansion which Baltic States experienced prior to 2007 was mainly due to a large capital supply from foreign parent banks (shown by increased other investment) to their Baltic subsidiaries. This was demonstrated by high loan-to-deposit ratios in the Baltics (and Hungary), compared to the three CEES. According to ECB (2008b), loan-to-deposit ratio of Baltic States was over 140\% in 2007, that of Hungary was $128 \%$, while in the three CEES the ratio ranged between $72 \%$ and $91 \%$.

We can therefore conclude that high loan-to-deposit ratios in the Baltics and Hungary mean that when funding the credit supply, instead of reliance on local deposits only, banks in these countries relied on borrowing from foreign parent banks,. On the other hand, foreign banks in the 3 CEES relied on local deposits.
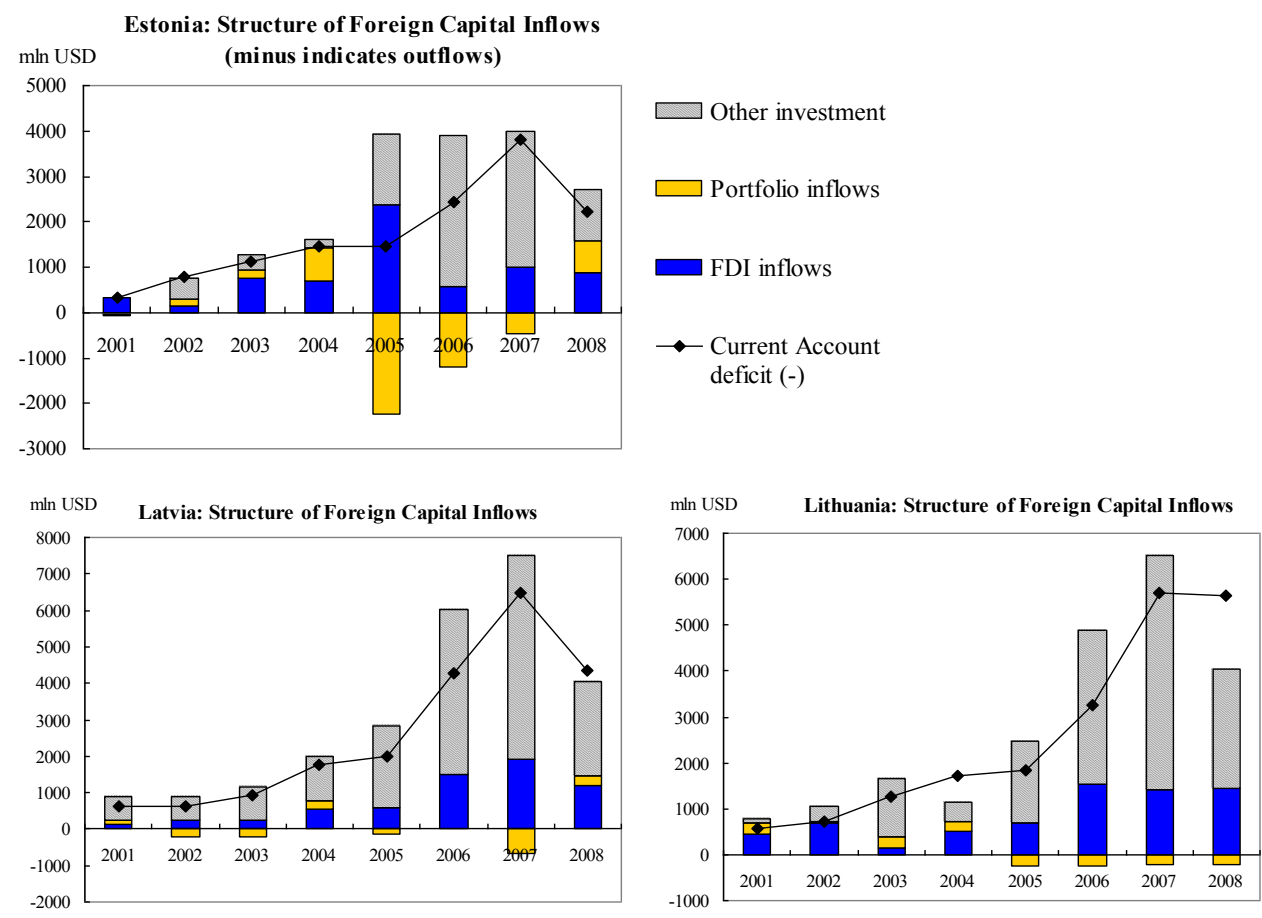

Figure 4. Structure of Foreign Capital Inflows in Baltic States (minus indicates outflows) Source: IMF, International Financial Statistics and National Central Banks
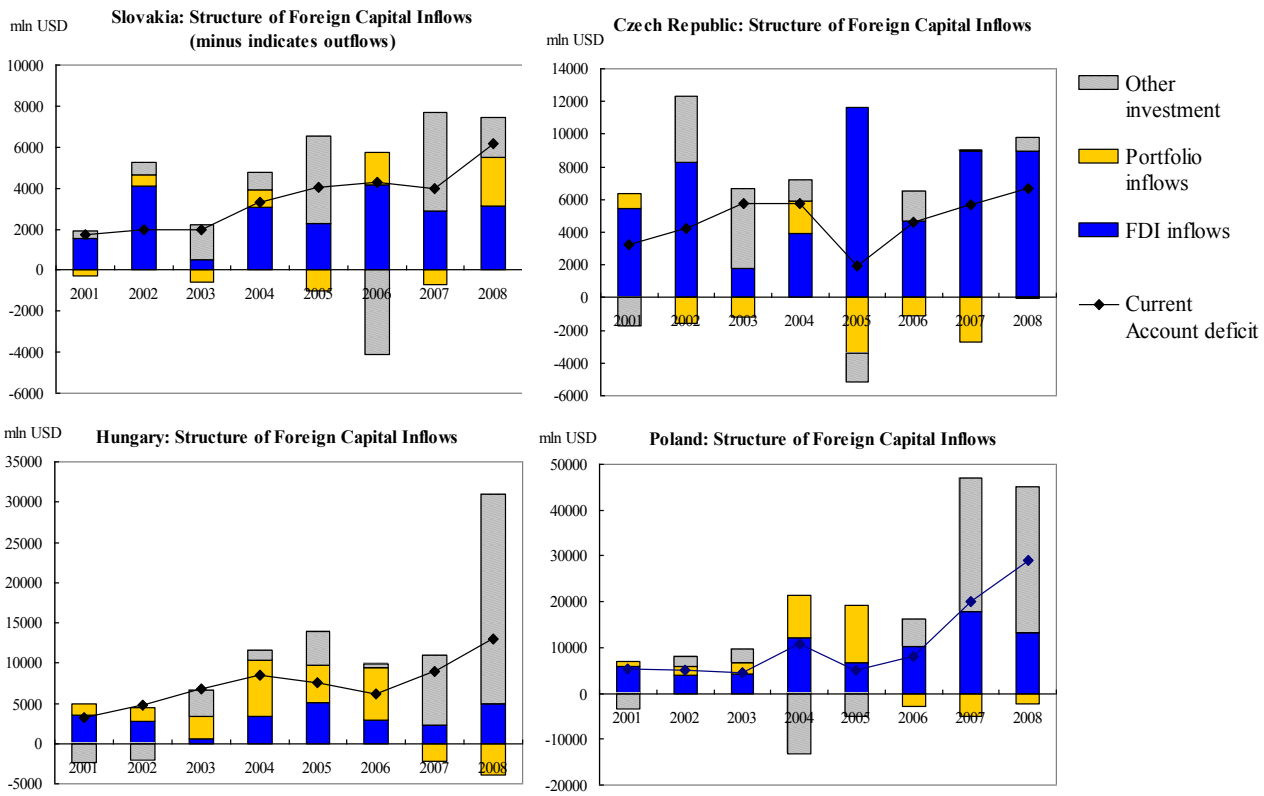

Figure 5. Structure of Foreign Capital Inflows in CEES (minus indicates outflows) Source: IMF, International Financial Statistics and National Central Banks. 


\section{Financial Crisis and Banking Sectors of CEES and Baltic States}

Let us now examine to what extent the financial crisis affected banking sectors of CEES and Baltic States. Data from MNB (2009) shows that after 2007 Baltic States and Hungary experienced a much larger decrease in loan-to-deposit ratios than the three CEES due to restricted lending. This mainly reflects the fact that the financial crisis made it more difficult for foreign banks active in the region to find market funding. Swedish banks in particular are highly dependent on market funding and were thus affected by increased funding costs.

Overall, loan quality in the whole of Eastern Europe deteriorated. Latvia and Lithuania have been experiencing the deepest recession among the seven states compared in this paper and therefore had much higher nonperforming loan ratios than all CEES and Estonia in 2009. As Figure 6 shows, the pre-crisis significant increase in bank assets of Baltic subsidiaries has generally been followed by their decrease in 2009, whereas in most CEES subsidiaries the bank assets increased in the 2008-09 period. Another contrasting difference between CEES and Baltic States can be observed in banks' profitability, as shown by Return on Equity (ROE). Since 2008, only in the case of Baltic subsidiaries did the ROE decrease and eventually turn negative. Swedish banks' subsidiaries in Baltic States thus experienced increased credit losses throughout 2009 and the market now clearly associates the two Swedish banks most exposed to the Baltics (Swedbank and SEB) with higher risks than other banks (as shown by their high CDS premiums).

\begin{tabular}{|c|c|c|c|c|c|c|c|c|c|c|c|c|}
\hline & \multicolumn{3}{|c|}{ Size of Assets (USD bln) } & \multicolumn{4}{c|}{ ROE (\%) } & \multicolumn{4}{c|}{ NPL (\%) } \\
\hline Bank & 2003 & 2006 & 2008 & 2009 & 2005 & 2006 & 2008 & 2009 & 2005 & 2006 & 2008 & 2009 \\
\hline $\begin{array}{c}\text { Swedbank } \\
\text { Estonia }\end{array}$ & 8.08 & 25.5 & 35.1 & 31.5 & 28.2 & 28.9 & 24.5 & -115 & 0.4 & 0.4 & - & 14.0 \\
\hline Swedbank Latvia & 3.78 & 7.17 & 11.1 & 9.53 & 33.9 & 34.7 & 17.5 & -65.8 & 0.3 & 0.2 & - & 22.8 \\
\hline SEB Lithuania & 3.10 & 8.04 & 12.0 & 12.4 & 18.2 & 30.7 & 19.9 & -96.3 & 1.2 & - & 4.6 & 16.6 \\
\hline CSOB * (Czech R.) & 23.6 & 36.5 & 36.5 & 46.7 & 38.9 & 33.7 & 37 & 51.9 & 1.7 & 1.7 & 1.7 & 3.2 \\
\hline MKB * (Hun) & 5.97 & 7.73 & 15.3 & 16.5 & 20.4 & 13.0 & 5.0 & 45.9 & 3.8 & 3.2 & - & 6.3 \\
\hline Pekao * (Poland) & 16.8 & 23.2 & 44.5 & 47.4 & 31.4 & 34.8 & 39.7 & 20.6 & 16.2 & 11.4 & - & 6.8 \\
\hline Tatra Bank (Slov.) * & 4.15 & 5.77 & 14.8 & 12.9 & 26.8 & 34.3 & 36.3 & 21.0 & - & 1.1 & 1.4 & 3.8 \\
\hline
\end{tabular}

Figure 6. Selected Bank Performance Indicators. Source: The Banker, various issues. *CSOB is owned by Belgian KBC Group; MKB is owned by German Bayerische Landesbank; Bank Pekao is owned by Italian UniCredit; Tatra Banka is owned by Austrian Raiffeisen International.

However, the risk of financial contagion in both CEES and Baltics is mitigated by several factors. Firstly, foreign banks have regionally diversified operations and their exposure to these states remains very small from the bank group perspective, which limits the risk of negative spillover from subsidiaries to the parent. Secondly, loan portfolios in CEES and Baltics remain generally more stable compared to other East European subsidiaries. Thirdly, foreign banks have maintained their commitment to the region by taking measures to absorb current and future loan losses (often with the support of governments in their home countries). For instance, Loan Guarantee Fund of Swedish government enables banks to issue debt with government acting as a guarantor. Fourthly, major banks officially stated their commitment to support their bank subsidiaries and it is evident that banks also employ non-traditional methods to deal with worsened financial situations of their clients (for example, since January 2010 Nordea Bank made an agreement with Riga Property Management regarding the re-assessment and support towards the bank clients who became unable to pay their rents).

\section{$5 \quad$ Issues of Financial Supervision and Regulation}

Let us inspect the main problems which the financial supervision authorities experienced in Baltic States and the recent improvements in the crisis prevention and management. It is important to point that in the context of the EU, subsidiaries of foreign banks are supervised by authorities of the host country, while foreign bank branches are supervised by their home country authorities.

It has been indicated that local supervisory authorities were not able to curb the excessive lending and risktaking by Scandinavian banks in the Baltics. Firstly, local authorities in Baltic States lacked sufficient instruments for restricting excessive lending (measures such as moral suasion, information exchange with home country authorities failed to be effective), as pointed out by Enoch Ch. and Otker-Robe Inci (2007). Secondly, there are indications that host-country authorities tended to be reluctant in implementing stricter measures towards foreign banks (one of the reason being the perception that the home-country supervisory authorities have more experience and know-how in supervision). Thirdly, the local real estate market has been transformed very quickly, which made it easier for market players to avoid certain regulations (for instance, regulation by loan-tovalue ratio was difficult to implement in newly developed areas which differed from standard buildings projects that the regulation covered). Fourthly, regulation of cross-border banking groups remained a complex issue (for instance, Srejber, E. and M. Noreus (2005) point out that six Scandinavian cross-border banking groups had to respond to rules of seven supervisory authorities and eight central banks). 
However, these issues could be addressed by a more effective regulations coordinated at the EU level. A highlevel group chaired by Jacques de Larosiere was mandated by the European Commission to recommend changes in the European financial supervision system. Based on the group's recommendations published in February 2009, a reform of the financial regulation and supervision in the EU started since 2009 and it was agreed that the new EU supervisory framework should include both microprudential and macroprudential supervision. Therefore, ESRB (European Systemic Risk Board) will identify macro-financial risks and will be in the position to recommend appropriate action to curb excessive credit growth. Concerning the need of a coherent framework for crisis management and resolution, the above-mentioned group's final report in Recommendation 13 emphasized measures needed to set up a new EU framework for crisis management in the banking sector and these measures have been consulted by the European Commission. Since the EU lacked a coherent framework for crisis management and resolution (for example, the issue of burden sharing in case of cross-border bank failures remains largely unresolved), the increase of bank deposit guarantees at the EU level for stabilization of each country's domestic bank system has been an important step forward (Estonia and Latvia raised their bank deposit guarantees to 50,000 Euro and Lithuania to 100,000 Euro).

In each Baltic State reporting and information exchange on the cross-border base and risk management measures were strengthened. For example, a new regulation implemented since December 2010 in Lithuania will improve risk management of banks by limiting their overexposure to a particular industry segment or to a particular counterparty. Furthermore, concrete plans for financial crisis prevention and management which have recently been adopted in Baltic States (such as in Lithuania in November 2008) aim to strengthen the cooperation between the bank supervisory authorities and other institutions in the financial market (such as Central Bank, Ministry of Finance etc.). Cooperation and information exchange has been strengthened between Baltic supervisory authorities and their counterparts in Scandinavian States (Baltic-Nordic Memorandum of Understanding issued in August 2010 is one of concrete examples of such cooperation).

\section{Conclusion}

What implications can be thus drawn from the crisis? This paper outlined the developments in the banking sectors of four Central and Eastern European countries and three Baltic States and showed that these states' divergent economic developments prior to 2007 can explain why the financial crisis affected them to a different extent. Previous research showed that the CEES and Baltic States' banking sectors have become dominated by foreign banks in the context of an integrated EU financial market and that the presence of foreign banks brought many benefits. However, this paper illustrated an example in Baltic States of how over-dependence on easily accessible capital from foreign parent banks (demonstrated by increased other investment) can fuel credit booms. There is still a lack of research on the stability of the foreign-bank dominated systems of new EU members during a large-scale financial crisis. In this regard, this paper showed several mitigating factors within the EU framework concerning financial stability. We showed that foreign banks involved in the Baltic States have been able to cope with economic downturn in these countries. However, the case of Baltic States also illustrated the need for reform of the EU financial regulation and supervision and active efforts in this direction have been pointed out.

\section{References}

- Banincova E. (2008a), "FDI Pattern in Central and Eastern Europe and in the three Baltic countries since 1990s - Analysis by Investing Country and Industry", The Keizai Ronkyu, No. 131, Kyushu- Daigaku, Daigakuin- Keizaigakukai, July, pp.67-81 (in Japanese).

- Banincova E. (2008b), "EU Enlargement and Foreign Direct Investment in Central and Eastern Europe and three Baltic states", Kyusyu Keizaigakkai Nenpo, No.46, December, pp.31-37 (in Japanese).

- $\quad$ BSCEE (Banking Supervisors from Central and Eastern Europe) Review 2007.

- De Larosiere J. (2009), The High-Level Group on Financial Supervision in the EU, Report, European Commission, February.

- $\quad$ ECB (2008a), Convergence Report, May.

- $\quad$ ECB (2008b), EU Banking Structures, October.

- $\quad$ Enoch Ch. and Otker-Robe Inci, editors (2007), Rapid Credit Growth in Central and Eastern Europe: Endless Boom or Early Warning?, IMF, Palgrave Macmillan.

- European Commission (2008), Convergence Report, European Economy 3/2008, May.

- IMF (2009a), Regional Economic Outlook: Europe- Addressing the Crisis, World Economic and Financial Surveys, May.

- IMF (2009b), "Global Financial Stability Report: Navigating the Financial Challenges Ahead”, World Economic and Financial Surveys, October. 
- Iwata K. (2009), "Why did the crisis in Europe become tangible?", World Economic Review Vol. 53, No.3, Association for World Economic Studies, March, pp.33-45 (in Japanese).

- Magyar Nemzeti Bank (2009), Report on Financial Stability, November.

- Riksbank (Central Bank of Sweden), Financial Stability Report, various issues.

- $\quad$ Rosenberg Ch. B. and Tirpak M. (2008), "Determinants of Foreign Currency Borrowing in the New Member States of the EU”, IMF Working Paper WP/08/173, July.

- $\quad$ RZB Group Raiffeisen Research, CEE Banking Sector Report, various issues.

- $\quad$ Srejber, E. and M. Noreus (2005), "The future relationship between financial stability and supervision in the EU”, Economic Review 2005:4, Central Bank of Sweden.

- World Bank (2009), EU10 Regular Economic Report, February.

- BIS, Consolidated Bank Statistics: www.bis.org/statistics/consstats.htm

- European Commission, Economic and Financial Affairs, "Communication on the Financial Supervision in the EU": http://ec.europa.eu/economy_finance/focuson/crisis/

- Eurostat: http://epp.eurostat.ec.europa.eu 


\title{
Ukraine Pension System and Financial Markets: Conceptualization Problems
}

\author{
Nataliya Rad (Donetsk National University of Economics and Trade, Ukraine)
}

\begin{abstract}
The paper analyzes some aspects of Ukrainian pension system formation. All its three levels taken as a whole are a real source for the formation of domestic investment resources and implementation of their potential through financial market instruments. At the present stage relationship of these two institutes is pronounced in the frameworks of non-state pension funds. Implementation of the accumulative level of pension system has only to accelerate processes at work. Investigation is focused on the problems of integrating pension system investment resource into financial market infrastructure. It is noted that in the current conditions infrastructure of domestic financial market is being formed. Its instruments are developed and are functioning irregularly. However, there exist general problems that require their solution. They are related to insufficient operational capacity and efficiency of financial market regulating mechanism and other factors. Analysis of the quality of implementation of financial market basic macroeconomic function associated with redistribution of pension savings allowed us to make conclusion on the incompatibility of the achieved level of its development with the current needs adjusted for pension reform. Proposals for improvement of the concept of pension system and financial market along the lines of their harmonization and enhancement of the functioning efficiency in the context of social-economic development of Ukraine are worked out.
\end{abstract}

JEL codes: D53, G23, G28

\section{Problem definition}

Pension system reforming is part of transformational processes which are under way in Ukraine in recent times. Status of the social welfare state declared by the Ukrainian Constitution provides for formation of high social standards for its citizens (Verkhovna Rada of Ukraine, 1996). Pension system transformation that has been starting in 2004 was aimed at solution of a wide range of social problems. Insurance principles that determine dependence of pension amount on the length of pensionable service and wage level (insurance contributions) were accepted as a basis for a new pension system concept (Verkhovna Rada of Ukraine, 2003a). However, opportunities of insurance mechanism are far beyond the scope of task performance. Functioning of the second and third levels gives opportunity to form domestic investment resources which can be directed to development of the economy. Effective implementation of investment opportunities of financial defined contributions and occupational retirement insurance is possible in the presence of developed financial market, its infrastructure and instruments. The nature, backbone and features of domestic pension scheme and financial market formation under present-day conditions are studied in the works of the leading Ukrainian scientists and practicians, in particular, Yu. Kovalenko, V. Evstegneeva, G. Tereshchenko, S. Naumenkova, G. Belinskaya, S. Kulpinskaya, G. Degtyaryov, B. Zaitchuk and many other. In spite of strong conceptual framework of the items mentioned above, problems related to formation of financial market in the context of pension system development continue to call for sequential analysis and evaluation of functioning. This explains the urgency of our research. Thus, object of the paper is the analysis of formation of pension system investment resources and their integration into the infrastructure of financial market; identification of its conformity to the needs of the developing pension system; working out guidelines for improvement of the pension system and financial market concept in the context of social and economic development of society.

\section{Problem description}

Nowadays mechanism of three-level pension scheme potentially covers all categories of citizens and business activity participants and depends on the level of participation of each of these categories. Besides, efficiency of financial defined contributions and private pension insurance system depends on the level of return of investment resources. It is pertinent to note that definitions of the essence and interpretation of the notion financial market are many-sided. Their basis forms the categories financial assets, financial instruments, financial institutions, financial intermediaries (Kovalenko, 2010). Yuriy and Lutsishin interpret financial market as a complex of economic relations connected with distribution of financial resources, purchase and sale of temporarily disposable monetary resources and securities (Yuriy and Lutsishin, 2010). It must be emphasized that formation of financial market is influenced by a lot of factors shown in Figure 1. 


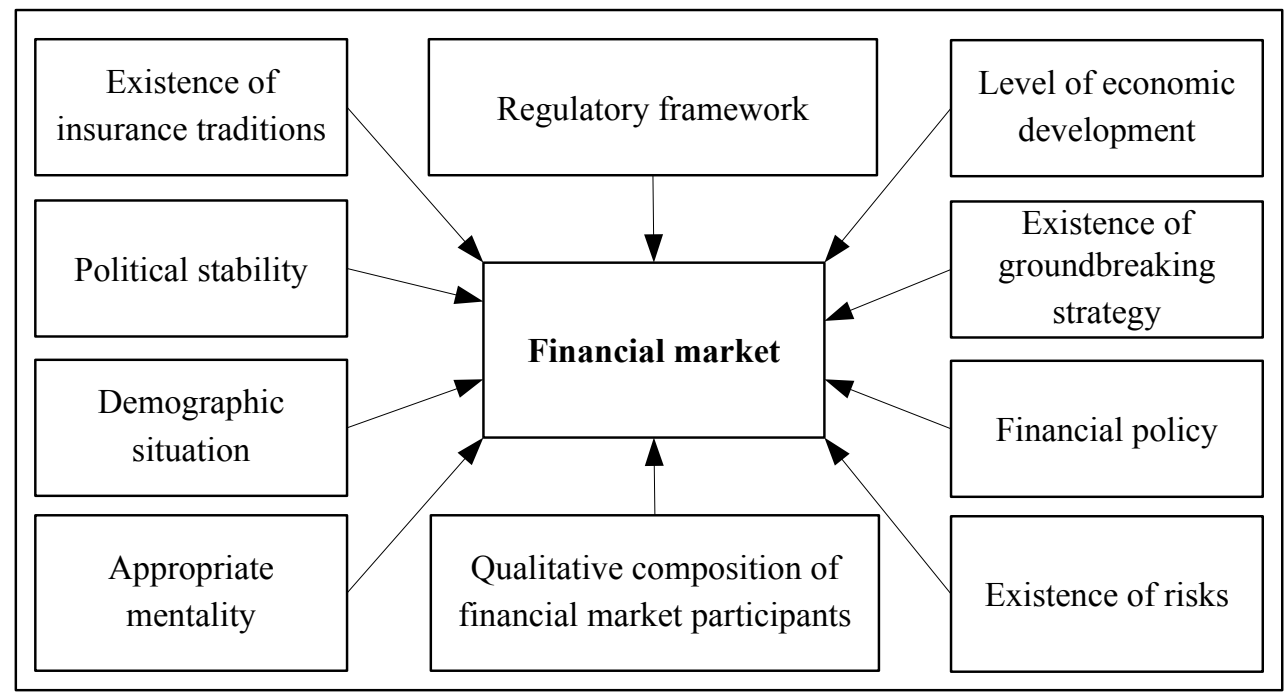

Figure 1. Factors influencing development of financial market.

Among the above listed factors we can identify those inherent to financial defined contributions: indicators of demographic development, existence of insurance traditions, appropriate mentality (that implies necessity of the availability of such human qualities as responsibility for financial security of chair days, capability of adequate assessment of pension assets formation and decision-making, prudence).

Financial market implementing the above mentioned spectrum of functions also influences other spheres of society shown in Figure 2.

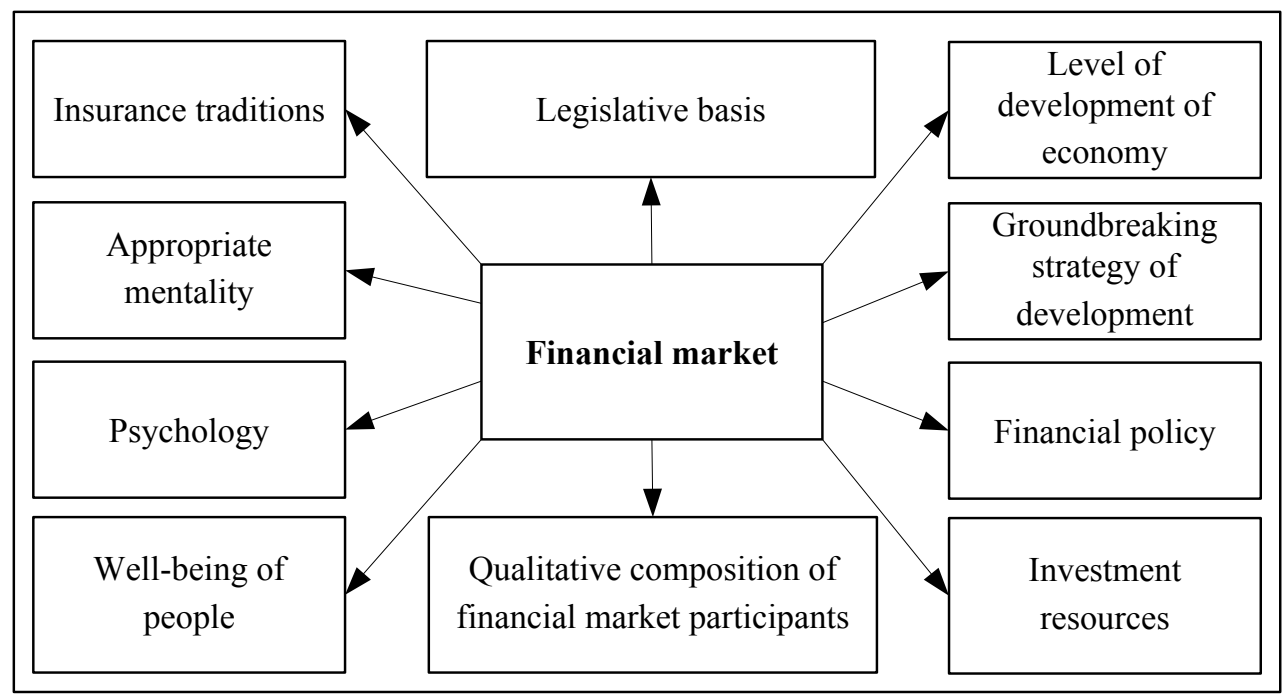

Figure 2. Components of financial market that influence development of society.

Present mechanism of three-level pension system potentially covers all categories of citizens and participants of economic activity. It should be noted that its accumulative elements play important role of supplier of financial resources for their further transformation into investment resources. In interaction they actualize a complex of purposes shown in Table 1.

\begin{tabular}{|c|c|c|}
\hline Purposes & Mechanism of actualization & Expected effect \\
\hline Improvement of living standard & $\begin{array}{c}\text { Diversification of insurance contributions of } \\
\text { the insured }\end{array}$ & High level of pension payments \\
\hline Activation of economic activity & $\begin{array}{c}\text { Formation of inexpensive investment } \\
\text { resources }\end{array}$ & $\begin{array}{c}\text { Growth of number of work places and } \\
\text { employees }\end{array}$ \\
\hline $\begin{array}{c}\text { Investment character of } \\
\text { development of economy }\end{array}$ & $\begin{array}{c}\text { Formation of inexpensive investment } \\
\text { resources }\end{array}$ & Improvement of competitiveness \\
\hline $\begin{array}{c}\text { Improvement of pension system } \\
\text { financial stability }\end{array}$ & $\begin{array}{c}\text { Maximal coverage by participation in three- } \\
\text { level pension systems }\end{array}$ & $\begin{array}{c}\text { Sufficiency of funds in the pension } \\
\text { system for fulfillment of obligations }\end{array}$ \\
\hline $\begin{array}{c}\text { Improvement of quality of inter- } \\
\text { age relations }\end{array}$ & $\begin{array}{c}\text { Improvement of confidence in pension } \\
\text { system }\end{array}$ & $\begin{array}{c}\text { Participation in three-level pension } \\
\text { systems }\end{array}$ \\
\hline
\end{tabular}

Table 1. Target guiding lines for functioning of financial market and pension fund 
We should emphasize that target guiding lines for interaction of financial market and pension system are both of material and non-material character. Financial market includes credit market (market of banking credits), equity market (including market of derivative financial instruments), currency-monetary market, market of insurance services and gold market (Supakshin, 2008). In exercising its activity financial market realizes functions manifestation of which can be traced through indicators of pension system shown in Table 2 .

\begin{tabular}{|c|c|c|}
\hline $\begin{array}{c}\text { Function } \\
\text { description }\end{array}$ & $\begin{array}{c}\text { Manifestation through financial } \\
\text { market }\end{array}$ & Manifestation through pension system \\
\hline Distributive & $\begin{array}{l}\text { Re-distribution of financial resources } \\
\text { (savings) }\end{array}$ & Capitalization of monetary savings of the insured \\
\hline Investment & Investment into economy & $\begin{array}{l}\text { Creation of new work places, wage raise (rise of } \\
\text { income), broadening the circle of the insured }\end{array}$ \\
\hline Economic & Development of branches of economy & $\begin{array}{l}\text { Creation of new work places, wage raise (rise of } \\
\text { income), broadening the circle of the insured }\end{array}$ \\
\hline Financial & $\begin{array}{c}\text { Development of instruments of financial } \\
\text { system of the state }\end{array}$ & Capitalization of monetary savings of the insured \\
\hline $\begin{array}{l}\text { Groundbreak } \\
\text { ing }\end{array}$ & $\begin{array}{l}\text { Development of groundbreaking } \\
\text { branches of production }\end{array}$ & $\begin{array}{l}\text { Creation of new work places, wage raise (rise of } \\
\text { income), broadening the circle of the insured }\end{array}$ \\
\hline Incentive & $\begin{array}{l}\text { Induces positive processes in } \\
\text { development of economy and other } \\
\text { spheres of society }\end{array}$ & $\begin{array}{c}\text { Participation in accumulative forms of retirement } \\
\text { insurance }\end{array}$ \\
\hline Educational & $\begin{array}{l}\text { Promotes formation of financial initiative } \\
\text { and responsibility of citizens }\end{array}$ & $\begin{array}{c}\text { Participation in accumulative forms of retirement } \\
\text { insurance }\end{array}$ \\
\hline
\end{tabular}

Table 2. The main functions of financial market in the context of pension system functioning.

Financial market is characterized by complexity of organization, a rattling good variability speed, unpredictability of behavior and subsequent results. The basis for mutual relations of financial market and pension system institutions is social component related to formation of pension payments. This feature requires definiteness, stability and predictability of the results in the longer term. Within the context of those set forth the category financial market in the author's opinion can be represented as a sphere of social relations for redistribution of pension assets through instruments of financial market in the form of investment resources in Ukrainian economics, the result of which is obtaining capitalization products for respective pension payments (see Figure 3).

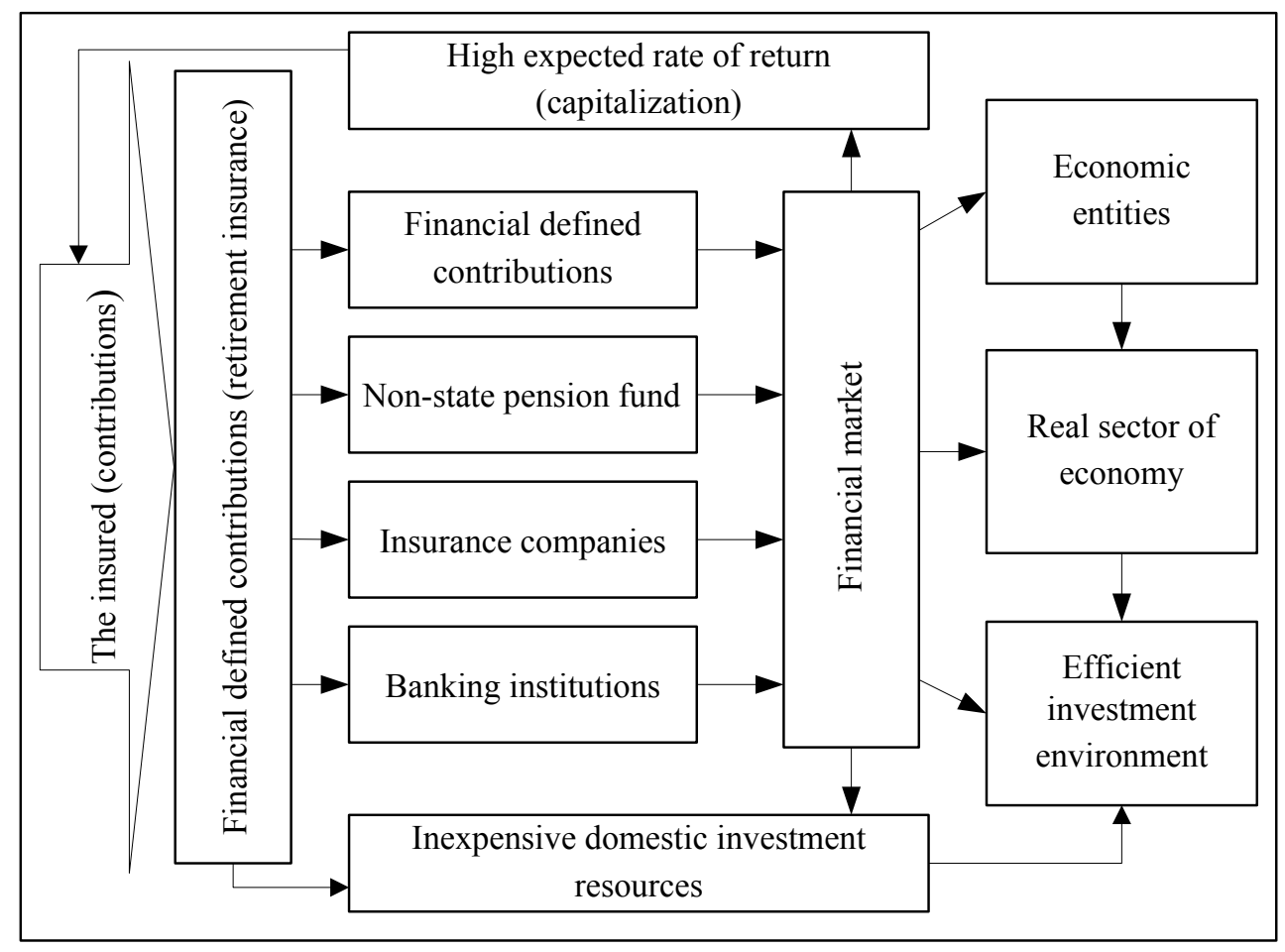

Figure 3. Structural-logic diagram of financial defined contributions (retirement insurance).

It should be stressed that the basis for interaction of financial market and pension system institutions is interage interaction of its main participants: the insured and pensioners (see Figure 4). 


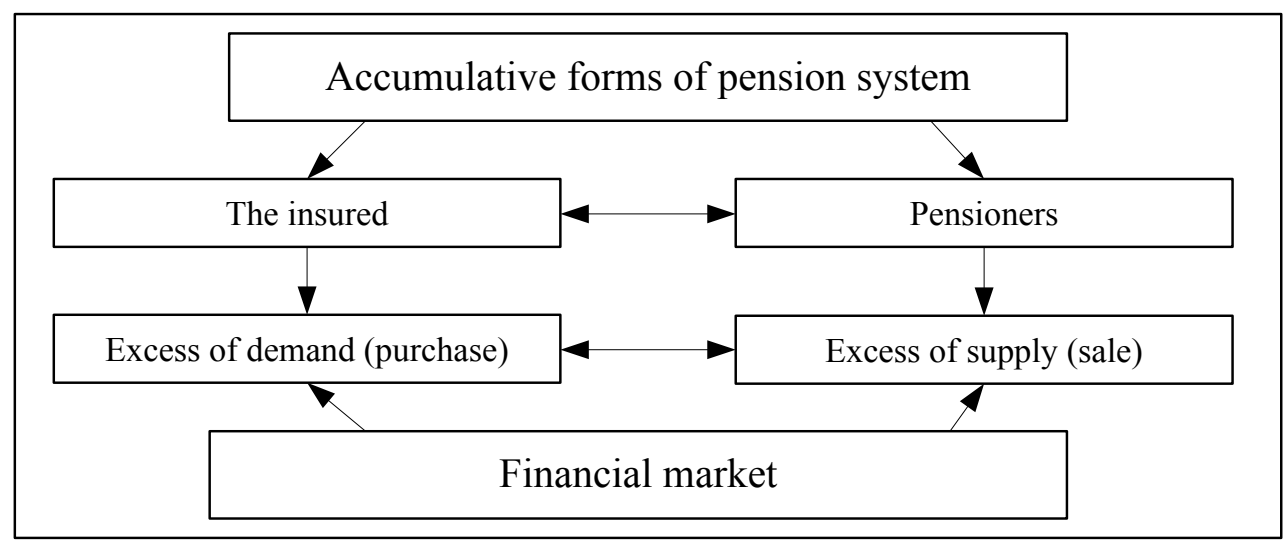

Figure 4. The Structural-logic scheme of the interaction of accumulating pension insurance in the financial market

The main (demographic) dependence among the mentioned categories of participants causes considerable changes in functioning of financial markets. For example, excess of the number of the insured (over pensioners) forces up the flow of financial resources and demand for financial market instruments that contributes to their development and growth of prices. In case when the number of pensioners begins exceeding the number of the insured necessity to release funds for extinction of obligations to pensioners arises. This results in the corresponding response of financial market: increase in sales operations and parallel decrease in demand (a cut in prices) for securities. This problem requires study and regulation concerning decrease of risks related to demographic (inter-age) differences in functioning of accumulative pension systems (financial defined contributions) in financial market.

In ideal conditions the process of investing funds of defined contribution pension systems assumes availability of integrated investment strategy and appropriate investment objects. However, there is a particularity of behavior of the participants of relations related to the functioning of pension fund resources as investment resources. It consists in that the insured parties expect maximal capitalization of investments, and business activity participants assume obtaining inexpensive domestic investment resources. For that reason making of the optimum relationship of parameters is required.

It should be noted that activity of defined contribution pension systems also exerts substantial influence on financial market functioning (see Figure 5).

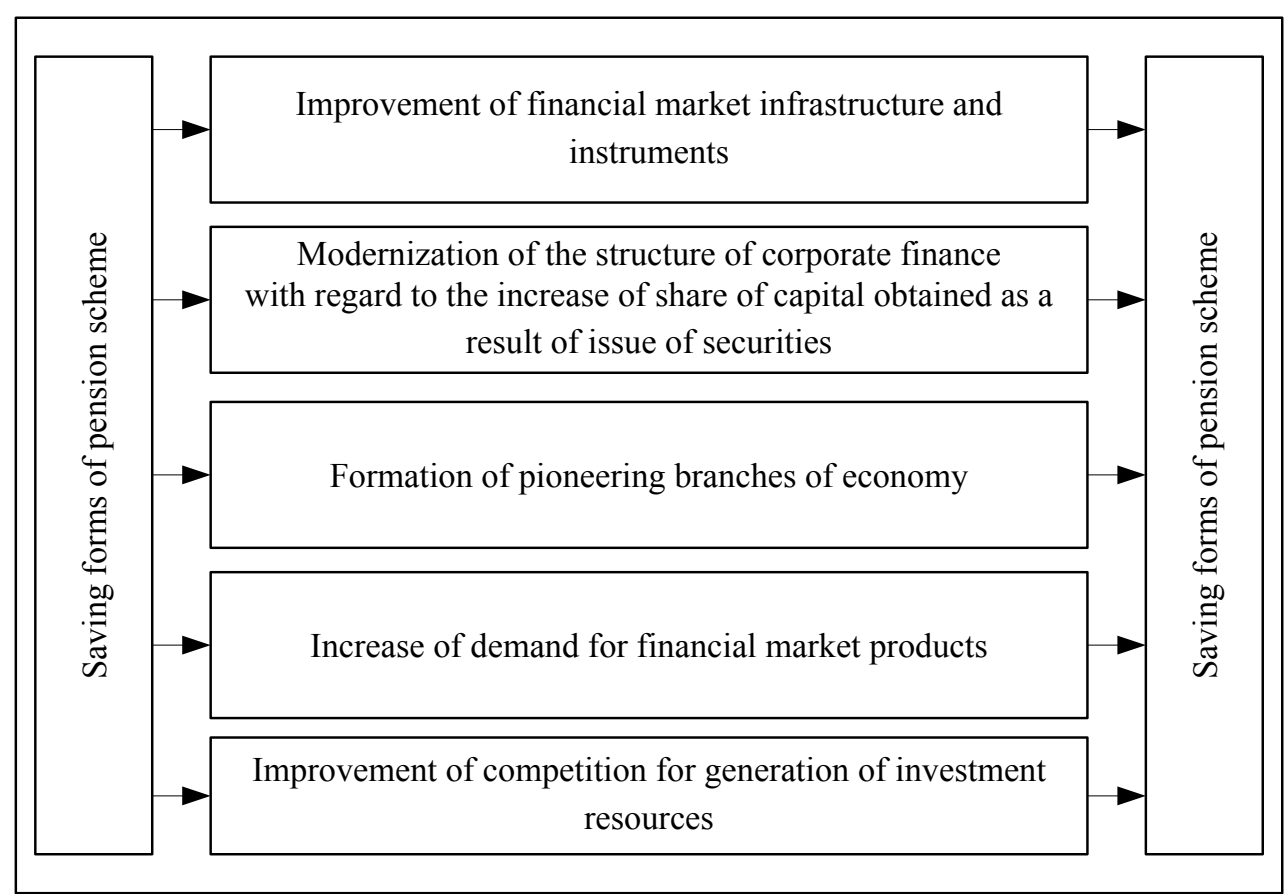

Figure 5. Diagram of the influence of defined contribution pension systems on financial deepening.

Particularities of the functioning of non-state pension system in the current context of financial market are identified. They consist in division of assets of the insured parties and founding shareholders; separation of the 
processes of administration, management and preservation of assets and also diversification of directions for investment of pension fund assets (Tkachenko and Tsikanovska, 2010). However, it should be appreciated that diversification of pension system financial resources is limited by provisions of law (see Table 3 ).

\begin{tabular}{|c|c|c|}
\hline Type of investment instrument & $\begin{array}{c}\text { Limitation of investment in } \\
\text { defined contribution pension } \\
\text { system }\end{array}$ & $\begin{array}{c}\text { Limitation of investment } \\
\text { in non-state pension system }\end{array}$ \\
\hline $\begin{array}{c}\text { Cash in bank and deposit accounts, } \\
\text { savings certificates }\end{array}$ & 50 & 40 \\
\hline Government securities & 50 & 50 \\
\hline Ad bonds & 10 & 20 \\
\hline Corporate bonds of Ukrainian issuers & 20 & 40 \\
\hline Stocks of Ukrainian issuers & 40 & 40 \\
\hline $\begin{array}{c}\text { Government securities of foreign } \\
\text { issuers }\end{array}$ & $\begin{array}{c}5 \text { and not more than } 10 \% \\
\text { in securities of one issuer }\end{array}$ & 20 \\
\hline $\begin{array}{c}\text { Other assets not prohibited by } \\
\text { Ukrainian legislation }\end{array}$ & 5 & 5 \\
\hline
\end{tabular}

Table 3. Limitations of investment of pension assets.

It is pertinent to note that consolidated profit (negative profit) from investment of pension fund assets consists of consolidated profit (negative profit) from implementation of operations with its assets, passive incomes (gains on assets placed in securities) (Verkhovna Rada of Ukraine, 2003b). Structure of actual investment of assets of non-state pension funds in 2010 is shown in Figure 6.

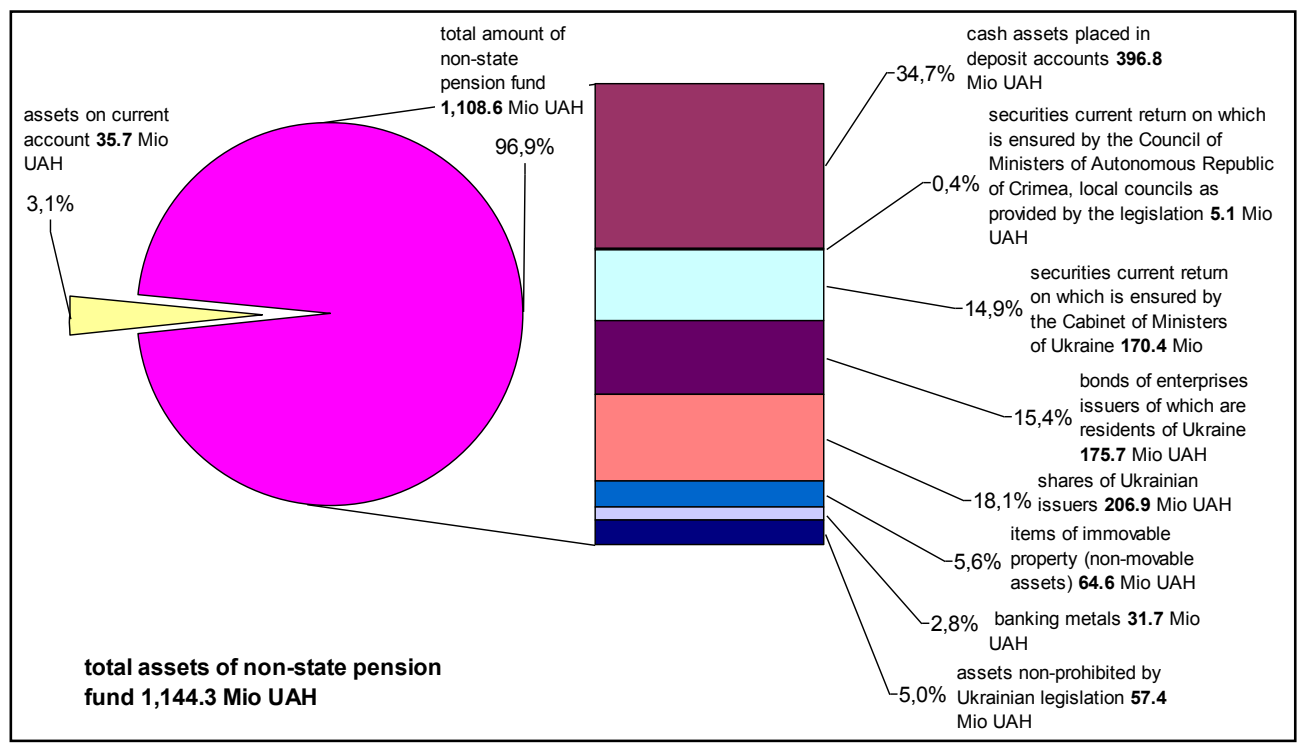

Figure 6. Structure of investment of assets of Ukrainian non-state pension funds in 2010.

Data in the diagram above shows full-scale range of investment instruments (State Commission for Regulation of Financial Services Markets, 2010). However, evident become risks that accompany operational investment strategy. In the structure of consolidated portfolio the largest ratio falls within the instruments liable to risks of instability the confirmation of which serves recent crisis of banking sector. In the structure of the shares of domestic issuers the primary is the share of key branches (metallurgical, energy, engineering, chemical industries) which have high degree of dependence on economic situation and level of world market prices. Consequently, for efficient application of pension system investment resources definition of the integrated groundbreaking development strategy is required taking into account capacity of pension system resources for long term perspective. Function of saving forms of pension system also requires construction of the right strategy. Administration of pension fund cash flows is characterized by large volumes of changing information that requires quick information gathering, systematization, assessment, and decision making. Pension funds feature either aggressive-character strategy that ensures high level of income and risks or conservative strategy in conditions of low level of incomes and minimal riskiness of operations. Mixed-character strategies are also present. According to analysts' estimates, pension fund functioning strategy which amount of capitalization of invested funds exceeds rate of inflation plus 4-5\% per annum appear worthy of positive estimation. However, there are opinions on the minimal criterion of positive estimation for pension fund functioning provided saving citizens' retirement savings. Thus, we need defining the optimal parameters of investment strategy for defined 
contribution pension systems which would combine sufficient return level and protection against risks of loss (depreciation) of retirement assets of the insured.

\section{Conclusions}

Summarizing all above-mentioned we may conclude that pension system in Ukraine is an efficient mechanism for formation of investment resources, development of financial market and economy. To achieve gains in this process, to our opinion, it is necessary:

i. To define parameters of the optimal correlation of capitalization of pension fund investment resources through financial market for its participants.

ii. To work out national groundbreaking strategy taking into account capacity of pension system investment resources for their effective application for long-term perspective.

iii. To create algorithm for construction of the efficient pension fund investment strategy, that would combine sufficient return level and protection against risks of loss or depreciation of retirement assets of the insured.

iv. To work out protective mechanism against demographic differences in the system of financial defined contributions (accumulative pension systems) and financial market interrelations.

Implementation of the abovementioned measures will allow activating the process of functioning of the third and introduction of the second level of pension system and also will contribute to financial market development in the context of realization of national priorities for innovative economic development.

\section{References}

- Verkhovna Rada of Ukraine, 1996. Constitution of Ukraine, http//zakon1.rada.gov.ua/cgibin/laws/main.cgi?nreg=254\%EA\%2F96-\%E2\%F0

- Verkhovna Rada of Ukraine, 2003. Act of Ukraine no. 1058 On the obligatory state pension insurance, http://zakon1.rada.gov.ua/cgi-bin/laws/main.cgi?nreg=1058-15

- Kovalenko, 2010. "Modern financial market structure”, Finances of Ukraine, 178, p. 92.

- Yuriy and Lutsishin, 2010. "Financial service market as an institutional basis of market economy", Finances of Ukraine, 180, p. 54.

- Supakshin, 2008. Financial markets and economic policy of Russia. Nauchny expert, Moscow.

- Tkachenko and Tsikanovska, 2010. "The role of non-state pension funds in development of Ukrainian financial market", Finances Ukraine, 181, p. 73.

- Verkhovna Rada of Ukraine, 2003. Act of Ukraine no. 1057 On the non-state pension provision, http://zakon1.rada.gov.ua/cgi-bin/laws/main.cgi?nreg=1057-14

- State Commission for Regulation of Financial Services Markets, 2010. Results of non-state pension provision system development in 2010, http://www.dfp.gov.ua 


\title{
The Importance of Ethics in the Sphere of Employment in Polish Banking Sector
}

\author{
Jerzy Kaźmierczyk (Poznan University of Economics, Poland) \\ Mirosław Świt (University of Zielona Gora, Poland)
}

\begin{abstract}
There have been big changes in functioning of Polish banking sector in the past two decades. Formerly one of the least efficient sectors of the economy, it has become a highly profitable industry, in which the same organizational solutions as the ones in Western countries are used. Such a dynamic change requires a strong reorientation in the manner of, and in the perception of, banking activities, including work in the bank. The application of market solutions changes the ethical and moral rules in the banking environment. We can see increasing importance of such criteria as profit and productivity. At the same time banks are increasingly fashionable and formalize the rules of work in the form of codes of ethic. However, the authors intend to confirm the thesis that, with the implementation of codes of ethic, there is no observed analogous concern about moral principles. To confirm the above, a survey among workers employed in the banks was conducted. In addition, interviews with selected bank HR managers and members of the boards of directors were conducted. This paper deals with issues such as: the functioning of the bank's code of ethic, looking for workers with the use of informal contacts between employees, putting personal pressures aimed at increasing acceptance of privatization, and offering competitive wages and employment conditions for employees of other banks. The collected data allowed us to accept the thesis. Banks frequently approve of ethical codes that continue to be a theory not necessarily related to morality.
\end{abstract}

JEL Codes: G21, M54.

\section{Introduction}

The change of political system in Poland after 1989 led to a transformation in many spheres of human activity, including the banking sector. In short time it became a highly profitable sector. The changes were very dynamic, almost comparable to the so-called "shock therapy". Especially organizational solutions used in Western countries, which were achieved there sometimes after decades, were applied fast in organizationally backward Polish banking sector. Employees of Polish banks in the early 90s were unprepared both mentally and professionally to function under market conditions. The changes were taking place not only in the economic sphere, but also in the social sphere. Changes in the market forced changes in the ethical sphere. Ethical solutions have little in common with morality. The most important criteria are profit and productivity. Hence, banks succumbing to fashion, formalize rules of work in the form of codes of ethics, often misinterpreting the responsibilities of employees as social values. Thus, the authors intend to prove that with the implementation of codes of ethics, a similar concern about the moral principles did not occur. Social values, for instance respect, solidarity and extremely important, not only in social, but also in economic life - trust, were vanishing.

In order to confirm this, surveys among employees in the banks were carried out. In addition, interviews with purposefully selected bank employees and members of the banking boards of directors were conducted. Technique of surveys and interviews allowed us to examine the situation that prevails in the Polish banking sector in terms of ethics (266 questionnaires were collected from non-management employees and 59 from managers). The article considered the humanistic aspects of work. This paper deals with issues such as: the functioning of the bank's code of ethic, looking for workers by the use of informal contacts between employees, personal pressures aimed at increasing acceptance of privatization, and offering competitive wages and working conditions for employees of other banks.

\section{Work as a humanistic value}

The employment of particular rules of conduct related to a human activity (e.g. political, social, economic, etc.) is willingly combined with an extremely pure let alone justified concept which is the concept of ethic and ethical behaviour. Certain professional groups or corporations frequently implement ethic in line with their needs. Consequently, we may consider the concept of medical, teaching or business ethic, which is recently in fashion to a great extent. Intentions to act ethically are honourable, so they always are. However, carrying-out of those intentions may be quite disappointing. Why? Probably due to the misunderstanding of two basic premises determining people's behaviour. These are ethic and morality. There are two issues to be considered: 1) can one be ethical without being moral?; and 2) can one be moral without being ethical? To be more specific, can an immoral businessman be ethical? And, can an unethical businessman be moral? It is possible taking into account the ethical condition of today's business. People would not hear of the increasing dishonesty, shady transactions 
or continuous scandals and financial deceptions. John C. Maxwell states that the bad condition of business ethic is the result of three factors: people perform actions profitable for them, people perform actions enabling them to win, and people's decisions result from relativism. Consequently, ethical relativism is increasing since everyone establishes their own standards and alters them according to the situation (Maxwell, 2010).

The above mentioned questions will be more comprehensible if we define precisely the concepts of ethic and morality. Both the terms refer to social values yet they differ in meaning.

According to Hegel's idea, the term of ethic derives from the Greek word ethos and it is connected with the community in which a person functions. Community establishes a well-ordered system of values, defines what is good and what is wrong. A person is born in this group and accepts the values (Stawrowski, 2008). Ethical behaviour is in other words identification with a person's ethical community. The system of ethical values functioning in a community establishes which actions are right. But it is the person's inner judgement of an action that may make it immoral, although it is ethical.

The concept of morality was defined considerably later and it is as universal as the concept of ethical behaviour. Socrates was the first to make attempts to describe morality (daemon). Christianity operated on a vision of clear and guilty conscience. Nevertheless, morality became common after the Reformation and its most developed definition was provided by Immanuel Kant. Morality results from the awareness of freedom and the person's ability to use their reason properly. Therefore, conscious morality appears at a certain stage of our personal development (Stawrowski, 2008).

Morality is the act of free will performed by an autonomous entity. The action may be acknowledged as moral when a person is conscious of its possible consequences and is able to differ between right and wrong. Morality results from a conscious decision while ethical behaviour is not more than imitating community's other members. What is more, morality does not develop automatically just because of the awareness of being free. This is so due to the fact that free will depends on external sensory impulses. According to Immanuel Kant, human being acting in accordance with senses is able to choose both right and wrong behaviour (Kant, 2007). There is a moral imperative necessary for the act of free will to become a moral code.

Immanuel Kant discussed the issue of an uncompromising imperative obliging a person to "follow such maxim which could become a common law! - First, judge your actions in accordance with subjective principles, however, you will recognize if the principle is also objectively valid when reason has tested it by giving you an image of being the lawmaker yourself" (Kant, 2007). The origin of morality lies in the rational being's autonomous will. Ethical empiricism must be overcome for morality to be real (Höffe, 2003). Immanuel Kant wrote that if " (...) someone is tempted to use empiricism to origin moral principles, they will be exposed to disaster" (Kant, 2007). Considerably earlier, Aristotle assumed that a human being is not self-sufficient and needs to live in a community to be fully developed. And, morality is essential for the human to live in a community (ethic and morality were not distinguished between in Aristotle's time). Morality is not innate, it has to be learned. The Stagirite claimed that "(...) human without moral conscience is the most contemptible and the wildest creature, he's the basest in lust and gluttony" (Aristotle, 2006). When a person is indifferent to spiritual matters, they become unable to evaluate their conduct and, at the same time, to distinguish between right and wrong. What is more, goodness will not come to exist by itself (Koneczny, 1999). Therefore, the world we live in and its depiction depends on our awareness and rational (or irrational) activity.

After the concepts of ethic and morality have been defined, it is easier to understand why in spite of business ethic there is so much base behaviour and people are treated like objects not subjects. Work is not anymore the source of satisfaction, instead, it is frequently the source of suffering. This is due to the objectifying personnel management. Consequently, a mistreated employee may begin to behave inappropriately by resorting to lie or thief as an expression of his or her willingness to settle a score. This may make company's credibility questioned (Blanchard and Peale, 2010).

Business ethic is one of the fields of ethic. It formulates certain principles of behaviour and, even though those principles are more precise than the general values, like for example goodness or justice, they do not result in the increase of morality. On the contrary, morality is decreasing nowadays. One may say that there is a phenomenon of miniaturization of morality happening. This is due to the fact that there is a common belief in moral relativism resulting from too powerful autonomy and a belief that there is no system of values and standards which could predominate over other systems of values (Fukuyama, 2000). Therefore, the diversity of fields of ethic not only increases moral relativism, but it also decreases morality. An individual feels no longer responsible for his or her deeds. People do not trust each other. And, trust is fundamental for the society to exist and for human relationships occurring at work. Trust enhances those relationships and a sense of identity, it inspires solidarity among people, willingness to cooperate, optimism, tolerance and respect for others. Distrust, just the opposite, enhances isolation and atomization of a community. Human relationships vanish and hostile stereotypes, prejudices and xenophobia appear. Distrust triggers alienation and loss of identity. According to P. Sztompka, trust cannot result from the effectiveness of controlling mechanisms if it is to be common and stable. Such mechanisms should be used only as a last resort and in situations when trust is overused. Institutionalized distrust 
is more effective in restoring trust when it is "concealed at a standard level and is not converted into obvious, routine practice" (Sztompka, 2007). Work is an essential trust factor because at work people spend a significant amount of time and regardless of the position occupied they constitute a community. Lack of trust at work causes resentment and reluctance to perform duties conscientiously. Company management should not be focused only on gaining profit because in such case it could be compared to a tennis match in which the competitor is focused on the scoreboard instead of the ball (Blanchard and Peale, 2010). Managers should also remember about people who work in the company since they play a significant role in achieving success. The credit goes to the team not only to the board (Maxwell, 2010). There is a strong connection between trust and morality. It is the trust that influences the increase of morality, not freedom to a great extent, as it was suggested by Friedrich A. Hayek. The higher the level of trust, the higher the level of morality. The author of The Constitution of Liberty claimed that liberty and morality are strongly connected. In his opinion, liberty conditioned the existence of moral values, and morality is necessary to maintain liberty. He stated that "moral standards of a nation or a social group tend to be high if the group have been free for a long time - the proportion is related to the level of liberty of the group" (Hayek, 1998). Hayek's thesis is too optimistic. Contemporary realities prove that it is quite the opposite. There is a progressing erosion of morality in the countries which have been independent the longest. The relation between liberty and morality suggests a completely different conclusion. Namely, the more liberty, the less morality. Why is this so? As a far-reaching absolutization of the freedom to choose occurred. According to V. Possenti, a social consequence of such defining of the freedom to choose is that "the absolutization of the freedom to choose and simultaneously forgetting about the goodness is the definitive principle of social order. The question of goodness is omitted so that the main factor of morality is liberty and not the goodness" (Possenti, 2005). Thus, if liberty is to influence the increase of morality, it needs to be perceived as the right usage of the freedom to choose, supported by a high level of trust at the same time

\section{Methodology}

Questionnaires and interviews were conducted in 2009 and 2010. Two types of anonymous questionnaires were used, depending on the position the surveyed occupy in the company i.e. managerial or non managerial one, the surveyed were asked to fill in an adequate, anonymous questionnaire. The questionnaire-based survey was conducted because of the lack of any statistical data other than aggregated data for the whole financial sector. Official correspondence, e-mails and phone calls with the Central Statistical Office (GUS), the Polish Financial Supervision Authority (KNF), the National Bank of Poland (NBP) and the Polish Bank Association (ZBP) show that the institutions do not gather detailed data on employment in the sector. Pilot research was conducted in the last quarter of 2009. First, 93 students of the Poznań University of Economics were asked to fill in the questionnaire. Their comments and suggestions concerning construction of the questionnaire were taken into account and the improved questionnaire was distributed among 37 bank employees (both in the region of Wielkopolska, Lubuskie, Dolnośląskie, Pomorskie and Lódzkie). Guidelines received from the employees were again used improve the questionnaires. The minimum sample size was taken from the equation $\mathrm{n}=$ ualfa $2 /\left(4 * d^{\wedge} 2\right)$, for: estimation error $d=0,05 ; 1$-alfa $=0,9$; ualfa $=1,64$. (Szuman 2008, p 57-59). The minimum sample size was 269. During the research a snowball technique was used. Answers were received from 342 bank employees (out of which 17 were rejected due to their low reliability and credibility). Finally 266 questionnaires were collected from non-management employees and 59 from managers. It should be emphasized that the banks which employees took part in the survey account for over $90 \%$ of the total banking sector assets in Poland and employ over $74 \%$ of all banking sector employees in the country. Due to its superior position over the rest of the banks, the NBP was not covered by the survey. The questionnaire encompasses years 1996-2008, although employees referred also to the changes that took place after 2008. Opinions provided by the surveyed were later analyzed and divided into 32 categories.

\section{Codes of ethic and their application in banking practice}

Recently, the issue of business social responsibility has been in fashion. In consequence, the codes of ethic and similar solutions became fashionable as well. Therefore, bank employees were asked a question whether a code of ethic, decency or another principles of behaviour function in their bank. The majority of both employees occupying managing positions $(81,36 \%)$ and other employees $(69,55 \%)$ responded affirmatively. However, some interviewees made annotations saying: "there is a code, but nobody obeys it" - those were found in twelve surveys. Questionnaires carried out among human resources managers indicate that banks do have some codes of ethic and attempt to observe them. It is probable, however, that this is an official statement which is not in conformity with the reality.

Codes of ethic are more common in banks in which foreign capital shares are in the majority $(91,89 \%$ of the managers and $73,15 \%$ of other employees). In banks with the majority of domestic capital the percentages are lower: $60 \%$ of the managers and 59,02\% of other employees. Systems of any morals are also less frequent than on average in cooperative banks $(57,15 \%$ of the managers and $42,86 \%$ of other employees). Generally, it should be pointed out that the managers acknowledged the existence of a code of ethic in their bank more frequently 
than other employees (taking into account all the analysed criteria). It signifies that the managers are more aware in this field.

The code of business ethic has been functioning in Bank Zachodni WBK since the beginning of 2004. This is the code observed in the whole group AIB - that is the group of the headquarters (The Report of the Board on the Activity of the Bank Zachodni WBK S.A. in 2005, p. 30). Similar solutions based on the stipulations binding on the whole financial group functioned among others in:

- Pekao (The Card of Principles UCI introduced in 2005) (The Annual Report of the Bank Pekao SA 2005, p. 29);

- $\quad$ BPH (The Code of Conduct GE - The Spirit and The Letter) (Business Social Responsibility - The 2008 Report, BPH, p. 4);

- $\quad$ BGK (A Collection of Moral Principles for the BGK Employees) (http://www.bgk.com.pl, 22.07.2011).

\begin{tabular}{|c|c|c|c|c|c|c|c|c|c|}
\hline Criterion & Everyone & & . Yes & \multicolumn{2}{|c|}{ B. No } & \multicolumn{2}{|c|}{ C. It is difficult to say } & \multicolumn{2}{|c|}{ No answer } \\
\hline \multicolumn{10}{|c|}{ Other employees } \\
\hline Altogether & 266 & 185 & $69,55 \%$ & 34 & $12,78 \%$ & 42 & $15,79 \%$ & 5 & $1,88 \%$ \\
\hline Commercial banks & 178 & 129 & $72,47 \%$ & 22 & $12,36 \%$ & 23 & $12,92 \%$ & 4 & $2,25 \%$ \\
\hline Cooperative banks & 28 & 12 & $\underline{42,86 \%}$ & 5 & $17,86 \%$ & 10 & $35,71 \%$ & 1 & $3,57 \%$ \\
\hline Domestic & 61 & 36 & $59,02 \%$ & 9 & $14,75 \%$ & 14 & $22,95 \%$ & 2 & $3,28 \%$ \\
\hline Foreign & 149 & 109 & $73,15 \%$ & 16 & $10,74 \%$ & 21 & $14,09 \%$ & 3 & $2,01 \%$ \\
\hline \multicolumn{10}{|c|}{ Managers } \\
\hline Altogether & 59 & 48 & $81,36 \%$ & 4 & $6,78 \%$ & 2 & $3,39 \%$ & 5 & $8,47 \%$ \\
\hline Commercial banks & 45 & 38 & $84,44 \%$ & 1 & $2,22 \%$ & 1 & $2,22 \%$ & 5 & $11,11 \%$ \\
\hline Cooperative banks & 7 & 4 & $57,14 \%$ & 3 & $42,86 \%$ & 0 & 0 & 0 & 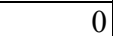 \\
\hline Domestic & 15 & 9 & $60 \%$ & 3 & $20 \%$ & 1 & $6,67 \%$ & 2 & $13,33 \%$ \\
\hline Foreign & 37 & 34 & $91,89 \%$ & 1 & $2,7 \%$ & 0 & 0 & 2 & $5,41 \%$ \\
\hline
\end{tabular}

Table 1. Code of ethic, decency or similar solutions functioning in banks.

\begin{tabular}{|c|c|c|c|c|c|c|c|c|c|}
\hline Criterion & Everyone & \multicolumn{2}{|c|}{ A. Yes } & \multicolumn{2}{|c|}{ B. No } & \multicolumn{2}{|c|}{$\begin{array}{c}\text { C. It is difficult to } \\
\text { say }\end{array}$} & \multicolumn{2}{|c|}{ No answer } \\
\hline Altogether & 59 & 33 & $55,93 \%$ & 18 & $30,51 \%$ & 1 & $1,69 \%$ & 7 & $11,86 \%$ \\
\hline Commercial banks & 45 & 29 & $64,44 \%$ & 9 & $20 \%$ & 1 & $2,22 \%$ & 6 & $13,33 \%$ \\
\hline Cooperative banks & 7 & 1 & $14,29 \%$ & $\underline{5}$ & $71,43 \%$ & 0 & 0 & 1 & $14,29 \%$ \\
\hline Domestic & 15 & 3 & $20 \%$ & 9 & $60 \%$ & 0 & 0 & 3 & $20 \%$ \\
\hline Foreign & 37 & $\underline{28}$ & $75,68 \%$ & $\overline{5}$ & $13, \overline{51 \%}$ & 1 & $2,7 \%$ & 3 & $8,11 \%$ \\
\hline $\begin{array}{c}\text { Low-ranking } \\
\text { managers }\end{array}$ & 14 & $\underline{6}$ & $42,86 \%$ & $\underline{6}$ & $\underline{42,86 \%}$ & 0 & 0 & 2 & $14,29 \%$ \\
\hline $\begin{array}{c}\text { Medium-ranking } \\
\text { managers }\end{array}$ & 30 & $\underline{19}$ & $\underline{63,33 \%}$ & 7 & $23,33 \%$ & 1 & $3,33 \%$ & 3 & $10 \%$ \\
\hline $\begin{array}{l}\text { High-ranking } \\
\text { managers }\end{array}$ & 10 & 7 & $\underline{70 \%}$ & 3 & $30 \%$ & 0 & 0 & 0 & 0 \\
\hline $\begin{array}{l}\text { Those who have } \\
\text { codes of ethic }\end{array}$ & 48 & $\underline{31}$ & $\underline{64,58 \%}$ & 14 & $29,17 \%$ & 1 & $2,08 \%$ & 2 & $4,17 \%$ \\
\hline $\begin{array}{l}\text { Those who do not } \\
\text { have codes of ethic }\end{array}$ & 4 & 2 & $50 \%$ & 2 & $50 \%$ & 0 & 0 & 0 & 0 \\
\hline
\end{tabular}

Table 2. Seeking after employees by means of informal contacts (in the managers'opinion).

It is worth also to point out some practical solutions connected with the ethic functioning in banks. In 2005 , $\mathrm{BPH}$ created a fund to help those employees who found themselves in a difficult situation because of health problems or some accident. The institution helped to cover the costs of treatment or finance rehabilitation. It paid family allowances for the late employees' children, funded partially the household budget or the purchase of an expensive life-supporting equipment (The 2006 Annual Report, BPH, p. 55). Whereas, in Citi Bank there is a program of volunteer work (The Report on the Activity of the Capital Group of the Bank Handlowy in Warsaw S.A. in the first half year 2007, p. 36).

Some bank managers were asked whether a bank happens to seek after employees by means of informal contacts. The majority of them answered affirmatively. Exceptionally, the majority of the cooperative banks managers responded negatively $(71,43 \%)$. A negative response was also given by the managers employed in the banks with the majority of domestic capital $(60 \%)$.

However, it would be difficult to draw explicit conclusions on the basis of the accessible literature. What is interesting, the majority of the managers employed outside Poznan denied using informal contacts to seek after new employees $(58,82 \%)$. Such a huge divergence of opinions expressed by the managers from Poznań $(14,71 \%$ negative answers) and other places may be the result of the centralization of banks. Retail outlets located outside Poznań are treated as a chain which is deprived of the decision-making entitlements referring to the whole 
region. On account if that decisions on employing a person are made by the personnel from Poznań or the head office. In the recruitment process to commercial banks, applications are usually collected by the personnel from regional outlets or the head office. The Human Resources Personnel analyse the documents received and suggest those applicants who meet the requirements to the managers of the branches. It is possible that the relations between local branches outside Poznań and the Human Resources Personnel are not so close as such relations between branches from Poznań and the Human Resources Personnel. If it is so, potential informal information is transferred rather by the employees from Poznan than from the local branches. Nevertheless, these are sheer conjectures which require further analysis. What is more, informal contacts are apparently more frequent among the high-ranking managers, or, possibly, those managers tend to admit more willingly the existence of such contacts.

Another question designed to diagnose the condition of ethic and morality in banks was the question about personal pressures. The managers who had some experience in privatized or consolidating banking did not feel any pressures on the issue of accepting the privatization or consolidation. It may be supposed that the privatization or consolidation decision was made without their participation on a higher organizational level. Furthermore, there were situations when employees who were not managers could not respond to the question. This was due to the fact that some of them did not work in a bank during the privatization which took place a few or a dozen or so years ago. In Poland, employers decided on the labour market for a long time. However, after Poland had acceded to the European Union, the situation began to change as a result of for example emigration for economic reasons. Due to the 2007-2009 crisis, employers regained the right to decide on labour market. It is worth to evaluate the banking labour market in this particular context.

It is assumed that when the labour market lacks appropriate applicants, banks tend to outbid other banks' employees. Apparently, 37,29\% of the managers and almost half of other employees $(48,87 \%)$ confirm that a bank offers better-paid jobs and competitive working conditions when employing people from other banks. In the employees' opinion (57,14\% of the managers and $50 \%$ of other employees), cooperative banks frequently outbid personnel. On the other hand, major banks are less inclined to attract applicants by means of working conditions and salaries $(33,33 \%$ of the managers and $38 \%$ of other employees). What is interesting, interviews carried out among banking Human Resources Personnel depict that outbidding employees usually takes place in new banks which lack personnel and need to complete their staff. The most frequent example given by the interviewees was the Alior Bank.

There was also another question which was answered by employees who claimed that in case of employing personnel from other banks, their bank offers that personnel competitive working conditions and better-paid jobs. Those employees were asked about the motifs of such practice. Apparently, in the bank employees' opinion, lack of the possibility to recruit a qualified employee from the local labour market is of no significance to a great extent. Both the managers $(54,55 \%)$ and other employees $(73,85 \%)$ claimed that banks outbid personnel due to the fact that it is less expensive to recruit a professional from a competitor that to train a newly-employed staff.

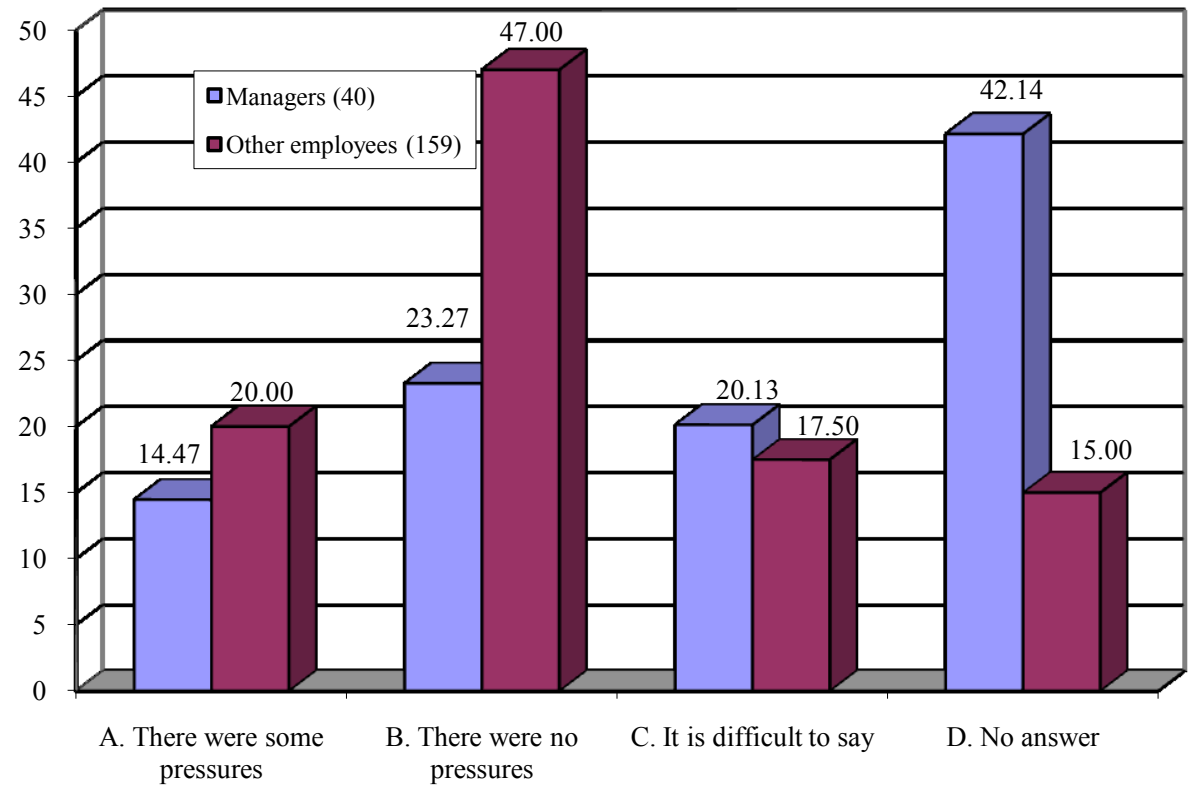

Chart 1. Personal pressures supposed to increase the acceptance of privatization or consolidation by the employees (according to the managers and other employees) (expressed in percentage terms). 


\begin{tabular}{|c|c|c|c|c|c|c|c|c|c|}
\hline Criterion & Everyone & \multicolumn{2}{|c|}{ A. Yes } & \multicolumn{2}{|c|}{ B. No } & \multicolumn{2}{|c|}{$\begin{array}{c}\text { C. It is difficult to } \\
\text { say }\end{array}$} & \multicolumn{2}{|c|}{ No answer } \\
\hline \multicolumn{10}{|c|}{ Other employees } \\
\hline Altogether & 266 & 130 & $48,87 \%$ & 42 & $15,79 \%$ & 91 & $34,21 \%$ & 3 & $1,13 \%$ \\
\hline Commercial banks & 178 & $\underline{82}$ & $46,07 \%$ & 29 & $16,29 \%$ & 64 & $35,96 \%$ & 3 & $1,69 \%$ \\
\hline Cooperative banks & 28 & $\overline{14}$ & $50 \%$ & 2 & $7,14 \%$ & $\underline{12}$ & $42,86 \%$ & 0 & 0 \\
\hline $\begin{array}{l}\text { Divisions of credit } \\
\text { institutions }\end{array}$ & 6 & 3 & $50 \%$ & 0 & 0 & 3 & $50 \%$ & 0 & 0 \\
\hline Major & 100 & 38 & $38 \%$ & 17 & $17 \%$ & $\underline{44}$ & $\underline{44 \%}$ & 1 & $1 \%$ \\
\hline McBanks & 11 & 6 & $54,55 \%$ & 1 & $9,09 \%$ & $\overline{4}$ & $3 \overline{6,36 \%} \%$ & 0 & 0 \\
\hline Other banks & 96 & 54 & $56,25 \%$ & 11 & $11,46 \%$ & 29 & $30,21 \%$ & 2 & $2,08 \%$ \\
\hline $\begin{array}{l}\text { Those who have } \\
\text { codes of ethic }\end{array}$ & 185 & 93 & $50,27 \%$ & 26 & $14,05 \%$ & 66 & $35,68 \%$ & 0 & 0 \\
\hline $\begin{array}{l}\text { Those who do not } \\
\text { have codes of ethic }\end{array}$ & 34 & 18 & $52,94 \%$ & 10 & $29,41 \%$ & 6 & $17,65 \%$ & 0 & 0 \\
\hline \multicolumn{10}{|c|}{ Managers } \\
\hline Altogether & 59 & 22 & $37,29 \%$ & 10 & $16,95 \%$ & 27 & $45,76 \%$ & & 0 \\
\hline Commercial banks & 45 & 16 & $35,56 \%$ & 7 & $15,56 \%$ & 22 & $48,89 \%$ & & 0 \\
\hline Cooperative banks & 7 & 4 & $57,14 \%$ & 2 & $28,57 \%$ & 1 & $14,29 \%$ & & 0 \\
\hline $\begin{array}{l}\text { Divisions of credit } \\
\text { institutions }\end{array}$ & 1 & 0 & 0 & 0 & 0 & $\underline{1}$ & $\underline{100 \%}$ & & 0 \\
\hline Major & 21 & 7 & $33,33 \%$ & 5 & $23,81 \%$ & $\underline{9}$ & $\underline{42,86 \%}$ & & 0 \\
\hline McBanks & 4 & 2 & $50 \%$ & 1 & $25 \%$ & 1 & $25 \%$ & & 0 \\
\hline Other banks & 27 & $\underline{11}$ & $40,74 \%$ & 2 & $7,41 \%$ & 14 & $51,85 \%$ & & 0 \\
\hline $\begin{array}{l}\text { Those who have } \\
\text { codes of ethic }\end{array}$ & 48 & $\underline{20}$ & $\underline{41,67 \%}$ & 7 & $14,58 \%$ & $\underline{21}$ & $\underline{43,75 \%}$ & & 0 \\
\hline $\begin{array}{l}\text { Those who do not } \\
\text { have codes of ethic }\end{array}$ & 4 & 2 & $50 \%$ & 2 & $50 \%$ & 0 & 0 & & 0 \\
\hline
\end{tabular}

Table 3. Offering competitive working conditions and better-paid jobs to other banks' employees in order to outbid them (in the managers and other employees'opinion).

\begin{tabular}{|c|c|c|c|c|c|c|c|}
\hline Criterion & $\begin{array}{l}\text { All the } \\
\text { respondents }\end{array}$ & \multicolumn{2}{|c|}{$\begin{array}{l}\text { A. Lack of possibility } \\
\text { to recruit a qualified } \\
\text { employee from the } \\
\text { local labour market }\end{array}$} & \multicolumn{2}{|c|}{$\begin{array}{l}\text { B. Recruiting professionals } \\
\text { among the competitors is } \\
\text { less expensive than newly- } \\
\text { employed staff training }\end{array}$} & \multicolumn{2}{|c|}{ No answer } \\
\hline \multicolumn{8}{|c|}{ Other employees } \\
\hline Altogether & 130 & 17 & $13,08 \%$ & $\underline{96}$ & $73,85 \%$ & 9 & $6,92 \%$ \\
\hline $\begin{array}{l}\text { Divisions of credit } \\
\text { institutions }\end{array}$ & 3 & 0 & 0 & $\underline{\mathbf{3}}$ & $\underline{100 \%}$ & 0 & 0 \\
\hline Major & 38 & 5 & $13,16 \%$ & 29 & $76,32 \%$ & 2 & $5,26 \%$ \\
\hline Privatized & 46 & 5 & $10,87 \%$ & 37 & $80,43 \%$ & 1 & $2,17 \%$ \\
\hline \multicolumn{8}{|c|}{ Managers } \\
\hline Altogether & 22 & 7 & $31,82 \%$ & 12 & $54,55 \%$ & 2 & $9,09 \%$ \\
\hline $\begin{array}{l}\text { Divisions of credit } \\
\text { institutions }\end{array}$ & 0 & 0 & 0 & 0 & 0 & 0 & 0 \\
\hline Major & 7 & 4 & $57,14 \%$ & $\underline{3}$ & $\underline{42,86 \%}$ & 0 & 0 \\
\hline Privatized & 7 & 4 & $57,14 \%$ & $\underline{3}$ & $42,86 \%$ & 0 & 0 \\
\hline
\end{tabular}

Table 4. Primary causes of offering competitive working conditions and better-paid jobs to other banks' employees (in the managers and other employees'opinion).

Whereas the response that there is a lack of possibility to recruit a qualified employee from the local labour market was the most frequent among the managers employed in major banks $(57,14 \%)$, in credit institutions outlets $(100 \%)$ and in privatized banks $(57,14 \%)$. This may mean that major banks have some problems recruiting personnel in smaller towns and minor banks have some problems with recruiting professionals. Thereby, professionals are more willing to be employed in a major bank which may provide better working conditions and a higher salary. Similar opinions were expressed by Human Resources Personnel.

\section{Conclusion}

A great majority of Polish banks introduced some codes of ethic or similar solutions, as may be concluded from the analysis carried out. Simultaneously, volunteer work programs or other form of help for employees with a difficult life situation function in some banks. However, there is an impression that formal principles referring to morality are not always practised. To summarize the conclusions, it may be stated that rational use of liberty and mutual trust are sufficient conditions for morality to develop. Whereas, creating a business code of ethic is a 
kind of individual's escape from responsibility and moral dilemmas. Thus, to be moral, it is not necessary to follow any ethical system. Nowadays, it is possible to live "outside the ethic" (Jenkins, 2006) successfully and without any loss. There is only one condition - using the reason in the appropriate manner.

\section{Acknowledgement}

Jerzy Kaźmierczyk is a scholar with Sub-measure 8.2.2 Regional Innovation Strategies of Measure 8.2 Transfer of knowledge, Priority VIII Regional human resources for the economy Human Capital Operational Programme co-financed by European Social Fund and state budget.
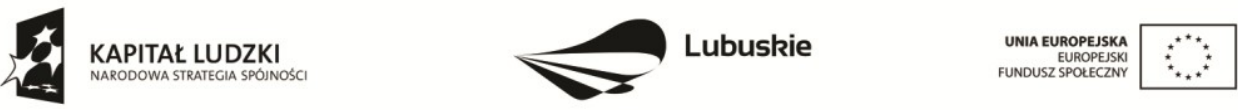

\section{References}

- Maxwell, 2010. Etyka. Studio Emka, Warszawa, p. 13-18.

- Stawrowski, 2008. Niemoralna demokracja. Ośrodek Myśli Politycznej, Kraków, p. 100-101.

- $\quad$ Kant, 2007. Metafizyka moralności. PWN, Warszawa, p. 20, 33-36.

- Höffe, 2003. Immanuel Kant. PWN, Warszawa, p. 163.

- $\quad$ Arystoteles, 2006. Polityka. PWN, Warszawa, p. 28.

- Koneczny, 1999. O ład w historii. Norton, Wrocław, p. 22.

- $\quad$ Blanchard, Peale, 2010. Etyka biznesu. Emka, Warszawa, p. 108-109.

- Fukuyama, 2000.Wielki wstrząs. Politeja, Warszawa, p. 254.

- Sztompka, 2007. Zaufanie. Fundament społeczeństwa. Znak, Kraków, 306-308, 353.

- $\quad$ von Hayek, 1998. „Czynnik moralny w wolnej przedsiębiorczości”, in Moralność kapitalizmu, ed. G. Nowak. Instytut Liberalno-Konserwatywny, Lublin, p. 71.

- Possenti, 2005. Religia i życie publiczne. Chrześcijaństwo w dobie ponowożytnej. Instytut wydawniczy PAX, Warszawa, 259-260.

- Chromińska M., Roeske-Słomka I., Szuman A., Wnioskowanie statystyczne. Zeszyt II, Akademia Ekonomiczna w Poznaniu, Poznań 2008, p. 57-59.

- The Report of the Board on the Activity of the Bank Zachodni WBK S.A. in 2005, p. 30.

- $\quad$ The Annual Report of the Bank Pekao SA 2005, p. 29.

- Business Social Responsibility - The 2008 Report, BPH, p. 4.

- A Collection of Moral Principles for the BGK Employees, http://www.bgk.com.pl

- $\quad$ The 2006 Annual Report, BPH, p. 55.

- The Report on the Activity of the Capital Group of the Bank Handlowy in Warsaw S.A. in the first half year 2007, p. 36.

- Jenkins, 2006. „Żyć w czasie, lecz poza historią; żyć w moralności, lecz poza etyką”, in: Pamięć, etyka i historia, ed. E. Domańska. Wydawnictwo Poznańskie, Poznań, p. 237. 


\title{
Gelişen Liberal Ekonomilerde Bürokrasinin Maliyeti: Türkiye Örneği
}

\author{
Doğan Nadi Leblebici (Hacettepe University, Turkey) \\ Ayşegül Kurban (Hacettepe University, Turkey)
}

\section{The Cost of Bureaucracy in Emerging Liberalized Economies: The Case of Turkey}

\begin{abstract}
During 1980s, developed and developing economies have tended to be more liberalized for the sake of effectiveness assumed to be realized by the virtue of free market economy. Through with this tendency, public bureaucracies have been oriented to utilize productivity methods and techniques of private sector which acts and proofs itself within free market economy. This model for public sector was called "new public management". By this new model, it was supposed that wastefulness in public bureaucracies would be eliminated and they would become more productive. In Oliver Williamson's terms, experienced economic crises in 1970s have been thought to be as a result of bureaucratic failure, and this could be compensated by replacing bureaucracy with market economy. After 30 years of experiencing new public management, and new global economic crises, this assumption seems to need to be tested with relevant comparative data of bureaucratic cost. For testing the hypothesis, longitudinal data of annual budgets of certain ministries in Turkey having voluminous bureaucracies and budgets were collected and compared. Results showed that increasing cost of bureaucracies may require new measures to prevent new economic crises. However, it is not clear that market economy is capable of overcoming economic problems and of filling the gap of a possible lack of regulatory mechanisms.
\end{abstract}

JEL Code: E02

\section{Giriş}

1970’lerin ortasından itibaren kendisini gösteren küresel ekonomik kriz devleti mali ve idari sorunlarla karş1 karşıya bırakmış ve devletler kamu yönetiminde verimliliğin nasıl sağlanabileceğinin arayışına girişmiştir. Bu arayış hükümetleri verimliliği artırmak için özel sektörün işletmecilik tekniklerini kullanarak verimliliği sağlayabilecekleri anlayışına itmiştir (Leblebici, 2004: 11). Bu anlayış, kamunun iktisadi hayattaki rolünün azaltılması, devletin klasik işlevleri olan düzenleme ve denetim alanına doğru çekilerek küçültülmesi, piyasa mekanizmasının sosyal ve ekonomik düzende hakim kılınması, özel sektör yönetim tekniklerinin kamu yönetimine aktarılması; kamu hizmetlerinin kamu sektörü, özel sektör ve sivil toplum örgütleri (üçüncü sektör) ile sunulması tezlerini işleyerek sorunlara çözüm önerileri sunmuşlardır (Güler, 2010: 315). Bu yaklaşım 1980’lerden itibaren Yeni Kamu İşletmeciliği (YKİ) akımının doğması ile neticelenmiştir (Ömürgönülşen, 1999: 142-149). Yeni kamu işletmeciliği yaklaşımı neo-liberal politikalara başat biçimde uygulanmıştır. Bürokratik işlemlerin azaltılması, devletin küçültülmesi, piyasa ekonomisinin desteklenmesi söz konusu yaklaşım içerisinde başta gelen konular olmuştur. Söylemin eylemle ne ölçüde örtüştüğünü görmek için devletin yönetim aygıtı olan bürokrasinin yıllar itibariyle maliyetinin araştırılması gerekir. Böyle bir araştırma mevcut devlet sistemin işleyebilmesi için ortaya çıkan maliyete işaret etmektedir. Williamsson (1981: 549) işlem maliyeti analizi de dahil örgütleri incelemeye dönük ekonomik yaklaşımların genellikle verimliliğe odaklandığını söylemektedir. Maliyet ve verimlilik arasındaki ilişki bürokrasi açısından çok açık olmasa da kabul edilebilir bir ilişkidir. Yeni kurumsal iktisatçıların devletin ekonomik hayat içerisindeki rolünü ve fonksiyonlarını sınırlandırma (Aktan ve Vural 2006: 21) yönündeki görüşleri de esasen bürokrasinin maliyet ve verimlilik bakımından değerlendirilmesi gerektiğine işaret etmektedir. Burada sormamız ve yanıt aramamız gereken bir soru da devletin ve onun idari aygıtı olan bürokrasinin liberal ekonominin aktörlerinden birisi olarak kabul edilip edilemeyeceğidir. Görünen odur ki düzenleyici yapısı ile devlet piyasanın aktörlerinden birisidir. Bu noktada yeni kurumsalcı iktisat açısından devletin maliyetinin ekonominin verimliliği açısından ne olması gerektiğinin sorgulanması gerekir. Hiçbir iktisatçı piyasa ekonominde devlete yer olmadığını söylememiştir. Bunun tersine devletin gerekliliğine vurgu yapılmış ancak devletin rolünün ve kudretinin ne olması gerektiği sorgulanmıştır. Devletin rolü ve kudreti hakkında ne söylenirse söylensin iktisadi arenada bunu hissettirecek olan devletin maliyetinin ne olduğunun anlaşılması olacaktır. Kuramsal açıdan devlet veya onun idari aygıtı olan bürokrasinin tüm fonksiyonlarını piyasa ekonomisinde üretim fonksiyonu dışında kalan düzenleyici işlemler olarak görmek mümkündür. Nitekim liberal düşünürlerin dışında Marx da bürokrasinin üretim süreci ile doğrudan ilişkili olmadığına vurgu yaparak düzenleyici rolüne radikal biçimde dikkat çekmiştir. Marx'a göre bürokrasi toplumlar için bir yük, bir maliyettir. Bürokrasi bir zenginlik yaratmaz. Zenginliğin üretimini, paylaşımını ve tüketimini kontrol eder ve yönetir. Bürokrasi temel gelirini de zenginliğin yaratılması sırasında insan emeğinin ortaya çıkardığı artı değerden alır (Draper, 1977). Uygulamada devletin işlemleri gerçekten düzenleyici özellikte midir? Bu çok tartışmalı bir 
konudur. Her halükarda devletin düzenleyici işlemler veya mal/hizmet üretimine aktardığı kaynakların verimliliği sorgulanmalıdır.

Bu çalışmada Türkiye'de hacimli kabul edilebilecek dört Bakanlığın 2004 yılından başlamak üzere 2009 yılına kadar yıllık bütçeleri incelenmekte ve bütçe artışlarından yola çıkılarak işlem maliyeti kuramı çerçevesinde bir değerlendirme yapılmaktadır. 2004 yılının başlangıç olarak ele alınmasının bir nedeni, üçüncü dönemdir iktidarda bulunan AKP hükümetlerinin neo-liberal politika söylemi içerisinde devletin küçültülmesi bağlamında nasıl hareket ettiğinin görülmesi olarak açıklanabilir. 2004 yılı aynı zamanda daha önce ekonomide gerçekleşen bazı yapısal reformların sonuç vermeye başladığı yıl olması açısından da önemlidir. Analizde 2009 yılının son yıl olarak alınmasının nedeni ise araştırmanın bir sınırlılığı olarak bütçe verilerinin kesinleşmiş olarak elde edilebildiği son yıl olmasıdır. İncelemeye tabi tutulan Bakanlıklar İçişleri Bakanlığı, Milli Eğitim Bakanlığı, Sağlık Bakanlığg ve Milli Savunma Bakanlığıdır.

\section{Türkiye'de Dört Bakanlığın Yıllar İtibariyle Bütçeleri}

Türkiye'de İçişleri, Milli Eğitim ve Sağlık Bakanlıkları toplam memur sayısının çok önemli bir kısmını istihdam eden, sundukları hizmetler itibariyle neredeyse tüm toplumu kapsama alanına alan ve bütçeleri itibariyle en büyük kamu örgütleri konumundadır. Milli Savunma Bakanlığı ise bu üç kuruluşa personel sayısı anlamında değilse de büyük bütçeli olmak anlamında bu bakanlıklara ilave edilebilir. Bu Bakanlıkların Milli Savunma Bakanlığı hariç tümünde personel giderleri toplam bütçe içerisinde en yüksek paya sahip olmaktadır. Bunun yanında bütçe büyüklükleri itibariyle bakıldığında sırasıyla Milli Eğitim Bakanlığı, Sağlık Bakanlığı, Milli Savunma Bakanlığı ve İçişleri Bakanlığı gelmektedir. Dikkati çeken bir husus özellikle son yıllarda İçişleri Bakanlığı'ndaki; görev zararları, hazine yardımları (çeşitli kurumlara kaynak aktarımı), kar amacı gütmeyen kuruluşlara yapılan transferler, hane halkına yapılan transferler (burs, sağlık, eğitim, yiyecek, barınma vb), yurt dışına yapılan transferler (uluslar arası kuruluşlara katkı, yardım vb) gibi ödemeleri içeren "cari transfer" harcamalarının toplam bütçenin üçte biri büyüklüğüne ulaşmış olmasıdır. Sağlık Bakanlığında ise en fazla artış gösteren bütçe kaleminin büro malzemesi alımları, kira, yakıt, elektrik ödemeleri ile parasal limitlere bakılmaksızın rutin bakım-onarım ödemelerini, telefon vb. haberleşme giderlerini, yolluk giderlerini, taşıma giderlerini, düşük değerli veya bir yıldan az kullanım ömrü olan ekipmanlar için yapılan ödemeler ile çeşitleri ve benzeri giderleri içeren "mal ve hizmet alımları" olduğu görülmektedir. Bütçe kalemlerindeki artışları ve bu artışların kurumların toplam bütçeye oranlarının değişmesini hükümetlerin değişen politika öncelikleri ile izah etmek mümkündür. Ancak bütçe toplamlarında (GSYİH'a oranları anlamında) meydana gelen artışların tamamıyla hükümet politikalarına bağlanması mümkün görünmemektedir. Aşağıda toplam bütçe ve çeşitli bütçe kalemleri açısından farklı tablolarda yıllar itibariyle bütçe durumu verilmiştir.

\begin{tabular}{|c|c|c|c|c|c|c|c|c|}
\hline Y1llar & \multicolumn{2}{|c|}{ İçişleri } & \multicolumn{2}{c|}{ Milli Ĕ̆itim } & \multicolumn{2}{c|}{ Sağlik } & \multicolumn{2}{c|}{ Milli Savunma } \\
\hline & Toplam & $\begin{array}{c}\text { GSYİH } \\
\text { Oran1 \% }\end{array}$ & Toplam & $\begin{array}{c}\text { GSYİH } \\
\text { Oran1 \% }\end{array}$ & Toplam & $\begin{array}{c}\text { GSYİH } \\
\text { Oran1 } \%\end{array}$ & Toplam & $\begin{array}{c}\text { GSYİH } \\
\text { Oran1 \% }\end{array}$ \\
\hline 2004 & 652.738 & 0.0011676 & 13.003 .987 & 0.0232616 & 4.461 .251 & 0.0079803 & 9.440 .386 & 0.0168870 \\
\hline 2005 & 797.372 & 0.0012287 & 14.845 .001 & 0.0228761 & 6.766 .994 & 0.0104279 & 10.282 .350 & 0.0158450 \\
\hline 2006 & 907.622 & 0.0011968 & 16.460 .865 & 0.0217050 & 7.471 .587 & 0.0098519 & 11.877 .533 & 0.0156615 \\
\hline 2007 & 1.170 .164 & 0.0013878 & 21.249 .534 & 0.0252017 & 10.354 .283 & 0.0122801 & 13.099 .088 & 0.0155354 \\
\hline 2008 & 1.331 .945 & 0.0014013 & 22.767 .845 & 0.0239527 & 10.823 .840 & 0.0113871 & 13.272 .707 & 0.0139634 \\
\hline 2009 & 1.850 .991 & 0.0019432 & 27.027 .639 & 0.0283737 & 12.451 .274 & 0.0130714 & 14.532 .622 & 0.0152564 \\
\hline
\end{tabular}

Tablo 1. Bakanlıkların Toplam Bütçeleri (1000 TL) ve Gayri Safi Yurt İçi Hasılaya Oranları

Tablo 1'de görüldüğü gibi araştırmaya dâhil edilen Bakanlıkların bütçeleri Milli Savunma Bakanlığg hariç GSYİH'daki payları itibariyle yıllara göre artış göstermiştir. Milli Savunma Bakanlığı bütçesinde toplamda olmamakla birlikte GSYİH içerisindeki payı itibariyle meydana gelen azalmada cari transferlerdeki büyük azalma etkili olmuş gibi görünmektedir. Diğer Bakanlıklardaki artışın enflasyon, ekonomik büyüme vb nedenlerden kaynaklanmış olabileceği düşünülerek GSYİH içerisindeki pay itibariyle de durum değerlendirilmiştir. Görülen odur ki, Bakanlıkların bütçelerindeki artış bütçelerin GSYİH içindeki payı itibariyle de artmıştır. Aşağıda her bakanlık itibariyle yıllık bütçenin GSYİH oranlarının grafik gösterimleri sunulmaktadır.

Analize tabi tutulan büyük bürokratik yapıların bütçelerindeki artma eğilimlerinin kesinleşmemiş bütçeler itibariyle 2010 ve 2011 yılında da sürdükleri müşahede edilmiş, 2012 ve 2013 yılı bütçe tahminlerinin de artış eğilimine işaret ettiği gözlenmiştir. Bu rakamlara kesinleşmiş olmamaları nedeniyle yer verilmemiştir. Ayrıca burada ele alınmayan özellikle devletin piyasayı nesnel biçimde düzenlemesinin bir aracı olarak görülen ve geleneksel bürokrasiden ayrı yapılar olarak tezahür eden, varlıkları tartışmalı biçimde süren düzenleyici bağımsız idari otoriteler de dahil olmak üzere neredeyse kamu bürokrasisinin tamamında artış eğiliminin görüldüğü söylenebilir. Daha sonraki yıllara ilişkin olarak ortaya çıkacak kesinleşmiş bütçe verileri muhtemelen bu artış eğilimini teyit edecektir. 


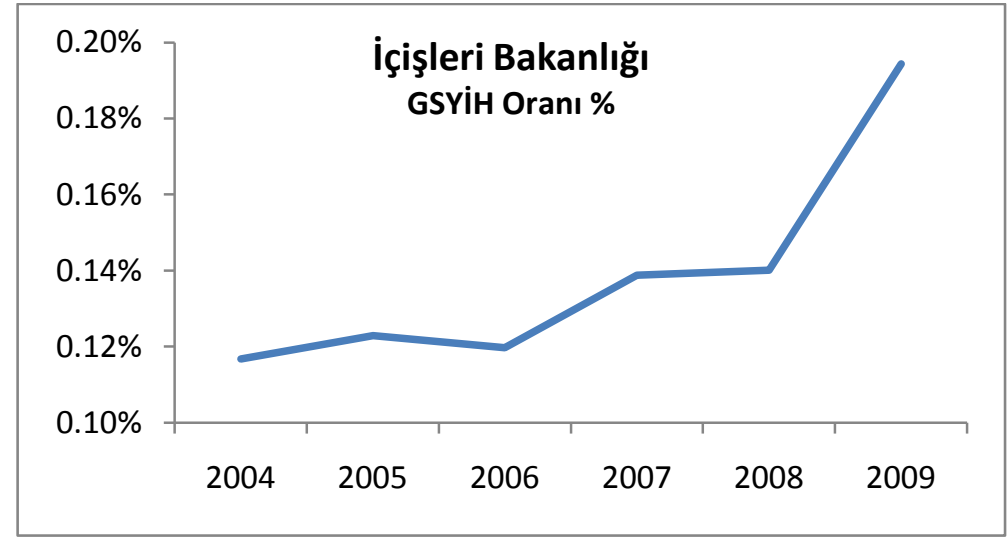

Grafik 1. İçişleri Bakanlığı Bütçesinin Yıllar Itibariyle Gayri Safi Yurt İçi Hasılaya Oranları

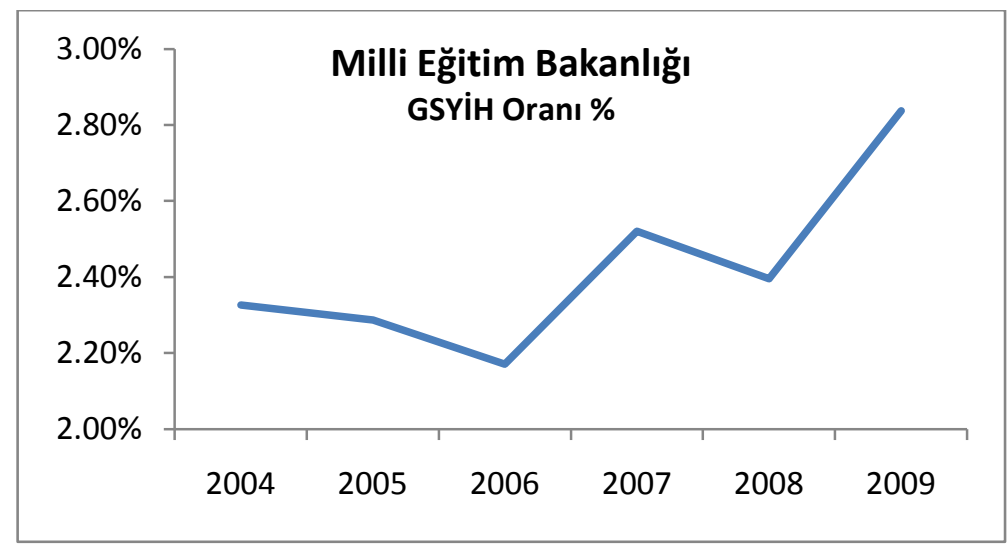

Grafik 2. Milli Eğitim Bakanlı̆̆ı Bütçesinin Yıllar İtibariyle Gayri Safi Yurt İçi Hasılaya Oranları

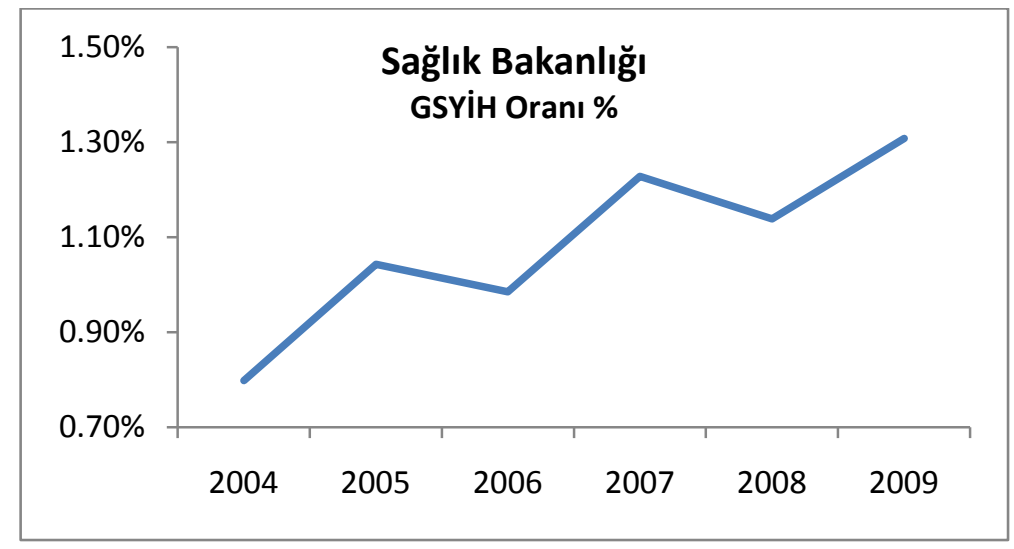

Grafik 3. Sağlık Bakanlığı Bütçesinin Yıllar İtibariyle Gayri Safi Yurt İçi Hasılaya Oranları

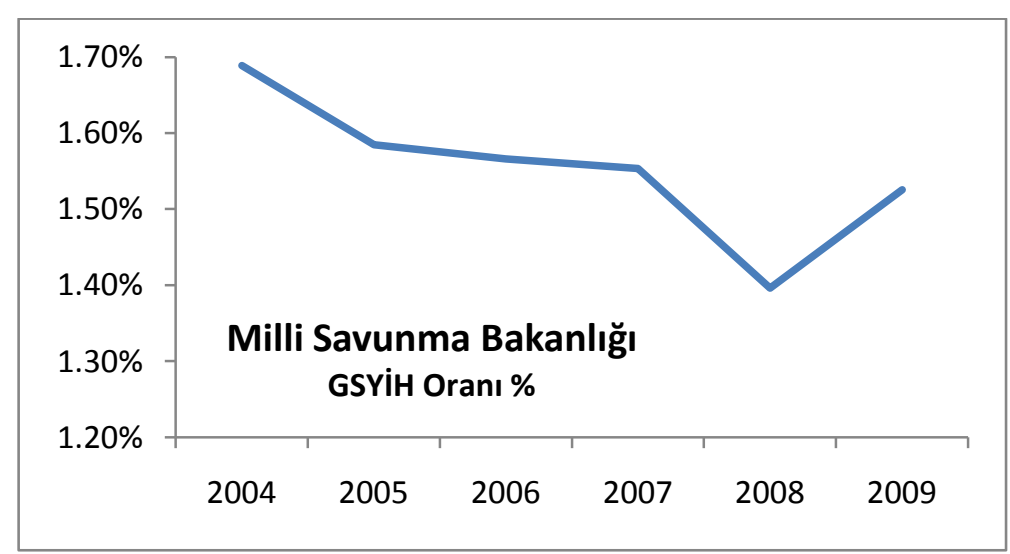

Grafik 4. Milli Savunma Bakanlı̆̆ Bütçesinin Yıllar İtibariyle Gayri Safi Yurt İçi Hasılaya Oranları 


\section{Bürokratik Maliyete İlişkin Tartışma}

Weber bürokrasinin modern zamanların en geniş çapta organize olmuş en verimli yönetim aygıtı olduğunu ve modern sosyal düzenin geniş ölçüde ona dayandığını ifade etmiştir. Parsons (1964: 54) bunu Weber'in (1964) sosyal düzen ve sosyal düzenin kurumları üzerine önemli ekonomik analizler yaptığı "Sosyal ve Ekonomik Örgütün Teorisi” isimli çalışmasının çevirisine yaptığı giriş kısmında belirtmektedir. Aynı eserin ilerleyen kısımlarında Weber'in kendi kaleminden bürokrasinin modern anlamda en rasyonel ve en verimli yönetim aygıtı olduğuna dair bir çok çıkarım bulunabilir.

Weberyan anlamda bürokrasi devletin tarafsız yönetim aygıtı olarak kabul edilir. Bu taktirde liberal bir bakış açısından devletin bu aygıtla neyi yönettiği veya yönetmesi gerektiği sorusu sorulabilir. Bu sorunun cevabı sosyal, siyasal ve iktisadi düzlemlerde verilebilir. Birincisi devlet sosyal düzenin koruyucusudur. Bu devletin rolü açısından en az tartışmalı alandır. Devlet toplumda insanlar arasındaki sosyal ilişkileri düzenler ve sosyal barışı sağlar. Kimsenin buna fazlaca bir itirazı olamaz. Ancak ikinci ve üçüncü alanlar, diğer bir deyişle devletin siyasal ve iktisadi rolü ne olmalıdır konuları oldukça tartışmalı alanlardır. Her ne kadar devletin siyasal rolü dışarıda bırakılarak sosyal ve iktisadi rolü üzerinde ne ölçüde sağlıklı yorum yapılabileceği ayrı bir tartışma konusu olsa da bu çalışmada devletin siyasal rolünün ne olması gerektiğine ilişkin tartışmalar dişarıda bırakılmıştır. O halde elimizde şu soru kalmaktadır: "devlet iktisadi hayatı düzenlemeli midir?” veya "devlet iktisadi hayatı ne ölçüde düzenlemelidir?”. Liberal söylemden yola çıkarak devlete iktisadi hayatta minimal roller biçmek ne ölçüde gerçekçi olacaktır? Devletin doğası buna uygun mudur? Kurumsal iktisadın içerisinde yer alan "işlem maliyeti kuramı" açısından bakıldığında devletin ve onun yönetim aygıtı bürokrasinin doğası hakkında minimalist devlet anlayışına pek de uygun olmayan durumlar ortaya çıkmaktadır. Bürokrasinin düzenleyici işlemlerine baz teşkil eden kararlar konusunda bürokrasi çoğu kez rasyonel değil politik gereklere göre hareket etmektedir. Bürokrasi maliyetler konusunda piyasaya göre daha bağışlayıcıdır. Bürokrasi aşırı yönetmeye eğilimlidir (Williamson, 1985:149-153). Demokrasilerde seçilmişlerin atanmışlara üstünlüğünün esas olduğu düşünülürse bürokrasinin kararlarında politik gereklere göre hareket etmesi fazlaca eleştirilmemelidir. Diğer taraftan bürokrasinin verimlilik konusunda maliyet unsurunu fazlaca dikkate almaması tartışılması gereken bir husustur.

Bürokrasi hakkındaki bu olumsuzluklar bir tarafa, bürokrasinin işlere ne zaman müdahil olması gerektiği, ne zaman piyasadaki düzenleyici rolü konusunda da işlem maliyeti kuramı birkaç şey söylemektedir. Williamson (1975: 26) piyasada güveni ortadan kaldıracak "fırsatçılık" hakim bir davranış kalıbı haline gelmiş ise ve bunu kullanacak alternatif aktörlerin sayısı sınırlı ise (diğer bir ifadeyle tröstler, oligopoller vb yapılar söz konusu ise) düzenleyici gözetim ve denetim sistemlerine olan ihtiyacın artacağına işaret etmektedir. Her ne kadar Williamson söz konusu mekanizmalar ile doğrudan doğruya bürokrasiye işaret etmese de piyasa başarısızlığı durumlarında bu mekanizmaların piyasa içerisindeki aktörler tarafından değil de yine piyasanın vazgeçilmez bir aktörü sayılan devlet ve onun bürokrasisi tarafından devreye sokulduğu iyi bilinmektedir. Williamson'un sözünü ettiği şartlar aynı zamanda piyasadaki amaç çatışmasını ve performans belirsizliğini artıracaktır. Ouchi (1980) de amaç çatışması ve performans belirsizliğinin yüksek olduğu bu noktada bürokrasinin etkili bir arabuluculuk ve denetim birimi olabileceğine vurgu yapmaktadır.

Görünen odur ki, gerek kurumsal iktisat ve gerekse diğer liberal iktisat anlayışları ekseriyetle devletin piyasanın bir aktörü olduğu konusunu açıktan veya zımnen kabul etmektedir. Devletin piyasaya hiç karışmaması noktasındaki anarko-liberal ve ultra liberal görüşler son dönemlerde dünya üzerinde yaşanan büyük ekonomik krizlerde geçerliliğini yitirmiş görünmektedir. Piyasa krizlerine devletler elindeki tüm iktisadi aygıtları kullanarak müdahale etmektedir. Ancak bu müdahalelerin düzenleyici olmanın ötesine geçmediğini söyleyebiliriz. Madem ki devlet piyasanın bir aktörüdür, o halde piyasanın kendi yasaları içerisinde nasıl ki, her bir işletme maliyetleri üzerinden verimlilik anlamında sorgulanıyor ve verimsizlik halinde sert biçimde cezalandırılıyorsa, bürokrasi de düzenleyici işlemlerinin (ki bunların piyasa açısından çoğu kez gözetim ve denetim olduğu söylenir) maliyetlerinin verimlilik anlamında sorgulanması gerekir. Bu çalışmada Türkiye'deki (sınırlılıklar nedeniyle) bazı bürokratik yapıların maliyetlerinin sorgulanmasının amacı budur. Bazıları bu noktada, maliyetler sorgulanırken bu kurumların hizmet üretimlerinin de sorgulanması gerektiğini ileri sürerek sadece maliyet artışları üzerinden verimlilik üzerine yorum yapılamayacağını ifade edebilir. Bu çalışmada verimlilik ölçümü üzerine herhangi bir araştırma yapılmamıştır ve böyle bir şeyin yapılması bu çalışmayı farklı boyutlara götürecektir. Burada amaç biraz da bürokrasinin artan maliyetlerine dikkat çekmek ve bu artan maliyetlerin minimal devlet söylemleri ile örtüşmediğine vurgu yapmaktır.

\section{Sonuç ve Değerlendirme}

Sınırlı verilerden yola çıkarak söylenebilecek tek şey Türkiye'de bürokrasinin maliyetinin giderek yükseldiği görüntüsü olacaktır. Genel olarak bakıldığında 2001 yılından 2006 yılına kadar azalan bütçe açı̆̆ bu tarihten itibaren tekrar artmaya başlamış ve kamudaki borçlanma gereği de buna paralel olarak artmıştır (Hazine Kontrolörleri Derneği İnternet Sitesi, 2011). Kamu mali yönetim açısından oldukça olumlu şeyler (kamu net borç stokunun önemli ölçüde azalmış olması gibi) söylemek mümkün iken bürokrasinin artan maliyetleri açısından 
aynı şeyi söylemek zor görünmektedir. Yine merkezi yönetim bütçesinin GSYIH içerisindeki payının 2006 y1lından 2009'a kadar yükseldiği söylenebilir.

Değişen devlet politikaları, sunulan hizmetlerin çeşitliliği ve miktarı, milli ekonomik büyüme oranlarının olumlu seyri, vb nedenler bürokrasinin maliyetindeki artışın nedenleri olabilir. Bu artı̧̧ı iktisadi yaşam üzerindeki etkileri de benzeri nedenlerle hissedilmiyor olabilir. Bürokrasi GSYIH içerisinde payının artmasından hiç kuşkusuz memnun olacaktır. Ancak, bu durum ekonomide işler yolunda gidiyorken geçerli bir durumdur. Söz konusu olumlu göstergeler bürokrasinin iktisadi anlamda düzenleyici rolünü ne kadar iyi oynadığının işareti sayılmamalıdır. Böyle düşünülürse Türkiye açısından ekonomideki olumlu gelişmelerin mimarı sayılan bir bürokrasi gün gelir ekonomideki olumsuz gelişmelerin "baş mimarı" sayılabilir. Türkiye açısından cari açığın her geçen gün büyümesinin iktisadi olumsuzluk işareti sayıldığı bir ortamda bir diğer olumsuzluk bürokrasinin giderek artan maliyetidir. Bu maliyetin bir gün karşılanamaz hale gelmesi söz konusu olabilir. Vergi politikaları bu açıdan önemli olmasına rağmen bir toplumda vergilerin katlanılabilir eşiği geçme riskine karşı dikkatli olunması önemlidir. Bürokrasinin artan maliyetleri bu açıdan belki bugün dikkat çekmese de bir risk oluşturmaktadır.

Türkiye küresel krizlerin ortasında (Türkiye'nin aslında şu anda ne kadar bağışık durumda olduğu ve krizi ne ölçüde hissettiği veya hissetmediği tartışmalı olmakla birlikte) uzun süre bağışık vaziyette durabilir mi? Birçok iktisatçı buna olumlu yanıt vermeyecektir. Türkiye'yi ciddi biçimde etkileyecek bir ekonomik krizde bürokrasi artan maliyetleri ile tıpkı 1970'lerin ikinci yarısında olduğu gibi günah keçisi olmaya namzet olacaktır. Yapılması gereken bazı bürokratik reformların gözden geçirilmesi, bürokraside dual (aynı işi yapan veya yapmaya aday birden fazla bürokratik yapı) yapılanmadan vazgeçilmesi, sadece yapısal reformların ötesinde insanı merkeze alan bir devlet personel reformunun gerçekleştirilmesidir. Zira bugün bürokrasinin en büyük maliyet kalemi personel harcamaları olmaktadır. Daha özetle söylemek gerekirse yapılması gereken bürokrasinin maliyetinin azaltılması, bu mümkün olamıyorsa maliyet artışının önüne geçilmesidir.

\section{Kaynakça}

- Aktan, Coşkun C. ve Tarık Vural, 2006. Yeni Kurumsal İktisat, Kurumsal İktisat (Editör: Coşkun Can Aktan), Ankara: SPK, 19-42.

- Draper, Hal, 1977. Karl Marx's Theory of Revolution, I: State and Bureaucracy. New York and London: Monthly Review Press, 1977.

- Güler, B. A., 2010. Türkiye’nin Yönetimi-Yapı, İmge Kitabevi, Ankara, (2. Baskı).

- Hazine Kontrolörleri Derneği İnternet Sitesi, 2011 (Verilerin alındığı tarih 21.08.2011). http://www.hazine.org.tr/ekonomi/kfinansmani.php

- Leblebici, Doğan Nadi, 2004. Kamu Yönetimi: Dünyada ve Türkiye'deki Gelişimi, Kamu Yönetimi Gelişimi ve Güncel Sorunlar (Ed. M.K. Öktem ve U. Ömürgönülşen), 7-25

- Ouchi, William G., 1980. Markets, Bureaucracies, and Clans, Administrative Science Quarterly, 25(1), 129-141.

- Ömürgönülşen, Uğur, 1999. Different Positions Concerning the Management Function in the Public and Private Sectors, and Distinctive Place of public Management in the Spectrum of These positions, H.Ü. İiBF Dergisi, 17(1), 125-168.

- Parsons, Talcott, 1964. Introduction in The Theory of Social and Economic Organization, (Translated by A. M. Hendeson and Talcott Parsons, Edited with an Introduction by Talcott Parsons), New York: Free Press: 3-86.

- Weber, Max, 1964. The Theory of Social and Economic Organization, (Translated by A. M. Hendeson and Talcott Parsons, Edited with an Introduction by Talcott Parsons), New York: Free Press.

- Williamson, E. Oliver, 1975. Markets and Hierarchies: Analysis and Antitrust Implications, New York: Free Press.

- Williamson, E. Oliver, 1981. The Economics of Organization: The Transaction Cost Approach, The American Journal Of Sociology, Vol. 87, No: 3: 548-577.

- Williamson, E. Oliver, 1985. The Economic Institutions of Capitalism, London: Free Press. 


\title{
Sosyal Parafiskal Yük Açısından Avrupa Birliği ve Türkiye Karşılaştırması (1995-2008)
}

\author{
Sevilay Gümüş (Hacettepe University, Turkey)
}

\section{A Comparison of European Union and Turkey from the Perspective of Social Parafiscal Burden (1995-2008)}

\begin{abstract}
While the need for human to protect themselves againist dangers they may face all through their lifes has introduced the social security concept; reducing the harm caused to humans faced with dangers has conceived the social insurance concept. In time, the context of social security broadend and following World War II it has became an increasingly important issue around the world. The main area of the study regarding this issue is to make a comparison between the social security subsidies paid by EU member countries and Turkish Republic citizens between 1995-2008 in terms of social parafiscal burden on the citizens of that country. İn this context, the data of EuroStat, OECD, SPO and Turkish Republic Social Security Institution has been benefited from in order to make an assessement. In conclusion, the EU shows a more balanced profile in terms of social parafiscal burden and social expenditure compare to Turkey and even though the social parafiscal burden depending on the observed high informal economy, seems low in terms of numbers; it can be said that the social parafiscal burden on Turkish citizens quite heavy.
\end{abstract}

JEL Code: H55

\section{Giriș}

$\mathrm{Bu}$ çalışmanın konusunu oluşturan parafiskal gelirler bazı kamu ya da yarı kamu kuruluşu niteliğindeki ekonomik sosyal veya mesleki kuruluşlar tarafindan belirli amaçların finansmanına tahsis edilmek üzere, kamu otoritelerince gelir toplama yetkisinin verilmesiyle ortaya çıkan bütçe dışı bir kamu geliridir (Herekmen, 1972;s.5). Sayar (1975;s.249) ise resmi ya da yarı resmi nitelikteki ekonomik sosyal ve mesleki kuruluşların yaptıkları hizmetler karşıllı̆ında, bu hizmetlerden direkt veya endirekt bir şekilde faydalanan ya da faydalanacak durumda olanlardan çeşitli adlarla aldıkları paraları parafiskal gelirler olarak nitelendirmiş̧tir. Cebren alınması, yükümlülükten kaçınılamaması ve sağlanan fayda ile ödenen miktar arasında bir ilişki bulunmaması dolayısı ile vergiye benzerken, bireysel bir karşılık sağlanması, tahsil ve harcama usullerin farklı olması ve devlet bütçesinde yer almaması dolayısı ile de vergiden ayrılır. Dünya literatüründe de sosyal güvenlik hizmetlerinin sunulması için gereken kesintiler zorunlu olarak alınan katılım payı (Social Security Contributions) veya vergi (Social Security Taxes, Les Taxes Parafiscales) olarak adlandırılmışlardır.

\section{Gayri Safi Sosyal Parafiskal Yük ve Analizler}

Giriş kısmında da belirtildiği üzere bu çalışma parafiskal gelirlerin sosyal boyutunu ele almaktadır. Sosyal parafiskal gelirlerin konusu sosyal parafiskal gelir toplama yetkisi verilmiş sosyal güvenlik kuruluşlarına üyeliktir. Bu kapsamda sosyal güvenlik kurumlarına üye olan ve prim ödeme yükümlülüğü altına giren kişiler ise sosyal parafiskal gelirlerin mükellefleri olmaktadır. Gerek işçi gerek memur olarak bordro bazında çalışan mükelleflerden devlet sigorta prim ya da aidatlarına esas maaş ve ücretleri baz alarak sosyal güvenlik primi kesintisi yapar ki aslında bu primler devletin aslında sosyal güvenlik ile koruma altına alınmamış vatandaş bırakmama çabasının bir sonucu olarak tezahür eden zorunlu kesintilerdir. "İşveren ise zorunlu olarak bir ödeme yaptığı halde karşıllı̆ında herhangi bir hizmetten yararlanamaması dolayısıyla vergiye benzer bir nitelik taşımaktadır” (Akdoğan,1999;s.376). Fakat, çalışan kesimin soysal güvenlik katkılarının “ işverene ek bir yükümlülük yaratmaktan ziyade çalı̧̧anların verimliliklerini arttırması dolayısıyla yarar sağladığı, bu ödemeler yapılmamış olsaydı işveren çalışanına daha çok maaş ve ya ücret sağlamak zorunda olacağına dair görüşler de mevcuttur" (Herekmen, 1972;s. 22).

Ekler kısmında yer alan grafiklerden Grafik 1'de on y1llar bazında Avrupa ülkelerinin çoğunda ve Türkiye'de 1970 'ten günümüze sosyal güvenlik gelirlerinin toplam vergi gelirleri içerisindeki payı artan bir trend göstermiştir. Ancak İskandinavya ülkelerinden Danimarka'da sosyal güvenlik primlerinin vergi gelirleri içerisindeki payı on yıllar bazında ortalaması \%2,39 olmak üzere oldukça düşüktür. Oysa Danimarka GSYIH'sına oranla ortalama \%33 oranında vergi geliri toplamaktadır. Bu durum Danimarka'nın toplam vergi gelirleri sektörel bazda incelendiğinde kazanç ve gelirlerden elde ettiği vergi gelirlerinin çok yüksek olmasıyla ilintilidir. Yani, Danimarka hükümeti sosyal güvenlik hizmetini doğrudan prim toplayarak finanse etmek yerine kazanç ve gelirlerden elde ettiği vergilerle finanse etme yolunu seçmiştir. Avrupa Sosyal Kodu olarak nitelendirebileceğimiz Sosyal Devlet anlayışını benimsediğini deklare eden Fransa, Almanya gibi ülkelerin ise 
sosyal güvenlik primlerinin toplam vergi içerisinde sırasıyla on yıllık ortalamalar olarak \%39,63 ve \%35,62 olarak değiştiği görülmektedir. Türkiye ise on yıllar bazında bu skala da \%14,76 ile ortalarda yer almaktadır. Ancak Türkiye'de kayıt dışı ekonominin yüksek oranlarda olduğu, sosyal güvenlik primleri değerlerinin sosyal güvenlik primleri ödeyen kişilerden yola çıkarak hazırlandığı, birçok işverenin daha az vergi ve sosyal güvenlik primi ödemek adına sosyal güvenlik primine esas teşkil eden maaş ve ücretleri düşük gösterdiği ve çoğunlukla kamu kesiminde ya da kurumsallaşmış özel sektörde bordro bazında çalışanlardan sağlıklı biçimde bu primlerin toplandığı da bu kapsamda ayrıca dikkate alınmalıdır.

Grafik 2 ise 27, 25 ve 16 Avrupa Birliği üye ülkesinin sosyal güvenlik primlerinin toplam vergi gelirleri içerisindeki ağırlıklı ortalamasını yansıtmaktadır. 1995-2008 arasında 16 Avrupa Birliği üye ülkesinin sosyal güvenlik prim gelirlerinin toplam vergi gelirleri içerisindeki pay1 \%36,35 iken 25 Avrupa Birliği üye ülkesinin aynı konuya ilişkin payı \%32,52dir. 1990’lı yılların sonunda 25 AB üyesi ülke için ortalama \%34 düzeyinde olan bu pay, 2000li y1llar düşünüldüğünde \%32'ye düşmüştür. Seçilen Avrupa ülkeleri içinse 1960'tan 1990'da dâhil olmak üzere \%25,26'dır. EuroStat'ın 27, 25 ve 16 Avrupa Birliği üyesi ülke örneklemleriyle bu çalışmada yapılan çıkarımın Türkiye ile yapılan bir karşılaştırma için daha iyi bir örneklem verebilmek kaygısı ile ayrıca 1965-2008 yılları arasında Belçika, Fransa, Hollanda, Lüksemburg, Almanya, İtalya, İspanya ve İngiltere'den oluşan örneklem için OECD ve EuroStat verileri baz alınarak bir karşılaştırma yapılmıştır. EuroStat verilerine göre bu sekiz ülkenin sosyal güvenlik gelirlerinin toplam vergi gelirleri içerisindeki payı 1995-2008 y1lları arasında \%32,35tir. İçlerinde en düşük ortalama \%17,65 ile İngiltere'nin iken \%41,52 ile en yüksek ortalama Almanya'nındır. Bu rakamların ise EuroStat 25 Avrupa Birliği üye ülkesi için ortalama olarak bulunan rakamdan çok farklı olmadığı görülmektedir. Beş yıllar bazında 1995-2009 arasında ise yukarda seçilen örneklemdeki ülkeler için OECD verilerine göre sosyal güvenlik primlerinin toplam vergi gelirleri içerisindeki payına ilişkin bulunan ortalama ise \%32,79. İngiltere 1965-2009 arası beş yıllık periyotlarda \%17,16 ile sosyal güvenlik primleri toplam vergi gelirleri içerisinde en az paya sahip ülke olurken, EuroStat 1995-2008 verilerinin işaret ettiğinden farklı olarak Fransa \% 39,63 ve sonrasında İspanya \%38,20 ile vergi gelirleri içinde en yüksek sosyal güvenlik primleri gelirine sahip ülke olmaktadırlar.

1965-2009 yılları arasında beş yıllık dönemler baz alınarak bir inceleme yapıldığında ise Grafik 3'te de görüleceği üzere sosyal güvenlik primleri artan bir trend izlemektedir. Finlandiya, Yunanistan, Portekiz ve Türkiye sosyal güvenlik primlerinin GSYIH'ya oranı ya da sosyal parafiskal yük olarak dramatik bir artış profili çizerken Lüksemburg, İsveç ve İngiltere ve sosyal güvenlik yükü çok fazla olsa dahi İsveç daha dengeli bir profil çizmektedir. Fransa 1965lerden 90ların sonuna kadar yüksek sosyal parafiskal yüke sahip iken 2000li yıllarda sosyal güvenlik primlerinin gayrisafi yurtiçi hâsılaya oranını önceki yıllara göre düşürmüştür. Danimarka en düşük sosyal parafiskal yüke sahip ülke olurken aslında daha öncede belirttiğimiz bu misyonunu tarihsel olarak taşıdığını da gözler önüne sermektedir. Genel itibariyle bakıldığında birçok Avrupa ülkesinin sosyal parafiskal yükünün arttığı Türkiye'nin de bu trende uyum gösterdiği hatta sosyal parafiskal yükünün diğer gelişmiş ülkelere kıyasla son derece düşük olmasından ötürü onlardan daha iyi bir konumda olduğu düşünülebilir. Ancak böyle bir düşüncenin neden temelsiz olduğu çalışmanın ilerleyen kısımlarında daha net anlaşılacaktır.

Çalışmada 1995-2009 yılları arasında en yüksek sosyal parafiskal yük ortalamasına sahip ülkenin Fransa, en düşük sosyal parafiskal yük ortalamasına sahip ülkenin ise Danimarka olduğu gözlemlenmiştir. Grafik 4, bahsedilen sosyal parafiskal yük ortalamalarını göstermektedir. Seçilen Avrupa ülkelerine yönelik toplam ortalama sosyal parafiskal yük ise, Türkiye hariç, \%11,9dur. Türkiye ise 1995-2009 aralığında \%4,65 ortalama sosyal parafiskal yük oranına sahiptir. EuroStat'ın verilerine göre ise 25 ve 16 Avrupa Birliği üye ülkesinin aynı tarih aralığı içerisinde sahip olduğu ortalama gayrisafi yurtiçi hâsıla ağırlıklı parafiskal yük değişimi ise Grafik 5'de sunulmuştur. Bu grafikte Avrupa Birliği’ne yeni katılan ülkelerin Avrupa Birliği için sosyal parafiskal yük oranını azalttığı görülmektedir.

Türkiye'de toplanan sosyal güvenlik primlerinin Gayri Safi Yurtiçi Hâsıla içerisindeki payı ise Grafik 6'da gösterilmektedir. Türkiye'de toplanan sosyal güvenlik gelirleri 1965 yılından 2009 yılına kadar dramatik bir artış göstermiş, 1995, 1999, 2002 ve 2005 yıllarında ise kırılma yaşanmaktadır. 1995 ve 2002 yıllarında görülen düşüş ülkede yaşanan ekonomik krizlere bağlanabilir. Nitekim ülkede 1995 krizinde işsizlik oranı artmıştır. 2002 yılındaki kırılma ise 2001 yılında yaşanan krizin arţ̧ılıdır. Kriz dönemde ülkede işsiz sayısının artması, ekonomik bireylerin gelecekte de durumun değişmeyeceği kanaati ile tasarruflarını saklaması bu düşüşlerin sebeplerinden bazılarıdır. Ayrıca, 2003 yılında ülkede yapılan sosyal güvenlik reformunun taslağının 2002'de hazırlanışı 2003 Ocak’ta yürürlüğe girişi ise bir başka nedendir. 1996,97 ve 98 yıllarında sosyal parafiskal yük kısmen sabit kalmış, 1999 yılından başlayarak artış göstermiştir. 2005 yılında başlayan düşüş trendi ise 2007'de \%5,22 olmuş ve sonrasında artış göstermeye devam etmiştir. Yapılan reformlara rağmen, Avrupa ülkelerinde özellikle de Fransa, Almanya, İngiltere gibi gelişmiş ülkelerinde sosyal parafiskal yük açısından çok az değişmeler yaşanırken Türkiye'de sosyal parafiskal yük açısından yaşanan dramatik artışlar sosyal güvenlik reformları ve primlerin vatandaşa yüklediği yük açısından daha çok yol kat edilmesi gerektiğini işaret etmektedir. 2005 tarihinden itibaren TL'sından 6 sıfır atılmasıyla prim yükü alt ve üst sınır değerlerinin değişmiştir. Çalışmanın bu belgede ilgilendiği kısmı ise alt ve üst sınır yüzdeleri oluşturmaktadır. Bu belgeye göre Türkiye'de toplanan sosyal güvenlik prim gelirlerinin sosyal güvenlik sigortasına esas teşkil eden maaş ve 
ücretlere bölünmesi sonucu elde edilecek gayrisafi sosyal parafiskal yük’ün 1995-2011 arasındaki alt sınırı \%33,5 iken üst sınırı \%39'dur. Yani Türkiye Cumhuriyeti vatandaşlarının yaklaşık olarak hissettikleri gayrisafi sosyal parafiskal yük ağırlığı bu bant içerisinde gidip gelmektedir. 2008 senesi itibariyle yıllık asgari 651 lira kazanan bir kişi maaşının 218 ila 254 lirasını sosyal güvenlik primi olarak bu primleri toplayan kuruma vermektedir ki hatırı sayılır derecede büyük bir orandır.

Sosyal Parafiskal Yük'ün ne kadarına çalışan kesimin ne kadarına işverenin katıldığı, toplam sosyal parafiskal yük ile çalışan ve işveren payları toplamı arasındaki farkın ne kadar olduğu ve bu farkın nereden kaynaklandığı da yapılan araştırma için önemlidir. Bu sebepten ötürü çalışmanın bu kısmında öncelikle çalışan kesimin sosyal parafiskal yükü, sonrasında ise işverenin sosyal parafiskal yükü hakkında analizler yapılacak ve konu detaylandirılacaktır.

Sosyal güvenlik yükünün en düşük olduğunu saptadığımız Danimarka'da çalışankesim üzerindeki sosyal parafiskal yük Grafik 7'den de anlaşılacağı üzere 1980 yılında yaklaşık \% 0,4 iken 1990 yılında yaklaşık \%1'e 2000 yılında ise \%1.76'ya çıkmıştır. Çek Cumhuriyeti'nde 2000'den 2009'a yaklaşık \%0,5 lik bir azalış göstermekle beraber ülke hakkında bu tarihten öncesi hakkında veri bulunamadığı için sağlıklı bir karşılaştırma yapmak da şu an itibariyle mümkün olmamaktadır. Fransa'da 1990 sonrası, İspanya'da 1980 sonrası çalışan kesimin sosyal parafiskal yükünde bir azalış görülse de 1970-2009 arasında on yıllık veriler baz alınarak değerlendirilen GSYIH ağırlıklı ortalama Fransa için yaklaşık \%4,08, İspanya için \%1,81'dir. İngiltere çalışan kesimin sosyal parafiskal yükü açısından binde değerleriyle ifade edilebilecek küçük artışlara sahip olsa da yine dengeli bir duruş sergilemektedir. Türkiye dâhil olmak üzere diğer Avrupa ülkelerinde ise çalışan kesimin sosyal güvenlik katkılarının gayri safi yurtiçi hâsıla içerisindeki payı artan bir seyir izlemektedir.

Hollanda 19901ı yıllarda çalışanlarından aldığı sosyal güvenlik primlerinin GSYIH içindeki payını 1997 sonrası yaklaşık \%3 sayılabilecek radikal bir biçimde düşürmüştür. "1992 yılında yürürlüğe giren yeni düzenlemeler kapsamında hastalık halinde işe devamsızlı̆̆ın ilk 6 haftasına ilişkin maliyetlerin işveren tarafından karşılanması, halkın istisnalar hariç sadece bir yıldan fazla süren riskler açısından koruma kapsamına alınması" (Egeli,2009;s.65) ve "hükümet tarafindan bireysel emekliliğin özendirilmesiyle ülkede çalışanların \%90'ınan yakınının bireysel emeklilik sistemine girmesi” (Tuncay,2000;s.5) ve "yaşlılık aylı̆̆ııın son maaş yerine ortalama maaş üzerinden hesaplanarak emeklilik sisteminin yükünün azaltılmaya çalışılması", (Tüsiad, 2004;s.92) gibi uygulamalar bu düşüşün sebepleri olarak gösterilebilir. Türkiye'de ise 1995'te \%0,79 olan çalışan kesimin sosyal parafiskal yükü sürekli bir artış göstermiş 2009 yılında \%2,21'e çıkmıştır. Sadece Yunanistan ve Türkiye örneklerinde görülen bu artış Yunanistan için \%0,9 düzeyinde gerçekleşirken Türkiye için yaklaş1k \% 1,5 düzeyinde olmuştur.

İşverenlerin sosyal güvenlik gelirlerine katkısının gayri safi yurtiçi hâsıla içindeki payının gösterildiği Grafik 8'den görüleceği gibi Avusturya, Belçika, Fransa, Almanya gibi sosyal devlet anlayışını benimsemiş ülkelerde 1970'den bu yana 10 yıllar bazında işverenin sosyal parafiskal yükü artmıştır. İskandinavya ülkelerinden Finlandiya'da bu oran artarken diğer İskandinavya ülkelerinde azaldığ işveren üzerindeki sosyal parafiskal yükün 2009 'da \%0,01 düzeyine gerilediği gözlemlenmektedir. Verilerin de işaret ettiği üzere, 1992 yılında yeni düzenlemeler yapılmadan önce de bu ülkedeki sosyal parafiskal yük tanımı itibariyle, prim şeklinde alınması, düşüktür. Bunun sebepleri içerisinde devletin sosyal güvenlik primlerini yüksek tutmak yerine kazanç ve gelirlerden vergi geliri elde etmeyi tercih etmesi, yardımların çoğunun işçi ve işveren primlerinin yanı sıra devletin katkılarıyla yapılması yer almaktadır. İsveç’te 1970 yılında \% 4,45 olan işverenin sosyal parafiskal yükü 2009 yılında \%8,50olmuştur. İspanya'da ise 2009 ile 1970 yılları arasındaki fark \%3,80'dir. Finlandiya'da ise bu fark \%6,80'e çıkmaktadır. İsveç'te genel anlamda sosyal parafiskal yükün yüksek olmasının sebebi "kazançlar oranında yüksek primlere dayalı sosyal güvenlik sisteminin benimsenmiş" (Egeli,2009;s.66) olmasıdır. Yine Egeli (a.g.e;.66)'nin aktardığı üzere yaşlılara yapılan yardımlar ücretin \%95'i oranındadır ki bu yardımlar sadece işveren tarafından karşılanmaktadır. İşveren üzerindeki sosyal parafiskal yükün İsveç’te yüksek olmasının sebeplerinden biride budur denilebilir. Ayrıca, İsveç hükümetinin artan sosyal harcamalar ve bütçe açıkları sebebiyle çoçuk yardımları, işsizlik sigortası gibi ödemelerde kesintiye gittiği, işçilerin prim ve vergilerini arttırdığı (Bilgili, 2008;s.8: akt. Egeli, a.g.e;s.66) da bilinmektedir. Ancak, tüm bunlara rağmen 1990 sonrası İsveç’teki işverenlerin sosyal parafiskal yükleri 1980 sonrasına göre yaklaşık \%4 oranında azalmıştır. Finlandiya içinde kısıtlamalardan ve yük oranlarının artırımından bahsedilebilir.

Türkiye için ise 1970 ’te \%0,37 olan işverenin sosyal güvenlik katılımlarının gayri safi yurtiçi hâsıla içerisindeki payı 2009'da \%3,30'a çıkmıştır. Bu ise yaklaşık \%3lük bir artış demektir ki bu tür bir yükün sürekli artış göstermesi dikkat çekicidir. 2001 yılında Türkiye'de bu yük çeşidinin \%0,97 yani neredeyse \%1'lik bir artış yaptığı görülmektedir ki çalışan kesimin sosyal parafiskal yük oranı ve toplam sosyal parafiskal yük oranı göz önüne alındığında ülkede o sene yaşanan kriz ortamında işverenin sosyal parafiskal yükü daha çok sırtladığı söylenebilir.

Bu noktada belirtilmesi gereken bir başka husus ise işveren sosyal güvenlik katılımlarının içerisinde sadece çalışanı için yaptığı sosyal güvenlik prim ödemeleri yoktur. Kendisi ve aile fertlerinden çalışmayanlar için yaptığı prim ödemeleri de vardır ki özellikle Türkiye örneğinde üzerinde durulması gerekir. Bu çerçeveden bakıldığında 2001 yılında işverenin sosyal güvenlik primleri ödemesinin gayri safi yurt içi hâsıla içindeki 
payının artmasının sebeplerinden biri olarak ülkede yaşanan kriz sonrası işsiz aile fertleri, akraba ve hısımların primlerinin doğrudan işverenin cebinden çıkmamış olsa dahi işverenin firması üzerinden yatırılması ihtimali de gösterilebilir. Ayrıca 1995-2009aralığında işveren sosyal parafiskal yükünün çoğu Avrupa ülkesi için düşerken Türkiye için artması bir başka dikkat çekici unsurdur.

OECD ve EuroStat verileri incelendiğinde sosyal güvenlik katkılarının önemli bir kısmının özellikle bordro ile çalışan işçi, memur ve bu bazda kişi çalıştıran işverenden alındığı görülmektedir. Gelir bazında bakıldığında sosyal güvenlik primleri bakımından çok fazla veri bulunamaması ya da başka bir ifade ile sadece bir iki istisnai ülke için veri bulunabilmesi hem ülkelerin bu alanda hassasiyet göstermemelerinin, hem uyguladıkları sosyal politikalarda hangi kesimi hedef aldıklarının hem de kayıt dışı ekonomilerin varlığının birer göstergesi olarak kabul edilebilir. Bu tespitlerin yanı sıra sosyal güvenlik primlerinin kamu kesimi son derece geniş olan Türkiye gibi ülkelerde çalışanların büyük bir kısmı kamu sektöründe faaliyet göstermekte iken sosyal parafiskal yüke de büyük ölçüde bu kesimin katlandığını söylemek de yanlış olmayacaktır.

\section{Sosyal Güvenlik Harcamaları ve Sosyal Güvenlik Açı̆̆ı Analizleri}

Devletlerin elde ettiği sosyal parafiskal gelirler kadar bu gelirlerin yapılan sosyal harcamaları karşılayıp karşılamadığı, karşılamıyor ise aradaki farkın nasıl kapatıldığı da sosyal parafiskal yük kapsamında merak ettiğimiz bir konu olduğundan, çalışmanın bu bölümünde sosyal harcamalara ve arada kalan finansman açıklarının özellikle Türkiye örneğinde ne kadar olduğuna ve nasıl kapatıldığına yer verilecektir.

Grafik 9'un işaret ettiği üzere, Avrupa ülkelerinin genelinde sosyal harcamalar 1980'ten bu yana artma eğilimindedir. İrlanda, Hollanda, Polonya, Slovak Cumhuriyeti ve Slovenya'da ise y1llar içinde sosyal harcamaların azaldığı gözlemlenmektedir. Polonya'da 1999 yılında yapılan reformlar, işsizlik sigortası ve hastalık ödemelerinin kötüye kullanılan kısmı kısılarak yapılan iyileştirme çalışmaları ile emeklilik yaşının kademeli arttırılışı (Egeli,2009;s.76) bu azalmanın sebepleri arasında sayılabilir. Gerek Slovak Cumhuriyeti'nde gerekse Slovenya'da Polonya'da olduğu gibi kısıtlamalara gidilmiş, Slovenya'da isteğe bağlı emeklilik sistemine geçilmiştir. Katkı paylarının gittikçe azalması ve sosyal güvenlik harcamalarındaki artışlar ülkeyi tedbirler almaya yöneltmiş, işsizlik sigortası, emeklilik, sağlık hizmetleri maliyetlerinin düşürülmesine karar verilmiştir. İrlanda'nın durumunu analiz edebilmek içinse konuya daha derinlemesine bakılmalıdır. İrlanda'da özellikle sosyal içerikli politikaların uygulanmasında devletteki birimler arası inisiyatifler ve işbirliği üst düzeydedir ki İrlanda'nın 2000 sonrası başlayan hızlı gelişmesinin bir sebebi de toplumsal dayanışmadır. Bu sosyal dayanışma kurumların yapılanmasına da yansımış, sivil toplum örgütlerinin yardımlaşma adına oynadığı rol yıldan yıla artmıştır. 30 yıl öncesinde bölge halkının çoğunluğunun yaşlılardan oluştuğu ve sosyal yardımlarla geçindiği de göz önünde bulundurulursa 90ların sonundan itibaren hızlı bir gelişmeyle beraber sosyal güvenlik harcamalarının da düşüş nedenlerine ulaşılabilir (www.aile.gov.tr)

1980'den 2007'ye sosyal güvenlik harcamaları en çok artmış ülkeler sırasıyla Portekiz, Yunanistan, İsviçre ve Fransa'dır. Fransa sosyal güvenlik harcamalarındaki artışın 1985 sonrası başladığı 1992'den sonra ise ivme kazandığı görülmüştür. 1993-1995 döneminde emekli aylıklarının hesaplanmasında esas teşkil eden kazançların yeniden değerlendirilmesi ve emekli aylıklarında fiyat değişmelerine göre ayarlamalar yapılmasına (TiSK,1997;s.17) dair düzenlemeler yapılmıştır. Ancak kısıtlamalar sosyal güvenlik sistemin yetersiz olduğu noktada devreye giren çocuk yardımları (genelde 16 yaşına kadardır ama eğitim, sağlık gibi belirli şartlarda süre uzayabilir), aile yardımları, hastalık yardımları gibi sosyal güvenlik yardımları (Kaufman, çvrn: Centel, 1999; 11-15) devreye girer. Bu yardımlar artışın temel sebebi olmamakla beraber bir kısmını açıklayabilir ki konuyla ilgili diğer bir boyutta Fransa'da yaşayan bireylerin yaşlandığı olgusudur ki Holzman (2003,s.3) Avrupa ve OECD ülkeleri arasında yaptığı karşılaştırma da Avrupa ülkelerinin sosyal güvenlik harcamalarındaki artışın ve bu ülkelerde ki harcamaların artış oranının OECD ülkelerinin sahip olduğu sosyal güvenlik harcamaları artış oranından fazla oluşunu bahsedilen yaşlılık olgusu ile açıklar.

Türkiye'de de sosyal güvenlik harcamaları 1993 ve 2009 yılları düşünüldüğünde yaklaşık 2 katı kadar bir artış vardır. 1995 yılında GSYIH'ya oranla \%0,2 düşen sosyal güvenlik harcamaları 1999 yılına kadar çıkış yaşamış, 2000 yılında 1999 yılına kıyasla \%0,5 düşmüştür. Grafik 8, Türkiye için sosyal güvenlik gelir ve giderlerinin gayri safi yurtiçi hâsıla içindeki paylarını göstermektedir. 2003 yılında gerçekleştirilen sosyal güvenlik reformuna rağmen 2001'den sonra açılmaya başlayan makas 2006'da giderlerin yaklaşık \%3 kadar düşmesi ile birlikte kapanmaya başlamış iken 2007 sonu 2008 başı itibariyle sosyal güvenlik primlerinin düşmesi harcamalarının ise artmaya başlamasıyla beraber yine açılmıştır.

1995 yllında 691.8 milyon TL sosyal güvenlik geliri toplanmış 945.19 milyon TL de sosyal güvenlik harcaması yapılmış. 2012 için Devlet Planlama Teşkilatı'nın tahminlerine göre 103230 milyon sosyal güvenlik geliri toplanırken 133835 milyon TL sosyal güvenlik harcaması yapılacaktır. 2009 yılında toplanan sosyal güvenlik katkıları 74173 milyon, sosyal güvenlik harcamaları ise 102671 olarak gerçekleşmiştir. Sosyal güvenlik gelir ve giderlerinin GSYIH'ya oranı itibariyle 2006'da finansman açık makası harcamaların yaklaşı \%3 oranında düşmesiyle ile bir nebze kapanmıştı. 2005 ve 2006 senelerinde toplanan primler sırasıyla 39024 ve 51221 milyon TL iken harcamalar 59081 ve 68884 olarak gerçekleşiştir. Giderler ve gelirler arasında tutar 
itibariyle var olan açık 2005 yılında 20057 milyon TL iken 2006'da 17663 milyon TL'ye düşmüştür. Avrupa ülkelerinde ise sosyal güvenlik açıkları 1980de yaklaşı \%10 iken 1990'larda \%11, 2005'te ise \%12,71 olarak tespit edilmiştir. Türkiye'de ise 1995'te \%1,5 olan gelir gider farkı 1999'da 2 katına, 2004 ve 2005'de sırasıyla $\% 3,8$ ve $\% 4,1$ 'eçıkmış 2006 'da 2005 rakamının yarısına düşmüş, 2009 da ise \%2,29'a çıkmış. Avrupa ülkeleri hemen hemen dengeli bir profil çizerken Türkiye'deki sosyal gelir gider açıklarının bu kadar dalgalanması 2003 yılında yapılan sosyal güvenlik reformuna rağmen aslında optimist bir tablo da çizilemeyeceğine işaret etmektedir.

\section{Sonuç}

Türkiye'de vergi yükü ve sosyal parafiskal yük oranları Avrupa ülkelerine göre görece düşük görünmekle beraber sosyal güvenlik primlerinin gayrisafi yurtiçi hasılaya oranı olarak ifade edilen sosyal parafiskal yük'ün 16 ve 25 Avrupa Birliği üye ülkesinin gayrisafi hâsıla ağırlıklı ortalamasına göre 1995 ve 2008 verileri dikkate alındığında sırasıyla \%1,4 ve \%1,1 oranında düştüğü, buna karşılık Türkiye Cumhuriyeti’nde 2008 yılında 1995 yılına göre sosyal güvenlik yükünün \%4,03 arttığ1 gözlemlenmiştir. 22 Avrupa Birliği üye ülkesi için 2007 yılında gerçekleşen ortalama sosyal güvenlik harcamaları 1995 senesindeki seviyesine \%0,5 artarken, Türkiye'de 2007 yılında sosyal güvenlik harcaması 1995 yılındakine göre DPT verileri bazında değerlendirme yapıldığında \%4,23 artmıştır. Avrupa Birliği üye ülkelerinin gelir ve gider açıkları ortalaması 2007 yılında 1995 yılına göre $\% 0,7$ artarken, Türkiye'de sosyal güvenlik gelir-gider açıkları, DPT verilerine göre \%1,43 artmıştır. Sonuç olarak, Avrupa Birliği gerek sosyal parafiskal yük, gerek ise sosyal harcamalar açısından Türkiye’ye göre daha dengeli bir profil çizmekte; 2003 yılında Türkiye'de yapılan sosyal güvenlik reformuna ve verilerde Türkiye Cumhuriyeti'nde tecrübe edilen yüksek kayıt-dışı ekonomiye bağlı olarak sosyal parafiskal yük Avrupa ülkelerine göre rakamsal açıdan küçük görünmesine rağmen Türkiye'de vatandaşın üzerindeki sosyal güvenlik prim yükü son derece ağırdır ve artan oranlı bir seyir izlemektedir. Bu bağlamda Türkiye'nin politik açıdan söylenenlerin aksine sosyal güvelikle ilgili atması gereken daha çok adım vardır.

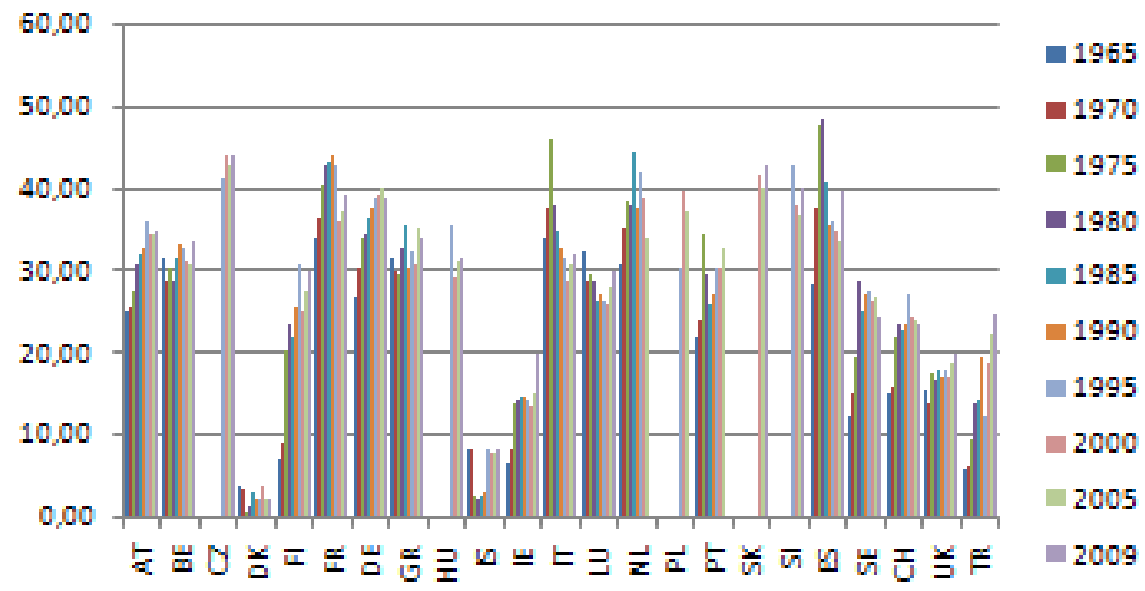

Grafik 1-Sosyal Güvenlik Primlerinin Toplam Vergi Gelirleri İçindeki Payı (\%) 1965-2009 arası (Kaynak: OECD/Revenue Statistics/ Comparative tables/ 2000

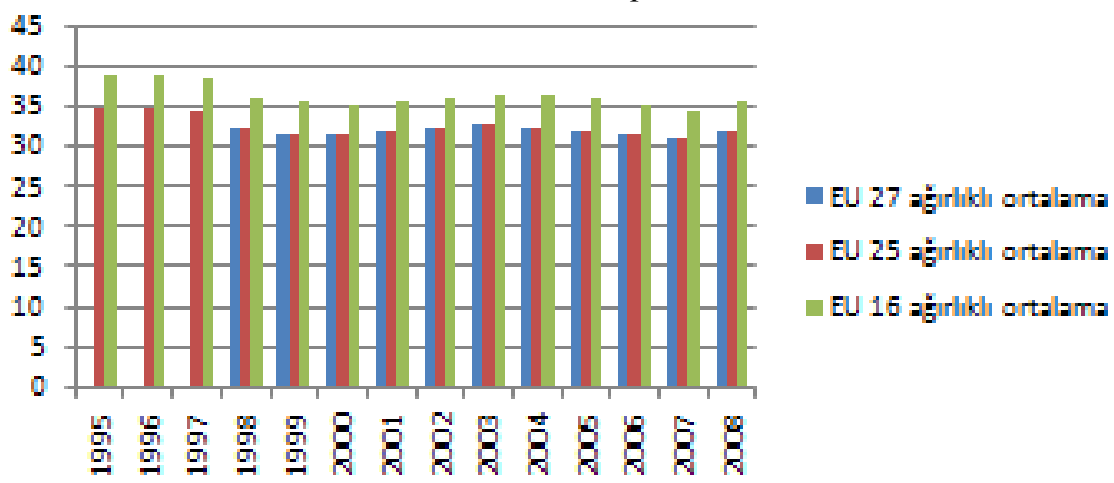

Grafik 2- Avrupa Birliği 27,25 ve 26 üye ülke ortalaması bazında Sosyal Güvenlik Primlerinin Toplam Vergi Gelirleri İçerisindeki Payı (\%)1995-2008 arası (Kaynak: Taxation trends in the European Union, 2010 edition) 


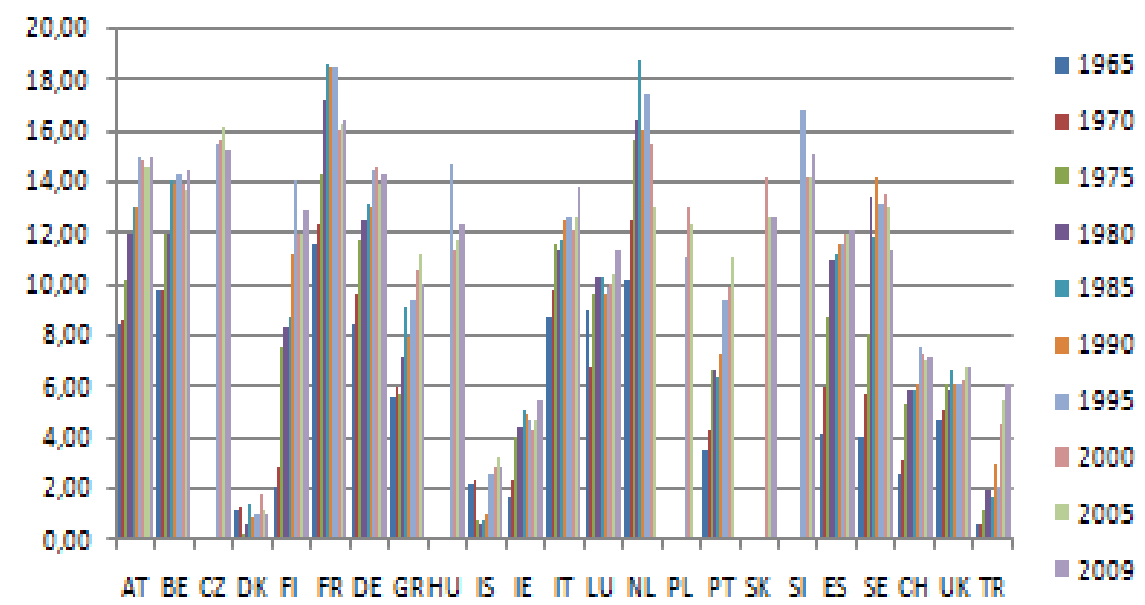

Grafik 3- Sosyal Güvenlik Primlerinin GSYIH içindeki payı (\%) 1965-2009 arası

Kaynak: OECD Revenue Statistics-Comparative Tables (2000)

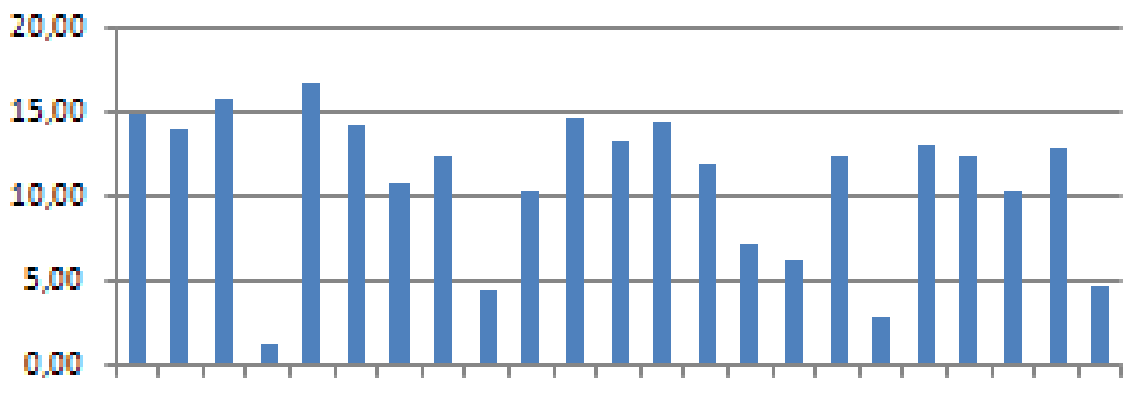

AT BE CZ DK FR DE GRHU IE LU NL SK SI ES CHUK FI IS SE PL PT IT TR

Grafik 4- Seçilmiş bazı Avrupa ülkeleri ile Türkiye Cumhuriyeti'nin 1995-2009 yılları arasında sosyal parafiskal yük ortalamalarl Kaynak: OECD Revenue Statistics - Comparative Tables

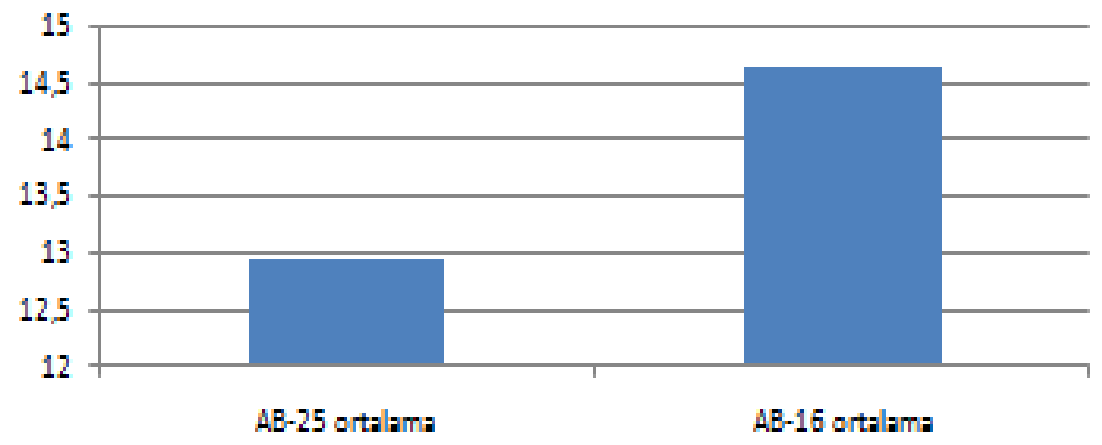

Grafik 5-1995-2009 yılları arasında 25 ve 16 Avrupa Birliği üye ülkesinin GSYIH ă̆ırlılı sosyal parafiskal yük ortalamaları Kaynak: Taxation trends in the European Union, 2010 edition Table A ve Table B den çıkarılmıştır ISBN 978-92-79-15802-5 ISSN 1831-8797

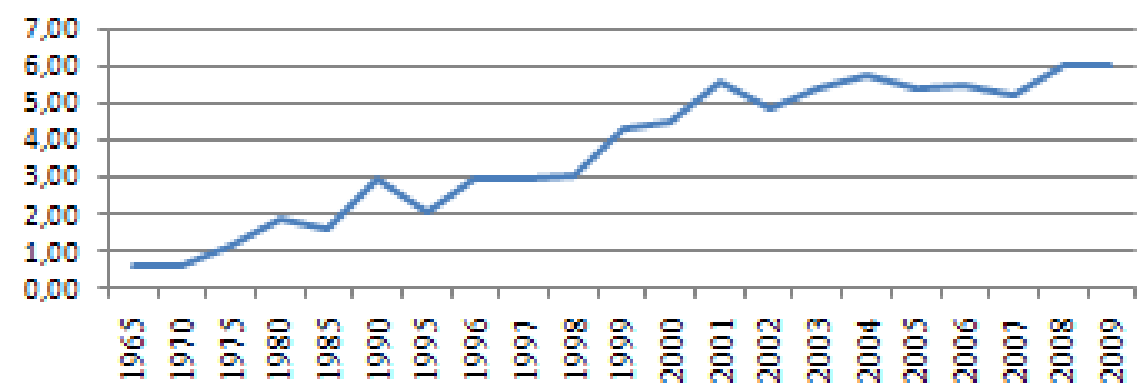

\begin{tabular}{|l|l|l|l|l|l|l|l|l|l|l|l|l|l|}
\hline 1995 & 1996 & 1997 & 1998 & 1999 & 2000 & 2001 & 2002 & 2003 & 2004 & 2005 & 2006 & 2007 & 2008 \\
\hline 2,03 & 2,98 & 3 & 3,06 & 4,29 & 4,53 & 5,62 & 4,87 & 5,4 & 5,75 & 5,44 & 5,49 & 5,22 & 6,06 \\
\hline
\end{tabular}

\begin{tabular}{|l|c|c|c|c|c|c|c|c|c|c|c|c|c|}
\hline 2,03 & 2,98 & 3 & 3,06 & 4,29 & 4,53 & 5,62 & 4,87 & 5,4 & 5,75 & 5,44 & 5,49 & 5,22 & 6,06 \\
\hline
\end{tabular}

Grafik 6 ve Tablo 1- 1965-2009 yılları arasında Türkiye Cumhuriyeti’nde Sosyal Parafiskal Yük. Kaynak: OECD Revenue Statistics - Comparative Tables (2000) 


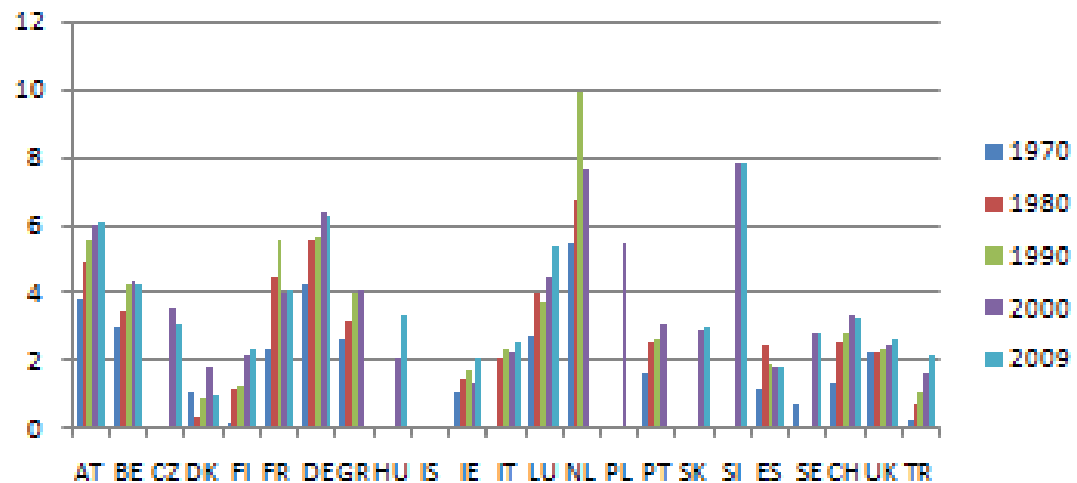

Grafik 7- 1970-2009 yılları arasındaki on yıllık dönemlerde Bazı Avrupa Ülkeleri ile Türkiye Cumhuriyeti'nde çalışan kesim üzerindeki sosyal parafiskal yük. Kaynak: OECD Revenue Statistic-Comparative Tables

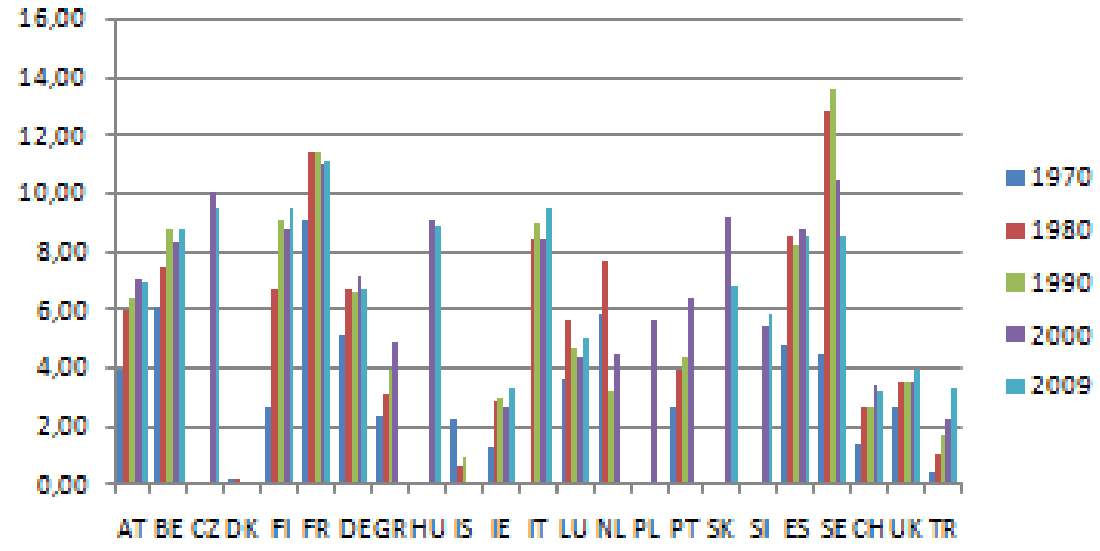

Grafik 8- 1970-2009 yılları arasındaki on yıllı dönemlerde Bazı Avrupa Ülkeleri ile Türkiye Cumhuriyeti'nde işveren üzerindeki sosyal parafiskal yük (işveren sosyal güvenlik katkılarının GSYIH payı (\%)) Kaynak: OECD Revenue Statistic- Comparative Tables (2200)

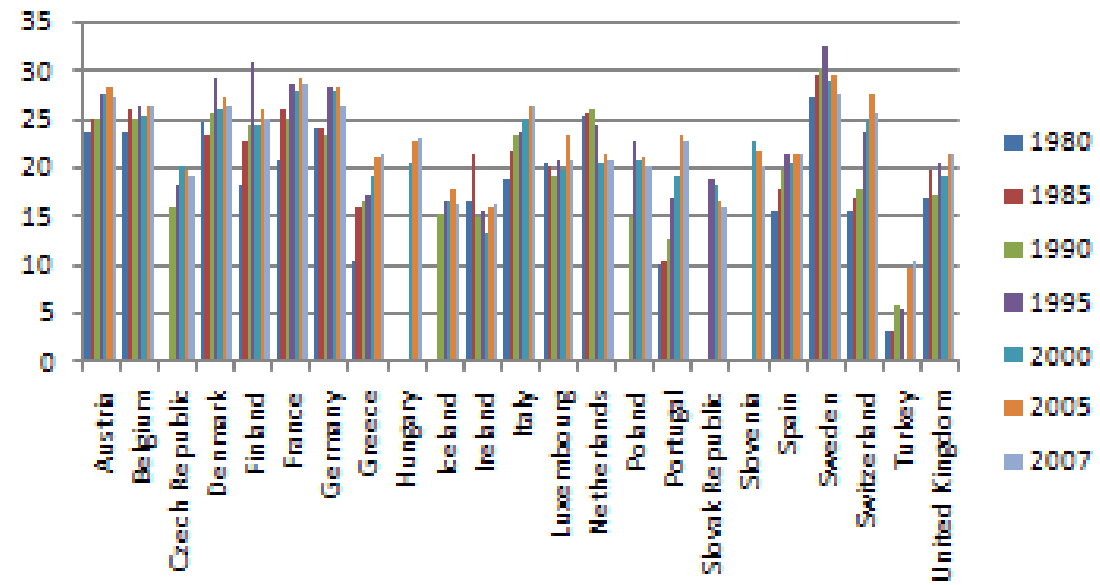

Grafik 9- 1980-2007 yılları arasındaki beş yıllık dönemlerde Bazı Avrupa Ülkeleri ile Türkiye Cumhuriyeti'nde işveren üzerindeki sosyal harcamaların GSYIH içindeki payı (\%). Kaynak: OECD Social and Welfare StatisticsSocial Expenditure-Aggregated Data. 


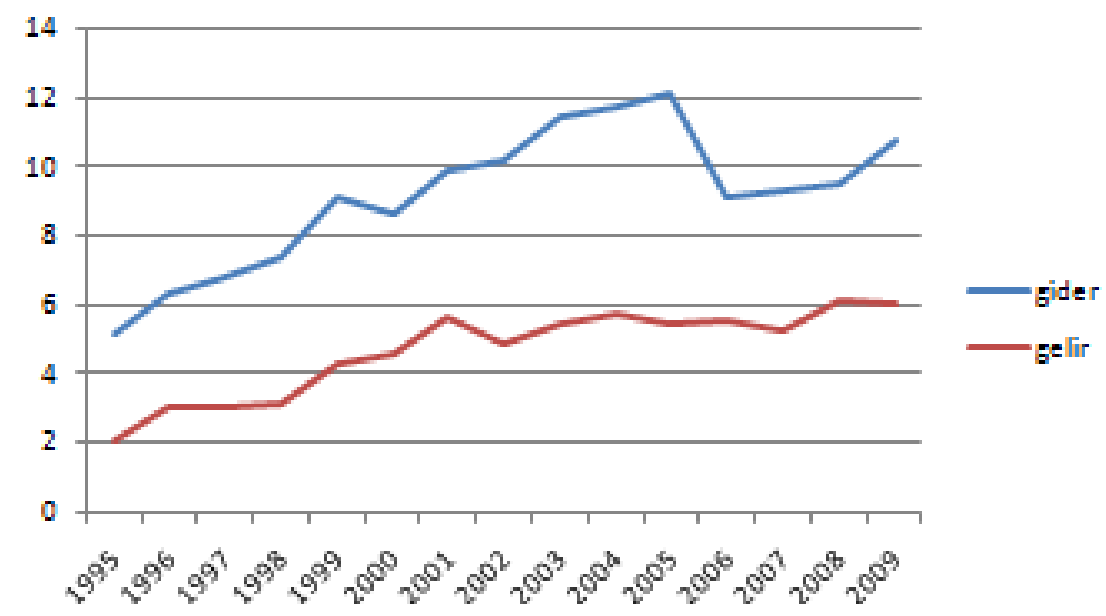

Grafik 10-1995-2009arası Türkiye Cumhuriyeti sosyal güvenlik gelir ve giderlerinin GSYIH içindeki payları (\%) Kaynak: OECD Revenue Statistics - Comparative Tables (2000) http://stats.oecd.org/index.aspx? 8 May 2011 ve DPT yıllık istatistiklerinden her yılın verileri kesinleştikleri yıllık planlardan alınarak oluşturulmuştur.

\section{Kaynakça}

- AKDOĞAN, Abdurrahman; “Kamu Maliyesi”,1999, Gazi Kitapevi, 7. Bask1, Ankara

- BİLGILİ, Özkan; “Yeni Sosyal Güvenlik Uygulaması”,2008, İzmir SMMM Odası Yayınları, Bizim Repro, İzmir (alıntı yaparak aktaran: Egeli, 2009; a.g.e.)

- EGELI, Haluk, “Parafiskalite ve Parafiskal Yükümlülükler (Sosyal Güvenlik Reformu Kapsamında)”, 2009, Altın Nokta Basım Yayın Dağıtım, 1. Basım, İzmir

- $\quad$ HEREKMEN, Aykut; “Teoride ve Türkiye'de Parafiskal Gelirler”, 1972, E.İ.T.İ.A. Yayını No:99/55, Ankara

- HOLZMAN, Robert, Landis MacKellar ve Michal Rutkowski; “Accelerating European Pension Reform Agenda:Need, Progress and Conceptual Underprintings”, 2003, Pension Reform in Europe: Process and Progress (eds. Robert Holzman, Mitchell Orenstein and Michal Rutkowski). Washington D.C.: World Bank

- KAUFMAN, Otto, çeviren: Tankut Centel; “Fransa'da Sosyal Güvenlik-Genel Sistem”, Ocak 1999, Çimento İşveren Dergisi Sayı:1 Cilt: 13

- ÖNCEL, Türkan ; "Gelirin Yeniden Dağılım Politikası Aracı Olarak Negatif Gelir Vergisi”, 1982Maliye Araştırmaları Konferansları, 28. Seri-198171982 İ.Ü. İktisat Fakültesi Maliye Araştırma Merkezi Yayınları, No: 3127/497-67, İstanbul (alıntı yaparak aktaran: Akdoğan, 1999;a.g.e.)

- SAYAR, Nihat; “ Kamu Maliyesi”, 1975, Nihat Sayar Yayın ve Yardım Vakfı Yayınları, No: 256, Cilt 1, İstanbul İ.T.I.A., İstanbul

- TİSK; “Gelişmiş Ülkelerde ve Türkiye'de Sosyal Güvenlik Sistemlerinin Yeniden Yapılandırılması”, 1997, TíSK İnceleme Yayınları, No:18, Ankara

- TUNCAY, Can; “Bireysel Emeklilik Rejimi Üzerine”,2000, Çimento İşveren Dergisi, Mart 2000 sayıs1, Sayı:2 Cilt:14

- $\quad$ T.C. Başbakanlık Aile ve Sosyal Araştırmalar Genel Müdürlüğü; www.aile.gov.tr/files/IRLANDA_RAPORU_IRLANDA_RAPORU.DOC erişim tarihi: 20.05.2011 11:32

- DPT; http://www.dpt.gov.tr/PortalDesign/PortalControls/WebIcerikGosterim.aspx? Y1llik İstatistikler

- European Commission, Taxation Cumstoms, Taxation Trends in European Union 2010 Edition http://epp.EuroStat.ec.europa.eu/cache/ITY_OFFPUB/KS-DU-10-001/EN/KS-DU-10-001-EN.PDF

- OECD Revenue Statistics - Social and Welfare Statistics http://stats.oecd.org/index.aspx? 


\title{
Türkiye'deki İç Göçleri Belirleyen Faktörlerin Modellenmesi
}

\author{
Mustafa Ercilasun (Beykent University, Turkey) \\ E. Ayşen Hiç Gencer (Istanbul Aydın University, Turkey) \\ Özgür Ömer Ersin (Beykent University, Turkey)
}

\section{Modeling the Determinants of Internal Migration in Turkey}

\begin{abstract}
This paper aims to investigate major determinants of interprovincial migration in Turkey until 2010. In recent decades the magnitude of migration in absolute terms has increased considerably: During 1975-1980, 3.6 million people migrated, which constitutes $9.4 \%$ of the total population. These numbers have increased to 6.7 million people and $11.2 \%$ in the $1995-2000$ period. The rate of increase is especially tremendous for the $1985-1990$ period with $41 \%$. Over the years the composition of migration has also changed: In the past rural-to-urban migration was predominant; however, today there is remarkable amount of urban-to-urban migration. During $1975-1980,66 \%$ of the total migrants were towards urban centers, which increased to $75 \%$ during $1995-2000$. On the other hand, the percentage of total migrants towards the village centers declined from 34 to 25 in the respective periods.

From 2008 on, the Turkish Statistical Institute (TUIK) started publishing yearly unemployment statistics at provincial level, which permits an analysis of Turkey's migration patterns within the Harris-Todaro framework. Moreover since 2007, TUIK started implementing Address Based Population Registration System, which enables tracking migration moves continuously, rather than by intermittent five to ten year periods. However, data was not adequate to test Turkey's migration within the Harris-Todaro framework, especially due to lack of average wages at the provincial level. Therefore, utilizing the 2010 provincial level data, we tried to explain Turkey's internal migration based on variables such as population born outside of their current province, number of university students, and a proxy variable we developed for average wages.
\end{abstract}

JEL Codes: J61, O15, R23

\section{Giriş}

Türkiye ekonomisinin tarımdan sanayi ve hizmet sektörüne dönüşümünde iç göçler 1950li yıllardan başlayarak önemli bir rol oynamıştır. Bu çerçevede kırsal yörelerden şehir merkezlerine yönelen göçler şehirleşmeyi hızlandırmış; İstanbul, Ankara ve İzmir gibi şehirlerin aşırı büyümesine sebep olmuştur (Ercilasun, 1980). Bugün de bu kentler aşırı göç alan merkezler olmakla beraber, son zamanlarda göçlerin yeni cazibe merkezlerine de yöneldiği, hatta kentsel merkezlerden kırsal bölgelere de kaydığı gözlemlenmektedir.

Büyüme ve gelişme ekonomisi ve çalışma ekonomisi literatürlerinde, göçler insan sermayesine yapılan bir yatırım olarak değerlendirilmiştir. Rasyonel hareket eden bireylerin göç maliyetlerini ve göç getirilerini karşılaştırarak karar verdikleri, dolayısıyla göçlerin düşük kazanç bölgelerinden yüksek kazanç bölgelerine yöneldiği ileri sürülmüştür (Sjaatad, 1962). Kırsal bölgelerden kentsel bölgelere yönelen göçlerin esasen köyşehir arasındaki ücret düzeyi veya gelir farklarından kaynaklandığı, bireylerin şehir merkezlerindeki yüksek gelir potansiyelini değerlendirmek için göç ettiği ortaya konmuştur (Greenwood, 1971).

Gelişmekte olan ülkelerde, köylerden şehirlere doğru göçler ekonomik büyüme ile alakalı olarak Michael P. Todaro ve John Harris tarafindan modellenmiştir (Todaro, 1969; Harris ve Todaro, 1970). Harris veTodaro, köyşehir arasındaki gelir seviyesi farklarının mutlak değerler ile ele alınmasının doğru olmadığını, bu farkların gelir beklentileri olarak irdelenmesi gerektiğini savunmuşlardır. Harris-Todaro modelinde, gelir beklentileri ise, bireylerin şehir merkezlerinde iş bulabilme ihtimali ile ilişkilendirilmiştir. İşsizlik oranlarının genellikle yüksek olduğu şehir merkezlerinde iş bulabilme ihtimali düşük olduğu için, bu yerlerlerdeki yüksek gelir seviyelerinin beklentiler çerçevesinde azaltılarak değerlendirilmesi gerekmektedir. Dolayısıyla göçler, bölgelerarasındaki gelir farklarının yanısıra, bölgelerarası işsizlik oranı farklarından da olumlu veya olumsuz şekilde etkilenmektedir.

Harris-Todaro modeli, gelişmekte olan bazı ülkelerde ampirik olarak incelenmiş, ve bu teorinin doğruluğu yönünde bulgular ortaya konmuştur: Mitze ve Reinkowski (2010), Almanya'da 1996-2006 yılları arasında 96 bölgenin değerlendirildiği dinamik panel veri modellerinde, iç göçün açıklanmasında başta bölgelerarası işsizlik oranları farklılıkları ve gelir farklılıkları olmak üzere başlıca emek piyasasına ilişkin değişkenlerin bağımsız değişken olarak modele dahil etmekte, bölgelerarasında ücret farklılıklarının net göç üzerindeki pozitif etkisine ek olarak, bölgelerarası işsizlik farklılıkları ve net göç arasındaki negatif ilişkiyi vurgulamaktadır. Harris-Todaro modelinde değinilen temel değişsenlere ek olarak, az gelişmiş ülkelerin kendilerine has bazı özelliklerinin göç kararlarında önem taşıdığı görülmektedir. Issah, Khan ve Sasaki (2003), Gana'da 1970-1999 dönemi için test ettikleri Harris-Todaro modelinde işsizlik oranı değişkeninin Harris-Todaro modelinde beklenenin aksine pozitif tahmin edildiğini vurgulamakta, bu olgunun oluşmasında iki bölge arasında altyapı yatırımları farklılıklarının 
önem taşıdığına, altyapı yatırımları sonucu göçün cazibesinin kentsel işsizliği arttırıcı etkisine dikkat çekmektedir. Bhattacharya (2002), Hindistan'da 1981 nüfus sayımı verilerinden hareketle elde ettikleri ampirik bulgular kapsamında, sosyal ağların önemine dikkat çekmekte, gelişmekte olan ülkelerde göç akımlarının formel ve informel sektöre yönelik iki ayrı akım olarak değerlendirilmesi gerektiğini vurgulamaktadır. Mitra ve Murayama (2008), Hindistan'da kırsal-kentsel göçünün önemli bir açıklayıcı faktörünün okur-yazarlık ve eğitim olduğunu, cinsiyet farklılıklarının önemine ve kadın göçünde erkek göçünün tamamlayıcı olduğunu, klan ve kabilenin önem taşıdığı toplum yapısında sosyal bağların ise göç üzerindeki önemli etkilerinin reddedilemeyeceğini ortaya koymaktadır. Bu bağlamda, ücret ve işsizlik dışında olası faktörler incelendiğinde, göç kararlarının alınmasında göç sonrası kentsel istihdama ilişkin belirsizliğin azaltılmasının amaçlanmasından hareketle, kırsal kesimdeki bağların kente göç öncesinde kullanılmasıyla kentte istihdam ihtimalinin arttırılması (Banerjee, 1991; Banerjee ve Bucci, 1995; Connell v.d., 1976), istihdam edilme ihtimalinin arttrrılmasında eğitimin göç edilen şehirde iş bulma ihtimalini arttırıcı etkisi (Kochar, 2004), beşeri sermayenin kentte kırdan farklı olarak daha fazla ödüllendirileceği beklentisi (Agesa, 2001), göç etmiş tanıdıkların varlığının belirsizliği azalatmadaki rolü (Roberts, 2001), daha yüksek yaşam kalitesi beklentisine ek olarak (De Haan and Rogally, 2002) klan v.b. sosyal bağlar, cinsiyet eşitsizliği gibi bir çok faktörün önem taşıması söz konusu olmaktadır.

Çalışmanın ikinci kısmında, Türkiye'de iç göçlerin değerlendirilmesi hedeflenmiş; göçe ilişkin iktisat yazınına bir bakış sunulması amaçlanmıştır. Çalışmanın üçüncü kısmında, Türkiye'de göç verileri tartışılmış, hesaplanan reel ücrete ve eğitime ilişkin değişkenlere ek olarak, işsizlik oranı ve göç stokuna ilişkin değişkenlerden hareket edilerek tahmin edilen ekonometrik modeller incelenmiştir. Sonuçlar ve değerlendirmeler çalışmanın dördüncü kısımda yer almaktadır.

\section{Türkiye'de İç Göçler}

Türkiye'de, 1940-1950 arasında \%20 olan şehir merkezlerindeki nüfusun büyüme hızı, 1950-1960 döneminde \%80 seviyelerine yükselmiştir (Keleş, Yavuz, Geray,1978). Tarımda makineleşmeden kaynaklanan işsizlik sonucu ortaya çıkan göç hareketleri ,1960'lardan sonra Türkiye'de kırsal bölgelerdeki nüfusun azalmasına ve şehirleşmenin artmasına sebep olmuştur. Aşırı şehirleşme ise, çeşitli çevre sorunları yaratmış ve gecekondu mahallelerin artmasına yol açmı̧̧ır (Karpat, 1976).

Eski adı ile Devlet İstatistik Enstitüsü (DİE), bugünkü adı ile Türkiye İstatistik Kurumu (TUİK), ilk defa olarak 1970 genel nüfus sayımlarında kişilerin bir önceki sayımda ikamet ettikleri yeri sormuş ve yayınlamıştır. Bu soru, 1975 genel nüfus sayımları hariç, daha sonraki genel nüfus sayımlarında tekrarlanmıştır. Bu bilgi, Türkiye'de iç göçlerin hesaplanmasına imkan sağlamıştır. Nitekim, Devlet Planlama Teşkilatı (DPT)' den Samiha Yener, 1970 genel nüfus sayımlarını kullanarak 1965-1970 döneminde illerarası göçler ve göç edenlerin niteliklerinin dökümünü yapmıştır (Yener, 1977).

Ayşe Gedik tarafından yapılan başka bir çalışma ise, 1965-70, 1975-80, 1980-85 ve 1985-90 dönemlerindeki göç hareketlerini incelemiştir (Gedik, 1997). Bu çalışmanın önemli bulguları, ilk dönemlerde köyden şehire doğru olan göç hareketlerinin zamanla niteliğinin değiştiği, ve şehirden şehire göçlerin payının arttığı, ve hatta şehirden köye göçlerin de başladığıdır.

Yener'in çalışmasına benzer bir diğer çalışma ,yine DPT'den Tuncer Kocaman tarafindan yapılmış, ve bu kez 1965-2000 yılları arasında göç edenlerin niteliklerinin dökümü yapılmıştır (Kocaman, 2008). Bu çalışmada, 1990-2000 döneminde nüfusun \%11'inin, ülkenin göreceli olarak sosyal ve ekonomik bakımdan yeterince gelişmemiş bölgelerinden ve illerinden gelişmiş batı bölgelerine ve metropollerine göç ettiği ortaya çıkmıştır. $\mathrm{Bu}$ kişilerin genellikle eğitimli, bekar, orta yaş grubunda, çoğunluğunun erkek olduğu, iş bulma/arama nedeniyle göç ettiği ve tarım dışı ekonomik faaliyet alanında hizmetler sektöründe ücretli, maaşlı ve yevmiyeli olarak çalıştı̆̆ görülmektedir (Kocaman, 2008, s.67).

Mustafa Ercilasun, 1970 nüfus sayımını kullanarak kırsal bölgelerden şehir merkezlerine olan göçleri ampirik olarak ele almış, köy-kent göçlerinde çekici faktörlerin yetenekli göçmenleri, itici faktörlerin ise becerisi zayıf göçmenleri harekete geçirdiğini ortaya koymuştur (Ercilasun, 1980).

Alpay Filiztekin ve Ali Gökhan, 1990-2000 dönemini inceleyerek Türkiye'de iç göçleri belirleyen faktörleri araştırmışlardır (Filiztekin ve Gökhan, 2008). Bu çalışmada, göçleri insan kaynaklarına yapılan bir yatııım olarak değerlendiren göç teorilerinin ileri sürdüğü beklentileri destekleyen bulgular elde edilmiştir. Gelir farklarının, işsizlik oranlarının, yaşın, eğitim seviyesinin, mesafenin ve sosyal ağların göçleri etkileyen en önemli faktörler olduğu belirlenmiştir. Çalışmanın getirdiği önemli bir yenilik ise, göçlerin Daveri-Faini (1999) yaklaşımı ile belirsizliklerin de göz önüne alınarak modellenmesidir. Gelecek ile ilgili belirsizlikler gelirdeki varyans ile ölçülmüş ve yüksek varyansın göçleri hangi şartlarda teşvik ettiği irdelenmiştir.

Rahmi Yamak ve Nebiye Yamak, 1980-90 döneminde illerarası net göçler ile kişi başına düşen gelir arasındaki ilişkiyi ampirik olarak incelemişlerdir (Yamak veYamak, 1999). Bu çalışmada, bölgesel bazdaki gelir dengesizliklerinin iç gö̧̧ üzerindeki etkisi araştırılmış, ve bu etkinin net göç veren illerin düşük gelir seviyesinden ziyade, net göç alan illerin yüksek gelir seviyesinden kaynaklandığı ortaya koyulmuştur. Diğer bir ifade ile, itici faktörlerden ziyade çekici faktörlerin önemi vurgulanmıştır. 


\section{Veriler, Yöntem ve Ekonometrik Sonuçlar}

\subsection{Veriler ve Yöntem}

Uzun süreler Türkiye' de işgücü istatistikleri, iller bazında değil, sadece ülke bazında yayınlandığından dolayı, iç göçleri işsizlik oranları ile ilişkilendirerek bir ampirik çalışma yapmak mümkün olmamıştır. İlk defa 2008 yılında Türkiye İstatistik Kurumu (TUIKK), işsizlik oranlarını iller bazında yayınlamaya başlamıştır. Dolayısıyla bu çalışma, iller bazındaki bu yeni işsizlik verilerini değerlendirerek Harris-Todaro modelini Türkiye'ye uygulamayı hedeflemekteydi. Ancak, bu veriler dahi Türkiye'nin iç göçlerini Harris-Todaro modeli çerçevesinde test etmek için yeterli olamamıştır. Bu durumun başlıca sebebi, iller bazında güvenilir ortalama reel ücret ve ortalama reel gelir istatistiklerinin varolmamasıdır. Buna rağmen, bu çalışmada bu eksiklikleri giderecek şekilde birtakım ikame değişkenler belirlenerek Türkiye'deki iç göçleri etkileyen faktörler ekonometrik bir analiz çerçevesinde değerlendirilmeye çalışılmıştır. Bu çalışmada, tüm veri serileri İstatistiki Bölge Birimleri Sınıflandırılması (İBBS3: 81 il) üçüncü düzeyinde incelenmiştir.

Bağımlı değişken, öncelikle birinci model olarak net iç göç hızı serisi şeklinde ve 2010 yılına ait ele alınmış, daha sonra ikinci model olarak net iç göçler mutlak kişi sayısı serisi şeklinde ve yine 2010 yılına ait ele alınmıştır. Her iki veri serisi de TÜİK, Adrese Dayalı Nüfus Kayıt Sistemi (ADNKS) Sonuçları, 2010 yayınından elde edilmiştir. Net göç, bir ilin aldığı göçten verdiği göçün çıkartılması olarak hesaplanmaktadır. Net göç hızı ise, her il için net göçün ilgili ilin toplam nüfusuna bölünmesi ile bulunmaktadır. Diğer değişkenler olarak kullanılan seriler, ait oldukları yıllar, bunlara dair birimler, alındıkları kaynaklar ve gerekli görülen açıklamalar Tablo 1'de listelenmiştir.

\begin{tabular}{|c|c|c|c|c|}
\hline Değişkenler & Yll & Birim & Kaynak & Açıklama \\
\hline $\begin{array}{l}\text { başka ilde doğanların ikamet } \\
\text { ettiği ilin toplam nüfusuna oranı }\end{array}$ & 2000 & $\%$ & Kocaman, DPT, 2008 & $\begin{array}{l}2000 \text { yılı genel nüfus } \\
\text { sayımlarından hesaplanmıştır }\end{array}$ \\
\hline $\begin{array}{l}\text { sosyo-ekonomik gelişmişlik } \\
\text { endeksi }\end{array}$ & \multirow{4}{*}{2003} & & \multirow{4}{*}{$\begin{array}{l}\text { Dincer, Özaslan ve } \\
\text { Kavasoğlu, DPT, } \\
2003\end{array}$} & \\
\hline sağlık sektörü gelişmişlik endeksi & & & & \\
\hline $\begin{array}{l}\text { eğitim sektörü gelişmişlik } \\
\text { endeksi }\end{array}$ & & & & \\
\hline $\begin{array}{l}\text { sağllk ve eğitim sektörleri } \\
\text { gelişmişlik endeksi }\end{array}$ & & & & $\begin{array}{l}\text { eğitim sektörü ve sağlık sektörü } \\
\text { gelişmişlik endekslerinin çarpımı } \\
\text { olarak hesaplanmıştır }\end{array}$ \\
\hline şehirleşme oranı & 2010 & $\%$ & $\begin{array}{l}\text { Bölgesel Göstergeler, } \\
\text { 2010, TÜİK }\end{array}$ & $\begin{array}{l}\text { şehir nüfusunun toplam nüfus } \\
\text { içindeki oranı }\end{array}$ \\
\hline TÜFE (tüketici fiyat endeksi) & 2010 & & $\begin{array}{l}\text { Türkiye İstatistik } \\
\text { Y1llı̆̆1, 2010, TÜİK }\end{array}$ & \multirow{4}{*}{$\begin{array}{l}\text { IBBS2 ( } 26 \text { bölge birimi) } \\
\text { düzeyinde verilmiş olması } \\
\text { dolayısıyla IBBS3 ( } 81 \text { il) } \\
\text { düzeyine dağıtılmıştır }\end{array}$} \\
\hline kişi başına gayri safi katma değer & 2008 & $\$$ & \multirow{4}{*}{$\begin{array}{l}\text { Bölgesel Göstergeler, } \\
\text { 2010, TÜİK }\end{array}$} & \\
\hline reel ücret ortalaması & 2010 & TL & & \\
\hline $\begin{array}{l}\text { reel gayri safi katma değer } \\
\text { ortalaması }\end{array}$ & 2010 & $\$$ & & \\
\hline çalışabilir nüfus & 2010 & $\begin{array}{c}\text { mutlak kişi } \\
\text { sayısı }\end{array}$ & & $\begin{array}{l}\text { 15-64 yaş arası olan kişilerin } \\
\text { sayısı }\end{array}$ \\
\hline işsizlik oranı & 2010 & $\%$ & $\begin{array}{l}\text { İl Bazında Temel } \\
\text { İşgücü Göstergeleri, } \\
\text { 2010, TÜİK }\end{array}$ & \\
\hline $\begin{array}{l}\text { üniversitede okuyan toplam } \\
\text { öğrenci sayısı }\end{array}$ & 2007 & $\begin{array}{c}\text { mutlak kişi } \\
\text { sayısı }\end{array}$ & $\begin{array}{l}\text { Yükseköğretim } \\
\text { Kurumu resmi sitesi, } \\
\text { Kuruluş Yıllarına } \\
\text { Göre Üniversiteler } \\
\text { sayfası, } 2009\end{array}$ & $\begin{array}{l}2007 \text { girişlilerin } 2011 \text { yılında } \\
\text { mezun olmaları gözönüne } \\
\text { alınmıştır }\end{array}$ \\
\hline
\end{tabular}

Tablo 1: Değişkenler Listesi

Harris ve Todaro modeli çerçevesinde önem taşıyan temel değişkenler olan ücret ve işsizlik verilerinin göç olgusunu açıklamada açıklayıcı gücünün incelendiği çalışmada, reel ücret serileri ve reel gayri safi katma değer serilerinin kullanılması hedeflenmiştir. Öte yandan, iller bazında güvenilir reel ücret ve reel gelir istatistiklerinin varolmaması nedeniyle, Tablo 1.'de yer alan verilerin kullanılmasıyla şu şekilde hesaplanmışlardır: Nominal ücret ortalaması serisi, il bazında ücret, maaş ve yevmiyeler toplamının çalışabilir nüfus olarak nitelendirilen 1564 yaşları arasındaki mutlak kişi sayısına bölünmesi ile elde edilmişlerdir. Nominal kişi başına ücret serisi il için hesaplanan TÜFE endeksi kullanılarak reel ücret serisi hesaplanmıştır. Bu noktada, Türkiye için hesaplanan 2010 TÜFE endeks değeri 100'e eşitlenmiş, ilgili il için hesaplanan 2010 TÜFE serisi, ilgili ilin Türkiye geneli ile karşılaştırıldığında, fiyatlar genel düzeyi açısından farklılıklarının her il için hesaplanan reel ücret serisi 
üzerindeki etkisini farklılaştıracağı şüphesizdir. Ücret serilerinin bir diğer temsili göstergesi olan nominal gayri safi katma değer serisi, 15-64 yaşları arasındaki mutlak kişi sayısına bölünerek elde edilen kişi başına nominal katma değer serisi, TÜFE $(2010=100)$ endeksi kullanmak sureti ile reel hale dönüştürülerek oluşturulmuştur. Değerlendirilen bağımsız değişkenlere dair beklenen katsayı işaretleri şu şekilde belirlenmektedir: Ĕger bir bağımsız değişken alınan göçü aynı (pozitif) yönde, fakat verilen göçü ters (negatif) yönde etkiliyorsa, o zaman net göç pozitif yönde etkilenecektir. Diğer taraftan, eğer bir bağımsız değişken alınan göçü ters (negatif) yönde, fakat verilen göçü aynı (pozitif) yönde etkiliyorsa, o zaman net göç negatif yönde etkilenecektir. Eğer bir bağımsız değişken hem alınan göçü hem de verilen göçü aynı yönde ekiliyorsa, o zaman net göçe olan etki değişkenlerin büyüklüklerine göre değişecektir.

\subsection{Ekonometrik Bulgular}

En küçük kareler yöntemi (OLS) ile iki adet regresyon tahmin edilmiştir. Birinci modelde 2010 yllı net göç hızı, ikinci modelde ise net göç mutlak kişi sayısı şeklinde ve yine 2010 yılına ait bağımlı değişken olarak ele alınmıştır. Regresyon sonuçları Tablo 2'de verilmiştir.

\begin{tabular}{|c|c|c|}
\hline & MODEL 1 & MODEL 2 \\
\hline & Net Göç Hızı $\{2010\}$ & Net Göç $\{2010\}$ \\
\hline BAĞIMSIZ DEĞİŞKENLER & $\begin{array}{c}\text { katsayı } \\
\text { [t-istatistiği] }\end{array}$ & $\begin{array}{c}\text { katsayı } \\
{[\text { t-istatistiği] }}\end{array}$ \\
\hline sabit terim & $\begin{array}{c}-21.892 * * * \\
{[-4.383]}\end{array}$ & $\begin{array}{l}-12691.771 * * * \\
{[-8.643]}\end{array}$ \\
\hline $\begin{array}{l}\text { eğitim ve sağlık sektörleri } \\
\text { gelişmişlik endeksi }\end{array}$ & $\begin{array}{l}0.979 * \\
{[1.670]}\end{array}$ & \\
\hline şehirleşme oranı & $\begin{array}{l}0.174 * * \\
{[2.574]}\end{array}$ & \\
\hline $\begin{array}{l}\text { reel gayri safi katma } \\
\text { değer ortalaması }\end{array}$ & $\begin{array}{l}5.941 * * \\
{[2.034]}\end{array}$ & \\
\hline net göç hızı $\{2009\}$ & $\begin{array}{l}-0.236 * * \\
{[-2.459]}\end{array}$ & \\
\hline net göç hızı $\{2008\}$ & $\begin{array}{c}0.372 * * * \\
{[4.923]}\end{array}$ & \\
\hline işsizlik oranı & $\begin{array}{c}-0.083 \\
{[-0.311]}\end{array}$ & \\
\hline $\begin{array}{l}\text { başka ilde doğanların ikamet ettiği } \\
\text { ilin toplam nüfusuna oranı }\end{array}$ & & $\begin{array}{c}292.093 * * * \\
{[4.110]}\end{array}$ \\
\hline $\begin{array}{l}\text { üniversitede okuyan } \\
\text { toplam öğrenci sayısı }\end{array}$ & & $\begin{array}{l}0.264 * * * \\
{[11.420]}\end{array}$ \\
\hline \multirow[t]{2}{*}{ reel ücret ortalaması } & & $\begin{array}{c}0.266^{* *} \\
{[2.067]}\end{array}$ \\
\hline & $\begin{array}{c}R^{2}=0.518 \\
\text { adj } R^{2}=0.479 \\
F=13.276\end{array}$ & $\begin{array}{c}R^{2}=0.802 \\
\text { adj } R^{2}=0.794 \\
F=103.993\end{array}$ \\
\hline
\end{tabular}

Tablo 2: Regresyon Sonuçları

Not: ***, **, * sırasıyla \%1, \%5 ve \%10 istatistiksel anlamlılık düzeyine karşllıktır

Birinci modelde, bağımlı değişken olan 2010 yılı net göç hızı, eğitim ve sağlık sektörleri gelişmişlik endeksi, şehirleşme oranı ve işsizlik oranı serilerine ek olarak modeli dinamik bir yapıya kavuşturan 2009 net göç hızı ve 2008 net göç hızının bir fonksiyonudur. Gecikmeli serilerin modele dahil edilmesi ile, bağımlı değişkende gerçekleşen değişimlerde bir ve iki yıl önce gerçekleşen net göç hızı değişimlerin etkisinin modele katılması amaçlanmıştır. Eğitim ve sağlık sektörleri gelişmişlik endeksi serisi için tahmin edilen katsayı pozitif olup 0.979 olarak hesaplanmaktadır. Beşeri sermayenin önemli göstergeleri olarak kabul edilen eğitim ve sağlık endeksinde bir birim artışın net göç hızında bire bire çok yakın bir etkisinin olduğu \%10 anlamlılık seviyesinde kabul edilmektedir. Kentsel gelişimin göç üzerindeki etkisinin ölçülmesi için modele dahil edilen şehirleşme oranı serisinin beta tahmini 0.174 olarak pozitif hesaplanmış, \% 1 anlamlılık seviyesinde istatistiksel olarak anlamlı bulunmaktadır. Model çerçevesinde, şehirleşme oranında gerçekleşen bir birim artışın net göç oranını arttırıcı etkisi söz konusudur.

Ücretlerdeki değişimlerin net göç üzerindeki etkisinin ölçülmesi bağlamında modele dahil edilmiş olan reel gayri safi katma değer için hesaplanan katsayı 5.941 olarak tahmin edilmiş olduğundan, reel ücretlerde gerçekleşen bir birim artışın, net göç hızı üzerinde 5.94 birimlik bir artışla sonuçlandığı görülmüştür. Öte yandan, işsizlik oranının beta tahmini -0.083 olup negatif bulunurken, istatistiksel olarak anlamlı bulunmamaktadır. Bu durumun oluşmasında, kırsal kesimden kentsel kesime göç kararlarında, göç eden bireyin 
kentsel işsizlik oranını gözetmeden hareket ettiği sonucuna varılmakla beraber, işsizliğin göz ardı edilmesinde, ilgili işsizlik oranının formel sektör işsizlik oranı olması bir diğer husustur. Gerçekte informel sektörün boyutu önem arz etmekle beraber, istihdam edilme ihtimalinin birey tarafindan yüksek algılanıyor olmasında kırsal kesimden devralınan sosyal bağların etkisi ise bir diğer husustur. Öte yandan, kırsal kesimdeki bireyin kentsel işsizliğe karşı kayıtsız olması ve informel sektörün varlığı gerçekte modelin Lewis modeli yapısında özellikler içerdiğinin bir göstergesi olarak kabul edilmiştir. Net göçün 2009 ve 2008 değerlerini içeren seriler için tahmin edilen beta katsayıları istatistiksel olarak anlamlı bulunmaktadır. Bu kapsamda, bir yıl ve iki yıl önceki net göç değerleri, bağımlı değişken olan cari net göç değeri üzerinde etkili bulunmakta, model statik bir modelden dinamik yapıya kavuşmaktadır. Raporlanmamakla beraber, her iki gecikmenin eklenmesiyle tahmin edilen birinci modelde, Durbin Watson test istatistiği 2.18 olup otokorelasyon probleminin olmadığına işaret etmektedir. Bu durum, hata terimlerinin korelogramına bakılarak teyit edilmiştir.

İkinci modelde, bağımlı değişken 2010 yılı net göç serisi olup açıklayıcı değişkenler, başka ilde doğanların ikamet ettiği ilin toplam nüfusuna oranı, üniversitede okuyan toplam öğrenci sayısı ve reel ücret ortalaması olarak belirlenmiştir. İkinci modelde, birinci modelden farklı olarak açıklayıcı değişkenler brüt değerler olarak belirlenmiştir. Başka ilde doğanların ikamet ettiği ilin toplam nüfusa oranı serisi, bir ilde ikamet eden bireylerin yüzde kaçının doğum yerinin başka ilde kayıtlı olduğunu gösterdiğinden, Harris-Todaro teorisi çerçevesinde, net göçün pozitif gerçekleşmesinde göç alan ilde ikamet eden göç stokunun çekici etkisini ölçen bir değişken olup sosyal bağların ve kırsal bağlantıların bir göstergesi olarak tayin edilmiştir. Üniversitede okuyan öğrenci sayısı serisi, ilin aldığı yüksek öğrenim yapmak amacıyla gelen öğrencilerin o ile göç etmelerinin bir açıklayıc1 değişkeni olmanın yanında, yüksek öğrenimin kentsel çekimi arttırıp arttırmadığına ilişkin etkilerin ölçülmesini amaçlamaktadır. Modelde, birinci model ile benzer yapıda, reel ücretlerin eklenmesi ile, Harris-Todaro modeli yapısında, illerdeki reel ücret değerlerinin göç üzerindeki etkilerinin ölçülmesi hedeflenerek modele eklenmiştir. Başka ilde doğanların ikamet ettiği ilin toplam nüfusuna oranı için tahmin edilen katsayı 292.093 olup istatistiksel olarak anlamlı bulunduğundan, bir ilde ikamet edenlerin başka ilde doğmuş olanlardan oluşan nüfusu arttıkça, bu durumun net göç miktarını arttırıcı etkisi olduğu görülmektedir. Üniversitede okuyan toplam öğrenci sayısı serisi için tahmin edilen beta katsayısı 0.264 olup pozitif olduğundan yüksek öğrenim öğrencilerinde bir birim artışın net göçü 0.26 arttırdığı kabul edilmektedir. İller bazında reel ücret ortalaması değişkeninin parametre tahmini 0.266 olup \%5 anlamlılık seviyesinde istatistiksel olarak anlamlı bulunduğundan, reel ücretin bir birim yükseliş gösterdiği illere net göçün 0.266 birim arttığı sonucuna varılmıştır.

\section{Sonuç ve Değerlendirme}

Bu çalışmada ortaya çıkan en ilginç sonuç, Türkiye'de bireylerin iç göç kararlarını etkileyen en önemli faktörün bir yere daha önceden göç etmiş olanların çekici gücü olmasıdır. Bu durum her iki modelde de açıkça görülmektedir: Net göç hızının açıklanmaya çalışıldığı birinci modelde bu gerçek, net göç hızının bir önceki ve iki önceki yıllara ait şekilde birer etken olarak önemli çıkmalarıyla tespit edilmiştir. Net göçlerin mutlak kişi sayısı şeklinde açıklanmaya çalışıldığı ikinci modelde ise, evvelki yıllarda o yere yerleşmiş göçmenlerin yüksek sayıda varoluşlarının çok önemli bir etken olarak bulunmasıyla kanıtlanmıştır. Hakikaten, Türkiye'de aile, arkadaşlık, hemşehrilik kavramları birçok alanda belirleyici rol oynar.

Çalışmanın bir diğer göze çarpan sonucu, bireylerin göç kararlarını illerdeki üniversite kapasitesinin yüksekliğine dayandırmalarıdır. Bu durum yine her iki modelde de açıç̧a görülmektedir: Birinci modelde bu gerçek eğitim ve sağlık sektörleri gelişmişlik endeksinin, ikinci modelde ise üniversite öğrencilerinin mutlak sayısının anlamlı çıkmalarıyla göz önüne serilmiştir. Demek ki, Türkiye'de üniversite eğitiminin önemi son yıllarda giderek artmıştır.

Esasen bu çalışmanın başında hedeflenen, işsizlik oranları ve ortalama ücretleri temel alan Harris-Todaro modelini Türkiye'ye uygulamaktı. Ancak, veri derleme safhasında bu bilgilerin gereken detayda olmadığg ortaya çıkmıştır. Son yıllarda TÜİK tarafından işsizlik oranlarının iller bazında yayınlanması memnuniyet verici olmakla beraber, aynı şeyi ücretler ve gelirler için söyleyemeyiz. Bu yetersizlik, göç analizlerini zorlaştırdığ gibi, diğer taraftan göç kararı verme durumunda olan bireyler açısından da belirsizlik ve dolayısıyla risk derecelerini arttırmaktadır. Bireyler bu bilgilere sahip olarak kararlarını verir duruma gelebilirlerse, uzun dönemde illerarası ücret farkları ve dolayısıyla gelir dağılımı dengesizlikleri ortadan kalkacaktır.

\section{Kaynakça}

- Agesa R. (2001) "Migration and the Urban to Rural Earnings Difference: A Sample Selection Approach", Journal of Development Studies, Vol.49, No.4, pp: 847-65.

- Banerjee B. (1991) "The Determinants of Migrating with a Pre-Arranged Job and the Initial Duration of Urban Unemployment: An Analysis Based on Indian Data on Rural to Urban Migrants”, Journal of Development Economics, Vol.36, pp: 337-51.

- Banerjee B. ve G. Bucci (1995) “On-the-job Search in a Developing Country: An Analysis Based on Indian Data on Migrants", Economic Development and Cultural Change, Vol.43, No.3, pp:565-583. 
- Bhattacharya, P. (2002, October) "Rural to Urban Migration in LDCs: a Test of Two Rival Models", Journal of International Development, Vol.14, No.7, pp: 951-972.

- Connell, J. (1976) Migration from Rural Areas: the Evidence from Village Studies, Delhi, Oxford University Press.

- Daveri, Francesco ve Faini, Riccardo (1999) “Where Do Migrants Go?”, Oxford Economic Papers, Vol.51, pp:595-622.

- De Haan, A. ve Rogaly, B. (2002) "Migrant Workers and their Role in Rural Change", Journal of Development Studies, Vol.38, No.5, pp: 1-14.

- Devlet İstatistik Enstitüsü (DİE), çeşitli yayınları.

- Dincer, Bülent; Özaslan, Metin ve Kavasoğlu, Taner (2003, Mayıs) İllerin ve Bölgelerin Sosyo-Ekonomik Gelişmişlik Sıralaması, T.C. Devlet Planlama Teşkilatı Yayınları.

- Ercilasun, Mustafa (1980) "Rural-Urban Migration in Less Developed Countries with an Application to Turkey", M.A. thesis, The Pennsylvania State University.

- Ercilasun, Mustafa (1986) "Family Migration Decision Making in a Rural-Urban Setting: The Case of Turkey, 1974-1978”, Ph.D. thesis, SUNY- Binghamton.

- Filiztekin, Alpay ve Gökhan, Ali (2008) “The Determinants of Internal Migration in Turkey”, Sabancı Üniversitesi.

- Gedik, Ayşe (1997) "Internal Migration in Turkey, 1965-1985: Test of Conflicting Findings in the Literature”, Review of Urban and Regional Studies, Vol.9, pp:170-79.

- Greenwood, Michael J. (1971, August) “A Regression Analysis of Migration to Urban Areas of a Less Developed Country: The Case of India”, Journal of Regional Science, pp:253-262.

- Harris, John ve Todaro, Michael P. (1970, March) "Migration, Unemployment and Economic Development: A two-sector Analysis”, American Economic Review, pp:126-142.

- Issah, I., Khan, T., ve Sasaki, K. (2003) "Do Migrants React to Infrastructure Difference between Urban and Rural Areas? - Development and Application of an Extended Harris-Todaro Model”, Working Paper Series, Graduate School of Information Sciences, Tohoku University.

- Karpat, Kemal (1976) The Gecekondu: Rural-Urban Migration and Urbanization, Cambridge University Press, London.

- Keleş, Ruşen; Yavuz, Fehmi ve Geray, Cevat (1978) Şehircilik Sorunları, Uygulama ve Politika, Ankara Üniversitesi, Siyasal Bilgiler Fakültesi Yayınları, No.415, Ankara.

- Kocaman, Tuncer (2008, Nisan) Türkiye’de İç Göçler ve Göç Edenlerin Nitelikleri (1965-2000), T.C. Devlet Planlama Teşkilatı Yayınları.

- Kochar A. (2004) "Urban Influences on Rural Schooling in India”, Journal of Development Economics, Vol.74, pp: 113-36.

- Lewis, Arthur W. (1954, May) "Economic Development with Unlimited Supplies of Labor", The Manchester School of Economic and Social Studies, pp:139-191.

- Mitra, A. ve Murayama, M. (2008) "Rural to Urban Migration: A District Level Analysis for India", IDE Discussion Paper Series, No.137.

- Roberts K. (2001) "The Determinants of Job Choice by Rural Labor Migrants in Shanghai”, China Economic Review, Vol.12, pp: 15-39.

- Sjaastad, Larry A. (1962) “The Costs and Returns of Human Migration”, Journal of Political Economy, Vol.70, pp:80-93.

- $\quad$ Todaro, Michael P. (1969, March) “A Model of Labor Migration and Urban Unemployment in Less Developed Countries", American Economic Review, pp: 138-148.

- Todaro, Michael P. (1977) Economic Development in the Third World, Longman Group Limited, London, pp:184-203.

- Türkiye İstatistik Kurumu (TÜİK), çeşitli yayınları.

- Yamak, Rahmi ve Yamak, Nebiye (1999) “Türkiye’de Gelir Dağılımı ve İç Göç”, Dokuz Eylül Üniversitesi, Sosyal Bilimler Enstitüsü Dergisi, Vol.1, No.1, pp:16-28.

- Yener, Samiha (1977, Nisan) 1965-1970 Döneminde İllerarası Göçler ve Göç Edenlerin Nitelikleri, T.C. Devlet Planlama Teşkilatı Yayınları. 


\title{
Zorunlu Göç ve Fakirliğin Diğer Adı: Mülteciliğin Dünya'da ve Türkiye'deki Gelişimi (2004-2007)
}

\author{
Adem Palabıyık (Muş Alparslan University, Turkey) \\ Yunus Koç (Muş Alparslan University, Turkey)
}

\section{Life under Forced Migration and Poverty: Refugees in the World and Turkey (2004-2007)}

\begin{abstract}
The "refugee" notion in the international law means the persons who are outside their native countries and who do not desire to return or could not get back to their native countries by reason of the fact that "they are afraid of being persecuted because of their social belonging to a definite group or their political opinions for justifiable reasons". The legislative framework with regard to the refugees accepts that they need to a specific international protection due to the fact that their native countries could not provide any protection. Therefore, the refugees use the same itineraries or leakage paths with the immigrants in general as well as they unlike the immigrants and they subject to similar violations of human rights in the countries that they come or make a transit pass.

In this study, after making a global assessment related with refugee, we will discuss how the refugees exhibit dynamism in the World and Turkey as a result of the poorness and expectation of life and where the refugees appear mostly for which reasons and also the costs of these for the World economy. The method for attaining information is to examine the Statistics of the World and Turkey published by UNHCR (United Nations High Commissioner's Office for Refugees) and the data of Security General Directorate and General Commandership of Gendarmerie, and then a general assessment will be made in the light of information acquired from these data.
\end{abstract}

JEL Codes: I3, F22, R23

\section{Türkiye ve Mültecilik}

Mültecilik görece yeni tanımlanan hukuki bir statü olsa da, sığınma hakkı ve göçmenlik neredeyse bilinen insanlık tarihi kadar eski kavramlardır. Özellikle tarihin göçebe kavimler tarafından yapıldığı görüşü kabul edilecek olursa, geçmişte olduğu kadar günümüzdeki göç olgusunun önemi daha iyi kavranabilir. Bilindiği gibi, modern denen zaman öncesi uygarlık, yerleşik bir kavmin kurduğu uygarlığın göçebe bir kavim tarafından işgal edilmesi ve yaşanan karanlık kaotik dönemin ardından yeni ve melez bir uygarlığın ortaya çıkmasıyla ilerler. Bu ilerlemenin ne kadar ya da nasıl bir ilerleme olduğu elbette tartışmalıdır. Fakat önemli olan soru tarihin uzun bir aradan sonra tekerrür edip etmediğidir. İnsanın coğrafi hareketliliği ve bu hareketin yol açtığı nüfus dinamiği (Emiroğlu ve Aydın, 2003: 341) olarak tanımlanan göç (az veya çok) bireylerin ya da grupların sembolik veya siyasal sınırların ötesine, yeni yerleşim alanlarına ve toplumlara doğru kalıcı hareketini içerir (Marshall, 1999: 685). Dünyada toplumların iç işleyişi, sınıfsal, etnik, dinsel gruplar arası ilişkileri ile dış dünyadaki çekim merkezlerinin yapısına bağlı bir olgu olan göç'ün (Somersan, 2004: 152) küreselleşme süreciyle yeni ve karmaşık bir boyut kazanması en çok da uluslararası boyutunun yani küreselliğinin şekillenmesi, daha doğrusu iyice netleşmesi durumu söz konusudur. Günümüzde göçün belirgin özelliği sadece gittikçe daha küresel bir hal alması değildir. Günümüzde gerçekleşen göçler, bir tercih değil zorunluluk olarak ortaya çıkmaktadır. Daha doğru bir ifadeyle artık göç, yerinden olmaya (edilmeye) karşılık gelir. Göçün değişen tabiatı, zorla yerinden edilmeye tekabül etmiştir. Mültecilik, sığınmacılık, yerinden edilenler, vatansızların ortaya çıkışı bir tesadüf değildir ve tam da bu gerçekliğe işaret etmektedir. Göçe tarihsel, coğrafik ve toplumsal olarak aşina olan bir ülke olarak Türkiye, yasadışı göçten nasibini almaya başladığından beri büyük yüklerin altına girmiştir. Öte yandan umuda yolculuk olarak nitelenen bu göç hareketlerinin dramatik sonla bitenleri de Türkiye'nin belleğinde yerini bulmaktadır (Kara-Kokrut, 2010: 154).

Kuşku yok ki, Türkiye'de yakalanan veya basına haber konusu olan nüfus, buzdağının sadece görünen yüzüdür. Hareket halinde olan bu nüfusun bir kısmının ekonomik nedenler ile göç eden göçmenler olduğu gerçekliğini kabul etmemizin yanı sıra diğer bir kısmının doğu ve güneyimizdeki bazı ülkelerdeki etnik, ideolojik, dini ve benzeri baskılardan ötürü hapis, işkence veya ölüm cezası gibi "zulüm” tehditlerinden kaçan mültecilerden müteşekkil olduğu da tüm dünya kamuoyunca bilinmektedir. Türkiye tarihi mülteci hakları konusunda göreli oldukça iyi sayılabilecek bir geçmişe sahiptir. Ancak günümüzde hem hukuk hiyerarşimizde konuya biçmiş olduğumuz dar mevzuat, hem kolluktaki uygulamacılarda görülen konuya ilişkin bilgisizlik ve 'yabancıya' dair tahammülsüzlük, toplum olarak konuya kör ve sağır oluşumuz nedeniyle "onlar" gündemimize hiç gir(e)miyorlar. Çok ciddi sayılabilecek rakamlara ulaşan bir nüfus hareketi Türkiye'de bu sorunu sicak bir şekilde yaşarken ve Türkiye'de özellikle bazı illerde bu sorun sadece dar çerçevede bazı ilgilileri "uğraştırırken" 
konu Türkiye kamuoyunun gündeminde olması gereken yoğunlukta değerlendirilemiyor. Oysa şimdi bu konuda çok fazla düşünme ve tarihi/insani sorumluluğun yeniden kuşanılması için bir firsat önümüzde durmakta. Türkiye-AB üyelik müzakere sürecinde ve müktesebat uyum çalışmalarında konu hakkında yapılması gereken çok iş var ve bu vesile ile Türkiye'deki mülteci hukuku perspektifine ve uygulamasına sivil toplumun da katkısı ile çok önemli ve olumlu bir açılım getirilebilir (Kılıç). Bunların dışında pek çok sığınmacı da, Türkiye'ye yasal yollarla giriş yaptıktan sonra yasal sürenin bitiminde çıkış yapmayıp yasadışı konumda kalmakta, sahte seyahat belgeleri ile Türkiye'ye giriş-çıkış yaparak veya herhangi bir yolla başka bir ülkeye geçiş yapmaya çalışarak değişik sorunlara neden olmaktadırlar (Tekin, 2009: 27). Şu aşamaya kadar verdiğimiz bilgilerin verileri 1şındaki değerlendirmesini birkaç tablo üzerinden ele almak konunun daha da iyi analaşmasını sağlayacaktır. İlk olarak aşağıdaki tabloda yıllara göre Türkiye’ye gelen mültecileri göstermektedir.

\begin{tabular}{|c|c|c|c|c|c|c|}
\hline Yıl & İranlılar & Iraklılar & Diğerleri & Genel Oran & \multicolumn{2}{|c|}{ Toplam Kabul Edilen } \\
\hline & & & & & Dosya & Kişi \\
\hline 1997 & $52 \%$ & $25 \%$ & $24 \%$ & $35 \%$ & 578 & - \\
\hline 1998 & $56 \%$ & $30 \%$ & $30 \%$ & $40 \%$ & 891 & 2,230 \\
\hline 1999 & $59 \%$ & $18 \%$ & $31 \%$ & $43 \%$ & 841 & 1,903 \\
\hline 2000 & $57 \%$ & $27 \%$ & $28 \%$ & $49 \%$ & 1186 & 2726 \\
\hline 2001 & $70 \%$ & $34 \%$ & $56 \%$ & $61 \%$ & 1287 & 2867 \\
\hline 2002 & $72 \%$ & $38 \%$ & $35 \%$ & $63 \%$ & 1344 & 2885 \\
\hline 2003 & $79 \%$ & - & $45 \%$ & $76 \%$ & 1600 & 3300 \\
\hline 2004 & $75 \%$ & - & $31 \%$ & $69 \%$ & 934 & 1748 \\
\hline 2005 & $67 \%$ & - & $36 \%$ & $59 \%$ & 736 & 1368 \\
\hline 2006 & $90 \%$ & - & $39 \%$ & $79 \%$ & 1051 & 1878 \\
\hline 2007 & $88 \%$ & $\% 100$ & $72 \%$ & $85 \%$ & 3588 & 7121 \\
\hline
\end{tabular}

Tablo 1: Avrupalı Olmayan Mültecilerin Kabul Oranları (1997-2007)

Kaynak: http://www.egm.gov.tr/daire.yabancilar.asp, ayrlca bkz. ;http://www.UNHCR.org.tr/

Yukarıdaki tabloya bakıldığında ise Türkiye’ye gelen mülteci sayılarında en fazla Irak ve İranlı vatandaşların olduğu görülmektedir. Türkiye'nin bir geçiş ülkesi ve komşu ülke olmasından dolayı, bu kişiler tarafından ilk başvurulan ülke olarak karşımıza çıkmaktadır. Bu durum BMMYK'nın raporlarında da değindiği gibi siyasi sebepler, savaş nedeniyle, özellik ile doğu ülkelerinde mezhepler arasındaki çatışmalar insanları vatanlarında baskı altında sokar ve en nihayetinde yukarıdaki verilerde gösteriyor ki bu insanlar en yakın komşu ülkelere mülteci ya da sığınmacı olarak zorunlu veya hut bireysel isteğe bağlı olarak sığınırlar. Öte taraftan,Türkiye'de coğrafi konum itibari ile ve bölgede diğer komşu ülkelere nazaran daha istikrarlı olması hasabiyle yabancı hareketliliğinin boyutu tarih boyunca etkili olmuştur. Nitekim bu aşağıdaki 2000-2008 yıllarında ülkede ki yabancı hareketliliğini gösteren Tablo 2'de de görüldüğü üzere 2000 yıllarında yaklaşık 10 milyon olan yabancı hareketliliği yedi yıl sonra yaklaşık 30 milyona kadar yükselmiştir.

\begin{tabular}{|c|c|c|}
\hline Yıllar & Giriş Sayısı & Çıkıș Sayısı \\
\hline 2000 & $9,748,327$ & $9,393,355$ \\
\hline 2001 & $10,912,771$ & $10,530,600$ \\
\hline 2002 & $12,906,274$ & $12,606,264$ \\
\hline 2003 & $13,461,420$ & $13,180,903$ \\
\hline 2004 & $16,854,377$ & $16,503,781$ \\
\hline 2005 & $25,262,380$ & $24,736,280$ \\
\hline 2006 & $27,085,138$ & $26,649,373$ \\
\hline 2007 & $31,106,833$ & $30,865,912$ \\
\hline $2008(11$ Ay) & $23,923,963$ & $24,069,800$ \\
\hline
\end{tabular}

Tablo 2: Yabancıların Türkiye’ye Giriş - Çıkış Sayıları. Kaynak: Kara-Korkut, 2010: 157).

Türkiye'yi geçiş bölgesi olarak kaçak göçmenlerden sonra en sık kullanan mülteciler olmuştur. Nitekim Ortadoğu ve komşu ülkelerin baskıcı rejimlerinden kaçanlar mültecileri oluştururken ilk olarak 1979 İran devrimin den sonra muhalif ya da mağdurların transit bir bölge olarak (tahmini olarak 1980 - 1991 y1lları arasında Kuzey Avrupa ülkeleri ve Avrupa'ya 1,5 milyon İranlı göç etmiştir ) ilk durakları Türkiye olmuştur. İkinci büyük dalga ise İran - Irak savaşı, Saddam Hüseyin'in Halepçe katliamı ve Körfez savaşı ile 1988 -1991 yılları arasında meydana gelen koşullardan kaçan yine insanların bir kısmı Türkiye'yi transit bölge olarak kullanmışlardır (Kara,-Korkut, 2010, 157-158). 


\begin{tabular}{|c|c|}
\hline Yıllar & Sayı (Kişi) \\
\hline 1995 & 11362 \\
\hline 1996 & 18804 \\
\hline 1997 & 28429 \\
\hline 1998 & 29429 \\
\hline 1999 & 47529 \\
\hline 2000 & 94514 \\
\hline 2001 & 92365 \\
\hline 2002 & 82825 \\
\hline 2003 & 56219 \\
\hline 2004 & 61228 \\
\hline 2005 & 57983 \\
\hline 2006 & 51983 \\
\hline 2007 & 64290 \\
\hline 2008 & 50080 \\
\hline Toplam & 746492 \\
\hline
\end{tabular}

Tablo 3: Türkiye'de yakalanan yasadışı göçmenlerin yıllara göre dağılımı (1995 - 2008).

Kaynak: Kara-Korkuk, 2010: 159.

Türkiye'nin mülteciler için zorunlu ikamete tabi tuttuğu 30 tane il olmasına rağmen mülteciler daha fazla şehre dağılmış durumda. Yaklaşık 1500 kişi ile Van, 2500 kişi ile İstanbul, 300 ile 1000 arası mülteciler ile Afyon, Ankara, Gaziantep, Isparta, Kayseri, Konya ve Nevşehir en yoğun mülteci varlığını barındıran şehirlerdir. Mülteci ve sığınmacıların Türkiye'de yerleştirildiği şehirler incelendiğinde Orta Anadolu şehirlerinin ağırlıkta olduğu görülecektir. Bundaki gaye güvenlik ile açıklanabilmektedir. İçişleri Bakanlığı bu illeri belirlerken yabancıların daha kontrol edilebilir olacağı ve demografik bakımdan daha uygun gördükleri bu şehirleri belirlemişlerdir. Deniz kıyısı, sınır illeri gibi kontrol edilmesi zor bölgeler daha az tercih edilmiştir. BMMYK'nın verilerin bakıldığı zaman en fazla mültecinin ikinci olarak Van iline yerleştirildiğini görmekteyiz. Bunun temel nedeni Van ilinin bir sınır ili olması ve hem Iraklı hem de İranlı mültecilere oldukça yakın olması. Sonraki sayfalarda görüleceği gibi özellikle Irak mültecilik olgusunda önemli sıralarda yer almaktadır. İran İslam Cumhuriyeti de belirli dönemlerde mülteci sayısında yükseliş göstermektedir. Türkiye'nin hem sınır ülkesi hm de geçiş ülkesi olmasından dolayı Irak ve İranlı mülteciler buralara yerleşmektedir. Hakkâri ve Şırnak yerine Van iline gelen mülteciler için Van ilindeki yaşam koşulları diğer illere göre daha iyi olmakla birlikte, BMMYK'nın bir ofisi de Van ilinde bulunmaktadır. Bu da özellikle bölge için Van'ın önemli bir konuma sahip olduğunu göstermektedir.

\section{Dünya'da Mültecilik: 2004}

Birleşmiş Milletler Mülteci Yüksek Komiserliği’nin verilerin göre mülteciler ve sığınmacılar oldukça zor şartlarda kayıt edilmektedir. 2004'te 78 sekiz ülkede mültecilik ile ilgili istatistikler rapor edilmişken, 40 ülkede rapor edilen istatistikler doğru tahminlere dayanmaktadır. 29 ülkenin, 21 'inde ise mültecilerin kendisinden bilgiler elde edilmiştir (UNHCR Statistical Yearbook, 2004: 17). Tahmin yönteminin kullanıldığı 40 ülkenin 24'ünde-ki bu ülkeler sanayileşmemiş ülkelerdir- hiçbir mülteci kaydı yoktur. Bu 24 ülkede, BMMYK, mültecilik ile ilgili bilgileri 5 yada 10 yıllık dönem üzerinden tahmin ederek elde etmiştir. 2004 yılındaki Birleşmiş Milletler Mülteci Yüksek Komiserliği'ne başvuranların sayısı, 2003 yılına göre 2.5 milyon kişi artık göstererek 19.5 milyona ulaştı. Bu, 9.6 milyon mülteciyi, 838 bin yerinden edilmişi içermekteydi, ki bu mültecilerin 1.5 milyonu 2004 yılı boyunca benzer uyruklarının olduğu ülkelere gönderilmişlerdir (UNHCR Statistical Yearbook, 2004: 21). 2004 yılı boyunca küresel anlamda sığınmacıların sayısı \%16 azalırken, mültecilerin sayısı da 20 bin kişi civarında bir düşüş göstermiştir. Aynı periyotta, Birleşmiş Milletler Mülteci Yüksek Komiserliği'nin korumasında olan kendi ülkesinde yerinden edilenlerin sayısı \%30 artmışken, aynı yıl içinde bunların 53'si de yeniden yeri dönmüştür.2004 yılının sonunda Asya 7.2 milyon sı̆̆ınmacı ile birinci sıradayken, onu 4.9 milyon sığınmaciyla Afrika, 4.4 milyonla Avrupa, 2.1 milyon sığınmacı ile Latin Amerika ve Karayipler, 853 bin ile Kuzey Amerika ve 83 binle Okyanusya izlemiştir. 2004 yılının sonunda, sadece Kuzey Amerika'da sığınmacı sayılarına bir düşüş yaşanmışken, diğer tüm Birleşmiş Milletler yerlerinde (Karayipler, Latin Amerika ve Avrupa) \%57'lik bir artık yaşanmıştır (UNHCR Statistical Yearbook, 2004: 21-22). Yerinden edilmişlere dağılımına bakıldığı zaman Kolombiya'nın (2 milyon) 2004 yılı sonu itibariyle Birleşmiş Milletler Mülteci Yüksek Komiserliği ile alakalı olan nüfusun en büyük oranına sahip olduğunu görmekteyiz. Sırasıyla Pakistan 1.3 milyon, Afganistan 1.1 milyon, İran İslam Cumhuriyeti 1 milyon, Almanya 973 bin ve Sudan 846 bin yerinden edilmiş kişi barındırmaktadır (UNHCR Statistical Yearbook, 2004: 22).

\subsection{Sı̆̆ınmacılar ve Mülteciler}

Sığınmacılar, mültecilik ya da sığınma için başvuru yapmış ama başvuruları henüz resmi olarak onaylanmayan 
kimselerdir. Birleşmiş Milletler Mülteci Yüksek Komiserliği’nin koruması altındaki 19 milyon sığınmacı arasında, 2004 yılı sonunda birinci sırayı 3.3 milyon kişi ile Afganistan uyruklular oluşturmaktayken, 2.1 milyon ile ikinci sırada yer almaktadırlar. Onları 1.5 milyon kişi ile uyruksuzlar, onları 1.4 milyon kişi ile Sudanlılar, 932 bin kişi ile Liberyalılar, 833 bin ile Azerbaycanlılar izlemektedir. 2004 yılı sonlarına doğru Asya, Birleşmiş Milletler Mülteci Yüksek Komiserliği adına sığınmacı nüfusuna ev sahipliği yapmış aynı zamanda oranı en yüksek olan kıta olmuştur. 2004 yılı sonunda Birleşmiş Milletler Mülteci Yüksek Komiserliği’ne Asya kökenli 7.7 milyon insan kabul edilmiştir. Asya’yı, 5.3 milyon sığınmacı ile Afrika izlerken, Latin Amerika ve Karayipler 2.3 milyon ve Avrupa'da 2.2 milyon ile takip etmiştir. 1.5 milyon kişi ise herhangi bir uyruğa tabi olmadan Birleşmiş Milletler Mülteci Yüksek Komiserliği kayıtlarına geçirilmiştir (UNHCR Statistical Yearbook, 2004: 23). Küresel anlamda düşen mülteci sayısı Birleşmiş Milletlerin farklı bölgelerinde değişiklikler göstermektedir; bunlar Avrupa, Latin Amerika ve Karayipler'de \% 4'ken, Afrika ve Kuzey Amerika'da \% 6 civarında olmuştur. Asya ve Okyanusya'da ise \%10 civarında bir artış gözlenmiştir. Asya'daki artış oranı ise Pakistan ve Afganistan'daki mülteci nüfusunun tahmini değerlerine dayanmaktadır (UNHCR Statistical Yearbook, 2004: 23). BMMYK bölgeleri arasında Güney ve Batı Afrika'da, 2004 dönemi boyunca mülteci sayılarında büyük bir düşüş gözlenmiştir. Bunun temel nedeninin ise Birleşik Tanzanya Cumhuriyeti, Sierra Leone ve Liberya'daki mültecilerin geri dönüşü ile alakalı olduğu bilinmektedir. Mülteci sayısındaki düşüşler Avrupa'da -\%6, Amerika'da -\%4, CASWANAME'de $+\% 8$, Asya ve Pasifik'de $+\% 2$, Merkez Asya ve Büyük Göllerde $+\% 1$ ve Doğu Afrika'da +\%0.3 oranında kaydedilmiştir. Afrika ve CASWAVAME bürolarının her biri 2004'ün sonunda küresel mülteci nüfusunun yaklaşık \%30’una ev sahipliği yapmıştır. Buna ek olarak Avrupa \%24, Asya ve Pasifik \%9 ve Amerika \%6 oranları ile ev sahipliğini sürdürmüşlerdir. Birleşmiş Milletlerin büyük bölgelerinden biri olan ve mültecilerin yaklaşık yasını üreten Asya, neredeyse on yıl boyunca mültecilerin ana kaynağı olmuştur. Mülteci sayısının sürekli yükseldiği (\%36’dan, \%52'ye) Asya'da, 2003-2004 yılları arasında bu oran \%50'de sabitlenebilmiştir. Aynı zamanda 1990'lı yıllarda \%39'dan \%30'a düşen mülteci oranını barındıran Afrika, 2003-2004 yılları arasında yeniden \%39'a yükselmiştir. Afganistan ise büyük bir farkla yine mültecilerin yoğun olduğu bölge olmaya devam etmektedir. 2004 y1lı sonunda küresel mülteci nüfusunun \%25'ini oluşturan 2.4 milyon Afgan mülteci, tam 78 ülke tarafindan rapor edilmiştir. Pakistan ve İran İslam Cumhuriyeti tarafından yapılan sayım sonucunda Afgan mültecilerde bir geri dönüş olmasına rağmen, oran \% 13 artmıştır. Fakat 2001'den 2004' kadar Afgan mültecilerin dünya genelinde oranı \% 37 azalmıştır. Dünya genelinde mülteci sayılarında önemli bir düşüşün yaşandığı iki ülke Irak (-\%15) ve Burundi (-\%9) idi. Burundili mültecilerin sayılarındaki düşüşün en önemli sebebi, buradaki mültecilerin (89.000) Tanzanya Cumhuriyetleri Birliğine geri dönmesiydi. Ayrıca dünya genelinde kalıcı çözümlere yaklaşılmasıyla diğer ülkelerde de bazı düşüşler gerçekleşti. Bunlar: Bosna-Hersek -62.000, Sirbistan ve Karadağ -33.000, Liberya -18.000, Angola, 101.000 olarak kaydedilmiştir. Sudan'da devam eden iç çatışmadan dolayı ise buradan çıkan mülteci sayısı 2004 sonuna doğru 606.000'den, 731.000'e yükselmiştir. Aynı zamanda bazı ülkelerde de küresel mülteci sayısında artış gerçekleştirilmiştir. Bunlar: Endonezya (4\%72), Kolombiya (+\%25), Rusya Federasyonu (+\%12), Birmanya $(+\% 6)$ ve Eritre $(+\% 6)$ olarak kaydedilmiştir.

\subsection{Cinsiyet}

2004 yılı sonuna doğru Mülteci Kayıtlarına göre toplam 11.8 milyon kişinin 5.8 milyonu kadın olarak tespit edilmiştir fakat bu oran her yaştan kadınlar için geçerlidir. \% 47'si 18 yaş altındayken, \% 13'ü beş yaş altındadır. \% 6'sı da 60 yaş ve üzeridir. Gelişmekte olan ülkelerde meydana gelen çatışmalar yüzünden bir çok anne ve babanın öldüğü de Birleşmiş Milletler kayıtlarında yer almıştır. Bu nedenle 5 yaşından küçük çocukların en fazla oranla Afrika'da (\%18) olduğunu görmekteyiz. Bu oranı \%12 ile Asya ve Okyanusya izlemektedir. Avrupa'da ise bu oran $\% 2$ civarındadır. 18 yaş altındaki çocukların oranı ise Afrika'da \%55, Okyanusya'da \%50 ve Asya'da ise \%49 oranındadır. Bu oranlara karşılık Latin Amerika ve Karayipler'de bu oran \%25 ile sınırlıdır. 5 yaşından küçük olanların oranı en fazla Afrika'da, 5ile 17 yaş arası en fazla Asya, 18 yaşından küçükler en fazla Afrika, 18 ile 59 yaş arasındaki en yüksek oran Avrupa ve 60 yaş civarı da en fazla Avrupa'da görülmektedir. Toplam da ise BMMYK'nın toplam kadın oranların yüzde 87'sini sahip olduğu görülmektedir. Bunun sebebi ise yine mülteciler ve sığınmacılara ulaşma zorluğundan kaynaklanabilir.

\subsection{Mülteci Başına Düşen GSYİH}

Mülteci başına düşen GSYİH'nın en fazla incelendiği yer Pakistan olmalıdır. Çünkü Pakistan 2004 y1lında en büyük mülteci sayısını barındıran yer olmuştur, yaklaşık 3000 kişiye 1 dolar düşmektedir. Birleşik Tanzanya Cumhuriyeti ve Demokratik Kongo Cumhuriyetleri de büyük öneme sahiptir. Çünkü Kongo'da GSYİH 2.965 'ken Tanzanya'da GSYİH 2.434 oranındadır. Mülteciler adına kişi başına en düşük GSYİH'nin en yüksek olduğu ülkeler Sahra-Altı ülkelerdir. Bu GSYİH oranları sırasıyla; Etopya'da 1.699, Uganda'da 1.039, İran İslam Cumhuriyeti'nde 717, Zambia'da 637, Nepal'de 595, Gine'de 576 ve Sudan'da 559 olarak kaydedilmiştir. Normalde gelişmiş ülkelerde bu oranların daha fazla olması ve ilk onda yer almaları gerekmektedir fakat gelişmiş ülkelerdeki mülteci oranı ile Sahra-Altı ülkelerdeki mülteci oranı aynı değildir. Küresel mülteci nüfusu 0.3 oranında düşerken, en büyük düşün yerinden edilmişlerin, yerinden edildikleri yerlere geri dönüş ile sağlanmıştır. Yine 2004 yılı içinde sığınma başvuruları ise \%16 civarında bir azalma göstermiştir (UNHCR Statistical Yearbook, 2004: 8). 


\section{Dünya'da Mültecilik: 2005}

2003 y1lı sonunda hükümetlerden elde edilen veriler \%44 civarındayken, 2005 sonu itibariyle bu oran \%52'ye çıkmıştır. BMMYK'nın tahmini bu, 5-10 yıllık zaman dilimi içinde yapılan sığınmacı başvurularına dayanmaktadır. 2005 yılı sonuna kadar, BMMYK'nın ilgilendiği nüfus arasına giren kişi sayısı 1.5 milyon artış göstererek, 19.5 milyondan 21 milyona çıkmıştır. Bu rakamlar 8.7 milyon mülteciyi, 773.000 sığınmacıyı, 2005 yılı boyunca geri dönen 1.1 milyon mülteciyi, BMMYK tarafından desteklenen 6.6 milyon yerinden edilmişi, 2.4 milyon kimliksizi ve 960.000 BMMYK ile alakalı olan diğerlerini içermektedir. 2005 yılında mülteciler BMMYK ile alakalı olan küresel nüfusun \%41'ni oluşturmaktadırlar. BMMYK tarafindan yardım edilen yerinden edilmiş kişiler ise ikinci en büyük oranı (\%31) oluşturmaktadırlar. Onları ise vatansızlar/kimliksizler $\% 11$ 'lik oranla takip etmektedirler. (UNHCR Statistical Yearbook, 2005: 24). BMMYK'ni ilgilendiren toplam 21 milyon kişinin içinde, Asya, 8.9 milyon ile yine birinci sırayı korumaktadır, yani BMMYK'nin ilgi alanına giren her 10 kişiden 4'ü Asta kıtadında yer almaktadır. İkinci sırada yine BMMYK için önemli bir bölgeyi temsil eden Afrika vardır, 5.1 milyonluk bir mülteci nüfus sayısı ile. Afrika'yı, 3.7 milyon ile Avrupa, 2.5 milyon ile Latin Amerika Ve Karayipler, 717.000 ile Kuzey Amerika ve 82.000 ile de Okyanusya izlemektedir. Bunlar arasında Latin Amerika ve Karayipler; Sudan, Irak ve Kolombiya'nın kötüleşen durumları yüzünden epey bir mülteci/sığınmacı, vb. nüfus artışı kaydetmişlerdir. Buna karşın Kuzey Amerika ve Avrupa'da ise bir önceki yıla gçre 2005 'de bir düşüş gözlenmiştir. Kolombiya, 2005 sonuna kadar BMMYK'nın ilgi alanaına giren nüfusa ev sahipliği yapan ülke olarak kalacak gibi. Irak ise 1.6 milyon kişi ile onu ikinci sıradan takip etmektedir. Diğer ülkeler sırasıyla Pakistan (1.1 milyon), Sudan (1 milyon) ve İran İslam Cumhuriyeti (975.000) gelmektedir. Bu beş ülke, BMMYK ile ilgili olan küresel mülteci nüfusunun 6.7 milyonuna, yani \%32'sine ev sahipliği yapmaktadır. (UNHCR Statistical Yearbook, 2005: 26).

\subsection{Sığıncmaılar ve Mülteciler}

2005 yılı sonu itibariyle tahminen 8.7 milyon kişiye ulaşan mülteci sayısında 1980 yılından beri gerçekleşen en önemli düşüş yaşanmıştır. 2005 yılında Pakistan, İran İslam Cumhuriyeti ile birlikte mülteciler için sığınma yeri olmaya devam etmiş ve bu iki ülke, yıl sonuna kadar dünyadaki mülteci nüfusunun \%24'üne ev sahipliği yapmıştır. Fakat her iki ülke de 751.000 Afgan mültecilerinin gönüllü geri dönüşleri sonucu sahip oldukları mülteci nüfus oranında bir düşüş yaşadı. Almanya, yıl boyunca \%20'lik bir mülteci nüfusu düşüşüne rağmen, 2005 yılında üçüncü büyük sığınma bölgesi oldu. Tanzanya Birleşik Cumhuriyeti ve Amerika Birleşik Devletleri (BMMYK tahmini), 2005 yılında sırasıyla yüzde dokuz ve altı düşüşler yaşanıyor olmasına rağmen, dördüncü ve beşinci büyük sı̆̆ınma ülkeleri olarak kaldı. 2005 yılında sadece Çad (+15.500 mülteci) ve Kenya $(+11.400$ mülteci) mülteci nüfusunda çok önemli artışlar gösterdi (UNHCR Statistical Yearbook, 2005: 27-28). Afrika'nın \%83'lük gibi bir mülteciyi barındırdığını görebiliriz. Buoran Afrikalı mültecilere aitken, Afrika'da \%7 civarında da Avrupalı mülteci görünmektedir. Yine yerli mültecilere baktığımız zaman Avrupanın \%80 gibi bir oranla ikinci sırada olduğunu, Asyanın \%77gibi bir oranla üçüncü sırada olduğunu görmekteyken, Lain Amerika ve Karayipler de ise yerli mültecilerin (\%26) sı ğınmacılardan daha az bir orana sahip olduğunu görmekteyiz. 2005 yılı sonunda yapılan başvuruların ilk aşamada karara bağlanmadığı en fazla Amerika Birleşik Devletleri'nde $(169,700)$ gerçeklemişken onu sırasyıla, G. Afrika (140.100), almanya (71.600) ve Avusturya (40.700) izlemiştir. Fakat 2005 yılı sonunda yine bazı ülkelerde sonraki aşamalarda yapılan başvuruların sonuçlandırılması BMMYK tarafından da sağlanabilmiştir. Bunlar sırasıyla ABD (-93.000), Almanya (29.200), Hollanda (-13.800), İsviçre (-12.300)'dir. ABD'deki düşüşlerin temel nedeni ise 2005 yılı boyunca, El Salvador (44.400) ve Guetemala'da (-25.600) meydana gelen yönetimle ilgili değişimler ve gelişmelerdendir. Ayrıca 2005 yılında birikmiş başvurulardan dolayı artıl olan diğer yerler Tayland (31.100), G. afrika (24.900), Burundi (9.200) ve Ürdün (5.500)'dür (UNHCR Statistical Yearbook, 2005: 31). 31). 1996-2005 yılları arasında Afganistan'da ( 5.2 milyon), Ruanda'da (1.8 milyon), Sırbistan ve Karadağ'da (1 milyon), Burundi'de (564.000) ve Liberya'da (576.000), yani tahminen 12.9 milyon mültecinin durumuna kendi ülkesinde kalıcı çözüm bulundu. Mültecilerin bu ülkelere geri döünşü için asgari koşullar sağlanmaya çalışıldı. Ama bir ülkede barış için adımlar atıldığı zaman, mülteciler için o ülke geri dönülebilecek bir niteliğe sahip olabilmektedir. Böylece yıllardır kamplarda olan mülteciler geri dönebilmek için karar verebilirler. Böylece ülkeleine dönebilen mülteciler için BMMYK adına da daha net bir biçimde istatistik elde edilebilir. Bu tür geri dönüşler, sürdürülebilir bir düzelmenin başlangıcı olabilir (UNHCR Statistical Yearbook, 2005: 36). 2005 yılında BMMYK'nın yardımıyla yaklaşık 30.500 mülteci ilk sığınma başvurusu yaptığı yere yerleştirildi, ki bu oran 2004 (29.600) ile benzerlik göstermektedir. BMMYK bu dönem içerisinde çeşitli ülkelere (Somali 5.900, Liberya 4.700, Sudan 3.200, Afganistan 3.200 ve Myanmar 2.900) farklı sayılarda mülteciler yerleştirdi. 83 ülkede BMMYK, 2004'e nazaran, 2005 yılında mültecilerin girişlerini daha kolaylaştırdı. BMMYK'nın yardımı ile en fazla mülteci Kenya'ya (6.800) yerleştirilmişken, bunu sırayla Tayland (2.500), Gine (1.900), Gana (1.800) ve Misır (1.300) izlemiştir. 2001-2005 yılları arasında BMMYK'nın ilgi alanına giren mülteciler, Kenya'daki ofisler aracılığıyla Nairobi'ye yerleştirilmiştir.

\subsection{Cinsiyet ve Yaş}

BMMYK'nın verilerinin yaşa göre dağılımına bakıldığı zaman ise 5.8 milyon kişiden oluşan bir grubun yaş 
oranlarının düşük olduğu görülmektedir. 5 yaş altında çocuk oranı \%12 iken, 18 yaş altı çocuk oranı \%44'tür. Bunların yarısı 18-59 arasında bir yaş oranına sahipken, \%6'sı 60 yaş ve üzeridir. Yukarıda belirtildiği gibi elde edilen bu veriler, BMMYK'nın ofislerinden elde edilen ve aynı zamanda kesin olarak da doğru bilgileri sunmayan verilerdir, bu verilerin arasında ulaşılamadığı için tahmini değerler oldukça yüksektir. Bölgelere bakıldığında ise Afrika bölgesinin 18 yaş altı çocuk nüfusunun yarısından fazlasını barındırdığını görmekteyiz. Diğer bölgeler ise sırasıyla; Avrupa (\%22), Latin Amerika ve Karayipler (\%25), Kuzey Amerika (22) ve önceki y1llara göre önemli bir düşüşün olduğu yer olan Asya ise (\%43)'tür. BMMYK verileri, mülteci kampları ve yerleşim yerlerinden elde ettiği verilere göre Latin Amerika ve Karayipler dışındaki bölgelerde eşit oranda cinsiyet oranlarının olduğunu göstermektedir. Latin Amerika ve Karayipler de bu oran \%58 gibi bir fark ile belirlenmiştir. Gelişmiş ülkelerdeki mülteci kamplarında ise çocuk oranları yüksektir. Beş yaş altındaki çocukların durumlarına bakıldığında ise bu oranın en fazla Afrika'da (\%18) olduğu görülmekte, onu sırasıyla Okyanusya (\%12), Asya (\%11) izlemektedir, büyük bir düşüşün olduğu Avrupa'da ise bu oran (\%3)'tür. 18 yaş altı çocukların yarısından daha fazlası yine Afrika'da görülmekteyken, Okyanusya'da (\%49), Latin Amerika'da (\%2), Karayipler ve Avrupa'da ise (\%21) olarak görülmektedir. 2005’te, 270 kentsel bölge yaklaşık 4.700 kişiye ev sahipliği yapmıştır. Yine 2005'in sonuna doğru, 190'dan fazla kentsel alanda 1000 kişiden fazla sayıda mülteciye ev sahipliği yapılmıştır. Ev sahipliği yapılan bu yerlerde cinsiyet genelde eşit düzeydedir. Bu düzeylerin değiştiği yer ise Asya ve Afrika kıtalarıdır. Kentsel olmayan yerlerde görülen kadın nüfusu ise daha çok yine Afrika kıtasındadır (UNHCR Statistical Yearbook, 2005: 54). 5 yaşından küçük kadın nüfusunun kamp içinde en fazla Afrika'da olduğu bilinmekteyken, ketsel alanda ise en fazla Okyanusya'da olduğu bilinmektedir. 60 yaş üstü kadınların ise kamp ortamında da, kentsel alanda da en fazla Avrupa'da, olduğu görülmektedir. Bunun sebebi ise yukarıda belirtildiği gibi, diğer mülteci bölgelerine göre daha iyi yaşam koşullarına sahip olması ile alakalıdır.

\subsection{Mülteci Başına Düşen GSYHi}

Sahra-Altı az gelişmiş ülkelerde mülteci başına düşen GSYHİ oldukça düşüktür. 2005 sonunda kişi başına düşen GSYHİ hesaplandığı zaman karşımıza en yüksek mülteci oranını barındırdığı için en fazla payı alan ve en yüksek oranla karşımıza Asya ve Afrika çıkmaktadır. Yine 2005 sonunda az sayıda mülteciyi barındırdığı için Birleşik Tanzanya Cumhuriyeti düşük bir GSYHİ'ye sahip olmuştur. Onu ise 2005 sonunda dünyanın en büyük mülteci nüfusunu barındıran Pakistan ise ikinci küçük oranda GSYHİ’ye sahip diğer ülkedir. Pakistan'1 da sırasıyla Demokratik Kongo Cumhuriyeti izlemiştir. Sanayileşmiş ülkelerde ise durum farklıdır. Örneğin Fransa'da 49 mülteciye, birleşik Krallık da 37 ve Almanya ve ABD'de 34 kişiye 1 dolar düşmektedir. 2005 yılında, ülkelerin sahip olduğu mülteci sayısı, onların daha fazla pay aldığı yıl anlamına da gelmektedir. 1000 kişi başına düşen mülteci nüfusu, o ülkelerin mülteci kabul etmeleri için daha elverişli bir ortam oluşturmaktadır. $\mathrm{Bu}$ duruma göre Ermenistan en elverişli konuma sahip görünmektedir. Buna göre Ermeni nüfusunun \%8'i mülteci nüfusundan oluşabilir diyebiliriz. Sırbistan ve Karadağ 1000 kişiye düşen 28 mülteci sayısıyla ikinci sırada yer alırken, Cibuti (25), Kongo (23) ve Zambiya (19) mülteci sayısıyla sıralamada yer almaktadır. Yandaki şekilde bu oranlar gösterilmiştir.

\section{Dünya'da Mültecilik: 2006}

2006 yılında BMMYK' ği ile ilgili olan nüfus arasında 9.9 milyon mülteci nüfus bulunmaktadır. 2005 'de 2.4 milyon olan vatansız/uyruksuz kişi sayısı, 2006'da 5.8 milyona çıktı. Bu sayıya ulaşılmasının en önemli nedeni verilerin daha sağlam bir şekilde elde edilmesi ve Nepal'den gelen bilgilerin daha güvenilir olmasıydı. Normalde elde edilen veriler tahminiydi fakat kayıtlı verilen gelmesi, sayının elde edilmesinde daha güvenilir bilgiye sebep olmuştur. BMMYK tarafından yerleştirilenlerin ise en fazla Kolombiya, Irak ve Uganda'da olduğu görülmektedir. Küresel anlamda toplam 32.9 milyon içinden, 15 milyon gibi bir rakamla Asya kıtası yine en fazla sayıya sahiptir, 2006 sonu itibariyle. Asya'yı yüksek oranda takip eden ikinci yerleşim yeri ise 9.8 milyon kişiyle Latin Amerika ve Karayipler izlemekteyken, geriye kalan sıralama ise şöyledir: Avrupa 3.5 milyon, Kuzey Amerika 3.4 milyon, Okyanusya 1.1 milyon ve Avrupa dışı alanlar ise 86. 000'dir. Avrupa dişı alanlarda en fazla artık kaydeden yerler ise sirasıyla; Kolombiya, Irak, Sudan ve Nepal'dir. 2006 yılı sonunda en fazla artışın yaşandığı yer olarak 3.6 milyon kişi ile Nepal karşımıza çıkmaktadır. Onu Kolombiya, Irak ve Uganda (2.2 milyon) izlemekte, geriye kalan sayı1 ise Demokratik Kongo Cumhuriyeti (1.8 milyon) ve Sudan (1.6 milyon) izlemektedir. Bu beş ülke, 2006 yılı sonunda elde edilen sayının \%39'unu oluşturmaktadır. Geçen yıl, yani 2005 'te, mülteciler ile ilgili Asya'da elde edilen veriler kaynak açısından oldukça güvenilirdi fakat 2006 yılında tüm verilerin böylesine bir güvenle elde edildiği söylenmeyebilir. Fakat Asya geçen yıl gibi bu yılda, mültecilerin nereli olduğunu belirlemesi açısından birinci sırada olmayı 11.1 milyon Asyalı mülteci ile devam ettiriyor. Afrika kökenliler 10.1 milyon kişi ile ikinci sırasını korurken, onu sırasıyla Latin Amerika ve Karayipliler (3.7 milyon) ve Avrupalılar (1.6 milyon) izlemektedir. Yalnız bu rakamlara 5.8 milyon uyruğu belli olmayan/vatansızlar dahil edilmemiştir. 2006 yılında vatansızlar hariç Kolombiyalılar 3.6 milyon kişi ve Iraklılar 3.5 milyon kişi ile yüksek mültecilik sayısına sahiptirler. Uzun yıllar sonra Afganlı mültecilerin sayısı 2.8 milyona düşmüştür. Kökenlerine göre mülteci sınırlamasında son beş ülke ise şöyledir: Sudanlı 2.1 milyon, Demokratik Kongo Cumhuriyeti 2 milyon, Ugandalı 1.9 milyon ve Somalili 890.000 kişidir (UNHCR Statistical 
Yearbook, 2006: 24-25).

\subsection{Sığınmacılar ve Mülteciler}

Afganistan hariç, Birleşmiş Milletler Ortadoğu Mültecilerine Yardım ajansı tarafından desteklenen verilere göre 4.4 milyon kişi ile Filistin kökenli mülteciler ikinci sırada yer almaktadırlar. 2006 yılı sonu itibariyle 2.1 milyon Afgan mülteci BMMYK’nın ofisinin olduğu yaklaşık 70 ülkede yaşamaktaydı. İkinci en büyük mülteci grubunu ise 1.5 milyonla Iraklılar oluşturmaktaydı ve Iraklı mülteci sayısı 2006'da tam beş kat arttı. Sudan 686.000 kişi ile üçüncü sırayı aldı. Geriye kalan üç ülkeyi ise Somali (460.000), Kongo Demokratik Cumhuriyeti ve Burundi (400.000) oluşturmaktaydı. Miyanmar'daki küresel mülteci nüfusu yaklaşık \%23 civarında artmıştır. Ayrıca Malezya ve Tayland'da mülteci oranlarında artış olduğu yine BMMYK verilerin göre söylenebilir. Somali'de de mülteci sayılarında artış vardır, bunun temel nedeni ise Yemen ve Kenyalı mültecilerin buralar varmasıdır. $2006 \mathrm{da}$, ayrıca bazı yerlerde mülteci oranlarında önemli düşüşler gerçekleşti. Azerbaycan -\%46, Liberya -\%31, Burundi -\%10 ve demokratik Kongo Cumhuriyeti -\%7 olarak belirtilmiştir, yine buralardaki düşüşün nedeninin, bu ülkelerdeki mültecilerin geri dönüşlerinden kaynaklandığı söylenebilir. Ayrıca iki ülkede daha düşüşler rapor edilmiştir, bunlar 25.000 kişi ile Hırvatistan ve 24.000 kişi ile Togo olmuştur (UNHCR Statistical Yearbook, 2006: 28). 2006 sonu itibariyle, Asya kendi toprakları üzerinde \%80 Asyalı mülteci bulundururken, bu oran Afrika'da \%79'dur. Amerika kıtasındaki mültecilerin çoğu, ABD ve Kanada'ya sı̆̆ınma başvurusu yapan Latin Amerika ve Karayiplerden gelen mültecilerdir. Avrupalıların yarısından fazlası ise yine Avrupa topraklarına sığınmıştır. Buna karşın Kuzey Amerika'da yaşayan Avrupalı mültecileri ile alakalı elde edilen veriler tahminlere dayanabilmektedir. BMMYK'nın dönem içi raporlarına ek olarak, kendi ülkeleri içinde yerinden edilmişler de BMMYK ile ilişkili olan gruplar içerisine girer. Genellikle ülke içi hareketlenmeleri hükümetler kontrol ettiği için bilgi elde etmek bazen zor olabilmektedir. Kendi ülkeleri içinde yerinden edilmişleri belirlemek hem metodoloji açısından hem de yer tespiti açısından zor olduğu için BMMYK, buradakiler için bilgileri daha çok hükümetlerden almaktadır. BMMYK raporlarına göre 2006 yılı sonunda ülke içinde yerinden edilmişlerin sayısı 12.8 milyon olarak bildirilmiştir. Bu oran 2005 y1lında ise 5.5 milyondu, meydana gelen artışın üç önemli sebebi vardır: birincisi, özellikle Lübnan, Irak, Kolombiya, Sri Lanka ve Doğu Timor'da binlerce kişinin yerinden edilmesidir. İkincisi, bazı ülkelerde 1 Ocak 2006 itibariyle BMMYK, kamp ve benzeri türü uygulamalar için başrol oynamaya başladı, bu da ilgi alanına giren kişi sayısının artması demekti. Üçüncüsü ise bazı ülkelerde bu grup için elde edilen veriler yeniden kontrol edilmiş ve oranın yükseldiği gözlenmiştir. Örneğin Fildişi Sahili gibi bir bölgede, tahmin ile 38.000 olarak belirlenen sığınmacı sayısı, yerinde kontrol edildiği zaman 709.000'e yükselmiştir. Dünya genelinde ülke içinde yerinden olmuş kişi sayısına bakıldığı zaman, karşımıza ilk sırada Kolombiya çıkmaktadır, 2006 sonu itibariyle. Aynı zamanda Irak da 1.8 milyon yerinden edilmiş kişi sayısı ile, Kolombiya'yı takip etmektedir. Demokratik Kongo Cumhuriyeti ve Uganda'da, 1.1 milyon ve 1.6 milyon kişi ile, ülke içinde yerinden edilmiş sayısı ile tehlike arz etmektedir. Sudan da ise yine yıl sonu itibariyle yerinden edilmişlerin sayısı 1.3 milyon civarında tahmin edilmektedir. Lübnan'da yaşanan silahlı çatışmalar yüzünden 750.000 kişinin yerinden edildiği tahmin edilmektedir. Daha sonra BMMYK, bu bölgede devreye girmiş ve sayının 200.000'e düşmesini sağlamıştır. Sonuç olarak ülkeleri içinde yerinden edilmişlerin sayısındaki artık 325.000 olarak gözlemlenmiş, bu sayı tahminen ise 469.000 olarak belirlenmiştir. Doğu-Timor, Çad ve Orta Afrika Cumhuriyeti'ndeki verilerle 93.000 ile 150.000 rakamları arasında ek bir artışın yaşandığı tahmin edilebilir.

\subsection{Cinsiyet ve Yaş}

2006 yılında yaş ile ilgili olarak elde edilen bilgiler, 2005 yılındaki sayıdan 2 milyon daha fazladır, ki 2005'te bu sayı 5.8 milyondur. Yukarıda belirtildiği gibi yaş ile elde edilen veriler tam anlamıyla BMMYK tarafından elde edilen veriler değildir. Yaşla ilgili olan nüfusun ortalama olarak 7.8 milyonun \%45'i 18 yaşının altındadır, \%11'i 5 yaşının altındadır, \%19 ise 5 ile 11 yaş arasındadır. Nüfusun yarısı 18 ile 59 yaş arasındadır. \%5'i de 60 yaşın üzerindedir.Kadınların çoğu Orta Afrika ve Büyük Göller (\%54) ve Batı Afrika'daki \%52) kamplarda yer alır. Ayrıca Asya ve Pasifik, Güney Afrika ve Avrupa'nın kırsal bölgelerinde bulunur. Kadınlar ancak CASWANAME bölgelerindeki kentsel alanlarda temsil edilmektedir. Kırsal ve kentsel yerlere kıyasla, kamplarda yaşayan mültecilerin daha genç olduğu ortaya çıkmaktadır. Ayrıca gelişmekte olan ülkelerde çocukların sayısı daha fazladır. 5 yaşının altında olan çocukların cinsiyet ve yaşlarının net olarak bilgilerinin elde edildiği yerler daha çok Asta ve Pasifik (\%12) ve CASWANAME (\%10) olarak tespit edilmiştir. Bunlarla birlikte en düşük oran Avrupa’da (\%5) gözlenmektedir. (UNHCR Statistical Yearbook, 2006).

\subsection{Mülteci Başına Düşen Gsyhi}

2006 y1lı sonunda da yine kişi başına düşen GSYHI düşük görünmekte ve pek de fazla bir yükselişin olduğu gözlenmemektedir. 2006 sonunda kişi başına düşen GSYHİ hesaplandığı zaman karşımıza en yüksek mülteci oranını barındırdığı için en fazla payı alan ve en yüksek oranla karşımıza Asya ve Afrika çıkmaktadır. 7 SahraAltı ülkesi ve 3 Asya ülkesi 1 dolar başına düşen mülteci sayısında yine ilk 10'da yer almaktadırlar. Yine 2006 sonunda az sayıda mülteciyi barındırdığı için Birleşik Tanzanya Cumhuriyeti düşük bir GSYHİye sahip olmuştur, yani 1 USD başına düşen en fazla sayıda mülteciyi bu ülke barındırmaktadır. Onu ise 2006 sonunda dünyanın en büyük mülteci nüfusunu barındıran Pakistan ise ikinci küçük oranda GSYHİ’ye sahip diğer ülkedir. Pakistan'ı da sırasıyla Demokratik Kongo Cumhuriyeti izlemiştir. Sanayileşmiş ülkelerde ise durum farklıdır. 37 
ülke arasında 1 USD başına düşen mülteci sayısı 10'dan fazla olan ülkelerin 19'u Sahra-Altı ülkelerinden iken, 15'i Kuzey Afrika ve Asya'dadır. Bunların yanında Sırbistan ve Karadağ'da 1 USD balına düşen mülteci sayısı 34, Almanya'da 26 ve ABD'de 12'dir. Bu ülkelere ek olarak Birleşik Krallıkta 8, Fransa ve Kanada'da 4'tür. (UNHCR Statistical Yearbook, 2006: 77). 2006 yılında, ülkelerin sahip olduğu mülteci sayısı, onların daha fazla pay aldı̆̆ yıl anlamına da gelmektedir.

\section{Dünya'da Mültecilik:2007}

Global göç, sığınmacı ve mülteci durumu için bir meydan okuma durumu olsa da bu rapor karışık göç akımlarına hitap etmez. Bunun ana nedeni bu fenomenin analizi kesin kanıt için gerekli olan kesin istatistiksel veriler ve güvenliğinin eksikliğidir. Aksi belirtilmediği sürece, rapor 31 Aralık 2007 tarihinden sonra meydana gelen olaylar ile ilgili değildir (UNHCR Statistical Yearbook, 2007: 4).

\subsection{Mülteciler ve Sı̆̆ınmacılar}

2007 sonu itibariyle BMMYK sorumluluğu altında toplam nüfus 32,9 milyondan 2006 da 31,7'e düşerek 1,2 milyon insanın (-3\%) temsiliyetini kaybetmiştir. Yılsonu itibariyle IDP (yerinden edilmiş) gibi durumda olan 146,000 insan için de 13,7 milyon IDP' nin tamamı, BMMYK baş aracılığı veya bir ortaklığında Gruplandırma ve başka düzenlemelerin altında insani yardım almaktadır (UNHCR Statistical Yearbook, 2007: 5-6). 2007 yılı sonu itibariyle, -\%80’i Afganlardan oluşan- mültecilerin üçte biri Asya ve Pasifik bölge ülkelerinde yerleştirildi. Güney Doğu ve Kuzey Afrika bölgesi bütün mültecilerin çeyreğine ev sahipliği yaptı- öncellikle Irak’tan-, Afrika ve Avrupa da sırasıyla dünya mültecilerin yüzde 20'sine ve 14 'üne ev sahipliği yapmıştır. Amerika bölgesi ise en az sayıda mülteciye ev sahipliği yapmıştır, ki Kolombiyalılar bu grup içinde en büyük sayıyı oluşturan mültecilerdir (\%9) (UNHCR Statistical Yearbook, 2007: 7). Irak'taki istikrarsı durumun sonucu olarak Orta Doğu ve Kuzey Afrika'da mültecilerin rakamları artmıştır. Hükümetlerin tahminlerine göre Ürdün ve Suriye Arap Cumhuriyeti beraber yaklaşık 2 milyon Iraklıya ev sahipliği yapmaktadır. Tersine Afrika'da mülteci rakamları yıl boyunca yüzde 6 azald1, bundan dolayı öncelikle, Burundi (39.800), Liberya (44,400), Kongo Demokratik Cumhuriyeti $(59,800)$, Sudan'a $(130,700)$ başarılı bir şekilde geri dönüş işlemleri gerçekleşmiştir. Orta Afrika Cumhuriyeti, Çad, Kongo Demokratik Cumhuriyeti, Somali ve Sudan'da silahlı çatışmaların ve ağır insan hakları ihlallerinin tekrarlanmasına rağmen yaklaşık 120,000 insanın ülkelerinden çıkmasıyla mülteci sayısında yeniden artış görülmüştür, bu mülteciler ilk olarak Kenya (25,000 gelenler), Kamerun (25,000), Sudan $(22,500)$ ve Uganda'ya (9400) gelmişlerdir (UNHCR Statistical Yearbook, 2007: 7). Amerika, Asya ve Pasifik bölgelerinde tahmin edilen mülteciler üzerinde daha önce belirttiğimiz metodolojik değişiklikler önemli bir etkiye sahiptir. İkincisi toplam mülteci nüfusu, Pakistan'da mülteci köyü dışında yaşayan, mülteci durumunda olan 1,1 milyon Afgan'dan dolayı 1 milyon kadar arttı. Şimdi Ekvator'da Amerikalılar, Kolombiyalılar $(250,000)$ ve Venezüella'nın Bolivar Cumhuriyeti'nde (200,000) mülteci olarak kabul edilen insanlar da, bölgenin mültecilerine dâhil edilmiştir. Bundan başka ABD'de mülteci nüfusundan yerleşmiş mülteci nüfusu hariç rakamlar 844,000'den 281,000'e düşmüştür (UNHCR Statistical Yearbook, 2007: 7-8). Avrupa'da, Ermenistan'da kabul edilen bir anlaşmadan dolayı, Azerbaycan'daki bir grup Ermeni mülteci geri dönmüştür. Böylece mülteci rakamı yılın başlarında 113.700'den 2007'nin sonunda 4,600'e düşmüştür (UNHCR Statistical Yearbook, 2007: 8).

Sığınmacı (ayrılmış) ve Köken (varmış) ülkelerinden birleştirilmiş raporlar temel alınarak, 2007 boyunca gönüllü olarak geri dönen mültecilerin 731,000 olduğu tahmin edilmektedir, bu oran fiilen 2006'da da (734,000) aynı sayıdadır. Geri dönülen ana ülkelere Afganistan (374,000), Sudan (130,700), Kongo Demokratik Cumhuriyeti $(60,000)$, Irak $(45,400)$, ve Liberya $(44,400)$ dâhildir. En fazla geri dönen mülteci rakamları Pakistan (365,700), Uganda (76,700), Tanzanya Birleşik Cumhuriyeti (67,900), ve Suriye Arap Cumhuriyeti (45,000) tarafindan rapor edilmiştir (UNHCR Statistical Yearbook, 2007: 9-10). Oysa geçmiş on y1lda mültecilerin büyük ölçekli geri dönüş hareketleri görülür. Milyonlarca Afgan’ın başlıca geri dönüşlerinden dolayı 2006 ve 2007 boyunca geri dönen toplam mültecilerin rakamları geçmiş 15 y1lın en düşük ikinci ve üçüncüsü sırasındaydı. Yalnızca 2001'de geri dönenlerin rakamı (462,000) en azdır. Küresel olarak geçmiş 10 yılda eve geri dönen 11,4 milyon mülteci olduğu tahmin ediliyor, bunların 7,3 milyonu veya \% 65'i BMMYK'nın yardımı ile olmuştur (UNHCR Statistical Yearbook, 2007: 10). Şu anda mültecilerin yalnızca küçük bir azınlığı yeni yerleşim yerlerinden faydalanmaktadır. 2007'de yeni yerleşim yerlerinden doğrudan dünya mültecilerinin \%1'den az kişi yararlanmıştır. 1998-2007 boyunca, ülkesine geri gönderilebilen 11,4 milyon mülteci ile karşılaştırıldığında yaklaşık 821,000 mülteci, yerleşim programı sayesinde üçüncü sığınmacı ülkeler tarafından kabul edildi. Bundan dolayı iade edilen her mülteci 1998'e kadar yerleştirilmiştir (UNHCR Statistical Yearbook, 2007: 10). 2007'de, BMMYK, yeni yerleşim yerlerine 99,000 bireyi devletleraracılığıyla yerleştirmiştir, bu son 15 yılın en yüksek oranıdır. Kalıcı çözüm ve koruma amaçları için yeni yerleşimlerin daha çok bilinçli ve stratejik kullanılması ve bu çözüm ihtiyacında kimliği belirlenmiş mültecilere BMMYK'nın önceki yılları etkileyen gelişmiş yetenekleri üzerinden iddia edilen rakamlarda önemli artış olmuştur. Önceki yıllarda yaklaşık 20,400' den fazla iken, yıl boyunca 49,600 mülteci dâhil, hemen hemen 49,900 birey BMMYK yardımı ile ayrıldı. Milletlere (uluslara) göre BMMYK'nın kolaylaştırdığı yerleştirme programlarından yararlananlar; Myanmar'da (20,200), Burundi'de (6,300), Somali'de (5,900), Irak'ta (3,800), Kongo Demokratik 
Cumhuriyeti'nde (2,500) ve Afganistan'da (2,300) mültecidir (UNHCR Statistical Yearbook, 2007: 10). 2006'da sayısı sekiz'den daha az iken 2007 boyunca yaklaşı 76 BMMYK ülke ofisi, mültecilerin kolayca yeni yerleşim yerlerinden ayrılmaları ile meşgul olmuştur. Mültecilerin en büyük rakamı Tayland $(14,600)$, Kenya $(6,500)$, Tanzanya Birleşik Cumhuriyeti (6,200), Malezya (5,600), ve Türkiye (2,700)'den ayrılanlar BMMYK'nın yardımı ile yerleşmiştir. Bu beş BMMYK Ofisi 2007'de ayrılan her 10 BMMYK destekli yerleşim yerlerinin dışında 7'si için beraber hesaplanmıştır (UNHCR Statistical Yearbook, 2007: 10-11). Toplam 75,300 mülteci Amerika Birleşik Devletleri (48,300), Kanada (11,200), Avustralya $(9,600)$, İsveç $(1,800)$, Norveç $(1,100)$ ve Yeni Zelanda (740) dâhil 14 yeni yerleşim yeri ülke tarafından kabul edilmiştir. Genel olarak, bu $2006(71,700)$ için toplam da \%5'in üzerindedir. Son birkaç yıl içinde Amerika Birleşik devletleri yeni yerleşim yeri olarak ortaya çıktı, gerçi Kolombiyalı mülteciler için sunulan dayanıklı çözüm düşük bir düzeyde kalmıştır (UNHCR Statistical Yearbook, 2007: 11).

\subsection{Yaş ve Cinsiyet Özellikleri}

Cinsiyete göre (20 milyon insan) mevcut veriler BMMYK'nın sorumluluğu altına düşen çoğu nüfusun yarısını kadınların temsil ettiğini gösterir. Onlar mültecilerin ve sığınmacıların yarısından (\%47) azını göstermektedir. Kadınların en düşük oranı BMMYK'ya (\%37) bağlı kategorilerin dışında bulunur. Ortalama rakamlar, ancak en yüksek değerler eğilimlidir. Etiyopya'da Shilmelba'nın mülteci kampında örneğin Amnabak'ın Çadiyen kampında onlar 16.700 yerleşimin \%61'i kadar iken 16,000 yerleşim yerinin yalnızca \%23'ü kadınlar temsil etmektedir (UNHCR Statistical Yearbook, 2007: 12). Yaşa göre BMMYK ile alakalı bilgi 31,7 milyon insanın \%42'si için kullanılabilir. Bunların yaklaşık \%42'si 18 yaşın altında, \%10 5 yaşının altında olan çocuklardır. Nüfusun yarısı 18 ve 59 yaş arasında iken ancak \%5'i 60 yaş ve yaşlılardır. Mülteci gibi durumda insan ve mülteciler arsında nüfusun \%46'sını çocuklar oluşturmaktadır. Onların oranları bu mülteciler arasında 2007'de (\%60) eve dönmüş olanlar arasında önemli bir şekilde yükselmiştir. Bu durum yeniden topluma kazandırma programı için özelliklede eğitim açısından tesisler ile silahlı çatışma nedeni ile yıkım düzeyinin yüksek olduğu yerlerde önemli zorunluluktur. Buna karşılık sı̆̆ınmacıların yalnızca \%27'si çocuklardan oluşmakta iken belli bir nüfus ise sanayileşmiş dünyada özellikle geleneksel olarak bekâr erkekler tarafından oluşur (UNHCR Statistical Yearbook, 2007: 12-13).

\section{Sonuç ve Değerlendirme}

Mültecilere kapıların tam olarak açılması, bu ülkelere mülteci akını olacağı gerekçesiyle reddedilmektedir. Ancak, bilim ve teknolojide son derece gelişmiş ve büyük ölçüde zenginleşmiş bir dünyada mültecileri kaderleriyle baş başa bırakmak insan onuruna yakışan bir davranış değildir. Çünkü İnsan Hakları Sözleşmesinin 14. Maddesinin 1. Fıkrasında "herkesin zulüm altında başka ülkelere sığınma hakkı ve sığınma olanaklarından faydalanma hakkı vardır” denilmektedir (Kuyaksil, 2002: 263; Aktaran, Açıkgözv ve diğ., 2011: 8). Ülkeler bu bağlamda, mültecileri bir yük olarak görmekten ziyade, temel insan haklarını (beslenme, barınma, güvenlik vb.) temin edecek bir konuma sahip olmalıdırlar. Bu kişilerin, insan hakları çerçevesinde insanlık onurlarının korunması son derece önemlidir (Urk, 2010). Oysa mültecilerin, "okyanus ötesi yolculukları, kendi evlerinde mahrum bırakıldıkları bir yaşam için yapılan bir yolcuğa dönüşmüştü. Dengenin, huzurun, gündelik hayatın zevklerinin ve hızla küreselleşen dünyada adil bir payın peşindelerdi. Onların yolculuğu sınırları olmayan bir dünyada sınırlara meydan okunması anlamında farklı bir tür küreselleşmenin, onları eşitler olarak kucaklayacak hoşgörülü bir küreselleşmenin talep edilmesidir.” (Yaghmanian, 2003: 140) Bununla beraber insanın yapısına, değerine ve ihtiyaçlarına yakışır bir tavırla muamele görmeleri gereklidir. Sığınmacı ve mültecilerin, kalıcı yerleşmeleri sağlanana kadar özellikle beslenme, barınma, eğitim ve sağlık hizmetleri gibi temel hizmetlerden yararlanmaları için hükümetler, sivil toplum kuruluşları ve üniversitelerin ülke genelinde daha yoğun çabasına gereksinim vardır (Usanmaz, 2008).

\section{Kaynakça}

- $\quad$ Açıkgöz, R. ve diğ. (2011) Modern Dünyada Mülteci Sorunu, 3.Uluslararası Balkanlarda Sosyal Bilimler Kongresinde Sunulmuş Bildiri, 30-31 Mayıs, Bosna Hersek.

- Ataman, Senar,(2008), “Türkiye'nin İltica Politikası”, http://www.multeci.net/t_iltica_1.htm (Erişim Tarihi: 05.10.2008).

- Beter, Önder (2006), Sınırlar ötesi Umutlar: Mülteci Çocuklar, Ankara, Sabev Yayınları.

- Deniz, O. (?) "Mülteci Hareketleri Açısından Van Kentinin Durumu ve Kentteki Mültecilerin Demografik Profili”, Doğu Coğrafya Dergisi, Sayı: 22, ss, 187-204.

- Emiroğlu K. ve Aydın S., (2003). Antropoloji Sözlüğü, Bilim ve Sanat Yayınevi, Ankara.

- Hobsbawm, E. J. (1999) Sermaye Çăğ, Çev: Vedat Aslan, Dost Yayınları, Ankara.

- İçduygu, Ahmet (2007) 'The Politics of Irregular Migratory Flows in the Mediterranean Basin: Economy, Mobility and 'Illegality", Mediterranean Politics, Vol.12, No.2, s.141 - 161.

- Kaygalak, S. (2009) Kentin Mültecileri: Neoliberalizm Koşullarında Zorunlu Göç ve Kentleşme, 
Dipnot Yayınları. Ankara.

- Kara, P.-Korkut, R. (2010) Türkiye'de Göç, İltica ve Mülteciler” Türk İdare Dergisi, Sayı: 467, ss, $153-162$.

- Kılıç, T., Bir İnsan Hakkı Olarak İltica, Web : http://www.multeci.org.tr /images/ stories/pdf/br\%20nsan\%20hakki\%20olarak\%20ltca.\%20av.\%20taner\%20kl.pdf, Erişim: 15.07.2011.

- Ö̈zdogru, 2008, “Dünyada Mülteci Hareketleri, Türkiye'nin Konumu ve Mültecilerin Karsılastıkları Sorunlar”, Mülteci Sempozyumu Bildirisi, İstanbul, http://multeci.ihh.org.tr (04.11.2008).

- Peker, B.- Sancar, M. (2005), Mülteciler ve İltica Hakkı: Yaşamın Kıyısındakiler Hoşgeldin Diyebilmek, Ankara, İnsan Hakları Derneği Yayınları.

- Somersan, S. (2004) Sosyal Bilimlerde Etnisite ve Irk, İstanbul, İstanbul Bilgi

- Şenocak, S. O. (2007) Avrupa'da Mülteci Olmak: Karanlıktaki Gölge, Ozan Yayıncılık. İstanbul.

- Tekin, M. (2009) Türkiye'de Yaşayan Sığınmacı ve Mültecilerin Entegrasyonunda Yaşanan Sorunlar Ve Avrupa Birliği Uygulamaları Bağlamında Çözüm Önerileri, Polis Akademisi, Güvenlik Birimleri Enstitüsü, Uluslar arası Güvenlik Anabilim Dalı, Yayınlanmamış Yüksek Lisans Tezi. Ankara.

- UNHCR Statistical Yearbook (2004) http://www.UNHCR.org/statistics/STATISTICS /44e96c842.pdf, Erişim: 05.06.2011.

- UNHCR Statistical Yearbook (2005) http://www.UNHCR.org/statistics/STATISTICS /464478a72.html, Erişim: 05.06.2011.

- UNHCR Statistical Yearbook (2006) http://www.UNHCR.org/statistics/STATISTICS /478cda572.html, Erişim: 05.06.2011.

- UNHCR Statistical Yearbook (2007) http://www.UNHCR.org/statistics/STATISTICS /4852366f2.pdf, Erişim: 05.06.2011.

- Urk, M. (2010) Göç Olgusu Bağlamında Mülteciler, Sığınmacılar ve İnsan Hakları, Maltepe Üniversitesi, sosyal Bilimler Enstitüsü, İnsan Hakları Anabilim Dalı, Yayınlanmamış Yüksek Lisans Tezi. İstanbul.

- Usanmaz, G. (2009) Göç, Mülteciler ve STK'lar, Ankara Üniversitesi, Sosyal Bilimler Enstitüsü Siyaset Bilimi Anabilim Dalı, Yayınlanmamış Yüksek Lisans Tezi. Ankara. 


\title{
Kırgızistan'da Vergi Kültürü ve Belirleyenleri
}

\author{
Raziahan Abdieva (Kyrgyzstan-Turkey Manas University, Kyrgyzstan) \\ Jusup Pirimbaev (Kyrgyzstan-Turkey Manas University, Kyrgyzstan) \\ Tuncer Özdil (Kyrgyzstan-Turkey Manas University, Kyrgyzstan)
}

\section{The Tax Culture in Kyrgyzstan and its Determinants}

\begin{abstract}
Government needs healthy and permanent finance resource to carry out its functions successfully and effectively. Healthy and permanent finance resource depends on efficiency of tax system. There are two sides in taxation: the government who impose taxes and citizens who pay taxes. The relationship between these two sides, their views about each other's significantly influence the successiveness of tax system.

In our study we research taxpayers' perceptions of the tax, their tax conscience and their opinions about tax system and government. The results of the survey carried out in capital city of Kyrgyzstan between 500 taxpayers showed that the tax culture is low and the most important factors affecting the tax culture are: trust in the government, quality of public services and the informal economy. Moreover, proposals will be given, in order to establish more efficient tax system by improving tax culture.
\end{abstract}

JEL Codes: H20, H70, C38

\section{Giriş}

Son yıllarda mükelleflerin vergi uyumu ile ilgili yapılan çalışmalarda, iktisatçıları insanların niçin vergi ödedikleri konusu ilgilendirmeye başlamıştır. Allingham ve Sandmo (1972), vergi kaçakçıllı̆ı ile vergi denetiminin sıklığı ve cezaların ağırlığı arasında negatif bir ilişki olduğunu söyleyerek bir ekonomik model oluşturuşmuşlardır. Fakat, bu model çoğu iktisatçı tarafindan eleştirilmiştir ve yapılan amprik araştırmalar çoğu ülkelerde caydırma seviyesi düşük olmasına rağmen, vergi sorumluluklarına uyum seviyesinin yüksek olduğunu göstermiştir (Torgler, 2001, Halla, 2010, v.d. ). Bu durum iktisatçıların ilgisini daha da arttırmış ve çoğu iktisatçı bu bulmacanın anahtarının mükelleflerin vergi kültürü olduğunu düşünmüşlerdir (Alm et. al., 1992; Frey, 1997; Torgler, 2005 v.d.).

Vergi kültürü, mükelleflerin vergileri ödeme isteğidir (Frey and Torgler 2004: 7) veya "vergi ödemeye olan içsel motivasyon-(intrinsic motivation)"dur (Torgler, 2007). Akdoğan'a göre (2006: 180) ise vergi, müklleflerinin vergi yasalarından doğan yükümlülüklerini, gerçeğe uygun bir şekilde yerine getirme konusundaki davranışlarının düzeyi vergi kültürünü göstermektedir. Vergi kültürüyle ilgili yapılan tanımlarda genel olarak, vergi kültürünün insanın daha çok içsel duygularına odaklanması halinde, vergi kültürüyle ilgili bu içsel duyguların davranışlara ne kadar yansıdığı olgusu dikkat çekmektedir. Böylece, vergi kültürü, vergi mükelleflerinin vergisel yükümlülüklerini zamanında, doğru ve titizlikle yerine getirmelerine neden olan içgüdü ve bunun sonucunda vergi yükümlülüklerinin yerine getirilmesidir şeklinde tanımlanabilir. Vergi kültürü, mükelleflerin vergi yükümlülüklerini gönüllü bir şekilde yerine getirmelerine neden olan önemli bir etken olduğundan devletler için de çok önemli bir kavramdır. Vergi kültürünün yüksek olması vergi idaresi ile ilgili harcamaları azaltacak, devletin yeterli ve sürekli bir gelir temin etmesini sağlayacak ve bu yolla devletin fonksiyonlarının başarılı ve etkin bir şekilde yerine getirilebilmesini sağlayacaktır.

Vergi kültrünün bu özelliği, özellikle devletin kaynak bulmada ciddi mali sıkıntılar yaşadığı geçiş ekonomileri için daha da önemlidir. Bu nedenle, geçiş ekonomilerinde, vergi kültürünün ve vergi uyumunun geliştirilmesi için vergi kültürünü oluşturan faktörlerin belirlenmesi önemlidir. Çalışmamızda bir geçiş ekonomisi olan Kırgızistan'da vergi kültürü ve bunu etkileyen değişkenler inceleme konusu yapılmıştır. Bişkek'te yaşayan 500 vergi mükellefine uygulanan anketle Kırgızistan'da vergi kültürü ve vergi kültürünü etkileyen faktörlerin neler olduğu araştırılmıştır.

\section{Vergi Kültürü ve Vergi Kültürünü Etkileyen Faktörler}

Genel olarak vergi kültürü mükelleflerin vergi ödeme isteği olarak tanımlanabilmektedir. Ekonomilerde devletin en önemli gelir kaynağı vergi gelirleridir. Bu gelirle bütün kamu harcamaları finanse edilmekte veya vergi gelirleri yetersiz olduğunda kamu harcamalarında kısılmaya gidilmekte veya bütçe açıkları ortaya çıkarak ekonomide enflasyonist süreç oluşmaktadır. Kamu finansman açılarının giderilmesinde vergi gelirlerinin arttırılması önemli bir araçtır. Vergi kültürüne bağlı olarak artan vergi gelirleri vergi dairelerinin kontrol faaliyetleriyle masraflarını azaltırken kamu harcamalarının finansmanında da kolaylıklar sağlayacaktır.

Mükelleflerin vergi kültürünü etkileyen faktörleri, başlıca dörde ayırabiliriz (Kirchler, 2007). Bunlar, SosyalPsikolojik faktörler, Siyasi faktörler, Ekonomik faktörler ve Sosyal-demografik faktörlerdir. Sosyal-psikolojik 
faktörler vergi bilinci, vergi mükellefi, vergi psikolojisi, vergi zihniyeti, sosyal normlar, mükelleflerin adaletle ilgili görüş̧leri ve vergi uyumunun motivasyonundan oluşmaktadır. Mükellefler ödedikleri vergilerin adaletsiz olduğu kanaatinde iseler, onlara göre vergi kaçırmak da adaletli olacaktır. Bunun yanında son zamanlardaki yapılan ampirik araştırmaların sonuçlarına göre (Alm, Jackson ve McKee, 1992a; Falkinger ve Walther, 1991), vergi kültürünü yükseltmede cezalandırmalara göre teşvik edici politikalar istenen amaca ulaşmada daha etkin olduğunu göstermiştir. Bu çalışmalarda, vergi denetiminin sonucunda vergi yükümlülüklerini tamamıyla ve doğru bir şekilde yerine getiren mükelleflere ödül vermek, piyangoya katılımını sağlamak ve denetim sayısını azaltmak gibi teşviklerin verilmesinin vergi kültürüne önemli pozitif etkide bulunduğu tespit edilmiştir.

Vergi mükelleflerinin yaşı, cinsiyeti, medeni durumu, eğitim ve gelir seviyeleri, dinine bağlı olmaları gibi sosyo-demografik özellikler de vergi kültürünü etkilemektedir. Yapılan çoğu çalışmaların sonuçları mükelleflerin yaşı yükseldikçe, onların evli olmaları, eğitim ve gelir seviyesinin yüksek oması ve kadınların vergi kültürünün daha yüksek olduğunu göstermiştir (Alm and Torgler, 2006; Torgler, 2001; Torgler, 2003 v.d.).

Vatandaşların vergileri gönüllü ödeme isteğine, dolayısıyla vergi kültürü seviyesine etki eden en önemli faktörlerden biri de siyasi faktördür. Diğer bir deyişle, vatandaşların devlete ve yasal sisteme olan güveni, iktisadi ve mali politikaların yürütülmesinde onların istek ve ihtiyaçlarının da dikkate alınması ve halkın politik kararlara katılımının yüksek olması, bir başka deyişle doğrudan demokrasinin varlı̆̆ı (Torgler, 2005), vergi kanununun net, basit ve adaletli olması, vergi organlarının mükelleflere saygılı davranması (Feld and Frey, 2002), vergi mükelleflerinin vergi kültürlerinin yüksek olmasına neden olan en önemli siyasal faktörlerlerdir.

\section{Vergi Kültürüyle İlgili Yapılan Araştırmalar: Kırgızistan'da Vergi Kültürü}

Genelde gerek gelişmiş, gelişmekte olan ülkelerle gerekse de geçiş ekonomilerinde vergi kültürü ile ilgili yapılan araştırmalarda "Dünya Değerler Anketi (DDA) (World Values Survey)" adlı geliştirilmiş anket formundaki "İmkanım olursa vergiden kaçınırım" ifadesine verilen cevaplar kullanılmaktadır. Bu anketten elde edilen sonuçlara göre, OECD ülkelerinde 1990-1993 yıllarında \% 54,5'i, 1995-1997 yıllarında \% 58,7'i yukarıda belirtilen vergiden kaçınırım ifadesine "kesinlikle katılmadık"larını bildirmişlerdir. Ayrıca, Japonya'da katılımcıların \% 81,9'u, ABD'de \% 66,7'si ve Kuzey İlanda'da \% 69,7'si yukarıdakine benzer şekilde "kesinlikle katılmadık”larını ve görüşün doğru olmadığını bildirmişlerdir (Torgler, 2003).

Geçiş ekonomilerinde ise, SSCB'nin dağılmasıyla bu ülkelerde görülen iktisadi krizler, toplumdaki yapısal ve sosyal reformların etkinliğinin düşük olması, halkın yaşam seviyesinin düşmesi, yolsuzluk ve kayıt dişı ekonominin genişlemesi gibi unsurlar halkın devlete olan güvenini sarsmıştır. Önceki SSCB'nin üye ülkeleri olan Azerbaycan, Beyaz Rusya, Estonya, Gürcistan, Letonya, Litvanya ve Ukrayna gibi ülkelerde 'İmkanım olursa vergiden kaçınırım' ifadesine 1990-1993 yıllarında katılımcıların \% 56,9'u, 1995-1997 yıllarında \% 42,8'i katılmadıklarını bildirmişlerdir (Torgler, 2007).

Kırgızistan'da da, diğer tüm geçiş ekonomilerinde olduğu gibi, SSCB dönemindeki vergi sisteminde halktan toplanan vergilerin payının çok küçük olması (bütçe gelirlerinin \%7'si) vergi mükelleflerinin vergi bilinçlerinin düşük olmasına neden olmuştur.

SSCB'nin dağılımı ile çoğu üretim işletmelerinin durdurulması işsizliğin büyümesine ve halkın fakirleşmesine neden olmuştur. Gayrıresmi verilere göre, 2000'li yıllarda halkın \%80'inden çoğu fakirlikle yaşamıştır (Sarıbayev, 2002: 185).

Kırgızistan'da piyasa ekonomisi koşullarına göre vergi sistemi 1992 yılında düzenlenmeye başlamıştır. Yapılan reformların sonucunda özel sektörün genişlemesi ve bu sektörde çoğu işlemlerin gizli yapılması, vergi idaresinin piyasa ekonomisi koşullarında vergileri idare etme tecrübesinin olmaması ve kalifiyeli elemanların az olması, diğer yandan halkın yaşam seviyesinin düşük olması vergi idaresi sorununu ortaya koymuştur. Bu durumda, kayıt dışı ekonomi genişlemiştir. Karatalov'a göre (2010: 28) 2000'de Kırgızistan'da kayıt dışı ekonomi, GSYIH'nın \%46,3'ünü, 2008'de \% 42,3'ünü oluşturmuş̧tur. H.Yakışığın (2006: 190) hesaplamalarına göre ise kayıt dışı ekonomi 1995 yılında GSYIH'n'n \% 76'sını, 2005'te \% 92'sini oluşturmuştur.

Vergi sistemi reformunda; vergi mükelleflerinin görüşleri, anlayışları ve psikolojileri dikkate alınmadan uygulanan vergi politikasının ilk amacı; devletin mali sorunlarını çözme olarak hedeflenmiştir. Bu doğrultuda hem vergi oranları çok yüksek, hemde vergi sayısı tür olarak çok fazla tutulmuştur. Vergi kolaylıkları kaldırılmış, cezalar arttırılmıştır. Mükelleflerin hakları sınırlandırılarak, vergi organlarına sınırsız haklar verilmiştir. Böyle bir süreç, üretim yapma imkanını yok etmiş, ve gelirler saklanmaya, diğer bir deyişle, kayıt dışı ekonominin oluşmasına ve hızla genişlemesine neden olmuştur. Sonuçta mükellefler vergi kaçırabilmek için her yol ve yöntemi kullanmaya başlamışlar ve vergi kaçırma toplumda doğal kabul edilen bir sosyal norma dönüşmüştür. Böylece, 1991-1995 yıllarında vergi gelirleri GSYİH'nın \% 14-15' iken, 1996-2001 yıllarında bu oran \% 12'ye düşmüştür. 2002'den itibaren vergi gelirleri oranı yükselerek 2008-2009 yıllarında \%19'a ulaşmıştır. (KC. İstatistik Komitesi, www.stat.kg).

Kırgız Cumhuriyetinin vergi sistemindeki dolaylı ve dolaysız vergileri incelendiğinde, ülkede dolaylı vergilerin oran olarak daha çok olduğu görülmektedir. 2009 yılında dolaylı vergilerin toplam vergi gelirlerindeki 
pay1 \% 67,3’tür. Doğrudan vergilerin (kurumlar ve gelir vergisi) milli gelire oranı \% 10'dur. Gelir vergisinin hemen hemen tamamı, \%99-100’ü işverenler tarafindan ödenmektedir. Diğer bir deyişle, beyanname usulu ile gelir vergilerini ödeyenlerin payı yok denecek kadar azdır. "PricewaterhouseCoopers" adlı uluslararası kuruluşun araştırmalarına göre, Kırgız Vergi Sistemi karmaşıklığına göre sıralandığında 2010'da 150. sırada bulunmaktadır. $\mathrm{Bu}$ araştırmaya göre Kırgızistan'da işletmelerin karlarının \%57,2'si vergi olarak ödenmektedir. Dünya Bankası tarafından yürütülen 'İş İklimi ve İşletmelerin Faliyet Performansları' (BEEPS) araştırmalarının sonuçlarına göre, Kırgızistan; Bağımsız Devletler Topluluğu ve Doğu ve Merkezi Avrupa ülkelerinin arasında vergi organlarında ve yargı sisteminde yolsuzluğun en yüksek olduğu ülke olmuştur.

\section{Kırgızistan'da Vergi Kültürü Üzerine Bir Araștırma}

Kırgızistan'da yaşayan özel ve tüzel kişi vergi mükelleflerinin vergi sistemiyle ilgili düşüncelerini öğrenebilmek, vergi ödeme isteklerini, vergiden kaçınma eğilimlerini belirleyerek kısaca vergi kültürünü tanımlayabilmek için bir alan araştırması yapılmıştır.

\subsection{Araştırmanın Amacı, Yöntemi, Anakitlesi ve Örneklemi}

Araştırmanın temel amacı Kıgrızistan'da yaşayan vergi mükelleflerinin vergi ödeme eğilimlerini, vergi ve Kırgızistan'daki vergi sistemiyle ilgili görüşlerini öğrenmek ve vergi kültürünü etkileyen sosyo-ekonomik kültürel değişkenleri belirlemektir.

Bu amaçla Kırgızistan’ın başkenti Bişkek’te bulunan 100 tanesi tüzel kişi olan toplam 500 kişi üzerinde uygulanan bir anketle araştırmayla ilgili veriler elde edilmiştir. Araştırma konusunun kapsamı gereği Kırgızistan'da yaşayan tüm vergi mükellefleri araştırmanın anakitlesini oluşturmaktadır. Bu anakitle içerisinde hem özel hemde tüzel kişiler de vardır. Anakitlenin özelliği gereği, her an yeni kurulan ve kapanan işletmeler ve vergi mükellefi olma özelliğini yitiren ve kazanan kişiler olduğu düşünüldüğünde anakitle sınırsız anakitle olarak düşünülebilir.

Araştırmada bireysel çabalarla ancak 500 büyüklüğünde bir örnek kitle kullanılabilmiştir. Anakitlenin tamamına ulaşılamadığında örnek kitlenin anakitleyi temsil yeteneğiyle ilgili kuşkular her zaman geçerli olmakla birlikte, burada ulaşılan örnek büyüklüğünün elde edilen sonuçların istatistiksel olarak güvenilirliği bakımından yeterli olduğu düşünülmektedir. Elde edilen anket sonuçları frekans dağılımları ve betimleyici istatistik araçlarıyla değerlendirildikten sonra anlamlı farklılıklar tek örneklem "t" testiyle araştırılmıştır. Vergi kültürünü tanımlamada öne çıkan boyutun tanımlanabilmesi için görüş ve tutum belirten sorulara faktör analizi uygulanmıştır.

\subsection{Araştırmanın Geçerlilik ve Güvenilirliği}

Araştırmayla ilgili hazırlanan anket formu, konuyla ilgili yapılan literatür taraması, benzer araştırmalarda kullanılan sorular incelenerek elde edilen bilgiler ve araştırmanın yapıldığı doğal ortam gözlemlenerek titizlikle hazırlanmıştır. Bu yönüyle araştırmada kullanılan soruların araştırma hipotezlerini tanımlama ve araştırmanın genel hedeflerine ulaşmada yeterli ve geçerli olduğu düşünülmektedir.

Anket sorularına verilen cevapların içsel tutarlılı̆̆ı güvenilirlik analiziyle ayrıca incelenmiştir. Sosyal bilimlerle ilgili araştırmalarda likert ölçekli ve iki sonuçlu dikotomik değişkenlerin içsel tutarlılığının ölçülmesinde yaygın olarak kullanılan Cronbach Alpha katsayısı buradada görüş ve tutum belirten 65 değişken üzerinde uygulanmış, sözkonusu katsayı 0,790 olarak elde edilmiştir. Genel olarak 0,70'in üzerinde çıkan değerlerin güvenilir olduğu düşünüldüğünde burada elde edilen 0,79 değeriyle anketin içsel tutarlılığının sağlandığı, anket sonuçlarının istatistiksel olarak da güvenilir olduğu söylenebilir. Güvenilirlik analizinde anket sonuçlarının toplanabilirlik varsayımının sağlanıp sağlanmadığı Tukey eklenebilirlik testi ve anket sorularına verilen cevapların homojen gruplar oluşturup oluşturmadığı iki yönlü varyans analiziyle araştırılmaktadır.

Anket verileri için her iki test hesaplanmış ve 0,001 'den küçük önem seviyelerinde (fhesap=79,459, p=0,000 ve Thesap $=439,458, \mathrm{p}=0,000$ ) sıfır hipotez reddedilerek, toplanabilirlik varsayımının sağlandığ 1 ve sorulara verilen cevapların birbirine göre farklı olduğu bu yolla da hesaplanan güvenilirlik katsayısının istatistiksel olarak da geçerli ve güvenilir olduğu anlaşılmıştır.

\subsection{Ankete Katılanların Genel Özellikleri}

Ankete katılanların \%67'si 30 yaşından küçüktür. Katılanların genç kesimden oluşması gelecekte vergi politikasının yönünü belirlemek açısından önemlidir. Katılımcıların \% 58,9'u kadınlardır. Medeni durumlarına göre, özel kişilerin \%37'si evli, \%62'i bekar iken, tüzel kişiler adına cevaplandıran katılımcıların tam tersine $\%$ 63'ü evli, \%36'sını bekar olduğu görülmektedir. Ankete katılan özel kişilerin ailelerinin gelir seviyesi, 15.000 somdan düşük olanların oranı \%68'dir. Özel kişiler aile yapısı bakımından, tek kişi olarak yaşayanların oranı \%14.2, ailesi 2 kişiden oluşanların oranı \%10.5, 3-5 kişi arası olanların oaranı \% 50.5, ailesinde 6'dan fazla kişi olanların oranı ise \%23.5'dur. Katılımcıların yarısının ailesi 3-5 kişiden oluşan çekirdek kalabalık ailedir. Katılımcıların özel kişilerin \%52'si, tüzel kişi adına cevap verenlerin \%60'1 üniversite mezunu, \%20'si meslek okul, özel kişilerin \%20'si ve tüzel kişi adına katılanların \%9'u ortaokul ve yaklaşık \%5'inin de üniversite 
sonrası eğitim aldığı görülmektedir.

Ankete katılan tüzel kişilerin faaliyet süresine göre dağılımına baktığımızda, \%54'ünün faaliyet süresi 1 ve 5 yıl arası, \%19'unun 6 ve 10 yıl arası, $\% 18$ 'inin 11 ve 15 yıl arası, $\% 8$ 'inin faaliyet süresi ise 16 ve üzeri olarak elde edilmiştir. Kırgızistan'da çoğu firma bağımsızlık sonrası dönemde kurulduğundan firmaların çoğunun faaliyet süresi 1-5 yıl arasında çıkmıştır. Firmaların \%2'si tarım, \% 11'i üretim, \% 36'sı hizmet sektöründe faaliyet göstermekte ve $\% 50$ 'si de ticaretle uğraşmaktadır. Ankete katılanların \%80'ini küçük işletmeler, $\% 20$ 'sini de orta ve büyük işletmeler oluşturmaktadır. Katılımcıların çoğunun küçük işletmelerden oluşmasının bir nedeni de, büyük işletmelerin araştırmaya olan ilgisizliği olmaktadır.

Ankete katılanlara dünya görüşü olarak kendinizi nasıl tanımlarsınız diye sorulduğunda, özel kişilerin $\% 40.5$ 'i kendisini "dindar olmamakla birlikte doğruluk ve dürüstlük gibi ahlaki ilkelere çok önem verdiği”, $\% 28$ 'i "dinle ilgili olmadığını fakat Allah korkusu olduğu", \%20'si de "çok dindar", \% 7.8'i "laik dünya görüşüne sahip olduğu", \%1.8'i "ateist olduğu" şeklinde tanımlamıştır.

Ankete katılan özel kişilerin \%42.8'i gelir vergisini, \%40'1 KDV, \%12.5'i kurumlar vergisini ve \% 20.8'i diğer vergiyi ödediklerini belirtmişlerdir. Tüzel kişilerin \%59'unun gelir vergisi, \%53'ünün kurumlar vergisi, \%45'inin KDV ve \% 15'inin de diğer vergilerin yükümlüsü olduğu görülmektedir. Katılımcıların sadece \% 40'1 KDV yükümlüsü olduğunu söylemiştir. Halbuki, her satın alınan malın içinde söz konusu vergi olduğundan burada halkın bu vergiyi ödediğinin pek de farkınnda olmadığı görülmektedir.

\subsection{Katılımcıların Vergi Kültürüyle İlgili Görüsşleri}

Genel olarak katılımcıların vergi kültürüyle ilgili görüşlerini öğrenebilmek için ankette belirtilen sorulara cevaplar 1 kesinlikle katıliyorum 5 kesinlikle katılmıyorum olacak şekilde 1 ve 5 arasında verilen puanlarla alınmıştır. Puanlamada en ortada yer alan 3 puan kararsız olarak düşünülmüştür. Sorulara verilen puanların ortalamaları alınarak bu ortalamaların '3' puan olan kararsız seçeneğine göre farklılı̆ıının anlamlı olup olmadığı istatistiksel olarak tek örneklem $t$ testi ile araştıılmıştır. Elde edilen sonuçlar tablo 1 'de verilmektedir. 0,10 'dan küçük önem seviyelerinde elde edilen farklılıklar anlamlı farklılık olarak değerlendirilmiş, 3 'ten küçük ortalamalar katılım yönlü, 3 'ten büyük ortalamalar katılmama yönlü olarak düşünülmüştür. 0,10 'dan büyük önem seviyelerindeki farklılıklar ise istatistiksel olarak anlamlı farklılık olarak değerlendirilememiş, ve bu ifadelerdeki ortalamalar '3'e eşit gibi düşünelek "kararsız" olarak yorumlanmıştır.

Burada elde edilen sonuçlara göre, mükellefler vergileri kutsal bir ödeme olarak kabul ettiklerini göstermiştir. Bu da mükelleflerde vergi bilincinin var olduğunu göstermektedir. Fakat aynı zamanda, vergileri bir yük olarak saydıklarını ve elde edilen gelirlerin belli bir kısmının beyannamede göstermemenin doğal bir şey olduğunu bildirmişlerdir. Bununla birlikte vergilerin tamamın ödeyerek iktisadi faaliyette bulunmanın olanaksız olduğunu belirtmişlerdir. 'İmkanım olursa vergiden kaçınırım' ifadesine ankete katılan 500 mükellefin \%33'ü katıldıklarını, \% 24'ü kararsız kaldıklarını ve \% 41'i katılmadıklarını söylemişlerdir. Vergi mükellefleri ödemekte oldukları vergi yüklerinin ağır olduğunu, vergi sisteminin adaletli olmadığını, vergi kanunlarının yapısının karmaşık ve zor olduğunu bildirmişlerdir. Bununla birlikte mükellefler ülkede vergilerin gelir seviyesi yüksek olanlardan yüksek oranda, gelirleri düşük olanlardan düşük oranda alındığına ve her bir kişinin vergilerinin tamamıyla ödediğine inanmadıklarını söylemişlerdir. Mükellefler diğer mükelleflerin ne miktarda vergi ödediklerini bildiren güvenilir ve resmi bilginin olmasının ve vergi sisteminin şeffaflığının onların gönüllü vergi ödeme isteğini arttıracağını bildirmişlerdir.

Dindar insanlar, vergi ödeme yükümlülüklerini tam olarak yerine getirmesi gerektiğini düşünüyorlar. Bu da katılımcıların düşüncesine göre din ile vergi ahlakı arasında pozitif bir ilişki olduğu konusunda bize ipucu vermektedir. Katılımcılar Kırgızistan'da kanunilik ilkesinin çalışmadığını, ülke yargı sistemine, Parlamentoya ve Vergi İdaresine güvenmediklerini, vergilerle ilgili yargısal süreçlerin adaletli yürütülmediğini, vergi organlarının vergi mükelleflerinin haklarına saygı göstermediğini bildirmişlerdir. Bununla birlikte, mükellefler vergi gelirlerinin etkin ve doğru kulanılmadığını ve onların ödemekte oldukları vergilerin geri kamu hizmetleri şeklinde döneceğine inanmadıklarını söylemişlerdir. Katılımcılar Kırgızistan'da vergi kaçırmanın çok yaygın olduğunu, aynı zamanda vergi kaçıranları suçlu saymadıklarını ve bu kişilere normal davrandıklarını belirtmişlerdir. Ayrıca katılımcılar devlete güvenin olduğu ve kamusal hizmetlere olan ihtiyaçlarının karşılandığı durumda vergileri gönüllü ödeme isteklerinin artacağını bildirmişlerdir. 


\begin{tabular}{|c|c|c|c|c|c|}
\hline No & İfadeler & $\mathrm{N}$ & Ort. & Std.Sap & p. \\
\hline 1 & Vergi kutsal bir görevdir & 493 & 2,14 & 1,36 & ,00 \\
\hline 2 & Ben vergileri gönüllü olarak, devlet organlarının baskısı olmadan öderim & 486 & 1,95 & 1,31 & 00 \\
\hline 3 & Vergi kamu hizmetlerinin karşılığıdır & 493 & 2,27 & 1,05 & ,00 \\
\hline 4 & Vergi mükellefler üzerinde bir yüktür & 491 & 2,59 & 1,04 &, 00 \\
\hline 5 & İmkanım olursa vergiden kaçınırım & 490 & 2,92 & 1,17 & ,05 \\
\hline 6 & Elde edilen gelirin belli bir oranının beyan edilmemesi doğaldır & 487 & 2,66 & 1,06 &, 00 \\
\hline 7 & $\begin{array}{c}\text { Herkesin vergi ödediği veya kimin kaç som vergi ödediğiyle ilgili güvenilir ve } \\
\text { resmi bilgiye sahip olma, diğer bir değişle, vergilemede şeffaflık, vergileri gönüllü } \\
\text { ödeme isteğini arttırır }\end{array}$ & 498 & 2,43 & 1,12 & ,00 \\
\hline 8 & Ödediğim vergi yükünü ağır buluyorum & 496 & 2,53 & 1,05 & ,00 \\
\hline 9 & $\begin{array}{c}\text { Günümüz şartlarında vergileri tam olarak ödeyerek ekonomik faaliyette bulunmak } \\
\text { mümkün değil }\end{array}$ & 494 & 2,51 & 1,10 & ,00 \\
\hline 10 & Ülkemizin vergi sistemi adaletlidir & 494 & 3,49 & 1,09 & 00 \\
\hline 11 & $\begin{array}{l}\text { Ülkemizde gelir düzeyi yüksek olan bireylerden daha yüksek oranda, düşük olan } \\
\text { bireylerden daha düşük oranda vergi alındığına inanıyorum }\end{array}$ & 498 & 3,09 & 1,26 & ,00 \\
\hline 12 & Ülkemizde herkesin vergisini tam olarak ödediğine inanıyorum & 499 & 3,64 & 1,21 &, 00 \\
\hline 13 & Vergi kanunlarının yapısı zor ve karmaşıktır & 490 & 2,41 & 1,00 & ,00 \\
\hline 14 & Vergi kanununun zorunlu kıldığı ölçülerde kayıt düzenine uyulması çok zordur & 499 & 2,80 & 1,06 & 00 \\
\hline 15 & Vergi İdaresi özel kişilerin haklarına (mükellef olarak) saygı duymaktadırlar & 493 & 3,50 & 1,06 & ,00 \\
\hline 16 & Ben Kırgızistan'da adalete güveniyorum & 494 & 3,74 & 1,05 &, 00 \\
\hline 17 & Kırgızistan'da 'hukukun üstünlüğü' ilkesinin geçerli olduğunu düşünüyorum & 495 & 3,51 & 1,73 & 00 \\
\hline 18 & Jogorku Keneşe (Parlamentoya) güveniyorum & 495 & 3,63 & 1,14 & ,00 \\
\hline 19 & Vergilerin yargısal sürecinin adaletli yürütüldüğüne inanıyorum & 499 & 3,67 & 1,04 & ,00 \\
\hline 20 & Eğer devlete güvenirsem verdiği gönüllü öderim, hiç vergi kaçırmam & 495 & 2,31 & 1,14 & 00 \\
\hline 21 & Vergi idaresine güveniyorum & 492 & 3,50 & 1,01 & ,00 \\
\hline 22 & Ben hiç vergi kaçırmadım & 490 & 2,64 & 1,06 &, 00 \\
\hline 23 & Vergi kaçırma ahlaki değerlere uymayan bir davranıştır & 495 & 2,65 & 1,41 &, 00 \\
\hline 24 & Dindar insanlar vergi ödeme yükümlülüklerini tam olarak yerine getirmelidirler & 495 & 2,67 & 1,12 & ,00 \\
\hline 25 & Vergi kaçırmak bir hırsızlıktır & 491 & 2,73 & 1,18 &, 00 \\
\hline 26 & Ülkemizde vergi kaçaklığı çok yaygındır & 491 & 2,51 & 1,18 &, 00 \\
\hline 27 & Satış evrakları üzerinde sahtekarlık yapılarak vergi kaçırılmaktadır & 495 & 2,24 & ,97 &, 00 \\
\hline 28 & Vergi doğuracak ticari işlemleri kağıtlara geçirmeyerek vergi kaçırılmaktadır & 494 & 2,42 & 1,02 &, 00 \\
\hline 29 & Vergi idaresinde kayıttan geçmeden faaliyette bulunarak vergi kaçırılmaktadır & 497 & 2,33 & ,95 &, 00 \\
\hline 30 & Vergi Kanunundaki boşluklar kullanılarak vergi kaçırılmaktadır & 493 & 2,40 & ,88 &, 00 \\
\hline 31 & Vergi kaçıran bir meslektaşıma normal davranırım & 498 & 2,70 & 1,07 &, 00 \\
\hline 32 & Vergi kaçıranları ayıplayamayız & 492 & 2,63 & 1,07 &, 00 \\
\hline 33 & Kamu hizmetlerinden yeterli seviyede yararlanıyorum & 498 & 2,83 & 1,26 &, 74 \\
\hline 34 & $\begin{array}{l}\text { İhtiyaç duyduğumda, kamu hizmetlerinden yeterince yararlanabileceğime } \\
\text { inanıyorum }\end{array}$ & 497 & 3,13 & 1,20 & ,00 \\
\hline 35 & Ödediğim vergilerin kamu hizmeti olarak geri döneceğine inanıyorum & 497 & $3, \mathbf{0 3}$ & 1,18 & ,00 \\
\hline 36 & $\begin{array}{l}\text { Kamu hizmetlerine olan ihtiyacım yeterli seviyede giderilirse vergi ödeme isteğim } \\
\text { artar }\end{array}$ & 498 & 2,20 & 1,06 & ,00 \\
\hline 37 & Vergi gelirlerinin etkin ve doğru kullanıldığına inanıyorum & 499 & 3,48 & 1,16 &, 00 \\
\hline 38 & Kamu harcamalarının nasıl ve nelere harcandığını izliyorum & 496 & 3,38 & 1,11 &, 00 \\
\hline 39 & Kırgızistan'da vergi cezaları ağırdır & 494 & 3,02 & $\mathbf{1 , 0 0}$ &, 10 \\
\hline 40 & Yeni Vergi Kanunu vergi yükünü hafifletti & 497 & 3,22 & 1,06 &, 00 \\
\hline 41 & Yeni Vergi Kanunu iktisadi faaliyetlerin hızlanması için ek teşvikler getirdi & 496 & 3,25 & 1,00 & 00 \\
\hline
\end{tabular}

Tablo:1 Katılımclların Anket Sorularına Verdikleri Cevapların Ortalamaları

\subsection{Anket Sonuçlarının Faktör Analiziyle Değerlendirilmesi}

Faktör analizi ile birbirine benzer yapıda az sayıda faktör, gruplar oluşturulmaktadır. Böylece çok sayıda olan değişken daha kolay analiz edilebilecek şekilde az sayıda gruba indirgenir. Her bir faktörün toplam varyansı açıklama yüzdelerine bakılarak göreceli olarak önemli olan boyutlar, faktörler belirlenebilir. Burada da faktör analizi ile vergi kültürünün temel boyutları belirlenerek göreceli olarak hangi boyutun daha önemli olduğu açıklanmaya çalışılmıştır. Faktör analizi ile ilgili veri setinin faktör analizi için uygun olup olmadığı KMO istatistiği ile ölçülmektedir. KMO istatistiğinin 0,50 'den büyük olması veri setinin faktör analizi için uygun 
olduğu anlamında yorumlanmaktadır. Burada da sözkonusu istatistik 0,795 çıkmıştır. Buradan veri setinin faktör analizi için uygun olduğu anlaşılmaktadır. Bartlett testi ile hesaplanan korelasyon matrisinin birim matristen farkı araştrılmaktadır. Burada da, 000 'den küçük önem seviyesinde korelasyon matrisinin birim matristen farklı olduğu anlaşılmıştır (Chi-Square $4402, p=0,000$ ). Her bir değişken ifade için ortak varyansa göre hesaplanan korelasyon katsayılarında (communalities) en düşük katsayı 0,45 çıkmıştır. Faktörlerce toplam varyansın açıklanma yüzdesini arttırabilmek için ortak varyansı 0,30'dan küçük olan değişkenlerin analizden çıkarılması önerilmektedir (Kalayc1, 2006:342). Burada en küçük katsayı 0,30'dan büyük olduğu için herhangi bir değişken çıkarılmamıştır. Anabileşen (rotated component matrix) matrisinde 0,55 'in üzerindeki katsayılarla faktörler oluşturulmuştur. 41 ifadeye varimax yöntemine göre uygulanan faktör analizi sonuçlarına göre, 41 ifade 12 boyuta indirgenmiştir. Bu 12 boyutla toplam varyansın \%56'sı açıklanabilmektedir.

\begin{tabular}{|c|c|c|}
\hline Gruplar & İfadeler & Açıklanma \% \\
\hline \multirow{8}{*}{\begin{tabular}{|l|} 
Grup Adalet, \\
Devlete Güven
\end{tabular}} & Ülkemizin vergi sistemi adaletlidir & \multirow{8}{*}{14} \\
\hline & Ülkemizde herkesin vergisini tam olarak ödediğine inanıorum & \\
\hline & Vergi İdaresi özel kişilerin hakklarına (mükellef olarak) saygı duymaktadırlar & \\
\hline & Ben Kırgızistan'da adalete güveniyorum & \\
\hline & Kırgızistan'da 'hukukun üstünlüğü' ilkesinin geçerli olduğunu düşünüyorum & \\
\hline & Jogorku Keneşe (Parlamentoya) güveniyorum & \\
\hline & Vergilerin yargısal sürecinin adaletli yürütüldüğüne inanıyorum & \\
\hline & Vergi idaresine güveniyorum & \\
\hline \multirow{4}{*}{$\begin{array}{c}\text { Grup Kamu } \\
\text { Hüzmetlerinin } \\
\text { Kalitesi }\end{array}$} & Kamu hizmetlerinden yeterli seviyede yararlanıyorum & \multirow{4}{*}{8} \\
\hline & $\begin{array}{l}\text { İhtiyaç duyduğumda, kamu hizmetlerinden yeterince yararlanabileceğime } \\
\text { inanıyorum }\end{array}$ & \\
\hline & Ödediğim vergilerin kamu hizmeti olarak geri döneceğine inanıorum & \\
\hline & Vergi gelirlerinin etkin ve doğru kullanıldığına inanıyorum & \\
\hline \multirow{5}{*}{$\begin{array}{l}\text { Grup } \\
\text { Vergi Kaç. }\end{array}$} & Ülkemizde vergi kaçaklığı çok yaygındır & \multirow{5}{*}{6} \\
\hline & Satış evrakları üzerinde sahtekarlık yapılarak vergi kaçırılmaktadır & \\
\hline & \begin{tabular}{|l} 
Vergi doğuracak ticari işlemleri kağıtlara geçirmeyerek vergi kaçırılmaktadır \\
\end{tabular} & \\
\hline & Vergi idaresinde kayıttan geçmeden faaliyette bulunarak vergi kaçırılmaktadır & \\
\hline & Vergi Kanunundaki boşluklar kullanılarak vergi kaçırılmaktadır & \\
\hline \multirow{4}{*}{$\begin{array}{l}\text { Grup } \\
\text { Vergi Ahlak1 }\end{array}$} & Ben hiç vergi kaçırmadım & \multirow{4}{*}{4} \\
\hline & Vergi kaçırma ahlaki değerlere uymayan bir davranıştır & \\
\hline & $\begin{array}{c}\text { Dindar insanlar vergi ödeme yükümlülüklerini tam olarak yerine } \\
\text { getirmelidirler }\end{array}$ & \\
\hline & Vergi kaçırmak bir hırsızlıktır & \\
\hline \multirow{2}{*}{$\begin{array}{c}\text { Grup } \\
\text { Vergi } \\
\text { reformları }\end{array}$} & Yeni Vergi Kanunu vergi yükünü hafifletti & \multirow[b]{2}{*}{4} \\
\hline & Yeni Vergi Kanunu iktisadi faaliyetlerin hızlanması için ek teşvikler getirdi & \\
\hline \multirow[t]{2}{*}{ Grup VK bakış } & Vergi kaçıran bir meslektaşıma normal davranırım & \multirow{2}{*}{3,5} \\
\hline & Vergi kaçıranları ayıplayamayız & \\
\hline \multirow{2}{*}{$\begin{array}{c}\text { Grup } \\
\text { VK yapis1 }\end{array}$} & Vergi kanunlarının yapısı zor ve karmașıktır & \multirow[b]{2}{*}{3,2} \\
\hline & 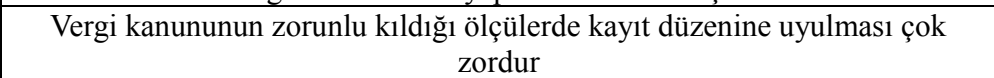 & \\
\hline \multirow{3}{*}{$\begin{array}{l}\text { Grup Vergi } \\
\text { ahlak1 }\end{array}$} & Vergi kutsal bir görevdir & \multirow{3}{*}{3} \\
\hline & Ben vergileri gönüllü olarak, devlet organlarının baskısı olmadan öderim & \\
\hline & Vergi kamu hizmetlerinin karşılığıdır & \\
\hline \multirow[t]{3}{*}{$\begin{array}{c}\text { Grup } \\
\text { Devlet ve } \\
\text { Mükellef }\end{array}$} & $\begin{array}{c}\text { Herkesin vergi ödediği veya kimin kaç som vergi ödediğiyle ilgili güvenilir ve } \\
\text { resmi bilgiye sahip olma, diğer bir değişle, vergilemede şeffaflık, vergileri } \\
\text { gönüllü ödeme isteğini arttırır }\end{array}$ & \multirow{3}{*}{2,8} \\
\hline & Eğer devlete güvenirsem verdiği gönüllü öderim, hiç vergi kaçırmam & \\
\hline & $\begin{array}{l}\text { Kamu hizmetlerine olan ihtiyacım yeterli seviyede giderilirse vergi ödeme } \\
\text { isteğim artar }\end{array}$ & \\
\hline \multirow[t]{3}{*}{ Grup Adalet } & $\begin{array}{l}\text { Ülkemizde gelir düzeyi yüksek olan bireylerden daha yüksek oranda, düşük } \\
\text { olan bireylerden daha düşük oranda vergi alındığına inanıyorum }\end{array}$ & \multirow{3}{*}{2,8} \\
\hline & Kamu harcamalarının nasıl ve nelere harcandığını izliyorum & \\
\hline & Kırgızistan'da vergi cezaları ağırdır & \\
\hline \multirow{3}{*}{$\begin{array}{l}\text { Grup Vergi } \\
\text { Yükü }\end{array}$} & Vergi mükellefler üzerinde bir yüktür & \multirow{3}{*}{2,6} \\
\hline & Ödediğim vergi yükünü ağır buluyorum & \\
\hline & $\begin{array}{c}\text { Günümüz şartlarında vergileri tam olarak ödeyerek ekonomik faaliyette } \\
\text { bulunmak mümkün değil }\end{array}$ & \\
\hline \multirow{2}{*}{$\begin{array}{c}\text { Grup } \\
\text { Vergi Kültürü }\end{array}$} & İmkanım olursa vergiden kaçınırım & \multirow{2}{*}{2,5} \\
\hline & Elde edilen gelirin belli bir oranının beyan edilmemesi doğaldır & \\
\hline
\end{tabular}

Tablo:2 Faktör Analizine Göre Soruların Gruplara Göre Dă̆ılımı 
Faktör analizinin sonuçları Kırgızistan'da mükelleflere etki eden en önemli 12 faktörü belirlemiştir. Bu 12 faktör toplam varyansın \% 56'sını açıklamaktadır. Sözkonusu faktörler şunlardır: Devlete güven; Bu faktör toplam varyansın \% 14'ünü açıklamaktadır. Vergi kültrünü etkileyen en önemli faktör - vatandaşların devlete, Vergi İdaresine, Parlamentoya ve tüm kamu sektörüne olan güvendir. Kamu hizmetlerinin kalitesi; Bu faktör toplam varyansın \% 8'ini açıklamaktadır. Vergi gelirlerinin etkin kulanılması ve vatandaşların ihtiyaçlarını karşılayabilen ve kaliteli kamusal hizmetlerin sunulması mükelleflerde ödemekte olduğu vergilerin faydalarının somut göstergeleri olduğundan sübjektif vergi yüklerinin azalmasına neden olmaktadır. Sonuçta vergi ödeme isteğine önemli pozitif etkide bulunmaktadır. Kayıt dışı ekonomi; Bu faktör toplam varyansın \% 6'sını açıklamaktadır. Kayıt dışı ekonominin büyük olması vergi yükünün dürüst mükellefler üzerinde yoğunlaşmasına, piyasada haksız rekabete ve yolsuzluğun artmasına neden olmaktadır. Vergi mükelleflerinin ahlaklı ve dürüslüğü toplam varyansın \% 4'ünü açıklamaktadır. Vergi reformların etkinliği toplam varyansın \% 4'ünü açıklamaktadır. Vergi mükelleflerinin vergi kaçıranlarla ilgili görüşleri - sosyal normlar toplam varyansın \% $3,5^{\prime}$ 'ini açıklamaktadır. Vergi kanunlarının yapısı ve karmaşıklığı - toplam varyansın \% 3,2'sini, Mükelleflerin vergi bilinci ve toplam varyansın \% 3'ünü açıklamaktadır, Vergilemenin şeffaflığı toplam varyansın \% 2,8'ini açıklamaktadır, Vergi sisteminin adaletliliği toplam varyansın \% 2,8'ini açıklamaktadır, Vergi yükü toplam varyansın \% 2,6'sını açıklamaktadır, Vergi kültürü toplam varyansın \% 2,5'ini açıklamaktadır.

\section{Sonuc}

Kırgızistan'da geçiş dönemi süresince vergi sistemi ile ilgili yapılan reformlar vergi sisteminin etkinliğini arttırmada başarısız kalmıştır. Bu sorunun daha da ayrıntılı geniş bir yaklaşımla incelenebilmesi için vergilemenin ikinci tarafı olan vergi mükelleflerinin vergi sistemi ile ilgili görüşlerinin ve vergi kültürlerinin analizinin yapılması gerekir. Kırgızistan'da yapılan bu amprik araştırma, mükelleflerin vergi bilincinin olduğunu göstermiştir. Mükelleflerin vergi kültürünün düşük olmasına etki eden en önemli faktörlerin; devlete güveninin olmaması, ödenen vergilerin karşılığının kamu hizmetleri olarak geriye dönmemesi, veya düşük kalitede kamu hizmetlerinin varlığı, kayıt dışı ekonominin varlığı ve vergi kaçakçılığının büyük olması, vergi kanunlarının yapısının karmaşıklığı, vergi sisteminin adaletsizliği ve yeterince şeffaf olmadığı şeklinde elde edilmiştir.Bu doğrultuda, mükelleflerin devlete güveninin oluşması için tüm kamu sektöründe yolsuzluğun yok edilmesi; kamuda kalifiye ve becerikli personelin istihdamının sağlanması; Yasaların etkin ve yargı sisteminin bağımsız ve adaletli çalışmasının sağlanması; Vergi İdaresinin mükelleflere yaklaşımının 'müşteri odaklı' olarak değimesi ve vergi sorunlarının en kısa zamanda ve etkin bir şekilde çözülmesi; kamu hizmetlerinin kalitesinin arttırılması; vergi sisteminin şeffaflığının arttırılması; kayıt dışı ekonomi ile mücadelede etkinliğin arttırılması ve ülkede vergi gelirlerinin sürekliliğinin temin edilmesi, vergi yükünün (özellikle sosyal sigorta kesintilerinin) azaltılması için yeni işyerlerinin yaratılması gerekmektedir.

\section{Kaynakça}

- Akdoğan, 2005. Kamu Maliyesi. Gazi Kitabevi. Ankara

- Allingham and Sandmo, 1972. Income Tax Evasion: a Theoretical Analysis. Journal of Public Economics, 1, 323-338.

- Alm and Martinez-Vazquez, 2003. "Institutions, Paradigms, and Tax Evasion in Developing and Transition Countries", Public Finance in Developing and Transition Countries, (Ed.) Essays in the Honor of Richard Bird, Cheltenham, UK, Edward Elgar, ss. 146-178.

- Alm and Torgler, 2006. 'Culture Differences and Tax Morale in the United States and Europe'. Journal of Economic Psychology, 27(2), 224_246.

- Alm, Jackson and McKee, 1993. Fiscal exchange, collective decision institutions, and tax compliance. Journal of Economic Behaviour and Organizations. 22: 285-303.

- Alm, Martinez-Vazque and Torgler, 2006. 'Russian Attitudes toward Paying Taxes _ before, during, and after the Transition', International Journal of Social Economics 33(12), 832_857.

- Alm, McClelland and Schulze, 1992. 'Why do People Pay Taxes?' Journal of Public Economics 48(1), 2138 .

- Cummings, Martinez-Vazquez, McKee, Torgler, 2005. Effects of Tax Morale on Tax Compliance: Experimental and Survey Evidence, Center for Research in Economics, Management and the Arts. Working Paper No. 29.Basel.

- $\quad$ Falkinger and Walther, 1991. 'Rewards versus penalties: on a new policy against tax evasion', Public Finance Quarterly 19, 67-79.

- $\quad$ Frey and Torgler, 2004. Taxation and Conditional Cooperation. Working Paper 2005-20, Center for Research in Economics, Management and Arts (CREMA), http://www.torgler.com/pdf/2004_20_frey_torgler.pdf

- Frey, 1997. Not Just for Money: An Economic Theory of Personal Motivation, Cheltenham, UK and Lyme, 
USA: Edward Elgar.

- Feld and Frey, 2002. 'Trust Breeds Trust: How Taxpayers are Treated', Economics of Governance 3(2), 87_99.

- Halla, 2010. Tax Morale and Compliance Behavior: First Evidence on a Causal Link. Working Paper No. 1005, The Austrian Center for Labor, Economics and the Analysis of the Welfare State, Austria.

- Kirchler, 2007. The Economic Psychology of Tax Behaviour. Cambridge, Cambridge University Press.

- Krrgız Cumhuriyeti İstatistik Komitesi. www.stat.kg

- Şenyüz, 1995. Vergilemede Yükümlü Psikolojisi. Bursa.

- Torgler and Murphy, 2005. Tax Morale in Australia: What Shapes it and Has it Changed Over Time? Working Paper No 58, Centre for Tax System Integrity Research School of Social Sciences Austrian National University, Canberra.

- Torgler, 2001. What do we know about tax morale and tax compliance? International Review of Economics and Business (RISEC). 48: 395-419.

- Torgler, 2003. Tax Morale: Theory and Empirical Analysis of Tax Compliance. Doktora Tezi. Basel Üniversitesi.

- $\quad$ Torgler, 2005. 'Tax Morale and Direct Democracy', European Journal of Political Economy 21(2), 521 531.

- Torgler, 2007. Tax Compliance and Tax Morale: A Theoretical and Empirical Analysis. Edward Elgar, Cheltenham, UK; Northampton, MA, USA.

- Torgler, B. (2004), "Tax Morale Trust and Corruption: Empirical Evidence from Transition Countries", CREMA Working Paper, No: 2004-5, Basel.

- Yakışık, 2006. Kırgızıstan'da Kayıt Dışı Ekonominin Boyutları: Etkileri ve Tahmini. Doktora Tezi. KTMÜ. Sosyal Bilimler Enstitüsü, İktisat Ana Bilm Dalı.

- Караталов, 2010. Налоги и «теневая» экономика. USAID. Бишкек, ОсОО Издательский дом «Салам». 


\title{
McKinnon'ın Para ve Fiziki Sermaye Arasında Tamamlayıcılık Hipotezinin Kırgızistan Örneğinde Testi
}

\author{
Harun Doğan (Kyrgyzstan-Turkey Manas University, Kyrgyzstan)
}

\section{A Test of the McKinnon's Complementarity Hypothesis between Money and Physical Capital in the Case of Kyrgyzstan}

\begin{abstract}
The main purpose of this study is to empirically investigate the validity of McKinnon's complementarity hypothesis on economic growth of Kyrgyzstan for the period of 1996-2009. McKinnon's (1973) central thesis argues poorly functioning financial systems in developing countries may effect investment quality and growth rate of the economy in negative direction. McKinnon's (1973) complementary hypothesis predicts that money and investment are complementary, to the contrast neoclassical and Keynesian theory, due to a self-financed investment in developing economies. In other words, according to McKinnon, financial liberalization should generate positive impacts on growth as consequence of positive relation between money and physical capital in developing countries after financial liberalization. The empirical researches conducted on complementarity hypothesis have found mixed results on the link between money and physical capital. However, empirical analysis of Kyrgyzstan's economy is very important because of its peculiarities, it has both a trancition and developing economy, which in case of the McKinnon's complementarity hypothesis is very essential. Thus, Kyrgyzstan, as many developing countries, have undertaken financial liberalization programs during the past twenty years after collapse of Soviet Union.

Therefore, the study analyzes long run and short run association among the real rate of interest on deposits, private investments, economic growth, and domestic savings behavior in Kyrgyzstan, using annual time series data for 1996-2009 with techniques of ARDL Cointegration Error Correction Model. The results does not support the McKinnon's complementarity hypothesis between money and physical capital on the period for 1996-2009 in the Kyrgyzstan's Economy.
\end{abstract}

JEL Codes: C12, E20, E40

\section{Giriş}

McKinnon (1973) ve Shaw (1973), gelişmekte olan ülkelerde baskı altına alınmış finansal piyasaların tasarrufları engelleyeceğini, kaynakların etkin dağılımını durduracağını, finansal piyasaların parçalanmasını artıracağını ve bankacılık sisteminin finansal aracılık rolünü olumsuz yönde etkileyeceğini iddia ettiler. Geçmişte birçok gelişmekte olan ülkede izlenmiş olan düşük faiz oranı politikası uygulamasının, yatırımı ve ekonomik büyümeyi ilerleteceği görüşü, temelde Neo-klasik ve Keynesyen teorilere dayanmaktaydı. Bu politikanın dayandığı Neo-klasik hipotez ise, sermayenin maliyetinin yüksekliği ve ödünç verilebilir fonların bulunmayışının, sermaye birikiminin geçerli kısıtı olması şeklindeki örtük varsayıma dayanan, para ve fiziki sermaye arasında ikame ilişkisinin varlığıdır. İlk olarak, McKinnon (1973) ve Shaw (1973) bu konvansiyonel inanışa ciddi biçimde karşı çıktılar.

McKinnon ve Shaw tezinin temel mesajı, düşük ya da negatif reel faiz oranlarının tasarrufları önleyeceği ve bundan dolayı ödünç verilebilir fonları azaltacağı ve dolayısıyla yatırımları kısıtlayarak ekonomik büyüme oranını düşüreceğidir. Aksine, reel faiz oranında bir artış, tasarrufta bulunanların daha çok tasarruf etmelerini uyarabilir ki, bu daha çok yatırımın meydana gelmesini mümkün kılar. Bu görüş, para balanslarının (finansal varlıklar) birikimi ve fiziki sermaye birikimi arasında temel bir tamamlayıcılık ilişskisini ortaya koymaktadır. Tamamlayıcılık hipotezi, (i) bütün ekonomik birimlerin kendi kendini finanse etmede kısıtlı oldukları ve (ii) bölünemezlikler nedeniyle yatırımların daha önceden para balansları birikimini zorunlu kıldığı şeklindeki iki anahtar varsayıma dayanmaktadır. Bundan dolayı, daha cazip para balansları birikimi süreci, daha büyük oranda yatırım yapmayı teşvik edecektir.

Araştırmacılar McKinnon'ın tamamlayıcılık hipotezini birçok gelişmekte olan ülke için test etmektedirler. Zaman içinde veri ve test tekniklerindeki gelişmekle birlikte problem hala araştırmaya açıktır. Örneğin, bir çok alıntıya konu olan ve Fry (1978) tarafından 7 Asya ülkesi için yapılmış ampirik çalışma, McKinnon’un tamamlayıcılık hipotezini çok az destekleyen kanıt bulmuştur. Fry, bunun yerine, reel faiz oranının yurtiçi tasarruflar ve ekonomik büyüme üzerinde pozitif bir etkiye sahip olduğunu bulmuştur. Daha yakın bir zamanda Watson (1992), McKinnon ve Shaw'ın finansal liberalizasyon hipotezini destekleyen sonuçlar elde etmiş, fakat Trinidad ve Tobago için yaptığı çalışma McKinnon’un tamamlayıcılık hipotezinin doğruluğunu tamamen ispatlayamamıştır. Diğer taraftan Laumas (1990), Thornton (1990) ve Thornton ve Poudyal (1990) sırasıyla Hindistan ve Nepal örneğinde tamamlayıcılık hipotezi için güçlü destek bulmuşlardır. Khan ve Hasan'ın (1998, 
583) ve Awan ve ark.'nın $(2010,79)$ çalışması, Pakistan'da tamamlayıcılık hipotezi için güçlü destek bulmuştur. Awan ve ark.'nın (2010) Pakistan için yaptığı çalışma, bizi benzer bir çalışmayla, konuyu Kırgızistan için incelemeye zorlamıştır. McKinnon'un tamamlayıcılık hipotezi, 1991'lerin başından itibaren pazar ekonomisine geçiş süreci yaşayan ve eski bir Sovyet Bloğu ülkelerinden olan Kırgızistan için, ampirik olarak test edilmeye çalışılmıştır. Bu amaçla, ikinci bölümde McKinnon'un tamamlayıcılık hipotezine ilişkin teorik model verilmekte, üçüncü bölümde veri, model ve yöntem sunulmakta, ampirik sonuçlar dördüncü bölümde elde edilmekte ve beşinci bölümde tavsiyelerle birlikte çalışmamız sonuçlandırılmaktadır.

\section{McKinnon'ın Tamamlayıcılık Hipotezi}

McKinnon'un tamamlayıcılık hipotezi aşağıdaki iki denklem tarafından gösterilebilir.

$$
\begin{aligned}
& M / P=f\left(y, I_{p} / Y, i-\dot{P}^{e}\right) \\
& I_{p} / Y=g\left(y, i-\dot{p}^{e}, S_{d} / Y\right)
\end{aligned}
$$

Birinci eşitlik, bir ölçek değişkeni olarak reel gelir (y), özel sektör yatırımının gayrisafi yurtiçi hasılaya (GSYİH) oranı ve firsat maliyeti değişkeni olarak reel faiz oranı ( $\left.i-\dot{p}^{e}\right)$ ile standart uzun dönem reel para talebi fonksiyonudur. İkinci eşitlik reel gelire, reel faiz oranına ve yurtiçi tasarrufun GSYİH'ya oranına ( $S_{d} / Y$ ) bağlı olarak belirlenmiş özel yatırım fonksiyonudur. Özel yatırım fonksiyonundaki son değişken olan yurtiçi tasarruf oranı, tamamlayıcılık ve ikame edebilirlik sorununa 1şık tutmak için dahil edilmiştir. Aşağıdaki kısmi türevler pozitifse tamamlayıcılık hipotezi geçerliliğini sürdürür.

$$
\begin{aligned}
& \frac{\partial(M / P)}{\partial\left(I_{p} / Y\right)}>0 \\
& \frac{\partial\left(I_{p} / Y\right)}{\partial\left(i-\dot{p}^{e}\right)}>0
\end{aligned}
$$

(3) ve (4) no'lu denklemler, finansal baskı altındaki ekonomilerde yatırımları kısıtlama değişkeninin sermayenin maliyeti değil, finansın varlığı olduğunu ortaya koymaktadır. Reel mevduat faiz oranı yükseldiğinde finansal kısıtlama gevşediği için yatırımlar da artar. Buna karşın, geleneksel teori ise, faiz oranında bir artışın yatırımları azaltacağını iddia etmektedir.

\section{Data, Model ve Yöntem}

\subsection{Data}

Çalışmamızda kullanılan Kırgızistan için yıllık zaman serileri datası (1996-2009) Kırgızistan Merkez Bankası ve İstatistik Komitesi'nden elde edilmiştir.

\subsection{Model ve Yöntem}

Reel mevduat faiz oranı, yurtiçi tasarruflar, özel sektör yatırımları ve ekonomik büyüme değişkenleri arasındaki kısa ve uzun dönemli ilişkiyi ampirik olarak test etmek için uygun bir ekonometrik model gereklidir. Araştırmaların çoğu uzun dönemli eşbütünleşme ilişkisini belirlemek için Johansen-Juselius (1994) ve EngleGranger (1987) eşbütünleşme tekniklerini kullanmaktadır. Bütün değişkenler aynı dereceden bütünleşmişse, Johansen-Juselius tekniği kullanılabilmektedir. Biz araştırmamızda Pesaran ve Pesaran (1997) tarafindan geliştirilmiş Autoregressive Distributed Lag Model (ARDL) yapısında kullanılan eşbütünleşmeye sınır testi (bounds test) yaklaşımını kullanıyoruz. Çünkü, ARDL Sınır Testi yaklaşımı bütün değişkenlerin aynı bütünleşme derecesini göz önüne almaksızın uygulanabilmektedir. ARDL Prosedürünün diğer bir avantajı ise, az sayıda gözlem içeren serilerin analizinde etkin bir şekilde kullanılabilmesidir (Fosu ve Magnus, 2006, 2080). Değişkenlerin bütünleşme derecesi I (0) , I (1) veya karması olabilir. ARDL Bounds testi standart olmayan dağılıma sahip F istatistiğine dayanmaktadır. Eşbütünleşme testi için Pesaran ve Pesaran (1997) tarafindan iki kritik sınır verilmektedir. Düşük kritik sınır bütün değişkenlerin I (0) olduğunu varsayarken, yüksek sınır bütün değişkenlerin I (1) olduğunu varsaymaktadır.

Aşağıdaki Autoregressive Distributed Lag (ARDL) modelini göz önüne alalım:

$$
\begin{aligned}
& \emptyset(L, P) Y_{t}=\sum_{i=1}^{k} \beta_{i}\left(L, q_{i}\right) X_{i t}+\delta w_{t}+\mu_{t} \\
& \emptyset(L, P)=1-\emptyset_{1} L-\emptyset_{2} L^{2}-\cdots-\emptyset_{p} L^{p} \\
& \beta_{i}\left(L, q_{1}\right)=\beta_{i 0}+\beta_{i 1} L+\beta_{i 2} L^{i 2}+\cdots+\beta_{i q} L^{q i} \\
& (\mathrm{i}=1,2, \ldots, \mathrm{k}) \\
& L Y_{t}=Y_{t-1} \text { gibi } L \text { bir gecikme operatörüdür ve } w_{t} \text { kesişme terimi ve zaman trendleri gibi s } \mathrm{x} 1 \text { deterministik }
\end{aligned}
$$

\footnotetext{
$L Y_{t}=Y_{t-1}$ gibi L bir gecikme operatörüdür ve $w_{t}$ kesişme terimi ve zaman trendleri gibi s $x 1$ deterministik
} 
değişkenler vektörüdür (Pesaran ve Pesaran, 1997).

Kısıtlanmamış Hata Düzeltme Modeli ARDL'nin genel biçimi olarak aşağıdaki gibi verilmiştir;

$\Delta Y_{t}=\beta_{0}+\lambda_{1} Y_{t-1}+\lambda_{2} X_{t-1}+\sum_{i=1}^{k} \beta_{3} \Delta Y_{t-i}+\sum_{i=1}^{k} \beta_{4} \Delta X_{t-1}+\epsilon_{t}$

Başlangıçta, bir uzun dönem ilişkisinin varlığı alternatifine karşı eşbütünleşmesizlik boş hipotezinin testi, aşağıdaki gibi bit $\mathrm{F}$ testi ile test edilmektedir;

$H_{0}=\lambda_{1}=\lambda_{2}=\cdots=\lambda_{n}=0$

$H_{0}=\lambda_{1}=\lambda_{2}=\cdots=\lambda_{n} \neq 0$

Hesaplanan $\mathrm{F}$ istatistiği Pesaran tarafindan geliştirilmiş $\mathrm{F}$ tablosunun üst sınır kritik değerinin üstünde ise, ilgili değişkenler arasında uzun dönem ilişkinin varlığı anlamına gelen eşbütünleşmesizlik boş hipotezi reddedilmektedir. Aksine, alt sınırın altına düşerse o zaman eşbütünleşmesizlik boş hipotezi reddedilememektedir. Eğer hesaplanan F istatistiği değeri bu iki sınır arasında ise, sonuç belirsizdir.

\section{Ampirik Sonuçlar}

Değişkenlerin bütünleşme düzeyini çok dikkatli belirlemek için DF-GLS ve Ng-Perron gibi standart testler kullanılmıştır. Literatürde çoğunlukla bütünleşme derecesini bulmak için ADF (Dicky and Fuller, 1979) ve PP (Philips and Perron, 1988) testleri sıklıkla yaygın olarak kullanılmaktadır. Bu testlerin zayıf boyutu ve güç özelliklerinden dolayı, küçük örnek veri seti için her iki test güvenilir değildir (Dejong ve ark., 1992). Bu testler doğru olduğunda boş hipotezleri aşırı reddeder ve yanlış olduğunda aşırı kabul eder gibi görünüyorlar. Son zamanlarda Elliot ve ark. (1996) tarafından geliştirilmiş olan DF-GLS (Dicky-Fuller Generalized Least Square) trendsizleştirme testi ve Ng-Perron (2001) testi bundan kaynaklanan problemi çözer gibi görünüyor. $X_{t}$ değişkeninin bütünleşme derecesini test etme ihtiyacının varlı̆ğ varsayımı üzerine Elliot et al. (1996) aşağıdaki regresyonda $H_{0}: \delta_{0}^{*}=0$ boş hipotezine dayalı trendsizleştirme prosedürü ve DF-GLS testi ile ADF'nin gücünü artırıyor;

$$
\Delta X_{t}^{d}=\delta^{*} X_{t-1}^{d}+\delta_{1}^{*} \Delta X_{t-1}^{d}+\cdots+\delta_{p-1}^{*} \Delta X_{t-p+1}^{d}+\eta
$$

$X_{t}^{d}$ trendsizleşmiş seridir ve bu testin boş hipotezi $X_{t}$ nin aşağıdaki gibi sürüklenmesi muhtemel bir tesadüfi yürüyüş trendine sahip olduğudur;

$$
X_{t}^{d}=X_{t}-\hat{\varphi}_{0}-\hat{\varphi}_{1} t
$$

Temel olarak iki hipotez önerilmektedir: (i) $X_{t}$ doğrusal bir zaman trendi etrafında durağandır ve (ii) sıfır ortalaması fakat doğrusal olmayan zaman trendli durağandır. Alternatif hipotezleri gözönüne alalım: DF-GLS testi genelleştirilmiş en küçük kareler tekniğini kullanarak kesişme ve trendin ilk tahmini tarafindan gerçekleşmektedir.

Geçen zamanda Ng-Perron (2001) GLS trendsizleştirilmiş veri $D_{t}^{d}$ kullanan dört test istatistiği geliştirdi. Bu testlerin hesaplanmış değerleri optimal test istatistiklerini yaratan Phillips-Perron (1988) $Z_{a}$ ve $Z_{t}$ istatistiklerine, Bhargava (1986) $R_{1}$ istatistiği ve Elliot ve ark. (1996) biçimlerine dayanmaktadır. Terimler aşağıdaki gibi tanımlanmaktadır;

$$
k=\sum_{t=2}^{T}\left(D_{t-1}^{d}\right)^{2} / T^{2}
$$

Trensizleștirilmiş GLS istatistiği aşağıdaki gibidir;

$$
\begin{aligned}
& M Z_{a}^{d}=\frac{\left(T^{-1}\left(D_{T}^{d}\right)^{2}-f_{0}\right)}{(2 k)}, M Z_{t}^{d}=M Z_{a} x M S B, M S B^{d}=\left(k / f_{0}\right)^{1 / 2}, \\
& M P_{T}^{d}=\left\{\frac{\left(\begin{array}{l}
-2 \\
c^{k}
\end{array} c^{T-1}\left(D_{T}^{d}\right)^{2}\right)}{f_{0}} v e \frac{\left(\begin{array}{l}
-2 \\
c^{k}
\end{array}(1-c)\right) T^{-1}\left(D_{T}^{d}\right)^{2}}{f_{0}}\right\}
\end{aligned}
$$

İlk durumda $x_{t}=(1)$ ise, o zaman ikinci durumda $x_{t}=(1, t)$ olacaktır.

Verinin durağanlık kontrolü için DF-GLS ve Ng-Perron Birim Kök Testleri sonuçları Tablo 1'de gösterilmektedir. 


\begin{tabular}{|c|c|c|c|c|}
\hline Değişkenler & \multicolumn{2}{|c|}{ Düzeyde DF-GLS } & \multicolumn{2}{|c|}{ Birinci Fark da DF-GLS } \\
\hline LNRRID & \multicolumn{2}{|c|}{$-2.106902 * *$} & \multicolumn{2}{|c|}{$-4.4822251 * *$} \\
\hline$\Delta$ LNLRDS & \multicolumn{2}{|c|}{$-3.979394 *$} & \multicolumn{2}{|c|}{$-5.982171 *$} \\
\hline LNLRGDP & \multicolumn{2}{|c|}{$-2.324392 * *$} & \multicolumn{2}{|c|}{$-3.469375 * *$} \\
\hline$\triangle \mathrm{LNRBD}$ & \multicolumn{2}{|c|}{$-3.264909^{*}$} & \multicolumn{2}{|c|}{$-4.066833 *$} \\
\hline LNRPI & \multicolumn{2}{|c|}{$-2.145695 *$} & \multicolumn{2}{|c|}{$-2.830750 *$} \\
\hline \multicolumn{5}{|c|}{ Düzeyde Ng-Perron } \\
\hline Değișkenler & MZa & MZt & MSB & MPT \\
\hline RRID & $-5.93227 *$ & $-1.68668 *$ & $0.28432 *$ & $15.2834^{*}$ \\
\hline LDS & $-6.46023 * * *$ & $-1.77806^{* * *}$ & $0.27523 * * *$ & $3.84996^{* * *}$ \\
\hline LRGDP & $-80.4848 *$ & $-6.1737 *$ & $0.07673 *$ & $0.62883^{*}$ \\
\hline LNRBD & $-6.46686^{*}$ & $-1.77561^{*}$ & $0.27457^{*}$ & $14.0754^{*}$ \\
\hline LNRPI & $-4.05414 *$ & $-1.36598^{*}$ & $0.33693^{*}$ & $21.7604^{*}$ \\
\hline \multicolumn{5}{|c|}{ Birinci Fark da Ng-Perron } \\
\hline$\Delta \mathrm{RRID}$ & $-17.1971 * * *$ & $-2.93137 * *$ & $0.17046 * * *$ & $5.30417 * * *$ \\
\hline$\Delta \mathrm{LDS}$ & $-2380.86^{*}$ & $-34.5022 *$ & $0.01449 *$ & $0.01046^{*}$ \\
\hline$\Delta$ LRGDP & $-25.8811 *$ & -2.91576 & $0.11266^{*}$ & $2.83837^{*}$ \\
\hline$\triangle \mathrm{LNRBD}$ & $-19.8868 *$ & $-3.12185^{*}$ & $0.15698^{*}$ & $4.75701 *$ \\
\hline$\Delta \mathrm{LNRPI}$ & $-15.1555^{*}$ & $-2.74206^{*}$ & $0.18093 *$ & $0.06991 *$ \\
\hline
\end{tabular}

***,*** sirasıly \%10, \%5ve \%1de dură̆anlıkları gösterir.

Tablo 1: DF-GLS ve Ng-Perron Birim Kök Testi

DF-GLS ve Ng-Perron testlerinin sonuçları, birim kökün varlığı boş hipotezinin reddedilmesi nedeniyle LDS ve LRGDP değişkenlerinin düzeyde durağan olduklarını I(0) ortaya koymaktadır. Diğer değişkenler birinci farkları alındıktan sonra durağan oldukları için I(1) düzeyde durağan değillerdir.

Her bir değişkenin birinci farkına farklı gecikmelerde değişkenlerin $\lambda_{s}$ işaretleri ile ortak anlamı için " $F$ " istatistiği hesaplanmıştır. ARDL sınır testi yaklaşımı değişkenler arasında uzun dönem ilişkisinin olup olmadığını test etmek için kullanılmıştır. Modelde yer alan değişkenler arasında uzun dönem ilişkisinin olup olmadığını sınamak için F testi yapılmıştır. Sonuçlar Tablo 2. de verilmiştir.

\begin{tabular}{|c|c|c|}
\hline Hesaplanan & \multicolumn{2}{|c|}{ Kritik Değerler } \\
\cline { 2 - 3 } F Test İstatistiği & Alt sınır I(0) & Üst sınır I(1) \\
\hline 1.644056 & 3.79 & 4.85 \\
\hline
\end{tabular}

Tablo 2: Sınır Testinde Hesaplanan Sonuçlar

Hesaplanan " $F$ " istatistiği değeri 1.644056 ve $\% 5$ anlamlılık düzeyinde tablo "F" istatistiği alt sinır 3.79 ve üst sınır 4.85 olduğu ve F istatistiği kritik değerinden daha küçük olduğu için değişkenler arasında eşbütünleşme yoktur. "F" istatistiğinden elde edilen sonuç, değişkenler arasında bir uzun dönem ilişkisinin var olmadığıdır. Pesaran ve ark.'nın (2001) hesapladıkları kritik değerlerin 500 ve 1000 arasındaki gözlem sayısına sahip örneklemler için üretildiklerini ve daha küçük gözlem sayıları için bu kritik değerlerin kullanılmasının yanıltıcı sonuçlara yol açabileceğini ortaya koyan Narayan $(2005,1988)$ da kritik değerler hesaplamıştır.

$\mathrm{D}, \mathrm{L}$ ve R ifadeleri sırasıyla, birinci fark, logaritma ve reel anlamlarına gelmektedir. Lag ifadesi ise gecikmeyi göstermektedir. Değişkenler arasındaki uzun dönem ilişkisinin yokluğu veriyken, denklem (11) deki değişkenlerin uzun dönem ve kısa dönem dinamiklerini görmek için ARDL modeli tahmin edilmektedir. Uzun dönem ilişkisini açıklayan modellerde tanımlama hatası için Ramsey Reset Testi, otokorelasyon için Breusch Goldfrey LM Testi, değişen varyans için White testi yapılmıştır. Uzun dönem sonuçları tablo 3 de sunulmaktadır.

Uzun dönem istatistiği reel mevduat faiz oranınınyurtiçi tasarruf davranışını belirlemede anlamlı bir faktör olmadığını gösteriyor. RRID (reel mevduat faiz oranı) katsayısı pozitif fakat oldukça küçük değeriyle (0.00005) yüzde $\% 5$ olasılık düzeyinde oldukça düşük anlamlılığa sahiptir. Bu reel mevduat faiz oranında \% 1 lik bir artışın yurtiçi tasarrufta \% 0.05 bir artışı uyardığını gösteriyor. Katsayı çok küçüktür ve daha fazla faiz oranı serbestleşmesine işaret ediyor. Kırgızistan için mevcut reel faizlerin tasarrufu açıklama gücündeki bu zayıflık, tasarrufun birincil dayanağı olan gelirdeki dalgalanmadan da kaynaklanıyor olabilir. Bu çalışmanın sınırının oldukça dar tutulmuş olması bu konuda daha geniş bir değişkenler seti ve daha uzun zaman aralığına sahip veri ile çalışmalar yapılmasını gerektirmektedir. Çalışmada kullanılan değişkenlere ilişsin veri setinin 14 yıl gibi istatistik anlam bakımından makul olmayan çok küçük gözlem sayısı, çalışmanın sonuçlarının güvenilirliğini sorgulamamızın en önemli nedenidir.

Tasarruf ve reel mevduat faiz oranı arasındaki pozitif ilişkiye rağmen t değerinin çok küçük olması (0.79), Awan ve ark (2010), Athoukarala (1998), Ghatak (1997), McKinnon (1973), Shrestha ve Chowdhury (2007) tarafından yapılmış önceki çalışmalarla çelişkilidir.

Athukorala ve Rajapatirana (1993) reformlardan sonra faiz oranındaki değişmenin elde tutulan reel nakiti negatif etkilediğini ve reel tasarrufları ve vadeli mevduatları pozitif etkilediğini bulmuştur. Khatkhate (1988) ise, 
64 ülke üzerinde yaptığı araştırmada faiz oranı ile finansal varlıklar ve tasarruf-büyüme ilişkisine ilişkin anlamlı bir ilişki bulamamıştır.

Çalışmamızın sonuçları GSYİH büyümesinin yurtiçi tasarruflar üzerinde pozitif etkisini gösterirken, katsayısı da oldukça düşük anlamlılığa sahiptir.

Modeller tüm standart tanımlayıcı testlerden geçmesine rağmen, istatistiksel olarak anlamlı bir ilişki göstermemektedir. Uzun dönem istatistiği reel mevduat faiz oranının yurtiçi tasarruf davranışını belirlemede çok az da olsa anlamlı bir faktör olduğunu gösteriyor. RRID (reel mevduat faiz oranı) katsayısı pozitif değeri olmasına rağmen bir hayli küçük bir değere sahip olduğu için açıklama gücü çok zayıftır.

\begin{tabular}{|l|c|c|}
\hline \multicolumn{3}{|c|}{ Bağımlı Değişken: $\Delta$ LDS } \\
\hline \multicolumn{1}{|c|}{ Değişkenler } & Parametre & T - İstatistiği \\
\hline Sabit & -0.00263 & -0.732489 \\
\hline$\Delta$ RRID & 0.0000503 & 0.794984 \\
\hline$\Delta$ RRID(-1) & -0.0000302 & -0.480344 \\
\hline$\Delta$ LRGDP & $1.03 \mathrm{E}-08$ & 0.456845 \\
\hline$\Delta$ LRGDP(-1) & $3.56 \mathrm{E}-08$ & 0.47316 \\
\hline$\Delta$ LDS(-1) & 0.359774 & 0.593966 \\
\hline LDS(-1) & -1.98434 & -2.137489 \\
\hline RRID(-1) & 0.000132 & 1.032158 \\
\hline LRGDP(-1) & $1.68 \mathrm{E}-08$ & 0.791045 \\
\hline \multicolumn{3}{|c|}{$R^{2}=0.776$, Ramsey Reset $[1]=0.846(\mathrm{prob}=0.454)}$, \\
Breusch Goldfrey LM Test $[1]=0.005(\mathrm{prob}=0.949)$, \\
\hline
\end{tabular}

Tablo 3: $\operatorname{ARDL}(1,1,1,1,1)$ Uzun Dönem Sonuçlarl

Değişkenler arasında uzun dönem ilişkisini belirleyen eşbütünleşme testinden olumlu bir sonuç alınmamasına karşın yine de ARDL uzun dönem testi merak edilerek yapılmış ve sonuçlar beklenildiği gibi değişkenler arasında uzun dönem ilişkisi vermemiştir. Yani Uzun dönem ilişkisi yoktur. Değişkenler arasında eş bütünleşme olmadığı için, kısa dönem ilişkilerini veren hata düzeltme (error correction) regresyonu uygulanamamaktadır. Hata düzeltme (error-correction) tekniğindeki temel mantık, bir önceki dönemdeki dengesizliğin bir bölümünün izleyen dönemde düzeltilmesidir. İki değişkenli bir hata düzeltme tekniğinde, herhangi bir değişkende meydana gelen değişmeyi hem geçmişteki denge hatalarına, hem de her iki değişkende de meydana gelen değişmelere bağlar. İki seri arasında eş-bütünleşme olması, aralarında uzun dönemli bir denge ilişkisinin olduğunu gösterir. Şüphesiz, kısa dönemde ikisi arasında bir denge ilişkisi olmayabilir. Bu nedenle, bulunan hata terimi "'dengeleyici hata terimi" (equilibrating error) olarak ele alınabilir ve bu hata terimi $y_{t}$ 'nin kısa dönem değerleri ile uzun dönem değerleri arasında bir köprü rolü oynar. Değişkenler arasında bir tane bile eşbütünleşme vektörü bulunamadığı için Hata Düzeltme Modeli uygulanmamıştır.

Katsayılara uygulanan ARDL istatistiği sonucunda katsayılar anlamlı çıkmadığı için hata düzeltme modeli uygulanmamış bu nedenle de CUSUM ve CUSUMQ istikrar testleri uygulanmamıştır.

Sonuçlar RRID (reel mevduat faiz oranı) daki değişmenin ve gecikmesinin politik ve ekonomik istikrarsızlık nedeniyle yurtiçi tasarruftaki değişme üzerinde bir etki ortaya koymadığı gösterirken, reel mevduat faiz oranının finansal gelişme üzerinde kısa dönem etkisinin pozitif, fakat çok küçük olduğunu ortaya koyuyor.

Anlamlı veya bir uzun dönem ilişkisi bulunamamış olmasının sezgisel bazı nedenleri şöyle sıralanabilir:

i. Ele alınan döneme ilişkin gözlem sayısı bir zaman serisi ekonometrisi bakımından çok yetersizdir.

ii. Kırgızistan ekonomisinin 1996-2009 yılları yıllık gözlemlerinin kullanıldığı çalışmada bir başka önemli olgunun piyasa mekanizması kurum ve kurallarının uygulanma biçiminin tam bir geçiş ekonomisi özelliği göstermesi.

iii. Kırgızistan Ekonomisinde kayıt dışılığın çok yaygın olduğu konusunda önemli bir anlaşmanın varlığı, bizi veri setinin sağlamlığı konusunda da şüpheye düşürmektedir.

iv. Ayrıca, finansal piyasanın çok yaygın biçimde ikili bir yapıya sahip olması ve "Lombard" adı verilen nerdeyse tamamına yakını gayriresmi (informal) ödünçlerden oluşan finansal aracıların varlığı, gibi faktörler sayılabilir.

Çalışmanın para ve fiziki sermaye arasında tamamlayıcılık ilişkisi aleyhinde sonuç vermesinin, yukarda saymaya çalıştığımız nedenlerden dolayı önümüzdeki zamanlarda konunun daha detaylı olarak araştırılması gereğini bize göstermektedir.

\section{Sonuç ve Politika Önerileri}

Bu çalışmanın amacı, Kırgızistan için McKinnon'ın (1973) tamamlayıcılık hipotezini test ederek ampirik bir kanıt sağlamaktır. McKinnon'ın temel görüşü, finansal sistemini liberalize eden bir gelişmekte olan ülkenin faiz 
oranları üzerindeki baskının kalkacağı, faiz oranlarının yükseleceği ve reel faiz oranlarındaki bir artışın tasarruf sahiplerini daha fazla tasarruf için teşvik edeceği ve yatırımlar için gerekli olan kaynağı artırarak yatırımları ve ekonomik büyümeyi artıracağıdır. Yani, ekonomide pozitif reel faiz oranlarının artması bankacılık sistemine doğru para akışııı hızlandırıp toplam finansal varlık miktarını artıracak ve yatııımlara kanalize olan finansal varlıklar ile fiziki sermaye miktarında artış meydana gelecektir. McKinnon'a göre gelişmekte olan ekonomilerde finansal varlıkların birikimi ve fiziki sermayenin birikimi arasında tamamlayıcılık ilişkisi vardır.

Çalışmanın ampirik sonuçları pazar ekonomisine geçiş sürecinde bir ülke olan Kırgızistan'da izlenen finansal liberalizasyonun tasarruflar üzerindeki etkisi çok küçük ve pozitiftir. Sonuçlar, McKinnon'ın hipotezinin aleyhindedir.

Bulgularımız, Khan ve Hasan (1998), Laumas (1990), Thornton (1990), Thornton ve Poudyal (1990) ve Awan ve ark. (2010) ile zit yöndedir.

$\mathrm{Bu}$ çalışmanın sonuçlarına dayanan öneriler aşağı sıralanmıştır.

i. Ekonomide finansal sistemin yapısını iyi biçimde geliştirmek için politik istikrar olmalıdır.

ii. Ülkede kısa ve uzun dönemde uygulamaya konulan makroekonomi politikaları tutarlı olmalı ve ekonomik istikrarı sağlamalıdır.

iii. Elverişli bir ekonomik ortamı yaratmak için fiyat istikrarını gerçekten sağlama ihtiyacı vardır.

iv. Kırgızistan Merkez Bankası'nın finansal kurumları ve aracıları kontrol etme kapasitesini güçlendirmek ve finansal piyasa katılımcılarının faaliyetlerine rehberlik etmek fonksiyonunun artırılması gerekmektedir.

v. Merkez bankasının dışında bankacılık sektörünü düzenleyecek bir üst kuruma ihtiyaç vardır. Banka kurma, banka şubesi açma ve bankaların faaliyetlerinin evrensel bankacılık fonksiyonları ve rekabet ilkelerine uygun olarak yapılıp yapılmadığını sürekli denetleyen, gözetleyen ve koyduğu kuralların yerine getirilmesini sağlayan bir bankacılık düzenleme ve denetleme kurumuna ihtiyaç vardır.

\section{Kaynakça}

- Athukorala, 1998. Interest Rates, Saving and Investment: Evidence from India. Journal of Oxford Development Studies. 26 (2). 153-169.

- Athukorala and Rajapatirana, 1993. Liberalization of the Domestic Financial Market: Theoretical Issues with Evidence from Sri Lanka. International Economic Journal. 7 (4). 17-33.

- Awan and et. al., 2010. Rate of Interest, Financial Liberalization\&Domestic Savings Behavior in Pakistan. International Journal of Economics and Finance. 2 (4). 75-81.

- Bhargava, 1986. On the Theory of Testing for Unit Roots in Observed Time Series. Review of Economic Studies. 53(3). 369-84.

- DeJong and Savin, 1992. Integration versus Trend Stationarity in Time Series. Econometrica. 60(2). 423-33.

- Elliott and et. al., 1996. Efficient Tests for an Autoregressive Unit Root. Econometrica. 64(4). 813-836.

- Fosu and et. al., 2006. BoundsTesting Approach to Cointegration: An Examination of Foreign Direct Investment Trade and Growth Relationships. American Journal of Applied Sciences. 3 (11). 2079-2085.

- Fry, 1978. Money and Capital or Financial Deepening in Economic Development. Journal of Money, Credit and Banking. 10 (4). 464-475.

- Fry, 1995. Money, Interest and Banking in Economic Development. Baltimore: Johns Hopkins University Press.

- Dickey and Fuller, 1979. "Distribution of the Estimators for Autoregressive Time Series with a Unit Root. Journal of the American Statistical Association. 74 (366). 427-431.

- Ghatak, 1997. "Financial Liberalization: The case of Sri Lanka. The Empirical Economics. 22 (1). 117129.

- Johansen and Juselius, 1990. Maximum Likelihood Estimation and Inference on Cointegration - with Application to the Demand for Money. Oxford Bulletin of Economics and Statistics. 52 (2). 169-210.

- Khan and Hasan, 1998. Financial Liberalization, Savings, and Economic Development in Pakistan. Economic Development and Cultural Change. 46 (3). 581-597.

- Khatkhate, 1988. Assessing the Impact of Interest Rates in Less Developed Countries. World Development. 16 (5). 577-588.

- Laumas, 1990. Monetization, Financial Liberalization, and Economic Development. Economic Development and Cultural Change. 38 (2). 377-390.

- McKinnon, 1973. Money and Capital in Economic Development. Washington D.C.: Brookings 
Institution.

- Narayan, 2005. The Saving And Investment Nexus for China: Evidence From Cointegration Tests. Applied Economics. 37 (17). 1979-1990.

- $\quad \mathrm{Ng}$ and Perron, 2001. Lag Length Selection and Construction of Unit Root Tests with Good Size and Power. Econometrica. 69 (6). 1519-1554.

- Pesaran and Pesaran, 1997. Working with microfit 4.0: Interactive Econometric Analysis. Oxford University Press.

- Pesaran and et. al., 2001. Bounds Testing Approaches to the Analysis of Level Relationships. Journal of Applied Econometrics. 16 (3). 289-326.

- $\quad$ Phillips and Perron, 1988. Testing for a Unit Root in Time Series Regression. Biometrika. 75(2). 335-346.

- Shaw, 1973. Financial Deepening in Economic Development. New York: Oxford University Press.

- Shrestha and Chowdhury, 2007. Testing Financial Liberalization Hypothesis with ARDL Modeling Approach. The Applied Financial Economics. 17 (18). 1529-1540.

- Thirlwall, 2002. The Mobilisation of Savings for Growth and Development in Developing Countries. The IUP Journal of Applied Economics. 1 (1). 7-30.

- Thornton, 1990. The Demand for Money in India: A Test of McKinnon's Complementarity Hypothesis. Savings and Development. 14. 153-158.

- Thornton and Poudyal, 1990. Money and Capital in Economic Development: A Test of McKinnon Hypothesis for Nepal. Journal of Money, Credit and Banking. 22 (3). 395-399.

- Watson, 1992. Savings, Rates of Interest and Growth in a Small Open Economy: The Trinidad and Tobago Experience. Social and Economic Studies. 41. 1-24. 


\title{
Türk Cumhuriyetlerinde Kurumsal Yeniden Yapılanma ile Ekonomik Büyüme / Beşeri Gelişmişlik Düzeyi Arasındaki İlişkiler
}

\author{
Mine Gerni (Marmara University, Turkey) \\ Mustafa Ersungur (Ataturk University, Turkey) \\ Dilek Özdemir (Ataturk University, Turkey)
}

\section{The Relationships between Enterprise Restructuring and Economic Growth / Human Development Level in Central Asian Republics}

\begin{abstract}
Considering the performance of growth, it is observed that the Central Asian Turkish republics achieved their income levels of 1991, the year they gained political independence, very lately as compared to the other transition economies. It is argued that those factors such as enterprise restructuring and insufficient political rights and individual freedoms came into play for their failure. Thus, it can be said that reflections which are described as economic growth flourishes privately from the lack of entrepreneurship, and also lack of entrepreneurship stems mostly from insufficient libertarian structures. In this paper, enterprise restructuring and price liberalization values published periodically by European Bank for Reconstruction and Development and the indicators of political rights and civil liberties published by Freedom House are taken into consideration, and the effects of these on economic growth and/or on human development as a much comprehensive indicator are investigated. In this perspective, instead of the effects of quantitative variables, the effects of four important qualitative variables on Central Asian Republics' growth/human development are studied.
\end{abstract}

JEL Codes: C33, O15, P11.

\section{Giriș}

1980’lerin borç krizleri ile sonrasındaki ödemeler bilançosu krizlerinin ortaya çıkardığ yapıda, içe dönük ve müdahaleci sanayileşme stratejilerinin yerini, dışa açık ve liberal rejimlerin başarı örneklerinin etkisiyle, ihracata yönelik sanayileşme stratejileri almıştır. Bu stratejide ihracat kazançlarını ve sermaye girişlerini besleyecek kur rejimi uygulamaları esastı. Söz konusu uygulamalar içerisinde ticari, finansal ve yatırımların hızlıca liberalize edilmesinin dünya ekonomisi ile zımnen entegrasyonu sağlayarak, aynı zamanda krizlere karşı temel reçete olacağ1 kabulü bulunmaktaydı (Akyuz, 1999). Diğer taraftan sosyalist bloğun başlangıçta gösterdiği büyüme mucizesinin sonraki süreçte durağanlığa düşüşüne karşı ıslahat arayışlarında da blok içerisinde kısmen liberal politika arayışlarının bulunduğu dikkat çekmektedir. Şöyle ki, başarılı büyüme oranları ile dikkat çeken Sovyetler'de, 1928-1984 döneminde ortalama \%4.3-4.8 arasında büyüme skorları yakalanmıştır. Bu orana 18741984 arası dönem için ancak \%4.5'lik bir ortalamayı tutturan Japonya yaklaşabilmiştir. Sosyalist planlamacılığın bu başarısının 1975'lerden itibaren düşüşe geçtiği ve 1980'lerde de durgunlaşmaya başladığı belirgin bir şekilde gözlenmiştir. Bu durum 1976-1980, 1981-1985 ve 1986-1990 arası dönemlerde ortalama büyüme skorları açısından sırasıyla \%3.7, \%3.2 ve \%1.3 olarak gerçekleşmiştir (Kuşkay, 2001: 8-9). Dolayısıyla sıklıkla ifade edildiği üzere Sovyetlerde duraksama, hatta çöküş sinyalleri özellikle yüksek oranlı büyüme hızının hemen hemen yarı yarıya düştüğü 1960'larda ortaya çıkmıştır. 1960'lara kadar yüksek büyüme performansı sergileyen sistem, ardı ardına iki on yıllık dönemde kesintisiz bir şekilde büyümede durağanlığı yaşamıştır (Campos, 2001: 664). Büyümede sürdürülebilirliğin koşulunun kişi başına gelir ve işçi başına verimliliğin artırılmasıyla tanımlanabileceğini ileri süren Kuznets, bunun da yine sürekli yapısal değişimle mümkün olabileceğini iddia etmiştir (Ofer, 1987: 1769). Genelde dünya ve özelde de Sovyet toplumlarına önerilen reçete, durağanlığın toplumsal dinamiklerin harekete geçirilebilmesi ile aşılacağıdır. Başlangıçta ihtilal(ler) ile siyasal, ekonomik ve sosyal yapısı kırılmaz kalıplara büründürülen sistemin, belki (sosyalist) ihtilal ile çağı yakalaması ve hatta öne geçmesine karşılık; devam eden süreçte çağın gerisinde kalması en temel sorun olarak ortaya çıkmıştır. Toplumsal dinamikler içerisinde büyüme kalıbının en temel belirleyicisi sürekli devinimi bünyesinde taşıyan yapısal değişimlerdir. Bu yapısal değişimler de kendi iç dinamikleri ile hareketi sürdüren ve dolayısıyla siyasal, ekonomik ve sosyo-kültürel alanlarda liberal politika uygulamalarıyla sağlanacağı savına dayalıdır.

Dönüşümün temelinde liberal ve demokratik yapının olduğu kabulünden hareketle, bu yapının kurumlara ve kurumsallaşamaya dayalı olduğu kabul edilir. Bu çerçevede 1998'de Dünya Bankası, kurumları formel ve informel kurallar ile toplumda birey ve örgütlerin davranışını şekillendiren güç mekanizmaları olarak tanımlamıştır. Resmi kurumlara örnek olarak yasa-yönetmelik ve sözleşmeler verilirken; gayri resmi kurumlar 
arasında da güven, etik ve politik normlar bulunmaktadır. Organizasyonlar ise siyasi (yasama, siyasal partiler, devlet kurumları, yargı), ekonomik (özel şirketler, sendikalar, meslek kuruluşları) ve sosyal (sivil toplum kuruluşları ve okullar) boyutunu kapsar. Kurumsal büyüme literatüründeki tanımlamasıyla ele alınacak olduğunda, kurumların her türlü politikaya hâkim unsur olması olarak tanımlanır. Bu tanımlamada, güç dengelerinin sağlanarak güçlü mülkiyet hakları ile birlikte eğitimin de dahil edildiği her türlü firsat eşitliğini sağlayan üst hukuki düzenlemelere vurgu yapılır (Fischer ve Sahay, 2004: 5-6). Kurumsal yeniden yapılanmanın bu geniş kapsamlı tanımlamasının aslında ekonomik büyümenin lokomotif gücü olan girişim unsurunun temel besleyicisi olduğu söylenebilir. Özellikle yatırım ve istihdam olanakları yaratarak, toplumsal gelirin sürekli artışını sağlayan girişim unsurunun da serbestiyete dayalı iklimlerde olgunlaştığı açıktır. Bu açıdan zenginliğin kaynağını para arzı olarak gören Merkantilist yaklaşımın aksine, bu durum A. Smith'de ulusların servetinin kaynağı olarak üretim güçlerine ve bunun içerisinde girişime-girişimciye bırakmıştır. Dolayısıyla A. Smith ekonomik milliyetçilik yerine, kişisel girişime konan sınırlamaların kaldırılması yoluyla ulusların zenginliğinin artacağını savunmuştur. Böylece ekonomik liberalizm, serbest ticaret ve ekonomide devletin rolünün azaltılması gerektiğini öngörmüştür (Güran, 1991: 119-120). Smith'in düşüncelerinde şekillenen zenginlik kaynağ1, iktisat ve yönetim bilimlerinin geçirdiği evrim ile birlikte daha da olgunlaşarak günümüz anlamıyla iktisadi büyüme yazınında yeni büyüme teorilerinde yer bulurken; yönetim yazınında iyi yönetişim (good governance) ile ele alınır olmuştur. Ancak gerek büyüme/kalkınma, gerekse yönetim literatürünün bu noktada ortak paydası yönetişim kalitesi üzerinedir.

Yönetişim göstergelerinin altı boyutu olduğu konusunda bir konsensüs bulunmaktadır: (i) Sorumluluk/Hesap verebilirlik, (ii) Politik istikrar ve şiddetin/terörün olmayışı, (iii) Hükümetin etkinliği, (iv) Düzenlemelerde kalite, (v) Hukukun üstünlüğü, (vi) Yolsuzluğun kontrolü (Kaufman ve diğ, 2008: 1). Bu değişkenlere ilişkin açıklamaları aşağıdaki şekilde kısaca vermek mümkündür (Kaufman ve diğ., 2002: 254-255; T.C. Maliye Bakanlığ1, 2003):

i. $\quad$ Sorumluluk / Hesap verebilirlik: Siyasal sürecin göstergeleri sivil özgürlükleri ve politik hakları içerir. Bu göstergeler hükümetin seçime katılan vatandaşlarına olan mesafesini ölçer. Ayrıca medyanın bağımsızlığını ölçüm göstergelerini de içermekte olup medyanın faaliyetlerinde otoriteye karşı sorumluluğunun aynası konumundadır.

ii. Politik istikrar ve şiddetin/terörün olmayışı: Hükümetin gücünün anayasaya aykırı veya şiddet yoluyla istikrarsızlaştırılması ya da alaşağı edilmesi gibi göstergelerden oluşur.

iii. Hükümetin etkinliği: Hükümetin etkinliği kamu hizmetlerinin kalitesini, bürokrasinin niteliğini, sivil hizmetlerin yeterliliğini ve yetkinliğini, hükümetin politik yükümlülüğünün güvenilirliğini içerir.

iv. Düzenlemelerde kalite: Politikaların kendisine yoğunlaşır. Fiyat kontrolleri ya da yetersiz banka denetimleri gibi piyasa yanlısı olmayan politikaların ve dış ticaret ile iş geliştirme gibi alanlarda aşırı düzenlemelerin getirdiği yüklerin ölçülmesini kapsar.

v. Hukukun üstünlüğü: Vatandaşların iyi bir şekilde toplum kurallarına nasıl uyması gerektiğini ölçen göstergelerdir. Bunlar suçların tekrarlanma derecesinden, hâkimlerin etkinliğinden-öngörülerinden ve sözleşmelerin uygulanabilirliğinden oluşur. Diğer taraftan bu göstergeler iktisadi ve sosyal etkileşimler ile mülkiyet haklarının korunduğu temelde adil ve öngörülebilir bir çevrede toplumun başarısını ölçer.

vi. Yolsuzluğun kontrolü: Geleneksel olarak bireysel menfaatler için kamu gücünün boyutu olarak tanımlanan yolsuzlukların algılanmasını ölçer. Yolsuzluk tanımlamasında yolsuzluğu ortaya çıkaran aktörler ile nesnelerin varlığı söz konusu edilmektedir.

Dünya Bankası tarafından yapılan altı bileşene dayalı tasnifin yanı sıra Avrupa İmar ve Kalkınma Bankası (EBRD) tarafından özellikle geçiş ekonomileri üzerine yaptığı liberalizasyon indeksi içerisinde de kurumsal yeniden yapılanma ele alınmaktadır. Dolayısıyla kurumsal yeniden yapılanmanın da içerisinde bulunduğu EBRD indeksinde; büyük ölçekli özelleştirme, küçük ölçekli özelleştirme, kurumsal yeniden yapılanma, fiyat liberalizasyonu, ticaret ve foreks sistemi, rekabet politikası, bankacılık reformları ve faiz liberalizasyonu, menkul kıymet piyasaları ve bankacılık dışı mali kurumlar, genel altyapı reformları olmak üzere dokuz değişken bulunmaktadır. Bu çalışmada her türlü girişimin ve mülkiyet haklarının 71 yıl devlet tekelinde tutulduğu ve bu açıdan bireyciliğin törpülendiği sosyalist-planlamacı yapıdan liberal-piyasa yönelimli geçiş süreci içerisinden bulunan Türk Cumhuriyetleri'nde büyüme-gelişmişlik ile kurumsal yeniden yapılanma ilişkilerinin araştırılması planlanmıştır.

\section{Literatür İncelemesi ve Model Rasyonalitesi}

Kurumsal yeniden yapılanma ve ekonomik büyüme ilişkilerini ele alan literatür incelendiğinde, kurumsal yeniden yapılanma olarak EBRD liberazliasyon indeksinin 9 değişkeninin toplamını alan çalışmalara rastlandı ̆̆ gibi, bu indeksin tümünü değil, bir ya da birkaçını alan çalışmalar da bulunmaktadır. Diğer taraftan yine kurumsal yapılanma değişkeni olarak Dünya Bankası tarafından hazırlanan yönetişim göstergeleri de kullanılmaktadır. Kurumsal yeniden yapılanmayı demokratikleşmeyle eşanlamlı tutan çalışmalar ise Freedoom 
House tarafından hazırlanan politik haklar ve sivil özgürlükler indeks değerlerini dikkate almışlardır.

EBRD indeksi içerisinde yer alan kurumsal yeniden yapılanma indeks değerleri ile birlikte büyük ölçekli özelleştirme, yönetişim olguları ve fiyat liberalizasyonunun büyümeyi ilk etapta olumsuz yönde etkilediğii, ancak gecikmeli olarak pozitif etkilerinin ortaya çıtığına dair araştırmalar arasında Radulescu and Barlow (2002)'un çalışması başta gelmektedir. Bu çalışmada liberalizasyon uygulamalarının enflasyonun düşmesine katkıda bulunduğu ve dolaylı olarak enflasyon ile büyüme arasında da ters yönlü ilişkilerin bulunduğu ifade edilmiştir. Benzer şekilde Lawson and Wang (2004) da özellikle fiyat liberalizasyonu ve kurumsal reformların başlangıçta büyümeyi olumsuz yönde etkilediğine dair bulgulara ulaşırlarken; negatif etkilerin 1991'de başlayıp 1995'e kadar devam ettiğini ortaya koymuşlardır (Falcetti ve diğ., 2006: 425).

29 geçiş ekonomisinden 25'i için 1989-2007 arası dönemde büyüme ve kurumsal yapı arasındaki ilişkilerin araştırılmasında büyüme performansında EBRD indeks değeri toplamı ile ifade edilen kurumsal yapının anlamlı etkilerinin olduğu belirlenmiştir. Diğer taraftan geçiş süreci ne kadar uzun olursa, geçiş resesyonunun da o kadar kısa ve U eğrisi şeklinde ortaya çıkan negatif büyüme etkilerinin de o kadar zayıf olacağı görülmüştür (Cerović ve Nojković, 2009: 7-31).

Yapısal reform indeksi olarak içsel liberalizasyon (fiyat liberalizasyonu ve ticaret monopolleri), diş liberlizasyon indeksi (kota, ticari kısıtlamalar ve kur kısıtları) ve özel sektör indeksi (özelleştirme ve finansal serbestiyet) ile makroekonomik değişkenler arasında ilişkiler araştırılmıştır. Elde edilen bulgularda liberal politikalara hız veren ülkelerde geçiş resesyonunun derin etkilerinden daha çabucak kurtulmanın mümkün olabildiği tespit edilmiştir (Berg ve diğ., 1999: 20-21).

Geçiş ekonomilerinin ekonomik gelişim temellerinin incelenmesinde kurumsallaşmanın inşasının önemine vurgu yapılırken, bu anlamda Dünya Bankası yönetişim göstergeleri de kullanılmıştır. Bu bağlamda kurumsal inşanın ana belirleyicileri olarak sosyalizm altında geçen yıl sayısı ve doğal kaynak zenginliğinin kurumsallaşmadaki rolü belirlenirken, yöntem olarak yatay kesit analizler yapılmıştır. Doğal kaynaklara dayalı bir ekonomik yapısı olan ve sosyalizm altında geçirdiği yıl sayısı fazla bulunan ekonomilerin piyasa ekonomisine uyumlu kurumlar inşa edemedikleri gözlenmiştir. Analizlerde kişi başına GSYİH büyümesi ile kurumsal gelişmenin bileşenleri (kurumsallaşma) arasında güçlü bir nedensellik ilişkisi yakalanmıştır (Beck ve Laeven, 2006: 157-186). Literatür incelmesi ve uygulama sonuçlarında siyasal istikrarın da büyüme üzerine anlamlı etkiler ortaya koyduğu belirlenmiştir (Brunetti ve Weder, 1995).

1990-1998 yılları arasında 25 geçiş ekonomisi için FDI (doğrudan yabancı yatırımlar) ve büyümenin belirleyicisi olarak kurumsallaşmanın önemi araştırılmıştır. Tahmin sonuçlarında özellikle devlet kurumlarının yabancı yatırımlar ve büyüme için oldukça önemli olduğu tespit edilmiştir. Ayrıca kurumsallaşmadan ekonomik büyümeye doğru güçlü nedensel ilişkiler tespit edilirken; FDI'ya doğru ise zayıf nedensel ilişkiler bulunmuştur (Grogan ve Moers, 2001).

Büyüme ve demokrasi ilişkileri açısından yaklaşık 100 ülke üzerine 1960-1990 aralığını kapsayan çalışmada siyasal özgürlük indeksleri kullanılmıştır. Elde edilen bulgularda büyüme üzerine olumlu etkilerin hukukun üstünlügü, serbest pazar, kamu harcamalarının küçüklüğü ve beşeri sermaye unsurları olduğu tespit edilmiştir. Politik özgürlüklerin de GSYİH ile ölçülen yaşam standartlarında, sağlık ve eğitim koşullarındaki iyileşmelerden etkilendiği belirlenmiştir. (Barro, 1996: 1-27).

Literatür incelemelerinde, hem genelde liberalizasyon indeksi veya özelde yeniden yapılanma değerleri açısından hem de yönetişim göstergeleri bakımından iyileşmelerin sağlanması ile yansımaları, geçiş sürecinin daha az sancılı atlatıldığına işaret eden bulgulara rastlanmıştır. Geçiş sürecinin daha az sancılı atlatılması ise hem geçişte gözlenen daralmanın daha az ve kısa zaman diliminde olması hem de istikrarsızlıkların sebebiyet verdiği yüksek veya hiper enflasyon süreçlerinin yaşanmaması anlamındadır. Bu kalite değerlerdeki iyileşmelerin ekonomik yansımaları olumlu olurken; merkezi planlama ile geçiş ekonomilerinin karakteristikleri aşağıdaki şekilde özetlenmiştir. 


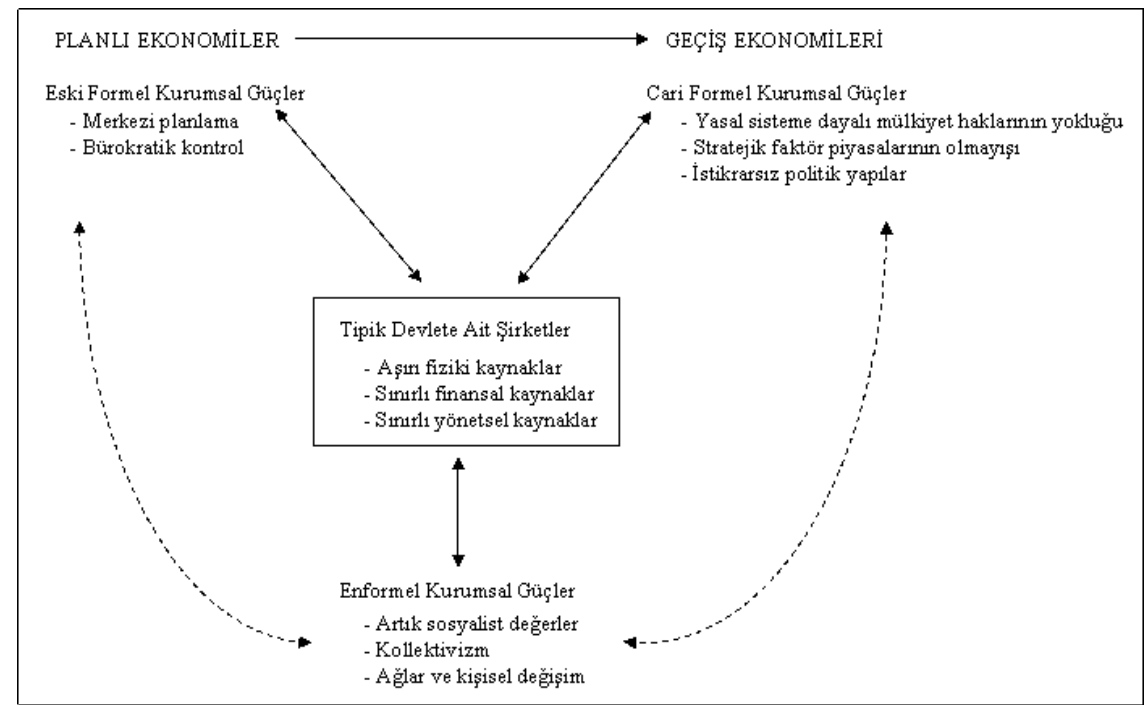

Şekil 1. Eski Planlı Ekonomilerde Kurum ve Kuruluşların Etkileşimleri. Kaynak: Peng ve Heath, 1996: 501.

Literatürde, Dünya Bankası'nın altı yönetişim göstergesinin kurumsal kaliteyi ifade etmesine karşılık, EBRD tarafından hazırlanan kurumsal yeniden yapılanma göstergeleri değerlendirildiğinde, bu iki bileşendeki iyileşmelerin iktisadi gelişmişliği beslediği ve benzer şekilde iktisadi gelişme sürecinin de bu kalite göstergelerinde iyileşmelere yol açtığı ileri sürülmektedir. Diğer bir ifadeyle kurumsal yeniden yapılanma ve yönetişim göstergeleri ile iktisadi gelişmişlik düzeyi (Dünya Bankası verilerinden reel GSYİH ve/veya UNDP verilerinden insani gelişmişlik indeksi-HDI) arasında karşılıklı bir nedensel ilişkinin bulunduğu söylenebilir.

$\mathrm{Bu}$ çalışmada, kurumsal yeniden yapılanmanın liberalizasyon indeksi içerisinde ele alınmasından farklı olarak, kurumsal yeniden yapılanmanın belirleyicileri olarak Dünya Bankası yönetişim göstergeleri, dışa açıklık oranları ve Freedoom House tarafından düzenlenen politik haklar ve sivil özgürlükler indeks değerleri alınacaktır. Siyasal haklar, demokratikleşmedeki mesafeyi yansıtırken; sivil özgürlükler, bireysel hak ve özgürlükleri ifade eder ve aynı zamanda girişim yapabilme zemini olarak da tanımlanır. Benzer şekilde ekonominin Dünya Bankası verilerinden hareketle oluşturulan dışa açıklık derecesi de liberal yapıların varlığına işaret ederken, aynı zamanda yenilikçilik (innovation) boyutu olmasa da taklitçilik (imitation) boyutuyla ülke girişimine açılım sağlayacağı düşünülebilir. Dolayısıyla mevcut literatür eşliğinde, bu çalışmadaki model aşağıdaki şekilde tasarlanabilir:

$$
R E_{t, i}=F\left(C L_{t, i} ; P R_{t, i} ; \operatorname{INST}_{t, i} ; \operatorname{OPEN}_{t, i}\right)+\varepsilon_{\mathrm{i}}
$$

(1) nolu modelde yer alan sembollerden t, zaman dilimini; i, ülkeleri ifade eder. Bağımlı değişken olarak alınan RE, yeniden yapılanma göstergesi; CL, sivil özgürlükleri; PR, siyasal hakları; INST, yönetişim göstergesini; OPEN, ekonominin dışa açıklığını tanımlar. (1) nolu eşitlik ile tahmin edilen RE değerlerinden bu kez reel GSYİH (reel Y) ve/veya insani gelişmişlik göstergeleri (HDI) ilişkileri araştırılır. Bu da (2) nolu eşitlikle ifade edilir:

$$
\text { Reel } Y_{t, i} \text { veya } Y_{t, i}=F\left(R E_{t, i}\right)+\varepsilon_{\mathrm{i}}
$$

Dolayısıyla (2) nolu eşitlikte birinci tahminden sonra elde edilecek yeni-tahmini kurumsal yeniden yapılanma değerleri ile iktisadi gelişmiş̧liğin bir ölçütü olarak reel GSYİH değerleri ve UNDP tarafindan düzenlenen HDI göstergeleri arasında nedensellik ilişkileri araştırılacaktır.

\begin{tabular}{|c|c|c|c|c|c|c|c|c|}
\hline & HDI & Reel Y & RE & CL & PR & \multicolumn{2}{|c|}{ INST } & OPEN \\
\cline { 2 - 9 } & Seviye & Seviye & Seviye & Seviye & Seviye & Seviye & I. Fark & Seviye \\
\hline $\begin{array}{c}\text { Levin, Lin } \\
\text { \& Chu t }\end{array}$ & $-5.028^{(\mathrm{a})}$ & $-2.932^{(\mathrm{a})}$ & $-1.4 \mathrm{E} 15^{(\mathrm{a})}$ & $-4.586^{(\mathrm{a})}$ & $-2.611^{(\mathrm{a})}$ & 0.015 & $-10.86^{(\mathrm{a})}$ & -9.080 \\
\hline $\begin{array}{c}\text { Breitung } \\
\text { t-stat }\end{array}$ & -0.533 & 2.085 & 0.019 & -0.333 & 0.198 & $-3.25^{(\mathrm{a})}$ & $-1.537^{(\mathrm{c})}$ & 0.652 \\
\hline $\begin{array}{c}\text { Im, Pesaran, } \\
\text { Shin W-stat }\end{array}$ & -0.551 & -0.483 & $-4.9 \mathrm{E} 12^{(\mathrm{a})}$ & -0.817 & -0.277 & 1.253 & $-1.892^{(\mathrm{b})}$ & $-1.884^{(\mathrm{b})}$ \\
\hline $\begin{array}{c}\text { ADF-Fisher } \\
\text { Chi-square }\end{array}$ & $16.435^{(\mathrm{c})}$ & $19.590^{(\mathrm{b})}$ & 7.105 & $11.449^{(\mathrm{c})}$ & 2.801 & 3.945 & $30.758^{(\mathrm{a})}$ & $29.137^{(\mathrm{a})}$ \\
\hline $\begin{array}{c}\text { PP - Fisher } \\
\text { Chi-square }\end{array}$ & $18.524^{(\mathrm{b})}$ & $29.121^{\text {(a) }}$ & 8.265 & $18.66^{(\mathrm{a})}$ & $11.422^{(\mathrm{a})}$ & 3.001 & $28.150^{(\mathrm{a})}$ & 8.208 \\
\hline Hadri Z-stat & $3.882^{(\mathrm{a})}$ & $5.208^{(\mathrm{a})}$ & $7.297^{(\mathrm{a})}$ & $5.339^{(\mathrm{a})}$ & $4.537^{(\mathrm{a})}$ & $6.350^{(\mathrm{a})}$ & $6.6457^{(\mathrm{a})}$ & $7.778^{(\mathrm{a})}$ \\
\hline
\end{tabular}

Tablo 1. Birim Kök Sinmalarl.

Not: Fisher testlerinin Olasılıklar asimptotik Ki-kare dă̆llımı kullanılarak hesaplanırken; diğer testler asimptotik normallik dă̆llımı gösterir. (a) \%1, (b) \%5 ve (c) \%10 önem seviyesinde anlamlılık göstermektedir. 


\section{Uygulama Sonuçları}

Geçiş ekonomilerinden Türk Cumhuriyetlerinde (Azerbaycan, Kazakistan, Kırgızistan, Özbekistan ve Türkmenistan) yeniden yapılanma ve ekonomik büyüme ilişkilerini araştıran bu çalışmanın modellemesi, literatürden hareketle yukarıdaki (1) ve (2) nolu eşitliklerle oluşturulmuştur. (1) nolu modelde yeniden yapılanma (RE) değişkeni bağımlı kabul edilerek, bu değişkeni açıklayacağı düşünülen sivil özgürlükler (CL), siyasal haklar (PL), yönetişim göstergeleri (INST) ve dışa açıklık (OPEN) değişkenleri kullanılmıştır. Daha sonra (2) nolu eşitlikte de (1) nolu eşitlikten hareketle hesaplanan RE değerleri ile reel GSYİH ve/veya HDI göstergeleri arasında ilişkiler araştırılacaktır. Çalışmada 1991-2008 arası dönem için 5 geçiş ekonomisine ait 7 değişken kullanılarak analizler yapılacağından, bu değişkenlere ilişkin birim kök sınaması yapılması gerekmektedir. Birim kök sınama sonuçları Tablo 1'de verilmiştir.

Değişkenlere ilişkin birim kök sınama sonuçlarına göre INST değişkeni dışında kalan 6 değişkenin seviye değerlerinde durağan olduğu görülürken; INST değişkeninin 1. farklarda durağan olduğu tespit edilmiştir. Dolayısıyla ilk model için yapılacak tahmin sürecinde INST değişkeninin birinci farklarının alınması, yani [D(INST)] olarak modelde kullanılması yoluna gidilmiştir. (1) nolu model için yapılan tahminlerde, ortak sabitlik ve sabit etkili ile tesadüfi etkili modeller açısından tahmin süreçleri işletilmiştir. Tahmin süreçlerine bağlı olarak gerek F testi, gerekse Hausman testleri sabit etkili modelin tutarlılığına işaret etmiştir. Sabit etkili tahmin sonuçları ile $t$ istatistikleri aşağıdaki gibidir.

$$
\begin{array}{lll}
\mathrm{RE}_{\mathrm{it}}=1.4817+0.2313 \mathrm{CL}+0.0123 \mathrm{PR}+0.0076 \mathrm{D}(\mathrm{INST})+0.0313 \mathrm{OPEN} \\
(2.142)(1.050) & (0.122)(0.101) & (0.254) \\
\mathrm{R}^{2}=0.887 & \mathrm{~F}=35.531 & \mathrm{D} . \mathrm{W}=1.085
\end{array}
$$

RE değişkeninin tahmin sürecinde kullanılan 4 değişkenin de parantez içerisinde yer alan t değerleri açısından anlamlılık taşımadıkları görülmektedir. Dolayısıyla literatürden hareketle RE’yi açıklayacağı düşünülen CL, PR; INST ve OPEN değişkenlerinin hiçbirisinin istatisitiki bakımdan anlamlılığı tespit edilememiştir. Bu nedenle iktisadi gelişmişlik ölçütü olarak alınacak reel GSYİH ve/veya insani gelişmişlik indeksi, yani HDI değerleri ile tahmin edilen RE arasında ilişki araştırmasından ziyade; reel GSYİH ve/veya HDI değerleri ile cari RE değerleri

\begin{tabular}{|c|c|c|c|c|c|c|c|}
\hline \multirow[b]{2}{*}{$\mathrm{H}_{0}$ Hipotezi } & \multirow[b]{2}{*}{ Gözlem } & \multicolumn{2}{|c|}{ Gecikme Uzunluğu: 1} & \multicolumn{2}{|c|}{ Gecikme Uzunluğu: 2} & \multicolumn{2}{|c|}{ Gecikme Uzunluğu: 3} \\
\hline & & F-İstatistiği & Olasilik & F-İstatistiği & Olasilik & F-İstatistiği & Olasilık \\
\hline $\begin{array}{l}\text { HDI, RE'nin nedeni } \\
\text { değildir. }\end{array}$ & \multirow[t]{2}{*}{45} & 0.25354 & 0.6172 & 0.59418 & 0.5574 & 1.22623 & 0.3186 \\
\hline $\begin{array}{l}\text { RE, HDI'nin nedeni } \\
\text { değildir. }\end{array}$ & & 3.58538 & 0.0651 & 3.86853 & 0.0303 & 2.80119 & 0.0581 \\
\hline $\begin{array}{l}\text { Reel Y, RE'nin nedeni } \\
\text { değildir. }\end{array}$ & \multirow{2}{*}{45} & 0.05151 & 0.8215 & 0.22370 & 0.8006 & 0.16251 & 0.9206 \\
\hline $\begin{array}{c}\text { RE, Reel Y'nin nedeni } \\
\text { değildir. }\end{array}$ & & 0.26606 & 0.6086 & 0.20178 & 0.8182 & 0.57488 & 0.6362 \\
\hline $\begin{array}{l}\text { D(INST), RE'nin nedeni } \\
\text { değildir. }\end{array}$ & \multirow[t]{2}{*}{45} & 0.25649 & 0.6155 & 0.17940 & 0.8366 & 0.08447 & 0.9678 \\
\hline $\begin{array}{c}\text { RE, D(INST)'in nedeni } \\
\text { değildir. }\end{array}$ & & 0.06534 & 0.7996 & 1.13600 & 0.3345 & 0.45736 & 0.7146 \\
\hline $\begin{array}{l}\text { Reel Y, D(INST)'in } \\
\text { nedeni değildir. }\end{array}$ & \multirow[t]{2}{*}{45} & 2.51784 & 0.12108 & 2.08409 & 0.1421 & 0.62669 & 0.6051 \\
\hline $\begin{array}{c}\text { D(INST), Reel Y'nin } \\
\text { nedeni değildir. }\end{array}$ & & 0.90609 & 0.34733 & 2.63368 & 0.0884 & 0.99801 & 0.4115 \\
\hline $\begin{array}{l}\text { HDI, D(INST)in nedeni } \\
\text { değildir. }\end{array}$ & \multirow[t]{2}{*}{45} & 2.18992 & 0.1474 & 0.25368 & 0.7776 & 0.75694 & 0.5297 \\
\hline $\begin{array}{l}\mathrm{D} \text { (INST), HDI'nin } \\
\text { nedeni değildir. }\end{array}$ & & 1.81760 & 0.1858 & 0.25832 & 0.7741 & 0.75222 & 0.5323 \\
\hline $\begin{array}{l}\text { Reel Y, HDI'nin nedeni } \\
\text { değildir. }\end{array}$ & \multirow[t]{2}{*}{45} & 0.08309 & 0.7746 & 0.16729 & 0.8466 & 0.88397 & 0.4614 \\
\hline $\begin{array}{l}\text { HDI, Reel Y'nin nedeni } \\
\text { değildir. }\end{array}$ & & 3.22971 & 0.0795 & 0.99362 & 0.3804 & 0.41217 & 0.7455 \\
\hline
\end{tabular}
ve/veya INST değerleri arasında ilişkilerin araştırılması yoluna gidilecektir. Söz konusu ilişkilerin araştırılması amacıyla nedensellik testleri yapılmış ve sonuçlar Tablo 2'de verilmiştir.

Tablo 2. Granger Nedensellik Test Sonuçları

Nedensellik sınamalarında tek yönlü nedensel ilişkiler sadece üç değişken arasında yakalanabilmiştir. Bu ilişkiler de aşağıdaki şekilde özet olarak ifade edilmiştir. 


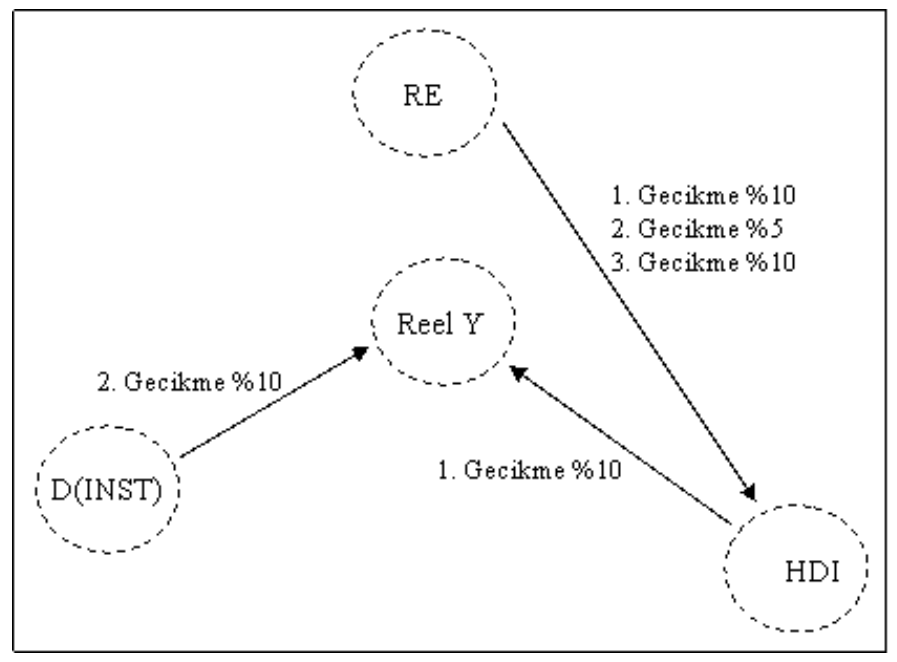

Şekil 2. Değişkenler Arasındaki Nedensel İlişkiler

Nedensellik sınamalarında reel GSYİH değeri HDI'nın 1. gecikmesinden \%10'da ve D(INST)'in de 2. gecikmesinde $\% 10$ düzeyinde etkilenmekte iken; HDI ise RE'nin 1 . gecikmesinden $\% 10,2$. gecikmesinde $\% 5$ ve 3. gecikmesinde \%10 önem düzeyinde etkilenmektedir. Nedensellik ilişkilerinin kısa dönemli ilişkiyi ortaya koyma boyutunun yanı sıra aynı düzeyde durağan olan RE ile reel Y arasındaki uzun dönemli ilişki araştırması da Pedroni eş-bütünleşme testleri ile yapılmıştır. Sonuçlar aşağıdaki tablodaki gibidir.

\begin{tabular}{|c|c|c|c|c|c|c|c|}
\hline & $\begin{array}{c}\text { Panel } \\
\text { v-İst. }\end{array}$ & $\begin{array}{c}\text { Panel } \\
\text { rho-İst }\end{array}$ & $\begin{array}{c}\text { Panel } \\
\text { PP-İst }\end{array}$ & $\begin{array}{c}\text { Panel } \\
\text { ADF-İst }\end{array}$ & $\begin{array}{c}\text { Grup } \\
\text { rho-İst. }\end{array}$ & $\begin{array}{c}\text { Grup } \\
\text { PP-İst. }\end{array}$ & $\begin{array}{c}\text { Grup } \\
\text { ADF-İst. }\end{array}$ \\
\hline RE-reel Y & -84.468 & -1.595 & $-3.490^{(b)}$ & $-3.573^{(b)}$ & 0.113 & $-1.779^{(b)}$ & $-1.912^{(b)}$ \\
\hline Reel Y-RE & 0.248 & 0.873 & 1.372 & 2.174 & 1.721 & 2.169 & 3.915 \\
\hline RE-HDI & -94.281 & $-1.954^{(\mathrm{c})}$ & $-3.261^{(\mathrm{a})}$ & $-3.302^{(\mathrm{a})}$ & -0.106 & $-1.555^{(\mathrm{c})}$ & $-1.619^{(\mathrm{c})}$ \\
\hline HDI-RE & 1.108 & -0.639 & -1.429 & -0.842 & 0.651 & -0.316 & 0.134 \\
\hline
\end{tabular}

Tablo 3. Pedroni Eş-bütünleşme Test Sonuçları. Not: Parantez içerisindeki değerler test istatistiğine iliş̧kin olasılık değerlerini vermektedir. (a) \%1, (b) \%5 ve (c) \%10 önem düzeyinde anlamlıliğ yansıtır.

Çalışmada yeniden yapılanma ve/veya yönetişim göstergelerinin iktisadi gelişmeyi etkileyeceğine dair teorik argümanların Türk Cumhuriyetleri özelinde sadece kısa dönemde yönetişimden reel GSYİH'ya doğru ilişkisi yakalanabilmiştir. Uzun dönemli ilişki araştırmasında INST, yani yönetişim göstergesi birinci farklarda durağan olması nedeniyle inceleme dışı bırakılmıştır. Buna karşılık uzun dönemli ilişki araştırmasında seviye cinsinden durağan olan RE ile reel Y ve HDI arasındaki ilişkiler Pedroni eş-bütünleşme testleri ile sınanmıştır. Yapılan testlerde RE'den reel Y'ye ve yine RE'den HDI'ya doğru uzun dönemli ilişkiler yakalanmıştır. Dolayısıyla Türk Cumhuriyetleri'nin reel ekonomik büyümesinde ve insani gelişmişlik indeksinin kalite boyutunun iyileşmesinde yeniden yapılanma etkilerinin özellikle uzun dönemde ortaya çıktığı tespit edilmiştir. Sonuçlar genel olarak değerlendirildiğinde, Türk Cumhuriyetleri'nin daha çok antidemokratik yapıya sahip olmalarının bir sonucu olarak iktisadi gelişmede kalitatif iyileşmelerin etkisinin zayıf olmasına rağmen, yine de uzun dönemde sürdürülebilir büyümenin temel belirleyicisinin yönetişimde kalitenin artması ve kurumsal yeniden yapılanma yolunda gelişmeler kaydetmenin önemli etkileri olduğu tespiti yapılmıştır.

\section{Genel Değerlendirme ve Sonuç}

Dünya ekonomisinde ülkelerin büyüme kalıplarının standart büyüme teorilerinden farklı argümanlarla açılanması yönünde eğilimlerin ortaya çıkmasında, özellikle sermaye ve emek gibi iki temel üretim faktörünün ekonomik gelişmeyi açıklamadaki yetersizliklerinin sonucu olmuştur. Diğer taraftan sosyalist planlı ekonomik yapıdan piyasa ekonomisine yönelim içerisinde bulunan ülkelerde de sermaye ve emek unsurunun etkilerinin önemli farklılıklar sergilediği gözlenmiştir. Bu noktada, standart girdi bileşenlerinin daima aynı çıktı vereceğine dair teorik iktisadi büyüme-kalkınma kalıpları da sorgulanmaya başlamıştır. Söz konusu sorgulamalar neticesinde üretim ve/veya ekonomik büyüme kalıbının kantitatif iki unsur, yani emek ve sermaye dışındaki faktörlerden, kalitatif unsurlardan etkilendiğine dair düşünceler, özellikle matematiksel iktisattaki gelişmelerle açıklanabilir olmanın sonucu olarak modellenmeye başlamıştır. Bu gelişmelerle birlikte büyümede kalite boyutunu daha çok yeniden yapılanmayı da bünyesinde taşıyan liberalizasyon indeksleri, sivil haklar ve politik özgürlükler skorları ile yönetişim kalitesini ifade eden göstergeler yardımıyla açıklanmaya başlanmıştır.

Liberalizasyon-demokratikleşme-iyi yönetişim unsurları ile ekonomik büyüme ilişkilerini ele alan araştırmaların çoğunda, bu değişkenlerdeki iyileşmelerin ekonomik büyümeyi etkilediğine dair bulgular elde 
edilmiştir. Bu çalışmada da siyasal bağımsızlığının henüz 20. yılını idrak etmekte olan ve dolayısıyla kurumsal yapılardan mahrum kalan Türk Cumhuriyetleri'nde liberalizasyon-demokratikleşme-iyi yönetişim unsurlarının ekonomik gelişmişlik üzerine etkileri araştırılmıştır. Elde edilen bulgular literatürdeki gibi kuvvetli ilişkilerin varlığını ortaya koymasa da, özellikle uzun dönemde kurumsal yeniden yapılanmadaki iyileşmelerin ekonomik gelişmişliği olumlu yönde etkilediği tespit edilmiştir. Cari büyümelerinin büyük bir kısmını tarım ve yeraltı kaynaklarına dayalı olarak sürdüren Türk Cumhuriyetleri'nin istikrarlı ve güven veren bir ekonomik yapıya ulaşabilmelerinin kurumsallaşma yönündeki gelişmelerle daha sağlam temellere dayandırabilecekleri söylenebilir.

\section{Kaynakça}

- Akyuz, Yilmaz, 1999. "Enterprise Restructuring and Economic Growth”, Factors of Economic Growth in Ukraine, pp: 41-47. (Http://Ta.Swap-

Rural.Org.Ua/Files/Library/200910301404270.Fostering\%20Sustainable\%20Growth\%20in\%20Ukraine\%2 0(IEA).Pdf). (Temmuz 2011).

- Barro, Robert J., 1996. "Democrasy and Growth”, Journal of Economic Growth, 1: 1-27.

- Beck, Thorsten and Luc Laeven (2006), "Institution Building and Growth in Transition Economies", Journal of Economic Growth, 11: 157-186.

- Berg, Andrew, Eduardo Borensztein, Ranta Sahay and Jeromin Zettelmeyer, 1999. The Evolution of Output in Transition Economies: Explaining the Differences, Working Paper No. 99/73. IMF, Washington, DC.

- Brunetti, Aymo and Beatrice Weder, 1995. "Political Sources of Growth: A Critical Note on Measurement", Public Choice, 82: 125-134.

- Campos, Nauro F., 2001. "Will the Future Be Better Tomorrow? The Growth Prospects of Transition Economies Revisited", Journal of Comparative Economics, 29: 663-676.

- Cerović, B and A. Nojković, 2009. "Transition and Growth: What was Taught and What Happened", Economic Annals, Volume LIV (183): 7-31.

- Efendic, Adnan, Geoff Pugh, and Nick Adnett, Institutions and Economic Performance: System GMM Modelling of Institutional Effects in Transition, 2010, http://www.riinvestinstitute.org/pdf/Efendic_et_al.pdf (Temmuz 2001).

- Falcetti, Elisabetta, Tatiana Lysenko, and Peter Sanfey, 2006. "Reforms and Growth in Transition: ReExamining the Evidence", Journal of Comparative Economics, 34 (3): 421-445.

- Fischer, Stanley and Ranta Sahay, 2004. Transition Economies: The Role of Institutions and Initial Conditions, IMF mimeo, Washington DC.

- Grogan, Louise and Luc Moers, 2001. "Growth Empirics with Institutional Measures for Transition Countries”, Economic Systems, 25: 323-344.

- Güran, Tevfik, 1991. İktisat Tarihi, Acar Matbaacılık Yayınc1lı, İstanbul.

- Kaufman, Daniel, Aart Kraay and Mossimo Mastruzzi. 2002. "Governance Matters III: Governance Indicators for 1996, 1998, 2000, and 2002”, The World Bank Economic Review, 18 (2): 253-287.

- Kaufman, Daniel, Aart Kraay and Mossimo Mastruzzi. 2009. Governance Matters VIII: Aggregate and Individual Governance Indicators 1996-2008, The World Bank, Policy Research Working Paper 4978.

- Kuşkay, S. Yılmaz, 2001. Sovyet-Tipi Ekonomilerin Merkezi Plandan Serbest Piyasaya Geçiş Deneyimi (1989-2000): Türkiye ve Diğer Gelişmekte Olan Ülkelere Dersler, Atatürk Üniversitesi SBE (Yayınlanmamış Doktora Tezi).

- Lawson, Colin, Wang, Haifeng, 2004. Economic Transition in Central and Eastern Europe and the former Soviet Union: Which Policies Worked?, Mimeo. Department of Economics and International Development, University of Bath.

- Ofer, Gur, 1987. “Soviet Economic Growth: 1928-1985”, Journal of Economic Literature, 25 (4): 17671833.

- Peng, Mike W. and Peggy Sue Heath, 1996. "The Growth of the Firm in Planned Economies in Transition: Institutions, Organizations, and Strategic Choice", The Academy of Management Review, 21(2): 492-528.

- Radulescu, Roxana and David Barlow, 2002. "The Relationship between Policies and Growth in Transition Countries", Economics of Transition, 10 (3): 719-745.

- T.C. Maliye Bakanlı̆̆ı, 2003. İyi Yönetişimin Temel Unsurları, T.C. Maliye Bakanlığı Avrupa Birliği ve Dış İlişkiler Dairesi Başkanlığı Yayını, Ankara. 


\title{
Avrasya Ülkelerinde Kurumsal Faktörlerin İktisadi Büyüme Üzerindeki Etkileri
}

\author{
İrem Yendi (Hacettepe University, Turkey)
}

\section{Effects of Institutional Factors on Economic Growth in Eurasian Countries}

\begin{abstract}
Economic growth is a complicated process which is affected by several factors. Standard neoclassical economic approach didn't address the effects of institutional factors on economic growth but such effects are started to be considered in economic growth literature together with the new institutional economy. According to the new institutional economic approach institutions decrease the uncertainty are effective on the cost of transaction and conversion and also impact economic performance by directing economic activities towards productive or non- productive fields. Within this framework, effects of institutional factors on economic growth in Eurasian Countries between 1996 and 2008 are searched via panel data analysis method by use of World Bank's, Heritage Foundation and Freedom House data sets. According to the findings collected, guaranteeing property rights, increasing quality of regulation and civil liberties affect positively economic growth on Eurasian Countries.
\end{abstract}

JEL Codes: O43, C23

\section{Giriş}

İktisadi büyüme konusu iktisat bilimindeki tartışmaların başlangıç noktasını oluşturmuştur. En genel tanımıyla iktisadi büyüme kişi başı reel gelirde uzun dönemde meydana gelen artıştır. Söz konusu artış, üretim faktörlerinin miktarlarındaki ve/veya verimliliklerindeki artıştan kaynaklanabilir. İktisadi büyüme teorileri, iktisadi büyümenin belirleyicilerini araştırırken başlangıçta daha çok iktisadi faktörler üzerine yoğunlaşmış, kurumsal faktörlerin iktisadi büyüme üzerindeki etkisi ihmal edilmiştir. Ancak söz konusu modeller iktisadi büyüme sorunsalını açıklamada yetersiz kalmışlardır. Kurumsal iktisat yaklaşımıyla birlikte iktisadi büyümenin temelde iktisadi olmayan faktörler tarafından belirlendiği ve bu faktörlerin ülkelerin tarihsel gelişme süreci içinde şekillendiği görüşü gündeme gelmiştir. Bu çerçevede, çalışmada, Avrasya ülkelerinde 1996-2008 y1lları arasında iktisadi büyümeye etki eden faktörler panel veri analizi yöntemi ile araştırılmıştır. Bu amaçla, çalışmanın ikinci bölümünde iktisadi büyüme sorunsalına ilişkin literatürde yer alan çalışmalar kısaca ele alınmış, üçüncü bölümde ise, iktisadi büyüme konusu kurumsal yaklaşım 1şı̆̆ında değerlendirilmiştir. Çalışmanın dördüncü bölümünde ise, kurumsal faktörlerin iktisadi büyümeye etkisi Avrasya ülkeleri bağlamında panel veri analizi yöntemiyle araştırılmıştır. Çalışmanın sonunda kurumsal iktisat yaklaşımının iktisadi büyümeye ilişkin öngörülerinin Avrasya ülkeleri bağlamında geçerli olduğu sonucuna ulaşılmıştır.

\section{2 İktisadi Büyüme Sorunsalına Literatürde Kısa Bir Bakış}

“Neden bazı ülkeler daha zengin?” sorusuna yönelik cevap arayışları tarih boyunca iktisat biliminin en temel ilgi alanlarından birini oluşturmuştur.

William Petty, tarafından 1656 yılında dile getirilen "Fransızlar çok hızlı büyüyor" ifadesi büyüme ve kalkınma iktisadının en erken tartışmalarından birini oluşturmuştur. Petty, sadece iktisadi büyüme sorunsalı ile ilgilenmemiş aynı zamanda hayat standardı gibi kalkınma problemlerini de araştırmıştır. Milli gelirin, gelir ve harcama yöntemleri ile hesaplanması da Petty tarafından gerçekleştirilmiştir. Petty bu çalışmalarıyla modern büyüme iktisadının kurucularından biri olmuştur. (Sen, 1998:10)

Adam Smith'in "Milletlerin Zenginliğinin Doğası ve Sebeplerine Yönelik Bir Araştırma” başlıklı, iktisat bilimi alanındaki temel yapıtlardan biri olan, kitabı iktisadi büyüme konusunun kendisini izleyen diğer klasik iktisatçılarda olduğu gibi analizinin merkezinde olduğunu göstermektedir. (Tezel, 2003:121) Adam Smith'in ve diğer klasik iktisatçıların büyüme analizine dönemin hakim düşünce tarzı olan Newtongil Doğa ve Bilim Paradigması önemli etkilerde bulunmuştur. $\mathrm{Bu}$ düşünce sisteminin etkisiyle ekonomi kapalı doğal bir sistem olarak görülmüştür. Buna göre, tüm toplumlar engellenmedikleri takdirde zenginleşeceklerdir. (Tezel, 2003:122) Smith, söz konusu mekanistik yaklaşımında toplumların üç farklı doğal aşamadan geçtiğini ifade etmiştir. Bu noktada dikkat edilmesi gereken husus, bu aşamaların her toplum için doğal süreçlerken, söz konusu aşamaların ekonomik, sosyal teknolojik ve kurumsal faktörlerden etkilendiğidir. Smith’e göre, Çin ve Türkiye gibi ülkeler kötü yönetim, temel insan hak ve özgürlüklerinin korunamaması ve mülkiyet haklarının sağlanamaması gibi nedenlerle büyüme aşamalarının birincisinde bulunmaktadırlar. Diğer taraftan, İngiltere ve Kuzey Amerika gibi ülkeler ise, ekonomik özgürlüklerin sağlanmasından dolayı ikinci aşamadadırlar ve devam eden bir büyüme 
sürecine sahiptirler. Smith kendi döneminde hiçbir ülkenin üçüncü büyüme aşamasında bulunmadığını belirtmiştir. Smith'e göre doğal çevre belirli bir süre sonra büyümeyi sınırlayacaktır. Kar oranlarının düşmesi sonucunda büyüme duracaktır. (Kibritçioğlu ve Dibooğlu, 2001:2)

Smith'in ortaya koyduğu uzun dönem durağan durum yaklaşımı Keynesyen büyüme modellerini de etkilemiştir. Harrod-Domar büyüne modelinde dinamik bir yaklaşım getirilmeye çalışılsa da model, en çok sabit sermaye hasıla oranı varsayımının girdiler arası ikameye olanak vermemesi nedeniyle eleştirilmiştir.( Tezel, 2003:189-210)

Harrod-Domar modelinin uzun dönemli büyüme sorunsalına olan ilgiyi yeniden canlandırmasına rağmen neoklasik iktisat yaklaşımı iktisadi büyüme sorunsalına olan ilgiyi daha fazla arttırmıştır. Bu çerçevede, neoklasik yaklaşım büyüme iktisadında başat yöntem haline gelmiştir. (Tezel, 2003:211) Standart tek sektörlü neoklasik büyüme modeli, ölçeğe göre sabit getiri, sermayenin azalan marjinal verimliliği, teknolojinin dışsallı̆̆ı, faktörler arası ikamenin olması ve bağımsız bir yatırım fonksiyonunun bulunması varsayımlarına dayanmaktadır. Modelde teknoloji dışsal olarak belirlenmektedir. Söz konusu varsayımlar çerçevesinde modelde uzun dönem büyüme hızı sıfır olmakta, hükümet politikalarının uzun dönem iktisadi büyüme üzerinde etkisi bulunmamaktadır. Ancak, modelde dışsal olarak ele alınan teknolojik gelişme sermayenin marjinal verimliliğindeki azalmanın iktisadi büyüme üzerindeki etkisini telafi ederek uzun dönemde sürekli teknolojik gelişme sayesinde pozitif büyüme oranları sağlanabilmektedir. Modelde nüfus dişsal olarak belirlenen sabit bir hızda büyümekte ve uzun dönemli büyüme hızını belirlemektedir. Neoklasik büyüme modelinin ortaya koyduğu bir diğer sonuç ise sermayenin getirisinin yüksek olduğu gelişmekte olan ülkelere gelişmiş ülkelerden bir sermaye transferinin olacağı böylece farklı gelişmişlik düzeyi arasındaki ülkeler arasında mutlak bir yakınsamasının gerçekleşeceği yönündedir. Ancak neoklasik yaklaşımın öngörülerinin tersine gelişmiş ve gelişmekte olan ülkeler arasında böyle bir yakınsama gerçekleşmemiştir. Bunun nedeni ise, söz konusu yaklaşımın ülkeler arasındaki kurumsal farklılıkları dikkate almamasıdır. Diğer taraftan neoklasik büyüme modeline getirilen bir diğer önemli eleştiri ise, uzun dönemde sürekli iktisadi büyümenin belirleyicisi olan teknolojinin dışsal olarak ele alınması, teknolojik gelişmenin model içerisinde açıklanmamasıdır. (Kibritçioğlu, 1998:8-9)

Standart neoklasik büyüme modelinde bir "kara kutu" olarak ele alınan teknolojik gelişme, içsel büyüme modellerinde açıklanmaya çalışılmıştır. İçsel büyüme modellerinin standart neoklasik büyüme modellerinden bir diğer farkı da hükümetin eğitim, sağlık maliye ve teknoloji politikalarıyla tarihsel, kültürel ve sosyolojik faktörleri de uzun dönemli iktisadi büyümenin belirleyicisi olarak ele almasıdır.(Kibritçioğlu ve Dibooğlu, 2001:5) Büyüme oranlarının uzun dönemde sıfır olmadığı içsel büyüme modellerinin ilk türünde araştırma ve geliştirmeye yapılan harcamalardan, beşeri sermaye yatırımlarından ve hükümetin teknolojiye yönelik yatırımlarından kaynaklanan taşmaların artan marjinal faktör verimliliği ve ölçeğe göre artan getiri sağlayacağ belirtilmektedir. İkinci türde ise, standart modelde olduğu gibi teknolojik gelişme dişsal olarak kabul edilmiş, toplumsal sermayenin marjinal verimliliğinin azalmadığ belirtilmiştir. (Kibritçioğlu, 1998:10-16) Ancak söz konusu modelin ölçeğe göre artan getiri varsayımı ampirik çalışmalarda desteklenmemiştir.(Kibritçioğlu ve Dibooğlu, 2001:5)

Ele alınan iktisadi büyüne kuramları yukarıda bahsedilen bazı tartışmalı varsayımları ve ampirik çalışmalarda desteklenmemelerinden ötürü iktisat bilimini uzun zamandır meşgul eden "neden bazı ülkeler daha zengin?" sorusunu cevaplayamamıştır. Bu çerçevede, ülkelerin farklı ekonomik büyüme performanslarının nedenlerini açıklamada kurumsal teşvik mekanizmasının etkilerini inceleyen yaklaşım ön plana çıkmıştır.

\section{Kurumsal Yaklaşım ve İktisadi Büyüme}

Standart neoklasik iktisat yaklaşımı iktisadi olmayan faktörlerin ekonomik büyüme üzerindeki etkisini göz ardı etmiştir. Polanyi 1957 yılında yayınlanan "The Economy as Instituted Process" (Kurumsallaşmış Süreç Olarak Ekonomi) başlıklı makalesinde, ekonominin iktisadi ve iktisadi olmayan kurumlarla birlikte bir bütün olduğuna vurgu yaparak kurumsal faktörlerin önemine dikkat çeken öncü çalışmalardan olmuştur. Polanyi'ye göre iktisadi olmayan kurumların analize dahil edilmesi önem taşımaktadır. Ekonominin yapısı ve işleyişi için din ve hükümet (ki burada North'un (2002) tanımıyla formel ve enformel kurumlar ) iktisadi faktörler kadar önemlidir. (Polanyi, 1957)

Kurumlar, kurumsal iktisat yaklaşımına göre, bir toplumda oynanan oyunun kurallarıdır, insanlar arasındaki etkileşimi (mutlaka etkin olması gerekmeyen bir şekilde) biçimlendiren kısıtlamalardır. (North, 2002:9) Kurumlar belirsizliği azaltırlar, insanlar tarafından getirilen yazılı kurallar gibi formel, ya da teamül, örf ve adet gibi enformel olabilirler.(North, 2002:51-73) Kurumlar iktisadi bir anlatımla, bireylerin tercih kümesini belirler ve sinırlar.(North, 2002:10) Bu noktada, kurumlar değişim ve üretim maliyetleri aracılığıyla ekonomik performansı etkiler. Kurumların ekonomik performans üzerindeki etkisi North'un (2002) kurumsal iktisatla ilgili çalışmalarda en çok alıntılanan paragrafı burada bir kez daha ele alınarak değerlendirilebilir. North'a göre (2002:14) insanlık tarihinin en karmaşık sorunlarından birisi toplumların birbirinden nasıl farklılaştığının açıklanmasıdır. Neoklasik ve uluslararası ticaret teorilerine göre birbirleriyle mal ve hizmet alışverişi yapan 
toplumlar birbirleriyle yakınlaşacaklardır. Ancak, tarih, toplumların çok farklı dini, etnik, kültürel, siyasi ve ekonomik toplumlar olarak geliştiğini göstermiştir. Burada kurumsal iktisat yaklaşımında dikkat edilmesi gereken nokta her toplumun karşılaştı̆̆ı sorunlara farklı çözüm yolları bulması, bunun da toplumların farklı patikalar izlemesine neden olmasıdır. Belirsizliği azaltmak için toplumlar tarafından oluşturulan kurumlar başka türlü olabilecekken o şekilde olmuş toplumsal faaliyetleri verimli ya da verimsiz alanlara yönlendiren teşvik mekanizmalarından oluşmuştur.

Kurumsal iktisat analizinde önemli bir yer tutan diğer birim ise kuruluşlardır. Kuruluşlar, kurumların sunduğu kısıtlar çerçevesinde amaçlarına ulaşmaya çalışırlar. Kurumsal değişimin izleyeceği yolu ise kuruluşlarla kurumlar arasındaki ilişki ve göreli fiyat değişimi belirler. (North, 2002:15)

Yukarıda belirtildiği üzere kurumların mutlaka verimliliği arttıracak şekilde oluşturulacak olması gerekmezken, aynı zamanda kurumsal değişim de daha etkin bir yöne olmak zorunda değildir. North (2002:1617) bu çerçevede, 19. Yüzyıl Amerika ekonomisinin başarı öyküsüyle Üçüncü Dünya ülkelerinin karşılaştıkları sorunları ele almıştır. Amerika'da 19. Yüzyılın başında oluşan kurumsal çerçeve, çalışmayı ödüllendirmiş, bu kurumsal çerçeve 1şı̆̆ında ortaya çıkan ekonomik ve siyasi kuruluşlar da üretimi en çoklaştırmaya çalışmış ve söz konusu kuruluşlar da üretkenliği arttıran yönde kurumsal çerçeveyi değiştirmiştir. Öte yandan Üçüncü Dünya ülkelerindeki kurumsal çerçeve, firsatları kuruluşların önüne yeterince koymamış, üretim faaliyetleri yerine yeniden dağıtım faaliyetleri ve tekelleri teşvik eden firsatlar oluşturmuştur.

Üzerinde durulması gereken bir başka önemli konu ise, işlem maliyetlerinin toplumsal, ekonomik ve siyasi kurumların temeli olduğudur. İşlem maliyeti, mübadele edilen unsurun değerli özelliklerini ölçmenin bedeli ile hakları korumanın, anlaşmaları yürürlüğe sokma ve denetlemenin maliyetidir. (North, 2002:39) Neoklasik iktisat yaklaşımı işlem maliyetlerinin olmadığı sürtünmesiz bir dünya varsaymıştır. Oysa, üretim maliyetinin bir kısmını işlem maliyeti oluşturmaktadır. Üretim maliyeti, hem malın fiziksel özelliklerini değiştirmek hem de işlemmülkiyet haklarını tanımlamak, korumak ve uygulamak (kullanma hakkı, kullanımdan gelir sağlamak, dışlamak ve mübadele yapmak) için gerekli toprak, emek ve sermaye gibi girdileri içerir. (North, 2002:40) Bu yaklaşım çerçevesinde kurumlar işlem maliyetlerinin azaltılması ve mülkiyet hakkının korunması ve bu yolla ekonomik performansın arttırılması aşamasında önemli rol üstlenirler. Tersi durumda, örneğin sözleşmelerin yürürlüğe konması ve uygulanmasına yönelik işlem maliyetini azaltacak kurumlar bulunmazsa, üretim maliyetinin önemli bir kısmını işlem maliyetinin oluşturmasıyla iktisadi birimler o üretim faaliyetini gerçekleştirmeyecektir. Aynı şekilde mülkiyet haklarının sağlanmaması da bireyleri üretimden geri çeken bir faktördür. İşlem maliyetlerinin ekonomik performansı olumsuz yönde etkilemesine yönelik olarak en çok verilen örneklerden biri Üçüncü Dünya ülkelerinde yeni bir işe başlamanın maliyetidir. Üçüncü Dünya ülkelerinde yeni bir işe başlama hem işlemleri tamamlamak için gerekli olan gün hem de katlanılan maliyetler açısından gelişmiş ülkelerin çok üstündedir. Bu durum, Üçüncü Dünya ülkelerindeki üretken yatırımları engellemektedir.

Peki ülkeler neden iktisadi açıdan etkin olmayan bu kurumlar yerine yenilerini inşa edememektedir? Bu noktada North'un (2002) patika bağımlılığı kavramı karşımıza çıkmaktadır. Bir toplum karşılaştığı sorunlar karşısında oluşturduğu kurumlarla belli bir yola girdikten sonra o yolu değiştirmesi zordur. Çünkü geçmişte birikmiş ve bugüne miras aldığımız kısıtlar bugünümüzü, bugünde yapacağımız tercihleri sınırlar, kurumsal değişim tedricidir ve başlangıçtaki kurumların sunduğu fırsatlarla evrilen kuruluşların söz konusu kurumlar yerine yenilerin oluşturulmasına karşı direnç göstermesi de muhtemeldir.

\section{Kurumsal Faktörlerin İktisadi Büyüme Üzerindeki Etkileri: Panel Veri Analizi}

Çalışmada Avrasya ülkelerinde kurumsal faktörlerin iktisadi büyüme üzerindeki etkilerini araştırmak amacıyla 12 Avrasya ülkesi için 1996-2008 yılları arasında panel veri analizi yapılmıştır.

\subsection{Yöntem}

Panel veri analizi yöntemi, çalışanlar, firmalar, hanehalkları, ülke vb. kesit gözlemlerin belli bir zaman dönemi içerisinde bir araya getirilmesinden oluşmaktadır. (Baltagi, 2001:1; Arellano, 2003:1) Çalışmada, 12 ülkenin 1996-2008 yılları arasındaki kişi başı reel gelir büyüme hızı ve kişi başı reel gelir büyüme hızına etki eden çeşitli faktörlere ilişkin gözlemler kullanılarak ülke paneli elde edilmiştir. Panel veri regresyonu Stata 8.0 programı ile tahmin edilmiştir. Panel veri analizinin seçilmesinin nedeni, panel veri analizinin kesit ve zaman serisi gözlemleri birleştirdiğinden gözlem sayısı arttırmaktadır. Panel veri yönteminin seçilmesinin bir diğer önemli nedeni ise, panel veri analizinin ülke gruplarının heterojenliklerini kesite özgü bazı değişkenler vererek hesaba katmasidır. (Baltagi, 2001:5-9)

Panel veri analizi yönteminde; sabit, eğim ve hata terimine ilişkin varsayımlar farklılaştığında tahmin yöntemi de değişmektedir. Üzerinde ayrıntısıyla durulmayacak farklı varsayımlara göre panel veri analizinde "sabit etkiler modeli" ve "rassal etkiler modeli" kullanılmaktadır. Sabit etkiler modeli genellikle, kesit büyüklüğünün küçük, zaman boyutunun büyük olduğu durumda kullanılırken rassal etkiler modeli tersi duruma daha uygun olmaktadır. Hangi modelin kullanılmasının uygun olduğu ise Haussman Testi ile belirlenebilmektedir. Söz konusu test, yatay kesite ilişkin özellikler ile bağımsız değişkenler arasında korelasyon olup olmadığına dayanmaktadır. Eğer korelasyon katsayısı sıfır ise, rassal etki modelinin kullanılması gerektiği sonucuna 
ulaşılmaktadır. (Baltagi, 2001:11 -20) Çalışmada, Hausmann Testi uygulamasıyla modelin sabit etki varsayımına dayanarak oluşturulması gerektiği sonucuna ulaşılmıştır.

\subsection{Model ve Değişkenler}

Panel veri analizi Tablo-1'de görülen 12 Avrasya ülkesinin 1996-2008 yılları arasındaki kişi başına reel gelir büyüme hızı ve kurumsal özelliklerine ilişkin değişkenler kullanılarak uygulanmıştır.

\begin{tabular}{|c|c|}
\hline Azerbaycan & Moldova \\
\hline Beyaz Rusya & Özbekistan \\
\hline Ermenistan & Moldova \\
\hline Gürcistan & Tacikistan \\
\hline Kazakistan & Türkmenistan \\
\hline Kirgizistan & Ukrayna \\
\hline
\end{tabular}

Tablo-1: Panel Veri Analizi Uygulanan Ülkeler

Oluşturulan modelin, bağımlı değişkeni ve bağımsız değişkenleri Tablo-2'de yer almaktadır.

\begin{tabular}{|c|c|c|c|c|}
\hline Bağımlı Değişken & \multicolumn{4}{|c|}{ Kişi Başı Reel Gelir Büyüme Hızı } \\
\hline $\begin{array}{c}\text { Bağımsız } \\
\text { Değişkenler }\end{array}$ & $\begin{array}{l}\text { Mülkiyet } \\
\text { Hakları }\end{array}$ & $\begin{array}{c}\text { Düzenleyici } \\
\text { Sistemin Kalitesi }\end{array}$ & Politik Haklar & Sivil Haklar \\
\hline
\end{tabular}

Tablo-2: Modelin Değişkenleri

Kişi Başı Reel Gelir Büyüme Hızı: Kişi başı reel gelir değişkenine ilişkin veriler Dünya Bankası veri tabanından elde edilmiş logaritması alınarak kullanılmıştır.

Mülkiyet Hakları: Mülkiyet hakları endeksi Heritage Foundation veri tabanından elde edilmiştir. Söz konusu endeks devletin özel mülkiyeti koruyan kurallar koyma ve bu kuralları uygulayabilme kapasitesini ölçmektedir. Endeks aynı zamanda yargının bağımsızlı̆̆ı, yargıda yolsuzluğun olmaması ve sözleşmelerin uygulanabilirliğine ilişkin algıları içermektedir. (Heritage Foundation, 2010)

Düzenleyici Sistemin Kalitesi: Düzenleyici sistemin kalitesi endeksi, Dünya Bankası Dünya Yönetişim Göstergeleri (World Governance Indicators) veri tabanından elde edilmiştir. Söz konusu gösterge hükümetin özel sektörü teşvik eden, özgürlükleri kısıtlamayan, maliyetleri arttırmayan politikaları oluşturabilme ve uygulayabilmesine yönelik algıları içermektedir. (Kaufmann vd, 2009:4-12)

Politik Haklar: Politik haklar endeksi Freedom House veri tabanından elde edilmiştir. Endeks, seçim sisteminin bağımsızlığı, politik çoğulculuk ve katılım ile hükümetin işlevselliğine ilişkin kriterlerden oluşmaktadır. Bu çerçevede, hükümet ve yasama organının adil seçimlerle iktidara gelmesi, bireylerin siyasi partiler ve örgütlenmeler oluşturma hakkı, muhalefetin etkinliği, insanların siyasal tercihlerini baskı altında kalmadan yapabilmeleri, seçimle iktidara gelen hükümetin kendi politikalarını yolsuzluğa bulaşmadan uygulayabilmesi gibi hususlar değerlendirilmektedir. Endeks bir bakıma söz konusu ülkenin demokrasinin düzeyini ölçmektedir. (Freedom House, 2011)

Sivil Haklar: Freedom House veri tabanından elde edilen sivil haklar endeksi, inanç ve ifade özgürlüğü, birlik oluşturma ve örgütlenme hakkı, hukukun üstünlüğü, yasalar önünde eşitlik gibi kriterlerden oluşmaktadır. (Freedom House, 2011)

Modelde kullanılan bağımsız değişkenlere ilişkin endeksler aşağıda yer alan formül çerçevesinde 0-1 arasında değerler alacak şekilde dönüştürülmüştür: (Bollen, 1990; Helliwell, 1996)

$$
\mathrm{E}^{* *}=\left(\mathrm{E}_{\max }-\mathrm{E}_{\mathrm{t}}\right) /\left(\mathrm{E}_{\max }-\mathrm{E}_{\min }\right)
$$

Buna göre endeks değerinin artması daha iyi kurumsal yapıyı ifade etmektedir. Bu çerçevede, bağımsız değişkenlerin katsayılarının beklenen işaretleri pozitiftir. Bağımsız değişkenlere kısaca baktığımızda, mülkiyet haklarının sağlanmasının üretken faaliyette bulunan iktisadi birimin bu faaliyet sonucu elde ettiği ürün üzerinde kullanım, mübadele vb. haklara sahip olması ekonomik performansı olumlu yönde etkileyecektir. Öte yandan işlem maliyetlerini azaltan bir düzenleyici sistemin de ekonomik büyümeyi teşvik edeceği söylenebilir. Diğer taraftan, demokrasinin sağlandığı bir ortamda iktisadi birimler üretim kararlarını özgürce alabileceklerdir, bu da iktisadi büyümeyi arttıracaktır. Sivil haklar endeksi tarafından içerilen inanç ve ifade özgürlüğünün sağlanmış olması bilimsel çalışmaları teşvik edecek ve teknolojik gelişme üretime yansıyabilecektir. Diğer taraftan, hukukun üstünlügünün sağlanmış olması da sözleşmelerin yürürlüğe girmesi, uygulanması ve yaptırımları hususunda bireylere güvence verecek böyle bir güven ortamından iktisadi büyüme pozitif yönde etkilenecektir.

\subsection{Panel Veri Analizi Sonuçları}

12 Avrasya ülkesinde kurumsal faktörlerin iktisadi büyümeye etkisini araştırmak amacıyla sabit etkiler varsayımına göre gerçekleştirilen panel veri analizi sonuçları Tablo-3’te yer almaktadır. Testin açıklama gücüne ilişkin istatistiklere bakıldığında, tüm açıklayıcı değişkenlerin katsayılarının sıfır olduğuna dair hipotez \%1 anlamlılık düzeyinde reddedilir.(Ho: $\beta 1=\beta 2=\beta 3=\beta 4=\beta 5=\beta 6=0) \mathrm{R}^{2}$ değerleri düşük çıkmakla birlikte panel veri 
analizi yapıldığı için bu durum dikkate alınmayabilir. Katsayılara ilişkin anlamlılık sınaması sonuçlarına bakıldığında ise, p değerlerine göre; mülkiyet hakları, düzenleyici sistemin kalitesi ve sivil haklar değişkenleri \%1 düzeyinde anlamlı çıkmıştır. Söz konusu değişkenlerin katsayılarının işaretleri beklendiği gibi pozitiftir. Buna göre, ele alınan dönemde Avrasya ülkelerinde mülkiyet haklarının sağlanması, düzenleyici sistemin kalitesinin arttırılması ve sivil hakların sağlanması ekonomik büyümeyi pozitif yönde etkilemektedir. Öte yandan, politik haklar değişkeni \%1 düzeyinde anlamsız çıkmıştır. Bununla birlikte politik haklar değişkeninin katsayısının işareti beklenenin tersine negatiftir.

\begin{tabular}{|c|c|c|c|c|c|}
\hline \multicolumn{3}{|c|}{ Fixed-effects (within) regression } & \multicolumn{3}{|c|}{ Number of obs $=144$} \\
\hline \multicolumn{3}{|c|}{ Group variable (i): code1 } & \multicolumn{3}{|c|}{ Number of groups $=12$} \\
\hline $\begin{array}{c}\text { R-square: } \\
\text { within }=0.4220 \\
\text { between }=0.0026 \\
\text { overall }=0.1304 \\
\end{array}$ & \multicolumn{2}{|c|}{$\begin{array}{c}\text { Obs. per group: } \\
\min =11 \\
\max =13 \\
\operatorname{avg}=12.0\end{array}$} & \multicolumn{3}{|c|}{$\begin{array}{c}\mathrm{F}(4,128)=23.36 \\
\operatorname{corr}\left(\mathrm{u}_{-} \mathrm{i}, \mathrm{Xb}\right)=-0.2192 \\
\operatorname{Prob}>\mathrm{F}=0.0000\end{array}$} \\
\hline gdppergrowth & Coef. & Std. Err. & $\mathbf{t}$ & $\mathbf{P}>|\mathbf{t}|$ & [95\% Conf. Interval] \\
\hline Mülkiyet hakları & 2.994623 & .7497737 & 3.99 & 0.000 & 1.5110684 .478179 \\
\hline $\begin{array}{l}\text { Düzenleyici sistemin } \\
\text { kalitesi }\end{array}$ & 1.972963 & .4255215 & 4.64 & 0.000 & 1.1309962 .81493 \\
\hline Politik haklar & -1.205137 & .5253563 & -2.29 & 0.023 & $-2.244644-.1656297$ \\
\hline Sivil haklar & 2.908322 & .655035 & 4.44 & 0.000 & 1.6122244 .204421 \\
\hline Sabit terim & 3.050085 & .5499542 & 5.55 & 0.000 & 1.9619074 .138264 \\
\hline \multicolumn{3}{|l|}{$\begin{array}{l}\text { sigma_u } \mid .78726206 \\
\text { sigma_e } \mid .46708962 \\
\text { rho } \mid .73963649 \text { (fractic }\end{array}$} & \multicolumn{3}{|c|}{$\begin{array}{l}\text { F test that all } \mathrm{u}_{\mathrm{i}}=0 \text { : } \\
\mathrm{F}(11,128)=29.75 \\
\text { Prob }>\mathrm{F}=0.0000\end{array}$} \\
\hline
\end{tabular}

Tablo-3: Panel Veri Analizinin Sonuçları

\section{Sonuç}

İktisadi büyüme çok sayıdaki faktör tarafindan etkilenen karmaşık bir süreçtir. İktisadi büyüme literatüründe iktisadi faktörler yerine kurumsal faktörlerin büyüme sürecinde asıl belirleyici olduğunu savunan yaklaşımlar son yıllarda ön plana çıkmıştır. Kurumsal yaklaşıma göre, kurumsal faktörler üretimi verimli ya da verimsiz alanlara yönlendirerek iktisadi büyümeyi etkilemektedir. Kurumsal yaklaşımın ilgili süreci açıklarken en önemli katkılarından biri kurumların her ülkeye özgü olması ve ülkelerin tarih boyunca karşılaştığı koşullara cevap olarak üretilmesidir. Bu kurumsal farklılıklar ülkeler arasındaki performans farklılıklarının temelini oluşturmaktadır. Kurumların mutlaka etkin bir üretim süreci sağlayacak şekilde evrilmesi gerekmemektedir. Peki neden ülkeler kurumlarını ekonomik performanslarını arttıracak şekilde değiştirememektedir? Bunun nedeni kurumsal değişimin uzun sürede gerçekleşmesi ve başlangıçtaki kurumlara göre oluşan kuruluşların değiş̧ime karşı direnç gösterebilmesidir.

Üretimi teşvik eden kurumlar sayesinde ekonomik performansın artacağı kurumsal yaklaşımın temel önermelerindendir. Buna göre, dördüncü bölümde gerçekleştirilen panel veri analizi sonuçlarına göre, mülkiyet haklarının korunmasının, piyasa ekonomisinin işleyişine olanak sağlayan düzenlemelerin getirilmesinin, sözleşmelerin güvence altına alınmasının, inanç ve düşünce özgürlüğünün sağlanmasının Avrasya ülkelerinde ekonomik performansı olumlu yönde etkilediği sonucuna ulaşılmıştır. Kurumsal yaklaşımın önermelerinin Avrasya ülkeleri bağlamında doğrulanması, geçmişten gelen kurumsal kısıtların bugüne getirdiği sınırlamaların var olduğunu da akılda tutarak kurumsal değişimin ekonomik performansı arttıracak yönde gerçekleşmesini sağlamak için siyasi irade ve özel sektör eşgüdümü ile birlikte uygun politikaların zaman kaybetmeden ortaya konması gerektiğini göstermektedir.

\section{Kaynakça}

- Arellano, Manuel, 2003. Panel Data Econometrics, Oxford University Press. New York.

- Baltagi, Badi, H., 2001. Econometric Analysis of Panel Data, Second Edition, John Wiley\& Sons, Ltd., Chichester.

- Bollen, Kenneth A., 1990. "Political Democracy: Conceptual and Measurement

- Traps", Studies in Comparative International Development, Spring, p. 7-24.

- Freedom House, 2011. Freedom in the World Data. http://www.freedomhouse.org/template.cfm?page=15

- Helliwell, John 1996. "Do Borders Matter for Social Capital? Economic Growth and Civic Culture in U.S. States and Canadian Provinces", NBER Working Paper, 5863.

- Kauffman, Daniel, Kraay, Aart, Mastruzzi, Massimo, 2009. “Governance Matters VIII Aggregate And Individual Governance Indicators 1996-2008”, World Bank Policy Research Working Paper, 4978. 
- Kibritçioğlu, Aykut, 1998.” İktisadi Büyümenin Belirleyicileri ve Yeni Büyüme Modellerinde Beşeri Sermayenin Yeri”, Ankara Üniversitesi Siyasal Bilgiler Fakültesi Dergisi, Cilt 53, No.1-4, s.207-230.

- Kibritçioğlu, Aykut, Selahattin Dibooğlu, 2001. "Long-Run Economic Growth: An Interdisciplinary Approach", Office of Research Working Paper, 01-0121.

- $\quad$ North, Douglas, 2002. Kurumlar, Kurumsal Değişim ve Ekonomik Performans. (çev. Gül Çağalı Güven) Sabancı Üniversitesi Yayınları, İstanbul.

- Polanyi, Karl, 1957. "The Economy as Instituted Process”, (Kurumsallaşmış Süreç Olarak Ekonomi, çev. Yahya Sezai Tezel), http://www.yahyatezel.com/onlinep_3.php?no=33

- Sen, Amartya, 1998. "The Concept of Development”, içinde Handbook of Development Economics, Vol. I, (ed. Chenery, H., Srinivasan, T. N.)

- Tezel, Yahya Sezai, 2003. İktisadi Büyüme. İmaj Yayınevi, Ankara.

- The Heritage Foundation, 2010. Index of Economic Freedom. http://www.heritage.org/index/

- The World Bank, 2010. World Development Indicators Data. http://www.data.worldbank.org/indicator 


\title{
Образование - фундамент качественного человеческого
} капитала

\author{
Turar Koychuev (Kyrgyzstan-Turkey Manas University, Kyrgyzstan)
}

\section{Education - the Foundation of High Quality Human Capital}

\begin{abstract}
The article examines the importance of education as the main factor of high quality human capital, vital and having prospects in the modern world; analyses current problems and recent trends, conditions of education in Kyrgyzstan and recommends ways to improve quality of organization and management, to create favourable conditions for building high quality human capital.
\end{abstract}

JEL Code: P36

Знанию естественно суждено приобретать глобальный характер, переходя границы континентов и стран, различных структур материального мира и сфер человеческой деятельности, времен развития Мира и Человечества, проникая и освещая прошлое, предвосхищая будущее. Чтобы оценить и признать значимость нового знания, объективно необходимо сравнить, а оно не было открытым в прошлом или в других странах. Обмен знаниями и научной информацией между научными кругами различных стран это необходимый, естественный компонент и стимул развития знаний и науки, получения новых открытий. Глобализация знаний - естественный компонент их развития и она угрозу Миру и Человечеству не представляет, а является важнейшим фактором экономического поддержания, сохранения и улучшения Мира и достижения дальнейшего прогресса Человечества на пути цивилизованного развития. Другое дело, государствами, властями и определенными общественными силами в каких целях и как используются новые знания и новые научные открытия. Конечно, каждая страна должна быть в состоянии определенной готовности к вызовам науки. И степень этой готовности стран различается, порой полярно.

Какие условия должны отражать науковосприимчивость и знаниевосприимчивость стран. Первое - должна быть качественная система образования, способная подготовить квалифицированные кадры и обеспечить их приток в науку. Второе - должны быть действующие, высококвалифицированные талантливые научные кадры, способные к выдающимся творческим прорывам и открытиям. Третье - в стране должны быть научная материально-техническая база и научные структуры, на базе которых можно развивать новое направление. Четвертое - страна должна обладать достаточными ресурсами инвестиционными ресурсами для развития новых знаний и направлений науки. Пятое - экономика страны, в особенности реальная, должна испытывать потребность в науке и способной технико технологически и экономически к использованию научных достижений.

Каково положение в Кыргызстане с этими необходимыми условиями для освоения и использования новых знаний, технических, технологических решений, методов и форм организации производства и управления.

О первом условии. Общеизвестна истина, что чем дальше и вперед идем по пути цивилизационного прогресса, тем выше должна быть роль образования в развитии человеческого общества и тем качественнее сама система образования. 1991 год стал переломным в общественном развитии для постсоветских стран. Народы освободились от авторитарного режима, выбрали путь полного государственного суверенитета, политической демократии и свободной, открытой, социальной экономики. Это шаг вперед и подъем на ступеньку выше в цивилизационном развитии. Но прошедшие 20 лет были годами отказа от старых стереотипов в мышлении, психологии, действиях и поступках, реформирования всех сторон жизнедеятельности общества, трудных испытаний, проб и ошибок, поиска и выбора верных решений. Но реформенные процессы до конца не завершены, не везде найдены верные решения и поиски их продолжаются.

За эти 20 лет система образования получила ли соответствующее развитие, чтобы отвечать духу и требованиям времени, оказывать позитивное и действенное влияние на общественное развитие? Какими критериями и показателями можно определить и оценить влияние системы образования на социальноэкономические преобразования в постсоветском пространстве?

Прежде чем ответить на заданные вопросы, порассуждаем немного о Миссии системы образования. Она открывает дорогу к знаниям, воспитывает культурой, подготавливает к самостоятельной жизни, дает профессии и квалификации, преобразует и адаптирует к новым, изменяющимися условиям жизни. Учит мыслить, чувствовать и действовать.

В результате общественное значение системы образования гораздо шире и глубже, чем мы привыкли обывательски думать - дали человеку образование и все. И последующие результаты сказываются во всех 
основополагающих характеристиках дееспособности общества.

Люди, получившие достойное, качественное, глубокое знание, могут внести свой существенный вклад в экономический рост. Чем больше образованных и культурных людей, тем выше интеллектуальный и духовный уровень общества. Образованные люди лучше понимают законы общественного развития, осознают истинные ценности и более толерантны. Образованные люди социально солидарны и терпимы в межэтнических отношениях, менее подвержены насильственным и противоправным действиям. Социально стабильную обстановку формирует прежде всего образованное население. И оно патриотично и более активно участвует в позитивных общественных преобразованиях. Образование в широком смысле - ум и душа нации.

Сегодняшняя система образования в состоянии соответствовать требованиям времени и выполняет ли полностью свои функции? Ведь, от востребованности и соответствия образования зависит развитие общества, зависит экономическая и социальная безопасность страны. Я не отвечу «за всю Одессу», но развитие системы образования в Кыргызстане не соответствует требованиям времени и общества. Хочу поделиться некоторой информацией и некоторыми выводами. «Может быть, что - то идентичное встречается и в России, а потому кое - что из мною сказанного представит интерес»

Первое положение - качество образования на всех уровнях системы, начиная от школьного и кончая высшим, падает. И предполагаемые, предлагаемые для школьных выпускников формы выпускных испытаний не столько дают возможность объективно оценить уровень знаний, сколько «бюрократически» отрапортовать успехи и «выпустить» аттестаты «об окончании школы», а не самих школьников, оканчивающих школы. Возведение в роль основных и обязательных одних предметов, дискриминируя других и низведение их в положение необязательных - это путь к снижению образования.

Высшее образование теряет свою главную роль - дать людям специальную профессию. На первый план выходит «делать деньги». Государственные вузы практически уже негосударственные. Они функционируют в преобладающей степени за счет контрактных плат студентов за обучение. Потерян или изжит контроль за качеством обучения. А у многих контрактных студентов психология такова: «Мы заплатили - ставьте оценки и выписывайте дипломы». А требование: «дай достойное образование» встречается гораздо реже. А именно это требование должно стать единственным. Вузы должны выпускать стоящих выпускников, получивших глубокие знания и состоявшихся как специалисты, а не «выпускать» дипломы о высшем образовании.

Второе положение - нехватка учителей в школах. Из аттестатов об окончании школы просто исчезают одни предметы, т.е. они уже изымаются, поскольку не преподавались по причине отсутствия учителей. Из - за низкой заработной платы учителя убегают из школ, а выпускники вузов не идут в школы и ищут работу и находят не по специальностям по той же причине: из - за низкой заработной платы. Третье положение - государство пустило на самотек и не контролирует, не координирует вузовскую подготовку и выпуск специалистов по профессиям и с учетом потребностей в соответствующих отраслях экономики и социальной сферы.

В республике в 2009/2010 учебном году функционировали 54 вуза, в которых учились 233,6 тыс. студентов; из них 22 частные вузы с 26,3 тыс. студентами. Для республики с 5,4 млн жителей и со скромными масштабами экономической и социальной сферой, в которых занято 927,3 тыс. людей, столько потребностей в 233,6 тыс. специалистах высшей квалификации, а значит, в стольких 54-х вузах просто нет. Вузы в погоне за контрактными деньгами все больше и больше увеличивают приемы абитуриентов. Конкурс - фикция, превращен в анекдотичный «бесхозный проходной двор». Он проходит в 3-тура: абитуриенты заплатили и участвуют в I туре - часть выдержала, часть не выдержала. Не выдержавшие испытания подают заявления, платят и участвуют во II туре - и здесь одни проходят, другие остаются за бортом. Оставшиеся за бортом снова подают заявление, платят деньги и участвуют в III туре. Практически поступают подготовленные и неподготовленные; способные и посредственные. Вузы забыли о том, что надо набирать способных студентов, а не собирать деньги. Нельзя систему образования полностью и бесконтрольно отдавать «во власть» рынка. Здесь должны быть учтены особенности сферы. Ведь, вузы выпускают не товары, а специалистов. Люди - не товары.

Непродуманное вовлечение вузов в рыночные отношения привело к тому, что система вузов становиться коррумпированной. Этому способствует и низкий уровень заработной платы профессорскопреподавательского состава. Нужда толкает преподавателей на взятки. Глядишь, ничтожную зарплату получает иной преподаватель, а живет на «широкую ногу»: двух-трех этажный особняк, зарубежной престижной марки автомобиль, шикарные импортные мебель и техника в доме и одежды, дача за городом.

Четвертое положение - повышать качество образования на всех уровнях подготовки специалистов: в профессионально - технических училищах, средних специальных учебных заведениях, лицеях, колледжах, в вузах можно не снижением требований и «облегчением» получения соответствующих 
дипломов, а повышением требований к качеству подготовки и достижением такого уровня образования. Для этого нужно укрепить материальную - техническую базу системы образования, полностью укомплектовывать преподавательскими кадрами, достойно платить преподавателям. Они делают человека Человеком, а такой труд должен цениться не ниже, чем труд производящего товары и оказывающего транспортные, торговые, бытовые и иные услуги.

В республике практически отсутствует единая, общепризнанная государством, по-настоящему координируемая система высшего образования. Сосуществуют параллельно пятилетняя система советского «законченного» высшего образования, бакалавриат (4 года обучения) и магистратура (2 года). Утверждать, что бакалавриат и магистратура уже доказали свою жизнеспособность и в экономику и другие сферы жизнедеятельности общества вливаются квалифицированные бакалавры и талантливые магистры, пока невозможно.

O втором условии. В 1990-2011 гг. происходила утечка умов. Высококвалифицированные, заметные в научных кругах ученые выехали за пределы республики в поисках лучшей жизни, а новоявленные дипломированные собственной, национальной аттестационной комиссией ученые не всегда оказываются на достойном уровне. Конечно, есть талантливые и способные к прорывам специалисты. Но условия не созданы. Трудно найти «кыргызское» научное открытие за годы суверенитета, которое стало ярким и значительным событием хотя бы в пределах СНГ.

O третьем условии. В стране сохранились и работают Национальная академия наук, научноисследовательские учреждения Министерства сельского и водного хозяйства и перерабатывающей промышленности, а также системы здравоохранения. Исследования проводятся и в вузах страны. Но все они нормально не финансируются. Материально - техническая база приходит в упадок, кадры уходят, темы исследований нельзя признать в полной мере достаточно актуальными, новыми и значимыми.

Нужно вернуть Национальной академии наук дух творческой, соревновательной и доброжелательной, действительно демократической атмосферы. За последнее время проведена определенная работа по специализации институтов, отделов, по поиску и выбору интересных в теоретическом плане и перспективных в прикладном смысле направлений и тем. Кое-что уже сформулировано и пущено в работу. Конечно, нужно время, чтобы она дали результаты. Необходимо повышать роль Общего собрания НАН как катализатора идей и в выборе направлений, проблем и тем.

Научные исследования, проводимые в системе Министерстве образования и науки разноплановые, что связанные со спецификой вузов. Но вместе с тем целесообразно вузам формировать общевузовские комплексные крупные темы, представляющие для науки и практики значимый интерес. За последние годы чувствуется, что проведена определенная работа по совершенствованию процесса формирования проблем, направлений и тем исследований. В особенности тех тем, которые проводятся в научных учреждениях сельхознаправлений, медицинских, которые не относятся сугубо к вузовским. Но по части вузовских исследований положение не сильно изменилось. А должно было быть так, чтобы каждый вуз имел свое узнаваемое и привлекательное творческое лицо.

$O$ четвертом. Республика слабо финансирует научные исследования. В 2010 г. затраты на науку составили 0,11 \% ВВП. С такими затратами на науку трудно говорить об обеспечении коренного перелома в науке и серьезном внимании государства к науке, осознавая ее значимость в экономическом и социальном прогрессе.

О пятом условии. Конечно, экономика и другие сферы жизнедеятельности Кыргызстана нуждаются в научной поддержке и новых знаниях и открытиях. Но, когда сельское хозяйство с механизированного уровня спустилось до примитивного «ручного», промышленность потеряла свою техникотехнологическую оснащенность вообе и целые индустриальные подотрасли (предприятия машиностроения), экономика оказалась в таком состоянии, что не может воспринять научно-технические достижения. Грустно: нуждаясь, не в состоянии освоить и использовать.

Сложное положение в Кыргызстане с условиями обеспечения восприимчивости к науке создает трудности в развитии научных связей с внешним миром и использовании мировых достижений, в получении новых знаний и открытий, учреждения - высшие научные учреждения стран СНГ и ряда других.

Как видим, не совсем достойно состояние 5-и базовых условий развития науки, о которых было упомянуто. И безотлагательно необходимо принять меры к улучшению этих 5-и условий.

По первому условию. Систему высшего образования нужно, не откладывая и последовательно, реформировать. Для Кыргызстана вовсе не нужно иметь 54 высших учебных заведения, численность которых, если считать всевозможные филиалы, открытые там, где нет никаких материально-технических и интеллектуальных кадровых предпосылок - будет еще больше. В погоне за деньгами во всех почти университетах открыты факультеты (экономического и юридического профилей), которые вообще не подходят к основному их профилю. Размывается и стирается лицо вузов. Необходимо обеспечить более строго специализацию вузов и, не оглядываясь, решительно сократить их количество. 
Серьезное внимание нужно придать улучшению состояния государственных вузов.

Государственный статус обязывает обеспечить приличное финансовое обеспечение, увеличить заработную плату профессорско-преподавательскому составу и платить стипендию студентам, резко повысить уровень подготовки. В государственных вузах должна быть вообще отменена форма контрактного обучения обесценила качество подготовки. Государственные вузы должны стать образцом для подражания, а не плестись в хвосте. Все остальные вузы, оставшиеся после ликвидации определенных из них, должны иметь статус смешанных муниципально-частных и частных.

Нужно подумать о статусе дипломов. Дипломы государственного образца должны выдаваться только в государственных вузах. Муниципально - частные и частные дипломы могут быть дипломами соответствующего образца. Статус диплома должен отражать качество подготовки и ответственность того, кто несет ответственность за выпуск специалистов. Государственная власть, выдавая лицензии муниципально-частным и частным вузам, только подтверждает наличие условия для открытия вуза, а контролируя и участвуя при аттестациях только определяет соответствие общим требованиям, но за качество не может нести ответственность. Такие меры ответственности за подготовку и выдачу дипломов повысят ответственность за обучение, а у кого-то исчезнет интерес к не очень чистому бизнесу в вузе и не будет открывать лжеуниверситеты.

По второму условию. Необходимо решительно обновлять научные кадры талантливыми молодыми специалистами. Необходимо открывать новые научные структуры по новым актуальным направлениям и привлечь молодые кадры. Нужно закрывать структуры, которые десятилетиями работают над проблемами, которые уже потеряли актуальность и свою ценность как для теории, так и для практики. Они даже для самих исполнителей не представляют любопытство, а стали упражнением для забавы и получения зарплаты за потраченное в общем-то бездарно время. Нужно по-настоящему возродить подготовку научных сотрудников через аспирантуру и докторантуру с выплатой стипендий аспирантам и докторантам и зарплату за осуществляемое научное руководство.

По третьему условию. Безусловно, сохранившиеся научные центры страны (Национальная академия наук, научно- исследовательские центры сельского и водного хозяйства, системы образования и здравоохранения) должны стать для государства объектом более серьезной работы и в плане укрепления материально-технической базы, и в плане повышения заработной платы научным сотрудникам. Но научные учреждения должны финансироваться не за то, что они существуют, а за выполненные работы. Поэтому финансирование должно стать проектно-программно-целевым по каждому направлению и по каждой теме.

По четвертому условию. Государство обязано инвестировать в науку, в те ее направления, которые представляют значимый теоретический интерес или могут внести в масштабы страны выдающийся вклад в решение практических проблем развития экономики и других сфер жизнедеятельности республики. Вместе с тем, сами научные учреждения должны развивать необходимые связи с международными организациями, научными учреждениями зарубежья, экономическими структурами зарубежья и собственной страны и выигрывать гранты, получать донорскую поддержку, «зарабатывать» финансирование за проводимые исследования и т.д. не надо надеяться только на государство. В условиях рынка необходимо проявлять и развивать предприимчивость, создавать совместные научнопроизводственные, научно-предпринимательские, научно-инновационные и другие структуры.

По пятому условию. Конечно, на более привлекательном уровне развития и подъема, экономика страны будет более восприимчивой к науке. Но от науки сегодня многое зависит, чтобы приблизить это время. Поэтому государство чаще и обязательно, ради дела (а не для «протокола»), должно приглашать научные силы страны к выработке концепций развития страны, определению экономической и социальной политики государства. Государство должно выработать и утвердить Комплексную научнотехническую политику, которая должна стать руководством к действию и для научных сил страны, и для самого Государства как власти !

При улучшении названных 5-ти базовых условий развития науки, несомненно, глобализация более глубоко и широко охватит образование и науку Кыргызской Республике и создаст новые предпосылки для развития и достойного представления себя в мировой образовательной и научной системе. Образование только тогда станет важным, действенным фактором экономического и общественного, шире вообе национальной безопасности страны, когда общество и государство воздадут ему должное, которого оно заслуживает!

\section{Литература:}

- Койчуев Т. Есть ли у Кыргызстана будущее ? -Б., 2010.-324 с.

- Койчуев Т. Мировая экономика и постсоветская Центральная Азия. - Б., 2011. - 122 с.

- Официальные материалы Национального Статистического комитета КР, Национальной академии наук, Министерства образования и науки, Национального аттестационного комитета. 


\title{
Кыргызстандагы жумушчу күчү сапатынын азыркы кездеги проблемалары
}

Jypar Aituganova (Kyrgyzstan-Turkey Manas University, Kyrgyzstan)

\section{Current Problems in Labor Quality in Kyrgyzstan}

\begin{abstract}
Formation or implementation of high-quality labor is an actual problem of the world economy and always considered in the theory and practice. Labor quality is the realization of increased productivity and performance of the work and responsibilities, also it is known as the main factor of economic growth in economics. Since 1991, the importance of labor quality for development of national economy and macroeconomic stability in Kyrgyzstan is growing and becoming actual in globalization and integration process, financial, informational, scientific and technical cooperation, is requiring researching. This problem studied by academics O. Bogomolov, L. Kudryavtsev, G.Kolodko, T.Koychuev and others. In economics labor defines as a set of three groups of labor skills and abilities of individuals. This group of skills combines the biological, economic and social side of man. Development of labor quality is considered at three levels: low, medium and high quality. In all states, there are complex of integrated structures that seek efficiency in own activity. In the transition period for Kyrgyzstan it is necessary to solve social problems, improve living standards. It's necessary to abide execution of laws by from the President to the citizen, establish the subordination of society to laws, improve moral of public servants, gain people's trust in government, form up the economic culture, to eliminate the shadow economy and corruption. Economic culture must become an integral part of national ideology.
\end{abstract}

JEL Code: J24

Бүт дүйнө жүзүндөгү дайыма эң маанилүү проблемалардын бири болуп жумушчу күчүнүн сапаты, мамлекеттеги аны калыптандыруу системалары жана аны реализациялоо системалары, структуралары, шарттары (жумушчу орун менен камсыз болуу) маселелери турат. Экономикалык илим коомдогу негизги өндүргүч күч катары эң алгач адамдын жумушчу күчүнүн сапатына, анын деңгээлинин мүнөздөмөсүнө өзгөчө маани берет. Жумушчу күчүнүн сапаты жөнүндөгү проблемаларды чечүү теорияда да, практикада да дайыма каралып жатат. Себеби, жумушчу күчүнүн сапаттуу болушунун максаты - анын жогорку эмгек өндүрүмдүүлүктө реализацияланышы жана ишти, кызматты сапаттуу аткаруу. Мындай процесстер ар бир өлкөнүн экономикалык, социалдык, маданияттык, геосаясий, укуктук өнүгүүсүнө жараша өтөт жана кайсы экономикалык системанын ичинде болгондугуна байланыштуу болот.

Советтер Союзу убагында социалисттик экономикалык илимде «жумушчу күчүнүн сапаты» термины каралган эмес, дайыма жумушчу күчүнүн саны жөнүндө, сан жагынан мүнөздөмөсү жөнүндө гана сөз болгон. Экстенсивдүү тип менен экономиканы алып барууда чечүүчү ролду сандарга тийиштүү көрсөткүчтөр, параметрлер, сандарына тийиштүү факторлор каралган. Ал эми рыноктук системада, өндүрүштү интенсивдештирүүдө, обьективдүү түрдө сапаттык көрсөткүчтөр, сапаттык факторлор, илимге, техникага, технологияга таянган жумушчу күчүнүн өнүгүүсү керектүү жана маанилүү. Бирок бул маселелердин бардыгы өтө ар тараптуу, комплекстү, көп структуралуу болгондугу үчүн улам бир аспекттери чечилиш мезгилин тезинен күтөт.

Көз карандысыздыкка ээ болгон суверендүү Кыргызстанда 1991 жылдан бери да жаңы улуттук экономиканы калыптандыруу үчүн жана анын макроэкономикалык стабилдүүлүгүнө, жакшы сапаты, ролу, реализациясы жана анын айкындатылган, жакындатылган ( адекватту) акыга ээ болгондугу же болбогондугу проблемалары өтө зор жана актуалдуу. Демек, мындан улам келип чыккан маселелерди чечүү зарыл, алар төмөнкүлөр:

жогорку сапаттагы жумушчу күчүнүн калыптанышы, буга тийиштүү структуралардын иш- аракеттери, Кыргызстандагы эмгек рыногундагы жумушчу күчүнө болгон суроо- талап жана сунуштун абалы, жумушчу орундардын жетишпестиги, эмгек акысынын төмөн деңгээли, ички жана тышкы миграциянын себептери ж. б. көйгөйлөр, проблемалар өтө көп жана дагы деле изилдөөлөрдүн улантылышын талап кылышат.

Жумушчу күчү сапатынын аныктамасына кайрылсак, акыркы убакытта экономикалык илимде жалпы кабыл алынгандай:

Үч группадан турган адамдын өзүнүн эмгек аткарууга байланыштуу жөндөмдүүлүктөрүнүн, сапаттарынын жыйындысы. Алар жалпысынан адамды биологиялык да социалдык да тараптарын бириктирет жана төмөнкүлөрдү камтыйт:

1) физикалык- психологиялык, 
2) профессионалдык (адистик) жана

3) социалдык сапаттардын бирикмесинин деңгээли жана алардын эмгектик иш аракеттеринин натыйжасында реализацияланышы эсептелинет.

Адамдын өзүнүн адам катары касиеттери эмгекке болгон жөндөмдүүлүктөрү менен тыкыс байланыштуу. Адамдын билогиялык, физиологиялык, укуктук, саясий, тарыхый, философиялык, социологиялык, жарандык, медициналык ж. б. көптөгөн жактары жөнүндө, анын ар тараптуулугу жөнүндө 200 дөн ашык илимдерде каралат, изилденет, анализденет жана практика үчүн чаралар сунушталат. Бирок, адамдын негизги маңыздык касиети бул эмгекке болгон жөндөмдүүлүктөрү, өндүрүштүн талабына жооп берүүсү, өндүрүш каражаттарына, техникага, технологияга айкалышуусу да ар түрлүҮ улам жаңы продукция чыгаруусу жана тейлөө, кызматтарды жогорку сапатта аткаруусу. Демек, мындай нерсеге даярданыш керек. Бул мамлекеттик жана ар бир инсандын милдети, максаты. Коомдо жумушчу күчүнүн сапатына тийиштүү татаал системалары уламдан улам өнүгүп келе жатат.

Жумушчу күчүнүн өнүгүшү үч деңгээлде каралат: төмөнкү сапат, орточо сапат, жогорку сапат (мындай бөлүштүрүүнү К. Маркс өзүнүн «Капиталынын» 1-чи томунда белгилеген). Адам идеалдуу түрдө өмүр бою жумушчу күчүнүн сапатын өнүктүрөт жана аны жогорку деңгээлге жеткирүүгө умтулуш керек. Себеби, адамдын адам катары маңыздуу күчтөрүнүн өнүгүшү мына ушунда жатат.

Демек, каралып жаткан маселе өтө татаал, көп кырдуу, системдүү, мамлекеттик; андан да мамлекет аралык деңгээлде жумушчу күчүнүн сапатын адам өзүнүн мүмкүнчүлүктөрүнө карата өнүктүрөт жана өлкөдөгү тийиштүү структуралык субьекттер менен чечилет.

Жумушчу күчүнүн биринчи группадагы сапаттары ден-соолугуна жана адамдын психологиясына байланыштуу. Мамлекетте жумушчу күчүнүн бул түзүүчүсү системдик түрдө ишке ашырылат: денсоолукка байланыштуу структуралар жана физикалык маданият, спорт ж.б. структуралар кирет. Буларга төмөнкү физикалык- психологиялык сапаттар кирет: психикалык ден-соолук, физикалык ден- соолук акыл- эси, чыдамкайлык, күч- кубат, көздүн курчу, кара күч, угуу сезими, эмоциялар, чечкиндүүлүк, эрк, эстөө сезими ж. б. Алар болсо социалдык секторда - медицина, спорт маданияты тармактарында; коомдун, үй- бүлөнүн стабилдүүлүгү, нормалдуу адеп- ахлактык климаттарына жараша болот. Аны менен бирге акыркы кезде

ИТРнын өнүгүүсүндө өндүрүштүн, жашоонун чыңалышы, интенсивдүүлүгү менен психология проблемалары өтө эле чоң мааниге ээ. Адамдын эң мурда психикасынын чың болушу эмгекке жөндөмдүү же жөндөмсүз, коллективге, жамаатка сыйымдуулугун, адаптивдүүлүгүн, толеранттыгын, чыдамдуулугун, сабырдуулугун, коммуникативдүүлүгүн көрсөтө алат же критерий боло алат. Азыркы ишке алуу рекламалардын критерийлеринде - коммуникабелдүүлүк деген сапат такай жазылып калды. Бирок, мурунку Советтер убагында кызматкерлердин, жумушчулардын психикалык ден- соолугуна, жалпы ден- соолугуна жетиштүү көңүл бурулган эмес. Мындай көрүнүш Советтер Союзунун жетекчилеринен байкалды. Алар иштеп кеткенден кийин гана ачык түрдө психикалык жана дене денсоолук абалдары жөнүндө коомго информация берилген. Алардын психикалык оорулары бар экендиги жөнүндө элге кийин айтылган. Убагында, кызматка алынып жатканда, эч кандай илимий- психологиялык тесттер, текшерүүлөр жүргүзүлгөн эмес. Ал тургай спорт маданияты менен кызыгуулары жөнүндө коомчулукка эч кандай маалымат берилген эмес. Алардын кайсы жашка чыккандыктары, ал убактысына дал келген ден-соолугуна, психикалык абалына элден жашыруун түрдө көз салып турушкан, даарылантып, көзөмөлдөп турушкан. . Психикалык ден- соолукка, жалпы ден соолукка мындай мамиле жетекчилердин иш- аракеттеринде, мамлекеттик деңгээлде- макроэкономикада, коомдук процесстерде өтө терс көрүнүштөрүн алып келген. Мисалы, чет өлкөлүк инвестициялар, тышкы жана ички экономикалык аракеттердин көлөмү да азайып кетип жаткан.

Адамдын жумушчу күчүнүн биринчи группадагы сапаттарды калыптандыруу, аларды жакшыртуу азыркы мезгилде бүтүн дүйнөдө, өзгөчө өнүккөн өлкөлөрдө зор мааниге ээ. Азыркы учурда психологдордун кызматтарына иште да, үй- бүлөдө да суроо- талап бар жана ал канагаттандырылыш керек. Кыргызстанда бул проблеманы чечиш кыйынга турат, керектик муктаждыктар бар, суроо- талап бар, психологтор керек, бирок психологдордун кызмат акылары өтө төмөн, бул адистик престиждүҮ эмес Же болбосо кыргызстандыктардын өзүлөрүнүн психологдорго, башка докдурларга кайрылыш үчүн акча каражаттары жетишсиз.. Азыркы министр С. Джумабеков айткандай Кыргызстанда бир пациентке бир жылда 20 доллар сарпталат, Россияда болсо - 466 доллар.

Стационарда пациентке бир күндө дарыларга 75 сом каралат, ал эми тамакка- 38 сом. 75 сомго эмне сатып алса болот? Ошондуктан, биз ооруларларга дарыларды сатып келишин айтабыз, ал эми 38 сомгочу?

2005- 2007 ж.ж. мамлекеттик бюджеттен саламаттыкты сактоого 2,2\% - 2, 6\% каражат каралган. Саламаттыкты сактоо боюнча Бүт Дүйнөлүк Уюм Кыргызстандын ИДПнун 4-5\%3ын ооруларга жумшоого сунуштаган, андай болсо 100 доллар чыгат экен, бирок медиктердин айтуусу боюнча, абал анча деле оңолбойт. Кыргызстандыктар бир жылда 4,5 млрд сомду медициналык тейлөөгө кетиришет, 
көп бөлүгү дары- дармекке, аз бөлүгү тамактанууга.

Экинчи группадагы сапаттарды даярдоо системалары: жумушчу күчүнүн сапатын калыптандыруу, даярдоо, өнүктүрүү процесстерге караштуу мамлекеттик жана жекече структуралар. Бул группадагы сапаттар төмөнкү: специалист- терең адис болуу, профессионалдуулук, компетенттүүлүк, жогорку, орточо квалификациялуулук, устаттык, тажрыйбалуулук ж. б. сапаттар. Булардын баарына ээ болуш үчүн маанилүү негиз болуп - билимдүүлүктүн деңгээли эсептелинет.

Рыноктук экономика көздөй бет алган Кыргызстанда социалдык секторга тийиштүү мамлекеттик, жеке менчикте болгон мектепке чейинки, жалпы билим берүү, адистик орто окуу жайлар, ар кандай адистик курстар, колледждер жогорку окуу, өзгөчө өнүккөн мамлекттерде эң чоң чет өлкөлүк окуу жайлар да салымын кошууда, Кыргызстандын көптөгөн бүтүрүүчүлөрү билимдерин, адистигин бул өлкөдө гана эмес АКШ, Германия, Франция, Япония ж. б. окуу жайларында алышууда.

Мамлекетте укуктук- нормативдик негиздер Кыргыз Республикасындагы Жогорку Кенеш, Билим берүү жана илим боюнча министрлик тарабынан түзүлүп жатат. Мисалы, бул жөнүндөгү мыйзамдарды жана буйруктарды толугу менен төмөнкү сайтта көрсө болот: http://www.adviser.kg (М.: ЗАКОН КР от 29 июня 2009 года N 198 "О дошкольном образовании" ж.б. мыйзамдарды.)

Учурда дүйнөдө эркектер жана аялдардын арасында 100\% дык сабаттуулукту КМШ, АКШ, Канада, Австралия, Жаңы Зеландия, Япония өлкөлөру ээлешет. Демек, мунун ичинде Кыргызстан да бар.

Жалпысынан, биз көргөндөй, кыргызстандыктар сабатту, билимдүү мамлекеттерге кошулат, бирок Кыргызстанда өткөөл экономикалык, транзиттик абал, экономикалык өсүштүн жетишпеген темптери, турмуш деңгээлинин төмөндүгү эң биринчи билимдүүлүктүн төмөнкү баскычына терс таасирин тийгизүүдө жана төмөнкү сапаттагы жумушчу күчүнө өбөлгө түзүүдө. Мындай өтө курч абал окубай иштеп жүргөн жаш балдардын санын көбөйтүүдө, маалыматтарга караганда 100 миң бала окубайт жана иштөөгө мажбур. Андан ары Кыргызстандык мектеп окуучулардын арасында Эл аралык PISA (07.12.20010) жүргүзгөн изилдөөлөрүндө ( ар бир 3 жыл сайын өткөзүлөт) алар төмөнкү натыйжаларды көрсөтүштү. Кыргызстандык мектеп окуучулар рейтинг боюнча акыркы орунду ээлешти. Изилдөөгө 65 өлкө катышып, математика, химия, биология, физика, физикалык география, түшүнүү, китеп окуу боюнча предметтерден текшерилген, алардан жакшы көрсөткүчтөргө Кытай, Корея, Финляндия, Гонконг, Сингапур, Канада, Жаңы Зеландия, Япониянын окуучулары ээ болушкан. (http:/diesel.elkat.kg)

Кыргыз Республикасында жумушчу күчүнүн сапатынын ар кайсы деңгээлде калыптанышы: төмөнкү же жогорку экендиги белгилүү болду. Эми аны реализациялоо системасында өтө курч проблемалар бар: жогорку, орто сапаттагы жаш адистер үчүн жумушчу орундар жетишпейт, эмгек акылар жетиштүү эмес, стандарттык жашоо минимумуна аз жетишерлик, сарпталган эмгекке айкалышпайт, тете эмес. (http://www.regnum.ru/news/medicine)

Кыргыз Республикасынын 20011- 2014 жылдагы өнүгүүсүнүн негизги социалдык - экономикалык көрсөткүчтөрүнөн эмгектик ресурстарын карап көрсөк төмөнкүчө маалымат бар:**

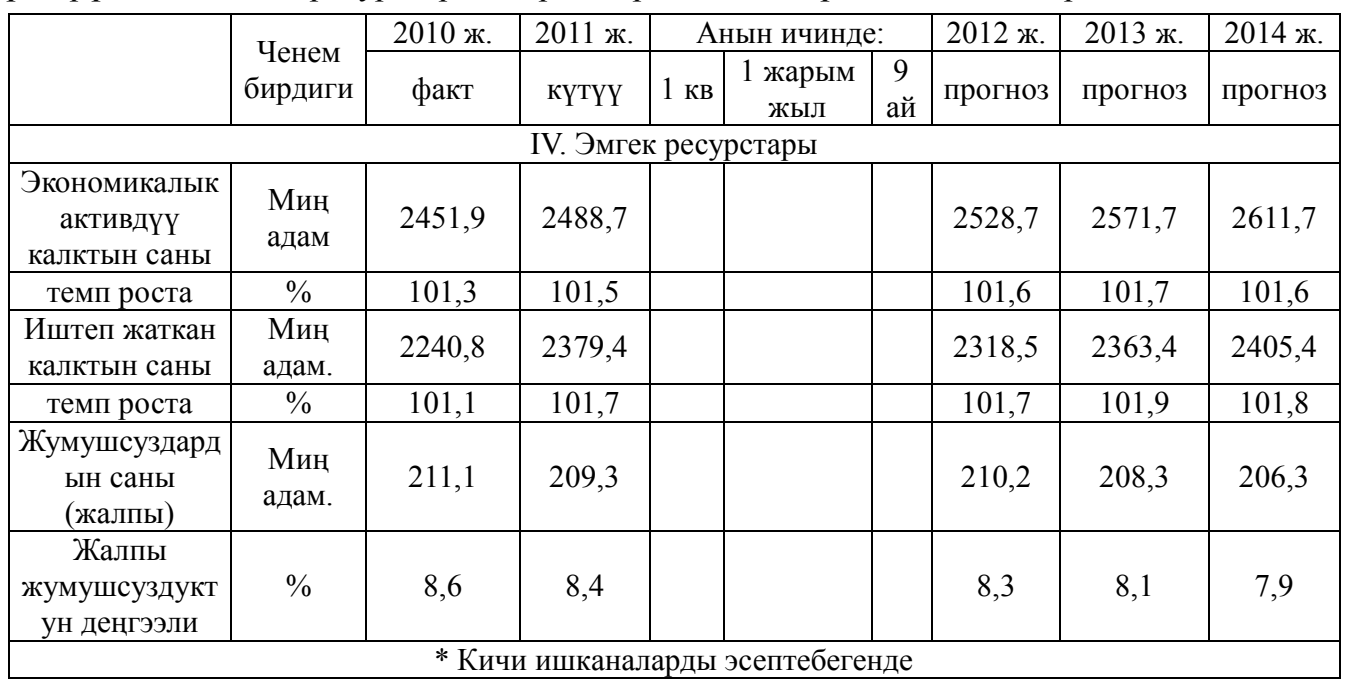

**Среднесрочный прогноз социально-экономического развития Кыргызской Республики на 2012-2014 годы

Бул маалыматтарга караганда жумушсуздук официалдуу түрдө көрсөтүлгөн, ал эми 2011 жылы Кыргызстандагы жумушсуздук деңгээли 12\% га өсөт ал, болсо 295 миң адамды түзөт деп - 18 октябрдагы пресс-конференцияда эмгек, жумуш менен камсыз кылуу, миграция министри А. Рыскулова айткан. Европада жумушсуздук 10\% болсо кризистик абал деп эсептелинет, демек Кыргызстанда бул багытта кризис болгондугу өкүнүчтүҮ. Кыргызстандыктардын 11\% - 600 миң адамы Россияда, Казакстанда 
иштешет, бирок так санды айтууга болбойт, регистрациядан толугу менен өтүшпөйт. Кыргызстанда жашоо минимумдан төмөн эмгек акы алгандар - 30\% түзүшөт. ООН (ЮНИСЕФ) тин маалыматына караганда Кыргызстанда 24 миң мугалим жакырчылыктын чийинин астында жашашат. (http://www.report.kg/ussr/1499)

Эмне кылыш керек? Чет өлкөлөрдөгү жумушчу орундарды ээлеп калганга мажбур болуу, демек, Кыргызстан эң мыкты таланттуу жаштарга дагы, адистерге дагы ээ, бирок алар Европага, Казакстанга, Россияга кеткендиктерине мамлекет, бүгөт койё албай жатат.

Жумушчу күчү сапатынын 3)чү группасы боюнча, булар социалдык касиеттер: саясий эрк, жоопкерчилик, жакшылыктарды каалагандык, акниеттүүлүк, чынчылдык, патриоттуулук, күйүмдүүлүк, адамкерчиликтик, экономикалык маданияттулук, башка адамдарды сыйлоо, тактык, пунктуалдуулук ж. б. Бул касиеттер өтө маанилүү, өзгөчө өткөөл мезгил убагында, жаңы рыноктук тартип калыптанып жатканда, жаңы улуттук экономиканы жана социалдык чөйрөнү жогорулатыш үчүн социалдык касиеттер өтө керек. Биз билебиз япондуктардын, немецтердин бул жактагы касиеттерин. Алар экономиканын өсүшүнө чоң өбөлгө болгон_жана болуп турат. Жумушчу күчү сапатынын бул касиеттери азыркы кезде экономикалык илимде кызыгуу менен каралуучу маселелердин бири. Эң биринчи булар жетекчилерден, мамлекеттик кызматчылардан талап кылынат. Бирок Кыргызстандагы коррупцияны, экономикалык маданияттын жоктугун Республикадагы биринчи жана экинчи Президенттери үй- бүлөлөрү менен көрсөтүштү. Демек, Кыргызстанда социалдык сапаттардын кризиси десек болот. Жумушчу күчү сапатынын бул группадагы касиеттери азыркы ааламдашуу, интеграцияланышуу, ар кандай кызматташуу, финансылык, информациондук, илимий, техникалык мейкиндиктерге аралашуу иш- аракеттерде азыркы кезде экономикалык илимде терең каралуучу, актуалдуу маселелердин бири болуп калды.

Бул проблемага Оруссиядагы академиктер өзгөчө көңүл бурушкан. Мисалы, россиялык академик О. Богомолов « Социалдык - экономикалык прогресстин адеп- ахлактык фактору» («Нравственный фактор соцально- экономического прогресса» Ж. Вопросы экономики.2007. №11, с.55) деген макаласында адепахлактык жана рухий кризис азыркы кезде коомдордун баарын жана анын элитасын каптап, коомдорду реформациялоого түртүп жаткан кези. Экономикалык жана социалдык прогресс жогорку маданиятты, профессионализмди, жарандык жоопкерчиликти, чынчылдыкты талап кылат, себеби бул сапаттар коомдук процесстерди эффективдүү башкаруунун шарты катарында болушат. Экономика жана адепахлактык касиеттер өз ара таасир этишет жана бул маселе өнүккөн Батышка дагы, өткөөл өлкөлөргө дагы өтө керектүY.

Дагы бир окумуштуу Л. Кудрявцев «Заманбап коом жана адеп- ахлактык» (М. Наука, 2000 с. 9) деген макаласында төмөнкүчө жазган: тарыхта, деген, экономикасы нормалдуу өнүккөн өлкөлөр кээде кыйрашкан, себеби калктын моралдык деңгээли түшүп, өзгөчө мамлекеттик чиновниктердин коррупцияга чөгүп кетип, бузулушкан.

Гж. В. Колодко «Бизнестеги, экономикадагы, саясаттагы этика» (Ж. Вопросы экономики. 2007, №11 c.44) деген эмгегинде..... улуттук экономикалардын либерализациясы, локалдык жана регионалдык рыноктордун дүйнөлүк рынокко интеграцияланышы өзүнүн моралдык принциптер тарабынын аныкталган өндүрүштүн, сооданын, капиталдардын жана инвестициялардын трансферттерине, сактоолордун жана кредиттөөнүн ж. б. таталдыктарына ээ. Фирма, регион, өнөр жай кызыкчылыктары рыноктун кайсы бир сегментинин экономикалык рационалдуулугуна, гумандуулугуна туура келбеси ыктымал.

Кыргызстандык акад. Т. Койчуев мындай жагдайды төмөнкүчө белгилейт: «... жалгыз гана илим, техника, билим берүү коомдук жалпысынан, тактаганда экономикалык жана социалдык прогресстин ири факторлору болбостон, рухий байлык, адамдардын сезимдеринин, эмоцияларынын, адеп- ахлактык, ыймандуулуктун тазалыгы дагы болуп турушат. Адам экономикага кандай көз караш менен карайт, ыймандуулук мененби же эмеспи? Мына ушундан көп нерсе көз каранды.» (Койчуев Т. Есть ли у Кыргызстана будущее? - Б., 2010. стр. 220)

Демек, жогорку сапаттагы жумушчу күчүнүн үчүнчү группадагы социалдык сапаттар - жарандык, ыймандуулук, чыныгы инсандык, патриоттук ж. б. көп касиеттерге ээ болуусу абзел.

Мыйзамдар боюнча, жумушка жарамдуу адамдар жана мамлекеттин жумушчу күчүнүн сапатын өнүктүргөн көптөгөн структуралардын ар кайсы коомдо болуп турган максаты жана ыйык маселеси - бул жогорку сапаттагы жумушчу күчүн даярдоо, жана аны жогорку сапатта иштетүү, колдонуу, реализациялоо мүмкүнчүлүктөрүн көбөйтүү керек.

Буга карата чечүү жолдору кандай? Кыргызстанда эмгек акыны эмгек өндүрүмдүүлүккө карата төлөп берүҮ зарыл, жумуштун сапатына карата жогорулатуулар керек. Социалдык проблемаларды туура жана өз убагында чечүү, жашоо деңгээлин жогорулатуу, мыйзамдарды Президенттен баштап жөнөкөй адамга чейин аткаруу, коомдун бүтүндөй аларга (мыйзамдарга) баш ийүүсү, өкмөттөгү кызматчылардын, бийлик тараптагылардын үлгүлөрү керек, моралдык бийиктиктери керек, аларга болгон элдин ишенимин 
жогорулатуу керек. Үй- бүлөдөн баштап ыймандуулукка, рухий баалуулуктарга тарбиялоо. экономикалык маданиятка тарбиялоо, себеби азыркы кезде адамдар жогорку билимдүү, маданияттуу болгону менен коррупционер, көмүскө экономикадагы адамдары болгону Кыргызстанда белгилүү нерсе. Экономикалык маданият бүт улуттук деңгээлде каралышы керек: булар ишкердүүлүк маданияты, чарбачылык маданият, салыктык маданият, финансылык маданият, экономикалык этика же иш этикасы, информациондук маданият, керектөөчүлүк маданият, экономикалык өз -ара байланыштардын маданияттарынын жыйындысы деп айтсак болот жана экономикалык маданияттын мааниси бардык өнүгүүнүн улуттук идеясынын орчундуу бөлүгү болууга тийиш, себеби глобалдык экономикаларда бүгүнкү күндө экономикалык маданият биринчи зор маселеге айлангандыгы белгилүү болуп жатат.

\section{Колдонулган адабияттар}

- Среднесрочный прогноз социально-экономического развития Кыргызской Республики на 2012-2014 годы. Одобрено Постановлением Правительства Кыргызской Республики от «3» июня 2011 года № 287

- О. Богомолов. Нравственный фактор социально- экономического прогресса. Ж. « Вопросы экономики», 2007, № 11

- Л. Кудрявцев « Современное общество и нравственность». М. Наука, 2000

- Гж. В. Колодко. Этика в бизнесе, экономике и политике. Ж. «Вопросы экономики», 2007, № 11

- Т. Койчуев. Есть ли у Кыргызстана будущее? - Б. , 2010

- Дж. Айтуганова. О некоторых аспектах качества формирования рабочей силы в Кыргызстане. В книге: Интеграция и экономическое развитие в переходных экономиках. Межд. научнопрактический конгресс, посв. акад. Т. Койчуеву. Бишкек. 2008

- Ж. Айтуганова. Кыргызстандагы улуттук экономикалык маданият проблемасы. 7.Uluslararas1 Türk Dünyası Sosyal Bilimler Kongresi. Küreselleşme ve Türk Dünyası Sempozyum Tebliğleri-2, 9-11 Haziran 2009, Calalabat-Kırgizistan. 


\title{
Роль Интернет-технологий в повышении эффективности администрирования налогов
}

\author{
Valentina Orlova (Donetsk National University of Economics and Trade, Ukraine)
}

\section{The Role of Internet Technologies in Improvement of Tax Administration Efficiency in Ukraine: Problems and Prospects}

\begin{abstract}
In the current context information technologies including Internet technologies are the most important factor in providing sustainable social and economic development of the nation. Taking part in implementing government functions they represent a new form of citizens public authorities communication within the bounds of egovernment. Offices of State Tax Administration of Ukraine are part of public electronic space and are actively employing Internet technologies in administering their functions. They are represented by hardware and software for information collection, processing, transfer and storage, and also serve as active communication medium with taxpayers. Official website of tax administration of Ukraine has 20 sections, 163 sub-sections and more than 400 heads in Ukrainian, Russian and English languages. In conditions of taxation system reforming it provides on-line access to live information and is efficient tool in forming optimal ties with taxpayers providing feedback in discussing topical taxation questions. Introduction into effect of the Tax Code has made fundamental changes in tax procedure and administration methods. Procedure of submitting tax accounts in electronic form through Internet has been improved. It enables to aggregate taxpayers review data and tax offices accounting data into unified technological process. The paper gives analysis of the influence of IT on improving efficiency of tax administration in the current context and assessment of the prospects for its further improvement.
\end{abstract}

JEL codes: E62, H11, M15

\section{1 Постановка проблемы}

Актуальность проблемы внедрения Интернет - технологий и повышения их роли в росте эффективности администрирования налогов не вызывает сомнений. Прежде всего, это связано с тем, что в современных условиях информационные технологии, включая Интернет - технологии, являются важнейшим фактором обеспечения устойчивого социально-экономического развития государства. Участвуя в реализации функций государства, они представляют новую форму общения субъектов хозяйствования - юридических лиц, граждан и органов государственной власти в рамках системы "Электронного правительства". Органы государственной налоговой службы являются частью электронного пространства и активно используют Интернет - технологии в администрировании налогов и сборов, как основных источников наполнения государственного бюджета Украины. Интернет технологии, используемые государственной налоговой службой Украины, представлены техническими и программными средствами по сбору, обработке, передаче и хранению информационных ресурсов, а так же служат средством активной коммуникации с налогоплательщиками. В этой связи особенно важным является введение Налогового Кодекса, которым внесены существенные изменения в порядок и методы администрирования налогов. В частности, законодательно предусмотрено новый порядок предоставления налоговой отчетности в электронном виде посредством сети Интернет. Это дает возможность отчетные данные налогоплательщиков и учетные данные налоговых органов агрегировать в единый технологический процесс, способствующий: росту экономики путем внедрения системы раннего выявления плательщиков налогов тяготеющих к укрытию доходов; достижению баланса интересов государства и субъектов хозяйствования в процессе администрирования и возмещения налога на добавленную стоимость; улучшению обслуживания плательщиков налогов с целью ограничения поводов вмешательства государства в легально действующий бизнес.

Известно, что для стратегии долгосрочного развития национальной экономики и реализации антикризисных программ необходимы механизмы целевого использования бюджетных, кредитных, инвестиционных ресурсов, позволяющих в полной мере обеспечить финансовыми ресурсами целевые программы развития государства. Наличие финансовых ресурсов и возможность их эффективного использования в пределах расходной части государственного бюджета зависит, прежде всего, от четко разработанной национальной налоговой политики, системы налогообложения, а также от эффективности деятельности государственной налоговой службы.

Исследования показали, что эффективность налоговой политики ее адекватность направлениям социально-экономического развития общества является одним из основных факторов успешного развития экономики государства, успешного проведения реформ в сфере налогообложения и 
инновационной активности в деятельности государственной налоговой службы - главного контролирующего органа в сфере налогообложения. Налоговая служба Украины в течении всех лет независимости постоянно находится в эпицентре экономических и социальных процессов происходящих в стране. Введенный в действие с 01.01.2011 года Налоговый кодекс подытожил деятельность налоговой службы и указал пути дальнейшего усовершенствования на основе эффективного применения информационных систем и Интернет - технологий с целью повышения эффективности администрирования налогов, сборов (обязательных платежей).

Практика налогообложения, анализ отчетных данных по налогообложению дают основание сделать вывод о том, что принятие Налогового кодекса открыло новый этап в развитии налоговой системы и государственной налоговой службы Украины. Очевидным является то, что в 2011 году в Украине наблюдается всплеск экономической активности. Например, в текущем году крупные промышленные компании увеличивают объемы производства, восстанавливают позиции на мировых рынках. Наметились положительные тенденции в развитии малого и среднего бизнеса. Согласно данных налоговой службы Украины в текущем году 24 тысячи предпринимателей прошли государственную регистрацию и открыли свою деятельность. Кроме того 163 тысячи субъектов малого бизнеса - плательщиков единого и фиксированного налогов нарастили объемы реализации и перешли на уплату налогов по общей системе налогообложения, что способствует росту поступлений в бюджеты всех уровней. В целом по Украине в общий фонд государственного бюджета за пять месяцев 2011 года поступило 77,8 млрд. грн., что более чем в два раза больше против соответствующего периода прошлого года. Объем поступлений в бюджеты всех уровней по итогам 5-ти месяцев составил 109 млрд. грн. (Захарченко, 2011). При этом значительно снижено налоговое давление на бизнес, что свидетельствует о повышении эффективности налогового администрирования.

Вопросам повышения эффективности администрирования налогов много внимания уделяют известные ученные: Азаров Н.Я., Варналий 3.С., Вишневский В.П., Геец В.М., Мельник П.В., Папаика А.А., Тарангул Л.Л., Ярошенко Ф.А. Вместе с тем в научной литературе еще недостаточно освещено влияние информационных систем и технологий управления на повышение эффективности администрирования налогов.

Учитывая вышеизложенное, целью статьи является выявление направлений воздействия информационных систем и технологий управления, в частности Интернет - технологий, на повышение эффективности администрирования налогов в современных условиях, а также оценка перспектив их дальнейшего усовершенствования.

\section{2 Изложение основного материала}

Анализ теоретических основ налогового администрирования показал, что важным условием стимулирования социально-экономического развития Украины является реформирование налоговой системы и модернизация государственной налоговой службы. Последовательное осуществление мероприятий по реформированию государственной налоговой службы начато в 1997 году с разработки концепции и стратегических направлений развития государственной налоговой службы Украины (Державна податкова адміністрація України, 2003). Начиная с 2000 года, Государственная налоговая служба совместно с Мировым банком реализует долгосрочную Программу модернизации государственной налоговой службы. Целью этой Программы является создание стабильной системы государственных доходов путем обеспечения надежного фундамента для организации работы. Программой модернизации определены основные направления работы и задачи стратегического развития государственной налоговой службы Украины на период с 2000 по 2013 год, что схематично представлено на рисунке 1. 


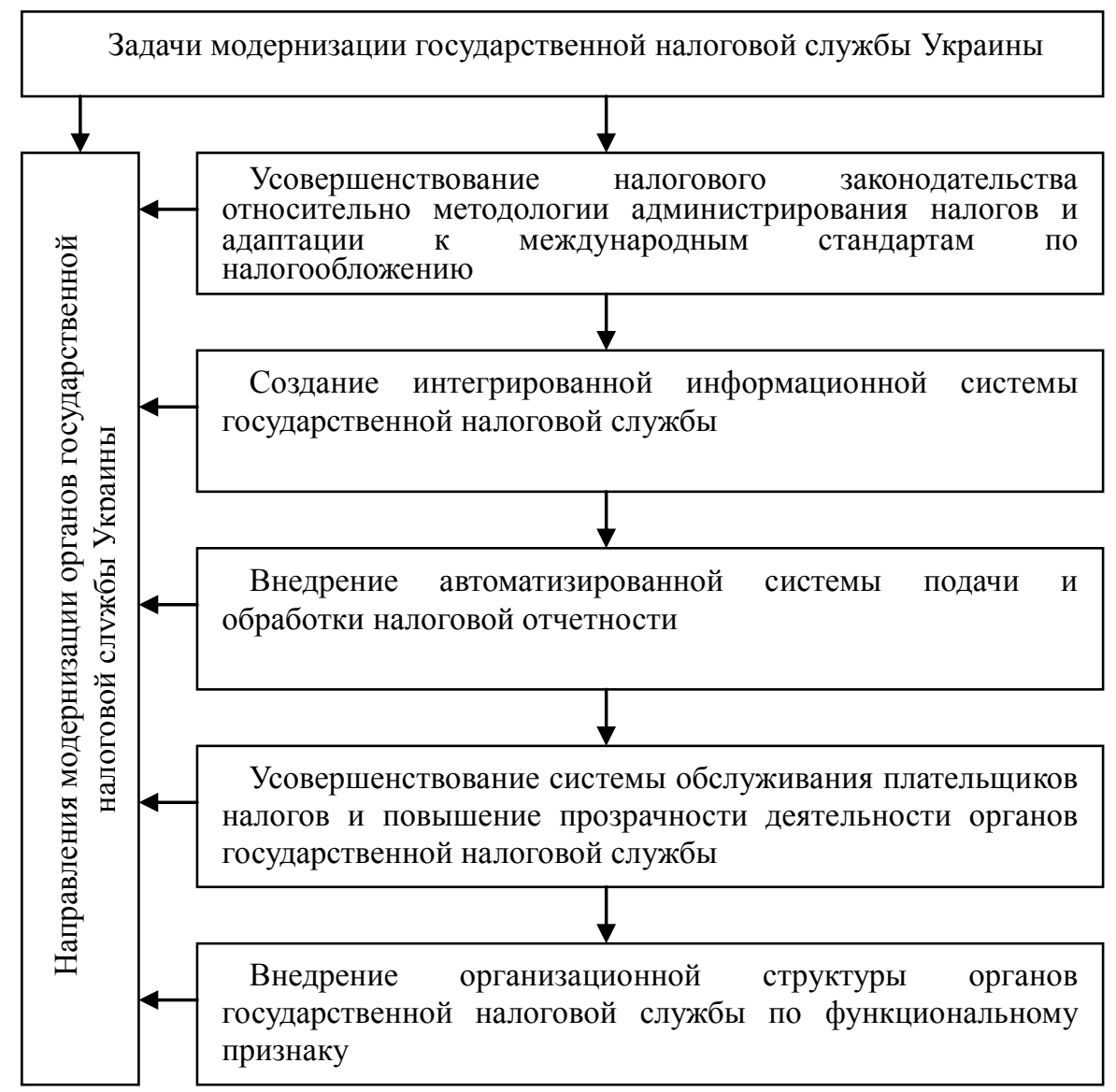

Рисунок 1. Основные задачи и направления модернизащии органов налоговой службьи Украинь

Анализ основных направлений модернизации государственной налоговой службы Украины позволяет сделать вывод, что основные цели реформирования налогового законодательства нашли отражение в Налоговом кодексе Украины:

- повышение конкурентоспособности национальной экономики;

- обеспечение устойчивого экономического развития, формирование человеческого капитала на инновационной и инвестиционной основе при условии увеличения объемов налоговых поступлений в бюджеты всех уровней;

- создание фискальных условий для роста доходов государства;

- дальнейшая демократизация налоговой службы, установление равноправных отношений между плательщиками налогов и налоговыми органами.

Таким образом, принятый в Украине Налоговый Кодекс способствует построению современной, справедливой фискальной политики, обеспечивающей общий характер налогообложения, равенство всех плательщиков налогов перед законом, достижению стратегических целей устойчивого развития экономики страны в соотвествии с программой экономических реформ на 2010-2014 годы.

С целью создания в Украине стабильной налоговой системы, способствующей эффективному функционированию экономики и внедрению прозрачных процедур администрирования налогов, государственная налоговая служба Украины осуществляет работы по созданию интегрированной информационной системы (ИАИС), которая позволяет применять современные технологии процессов управления, сбора, накопления, поиска, обработки, защиты и использования налоговой информации. Исследование также показало, что более качественному обслуживанию плательщиков налогов и повышению эффективности налогового администрирования может способствовать интегрированная автоматизированная информационная система, включающая Интернет - технологии, не смотря на ряд факторов, ограничивающих применение таких технологий в деятельности государственных налоговых органов. Схема предлагаемой ИАИС представлена на рисунке 2. 


\begin{tabular}{|c|c|}
\hline \multirow{6}{*}{ : } & $\begin{array}{c}\text { Корпоративная } \\
\text { информационная сеть органов ГНС Украматизированная }\end{array}$ \\
\hline & $\begin{array}{l}\text { Корпоративный Интернет-портал, как инструмент } \\
\text { продвижения налоговой информации }\end{array}$ \\
\hline & $\begin{array}{l}\text { Автоматизированная система приема, электронной } \\
\text { отчетности, передаваемой в } \\
\text { плательшиками налогов }\end{array}$ \\
\hline & $\begin{array}{c}\text { Система } \text { оперативной } \text { обработки } \\
\text { информации о плательщиках налогов }\end{array}$ \\
\hline & $\begin{array}{ccc}\text { Комплексная система } & \text { защиты } & \text { налоговой } \\
\text { информации и информационно-справочный центр }\end{array}$ \\
\hline & $\begin{array}{l}\text { Система обмена информацией с государственными } \\
\text { комитетами, министерствами и ведомствами }\end{array}$ \\
\hline
\end{tabular}

Рисунок 2. Схема предлагаемой интегрированной автоматизированной информационной системы ГНС Украинь

Таким образом, формирование ИАИС на нынешнем этапе модернизации ГНС Украины позволяет внедрять новые услуги для плательщиков налогов и создавать мощные инструменты для выполнения требований предусмотренных Налоговым Кодексом Украины и другими законодательными актами в сфере налогообложения.

Например, органами государственной налоговой службы на нынешнем этапе модернизации ГНС Украины осуществляется:

- централизация потоков налоговой информации, позволяющая плательщикам налогов получать информацию о состоянии расчетов с бюджетом по персональным счетам в режиме on-line на корпоративном Интернет- портале;

- обеспечение процедуры подачи электронной налоговой отчетности через Интернет в режиме on-line на корпоративном портале и средствами e-mail;

- создание условий для доступа специалистов налоговых органов к автоматизированным базам всесторонней и актуальной информации о плательщиках налогов с целью их отбора для осуществления экономического анализа деятельности и документальных проверок субъектов хозяйствования;

- расширение Интернет - технологий с целью постепенного снижения потребности в персональном общении плательщиков налогов с сотрудниками органов ГНС, что снижает вероятность случаев коррупционных деяний.

Учитывая вышеизложенное, можно сделать вывод о том, что внедрение ИАИС в государственной налоговой службе позволяет реформировать процессы администрирования налогов и в целом продолжить модернизацию налоговой службы Украины, акцентируя внимание на необходимости и целесообразности внедрения в деятельность налоговых органов Интернет - технологий. Более того, практика налогообложения подтверждает, что после введения в действие Налогового Кодекса происходят существенные изменения в процессе администрирования и возмещения НДС поскольку Налоговым Кодексом предусмотрено автоматизированное возмещение этого налога. По данным налоговой службы Украины процесс автоматизированного возмещения НДС становится более динамичным. Например, если в январе 2011 года, сразу же после введения в действие Налогового Кодекса, право на автоматизированное возмещение общегосударственного налога получило только 24 плательщика НДС, то в мае 2011 года по декларациям представленным в налоговые органы за апрель, право на автоматизированное возмещение получили уже 122 плательщика НДС, или в пять раз больше против января. Кроме того по итогам первого полугодия право на автоматизированное возмещение НДС получили плательщики НДС 25 из 27 регионов Украины (Кацан, 2011). Введение инноваций в вопросах возмещения НДС из госбюджета изменило психологию собственников и менеджеров крупного, среднего и малого бизнеса, как плательщиков налогов, убедившихся на собственном примере, что иностранные бизнес партнеры усматривают одним из критериев цивилизованного ведения бизнеса в Украине именно автоматизированное возмещение НДС хозяйствующим субъектам , с которыми они планируют заключать международные соглашения о сотрудничестве.

Введение Налогового Кодекса Украины оказало существенное влияние на организацию контрольно- 
проверочной работы. Благодаря постоянному наращиванию введения Интернет - технологий органы Государственной налоговой службы отошли от планирования документальных проверок по отраслевому принципу. В нынешних условиях активно используется автоматизированная система отбора плательщиков налогов для документальных проверок, благодаря чему в национальный план документальных проверок попадают только те предприятия, которые имеют высокие риски неуплаты налогов. Все это способствует повышению качества и эффективности документальных проверок плательщиков налогов.

Учитывая зарубежный опыт выявления субъектов теневой экономики и использование автоматизированной системы аудита, государственной налоговой службой Украины активно проводятся работы по выявлению плательщиков налогов тяготеющих к участию в схемах уклонения от уплаты налогов. Это положительно сказывается на налоговых поступлениях, выводит экономику из тени и очищает страну от "паразитирующих" структур, зарабатывающих на том, что помогают уклоняться хозяйствующим субъектам от налогообложения.

Таким образом, принятие Налогового Кодекса Украины и изменение принципов фискальной политики послужили мощным толчком к внедрению инновационных Интернет - технологий в деятельность налоговых органов, что способствует повышению эффективности администрирования налогов. Однако очевидным является и то, что необходима дальнейшая перестройка структуры государственной налоговой службы и переориентация сотрудников на новый круг задач.

\section{3 Выводы}

Рассмотрение проблем и перспектив внедрения Интернет - технологий в деятельность Государственной налоговой службы и их роль в повышении эффективности администрирования налогов показало, что государственная налоговая служба Украины обеспечивая более $60 \%$ поступлений налогов в бюджеты всех уровней преобразовалась в один из наиболее мощных органов исполнительной власти, способствующий воплощению в жизнь программы социально-экономического развития страны. Однако, высокий уровень давления на легальный бизнес и на добросовестных плательщиков налогов, большое количество выездных документальных проверок субъектов хозяйствования, обращение в теневом секторе экономики более $16 \%$ денежных средств крупного, среднего и малого бизнеса с объемом валовых доходов свыше 1млн.грн., требуют дальнейшей модернизации налоговой службы Украины, использования современных методов администрирования налогов, укрепления партнерских отношений с плательщиками налогов с целью обеспечения добровольной и своевременной уплаты налогов. Учитывая вышеизложенное целесообразно:

- более активно внедрять Интернет - технологии в деятельность органов налоговой службы, развивая телекоммуникационную и информационную инфраструктуру службы;

- определить основные факторы ограничивающие применение Интернет - технологий в работе национальных предприятий - плательщиков налогов с целью дальнейшего развития партнерских отношений между государством и плательщиками налогов;

- ввести электронный дистанционный налоговый мониторинг с целью раннего выявления субъектов теневой экономики;

- создать на уровне государственной налоговой службы электронный аудит плательщиков налогов, что позволит минимизировать контакты между должностными лицами плательщиков налогов и налоговых органов;

- способствовать ускорению реформирования упрощенной системы налогообложения что позволит, исключить использование механизма налогообложения малого бизнеса для уклонения от уплаты налогов.

\section{Литература}

- Захарченко, 2011. "Налоговый кодекс подытоживает многолетний опыт деятельности налоговой службы". Вестник налоговой службы Украины, 644, с.2-5;

- Державна податкова адміністрація України, 2003. "Про затвердження Стратегічного плану розвитку державної податкової служби на період до 2013", Наказ від 07.04.2003, номер 160,

- $\quad$ http://zakon.nau.ua/doc/?uid=1008.2278.0

- Кацан, 2011. "Быть в перечне предприятий, которым автоматически возмещено НДС- престижно". Вестник налоговой службы Украины, 646, с.11. 


\title{
Меры социальной поддержки молодых специалистов аграрного профиля в Казахстане
}

\author{
Timur Taipov (National Agrarian University, Kazakhstan)
}

\section{Measures of Social Support for Young Agrarian Specialists in Kazakhstan}

\begin{abstract}
The issues of personnel policy in agricultural sector of Kazakhstan have been considered and the reasons causing low level of employment of graduates of agricultural universities, incentives for the return of young professionals to the countryside. Despite the measures taken by the State in the use of labor resources in villages and increasing of employment in rural areas, still there are many weaknesses: incomplete and uneven employment of rural workforce during the year; weak supply of agricultural enterprises with specialists and production personnel with needed skills.

The main factors that can provide the solution of the mentioned problems are: economic conditions: the sustainable development of enterprises of agricultural sector, reasonable wages consistently paid in cash; social conditions of life: housing, culture of rural life, rural infrastructure, availability recreational facilities in the villages; legal: adjustment of existing laws and legislative regulations in the field of labor and social-labor relations in agriculture, taking into account their different characteristics. The development of Program of increasing social support for young professionals in these areas of employment to 2015 is very important, which will allow to implement a mechanism of State support for young professionals and create conditions for active use of long-term housing loans for the solution of housing problem and attracting agricultural specialists in rural areas. Main aims and objectives of the Program, resource supply and mechanisms for its implementation have been described.
\end{abstract}

JEL Codes: Q14, Q19, J43

\section{1 Введение}

В условиях рыночной экономики, когда предприятия являются самостоятельными экономическими субъектами, функционирующими в жесткой конкурентной среде, выдвигаются новые требования к профессиональному составу производственных кадров и специалистов, уровню их квалификации, результативности труда и ответственности.

Все это свидетельствует о том, что в сложившейся ситуации для обеспечения сельскохозяйственного производства квалифицированными кадрами необходимо принятие специальных проектов, реализация которых обеспечит приток в село на добровольной основе молодых специалистов - выпускников профессиональных учебных заведений, повысит их мотивацию жить и работать в сельской местности по полученной специальности.

\section{2 Актуальность}

Кадровый потенциал сельского хозяйства, качество персонала сельхозпредприятий являются важнейшими факторами развития экономики Казахстана. Стратегическая кадровая политика становится одним из ключевых компонентов государственного управления. С каждым годом все более актуальна проблема мобильного резерва аграрных кадров, особенно для отраслей, в которых произошел отток молодых, наиболее высококвалифицированных и инициативных специалистов.

\section{3 Цель}

Показать необходимость социальной поддержки молодых специалистов аграрного профиля в Казахстане и предложить мероприятия для обеспечения сельскохозяйственного производства квалифицированными кадрами.

\section{4 Методы}

Аналитический и экспертные оценки

В аграрной политике Казахстана большое внимание уделяется техническому перевооружению агропромышленного комплекса, внедрению современных технологий в сельскохозяйственное производство, необходимых для увеличения объемов выпуска качественной продукции и сырья, а также 
кадровому потенциалу сельского хозяйства, качеству персонала сельхозпредприятий, которое является важнейшим фактором развития экономики страны.

Цена ошибки в кадровой политике часто бывает достаточно высокой. Уменьшить риски и как следствие повысить результативность аграрного сектора, снизить прямые потери в сфере кадрового обеспечения агропромышленного производства, дать ощутимую отдачу, обеспечить предупреждение и снижение рисков в данной отрасли может действенная социальная поддержка молодых специалистов, получивших сельскохозяйственное образование (Миниханов, и т.д., 2003) .

Аграрная сфера является одним из динамично развивающихся направлений экономики, где создаются наиболее благоприятные условия для трудоустройства молодежи. Однако, несмотря на принятые меры, республика испытывает дефицит кадров. Это прежде всего связано со спецификой отрасли, которая вопервых, остается одной из низкооплачиваемых, во-вторых, социальная инфраструктура сельской местности все еще значительно отстает от городской., в-третьих, условия труда сельских работников более трудоемкие, чем работников других отраслей. Эти причины обуславливают низкий уровень трудоустройства выпускников аграрных специальностей. Еще одна проблема в том, что сфера образования не успевает удовлетворять все потребности.

Для молодых специалистов сельского хозяйства дополнительным стимулом возвращения на работу в сельскую местность служит реализация программы льготного микрокредитования, позволяющая решать проблемы молодых специалистов сельскохозяйственного и ветеринарного профиля, а также предоставлять дополнительные меры по обустройству и получению работы по специальности.

В условиях рыночной экономики, когда предприятия являются самостоятельными экономическими субъектами, функционирующими в жесткой конкурентной среде, выдвигаются новые требования к профессиональному составу производственных кадров и специалистов, уровню их квалификации, результативности труда и ответственности (Кажымурат, 2008).

Кроме того, эти условия продиктованы тем обстоятельством, что предприятия всех форм собственности ориентированы на инвестиционные технологии, которые могут быть быстро и эффективно освоены только технически подготовленным, профессионально грамотным персоналом работников.

Отсюда вытекают тесно взаимосвязанные следующие задачи:

- подготовка специалистов с высшим, средним специальным образованием массовых профессий в количествах, необходимых для обеспечения полной потребности в них предприятий всех форм собственности;

- обеспечение притока молодых специалистов - выпускников профессиональных учебных заведений аграрного профиля в сельскую местность для работы по специальности с последующим их закреплением на производстве.

В стране принят ряд заслуживающих внимания организационно-экономических и нормативноправовых актов, программ и проектов, в которых нашли отражение механизмы реализации этих задач, обеспечивающие повышение эффективности использования сельских трудовых ресурсов, улучшение социальных условий жителей села.

По стране в целом численность экономически активного сельского населения за 2001-2008 гг. увеличилась на 40,3\%, в областях южного региона - до 1,5 раза. Одновременно за эти годы больше стало занятого экономической деятельностью сельского населения - на 52\% в среднем по республике, с колебаниями от 32,5\% в Северном Казахстане до 64,0\% - на юге республики (Баймуратов, 2009).

Позитивную роль сыграли рост объемов сельскохозяйственного производства за счет восстановления посевных площадей сельскохозяйственных культур и поголовья скота, создания и реконструкции на селе предприятий переработки сельхозпродукции, строительства в сельской местности в рамках реализации Государственной программы развития сельских территорий на 2004-2010 гг. объектов социальной сферы.

В сельском хозяйстве низок уровень производительности труда, номинальные денежные доходы на душу сельского населения в 2 раза меньше по сравнению с другими сферами экономической деятельности. Недопустимо упала прежде значимая роль технологов сельскохозяйственного производства: агрономов, специалистов ветеринарной службы, зоотехников, инженеров-механиков, инженеров-электриков, а также технически грамотных кадров среднего звена. Не хватает в сельской местности специалистов высокой квалификации по переработке продукции животноводства и изготовлению готовых к потреблению пищевых продуктов, а также квалифицированных рабочих кадров для обслуживания основных и вспомогательных отраслей сельскохозяйственного производства.

Как следствие низкой мотивации труда редким явлением стал отток на постоянную работу в село лиц, окончивших профессиональные учебные заведения аграрного профиля. В результате средний возраст работников сельхозпредприятий и крестьянских хозяйств в основном составляет 45 лет и выше.

В республике для сельскохозяйственного производства готовится немало нужных специалистов, однако 
многие из них остаются невостребованными в качестве кадровых работников отрасли в соответствии с полученными специальностями. Как показывают исследования, подготовка кадров осуществляется зачастую в отрыве от реальных запросов производства.

В настоящее время в стране реализуется Закон РК от 24 декабря 2008 г. № П1-1У ЗРК «О внесении изменений и дополнений в некоторые законодательные акты по вопросам социальной поддержки и стимулирования работников социальной сферы СНП». Поэтому назревшая проблема социальной поддержки специалистов и квалифицированных рабочих кадров должна решаться в комплексе. Пребывающие в село, выпускники аграрных профессиональных учебных заведений поддерживаются соответствующими компенсациями и субсидиями, другими стимулирующими мерами за счет бюджетных ресурсов.

Механизм формирования и регулирования рынка труда должен постоянно совершенствоваться в соответствии с новыми требованиями все более углубляющегося рыночного метода хозяйствования, структурной перестройкой и институциональными преобразованиями в экономике. При этом следует признать, что приоритетами в развитии аграрного образования является обеспечение его доступности для сельской молодежи, подготовка квалифицированных кадров соответствующего уровня и профиля конкурентоспособных на сельском рынке труда, заинтересованной их работы в сфере сельскохозяйственного производства и смежных с ним отраслях экономики (Днишев, 2007).

Однако, несмотря на принимаемые государством меры в использовании трудовых ресурсов села и рост занятости населения в сельской местности, в данной области еще немало недостатков. К ним в первую очередь относятся:

- неполная и неравномерная в течение года занятость сельских трудовых ресурсов;

- слабая обеспеченность сельхозформирований специалистами и производственными кадрами нужных профессий.

Основными факторами, воздействовав на которые можно решить вышеперечисленные проблемы, являются:

- экономические условия: устойчивое развитие предприятий аграрного сектора, приемлемая заработная плата, стабильно выплачиваемая в денежной форме;

- социальные условия жизнедеятельности: жилищные условия, культура сельского быта, инфраструктура сельской местности, наличие в селах оздоровительных учреждений и т.д.;

- правовые: корректировка существующих законов и законодательно-нормативных актов в области труда и социально-трудовых отношений в сельском хозяйстве, с учетом их особенностей;

Во многих аграрных вузах страны сегодня имеются кафедры, где сосредоточен достаточный научнопрактический потенциал, способный обеспечить качество преподавания сельскохозяйственных дисциплин. Только таким образом преподаватели могут поддерживать интерес к обучению у студентов. Ведь важнейшей характеристикой личности при подготовке квалифицированного, конкурентоспособного специалиста в области сельского хозяйства является устойчивый профессиональный интерес. Такая мера должна заинтересовать молодых предпринимателей в развитии сельского хозяйства в Казахстане, а также создать стимул для студентов-аграрников (Барлыбаева, 2006).

Было бы целесообразным проведение конкурсов «За достижение высоких результатов в сфере устойчивого развития сельских территорий». Цель конкурса - отбор хозяйствующих субъектов агропромышленного комплекса, районов, сельских населенных пунктов, достигших высоких результатов в сфере устойчивого развития сельских территорий. Организатор конкурса - Министерство сельского хозяйства Республики Казахстан. Конкурс должен проводиться по трем номинациям: I - «Высокая социальная ответственность хозяйствующих субъектов агропромышленного комплекса», II «Эффективное управление развитием сельских территорий на муниципальном уровне», III «Формирование комфортной среды жизнеобеспечения в сельских поселениях».

Участниками конкурса могут быть предприятия и индивидуальные предприниматели, занятые в агропромышленном комплексе, крестьянские хозяйства.

Функции конкурсной комиссия включают оценку представленных участниками конкурса материалов на основе следующих показателей:

По I номинации:

- осуществление хозяйствующими субъектами АПК работ по содержанию в надлежащем состоянии объектов социально-инженерной инфраструктуры, расположенных на территории населенного пункта, в котором проживают работники данной организации;

- предоставление социальных гарантий работникам;

- оказание поддержки в обеспечении работников жильем (предоставление займов, строительство 
жилья хозяйственным способом, оказание услуг по предоставлению транспорта и т.п.);

- использование различных форм поощрения работников за достижение высоких показателей в работе;

- $\quad$ проведение работы по привлечению и закреплению молодых специалистов (заключение договоров в рамках целевой контрактной подготовки, вы-плата единовременной материальной помощи на хозяйственное обустройство и др.).

По II номинации:

- $\quad$ наличие утвержденной программы социально-экономического развития района, предусматривающей мероприятия по комплексному развитию сельских территорий;

- результаты участия района в региональных программах развития;

- уровень благоустройства жилищного фонда в сельской местности;

- обеспеченность сельского населения объектами социальной инфраструктуры;

- транспортное обслуживание сельского населения;

- создание условий для обеспечения сельских жителей услугами связи, общественного питания, торгового и бытового обслуживания;

- оказание содействия развитию малого и среднего предпринимательства в сельской местности.

По III номинации:

- уровень благоустройства жилищного фонда в сельском населенном пункте;

- обеспеченность сельского населения объектами социальной инфраструктуры;

- создание условий для обеспечения сельских жителей услугами связи, общественного питания, торгового и бытового обслуживания.

В настоящее время важнейшей задачей является преодоление отставания села от города по уровню и условиям жизни. При этом отток молодых специалистов сельскохозяйственной и ветеринарной специальностей приводит к сворачиванию необходимой для нормальной жизни инфраструктуры и сокращению в сельской местности квалифицированных специалистов всех специальностей.

В связи с этим чрезвычайно важным является разработка Программы повышения социальной поддержки молодых специалистов этих сфер занятости до 2015 года, которая позволит реализовать механизм государственной поддержки молодых специалистов и обеспечит создание условий для активного использования системы долгосрочного жилищного кредитования для решении жилищной проблемы и закрепления аграрных кадров на селе.

Основными целями и задачами Программы должны стать:

- бюджетная поддержка молодых специалистов путем предоставления социальной выплаты для частичной оплаты приобретения жилья, или строительства индивидуального жилья;

- финансирование программы за счет средств республиканского и местного бюджетов;

- нуждаемость молодых специалистов в улучшении жилищных условий в соответствии с действующим законодательством;

- намерение молодого специалиста работать в предприятиях агропромышленного комплекса или в социальной сфере;

- расчет размера социальной выплаты на основе $30 \%$ рыночной стоимости жилья;

- $\quad$ предоставление дополнительных мер государственной поддержки семьям молодых специалистов в случае рождения детей;

- $\quad$ требование платежеспособности участника.

Основными источниками финансирования Программы являются средства республиканского, областного и районного бюджетов, участников Программы, используемые для частичной оплаты стоимости приобретения жилья или строительства индивидуального жилья, кредитных организаций для кредитования участников Программы, предприятий - работодателей, заинтересованных в привлечении и закреплении квалифицированных трудовых ресурсов.

Механизм реализации Программы основан на предоставлении субсидий предприятиям для их последующего предоставления молодым специалистам, работающим в сельской местности данного района.

Размер первоначального взноса должен составлять не менее $10 \%$ фактической стоимости жилья.

Мониторинг выполнения Программы, текущее управление и оперативный контроль за ее реализацией осуществляет Департамент сельского хозяйства области. Реализация Программы обеспечит увеличение объемов жилищного строительства на селе, объектов социальной инфраструктуры, будет способствовать 
привлечению и закреплению сельскохозяйственных кадров в сельской местности, следовательно развитию агропромышленного производства, предупредит и снизит рисковые ситуации в данной отрасли.

\section{5 Выводы:}

В целях совершенствования системы государственного заказа и целевой подготовки кадров для сельского хозяйства, создания условий для закрепления специалистов в сельскохозяйственном производстве необходима скорейшая реализация мероприятий, направленных на удовлетворение потребностей агропромышленного комплекса республики в квалифицированных кадрах и научнотехническое обеспечение агропромышленного производства, их трудоустройство и закрепление на селе.

Проблема социальной поддержки специалистов и квалифицированных рабочих кадров должна решаться в комплексе. Пребывающие в село, выпускники аграрных профессиональных учебных заведений должны поддерживаться соответствующими компенсациями и субсидиями, другими стимулирующими мерами за счет бюджетных ресурсов.

Назрела необходимость разработки долгосрочной программы «Кадровое обеспечение агропромышленного комплекса на 2011-2015 гг.», цель которой - формирование кадрового потенциала, способного обеспечить эффективное функционирование агропромышленного комплекса республики в современных условиях на основе соответствующей требованиям рыночной экономики системы подбора, подготовки и использования кадров.

\section{Литература}

- Миниханов Р.Н.,Алексеев В.В., Файзрахманов Д.И., Сагдиев М.А., 2003. Инновационный менеджмент в АПК. МСХ. Москва.

- Кажымурат К., 2008. Избранные научные труды. Қазақ даму институты Қазақ даму институты. Алматы.

- Баймуратов У., 2009. Национальная экономическая система. Ғылым. Алматы.

- Днишев Ф.М., 2007. Научно-техническое развитие в условиях становления национальных производительных сил: стратегия и механизм. Ғылым. Алматы.

- Барлыбаева Н.А., 2006. Национальная инвестиционная система Казахстана. НЦ НТИ РК. Алматы. 


\title{
Strategies for Tourism Industry under the Global Economic Crisis: A Swot Analysis of Turkish Tourism
}

\author{
Orhan Akova (Istanbul University, Turkey) \\ Mehmet Sarışık (Sakarya University, Turkey) \\ Dilek Dönmez (Çanakkale 18 Mart University, Turkey)
}

\begin{abstract}
This paper outlines the relations between the global economic crisis around the world and tourism and analyzes related strategies of Turkish tourism against them by conducting a qualitative view. It notes the growing importance of economic crisis for the tourism industry and its affects on Turkish tourism. The paper also tries to point out important strategies for Turkish tourism related to global economic crisis-especially the one that affected the whole world in the 2008 the global financial crisis will be held.

Turkish tourism has not been affected as much as its competitors as global economic crisis affected during the last crisis term. While in most countries around the world tourist arrivals have been declined, Turkey has received a higher rate in tourist arrivals since the global economic crisis started. Although tourist arrivals have been arose, the tourism revenues have been declined in the year of 2009 and 2010 according to previous years. In this paper it is going to be analyzed the conditions and related strategies of Turkish tourism against global economic crisis. In order to assess all industrial conditions, Turkish Tourism has been taken in hand in SWOT view. Depending upon SWOT outputs some relevant strategies will be discussed for the Turkish future policies about tourism industry.
\end{abstract}

JEL codes: G01, F01

\section{Introduction}

Natural disasters and crises are neither rare nor new phenomena but in recent years they have achieved considerable prominence largely because of the globalization of business and international communications (Sausmarez, 2004). The world is becoming more interdependent and connected so that small-scale crises in one part of the world can have a significant impact on other parts of the world. Political instability, economic recession, disasters, terrorist attacks or the outbreak of war in one part of the world can dramatically reduce tourist travel patterns to other parts of the world. Tourism is therefore highly susceptible to external factors and pressures in the wider operating environment (Ritchie, 2004). World economy faces an unprecedented crisis, triggering one of the most severe recessions in generations. The world's GDP is forecast to decline by some $1.4 \%$ in 2009, according to the International Monetary Fund (IMF, July 2009), the exports have been dramatically reduced and all advanced economies are in recession (WTO,2009). Global tourism has been severely affected by the current financial and economic downturn. According to the United Nations World Tourism Organization (UNWTO) data, international tourism started to decline during the second semester of 2008, (Papatheodorou et,al, 2010) Tourism, though resisting better than some sectors, has become one of the latest sectors to feel the effects of the global recession. Markets started to deteriorate by mid 2008. UNWTO market monitoring indicates that the plummeting results of international tourism during the last part of 2008 have continued during the first months of 2009 (WTO, 2009). Moreover, while financial institutions around the world confirm the intensity of the crisis through various indicators, the negative trend in international tourist arrivals intensified during the first semester of 2009 in line with the prevailing financial situation (Papatheodorou et.al, 2010). Despite this fragility, few countries appear to make any advance preparations or provision for their tourism sectors in anticipation of a crisis. Instead, they tend to wait until after the event before starting to consider what action to take (Sausmarez, 2004).

Tourism industry has direct and indirect impacts on both developed and developing countries economies. if any crisis arise the repercussions extend beyond activities directly associated with tourism (notably, airlines, hotels, and catering), to those supplying intermediate or final goods purchased by firms and employees in the industry, so that all sectors of the economy are affected to a greater or lesser extent. Governments then need to implement a range of policies to offset the crisis. Goverments are also faced with the difficult decision of what, if any, measures to take, particularly since the implementation of many measures is costly and their relative effectiveness varies. Policymakers need to evaluate the relative merits of alternative responses and consider the combination of policies to cope with the crisis (Blake and Sinclair, 2003). That means that policymakers should analyse the environment constantly and should predict the following crisis so that the tourism industry is ready for any crisis that could occur any where in the world.

Turkish tourism has not been affected as much as its competitors as global economic crisis affected during the last crisis term. While in most countries around the world tourist arrivals have been declined, Turkey has 
received a higher rate in tourist arrivals since the global economic crisis started. Although tourist arrivals have been arrised, the tourism revenues have been declined in the year of 2009 and 2010 according to previous years. In this paper it is going to be analysed the conditions and related strategies of Turkish tourism against global economic crisis by conducting a qualitative view. In order to assess all industrial conditions, Turkish Tourism has been taken in hand in SWOT view. Depending upon SWOT outputs some relevant strategies will be discussed.

\section{The Literature Review of Crisis and Global Economic Crisis and its Effect on Tourism Industry}

Undoubtedly, the tourism industry is one of the most susceptible and vulnerable industries to crises. (Santana, 2004) However the literature on crisis and related strategies for tourism industry under the global economic crisis in tourism is limited. These studies that have published have mainly examined the impact of specific crises on a tourist destination or region and a country (Lee et.al., 1996; Henderson, 1999; Faulkner, 2001; Hope \& Klemm, 2001; Pizam and Fleischer 2002; Huang and Min 2002; Blake and Sinclair 2003; Taylor and Enz 2002, Coles, 2003; Okumuş and Karamustafa 2005, Okumuş et.al.2005; Lim and McAleer, 2005; Anderson, 2006; Athanasopoulos and Hyndman, 2008; Chu, 2008). The study by Taylor and Enz (2002) reveals that the tragic events of September 11 in the United States affected hotel segments in different ways; for example, high-priced hotels experienced a greater decline in business than budget ones. Upscale hotels relied on marketing strategies to attract new customers, while budget ones offered discounts. The manner in which governments respond to shocks in the tourism industry is important, as it may influence the rate of recovery of the industry (Prideaux, et.al., 2003). After September 11, the US government passed a \$15 billion relief package that helped its faltering tourism industry recover, and this saved many businesses from bankruptcy. Blake and Sinclair (2003) claim that if there had been no such relief package, the US industry would have suffered from the terrorist attacks much more than it did. Blake and Sinclair (2003) studied the low season of the US tourism industry after the September 11 attacks, and found that tax reductions were the most efficient way to handle the crisis. The immediate government responses to the September attacks included law enforcement activity, disaster relief, and security measures. Eleven days after the attacks, Congress passed the Air Transportation Safety and System Stabilization Act, to "preserve the continued viability of the United States air transportation system". This Act provided federal credit to airlines totaling $\$ 10 \mathrm{bn}$; compensation to airlines totaling $\$ 5 \mathrm{bn}$; compensation for airlines facing increased insurance premiums; limitation of the extent of liability by airlines for the results of terrorist acts; allowances for airlines to make late payment of excise taxes; compensation for individuals killed or injured in the September attacks; and spending of \$3bn on airline safety. (Blake and Sinclair, 2003). Chu (2008) used the Asian financial crisis and the September 11 attacks as examples of economic and political blows, and analysed the accuracy of using a fractionally integrated ARMA model to predict tourism and make comparisons. Pizam and Fleischer (2002) showed that, between May 1991 and May 2001, tourism demand in Israel was highly dependent upon the frequency of terrorist activities. Terrorist attacks resulted in a drastic reduction of international tourists arriving in Israel. According to Mansfield (1999), the Israeli government often failed to give support to tourism organizations during and after several crises. Henderson (1999) reports that the results of a survey of leading tourist attractions in Singapore investigating the consequences of the Asian financial crisis indicated that there was no crisis management planning and that there was a need for such planning in the light of the nature of the travel and tourism industry, with its exposure to risk and disaster. By contrast, Coles (2003) reports that in the case of the Food and Mouth Disease in the United Kingdom, regional tourism offices in the southwestern part of England where the disease had broken out sponsored marketing strategies that helped the region overcome the negative impacts of the crises. On the other hand there are many studies that emphasize that the impact of crisis events on the demand for tourism was not as large as expected. For example, Lee, Var, and Blaine (1996) indicated that the oil crisis and the 1988 Olympics did not significantly influence inbound tourism in South Korea. Athanasopoulos and Hyndman (2008) examined the influence of the Sydney 2000 Olympics and the bomb blast in Bali in 2000 on domestic tourism demand in Australia, and found that Sydney 2000 promoted an immediate demand in business travel, whereas the number of visitors meeting friends and relatives increased significantly after the blast in Bali. Huang and Min (2002) examined the impact of the 21st September 1999 earthquake in Taiwan, and found that the recovery period exceeded 11 months, with restricted growth of inbound tourist arrival. According to de Sausmarez (2003), marketing strategies supported by the government of Malaysia, helped to increase domestic and inbound tourism in the aftermath of the Asian financial turmoil. Lim and McAleer (2005) examined how two financial crises, the stock market crash in 1987 and the Asian financial crisis in 1997, affected Japanese tourists traveling to Australia from 1976 to 2000. According to Okumuş and Karamustafa (2005) the economic crisis in the year 2001 neither tourism firms nor the government could foresee the event and therefore failed to make advance preparations. The crisis was responded to with reactive and adhoc measures at the organizational, regional, and national levels. It is worth noting that the industry faced this crisis (and several previous ones) but could not respond to it well because of major shortcomings in the governance. (Okumus and Karamustafa 2005; Buultjens \& Howard, 2001). A study involving registered club managers in New South Wales indicated that the most important areas of flexibility were work-time, functional 
and numerical flexibility (Buultjens \& Howard, 2001). They report the results of a survey of small businesses in Pennsylvania and New York, which indicated from the 162 responses, that little emphasis had been placed on crisis planning in these businesses, the majority of which had less than 25 employees. The study also concluded that 'concern for crises was generated from the past experience of those crises...' (Spillan and Hough, 2003). Okumus et al. (2005) investigated the impact of the economic crisis in February 2001 in Turkey on tourism in northern Cyprus, and found that a majority of the industry players in northern Cyprus failed to predict a financial crisis or take any preventive measures. The few reports that have investigated the impact of natural disasters and financial crisis on tourism have determined that they do significantly affect the tourism industry (Chu, 2008; Huang and Min, 2002; Lim and McAleer, 2005; Okumus et al., 2005; Pizam and Fleischer, 2002 and Prideaux and Witt, 2000). The impact of a major disaster and aconomic crisis are so immense that the production value of the tourism industry can fall dramatically; however, the industry has always managed to resume or exceed its former production values within a period of just one or two years. Such a phenomenon is worth investigating so that the public may learn from past problems and develop prevention and improvement measures (Wang 2009).To cope with a crisis it is neccesary for the goverments to have action plans before the crisis started and have to analize the environment periodically so that they can take some measures. The policies for the crisis should be prepared by all part of tourism sector and organisations. It is also important to ensure that in the rush to return to the 'status quo', valuable lessons are not forgotten which would help guide responses to the next crisis which will inevitably occur. Faulkner (2001) suggests that good management means having strategies for coping with unexpected events over which organisations have no control (Anderson, 2006). To provide a deep insight into this complex environment, it is necessary to perform more studies on how tourism organizations respond to and cope with crises. In most of these cases, where governments have actually recognized the importance of the tourism downturn and acknowledged the need for a policy response, they have operated in an environment where very little research into the merits of offsetting policy responses has been conducted ( Wang, 2009).

\section{Related Strategies For Tourism Industry in Crisis}

Crisis is a "disruption that physically affects a system as a whole and threatens its basic assumptions, its subjective sense of self, its existential core ( Pauchant and Mitroff, 1992). There are different categories of crises, including ecological, financial, regional, and global. Even if they are categorized under different names, important similarities exist among them, and one type can lead to other types (Okumuş and Karamustafa 2005; Kovoor-Misra, Clair and Bettenhausen 2001; Richardson 1994)The sub-prime mortgage crisis in the U.S. was the prelude to a financial and economic crisis the effect which have been felt all around the world. The effects was so strong to whose financial sectors had been highly internationalized and whose economies were closely linked to the U.S. were particularly badly effected. As regards the measures adopted by many countries response to the global financial crisis, has relied heavily on monetary and fiscal policy to cope with the impact of the crisis. They have adopted a relaxed monetary policy and cut interest rates so as to boost bank liquidity.and they tried to stimulate consumer spending, help small and medium enterprises to secure funding, promoting investment, and boosting exports. The main measures adopted to boost consumer spending included programs to encourage consumers to replace old appliances and other consumer durables with new, low-energy-consumption, environmentally-friendly appliances. Absence of some form of crisis srategies perhaps reflects the fatal mistake made by many businesses that a crisis will not happen to them (Wang, 2010).

Tourism crisis is defined as: . . . any occurrence which can threaten the normal operation and conduct of tourism-related businesses; damage a tourist destination's overall reputation for safety, attractiveness, and comfort by negatively affecting visitor's perception of that destination; and, in turn, cause a downturn in the local travel and tourism economy, and interrupt the continuity of business operations for the local travel and tourism industry, by the reduction of tourist arrivals and expenditures. Each crisis situation is unique and difficult to resolve with simple formulas. (Sonmez et al, 1999). The strategies for crisis that can effect tourism can be catogorized in two ways one which the goverments should handle the other the tourism firms should handle. First both sides should have an action plan before crisis. Goverments should respond to shocks in the tourism industry so that it may influence the rate of recovery of the industry. The strategies that goverment can apply for the tourism firms and related sectors are ; tax reductions, compensation to tourism firms and related sectors, increased insurance premiums; limitation of the extent of liability by tourism firms and related industries for the results of global economic crisis; allowances to make late payment of excise taxes and compensation to employees. Governments can pass relief package that can help faltering tourism industry recover, and so can save many businesses from bankruptcy. Goverments can also be one of the big sponsore for marketing strategies that can help the country overcome the negative impacts of the crises. The strategies that can tourism firms apply are ; for example upscale hotels can rely on marketing strategies to attract new customers, while budget ones can offer discounts. The Tourism firms can adjust work-time, functional and numerical flexibility as mentioned above. Tourism firms can also promote themself to new markets and can change their marketing strategies according to domestic and global market. 


\section{Strategies for Strengthening Turkish Tourism Sector}

According to Okumus and Karamustafa (2005) the economic crisis in the year 2001 neither tourism firms nor the government could foresee the event and therefore failed to make advance preparations. Although Turkey has become one of the ten leading destination in the world. Again in the year 2008 neither tourism firms nor the government could foresee the event and therefore failed to make advance preparations. But in 2007 goverment declareted 2023 strategic action plan. This plan helped Turkey to find the way for the right strategies. In the years of the crisis the goverment supported domestic tourism by the 2023 strategy so Ministry of Culture and Tourism, Turkish Hotelier Federation, Turkish Travel Agency Association and Turkish Airlines worked together to stimulate domestic tourism by advance booking program so that local people can reach tourism product as cheap as the foreign tourist so that the hotel occupancy rates could get a higher level and the hotelier could cope with the global financial crisis. This program also included payment facilities, transportation and accomodation discounts. All inclusive tours also attracted foreign tourist as a main marketing tool to Turkey for the tourist who want to know how much money he can spent for vocation. Tourist profile has changed. In 2009 the number of tourist coming from Middle East countries increased about \%21-\%50 because of Turkish politics against İsrail and Turkish TV series broadcasting in these conutries make Turkey popular destination for Arap tourists. Turkish goverment invested on new tourism products such as culture, health, education, younth, nature, belief, yachting, golf, winter and convention tourism ect.. Price-and quality has balanced according to privious years. Turkey invested new destinations. Turkish destinations are new and undiscovered correpending its competitors. Turkish hotels age are younger than France, Spain, Greece and other Mediterenian Contries. For example avarage hotel age in Turkey is 6- 6.5 years while in france 24, in Italy 27 in spain 30 and in Greece 21 This make Turkish hotels much modern and qualified than the others. Turkey is also close destination for european tourists. This is an advantage for the tourist who want to stay long and pay less. Support from big European tour operators (for example TUI and Thomas Cook) helped Turkey to receive more tourists from western Europa (http://www.euractiv.com.tr). While the number of tourist visiting to Turkey from Middle East increased the number of tourist visiting Turkey from Europe and America is declined (http://www.turofed.org.tr/). Turkey also started to receive more tourist from Russia, Bulgaria, Georgia, Azerbajan and Iran and The tourist comig from OECD countries are declined.(http:/www.patronturk.com/turizm-sektorunde-son-durum). Goverment also compenseted employees and the tourism firms by late payment of excise taxes and labour tax compensetion to the tourist firms that effected by the economic crisis. On the other hand Turkey received much more tourist than previous years because of the changing profile of tourist conbinations. So the crisis was responded to with reactive and ad-hoc measures at the organizational, regional, and national levels. But 2023 action plan helped tourism firms and goverment to find the right strategies for the tourism industry. This action plan is given below. Countries in which tourism industry has a big importance have developed action plans to ensure development is working with the sectors concerned. Turkey has established action plan for tourism in 2023. The Ministry of Culture \& Tourism has issued Turkey's 2023 Tourism Strategy with the intention of guiding the tourism industry in production management and implementation phases, by creating a roadmap for the sector. According to this plan and introduced measures in the basic findings are as follows (www.turizm.gov.tr, 2011). Table-1 shows strategies for strengthening the tourism sector generated by the Culture and Tourism Ministry (2011). 


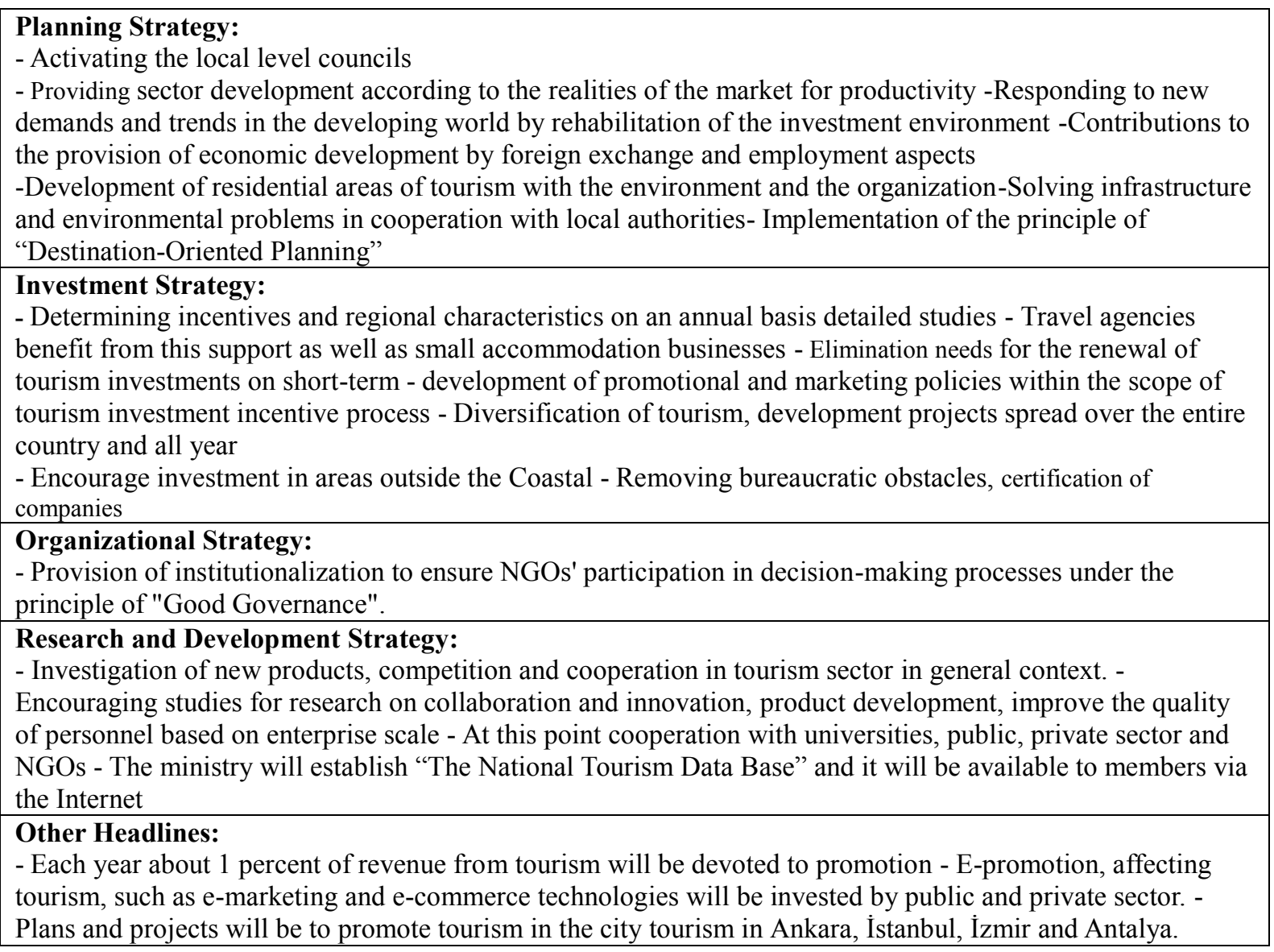

Table 1. Strategies for the Tourism Sector in Turkey

\section{A Swot Analysis of Turkish Tourism}

Tourism is an important sector for the Turkish economy and Turkey is one of the world's fastest growing tourism markets. The number of foreign tourists visiting Turkey swelled 17.8 fold in the past three decades, from 1.523 million in 1980 to a record 27.077 million in 2010, according to the Turkish Statistics Institute. In 2009, the country had $3.34 \%$ share in the global tourism market share, up from $2.7 \%$ in 2005 . By 2013 , Turkey aims to attract 38 million tourists annually and earn 34.4 billion a year from tourism, according the State Planning Organization's Ninth Five Year Development Plan (Turkish Statistics Institute, 2009). Statistics related to the year 2010 and expectations in 2011 are as follows (TUROFED, 2011):

1. Turkey expecting 31 million tourists and earn 25 billion during 2011 .

2. Turkey hosted $28,632.204$ tourists in 2010 . The number of tourists Istanbul city hosted in 2010 decreased 7.31 percent when compared to 2009.

3. World Tourism Organization (WTO) envisaged a four percent rise in the number of tourists, and a five percent increase in tourism expenses.

4. According to WTO figures, Turkey ranked the 7th in the number of tourists, and 9th in tourism incomes among top ten countries in the world.

5. Number of passengers, who used 46 airports across Turkey, increased 20.1 percent to 103 million in 2010, adding that their target was 125 million passengers in 2011. SWOT analysis was carried out for Turkish tourism and the results are summarised as follows (Akça, 2006; Karadeniz, Kandır ve Önal, 2007; Gürkan, 2009; Turkish Tourism Industry Report, 2010; ): 


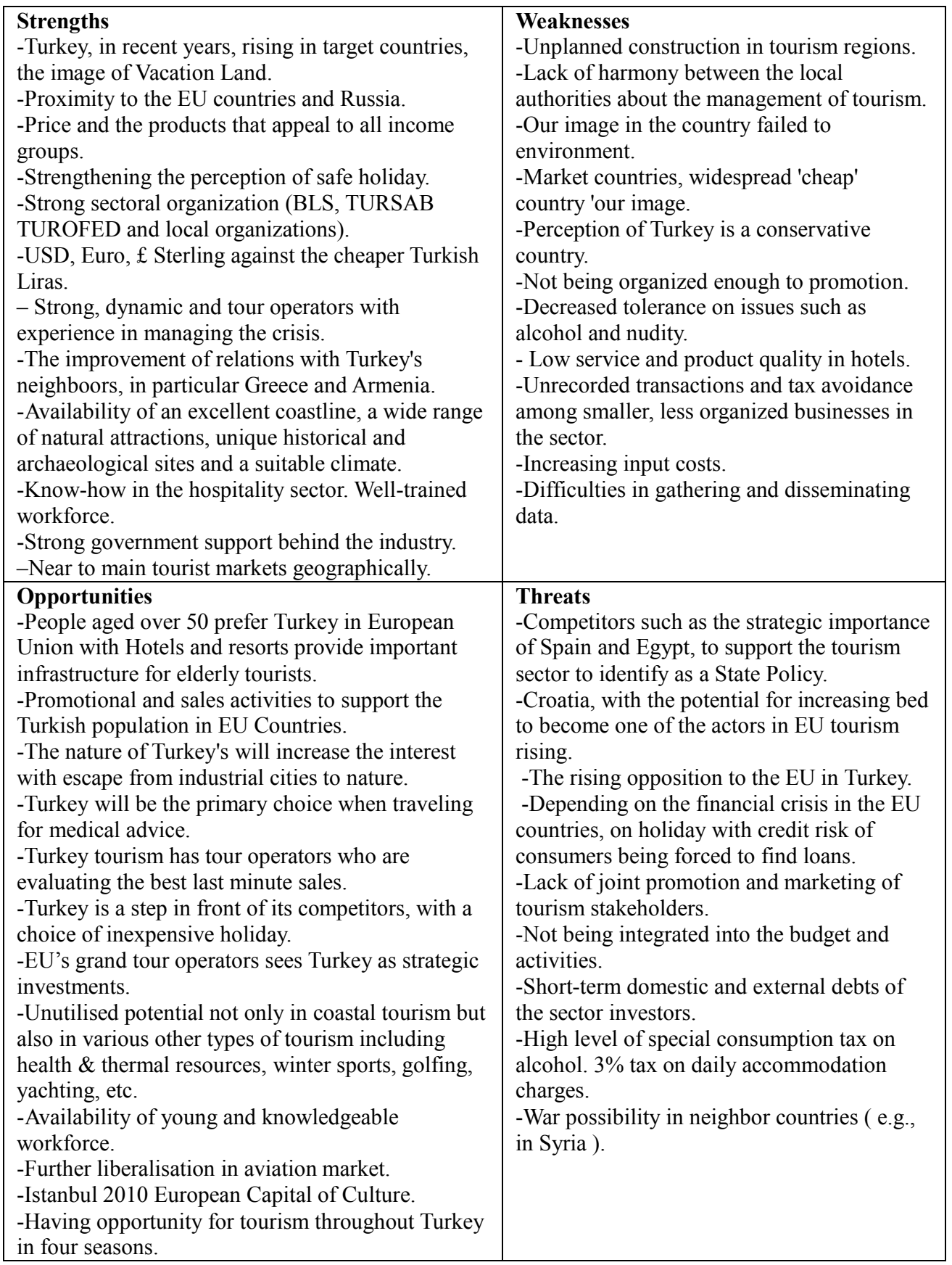

Table 2: A Swot Analysis of Turkish Tourism

As seen in Table 2, Turkey has the strengths of the industry that are able to meet the demands of tourists as like safe holiday image, strong sectoral organization, good relations with neighboors, natural and historical attractions, well-trained workforce. Turkish tourism sector can evaluate and use all these components to have strategic advantage.

Turkish tourism industry also has weaknesses and this includes the following - unplanned construction, lack of harmony between the local authorities about the management of tourism, low service and product quality, increasing input costs, 'cheap' country ' image. For success of Turkey tourism, these weaknesses must be solved urgently.

Turkey has also opportunities about tourism industry. Table-2 shows also these opportunities. These are; important infrastructure for elderly tourists, the primary choice when traveling for medical advice, good image for EU's grand tour operators, young and knowledgeable workforce, a choice of inexpensive holiday. If Turkish tourism sector can use these opportunities strategically, it can be succesfull.

If there are opportunities, there are threats. Danger and threats are the factors that affect both Turkey and the tourism sector negatively. Some of them are: competitors such as Spain and Egypt, the rising opposition to the EU, Lack of cooperation among tourism stakeholders, debts of the sector investors, ratio of taxes, war possibility 
in neighbor countries. For competitive advantages in tourism industry, Turkey must analyse all these points, and must manage tourism industy strategically.

\section{Conclusions}

Tourism is increasingly making big contribution to national economies, particularly in developing countries like Turkey. Tourism has been one of the fastest growing industries. In addition, tourism has also a significant potential to change and influence the natural and cultural resources in a number of regions. Tourism is an industry that can be affected by external factors easily and quickly such as politics, wars, diseases, global economic crises and etc. Therefore, the tourism product developers and supply side of countries should organize plans and strategies to provide best tourism product for tourists in times of crisis. Tourism product developers and supply side have to understand that tourism have sensitive characteristics to external factors.

This paper triedto analyse the affect on the tourism industry by the global economic crises and what new strategies emerge during this situation with the SWOT analysis. Economists and tourism industry experts take into consideration the past economic global crises to get lessons from the past. In case of crisis, it has been understood that tourism will not stop but will flow in a different situation. There will be a change in the travelling and holiday behavior of the people and therefore the tourism businesses have to adopt a different strategies to survive in case of crisis. Crisis wil always be a risk for all tourist attracted countries and for all tourism firms so this means that we all have to be ready and have an action plan and strategies for the potential crisis and most of times this action plans and stretegies need to be flexible and need to be adaptable for new strategies.

Analysis and suggestions in this paper are making contribution but there are no success stories as example and detailed information about how to deal with global economic crisis. But based on the results of this study and the realities of today's tourism marketplace, the following recommendations are put forth.

Firstly, during the global economic crisis, "price" of tourism products and services has become very important factor. So pricing strategies are needed but it should be noted that the tourist is looking for quality and experience and is also willing to pay more for this. The supply side should be sensitive and flexible because they have to compete on the market and should be able to respond on new trends that keep rising especially due to the global economic crisis. Secondly, it can be identified some main ways out of the crisis. These are; intelligent pricing, cooperation between stakeholders, positioning and differentiation of tourism products, innovation and technology as with all other sectors. When SWOT analysis is examined, Turkey may be strong enough to manage these ways. Then, under a plan, the Turkish government is taking steps to protect the tourism industry in the face of global economic crisis with plan of "Turkey's 2023 Tourism Strategy". On the other hand, Turkish government and tourism authorities should almost certainly require some revisions to think and act strategically. This will make the strategies adabtable and it wil be easy to cope with the new crisis. Further researches should analyse the effects of crisis on hotels, tourism employees, and related sectors and it is necessary to research what they did and what they will do for the next crisis.

\section{References}

- Akça, 2006. “Assesment of Rural Tourism in Turkey Using SWOT Analysis”, Journal of Applied Sciences, 6 (13), pp.2837-2839.

- Anderson, 2006. "Crisis management in the Australian Tourism Industry: Preparedness", Personnel and Tourism Management, 27(6), pp.1290-1297.

- Athanasopoulos and Hyndman, 2008. "Modelling and Forecasting Australian Domestic Tourism", Tourism Management, 29 (1), pp.19-31.

- Blake and Sinclair, 2003. "Tourism Crisis Management: US Response to September 11", Annals of Tourism Research, 30 (4), pp. 813-832.

- Buultjens and Howard, 2001. "Labour Flexibility in the Hospitality Industry: Questioning the Relevance of Deregulation”, International Journal of Contemporary Hospitality Management, 13 (2), pp.60-69.

- Chu, 2008. "A Fractionally Integrated Autoregressive Moving Average Approach to Forecasting Tourism Demand", Tourism Management, 29 (1). pp.79-88.

- Coles, 2003. "A Local Reading of a Global Disaster: Some Lessons on Tourism Management from an Annus Horribilis in South West England", Journal of Travel and Tourism Marketing, 15(2/3,4), pp.173-197.

- Gürkan, 2009. "A SWOT Analysis for 2009", http://www.turizmdebusabah.com/haber_detay.asp?haberNo=44183 (Available:28.04.2011).

- Henderson, 1999. "Managing the Asian Financial Crisis: Tourist Attractions in Singapore", Journal of Travel Research, 38(2), pp. 177-181.

- Hope and Klemm, 2001. "Tourism in Difficult Areas Revisited: The Case Of Bradford", Tourism Management, 22 (4), pp. 629-655.

- Huang and Min, 2002. "Earthquake Devastation and Recovery in Tourism: the Taiwan Case", Tourism 
Management, 23 (2), pp. 145-154.

- IMF, 2009. "World Economic Outlook Update Contractionary Forces Receding But Weak Recovery Ahead", www.imf.org, (Available: 08.07.2009).

- Karadeniz, Kandır ve Önal, 2007. "Seçilmiş Paydaşların SWOT Yöntemiyle Türk Turizm Yatırımlarını Değerlendirmesine Yönelik Bir Pilot Çalışma”, Anatolia: Turizm Araştırmaları Dergisi, 18 (2), Güz: pp.195-205.

- Kovoor-Misra, Clair, and Bettenhausen, 2001. "Clarifying the Attributes of Organizational Crises", Technological Forecasting and Social Change, 67 pp.77-91.

- Lee, Var and Blaine, 1996. "Determinants of Inbound Tourist Expenditures", Annals of Tourism Research, 23 (3), pp. 527-542.

- Lim and McAleer, 2005. "Analysing the Behavioral Trends in Tourist Arrivals from Japan to Australia", Journal of Travel Research, 43, pp. 414-421.

- Mansfield, 1999. "Cycles of War, Terror, and Peace: Determinants and Management of Crisis and Recovery of the Israeli Tourism Industry”, Journal of Travel Research 38(1), pp.30-36.

- Okumus, Altinay and Arasli, 2005. "The Impact of Turkey's Economic Crisis of February 2001 on the Tourism Industry in Northern Cyprus", Tourism Management, 26, pp.95-104.

- Okumus and Karamustafa, 2005. "Impact of an Economic Crisis Evidence From Turkey", Annals of Tourism Research, 32(4), pp. 942-961.

- Papatheodorou, Rosselló, and Xiao, 2010, “Global Economic Crisis and Tourism: Consequences and Perspectives” Journal of Travel Research, 49(1), pp. 39-45.

- Pauchant and Mitroff 1992. Transforming the Crisis-Prone Organization: Preventing Individual, Organizational, and Environmental Tragedies Jossey- Bass Publishers, San Francisco, CA.

- Pizam and Fleischer, 2002. "Severity Versus Frequency of Acts of Terrorism: Which has a Larger Impact on Tourism Demand?", Journal of Travel Research 40, pp. 337-339.

- Prideaux,. Laws and Faulkner 2003. "Events in Indonesia: Exploring the Limits to Formal Tourism Trends Forecasting Methods in Complex Crisis Situations", Tourism Management, 24, pp.475-487.

- Prideaux and Witt, 2000. "The impact of the Asian financial crisis on Australian Tourism", Asia Pacific Journal of Tourism Research, 5 (1), pp 1-7.

- Richardson, 1994. "Crisis Management and Management Strategy: Time to "Loop the Loop"? ", Disaster Prevention and Management, 3(3), pp.59-80.

- $\quad$ Ritchie, 2004. "Chaos, Crises and Disasters: A Strategic Approach to Crisis Management in the Tourism Industry”, Tourism Management, 25 (6), pp. 669-683.

- Sausmarez, 2003. "Malaysia's Response to the Asian Financial Crisis: Implications for Tourism and Sectoral Crisis Management”, Journal of Travel and Tourism Marketing, 15(4), pp.217-231.

- Sausmarez, 2004. "Crisis Management for the Tourism Sector:Preliminary Considerations in Policy Development”, Tourism and Hospitality Planning \& Development, 1(2), pp.157-172.

- Santana, 2004. "Crisis Management and Tourism”, Journal of Travel \& Tourism Marketing, 15(4), pp.299 -321 .

- Spillan and Hough, 2003. "Crisis Planning in Small Businesses: Importance, Impetus and Indifference”, European Management Journal 21(3), pp.398-407.

- Sonmez, Apostolopoulos and Tarlow, 1999. Tourism in Crisis: Managing the Effects of Terrorism”, Journal of Travel Research. 38 (1), pp.13-18.

- Taylor and Enz, 2002. "Voices from the Field GMs' Responses to the Events of September 11 2001", Cornell Hotel and Restaurant Administration Quarterly 43 (1), pp. 7-20.

- Turkish Tourism Industry Report, 2010. Republic of Turkey Prime Ministry, Investment Support and Promotion Agency of Turkey, Deloitte,

- "Three top economists agree 2009 worst financial crisis since great depression; risks increase if right steps are not taken."(2009). Reuters. Retrieved 2009-09-30, from Business Wire News database.

- TUROFED, 2011. available “turofed.org.tr" (Available:01.06.2009).

- Wang, 2009. "The İmpact of Crisis Events and Macroeconomic Activity On Taiwan's International Inbound Tourism Demand", Tourism Management, 30(1), pp.75-82

- Wang, 2010. “The Strategies Adopted by Taiwan in Response to the Global Financial Crisis, and Taiwan's Role in Asia-Pacific Economic Integration”, Japan and the World Economy, 22, pp.254-263.

- World Tourism Organization, 2009. Tourism and Economic Stimulus - Initial Assessment Madrid, Update September, Madrid.

- $\quad$ http://www.turofed.org.tr/webfolders/istatistik/TURIZM_RAPORU

- http://www.euractiv.com.tr/ab-ve-turkiye/link-dossier/turk-turizminin-ekonomik-krizden-daha-azetkilenmesinin-nedenleri-000105

- http://www.patronturk.com/turizm-sektorunde-son-durum. 


\title{
An Analysis of Cultural Tourism Cluster: The Case of Aksaray Province
}

\author{
Muhammet Saygin (Aksaray University, Turkey) \\ Himmet Karadal (Aksaray University, Turkey)
}

\begin{abstract}
A business cluster is a geographic concentration of interconnected businesses, suppliers, and associated institutions in a particular field. Clusters are considered to increase the productivity with which companies can compete, nationally and globally, so the cluster arises because it provides the increase of productivity and innovation abilities; for this reason its development should be supported not only by central governments but also by the local authorities. It is a known fact that tourism, one of the most effective aims for development, is considered to be a leading factor in cultural, economical and social perspectives through cluster types. In this study, the potential of cultural tourism cluster and competitiveness of Aksaray province has been analyzed in terms of Porter's Diamond Model. Several data sources including strategic development plan and academic literature have been taken into consideration. In this regard, findings about whether there is really a tourism cluster in Aksaray province have been stated and recommendations have been suggested to empower the innovative advantage of cultural tourism cluster.
\end{abstract}

JEL Codes: O10, O12

\section{Introduction}

Tourism is considered to be a leading factor in cultural, economical and social perspectives. It creates the development climate for the nations. Although it has significant effects for the nations, development process of the tourism is thought to be started in regional conditions. As Opperman (1993) pointed out that if tourism importance is significant at a national level, at a regional level this sector is presented as an essential tool in regional development and economic growth, believing to be one of the weapons to avoid desertification and regions economic stagnation, namely in the inner regions. This research is structured as follows: it is designs a literature background which allows defining and explaining a number of concepts related to the clusters, in particular of tourism, in terms of many researchers' point of view. Then it presents some evidences about regional development samples and lastly it includes the adaptation of Porter's Diamond Model of Aksaray Province. It also tries to present a conceptual model of regional competitiveness of a tourism cluster which is aiming to help filling the gap within this field besides the providing a possible tool fort he next studies about the regional development processes for the other cities in Turkey.

The overall purpose of this study is to emphasize the importance of clusters within tourism sector. It aims to provide an understanding that clusters not only provide an opportunity of economic development, but also a higher level of innovation and an increased competitiveness to the tourism sector. In this study, the potential of cultural tourism cluster and competitiveness of Aksaray province is analyzed. Several data sources including strategic development plans and academic literature have been taken into consideration. In this regard, findings about whether there is really a tourism cluster in Aksaray province are stated and recommendations are suggested to empower the innovative advantage of cultural tourism cluster.

\section{Theoretical Framework}

There are many studies dealing with the clusters, tourism and innovation in the world, but as a tourism paradise, Turkey still has a few academic works about these concepts. In today's world, innovation is the key concept for the development in each field, so it is obviously vital that innovation should be clarified before dealing with the clusters. The term innovation derives from the Latin word innovatus, which is the noun form of innovare "to renew or change," stemming from in-"into" + novus-"new". Although the term is broadly used, innovation generally refers to the creation of better or more effective products, processes, technologies, or ideas that affect markets, governments, and society. Innovation differs from invention or renovation in that innovation generally signifies a substantial change compared to entirely new or incremental changes (URL 1). Innovation is not an activity of a single business; it requires an active search involving several firms to tap new sources of knowledge and technology and apply these in products and production processes. In many countries, clusters of innovative firms are driving growth and employment. Innovative clusters of economic activity are becoming magnets for new technology, skilled personnel and research investment. These groups of enterprises tend to be well established and stable, innovating through strong backward and forward linkages with suppliers and customers. Co-operation in clusters has increasingly become a requirement for success. Moreover, co-operation offers a direct way to improve economic performance and reduce costs (OECD, 1999). According to Porter 
(1998), "In theory, location should no longer be a source of competitive advantage. Open global markets, rapid transportation, high speed communications should allow any company to source any thing from any place at any time." This may be absolutely true, but in today's world, locations lose their importance because of the use of information technologies, but locations are also the key concept for providing competitive advantages. The cluster term indicates that businesses grow in certain regions as opposed to others for other reasons than pure economical factors. It highlights the importance of research and innovation as well as access to skilled workforce, quality education and investment capital (Nordin, 2003). The cluster concept focuses on the linkages and interdependencies among actors in the value chain in producing products and services and innovating. Clusters differ from other forms of co-operation and networks in that the actors involved in a cluster are linked in a value chain. The cluster concept goes beyond "simple" horizontal networks in which firms, operating on the same end-product market and belonging to the same industry group, co-operate on aspects such as R\&D, demonstration programmes, collective marketing or purchasing policy (OECD, 1999). Clusters are used to represent concentrations of companies, so that they can produce synergy, through their geographical proximity and their interdependence (Rosenfeld, 1997). Feser (1998) points out those economic clusters don't refer only to industries and institutions, but to the highly competitive industries and institutions. This competitiveness is because of the relations between them. An innovative cluster is defined as a large number of inter-related industries with a high degree of collaboration, and that operates in the same market with the same characteristics (Simmie and Sennett, 1999). Clusters are important for competition since they increase productivity, they direct the path of innovation and stimulate the formation of new businesses, in addition, the geographical concentration allow companies to operate with greater productivity in the search for inputs such as specialized labour and specialized machinery and components suppliers, aside from facilitate access to information and technology. Tourism cluster is a geographic concentration of companies and institutions interconnected in tourism activities. This includes suppliers, services, governments, institutions, universities and competitors (Capone, 2004). According to Ferreira (2003) tourism cluster includes, in addition to the activities considered in the tourism sector, namely accommodation, catering, entertainment and various attractions, operators and travel agencies, guides, crafts, car rentals and touristic transport, other services and related and support activities, like organizations and support services, transport infrastructure, education and training, consultancy and other business services. We can verify that there are no substantial differences between the cluster's definition in a general scope, and the cluster's concept when applied to the tourism industry. The tourism cluster, as clusters in general, is defined as a geographical concentration in a region of companies and institutions inter-related. According to Jackson and Murphy (2002), the very governments are who identify tourism as a possible way to achieve economic development given the employment scarcity in the traditional sectors of economy. According to Botti et al. (2008), geographical proximity plays an important role in the perception of the performance of tourism organizations, in order to maintain the survival of tourism businesses and contribute to the competitiveness of the tourism sector. According to Botti et al. (2008), geographical proximity plays an important role in the perception of the performance of tourism organizations, in order to maintain the survival of tourism businesses and contribute to the competitiveness of the tourism sector.

\section{Findings}

Launched in March 2007, "Development of a National Clustering Policy" is an EU-funded technical assistance project that seeks to contribute to elaboration of a national clustering policy through development of a whitepaper on clustering. The Project has been implemented by the under secretariat for Foreign Trade with the technical assistance of an international consortium. The Project was composed of three components: institution building, policy development, a cluster mapping. The project involved ten cities in Turkey, but unfortunately Aksaray was not involved in this cluster list.

In 2011, Aksaray province strategical development plan has been developed by supports of the academicians, politicians, businesses and volunteers. According to this report, tourism sector in Aksaray province is not a cluster example but shows the potential of cultural tourism clustering. Especially, centre of the town, Ihlara and Monastery Valley, Güzelyurt, and Gülağaç have the potential of cultural tourism cluster. Table 1 illustrates the numbers of visitors and we may imply the potential of cultural tourism of the province.

\begin{tabular}{|l|c|c|c|c|c|c|}
\hline & \multicolumn{3}{|c|}{ Number of the Visitors } & \multicolumn{3}{c|}{ Occupancy } \\
\hline & Foreigner & Native & Total & Foreigner & Native & Total \\
\hline Aksaray & 5582 & 34439 & 40021 & 2,32 & 12,72 & 15,03 \\
\hline Kırıkkale & 47 & 11277 & 11324 & 0,15 & 31,86 & 32,02 \\
\hline Kırşehir & 73 & 9755 & 9828 & 0,09 & 43,93 & 44,02 \\
\hline Nevşehir & 80136 & 173396 & 253532 & 5,37 & 7,39 & 14,77 \\
\hline Niğde & 3364 & 33985 & 37349 & 4,14 & 47,06 & 51,20 \\
\hline Turkey & 4115212 & 11468804 & 15584016 & 13,32 & 15,57 & 28,89 \\
\hline
\end{tabular}

Table 1: Number of the visitors in terms of the cities 
As it is indicated in this report, the most significant tourism cluster examples are given as İstanbul, Cappadocia, Antalya, Muğla, İzmir, Beypazarı, Safranbolu and Bursa. From this point of view, Aksaray province which has a high potential of cultural tourism potential at the regional level should be analyzed in terms of the Porter's Diamond Model. This model includes determinants of national advantage. In his famous study, The Competitive Advantage of Nations, Porter (1990) indicates that;

- Factor conditions can be thought as human resources, physical resources, knowledge resources, capital resources and infrastructure etc. They also include factors like quality of research on universities, deregulation of labour markets, or liquidity of national stock markets. It is pointed out that these factors are not necessarily nature-made or inherited.

- Demand conditions can help businesses create a competitive advantage. These conditions have impact on the direction of innovation and product development.

- Related and supporting industries create the view of existence or non-existence of internationally competitive supplying industries and supporting industries. These industries can produce inputs which are important for innovation and internationalization.

- Firm strategy, structure and rivalry terms imply the conditions in a country and characteristics of domestic competition. They constitute the fourth determinant of competitiveness. The way in which companies are created, set goals and are managed is important for success.

\begin{tabular}{|c|c|c|}
\hline $\begin{array}{c}\text { Diamond } \\
\text { Model }\end{array}$ & Advantages & Disadvantages \\
\hline $\begin{array}{c}\text { Factor } \\
\text { Conditions }\end{array}$ & $\begin{array}{l}\text {-Closeness to Cappadocia region } \\
\text {-Closeness to religious tourism areas like } \\
\text { Konya and Kayseri } \\
\text { - Presence of Ihlara and Monastery Valleys } \\
\text {-Presence of many historical artefacts for } \\
\text { religious tourism } \\
\text {-Confluence point for the big cities: Konya, } \\
\text { Kayseri, Ankara } \\
\text { Presence of potential for the cultural, winter, } \\
\text { religious tourism }\end{array}$ & $\begin{array}{l}\text {-Absence of vocational courses and in- } \\
\text { service training seminars about tourism } \\
\text {-Airport is an hour away } \\
\text {-University-tourism cooperation is not } \\
\text { sufficient } \\
\text {-Unwillingness of the businesses for } \\
\text { establishing a web of relationships at the } \\
\text { national and regional scale. } \\
\text {-Absence of a planning for provincial } \\
\text { coordination }\end{array}$ \\
\hline $\begin{array}{c}\text { Demand } \\
\text { Conditions }\end{array}$ & $\begin{array}{l}\text {-Being in the middle of Turkey } \\
\text {-Developing relations with the Middle East. } \\
\text {-Close cultural relations with Arab and } \\
\text { Islamic Regions. } \\
\text {-Increasing demand for the cultural and } \\
\text { religious tourism in the world and in our } \\
\text { country }\end{array}$ & $\begin{array}{l}\text {-Less qualified accommodation and catering } \\
\text { facilities } \\
\text {-Lack of travel agencies working in the } \\
\text { region } \\
\text {-Ihlara Valley being not included in The } \\
\text { World Heritage List } \\
\text {-Monastery Valley being not included in The } \\
\text { World Heritage List } \\
\text {-Facilities of Hasan Mountain has not been } \\
\text { completed }\end{array}$ \\
\hline $\begin{array}{l}\text { Firm } \\
\text { Strategy, } \\
\text { Structure, } \\
\text { and Rivalry }\end{array}$ & $\begin{array}{l}\text {-Existence of potential for cultural tourism } \\
\text { - Initial investment and operating costs for } \\
\text { investors in the tourism industry are more } \\
\text { attractive than other sectors } \\
\text {-The presence of small and medium-sized } \\
\text { businesses in the hospitality industry and their } \\
\text { susceptibility to co-operation } \\
\text {-unique opportunities for cultural tourism in } \\
\text { terms of pensioning }\end{array}$ & $\begin{array}{l}\text {-Underdeveloped entrepreneurial culture } \\
\text {-New markets' underdeveloped research } \\
\text { culture } \\
\text {-The problem of institutionalization, } \\
\text {-Cooperation among firms is } \\
\text { underdeveloped } \\
\text {-The scale problem } \\
\text {-Underdeveloped marketing and branding } \\
\text { skills on the basis of destinations }\end{array}$ \\
\hline $\begin{array}{l}\text { Related and } \\
\text { Supporting } \\
\text { Industries }\end{array}$ & $\begin{array}{l}\text {-Closeness to Cappadocia region } \\
\text {-Strong potential of cultural tourism as well as } \\
\text { winter tourism, city tourism, rural tourism and } \\
\text { spa tourism }\end{array}$ & $\begin{array}{l}\text {-City tourism infrastructure } \\
\text {-Rural tourism infrastructure } \\
\text {-Winter tourism infrastructure } \\
\text {-Thermal tourism infrastructure }\end{array}$ \\
\hline $\begin{array}{l}\text { The Role of } \\
\text { Government }\end{array}$ & $\begin{array}{l}\text {-The presence of incentives } \\
\text {-The strong co-ordination -between the } \\
\text { Ministry of Culture and Tourism, the } \\
\text { Governor, Chamber of Commerce and the } \\
\text { University for the development of tourism } \\
\text { studies }\end{array}$ & $\begin{array}{l}\text {-Lack of region-specific tourism incentives } \\
\text {-Lack of communication between local } \\
\text { agencies and the private sector } \\
\text {-Government incentives are not adequate }\end{array}$ \\
\hline
\end{tabular}

Table 2. Diamond model analysis 
- Government can influence each of the above four determinants of competitiveness. Clearly government can influence the supply conditions of key production factors, demand conditions in the home market, and competition between firms.

Porter's diamond model suggests that there are inherent reasons why some nations, and industries within nations, are more competitive than others on a global scale. As it can be seen in the Table 2, there are many advantages as well as disadvantages for Aksaray in terms of cultural tourism clusters. Factor conditions indicate that this province is in the middle of Turkey and very close to other Cultural tourism centres as Cappadocia and Konya. Also its adjacent provinces are Niğde to the southeast and Kirşehir to the north and of course Nevşehir to the east. The absence of vocational courses and in-service training seminars about tourism sector and absence of a close airport besides the non-sufficient cooperation and unwillingness of businesses occur as the disadvantages of this province. Also the lack of planning for the provincial conditions makes us think about the negative sides.

Fortunately, this is a region of great natural beauty and Aksaray is one of the four much-visited provinces in the area of Cappadocia, along with Nevşehir, Niğde and Kayseri. Also the 3,000 m volcano Mount Hasan stands between Aksaray and Niğde. The $2400 \mathrm{~km}^{2}$ salt lake, lies within the boundaries of Aksaray, a large area of swamp with a maximum depth of 1 meter. Having the important historical places like Aşıklı Höyük, a burial mound 25 $\mathrm{km}$ east of the city, Acemhöyük, an early Bronze Age settlement, which is $18 \mathrm{~km}$ north-west of the city, the ancient city of Nora and a great number of historical mosques and churches in Ihlara Valley. Besides that, advantages and disadvantages of the city are indicated and differences in terms of the factor conditions, demand conditions, firm strategy, structure, and rivalry, related-supporting industries and the role of government can easily be seen in the figure 1 (Barca and Others, 2011).

\section{Conclusion}

Tourism is the leading factor of development for the countries. It not only creates the appropriate climate but also serve as a regional opportunity, but in today's world only tourism is not the key of success, it should be combined with other processes. For example, people in the sector should follow the technological chances and deal with the innovations. They should pursue their dreams. Otherwise if the sector remains still while the world is changing, there is no doubt that there won't be any improvements. So, tourism concept should be dealt with the cluster term which is the concentration of interconnected businesses within the same sector. In this study, potential of cultural tourism cluster and competitiveness of Aksaray province has been analyzed. Strategic development plan of the city which was carried out in 2011 and other academic studies have been presented in order to prove the potential of cultural tourism. Also, Porter's Diamond Model was applied for the city, advantages and disadvantages for different condition types have been given. Findings about if there is really a tourism cluster in Aksaray province have been tried to be stated, so it is concluded that there is a great potential but it can not be said that there is cluster tendency actually. In this regard, findings show us that the city is in the middle of the country and this makes the transportation easy. Also developing relations with the Middle East close cultural relations with Arab and Islamic Regions and increasing demand for the cultural and religious tourism in the world and in our country show the potential of cultural tourism and indicate the need for clusters. Though the absence of vocational courses and in-service training seminars about tourism sector and absence of a close airport besides the non-sufficient cooperation and unwillingness of businesses occur as the disadvantages and the lack of planning for the provincial conditions makes us think about the negative sides, but they are not the insoluble problems. In addition to the results of the study, recommendations should be given. In this respect, we believe that except for the written studies, there should be digital information supplies giving information about the beauties of the region because this is the region of great natural beauty and Aksaray is one of the four much-visited provinces in the area of Cappadocia. Having the important historical places like Aşılı Höyük, Acemhöyük, the ancient city of Nora and a great number of historical mosques-churches in Ihlara Valley, the potential of cultural tourism is increased. Furthermore, people dealing with the tourism sector should know the effects of information technologies and of course the internet. What is implied here is that tourism sector needs to people who have internet knowledge urgently. These people will bring both necessary know-how and dynamism to the sector. 


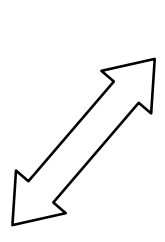

Demand

Conditions

Advantages

*Being in the middle of Turkey,

*Developing relations with the Middle East,

*Close cultural relations with Arab and Islamic

Regions,

*Increasing demand for the cultural and religious tourism in the world and in our country.

\section{Disadvantages}

*Less qualified accommodation and catering facilities, *Lack of travel agencies working in the region,

*Ihlara Valley being not included in The

World Heritage List,

*Monastery Valley

being not included

in The World

Heritage List,

*Facilities of

Hasan Mountain

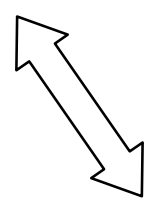

\section{Factor Conditions}

\section{Advantages}

*Closeness to Cappadocia region, *Closeness to religious tourism areas like Konya and Kayseri, *Presence of Ihlara and Monastery Valleys, *Presence of many historical artifacts for religious tourism, ${ }^{*}$ Confluence point for the big cities: Konya, Kayseri, Ankara, ${ }^{*}$ Presence of potential for the cultural, winter, religious tourism.

\section{Disadvantages}

*Absence of vocational courses and inservice training seminars about tourism, *Airport is an hour away, *Universitytourism cooperation is not sufficient, *Unwillingness of the businesses for establishing a web of relationships at the national and regional scale, *Absence of

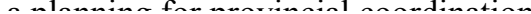

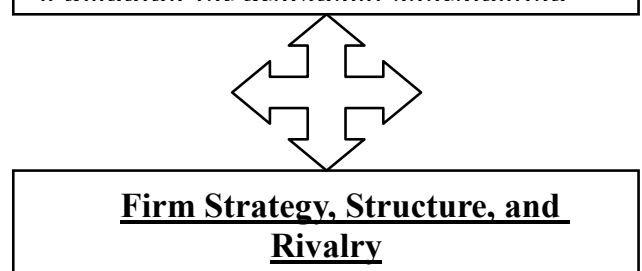

\section{Advantages}

*Existence of potential for cultural tourism, *Initial investment and operating costs for investors in the tourism industry are more attractive than other sectors, *The presence of small and medium-sized businesses in the hospitality industry and their susceptibility to co-operation*Unique opportunities for cultural tourism in terms of pensioning.

\section{Disadvantages}

*Underdeveloped entrepreneurial culture, *New markets' underdeveloped research culture, ${ }^{*}$ The problem of institutionalization, *Cooperation among firms is underdeveloped, *The scale problem *Underdeveloped marketing

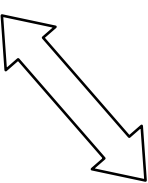

\section{$\underline{\text { Related and }}$ Supporting $\underline{\text { Industries }}$}

\section{Advantages}

*Closeness to Cappadocia region,

*Strong potential of cultural tourism as well as winter tourism, city tourism, rural tourism and spa tourism.

\section{Disadvantages}

*City tourism infrastructure

*Rural tourism infrastructure

*Winter tourism infrastructure

*Thermal tourism infrastructure

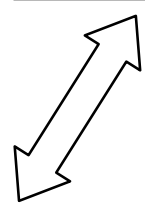

Figure 1: Diamond Model of Aksaray Cultural Tourism

\section{References}

- BARCA, M., KARADAL H., HIZIROĞLU M., GÜLÇUBUK, B., GÜNDOĞGU, G., HIZIROĞLU, A., DÖVEN, M.S., SERTER, G. and DEMIREL, A.Z. (2011). Aksaray İli Ekonomik Kalkınma Araştırma Raporu, (unpublished study), Aksaray.

- $\quad$ BOTTI, L., CAMPRUBI, R. and TORRÈS, O. (2008). "Tourism and Regional Development: Small Businesses and Social Network for Competitiveness", Research Entrepreneurship and Small Business XXII, Universidad Beira Interior, Covilhã.

- CAPONE, F. (2004). "Regional Competitiveness in Tourism local Systems", 44 European Congress of the European Regional Science Association, Regions and Fiscal Federalism, Universidad the Porto.

- FERREIRA, M., (2003). "Estratégia e Planeamento Regional do Turismo", Investigação em Turismo - Livro de Actas, pp. 67-82. 
- $\quad$ FESER, E. (1998). "Old and New Theories of Industry Clusters", in Steiner, M. (1998), Cluster and Regional Socialization: On Geography, Technology and Networked, Londres, Pion, pp. 18-40.

- JACKSON, J. and MURPHY, P. (2002). “Tourism Destinations as Clusters: Analytical Experiences From The New World", Tourism and Hospitality Research, Vol.4, No1, pp. 36-52.

- $\quad$ NORDIN, S. (2003). “Tourism Clustering \& Innovation”, European Tourism Research Institute, MidSweden University, Sweden.

- OECD Proceedings, 1999, "Boosting Innovation The cluster Approach" http://books.google.com.pe/books/about/Boosting_Innovation.html?hl=en\&id=Go0Q3GJjaCgC

- OPPERMAN, M. (1993). "Tourism Space in Developing Countries”, Annals of Tourism Research, Vol.20, $\mathrm{N}^{\mathrm{o}} 4$, pp.535-556.

- PORTER, M.E. “Clusters and the New Economics of Competition”, Harvard Business Review, Vol 76, Issue 6, Nov/Dec 1998.

- $\quad$ PORTER, M.E. The competitive advantage of nations. New York: Free Press. (1990)

- SIMMIE, J. and SENNETT, J. (1999). "Innovation in the London Metropolitan Region”, in Hart, D., Simmie, J., Wood, P. e Sennett, J., "Innovative Clusters and Competitive Cities in the UK and Europe", Working Paper 182, Oxford Brookes School of Planning.

- URL-1, http://www.businessmate.org/Article.php?ArtikelId=49 


\title{
The Effect of Information Technology on Innovation Abilities: A Research on SMEs
}

\author{
Himmet Karadal (Aksaray University, Turkey) \\ Muhammet Saygın (Aksaray University, Turkey)
}

\begin{abstract}
The use of information technologies (IT) and increase of innovation activities within Small and Medium Sized Enterprises (SMEs) which can easily adapt to the dynamics and changes can contribute to the regional development process. Though some studies have been concerned about the effect of information technologies or innovation on management performance, it can be easily seen that there has been very little empirical work for Small and Medium Sized Enterprises. Accordingly, the purpose of this study is to analyze the effects of information technologies within Small and Medium Sized Enterprises on innovation (product or process innovation) and management performance. In this study data will be collected through SMEs in Aksaray province and in this way study will deal with the relationship between information technology, innovation and management performance. Data for the research will be collected through survey system. The questions of the survey will be created by using the theoretical and applied literature (validity and reliability tested in various contexts) including information technologies, innovation and performance. Unlike some of the questions taken from previous studies, the new ones will be developed in terms of literature review, recommendations of academic staffs and business managers. The analysis of collected data will be carried out through SPSS package program and by using the techniques of some tests like single sample - t- test and ANOVA test.
\end{abstract}

JEL Codes: O31, O33

\section{Introduction}

The concept of IT has improved its importance in recent years and become indispensable for operational areas as well as management science. IT is affecting not only academic committees, businesses, local authorities and international institutions but also individual users in every aspects of life. The use of information technologies and increase of innovation activities within Small and Medium Sized Enterprises which can easily adapt to the dynamics and changes can contribute to the regional development process.

In the world of globalization, information technologies playing the key role of change and actuality are also undertaking the basis of innovation. Organizations dealing with the IT management should tend to innovation efforts and need to work on different models and methods in order to differentiate themselves against global competition. In our globalized world where the growth and development no longer depend on individual factors, the rapid increase of technological improvement reveals the importance of innovation and informatics. The concept of innovation which is both one of the most critical factors of both micro and macro - economic growth and development and providing a competitive advantage has a connection with information systems and its effect in management level occur as a phenomenon emerging in all areas. The use of information technologies and increase of innovation activities within Small and Medium Sized Enterprises should be analyzed. Though some studies have been concerned about the effect of information technologies or innovation on management performance, it can be easily seen that there has been very little empirical work for Small and Medium Sized Enterprises.

In this study, use of information system levels within the enterprises located in Aksaray was determined, their innovation capabilities were questioned and the relationship between information and innovation through the management based inferences were indicated. Unlike some of the questions taken from previous studies, the new ones were developed in terms of literature review, recommendations of academic staffs and business managers. The analysis of collected data was carried out through SPSS package program and by using the techniques of some tests like single sample $-\mathrm{t}$ - test and ANOVA test.

\section{Theoretical Framework}

Prior to addressing the information technologies, it might be important to mention about the different aspects of data, information, knowledge and wisdom terms. These four concepts of data, information, knowledge and wisdom are fundamental in terms of information technologies and meaning differences among these terms should be identified. Attempts to define these concepts are numerous and produce slightly different results, depending on which discipline is looking at them. Data are defined by dictionaries as factual information used as a basis for reasoning, discussion, or calculation; information as the communication or reception of knowledge; knowledge as the condition of knowing something gained through experience or the condition of apprehending truth or fact through reasoning (Bouthillier and Kathleen, 2002). For Meadow, et al. (2000), data refer to a string 
of elementary symbols, such as digits or letters. As it is pointed out, information "has no universally accepted meaning, but generally it carries the connotation of evaluated, validated or useful data". Knowledge, on the other hand, involves "a higher degree of certainty or validity than information" and "has the characteristic of information shared and agreed upon within a community. To conclude the meanings of these three terms, the term data refers to qualitative or quantitative attributes of a variable or set of variables. Data which are the plural form of datum are typically the results of measurements and can be the basis of graphs, images, or observations of a set of variables. Data are often viewed as the lowest level of abstraction from which information and then knowledge are derived. (URL-1). Information meets the definition for knowledge by description and is differentiated from data in that it is useful. Information is inferred from data in the process of answering interrogative questions (Rowley and Hartley, 2006). American educator Bob Boiko defines information only as "matter-of-fact" (Wallace, 2007). Knowledge is a fluid mix of framed experience, values, contextual information, expert insight and grounded intuition that provides an environment and framework for evaluating and incorporating new experiences and information. It originates and is applied in the minds of knowers. In organizations it often becomes embedded not only in documents and repositories but also in organizational routines, processes, practices and norms (Davenport, 1998). Lastly, wisdom which is commonly included as a level in data, information, knowledge, has a limited reference to wisdom. Wisdom is the ability to increase effectiveness. Wisdom adds value, which requires the mental function that we call judgment. The ethical and aesthetic values that this implies are inherent to the actor and are unique and personal (Rowley and Hartley, 2006).

The concept of IT is defined as an information system which is collecting the necessary information from various sources; processing, storing and reporting the data in order that manager can decide (Tekin, 2003). Information technology has a dramatic impact on organizational structure and re-design of the individual's position. The presence of information and communication technologies in organizations has expanded significantly to a point where there is no organization that can function without these tools. Coupled with this expansion is an increasing recognition of information and knowledge as indispensable and valuable assets in every organization (Parsons 2004). The success of every organization depends largely on how well it uses information technology to manage its information and knowledge resources (Cascio 2001).

In this study, we analyzed the relationship between IT use and innovation within the businesses; in this regard innovation concept should be identified. In recent years, the word innovation became one of the most popular concepts in daily life. It can be seen everywhere. However, this widespread usage of innovation lets us indentify the meaning. There are many innovation meanings in the literature. According to academic and business literature, innovation means to make an idea technically and commercially marketable and accessible to larger production in order to continue with sales (Casper and Waarden, 2003). Innovation is a pervasive attitude, a feeling, an emotional state, an ongoing commitment to newness. It is a set of values that represents a belief in seeing beyond the present making that vision a reality (Kuczmarzki, 2003). There are several perspectives for explaining innovation types. For example Tidd, Bessant \& Pavitt (2005) base their classification of innovation on change. They focus on four broad categories, these are:

- Product innovation - Changes in the things which an organization offers;

- Process innovation - Changes in the ways in which the products/services are created and delivered;

- Position innovation - Changes in the context in which the products/services are introduced

- Paradigm innovation - Changes in the underlying mental models which frame what the organization does

\section{Findings}

This research was conducted in order to be a framework for the small and medium sized enterprises in Aksaray province. In this study, one faculty member at University of Aksaray and one specialist from the same university were involved. A variety of methods were used to collect the data: (1) semi-structured interviews with the managers; (2) in-dept questionnaires completed by the managers and the top management team of the businesses and (3) publicly available internet connections (eg: annual reports, web sources and web sites). The reason why these three methods were used actually indicates the purpose of this study. That is, the use of first method makes the study more realistic. When the managers of these businesses were interviewed before the questionnaires' application, researchers more easily gained the access to have answers for the questions in data collection tool. Thus, interviews with the managers let us collect the data more accurately and more easily. One more benefit of this multi-method approach occurred as the avoidance of method variance, as different groups of the variables were determined from the use of this three data collection method (Campbell \& Fiske, 1959). Besides that, the data collection tool was designed in terms of the literature analysis and many questions were taken and some of the questions were designed from the study of Bülbül (2003) and Güleş (1996). 


\begin{tabular}{|c|c|c|c|}
\hline Level of IT Use & Mean & (n) & St. Dev. \\
\hline IT Systems - 5 Years Ago & 35,2692 & 104 & 13,16234 \\
\hline IT Systems - Actual & 52,1058 & 104 & 21,19164 \\
\hline
\end{tabular}

Table 1: The Use of Information Technologies in SMEs

The table 1 indicates that there is a meaningful difference between the past and actual use levels. That is, 104 businesses attended to the research have an increase in terms of the usage levels of information technologies in their businesses. This implies that businesses in Aksaray province try to follow the new technologies and adapt these technologies to their production and management methods. It can also be understood as an improvement for the future plans of the city itself.

\begin{tabular}{|c|c|c|c|c|}
\hline Difference Indicator & Mean & St. Dev. & Df & $\mathrm{p}$ \\
\hline ITbefore - ITnow & $-16,83654$ & 15,11452 & 103 &, 000 \\
\hline
\end{tabular}

Table 2: Increase in the level of IT use in SMEs. Note: (i): $t: 11,360 ;$ (ii): $p:<001$

The indicated results of the increases of the use of information technologies is shown in the table 2 and this table indicates that the increase level occurs as $-16,83654$ so we can conclude that there is a meaningful increase level and businesses are really interested in changes and developments. That is there can be a potential both for the businesses themselves and the Aksaray province because it should be believed that the more potential within the city and its businesses, the more easily the improvements are carried out.

\begin{tabular}{|c|c|c|c|c|c|}
\hline Effects of IT on Innovation Concepts & (n) & Min. & Max. & Mean & St. Dev. \\
\hline IT has an effect on the new production \\
ideas & 104 & 1 & 5 & 3,14 & 1,234 \\
\hline $\begin{array}{c}\text { IT has an effect on the innovation of } \\
\text { production works }\end{array}$ & 104 & 1 & 5 & 2,32 & 1,457 \\
\hline $\begin{array}{c}\text { IT has an effect on the decrease of } \\
\text { development process of the new products }\end{array}$ & 104 & 1 & 5 & 2,46 & 1,350 \\
\hline $\begin{array}{c}\text { IT has an effect on the decrease of the } \\
\text { changes in product designs }\end{array}$ & 104 & 1 & 5 & 2,39 & 1,325 \\
\hline $\begin{array}{c}\text { IT has an effect on the convenience of the } \\
\text { new product for the customers }\end{array}$ & 104 & 1 & 5 & 3,11 & 1,481 \\
\hline
\end{tabular}

Table 3: The Effects of IT on Innovation. Note: (i): Scale: 1-don't agree ......5-definitely agree

In the data collection tool, businesses were asked to determine the effects of information technologies on innovation within their businesses and five variables were given to the managers. These variables were taken form the studies of Güleş (2003) and given results were taken from the unpublished master thesis of Saygın (2011). According to these data, businesses share the idea that information technologies have an effect especially on the new product ideas. Besides that the second most common answer for this question is that information technologies have an effect on the convenience of the new product for the customers. It shows us that businesses in Aksaray province choose the new product ideas more commonly as a reason for the information technologies' use.

\begin{tabular}{|c|c|c|c|c|c|}
\hline Innovation Abilities & $(\mathrm{n})$ & Mean & St. Dev. & $\mathrm{t}$ & $\mathrm{p}$ \\
\hline New products & 104 & 3,40 & 1,235 & 3,335 & $<.001$ \\
\hline New production methods & 104 & 2,74 & 1,435 & $-1,845$ & $<.005$ \\
\hline New organizational types & 104 & 2,23 & 1,443 & $-5,436$ & $<.001$ \\
\hline $\begin{array}{c}\text { New methods of procurement and } \\
\text { distribution }\end{array}$ & 104 & 2,31 & 1,455 & $-4,851$ & $<.001$ \\
\hline
\end{tabular}

Table 4: Innovation Abilities of the Businesses.

Note: (i) n=104; (ii) one sample t-test; (iii) Scale: 1- never done ......5-very highly done

The table indicates that businesses have different reasons for the innovation and these differences are given by the table 4. According to this, businesses prefer making innovations on new products. The variable occurs as the most preferred choice for innovation abilities. Besides that, new production methods are also chosen as a way of making innovation.

\section{Conclusion}

In this study, use of information system levels within the businesses located in Aksaray was determined and the levels were indicated in the study. First of all, the difference between past and the actual use levels were given. According to this, businesses in Aksaray province definitely increased their levels of IT use. That is when 
today's situation is compared with the five years ago, it can easily be seen that there is an effort to adapt at changes in the world. Secondly, innovation effects for the businesses are tried to be explained and it has been clearly seen that businesses share the opinion of that there is a definite effect of IT on the new product ideas. So, it can be concluded that businesses are trying to create new products to compete with the other businesses and for this aim they are using the information technologies. When the businesses asked for other important effects of IT, the second outstanding answer about this question occurs as convenience of the new products for the customers. To sum up, businesses use the information technologies in an active way and try to create new product ideas and make their productions convenient for their customers' needs. Thirdly, innovation abilities of the businesses are tried to be explained and the results of the data collection tool showed that businesses are mostly capable of new products. Most of the businesses have indicated that they are trying to create new products. When it is analyzed through the globalization term, this should make us hopeful about the future of the city and of course the country so that there is a great potential of production abilities in the city. In conclusion, collected data confirm that there is an increase for the levels of information technologies use within the businesses in Aksaray province and these businesses are trying to adapt these technologies to their innovation abilities.

In this regard, though there are a lot of benefits of IT use for the businesses, they want to take advantage of new production capabilities and among the many different ways for their innovations, the most outstanding one occurs as the choice of creating new products.

\section{References}

- Bouthillier, B. and Kathleen, S., 2002, Understanding Knowledge Management and Information Management: The Need for an Empirical Perspective, Information Research, Vol. 8 No: 1, Graduate School of Library and Information Studies McGill University Montreal, Canada.

- Casper, S. and Waarden, F., 2005. Innovation and institutions: a programmatic study, Cheltenham, UK.

- Cascio, WF 2001. Knowledge creation for practical solutions appropriate to a changing world of work, Journal of Industrial Technology, 27(AO): 14 - 16.

- Davenport, Thomas H.; Laurence Prusack (1998). Working Knowledge: How Organizations Manage What They Know. Boston: Harvard Business School Press. pp. 5. ISBN 0585056560.

- Kuczmarski, T.D., 2003. Why is innovation? Why aren't companies doing more of it?, Journal of Consumer Marketing, 20, 536-541.

- Meadow, C. T., Boyce, B.R. and Kraft, D.H.(2000) Text information retrieval systems, $2^{\text {nd }}$ ed. San Diego, CA: Academic Press.

- Parson, M. 2004. Effective knowledge management for law firms. Oxford: Oxford University Press.

- Rowley, Jennifer; Richard Hartley (2006). Organizing Knowledge: An Introduction to Managing Access to Information. Ashgate Publishing, Ltd. pp. 5-6. ISBN 9780754644316.

- Saygin, M., 2011, “An Analysis Of Relationships Between Use Of It Technologies And Innovation Abilities Within Businesses”, Unpublished MBA Thesis, Aksaray University, Institute of Social Sciences, Master of Business Administration, Aksaray, Turkey.

- $\quad$ Tekin, M., Güles, H.K., Ögüt, A., 2003. Değişim Çağında Teknoloji Yönetimi, Nobel Yayın

- Dağıtım, 2. Baskı, Ankara, s.139.

- Tidd, J., Bessant J., \& Pavitt, K. (2005). Managing Innovation - Integrating Technological, Market and Organizational Change (3rd Ed.). UK: John Wiley \&Sons.

- Wallace, Danny P. (2007). Knowledge Management: Historical and Cross-Disciplinary Themes. Libraries Unlimited. pp. 1-14. ISBN 9781591585022.

- URL-1, http://en.wikipedia.org/wiki/Data 


\title{
Software Production in Kyrgyzstan: Potential Source of Economic Growth
}

\author{
Rahat Sabyrbekov (American University of Central Asia, Kyrgyzstan)
}

\begin{abstract}
In recent years, software development in the Kyrgyz Republic demonstrated $60-70 \%$ growth rate. Kyrgyz software products are exported to Central Asian neighbors and to the Western countries such as Italy, Australia and Holland. With the highest Internet penetration in the region and pool of qualified staff Kyrgyzstan has real chances to sustain the growth rate of the industry. Moreover, the cheap labor creates comparative advantage for local software producers. The break-up the Soviet Union lead to bankruptcies of traditional industries in the Kyrgyz Republic and thousands of highly qualified engineers were left unemployed. Simultaneously since independence Kyrgyz government implemented number of reforms to encourage development of Information and Communication Technologies which lead to the establishment of ICT infrastructure in the region.

The paper analyzes the development trend of the software production industry in the Kyrgyz Republic. We will also overview international experience as in the leading software producers as well as in neighboring countries. The study also builds projections for the next decade and draw on certain policy implications. In addition the paper will provide policy recommendations. The data used is from by the Association on IT companies, questionnaires, National Statistics Committee, Word Bank and Asian Development Bank.
\end{abstract}

JEL codes: F1, O34, O38

\section{Introduction}

Innovative economy, knowledge economy, information communication technology sector are probably most popular topics discussed in mass media and among politicians. There are tons of literature about structural changes in the economy and shift to the knowledge economy in new modern world.

The software industry is one of the main examples of knowledge economy, as the value of what a software company produces is almost entirely in the knowledge embodied in its products and services. However there are very few papers found on software production in the post-Soviet countries.

It is a fast growing industry producing high value services for its customers. The unique feature of the IT sector is indeed free access into the market and almost zero transportation costs due to Internet penetration.

Dynamic ICT growth in Kyrgyzstan along with positive or neutral government polices have established ground for software production. One of the distinct features is that $80 \%$ of the cost is labor, which is variable cost and labor of Kyrgyz software developers are lowest among main competitors.

\section{Software industry in developing countries and Kyrgyzstan}

The global software market had total revenue of \$198 billion in 2010 with compound growth of 5.4\% between 2006 and 2010. The performance of the market is forecast to accelerate with anticipation that the market in 2015 will have value of \$259.1 billion (Global Software Highlights, 2010).

Major suppliers and consumers of packaged software are in the developed countries. 


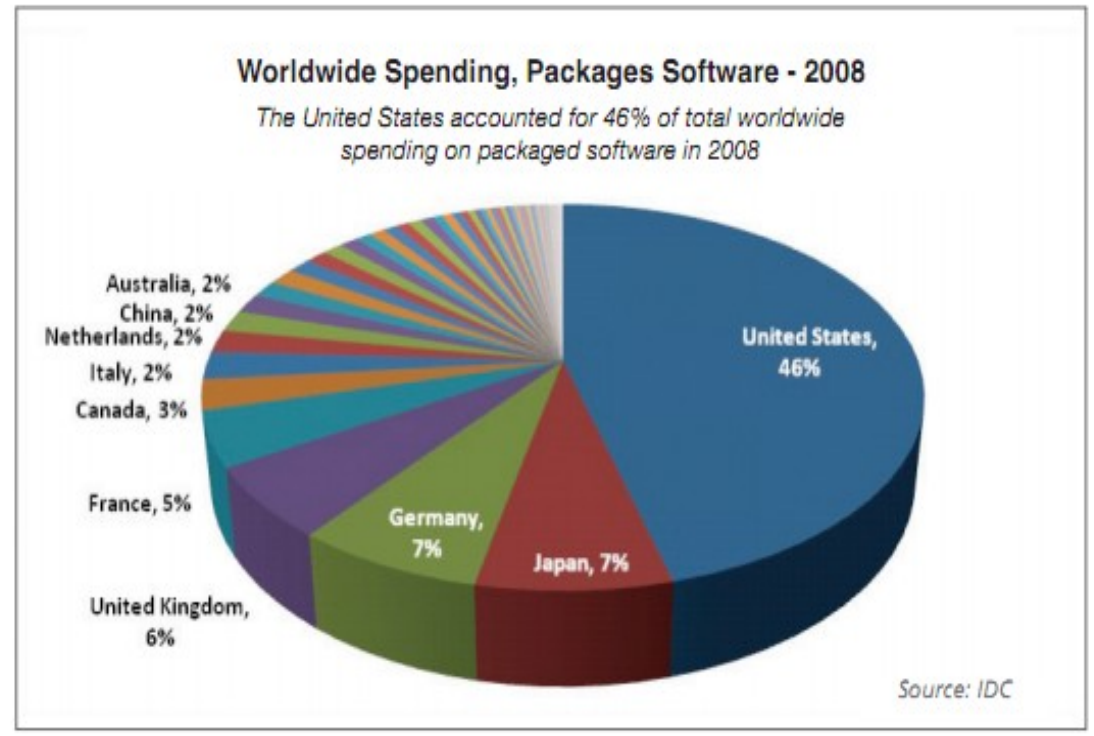

Figure 1. World spending of software, 2008. Source: International Data Corporation

Today companies from developing economies do not have significant share in the global software industry, but demonstrate fast growth. While companies from developing world are slow to become world leaders more and more software companies from the former Soviet bloc are emerging.

India has been the most successful among developing countries in establishing a major domestic computer software industry (Heeks, 1996; Bhatnagar and Madon, 1997). The Indian computer software industry has grown rapidly, in terms of its computer software and services trade. From virtually no exports in 1980, by 1994-1995 it had over \$160 million worth of exports and its rapid growth continues. Between 1990 and 1998 exports increased by over 50 per cent per year. This trend is expected to be sustained.

Since India achieved a major success in software industry policymakers in developing countries are paying close attention to the sector and Kyrgyzstan is no exception.

The case of India demonstrated that developing countries might have a piece of this lucrative market. The developing countries have an opportunity to compete with North due to lower input costs and the software production along with higher levels of ICT development offers developing economies an opportunity for economic growth (Costinot, 2008).

The break-up of the Soviet Union led to economic transformations in the Kyrgyz Republic. Once dominant and strategic sectors such as industrial and agricultural production lost their positions in favor of trade and services. However educational system was slow to change and technical institutes continued to produce engineers.

This coincided with IT-favored government policy. From the very first days of independence Kyrgyz government was keen on creating favorable conditions for ICT. In the early1998 the government adopted the National Strategy on ICT Development and since then the industry was left for self-development. However the IT sector grew and software production started to develop.

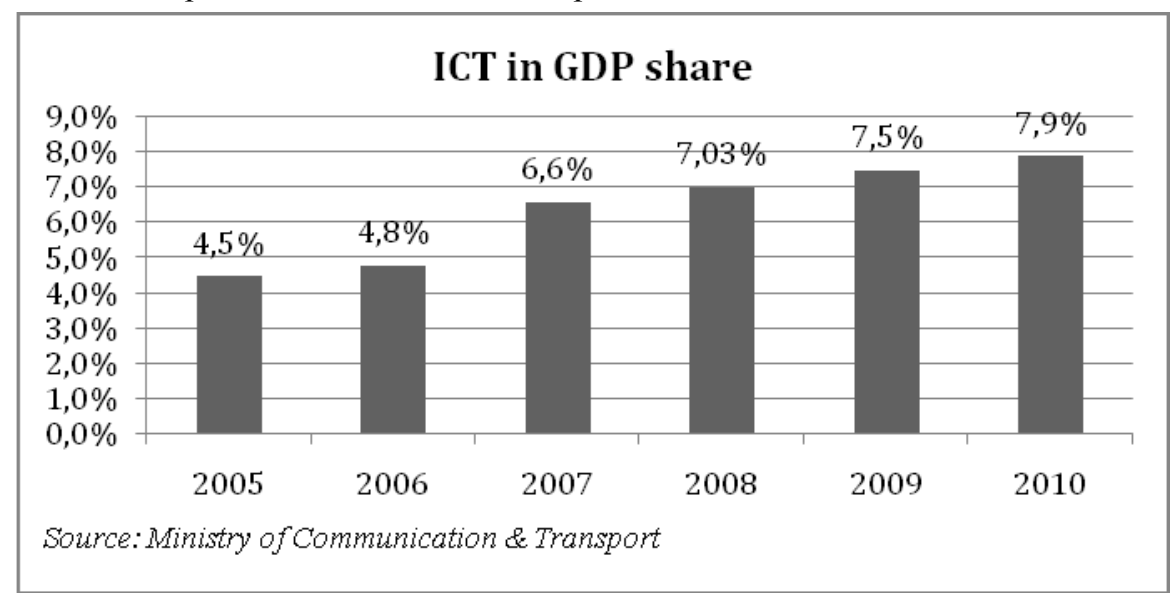

Figure 2. ICT share in GDP (2005-20010) Source: Ministry of Communication and Transport 
The data in Figure 2 demonstrates steady growth of ICT sector in the GDP. This growing trend confirms and creates favorable environment for the software production. Kyrgyzstan has developed fiber-optic network among major cities and has almost 100\% mobile Internet coverage. At the same time there are thirteen universities which produce IT specialists.

Presence of the reliable Internet connection and Internet penetration is another major condition for software development. Kyrgyzstan has the highest Internet penetration in the Central Asia (Table 1).

\begin{tabular}{|c|c|c|c|c|c|}
\hline ASIA & $\begin{array}{c}\text { Population } \\
\text { ( 2011 Est.) }\end{array}$ & $\begin{array}{c}\text { Internet } \\
\text { Users, } \\
\text { (Year } \\
\mathbf{2 0 0 0 )}\end{array}$ & $\begin{array}{c}\text { Internet } \\
\text { Users, } \\
\text { Latest } \\
\text { Data }\end{array}$ & $\begin{array}{c}\text { Penetration } \\
(\% \\
\text { Population) }\end{array}$ & $\begin{array}{c}\text { User } \\
\text { Growth } \\
(\mathbf{2 0 0 0 - 2 0 1 1 )})\end{array}$ \\
\hline Kazakhstan & $15,522,373$ & 70,000 & $5,300,000$ & $34.1 \%$ & $7,471.4 \%$ \\
\hline Kyrgyzstan & $5,587,443$ & 51,600 & $2,194,400$ & $39.3 \%$ & $4,152.7 \%$ \\
\hline Tajikistan & $7,627,200$ & 2,000 & 700,000 & $9.2 \%$ & $34,900.0 \%$ \\
\hline Uzbekistan & $28,128,600$ & 7,500 & $7,550,000$ & $26.8 \%$ & $100,566.7 \%$ \\
\hline
\end{tabular}

Table 1. Internet penetration, 2011 Source: Internet World Stats July 2011.

The data on the software industry is scarce. The most detailed and available data is from two surveys held by Kyrgyz Software and Service Developers Association (KSSDA) in 2008 and 2010 (KSSDA, 2008, 2010). KSSDA incorporates 13 large software-producing companies. The survey was in form of online anonymous questionnaire.

The intentional and unintentional public actions have lead to the establishment of significantly developed software production sector with strong export potential. Today according to Kyrgyz Software and Service Developers Association (KSSDA) the local software is exported not only to neighboring Kazakhstan but also to CIS and the European Union.

The available data suggests that there are about 30 companies which develop software and 100-200 freelancers. At the time when this paper was written GURU.COM - global leading freelancer finder - had portfolios of 39 Kyrgyz freelancers. The data suggests also that $60 \%$ of the companies who participated in the survey ( 21 companies) are engaged on export. Average number of employees per company is 18 . The biggest company employs - 45 people, smallest -7 .

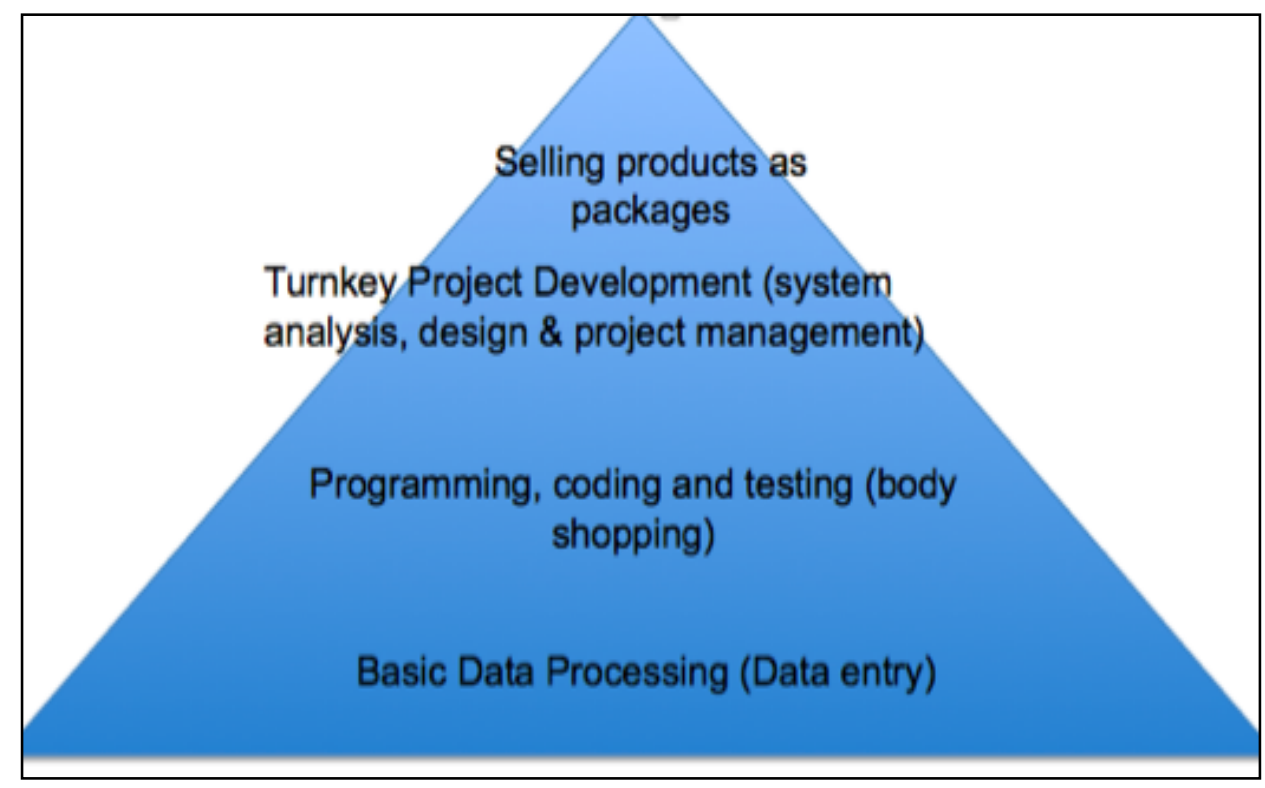

Figure 3. Value chain in software industry. Source: designed on the basis of software industry research

Based on the software production value chain majority of the Kyrgyz software developers are at the second and third steps. While very few companies are at the top producing software packages. The revenues of the individual companies range from $\$ 50000$ to more than $\$ 1$ mln.Exported software products include: ERP, HRMS, DMS, CRM, Web-applications and Mobile applications.

However there is a huge gap between government and private sector data on software export. Anonymous survey held by KSSDA show that the exports are about $\$ 10 \mathrm{mln}$ per year while National Statistics Committee show \$1.4 mln (National Statistics Committee, 2010). 


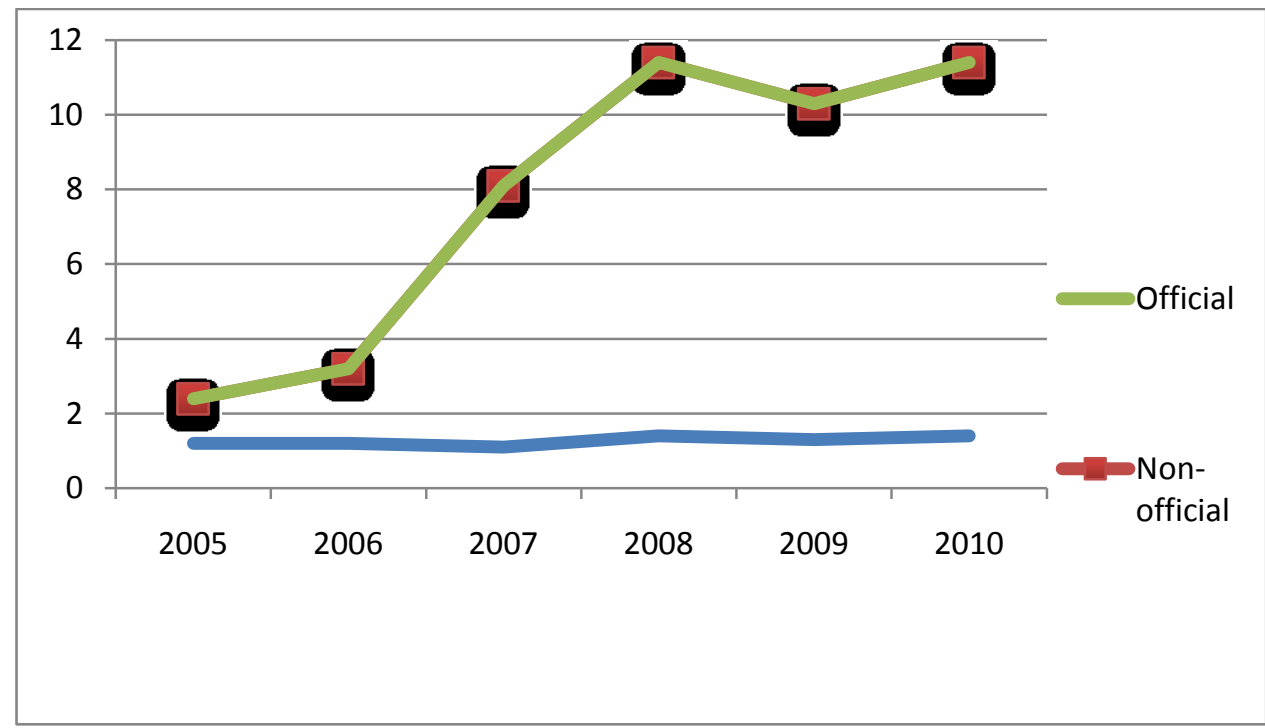

Figure 4. Official vs non-official export, (2005-2010, mln. USD) Source: Information and Communication Technologies in the Kyrgyz Republic 2006-2000 and KSSDA Report 2010

Figure 4 is comparison of the data provided by National Statistics Committee and independent association of software developers - KSSDA. We can notice that there is a huge difference between two lines. This suggests that most of the software producers work in shade economy. According to KSSDA survey $80 \%$ of software developers are not officially registered.

Kyrgyz software producers have comparative advantage. The cost of labor is much lower than in neighboring countries and there are no borders in software market. Thus all participants of the world market have equal access to the market. Another special feature of the software industry is that the main cost is the labor. Other inputs are relatively same which is even more flat in the region. The typical salary of the software engineer in Kyrgyzstan in 15-20 USD per hours while in Russia and Kazakhstan starts from 40USD per hour and in Western countries it starts from 50USD.

\begin{tabular}{|c|c|c|c|}
\hline Country & Wage per hour & $\begin{array}{c}\text { Average wage } \\
\text { per hour }\end{array}$ & $\begin{array}{c}\text { Cost of 100 hour product } \\
\text { (with average wage) }\end{array}$ \\
\hline Kyrgyzstan & $15-20$ & 17 & 1700 \\
\hline Kazakhstan & $30-40$ & 35 & 3500 \\
\hline Russia & $30-50$ & 40 & 4000 \\
\hline Western countries & $50-250$ & 150 & 15000 \\
\hline
\end{tabular}

Table 2: Comparative table of wages of software developers in USD (2011, USD) Source: calculated from various reports and surveys

The comparative advantage of Kyrgyzstan becomes clear if we use standard cost function: $Y=a+b x$

Where $Y$ is cost of production, $a$ - fixed cost, $b$ - variable cost of unit $x$. In order to compare the costs in the countries we will assume that $a$ is the same for all countries. Second assumption is that the cost function has only one variable - labor. Cost of labor in Kyrgyzstan is cheaper then in competing countries thus it creates the comparative advantage for Kyrgyz producers.

Apart from cheap labor Kyrgyz software sector also enjoys political support and share common language Russian. Today the development of Information Communication Technologies is still one of priorities for Kyrgyz government. In July 2011 the government adopted the Law on High Technologies Park. The law lowers the income tax for software developers down to $5 \%$ while nationwide it is $18 \%$ (Law on High-Tech Park, 2011). The law is designed to create a chain of software companies which will export its product and services. One of the most probable consequences of the law is "moving-out" of the companies from shade economy.

However one of the main criterions for the successful global scale software industry is investments from already established large software multinational corporations and thus the Kyrgyz government should establish more favorable conditions for welcoming international investors.

\section{Conclusion}

Most academic papers and government strategic policies are aimed at the development of traditional and well- 
studied sectors of economy. However this paper makes attempt to shed a light on new perspective industry. From the available data it is clear that the software industry is growing rapidly in Kyrgyzstan. High ICT development and pool of IT specialists along with government's non-interference policy created a fertile soil for software production. Proficiency in Russian language also can be attributed to the positive externalities for software production growth in Kyrgyzstan.

Despite the fragmented data the evidence of flourish innovative industry is seen. There are about 30 software producing companies which mainly work for the foreign partners.

Cost function analysis showed that labor is the heaviest cost in the software production and Kyrgyzstan has the lowest labor cost in comparison to neighbors. Moreover recent legislation creates new favorable conditions for software producers and it is expected that the industry will be legalized. The legalization of the industry will lead to higher visibility and attracting bigger international partners. It is also expected that the new legislation will lead to growth of local software market.

\section{References}

- Global Software Highlights, http://www.softwaretop100.org/global-software-top-100-edition-2010-thehighlights, 20 July 2010.

- Heeks, Richard, 1996. India's software industry: State policy, liberalization, and industrial development, New Delhi : Sage Publications.

- $\quad$ Bhatnagar S.C.; Madon S., 1997, "The Indian software industry: moving towards maturity. Journal of Information Technology”, Volume 12, Number 4, December 1997, pp. 277-288(12).

- Arnaud Costinot, 2009, “On the origins of comparative advantage”. Journal of International Economics, Volume 77, Issue 2, April 2009, Pages 255-264.

- $\quad$ Report of Kyrgyz Software and Service Developers Association, (KSSDA) 2008.

- Report of Kyrgyz Software and Service Developers Association (KSSDA), Promotank HQ 2010.

- Information and Communication Technologies in the Kyrgyz Republic 2005-2010, National Statistics Committee, 2010.

- Business finances of the Kyrgyz Republic 2006-2009, National Statistics Committee, 2010.

- $\quad$ Law on High-Tech Park, adopted by Jogorku Kenesh on 10 June of 2011. 


\title{
Avrupa Birliği Bölgesel Kalkınma Politikaları: Yapısal Fonlar ve Diğer Mali Araçlar Çerçevesinde Bir Değerlendirme
}

\author{
Ahmet İncekara (Istanbul University, Turkey) \\ Burcu Kılınç Savrul (Istanbul University, Turkey)
}

\section{Regional Development Policies of the European Union: An Evaluation in the Framework of Structural Funds and Other Financial Instruments}

\begin{abstract}
Regional policy of the European Union (EU) is implemented in order to improve welfare and quality of life in specific regions of EU member countries, minimize inter-regional income differences and restructure less developed industrial areas. regions of the EU countries has urban and regional development differences in themselves. Regional policies have gained importance in the process of EU enlargement. Increases regional disparities has been observed to occur with the first expansion. Although the tools that the Community could use for regional inequality were initially limited, they began to increase over the years in the process of development of regional policy of the EU.

In this respect, this study will focus primarily on the EU regional development policies, the structural funds in line with the measures taken to ensure economic and social cohesion in EU countries and European Investment Bank and the new tools such as community tool will be discussed.
\end{abstract}

JEL Codes: N14, N94

\section{Giriş}

Bölgesel Politika, bölgeler arasındaki sosyo-ekonomik farklılıkların azaltılmasına yönelik bütün çalışmaları kapsar. Avrupa Birliği de, üye ülkeler arasındaki sosyo-ekonomik farklılıklar ve ülkelerin kendi bölgeleri arasındaki dengesizlikleri azaltabilmek amacı ile bir Bölgesel Politika geliştirmiştir. AB Bölgesel Politikası, bölgelerarası farklılıkları gidermek amacıyla birliğin gündemine gelmiş bir ortak politikadır. Özellikle son genişlemeden sonra AB'de bölgelerarası farklılıklar daha da artmış ve bu genişleme süreciyle birlikte bölgesel politikalar ön plana çıkmıştır. Geri kalmış bir bölgenin geliştirilmesi sayesinde, gelişmiş sanayi bölgelerine olan göç önleneceğinden, bu tür bölgelerin de aşırı kalabalıklaşmasının önüne geçilmeye çalışılmıştır.

AB kuruluşundan günümüze alan ve nüfus olarak genişlemeye devam etmektedir. Bunun sonucunda birlik, temel olarak işsizlik oranları ve kişi başına GSYİH değerlerine göre geri kalmış bölgeleri belirlemektedir. Bölgesel Politika, sadece üye devletlere yönelik bir politika olmaktan çıkmıştır, AB'ye aday ülkeler için bile, katılım öncesi strateji çerçevesinde bölgesel politikalar geliştirilmiştir.

\section{Bölge Kavramı ve Bölgesel Kalkınma}

Bölge kavramının etimolojik kökleri Latince, regio yani; çevre, alan anlamına gelmektedir. Genel olarak bölge; kentten daha geniş, ülkeden daha küçük, yönetsel sınırları ulus yönetsel birim sınırlarıyla çakışan ama etkileşim açısından o sınırları aşabilen, yerinden yönetilen, katılımcı bir yönetime ve bütçeye sahip yönetim birimidir (Arslan, 2010: 88).

Bölgesel kalkınma, hedeflenen yörelerde ve sektörlerde yatırım düzeyinin yükseltilmesini, böylece bu yörelerde ekonomik kalkınmanın sağlanmasını öngörür. Bölgesel kalkınmanın gerçekleştirilmesi için yatırım kararlarının çeşitli araçlar kullanılarak uygulanması gerekmektedir. Bunun için öncelikle bölgenin ekonomik potansiyelinin ortaya çıkarılması gerekir (Arslan, 2005: 278,291).

\section{Avrupa Birliği’nde Bölgesel Kalkınma Politikaları}

\subsection{Birinci dönem (1957-2000)}

1957-2000 arasında, birliğin bölgesel politikasının temelleri atılmıştır ve bu dönemde bölgesel politikaların temeli Avrupa Topluluğu'nu kuran antlaşmalara dayanmaktadır.

Fransa, Almanya, İtalya, Belçika, Hollanda ve Lüksemburg tarafından 1957 yılında imzalanan Roma Antlaşması ekonomik birliği güçlendirmek ve bölgeler arasındaki gelişmişlik farklarını kapatacak uyumlu bir kalkınmayı gerçekleştirmek gerektiğini belirtmiştir. Bölgesel farklılıkların kapatılmasına yönelik politikaları geliştirme sorumluluğu henüz ulusal düzeyde ele alınmıştır (Can ve Akdenizli Kocagül, 2008:9).

1958 'de ise Roma Antlaşması'na bağlı olarak AB üye ülkelerinin sosyal ve ekonomik entegrasyonunu ve 
dengeli büyümelerini sağlamak amacıyla az gelişmiş bölgelerin kalkınmasına yönelik projelerin desteklenmesi için, Avrupa Yatırım Bankası kurulmuştur (Altınışık ve Peker, 2010: 149). Yine aynı yıl ortak pazar içinde iş̧̧ilerin istihdam olanaklarını iyileştirmek ve yaşam standartlarının yükseltilmesine katkıda bulunmak amacıyla Avrupa Sosyal Fonu (Can ve Akdenizli Kocagül, 2008: 10) ve 1962 yılında fiyatların düzenlenmesi, çeşitli ürünlerin üretim ve pazarlanması için gerekli olan desteğin temini ve tarımsal altyapıyı geliştirmek için Avrupa Tarımsal Yönlendirme ve Garanti Fonu kurulmuştur. 1970'lere kadar topluluk bölgesel politikayla ilgili olarak fazla girişimde bulunmamıştır. 1975 tarihinde ekonomik ve sosyal gelişmişlik düzeyi açısından AB'nin gelişmiş bölgelerinin gerisinde kalan bölgelerin kalkınmasına katkı sağlayabilmek amacıyla Avrupa Bölgesel Kalkınma Fonu oluşturulmuştur (Yıldız ve Akdağ, 2006: 2,3).

1973'e gelindiğinde genişleme ile birlikte diğer topluluk politikalarının yanı sıra, bölgesel politikaların önemi daha da artmıştır. 1987'de yürürlüğe giren Tek Avrupa Senedi ile Roma Antlaşması'nda bazı değişiklikler yapılmıştır. Tek Senet çerçevesinde; ekonomik ve sosyal birliğin geliştirilmesi, özellikle çeşitli bölgeler arasında var olan farklılıkların azaltılması, az gelişmiş bölgelerin geri kalmışlığının azaltılması, ortak pazarın uygulanması sırasında bu amaçlara ulaşılması için yapısal fonların, Avrupa Yatırım Bankası'nın ve diğer mali araçların kullanılması hedeflenmiştir. Tek Avrupa Senedi ile ayrıca Avrupa Sosyal Fonu, Avrupa Tarımsal Yönlendirme ve Garanti Fonu ve Avrupa Bölgesel Kalkınma Fonu'nun Yapısal Fonlar adı altında bir araya getirilmiştir (Altay, 2005: 82 ; Can ve Akdenizli Kocagül, 2008: 18-19). Çünkü farklı tarihlerde farklı amaçlarla kurulan yapısal fonların birbirlerinden bağımsız hareket etmeleri, fonların etkinliğini azaltmıştır.

1994 yılında yapısal fonlar tarafindan finanse edilecek projelerin tespitinde objektif kurallar konmuştur. Bu kurallar 1994-1999 yılları arasında uygulanmak üzere altı ana hedefi kapsamaktadır. 2000 y1lına kadar bu hedefler ile belirlenen bölgelere kaynak aktarılmaya devam edilmiştir (Can ve Akdenizli Kocagül, 2008: 29-30 ; Goulet,2008: 15);

- Hedef 1: GSMH'sı AB ortalamasının \%75'inden az olan en fakir bölgeler için belirlenmiştir. Özellikle İspanya, Portekiz, Yunanistan, İtalya ve Doğu Almanya bu hedeften yararlanmıştır.

- Hedef 2: Yüksek işsizlik oranlarının olduğu veya iş kayıplarının yaşandığı alanlar için belirlenmiş̧ir. Özellikle eski üretim teknolojilerine sahip, endüstriyel alanda çöküşün yaşandığı Merkezi-Kuzey Avrupa bölgeleri ile İtalya ve İspanya'nın bazı bölgeleri için tanımlanmıştır.

- Hedef 3 ve 4: Uzun süreli işsizlik ile mücadele, genç nüfus için yeni iş alanlarının yaratılması amacıyla belirlenmiştir. İngiltere, Fransa, Almanya, İspanya ve İtalya bu hedeften en fazla yararlanan ülkelerdir.

- Hedef 5: Tarımsal ve kırsal alanlara yardım edilmesi amaçlanmıştır.

- Hedef 6: Birliğin 1995 genişlemesinden sonra, Kuzey Avrupa'nın düşük yoğunluklu bölgeleri için bu hedef eklenmiştir.

\begin{tabular}{|c|c|c|c|c|}
\hline Üye Ülke & $\begin{array}{c}\text { Geri Kalmıs } \\
\text { Bölgeler } \\
\text { (Hedef 1) }\end{array}$ & $\begin{array}{c}\text { Sanayi } \\
\text { Bölgeleri } \\
\text { (Hedef 2) }\end{array}$ & $\begin{array}{c}\text { Kırsal } \\
\text { Bölgeler } \\
\text { (Hedef 5b) }\end{array}$ & $\begin{array}{c}\text { Düşük Nüfus } \\
\text { Yoğunluğu Olan } \\
\text { Bölgeler (Hedef 6) }\end{array}$ \\
\hline Belçika & 730 & 342 & 195 & 0 \\
\hline Danimarka & 0 & 119 & 54 & 0 \\
\hline Almanya & 13640 & 1566 & 1227 & 0 \\
\hline Yunanistan & 13980 & 0 & 0 & 0 \\
\hline İspanya & 26300 & 2416 & 664 & 0 \\
\hline Fransa & 2190 & 3774 & 2238 & 0 \\
\hline İrlanda & 5620 & 0 & 0 & 0 \\
\hline İtalya & 14860 & 1463 & 901 & 0 \\
\hline Lüksembourg & 0 & 15 & 6 & 0 \\
\hline Hollanda & 150 & 650 & 150 & 0 \\
\hline Avusturya & 162 & 99 & 403 & 0 \\
\hline Portekiz & 13980 & 0 & 0 & 450 \\
\hline Finlandiya & 0 & 179 & 190 & 247 \\
\hline İsveç & 0 & 157 & 135 & 0 \\
\hline Birleşik Krallık & 2360 & 4581 & 817 & 67 \\
\hline Toplam AB-15 & 93972 & 15360 & 6862 & \\
\hline
\end{tabular}

Tablo 1. 1994-1999 Yllları Arası AB Bölgesel Kalkinma Fonları (1994 fiyatlartyla, Milyon ECU). Kaynak: (ESPON: 46)

1990 yılında, Avrupa Komisyonu ilk defa sinır bölgelerinin desteklenmesi amaciyla Interreg topluluk girişimini yürürlüğe koymuştur. 1990-1993 döneminde, Interreg I programlarına 1,082 milyar ECU kaynak aktarılmış̧ır. Kaynağın büyük bir bölümü Hedef 1 bölgeleri olan sınır bölgelerinde kullanılmışıtır. Hedef 1 bölgeleri dışında kalan sınır bölgelerinde Interreg I'den 125 milyon ECU kaynak kullanılmıştır. Interreg I programlarıyla, sınır bölgelerinin ekonomik kalkınması ve yeniden yapılandırılması amaçlanmıştır. 1992 yılında 
Interreg topluluk girişiminin, 1994-1999 döneminde de devam ettirilmesine karar verilmiştir. 1994 yılında Interreg II Programı yayımlanmıştır. Bu program 3,519 milyar € toplam bütçe ile topluluk girişimleri içinde en büyük payı almıştır (Ohtamış, 2008: 7).

1994-1999 yılları arasında AB bütçesi içinde yapısal fonların miktarı birlik bütçesinin 1/3'ü yani (ECU'ya göre) 141 milyardır. Bunun nedeni birliğe yeni üye olan ülkelerin birlik içindeki geri kalmış bölgelerinin oranının yüksek olmasıdır (Prince, 24,25).

1993 yılında yürürlüğe giren Maastricht Antlaşması ile topluluk, farklı bölgelerin kalkınmışlık düzeyleri arasındaki dengesizlikleri azaltmayı hedeflemiştir. Antlaşma ile ekonomik ve parasal birliğin tamamlanması için konan hedeflere ulaşılması amacıyla İrlanda, Yunanistan, Portekiz ve İspanya'yı desteklemek üzere Uyum Fonu (Cohesion Fund) ile balıkçılık sektörüne yönelik Balıkçılığı Yönlendirme Mali Aracı FIFG- Financial Instrument for Fisheries Guidance) kurulmuştur. 1987-1997 döneminde Uyum Fonu kapsamında yer alan bu dört ülkede kişi başı GSMH \% 67.6'dan \% 78.8'e yükselmiştir. Fonlar tarafından desteklenen bölgelerde yine bu dönemde 2.2 milyon iş yaratılmıştır (Karabacak, 2004: 74 ; Onur, 2009: 49).

\section{2 İkinci Dönem (2000-2006)}

1997 tarihinde kabul edilen ve AT Komisyonu tarafından hazırlanan Gündem 2000, AB'nin genişlemesi, 1999 tarihinden sonra AB'nin mali çerçevesinin nasıl olması gerektiğini açıklayan bir belgedir (Can ve Akdenizli Kocagül, 2008: 36 ; Onur, 2009: 48). Yine 2000 y1lında Lizbon Zirvesi'nde onaylanan ve Lizbon Stratejisi adıyla anılan belgede istihdamı, ekonomik reformları ve sosyal uyumu güçlendirmek, 2010 yılında AB'nin sürdürülebilir bir ekonomik büyüme ortamında, dünyanın en rekabetçi ekonomik bloğu haline getirilmesi hedeflenmiştir. Gündem 2000 ve Lizbon Stratejileri doğrultusunda AB Bölgesel Politikası 2000-2006 döneminde yeniden yapılandırılmıştır (Atakişi,2006: 15; Yılmaz, 2010: 24).

\begin{tabular}{|c|c|c|c|}
\hline \multirow{5}{*}{$\begin{array}{l}\text { İlgili } \\
\text { Fon }\end{array}$} & Hedef 1 & Hedef 2 & Hedef 3 \\
\hline & $\begin{array}{l}\text { Avrupa Bölgesel Kalkınma Fonu } \\
\text { (ERDF) }\end{array}$ & $\begin{array}{l}\text { Avrupa Bölgesel Kalkınma } \\
\text { Fonu (ERDF) }\end{array}$ & $\begin{array}{l}\text { Avrupa Sosyal } \\
\text { Fonu (ESF) }\end{array}$ \\
\hline & Avrupa Sosyal Fonu (ESF) & Avrupa Sosyal Fonu (ESF) & - \\
\hline & $\begin{array}{l}\text { Avrupa Tarımsal Yönlendirme } \\
\text { ve Garanti Fonu-Yönlendirme } \\
\text { Kısmı (EAGGF) }\end{array}$ & - & - \\
\hline & $\begin{array}{l}\text { Balıkçılık Yönlendirme Mali } \\
\text { Aracı (FIFG) }\end{array}$ & - & - \\
\hline
\end{tabular}

Tablo 2. 2000-2006 Dönemi Hedefleri ve Mali Araçlarl. Kaynak: (Gençkol, 2003: 22).

$\mathrm{Bu}$ dönemde $\mathrm{AB}$ 'de yapısal fonların etkinleştirilmesi amacıyla altı olan hedef sayısı üçe indirilmiştir. Bunlar (Y1ldız ve Akdağ, 2006:4);

- Hedef 1 :Gelişmede geri kalmış bölgelerin kalkınma ve yapısal uyumunun teşviki olarak kabul edilmiştir. Hedef 1 ve Hedef 6, 2000-2006 döneminde bu hedef altında birleştirilmiştir. Hedef 1 kapsamındaki bölgelerin, Avrupa Bölgesel Kalkınma Fonu (ERDF), Avrupa Sosyal Fonu (ESF), Avrupa Tarımsal Yönlendirme ve Garanti Fonu (EAGGF) ile Balıkçılık Yönlendirme Mali Aracı'ndan yararlanacağı belirtilmiştir.

- Hedef 2 :Yapısal sıkıntı içinde ve sosyo-ekonomik dönüşüm içerisinde olan bölgelerin ekonomik ve sosyal değişiminin desteklenmesini ele almaktadır. Eski Hedef 2 ile 5b ve 5a'nın bir bölümü olarak balıkçılık sektörüne bağlı kriz bölgeleri de burada ele alınmaktadır. Bu bölgeler Avrupa Bölgesel Kalkınma Fonu ve Avrupa Sosyal Fonu tarafindan desteklenmektedir.

- Hedef 3 :Hedef 1 ve Hedef 2 bölgelerinde ele alınmayan bölgeleri kapsar. Eski Hedef 3 ve 4 buraya girmektedir. Bu konudaki önlemler Avrupa Sosyal Fonu tarafından desteklenmektedir.

Yapısal fonlar için, 2000-2006 döneminde 195 milyar Euro olan toplam bütçenin, Destek Fonları hariç \%70’i Hedef 1 bölgeleri, \%11,5 Hedef 2 ve \%12'si Hedef 3 bölgeleri için ayrılmıştır (Reeves, 2006: 41).

2000-2006 döneminde, Topluluk Girişimleri adı altında Urban II, Equal, Leader+ ve Interreg III programları yürütülmeye devam edilmiştir.

Interreg Ill : Interreg III, AB'de sınır ötesi, uluslararası ve bölgelerarası işbirliğini teşvik ederek, ekonomik ve sosyal uyumu güçlendirmeyi hedefler (Valencıana, 2006: 9). Avrupa bölgesinin uyumlu ve dengeli kalkınmasını amaçlar. Avrupa ötesi işbirliği ile ilgili topluluk girişimidir. Girişim topluluk içindeki ortak sınır bölgelerinde, topluluk üyesi ülkelerle sınırları bulunan ülkelerin sınır bölgeleri arasında ve topluluğun kendi içindeki bölgeleri arasında dengeli bir kalkınma için işbirliği öngörür. Bu girişimlerin finansmanı ABKF tarafından sağlanmıştır (Yıldız ve Akdağ, 2006: 4-5).

Interreg programı, 1990-2006 döneminde üç evreden geçiştir: Interreg I (1990-1993), Interreg II (19941999) ve Interreg III (2000-2006). Giderek önemi artan bir topluluk girişimi olan Interreg, 2007-2013 
döneminde (2006 tarihinde) Avrupa Bölgesel Kalkınma Fonu, Avrupa Sosyal Fonu ve Uyum Fonu hakkında genel kuralları koyan Avrupa Alansal İşbirliği (European Territorial Cooperation) adı altında AB uyum politikasının üç temel hedefinden biri haline gelmiştir. 2000-2006 döneminde Interreg III'e, ABKF'den 4,875 milyar Euro kaynak aktarılmıştır (Ohtamış, 2008: 6,7 ; European Union, 2004: 4,5).

Interreg III, dış sınırları ve bazı deniz sınırlarını da içeren sınır-ötesi komşular arasında entegre edilmiş bir bölgesel kalkınmayı teşvik etmeyi amaçlamaktadır. Interreg III bu kapsamda 2004-2006 arasında TürkiyeYunanistan Sınır Ötesi İşbirliği Programı’nı oluşturmuştur. İkinci olarak topluluğun her yanında uyumlu bölgesel entegrasyona katkıda bulunma amaçlanmaktadır. Son olarak da ulus ötesi, bölgeler arası işbirliği aracılığıyla bölgesel kalkınmayı ve uyum tekniklerini iyileştirme ve bilgi, tecrübe paylaşımı amaçlanmaktadır (European Union Panteia, 2010: 12; Devlet Planlama Teşkilatı Müsteşarlığı, 2005: 42).

Üye olmayan ülkelerin AB yapısal fonlarından para kullanması uygun olmadığından, aday ülkelere PHARE programından fon kullanabilme imkanı tanınmıştır. PHARE, 1989 yılında G7 ülkeleri tarafından oluşturulmuştur. Polonya ve Macaristan'ın siyasi ve ekonomik değişim sürecinin desteklenmesini öngören bir programdır. Daha sonra bu programa AB'ye aday olan tüm Orta ve Doğu Avrupa ülkeleri dahil edilmiştir. 2000 yılına kadar, Batı Balkan ülkelerinden Arnavutluk, Bosna-Hersek ve Mekodonya da PHARE fonlarından yararlanmışlardır. Ancak 2001'de bu ülkelere CARDS programı ile (Community Assistance for Reconstruction, Development and Stability in the Balkans) finansal yardım yapılmaya başlanmıştır (Bilgili, 2006: 70).

Leader+ : Kırsal kalkınma için oluşturulan topluluk girişimidir. Girişimin amacı, kırsal kalkınmaya yönelik teşviki sürdürmektir. Girişim Leader+ fonlarından yararlanmayanlar da dahil olmak üzere tüm AB kırsal alanlarının ağlandırılmasını kapsar (European Court of Audıtors, 2010: 8). Leader'in finansman kaynağı ATYGF'nun Yönlendirme Bölümü olarak belirlenmiştir (Gençkol, 2003: 20).

Equal: $\mathrm{Bu}$ girişim istihdamda eşitsizlik ve ayrımcılıkla mücadeleyi amaçlayan projelere finansman sağlamaktadır. Girişim, erkeklerin ve kadınların iş bulmasına engel olan ayrımcılık ve eşitsizliğin tüm biçimleriyle savaşır. $\mathrm{Bu}$ alandaki projeler, ASF tarafından finanse edilmiştir (Bernard Brunhes Internatıonal, 2006: 2).

Urban II: Kentsel alanlarla ilgili topluluk girişimidir. Bu program 1994-1999 yılları arasında uygulanmış bulunan Urban I programının devamı niteliğindedir. Urban girişimi sorunlu bölgelerin sosyal, sağlık ve güvenlik koşullarını iyileştirmeyi, sürdürülebilir kentsel kalkınmayı amaçlar. Bu girişim şehir ve köylerin toplumsal ve ekonomik yönden canlandırılması için yenilikçi stratejiler önermiştir. Finansman kaynağı ABKF olarak belirlenmiştir (Can ve Kocagül, 2008: 55).

Orta ve Doğu Avrupa ülkelerinin kalkınma çabaları için, 2000-2006 yılları arasında, PHARE, ISPA ve SAPARD gibi katılım öncesi mali yardım araçları çerçevesinde, birliğe aday ülkelerin birliğin bölgesel kalkınma politikaları ile ekonomik ve sosyal uyumunu sağlayabilmek amacıyla mali yardım aktarılmıştır. Bu bağlamda, on aday ülke için, katılımları gerçekleşinceye kadar üç değişim katılım öncesi araç kabul edilmiştir.

SAPARD (Tarım ve Kırsal Kalkınma İçin Özel Katılım Programı): SAPARD, aday ülkelerin tarımsal sektörleri ve kırsal alanda yapısal uyumla birlikte topluluk ortak tarım politikasını içeren Topluluk müktesebatının uygulanmasına ilişkin sorunlarının çözümüne yardımcı olmayı amaçlamaktadır. Program, çiftçilikte ve gida sanayide rekabet edebilirliği güçlendirmeye, istihdam yaratmaya ve kırsal alanlarda sürdürülebilir kalkınmaya yönelik tedbirleri de desteklemektedir. Programın 2006 yılına kadar yıllık 520 milyon Euro'luk (1999 fiyatlarıyla) bir bütçesi bulunmaktadır. Aday ülkeler SAPARD'dan 2000 yılında başlamak üzere, Birliğe üye oldukları tarihe kadar yararlanabilmiştir (Ildırar, 2004: 155).

ISPA (Katılım Öncesi Yapısal Politika Aracı): ISPA, aday ülkelerin ulaştırma ve çevre altyapılarını güçlendirmeye yönelik projelere kaynak aktarır. Aday ülkelerin AB politika ve süreçleriyle yakınlaşmasını sağlar. Aday ülkeleri topluluk çevre standartlarıyla uyum çabalarında destekler. Trans-Avrupa şebekelerine aday ülkelerin girmesini ve bu şebekelerin aday ülkelere açılmasını sağlamaya çalışır. ISPA kaynakları, programdan faydalanan ülkeler arasında nüfus, kişi başına GSYİH ve ülke alanı kriterlerine dayanılarak paylaştırılmaktadır (Karataş, 2010: 57-62).

PHARE (Doğu ve Orta Avrupa Ülkelerini Yeniden Yapılandırma Programı): PHARE; SAPARD ve ISPA programlarının içermediği alanlarda, bölgesel kalkınma politikaları dahil, Topluluk programlarına iştirak ile sınai kalkınma ve KOBİ'lerin geliştirilmesine ilişkin projelere destek sağlar. PHARE Programı, aday ülkelere üyelik yükümlülüklerinin üstlenilmesi için gerekli yasal ve kurumsal alt yapının oluşturulma sürecini desteklemeye yönelik geliştirilmiştir. PHARE Programı, başlangıçta Polonya ve Macaristan'ın ekonomilerinin yeniden yapılandırılmasına yardımcı olmuştur. Bu program çerçevesindeki yardımlar hibe şeklindedir (Ildırar, 2004: 157).

PHARE Programı çerçevesinde Avrupa Birliği’ne aday ülkelere 2002 yılında toplam 1,4 Milyon Euro'Iuk yardım yapılmıştır. En fazla yardım Polonya’ya yapılmıştır. bu ödenekten en fazla pay alan ülke olmuştur. 2002 yılında 449,8 Milyon Euro ile en fazla Polonya'ya yardımda bulunulmuştur. En az yardım ise 40,4 Milyon Euro ile Estonya'ya yapılmıştır.

2000-2006 döneminde yapısal fonlara ayrılan kaynaklar arttırılmış, bölgesel politikanın 2007'den sonra 
izleyeceği yolun belirlenmesi ile ilgili stratejiler geliştirilmiş ve hedefler yeniden tanımlanarak yapısal fonlarda birtakım değişiklikler yapılmıştır.

\begin{tabular}{|c|c|c|c|}
\hline Ülke Adı & $\begin{array}{c}\text { Ödenek Tutarı } \\
\text { (Milyon Euro) }\end{array}$ & Ülke Adı & $\begin{array}{c}\text { Ödenek Tutarı } \\
\text { (Milyon Euro) }\end{array}$ \\
\hline Bulgaristan & 162,9 & Polonya & 449,8 \\
\hline Çek Cumhuriyeti & 103,8 & Romanya & 278,5 \\
\hline Estonya & 40,4 & Slovakya & 89,1 \\
\hline Macaristan & 120,7 & Slovenya & 41,9 \\
\hline Litvanya & 47,3 & Toplam & 1.405 \\
\hline Letonya & 80,5 & & \\
\hline
\end{tabular}

Tablo 3. PHARE Ülke Ödenekleri (2002-MiIyon Euro). Kaynak: (Ildırar, 2004: 158).

\section{3 Üçüncü dönem (2007-2013)}

2007-2013 dönemi için 7. Çerçeve Programı hazırlanmıştır. Program Lizbon hedeflerini gerçekleştirmek amacıyla, araştırmayla ilgili tüm AB girişimlerini bir araya toplamak, Avrupa Araştırma Alanı'nı kurma çalışmalarını daha ileriye götürmek, Avrupa'da bilgi temelli ekonomi ve toplumu inşa etmek üzere oluşturulmuştur. 7. Çerçeve Programı, İşbirliği Özel Programı, Fikirler Özel Programı, Kişiyi Destekleme Özel Programı ve Kapasiteler Özel Programı’ndan oluşmaktadır (Kara, 2008: 143,144);

- İşbirliği Özel Programı, sağlık, gıda, tarım ve biyo-teknoloji, bilgi ve iletişim teknolojileri, nano-bilimler, nano-teknolojiler, enerji, çevre, taşımacılık, sosyo-ekonomik ve beşeri bilimler ile güvenlik ve uzay konularını içerir.

- $\quad$ Fikirler Özel Programı, Avrupa'da mevcut Ar-Ge insan kaynağının niceliği ve niteliğini güçlendirmek üzere yaratıcı bilim adamlarını, mühendisleri ve öğretim görevlilerini desteklemeyi amaçlar. Bağımsız bir Avrupa Araştırma Konseyi’nin kurulması da öngörülmektedir.

- Kişiyi Destekleme Programı, insanları meslek olarak araştırmacı olmaya ve Avrupalı araştırmacıları Avrupa içinde kalmaya teşvik eder. Dünya genelindeki araştırmacıları ise Avrupa'ya çekerek, Avrupa'yı araştırmacılar için daha cazip hale getirmeyi amaçlar.

- Kapasiteler Özel Programı ise Avrupa genelinde araştırma ve yenilikçilik yeteneklerinin geliştirilmesini hedefler. Bu program dahilinde araştırma altyapıları, KOBİ yararına araştırmalar, toplumda bilim, araştırma politikalarının gelişimi, uluslararası işbirliği faaliyetleri ve bilgi bölgeleri konularında araştırma ve yenilikler desteklenecektir.

\section{AB Bölgesel Politikasının Uygulanmasına Yönelik Araçlar}

Yapısal fonların temel amacı üye devletler ve bölgeler arasındaki sosyal ve ekonomik gelişmişlik farklılıklarını azaltmaktır.

\subsection{Avrupa Bölgesel Kalkınma Fonu}

Avrupa Bölgesel Kalkınma Fonu (ABKF), 1975 yılında kurulmuştur. Fon, az gelişmiş bölgelerin kalkınması ve yapısal yönden iyileştirilmesi ile gerileyen sanayi bölgelerinin yeniden yapılanmasına katkıda bulunmak suretiyle temel bölgesel dengesizliklerin azaltılmasına yardım etmektedir. ABKF, sanayi ve hizmetler sektöründe yeni iş alanları yaratıcı veya mevcut iş olanaklarını koruyucu yatırımlar veya altyapı yatırımlarına hibe niteliğinde yardımda bulunmaktadır. 2006 yılında kentsel alanlarda ekonomik, sosyal ve çevresel sorunların çözülmesi, kırsal alanlar ve balıkçılık sektörüne dayalı alanlarda ekonomik çeşitliliğin arttırılması, en uzak bölgelerde çeşitli teşviklerin sağlanmasına ilişkin düzenlemeler yapılmıştır (Bozdoğan 2008: 64-66).

\subsection{Avrupa Sosyal Fonu}

Avrupa Sosyal Fonu, sadece belirli bölgeler için değil, Avrupa Birliği içindeki bütün bölgeler içindir. İşsizliği azaltmaya yönelik yeni iş sahaları açmayı, mesleki eğitimi ve iş sahibi olma konusunda danışmanlığı amaçlayan projeler, fon tarafından desteklenmektedir. Görev alanına giren yerleşim birimlerinde, personel istihdam eden, ekonomik, sosyal ve kültürel hizmetler yapan, yeni iş sahalarının açılmasında bizzat girişimci veya özel sektöre yol gösterici ve kolaylık sağlayıcı kurumlar olan yerel yönetimler, sayılan amaçları sağlamaya yönelik projeler için Avrupa Sosyal Fonu'ndan yardım alabilmektedir (Kösecik ve Koçak, 2004: 3).

\subsection{Uyum Fonu}

Maastricht Antlaşması ile, İrlanda, Yunanistan, Portekiz ve İspanya gibi GSMH'sı Topluluk ortalamasının \%90'ından az olan ülkeleri desteklemek üzere, Uyum Fonu'nun kurulması kararlaştırılmıştır. Fon ile bu ülkelerin çevre ve ulaşım altyapı ağlarının geliştirilmesi hedeflenmiştir. 2004 yılındaki büyük genişlemeden önce ağırlıklı olarak İspanya, Yunanistan, İrlanda ve Portekiz gibi 4 üyenin kullandığı Uyum Fonu'ndan, 2007-2013 döneminde Bulgaristan, Çek Cumhuriyeti, Estonya, Yunanistan, Kıbrıs, Litvanya, Letonya, Macaristan, İspanya, Malta, Polonya, Portekiz, Romanya, Slovenya ve Slovakya olmak üzere toplam 15 üye yararlanmaktadır (Bozdoğan, 2008: 68-70). 


\subsection{Diğer fonlar}

Avrupa Balıkçılık Fonu: 2007-2013 döneminde, Ortak Balıkçılık Politikası’nın uygulamasına yönelik tespit edilen; ekonomik, sosyal ve çevresel hedeflere mali destek sağlamak için 2007 yılında uygulamaya giren yeni bir mali araçtır. Balıkçılığı Yönlendirme Mali Aracı'nın yerini almıştır. Fon üye ülkelerdeki balıkçılık sektörünün büyüklüğüne, çalışan kişi sayısına ve balıkçılık sektörünün ihtiyaçları oranında kaynak aktarmaktadır (Doğan, 2011: 4,5).

Topluluk, 2005 yılında iki yeni fonun kurulmasını kararlaştırmıştır. Bunlar Avrupa Tarımsal Garanti Fonu (ATGF) ile kırsal kalkınma için Avrupa Kırsal Kalkınma Fonu (AKKF)'dur. ATGF kırsal kalkınmayı sağlayacak; AKKF ise kırsal alanda işsiz kalmış insanların kendi mesleklerine entegrasyonunu, kırsal genç nüfusu kendi meslekleriyle ilgili işlere entegre etmeyi, istihdam yaratmada genişlemeyi, AraştırmaGeliştirme'de eğitim ve insan potansiyelinin katkısını arttırmayı sağlayacak bir mali araç olarak belirlenmiştir (Yıldız ve Yardımcıŏlu, 2005: 82; Gürlük, 2001: 7).

\subsection{Yeni topluluk girişimleri}

2007-2013 döneminde, yapısal fonların ve uyum fonunun en etkin şekilde kullanımını sağlamak amacıyla, üç yeni Topluluk Girişimi oluşturulmuştur (Can ve Akdenizli Kocagül, 2008: 69-70);

- Jessica: Girişiminin amacı, kentsel alanlarda istihdamın, ekonomik büyümenin ve sürdürülebilir yatırımların arttırılmasıdır. Bu girişimin Avrupa Komisyonu, Avrupa Yatırım Bankası ve Avrupa Bankası Konseyi’nin işbirliğinde yürütülmesi öngörülmüştür.

- Jaspers: Girişiminin amacı, ulaşım ve enerji altyapı projeleri, enerji etkinliği ve yenilenebilir enerji projeleri gibi büyük ölçekli projelerde, üye devletlere teknik yardım ve uzman desteği sağlamaktır.

- Jeremie: Girişim küçük ve orta ölçekli işletmeleri finanse etmek amacıyla başlatılmıştır.

\subsection{Avrupa Yatırım Bankası}

Avrupa Yatırım Bankası 1958'de kurulmuştur. Bankanın temel faaliyet alanları bölgesel kalkınma; ulaştırma, iletişim, çevre ve enerji altyapıları; Avrupa sanayinin desteklenmesidir. Bankanın bölgesel etkisi olan faaliyetlere giderek daha fazla iştirak ettiği görülmektedir. Bu amaçla, geri kalmış bölgelerin kalkınması, ulusal fonlardan desteklenmeyen işletmelerin modernizasyonu ve yeni iş alanlarının oluşturulması, üye ülkelerin tek başlarına finanse edemeyecekleri ve Topluluk yararına olan büyük altyapı projelerine uzun vadeli krediler sağlanmaktır (Ildırar, 2004: 154,155).

\section{Sonuç}

$\mathrm{AB}$, hem üye ülkeler bazında hem de üye ülkelerin farklı bölgeleri bazında oldukça büyük gelişme farklılıklarını bünyesinde taşıyan bir birliktir. Birlik'in genişlemesine bağlı olarak gelişmişlik açısından önemli farklar ortaya çıkmış ve bu farklılıkların giderek daha da büyümesi, AB'yi bir bölgesel politika oluşturma sürecine götürmüştür. $\mathrm{AB}$ bölgesel politikası, ekonomik birliğin güçlendirilmesini, dengeli bir kalkınma için bölgesel farklılıkların azaltılmasını, geri kalmış bölgelerin rekabet gücünün arttırılmasını, iş olanaklarının çoğaltılmasını, ayrıca kırsal ve kentsel kesimlerde dengeli bir kalkınmayı amaçlamaktadır.

AB kendi üyeleriyle kalkınma odaklı programlar yürütmekte, bu alandaki projelere mali kaynak sağlamaktadır. $\mathrm{Bu}$ yardımlar istihdam üzerinde olumlu bir etki bırakmakta, bölgelerarası rekabet gücünü de arttırmaktadır. Birlik, bölgesel politikanın temel amaçlarının gerçekleştirilmesi doğrultusunda, temel olarak Yapısal Fonlar aracılığı ile mali kaynak sağlamaktadır. Yapısal Fonlar kapsamında üye ülkelere yapılan mali yardımlardan en fazla, geri kalmış güney ülkeler yararlanmaktadır.

Türkiye ise, AB üyesi olmadığı için Yapısal Fonlar kapsamında verilen mali yardımlardan yararlanamamaktadır. Ancak $\mathrm{AB}$, aday ülkelerin $\mathrm{AB}$ müktesebatına uyum sağlayabilmesi ve bu ülkelerin $\mathrm{AB}$ ile olan gelişmişlik farklarının azaltılabilmesi için de maddi destek sunmaktadır. Özellikle az gelişmiş bölgelerin kalkınması amacıyla verilen bu fonlar, AB'ye aday ülkelerinin bölgesel farklılıklarını azaltabilmektedir. AB, Türkiye'nin de çeşitli fonlardan yararlanabilmesine imkan sağlamaktadır. Bu çerçevede bu fonların Türkiye'nin ekonomik, sosyal ve kültürel açıdan AB ile uyum sorunlarını azaltmasının yanı sıra, Türkiye içindeki bölgesel gelişmişlik farklılıklarını da azaltacağı beklenmektedir.

\section{Kaynakça}

- Altay, İclal Kaya, 2005. “Avrupa Mekansal Gelişme Perspektifi'nde (ESDP) Kirsal Alan Politikaları”, MSGSÜ Şehir ve Bölge Planlama Böl. 7. Kırsal Alan Semineri, Planlama 2005/2, ss.82-88.

- Altınışık İsa ve Hasan Sencer Peker, 2010. "Bölgesel Kalkınma Ajansları, Ekonomik Önemi, Avrupa Birliği ve Türkiye'deki Durumları”, Bütçe Dünyası Dergisi, Sayı 34, 2010/2, ss. 145-156.

- Arslan, Erdal, 2010. "Kalkınma Ajansları ve Kalkınma Ajanslarının Türkiye Ekonomisine Beklenen Katkıları”, Kamu-İ̧ Dergisi, C:11, S:3/2010.

- Arslan, Kahraman, 2005. "Bölgesel Kalkınma Farklılıklarının Giderilmesinde Etkin Bir Araç: Bölgesel Planlama ve Bölgesel Kalkınma Ajansları”, İstanbul Ticaret Üniversitesi Sosyal Bilimler Dergisi, Yı1:4 
Sayı:7 Bahar 2005/1.

- Atakişi, Ahmet, 2006. “Avrupa Birliği Bölgesel-Kırsal Kalkınma Politikasının Yapısı ve İşleyişi”, Trakya Üniversitesi Sosyal Bilimler Dergisi, Haziran 2006, Cilt 8, Sayı 1, ss.10-26.

- Bernard Brunhes International, European Commission DG Employment and Social Affairs, 2006. EU-Wide Evaluation of the Community Initıatıve Equal 2000-2006 Final Report, Volume 1, July 2006.

- Bilgili, Emine, 2006. "Türkiye'nin Üyeliğinin Avrupa Birliği Bütçesine Muhtemel Etkisi”, Ç.Ü. Sosyal Bilimler Enstitüsü Dergisi, Cilt 15, Sayı 2, ss.61-80.

- Bozdoğan, Mine Nur, 2008. Bölgesel Kalkınmanın Sağlanmasına Yönelik Vergi Özendirme Önlemlerinin Türkiye Açısından İncelenmesi ve Etkinliğinin Analizi, Türkiye Odalar ve Borsalar Birliği, Ankara.

- $\quad$ ESPON 2.2.1, Territorial Effects of Structural Funds, Second Interim Reports, Nordregio, Sweden.

- Can, Ergüder ve Dilek Akdenizli Kocagül, 2008.Avrupa Birliği'nde Bölgesel Politika'nın Gelişimi ve Yapısal Fonlar, Türkiye Ekonomi Politikaları Araştırma Vakfı TEPAV Yayını, İstanbul.

- Commission of the European Communities, 2000. INTERREG III, Communication From The Commission To The Member States of 28.4.00, 28.4.00 C(2000) 1101-EN, Brussels.

- Devlet Planlama Teşkilatı Müsteşarlığı1, 2005. Türkiye-Avrupa Birliği Mali İşbirliği Kapsamındaki Bölgesel Kalkınma Programları, Şubat 2005, Ankara.

- Çağrı Doğan, 2011. AB Balıkçılık Politikası ve Türkiye’nin Uyum Sürecindeki Durumu, İzmir Ticaret Odası Yayını.

- European Union, INTERact, 2004. Frequently Asked Questions in INTERREG Programmes,

- European Union Panteia, 2010. INTERREG III Community Initiative (2000-2006) Ex-Post Evaluation, No. 2008.CE.16.0.AT.016, Final Report Zoetermeer.

- European Court of Auditors, 2010. Implementation Of The Leader Approach For Rural Development, Special Report No 5, Luxembourg: Publications Office of the European Union,

- Gürlük, Serkan, 2001. "Dünyada Ve Türkiye'de Kırsal Kalkınma Politikaları Ve Sürdürülebilir Kalkınma”, Uludă̆ Üniversitesi İktisat Fakültesi Dergisi, Cilt:19, Sayı: 4, Kış Dönemi Aralık, Bursa.

- Ildırar, Mustafa, 2004. Bölgesel Kalkınma ve Gelişme Stratejileri, Nobel Yayın Dağıtım, Ankara.

- Kara, Murat, 2008. Bölgesel Rekabet Edebilirlik Kavramı ve Bölgesel Kalkınma Politikalarına Yansımaları, DPT Yayın No: 2774, Ankara,

- Karabacak, Hakan, 2004. “Avrupa Birliği Mali Yardımları ve Türkiye ile Mali İşbirliğii”, Maliye Dergisi, Sayı: 146, ss.69-106

- Karataş, Halil, 2010. Avrupa Birliği Katılım Öncesi Mali Yardımları, Maliye Bakanlığı Strateji Geliştirme Başkanlığı, Yayýn No:2010/409, Ankara.

- Kösecik Muhammet ve S.Yaman Koçak, 2004. “Avrupa Birliği Bölgesel Politikası ve Yapısal Fonlar”, Kentsel Ekonomik Araştırmalar Sempozyumu Cilt II, Denizli, ss.1-19.

- Gençkol, Metin, 2003. Avrupa Birliği Mali İşbirliği Politikaları ve Türkiye, Devlet Planlama Teşkilatı Yayın No : 2679, Ankara.

- Goulet, Raphaël, 2008. EU Cohesion Policy 1988-2008: Investing in Europe's Future, European Commission, Regional Policy DG, Inforegio Panorama, No:26,

- Ohtamış, Erol, 20088. Avrupa Birliği Sınır Ötesi İşbirliği Programları Yönetim Yapıları ve Türkiye Uygulamaları, Devlet Planlama Teşkilatı Yayın No: 2772, Temmuz 2008, Ankara.

- Onur, Ayşenur, 2009. “IPA ve Yapısal Fonlar”, Bütçe Dünyası, Cilt 3 Sayı 31 Kış, ss.45-59.

- Prince, Jean Claude, Interregıonal Trade Unıon Councıls In Europe, Interregional Trade Union Councils in Europe, DWP 95.03.1 (E).

- Reeves, Teresa, 2006. “AB ve Türkiye’de Bölgesel Kalkınma”, TEPAV Bölgesel Kalkınma ve Yönetişim Sempozyumu Kitabı, Bölgesel Kalkınma ve Yönetişim Avrupa Perspektifi, ss.39-48.

- Valenciana, Generalıtat, 2006. Thrid Country Partıcıpatıon In Interregıonal Cooperatıon, European Union INTERact, November 2006, Spain.

- Y Yldız, Fatih Feramuz ve Kerem, Akdağ, 2006. “Avrupa Birliği Yapısal Fonları Kapsamında Bölgesel Kalkınma İle Kırsal Kalkınma Fonlarının Karşılaştırılması”, Tarım ve Köyişleri Bakanlığı Türktarım Dergisi, Sayı: 167, Ankara, ss.1-17.

- Yıldız Habib ve Fatih Yardımcıŏlu, 2005. "Türkiye’ye Yönelik Avrupa Birliği Mali Yardımları ve Aday Ülkelerle Karşılaştırılması”, C.Ü. İktisadi ve İdari Bilimler Dergisi, Cilt 6, Sayı 2, ss.75-106.

- Yılmaz, Latif, 2010. Avrupa Birliği'nin Sosyo-Ekonomik Geleceği: Lizbon Stratejisi ve Küreselleşme, Maliye Bakanlığı Avrupa Birliği ve Dış İlişkiler Dairesi Başkanlığı Araştırma ve İnceleme Serisi: 4, Ankara. 


\title{
Bağımsız Devletler Topluluğu Ülkelerinde Yakınsama: Satınalma Gücü Paritesine Göre Analiz
}

\author{
Hüseyin Avni Egeli (Dokuz Eylül University, Turkey) \\ Hakan Kahyaoglu (Dokuz Eylül University, Turkey) \\ Pınar Egeli (Celal Bayar University, Turkey)
}

\section{Convergence in the Commonwealth of Independent States: An Analysis of Purchasing Power Parity}

\begin{abstract}
In the early years following the break-up of the Communist system, people living in the Eastern Europe and Central Asian region experienced large-scale and swift economic and political changes. People in many of these countries have started to enjoy greater personal and political freedom. Moreover, these countries are demonstrating encouraging economic progress and growth. By reviewing the related literature, convergence denotes a decrease in difference between economic units according to determined criterion or criteria. Studies dealing with convergence particularly examines whether there exists a convergence between countries with respect to income increase. With respect to these findings, a literature has developed to investigate whether there exists a convergence between countries to specified criteria oriented. The main aim of this study is to test whether there exist a convergence according to purchasing power across Commonwealth of Independent States member countries. The existence of a convergence according to purchasing power parity across countries could show the substance of an economic integration. Moreover, this could yield information whether this area is a common market or not. In this paper for studying convergence Persyn ve Westerlund approach has been used.
\end{abstract}

JEL Codes: O15, O47, O57

\section{Giriş}

Komünist sistemin çöküşünü izleyen ilk yıllarda Avrupa ve Orta Asya (ECA) bölgesinde yaşayan insanlar hızlı bir ekonomik ve politik değişim süreci yaşadılar. Bu değişim sosyal yaşamın her düzeyinde etkili oldu: Toplum, sosyal gruplar ve sosyal organizasyonlar, aileler ve sosyal ağlar, bireyler. Yoksulluğun, eşitsizliğin ve savunmasızlığın artışına ve birbirine destek olmada aile ve toplulukların benimsediği geleneksel yöntemlerin zarar görmesine yol açan bu değişimler nedeniyle tüm bölge, elverişsiz koşullarla mücadele etmek durumunda kalmıştır.

Bu ülkelerin çoğu 1990 sonuna kadar olan sürede nüfus, kişisel ve politik özgürlük, büyüme ve ekonomik yenilik alanında umut verici ilerlemeler kaydettiler. Bununla birlikte, bitirilemeyen reformlar birçok BDT (Bağımsız Devletler Topluluğu) ülkesinde yoksulluk ve eşitsizliği daha kötü hale getirerek rüşvetin artmasına neden oldu. Örneğin tarımsal girişimin yeniden yapılanmasını da kapsayan piyasa reformları Orta Asya'da tamamlanmadan kalırken, birçok BDT hükümeti de vatandaşlarının yatırım grupları ve parti oluşturma özgürlüğünü kısıtlamaya devam etti.

Eski komünist ülkeler, toplumsal kalkınmalarında, farklı hız ve yönelimdeki reformlarla tanışmaktadırlar. Halen, toplumsal ve kurumsal sistemlerinin reformunda farklı aşamalarda bulunmaktadırlar. Bazı ülkelerde (çoğu AB katılımını sağlayan ülkelerden oluşan), "geçiş" dönemi sonlanmış, yeni ve etkin kurumlar oluşturulmuş ve sosyal katılım ve kaynaşma gibi konular başarılı bir şekilde çözümlenmiştir. Geçiş döneminin ilk yıllarında iktisadi, siyasi ve toplumsal yaşamdaki değişimlerle tanışan diğer ülkeler (BDT ülkelerinin bir kısmı) daha sonraları geri dönüşler yaşamıştır; toplumsal kararsızlık ve sapma düzeyi söz konusu ülkelerde en üst seviyededir. Belli düzeyde serbestleşme yaşasalar da diğer BDT ülkeleri, yaygın yoksulluk göstermeyen, güçlü insani gelişim göstergelerine sahip otoriter bir yönetim ve sıkı sıkıya yerleşmiş sosyalist bir ekonomiyi sahiplenmeyi halen sürdürmektedirler. Buna ek olarak, Güney Doğu Avrupa ülkeleri ve bir takım BDT ülkeleri, geçiş sürecinin zorluklarını ciddi biçimde arttıran siyasi istikrarsılık, çatışma ve savaş dönemi yaşamıştır.

İlgili literatürde yakınsama, ele alınan ekonomik birimler arasındaki belirlenen kriter veya kriterlere göre farklılığın azalması olarak ifade edilmektedir. Bu konuyu ele alan çalışmalar ilk olarak ülkelerin gelir artışlarına bağlı bir yakınsamanın olup olmadığını incelemişlerdir. Bu açıdan belirlenecek kriterlere göre ülkeler arasında bir yakınsamanın olup olmadığına yönelik bir literatür gelişmiştir. Bu çalışmanın amacı Bağımsız Devletler Topluluğu (BDT) içerisinde yer alan ülkeler arasında satın alma gücüne göre bir yakınsamanın olup olmadığını test etmektir. Satın alma gücü paritesi açısından ülkeler arasında bir yakınsamanın olması bu ülkeler arasında bir iktisadi entegrasyon olabileceğini göstermektedir. Ayrıca söz konusu alanın, ortak bir piyasa olabileceği yönünde de bilgi sağlayacaktır. 


\section{Bağımsız Devletler Topluluğu Ülkelerinde Başlıca Makro Göstergeler}

Sovyetler Birliği'nin dağılmasıyla beraber Bağımsız Devletler Topluluğu (BDT) ülkeleri serbest piyasa ekonomisine hızlı bir şekilde geçmiştir. Sovyetler döneminde teşebbüsler yüksek ölçüde endüstriyel bir bağ ile birbirlerine bağlı iken, sosyalist sistemin çöküşüyle ticaret arz bağlantıları bir gecede kırılmış, üretim kararları talep yapısındaki değişmelere ve oluşan yeni koşullara ayarlanmak zorunda kalmıştır (EGELİ, 2008). Yaklaşık 270 milyonluk nüfusu ile dünyanın en büyük pazarları arasında yer alan ve SSCB'nin eski etki alanını yeniden kazanma amacının ağırlıklı olarak hissedildiği BDT, 1991 yılında kurulmuştur. Katılımcı ülke sayısı 12 olan Topluluğa Baltık Devletleri ve Gürcistan hariç (Gürcistan, 2003 yılında Bağımsız Devletler Topluluğu'nun oluşturulması anlaşmasını imzalamış, ancak, 2008 Güney Osetya Savaşı ile başlayan ve Rusya ile aralarında çıkan savaş sonrası Gürcistan Cumhurbaşkanı Mihail Saakaşvili, BDT'den çıkmaya karar verdiklerini açıklamıştır. Gürcistan meclisinin onayıyla, söz konusu ülkenin Bağımsız Devletler Topluluğu üyeliği resmen 17 Ağustos 2009 yılında sona ermiştir), tüm eski Sovyetler Birliği Cumhuriyetleri üye bulunmaktadır. Topluluğa üye ülkeler; Beyaz Rusya, Ermenistan, Moldova, Rusya Federasyonu, Tacikistan, Ukrayna, Türkmenistan (ortak üye), Azerbaycan, Kazakistan, Kırgızistan, Özbekistan'dır.

Bağımsız Devletler Topluluğu ülkeleri içinde Rusya Federasyonu GSYİH açısından ağırlıklı bir paya sahiptir. Global kriz, Rus ekonomisinde 2009 yılında önemli ölçüde bir gerileme yaşanmasına (1994 yılından beri kaydedilen en büyük oransal düşüş) neden olmuş $(-\% 7,9)$ ve milli gelir, 2007 yılında bulunan seviyeye gerilemiştir. Öte yandan, 2009 yılının ikinci yarısında petrol fiyatlarının durumu Rus ekonomisinin daha büyük bir sıkıntı yaşamasını engellemiştir. 2010 yılında Rus ekonomisi 1,5 trilyon dolarlık bir büyüklüğe ulaşmıştır (Tablo:1). Rusya'dan sonra en büyük üretim gücüne sahip BDT ülkeleri arasında, 100 milyar doların üzerindeki rakamlarla Kazakistan (138.4 milyar dolar) ve Ukrayna (136.4 milyar dolar) gelmektedir. En düşük GSYİH değerine sahip ülke olan Kırgızistan'da (4.6 milyar dolar) 2010 yılında milli gelirdeki azalma, Kumtor altın madeni üretimi ile beraber değerlendirildiğinde, bir önceki yıla göre \%1,4'tür. Kişi başına düşen gelirin en yüksek olduğu ülkeler Rusya Federasyonu, Beyaz Rusya ve Kazakistan, en düşük gelire sahip ülkeler ise Tacikistan ve Kirgızistan'dır.

Krizden en çok etkilenen ve ekonomileri önemli ölçüde küçülen BDT ülkeleri arasında Ukrayna, Ermenistan ve Rusya federasyonu yer almaktadır. Krize rağmen en yüksek büyüme hızını yakalayan ülke ise \%9.3'lük oran ile Azerbaycan olmuştur. 2010 verilerine göre ise Kırgızistan hariç tüm BDT ülkeleri \% 4-9 arasında büyüme göstermişlerdir.

Ülkeleri insan kaynakları açısından değerlendirmeye yönelik uluslararası bir gelişmişlik göstergesi olan İnsani Kalkınma İndeksi (Human Development Index - HDI), büyüme yerine refah ve fakir ülkeler yerine her ülkedeki fakirler üzerinde durmaktadır. Bu kavram özellikle toplumların yaşam kalitesinin yükseltilmesine odaklanmıştır. Satın alma gücüne dönüştürülmüş gelir, ortalama eğitim süresi ile okur-yazar oranı ve ortalama yaşam süresi beklentisine göre hesaplanan indeks değerlerinde; 0.00 - 0.49 Düşük İnsani Gelişmeyi, 0.50 - 0.79 Ortalama İnsani Gelişmeyi, 0.80 - 0.89 Yüksek İnsani Gelişmeyi ve 0.90 - 1.00 Çok Yüksek İnsani Gelişmeyi göstermektedir.

Söz konusu ülkeler içinde Beyaz Rusya (dünya sıralamasındaki yeri 54) ve Rusya Federasyonu (dünya sıralamasındaki yeri 58) yüksek insani kalkınmaya, diğer ülkeler orta düzeyde insani kalkınma değerine sahiptir (Tablo:1).

\begin{tabular}{|c|c|c|c|c|c|c|}
\hline \multirow[t]{2}{*}{ Ülkeler } & \multirow{2}{*}{$\begin{array}{c}\text { GSYİH } \\
\text { (milyar \$) } \\
(2010)\end{array}$} & \multicolumn{2}{|c|}{$\begin{array}{c}\text { Büyüme Hızı } \\
(\%)\end{array}$} & \multirow[t]{2}{*}{$\begin{array}{c}\text { KBDG (\$) } \\
(2010)\end{array}$} & \multirow{2}{*}{$\begin{array}{c}\text { SGP'ne } \\
\text { Göre } \\
\text { KBDG (\$) } \\
(2010)\end{array}$} & \multirow{2}{*}{$\begin{array}{c}\text { İnsani } \\
\text { Kalkınma } \\
\text { Endeksi } \\
(2010)\end{array}$} \\
\hline & & 2009 & 2010 & & & \\
\hline Beyaz Rusya & 54.7 & 0.1 & 7.6 & 6.030 & 12.740 & 0.804 \\
\hline Ermenistan & 9.4 & -14.1 & 2.6 & 3.090 & 5.410 & 0.775 \\
\hline Moldova & 5.8 & -6.0 & 6.9 & 1.810 & 3.010 & 0.708 \\
\hline Rusya Federasyonu & 1465.1 & -7.8 & 3.9 & 9.910 & 18.330 & 0.802 \\
\hline Tacikistan & 5.6 & 3.9 & 6.5 & 780 & 1.950 & 0.673 \\
\hline Ukrayna & 136.4 & -14.8 & 4.2 & 3.010 & 6.180 & 0.788 \\
\hline Azerbaycan & 54.3 & 9.3 & 5.0 & 5.180 & 9.020 & 0.746 \\
\hline Kazakistan & 138.4 & 1.2 & 7.0 & 7.440 & 10.320 & 0.794 \\
\hline Kırgizistan & 4.6 & 2.9 & -1.3 & 880 & 2.200 & 0.696 \\
\hline Özbekistan & 38.9 & 8.1 & 8.0 & 1.280 & 2.910 & 0.702 \\
\hline Türkmenistan & 21.1 & 6.1 & 9.2 & 3.700 & 6.980 & 0.713 \\
\hline Gürcistan & 11.6 & -3.7 & 6.4 & 2.690 & 4.700 & 0.703 \\
\hline
\end{tabular}

Tablo 1. BDT Ülkelerinde Büyüme Hızı, GSYIH, KBDG ve İnsani Kalkınma Endeksi. Kaynak: http://hdr.undp.org, http://data.worldbank.org/indicators, http://www.imf.org 


\section{Bağımsız Devletler Topluluğunda Satın Alma Gücü Paritesine Göre Yakınsama}

\subsection{Yakınsama Yaklaşımı}

Yakınsama yaklaşımının gelişmesine dayanan literatür genel olarak büyüme ile ilgili teorilere dayalıdır. Literatürde iki yakınsama kavramı kullanılmaktadır. Bu kavramlardan ilki $\beta$ yakınsaması, ikincisi de Q yakınsamasıdır. $\beta$ yakınsaması yaklaşımı zaman içinde ya da bölgeler arasında, ülkeler arasında gelir ve diğer iktisadi değişkenler arasında bir yakınsamanın olup olmadığı araştırılmaktadır. Bu açıdan $\beta$ yakınsaması söz konusu ülke, bölge ve benzeri iktisadi alanlar arasındaki yakınlaşmanın hızının tahmininde bir araç olmaktadır. $\mathrm{Bu}$ çalışmadaki uygulama $\beta$ yakınsaması yaklaşımına dayanmaktadır. $\mathrm{Bu}$ nedenle $\mathrm{Q}$ yakınsaması açıklanmamıştır. Ancak Q yakınsamasının ülkeler arasında gelir dağılımı hakkında oluşturulmuş bir kavram olduğu belirtilmelidir (Martin ve Xavier, 1996). $\beta$ yakınsaması yaklaşımında ele alınan ülkelerin veya bölgelerin kurumsal yapısı ile temel iktisadi verilerinin yakın veya farklı olmasına bağlı olarak sırasıyla mutlak ve koşullu $\beta$ yakınsaması kavramları kullanılır (Mankiw, 1995). Koşullu $\beta$ yakınsaması yaklaşımında ülkeler arasında temel iktisadi verilerde bir farklılaşma olsa bile ülkeler arasında büyüme oranları arasında bir eşitlik veya bu yönde bir eğilim ortaya çıkabilmektedir. Mutlak $\beta$ yakınsamasına göre ülkelerin başlangıç koşullarının farklılığına rağmen, özellikle teknolojik gelişmeye bağlı olarak, ülkelerin kişi başına düşen geliri açısından bir yakınsama ortaya çıkacaktır.

$\mathrm{Bu}$ çalışmada ele alınan ülkelerin temel iktisadi verilerinin başlangıç koşulları benzer olduğu kabul edildiğinde mutlak $\beta$ yakınsaması yaklaşımına dayalı bir uygulama yapılmıştır. Uygulama sonucunda bir yakınsamanın olmadığı sonucuna ulaşılması durumunda Bağımsız Devletler Topluluğu içinde yer alan ülkelerin başlangıç koşullarına göre de farklılaşığı ortaya konmuş olacaktır. Bu çalışmada ele alınan ülkelerin satın alma gücü paritesine bağlı olarak GSMH açısından Rusya'ya yakınsayıp yakınsamadığı araştırılmaktadır.

Uygulamanın dayandığı temel eşitlik; $\log P P P_{R t}-\log P P P_{i t}=\alpha-\beta \log P P P_{i t}$ dir. Burada $\log P P P_{R t}$, Rusya'ya ait Satın alma Gücü Paritesine göre GSMH; , Log PPPit, Bağımsız Devletler Topluluğu içinde yer alan ülkelerin Satın alma Gücü Paritesine göre GSMH karşılık gelmektedir. $\beta>0$ olması durumunda ülkeler arasında bir yakınsama vardır. $\beta$, ülkeler arasında yakınsamanın hızını göstermektedir.

\subsection{Veri, Teknik Ve Bulgular}

$\mathrm{Bu}$ çalışmada kullanılan veriler World Outlook'tan alınmıştır. Uygulamada kullanılan panel eşbütünleşme tekniği Persyn ve Westerlund tarafindan geliştirilen yaklaşımla tahminlenmiş (Persyn ve Westerlund, 2008), tahmin sonuçları STATA 11 kullanılarak elde edilmiştir. Tahminlerin elde edilmesi için kullanılan teknik açıdan değişkenleri temsil eden serilerin bütünleşme derecesinin I (1) olması gerektiğinden, birim kök testleri yoluyla bu koşul analiz edilmiştir. Birim kök test sonuçları aşağıdaki tabloda özetlenmiştir. Tablo 2'de LOGPPP serisinin deterministik unsurlarla durağan olmaması ele alınan ülkeler arasında bir yakınsama olmadığı yönünde bilgi sağlamaktadır. Ancak uzun dönemli ilişkinin analizi için bu sonucun eşbütünleşme analizi ile desteklenmesi gerekmektedir. Bu amaçla daha önce de belirtildiği gibi Persyn ve Westerlund yaklaşımından yararlanılmıştır. $\mathrm{Bu}$ yaklaşım için gerekli olan serilerin aynı düzeyde durağan olma koşulunun tablo 3'de sağlandığı görülmektedir.

\begin{tabular}{|c|c|c|c|c|c|}
\hline & LLC & IPS & ADF & PP & HADRI \\
\hline LOGPPPIT & $0.32395(\mathrm{C})$ & $2.07400(\mathrm{C})$ & $19.8157(\mathrm{C})$ & $20.2754(\mathrm{C})$ & $7.74731^{* * *(\mathrm{C})}$ \\
& $-0.89050(\mathrm{C} \& \mathrm{~T})$ & $-0.14377(\mathrm{C} \& \mathrm{~T})$ & $22.6244(\mathrm{C} \& \mathrm{~T})$ & $25.4403(\mathrm{C} \& \mathrm{~T})$ & $5.76965(\mathrm{C} \& \mathrm{~T})$ \\
& $3.62437 *(\mathrm{None})$ & ------ & $58.1105 *(\mathrm{None})$ & $55.7163 *(\mathrm{None})$ & ------ \\
\hline LOGPPP & $6.48433(\mathrm{C})$ & $8.82002(\mathrm{C})$ & $0.88308(\mathrm{C})$ & $0.96076(\mathrm{C})$ & $7.58919(\mathrm{C})$ \\
& $-6.25492(\mathrm{C} \& \mathrm{~T})$ & $-3.92150(\mathrm{C} \& \mathrm{~T})$ & $55.1454(\mathrm{C} \& \mathrm{~T})$ & $55.7089(\mathrm{C} \& \mathrm{~T})$ & $4.62312(\mathrm{C} \& \mathrm{~T})$ \\
& $16.2176($ None $)$ & ------ & $0.08878($ None $)$ & $0.17644($ None $)$ & ----- \\
\hline
\end{tabular}

Tablo 2: Düzeyde Birim Kök Test Sonuçları

\begin{tabular}{|c|c|c|c|c|c|}
\hline & LLC & IPS & ADF & PP & HADRI \\
\hline LOGPPPIT & $-7.41084(\mathrm{C})$ & $-5.76710(\mathrm{C})$ & $70.6873(\mathrm{C})$ & $88.2710(\mathrm{C})$ & $2.70968^{* *(C)}$ \\
& $-5.78501(\mathrm{C} \& \mathrm{C})-$ & $-3.48225(\mathrm{C} \& \mathrm{~T})$ & $45.7462(\mathrm{C} \& \mathrm{~T})$ & $69.5963(\mathrm{C} \& \mathrm{~T})$ & $6.24472(\mathrm{C} \& \mathrm{~T})$ \\
& $8.43272($ None $)$ & ------ & $97.5424(\mathrm{None})$ & $98.4252(\mathrm{None})$ & ----- \\
\hline LOGPPP & $-7.20732(\mathrm{C})$ & $-5.71131(\mathrm{C})$ & $70.7753(\mathrm{C})$ & $81.0911(\mathrm{C})$ & $1.83248(\mathrm{C})$ \\
& $-5.34137(\mathrm{C} \& \mathrm{~T})-$ & $-1.84928(\mathrm{C} \& \mathrm{~T})$ & $33.6044(\mathrm{C} \& \mathrm{~T})$ & $57.2789(\mathrm{C} \& \mathrm{~T})$ & $3.84364(\mathrm{C} \& \mathrm{~T})$ \\
& $2.62743($ None $)$ & ------ & $37.5206($ None $)$ & $37.3598($ None $)$ & ------ \\
\hline
\end{tabular}

Tablo 3: Birinci Farklarda Birim Kök Test Sonuçları. LLC, IPS, ADF, PP için *\%1 anlamlık, **\%5 anlamlılık düzeyini göstermektedir. HADRI ***\%1 anlamlıllk düzeyi

LLC; IPS, ADF, PP test sonuçlarının boş hipotezi serilerin durağan olmadığına yöneliktir. Hadri yaklaşımında söz konusu hipotezin tersi test edilmektedir. Başka bir ifade ile Hadri yaklaşımında boş hipotez serinin durağanlığını göstermektedir (Şimşek, 2008). Serilerin aynı dereceden durağan olduğu tespit edildikten sonra Persyn ve Westerlund yaklaşımı ile seriler arasında uzun dönemli bir ilişkinin olup olmadığı araştırılmıştır. Söz 
konusu araştırma bulguları aşağıdadır.

\begin{tabular}{|c|c|c|c|}
\hline Parametreler & değer & | z-değeri & P-olasılık \\
\hline Gt & -16.553 & -58.630 & 0.000 \\
\hline $\mathrm{Ga}$ & -7.182 & 2.351 & 0.991 \\
\hline Pt & -5.990 & 1.185 & 0.882 \\
\hline $\mathrm{Pa}$ & -6.385 & 1.426 & 0.923 \\
\hline
\end{tabular}

Tablo 4: Eşbütünleşme Analiz Sonuçları

Yukarıda analizi yapılan eşbütünleşme analizinin boş hipotezi eşbütünleşme ilişkisinin olmadığıdır. Parametrelerin olasılık değerleri dikkate alınırsa ele alınan değişkenler arasında bir eş bütünleşme ilişkisinin olmadığının kabul edilmesi gerekmektedir. Ancak Gt parametresinin anlamlı olması yatay kesit etkilerden ortaya çıkabilecek etkilerin varlığının test edilmesini gerekli kılmaktadır. Bu amaçla Breusch-Pagan testi uygulanmıştır. Test sonucu göre $\mathrm{BP}=24.468,(\mathrm{Pr}=0.0064)$ olarak bulunmuştur. $\mathrm{Bu}$ durum yatay kesit köklerin ortak etkisinin varlığını gösterdiğinden dolayı söz konusu eşbütünleşme analizinin yorumlanması için dirençli tahmin yöntemi (bootstrap) de kullanılmıştır. Tahmin sonuçları aşağıdaki tabloda rapor edilmiştir.

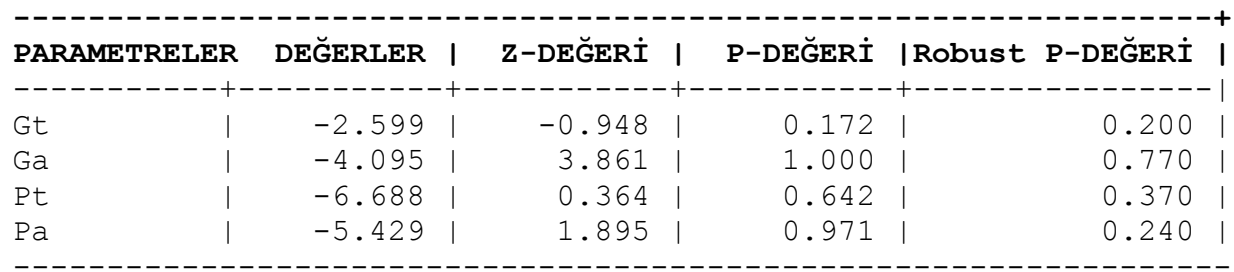

Tablo 5: Dirençli Regresyon Parametre Tahmin sonuçları

Tablo 5 tahmin sonuçlarına göre ele alınan değişkenleri temsil eden seriler arasında eşbütünleşme bulunamamıştır. Bunun anlamı ele alınan ülkeler ile Rusya'nın satın alma gücü paritesine göre GSMH arasında bir yakınsamanın olmadığıdır.

\section{Sonuc}

Bağımsız devletler topluluğunu oluşturan ve Rusya'nın siyasi olarak hakimiyetinin etkin olduğu bölge ülkeleri üzerinde yapılan panel eşbütünleşme analiz sonucuna göre ülkeler arasında bir yakınsamanın olmadığ bulunmuştur. $\mathrm{Bu}$ sonuç aynı zamanda söz konusu veri açısından bir ayrışmanın ortaya çıktığııı da göstermektedir. Ayrıca söz konusu sonuç siyasi olarak kurulan ilişkilerin ekonomik açıdan tamamlanmadığı veya desteklenmediğini konusunda bilgi sağlamaktadır. Bununla birlikte ülkelerin elde ettiği başarıların ve kazanımların ülke ekonomileri üzerinde önemli bir refah yaratıcı etkisinin olmadığı anlaşılmaktadır.

\section{Kaynakça}

- Damiaan Persyn, Westerlund Joakim, 2008, "Error-Correction-Based Cointegration Tests For Panel Data" The Stata Journal, ,8, Number 2, ss. 232-241, http://www.statajournal.com/sjpdf.html?articlenum=st0146Sala-i

- Egeli, Pınar, 2008. “Bağımsız Devletler Topluluğu Ülkelerinde İhracat-Milli Gelir İlişkisi”, Integration and Economic Development In Transition Economies, Krygyz-Turkish Manas University Department of Economics, No:106, Conference Series:14, Bishkek, p.271-277.

- International Monetary Fund- World Economic Outlook Database April 2011, http://www.imf.org/external/pubs/ft/weo/2011/01/weodata/index.aspx

- Mankiw Gregory, N., 1995. "Growth of Nations" Brookings Papers on Economic Activity,1, p.175-326, http://www. economics. harvard. edu/files/ faculty/40_Growth_of_Nations.pdf

- Martin, Xavier. X. , 1996. "The Classical Approach to Convergence Analysis" The Economic Journal, Vol:106, 437, p.1019-1036.

- Şimşek Nevzat, 2008, Türkiye'nin Endüstri-içi Dış Ticaretinin Analizi, Beta Yayınları, İstanbul,

- The World Bank- http://data.worldbank.org/indicators

- UNDP- International Human Development Indicators, 2010. http://hdr.undp.org/en/data/trends 


\title{
Demiryolu Ulaşım Sistemlerinde Verimlilik
}

\author{
Ali Kabasakal (Sakarya University, Turkey) \\ Ali Osman Solak (Ministry of Transportation, Turkey) \\ Productivity in Railway Transportation Systems
}

\begin{abstract}
Efficiency comparisons among transportation systems are an important matter for contemporary business making. Productivity of the transportation system may be considered as the efficiency while the reverse may be also partially correct. Thus, estimation of efficiency and/or productivity has a value in transportation. The aim of this study is to investigate productivity of railway transportation systems via panel data analysis. Railway transportation data of 23 countries across the world for the period of 2003-2008 is used for this study. Also average and marginal values across the nations are compared and discussed from the same perspective.

In this undergoing study; number of employees, number of railway engines, number of railways wagons, and length of the railway tracks for freight and passengers are the main variables to investigate efficiency. Findings indicate that panel data provides reasonable fine solutions for the investigation. Comparisons of 6-year average values across the nations also provide meaningful explanations on the issue.
\end{abstract}

JEL Codes: C33, D61, L92, R40

\section{Giriş}

İktisat biliminin ilgi alanındaki temel sorulardan biri; "kaynaklar etkin olarak kullanıliyor mu?" sorusudur. İktisatçılar bu soruyu statik ve dinamik etkinlik olarak iki farklı çerçevede ele alırlar. Statik etkinlik, mal ve hizmetlerin en düşük maliyetle üretilmesini ifade eden üretim etkinliği ve toplumdaki bir bireyin refahını düşürmeden diğerinin refahını yükseltmenin mümkün olmadığı durumu ifade eden tahsis etkinliğinden oluşur. Dinamik etkinlik ise, kaynakların uzun dönemdeki dağılımı ile ilgili olarak maliyetleri düşüren, kaliteyi artıran ve piyasaya yeni tür mal ve hizmetlerin sunumunu sağlayan yeniliklerin gerçekleştirilebilmesidir. Söz konusu bu iki etkinliğin sağlanabilmesi için uygun bir vasat gerekir ki, serbest rekabet piyasalarının bu vasatı sağladığı düşünülmektedir.

Ülke ekonomileri açısından etkin işleyen bir ulaştırma sektörünün varlığı büyük önem taşımaktadır. Üretilen mal ve hizmetlerin toplam maliyetinin önemli bir bölümünü ulaşım maliyetleri oluşturduğundan; ulaştırma sektörü, ulusal ve uluslararası rekabette önemli bir unsur haline gelmiştir. Ekonomideki diğer sektörlerin yararlandığı bir faaliyet alanı olan ulaştırma sektörünün etkin işlemesi, diğer sektörlerde etkinlik artışına, dolayısıyla ekonominin genelinde etkinlik artışına neden olur. Ayrıca ulaştırma sektörünün gerektirdiği altyapı yatırımları, genel yatırım ödeneklerinden büyük miktarda pay almakta ve ekonomide önemli etkiler meydana getirmektedir.

Demiryolu taşımacılığı; demiryolu hattı (raylar), çeken-çekilen araçlar ve belirli sayıda personelle yapılan bir taşımacılık türüdür. Herhangi bir güzergâhta yeni demiryolu hattının yapılarak taşımacılık faaliyetlerinin gerçekleştirilebilmesi için taşımacılık talebinin oluşması gerekir. İhtiyaç duyulan taşımacılık talebinin karşılanması için yapılan demiryolu hatları, aynı zamanda turistik amaçlı seyahatler gibi belirli bir ulaşım talebini de doğurmaktadır. Bir diğer ifade ile başta demiryolu hat uzunluğu olmak üzere demiryolu taşımacılığını oluşturan bileşenler ile demiryolu taşımacılığı arasında çift taraflı bir ilişkiden söz etmek mümkündür.

Bu çalışmada, demiryolu taşımacılığı gelişmiş olan 23 Avrupa ülkesi (Türkiye, Almanya, Avusturya, Belçika, Bulgaristan, Çek Cumhuriyeti, Danimarka, Finlandiya, Fransa, Hırvatistan, Lüksemburg, İngiltere, İrlanda, İspanya, İsveç, İsviçre, İtalya, Macaristan, Norveç, Portekiz, Romanya, Slovakya ve Yunanistan) için 2003-2008 yıllarına ait demiryolu verileri kullanılarak demiryollarının panel veri analizi yapılmıştır. Demiryolu taşımacılığında kullanılan personel sayısı, toplam hat uzunluğu, vagon sayısı ve vagon kapasitelerinin demiryolu taşımacılığını ne ölçüde etkilediği tahmin edilmeye çalışılmıştır. Analizde International Union of Railways (UIC) (2009) tarafından yayımlanan veriler kullanılmıştır.

\section{Veri Analizi}

Zaman ve yatay kesit verilerinin kullanılarak ekonomik ilişkilerin tahmin edilmesi yöntemine panel veri analizi adı verilmektedir. Bu yöntemde kesit analizi ve zaman serisi analizi birleştirilerek hem zaman hem de kesit boyutuna sahip veri seti oluşturulmaktadır. Dolayısıyla kesit ve zaman serisi analizlerine kıyasla panel veri analizi daha fazla gözlem sayısına sahiptir (Baltagi, 2005), (Grene, 2003) ve (Gujarati, 2003).

Panel veri analizinde gözlem sayısının fazla olması, serbestlik derecesini artırmakta ve açıklayıcı değişkenler arasında yüksek derecede doğrusal ilişki bulunma ihtimalini azaltmaktadır. 
Panel veriler her bir kesit için eşit uzunlukta zaman serilerinden meydana gelmişse dengeli (balanced) panel veriler, farklı uzunlukta zaman serilerinden meydana gelmişse dengesiz (unbalanced) panel veriler olarak adlandırılmaktadır.

"Sabit etkiler modeli" (fixed effects) ve "rassal etkiler modeli" (random effects) olmak üzere iki temel yaklaşımın söz konusu olduğu panel veri modelinin genel şekli aşağıda eşitlik (1)'de verilmektedir.

$$
\begin{aligned}
& \mathrm{Y}_{\text {it }}=\alpha+\beta_{1 i t} \mathrm{X}_{1 \text { it }}+\beta_{2 \text { it }} \mathrm{X}_{2 \text { it }}+\ldots+\beta_{\text {kit }} \mathrm{X}_{\text {kit }}+\varepsilon_{\text {it }} \\
& \mathrm{i}=1,2, \ldots, \mathrm{K} \\
& \mathrm{t}=1,2, \ldots, \mathrm{N}
\end{aligned}
$$

Modelde yer alan ( i ) kesitleri, ( t ) zamanı göstermektedir. Ayrıca hata terimi $\varepsilon$ 'nun ortalamasının sıfır ve sabit varyanslı olduğu varsayılmaktadır.

\subsection{Model, Değişkenlerin Tanımlanması ve Tahmin}

Bu çalışmada, Hausman testi sunucuna göre demiryolu taşımacılığının modellenmesi için rassal etkiler modeli kullanılmıştır. Uygulamada, ele alınan değişkenlerin değerleri logaritmaya çevrilmiştir. Dolayısıyla, bağımsız değişkenlerin katsayıları, bağımlı değişkenin ilgili bağımsız değişkene göre esnekliğini vermektedir. Analizde, E-Views 5.1 paket programı kullanılmıştır.

Demiryolu taşımacılığında kullanılan personel sayısı, toplam hat uzunluğu, vagon adetleri ve vagon kapasitelerinin demiryolu taşımacılığını ne ölçüde etkilediğini tahmin etmek için aşağıda yer alan regresyon modelleri oluşturulmuştur:

$$
\begin{aligned}
& \text { 1. } \log \text { YOLTKM }=\alpha_{0}+\beta_{1} \log \mathrm{DPS}+\beta_{2} \log \mathrm{AU}+\beta_{3} \log \mathrm{YOLVS}+\varepsilon \\
& \text { 2. } \log \text { OLTKM }=\alpha_{0}+\beta_{1} \log \mathrm{PPS}+\beta_{2} \log \mathrm{AU}+\beta_{3} \log \mathrm{YOLVK}+\varepsilon \\
& \text { 3. } \log \mathrm{YOLKM}=\alpha_{0}+\beta_{1} \log \mathrm{DPS}+\beta_{2} \log \mathrm{AU}+\beta_{3} \log \mathrm{YOLVS}+\varepsilon \\
& \text { 4. } \log \mathrm{YOLKM}=\alpha_{0}+\beta_{1} \log \mathrm{DPS}+\beta_{2} \log \mathrm{AU}+\beta_{3} \log \mathrm{YOLVK}+\varepsilon \\
& \text { 5. } \log \mathrm{YUKTKM}=\alpha_{0}+\beta_{1} \log \mathrm{PPS}+\beta_{2} \log \mathrm{AU}+\beta_{3} \log \mathrm{YUKVS}+\varepsilon \\
& \text { 6. } \log \mathrm{YUKTKM}=\alpha_{0}+\beta_{1} \log \mathrm{DPS}+\beta_{2} \log \mathrm{AU}+\beta_{3} \log \mathrm{YUKVK}+\varepsilon \\
& \text { 7. } \log \mathrm{TONKM}=\alpha_{0}+\beta_{1} \log \mathrm{DPS}+\beta_{2} \log \mathrm{AU}+\beta_{3} \log \mathrm{YUKVS}+\varepsilon \\
& \text { 8. } \log \mathrm{TONKM}=\alpha_{0}+\beta_{1} \log \mathrm{PPS}+\beta_{2} \log \mathrm{AU}+\beta_{3} \log \mathrm{YUKVK}+\varepsilon
\end{aligned}
$$

Modellerde kullanılan kısaltmaların temsil ettiği veriler de şu şekilde listelenebilmektedir:

- DPS : : Demiryollarında çalışan personel sayısı (kişi)

- AU : Anahat uzunluğu $(\mathrm{km})$

- YOLVS : Yolcu vagonları sayısı (adet)

- YOLVK : Yolcu vagonları Kapasitesi (koltuk)

- YUKVS : Yük vagonları sayısı (adet)

- YUKVK : Yük vagonları kapasitesi (ton)

- YOLTKM : Yolcu tren-km $\left(10^{3}\right)$

- YOLKM : Yolcu-km $\left(10^{6}\right)$

- YUKTKM : Yük tren-km $\left(10^{3}\right)$

- TONKM : Ton-km $\left(10^{6}\right)$

Modellerde açıklayıcı değişkenler olarak personel, hat uzunluğu, vagon sayısı ve vagon kapasitesi kullanılmıştır. Personel ve hat hem yolcu hem de yük taşımacılığı için ortak kullanılırken; vagonların kullanımı yük ve yolcu taşımacılığına göre farklılık arz etmektedir. Modellerde açıklayıcı değişkenlerin tamamı için pozitif katsayı beklenmektedir.

\subsection{Rassal Etkiler Modelinden Elde Edilen Sonuçlar}

Demiryolu taşımacılığının analizi için panel veri kullanarak Rassal Etkiler Modeline göre elde edilen tahmin sonuçları Tablo 1'de yer almaktadır.

Model 1'in açıklama gücünü gösteren $\mathrm{R}^{2}$ değeri \%42'dir. $\mathrm{Bu} \mathrm{R}^{2}$ değeri bağımlı değişkenin \%42'sinin, bağımsız değişkenler tarafından açıklandığı anlamına gelmektedir. F-istatistiği olasılık değeri, tüm değişkenlerin topluca istatistiksel olarak \%1 düzeyinde anlamlı olduğunu göstermektedir. DPS ve AU değişkenlerinin işaretleri beklendiği gibi pozitif ve sırasıyla $\% 5$ ve $\% 1$ anlamlılık düzeyinde istatistiksel olarak anlamlıdır. YOLVS değişkeninin işareti beklendiği gibi çıkmasına rağmen istatistiksel olarak anlamlı değildir. Personel sayısı (DPS)'ndaki \%1'lik artış yolcu trenlerinin yaptığı kilometreyi (YOLTKM) yaklaşık \%0,11 ve hat uzunluğu (AU)'ndaki \%1'lik artış yolcu trenlerinin yaptığı kilometreyi (YOLTKM) yaklaşık \%0,75 artırmaktadır.

Model 2'nin $\mathrm{R}^{2}$ değeri \%36'dır. Bu değer bağımlı değişkenin \%36'sının, bağımsız değişkenler tarafından açıklandığı anlamına gelmektedir. F-istatistiği olasılık değeri, tüm değişkenlerin topluca istatistiksel olarak \%1 düzeyinde anlamlı olduğunu göstermektedir. DPS ve AU değişkenlerinin işaretleri beklendiği gibi pozitif ve sırasılla \%10 ve \%1 anlamlılık düzeyinde istatistiksel olarak anlamlıdır. DPS'deki \%1'lik artış YOLTKM'yi 
yaklaşık \%0,11 ve AU'daki \%1'lik artış YOLTKM'yi yaklaşık \%0,76 artırmaktadır. YOLVK değişkeninin işareti ise beklenenin tersine olarak negatif ve \%1 anlamlılık düzeyinde istatistiksel olarak anlamlıdır. YOLVK'deki $\% 1$ 'lik artış YOLTKM'yi yaklaşık \%0,07 azaltmaktadır.

\begin{tabular}{|c|c|c|c|c|c|}
\hline & \multicolumn{4}{|c|}{ Modeller ve Bağımlı Değişkenler } \\
\hline & & $\begin{array}{c}\text { Model 1 } \\
\text { YOLTKM }\end{array}$ & $\begin{array}{c}\text { Model } 2 \\
\text { YOLTKM }\end{array}$ & $\begin{array}{c}\text { Model } 3 \\
\text { YOLKM }\end{array}$ & $\begin{array}{c}\text { Model } 4 \\
\text { YOLKM }\end{array}$ \\
\hline \multicolumn{2}{|c|}{ Kesit Sayıs1 } & 23 & 21 & 23 & 21 \\
\hline \multicolumn{2}{|c|}{ Top. Göz. Say. } & 138 & 126 & 138 & 126 \\
\hline \multirow{14}{*}{ 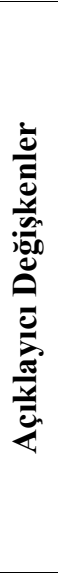 } & DPS & $0,108185^{* *}$ & $0,109618^{*}$ & $0,121659^{* *}$ & 0,045221 \\
\hline & & $(0,042048)$ & $(0,058074)$ & $(0,048260)$ & $(0,076367)$ \\
\hline & $\mathrm{AU}$ & $0,758115^{* * *}$ & $0,764500^{* * * *}$ & $0,959745^{* * *}$ & $1,086827^{* * *}$ \\
\hline & & $(0,084949)$ & $(0,103808)$ & $(0,093327)$ & $(0,117987)$ \\
\hline & YOLVS & 0,010133 & & $-0,016878$ & \\
\hline & & $(0,029477)$ & & $(0,033939)$ & \\
\hline & YOLVK & & $0,069702^{* * *}$ & & $-0,077163^{* * *}$ \\
\hline & & & $(0,018783)$ & & $(0,025588)$ \\
\hline & YUKVS & & & & \\
\hline & & & & & \\
\hline & YUKVK & & & & \\
\hline & & & & & \\
\hline & $\mathrm{C}$ & $3,309828^{* * *}$ & $4,106115^{* * *}$ & $-0,611146$ & $-0,180645$ \\
\hline & & $(0,659136)$ & $(0,813901)$ & $(0,712801)$ & $(0,878345)$ \\
\hline \multicolumn{2}{|c|}{$\mathrm{R}^{2}$} & 0,423935 & 0,359608 & 0,489951 & 0,444650 \\
\hline \multicolumn{2}{|c|}{ F-İstatistiği } & 32,87086 & 22,83613 & 42,90654 & 32,56044 \\
\hline & $59,221109^{* * *}$ & $35,789368^{* * *}$ & $52,650586^{* * *}$ & $34,406334^{* * *}$ \\
\hline \multirow{2}{*}{\multicolumn{2}{|c|}{ Hausman Testi }} & \multicolumn{4}{|c|}{ Modeller ve Bağımlı Değişkenler } \\
\hline & & $\begin{array}{c}\text { Model 5 } \\
\text { YUKTKM } \\
\end{array}$ & $\begin{array}{c}\text { Model } 6 \\
\text { YUKTKM } \\
\end{array}$ & $\begin{array}{c}\text { Model } 7 \\
\text { TONKM } \\
\end{array}$ & $\begin{array}{l}\text { Model } 8 \\
\text { TONKM }\end{array}$ \\
\hline \multirow{2}{*}{\multicolumn{2}{|c|}{$\begin{array}{c}\text { Kesit Sayıs1 } \\
\text { Top. Göz. Say. }\end{array}$}} & 19 & 18 & 20 & 18 \\
\hline & & 114 & 108 & 120 & 108 \\
\hline \multirow{14}{*}{ 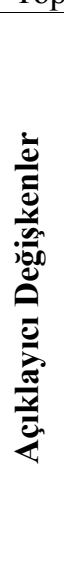 } & DPS & $0,366019^{*}$ & 0,098631 & $0,331204^{* *}$ & 0,191569 \\
\hline & & $(0,188195)$ & $(0,202340)$ & $(0,159041)$ & $(0,172192)$ \\
\hline & $\mathrm{AU}$ & $0,700090^{\text {**** }}$ & $0,723797^{\text {**** }}$ & $0,813257^{* * *}$ & $0,677319^{* * *}$ \\
\hline & & $(0,193929)$ & $(0,176352)$ & $(0,185467)$ & $(0,176507)$ \\
\hline & YOLVS & & & & \\
\hline & & & & & \\
\hline & YOLVK & & & & \\
\hline & & & & & \\
\hline & YUKVS & 0,024876 & & 0,043214 & \\
\hline & & $(0,092868)$ & & $(0,069770)$ & \\
\hline & YUKVK & & $0,326151^{\text {** }}$ & & $0,396896^{\text {**** }}$ \\
\hline & & & $(0,135739)$ & & $(0,116775)$ \\
\hline & $\mathrm{C}$ & $-0,270266$ & $-1,897630^{*}$ & $-1,946036$ & $-4,291796^{* * *}$ \\
\hline & & $(1,029034)$ & $(1,046026)$ & $(1,187992)$ & $(1,116220)$ \\
\hline & $\mathrm{R}^{2}$ & 0,467156 & 0,587094 & 0,404521 & 0,569795 \\
\hline & statistiği & 32,14652 & 49,29105 & 26,26709 & 45,91498 \\
\hline $\mathrm{Ha}$ & man Testi & $8,307725^{* *}$ & 3,957771 & $12,728909^{* * *}$ & $10,475099^{* *}$ \\
\hline
\end{tabular}

Tablo 1. Modellerin Tahmin Sonuçlarl. Not: ***\%1, **\%5, *\%10 anlamlılık seviyelerini simgelemektedir. Parantez içindeki değerler standart sapmalardır.

Model 3'ün $\mathrm{R}^{2}$ değeri \%49'dur. Bu değer bağımlı değişkenin \%49'unun, bağımsız değişkenler tarafından açıklandığı anlamına gelmektedir. F-istatistiği olasılık değeri, tüm değişkenlerin topluca istatistiksel olarak \%1 düzeyinde anlamlı olduğunu göstermektedir. DPS ve AU değişkenlerinin işaretleri beklendiği gibi pozitif ve sırasıyla $\% 5$ ve $\% 1$ anlamlılık düzeyinde istatistiksel olarak anlamlıdır. YOLVS değişkeninin işareti ise beklenenin tersine negatif ve istatistiksel olarak anlamlı değildir. DPS'deki \%1'lik artış YOLKM'yi yaklaşık $\% 0,12$ ve AU'daki \%1'lik artış YOLKM'yi yaklaşık \%0,96 artırmaktadır.

Model 4'ün $\mathrm{R}^{2}$ değeri \%44'tür. Bu değer bağımlı değişkenin \%44'ünün, bağımsız değişkenler tarafindan açıklandığı anlamına gelmektedir. F-istatistiği olasılık değeri, tüm değişkenlerin topluca istatistiksel olarak \%1 düzeyinde anlamlı olduğunu göstermektedir. DPS değişkeninin işareti beklendiği gibi pozitif çıkmasına rağmen istatistiksel olarak anlamlı değildir. AU değişkeninin işareti beklendiği gibi pozitif ve \%1 anlamlılık düzeyinde 
istatistiksel olarak anlamlıdır. YOLVK değişkeninin işareti ise beklenenin tersine negatif ve \%1 anlamlılık düzeyinde istatistiksel olarak anlamlıdır. AU'daki \%1'lik artı̧̧ YOLKM'yi yaklaşı \%1,09 artırmakta, YOLVK'deki \%1'lik artı̧̧ YOLKM'yi yaklaşık \%0,08 azaltmaktadır.

Model 5'in $\mathrm{R}^{2}$ değeri \%47'dir. Bu değer bağımlı değişkenin \%47'sinin, bağımsız değişkenler tarafindan açıklandığı anlamına gelmektedir. F-istatistiği olasılık değeri, tüm değişkenlerin topluca istatistiksel olarak \%1 düzeyinde anlamlı olduğunu göstermektedir. DPS ve AU değişkenlerinin işaretleri beklendiği gibi pozitif ve sırasıyla $\% 10$ ve $\% 1$ anlamlılık düzeyinde istatistiksel olarak anlamlıdır. YUKVS değişkeninin işareti beklendiği gibi pozitif çıkmasına rağmen istatistiksel olarak anlamlı değildir. DPS'deki \%1'lik artı̧̧ YUKTKM'yi yaklaşık $\% 0,37$ ve AU'daki \%1'lik artış YUKTKM'yi yaklaşık \%0,70 artırmaktadır.

Model 6'nın $\mathrm{R}^{2}$ değeri \%59'dur. Bu değer bağımlı değişkenin \%59'unun, bağımsız değişkenler tarafindan açıklandığı anlamına gelmektedir. F-istatistiği olasılık değeri, tüm değişkenlerin topluca istatistiksel olarak \%1 düzeyinde anlamlı olduğunu göstermektedir. DPS değişkeninin işareti beklendiği gibi pozitif çıkmasına rağmen istatistiksel olarak anlamlı değildir. AU ve YUKVK değişkenlerinin işaretleri beklendiği gibi pozitif ve sırasıyla $\% 1$ ve \%5 anlamlılık düzeyinde istatistiksel olarak anlamlıdır. AU'daki \%1'lik artış YUKTKM'yi yaklaşık $\% 0,72$ ve YUKVK'deki \%1'lik artış YUKTKM'yi yaklaşık \%0,33 artırmaktadır.

Model 7'nin $\mathrm{R}^{2}$ değeri \%40'dır. Bu değer bağımlı değişkenin \%40'ının, bağımsız değişkenler tarafından açıklandığı anlamına gelmektedir. F-istatistiği olasılık değeri, tüm değişkenlerin topluca istatistiksel olarak \%1 düzeyinde anlamlı olduğunu göstermektedir. DPS ve AU değişkenlerinin işaretleri beklendiği gibi pozitif ve sırasıyla $\% 5$ ve $\% 1$ anlamlllık düzeyinde istatistiksel olarak anlamlıdır. DPS'deki $\% 1$ 'lik artış TONKM'yi yaklaşık \%0,33 ve AU'daki \%1'lik artış TONKM'yi yaklaşı \%0,81 artırmaktadır. YUKVS değişkeninin işareti beklendiği gibi pozitif çıkmasına rağmen istatistiksel olarak anlamlı değildir.

Model 8'in $\mathrm{R}^{2}$ değeri \%57'dir. Bu değer bağımlı değişkenin \%57'sinin, bağımsız değişkenler tarafindan açıklandığı anlamına gelmektedir. F-istatistiği olasılık değeri, tüm değişkenlerin topluca istatistiksel olarak \%1 düzeyinde anlamlı olduğunu göstermektedir. DPS değişkeninin işareti beklendiği gibi pozitif çıkmasına rağmen istatistiksel olarak anlamlı değildir. AU ve YUKVK değişkenlerinin işaretleri beklendiği gibi pozitif ve ikisi de $\% 1$ anlamlılık düzeyinde istatistiksel olarak anlamlıdır. AU'daki \%1'lik artış TONKM'yi yaklaşık \%0,68 ve YUKVK'deki \%1'lik artış TONKM'yi yaklaşık \%0,40 artırmaktadır.

\section{Tahmin Sonuçlarının Genel Değerlendirmesi}

Bu çalışmanın temel amacı; demiryolu taşımacılığında kullanılan personel sayısı, toplam hat uzunluğu, toplam vagon sayısı ve toplam vagon kapasitesi ile demiryolu taşımacıllğı arasındaki ilişkinin (panel veri yöntemi ile) analiz edilmesidir.

Analiz sonuçlarından anahat uzunluğu ile yük ve yolcu taşımacıllı̆ı arasında pozitif yönlü güçlü bir ilişkinin olduğu görülmektedir. Buna dayanarak, taşımacılık talebinin yüksek olduğu ve bu talebin karayolu tarafindan karşılanamadığı şehirlerarası güzergâhlarda yeni demiryolu hatlarının yapılması ile demiryolu taşımacıllğını artırmanın mümkün olduğu söylenilebilir. Yeni demiryolu hatlarının yapılmasında ekonomik etkinlik açısından dikkat edilmesi gereken husus, mevcut taşıma sistemleri tarafindan ulaşım talebinin karşılanamaması halinde yeni hatların yapılması gerektiğidir. Mevcut ulaşım altyapısının etkin kullanılmaması ve atıl kapasitenin var olması halinde yeni demiryolu hatlarının yapılması ayrı bir etkinsizlik sebebi olur.

Toplam vagon sayısı ile yük ve yolcu taşımacılığı arasında bir ilişkinin olmadığı, toplam yük vagonu kapasitesi ile yük taşımacıllğ̆ arasında pozitif yönlü bir ilişkinin olduğu, toplam yolcu vagonu kapasitesi ile yolcu taşımacılığı arasında negatif yönlü bir ilişkinin olduğu görülmektedir. Buna dayanarak mevcut hatların yük taşımacılığında daha fazla kullanılmasının, demiryolu taşımacılığı açısından daha faydalı olacağı ve ekonomik etkinliği artıracağı sonucu çıkartılabilir.

\section{Kaynakça}

- BALTAGI, Badi H. (2005), Econometric Analysis of Panel Data, 3rd Edition, John Wiley \& Sons, Ltd.

- GREENE, William H. (2003), Econometric Analysis, 5th Edition, Prentice Hall, Upper Saddle River, New Jersey.

- GUJARATI, Damodar N. ( 2003), Basic Econometrics, 4th Edition, Mc Graw Hill Companies.

- UIC (International Union of Railways) (2009), Railway Time-Series Data 1970-2008. 


\title{
Kurumların Ekonomik Büyüme Üzerindeki Etkisi
}

\author{
Bekir Aşık (Beykent University, Turkey)
}

\section{The Effects of Institutions on Economic Growth}

\begin{abstract}
Do institutions have a positive impact on economic growth? The most empirical growth studies have provided a supporting answer to this question. The relation between institutions and economic growth becomes more popular as a result of these empirical Works indicating that some institutions are efficient in economic growth. Because of this importance of institutions, the effect of some institutions on economic growth is researched for 90 countries. In this paper some proxy variables are selected for 'market creating institutions', 'market stabilizing institutions', 'market regulating institutions', and 'market legitimizing institutions'. The panel data method is used to search the relation between these variables and economic growth. It showed that market creating institutions have the significant and positive impact on the long-run economic growth in all cases. Moreover, market stabilizing institutions and market regulating institutions has positive effects on growth. In contrast to these results market legitimizing institutions have no significant effect on the economic growth.
\end{abstract}

JEL Codes: O43; O47

\section{Giriş}

İktisat literatüründe ülkelerin büyüme sorunsalı Adam Smith'e kadar götürülse de modern zamanlarda büyüme denince ilk akla gelen teori Neo-Klasik Büyüme Teorisi'dir. Bu teoriyi Solow (1956) ve Swan (1956) birbirilerinden bağımsız olarak geliștirmişlerdir. Azalan verimler yasasına dayanan bu teoride tasarruf ve teknoloji dışsal olarak kabul edilmiştir. Bu nedenle, Neo-klasik büyüme teorisi Dışsal Büyüme Teorisi (Exogenous Grolvth Theory) olarak da bilinir. Bu çalışma 20. yüzyllın son dönemlerine kadar iktisat literatüründe hakim büyüme teorisi olarak kalmıştır. Ancak hem teknolojiyi hem de tasarrufu dışsal almasından dolayı ve buna ek olarak, modele büyümeyi etkileyen çeşitli faktörleri eklememesi nedeniyle eleştirilere maruz kalmıştır. Bu eleştirilerin yöneltilmesinin en önemli nedeni neo-klasik büyüme modelinin ülkeler arasındaki büyüme farklılıklarını açıklayamamasıdır.

1990'lı yıllarda Robert J. Barro'nun çalışmaları büyüme teorisinde ampirik çalışmalara farklı bir boyut getirmiştir (Barro; 1991 ve Barro-Lee;1994). Özellikle 1997 yılında yazdığı " Determinants of Economic Grovoth: A Cross-Country Emprical Study ${ }^{n}$ çalışması ampirik çalışmaları etkilemiştir. Bu çalışmada Barro, büyüme modelinde çok farklı değişkenlerin kullanılmasının yolu açmıştır. Hem teorik olarak farklı değişkenleri modele katması hem de ekonometrik olarak panel dataya yer vermesi ve içsellik (endogeneity) sorununa çözüm bulmasıyla literatürdeki diğer çalışmalardan ayrılır. Bu çalışma ile birlikte fiziki sermaye ile birlikte hem eğitim hem de sağlık değişkenleri ile beşeri sermaye, nüfus artış oranı, dışa açıklık, makroekonomik istikrara yönelik değişkenler, ekonomik büyümede kurumsal değişkenler ..v.b. değişkenler modele eklenmiştir.

Son yıllarda ise kurumsal değişkenlerin önemi fark edilmiş ve bu değişkenlerin ülkeler arası büyüme farklı1ıklarını etkilediği varsayılmıştır. Bu nedenle de ampirik çalışmalarda kurumsal değişkenlere yer verilmiştir. Kurumsal değişkenler ve bu kurumların değişmesini etkileyen başlıca faktörler şu şekilde sıralanabilir: demografik yapı, teknoloji ve ideolojide meydana gelen değişim (North, 2002). 'İyi' kurumların (etkin mülkiyet sistemi, adalet sisteminin iyi işlemesi, bürokratik yozlaşmanın minimumda tutulması, etkin bir demokratik sistem... v.b) yaratılması ile ekonomilerde yatırım ortamı iyileşecek ve bu da yatırımları olumlu yönde etkileyecektir. Böylece hem büyüme sağlanacak hem de kalkınma da birçok sorun çözülecektir. 'Kötü' kurumlar (etkin olmayan mülkiyet hakları sistemi, adalet sisteminin iyi işlememesi, bürokratik yapının kalitesizliği, demokrasinin yerleşmemesi... v.b.) ise uzun dönemli yatırımları, yeni teknolojilerin ülkeye gelmesini engelleyecek ve piyasa bozukluklarına neden olacaktır. Bu da yatırımı düşürecek ve buna bağlı olarak da büyümeyi ve kalkınmayı engelleyecektir.

Gelişmiş ülkeler incelendiği zaman bu tip sorunlarla karşılaşmadığı gözlenebilir. Bu ülkelerin en önemli özellikleri de sistemlerini demokrasi üzerine inşa etmeleri ve piyasa yapıcı kurumlarının sağlıklı işlediği görülür. $\mathrm{Bu}$ değişkenlerin ekonomik büyüme üzerindeki etkilerinin olumlu olması nedeniyle bu çalışma kapsamında seçilen ülkelerde demokrasinin ve piyasa yapıcı kurumların büyümeye etkileri incelenmiştir. Bu değişkenlerle birlikte büyüme için önemli olan 'mülkiyet hakları'm (property rights), piyasa istikrarlaştırıcı kurumları, piyasayı yöneten ve düzenleyen kurumları ve 'sivil özgürlükler' (civil liberties) ile 'siyasi özgürlükleri' temsil eden değişkenler de demokrasi değiş̧eni ile birlikte büyüme üzerindeki etkileri test edilmiştir. Çalışmanın bundan sonraki aşamaları şu şekildedir: İkinci bölümde kurumsal değişkenler ve büyüme arasmdaki ilişkileri inceleyen çalışmalara yer verilmiştir. Üçüncü bölümde çalışma kapsammda kul-lanılan ekonometrik model kısaca anlatılmıştır. Dördüncü bçlümde model için kullanılan veriler tanıtılmıştır. Beşinci bölümde ise ekonometrik 
modelin tah-min edilmesi ile birlikte ulaşılan sonuçlara ve yorumlara yer verilmiştir. Çalışma için sonuç bölümü ise altıncı bölümdedir.

\section{Literatür İncelemesi}

Uzun dönemli büyümeyi araştıran literatürde kişi başına düşen GSYİH'yi etkileyen birçok faktör bulunmuştur. Çeşitli faktörlerin büyümeyi etkilemesine rağmen birçok araştırmacı kurumsal değişkenlerin büyüme üzerinde olumlu etkisi olduğu konusunda fikir birliğine varmışlardır. Uzun dönemli büyümede düşük bir durağan durum dengesine sahip bir ülkenin veri bir başlangıç gelir seviyesinden başlayarak kendi durağan durumuna daha yavaş bir şekilde yakınsayacağı varsayılmıştır (Barro ve Sala-i Martin; 1995). Kurumsal yapısını iyi oluşturamamış ve bu nedenle mülkiyet haklarını ve sözleşmeleri kontrol altında tutamayan devletlerde birikimlerin yatırımlara yöneltilmesi mümkün olmayacağından büyüme hızları düşecektir. Bu bağlamda Knack and Keefer (1995) mülkiyet haklarının güvence altma alınmasının uzmanlaşmada dolayısıyla yatırımlarda ve ekonomik büyümede en önemli kurumsal değişken olduğunu iddia etmektedir.

Kurumsal yapını önemli olduğunu vurgulayan bir başka araştırmacı ise Dani Rodrik'tir. Dani Rodrik 1997 yılında yayımladığı makalesinde demokrasinin büyüme üzerinde olumlu etkisi olduğunu vurgulamıştır. Rodrik, her ne kadar Doğu ve Güneydoğu Asya ülkelerindeki otokratik yapının belli bir dönem büyüme-yi olumlu yönde etkilediğini belirtse de bu durumun istisnai bir özel-lik olduğunu da vurgulamıştır. Bu istisnai durumlara karşılık Bolivya, Ar-jantin, Brezilya ve Polonya'nin demokratik bir sistemde daha istikrarlı ve hı-zlı büyüme oranları yakaladığını iddia etmiştir. Rodrik'e göre demokratik bir yapıda uzun dönemli büyümenin daha doğru bir şekilde tahmin edileceğini ve istikrarlı bir yapı kurulacağmı, beklenmedik şoklarm maliyetinin en aza in-dirgeneceğini ve çalışanlara daha yüksek ücretler ödenebileceğini işaret etmiştir. Rodrik demokrasi için Knack ve Keefer'in aksine sivil özgürlükleri ve politik hakları gösterge değişken olarak almıştır.

Bir başka önemli çalışmada Dollar ve Kraay (2003) hukuksal yapının iyi kurulduğu ülkelerde kişi başma düşen reel GSYİH'nin arttığını vurgulamışlardır. Bu çalışmada regresyonlarda kurumsal değişkenlerle birlikte ticarete de yer verilmiştir. Her ne kadar kişi başma düşen reel GSYİH büyümesi artsa da uzun dönemde ticaret ve kurumsal değişkenlerin büyüme üzerindeki etkileri çok da bilgi vermemektedir.

Dollar ve Kraay'ın öne sürdükleri kurumlar ve ticaret için iyi birer araç değişken bulunmalı iddiasına Hall ve Jones (1999) kurumların etkisini araştırırken bu kurumların ülkelerin sömürge altında iken kurulduğuna dikkati çekerek ve bu kurumların orijininin bu sömürge dönemi olduğunu vurgulayarak cevap vermişlerdir.

Kurumsal yapı ile ekonomik büyüme arasında yapılan ampirik çalışmalarda önemli bir yer tutan bir diğer çalışma da "The Colonial Origins of Comperative Development: An Empirical Investigation" adlı çalışmadır (Acemoğlu, Johnson ve Robinson, 2001). Bu çalışmada kurumlarla yapılan ampirik çalışmalarda kurumsal değişkenlerin içsel olduğunu vurgulanmış ve bu değişkenler için araç değişkenler araştırılmıştır. Buldukları araç değişkenler kurumların tarihsel kökleridir. Bu araç değişken sömürge amacı ile yeni yerlere giden Avrupalı göçmenlerin ölüm oranlarıdır (settler mortality

Yukarıda anlatılan çalışmaya benzer bir başka çalışma da Rodrik, Subra-manian ve Trebbi (2004)'nin çalışmasıdır. Rodrik ve diğerleri, hem Frankel ve Romer'in (Frankel ve Romer, 1999) hem de Acemoglu ve diğerleri'nin (Ace-moğlu ve Romer 2001) çalışmalarını analiz etmişlerdir. Ancak çalışmalarında kurumsal değişkenlerin pozitif ve anlamlı sonuçlar verirken ticaret ve coğrafi değişkenlerin negatif ve anlamsız çıktığını vurgulamışlardır. Bu nedenle kurumsal değişkenlerin daha önemli olduğu iddiasını ön plana çıkarmışlardır.

Bu iki çalışmaya bir eleştiri Glasier ve diğerleri (2004) tarafından yöneltilmiştir. Bu araştırmacılara göre geçici koşullar altında bir yeri sömürmeye giden veya oraya yerleşmeye çalışan Avrupalılar'ın beraberinde götürdükleri hakkında kesin bir bilgiye ulaşılamayacaktır. Glaeser ve diğerlerine göre yerleşenler beraberinde kurumları değil beşeri sermayeyi ve fikirleri götürmüşlerdir. Sonuç olarak, kurumların olsa olsa ikinci derece önemi olacağını birinci derecede ise beşeri sermayenin daha etkin ve ön planda olacağını iddia etmişlerdir.

$\mathrm{Bu}$ yönde yapılan bir başka çalışma da Bhattarchayya (2005 ve 2008) 'dır. Bhattarchayya da Glasier ve diğerleri gibi kurumsal değişkenlerin sömürge dönemi orijinlerinin araç değişken olarak alınmasını doğru bulmamıştır. Analizine beşeri sermayeyi ve dışa açıklığı alarak kurumların büyüme üzerindeki etkisini incelemiştir. Analizini yaparken Rodrik ve diğerlerinin kullandığı kurumsal değişkenleri kullanmıştır. Sonuç olarak da büyüme üzerinde kurumların etkisinin belirsiz olduğunu belirtmiştir.

\section{Veri Analizi:}

İktisadi büyüme literatüründe sıklıkla kullanılan ekonometrik yöntem panel data yöntemidir. Bu yöntemde veriler yatay-kesit analizi ve zaman serisi birleştirilerek hem zaman hem de yatay-kesit boyutu incelenebilmektedir. Dolayısıyla yatay-kesit ve zaman serisi analizlerine göre panel veri yöntemi daha fazla gözlem sayısına sahiptir.

$\mathrm{Bu}$ çalışma kapsamında veriler analiz edilirken "Çift Yönlü Hata Bileşenleri Modeli” (Two-Way Error Component Regression Model) kullanılmıştır. Bu model kapsamında hem sabit etkiler hem de rassal etkiler 
modelleri test edilmiştir. Bu panel veri modelinin genel şekli aşağıda eşitlikte verilmektedir.

$$
\begin{gathered}
Y_{i t}=\mu_{i}+\beta_{1 i t} X_{1 i t}+\beta_{2 i t} X_{2 i t}+\cdots \cdots \cdots \cdots+\beta_{k i t} X_{k i t}+\lambda_{t}+v_{i t} \\
\quad \mathrm{i}=1,2, \ldots, \mathrm{N}
\end{gathered}
$$

Modelde yer alan (i) yatay-kesit birimleri (t) zaman-boyutunu göstermektedir. $\mu_{i}$ gözlenemeyen kişisel etkileri; $\lambda_{t}$ gözlenemeyen zaman etkileri; $v_{i t}$ stokastik hata terimini ifade eder. Bu değişken kişisel değişmeyen etkileri ve regresyona dahil edilmeyen zaman etkilerini gösterir. Üretimi etkileyen grevler, fiyatları etkileyen arz şokuna neden olan petrol fiyatları artışı ve tüketici davranışlarını etkileyen hükümet politikaları bu değişkene örnek olarak verilebilir (Baltagi, 2005).

Çalışmada 1970-2009 yılları arasmda 90 Az Gelişmiş, Gelişmekte ve Gelşimiş ülke seçilerek model tahmin edilmiştir. Modelde kullanılan kişi başma düşen GSYİH büyüme verileri Dünya Bankası'nın 'World Development Indicators' websitesinden alınmıştır. Kişi başına düşen GSYİH verileri 2000 yılına ait sabit dolar değerleridir. Başlangıç kişi başına düşen GSYİH değerleri ise Penn-World Table 7.0'ın websitesinden alınmıştır. Yatırım değişkeni de bu siteden alınmıştır. Yatırım değişkeni, yatırımın sabit GSYİH'ya oranıdır. Modelde kullanılan yaşam beklentisi değeri (life expectancy) 'World Development Indicators' websitesinden elde edilmiştir. Çalışmada beşeri sermaye olarak Barro-Lee'nin hazırladığı eğitim verileri kullanılmıştır. Eğitim verisi olarak toplam orta öğretime dahil olanların tüm nüfus içerisindeki 15 yaş ve üzeri kişilere oranı alınmıştır. $\mathrm{Bu}$ verilerden başlangıç kişi başına düşen GSYİH verisi ve yaşam beklentisi değişkenlerinin logaritması alınmıştır.

Çalışmada kullanılan kurumsal değişkenler şu şekildedir: piyasa yapıcı (market creating), piyasayı düzenleyen (market regulating), piyasa istikrarlaştırıcı (market stabilising) ve piyasayı yöneten (market legitimising) şeklinde tanımlayabiliriz. Kurumlar bu şekilde Rodrik ve diğerleri (2004) tanımlanmıştır. Bhattarchayya (2005) de bu tanımlamayı almıştır. Bu çalışma kapsammda da Bhattarchayya (2005)'in yaptı̆̆ı gibi tanımlanan kurumsal değişkenler için gösterge değişkenler (proxy variables) kullamlmıştır.

Rodrik ve diğerleri (2004)'ne göre piyasa yapıcı kurumlar mülkiyet haklarının ve sözleşmeleri güvence altına alan kurumlardır. Araştırmacılara göre bu kurumlar olmazsa ve mülkiyet hakları ile sözleşmelerin güvence altına almaması durumunda piyasa işlemeyecektir. Piyasayı yöneten kurumlar ise piyasa başarısızlıklarını engelleyen ve uzun vadede büyümeyi istikrarlı bir yapıya oturmasını sağlayan kurumlardır. Bu kurumlar sayesinde rekabeti engelleyecek davranışları, eksik bilgi altında karar alınmasını ve piyasadaki işlem maliyetlerinin artmasını minimize edecektir.

Piyasayı istikrarlaştırıcı kurumlar ise şoklara karşı esneklik sağlanmasını, enflasyonist baskıyı azaltmayı, makroekonomik değişkenliği (volatility) en aza indirmeyi ve finansal krizleri azaltmayı sağlar.

Piyasayı düzenleyen kurumlar ise geliri tekrar dağıtan, sosyal zıtllkları azal-tan ve krize karşı fakirlere sosyal yardımlar sağlayan kurumlardır. Piyasada tekrar gelir dağıtımı, sosyal koruma ve sigorta sistemi sosyal zıtlıkları gidermede büyük öneme sahiptir. (Bhattarchayya; 2005).

$\mathrm{Bu}$ çalışma kapsamında yukarıdaki kurumları için gösterge değişkenler almıştır. $\mathrm{Bu}$ değişkenler Fraser Enstitüsünün hazırladığı 'Dünya'daki Ekonomik Özgürlükler' listesindeki değişkenler arasından seçilmiştir. Piyasa yapıcı kurumlar olarak, 'Legal Yapı ve Mülkiyet Haklarımn Korunması' (Legal Structure and Security of Property Rights) değişkeni; piyasayı düzenleyen kurumlar için 'Kredi, Emek ve Iş Dünyası Düzenlemeleri' (Regulation of Credit, Labor and Business) değişkeni; piyasa istikrarlaştırıcı kurumlar için ' Güçlü Paraya Ulaşma imkanı (Access to Sound Money) değişkeni; piyasayı düzenleyen kurum olarak da 'Demokrasi' değişkeni alınmıştır. Bu değiş̧ken Polity IV Project' ten alınmıştır.

\section{Sonuçların Yorumlanması:}

Çalışma kapsamında kullanılan veriler Rodrik ve diğerleri'nin (2004) tanımladığı dört ana grup için seçilen verilerdir. Bu verilerin özet istatistikleri Tablo l'de verilmiştir.

\begin{tabular}{|c|c|c|c|c|c|}
\hline Değişkenler & Gözlem Sayısı & Ortalama & Std. Hat. & Min & Max \\
\hline Growth & 630 & 1.746732 & 2.927396 & -12.1 & 16.0753 \\
\hline LGDP & 630 & 8.301772 & 1.275742 & 4.764027 & 10.71072 \\
\hline I/GDP & 630 & 22.32255 & 10.01313 & -2.25684 & 76.8648 \\
\hline Yaşam & 630 & 4.132361 & .1884633 & 3.351937 & 4.401454 \\
\hline Eğitim & 616 & 27.23604 & 17.6376 & 0.5 & 77.8 \\
\hline Democ & 625 & 5.0952 & 4.17977 & 0 & 10 \\
\hline fi_leg & 483 & 5.419928 & 1.963116 & 1.1467 & 9.33249 \\
\hline fi_reg & 503 & 5.516565 & .9583747 & 2.70796 & 8.75543 \\
\hline fi_sm & 587 & 6.569139 & 2.251325 & 0 & 9.843 \\
\hline
\end{tabular}

Tablo1. Rodrik ve Digerleri (2004) Tanımladı̆̆ Kurumsal Değişkenler Özet İstatistikler 
Ayrıca regresyonlarda kullanılan değişkenlerin arasındaki ilişki ise Tablo 2'deki korelasyon matrisinde görülebilir. Veriler arasındaki korelasyon incelendiği zaman bazı değişkenler arasında yüksek korelasyon olsa da genelde değişkenler arasındaki korelasyon düşüktür. $\mathrm{Bu}$ sayede, tahmin yaparken bu verileri bir arada kullanılmasını engelleyen çoklu doğrusallık sorunun önüne geçilmiş olur.

$\begin{array}{cccccccccc}\text { Growth } & \text { Growth } & \text { linitial } & \text { I/GDP } & \text { Yasam } & \text { Egitim } & \text { Democ } & \text { fi_leg } & \text { fi_reg } & \text { fi_sm } \\ \text { linitial } & 0.156 & 1 & & & & & & & \\ \text { I/GDP } & 0.327 & 0.143 & 1 & & & & & & \\ \text { Yasam } & 0.248 & 0.851 & 0.225 & 1 & & & & \\ \text { Egitim } & 0.166 & 0.713 & 0.132 & 0.726 & 1 & & & & \\ \text { Democ } & 0.135 & 0.7 & 0.032 & 0.659 & 0.623 & 1 & & & \\ \text { fi_leg } & 0.249 & 0.714 & 0.073 & 0.588 & 0.584 & 0.587 & 1 & & \\ \text { fi_reg } & 0.124 & 0.376 & 0.106 & 0.302 & 0.369 & 0.421 & 0.444 & 1 & \\ \text { fi_sm } & 0.216 & 0.429 & 0.093 & 0.375 & 0.372 & 0.344 & 0.494 & 0.468 & 1\end{array}$

Tablo 2. Rodrik ve Digerleri (2004) Tanımladı̆̆ı Kurumsal Değişkenlerin Pairwise Korelasyonu

Araştırma kapsamında model sabit etkiler modeli ile tahmin edilmiştir. Bunun için STATA 11.0 kullanılmıştır. Tablo 3 'te Rodrik ve diğerleri (2004) tarafindan ortaya atılan kavramlar çerçevesinde elde edilen değişkenler tahmin edilmiştir. M1, M2, M3 ve M4 nolu regresyonlarda kurumlar bir kere kullanılmıştır.. Bu regresyonda başlangıç seviye kişi başına düşen GSYİH değeri beklendiği gibi negatif ve anlamlı çıkmıştır Eğitim değişkeni de beklenen işarette ancak anlamsız çıkmıştır. Yatırımın GSYİH içindeki payı ve yaşam beklentisi pozitif ve \% anlamlidir.

\begin{tabular}{|c|c|c|c|c|c|c|}
\hline Değişkenler & M1 & M2 & M3 & M4 & M5 & M6 \\
\hline IGDP & $\begin{array}{c}-3.460 * * * \\
(0.522)\end{array}$ & $\begin{array}{c}-3.064 * * * \\
(0.498)\end{array}$ & $\begin{array}{c}-3.036^{* * * *} \\
(0.453)\end{array}$ & $\begin{array}{c}-2.850 * * * \\
(0.402)\end{array}$ & $\begin{array}{c}-5.521 * * * \\
(0.664)\end{array}$ & $\begin{array}{c}-5.482 * * * \\
(0.677)\end{array}$ \\
\hline Yaşam & $\begin{array}{l}4.930 \\
(2.810)\end{array}$ & $\begin{array}{l}6.389^{*} \\
(2.521)\end{array}$ & $\begin{array}{l}4.896^{*} \\
(2.272)\end{array}$ & $\begin{array}{l}4.680^{*} \\
(1.870)\end{array}$ & $\begin{array}{l}4.321 \\
(2.949)\end{array}$ & $\begin{array}{c}4.307 \\
(2.953)\end{array}$ \\
\hline Ticaret & $\begin{array}{l}0.019^{*} \\
(0.008)\end{array}$ & $\begin{array}{l}0.007 \\
(0.006)\end{array}$ & $\begin{array}{c}0.006 \\
(0.009)\end{array}$ & $\begin{array}{l}-0.004 \\
(0.008)\end{array}$ & $\begin{array}{c}0.037 * * * \\
(0.007)\end{array}$ & $\begin{array}{c}0.034 * * * \\
(0.009)\end{array}$ \\
\hline $\begin{array}{c}\text { Hükümet } \\
\text { Harcamaları }\end{array}$ & $\begin{array}{l}-0.063 \\
(0.060)\end{array}$ & $\begin{array}{l}-0.096 \\
(0.057)\end{array}$ & $\begin{array}{l}-0.036 \\
(0.047)\end{array}$ & $\begin{array}{l}-0.061 \\
(0.040)\end{array}$ & $\begin{array}{c}0.026 \\
(0.064)\end{array}$ & $\begin{array}{c}0.025 \\
(0.065)\end{array}$ \\
\hline Yatırım & $\begin{array}{c}0.108^{* * *} \\
(0.025)\end{array}$ & $\begin{array}{c}0.098 * * * \\
(0.026)\end{array}$ & $\begin{array}{c}0.112 * * * \\
(0.022)\end{array}$ & $\begin{array}{c}0.099 * * * \\
(0.017)\end{array}$ & $\begin{array}{c}0.122 * * * \\
(0.025)\end{array}$ & $\begin{array}{c}0.122^{* * *} * \\
(0.027)\end{array}$ \\
\hline Eğitim & $\begin{array}{c}0.018 \\
(0.018)\end{array}$ & $\begin{array}{c}0.024 \\
(0.018) \\
\end{array}$ & $\begin{array}{c}0.006 \\
(0.017) \\
\end{array}$ & $\begin{array}{c}0.002 \\
(0.014) \\
\end{array}$ & $\begin{array}{c}0.030 \\
(0.015) \\
\end{array}$ & $\begin{array}{c}0.020 \\
(0.018) \\
\end{array}$ \\
\hline Prop. & $\begin{array}{c}0.367^{* *} \\
(0.113)\end{array}$ & & & & $\begin{array}{l}0.247^{*} \\
(0.110)\end{array}$ & $\begin{array}{l}0.248^{*} \\
(0.117)\end{array}$ \\
\hline Reg. & & $\begin{array}{l}0.590 * * \\
(0.207)\end{array}$ & & & $\begin{array}{c}0.208 \\
(0.220)\end{array}$ & $\begin{array}{c}0.218 \\
(0.222)\end{array}$ \\
\hline SM & & & $\begin{array}{l}0.201 * * \\
(0.072)\end{array}$ & & $\begin{array}{c}0.132 \\
(0.075)\end{array}$ & $\begin{array}{c}0.132 \\
(0.079)\end{array}$ \\
\hline Democ & & & & $\begin{array}{c}0.008 \\
(0.046) \\
\end{array}$ & $\begin{array}{c}0.010 \\
(0.056) \\
\end{array}$ & $\begin{array}{c}0.044 \\
(0.187) \\
\end{array}$ \\
\hline $\operatorname{Democ}^{\wedge} 2$ & & & & & & $\begin{array}{l}-0.006 \\
(0.020)\end{array}$ \\
\hline Sabit & $\begin{array}{c}6.011 \\
(12.137)\end{array}$ & $\begin{array}{c}-3.200 \\
(10.762)\end{array}$ & $\begin{array}{c}3.925 \\
(9.803) \\
\end{array}$ & $\begin{array}{c}5.541 \\
(8.267) \\
\end{array}$ & $\begin{array}{c}22.541 \\
(13.093) \\
\end{array}$ & $\begin{array}{c}22.189 \\
(13.161) \\
\end{array}$ \\
\hline $\begin{array}{c}\text { Gözlem } \\
\text { Sayısı (N) }\end{array}$ & 470 & 490 & 565 & 689 & 445 & 445 \\
\hline F-Testi & $\begin{array}{l}4.15 * * * \\
(0.0005)\end{array}$ & $\begin{array}{l}4.77 * * * \\
(0.0001)\end{array}$ & $\begin{array}{l}6.52 * * * \\
(0.0000)\end{array}$ & $\begin{array}{l}11.30 * * * \\
(0.0000)\end{array}$ & $\begin{array}{c}2.32^{*} \\
(0.0325)\end{array}$ & $\begin{array}{c}2.30^{*} \\
(0.0342)\end{array}$ \\
\hline $\mathrm{R}^{\wedge} 2$ & 0.2642 & 0.2441 & 0.2580 & 0.2489 & 0.3072 & 0.3074 \\
\hline Hausman & $\begin{array}{c}32.99 \\
(0.0017)\end{array}$ & $\begin{array}{c}29.66 \\
(0.0053)\end{array}$ & $\begin{array}{c}32.98 \\
(0.0017)\end{array}$ & $\begin{array}{c}32.41 \\
(0.0035)\end{array}$ & $\begin{array}{c}63.08 \\
(0.0000)\end{array}$ & $\begin{array}{c}63.25 \\
(0.0000)\end{array}$ \\
\hline
\end{tabular}

Tablo 3. Regresyonların Tahminlerinin Sonuçları .

Notlar: $* p<0.05, * * p<0.01, * * * p<0.001$. Parantez içindeki rakamlar standart hatalarl göstermektedir.

Tablodaki F-Testi zaman etkilerinin toplamda anlamlı olup olmadığını test etmektedir. Hausman Testi sonuçlarına göre modeller tahmin edilirken Sabit Etkiler Modeli kullanılmıştır. Hausman Testi teorik olarak da tercih edilen Sabit Etkiler Modeli kullanılmasını destekler yöndedir.

M1 nolu sütunda gösterilen spesifikasyonda kurumsal değişkenlerden 'Legal Yapı ve Mülkiyet Haklarının Korunması'na, (Prop) yer verilmiştir. Bu değişken pozitif işaretli ve istatistiki olarak \%10 anlamlılık düzeyinde 
anlamlıdır. Dolayısıyla piyasa yapıcı kurumların iktisadi büyüme üzerinde pozitif bir etkiye sahip olduğunu söyleyebiliriz.

M2 nolu sütundaki spesifikasyonda ise piyasayı düzenleyen kurumlar için belirlenen gösterge değişken 'Kredi, Emek ve İş Dünyası Düzenlemeleri' (Reg)'e yer verilmiştir. Bu değişken pozitif işaretli ve istatistiki olarak \%10 anlamlılık düzeyinde anlamlıdır. Bu regresyon bize piyasa düzenleyen kurumla büyüme arasında bir ilişki olduğunu ifade etmektedir. M3 nolu sütundaki spesifikasyonda ise piyasa istikrarlaştırıcı kurumlar için belirlenen gösterge değişken ' Güçlü Paraya Ulaşma İmkanı'na, (SM) yer verilmiş̧ir. Değişken anlamsız olmasına karşın işareti beklendiği gibi pozitif yöndedir. Bu kurumsal değişken de $\% 10$ anlamlılık düzeyinde istatistiki olarak anlamlıdır. M4 nolu spesifikasyonda ise piyasayı yöneten kurumsal değişken olarak regresyona dahil edilen demokrasi (Democ) değişkeninin katsayısı beklendiği gibi pozitif ancak istatistiki olarak anlamsızdır. Bu sonuca göre demokrasinin iktisadi büyüme üzerinde ektisi yoktur.

M6 nolu spesifikasyon tercih edilen regresyondur. Bu regresyonda dört farklı tipteki kurum da analize dahil edilerek, büyüme üzerindeki etkileri analize katılmıştır. Başlangıç seviyesi kişi başına düşen GSYIH negati işaretli ve $\% 1$ anlamlılık düzeyinde istatistiki olarak anlamlı; yatııımın GSYIH içindeki payı poztif işaretli ve \%1 anlamlılık düzeyinde istatistiki olarak anlamlıdır. Kurum değişkenlerinden sadece legal yapı ve mülkiyet haklarının korunması değişkeni istatistiki olarak anlamlıdır. Bu değişken pozitif ve $\% 5$ anlamlılık düzeyinde istatistiki olarak anlamlıdır. Bu regresyon bize piyasa yapıcı kurumların büyüme üzerinde etkisi olduğunu göstermektedir.

$\mathrm{Bu}$ sonuç bize piyasa yapıcı kurumun diğer kurumsal tiplerinden daha önemli olduğunu göstermektedir. Yukarıdaki açıklamalardan lineer regresyonlar sonucuna göre diğer kurum tiplerinin büyüme üzerinde bir etkisi olmadığı sonucu çıkmaktadır. Bununla birlikte, M6 nolu spesifikasyonda olduğu gibi non-lineer bir modelde sonuçlar pek de farklı çıkmamaktadır. Modele demokrasi değişkenin karesi eklendiği zaman da piyasa yapıcı kurumlar olarak alınan 'Legal Yapı ve Mülkiyet Haklarının Korunması' değişkeni

$\% 5$ anlamlılık düzeyinde istatistiki olarak anlamlıdır. Buna karşın, piyasayı düzenleyen değişken olan demokrasi değişkeni lineer yapıda pozitif, non-lineer yapıda ise negatiftir. Ancak her iki değişken de istatistiki olarak anlamsızdır. Bu durum bize demokrasinin büyüme için önemli olmadığını göstermektedir. $\mathrm{Bu}$ da gözlenmeyen bir durum değildir. Çin, Uzakdoğu Asya ülkeleri gibi demokratik sistemden uzak olan ülkelerin yüksek büyüme oranları yakalayabilmiş olması, bu sonucu mantıklı bir çerçeveye oturtur.

\section{Sonuç}

Bu çalışma kapsamında farklı kurumsal değişkenler seçilerek, bu değişkenlerin büyüme üzerindeki etkisi incelenmiştir. Piyasa yapıcı, piyasa düzenleyici, piyasayı istikrara kavuşturan ve piyasayı yöneten kurumların etkisi panel data yöntemi kullanılarak incelenmiştir. Piyasa yapıcı kurum olarak legal yapı ve mülkiyet haklarının korunması indeksi kullanılmıştır. Bu değişken hem hukuki yapının iyi yerleşmesi hem de baskı gruplarından bağımsız olmasını öngörür. Buna ek olarak, yargının mülkiyet haklarını iyi koruması gerektiğini savunur. Piyasa düzenleyici kurum olarak kredi, emek ve iş dünyası düzenlemeleri değişkenini almıştır. Bu kurumsal değişken kredi bulmayı kolaylaştıran, dışsallıkları ve aksak rekabet şartlarını engelleyen ve ölçek ekonomilerini gözeten kurumlardır. $\mathrm{Bu}$ düzenlemeler yatırımcının maliyetlerini minimize etmeyi amaç edinir. Piyasayı istikrara kavuşturan değişken olarak güçlü paraya ulaşma imkanı tercih edilmiştir. Bu değiş̧en düşük enflasyon oranı, döviz kurunun aşırı değerlenmesini engelleme ve makro ekonomik istikrarı gözetir. Son olarak da piyasa yöneten kurum olarak demokrasi analize katılmıştır. Demokratik bir ülkede tekrar dağııım yoluyla eşitsizliklerin engellenmesi, sosyal yardımlar ile de sosyal zıtlıkların önüne geçmek amaçlanır

Tahmin yöntemi olarak panel data yöntemi tercih edilmiştir. Spesifikasyon sonuçlarına göre ekonomik büyüme için piyasa yapıcı kurumlar daha ön plandadır. Bu sonuç yatırımların yapılmasının ve bu yatırımların büyümeye olumlu yansıması için piyasanın olmazsa olmaz olduğu koşulunu desteklemektedir. Hukuki sistemin iyi kurulduğu ve mülkiyet haklarına sahip çıkıldığı bir piyasada yatırımcılar hem yatııı yapmaktan hem uzun vadeli düşünmekten vazgeçmeyeceklerdir. Bu da büyümeyi olumlu yönde etkileyecektir. Bu sonuçla birlikte piyasa düzenleyici kurum olarak kredi, emek ve iş dünyası değişkeni de büyüme üzerinde olumlu etkiye sahiptir. Ayrıca güçlü paraya ulaşma değişkeni de büyüme üzerinde etkindir. İstikrarlı bir piyasada yüksek enflasyon oranları olumsuz şokun yatırımcılar üzerindeki etkisi ve aşırı değerli döviz kuruna izin verilmeyecektir. Bu önlemler de ekonomik büyümeyi arttıracaktır. Bir diğer önemli unsur da legal yapı ve mülkiyet hakları ile temsil edilen piyasa yapıcı değişkendir.

Çalışmadan çıkan bir başka sonuç da demokrasinin büyümeyi olumlu yönde etkilemediğidir. Bu sonuç teorik bakış açısıyla çelişkili gibi durmaktadır. Ancak seçilen ülkelerin sayısının çokluğu ve ülkelerin heterojen bir yapıda olması bu sonuca neden olmuş olabilir. Ayrıca Uzakdoğu Asya ülkeleri ve Çin gibi yüksek büyüme oranları yakaladıkları dönemlerde demokrasiden uzak oluşları da bu sonucu destekleyen bulgulardır. Buna karşın piyasanın sağlam temeller üzerine kurulduğu ve etkin çalıştığı bir ekonomide büyüme oranları da istikrarlı ve yüksek oranlı olacaktır. 


\section{KAYNAKÇA}

- Acemoğlu, D., S. Johnson, and J. Robinson. 2001. The colonial origins of comparative development: an empirical investigation. American Economic Review. 91(5). sf:1369-1401.

- Baltagi. Badi. 2005. Econometric Analysis of Panel Data. John Wiley \& Sons Ltd. England.

- Barro, R.J. 1991. Economic Growth in a Cross-section of Countries. Quarterly Journal of Economics. 106, sf: 407-443.

- Barro, R.J. 1997. Determinants of Economic Growth: A Cross-Country Empirical Study, NBER Working Papers, No: w5698.

- Barro, R.J. and J.W. Lee. 1994. Sources of Economic Growth. Carnegie Rochester Conference on Public Policy, 40, sf:1-46.

- Barro, R.J. and J.W. Lee. 2010. A New Data Set of Educational Attainment in the World, 1950-2010. NBER Working Paper Series. No: w 15902.

- Barro, R.J. ve J.W. Lee. 1994. Losers and Winners in Economic Growth Proceedings of the World Bank Annual Conference on Development Economics, The World Bank, sf: 267-297.

- Barro, R.J. ve X. Sala-i-Martin. 1995. Economic Growth. New York: McGraw Hill.

- Bhattacharyya. Sambit. 2005. Which Institutions Matter Most for Growth. Working Papers. http://papers.ssrn.com/sol3/papers.cfm?abstract_id=926487.

- Bhattacharyya. Sambit. 2008. Unbundled Institutions, Human Capital and Growth. Journal of Comparative Economics.

- Dollar, D., and A. Kraay. 2003. Institutions, Trade, and Growth, Journal of Monetary Economics, 50, pp. 133-162.

- Frankel, J., and D. Romer. (1999). “Does trade cause growth?” American Economic Review, 89(3), pp. 379399.

- Glaeser, E., R. LaPorta, F. Lopez-de-Silanes, and A. Shleifer. 2004. Do Institutions Cause Growth? Journal of Economic Growth, 9, pp. 271-303.

- Hall, R., and C. Jones. 1999. Why do some countries produce so much more output per worker than others? Quarterly Journal of Economics, 114(1), pp. 83-116

- Rodrik, D. 2003. Growth Strategies. NBER Working Paper No.w10050.

- Rodrik, D. 2000. Institutions for High-Quality Growth: What They Are and How to Acquire Them. Studies in Comparative International Development, 35(3), 3-31.

- Rodrik, D., A. Subramanian, and F. Trebbi. 2004. Institutions Rule: the Primacy of Institutions over Geography and Integration in Economic Development. Journal

- of Economic Growth, 9, pp. 131-165

- Rodrik, D., and A. Subramanian. 2003. The Primacy of Institutions and what this does and does not mean. Finance \& Development, 40(2), pp. 31-34.

- Solow, Robert. 1956. A Contribution to the Theory of Economic Growth. Quarterly Journal of Economics 70. sf: 65-94

- Swan, Trevor. 1956. Economic Growth and Capital Accumulation. Economic Record. 


\title{
Girdi-Çıktı Analizi Yaklaşımıyla Kazakistan Ekonomisinin Dışa Bağımlılığının İncelenmesi (2006-2009)
}

\author{
Tuncer Özdil (Kyrgyzstan-Turkey Manas University, Kyrgyzstan) \\ Ainura Turdalieva (Kyrgyzstan-Turkey Manas University, Kyrgyzstan) \\ Zamira Oskonbaeva (Kyrgyzstan-Turkey Manas University, Kyrgyzstan)
}

\section{An Evaluation of Independence of Kazakhstan Economy by Input-Output Analysis (2006-2009)}

\begin{abstract}
Input-output analysis is an analytical technique widely used both in developed and developing countries which reflects the production consumption relationships of production sectors of a country's economy.

At the same time it is the macroeconomic analysis tool that defines economic relations of each sector by production and consumption. During the process of globalization all developed and developing country economies are trying to open their economies in order to provide their economic development. However, the openness can lead to negative consequences in some countries such as increasing their external dependence. In this paper it is aimed to investigate the structure of foreign trade of Kazakhstan and to measure the external dependence of economy.

For this purpose, with the help of input-output tables prepared for the period of 2006-2009, the inverse import matrix will be calculated by using coefficients of foreign trade flows, consequently the import quantities necessary to meet final demand and their changes during the period will be examined. According to the results obtained the potential impact of Kazakhstan's foreign trade structure on both Kyrgyzstan and other Central Asian Turkish Republics will be discussed.
\end{abstract}

JEL codes: F14, C67, D57

\section{Giriş}

Girdi - çıktı analizi bir ülke ekonomisindeki ekonomik üretim sektörlerinin kendi aralarındaki üretim-tüketim ilişkilerini yansıtan kendi içinde tutarlılı̆̆ olan, günümüzde gerek gelişmiş gerekse de gelişmekte olan ülke ekonomilerinde ekonomik analiz aracı olarak yaygın biçimde uygulanan analitik bir tekniktir. Aynı zamanda sektörlerin birbirleriyle olan ekonomik ilişkilerini hem tüketim hemde üretim boyutuyla tanımlayan makroekonomik analiz aracıdır.

Küreselleşme sürecinde tüm gelişmiş ve gelişmekte olan ülke ekonomileri doğal olarak, ekonomik kalkınmalarını sağlayabilmek için dışa açılmaya özen göstermektedirler. Ancak dışa açılma bazı ülkeler için dış bağımlılığı arttıracak şekilde olumsuz sonuçlara da yolaçabilmektedir. Çalışmamızda girdi-çıktı analizi yaklaşımıyla Kazakistan ekonomisinin dış ticaret yapısı ve ekonomisinin dışa bağımlılığı incelenmeye çalışılmıştır.

$\mathrm{Bu}$ amaçla, Kazakistan için 2006-2009 yılları arasında hazırlanan girdi-çıktı tablolarından yararlanılarak dış ticaret akım katsayıları yardımıyla ithalat ters matrisleri hesaplanarak, girdi-çıktı çözümlemeleri yoluyla nihai talebi karşılamak için gerekli aragirdi ithalat miktarları ve bunların dönem içindeki değişimleri incelenecektir. Buradan elde edilen bilgilere göre Kazakistan'ın dış ticaret yapısının başta Kırgızistan olmak üzere bu coğrafyada yer alan diğer Orta Asya Türk Cumhuriyetlerine olan potansiyel etkilerine de değinilecektir.

\section{Kazakistan Ekonomisi ve Dış Ticareti}

Kazakistan eski Sovyetler Birliğinin dağılmasıyla 1990'lı yılların başında bağımsızlığını elde etmiş zengin petrol yatakları ve doğal gaza sahip 16,2 mln nüfuslu bir Orta Asya ülkesidir. 2009 yılı itibariyle ülkede kişi başına gelir 7257 \$'dır. Toplam ihrcat 43 195, $8 \mathrm{mln}$ \$, ithalat ise 28 408,7mln \$' dır. İhracatın ithalatı karşılama oranı $\% 152$ dır. Yı1lık enflasyon $\% 6,2$ olup, dış borçların milli gelire oranı firmalararası borçlar dikkate alındığında \%104,1 firmalararası borçlar dikkate alınmadığında dış borç oranı \% 58,8 olarak gerçekleşmiştir. 2009'da GSYH'nın yıllık reel büyüme oranı \% 3,3 olmuştur. Kazakistan ithalatının önemli bir kısmını sanayiye yönelik ara ve yatırım malları ithalatı oluşturmaktadır. 2008 yılı itibariyle ülkenin toplam ithalatında tüketim mallarının pay1 \% 19 , ara malların payı $\% 43$ '1 ve yatııım mallarının payı $\% 37$ olarak gerçekleşmiştir (Казахстан в цифрах). Aynı yıl için ithalatın mal gruplarına göre dağılımı incelendiğinde, $\% 35$ oranıyla Otomotiv ve yedek parçaları en yüksek paya sahip olup bunu \%26,8 ile Metal anasanayi ve mamulleri, \%12,1 ile Kimya Sanayi, $\% 9,6$ Madencilik izlemektedir. Tarım sektörüne ait hayvansal ürünler ve ağaç orman ürünleri ithalatının payı ise $\%$ 11,4 olmaktadır. İthalatın ülke gruplarına göre dağılımı incelendiğinde, 2008 yılı itibariyle ithalatın ençok 
yapıldığı ilk on ülke arasında \%13,8'lik payla Rusya dikkat çekmektedir. Bunu sırasıyla Çin, Almanya ve Ukrayna izlemektedir. Türkiye ilk 10 ülke arasında \%1'lik payla sekizinci sırada yeralmaktadır. İthalatın coğrafik olarak ülke gruplarına göre dağılımına bakıldığında, Avrupa ülkeleri \%47,1, BDT ülkeleri \%26,2, Asya ülkeleri \%22,3'lük paylara sahiptirler.

2009 y1lında, toplam ithalat hacminde Rusya \%30,3, Çin \%15,9, Ukrayna \% 9,1, Almanya \%7,6, ABD \% 6,1, İtalya \%3,8, Büyük Britanya \%2,3, Japonya \%2,3 paylara sahiptirler (Платежный баланс и внешний долг РК за 2009 год).

Kazakistan'ın şu anki dış ticaret yapısına göre toplam ithalatın önemli bir kısmını yatırım ve ara malları oluşturmaktadır. Hatta yapılan ihracat ile hammadde ithalatı bile karşılanamamaktadır. Bunun sonucunda ihracatta meydana gelen her artış ithalata yansımakta, bu ise dış açık sorununu gündeme getirmektedir. Cari açık sorununun yanı sıra aşırı boyutlardaki hammadde ithalatı yerli ara malı üreticilerinin üretim hacmini de daraltabilmektedır. Bunun sonucunda ülkedeki ihracat artışı başka ülkelerin üretim ve istihdam sürecine yansımaktadır. Günümüz koşullarında dünya ekonomisinin karşılıklı bağımlılık özelliği, elbette dışa bağımlılığın tamamen ortadan kaldırılmasını olanaksızlaştırmaktadır. Ancak gerek üretimden elde edilen gelirin büyük bir kısmının yurtiçinde tutulması, gerekse ürünlerin yerli katkı paylarının artırılması suretiyle, istihdam, yatırım ve yurtiçi katma değerin daha da artırılması, bu bağımlılığın mümkün olan en düşük seviyelere çekilmesini gerektirmektedir (Özdil, 2011, s.358.). Bu amaçla ekonomide ileri ve geri bağlantı etkileri yüksek endüstrilerin belirlenmesi ve bu sektörlerin gelişiminin sağlanması önem taşımaktadır. Çünkü ileri bağlantı etkisi yüksek olan endüstriler diğer sektörlerde girdi olarak kullanıldıkları için, ülke dışı kaynaklara olan bağımlılığı azaltılmasına, diğer taraftan geri bağlantı etkileri yüksek olan endüstriler ise diğer sektörlerden girdi talebinde bulunacağından ekonominin uyarılması ve canlanmasına sebep olmaktadır. Böylece sektörleri dışa bağımlılıktan kurtarabilmek için sektörel bazda alınması gereken önlemler belirlenebilecektir (Özdil, 2009, s.120). Bu doğrultuda çalışmada Kazakistan ekonomisinde dışa bağımlılıktaki değişme incelenmekte bunun ülke bölge ekonomilerine potansiyel etkilerine değinilmektedir.

\section{Girdi - Çıktı Analizi Yaklaşımıyla Dışa Bağımıııı}

Girdi- Çıktı Analizi, matematiksel ve istatistiksel teknikler yardımıyla, endüstrilerarası ilişkileri tutarlı olarak inceleyen bir modeldir. Bir ekonomik sistemin belirli yapısal özelliklerini tanımlayan bir veriler toplamı ve sistemin belirli bir zaman aralığı içinde belirli bir anındaki davranışını etkileyici ve açıklayıcı analitik bir teknik olarak tanımlanabilir (Todaro, 1987, s.17). Analizin temeli, herhangi bir ülke ekonomisinin kendi içerisinde homojen ya da birbirine benzer mallar üreten endüstrilere bölünebilmesi ve bu endüstrilerin birbirleriyle ve ekonomiyle olan etkileşimlerinin matematiksel ifadesine dayanır.

Girdi-çıktı analizi yaklaşımı temelde, her biri ayrı üretim fonksiyonuna sahip n sayıda üretici sektör ve nihai talep üzerinde durur. Belli bir mal sadece bir sektör tarafından üretilmekte olup sektörlerin çıtıları birbirleriyle ikame edilememektedir. Bu analiz ekonomide uzun dönemde denge konumu için geçerlidir(Korum,1963,s.10). Leontief tarafından oluşturulan girdi-çıktı tablosu yalnızca üretim faaliyetlerini ele almakta, tüketimi bir sonuç olarak görmektedir. Üretim değerlendirilirken ise ekonomi iki kesime bölünmüştür. Birincisi üretimin gerçekleştiği kesim, ikincisi ise üretimin nihai talep olarak kullanıldığı kesim. Bir ülkenin sektörel planlamasının yapılmasında temel tahmin yöntemi olarak değerlendirilen girdi-çıktı tablosunun sütunları girdileri; satırları çıktıları gösterir. Oluşturulan girdi-çıktı tablosunda satır ve sütun toplamları birbirine eşittir. Bir sektörün toplam üretimi ile ara tüketimi arasındaki fark katma değer olarak tanımlanır. Satırların nihai taleple toplamı sütunların katma değerle toplamına eşittir. Bu bize girdi-çıktı tablosunda genel dengeyi gösterir (Kepenek, 1977:70). Bir ekonomik analiz yöntemi olarak girdi-çıktı analizinde, her sanayinin ürünü hem nihai tüketim içinde talep edilen bir mal, hem de kendisinin ve başka sanayilerin üretiminde kullanılan bir girdi olarak düşünülür. Böylece bir ekonominin çeşitli sektörleri arasındaki karşılıklı bağımlılık incelenmeye çalışılır. Bu amaçla oluşturulan endüstriler arası akım tablosunda; sektörler bir yandan kullanan sektörler, bir yandan da üreten sektörler olarak satır ve kolonlarda ikişer kez yer alırlar. Böylelikle, bir ekonomide belli bir dönemdeki üretim ve kullanımın sektörler tarafından nasıl paylaşıldığı görülebilmektedir. Girdi-Çıktı akım tablosundaki satır ve sütunlar sektörler için önemli bilgileri kapsamaktadır. Her bir sütun ilgili sektör için üretimindeki girdi bileşimini verirken, satırlarda talep kompozisyonunu vermektedir (Miernyk, 1996,ss.31-42).

Bir sektörün üretimi, nihai talebindeki artışı kadar artar, ama bunun yanında bu artışı sağlayacak ek ara girdi talebi diğer sektörlerin üretimini de uyarır. Üretimi uyarılan sektörler yine ara girdi talebi yoluyla diğer sektörlerin üretimini uyarırlar. Bu çevrimsel etkileşim başlangıçtaki uyarının ekonominin tamamı üzerindeki uyarı düzeyini gösterir. Bu nedenlerle gerisel bağlantı etkileri enaz 1 değerini alırlar. 1'in üzerindeki değerler ek üretim uyarma derecesini gösterir (G. Şenesen, 2005: s.29).

Endüstriler arası akım tablosunda ithalat rakip ya da tamamlayıcı ithalat olarak iki şekilde yer alabilmektedir (Chenery, 1965, s.139). Tamamlayıcı ithalat sektörün kendi üretiminde kullandığı ithal girdiler olarak zaten I. Bölmedeki girdi kullanımları arasında yer almaktadır. Burada ihracat ve ithalatın modele dahil edilmesinde farklı varsayımlara göre farklı yaklaşımlar görülebilmektedir. Genel olarak, reel mal ve hizmet ihracatı tıpkı yurtiçi 
yatırım ve tüketim talebi gibi bir nihai talep unsuru gibi düşünülerek tabloda II. Bölme içerisinde kolon vektör olarak yer almaktadır. İthalat ise rakip ya da tamamlayıcı ithalat olmaya göre farklı yerlerde yer alabilmektedir. Tamamlayıcı ithalat I. Bölmede girdi katsayıları içerisinde yer almaktadır. Rakip ithalat ise bir yurt dışı arz kaynağı olarak algılanarak farklı yaklaşımlara göre modele dahil edilebilmektedir. Ancak ithalatın rakip ve tamamlayıcı olarak ayrımının zor olmasından dolayı, izlenen standart yaklaşım; ithal edilen malların hem üretimde hem de nihai kullanımda yurt içi üretime tam rakip oldukları varsayımıdır. Bu uç varsayıma göre, ithalat tam olarak bir rakip arz kaynağı olarak ele alınır ve nihai talep unsurları içerisinde eksi (-) değerli kolon vektör olarak yer alır. Bu durumda tüm çözümlemeler net değerler üzerinden yapılır (Aydoğuş, 1999, ss.60-65).

$\mathrm{Bu}$ tabloların kullanıldığı alanlardan birisi de, ithal gereklerini ve nihai talepteki belirli değişikliklerin ödemeler dengesine etkilerini tahmin etmektir (Thirlwall, 1990: s.237). İthalatın yapısı ile yurtiçi ve yurtdış1 endüstrilerinin birbirleriyle olan ara girdi alışverişi de yine bu tablolardan ortaya konulabilmektedir. Bunun için, özel bir ithalat matrisini kullanmak anlamlı olmaktadır. Bu matriste tıpkı yerli ara girdilerde olduğu gibi, yurtiçi endüstrilerin kullandıkları ithalat yer almaktadır. İthalat matrisi türetilmiş yardımcı bir araç olarak, yurtiçi GirdiÇıktı tablosuna ilave edilmek suretiyle farklı bir endüstri gibi işlem görmektedir (Fleissner, 1993: s.44).

Bir ekonominin ithalata bağımlılığının ölçülmesinde kullanılacak olan ithalat ters matris tekniği girdi-çıktı modelinden türetilmiş yardımcı tekniklerden birisidir. Herhangi bir yıla ait ithalat ters matrisi, o yıla ait ithal girdi katsayıları matrisi ile yerli girdi katsayıları matrisinin tersinin çarpılmasıyla elde edilmektedir. R, İthalat ters matrisini, $A_{m}$, İthalat girdi katsayıları matrisini, $A_{d}$, Yerli girdi katsayıları matrisini göstermek üzere sektörlerdeki ithal girdi akımlarını gösteren ithalat ters matrisi,

$$
R=A_{m}\left(I-A_{d}\right)^{-1}
$$

şeklinde gösterilmektedir (Bocutoğlu, 1990, s.153). Burada, Ters ithalat matrisinin sütun toplamları;

$$
R_{j}=\sum_{j=1}^{n} r_{j}(j=1,2,3, \ldots) .
$$

j endüstrisi malına olan nihai talep bir birim arttığında doğrudan ve dolaylı olarak tüm endüstrilerin çıktılarına karşı duyulan ithal gereksinimlerinin toplamını verir. Yani j endüstrisinin bir birimlik daha fazla üretim gerçekleştirebilmesi için bütün endüstrilerden satın alacağı ithal girdi miktarlarının toplamını verir. Belli bir zaman dilimi içinde sütun toplamları değerinin artması ilgili endüstrinin girdi yönünden ithalata bağımlılığının arttığını gösterir. Sütun toplamları endüstilerin ithalatta geriye doğru bağlantı etkisi olarak tanımlanır.

Ters ithalat matrisinin satır toplamları ise,

$$
R_{{ }^{\prime}}=\sum_{i=1}^{n} r_{i}(j=1,2,3, \ldots)
$$

olarak gösterilir. Tüm endüstrilerin mallarına olan nihai talep birer birim arttığında bu talep artışını karşılamak için yapılacak üretimin $i$.nci endüstri malının ithal gereğini gösterir. Bu toplamlar ithalatın ileriye doğru bağlantı etkisidir.

Böylelikle ters matris satır ve sütun toplamlarıyla ithalatın doğrudan ve dolaylı bağlantı etkileri bulunarak, herhangi bir sektörün nihai talebindeki bir birimlik artışın, veya ekonomideki diğer sektörlerin nihai taleplerindeki bir birimlik artışın sektörde ve ekonomide yaratacağı ithalat değerleri elde edilmiş olacaktır.

\section{Kazakistan Ekonomisinde Dışa Bağımııı̆ı̆ın Girdi-Çıktı Analizi Yaklaşımıyla İncelenmesi}

Orta Asya Türk Cumhuriyetleri içerisinde Kazakistan sahip olduğu doğal kaynaklar, ekonomik zenginlikler nedeniyle hem Türk Cumhuriyetleri hemde bulunduğu coğrafyada önemli bir yere sahiptir. Bu ülke ekonomisindeki olumlu veya olumsuz gelişmeler; ekonomik piyasalardaki psikolojik faktörler ve çarpan hızlandıran mekanizmalarıyla tüm bölge ülkelerini kısa sürede etkilemektedir. Küreselleşmenin de etkisiyle, ekonomik entegrasyonun gündemde olduğu günümüzde dışa bağımlılığı ortadan kaldırmak olanaksız ise de, enazından azaltmak veya bağımlılık artışının yolaçacağı sonuçları bilmek önemli olmaktadır. Bu ve benzer düşüncelerle bölgede aktif, önemli bir role sahip olan Kazakistan ekonomisinin dışa bağımlığını inceleyerek bunun başta Orta Asya Türk Cumhuriyetleri olmak üzere bölge ekonomilerine olası potansiyel etkileri araştırılmaktadır.

\subsection{Araştırmanın Amacı Yöntemi ve Veri Kaynakları}

Bu çalışmanın amacı, Kazakistan'da endüstrilerarası ara girdi kullanımlarında doğrudan ve dolaylı etkilerle ortaya çıkan ithalata bağımlılığın belirlenmesi ve 2006-2009 dönemindeki değişimin incelenmesidir. İthalata bağımlılığı etkileyen nihai talep kesimi otonom kalemlerden oluşmakta olup, çalışmanın kapsamı dışında tutulmuştur. Ayrıca rakip ithalat analize dahil edilmemiştir. 
Çalışmada kullanılan temel veri kaynağı Kazakistan İstatistik Ajansı tarafından hazırlanan araştırmanın yapıldığı döneme ilişkin Kazakistan Ekonomisi Girdi-Çıktı Tablolarıdır. Kazakistan'da bağımsızlık sonrası dönemde, 1999 yılından başlanarak 2001 ve 2002 yılları hariç her yıl düzenli olarak girdi-çıktı tabloları yayınlanmıştır. Son yayınlanan tablo 2009 yılına aittir. 2005 yılından önceki tablolarda sektörlerarası ithal girdi kullanımı akım tablosu yeralmamaktadır. Bu tablo ilk kez 2005 yılı ve sonraki yıllarda hazırlanan tablolarda yeralmaktadır. 2005 yılı Girdi-Çıktı tablosu 61 sektörlü tablo olarak hazırlanmışken 2006 ve sonraki yıllarda hazırlanan tablolar 59 sektörlü tablolardır. Çalışmada tablolar arasında sektör sayısı bakımından homojenliği sağlayabilmek için 2005 yılı tablosu analize alınmamış, analiz 2006, 2008 ve 2009 yılı tabloları kullanılarak gerçekleştirilmiştir.

Toplam ithalat ve ekonomi genelinde göreli payı çok küçük olan sektörler yorum ve hesaplama kolaylıkları nedeniyle toplulaştırılarak tablolar 50 sektöre indirgenmiştir. Uluslararası Endüstriyel Sektör Sınıflamaları (ISIC) notasyonlarına göre, sektör içerikleri incelenmiş 2007 y1lı hariç tüm tablolarda ekonomik üretim sektörlerinin aynı ad, sıra ve içerikte yeraldıkları görülmüştür. Sektörlerdeki ufak tefek farklılıklar nedeniyle yanıltıcı sonuçlar çıkabileceği düşüncesiyle 2007 yılı tablosu analizden çıkarılmıştır.

Bunlar dışında gerek Girdi-Çıktı Analizinin teorik varsayımlarından gerekse de tabloların hazırlanma yöntemlerinden kaynaklanabilecek sektör içerikleri, enflasyonun etkisi gibi türlü sorunların olmadığı veya bunların tüm tablolarda da olması nedeniyle karşılaştırmaya dayalı sonuçları etkilemediği varsayılmıştır.

2006, 2008 ve 2009 yılları için hazırlanan Girdi-Çıktı Akım tablolarından yararlanılarak 50 sektör üzerinden yurtiçi girdi kullanımlarıyla yurtiçi teknik katsayılar matrisi $\left(\mathrm{A}_{\mathrm{d}}\right)$, Sektörlerarası ithal aragirdi kullanımlarıyla ithal aragirdi katsayıları matrisi $\left(\mathrm{A}_{\mathrm{m}}\right)$ hesaplanmış, yerli teknik katsayı matrisinin birim matristen farkı alınarak elde edilen ters matris $\left(I-A_{d}\right)^{-1}$ ithal ara girdi kullanımları matrisiyle $\left(A_{m}\right)$ çarpılarak ithalat ters matrisi $(R)$ elde edilmiştir. Bu matrisin satır ve sütun toplamları alınarak, ithal girdi kullanımında doğrudan ve dolaylı talepler, yani toplam ileri ve geri bağlantı etkileri elde edilmiştir. Sonuçlar tablo 1 ve tablo 2'de görülmektedir.

\subsection{Kazakistan Ekonomisinde İthal Ara Girdi Kullanımında Geri Bağlantı Etkileri}

Ters ithalat matrisinin herhangi bir $\mathrm{j}$ sütunundaki elemanların toplamı, bu sütunun belirttiği sektörnü ürettiği mala karşı nihai talepte bir birimlik artışı karşılamak için ekonomiyi oluşturan tüm sektörlerin sözkonusu artış1 karşılayabilmek için yapmaları gereken ithalat artışlarını verir. Diğer bir ifadeyle geri bağlantı etkileri yüksek olan sektörler diğer sektörlerden ara girdi talebinde bulunarak ekonominin uyarılması ve canlanmasına sebep olurlar (Ersungur, 2009, s.154.). Araştırmanın yapıldığı dönemde Kazakistan ekonomisi için hesaplanan ithalat geri bağlantı katsayıları ve bu katsayıların büyükten küçüğe sıralanmalarıyla elde edilen sektörlerin göreceli olarak konumunu gösteren önem sırası sayıları tablo 1'de görülmektedir.

Dönem içerisinde ekonomi genelinde toplam geri bağlantı etkisi 2008 yılında azalmakla birlikte 2009 yılında tekrar artmakta, 2006 yılına göre geri bağlantı ekilerinde bağımlılık anlamında \%14 oranında artış gerçekleşmektedir. Sektörler incelendiğinde de, bazı sektörlerde katsayılardaki değişim oranı başlangıca göre negatif yönlü olup bağımlılıkta azalmayı gösterirken, 50 sektörün 29 tanesinde dönem içinde bağımlılığın arttığ görülmektedir. Tablodaki 01-07 numarlar arası, ilk 7 sektör genel olarak tarım ve tarıma dayalı sanayiler, 08-32 numaralar arası 25 sektör imalat sanayini geriye kalan 33-50 numaralar arası 18 sektör hizmet sektörlerini oluştırmaktadır. Buna göre, tarımda yeralan 7 alt sektörden 4 tanesinde, sanayide yeralan 25 alt sektörden 14 tanesinde, hizmetlerde yeralan 18 alt sektörden 11 tanesinde ithal aragirdi kullanımının arttığı görülmektedir (Tablo 1).

Geri bağlantı etkilerine göre 2009 yılı için ithal aragirdi kullanımı en yüksek olan ilk on sektör; 17. Kimya sanayii, 18.Kimyasal ve plastik hammadde imalatı 29.Diğer sınıflamalara dahil edilmeyen ürünler, 15.Basım ve yayım; kayıtlı medyanın çoğ., 10.Tekstil ürünleri imalatı, 09.Tütün ürünleri imalatı, 13.Kereste ve ahşap doğrama üretimi, 49.Araştırma ve geliştirme hizmetleri, 27.Motorlu kara taşıtı, römork ve yarı-römork im., 25.Radyo, televizyon, haberleşme teçh. cih. İm. altsektörleridir.

İmalat Sanayinde ithalata bağımlılığın arttı̆̆ı sektörlerde sektrölerin göreceli konumları birlikte değerlendirildiğinde, 09.Tütün ürünleri imalat1, 10.Tekstil ürünleri imalat1, 13.Kereste ve ahşap doğrama üretimi, 17. Kimya sanayii, 24. Elektrikli makine ve cihazlarının imalatı, 25.Radyo, televizyon, haberleşme teçh. cih. İm. ve 27. Motorlu kara taşıtı, römork ve yarı-römork im. sektörlerinde dönem içerisinde hem ithal ara girdi kullanımının arttığı hemde bu sektörlerin aragirdi kullanımlarına göre büyükten küçüğe sıralanmalarıyla elde edilen önem sırası sıralamalarında da belirgin olarak daha önlere geldikleri görülmektedir. Tam tersi olarak da, ithal aragirdi kullanımları azalan tüm imalat sanayi alt sektörlerinde de sıra sayılarında arkalara doğru gerilemelerin olduğunu görmekteyiz. Bu özelliğin bulunduğu imalat sanayi alt sektörlerine, 08. Gıda ürünleri ve içecek imalatı, 15.Basım ve yayım; kayıtlı medyanın çoğ., 16.Kok firını ve rafine edilmiş petrol ürün. ve 20 . Metalurji sanayii örnek verilebilir. Yani sektörün ithal aragirdi kullanımı azalmakla birlikte göreceli önemi de azalmaktadır (Tablo 1). Bu özellik hizmet sanayi alt sektörleri için de geçerlidir.

İthal aragirdi kullanımlarının geri bağlantı etkilerinde ithalat eğilimi artmasına rağmen imalat sanayi sektörlerinde önem sıralarında hiç değişme olmamakta veya birkaç basamak gerileme ortaya çıkmaktadır. 01 . Tarım, avcılık ve ilgili hizmetler, 14. Kağıt ve karton üretimi ve kağıt ürünleri alt sektörlerinde ithal girdi 
kullanımı artmasına rağmen sektörlerin görece önemleri değişmemiştir. 11.Giyim eşyası; kürk işleme ve boyama, 19. Diğer metal olmayan mineral ürünler im., 22. Makine ve teçhizat üretimi alt sektörlerinde sadece 2 basamak gerileme vardır. Hizmet sektörlerinde ise, 35. Toptan ticaret ve tic. komisyonculuğu (mot. hariç), 1 basamak, 42. Haberleşme alt sektöründe 2 basamak, 43. Mali aracılıkta hiç değişme yoktur, 45. Mali aracılık ve sigortacılıkta yardımcı işlemler sektörlerinde 2 basamak gerileme vardır (Tablo1). Yani bu sektörlerde aragirdi kullanımları artmasına rağmen sektörün toplam aragirdi ithalatında göreli öneminin değişmemesi sektöre özgü bazı ekonomik sorunların oluştuğu izlenimini uyandırmaktadır.

\subsection{Kazakistan Ekonomisinde İthal Ara Girdi Kullanımında İleri Bağlantı Etkileri}

Ters ithalat matrislerinin satır toplamları ise, her endüstrinin toplam üretimlerini birer birim artırmak için diğer endüstrilere satmak zorunda olduğu ithal ürün toplamını göstermekte olup, üretim artışıla birlikte ithal girdi kullanımının azalması o sektörün dışa bağımlılığının da azalması şeklinde yorumlanmaktadır. Buna göre sektörlerin ters ithalat matrisleri satır toplamlarından elde edilen değerler ve bunların göreceli önemini vurgulayabilmek için büyükten küçüğe sıralanmalarıyla elde edilen önem sırası sayıları tablo 2.'de gösterilmektedir.

Dönem içerisinde ekonomi genelinde 50 sektörden 29 tanesinde geri bağlantı etkileri bakımından ithal girdi kullanımlarının arttığı görülmektedir. Kalan 21 sektörde de dönem içinde ithal aragirdi kullanımları azalmıştır. 7 alt sektörden oluşan tarımda 01 . Tarım avcılık ve ilgili hizmetler ile 03 . Balıkçılık alt sektörlerinde ithal ara girdi kullanımı artmakta, ve bu sektörlerden balıkçılık alt sektöründe göreceli önem sıraları da azalmakta daha arkalara gitmektedir. İmalat sanayinde yeralan 25 alt sektörden 17 tanesinde ithal ara girdi kullanımı artmıştır. Hizmetlerde ise 18 alt sektörden 11 tanesinde ithal girdi kullanımı artmıştır. İthal ara girdi kullanımı artan imalat sanayi sektörlerinden, 13. Kereste ve ahşap doğrama üretimi, 14. Kağıt ve karton üretimi ve kağıt ürünleri, 16. Kok firını ve rafine edilmiş petrol ürün., 17.Kimya sanayii, 22. Makine ve teçhizat üretimi alt sektörlerinde ithal aragirdi kullanımları artmasına paralel bu sektörlerin göreli önemleri de artmaktadır. Önem sırasına göre bu sektörler sıralamada daha önlere gitmektedirler. Ancak 09. Tütün ürünleri imalatı ve 21. Hazır nihai metal ürünleri üretimi alt sektörlerinde ithal girdi kullanımı artmasına rağmen sektörün göreceli konumu çok az değişerek sadece 1 basamak öne gitmektedir. 10. Tekstil ürünleri imalatında ise aragirdi kullanımları artmasına rağmen sektörün göreli konumu 2 basamak geriye gitmektedir. İthal aragirdi kullanımları azalan sektörlerde de sektörün göreli önemi azalmakta daha gerilere doğru gitmektedir. Ancak 15. Basım ve yayım; kayıtlı medyanın çoğ., 24.Elektrikli makine ve cihazların imalatı, 07. Diğer madencilik alt sektörlerinde ithal ara girdi kullanımları artmasına rağmen sektörlerin göreli önemlerinin ya hiç değişmediği yada çok az birkaç sıra değiştiği görülmektedir (Tablo 2).

İthal aragirdi kullanımında, 2009 yılı için ileri bağlantı etkilerine göre ithalatın en yüksek olduğu ilk on sektör; 17. Kimya sanayii, 22.Makine ve teçhizat üretimi 50.Diğer (Kamu Yön.Eğitim-Sosyal Hizmetler) 20.Metalurji sanayii, 14.Kağıt ve karton üretimi ve kağıt ürünleri, 13.Kereste ve ahşap doğrama üretimi, 18.Kimyasal ve plastik hammadde imalatı, 10.Tekstil ürünleri imalatı, 21.Hazır/nihai metal ürünlerin üretimi, 05.Ham petrol ve doğal gaz çıkarımı ve ür. altsektörleridir.

Hem geri hem ileri bağlantı etkileri bakımından ilk on içinde yeralan sektörler; 17. Kimya sanayii, 13.Kereste ve ahşap doğrama üretimi, 18.Kimyasal ve plastik hammadde imalatı, 10.Tekstil ürünleri imalatı sektörleri olmuştur.

\section{Sonuç}

Küreselleşme sürecinde ülke ekonomilerinin hızlı bir dışa açılma süreci yaşadığı bilinmektedir. Artan yoğun iç ve dış rekabetle birlikte giderek daha fazla dışa açılma sürecine giren ülkeler kaçınılmaz olarak ihracatı arttırıp, ithalatı azaltarak dış dengeyi sağlamaya çalışmaktadır. Fakat dışa açılma her zaman ekonomik büyüme ve gelişmeyi beraberinde getiremeyebiliyor. Günümüz koşullarında dünya ekonomilerinin dışa bağımlılığını tamamen ortadan kaldırmak mümkün değildir. Ancak bu bağımlılığın mümkün olan en düşük seviyelere çekilmesini sağlamak gerekmektedir. Dolayısıyla, ekonomide ileri ve geri bağlantı etkileri yüksek endüstrilerin tespit edilmesi ve bu sektörlerin gelişiminin sağlanması, üzerinde durulması gereken önemli konu olarak karşımıza çıkmaktadır. Burada da, 1990'lı yıllarda bağımsızlığını alan Orta Asya Türk Cumhuriyetleri arasında yeralan bölgesinde lider, ekonomik yönden zengin bir ülke olan Kazakistan ekonomisinin dışa bağımlılı̆ı incelenmiştir.

2006-2009 döneminde, Girdi-Çıktı çözümlemelerine dayalı olarak sektörlerarası ithal aragirdi kullanımları üzerinden yapılan incelemede dönem içinde ekonomide ithalata bağımlılığın arttığı gözlenmiştir. 17.Kimya sanayii, 13.Kereste ve ahşap doğrama üretimi, 18.Kimyasal ve plastik hammadde imalatı, 10.Tekstil ürünleri imalatı sektörleri hem ileri hem geri bağlantı etkilerinin yüksek olduğu sektörler olarak görülmektedirler.

Kazakistan ençok ithal ettiği mal gruplarını; otomotiv ve yedek parçaları, metal anasanayi ve mamulleri, kimya sanayi, madencilik, hayvansal ürünler ve ağaç orman ürünleri oluşturmaktadır. Kazakistan ithalatının önemli bir kısmını bu sektörlerdeki ara ve yatırım malları ithali oluşturmaktadır. Burada da buradakilere benzer bulgular elde edilmiş̧ir. 
İthalatın ara ve yatırım mallarında yoğunlaşmasının hem Kazakistan hemde bölge ekonomileri bakımından çarpan hızlandıran mekanizmalarıyla olumlu sonuçlar doğurabileceğini belirtebiliriz. Ancak ithalatın önemli bir kısmının batı ülkeleri ve Rusya'dan yapılıyor olmasının bölge ekonomileri için potansiyel etkileri azaltan bir unsur olduğunu görmekteyiz. Bu nedenle Kazakistan açısından burada belirtilen sektörlerde ithalata bağımlılığı azaltacak politikaların uygulanmasının, bölge ekonomileri bakımından (Rusya, Beyaz Rusya ile oluşturulan Gümrük birliği çerçevesinde teknoloji transferi, üretim modernizasyonu vs) ise, Kazakistan'la diş ticareti geliştirecek önlemlerin hızla alınması gerektiği kanatindeyiz.

\section{Kaynakça}

- $\quad$ Aydoğuş O., Girdi-Çıktı Modellerine Giriş, Gazi Kitabevi Ankara, 1999.

- Bocutoğlu, E., Girdi - Çıktı Analizine Giriş, Karadeniz Üniversitesi İktisadi ve İdari Bilimler Fakültesi Ders Notlar1, Yayın No:23, Trabzon, 1990.

- Chenery H.B, Clark P.E, Endüstrilerarası İktisat, (Çev. Cemil Çınar), ODTÜ, Ankara, 1965

- $\quad$ Ersungur Ş., M., Ekinci D.,Takım A., "Türkiye Ekonomisinde İthalata Bağımlılıktaki Değişme: Girdi-Çıktı Yaklaşımıyla Bir Uygulama”, 10. Ulusal Ekonometri ve İstatistik Kongresi, Atatürk Üniversitesi İ.İ.B.F, 27-29 May1s 2009, Erzurum

- $\quad$ Fleissner, P. U. A., Input-Output Analyse-Eine Einführung in Theorie und Anwendungen, Wien, 1993.

- $\quad$ Kepenek Y. Türkiye İmalat Sanayiinin Üretim Yapısı (1963-1973), Ankara ODTÜ, 1977.

- Kepenek Y., Türk İmalat Sanayiinin Üretim Yapısı, Friedrich Ebert Vakfı Araştırma Sonuçları, İstanbul, 1991.

- $\quad$ Korum U., Input Output Analizi, Sevinç Matbaas1, Ankara, 1963.

- $\quad$ Korum U., Türk İmalat Sanayi ve İthal İkamesi: Bir Değerlendirme, Ankara Üniversitesi Siyasal Bilgiler Fakültesi Yayınları No:408, Ankara,1977.

- $\quad$ Miernyk W.H., The Elements of Input Output Analysis, Random House, West Virginia University, 2 Printing, 1966.

- Özdil T., Turdaliyeva A., Ganiyev C., "Girdi-Çıktı Analizi Yaklaşımıyla Kırgızistan Ekonomisinin İncelenmesi”, Atatürk Üniversitesi İktisadi ve İdari Bilimler Dergisi, 10. Ekonometri ve İstatistik Sempozyumu Özel Sayıs1, Cilt:25, Sayı:Özel, Y1l:2011, ss:353-373.

- Özdil T., Yılmaz C. .,"Elektrik Elektronik Sektörünün Türkiye Ekonomisi İçindeki Öneminin Girdi Çıktı Analiziyle İncelenmesi”, Kırgızistan Türkiye Manas Üniversitesi Sosyal Bilimler Dergisi, Sayı 21, Bişkek, 2009, ss, 117-127.

- Ş̧enesen, G., G., Türkiye'nin Üretim Yapısı: Girdi-Çıktı Modeli ile Temel Bulgular, TÜSİAD Büyüme Stratejileri Dizisi, No:3, İstanbul, 2005.

- Thirlwall, A.P., Growth and Development, Fourth Edition, McMillan Education Ltd., London, 1990.

- Todaro M.P., Kalkınma Planlaması (Modeller ve Yöntemler), (Çev. Orhan Sezgin), İstanbul, 1987.

- Агентство Республики Казахстан по статистике. Таблицы «Затраты-Выпуск» Республики Казахстан за 2006, 2008, 2009 годы. www.stat.gov.kz

- Агентство Республики Казахстан по статистике. Казахстан в цифрах. 2010. www.stat.gov.kz

- Агентство Республики Казахстан по статистике. Статистический ежегодник Казахстана «Казахстан в 2009 году». Астана 2010. www.stat.gov.kz

- Национальный Банк Республики Казахстан. Платежный баланс и внешний долг Республики Казахстан за 2009 год. 2010. www.nationalbank.kz 


\begin{tabular}{|c|c|c|c|c|c|c|c|c|}
\hline \multirow{2}{*}{$\begin{array}{c}\text { Sir } \\
\mathrm{a} \\
\text { No }\end{array}$} & \multirow[b]{2}{*}{ Ekonomik Sektörler } & \multicolumn{2}{|c|}{2006} & \multicolumn{2}{|c|}{2008} & \multicolumn{2}{|c|}{2009} & \multirow{2}{*}{$\begin{array}{c}\text { Değişim } \\
\text { Oranı } \\
(2006-09)\end{array}$} \\
\hline & & $R_{j}$ & $\begin{array}{l}\text { Önem } \\
\text { Sırası. }\end{array}$ & $R_{j}$ & $\begin{array}{l}\text { Önem } \\
\text { Siras1 }\end{array}$ & $\mathrm{R}_{\mathrm{j}}$ & $\begin{array}{l}\text { Önem } \\
\text { Siras1 }\end{array}$ & \\
\hline 01 & Tarım, avcılık ve ilgili hizmetler & 0,048 & 49 & 0,045 & 49 & 0,061 & 49 & 0,266 \\
\hline 02 & Ormancılık ve ilgili hizmetler & 0,086 & 38 & 0,054 & 44 & 0,062 & 48 & $-0,279$ \\
\hline 03 & Balık avlama ve hizmetler & 0,067 & 43 & 0,103 & 28 & 0,120 & 32 & 0,782 \\
\hline 04 & Maden kömürü, linyit ve turba çıkarımı & 0,128 & 26 & 0,143 & 12 & 0,122 & 30 & $-0,050$ \\
\hline 05 & Ham petrol ve doğal gaz çıkarımı ve ür. & 0,104 & 37 & 0,099 & 29 & 0,114 & 33 & 0,105 \\
\hline 06 & Metal cevheri madenciliği & 0,161 & 20 & 0,122 & 20 & 0,153 & 23 & $-0,045$ \\
\hline 07 & Diğer madencilik & 0,150 & 23 & 0,157 & 11 & 0,194 & 15 & 0,298 \\
\hline 08 & Gıda ürünleri ve içecek imalatı & 0,153 & 22 & 0,120 & 21 & 0,128 & 28 & $-0,160$ \\
\hline 09 & Tütün ürünleri imalatı & 0,123 & 28 & 0,167 & 9 & 0,292 & 6 & 1,374 \\
\hline 10 & Tekstil ürünleri imalatı & 0,180 & 13 & 0,139 & 13 & 0,304 & 5 & 0,689 \\
\hline 11 & Giyim eşyası; kürk işleme ve boyama & 0,161 & 19 & 0,134 & 15 & 0,191 & 17 &, 182 \\
\hline 12 & Deri ve deri ürünleri, ayakkabı üretimi & 0,106 & 35 & 0,086 & 35 & 0,125 & 29 & 172 \\
\hline 13 & Kereste ve ahşap doğrama üretimi & 0,105 & 36 & 0,064 & 41 & 0,284 & 7 & ,708 \\
\hline 14 & Kağıt ve karton üretimi ve kağıt ürünleri & 0,264 & 4 & 0,172 & 7 & 0,320 & 4 & 0,212 \\
\hline 15 & Basım ve yayım; kayıtlı medyanın çoğ. & 0,312 & 3 & 0,241 & 1 & 0,220 & 11 & $-0,297$ \\
\hline 16 & Kok firını ve rafine edilmiş $\mathrm{p}$ & 0,173 & 15 & 0,176 & 5 & 147 & 24 & 153 \\
\hline 17 & Kim & 0,208 & 7 & 0,168 & 8 & 0,342 & 2 & 647 \\
\hline 18 & sal ve plas & 0,315 & 2 & 0,221 & 3 & 0,455 & 1 & 445 \\
\hline 19 & Diğer metal olmayan mineral ürünler im. & 0,171 & 16 & 0,123 & 19 & 0,188 & 18 & 0,098 \\
\hline 20 & Metalurji sanayii & 0,184 & 12 & 0,108 & 24 & 0,104 & 38 & $-0,431$ \\
\hline 21 & Hazır/nihai $\mathrm{m}$ & 0,256 & 5 & 0,109 & 23 & 209 & 13 & 185 \\
\hline 22 & Makine & 0,165 & 18 & 0,097 & 32 & 0,192 & 16 & \\
\hline 23 & Büro ve bilgi işlem & 0,399 & 1 & 0,235 & 2 & 0,071 & 47 &, 822 \\
\hline 24 & Elektrikli makine ve c & 0,110 & 33 & 0,088 & 34 & 0,210 & 12 & 912 \\
\hline 25 & Radyo, televizyon, haberleşme teçh. cih. İm. & 0,143 & 24 & 0,105 & 26 &, 221 & 10 &, 545 \\
\hline 26 & Tibbi aletler; hassas, o & 0,195 & 10 & 0,117 & 22 & 0,168 & 21 & 0,138 \\
\hline 27 & Motorlu kar & 119 & 31 & 161 & 10 & 235 & 9 & \\
\hline 28 & Diğer u & 0,176 & 14 & 0,095 & 33 & 0,130 & 26 & 265 \\
\hline 29 & Diğer sınıflamalara dal & 0,075 & 41 & 0,105 & 27 & 0,325 & 3 & 315 \\
\hline 30 & İkincil işlemeler sanayisi & 0,160 & 21 & 0,082 & 36 & 0,080 & 43 & $-0,497$ \\
\hline 31 & Elektrik, gaz, buhar ve sıcak su üret.ve & 0,199 & 9 & 0,132 & 16 & 0,129 & 27 & $-0,352$ \\
\hline 32 & Suyun toplanması, arıtı & 0,124 & 27 & 0,127 & 17 & 0,114 & 35 & $-0,085$ \\
\hline 33 & $\mathrm{In}$ & 0,203 & 8 & 0,098 & 31 & 0,171 & 20 & \\
\hline 34 & Motorlu taşıtlar satış, bak & 0,062 & 45 & 0,046 & 47 & 0,060 & 50 & $-0,027$ \\
\hline 35 & Toptan ticaret ve tic. komisyonculuğu mot. hariç) & 0,076 & 40 & 0,074 & 38 & 0,090 & 41 & 0,175 \\
\hline 36 & Perakende ticaret, kişisel ve ev eşyalarının tamiri & 0,056 & 46 & 0,040 & 50 & 0,104 & 39 & 0,844 \\
\hline 37 & Otel, motel, pansiyon, kam & 0,166 & 17 & 0,137 & 14 & 0,120 & 31 & $-0,276$ \\
\hline 38 & & 0,131 & 25 & 0,108 & 25 & 0,147 & 25 & \\
\hline 39 & Denizyolu t & 0,213 & 6 & 0,181 & 4 & 0,114 & 34 & $-0,462$ \\
\hline 40 & Havayolu taşımacilığ 1 & 0,122 & 29 & 0,098 & 30 & 0,177 & 19 & 0,448 \\
\hline 41 & Destekleyici ve yardımcı ulaştırma faaliyetleri & 0,109 & 34 & 0,074 & 39 & 0,073 & 46 & $-0,335$ \\
\hline 42 & Haherles & 0,078 & 39 & 0,054 & 45 & 0,108 & 37 & 0,396 \\
\hline 43 & Mal1 & 0,073 & 42 & 0,075 & 37 & 0,089 & 42 &, 223 \\
\hline 44 & Sigortacıl1k & 0,050 & 48 & 0,045 & 48 & 0,079 & 44 & 0,576 \\
\hline 45 & Mali aracılık ve sigortacılıkta yardımcı işlemler & 0,052 & 47 & 0,054 & 46 & 0,078 & 45 & 0,507 \\
\hline 46 & Gayri menkul faaliyetleri & 0,114 & 32 & 0,072 & 40 & 0,094 & 40 & $-0,182$ \\
\hline 47 & Operatörsüz mak. ve teç. ile kişisel eşyal & 0,120 & 30 & 0,059 & 43 & 0,162 & 22 & 0,349 \\
\hline 48 & Hesaplama araçlarla ilgli faaliyetler & 0,194 & 11 & 0,124 & 18 & 0,112 & 36 & $-0,426$ \\
\hline 49 & Araştırma ve geliştirme hizmetleri & 0,008 & 50 & 0,062 & 42 & 0,240 & 8 & 27,410 \\
\hline 50 & Diğer (Kamu Yön.Eğitim-Sosyal Hizmetler) & 0,066 & 44 & 0,173 & 6 & 0,200 & 14 & 2,053 \\
\hline & Toplam & 7,2 & 213 & & & 8,2 & & 0,140 \\
\hline
\end{tabular}

Tablo 1: Kazakistan Ekonomisi Itthal Aragirdi Kullanımları Geri Bağlantı Etkileri (Sütun toplamları - .000 tenge) 


\begin{tabular}{|c|c|c|c|c|c|c|c|c|}
\hline \multirow[b]{2}{*}{$\begin{array}{l}\text { Sira } \\
\text { No }\end{array}$} & \multirow[b]{2}{*}{ Ekonomik Sektörler } & \multicolumn{2}{|c|}{2006} & \multicolumn{2}{|c|}{2008} & \multicolumn{2}{|c|}{2009} & \multirow{2}{*}{$\begin{array}{c}\text { Değişim } \\
\text { Oran1 } \\
(2006- \\
09)\end{array}$} \\
\hline & & $\mathrm{R}_{\mathrm{i}}$ & $\begin{array}{l}\text { Önem } \\
\text { Siras1 }\end{array}$ & $\mathrm{R}_{\mathrm{i}}$ & $\begin{array}{l}\text { Önem } \\
\text { Siras1 }\end{array}$ & $\mathrm{R}_{\mathrm{i}}$ & $\begin{array}{l}\text { Önem } \\
\text { Siras1 }\end{array}$ & \\
\hline 01 & Tarım, avcılık ve ilgili hizmetler & 0,007 & 34 & 0,073 & 20 & 0,237 & 13 & 33,269 \\
\hline 02 & Ormancılık ve ilgili hizmetler & 0,019 & 31 & 0,000 & 35 & 0,000 & 43 & $-1,000$ \\
\hline 03 & Balık avlama ve hizmetler & 0,000 & 37 & 0,025 & 26 & 0,000 & 42 & 0,433 \\
\hline 04 & Maden kömürü, linyit ve turba çıkarımı & 0,057 & 24 & 0,012 & 29 & 0,008 & 37 & $-0,854$ \\
\hline 05 & Ham petrol ve doğal gaz çıkarımı ve ür. & 0,360 & 5 & 0,387 & 6 & 0,272 & 10 & $-0,246$ \\
\hline 06 & Metal cevheri madenciliği & 0,043 & 28 & 0,056 & 25 & 0,037 & 24 & $-0,133$ \\
\hline 07 & Diğer madencilik & 0,027 & 29 & 0,014 & 28 & 0,018 & 30 & $-0,342$ \\
\hline 08 & Gıda ürünleri ve içecek imalatı & 0,172 & 13 & 0,360 & 7 & 0,164 & 16 & $-0,041$ \\
\hline 09 & Tütün ürünleri imalatı & 0,004 & 36 & 0,123 & 16 & 0,010 & 35 & 1,831 \\
\hline 10 & Tekstil ürünleri imalatı & 0,290 & 6 & 0,201 & 10 & 0,353 & 8 & 0,216 \\
\hline 11 & Giyim eşyası; kürk işleme ve boyama & 0,147 & 14 & 0,012 & 30 & 0,009 & 36 & $-0,937$ \\
\hline 12 & Deri ve deri ürünleri, ayakkabı üretimi & 0,004 & 35 & 0,061 & 23 & 0,002 & 40 & $-0,450$ \\
\hline 13 & Kereste ve ahşap doğrama üretimi & 0,173 & 12 & 0,097 & 18 & 0,434 & 6 & 1,509 \\
\hline 14 & Kağıt ve karton üretimi ve kağıt ürünleri & 0,238 & 9 & 0,432 & 4 & 0,535 & 5 & 1,243 \\
\hline 15 & Basım ve yayım; kayıtlı medyanın çoğ. & 0,057 & 23 & 0,065 & 22 & 0,037 & 25 & $-0,359$ \\
\hline 16 & Kok firını ve rafine edilmiş petrol ürün. & 0,137 & 16 & 0,357 & 8 & 0,271 & 11 & 0,974 \\
\hline 17 & Kimya sanayii & 0,565 & 3 & 0,686 & 1 & 1,805 & 1 & 2,193 \\
\hline 18 & Kimyasal ve plastik hammadde imalatı & 0,735 & 2 & 0,414 & 5 & 0,392 & 7 & $-0,467$ \\
\hline 19 & Diğer metal olmayan mineral ürünler im. & 0,285 & 7 & 0,219 & 9 & 0,258 & 12 & $-0,093$ \\
\hline 20 & Metalurji sanayii & 1,786 & 1 & 0,554 & 2 & 0,553 & 4 & $-0,690$ \\
\hline 21 & Hazır/nihai metal ürünlerin $\ddot{u}$ & 0,228 & 10 & 0,132 & 13 & 0,342 & 9 & 0,498 \\
\hline 22 & Makine ve teçhizat üretimi & 0,134 & 17 & 0,134 & 12 & 0,611 & 2 & 3,553 \\
\hline 23 & Büro ve bilgi işlem makineleri imalatı & 0,000 & 39 & 0,000 & 36 & 0,000 & 44 & 0,000 \\
\hline 24 & Elektrikli makine ve cihazların imalatı & 0,122 & 18 & 0,000 & 37 & 0,120 & 19 & $-0,016$ \\
\hline 25 & Radyo, televizyon, haberleşme teçh. cih. İm. & 0,000 & 40 & 0,000 & 38 & 0,163 & 17 & 0,000 \\
\hline 26 & T1bbi aletler; hassas, & 0,000 & 41 & 0,000 & 39 & 0,018 & 29 & 0,000 \\
\hline 27 & Motorlu kara taşıtı, römork ve yarı-römork im. & 0,007 & 33 & 0,068 & 21 & 0,180 & 15 & 25,032 \\
\hline 28 & Diğer ulaştırma araçları üretimi & 0,000 & 42 & 0,000 & 40 & 0,085 & 21 & 0,000 \\
\hline 29 & Diğer sınıflamalara dahil edilmeyen ürünler, & 0,056 & 25 & 0,001 & 32 & 0,008 & 38 & $-0,863$ \\
\hline 30 & İkincil işlemeler sanayisi & 0,000 & 43 & 0,000 & 41 & 0,000 & 45 & 0,000 \\
\hline 31 & Elektrik, gaz, buhar ve sicak s & 0,000 & 44 & 0,085 & 19 & 0,032 & 28 & 0,000 \\
\hline 32 & Suyun toplanması, arıtılması ve dağıtılmas1 & 0,000 & 45 & 0,000 & 42 & 0,000 & 46 & 0,000 \\
\hline 33 & İnşaat & 0,071 & 22 & 0,000 & 43 & 0,112 & 20 & 0,587 \\
\hline 34 & Motorlu taşıtlar satış, bak., onarım; perakende sat. & 0,000 & 46 & 0,000 & 44 & 0,000 & 47 & 0,000 \\
\hline 35 & Toptan ticaret ve tic. komisyonculuğu mot. hariç) & 0,000 & 47 & 0,000 & 45 & 0,001 & 41 & 0,000 \\
\hline 36 & Perakende ticaret, kişisel ve ev eşyalarının tamiri & 0,000 & 38 & 0,000 & 46 & 0,000 & 48 & $-1,000$ \\
\hline 37 & Otel, motel, pansiyon, kamp. ve diğer konak. Yer. & 0,051 & 27 & 0,000 & 47 & 0,156 & 18 & 2,066 \\
\hline 38 & Karayolu taşımacıllğ 1 & 0,277 & 8 & 0,483 & 3 & 0,016 & 32 & $-0,943$ \\
\hline 39 & Denizyolu taşımacılığı & 0,075 & 21 & 0,099 & 17 & 0,003 & 39 & $-0,955$ \\
\hline 40 & Havayolu taşımacıllı̆ 1 & 0,147 & 15 & 0,131 & 14 & 0,011 & 34 & $-0,925$ \\
\hline 41 & Destekleyici ve yardımcı ulaştırma faaliyetleri & 0,079 & 20 & 0,001 & 34 & 0,034 & 26 & $-0,575$ \\
\hline 42 & Haberleşme & 0,026 & 30 & 0,015 & 27 & 0,033 & 27 & 0,294 \\
\hline 43 & Mali aracılık & 0,056 & 26 & 0,126 & 15 & 0,045 & 23 & $-0,183$ \\
\hline 44 & Sigortac1lik & 0,105 & 19 & 0,060 & 24 & 0,016 & 31 & $-0,846$ \\
\hline 45 & Mali aracılık ve sigortacılıkta yardımcı işlemler & 0,000 & 48 & 0,000 & 48 & 0,000 & 49 & 0,000 \\
\hline 46 & Gayri menkul faaliyetleri & 0,000 & 49 & 0,001 & 33 & 0,000 & 50 & 0,000 \\
\hline 47 & Operatörsüz mak. ve teç. ile kişisel eşyaların kirası & 0,176 & 11 & 0,000 & 49 & 0,184 & 14 & 0,047 \\
\hline 48 & Hesaplama araçlarla ilgli faaliyetler & 0,009 & 32 & 0,012 & 31 & 0,054 & 22 & 5,244 \\
\hline 49 & Araştırma ve geliştirme hizmetleri & 0,000 & 50 & 0,000 & 50 & 0,011 & 33 & 0,000 \\
\hline 50 & Diğer (Kamu Yön.Eğitim-Sosyal Hizmetler) & 0,487 & 4 & 0,171 & 11 & 0,593 & 3 & 0,218 \\
\hline & Toplam & $\overline{7,2}$ & & $\overline{5,6}$ & & & & 0,140 \\
\hline
\end{tabular}

Tablo 2: Kazakistan Ekonomisi İthal Aragirdi Kullanımlarının İleri Bağlantı Etkileri (Satır toplamları- .000 tenge) 


\title{
Orta Asya Ülkelerinin İnsani Gelişmişlik Endeksleri Açısından Değerlendirilmesi
}

\author{
Volkan Öngel (Beykent University, Turkey) \\ İlyas Sözen (Beykent University, Turkey) \\ A. Alkan Çelik (Beykent University, Turkey)
}

\section{An Evaluation of Human Development Index in Central Asian Countries}

\begin{abstract}
Economic development and growth had been the most important target among all goverments throughout the history. In this respect, Kazakhstan, Turkmenistan, Uzbekistan, Tajikistan and Kyrgyzstan in Middle Asian Region had chosen development as primary target in 20 years time after their independence. Human capital is the leading factor to maintain economic development and growth.

Development and growth terms over which different meanings and concepts were imposed in time, necessitated several political economic alterations. Before 1970's, increase in income had been sufficient criterion for the development of a government. But nowadays economic development incorporates factors such as life expectancy at birth, school enrolment ratio, literancy rate, gender discrimination, poverty alleviation, equal distribution of income beyond economic growth. Herewith this change political preference and priorities has started to differentiate.

The aim of this study is to discuss human development index (HDI) data of 5 Middle Asian countries in 2010 and changes in HDI in years after their independence. Comparisan between Gross Domestic Product (GDP) and HDI rates are also performed within this analysis. This study consists of data of 5 Middle Asian countries between years 1990-2010. Basic, retrospective, illustrative library method is used as the study method.

In conclusion, we find that increase in GDP did not reflect over HDI in Middle Asian Countries within 20years period.
\end{abstract}

JEL Codes: O15, O53

\section{Giriş}

İktisadi kalkınma ve büyüme tarih boyunca tüm devletlerin en önemli hedefleri arasında yer almaktadırlar. Bu öncelikli hedefler ülke yöneticilerinin ekonomik ve politik alandaki karar ve tercihleri üzerinde etkin rol oynamaktadırlar. 1970'li yıllara kadar gelir artışı bir ülkenin kalkınması ve gelişmesi için yeterli olarak kabul edilmekteydi. Uzun yıllar boyunca literatürde gelir artışı eşittir iktisadi kalkınma ve gelişme şeklinde yer alan kavram, Hollanda Hastalığı'nın (Dutch Disease) ortaya çıkması, gelirinde büyük artışlar görülen çeşitli üst gelir grubu ülkelerde iktisadi kalkınmanın ve gelişmenin beklenen oranda sağlanamaması ya da nispeten düşük gelirli ülkelerin gelişmişlik düzeylerinin yüksek olduğunun görülmesi gibi çeşitli sebeplerle değişmeye başlamıştır. Günümüzde iktisadi kalkınma, ekonomik büyümenin yanı sıra, doğumda yaşam beklentisi, okur-yazar oranı, cinsiyet ayrımcılığının azaltılması, yoksulluğun düşürülmesi, eşit gelir dağılımı gibi çeşitli faktörleri de içerisinde barındırmaktadır.

Sovyetler Birliği'nin dağılmasıyla Orta Asya Bölgesinde bağımsız devletler olarak yer alan Kazakistan, Türkmenistan, Özbekistan, Tacikistan ve Kırgızistan da iktisadi kalkınma ve gelişmeyi öncelikli politika tercihleri içerisinde değerlendirmişlerdir. Fakat merkezi planlamacı ekonomik ve siyasi bir yapıya sahip birliğin dağılması sonrasında bağımsızlıklarını kazanan ülkeler üretim faktörleri açısından eşit şartlara sahip olamamışlardır. Bazı ülkeler (Kazakistan, Türkmenistan, Özbekistan başta olmak üzere) petrol, doğalgaz, altın gibi doğal kaynaklar açısından zengin iken aynı coğrafyada yer alan diğer ülkeler (Kırgızistan ve Tacikistan) bu doğal kaynak zenginliğinden görece olarak çok daha az yararlanabilmektedirler. Bu sebeple bölgedeki ülkeler için iktisadi kalkınmanın ve büyümenin sağlanabilmesinde beşeri sermayenin çok büyük etkisi olacağ düşünülebilmektedir.

$\mathrm{Bu}$ çalışmanın amacı 5 Orta Asya ülkesindeki (Kazakistan, Türkmenistan, Özbekistan, Tacikistan ve Kırgızistan) insani gelişmişlik endeksi verilerinin 2010 yılındaki durumunu ve bağımsızlık sonrası dönemde yıllar itibari ile değişimini değerlendirmektir. Bu inceleme sırasında ülkelerdeki kişi başına Gayrisafi Yurtiçi Hâsıla (GDP-GSYİH) değişim oranı ile insani gelişim endeksi (HDI-İGE) değişim oranları arasında dönemsel karşılaştırma yapılmıştır. Çalışma, 5 Orta Asya ülkesinin ilk ve son verilerinin elde edildiği 1990-2010 yılları ile sınırlanmıştır. Çalışma metod olarak; temel, geriye dönük (retrospektif), tasvir edici bir kütüphane çalışmasıdır. 
Sonuçta, Orta Asya ülkelerinde 20 yıllık süreçte GSYİH'daki yüksek oran artışlarının insani gelişim endeksine yansımadığı görülmüştür.

Çalışmanın ikinci bölümünde İnsani gelişim endeksinin içeriğine ve çalışmamızla ilgili literatüre kısaca değinilecektir. Üçüncü bölümde çalışmamız kapsamındaki Orta Asya ülkelerinin 2010 yılı insani kalkınma endeksleri ve bu endekslerin eşitliğe uyarlanmış durumu ele alınacaktır. Dördüncü bölümde söz konusu ülkelerin 1990 yılından başlayarak İGE'deki ve 2000 yılından başlayarak kiși başına gayrisafi yurt içi hâsılalarındaki 5'er yıllık dönemler itibariyle gözlenen değişimlere değinilecektir. Yine bu bölüm içerisinde ülkelerin İGE ve GSYİH arasındaki değişim oranları karşılaştırılacaktır. Son bölümde ise, çalışma ile ilgili bir genel değerlendirme yapilacaktır.

\section{2 İnsani Gelișim Endeksi}

İktisat literatüründe uzun bir dönem boyunca kalkınma ekonomik gelişme ile özdeşleştirilmiştir. Bu sebeple ekonomik performansı en iyi ölçen gösterge olması, ülkeler arası karşılaştırma ve sınıflandırmaya (zengin ve fakir, gelişmiş ve gelişmekte olan gibi) olanak sağlaması sebebiyle kişi başına düşen ulusal gelir (Kişi başına GSYİH) tercih edilen ve başvurulan sayısal gösterge olmuştur. (Jahan, 2004) Fakat 1970'li y1llarda ekonomik olarak büyük gelişme sağlayan bazı ülkelerde siyasi istikrarsızlıklar, yükselen işsizlik oranları, gelir dağılımında ortaya çıkan eşitsizlikler gibi sorunlar görülmeye başlanmıştır. Çeşitli yüksek gelirli ülkelerdeki yüksek suç oranları ve çevresel sorunlar önemli problemler yaratırken, orta gelir düzeyinde yer alan bazı ülkelerin insani refah açısından iyi noktalarda olmaları ekonomik büyümenin yoksulluğu azaltamadığı ve çeşitli toplumsal sorunlara çözüm getirmediği noktasındaki eleştiriler için güçlü dayanak oluşturmaktaydı. (Gürses, 2009)

İnsani gelişim endeksi (İGE-HDI) ilk olarak 1990 yılında Birleşmiş Milletler Gelişme Programı (UNDP) İnsani Gelişme Rapor Ofisi tarafından yayınlanmıştır. Her yıl yayınlanmakta olan bu endeks insanların refahının milli gelir dışındaki kısa bir tanımını içermektedir. (Kaya, 2008) Ekonomik kalkınma ile ilgili yaklaşımlara tepkilerin yoğun olduğu bir dönemde yayınlanan ilk rapor Pakistanlı İktisatçı Mahbub ul Haq önderliğindeki bir ekip tarafından hazırlanmıştır. (Gürses, 2009) Ülkelerde yaşayan bireylerin refah düzeylerini ölçen bu endeks, insani kalkınma kavramının ölçüsünü ifade etmektedir. İGE göstergeleri ile ilgili temel yaklaşım, insani yaşam kalitesinin buna bağlı olarak da kalkınmanın yalnızca ekonomik girdilerle sağlanamayacağıdır. Asgari bir gelir düzeyi, bireyin uzun ve sağlıklı bir yaşam elde edebilmesi ve yaşadığı ülkede toplumsal alana çıkabilmesi için yeterli değildir. Gelir, bu noktada, insani gelişmişlik için gerekli ama yeterli olmayan bir faktör olarak karşımıza çıkmaktadır. Gelirin yanında bireyin sağlıklı ve bilgili olması da gereklidir. Bu noktada en önemli kriter, ulusal zenginliğin, bireyler için gelişme olanakları yaratma kapasitesidir. (Karabulut ve diğerleri 2009) Şöyle ki, ekonomik olarak çıktının üretilebilmesi üretim faktörlerinin (fiziki sermaye, beşeri sermaye, işgücü, doğal kaynaklar gibi) bir araya getirilmesine bağlıdır. Kişilerin beşeri sermayelerinin artması iktisadi kalkınmaya önemli katkı sağlayabilmektedir. Bunun içinse çalışan kişilerin sahip oldukları beşeri sermayeyi kullanabilecekleri uygun ortam bulunmalıdır. Sadece ülkenin kişi başına GSYİH artışına dayalı bir kalkınma beşeri sermayeyi gelir artışına paralel olarak arttırmadığı ve kullanmadığı sürece, ülkelerdeki beşeri sermayenin israf edilmesi gündeme gelir. (Karataş ve Çankaya, 2010)

İnsani gelişim endeksi üç alt endeks kullanılarak oluşturulmaktadır. Bunlar; refah standardı, eğitim standardı ve sağlık standardıdır. Sosyal gelişme hedeflerine farklı ağırlıklarda katkı yapan bu üç kriter genel olarak aşağıdaki şekilde elde edilmektedir. (Demir, 2006)

- Refah Standardı: Tatminkâr bir yaşam sürmeyi sağlayacak kaynaklara ulaşmaya karşılık gelmektedir. Kişi başına düşen GSYİH'nın satın alma gücü paritesi ile hesaplanması sonucunda elde edilmektedir. Refah standardı endeksine göre, kişi başı GSYİH'da 1.000 USD artış insani gelişim endeksine 1998 yılında \%0,8, 2000 yılında \%0,6, 2005 yılında \%0,4, 2009 yılında ise \%0,3 etki sağlamaktadır.

- Eğitim Standardı: Eğitim standardı için iki boyutlu değişken kullanılarak ölçüm yapılmaktadır. Bunlar; yetişkinler arasındaki okuma-yazma oranı ve ortalama eğitim süresidir. Eğitim standardı alt endeksinde; yetişkin okur-yazar oranında \%1 artış İGE’ye \%0,2; okullaşma oranındaki yüzde 1 artış ise İGE’ye \%0,1 etkide bulunmaktadır.

- Sağlık Standardı: Bu alt endekse göre uzun ömür, sağlık standardı olarak nitelendirilmekte ve doğuştan yaşam beklentisi ile ölçülmektedir. Yaşam beklentisindeki 1 yıl artışın İGE'ye etkisi \%0,6 olarak görülmektedir.

Yukarıda sözü edilen 3 alt endeksten eğitim ve sağlık standartları yaşam kalitesi açısından önem taşımaktadır. $\mathrm{Bu}$ unsurlar bireylerin yaşam kalitesini geliştirmekte ve başka zenginliklere ulaşmalarını sağlayabilmektedirler. Refah standardı ise insanların başarma kapasitelerinin pek çoğu gelire bağlı olduğu için endekse eklenmiştir. (Gürses, 2009) 169 ülkenin yer aldığı 2010 yılı insani gelişim endeksine göre en yüksek insani kalkınma düzeyi 0,938 değerine sahip Norveç ile 0,788 değerine sahip 42.sıradaki Barbados arasındaki ülkelerden oluşmaktadır. Yüksek insani kalkınma düzeyi 0,784 endeks değerine sahip 43.sıradaki Bahamalar ile 0,677 endeks değerine sahip 85.sıradaki Tonga arasını kapsamaktadır. Ortalama insani gelişmişlik düzeyi 0,669 endeks değerine sahip 86.sıradaki Fiji ile 0,488 endeks değerine sahip 127. sıradaki Sao Tome ve Principe Demokratik Cumhuriyeti 
arasındaki ülkelerden oluşmaktadır. Düşük insani gelişmiş seviyesinde ise 0.470 endeks değerine sahip 128.sıradaki Kenya ile 0,140 endeks değerine sahip son sıradaki Zimbabwe arasındaki 42 ülke yer almaktadır. (UNDP, 2010)

Çalışmamız ile ilgili literatür incelemesinde ise ağırlıklı olarak İGE’nin hesaplanma kriterleri, 1990 yılından beri endekste gerçekleşen değişimlere ilişkin eleştiriler ve eklemeler göze çarpmaktadır. Ülkeler ve bölgeler bazında çeşitli çalışmalar bulunmasında rağmen çalışma sınırlarımız içerisinde yer alan Orta Asya Bölgesindeki ülkeler ile ilgili bire bir örtüşen herhangi bir çalışmaya rastlanmamıştır. Bölge ile ilgili yakın görülen tek çalışma Mıhıı'nın 2011 yılında "Soğuk savaş sonrası dönemde Geçiş Ekonomilerinin İnsani Gelişme Performansı” adlı çalışmasıdır. Buna göre Mıhçı tüm Bağımsız Devletler Topluluğu ülkelerine ele almış ve bu ülkelerin İGE değerlerinin göreli olarak düşük kalmasına rağmen, gelişmekte olan ülkelerle birlikte ele alındığında kalkınma performanslarının kendi gelir düzeyine göre umut verici olduğu sonucuna ulaşmıştır.

\section{Orta Asya Ülkelerinin 2010 Yılı İtibariyle İnsani Kalkınma Endeksleri}

Orta Asya Bölgesinde yer alan Kazakistan, Türkmenistan, Özbekistan, Kırgızistan ve Tacikistan'a ait 2010 y1lı İGE değerleri Tablo 1'de görülmektedir.

\begin{tabular}{|c|c|c|c|c|c|c|c|}
\hline $\begin{array}{l}\text { Dünya } \\
\text { İGE } \\
\text { Sirası }\end{array}$ & Ülke & $\begin{array}{c}\text { İnsani } \\
\text { Kalkınma } \\
\text { Endeksi } \\
\text { (İGE) }\end{array}$ & $\begin{array}{l}\text { Doğumda } \\
\text { Yaşam } \\
\text { Beklentisi }\end{array}$ & $\begin{array}{c}\text { Ortalama } \\
\text { Okullaşma }\end{array}$ & $\begin{array}{c}\text { Kişi } \\
\text { Başına } \\
\text { GSYİH* }\end{array}$ & $\begin{array}{c}\text { Kişi başına } \\
\text { GSYİH } \\
\text { Sıralaması } \\
\text { Eksi İGE } \\
\text { Sıralaması }\end{array}$ & $\begin{array}{c}\text { Gelir } \\
\text { Dışı } \\
\text { İGE } \\
\text { Değeri }\end{array}$ \\
\hline & & Değer & Yll & Yll & & & \\
\hline 66 & Kazakistan & 0,714 & 65,4 & 10,3 & 10.234 & 6 & 0,756 \\
\hline 87 & Türkmenistan & 0,669 & 65,3 & 9,9 & 7.052 & 1 & 0,719 \\
\hline $\begin{array}{c}01 \\
102\end{array}$ & Özbekistan & 0,617 & 68,2 & 10,0 & 3.085 & 17 & 0,721 \\
\hline 109 & Kurgizistan & 0,598 & 68,4 & 9,3 & 2.291 & 17 & 0,726 \\
\hline 112 & Tacikistan & 0,580 & 67,3 & 9,8 & 2.020 & 22 & 0,709 \\
\hline
\end{tabular}

Tablo 1: Orta Asya Ülkelerinin Insani Gelişme Endeksleri, 2010.

Kaynak: UNDP Human Development Report 2010, ss.143-147 yararlanılarak hazırlanmıştır. *Satın alma Gücü Paritesi- ABD \$2008

5 Orta Asya ülkesi içerisinde en yüksek İGE değerine sahip ülke Kazakistan'dır. 0,714'lük endeks değeri 2011 yılı insani gelişim endeksi içerisindeki 169 ülke arasında Kazakistan’1 66. sıraya yerleştirmektedir. Buna göre Kazakistan bölge ülkeleri içerisinde yüksek insani gelişmişlik düzeyinde yer alan tek ülkedir. 2010 İGE'ye göre diğer dört Orta Asya ülkesi orta insani gelişmişlik düzeyine sahiptir. Bu dört ülkeden 0,669 endeks değerine sahip Türkmenistan 87., 0,617 İGE değerine sahip Özbekistan 102., 0,598 endeks değerine sahip Kırg1zistan 109., bölge içerisindeki ülkeler arasında en düşük İGE değerine sahip Tacikistan ise 0,580 değeri ile dünya sıralamasında 112. sırada bulunmaktadır. Ülkelerin İGE gelişmişlik düzeyleri arasındaki farklar göz önüne alındığında 0,714 ile 0,580 değerlerine sahip Kazakistan ve Tacikistan arasında 0,134'lük bir fark bulunmaktadır. $\mathrm{Bu}$ fark neredeyse 2011 İGE'ye son sirada yer alan Zimbabwe'nin toplam İGE'sine eşittir. İnsani gelişim endeksini oluşturan alt endekslere ait veriler göz önüne alınarak iki ülke değerlendirildiğin de ise Tacikistan'ın doğumda yaşam beklentisi 67,3 yıl iken Kazakistan da bu rakam 65,4 yıldır. Ortalama okullaşma oranları arasında da sadece 0,5 yıl fark olduğu görülen bu iki ülke arasındaki endeks farkı ağırlıklı olarak kişi başına GSYİH değerinden kaynaklanmaktadır.

5 ülke arasındaki alt endeksler incelendiğinde doğumda yaşam beklentisinin 65,3 yıl ile en düşük olduğu ülke Türkmenistan, en yüksek olduğu ülke ise 68,4 yıl ile Kırgızistan'dır. Ortalama okula gitme yılına bakıldı̆ğında ise Kırgızistan 9,3 y1l ile son sırada yer alırken, Kazakistan 10,3 yıl ile ilk sırada bulunmaktadır. Bölgedeki en yüksek İGE değerine sahip Kazakistan ve Türkmenistan, kişi başına 10.234 ve 7.052 \$'lık GSYİH rakamları ile diğer ülkelerden önemli ölçüde yüksek değerlere sahiptirler. Tablo da yer alan Özbekistan, Kırgızistan ve Tacikistan'ın kişi başına GSYİH değerleri sırasıyla 3.085, 2.291 ve 2.020 \$'dır.

Bölge ülkeleri için dikkat çekici unsur tüm ülkelerin dünya içerisindeki İGE sıralamalarının, dünyadaki kişi başına GSYİH sıralamalarından düşük olduğudur. Dünya kişi başına GSYİH sıralaması eksi İGE sıralamasında Kazakistan 6 sıra kazanırken, Türkmenistan 1, Özbekistan ve Kırgızistan 17'şer, Tacikistan ise 22 sıra yukarı çıkmaktadır. Bundaki temel etken elde edilen gelirin insani gelişim için harcanamadığ ya da ülke ekonomilerinin büyümesi beşeri sermaye ile değil doğal kaynak ihracatı ile sağlanmaktadır.

Tablo 2'de Orta Asya ülkelerinin eşitliğe uyarlanmış İGE değerleri yer almaktadır. Eşitliğe uyarlanmış İGE değerleri kadın-erkek ayırımına yönelik eşitsizliği toplam insani gelişim endeksi içerisine adapte eden bir endeks olarak tanımlanabilmektedir. Tablo 2'de görüldüğü üzere 2010 yılı İGE verilerinin eşitliğe uyarlanmış durumunda tüm ülkelerin endeks değerlerinde kayıplar oluşmaktadır. Buradaki en büyük kayıp \%26,4'lük oranla Türkmenistan'da gerçekleşmesinin nedeni kadın-erkek ayrımcılığının yüksek oranda ve erkeklerin kadınlara göre daha iyi şartlara sahip olmasıdır. Bu durum İGE sıralamasında 87. sırada yer alan Türkmenistan'ın uyarlama sonrasında ortaya çıkan değerlere göre 12 sıra kaybederek dünya içerisinde 99 . sıraya gerilediğini 
göstermektedir. Diğer ülkelerde ise gelir dışındaki İGE’nin, kadına pozitif ayrımcılık yapıldığını göstermektedir. Eşitliğe uyarlanmış İGE’ye göre 2010 yılında Kazakistan 3, Özbekistan 17, Kırgızistan 15, Tacikistan ise 6 sıra yukarı çıkmaktadır.

\begin{tabular}{|c|c|c|c|c|c|c|c|c|c|c|}
\hline \multicolumn{2}{|c|}{$\begin{array}{l}\text { İnsani Kalkınma } \\
\text { Endeksi (İGE) }\end{array}$} & \multicolumn{3}{|c|}{$\begin{array}{c}\text { Eşitliğe } \\
\text { Uyarlanmış İGE }\end{array}$} & \multicolumn{2}{|c|}{$\begin{array}{c}\text { Eşitliğe } \\
\text { Uyarlanmış } \\
\text { Doğuştan } \\
\text { Yaşam } \\
\text { Beklentisi } \\
\text { Endeksi } \\
\end{array}$} & \multicolumn{2}{|c|}{$\begin{array}{c}\text { Eşitliğe } \\
\text { Uyarlanmış } \\
\text { Eŭitim } \\
\text { Endeksi }\end{array}$} & \multicolumn{2}{|c|}{$\begin{array}{c}\text { Eşitliğe } \\
\text { Uyarlanmış } \\
\text { Gelir } \\
\text { Endeksi }\end{array}$} \\
\hline Ülke & 离 & 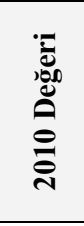 & 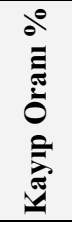 & 일 & 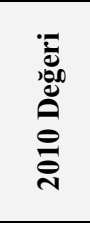 & 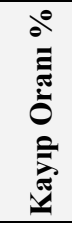 & 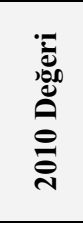 & 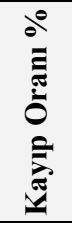 & 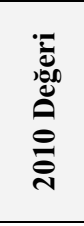 & 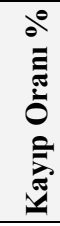 \\
\hline Kazakistan & 0,714 & 0,617 & 13,6 & 3 & 0,595 & 17,2 & 0,753 & 5,3 & 0,525 & 17,6 \\
\hline Türkmenistan & 0,669 & 0,493 & 26,4 & -12 & 0,520 & 27,5 & 0,647 & 10,2 & 0,355 & 38,7 \\
\hline Özbekistan & 0,617 & 0,521 & 15,7 & 17 & 0,565 & 25,9 & 0,672 & 1,4 & 0,372 & 17,9 \\
\hline Kırgızistan & 0,598 & $\mathbf{0 , 5 0 8}$ & 15,1 & 15 & 0,601 & 21,6 & 0,611 & 11,1 & 0,357 & 12,2 \\
\hline Tacikistan & $\mathbf{0 , 5 8 0}$ & 0,469 & 19,1 & 6 & 0,517 & 31,0 & 0,608 & 9,4 & 0,328 & 15,3 \\
\hline
\end{tabular}

Tablo 2: Orta Asya Ülkelerinin Eşitliğe Uyarlanmış İnsani Gelişim Endeksi, 2010.

Kaynak: UNDP Human Development Report 2010, ss. 152-155 yararlanılarak hazırlanmıştır.

\section{Orta Asya Ülkelerinin 1990-2010 Yılları Arasındaki İnsani Gelişme Endeksleri ve Kişi Başına Gayri Safi Yurt İçi Hasılalarındaki Değişimler}

Orta Asya ülkelerinin bağımsızlıkları sonrasında geçirdikleri 20 yıllık dönemde iktisadi, politik ve sosyal alanlarda önemli değişimler gerçekleşmiştir. Tablo 3'te Orta Asya ülkelerinin insani gelişim endekslerinin 19902010 yılları arasındaki değişimleri görülmektedir.

\begin{tabular}{|c|c|c|c|c|c|c|c|c|c|c|}
\hline \multirow{2}{*}{ Ülke } & \multicolumn{5}{|c|}{$\begin{array}{c}\text { İnsani Kalkınma Endeksi Değerleri } \\
\text { (İGE) }\end{array}$} & \multicolumn{4}{|c|}{ Yıllar İtibari İle Toplam Değișim } & \multirow{2}{*}{ 됩 } \\
\hline & 1990 & 1995 & 2000 & 2005 & 2010 & $\begin{array}{l}1990- \\
2000\end{array}$ & $\begin{array}{l}2000- \\
2005\end{array}$ & $\begin{array}{l}2005- \\
2010\end{array}$ & $\begin{array}{l}2000- \\
2010\end{array}$ & \\
\hline Kazakistan & 0,650 & 0,620 & 0,750 & 0,696 & 0,714 & 0,100 & $-0,054$ & 0,018 & $-0,036$ & -1 \\
\hline $\begin{array}{l}\text { Türkmen- } \\
\text { istan }\end{array}$ & $\begin{array}{l}\text { Veri } \\
\text { yok }\end{array}$ & $\begin{array}{l}\text { Veri } \\
\text { yok }\end{array}$ & $\begin{array}{l}\text { Veri } \\
\text { yok }\end{array}$ & 0,642 & 0,669 & - & - & 0,027 & - & 0 \\
\hline Özbekistan & $\begin{array}{l}\text { Veri } \\
\text { yok }\end{array}$ & $\begin{array}{l}\text { Veri } \\
\text { yok }\end{array}$ & 0,727 & 0 & 0,617 & - & -0 , & 0,029 & $-0,110$ & -1 \\
\hline Kırgizistan & 0,577 & 0,515 & 0,550 & 0,572 & 0,598 & $-0,027$ & 0,022 & 0,026 & 0,048 & $\mathbf{0}$ \\
\hline Tacikistan & 0,592 & 0,501 & 0,493 & 0,550 & 0,580 & $-0,099$ & 0,057 & 0,030 & 0,087 & $\mathbf{0}$ \\
\hline
\end{tabular}

Tablo 3: Orta Asya Ülkelerinin İnsani Kalkınma Endeksindeki Değişimler, 1990-2010. Kaynak: UNDP Human Development Report 2010, ss.148-151 yararlanılarak hazırlanmıştır.

Tablo 3'te yer alan Orta Asya ülkelerinin 1990-2010 yılları arasındaki insani gelişim endekslerindeki 5'er yıllık değişimler göz önüne alındığında tüm ülkeler için düzensiz değişimlerin olduğu görülmektedir. Tablodaki en dikkate değer veri 2005-2010 yılları arasında tüm ülkelerin İGE'lerinde pozitif yönlü bir değişim olduğudur. Fakat ülkelerin İGE'deki sıralamaları göz önüne alındığında; 2005-2010 yılları arasında Kazakistan ve Özbekistan'ın birer sıra gerilediği, Türkmenistan, Kırgızistan ve Tacikistan'ın sıralamalarının ise değişmediği görülmektedir. Bu verilere dayanarak Orta Asya ülkelerinin tamamı için İGE'de düzenli artışın olduğu periyotta dahi bu ülkelerdeki gelişmelerin dünyadaki diğer ülkelerden farklı olmadığıdır.

\begin{tabular}{lccc|ccc}
\hline & & Yıllar & \multicolumn{3}{c}{ Yllar Arası Değişim \% } \\
\multicolumn{1}{c}{ Ülke } & $\mathbf{2 0 0 0}$ & $\mathbf{2 0 0 5}$ & $\mathbf{2 0 1 0}$ & $\mathbf{2 0 0 0 - 2 0 0 5}$ & $\mathbf{2 0 0 5 - 2 0 1 0}$ & $\mathbf{2 0 0 0 - 2 0 1 0}$ \\
\hline Kazakistan & 4792 & 8704 & 12236 & 81,64 & 40,58 & 155,34 \\
Türkmenistan & Veri Yok & Veri Yok & $7500^{* *}$ & - & - & - \\
Özbekistan* & 1447 & 1911 & 2875 & 32,07 & 50,44 & 98,69 \\
Kirgızistan & 1338 & 1742 & 2246 & 30,19 & 28,93 & 67,86 \\
Tacikistan* & 886 & 1413 & 1840 & 59,48 & 30,22 & 107,67 \\
\hline
\end{tabular}

Tablo 4: Orta Asya Ülkelerinin Yıllar Itibariyle Kişi Başına Gayrisafi Yurtiçi Hasılası, 2000-2010 (\$)

Kaynak: Asian Development Bank, Key Indicators for Asia and the Pacific 2011.

*Özbekistan ve Tacikistan'a ait son kişi başına GSYIH verileri 2009 yılına aittir. **www.cia.gov/library/publications/theworld-factbook/geos/tx.html yararlanılarak hazırlanmıştır. 
Tablo 4'te Orta Asya ülkelerinin 2000, 2005 ve 2010 yıllarına ait kişi başına gayrisafi yurtiçi hâsıla verileri yer almaktadır. Buna göre 2000-2010 yılları arasında Kazakistan'daki gelir \%155,34 artarak 4792 \$'dan 12236 \$ seviyesine ulaşmıştır. Tacikistan'daki artış \%107,67, Özbekistan'da \%98,69, Kırgızistan'da \%67,86 olarak gerçekleşmiştir. Buradan 10 y1llık periyotta ülkelerin kişi başına gelirlerinde önemli artışların yaşandığ 1 söylenebilir. Ülkelerin 2005-2010 yılları arasındaki 5 yıllık dönemdeki gelir değişimlerinde de önemli artışların olduğu görülmektedir. 5 yıl içerisinde Kazakistan'ın kişi başına GSYİH \%40,58, Özbekistan'ın \%50,44, Kırgızistan'ın \%28,93, Tacikistan'ın ise \%30,22 artmıştır.

Orta Asya ülkelerindeki kişi başına düşen GSYİH değişimleri ile İGE arasındaki ilişkiyi gözlemleyebilmek amaciyla Tablo 3 ve Tablo 4'te yer alan verileri birlikte değerlendirilebilir. Buna göre;

- Kazakistan için 2000 yılındaki İGE değeri 0,750 iken 2010 yılındaki değer 0,714 olarak gerçekleşmiştir. Endeksteki değişim yaklaşık olarak eksi \%5 oranındadır. Buna karşın 2000 ve 2010 yılları arasındaki ülkedeki kişi başına gelir \%155,34 oranında yükselmiştir.

- Özbekistan'ın 0,727 olan 2000 İGE değeri 2010 yılına gelindiğinde 0,617 olarak hesaplanmıştır. Bu endeks değerinin yaklaşık olarak \%13 oranında düştüğünü göstermektedir. Aynı dönem için ülkenin kişi başı geliri 1447 \$'dan 2875 \$'a yükselmiştir. Bu gelirdeki \%98,69'luk bir artışa işaret etmektedir.

- Kırgızistan'ın 2000-2010 yıllarında 0,550'den 0,598'e yükselen İGE değerinde yaklaşık olarak \%8'lik bir artış görülmektedir. Buna karşın 2000-2010 yılları arasındaki gelir artış1 \%67,86 olarak hesaplanmıştır.

- Bölgedeki en düşük İGE değerine ve kişi başına gelire sahip ülke olan Tacikistan da 2000 yılında 0,493 olan İGE değeri 2010 yılında 0,580'e yükselmiştir. Yaklaşık \%22 olan bu değişim bölge içerisinde anılan dönemde görülen en yüksek oranlı değişimdir. Söz konusu yıllar arasında Tacikistan'ın kişi başına milli geliri de 886 \$'dan 1840 \$'a \%107,67'lik artış göstermiştir. Bu değişim Kazakistan'dan sonraki en yüksek oranlı artıştır.

\section{Genel Değerlendirme}

Sovyetler Birliği’nin dağılmasının ardından Orta Asya Bölgesindeki farklı doğal kaynak kapasitelerine sahip Kazakistan, Türkmenistan, Özbekistan, Tacikistan ve Kırgızistan için iktisadi kalkınma ve gelişme öncelikli politika tercihleri arasında yer almaktadır. Üretim faktörleri açısından eşit şartlara sahip olmayan ülkelerin, ulusal gelirlerini ağırlıklı olarak doğal kaynak ve tarımsal ürün ihracatına bağlamış oldukları görülmektedir. Ancak, sadece ülkenin kişi başına GSYİH artışına dayalı bir kalkınma, teorik olarak, beşeri sermayeyi gelir artışına paralel bir şekilde arttırmadığı ve kullanılmadığı sürece, ülkenin beşeri sermayesinin israfı anlamına gelebilmektedir. Bu durum Orta Asya ülkeleri için geçerli olabilmektedir. Rant ekonomisinin ülke büyümesine katkısı önemli oranlarda iken ülkenin insani kalkınmasına katkısı bu bölgedeki ülkelerde gerçekleşememektedir.

2010 yılı insani gelişim endeksine bakıldığında bölge ülkelerinden sadece Kazakistan'ın 0,714'lük endeks değeri ile yüksek insani gelişmişlik seviyesinde yer aldığı görülmektedir. 169 ülke içerisinde 66. sırada yer alan Kazakistan'1 0,669 endeks değerine sahip 87. sıradaki Türkmenistan izlemektedir. İnsani gelişim endeksini oluşturan alt endeksler incelendiğinde bu iki ülkenin diğer ülkelerden daha kısa bir doğuştan yaşam beklentisine sahip oldukları görülmektedir. Ortalama okullaşma oranında da bölge içerisindeki diğer ülkelere karşı önemli miktarda avantaja sahip olmayan Kazakistan ve Türkmenistan'ın göreceli yüksek İGE değerleri, petrol ve doğalgaz gibi ürünlerin ihracatına dayalı olarak elde edilen yüksek gelire dayanmaktadır.

Bölge içerisinde yer alan Özbekistan 0,617 endeks değeri ile 102. sırada, Kırgızistan 0,598 endeks değeri ile 109. sırada ve Tacikistan 0,580 endeks değeri ile 112. sırada bulunmaktadır. İnsani gelişim endeksine göre alt sıralarda yer alan üç ülkenin dünya kişi başına GSYİH sıralaması eksi İGE sıralaması dikkate alındığında; Özbekistan ve Kırgızistan'da 17, Tacikistan'da ise 22 sıralık bir değişim görülmektedir. Ortaya çıkan bu tablo ülkelerin kişi başına GSYİH değerlerinde eş değerlerine göre sahip oldukları görece üstünlüğü insani gelişimlerine taşıyamadıkları şeklinde yorumlanabilinir. Özellikle az gelişmiş ülkelerin kalkınmasının temelini oluşturacak beşeri sermayenin Orta Asya Cumhuriyetlerinde eksik olduğu ve var olan eksikliğin refah artışını engellediği söylenebilinir.

Bölge ülkeleri içerisinde dikkate değer bir diğer unsurda Türkmenistan dışındaki tüm ülkelerin eşitliğe uyarlanmış İGE’leri göz önüne alındığında daha yüksek endeks sıralarına sahip olmalarıdır. Bu durum bölgede kadınların insani gelişmişlik açısından görece olarak daha düşük imkânlara sahip olmadıkları ve pozitif cinsiyet ayrımcılığının önemli oranda etkili olduğu şeklinde ifade edilebilinir. Bölgenin bu özelliğini Sovyet sistemden kalan bir miras olarak da kabul edebiliriz.

Orta Asya bölgesinde yer alan ülkelerin bağımsızlık sonrası dönemdeki İGE değerleri ve 2000-2010 yılları arasındaki kişi başına GSYİH ve İGE değişimleri incelendiğinde ise, bölgenin tamamında ortaya çıkan gelir artışlarının insani gelişim endeksine paralel olmadığıdır. Bölge içerisindeki gelir artış oranları insani gelişim endeksindeki iyileşmelerden daha yüksek oranlarda gerçekleşmiştir. Sonuç olarak, Orta Asya ülkelerinde 20 yıllık süreçte kişi başına GSYİH'daki yüksek oranlı artışların insani gelişim endeksine yansımadığ görülmüştür. Yaşanan bu eksiklik bölge ülkelerinin ekonomik büyüme gerçekleştirse de ülkelerin kalkınmalarının önündeki en önemli engel olduğu söylenebilinir. 


\section{Kaynakça}

- Jahan 2004. "Measuring Human Development: Evolution of the Human Development Index", Journal of Social Studies-Dhaka, 2004. http://hdr.undp.org/en/media/Jahan_HDI.pdf .

- Gürses, 2009. “ “İnsani Gelişme’ ve Türkiye”, Balıkesir Üniversitesi Sosyal Bilimler Enstitüsü Dergisi, Cilt:12, Say1:21, Haziran 2009, ss.339-350.

- Kaya, 2008. "İnsani Gelişme Endeksi (İGE) Gelirin Ötesinde Yaşam Standardını ve Refahı Belirlemektedir", Eskişehir Üniversitesi Teknoloji Araştırma Merkezi, http://www.ogu.edu.tr/bduyuru.aspx?KID=1\&DID=502 .

- Karabulut ve diğerleri, 2009. "Ekonomik Kalkınma ve İşbirliği Örgütü’ne Üye Ülkelerin 2006 Yı1ı İnsani Gelişmişlik Düzeylerinin Analizi”, Niğde Üniversitesi İIBF Dergisi, 2009, Cilt:2, Say1:2, ss.1-18.

- Karataş ve Çankaya, 2010. "İktisadi Kalkınma Sürecinde Beşeri Sermayeye İlişkin Bir İnceleme”, Mehmet Akif Ersoy Üniversitesi Sosyal Bilimler Enstitüsü Dergisi, Y1l:2, Sayı:3, 2010-Güz, ss.29-55.

- Demir, 2006. "Birleşmiş Milletler Kalkınma Programı İnsani Gelişme Endeksi ve Türkiye Açısından Değerlendirme”, Sosyal Sektörler ve Koordinasyon Genel Müdürlüğü, Ankara.

- Mihc1, 2011. "Human Development Performance of Transition Economies in the Post-Cold War Period", H.Ü. İktisadi ve İdari Bilimler Fakültesi Dergisi, Cilt:29, Sayı:1, 2011, ss.21-42.

- United Nations Development Programme (UNDP), 2010. Human Development Report 2010, New York, November 2010.

- CIA Factbook, http://www.cia.gov/library/publications/the-world-factbook/geos/tx.html.

- Asian Development Bank, 2011. Key Indicators for Asia and the Pacific 2011, 42 $2^{\text {th }}$ Edition, August 2011. 


\title{
Ekonomik Büyüme ve Gelir Dağılımı İlişskileri: Geçiş Ekonomileri Deneyimi
}

\author{
Dilek Özdemir (Atatürk University, Turkey) \\ Ö. Selçuk Emsen (Atatürk University, Turkey) \\ Ayşen Hiç Gencer (Istanbul Aydın University, Turkey) \\ Cemil Hakan Kılıç (Istanbul Chamber of Commerce, Turkey)
}

\section{The Relationship between Economic Growth and Income Distribution: The Case of Transition Economies}

\begin{abstract}
In the literature on economic growth, Kuznets curve shows the relationship between growth and income distribution. According to the Kuznets curve, as per capita income rises, income distribution would first become more unequal, and then less unequal. This means that, in a less developed country poverty is shared; in a developing country the difference between the rich and the poor becomes wider; and in a developed country richness is shared. In economies in transition, from socialism to market economy, however, income distribution should be less unequal because of the socialist system. But during the transition, there occurred recessions that led to falls in income. Therefore, during the transition process, as income decreased, income distribution became more unequal. In this study, the relationship between per capita income and income distribution on the transition economies are investigated by means of panel data analysis. The results obtained are then compared with the Kuznets curve.
\end{abstract}

JEL Codes: C31, D63, O15.

\section{Giriş}

Büyüme ve gelir dağılımı arasındaki ilişki iktisat literatüründe ilk olarak Kuznets (1956) tarafından araştırılmış ve Kuznets hipotezi ortaya atılmıştır. Bu hipoteze göre, düşük gelir seviyeli ülkelerde gelir eşitsizliği nispeten azdır. Ekonomik büyüme ve fert başına düşen gelir artışıyla birlikte gelir eşitsizliği artar. Fakat büyümenin daha ileri safhalarında gelir dağılımı eşitsizliği azalma trendine girecektir. Bu tanımlamaya göre, gelir dağılımı ile gelir düzeyi arasındaki ilişki “ters U-eğrisi” şeklinde resmedilir. Robinson (1976) ise, gelişmeyle birlikte tarımdan sanayi sektörüne istihdam akımını hesaba katmak suretiyle, Kuznets'in hipotezini daha da geliştirmiştir. Robinson'un modeline göre, tarım ve kırsal sektör başlangıçta ekonominin büyük bir kısmını oluşturmaktadır. Tarım sektörünün temel karakteristiği düşük fert başına gelire sahip olmasıdır ve sektörde göreceli olarak daha az eşitsizlikler söz konusudur. Buna karşılık, sanayide ve kentsel sektörde fert başına gelir yüksek olup göreceli olarak daha fazla gelir eşitsizliği bulunmaktadır. Ekonomik gelişme ile birlikte istihdam da tarımdan sanayie yönelir. Tarım sektörüne göre, daha yüksek gelir elde edilmekle birlikte, gelir eşitsizliği de giderek artar. Dolayısıyla, gelişmenin ilk aşamalarında gelir artarken, gelir eşitsizliği de buna paralel bir seyir takip eder. Ancak, gelişme ile birlikte, kırsal kesimden kentsel kesimlere doğru oluşan göç, tarımda gizli işsizliği bertaraf ederek, marjinal verimliliği yükseltir, ve böylece tarım işçilerinin gelirleri de artar. Benzer şekilde sanayi sektöründe işçiler de basamak atlayarak üst sıralara doğru çıkmaya başlarlar ve bunların gelirinde iyileşmeler söz konusu olur. Diğer bir ifadeyle toplam gelir yükselirken, gelirler arasında da yakınlaşma ortaya çıkmaya başlar. Ampirik araştırmalarda ve aşağıdaki eşitlikte bu durum $\mathrm{Y}^{2}$ ' nin katsayısının negatif olması ile sembolize edilir (Li ve diğerleri, 2000: 952; Barro, 2000: 8-9):

$$
\mathrm{GINI}_{\mathrm{it}}=\alpha_{\mathrm{i}}+\beta_{\mathrm{i}} \mathrm{Y}_{\mathrm{it}}+\gamma_{\mathrm{i}}\left(\mathrm{Y}_{\mathrm{it}}\right)^{2}+\mathrm{u}_{\mathrm{it}}
$$

Yeni büyüme teorilerinden Barro ve Sala-i Martin (1997)'in geliştirmiş oldukları ve büyümenin belirleyicilerine ilişkin araştırmalarda, büyümenin bireysel refaha etkileri, dolaylı bir şekilde kamu harcamalarının gelir dağılımında adalet boyutuna yansımaları ile ele alınmaktadır. Bu çerçevede kamu harcamaları değişkeninin eğitim, sağlık, sosyal güvenlik, altyapı ve refahı artırıcı boyutlarının gelir dağılımında adaleti sağlayıcı etkilerinin olacağı kabul edilir. Gelir dağılımına kamu harcamalarının olumlu etkilerinin bulunacağına dair literatür içerisinde Adelman ve Robinson (1988), Lindert ve Williamson (1985), Brenner, Kaelble ve Thomas (1991), Papanek ve Kyn (1986)'in çalışmalar örnek verilmektedir (Li ve diğerleri, 2000: 937-953).

Diğer taraftan, Summers ve Heston (1995) tarafindan yapılan çalışmada, Levine ve Renelt (1992) büyüme modeli esas alınarak, gelir dağılımı formuna dışa açıklık değişkeni (OPEN) eklenmiştir. OPEN değişkeni toplam ticaret hacminin (ihracat ve ithalat toplamının) GSYİH’ya oranı olarak alınmıştır. Ayrıca nüfus artışı-PGRW, finansal gelişme-FNDP (M2/GSYIH), ticaret hadleri şokları-TOTSK $\left(\Delta \ln P_{X} / \Delta \ln P_{M}\right)$ gibi değişkenlerin de gelir dağılımı modeline dahil edilmiştir (Li ve diğerleri, 2000: 955). Dışa açıklık değişkeninin ihracat boyutuyla 
büyüme modellerine dahil edilmesinde özellikle Feder (1983) ve Balassa (1978)'nın ihracatın büyümenin önemli bir lokomotif gücü olduğuna dair iddiası etkili olmuştur (Gyimah-Brempong ve Camacho, 2006: 251).

Büyüme ve gelir dağılımı ilişkilerine bir başka bakış açısında, teorik olarak kayıt dışı ekonomi vergi gelirlerindeki düşüşler ve zayıflamış sosyal güvenlik ağlarıyla temsil edilirken, eşitsizlikteki artışlar da sosyal dayanışma ve güven erozyonu gibi daha kayıt dışı faaliyetlerin neden olduğu unsurlardan beslendiği kabul edilir. Kayıt dışı sektörün payındaki artışlar kamunun vergi gelirlerindeki azalışları tetikler. Kamu açısından kayıt dışı sektör arttığında, vergi gelirlerinde kayıplar söz konusu iken; kayıt dışı sektör daraltıldığında, vergi gelirlerindeki artışlar şeklinde birincisi iyi ve ikincisi kötü olan iki seçenek ortaya çıkar. Vergi gelirlerindeki kayıpları telafi etmek üzere formel sektörler üzerine vergilerin artırılmasına yönelik politikalar ise kayıt dışı sektörün daha da derinleşmesi sonucunu doğurur. Ancak, vergi gelirlerinin düşük tutulması da bu sefer sosyal güvenlik ağlarını zedeleyerek, gelir dağılımındaki eşitsizliği daha da derinleştirir (Rosser, Rosser ve Ahmed, 2000: 157). Diğer taraftan, gelir dağılımını düzeltmeye yönelik politikalar yüksek gelirlilerin çalışma motivasyonu kaybına yol açabilirken (Herzer ve Vollmer, 2011: 2); dolaylı bir şekilde hem kamusal hem de toplumsal gelir kayıplarına sebebiyet verebilmektedir.

Gelir dağılımında adalet ya da kalkınma hızı yüksekliği ikilemi şeklinde yansımaları olan politikalara karşı, İskandinav tipi refah devleti anlayışının daha az ayrıcalıklı sosyal içerme düzeyleri (örneğin eğitime ağırlık verilmesi) şeklinde tanımlanan politikaların daha sağlıklı sonuçlar verdiği ileri sürülmektedir. Zira kalkınma hızını yüksek tutmak ve buna karşılık gelir eşitsizliğine müdahalede bulunmamak şeklinde politika uygulamalarının ise toplumda çatışmacı yapıları besleyerek, kalkınmayı sekteye uğratabileceği kabul edilmektedir (Herzer ve Vollmer, 2011: 2).

Genel olarak gelir eşitsizliğinin artması ile refah arasında ters yönlü ilişkilerin varlığı daha çok Rawls'ın muhakeme (1971) veya Sen'in yetenek (1982, 1984) yaklaşımına dayalı olarak ortaya atılmıştır. Geçiş ekonomileri sürecin başlangıcında görece daha eşitlikçi bir yapıya sahipken; geçiş süreciyle birlikte yaşadıkları en önemli sonuçlardan birisi gelirde düşüşler ve gelir eşitsizliğinde artışlardır (Grün ve Klasen, 2001: 361).

Bu çalışmada araştırma konusu yapılan geçiş ekonomilerinin büyük bir kısmı üretimde kayıplar yaşarken, gelir dağılımında eşitliğin ölçütü olan Gini katsayısında da iki katına varan yükselişler vuku bulmuştur. Diğer bir ifadeyle, geçiş resesyonu, üretim ve gelirde azalışlar şeklinde yansımalara yol açarken; başta Rusya'da olmak, üzere birçok ülkede de fakirlikte ani artışlar söz konusu olmuştur. Bu konuyla ilgili cari literatürün büyük bir kısmı, toplumların iki zıt denge kalıbından birini seçme ile karşı karşıya bulunduğunu ortaya koyan çalışmalardan oluşmaktadır. Bunlardan ilki, sosyal dayanışma, yatay bağlantılar ile karşılıklı yardım ve güveni ifade ederken; ikincisi sınıf çatışması, dikey hiyerarşileri ve genel güvensizliği tanımlamaktadır. Birinci boyutu Putnam (1993) daha çok sosyal sermaye olgusu ile özdeşleştirirken; bu olgunun da güven unsuru ve işbirliğinden beslendiğini ileri sürmüştür. İkinci boyut ise ekonomide kayıt dışı sektörün payının artması ve kamu sektörünün performansı arasında ilişkiye yoğunlaşır ve nihayetinde bunun yansıması da gelir dağılımının giderek bozulmasidır (Rosser, Rosser ve Ahmed, 2000: 156-157).

Geçiş süreci öncesi restorasyon ruhu ile çağı yakalama çabalarının yetersiz kalması sonucu sistem yıkılıp, piyasa ekonomisi ve hürriyetçiliğin refahın temel belirleyicisi olduğunun tesciline bağlı olarak yaşanan gelişmelerde, gelirde toparlanmaların gecikmeli biçimde ortaya çıktığı ve buna karşılık eşitsizliğin daha da derinleştiği durum söz konusu olmuştur. Bu bağlamda ikinci kez başkanlık seçimlerinin yapıldığı günün akşamında Putin, ülkede istikrarın büyük ölçüde sağlandığını ve Rus halkının yaşam standartlarının yükseltilmesinin başlıca hedef haline geldiğini söyleyerek, "nüfusun en az dörtte birinin yoksulluk sınırı altında yaşadığını ve bu kesimi yoksulluktan kurtarmak için gerekenin tam olarak yapılmadığını belirtmiştir." (Mikail, 2008: 172). Dolayısıyla, Rusya özelinde ve geçiş ekonomileri genelinde ortaya çıkan durum, büyüme ve gelir dağılımında eşitsizlik olgusu arasında politika tercihini doğurmuştur. Gelinen nokta dikkate alındığında, geçiş ekonomilerinde gelir dağılımındaki eşitsizlik ve büyüme ilişkileri Kuznets hipotezi bağlamında analiz edilmeye çalışılmıştır.

\section{Literatür Özeti}

Gelir dağılımında eşitsizlik ile refahın göstergesi olan kişi başına gelir arasındaki ilişkilerle ilgili çalışmalarda, genelde Kuznets hipotezinin test edilmesi amaçlanmıştır. Bir kısım çalışmalarda Gini katsayısı bağımlı değişken olarak kabul edilmiş, başta kişi başına gelir olmak üzere bazı değişkenler de modele kontrol değişkeni olarak dahil edilmiştir. Diğer bir kısım çalışmalarda da standart büyüme modelleri bağlamında, gelirin belirleyicileri formuna Gini katsayısı bağımsız değişken olarak eklenmiştir. Dolayısıyla, bu çalışmada uygun model seçebilmek üzere literatür incelemesi yapılmıştır.

Seksendört ülkeden yirmidördünün yüksek gelirli ve kalanının da orta gelirli ülkelerden seçildiği bir örnek üzerine yapılan çalışmada, Gini katsayısı bağımlı değişken olmak üzere kişi başına reel gelir (Y) ve kamu harcamalarının GSYİH içerisindeki payı $(\mathrm{G})$ da açıklayıcı değişken olarak modele dahil edilmiştir. Analiz sonuçlarına göre, Y ve G’nin işaretleri negatif bulunmuştur. Buna göre, gelir ve kamu harcamalarındaki artışlar ile Gini katsayısı arasında ters yönlü ilişkiler tespit edilmiştir. Diğer bir ifadeyle, kamu harcamaları ile kişi 
başına reel gelirdeki artışların gelir dağılımında adaleti ifade eden Gini katsayısını düşürdüğü gözlenmiştir. Özellikle gelişmiş ülkelerde gelir dağılımındaki adaleti verimli kamu harcamalarının; gelişmekte olan ülkelerde ise ekonomik büyümenin daha etkili bir şekilde sağladığı vurgulanmıştır. Dışa açıklığın da modele dahil edilmesi sonucu yapılan analizlerde, bu değişkenin gelişmiş ülkelerde gelir dağılımında adaletsizliği azalttığı, ancak tüm örneklerde tam tersine, derinleştirdiği bulgusuna rastlanmıştır (Li ve diğerleri, 2000: 952-957).

1960-1995 dönemini kapsayan ve yüz ülkeyi ele alan çalışmada büyümenin belirleyicileri şeklinde bir araştırma formatı tesis edilmiştir. Buna göre, ayrı ayrı büyüme ve Gini katsayıları bağımlı değişken olmak üzere kamu harcamalarının GSYİH'ya oranı, hukuk kuralları indeksi, demokrasi indeksi, enflasyon oranı, okullaşmada yıl sayısı, ölüm oranları, yatırımların GSYİH'ya oranı ve ticaret hadleri alınmıştır. Elde edilen bulgularda dışa açıklık ile yatırımların GSYİH’ya oranı, gelir eşitsizliği üzerine pozitif ve anlamlı etkiler verirken; gelir ile Gini arasındaki ilişkilerin ise Kuznets hipotezini teyit edecek şekilde ülkelerin gelişmişliğine göre işlediği ortaya konulmuştur (Barro, 2000: 10-29).

1987 ile 1989 ve 1993 ile 1994 ortalamaları alınarak onaltı geçiş ekonomisi için kayıt dışı sektör ile gelir eşitsizliği arasındaki ilişkiler araştırılmıştır. Formel sektörü temsilen GSYİH değerleri ile kayıt dışı sektörün boyutunu temsilen de elektrik tüketim değerleri alınmıştır. Gelir dağılımındaki eşitsizlikler ise Gini katsayısı ile tanımlanmıştır. Yapılan betimleyici analizlerde gelir eşitsizliğinin kayıt dışı ya da kayıt dışı ekonomideki üretim artışı ile pozitif ilişkili olduğu tespit edilmiştir. Bu durum, gelir eşitsizliğindeki artışların gayrı resmi ekonomide üretilen çıktının payındaki artışlarla da ilişkili olduğuna dair teorik bakış açısıyla paralel bulgular yakalanmıştır (Rosser, Rosser ve Ahmed, 2000: 162-168).

Geçiş ekonomilerinden onsekiz ülke üzerine yapılan çalışma 1988-1995 arası dönemi kapsamıştır. Refah etkileri ile gelir dağılımı arasındaki ilişkilerin incelendiği çalışmada Macaristan ve Polonya dışındaki ülkelerde politik ve sivil özgürlüklerde mesafe kaydedilmesine rağmen, gelir dağılımında bozulmanın devam ettiği ve bunun da refah etkilerini düşürücü yönde yansımalarının olduğu tespit edilmiştir (Grün ve Klasen, 2001: 367 382).

Altyapı göstergeleri ile ekonomik büyüme ve gelir dağılımı ilişkilerinin incelendiği çalışmada yüzyirmibir ülkeye ait veriler için 1960-2000 dönemi alınmıştır. Altyapıyı temsilen kullanılan, bin kişiye düşen telefon sayısı, elektrik üretim değerleri ve taşımacılığı temsil için de, karayolu ağı uzunluğundan mürekkep değişkenler kullanılmıştır. Bu değişkenlerden hareketle tahmin edilen altyapı değişkeninin hem ekonomik büyüme üzerinde hem de gelir dağılımını düzeltme yönünde anlamlı etkilerinin olduğu görülmüştür. Dolayısıyla, altyapıdaki gelişmelerin ekonomik büyümeyi artırdığı ve gelir dağılımında eşitsizliği azalttığı belirlenmiştir (Calderón ve Servén, 2004: 13-26).

Yaşam beklentisi veya ölüm oranları ile gelir eşitsizliği boyutunu inceleyen çalışmalarda önemli ölçüde nedensel ilişkiler saptanırken, yaşam beklentisindeki artışların veya çocuk ölüm oranlarındaki azalışların da önemli kalkınma göstergeleri arasında yer aldığı kabul edilir. Bu çerçevede yapılan araştırmada Avrupa Birliği'nden onbeş ülke üzerine ve 1993 ile 2000 yıllarını kapsayan çalışmada panel veri analizleri kullanılmıştır. Panel veri analizlerde Hausman testinin temeli ise etkinsiz tahminciden hareketle farkının etkin tahmincinin kovaryansının sıfır olduğu kabul edilir ve bu da tesadüfi etkilere işaret eder. Tesadüfi etkili model sonucunda yaşam beklentisinin ve çocuk ölüm oranlarının belirleyicisi olarak GSYİH ve Gini katsayısı alınmış ve Gini katsayısının yaşam beklentisinde negatif; bebek ölüm oranlarında da pozitif etkilerinin olduğu tespit edilmiştir. Dolayısıyla, kalkınmışıı göstergeleri ile Gini katsayısı arasında teorik beklentilere uygun sonuçlar elde edilmiştir (Cantarero, Pacual ve Sarabia, 2005: 89-91).

Beş gelişmiş ülkede (ABD, Avustralya, İngiltere, İsveç ve Kanada) nüfusu ellibinin üzerindeki beşyüzyirmisekiz metropolitan kent üzerine ve 1990-1991 yıllarını kapsayan yatay kesit çalışmada yaşam beklentisi ile gelir eşitsizliği arasındaki ilişkiler araştırılmıştır. Genel olarak gelir eşitsizliğindeki azalmaların yaşam beklentisinin artırdığına dair bulguların gelir eşitsizliğinin yüksek düzeylerde olduğu ABD ve İngiltere'de daha güçlü olduğu belirlemesi yapılmıştır. Buna karşılık Avustralya, İsveç ve Kanada ise gelir dağılımında eşitsizliği azaltıcı politikaların varlığı, söz konusu ilişkinin zayıf kalmasının temel etkeni olarak görülmüştür (Ross ve diğerleri, 2005: 104-108).

Fraser Institute of Economic Freedom tarafından hazırlanan ve ekonomik özgürlükler ile gelir dağılımında eşitsizlikleri konu alan çalışmada, kontrol değişkenler olarak kişi başına gelir, siyasal yapı, eğitim, demografi ve endüstriyel kompozisyon dahil edilmiştir. Çalışmada 1975-79, 1980-84, 1985-89, 1990-94, 1995-99 ve 2000-04 dönemleri için altı gözlem ve otuzdokuz ülkeye ilişkin veriler kullanılmıştır. Panel veri analizlerinde bireysel, yani ülkeye özgü etkilerin olduğuna işaret eden sabit etkili tahmin sonuçlarından elde edilen bulgulara göre, ekonomik özgürlükler ile gelir dağılımı arasında pozitif ve istatistiki açıdan anlamlı ilişkiler bulunmuştur (Carter, 2006: 165-176).

Farklı gelişmişlik aşamasında bulunan altmışbir ülke üzerine yapılan çalışmada standart Barro-tipi büyüme (1991) modeline yolsuzluk göstergesi dahil edilmiştir. Büyüme modelinin diğer açıklayıcıları olarak eğitim, ihracat ve sermaye gibi unsurlar eklenmiştir. Bu kalıptan hareketle, gelir dağılımındaki eşitsizliğin ölçütü olarak Gini katsayısının bağımlı değişken olarak alındığı modelde, kişi başına gelir ve gelirin büyüme oranı, ihracat, 
yolsuzluk, kamu harcamaları ve eğitim göstergeleri dahil edilmiştir. 1980-1998 arası dönemi kapsayan uygulama sonuçlarına göre, büyüme ve gelir dağılımı üzerine yolsuzluğun negatif etkileri tespit edilmiştir. Yolsuzluğun büyümeye en olumsuz etkilerinin olduğu ülke grubu Afrika, ve gelir dağılımı üzerine de en yüksek etkilerinin olduğu grubu ise Latin Amerika ülkeleridir. Genel sonuçlara göre ise, yolsuzluğun büyüme üzerinde etkilerinin olmadığı, buna karşılık gelir eşitsizliğini azaltacağı tespit edilmiştir (Gyimah-Brempong ve Camacho, 2006: 250-268).

Fert başına gelir ile gelir eşitsizliği arasındaki ilişkileri kırkaltı ülkeyi içeren ve 1970-1995 dönemini kapsayan çalışmada gelişmiş ve gelişmekte olan ülke grupları bağlamında konuyu irdelerken; buna yatırımların GSYİH içerisindeki payı da dahil edilmiştir. Ayrıca bu tasnifin yanı sıra demokratik ve anti-demokratik ülkeler kategorisinde de incelemeler söz konusu olmuştur. Dolayısıyla, çalışmada fert başına gelir bağımlı değişken olmak üzere yatırım düzeyi ve gelir eşitsizliği bağımsız değişkenler olarak modellenmiştir. Panel eş-bütünleşme test sonuçlarında büyüme üzerine gelir eşitsizliğinin uzun dönemli etkilerinin önemli olduğu tespit edilmiştir. Diğer taraftan, gelir dağılımı ve büyüme ilişkileri boyutunda, gelişmiş-gelişmekte olan ve demokratik-antidemokratik ülke ayırımının ise önemli olmadığı; ekonomik büyümede fiziki sermayeden ziyade beşeri sermayenin daha güçlü etkilerinin bulunduğu belirlenmiştir (Herzer ve Vollmer, 2011: 5-13).

Gelir dağılımındaki eşitsizliğin belirleyicileri olarak Gini katsayısının gecikmeli değeri, finansal derinlik göstergesi, reel gelir ve enflasyon oranlarının alındığı çalışma otuzbeş gelişmekte olan ülke üzerine 1980-2000 dönemini kapsamıştır. Finansal derinlik göstergeleri olarak özel sektör kredileri ve likit yükümlülükleri gibi bankacılık sektörü göstergeleri ya da borsa kapitilzasyonu ve onunun ticari değeri gibi göstergeler vekil değişkenler olarak alınmıştır. Her iki gösterge baz alınarak yapılan tahminlerde finansal derinliğin gelir eşitsizliğini önemli ölçüde azalttığı görülmüştür. Diğer taraftan, eşitsizlik ve finansal derinlik arasındaki ilişki boyutunun "ters-U-eğrisi”" şeklinde olduğuna dair teoriyi destekleyen bulgulara ulaşılmıştır (Tan ve Law, 2011: 4-12).

\section{Gelir ve Dağılımına İlişkin Ampirik Bulgular}

Geçiş ekonomilerinin başlangıçta yaşadıkları resesyon ile birlikte milli gelirde önemli daralmalar yaşadıkları açıtır. Diğer taraftan, bu ekonomiler piyasa mekanizmasına yönelirken; ekonomilerini liberalize ederek aynı zamanda dışa açılma yönünde politikalar da uygulamışlardır. Dışa açık politikalar bağlamında, tüketim kalıplarının da hızla değiş̧iği geçiş ekonomilerinde, başlangıçta gelir dağılımında eşitlikçi yapıya yakın yapı da giderek eşitsizleşme yönünde değişim geçirmiştir. Bu durum, Rusya'daki yapıyı inceleyen çalışmada ters yönlü ilişki şeklinde ortaya konulmuştur (Stiglitz, 1999: 2).Genel ortalama itibariyle gelir ve dağılımı arasındaki ilişkiler incelendiğinde, gelirin düşüş gösterdiği 1994 yılına kadarki süreçte gelir dağılımındaki adaletsizliğin de derinleştiği gözükmektedir.

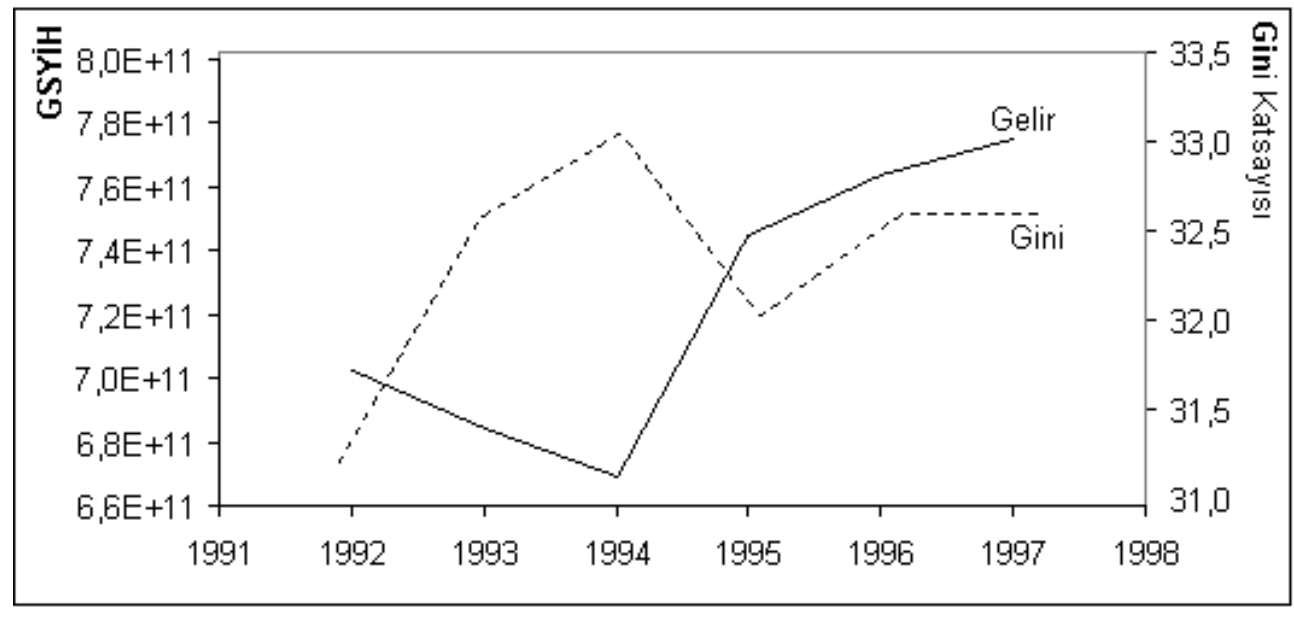

Şekil 1. Geçiş Ekonomilerinde GSYİH ve Gini Katsayısı

Geçiş resesyonunun bittiği 1994 yılından sonra gelirde toparlanmalar görülürken, gelir dağılımında da düzeltmeler söz konusu olmuştur. Çalışma, Gini katsayısı açısından sağlıklı veri setine ulaşılan onbeş geçiş ekonomisini (Beyaz Rusya, Bulgaristan, Çek Cumhuriyeti, Ermenistan, Estonya, Kırgızistan, Letonya, Litvanya, Macaristan, Makedonya, Moldova, Polonya, Romanya, Rusya ve Slovenya) üzerine 1992-2007 arası dönemi içermektedir.

Li ve diğerleri (2000) tarafından yapılan çalışmada standart gelir dağılımı ve Gini katsayısı ilişkilerini ele alan formata, Summers ve Heston (1995) ile Gyimah-Brempong ve Camacho (2006)'nun yaptıkları çalışmadaki dışa açıklık değişkeni de dahil edilmiştir. Diğer taraftan, geçiş resesyonunun ülkeden ülkeye farklılık arzetmesi nedeniyle, bu farklılığın gelirde düşüş ve gelir dağılımında eşitsizliği artırıcı etkilerinin olup olmadığını tespit 
amacıyla, bir kukla değişken ilavesi yapılmıştır. Dolayısıyla, çalışmanın modeli şu şekilde ifade edilmiştir:

$\mathrm{GINI}_{\mathrm{it}}=\alpha_{\mathrm{i}}+\beta_{\mathrm{i}} \mathrm{Y}_{\mathrm{it}}+\lambda_{\mathrm{i}}\left(\mathrm{Y}^{2}\right)_{\mathrm{it}}+\gamma_{\mathrm{i}}\left(\mathrm{OPEN}_{\mathrm{it}}\right)+\delta_{\mathrm{i}} \mathrm{D}_{\mathrm{it}}+\mathrm{u}_{\mathrm{it}}$

Burada GINI, gelir dağılım ölçütü olan Gini katsayısını; Y, 2005 yılı sabit fiyatlarla satın alma gücü paritesiyle kişi başına geliri; Y', Y'nin karesini; OPEN, ihracat ve ithalat toplamının GSYİH'ya oranını; D, geçiş resesyonunu ifade etmektedir. Gelir dağılımındaki eşitsizliğin gelir ve dışa açıklıktan etkilendiğine dair teorik ve ampirik çalışmalardan hareketle, bu çalışmada onbeş geçiş ekonomisi özelinde söz konusu ilişkilerin araştırılması yoluna gidilmiştir. Ele alınan değişkenlerin birim kök içerip içermediğinin tespiti amacıyla öncelikle birim kök sınamaları yapılmış ve sonuçlar Tablo 1'de kaydedilmiştir.

\begin{tabular}{|c|r|r|r|r|}
\hline \multirow{2}{*}{ Metot } & \multicolumn{2}{|c|}{ Y } & \multicolumn{1}{c|}{ GINI } & \multicolumn{1}{c|}{ OPEN } \\
\cline { 2 - 5 } & \multicolumn{1}{|c|}{ Seviye } & \multicolumn{1}{c|}{ 1. Fark } & \multicolumn{1}{c|}{ Seviye } & \multicolumn{1}{c|}{ Seviye } \\
\hline Levin, Lin \& Chu t* & -1.019 & $-6.296^{(\mathrm{a})}$ & $-7.703^{(\mathrm{a})}$ & $-7.387^{(\mathrm{a})}$ \\
\hline Breitung t-stat & 8.091 & $-1.846^{(\mathrm{b})}$ & -0.910 & 1.276 \\
\hline Im, Pesaran and Shin W-stat & 3.699 & $-3.112^{(\mathrm{a})}$ & $-6.628^{(\mathrm{a})}$ & $-4.578^{(\mathrm{a})}$ \\
\hline ADF - Fisher Chi-square & 29.466 & $57.883^{(\mathrm{a})}$ & $97.181^{(\mathrm{a})}$ & $77.791^{(\mathrm{a})}$ \\
\hline PP - Fisher Chi-square & $54.927^{(\mathrm{b})}$ & $54.621^{(\mathrm{a})}$ & $128.972^{(\mathrm{a})}$ & $77.757^{(\mathrm{a})}$ \\
\hline Hadri Z-stat & $9.668^{(\mathrm{a})}$ & $6.892^{(\mathrm{a})}$ & $5.868^{(\mathrm{a})}$ & $6.019^{(\mathrm{a})}$ \\
\hline
\end{tabular}

Tablo 1. Birim Kök Testi. Not: (a) \%1, (b) \%5 ve (c) \%10’da durağanlı̆̆l temsil eder.

Birim kök sınama sonuçlarına göre, fert başına gelir (Y) değişkeni birinci farklarda durağan iken; gelir dağılımında eşitsizliği ölçen Gini katsayısı (GINI) ile ihracat ve ithalat toplamının GSYİH'ya oranı (OPEN) değişkenleri ise seviye değerlerinde durağan çıkmıştır.

\begin{tabular}{|c|r|r|r|r|}
\hline & GINI & \multicolumn{1}{|c|}{ Y } & OPEN & \multicolumn{1}{c|}{ D } \\
\hline Ortalama & 33.13796 & 9002.183 & 102.1475 & 0.225000 \\
\hline Medyan & 33.30000 & 7798.500 & 103.7500 & 0.000000 \\
\hline Maksimum & 48.60000 & 26293.90 & 172.9000 & 1.000000 \\
\hline Minimum & 21.20000 & 1223.800 & 43.30000 & 0.000000 \\
\hline Standart Sapma & 6.085908 & 5498.939 & 31.24707 & 0.418455 \\
\hline Gözlem & 240 & 240 & 240 & 240 \\
\hline
\end{tabular}

Tablo 2. Tanımlayıcı Istatistikler

Onbeş geçiş ekonomisi açısından ortalama GINI değerinin 33.14 olduğu görülürken, 1992'de eşitsizliğin en düşük düzeyde olduğu ülke 21.2 ile Çek Cumhuriyeti ve 2000'de eşitsizliğin en üst düzeyde olduğu ülke 48.6 ile Ermenistan olarak tespit edilmiştir. Y değeri açısından da geçiş ekonomilerinde ortalama kişi başına gelir 9.002,18 dolardır. Y'nin en yüksek olduğu ülke 2007 yılı itibariyle 26.393,9 dolarla Slovenya, en düşük olduğu ülke 1995 yılı itibariyle 1.223,8 dolarla Kırgızistan'dır. Ekonominin dışa açıklığını temsil eden OPEN değişkeni açısından da ortalama dışa açıklığın \%102.15 düzeyinde olduğu ve bu yönüyle geçiş ekonomilerinin göreceli olarak, dışa açık ekonomiler kategorisinde değerlendirilebileceği söylenebilir. Dışa açıklığın en yüksek düzeyde gerçekleştiği ülke 2006 yılında \%172.9 ile Estonya olurken, en düşük düzeyde gerçekleştiği ülke ise 1992'de \%43.3 ile Litvanya olmuştur. D değişkeni, yani geçiş resesyonu-gelirde düşüşler açısından da resesyonun en uzun süre yaşandığı ülke (beş yıl) Moldova'dır. Geçiş resesyonunun hiç gözlenmediği ülke ise Polonya'dır.

Bu ülkeler için GINI değeri ile diğer değişkenler arasındaki ilişkiyi en basit şekliyle görmek üzere yapılan korelasyon katsayıları Tablo 3 ’te saptanmıştır.

\begin{tabular}{|c|c|c|c|c|}
\hline & GINI & Y & OPEN & D \\
\hline GINI & $\mathbf{1 . 0 0 0 0}$ & -0.4618 & -0.2447 & 0.0707 \\
\hline Y & -0.4618 & $\mathbf{1 . 0 0 0 0}$ & 0.2703 & -0.2702 \\
\hline OPEN & -0.2447 & 0.2703 & $\mathbf{1 . 0 0 0 0}$ & -0.0860 \\
\hline D & 0.0707 & -0.2702 & -0.0860 & $\mathbf{1 . 0 0 0 0}$ \\
\hline
\end{tabular}

Tablo 3. Korelasyon Matrisi

Korelasyon katsayılarının regresyon analizleri çerçevesinde değerlendirilmesi yapıldığında, geçiş ekonomilerinde gelir dağılımında eşitsizliği azaltan unsuru olarak OPEN'ın artmasının etkili olduğu görülmektedir.

Panel veri regresyon analizlerinde ise ortak sabitli, sabit etkili ve tesadüfi etkili tahmin sonuçları ile analizler yapılmıştır. Ortak sabitli ve sabit etkili arasında tercihte yatay-kesit F istatistik değeri 20.32 ve olasılığı da 0.00 olarak bulunmuştur. Bu durumda ortak sabit etkili modele göre, sabit etkili modelin anlamlılığının daha yüksek olduğu görülmüştür. Diğer taraftan, sabit etkili ile tesadüfi etkili model arasındaki tercih için de Hausman testi yapılmıştır. Hausman testinde 33.82 istatistik değeri ve olasılığının da 0.00 olduğu tespit edilmiştir. Bu sonuçlar açısından da yine sabit etkili modelin daha anlamlı tahmin verdiği belirlenmiştir. Dolayısıyla, buradaki modelde 
parametre katsayıları açısından sabit etkili, yani bireysel etkilerin anlamlı olduğu belirlemesi yapılmıştır. Bireysel etkilerin anlamlı olduğu sabit etkili tahmin sonuçları Tablo 4 'te verilmiştir.

\begin{tabular}{|c|c|c|c|c|}
\hline Değişkenler & Katsay1 & Std. Hata & t-istatistik & Olasılık \\
\hline C & 30.44875 & 1.739313 & 17.50619 & 0.0000 \\
\hline Y & 0.000342 & 0.000158 & 2.165513 & 0.0315 \\
\hline $\mathrm{Y}^{2}$ & $4.26 \mathrm{E}-08$ & $7.92 \mathrm{E}-07$ & 0.053819 & 0.9571 \\
\hline OPEN & -0.003640 & 0.014259 & -0.255242 & 0.7988 \\
\hline $\mathrm{D}$ & 0.345993 & 0.618345 & 0.559547 & 0.5764 \\
\hline $\mathrm{R}^{2}$ & 0.746283 & \multicolumn{2}{|c|}{ F-istatistik } & 33.66276 \\
\hline D.W. & 1.077823 & \multicolumn{2}{|c|}{ F Olasılık } & 0.000000 \\
\hline
\end{tabular}

\section{Tablo 4. Sabit Etkili Tahmin Sonuçları}

Bireysel etkilerin anlamlı olduğu sabit etkili tahmin sonuçlarına göre, gelir dağılımında eşitsizliğin ölçütü olan Gini katsayısının bağımlı değişken olarak alındığı modelde, gelir düzeyindeki artışların gelir dağılımında eşitsizliği daha da derinleştirdiği görülmektedir ve bu değişkenin istatistik açıdan anlamlılığı \%5 önem düzeyindedir. Eşitsizliğin asıl ölçütü olan $\mathrm{Y}^{2}$ katsayısı ise pozitif, ancak anlamsız bulunmuştur. Diğer taraftan, kukla değişken olarak alınan resesyon yılları ile ekonominin dışa açıklığının gelir dağılımı üzerine etkileri istatistiki açıdan anlamsız çıkmıştır.

Bulgular değerlendirildiğinde, resesyon sürecinde gelirdeki düşüşlerin gelir dağılımındaki eşitsizliği derinleştirdiği ve bir tür ıraksamanın gerçekleştiği söylenebilir; ancak, bunun istatistik açıdan anlamsızlığı, söz konusu ıraksamanın oldukça zayıf düzeylerde gerçekleştiğine işaret etmektedir. Dışa açıklığın gelir dağılımında adaletsizliği daraltıcı etkileri görülürken, resesyon kukla değişkeni gibi, bu da anlamsız bulunmuştur. Burada analizlere tabi tutulan onbeş geçiş ekonomisinde kişi başına gelir artışı ile gelir dağılımında eşitsizlikler arasında pozitif eğimli doğrusal yönde ilişkinin mevcudiyeti ve istatistiki açıdan anlamlılığı Kuznets eğrisinin ilk aşamasında bulunulduğuna işaret etmektedir. Diğer bir ifadeyle, geçiş ekonomilerinin kalkınmanın ilk aşamalarında gözlenen gelir dağılımında adaletsizlikte derinleşme ve kişi başına gelir artışları arasında doğrusal ilişkinin bulunduğu süreci yaşadıkları söylenebilir.

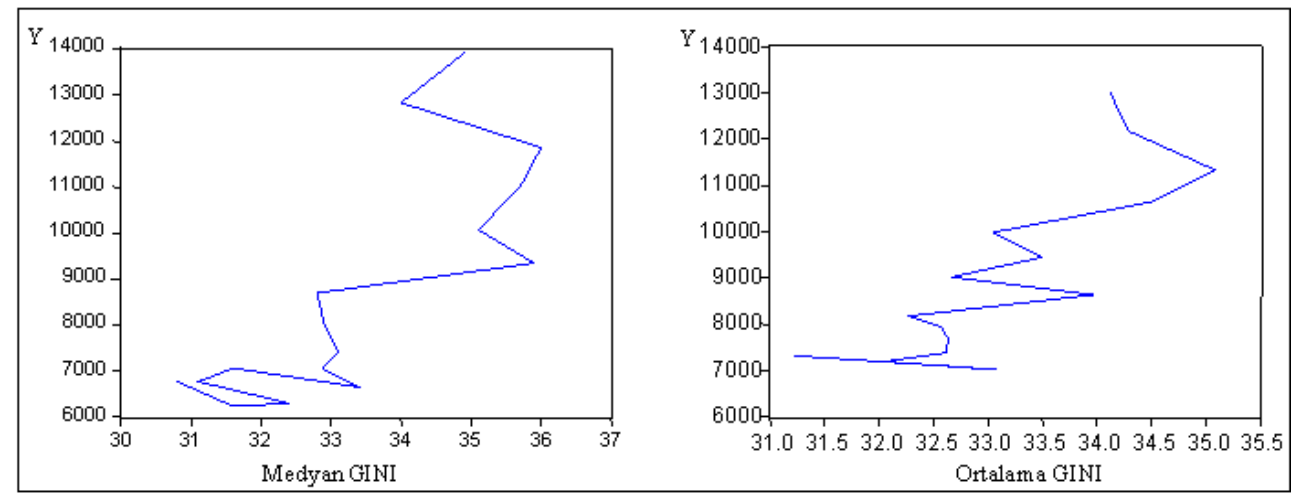

Şekil 2. Geçiş Ekonomilerinde Ortalama ve Medyan Gelir ve Gini Katsayısı

Geçiş ekonomilerinde kişi başına reel GSYİH (2005) değerlerinin ortalama ve medyan Gini katsayılarına göre, değişiminin yönünü ifade eden grafikler ise Şekil 2'de gösterilmiştir. Grafiklerde gelir ile Gini katsayısı arasında ilişkinin yönünün regresyon analizlerini teyit edecek şekilde pozitif yönlü olduğu gözlenmektedir.

\section{Sonuc}

Geçiş ekonomilerinin geçişin başlangıcında sosyalist sistemin yapısı gereği gelir dağılımında göreceli olarak daha az eşitsiz bir yapıda oldukları bilinmektedir. Ancak, bu ülkelerin çoğu, 1991'de siyasal bağımsızlığı kazanmalarına paralel olarak politik açıdan totaliter yapıdan demokratikleşmeye ve iktisadi bakımdan da sosyalist planlamacı yapıdan kapitalist piyasa ekonomisine yönelme içerisinde olmuşlardır. Kapitalist-piyasa ekonomisine geçiş süreci de başlangıç itibariyle ekonomik yapıda belirgin dönüşümleri beraberinde getirirken; üretim bağlarının kopması sonucu ulusal gelirlerde daralmalar, yüksek ve hatta hiper enflasyon süreçleri ve işsizlikte yaygınlaşmalara neden olmuştur ki, bunlar da gelir dağılımında göreceli eşitlikçi yapıyı bozucu unsurların ortaya çıkmasına yol açmıştır. Dolayısıyla, geçiş ekonomileri gelirde büyük çaplı düşüşler ve gelir dağılımında da giderek derinleşen eşitsizlikler tecrübe etmeye başlamışlardır.

Bu çalışmada literatürdeki tanımlamasıyla Kuznets hipotezi olarak bilinen gelir dağılımında eşitsizlik boyutu ile kişi başına gelir arasındaki ilişkiler inceleme konusu yapılmıştır. Kuznets hipotezine göre, kalkınmanın ilk aşamalarında kırsal kesimin ekonomide ağırlığı fazla ve buna karşılık kentsel kesimin payı azdır. Dolayısıyla, 
toplumsal gelir göreceli olarak daha düşük ve gelir dağılımında göreceli olarak eşitlikçi bir yapıyı yansıtacak şekilde Gini katsayısı da düşüktür. Bu durum, bir tür fakirlikte eş dağılıma-paylaşıma işaret eder. Gelir seviyesinde yükselmelerle birlikte, kentsel alanlarda yer alan sanayi sektöründe yatırımlar arttıkça, bu sektörde faaliyette bulunanların geliri kırsal alanda-tarım sektöründe faaliyette bulunanlardan daha fazla gelir elde ederler. Böylece, gelir dağılımında eşitsizlik artar. Bu durum, gelir dağılımında eşitsizlik ile gelir artı̧̧ı arasında pozitif yönlü ilişkinin varlığı olarak tanımlanır ve Kuznets eğrisinin ilk aşamasını oluşturur. Ancak, ekonominin olgunlaşmasıyla birlikte, kırsal sektörün payının azalması ve kentsel sektörünün payının artmasına paralel olarak gelir artarken, gelir dağılımında eşitsizlik de azalmaya başlar. Ortaya çıkan bu yeni durumda gelir artı̧̧ ile gelir dağılımı eşitsizliği arasında negatif yönlü ilişkiler doğurur ve geometrik olarak Kuznets eğrisinin ikinci aşaması teşekkül eder.

Geçiş ekonomilerinden onbeş ülke üzerine gelir eşitsizliği ile kişi başına gelir ilişkilerini ele alan ve 19922007 arası dönemi kapsayan araştırma sonuçlarına göre, geçiş ekonomilerinde gelir eşitsizliği ile kişi başına gelir arasında pozitif eğimli doğrusal ilişkilerin var olduğu tespit edilmiştir. Elde edilen bu sonuç, geçiş ekonomilerinin ekonomik yapı itibariyle Kuznets eğrisinin ilk aşamasında bulundukları söylenebilir. Dolayısıyla, gelir dağılımında eşitsizlik ile büyüme arasında değiş tokuş anlamında, daha çok eşitsizlik pahasına ekonomik büyümenin tercih edildiği bir durum söz konusudur. Şüphesiz böylesi bir tercihte büyümenin sürdürülebilirliğinin yanı sıra, kamunun vergi gelirlerinin artırılması hedefi de bulunmaktadır. Dolayısıyla, tercih edilen yapının ekonominin doğal sürecinde gelir dağılımını düzeltecek bir büyüme, olgunluğuna erişeceğini göstermektedir. Bu nedenle müdahalesiz yapıları içeren politika uygulamalarının sürdürülmekte olduğu dikkati çekmektedir. Ancak, bu durumun sakıncası, özellikle sosyal barışı ve güvenilir çalışma ortamını bozacak yapılanmalara gebe olmasıdır. Politika önlemi olarak özellikle İskandinav tipi müdahale, yani eğitim ve sağlık gibi beşeri altyapı ile fiziki altyapı olanaklarını geliştirici politika uygulamalarının adaletsizliği ve potansiyel sosyal çatışmacılığı telafi edeceği gibi, ekonomiye doğrudan müdahale edilmeksizin büyümenin sürdürülebilirliği söz konusu olabilecektir. Sürdürülebilir büyüme ise kamu gelirlerindeki artışlar ve bahsi geçen altyapı yatırımlarına da kaynak sağlayacaktır.

\section{Kaynakça}

- Adelman, Irma and Sherman Robinson (1988), "Macroeconomic adjustment and income distribution : Alternative models applied to two economies", Journal of Development Economics, vol. 29(1), pages 23-44, July.

- Balassa, Bela (1981), "The newly-industrializing developing countries after the oil crisis", vol. 117, issue 1(March), pp. 142-194.

- Barro, Robert (1991), "Economic Growth in a Cross Section of Countries", Quarterly Journal of Economics, vol. 106, issue 2(May), pp. 407-43.

- Barro, Robert J and Xavier Sala-i-Martin (1997), “Technological Diffusion, Convergence, and Growth”, Journal of Economic Growth, vol. 2, issue 1(March), pp.1-26.

- Barro, Robert J. (2000), "Inequality and Growth in a Panel of Countries", Journal of Economic Growth, 5: $5-32$.

- Brenner, Y. S., Hartmut Kaelble, Mark Thomas (1991), Income distribution in historical perspective, Cambridge University Press.

- Calderón, César and Luis Servén (2004), "The Effects of Infrastructure Development on Growth and Income Distribution", Central Bank of Chile Working Papers, No. 270.

- Cantarero, David, Marta Pascual and Jose María Sarabia (2005), "Effects of Income Inequality on Population Health: New Evidence from the European Community Household Panel", Applied Economics, 37: 87-91.

- Carter, John R. (2006), “An Empirical Note on Economic Freedom and Income Inequality”, Public Choice, 130: $163-177$.

- Feder, Gershon (1983), "On exports and economic growth”, Journal of Development Economics, vol. 12, issue 1-2, pp. 59-73.

- Grün, Carola and Stephan Klasen (2001), "Growth, Income Distribution and Well-being in transition Countries", Economics of Transition, 9(2): 359-394.

- Gyimah-Brempong, Kwabena and Samaria Munoz de Camacho (2006), "Corruption, Growth, and Income Distribution: Are there Regional Differences?", Economics of Governance, 7: 245-269.

- Herzer, Dierk and Sebastian Vollmer (2011), "Inequality and Growth: Evidence from Panel Cointegration", Journal of Economic Inequality, February, 9: 1-15.

- Kuznets, Simon (1956), Modern Economic Growth: Rate, Structure and Spread, New Haven and London: Yale University Press, 1966. xvii + pp 529. 
- Levine, Ross and David Renelt (1992), “A Sensitivity Analysis of Cross-Country Growth Regressions”, American Economic Review, American Economic Association, vol. 82(4), pages 942-63, September.

- Li, Hongyi, Danyang Xie and Heng-fu Zou (2000), “Dynamics of Income Distribution”, Canadian Journal of Economics, 33(4): 937-961.

- $\quad$ Lindert, Peter H. and Jeffrey G. Williamson (1985), "Growth, equality, and history", Explorations in Economic History, vol. 22(4), pages 341-377, October.

- Mikail, E. H.(2008), KGB Albaylığından Devlet Başkanlığına Putin Dönemi Rusya, IQ Kültür Sanat Yayınclilık, İstanbul, 2008.

- Papanek, Gustav F. and Oldrich Kyn (1986), “The effect on income distribution of development, the growth rate and economic strategy", Journal of Development Economics, vol. 23(1), pages 55-65, September.

- Rawls, John (1971), A Theory of Justice, Cambridge, Massachusetts: Belknap Press of Harvard University Press.

- $\quad$ Robinson, Sherman (1976), “A Note on the U Hypothesis Relating Income Inequality and Economic Development”, American Economic Review, vol. 66, no. 3(June), pp. 437-440.

- $\quad$ Ross, Nancy A., Danny Dorling, James R. Dunn, Göran Henriksson, John Glover, John Lynch and Gunilla Ringbäck Weitoft (2005), "Metropolitan Income Inequality and Working-Age Mortality: A Cross-Sectional Analysis Using Comparable Data from Five Countries", Journal of Urban Health: Bulletin of the New York Academy of Medicine, 82(1): 101-110.

- $\quad$ Rosser, J. Barkley, Jr., Marina V. Rosser and Ehsan Ahmed (2000), "Income Inequality and the Informal Economy in Transition Economies”, Journal of Comparative Economics, 28: 156-171.

- Sen, Amartya (1984), Growth Economics, Penguin Books, Baltimore, MD.

- Stiglitz, Joseph E. (1999), "Whither Reform? Ten Years of the Transition”, World Bank Annual Bank Conference on Development Economics, Washington, D.C.

- Summers, Robert and Alan Heston (1991), "The Penn World Table (Mark 5): an expanded set of international comparisons, 1950-1988”, Quarterly Journal of Economics, 106(2), May, 327-68.

- Tan, Hui-Boon and Siong-Hook Law (2011), "Nonlinear Dynamics of the Finance-Inequality nexus in Developing Countries", Journal of Economic Inequality, April, 9: 1-13. 


\title{
Kazakistan'da Yerleşik Türk Firmalarının Yapısı ve Geleceğe İlişkin Öngörü ve Öneriler
}

\author{
Osman Barak (Çankırı Karatekin University, Turkey)
}

\section{Structure of the Turkish Firms in Kazakhstan: Projections and Recommendations}

\begin{abstract}
This work puts forward both the current situation of Turkish enterprises in Kazakhstan according to production, marketing and financial dimensions; presents foresights and projections to future in respect of the structural dimension, and proposes advices to investors in the light of these foresights and projections. This work introduces the situation of Turkish enterprises based in Kazakhstan in the 20th year of independence by making the structural analysis. By looking to the findings (symptoms) of this work, in particular the datum findings of the SWOT analysis, we evaluate the problems of Turkish investors and present some solutions. In this paper benefited from the datum of the Turkish firms working in Kazakhstan.
\end{abstract}

JEL Codes: F21, F23

\section{Giriş}

Dünyada sanayi devrimi ile birlikte üretimin boyutları değişmiş, ticari faaliyetlerin gelişim hızı da artmıştır. Atölyelerden şehirlerdeki fabrikalara, fabrikalardan bölgesel fabrikalara, buradan da ulusal fabrikalara geçilmiştir. Bu gelişme yakın geçmişte de daha değişik boyutlar kazanarak; küçük çaplı ihracat olanakları olan ulusal işletmelerden, tek bir yönetim altında ve çeşitli ülkelerdeki faaliyetleri kapsayan çok uluslu şirketlere, günümüzde de küresel işletmelere kadar uzanmıştır.

Dünyadaki yeni ve hızlı değişim ve gelişmeler işletmeleri uluslararası ve küresel üretim yapmaya yöneltmektedir. Söz konusu gelişmelerin dişında kalan ya da küreselleşme süreci içerisinde yer almayan işletmelerin rekabet etme ve ayakta kalma şansı azalmaktadır. Bu durumu değişime bağlı yeni ticari yapılanmalar ve yeni yatırım alanları, gümrük duvarlarının kalkması, bölgesel birleşmelerin çoğalması, hızlı teknolojik gelişmeler, bazı ürünlerin dünya markası haline gelmesi, işletmelerin ölçek ekonomilerinden yararlanma isteği ve rekabet, stratejik ortaklıklar gibi nedenler desteklemekte ve işletmeleri istemese de çok uluslaşma sürecine sokmaktadır. Dolaysı ile bu ve benzeri gelişmeler, işletmeleri geleneksel büyüme yollarından daha çok diğer işletmelerle çeşitli şekillerde işbirliği yaparak daha etkili faaliyet göstermeye, daha hızlı büyümeye ve çok uluslaşma sürecine bir şekilde girmeye zorlamaktadır.

Dünya ülkeleri karşılaştırıldığında, ülkelerin uzun dönem ekonomik büyüme performanslarında önemli farklılıklar bulunduğu görülmektedir. Uzun dönem büyüme oranları arasındaki farklılıklar ekonomik büyümenin belirleyicileri tarafından açıklanır. Farklı ülkeler veya ülke grupları için ekonomik büyümenin belirleyicileri ve bunların büyümeyi nasıl etkilediklerini ortaya koyan çalışmalarda büyümenin; ekonomik faktörler, demografik faktörler, teknolojik gelişme, doğal kaynaklar, coğrafya ve iklim, siyasi, sosyal ve kültürel faktörler tarafindan açıklanamaya çalışıldığı görülmektedir. Büyümenin bu şekilde ifade edilebilecek olan belirleyicileri birbirilerinden ve daha önceki düzeylerinden bağımsız değildirler. Örneğin herhangi bir ülkedeki siyasi istikrar durumu büyümenin ekonomik belirleyicilerini de etkiler ya da daha önceki yıllarda ülkede sağlanan hızlı teknolojik gelişmeler gelecek teknolojik gelişmeler için zemin hazırlarlar (Ağayev, 2010:162).

Ülkeler belirli bir büyüme hızını yakalamak ya da gerekli gördüğü yatırımları gerçekleştirmek için yeteri düzeyde kaynağa sahip değillerse ya borç kullanırlar ya da yabancı sermayeleri kendilerine davet ederler. Bu da ülkeler arasında sermaye hareketliliğine neden olur.

Yabancı sermaye, dışarda yerleşik durumda bulunan kişi ve kuruluşların ülke içinde mali ya da fiziki yatırım yapmaları ya da ticari faaliyette bulunmaları şeklinde tanımlanabilir. Yabancı sermaye yatırımları bir ülkenin sabit sermaye stokunun artmasına katkıda bulunması, teknoloji ve işletmecilik bilgisi getirmesi, istihdam yaratması, rekabeti geliştirmesi, ödemeler dengesi açığını azaltması, iç piyasaya dinamizm kazandırması, teknik eleman ve yönetici açığını azaltması yönüyle katkıda bulunmaktadır. Söz konusu nedenlerle dünyadaki genel eğilim, yabancı sermaye yatırımlarını teşvik yönündedir (Tandırcıŏlu ve Özen, 2003:105).

Sermaye hareketleri portföy yatırımları ve doğrudan yabancı sermaye yatırımları şeklinde iki guruba ayrılırlar. Portföy yatırımları, herhangi bir yabancı ülkeden borç senedi, tahvil veya hisse senedinin satın alınmasını ifade eder. Doğrudan yabancı sermaye yatırımları ise yabancı ülkelere yeni bir şirketin kurulması, var olan bir şirketin satın alınması veya sermayesinin artırılması anlamına gelir (Ağayev, 2010:163).

Doğrudan yabancı sermaye yatırımları, OECD tarafından bir ülkedeki yerleşik bir birimin, başka bir ülkedeki 
işletmede sürekli bir menfaat ilişkisini elde etmek amacıyla yaptığı yatırım olarak tanımlanmaktadır (OECD, 2003:3). Başka bir ifadeyle, doğrudan yabancı sermaye yatırımları bir ekonomide yerleşik bir birim tarafından başka ülkede yerleşik olan bir teşebbüste kalıcı bir ekonomik bağ oluşturma amacıyla yapılan bir uluslararası yatırım kategorisidir (Delice, 2005:173). Doğrudan yabancı sermaye yatırımları, gelişmekte olan ülkelerin sermaye birikiminden yoksun olmaları nedeniyle büyük önem arz etmektedir. Yeterli sermaye birikimi bulunmadan üretim ilişkilerini konumlandırmak ve işgücünü bu üretim ilişkileri çerçevesinde yönlendirmek mümkün değildir. Bu nedenle doğrudan yabancı sermaye yatırımları, gelişmekte olan ülkeler açısından son derece önemlidir (Bülbül ve Emirmahmutoğlu, 2010:208).

Sermaye sahibi yatırımcının başka ülkelerde yatırım yaparken gözettiği amaç göz önünde bulundurulduğunda uluslararası sermaye yatırımları, doğrudan yabancı sermaye yatırımları ve dolaylı (portföy) yatırımları olmak üzere iki şekilde gerçekleşmektedir (Savaşan, 2006). Her ikisi de sermaye transferi olmakla birlikte doğrudan yabancı sermaye yatırımları sermaye ile birlikte teknoloji, know-how, işletmecilik bilgisinin aktarımını sağlamaktadır (Karluk, 1983:15).

Dünya ekonomisinde önemi gittikçe artan doğrudan yabancı sermaye yatırımları genel olarak, yatırım faaliyetlerini birden fazla ülkede sürdüren ve üretimle ilgili kararları bir merkezden alan veya çeşitli yollarla bağlı şirketlerin kararlarını etkileyen çok uluslu şirketler tarafından yapılmaktadır (Çalışkan, 2003). Çok uluslu şirketleri başka ülkelerde yatırıma yönlendiren temel güdü kâr ve karlılığın devamıdır. Kârın devamlılığını sağlayan en önemli etken ise ekonomik ve siyasi istikrardır (Güçlü, 2003). Yapılacak yatırımın niteliğine göre, ülkenin gelişmişlik seviyesi, piyasa büyüklüğü, dışa açıklık, vergi ve teşvik politikaları da önem taşımaktadır. Bu nedenle, yabancı yatırımları çekmek isteyen gelişmekte olan ülkeler bu konuda daha da özendirici düzenlemeler yapmaya başlamıştır. Bu düzenlemeler piyasaların serbestleşmesi, yatırım indirimi, vergi tatili, bedava arsa tahsisi, vergi indirimi olabileceği gibi tanıtımların yapılması ve hatta teşviklerin verilmesi şeklinde olabilmektedir (Göz, 2009:1).

İşletmelerin küresel değişikliklere ayak uydurabilmesi ve daha da önemlisi kendi yaşamını sürdürebilmesi için dünyadaki yeni gelişmeleri takip etmesi ve çok uluslaşma sürecine bir şekilde girmesi gerekmektedir.

Dünyada çok uluslu işletmeciliğin gelişmesi ve faaliyetlerinin çok büyük boyutlara ulaşması işletmelerin de önemini artırmıştır. Yapılan işletmecilik faaliyetleri ve bunun sonucu oluşan kazançların dünyadaki bazı devletlerin toplam kazançlarına ulaşması ve hatta geçmesi bu önemi daha da artırmıştır. Ayrıca bu gibi gelişmeler ülkelerin pazarlık gücünü yükseltmekte ve diğer ülkeler üzerinde nüfuz sağlamaktadır. Bu bağlamda işletmelerin uluslararası işletmecilik faaliyetleri içinde yer alması ve yurt dışında yatırımlara girmesi büyük önem arz etmektedir.

Çok uluslu işletmeler, iki ya da daha fazla ülkede ticari faaliyette bulunan, tek bir merkezden kontrol edilen, hukuken birbirinden bağımsız, ancak ekonomik olarak birbirine bağlı ortaklıklardan oluşurlar (Aydın, 1997:5). Çok uluslu işletmeler, yatırım faaliyetlerini birden fazla ülkede sürdüren ve çeşitli yollarla, bağlı şirketlerin kararlarını etkileyebilen işletmelerdir (Alpar, 1978:26). Başka bir tanıma göre çok uluslu işletmeler, gittikleri ülkede yabancı sermayeyi düzenleyen mevzuata uygun olarak direkt yatırım şeklinde özel bir yatırımda bulunan, örgüt yapısı, karar alma ve denetim davranışları açısından bir bütünlük gösteren ve uluslararası faaliyetleriyle tanınmış olan firmalardır (Yüksel, 1999:113).

Çok uluslu işletmeler, ülkelere çeşitli stratejiler kullanarak girerler. Bu stratejiler, ihracat, lisans, yetki ve teknoloji anlaşmaları veya ülke dışında üretim, portföy yatırımları, yönetim anlaşmaları, yabancı şube açma, yavru şirket, otak girişim vb. şeklinde sıralayabiliriz.

Türk firmaların çok uluslu işletmecilik faaliyetleri ve bunların gelişimi 1980'li yıllar ve daha çok 1990'lı yıllar ve sonrasında görülmektedir. Bunda da sermayenin yurt dışına ihracına ilişkin çıkarılan kanun ve sağlanan teşviklerin etkili olduğu söylenebilir.

İşletmelerin yurt dışındaki yatırımlarının hangi aşamada ve uluslararası işletmeciliğinde neresinde olduğu, hem devletler açısından hem de bu alanda yatırım yapacak diğer işletmeler açısından önem arz etmektedir. Bu kapsamda Kazakistan'da faaliyet gösteren Türk işletmelerinin Kazakistan yatırımları ile ilgili literatür incelendiğinde, hemen hemen bu konuda bilimsel anlamda bir çalışmanın yapılmamış olduğu ve yapılan çalışmaların da az ve sınırlı düzeyde çalışmalar olduğu görülecektir. $\mathrm{Bu}$ olgu da çalışmanın önemini artırmaktadır.

\section{Kazakistan'da Yerleşik Türk Firmalarının Yapısı ve Geleceğe İlişkin Öngörü ve Öneriler}

\subsection{Araştırmanın Amacı Ve Önemi}

Bu çalışmanın temel amacı, Kazakistan'da yerleşik Türk işletmelerinin, üretim pazarlama ve finansal anlamda geldiği noktayı ortaya koymak, yapısal anlamda değerlendirmelerde bulunmak, geleceğine ilişkin öngörüler yapmak ve bu öngörüler doğrultusunda yatırımcılara önerilerde bulunmaktır.

Türk işletmelerin Kazakistan’daki yatırımlarının hangi aşamada ve uluslararası işletmeciliğinde neresinde 
olduğu, hem makro karar vericiler açısından hem de bu alanda yatırım yapacak diğer işletmeler (mikro karar vericiler) açısından önem arz etmektedir. Ayrıca Türk işletmelerinin Kazakistan yatırımları ile ilgili literatür incelendiğinde, hemen hemen bu konuda bilimsel anlamda bir çalışmanın yapılmamış olduğu ve yapılan çalışmalarında az ve sınırlı düzeyde çalışmalar olduğu görülmektedir. Bu olguda çalışmanın önemini artırmaktadır. Elde edilen sonuçlar Türkiye'nin Kazakistan ekonomik ilişkileri konusunda hem fikir vermesi hem de olası durumlara karşı da önceden önlem alınmasına ve yeni projelerin geliştirilebilmesine de ışık tutacaktır.

\subsection{Araştırmanın Evreni ve Örneklem}

Araştırmanın evrenini Kazakistan'da faaliyet gösteren Türk işletmeleri oluşturmaktadır. Bu kapsamda Kazakistan'da faaliyet gösteren Kazak Türk İş Adamları Derneği'ne (KATIAD) üye işletmeler ve dernek üyesi olmayan (faaliyetlerini herhangi bir dernek üyeliği çatısı altında sürdürmeyen) işletmeler arasından çalışmanın örneklemi belirlenmiştir. Örneklem, belirlemede işletmelerin nitelikleri faaliyet konuları göz önünde bulundurulmuş, farklı sektörlerden işletme yöneticilerinin fikirlerini almak adına basit tesadüfi örneklemeden kaçınılmıştır. Çalışmanın niteliği de göz önünde tutularak olasılığa dayalı olmayan "yargısal örnekleme" ve "kartopu örneklemesi" tekniklerinden faydalanılmıştır. Bu kapsamda öncelikle KATİAD üyesi 150 işletmeye internet yolu ile anket gönderilmiş yeterli sayıda anketin geri dönmeyeceği anlaşılınca, yargısal örnekleme yöntemi kullanılarak faaliyet konuları ve çalışma alanları göz önüne alınarak 100 işletme belirlenmiş ve bu işletmeler adreslerinde ziyaret edilerek işletme yöneticilerine anket uygulanmıştır. Uygulama kapsamında anket uygulamasını kabul eden söz konusu işletmelerden 81 adet işletme yöneticisi ile görüşülmüş ve anket uygulanmıştır. Ayrıca bu görüşmeler esnasında, ilgili işletme yöneticilerinden anket uygulamasına yardımcı olabilecek başka işletme yöneticileri ile iletişim konusunda yardım sorulmuş ve onların tavsiye ve önerilerinden faydalanılarak KATİAD üyesi olmayan işletme yöneticileri ile temas kurulmuş ve bu kapsamda da 35 adet görüşsme yapılmıştır. Elde edilen toplam 116 anket formundan, bazıları eksik ve hatalı doldurmalar nedeniyle değerlendirmeye alınmamış olup, toplam 108 anket formu değerlendirme ve araştırma kapsamına alınmıştır.

\subsection{Verilerin Toplanması}

Çalışmaya ait verilerin toplanmasında, yatırımcılara yönelik 3 aşamalı bir anket formu oluşturulmuştur. Anketin birinci aşamasında işletmeye ilişkin genel bilgiler sorulmuştur. Anketin ikinci kısmında, işletmelerin sermaye yapılarına ilişkin sorulara cevap alınmıştır. Anketin üçüncü kısmında ise yatırımcıların karşılaştıkları sorunlar ve Türk yatırımcıların güçlü ve zayıf yanları ile karşı karşıya kaldıkları firsatlar ve tehditlere ilişkin görüşleri alınmaya çalışılmıştır. Araştırmada anketin birinci ve ikinci aşamasında açık uçlu sorular ve çoktan seçmeli ve/veya sıralamalı sorular kullanılmıştır. Anketin üçüncü aşamasında ise yatırımcıların karşılaştıkları sorunları belirlemek ve SWOT analizinde kullanılmak üzere açık uçlu sorulardan yararlanılmıştır. Açık uçlu soru kullanılmasının en temel nedeni sorunlara ilişkin yatırımcıları yönlendirmeden kaçınmaktır.

\subsection{Verilerin Analizi ve Yorumlanması}

Anket uygulaması gerçekleştirildikten sonra, değerlendirilmeye alınan veriler ankete katılan işletmelerin genel yapısını tespit etmek üzere yüzde ve frekans yöntemi kullanılarak analiz edilmiştir. Araştırmada veriler SPSS 15 paket programı kullanılarak analiz edilerek yorumlanmıştır.

\section{Araştırma İle İlgili Bulgular ve Değerlendirmeler}

\subsection{Kazakistan'da Türk Yatırımlarına İlişkin Genel Bilgiler}

Kazakistan'da Türk yatırımcılarının yatırım faaliyetleri Kazakistan'ın bağımsızlık süreci ile birlikte başlamıştır. Bu bağlamda Kazakistan'da faaliyet gösteren Türk işletmelerinin yaklaşık \%25'inin Bağımsızlığının ilk yıllarında kurulduğunu söyleyebiliriz.

\begin{tabular}{|l|r|r|}
\hline & Frekans & Yüzde \\
\hline 1 Y1l & 6 & 5,56 \\
\hline 2 y1l & 0 & 0,00 \\
\hline $3-5$ yll & 23 & 21,30 \\
\hline 6-10 y1l & 45 & 41,67 \\
\hline 11 y1l ve üzeri & 34 & 31,48 \\
\hline Toplam & $\mathbf{1 0 8}$ & $\mathbf{1 0 0 , 0 0}$ \\
\hline
\end{tabular}

Tablo 1. Kazakistan'daki Türk İşletmelerinin Faaliyet Süreleri

Tablo 1'den de görüleceği üzere Kazakistan'da on yıldan daha fazla sürede faaliyette bulunan yatırımcı işletmelerin oranı \%31,48'dir. Ankete katılan işletmelerin \%41,67'si 6 ila 10 yıl arasında Kazakistan'da yatırım faaliyetinde bulunan işletmelerdir. 3 ila 5 yıl arasında sürede faaliyet gösteren yatırımcı firmaların oranı ise $\% 21,30$ iken sadece $\% 5,56$ oranında yatırıme son bir yıl içinde Kazakistan'da yatırım faaliyetinde bulunan işletmelerdir. 2 yıl süre ile faaliyet gösteren herhangi bir Türk yatırımcısının olmaması da, dönemin Kriz yıllarına karşılık gelmesi anlamında dikkat çekmektedir. 
Tablo 2’de Kazakistan'daki Türk yatırımlarının sermaye büyüklüğü anlamında dağılımı görülmektedir. Araştırmaya katılan firmaların \%43,52'si bir milyon dalar ve altında sermaye ile işletmecilik faaliyetlerini yürütmektedirler. İşletmelerin \%32,41'i 1 ila 5 milyon dolar arasında yatırımı olan işletmelerdir. 5 ila 10 milyon dolar arasında sermaye yatırımı bulunan firmaların oranı \%8,33'dür. 10 milyon ile 50 milyon dolar arasında sermaye yatırımı bulunan işletme sayısı 11 ve bunların toplam içindeki payı da \%10,19'dur. Ankete cevap veren işletmelerin sadece \%5,56'ss 50 milyon dolar ve üzeri sermaye ile Kazakistan'da yerleşik olarak işletmecilik faaliyeti sürdüren Türk yatırımcılardır.

\begin{tabular}{|l|r|r|}
\hline & Frekans & Yüzde \\
\hline 1 milyon \$ ve alt1 & 47 & 43,52 \\
\hline 1 milyon \$ üzeri ile 5 milyon \$ aras1 & 35 & 32,41 \\
\hline 5 milyon \$ üzeri ile 10 milyon \$ aras1 & 9 & 8,33 \\
\hline 10 milyon \$ üzeri ile 20 milyon \$ aras1 & 5 & 4,63 \\
\hline 20 milyon \$ üzeri ile 50 milyon \$ aras1 & 6 & 5,56 \\
\hline 50 milyon \$ ve üzeri & 6 & 5,56 \\
\hline Toplam & $\mathbf{1 0 8}$ & $\mathbf{1 0 0 , 0 0}$ \\
\hline
\end{tabular}

Tablo 2. Kazakistan'daki Türk Yatırımcıların Sermaye Yatırımlarının Dă̆ılımı

Araştırma kapsamında Kazakistan'daki Türk yatırımlarının sektörel dağılımı incelenmiş ve inceleme kapsamında yatırımların, ticaret, imalat ve montaj sanayi, Müteahhitlik hizmetleri (İnşaat) ve turizm alanlarında yoğunlaştığı gözlenmiştir. Bu bağlamda sektörler itibariyle birinci sırada \%24,83 ile Ticaret yer almaktadır. Bunu \% 23,49 ile İmalat ve Montaj sanayi izlemektedir. Müteahhitlik hizmetleri \%16,11, Turizm sektörü \%12,75, Ulaştırma-Dağıtım, Tekstil ve Proje Danışmanlık Hizmetleri \%4,03 ile aynı sırayı paylaşmaktadırlar. Sağlık sektörü toplam Türk yatırımcılar içerisinde oran olarak \%3,36'lık bir paya sahip olsa da işletme büyüklükleri ve faaliyet alanları itibariyle dikkat çekmekte ve diğer işletmelere örnek teşkil edecek niteliktedirler.

\begin{tabular}{|l|r|r|}
\hline & Frekans & \multicolumn{1}{c|}{ Yüzde } \\
\hline Dağıtım birimleri (şirketleri) kurma & 89 & 82,41 \\
\hline Ortak girişim & 15 & 13,89 \\
\hline Kazakistan dışındaki İşletmeye bağlı şubeler & 12 & 11,11 \\
\hline Temsilcilik açma & 9 & 8,33 \\
\hline Lisans Anlaşması & 9 & 8,33 \\
\hline Franchising & 8 & 7,41 \\
\hline Anlaşmalı Üretim & 3 & 2,78 \\
\hline Stratejik Anlaşmalar & 3 & 2,78 \\
\hline Tamamen Entegre edilmiş üretim & 3 & 2,78 \\
\hline Yönetim Anlaşması & 1 & 0,93 \\
\hline Toplam & $\mathbf{1 5 2}$ & $\mathbf{1 4 0 , 7 4}$ \\
\hline
\end{tabular}

Tablo 3. Türk Yatırımcıların Kazakistan'da Uygulamış Oldukları Yatırım Modelleri

Kazakistan'da yerleşik Türk işletmelerinin uluslararasılaşma düzeyini görmek üzere Kazakistan dışında faaliyette bulunduğu ülkeler sorulmuş ve elde edilen veriler Türk işletmelerinin \%62'sinin Kazakistan dişında yatırımı olmadığını ve faaliyet göstermediğini ortaya koymuştur. Başka bir deyişle Kazakistan'daki Türk yatırımcılarının yaklaşık olarak \%38'inin Kazakistan dışında en az bir ülkede işletmecilik faaliyetinde bulunduğu sonucuna ulaşılmıştır. Yine Kazakistan'da yatırımı bulunan Türk yatırımcıların Kazakistan dışında en az iki ülkede yatırım faaliyeti içinde olma oran $1 \% 21$ 'dir. Bu verilerden hareketle Kazakistan'da yatırımı bulunan her 100 yatırımcıdan 21'inin Kazakistan dışında farklı iki ülkede daha yatırımları olduğu sonucuna ulaşılmaktadır. Bu bulgu Türk işletmelerinin uluslararasılaşma sürecinin de neresinde olduğunu göstermesi ve farklı ülkelerde faaliyet göstermenin işletmelerin ülke risklerini azaltması açısından da önemlidir. Ayrıca farklı ülkelerde var olmak ve faaliyetlerini sürdürmek işletme açısından ülke riskinin azaltılması açısından da önem arz etmektedir.

Tablo 3'de Türk yatırımcıların Kazakistan pazarına girişte uyguladıkları yatırım modellerini (stratejilerini) görmekteyiz. Türk işletmelerinin \%82,41'i kendi şirketini kurma ya da dağıtım birimlerini kurma şeklinde örgütlendiği görülmektedir. Yani Türk yatırımcılar Kazakistan'da faaliyetlerini büyük ölçüde kurmuş oldukları şirketler vasıtasıyla yürütmektedirler. Yatırım stratejisi olarak kullanılan ikinci model ise \%13,89 ile Ortak girişim modelidir. Bunu \%11,11 ile Kazakistan dişındaki işletmeye bağlı şubeler izlemektedir. Türk yatırımcılarının yatırımlarında \%8,33 oranında temsilcilik açma ve Lisans anlaşması modeli kullanılmaktadır. Yatırımcılar tarafından Franchising kullanımı ise\%7,41'dir. Araştırmaya 108 firma verisi kullanılmakta birlikte kullanılan modelin 152 olarak çıkması birçok yatırımcının Kazakistan pazarına birden fazla yatırım modeli ile girdiğini göstermesi açısından da önemlidir. Yani bir yatırımcı hem Lisans anlaşması hem Ortak girişim modelini kullanmakta hem de kendi şirketini kurarak faaliyetlerini sürdürmektedir. Bunun en önemli nedeni de bir 
yatırımcının birden çok sektörde faaliyette bulunmasıdır. Söz konusu veriler Türk yatırımcıların uluslararası işletmeciliğin neresinde olduğunu göstermesi bakımından anlamlıdır.

\subsection{Kazakistan'da Türk Sermaye Yatırımları ve Finansmanı}

Kazakistan'da ikamet eden Türk yatırımcıları, Kazakistan pazarında doğrudan sermaye ihracı şeklinde faaliyetlerini sürdürmektedirler. Araştırmaya katılan tüm yatırımcılar, ne Kazakistan'da ne Türkiye'de ne de başka bir ülkede dolaylı yatırım yapmadığını (dolaylı yatırımlarının olmadığını) belirtmişlerdir. Yatırımcıların tamamı "Kazakistan, Türkiye ya da başka ülkelerde işletme olarak dolaylı yatırımlarınız var mı?" sorusuna "Hayır" cevabı vermişlerdir. Tüm yatırımcılar yatırımlarını direk yatırım şeklinde organize etmektedirler.

\begin{tabular}{|l|r|r|}
\hline & Frekans & \multicolumn{1}{c|}{ Yüzde } \\
\hline Nakdi Sermaye transferi & 47 & 43,52 \\
\hline Sermaye Malı Transferi & 4 & 3,70 \\
\hline Nakdi sermaye + Sermaye Mali Transferi & 57 & 52,78 \\
\hline Toplam & $\mathbf{1 0 8}$ & $\mathbf{1 0 0 , 0 0}$ \\
\hline
\end{tabular}

Tablo 4. Yatırımlarda Kullanılan Sermayenin Niteliği

Yatırımcılar “İşletmenizin Kazakistan'da, yaklaşık olarak, sermaye yatırımların oranı nedir?” şeklindeki soruya da "\% 100 direkt yatırım” şeklinde yanıtlamışlardır. Direk yatırımların finansmanında kullanılan sermayenin niteliği ve yüzde dağılımı Tablo 4'de verilmiştir. Buna göre yatırımların finansmanında firmaların $\% 43.52$ nakdi sermaye transferi, \%3,78 sermaye malı transferi ve \%52.78'i de hem nakdi sermaye hem de sermaye malı transferi yoluna gitmişlerdir.

\begin{tabular}{|l|r|r|}
\hline & Frekans & \multicolumn{1}{|c|}{ Yüzde } \\
\hline Tamamen şirket öz kaynaklarından & 84 & 77,78 \\
\hline Öz kaynak + Borç-Banka kredisi ile & 20 & 18,52 \\
\hline Öz kaynak + Teşvik kredilerinden yararlanarak & 0 & 0 \\
\hline Tamamen Banka kredisi ile & 0 & 0 \\
\hline Ev sahibi ülke (Kazakistan) tarafindan sağlanan teşvikler ile & 0 & 0 \\
\hline Öz kaynak + Ev sahibi ülke teşvik kredileri ile & 0 & 0 \\
\hline Öz kaynak + Ev sahibi ülke teşvik kredileri+ Borç-Banka kredisi ile & 4 & 3,70 \\
\hline Toplam & $\mathbf{1 0 8}$ & $\mathbf{1 0 0}$ \\
\hline
\end{tabular}

Tablo 5. Yatırımların Finansmanı

Tablo 5 bulguları Türk yatırımcıların, Kazakistan yatırımlarının finansmanında tek başına banka kredisi ve ev sahibi ülke tarafından sağlanan teşvik kullanmadıklarını göstermektedir. Firmaların \%77,78’i tamamen işletme öz kaynakları ile yatırımlarını finanse etmişlerdir. Öz kaynak + Borç-Banka kredisi ile yatırımlarını finanse eden işletmelerin oranı \%18,52 ve Öz kaynak + Ev sahibi ülke teşvik kredileri + Borç-Banka kredisi ile yatırımlarını finanse eden firmaların oranı ise $\% 3,70$ 'dir.

\subsection{Kazakistan'da Türk Yatırımcılarının Temel Sorunları}

Türk yatırımcılarının karşılaştıkları temel sorunların bir kısmı Kazakistan’ın kendi yapısından kaynaklı sorunlar oluştururken bazılarının da Türkiye kaynaklı sorunlar olduğu görülmektedir. Bu sorunlar genel hatlarıyla, hukuki ve bürokratik yapıdan kaynaklı sorunlar, üretim ve pazarlamada karşılaşılan sorunlar, teknik alt yapı ve hammadde temininde karşılaşılan sorunlar ve yetişmiş insan gücü ve kalifiye eleman kaynaklı sorunlardır. Bu sorunlar önem sırasıyla;

1. Bürokrasi, hukuki alt yapı ve buna bağlı aşırı bürokratik işlemler ve bundan kaynaklı aşırı hantal işlemeyen kurumsal yapı ve farklı yasal uygulamalar,

2. Yetişmiş insan gücü problemi, kaliteli ve kalifiye eleman eksikliği,

3. Hukuki mevzuatın çok karmaşık olması, yapısal problemler, yasal yetersizlikler,

4. Kamudaki yolsuzluk ve rüşvetler, resmi kurumların gayrı resmi baskıları,

5. Elçilik personelinin yeterli derecede ilgi göstermemesi, girişimcileri sahiplenmemesi,

6. Pasaport kayıt işlemleri ve vize konusundaki zorluklar ve farklı uygulamalar,

7. Tahsilat problemleri ve kredili alacakların tahsili sorunu,

8. Yerel bürokrasinin Türk girişimciler tarafından yeterince bilinmemesi ve bundan kaynaklı sorunlar,

9. Altyapı sorunları (enerji kesintisi gibi) ve hammadde temininde karşılaşılan güçlükler,

10. Ara mal ve malzeme alt sanayi eksikliği, yan sanayinin gelişmemiş olması ve buna bağlı yükselen maliyetler,

11. Bakım-onarım servis hizmetlerinin yetersizliği, teknik servis alt yapı eksikliği,

12. Gümrük birliği sonrasında karşılaşılan aşırı gümrük tarifeleri ve buna bağlı ithalat zorlukları,

13. Sigorta ve emeklilik işlemlerine ilişkin ülkeler arasındaki farklı yasal uygulamalar, denklik sorunu ve Kazakistan'da yapılan sigorta ödemelerinin Türkiye'de kullanılamaması 
14. Lojistik problemi,

15. Türk yatırımcılar arasında birlikteliğin kurulamaması ve sorunların çözümüne yönelik ortak çözümlerin ortaya konulamaması ve ortak ticari birliklerin kurulamaması.

Temel sorunlar incelendiğinde, hukuksal sorunlar ve bürokraside yaşanan güçlükler yatırımcılar açısından ciddi bir sorun olarak görülmektedir. Bunun yanında yetişmiş insan gücü, kalifiye eleman sorunu da önemli bir başlık olarak karşımıza çıkmaktadır. Çalışma izinleri lisanslar vb. kısıtlamalar nedeniyle ülke dışından personel temin edemeyen işletmeler, yeni teknolojileri bilen çağın gereklerine uygun personel ihtiyacı ile karşı karşıya gelmekte ve bu da işletmecilik faaliyetlerini olumsuz etkilemektedir. Diğer taraftan yolsuzluk, rüşvet sorunu ve resmi kurumların gayrı resmi uygulamaları en önemli sorunlar arasında yer almakta ve birçok girişimci tarafından çeşitli şekillerde dile getirilmektedir.

\subsection{Kazakistan'da Türk Yatırımcıları ve Yatırımları}

Kazakistan'da Türk yatırımcıları ve yatırımları stratejik yönetim bakış açısı altında incelenmekte ve Kazakistan'daki Türk yatırımlarının ve yatırımcıların bir SWOT analizi yapılmaktadır (Tablo 6). Burada amaç Kazakistan'daki Türk yatırımlarını etkileyen çevresel koşullardaki değişmeleri göz önünde bulunduran ve bu değişimlerin ne gibi firsatlar yarattı̆̆ını ve ne gibi tehlikeleri beraberinde getirdiğini tespite çalışmaktır. Ayrıca Türk yatırımlarının ve yatırımcılarının kuvvetli ve zayıf yönlerini ayrı ayrı değerlemeye tabi tutarak kıt kaynakların ve imkânların etkin kullanımının sağlanması hususunda karar vericilere önerilerde bulunulması hedeflenmektedir.

\begin{tabular}{|c|c|}
\hline $\begin{array}{l}\text { GÜÇLÜ YÖNLER } \\
\text { - Bilgi birikimi tecrübe deneyim, } \\
\text { - Bir önceki iyi iş referanslar, } \\
\text { - Farklılaştırılmış ürünlerle piyasaya girebilme } \\
\text { imkânları, } \\
\text { - Girişimci ruhu ve problem çözme yetisi } \\
\text { - Hizmet farklılığı, } \\
\text { - Pazarı tanıyor olma, } \\
\text { - Politik siyasi kültürel yakınlık, } \\
\text { - Türk malının diğer mallar karşısındaki olumlu } \\
\text { imajı (kalite ve güven), marka tercihi (talep) ve } \\
\text { kalite standardı. }\end{array}$ & $\begin{array}{l}\text { ZAYIF YÖNLER } \\
\text { - Kazakistan hakkında donanımlı bilgi eksikliği, } \\
\text { - Piyasa araştırması güçlüğü, } \\
\text { - Ticari zihniyet farklılığı, } \\
\text { - Ticari problemler kaynaklı itici Kazak Türk } \\
\text { ilişkileri, } \\
\text { - Türklere bakış kötü Türk imajı, } \\
\text { - Yabancı olmak ve yerli firma olmamaktan } \\
\text { kaynaklanan sorunlar, } \\
\text { - Yabancılara yönelik yüksek kira miktarı } \\
\text { uygulamaları, } \\
\text { - Yasal olmayan uygulamalara maruz kalma } \\
\text { derecesi. }\end{array}$ \\
\hline $\begin{array}{l}\text { FIRSATLAR } \\
\text { - Pazarın yapısı, bakir bir pazar olması, } \\
\text { - Asya ülkelerine coğrafi yakınlık, } \\
\text { - Bölge ülkeleri içinde yüksek gelişmişlik oranı, } \\
\text { - Kazakistan'ın bölgede lider ülke konumunda } \\
\text { olması, } \\
\text { - Bağımsızlık sonrası yeniden yapılanma ve buna } \\
\text { bağlı büyük yatırım firsatları, } \\
\text { - Doğal kaynak zenginliği ve işlenmemiş topraklar, } \\
\text { - Kazakistan-Rusya-Belarus arasındaki gümrük } \\
\text { birliği anlaşmasıyla genişleyen büyük pazar } \\
\text { konumu, } \\
\text { - Satışların nakit yoğun yapıılması ve buna bağlı } \\
\text { yüksek nakit girişleri, } \\
\text { - Gelişen bir pazar yapısına sahip olması, buna bağlı } \\
\text { pazar boşluğu ve sektörel açıklar, } \\
\text { - Belirli bölgelerde ucuz işgücü imkânları, } \\
\text { - Rekabetin azlığı, yüksek kar marjları, } \\
\text { - Tarımsal faaliyetlerdeki gelişmeler, } \\
\text { - Yabancı yatırımcıların çeşitli risk olasılıkları } \\
\text { nedeniyle piyasaya girememesi, } \\
\text { - Ülkenin ekonomik olarak gelişme potansiyeli ve } \\
\text { üretim ihtiyacı. }\end{array}$ & $\begin{array}{l}\text { TEHDİTLER } \\
\text { - Altyapı imkânlarının yetersizliği, } \\
\text { - Bürokratik işlem farklılıkları, } \\
\text { - Çin malı ürünlerin pazardaki hâkimiyeti, } \\
\text { - Doğal kaynaklara (Hammadde kaynaklarına) bağlı } \\
\text { bir ekonomi olması, } \\
\text { - Etnik yapıdaki karışıklıklar ve buna bağlı olması } \\
\text { muhtemel riskler, } \\
\text { - Gelişmemiş hukuki yapı, yasal sorunlar ve } \\
\text { demokratik yapının tamamen oturmamış olması, } \\
\text { - Güven sorunu ve buna bağlı risk, } \\
\text { - İllegal baskılar ve yasalardaki zayıflıklar, } \\
\text { - Nitelikli eleman bulma zorlukları ve hizmete } \\
\text { ulaşmada sıkıntılar, } \\
\text { - Pazarın-piyasanın bilinmemesi, } \\
\text { - Pazardaki farklılıkların doğru analizinin } \\
\text { yapılamaması, } \\
\text { - Politik risk tek kişiye bağlı siyaset } \\
\text { - Yönetsel ve hukuki nedenlerden kaynaklı sektörler } \\
\text { içi haksız rekabet uygulamaları, } \\
\text { - Yabancı yatırımcıya olan olumsuz bakış açısı ve } \\
\text { kültürel uyumsuzluklar, } \\
\text { - Yetişmiş insan gücü eksikliği } \\
\text { - Zayıf özel sektör }\end{array}$ \\
\hline
\end{tabular}

Tablo 6. Kazakistan'da Türk Yatırımcıları ve İşletmelerinin Güçlü-Zayıf Yönleriyle Karşı Karşıya Oldukları Firsat ve Tehditler 
Yatırımcılar rekabet avantajı sağlamak veya mevcut avantajı devam ettirebilmek için çeşitli stratejiler geliştirerek uygulayacaklardır. Gerekli ve uygun stratejiyi kararlaştıramayan veya strateji uygulamasında başarısız olan işletmeler çevreleri ile uyumu sağlayamayacaklardır. Bu da işletmelerin rekabet avantajlarını kaybederek faaliyetlerini durdurmalarına yol açacaktır. SWOT analizi özetle dış çevredeki gelişmelerin firsat ve tehlike olarak nitelendirilmesi ile iç bünyedeki zayıf ve kuvvetli yönlerin tespitine ağırlık vermektedir (Koçel, 1999:274).

\section{Sonuç}

Kazakistan'da yerleşik Türk işletmelerinin, üretim pazarlama ve finansal anlam da geldiği nokta analiz edilmiş, Türk işletmelerinin ve yatırımcılarının karşı karşıya olduğu sorunlar ortaya konularak, Türk yatırımcılarının ve yatırımlarının SWOT analizi yapılmışır.

Araştırma kapsamında Kazakistan'daki Türk yatırımları değerlendirildiğinde, sektörel bazda Ticaret, imalat sanayi, müteahhitlik hizmetleri, turizm alanlarında yoğunlaşmakta, Proje ve Danışmanlık hizmetleri, ulaştırmadağıtım, tekstil, sağlık bankacılık alanlarında yatırımları olduğu görülmektedir.

Sektörler itibariyle Türk yatırımcılarının dağlımı incelendiğinde, 2 husus dikkati çekmektedir. Birincisi Türkiye'nin ve Türk yatırımcıların temel yetkinliği olan Tekstil sektöründe Kazakistan'da istenilen noktaya ulaşılamamış olmasıdır. Kazakistan'da Türk mallarına olan güven de göz önünde bulundurulduğunda Türk yatırımcıların bu sektördeki yatıımlarının azlığı dikkate değerdir. İkinci husus ise, Kazakistan Enerji ve maden kaynakları açısından Dünyanın önde gelen sayılı ülkeleri arasında olmasına karşın, Türk yatırımcıların bu alandaki yatırımlarının çok cüzi miktarda olması dikkat çekmektedir.

Kazakistan'daki Türk yatıımlarını gelmiş oldukları dönemler itibariyle ve yatırımcıların nitelikleri itibariyle sınıflandırdığımızda, üç tür yatırımcı tipi ile karşılaşmaktayız. Birinci tip yatırımcı, Kazakistan'ın bağımsızlığının ilk yıllarında gelip küçük çaplı yatırımlarla faaliyete başlayan ve buradan elde ettiği karı tekrar yatırıma dönüştürerek belli bir ölçeğe ulaşan işletmelerdir. Başarısız olanlar zaman süreci içinde ayıklandığı için geriye kalan, işletmeler etkin bir şekilde varlığını sürdürmektedirler. İkinci tip yatırımcı, birinci tip yatırımcıların başarılarını görerek gelen ya da Türkiye de değişik nedenlerle iş yapamamış ve buraya çeşitli şekillerde gelerek yatırım faaliyetinde bulunan yatıımcılardır. Bu yatırımcıların her birinin kendine özgü başarı öyküleri vardır. $\mathrm{Bu}$ öyküler dinlendiğinde aynı amaçlarla gelen birçok insandan çok azının başarılı olduğu birçoğunun da zarar ederek Türkiye'ye döndüğü anlaşılmaktadır. Üçüncü tip yatırımcı ise, Türkiye'den gelmeden önce araştırmalar yapıp projeler geliştirip ve kendine burada ya stratejik ortak bulup ya da ciddi danışmanlık hizmeti alarak yatırımlara girişen yatırımcılardır. Bu tip yatırımcılar Kazakistan'ın bağımsızlığın ilk günlerinden itibaren var olmakla birlikte son 7-8 yıl içinde yoğunlaşmaktadır. Bu yatırımcılar yatırımlarını profesyonel olarak planlamakta projelendirmekte ve bu projeler dâhilinde yürütmektedirler. Söz konusu yatırımcıların piyasaya gelmesi ikinci tip yatırımcıların da azalmasına neden olmaktadır.

Sermaye yapısına ilişkin bulgular Kazakistan'da Türk yatırımcılarının dolaylı yatıımlarının olmadığını ve $\% 100$ direk yatırım şeklinde pazarda faaliyet gösterdiklerini ortaya koymaktadır. Bunun en büyük nedeni Kazakistan sermaye piyasasının henüz çağdaş dünya normlarına ulaşmamış olmasıdır. Kuralları tam olarak oturmamış sığ bir sermaye piyasasının yabancı sermayeyi çekme imkânının olmadığı da açıkça görülmektedir.

Kazakistan'da ikamet eden Türk yatırımcıların sorunları incelendiğinde, hukuksal sorunlar ve bürokratik engeller ya da bürokraside yaşanan güçlükler yatırımcılar açısından ciddi bir sorun olarak karşımıza çıkmaktadır.. Bunun yanında Türk yatırımcıların karşı karşıya kaldıkları en önemli sorunlardan birisi de yetişmiş insan gücü, kalifiye eleman sorunudur. Çalışma izinleri lisanslar vb. kısıtlamalar nedeniyle ülke dışından personel temin edemeyen işletmeler, yeni teknolojileri bilen çağın gereklerine uygun personel ihtiyacı ile karşı karşıya gelmekte ve bu da işletmecilik faaliyetlerini olumsuz etkilemektedir. Biran önce çağdaş norm ve gereklere uygun eğitimli insan gücü alt yapısının oluşturulmasına yönelik çalışmaların ivedi olarak başlatılması da bir zorunluluktur. Diğer taraftan yolsuzluk, rüşvet sorunu ve resmi kurumların gayrı resmi uygulamaları en önemli sorunlar arasında yer almakta ve birçok girişimci tarafından çeşitli şekillerde dile getirilmektedir. Bağımsızlığının 20. Yılında Dünya ile bütünleşme hedefi içerisinde olan Kazakistan'ın biran önce hukuki ve bürokratik açıdan yapısal reformlara gitmesi bir zorunluluk olarak görülmektedir

Kazakistan'da ikamet eden Türk yatırımcıların birçoğu Elçilik çalışanlarından yakınmakta ve kendilerini sahipsiz ve yalnız hissetmektedirler. Türk iş adamları pasaport işlemleri (kayıt vb.) vize uygulamaları konusunda farklı ülke vatandaşlarına, farklı uygulamalar olduğunu belirtmektedirler. Örneğin ikamet izni olan ve Kazakistan dışına çıkıp tekrar gelen Türk vatandaşlarının 5 gün içinde ikamet ettiği yerdeki yabancılar polisine başvurarak kayıt yaptırması zorunlu iken bazı ülke vatandaşlarına bu uygulama zorunluluktan çıkarılmış durumdadır. Yatıımcıların birçoğu yerel bürokrasiye ilişkin yeterli bilgi sahibi değildir. Elçilik çalışanlarının belirli dönemler itibariyle Türk yatırımcılarına bilgilendirme amaçlı toplantılar yapması ve girişimcileri aydınlatması önem arz etmektedir. Ayrıca sigorta ve emeklilik işlemlerine yönelik çalışmaların başlatılması ve denklik sorunun çözülmesine ilişkin girişimlerde bulunulması da bir zorunluluktur. Bu husus (emekliliksigortalılık durumu) Türk girişimcilerin motivasyonunu ve yatırımlarını olumsuz etkilemektedir. Almatı dışında 
Türk iş adamları arasında iletişim ve dayanışmayı örgütleyecek sivil toplum kuruluşlarının oluşturulması konusunda Elçilik çalışanların öncülük etmesi gerekmektedir. Almatı'da Kazak Türk İş Adamları Derneği (KATİD) adı altında bir sivil toplum kuruluşu bulunmakta ve özellikle Almatı'da faaliyet gösteren Türk girişimcilerin bir araya gelmesi yeni gelişmeler konusunda bilgilendirilmesi ve Türk işletmeleri arasında yardımlaşma ve dayanışmanın sağlanması hususunda büyük hizmet icra etmektedirler. KATİAD benzeri derneklerin yöresel bazda kurulması Türk yatırımlarının gelişmesi açısından büyük önem arz etmektedir.

\section{Kaynakça}

- Ağayev, 2010. "Doğrudan Yabancı Sermaye Yatırımları ve Ekonomik Büyüme İlişkisi: Geçiş Ekonomileri Örneğinde Panel Eştümleşme ve Panel Nedensellik Analizleri”, Gazi Üniversitesi İktisadi ve İdari Bilimler Fakültesi Dergisi 12/1 s:159-184.

- Alpar, 1978. Çok Uluslu Şirketler ve Ekonomik Kalkınma, (Ankara İktisadi ve Ticari İlimler Akademisi Yayınları), Ankara.

- Aydın, 1997. Uluslar arası Doğrudan Yatırımlar ve Ortak Girişimler, (Eskişehir: Anadolu Üniversitesi Yayınlar1).

- Bülbül ve Emirmahmutoğlu, 2010, "Doğrudan Yabancı Sermaye Yatırımlarının İstihdam Etkisi: Türk Bankacılık Sektörü Örneği”, Gazi Üniversitesi İktisadi ve İdari Bilimler Fakültesi Dergisi 12/1 s:205-238.

- Çalışkan, 2003. "Dünya Yatırım Raporu-2002 Çerçevesinde Doğrudan Yabancı Yatırımlar Üzerine Değerlendirmeler”, Dış Ticaret Dergisi, S.27, Ocak.

- Delice, 2005. "Doğrudan Yabancı Yatırım İstatistiklerinde Kullanılan Verilerin Kalitesi ve Güvenilirliği”, Cumhuriyet Üniversitesi İktisadi ve İdari Bilimler Dergisi, C.6. S.2.ss.171-198.

- Göz, 2009. "Doğrudan Yabancı Sermaye Yatırımları ve Türkiye”, Çukurova Üniversitesi Sosyal Bilimler Enstitüsü, Yayınlanmamış Yüksek Lisans Tezi, Adana.

- Güçlü, 2003. "Yabancı Sermaye Çekimi, Yatırımların Karşılıklı Teşviki ve Korunması Anlaşmaları", Uluslararası Ekonomik Sorunlar Dergisi, S.8

- Karluk, 1983. Türkiye’de Yabancı Sermaye Yatırımları, ITO Ekonomik Yayınlar Dizisi, Yayın No: 13, İstanbul.

- Koçel, 1999. İşletme Yöneticiliği, 7. Baskı, Beta Yayınları, İstanbul.

- OECD, 2003. Foreign Direct Investment Statistics How Countries Measure FDI 2001, International Monetary Fund. www.oecd.org, (02.07.2011).

- Savaşan, 2006. "Vergisel Teşviklerin Yabancı Doğrudan Yatırımlar Üzerindeki Etkisi”, Mevzuat Dergisi, S.107.

- Tandırcıŏlu ve Özen, 2003, “Geçiş Ekonomilerinde Doğrudan Yabancı Sermaye Yatırımları”, Dokuz Eylül Üniversitesi Sosyal Bilimler Enstitüsü Dergisi, Cilt 5, Sayı 4, 105-129.

- Yüksel,1999. Uluslararası İşletme Yönetimi ve Türkiye Uygulamaları, Gazi Kitapevi, Ankara. 


\title{
Türkiye'de Mortgage Sistemi ve Ekonomik Kriz Açısından Değerlendirilmesi
}

\author{
Mustafa Topaloğlu (Beykent University, Turkey)
}

\section{An Evaluation of Turkish Mortgage System from the Perspective of Global Economic Crisis}

\begin{abstract}
Turkish mortgage system was established by the law number 5582 and the title of "The Law Amending the Laws Related to Housing Finance System" in 2007. Even though the entry into force of this act expressed as "Pay the rent as the landlord-performing", no bring up short of the interest rates of a housing loan were observed. In fact, Mortgage application could not be branch out yet. The distinguishing feature of the mortgage system, mortgage collateral pools of consumer loans with guaranteed by mortgage backed securities to be issued, sold in the capital market, also called the mortgage money is the safeguard of cheap funds. Using this fund for financing provided by banks as a result of re-housing resource for the consumer to pay the cost of housing loan interest rate is relatively go into a decline.

Meanwhile, after the abundance of finance in the world, the so-called subprime mortgage, loans to nonqualified borrower, triggered the world economic crisis occurred. May well be, Turkey was unimpressed the crisis because of the not being set secondary mortgage market. All the public in charge of economy has introduced prevention of packages of measures.
\end{abstract}

JEL Code: K22

\section{Genel Olarak Konut Finansman Sistemi}

Konut problemi, insanoğlunun uygarlığın başlangıcından beri en büyük sorunlarından birisi olmuştur. Bu sorunun çözümünde tasarruf sahipleri ile konut alıcıları arasında köprü oluşturarak daha uygun şartlarda kredi teminini sağlayacak finansman sisteminin önemli bir rolünün bulunduğu şüphesizdir. Konut finansman sistemi, bu temel fonksiyonunun yanı sıra, finansal piyasaların gelişmesini ve inşaat sektörünün canlanmasını sağlamak suretiyle, ekonomik kalkınmaya katkıda bulunacaktır.

Dünyada en gelişmiş ve köklü konut finansman sistemi ABD mortgage uygulamasıdır. Taşınmaz teminatı karşılığı kredi sistemi olan mortgage, ortaçağda İngiltere'de gelişerek daha sonra ABD hukukuna aktarılmıştır.

ABD'de 1930'lu yıllarda yaşanan büyük ekonomik depresyondan sonra devletin mortgage kredilerini kurmuş olduğu kamu kurumları aracılığıyla sigorta ederek garanti vermesi, hem konut sektörünün patlama yapmasını hem de uluslararası düzeyde taşınmaza dayalı sermaye piyasasının oluşmasını sağlamıştır.

\section{Mortgage Kavramı ve ABD'de Gelişimi}

Mortgage faizin yasak olduğu Ortaçağ İngiltere'sinde ortaya çıkmış bir teminat şeklidir. Alacaklı faiz alamadığı için verdiği borç karşılığında borçluya ait gayrimenkulün zilyetliğini devralmakta, alacağın vadesi geldiğinde gayrimenkulden elde ettiği kira ve diğer gelirleri borçtan düşmemektedir ( Hazeltine, 1993-1994; Nelson ve Whitman, 2001). Borçlu açısından rehin süresince tasarrufundan çıkmış olan gayrimenkul, ölü bir yatırım gibidir. Söz konusu teminat şekline ölü rehin anlamına gelen mort - gage denilmiştir (Werner, 2002; Karp ve Klayman,2003).

Mortgage uygulaması Kıta Avrupası hukuk sistemlerindeki ipoteğe dayalı kredi ilişkisini tam olarak karşılamamaktadır. Teminat olarak verilen gayrimenkulün mülkiyeti, mortgage kurulurken ya alacaklıya yada trustee denilen yediemine devredilmektedir. Yalnız bu devir şarta bağlı bir devir olup, borcun tamamı ödendiğinde mülkiyet tekrar borçluya dönmektedir. Bazı eyaletlerde (Title States) alacaklının mortgage ile yüklü gayrimenkulün zilyetliğini sözleşmenin kurulması ile birlikte devralma hakkı mevcut olsa da, alacaklılar temerrüt gerçekleşinceye kadar bu haklarını kullanmamaktadırlar(Sturges ve Clark, 1928; Moringiello, 1996; Küçük, 2007).

ABD hukukunda da sözleşme kurulurken alacaklının borç ödenmezse rehinli gayrimenkulün tam maliki (absolute title) olacağı yönündeki şartlar (lex commissoria) geçersiz sayılmaktadır ( Rubin ve Strohchein, 19931994; McNaB, 2000). Alacaklı borcun muaccel olması halinde mortgage ile yüklü gayrimenkulün paraya çevrilmesi (foreclosure) sürecini başlatmak zorundadır (Werner, 2002). Sözleşme kurulurken alacaklıya gayrimenkulü satış yetkisi (power of sale) verilmişse, alacaklı bu yetkisini kullanarak açık artırma ile satı̧̧ı gerçekleştirmektedir (Kratovil, 1979-1980). Ancak mahkemeler bu tür satışlardaki en ufak bir eksikliği dahi iptal sebebi saymaktadırlar (Nelson, ${ }^{1988}$ ). Bu yüzden diğer satış türü olan yargısal paraya çevirme (judical 
foreclosure) usulü daha yaygın olarak kullanılmaktadır (Wright, 2005; Pence, 2003).

ABD'de mortgage'in üçüncü kişilere devri mümkündür. Devir işlemi kıymetli evraklarda olduğu gibi teslim yada ciro yoluyla gerçekleşmektedir. Düzenli mortgage'de ciro veya temlik beyanından başka ayrıca resmi sicile tescil de gereklidir (Grimes, 1954). Bu tür mortgage finans piyasasında çok sık devir gördüğü için, tescil işlemi oldukça güçlük yaratmaktadır. Bu olumsuzluğu ortadan kaldırmak için resmi niteliği bulunmayan Mortgage Elektronik Tescil Sistemi (Mortgage Electronic Registration System - MERS) oluşturulmuştur.

Mortgage ile teminat altına alınmış alacaklar, menkul kıymetleştirilerek (mortgage based securities) ikincil piyasaya ihraç edilmektedir. Bunun için ilk önce çeşitli mortgage kredileri bir araya getirilerek bir havuz (pool) oluşturulmaktadır. Bu havuzda yer alan mortgage kredilerini temsil eden sertifikalar ikincil piyasada yatırımcıya satılmaktadır (Bradner, 1987). Yatırımcılar yalnızca satın aldıkları bu sertifika karşılığı havuzda yer alan kredilerin getirisinden pay alırlar. Buna karşılık, havuzun hiçbir maliyet unsuruna katılmadıkları gibi, hakları tek bir veya bir kaç mortgage kredisiyle sınırlandırılamaz. Alacaklı bu şekilde oluşturduğu mortgage havuzundan tekrar konut finansmanında kullanmak üzere likidite elde etmektedir (Werner, 2002).

\section{Türk Mortgage (Mortgage) Kanunu}

Türk kamuoyunda "mortgage" yada "tutsat" yasası olarak bilinen yasa tasarıs1 21.02.2007 tarih ve 5582 say1l Konut Finansmanı Sisteminde Değişiklik Yapılması Hakkında Kanunla kabul edilerek yasalaşmıştır. 5582 sayılı Kanun, 06.03.2007 tarih ve 26454 sayılı Resmi Gazete'de yayımlanarak bu konuda ümitlerin kesildiği bir anda yürürlüğe girmiştir.

Söz konusu düzenleme, mortgage veya ipotekli konut finansmanı kanunu denilebilecek ayrı ve bağımsız bir kanun öngörülmemektedir. Bunun yerine başta Sermaye Piyasası Kanunu olmak üzere, İcra ve İflas Kanunu, Finansal Kiralama Kanunu, Tüketicinin Korunması Hakkında Kanun ve çeşitli vergi kanunlarına eklemeler yapılarak bir model oluşturulmaya çalışılmıştır.

Esas olarak söz konusu Kanunla yatırımcılar ile tüketiciler arasında kurumsal bir bağ kurulmak suretiyle daha uygun şartlarda konut kredisi sağlanması amaçlanmıştır. Ayrıca, belirli bir büyüklüğe ulaşmış birincil konut kredisi piyasasının gelişmesine destek olacak ikincil piyasanın kurum, kural ve finansal araçlarıyla oluşturulması da kanunun amaçları arasındadır (Yalçıner, 2006).

\subsection{Türk Mortgage Kanununun Uygulama Alanı}

5582 Sayılı Mortgage Kanunu, "konut finansmanı" işlemlerine uygulanır. Esas itibariyle tüketicilere konut edinmeleri amacıyla kredi kullandırılması konut finansmanıdır. Konut edinme dışında başka bir parasal ihtiyacını karşılamak amaciyla tüketicinin önceden var olan konutunu ipotek etmek suretiyle tüketici kredisi alması, konut finansmanı sayılmaktadır. Konutların finansal kiralama yoluyla kiralanması da konut finansmanı sayılan diğer bir iştir. Kanunda yukarıda belirtilen her üç tip kredinin yeniden finansmanı (refinancing) amacıyla kredi kullandırılması da konut finansmanı olarak kabul edilmiştir.

Mortgage Kanunun yürürlüğe girdiği tarih olan 06.03.2007 tarihinden evvel düzenlenmiş bulunan ipotekli konut finansmanı tanımına uygun kredi ve finansal kiralama sözleşmelerinin tarafı olan tüketiciler, 06.06.2007 tarihine kadar sözleşme yaptıkları finansman kuruluşuna başvurarak söz konusu işlemin konut finansmanı işlemi kapsamı dışında bırakılması talebinde bulunabilirler. Bu süre içinde talepte bulunmayan tüketicilerin Kanun'un yürürlük tarihinden önce düzenlenmiş bulunan söz konusu işlemleri, "konut finansman işlemi” sayılır ve Kanun kapsamına dahil olur. Kanun bu suretle, önceki ipotekli konut kredisi işlemlerinin kendiliğinden ipotekli konut finansmanı işlemi sayılacağını kabul etmiş ve bunu istemeyen tüketicilere de yayım tarihinden itibaren üç ay içinde başvurarak konut finansmanı kapsamından çıkma seçeneği (opt-out) tanımıştır.

Ancak Geçici 11.maddeyle söz konusu seçenekten faydalanmayarak ipotekli konut finansmanı sistemine dahil olmuş önceki tarihli sözleşmelerin tarafı olan tüketicilere erken ödeme ile ilgili olarak önceki Tüketicinin Korunması Kanun'un 10.maddesindeki hakları kazanılmış hak olarak korunmuştur. Buna göre, söz konusu tüketiciler, toplum borcu bir defasında veya taksitleri vadesinden önce öderlerse, ilgili konut finansman kuruluşu faiz ve komisyon indirimi yapmak zorundadır. Doğal olarak bu durumda konut finansman sistemi ile getirilmiş olan “erken ödeme cezası”nın uygulanması söz konusu olamaz.

\subsection{Mortgage Kanununda Taraflar}

Konut finansman sistemi başlangıçta bir kredi işlemi olması itibariyle sözleşmenin tarafı olan ipotekli finans kurumları ile kredi kullanan tüketici arasında gerçekleşmektedir. İpotekli konut finansman sözleşmesinin kurulmasından sonra menkul kıymetleştirme aşamasında ipotek finansman kuruluşu ve yatırımcılar söz konusu olmaktadir.

5582 sayılı Mortgage Kanun'un 12.maddesine göre “konut finansmanı kuruluşları”, konut finansmanı amacıyla doğrudan tüketiciye kredi kullandıran ya da finansal kiralama yapan bankalar ile Bankacılık Düzenleme ve Denetleme Kurumu (BDDK) tarafından konut finansmanı faaliyetinde bulunması uygun görülen finansal kiralama şirketleri ile finansman şirketleridir. 
Ayrıca Kanunun 14.maddesiyle, münhasıran konut finansmanından kaynaklanan alacakların devralınması, devredilmesi, devralınan alacaklardan oluşan varlıkların yönetimi amacıyla "ipotek finansman kuruluşları" adı altında yeni bir kurum ihdas edilmiştir. İpotek finansmanı kuruluşları esas olarak konut finansmanı kuruluşlarına kredi sağlamak için düşünülmüştür. Bu nedenle söz konusu kuruluşlar, konut finansmanı kuruluşlarından farklı olarak tüketiciye doğrudan kredi vermeyeceklerdir (Lea, 2006).

İpotekli konut finansmanı, tüketici hukuku dizgisine bağlanarak çözülmek istenmiştir. Böylece Tüketicinin Korunması Hakkında Kanun'a göre tüketici sayılanlar bu sistemden faydalanabileceklerdir. Ayrıca henüz ferdi mülkiyete geçmeden kooperatif üyeliği sıfatına sahip gerçek kişiler de tüketici sayılarak doğrudan yada kooperatif dolayısıyla Mortgage sisteminden faydalanmaları sağlanmak istenmiştir (m.24).

\subsection{Konut Finansmanı İşımemine Konu Olması Bakımından İpotek}

Konut finansman sistemi esas itibariyle ABD'de Mortgage kavramına dayalı olarak gelişmiştir. Mortgage (Mortgage) kavramı, Türk Hukukundaki ipotek kavramını tam olarak karşılamamaktadır. ABD'de taşınmazın doğrudan borcun teminatı olarak gösterilmesinin yanında inançlı temlik işlemleri Mortgage sayıldığı gibi, bazen de taşınmazın teminatına ilişkin bir ibarenin yer aldığı bono (promissory note) düzenlenmesi dahi Mortgage kapsamında değerlendirilmektedir.

5582 sayılı Kanunda sadece teminat olarak ipoteğin gösterildiği kredilerden bahsedilmiş ve bunun dişında ipotekle ilgili herhangi bir hüküm getirilmemiştir. Bu durumda konut finansman işlemine konu olacak ipotekler, 4721 sayılı Medeni Kanun hükümlerine tabi olacaktır. Bu sistem kapsamında ipotek tesis etmek isteyen taraflar, mutlaka anapara ipoteği ve üst sınır ipoteği tipinden birini seçmek zorundadır (Önal ve Topaloğlu, 2007).

\section{4 İpotekli Konut Finansmanı Sözleşmesi}

Mortgage Kanunuyla Tüketicinin Korunması Hakkında Kanun'un 10. maddesine 10/B maddesi olarak "Konut Finansmanı Sözleşmeleri” başlıklı uzun bir madde eklenmiştir. Kanun yapma tekniğine uymayan bu madde ile konut finansmanı sözleşmesinin zorunlu içeriğinden faiz oranlarına, erken ödemeden temerrüde, kıymet takdirinden satış ve tahliyeye kadar ayrı bir kanun konusu olabilecek bütün bu hususlar bir madde ile düzenlenmiştir.

Konut finansmanı kuruluşları, işlemlere başlamadan önce tüketiciye kredi ile ilgili bilgileri içeren Sözleşme Öncesi Bilgi Formu vermek zorundadırlar. Tüketicinin kendisini uzun süre bağlayacak hukuki ilişkiyi yeterince değerlendirmesini sağlamak için söz konusu Formun alınmasından itibaren bir iş günü geçmeden konut finansmanı sözleşmesi akdedilmesi yasaklanmıştır.

\subsection{1. Ípotekli Konut Finansman Sözleşmesi’nde Faiz ve Erken Ödeme}

Yazılı olarak yapılması zorunlu olan konut finansmanı sözleşmesinde yer alan şartlar tüketici aleyhine değiştirilemez. Bu sözleşmelerde faiz oranı, sabit değişken veya aynı kredi için her iki yöntem esas alınmak suretiyle belirlenebilir. Oranın sabit olarak belirlenmesi halinde başlangıçta belirlenen oran, ancak her iki tarafın ortak rızası olmadan değiştirilmesi mümkün değildir.

Oranın değişken olarak belirlenmesi halinde ise, başlangıçta belirlenen oran, sözleşmede belirlenen yurtiçinde veya yurtdışında genel kabul gören bir endeks baz alınarak değiştirilebilir. Ancak değiştirilen faizin uygulanmasıyla oluşan yeni geri ödeme tutarı, başlangıçta sözleşmede belirlenen azami geri ödeme tutarını geçemez. Bu suretle uzun süreli bir riske giren konut finansmanı kuruluşu, değişen ekonomik şartlara sözleşmeyi uyarlama imkanına sahip olmaktadır. Geri ödeme tutarının belirli bir haddi geçemeyeceği öngörülmek suretiyle de, faiz uyarlaması sonucu tüketicinin ödeyemeyeceği bir taksit tablosu ile karşı karşıya kalması önlenmiş olmaktadır. Ayrıca, değişken faiz uygulamasında faiz oranı, sabit faize göre daha düşük olacağından aslında bu uygulama tüketicinin daha yararınadır (Alp, 1996).

Tüketici, konut finansmanı kuruluşuna borçlandığı toplam miktarı önceden ödeyebileceği gibi aynı zamanda bir yada birden fazla ödemeyi vadesinden önce yapabilir. Her iki durumda da konut finansman kuruluşu, vadesinden önce ödenen taksitler için gerekli faiz indirimini yapmak zorundadır. Ancak erken ödeme, kredi veren finansman kuruluşu açısından bir risk oluşturur (prepayment risk). Bu nedenle 5582 sayılı Kanunda, faiz oranının sabit olarak belirlendiği durumlarda, finansman kuruluşuna erken ödenen tutarın yüzde ikisini geçmemek üzere erken ödeme ücreti (aslında ceza) talep etme hakkı tanınmıştır (Topaloğlu, 2009).

\subsubsection{Ipotekli Konut Kredisi Kullanan Tüketicinin Temerrüdü}

Söz konusu Kanun, ipotekli konut finansman kredilerinde temerrüt konusunu tüketici kredilerine benzer şekilde düzenlemiştir. Buna göre, konut finansmanı kuruluşu, borcunu ödemede temerrüde düşen tüketiciye temerrüt tarihinden itibaren beş işgünü içerisinde iadeli taahhütlü posta yoluyla bildirimde bulunmakla yükümlüdür.

5582 sayılı Kanun yine tüketici kredilerinde olduğu gibi konut finansmanı sözleşmesine muacceliyet şartı konulmasına izin vermektedir. Konut finansman kuruluşu, sözleşmede kararlaştırılmak şartıyla, tüketicinin birbirini izleyen iki taksiti ödemede temerrüde düşmesi halinde kalan borcun (outstanding debt) tamamını talep edebilir. Ancak konut finansman kuruluşunun bu hakkını kullanabilmesi için en az bir ay süre vererek 
muacceliyet uyarısında bulunması şarttır. ABD'de temerrüde düşen borçluya en az beş hafta ödeme süresi tanınmaktadır. Tüketici kredileri için bir hafta olan ödeme süresinin konut finansmanı kredileri için bir aya çıkarılması yerinde olmuştur. Zira konjüktürel sebeplerle gelirlerinde azalma olan tüketicilere muhtemelen üç ay daha ödeme süresi tanınmıştır. Ayrıca bu değerlendirmede, konut finansmanında tüketicilerden sağlanacak geri ödemelerin, ikincil piyasada işlem gören ipoteğe dayalı menkul kıymetlerin teminatını teşkil ettiği de göz önünde tutulmalidir.

Konut finansman kuruluşu, muacceliyet uyarısına rağmen verilen süre içersinde ödeme yapılmaz ise, geri kalan borcu tahsil etmek istiyorsa sözleşmeyi feshetmelidir. Geri kalan tüm bakiyenin tahsili amacıyla sözleşmenin feshi halinde de, ipotekli konutun derhal satışa çıkarılması gerekir.

\subsection{Konut Finansmanından Kaynaklanan Alacakların Menkul Kıymetleștirilmesi}

Mortgage sisteminin temel esprisi, konut finansmanından kaynaklanan alacakları menkul kıymetleştirmek yoluyla Batılıların "mortgage money-Mortgage parası) dedikleri ayrı bir fon yaratmaktır. Yaratılan bu para yada fon tekrar konut sahibi olmak isteyen tüketiciye Mortgage kredisi olarak verilerek sisteme geri dönmektedir. Üstelik Mortgage Kanunu yürürlüğe girmeden önce, bankalar yabancı finans kurumlarından yada mevduat faizinden sağladıkları kredileri konut kredilerinin finansmanında kullanmaktaydılar. Mortgage sisteminden menkul kıymetleştirme yoluyla sağlanan fon, sendikasyon kredisi yada mevduat faizinden sağlanan fondan daha düşük maliyetli olduğu için göreceli olarak Mortgage kredilerinin faiz oranları klasik konut kredilerinin faizinden daha düşük olması beklenmektedir. Sistem bu şekilde çalıştığı zaman daha uzun vadeli ve daha düşük faizle kredi verilebilecek; belki o zaman "kira öder gibi ev sahibi olma" hayali gerçekleşebilecektir.

Öte yandan Mortgage kredilerinin 15-20 yıl vadeli olması Türk menkul kıymet piyasasında bu kadar uzun vadeli yatırım aracı ihracına olanak verecektir. Uzun vadeli yatırım yapmak isteyen yatırımcılar güvenli bir yatırım enstrümanını seçme şansına sahip olacaklardır. Yine söz konusu menkul kıymetler emeklilik fonları ve yabancı yatırımcıları yatırım yapmak üzere ülkemize çekebilecektir.

5582 sayılı Kanunun gerekçesinde açıklandığı üzere, konut finansmanına ilişkin alacakların menkul kıymetleştirmesi özellikle Kıta Avrupası'nda kullanılan menkul kıymet türü olan teminatlı tahvil "covered bond" ve ipoteğe dayalı menkul kıymet "mortgage based securities" aracılığıyla gerçekleştirilecektir (Barresi, 2005; Ferran 1992). Mortgage Kanunu'nda bu amaçla, "ipotek teminatlı menkul kıymet” ve "ipoteğe dayalı menkul kıymet" adıyla iki yeni menkul kıymet tipi öngörülmüştür (Berkant 2005). SPK kaydına alınmak suretiyle İMKB'de ihraç edilecek bu iki yeni menkul kıymet türü, Medeni Kanun'da öngörülen ipotekli borç senedi ve irad senedinden tamamen farklıdır.

\subsubsection{Ipotek Teminatlı Menkul Klymetler}

5582 sayılı Kanuna göre, hem konut finansman kuruluşları hem de ipotek finansman kuruluşları ipotekli menkul kıymet ihraççısı olabilirler. 5582 sayılı Kanunda ipotek teminatlı menkul kıymetler, ihraççıların genel yükümlülüğü altında oluşturdukları teminat havuzundaki varlıklar karşılık gösterilerek ihraç ettikleri borçlanma senetleri olarak tanımlanmıştır (m.13).

Teminat havuzu da, yapı kullanma izni alınmış konut ve diğer gayrimenkuller üzerine ipotek tesis edilmek suretiyle teminat altına alınmış alacaklar, ikame varlıklar ve bunların riskten korunması amacıyla yapılan sözleşmelerden oluşur. Yapı kullanma izni alınmış konutlar üzerine ipotek tesis edilmek suretiyle teminat altına alınmış alacakların ilgili konutun değerinin yüzde yetmişbeşini, yapı kullanma izni alınmış diğer gayrimenkuller üzerine ipotek tesis edilmek suretiyle teminat altına alınmış alacakların ise ilgili gayrimenkulun değerinin yüzde ellisini aşan kısmı, teminat değerinin hesaplanmasında dikkate alınmaz. Buradaki ikame varlıklardan kasıt ise, devlet iç borçlanma senetleri, hazine garantili menkul kıymetler ile Kurulca uygun görülen benzer nitelikli varlıklardır. Teminat havuzunu izlemek ve denetlemek için bir teminat sorumlusu atanır.

Ípotek teminatlı menkul kıymetler itfa edilinceye kadar, teminat havuzlarında yer alan varlıklar, teminat amacı dışında tasarruf edilemez, rehnedilemez, teminat gösterilemez, kamu alacaklarının tahsili amacı da dahil olmak üzere haczedilemez, ihtiyati tedbir kararı verilemez ve iflas masasına dahil edilemez. İhraççı kuruluşların teminat havuzuna giren alacak ve teminatlar üzerindeki tasarruf hakkı ortadan kaldırılmak ve hiçbir surette bunlara müdahale edilemeyeceği hüküm altına alınmakla, güçlü bir teminat işlevi sağlanmıştır.

İpotek teminatlı menkul kıymetler, ihraççı kuruluşun bir borçlanma senedi niteliğindedir. Bundan dolayı, ipotekli menkul kıymet sahipleri, teminat havuzundan alamadıkları alacakları için ihraççının diğer malvarlığına başvurabilirler.

\subsubsection{Konut Finansman Fonu ve İpoteğe Dayalı Menkul Klymetler}

İpoteğe dayalı alacakların menkul kıymetleştirilmesinde diğer yöntem kurulacak fonlar aracılığıyla ipoteğe dayalı menkul kıymet ihracıdır. 5582 sayılı Kanun, bilanço dışı olarak nitelenen bu yönteme ilişkin olarak konut finansmanı fonu kurulmasını öngörmektedir. Konut finansman fonu, yurt dışındaki “trust”lar ve Türkiye'de menkul kıymet yatırım fonlarına benzer şekilde yapılandırılmıştır.

Konut finansman fonu, ihraç edilen ipoteğe dayalı menkul kıymetler karşılı̆̆ında toplanan paralarla, ipoteğe 
dayalı menkul kıymetler hesabına inançlı mülkiyet esaslarına göre oluşturulan malvarlığıdır (Önen 2006). Fon malvarlı̆̆ına devredilen menkul kıymetlerin nakit akımlarından elde edilen gelirler, yatıımcılara ait olmaktadır.

Konut finansmanı fonlarının tüzel kişiliği yoktur ve bilanço dışı olduğu için fonu oluşturan kurucunun malvarlığından ayrıdır. Fon malvarlı̆̆ının ihraç edilen ipoteğe dayalı menkul kıymetler itfa edilinceye kadar, başka amaçla tasarruf edilmesi, haciz ve tedbire konu olması yada iflas masasına girmesi yasaktır.

İpotekle teminat altına alınmış kredi veya alacağın fon portföyüne alınması halinde, kredi veya alacağın fona devredildiği hususu ilgili gayrimenkulün beyanlar hanesine kaydedilir.

Kurucular ihraç edilen ipoteğe dayalı menkul kıymetlerin sahiplerinin haklarını koruyacak şekilde fonu vekalet sözleşmesi hükümlerine göre temsil eder ve yönetir. Kurucular ayrıca garanti vermedikçe, ihraç edilen sermaye piyasası araçlarının geri ödemelerinin fon malvarlığından karşılanmayan kısmından sorumlu değildir.

\section{Türkiye’de Mortgage Sisteminin Küresel Ekonomik Krizden Etkilenmemesinin Nedenleri}

Türk bankacılık sektörü genel anlamda krize sağlam girmiştir. Bunun birden fazla faktöre bağlı olduğunu söylemek mümkündür. 2001 sonrası yeniden yapılanmanın bankacılık sektörünün krize sağlam girmesinde etkisi büyük olmuştur. Ancak, Türkiye'de 2001 öncesi döneme bakılırsa, aslında patlayıcı bir krizin temellerinin Türkiye'de oluşmuş olmasına rağmen, Amerika'da FED'in yaptığının aksini yaparak, buna Merkez Bankası'nın engel olduğu söylenebilir. 2001 sonrasında yapılan reformlar ve hükümetin başarı ile uyguladığı mali disiplin sonucunda kamu bütçe açığı önemli ölçüde kontrol altına alındı ve bununla da kamu borçlanma ihtiyacı azalmıştır. Bu durum Devletin borçlanma piyasalarındaki dışlama etkisinde azalmaya neden olmuştur. Aslında 1994 ve 2001'de ortaya çıkan krizin temel nedeni devletin sürdürülemez hale gelen borç servisi ve bunun piyasada yarattı̆̆ı dışlama etkisi idi. 2001 sonrasında alınan tedbirler ile bu temel sebebinin yok olması sonucunda, bütçe açığı ve buna paralel enflasyon düşüşe geçmiştir. Bu noktada, artık Hazineye yüksek getirili-az riskli borç veremeyen Türk bankaları yabancı bankalar gibi parasal kaynakları için adres aramaya başlamışlardır. Bu adres, Türkiye'de de Amerika'da olduğu gibi hanehalkları olmuştur. Konut kredileri, kredi kartları ve bireysel ihtiyaç kredileri önemli büyüme göstermiştir. Ama bankaların, yeni şubeler açarak, reklam vererek, kampanyalar düzenleyerek gösterdikleri bütün çabalara rağmen yine de dünyada birçok ülkede gerçekleşen büyümeye paralel bir büyüme olmadı. Bunun en önemli sebebi, konut sahibi olmak için borç almanın çok cazip hale gelememesidir. $\mathrm{Bu}$ da hep faizlerin yüksek kalmış olmasından kaynaklanmaktadır. En düşük seviyesinde bile konut kredileri faizi aylık yüzde 1 veya yıllık bazda yüzde 12'nin altına düşmemiştir. Merkez Bankasının faizleri yüksek tutması bunun başlıca nedeni olmuştur. Yüksek faizin büyümeye çok önemli bir engel olduğu doğru olsa da, Merkez bankası bu yolla enflasyonu kontrol ederken büyümeyi de kontrol etmiştir. Büyüme hızının orta seviyelerde kalması bankaların kredilerinin mevduat tabanından daha fazla büyümesini engellemişlerdir. TCMB eğer faizleri düşürseydi, artan kredi talebine karşı bankalar muhtemelen tüm kaynaklarını seferber etmeleri ve yüksek riskli kredileri aktiflerinde barındıracaklardı. Daha da ileri giderek mevduat kaynaklarının ötesine geçerek, yurtiçinden ve dışından daha büyük borçlanmalar yapmanın yolunu bulacaklardı. Bu nedenlerle kriz döneminde, $\mathrm{ABD}$ ve Avrupa'nın tersine Türkiye'de tüm mortgage veya konut kredili emlak satışlarının miktarı toplam emlak satışları içerisinde \%10’u geçememiştir.

Diğer bir yandan Türkiye'deki konut finansmanı veya konut kredisinin işleyiş şekli mortgage sistemine dayalı bir kriz yaşanmayacağını ortaya koymaktadır. Türkiye'de aslında bankalar krediyi zamanında ödemeyen müşteriyi dışlamayıp bilakis böyle müşterileri tutarak cari faizlerden daha yüksek olan temmerüt faizi tahsil etmek isterler. Bunun anlamı: Eğer kişi kredi kartını zamanında ödemiyorsa, asgari tutarı ödüyorsa, tüketici kredisini aksatıyorsa, konut kredisi taksidini iki ay üst üste ödemiyorsa, bu müşteri bankalar için en karlı müşteridir. Çünkü Türkiye'de banka hem gayrimenkule ipotek hem kefiller almakta, hem de hayat sigortaları dahil sigortalar yapmaktadır. Bu şekilde konut kredileri, ipotek dışında güçlü bir teminata sahip olmaktadır. Konut kredisinin ödenmemesi nedeniyle açılan icra takiplerinde ipotekli konutun ihaleyle satışı kolaylıkla gerçekleşmektedir. Zira, toplumunun emlak merakı, ipotekli taşınmazların elden çıkarılmasını kolaylaştırıcı bir faktördür. Bazı durumlarda da icra takibine dahi gerek kalmadan temerrüde düşen borçlunun rizasıyla dahi ipotekli konutun satışı gerçekleşebilmektedir. Ayrıca sigorta ve kefillerden de ipotekli gayrimenkulün satışından kalan bakiye borç miktarı da tahsil edilebilmektedir. Yine Türk toplumunda, güçlü aile bağları nedeniyle eş dost veya akraba çevresinden sağlanan yardımlar da ipotekli konut kredisi alacağının tasfiyesinde paya sahiptir. Türkiye'de toplumun krize rağmen düşmeyen konut talebi konut fiyatlarında düşmeye neden olmamıştır. Sürekli artan konut fiyatları da ipotekli konutların yüksek fiyatlarla paraya çevrilmesini kolaylaştırmıştır. Bu nedenle Türkiye'de ABD benzeri konut kredilerinin ödenmemesinden kaynaklanan bir krizin çıkması kolay değildir.

Üstelik Türkiye'de yakın zamana kadar yasal mevzuat ve sistem oluşturulmasına rağmen ipoteğe dayalı menkul kıymet veya ipotek teminatlı menkul kıymet ihracı gerçekleş̧irilememiştir. Başka bir deyişle ipotekli menkul kıymetleştirmeye dayalı türev piyasalar gelişememiştir. Sistemin adı, mortgage-konut finansman sistemi olmasına rağmen, normal bir tüketici kredisi olmaktan öteye gidememiştir. Bankalar sendikasyon kredileriyle yurtdışından sağladıkları kredileri mortgage kredisi adı altında tüketicilere plase etmişlerdir. Hiçbir şekilde 
mortgage sisteminin belirleyici unsuru olan ve ipotekli konut kredilerinden oluşan mortgage havuzu dolayısıyla konut kredisine finansman sağlanması mümkün olmamıştır. Bu nedenle Anglo Sakson örneğinde görülen ölçüsüz ve sınırsız menkul kıymetleştirme çılgınlığının tetiklediği bir mortgage krizi Türkiye’de yaşanmamıştır. Aslında mortgage sistemi gerçek anlamda menkul kıymetleştirme yoluyla işlese bile Türkiye'de ABD benzeri bir konut kredisi krizinin yaşanmayacağı düşünülmektedir. Zira, Türkiye'de ancak gayrimenkulün değerinin \% 75 'ine kadar kredi verilebilmekte olduğundan LTV oranı hiçbir şekilde \%100'e ulaşamaz. Oysa ki kriz öncesi ABD'de gayrimenkulün değerinin tamamı kredilendirildiği gibi ilave olarak tamir ve sigorta masrafları için dahi mortgage kredisi verilmekte ve LTV oranı \%120'lere kadar çıkabilmekteydi. BDDK'nın sıkı denetiminde olan Bankalar müşterilerin kredi yeterliliklerini çok sıkı şekilde araştırmaktadırlar. SPK'nın sıkı disiplini altında bulunan değerleme firmaları tarafından yapılan İpotek alınacak gayrimenkullerin kıymet takdirlerinde de gerçek piyasa fiyatlarına yakın şekilde gayrimenkul değeri saptanmaktadır. Bunun sonucunda kredi yeterliliği olan firmalara gerçek piyasa değeri üzerinden alınan ipoteklerle mortgage kredisi verildiğinden temerrüt gerçekleşse bile kredinin tahsilinde sorun yaşanmamaktadır. Ayrıca, gerçek anlamda mortgage sistemi işlese bile, mortgage havuzlarına alınacak kredi ve ipotekler için SPK tebliğleriyle çok sıkı teminat-uyum ilkeleri getirildiğinden, menkul kıymetleştirmeden sonra bile bir sorun yaşanması olasılığı çok zor görülmektedir.

\section{Sonuç}

Türkiye'de 21.02.2007 tarih ve 5582 sayılı Konut Finansmanı Sisteminde Değişiklik Yapılması Hakkında Kanunla mortgage yada yasal deyimiyle konut finansman sisteminin alt yapısı oluşturulmuş ve SPK tebliğleriyle de menkul kıymetleştirmenin ikincil düzenlemesi öngörülmüştür. Esas itibariyle, tüketicilere konut edinmeleri amacıyla kredi kullandırılması konut finansmanıdır. Konut edinme dışında başka bir parasal ihtiyacını karşılamak amacıyla tüketicinin önceden var olan konutunu ipotek etmek suretiyle tüketici kredisi alması, konut finansmanı sayılmaktadır. Konutların finansal kiralama yoluyla kiralanması da konut finansmanı sayılan diğer bir iştir. Kanunda yukarıda belirtilen her üç tip kredinin yeniden finansmanı (refinancing) amacıyla kredi kullandırılması da konut finansmanı olarak kabul edilmiştir.

Konut finansmanına ilişkin alacakların menkul kıymetleştirmesi özellikle Kıta Avrupası'nda kullanılan menkul kıymet türü olan teminatlı tahvil "covered bond" ve ipoteğe dayalı menkul kıymet "mortgage based securities" aracılığıyla gerçekleştirilecektir. Mortgage Kanunu'nda bu amaçla, “ipotek teminatlı menkul kıymet” ve "ipoteğe dayalı menkul kıymet” adıyla iki yeni menkul kıymet tipi öngörülmüştür. Ne var ki, yakın zamana kadar söz konusu menkul kıymetler bir türlü ihraç edilememiş ve bankalar sendikasyon kredileriyle yurtdışından sağladıkları kredileri mortgage kredisi adı altında tüketicilere plase etmişlerdir. Hiçbir şekilde mortgage sisteminin belirleyici unsuru olan ve ipotekli konut kredilerinden oluşan mortgage havuzu dolayısıyla konut kredisine finansman sağlanması mümkün olmamıştır. Bu nedenle Anglo Sakson örneğinde görülen ölçüsüz ve sınırsız menkul kıymetleştirme çılgınlığının tetiklediği bir mortgage krizi Türkiye'de yaşanmamıştır.

Türkiye'de Merkez Bankasının büyümeyi kontrol etmek için faizleri yüksek tutması mortgage kredilerini aylık $\% 1$ 'in altına inmesine engel olmuş ve bu durum da mortgage kredilerine talebin fazla büyümesini engellemiştir. Global kriz döneminde ABD ve Avrupa'nın tersine Türkiye'de tüm mortgage veya konut kredili emlak satışlarının miktarı toplam emlak satışları içerisinde \%10 oranını geçememiştir.

Türkiye'de banka hem gayrimenkule ipotek hem kefiller almakta, hem de hayat sigortaları dahil sigortalar yapmaktadır. Bu şekilde konut kredileri, ipotek dişında güçlü bir teminata sahip olmaktadır. Konut kredisinin ödenmemesi nedeniyle açılan icra takiplerinde ipotekli konutun ihaleyle satışı kolaylıkla gerçekleşmektedir. Zira, toplumunun emlak merakı, ipotekli taşınmazların elden çıkarılmasını kolaylaştırıcı bir faktördür. Bazı durumlarda da icra takibine dahi gerek kalmadan temerrüde düşen borçlunun rızasıyla dahi ipotekli konutun satışı gerçekleşebilmektedir. Ayrıca sigorta ve kefillerden de ipotekli gayrimenkulün satışından kalan bakiye borç miktarı da tahsil edilebilmektedir. Yine Türk toplumunda, güçlü aile bağları nedeniyle eş dost veya akraba çevresinden sağlanan yardımlar da ipotekli konut kredisi alacağının tasfiyesinde paya sahiptir. Türkiye'de toplumun krize rağmen düşmeyen konut talebi konut fiyatlarında düşmeye neden olmamıştır. Sürekli artan konut fiyatları da ipotekli konutların yüksek fiyatlarla paraya çevrilmesini kolaylaştırmıştır. Bu nedenle Türkiye'de $\mathrm{ABD}$ benzeri konut kredilerinin ödenmemesinden kaynaklanan bir krizin çıkması kolay değildir.

\section{Kaynaklar}

- $\quad$ Bradner, 1987. The Secondary Mortgage Market and State Regulation of Real Estate Financing, EMORY LAW JOURNAL, Vol.36, No.1.

- $\quad$ Burkhart, 1999. Lenders and Land, MISSOURI LAW REVIEW, Vol.64, No.249.

- Chaplin, 1890. The Story of Mortgage Law, HARVARD LAW REVIEW, Vol.IV, No.1.

- Grimes, 1954. Mortgages: Effect of Failure to Record a Mortgage Assignment in Florida, FLORIDA LAW. REVIEW, Vol.7.

- Hazaltine, 1903-1904. The Gage of Land in Medievel England, HARVARD LAW REVIEW, Vol.XVII, 
- Karp ve Klayman, 2003. Real Estate Law, Fifth Edition, Chicago.

- Kratovil, 1979-1980. Mortgage Law Today, THE JOHN MARSHAL LAW REVIEW, Vol.13.

- Küçük, 2007. Özel Tutulu Satış Sigortası, TERAZİ Aylık Hukuk Dergisi, S.2.

- Lea, 2006. Mortgage Finance Corporations, Turkey Hausing Finance Workshop, Istanbul.

- McNab, 2000. Minnesota Loss Payable Clauses in Fire Insurance Policies: Falling Short of the Minimum Coverage Requirements, WILLIAM MITCHELL LAW REVIEW, Vol.26.

- Moringiello, 1996. A Mortgage By Any Other Name: A Plea For The Uniform Treatment Of Installment Land Contracts And Mortgages Under The Bankruptcy Code, 100 DICKINSON LAW REVIEW.

- Nelson, 1988. Rosenberg v. Smidts: Dramatic Ramifacation for Nonjudical Foreclosure Sales in Alaska, ALASKA LAW REVIEW, Vol.V.

- Nelson ve Whitman, 2001. Real Estate Finance Law, Fourth Edition, St.Paul, MINN.

- Pence, 2003. Foreclosing on Opportinity: State Laws and Mortgage Credit.

- Rubin ve Strohchein, 1993-1994. Developments in the Law, LOUISIANA LAW REVİEW, Vol.55.

- Topaloğlu, 2007. İpoteğe Dayalı ve İpotek Teminatlı Menkul Kıymetler, Adana.

- Topaloğlu, 2009.Türk Hukukunda İpoteğe Dayalı ve İpotek Teminatlı Menkul Kıymetler, Prof.Dr.Ali Naim İnan'a Armağan, Ankara.

- Topaloğlu, 2010. Mortgage Kredilerinde Erken Ödeme Ücreti (Cezas1), Prof. Dr. Attila ÖZER'e Armağan, Ankara.

- $\quad$ Sturges ve Clark, 1928. Legal Theory of Real Property Mortgages, YALE LAW JOURNAL, Vol.XXXVII, No.6.

- Werner, 2002. Real Estate Law, Eleventh Edition, Chicago- Illionis, s.244;

- Wright, 2005. The Effect of New Deal Real Estate Residential Finance and Foreclosure Policies Made in Response to the Real Estate Conditions of the Great Depression No:1, ALABAMA LAW REVIEW, Vol.57.

- Yalçıner, 2006. İpotek Karşılığı Menkulleştirilmiş Krediler, Ankara.

- Yıldırım ve Topaloğlu, 2007.İpotekli Konut Finansmanı ve Hukuku - Mortgage (Tutsat), Adana.

- http://family.findlaw.com/homeownership/home-buying/home-buying-mortgage-overview(1).html

- http://family.findlaw.com/homeownership/home-buying/home-buying-mortgage-overview(1).html

- http://www.spk.gov.tr/konutfinansmani/kf/konut_finansmani_spk_taslak.pdf

- $\quad$ http://www2.tbmm.gov.tr/d22/1/1-1148.pdf 


\title{
Sermaye Şirketlerinde Mali Durumun Bozulmasının Nedenleri
}

\author{
Ahmet Tuncay (Supreme Court, Turkey)
}

\section{The Reasons for Financial Failure in Capital Stock Companies}

\begin{abstract}
In capital stock companies, in their financial structure, failure may occur in paying balance under the situations to changings in economy markets, crisis or the situations of bad assistance of company. The failure in financial structure, insufficiency of partnership assets to afford debts, cause to decrease capital of company and breakdown of paying debts. Continuance of this situation can cause the result of corporate bankruptcy. A corporate bankruptcy effects economy of the state which contains this company, in a bad way. Under this heading, the reasons of failure in financial structure of companies will be explained.
\end{abstract}

JEL Code: K22

\section{Giriș}

Şirketleri birçok yönden tasnif etmek mümkündür. Şirketin yapısını oluşturan şahıs ve sermayeden hangisinin ön planda olduğu dikkate alınarak klasik şekilde ayrım yapıldığında şirketleri; şahıs şirketleri ve sermaye şirketleri olarak gruplandırmak mümkündür.

Türk Ticaret Kanununun 136. maddesinde öngörülen ticaret şirketleri şunlardır:

- Kollektif Şirket (TTK'nın 153-242);

- Komandit Şirket(TTK'nın 249-268);

- Sermayesi Paylara Bölünmüş Komandit Şirket (TTK'nın 475-484);

- $\quad$ Anonim Şirket (TTK'nın 269-474);

- Limited Sirket,(TTK'nın 503-556)

Bu şirketlerden Kollektif Şirketler ve Komandit Şirketler şahıs şirketleri, Sermayesi Paylara Bölünmüş Komandit Şirketler, Limited Şirketler ve Anonim Şirketler ise sermaye şirketleridir. Ticaret şirketlerinin amac1 ticari faaliyetlerden kazanç temin edip, bu kazancı ortaklarıyla paylaşmaktır. Kazanç temin edilebilmesi ve şirket tüzel kişiliğinin mal varlığının meydana gelebilmesi, ortakların şirkete sermaye olarak koyacakları değerler sayesinde mümkündür. Sermaye koyma, ortağın şirkete belirli bir para ile katılma (nakit sermaye), şirkete taşınır ve taşınmaz mal koyma şeklinde (ayın sermaye) ya da bedeni ve fikri çalışmanın konulması (maddi olmayan haklar) şeklinde olabilir. Sermaye olarak konulabilecek değerler TTK'nın 139. maddesinde belirtilmiştir.

Bunlar:

- Para, alacak, kıymetli evrak ve menkul şeyler;

- İmtiyaz ve ihtira beratleri ve alameti farika ruhsatnameleri gibi sinai haklar;

- Her nevi gayrimenkuller;

- Menkul ve gayrimenkullerin faydalanma ve kullanma hakları;

- Şahsi emek;

- Ticari itibar;

- Ticari işletmeleri;

- Telif hakları, maden ruhsatnameleri gibi iktisadi değerleri olan sair haklardır.

Yukarıda sınırlı şekilde sayılan değerlerin biri veya bir kaçı şirkete sermaye olarak konulabilir. Sermaye şirketlerinde ortaklar ikinci planda olup asıl olanın şirkete getirilen sermaye olması nedeniyle bu tür ortaklıklara sermaye şirketi denmektedir. Şirket gücünü ve itibarını sermayesinden ve yönetiminden alır.

\section{Mali Durum Kavramı ve Mali Durumun Bozulma Nedenleri}

Yukarıda belirtilen şirketlerin tamamında, mali durumlarında bozulmalar görülebilir. Mali durumda bozulma, esas itibariyle şirketin bilanço yapısında bir bozulmayı ifade eder. Bir ticaret şirketinde hem iç hem de dış etkenler mali durumda bozulmaya neden olabilir.

\subsection{Mali Durum Kavramı}

Mali durum, gerçek veya tüzel kişiye ait mal varlığının para, mal, alacak ve her türlü ekonomik değeri olan; marka, fikri ve sınai haklardan oluşan; aktif toplamıyla, borç ve yükümlülüklerden oluşan pasifler toplamının belirli bir dönemdeki durumudur. Mali durum kural olarak bilanço aracılı̆̆ııla tespit edilir.

\subsection{Mali durumun Bozulma Nedenleri}

Şirketlerin mali durumlarının bozulmasının birçok nedeni vardır. Bunları iç ve dış etkenler olarak 
siniflandırabiliriz.

\subsubsection{Iç Etkenler}

Şirketin kuruluşundan idari ve ticari olarak sevk idaresindeki bazı olumsuz durumlar mali durumu bozucu etki gösterir. Bunlar şu şekilde sıralanabilir:

- Gereksiz üretim yapılması, bu nedenle satış hacminin yeterli düzeye ulaşmaması,

- Üretilen malların pazar araştırmalarının yetersizliği, ilgili endüstri dalındaki gelişmelerin izlenememesi, yeni ürünler geliştirilememesi, üretim-pazarlama bölümleri arasındaki koordinasyon eksikliği nedeniyle pazarlanamaması dolayısıyla satış hacminin yeterli düzeye ulaşamaması,

- Yöneticilerin ihmal ve yetersizliği nedeniyle yönetimde yanlış karar alınmasından dolayı şirketin mali kaynaklarının verimli kullanılmaması,

- Personel istihdam politikasında uygulama eksiklikleri,

- Alacakların zamanında tahsil edilememesi nedeniyle ödemeler dengesinin bozulması,

- Faaliyet giderlerinin aşırı derece yüksek olmasından dolayı rekabet olanaklarının zayıflaması,

- Şirketin kuruluş amacını gerçekleştirmeye yeterli sermaye ile şirket faaliyetine başlanılmaması,

- Şirketin sermaye ve kapasitesi üzerinde yatırım yapması sonucu oluşan aşırı borçlar,

- Maddi duran varlıklara aşırı yatırım yapılarak atıl üretim kapasitesi oluşması,

- Şirketin kuruluş yerinin hatalı seçilmesi.

Görüldüğü gibi, şirketin kendi içsel yapısında ortaya çıkan organizasyon ve yönetim hataları şirketin mali durumunun bozulmasına neden olmaktadır. Yukarıda sayılan etkenlerin bazen biri bazen de birkaçı bir araya gelerek şirketin mali durumunun bozulmasına neden olmaktadır.

\subsubsection{Dıs Etkenler}

Dış etkenler, şirketin iç yönetimi dışında çevresel faktörlerden oluşmaktadır. Aslında iyi bir yönetim anlayışı çevresel bu faktörlerin de önceden hesaba katılmasını gerektirir. Şirketim mali durumunu bozan dış etkenler şu şekilde sıralanabilir:

- Ekonomik koşullarda beklenmedik gelişmeler, kriz dönemleri ( Ekonomik kriz, aniden ve beklenmedik bir şekilde ekonomide ortaya çıkan olayların makro açıdan ülke ekonomisini, mikro açıdan ise firmaların işleyişini ciddi anlamda bozacak etkiler oluşturmaktadır. Türkiye'de 1994, 2001 ve 2008 yıllarında ekonomik krizler yaşanmıştır.), Global finansal krizler nedeniyle küresel ekonomideki olumsuz gelişmeler ve bunların yansımaları (kriz döneminde yükselen faiz oranları ve döviz kurları gibi) firmaların mali durumunu bozacak etkiler oluşturur. Dünyada 1994 Meksika Pesosu Krizi, 1997 Güney Doğu Asya Finansal Krizi, 1998 Rusya Krizi, 2008 ABD Krizi global krizleri örnek olarak gösterilebilir.

- Doğal afetler,

- Aşırı vergi yükümlülüğü içeren yasal düzenlemeler,

- İdari kararlar,

- Uzun süreli grevler,

- Enflasyon.

İşletmelerin ekonomik dar boğaza düşmesiyle ödemeler dengesinin bozularak aciz hale gelmesi yukarıda sayılan etkenlerin tamamının veya bir kısmının bir araya gelmesi ile oluşur.

Türkiye'de işletmelerin mali durumlarının bozulmasının ana nedenleri olarak, kötü işletmecilik, yetersiz yönetim, şirketin sermaye ve kapasitesi dikkate alınmaksızın dengesiz ticari faaliyetlerinde bulunması, ayrıca büyük ekonomik kriz dönemleri sayllabilir. (2001, 2008 krizleri gibi...)

\section{Mali Durumun Bozulması Kavramı ve Tespiti}

Mali durumun bozulması göreceli bir kavram olup, bu konuda kesin bir tanım yapılması güçtür ve mali durumun bozulması hali her şirkete göre farklılık gösterir. İşletme ekonomisi açısından mali durumun bozulması, şirketin faaliyet alanını kendi mali kaynakları ile finanse edememesi, şirkete dışarıdan sermaye girişi sağlayamaması, alacaklarının borçlarını karşılayamaması, nakit girişini sağlayamaması şeklinde olabilir. Mali durumun bozulması ile ilgili yasal düzenlemeler Türk İcra ve İflas Kanunu ile Türk Ticaret kanununda bulunmaktadır. İIK'nın 179. maddesinde borçların mevcut alacaklardan fazla olmasından, İİK'nın 178. maddesinde ise aciz halinden, Türk Ticaret Kanununun 324. Maddesinin kenar başlığında ise "Şirketin Mali Durumunun Bozulması"ndan bahsedilmiş ancak herhangi bir tanım yapılmamıştır. Türk Ticaret Kanunu anonim şirketlerde mali durumun bozulması ve bu yönde yapılması gerekli işlemleri üç kademeli bir sistemde ele almıştır.

\subsection{Esas Sermayenin Yarıdan Azının Karşılıksız Kalması}

Esas sermayenin yarıdan azının eksildiği, kural olarak bilanço aracıllğıyla anlaşılır. Bu bilanço, yıllık bilanço olabileceği gibi, ara veya tasfiye bilançosu da olabilir. Bu durumda yönetim kurulu derhal toplanmak ve durumu genel kurula bildirmek zorundadır. (TTK. 324/1) 
Şirket genel kurulu ya şirketin aynı sermaye ile devamına veya sermayenin artırılmasına ya da şirketin feshine karar verebilir.

\subsection{Esas Sermayenin Üçte İkisinin Karşılıksız Kalması}

TTK'nun 324. maddesinde $1 / 2$ oranında sermaye kaybına ilişkin düzenlemeden farklı olarak $2 / 3$ oranında sermaye kaybı halinde durumun genel kurula bildirileceğini açıkça belirtmemiştir. Ancak bu durumda genel kurul ya sermayenin tamamlanmasına ya da kalan sermaye ile yetinmeye yani sermaye azaltılması suretiyle zararın sermaye dışına atılmasına karar verilmesi zorunlu olduğundan usulünce toplantıya davet edilmesi gerektiği açıktır.

\subsection{Aktiflerin Borçları Karşılayamaması Hali}

Türk Ticaret Kanunu'nun 324. maddesi ve İIK'nın 179. Maddesi gereğince borca batıklık hali varsa şirket yönetiminin durumu hemen mahkemeye bildirmesi zorunludur. Sermaye şirketleri açısından borca batıklık iflas nedeni olarak kabul edilmiştir. Mali durumun bozulmasının tespitinde şirketin sermaye durumu önemli bir göstergedir. Sermaye azalmasının yanı sıra ortaklığın aktiflerinin borçlarını karşılamaya yetmemesi, likidite sıkıntısına bağlı ödeme güçlüğü, şirketin toplam kısa, orta ve uzun vadeli borçları ile borç toplamının öz sermayeye oranı da önemli unsurlardandır.

\section{Mali Durumun İyileştirilmesine Yönelik Tedbirler}

Mali durumu bozulan şirketlerde sermaye ilavesi yoluyla şirketin rehabilitasyonu yoluna gidilebilir (TTK m.391 vd.). Bundan başka İcra ve İflas Kanunu'nda borçların uzlaşma yoluyla yeniden yapılandırılması (m.309), konkordato (m.285-309 ve iflasın ertelenmesi (m.179 vd.)olmak üzere üç ayrı iyileştirme yolu öngörülmüştür.

\subsection{Sermayenin Tamamlanması}

Ekonomik açıdan sermayenin tamamlanmasından değil artırılmasından söz edilebilir. Hukuksal olarak sermayenin tamamlanması esas sermaye indirimi ile sermaye artımı yoluna gidilmesi veya pay sahiplerinin taahhütlerinin arttırılması yöntemlerinden biriyle gerçekleştirilebilir.

\subsection{Borçların Uzlaşma Yoluyla Yeniden Yapılandırılması}

İIKK.'nın 309/m ve devamı maddelerinde muaccel para borçlarını karşılamaya yetmeyen ya da bu hallerden birine düşme tehlikesiyle karşı karşıya kalması kuvvetle muhtemel olan sermaye şirketleri ve kooperatiflerin belirli koşullar altında uzlaşma yoluyla yeniden yapılandırma yoluna başvurulabileceği belirtilmiştir.

\subsection{Konkordato (ïIK. m. 285-309)}

Hukuksal anlamda konkordato, şirket elindeki mevcut mal varlığının, şirketin borçlarının tamamını ödemeye yetmeyen iyi niyetli borçlunun alacaklılarla yaptı̆̆ 1 ve mahkemece de onaylanan bir anlaşmadır. Bu anlaşmada alacağın bir kısmından vazgeçilmek veya borçluya belirli bir süre tanınmak yahut hem alacağın bir kısmından vazgeçilmek hem de kalan alacağın ödenmesi için borçluya belirli bir süre tanımak suretiyle, borçluya borçlarını ödemesi olanağı sağlanmasıdır. Borç yapılandırma anlaşmasının ve konkordatonun mahkemece onaylanması gerekir.

\subsection{Ifflasın Ertelenmesi}

İIK.'nın 179. maddesi gereğince borca batıklık hali zorunlu ve doğrudan iflas hali olarak öngörülmüş olup, bu durumda bulunan sermaye şirketlerinin iflaslarının mahkemece, yasal koşulların varlığı halinde, belirli bir süreyle ertelenmesine karar verilebilir.

\section{Sonuç}

Şirketler sermaye birikimi sağlayarak, önemli yatırımlar yapmak suretiyle istihdam alanı yaratarak, iş gücü gereksinimlerini karşılayarak işsizlik ve eksik istihdam gibi sorunların çözümlenmesini, ekonomik büyüme ve kalkındırmayı canlandırarak bireylerin yaşam standartlarının yükselmesini, ayrıca vergi ödemek suretiyle de kamu hizmetlerinin, devletin üstlendiği görevlerin yerine getirilmesine katkı sağlarlar. Bir ülkenin ekonomisinin sağlığı, gücü ve gelişmesi işletmelerin sağlığı, gücü ve gelişmesine bağlıdır. Bu nedenle işletmelerin varlıklarını devam ettirmeleri büyük önem taşır. Mali durumu bozulan, borca batık hale gelen sermaye şirketlerinin iflasının önlenmesi ve yeniden ülke ekonomisine kazandırılması ülkenin ekonomik gelişimi için çok önemlidir. Devletin, şirketlerin mali durumunun bozulmasına yol açacak aşırı vergi yükümlülüğü içeren yasal düzenlemelerden, büyümeyi engelleyecek olumsuz idari kararlardan kaçınması gerekir. Mali durumu bozulan, ancak mali durumlarının iyileştirilmesi ümidi bulunan şirketlerin normal faaliyetlerine devam edebilmeleri ihtimalinin yüksek olması halinde dürüst borçlu işletmelerin iflaslarının önlenmesi, bu tür şirketlerin ticari faaliyetlerinin ve dolayısıyla ülke ekonomisine katkılarının devamını sağlamak amacıyla mali durumlarının iyileştirilmesini sağlayacak ekonomik ve hukuki tedbirlerin alınması gerekir. 


\section{Kaynaklar}

- Atalay, 2007. Borca Batıklık ve İflasın Ertelenmesi, İzmir.

- Erten, 2006. Mali Durumu Bozulan Sermaye Şirketlerinin Uzlaşma Yoluyla Yeniden Yapılandırılması, İstanbul.

- Gençtürk, 2008. İşletmelerin Finans Kararlarına Finansal Krizlerin Etkileri, Bursa 2008.

- Kayar, 2007. Anonim Ortaklıkta Mali Durumun Bozulması ve Alınacak Tedbirler, Konya.

- Pulaşl1, 1995. Şirketler Hukuku, Konya.

- Türk, 1999. Anonim Ortaklıkta Sermaye Kaybı ve Borca Batıklığın Hukuki Sonuçları, Ankara. 


\title{
Türk Hukukunda Mali Yapısı Bozulan Sermaye Şirketleri ve Kooperatiflerde İflasın Ertelemesi
}

Uğur Sayın (Supreme Court, Turkey)

\section{Postponement of Bankruptcy in Capital Stock Companies and Cooperatives}

\begin{abstract}
In earning capital stock company which its financail structure failed, which cannot pay debts to creditors and which become deeply involved in debt, to trade economy, partnerships, working people of company and other companies that are creditors of company have a big utility. It effects state economy directly. One of the ways of earning a company or cooperative that is deeply involved in debt, is the institution to delay debt. Bankruptcy deferment, under the surveillance of judge, providing to continue its activity of capital stock company or cooperative that is deeply involved in debt with effectuating of presented healing project, is giving helping hand to company. In this way, both company become operation condition again and receiving credits of creditors are guarented. So, stabiliy in commercial life continues. Under this heading, procedures of delaying bankruptcy, conditions and the way of practising will be explained.
\end{abstract}

JEL Code: K22

\section{1 İflas ve İflasın Ertelenmesi Hakkında Genel Bilgi}

İflas, bir şirketin veya tacirin malvarlığının tümü tasfiye edilerek alacaklılara pay edilmesi ve bu suretle ticari hayattan silinmesidir. İcra İflas Yasası'nda, icra takibi ile istenilen, vadesi gelmiş bir borcun depo kararına rağmen ödenmemesi, borçlunun da iflasa tabi kimselerden olması hali olan genel iflas nedeni yanında özel iflas nedenleri de vardır. Sermaye şirketlerinin veya kooperatifin aktifinin pasiflerini karşılamaya yetmemesi hali de özel iflas nedeni sayılır. Her iki halde de iflas kararını Ticaret Mahkemesi verir.

Anonim, limited ve paylı komandit şirketler ile kooperatifler TTK 136. maddesine göre Ticaret şirketleri sayılır. TTK 18 ve 20. Maddesi uyarınca bu sermaye şirketleri tacir sayıldıklarından her türlü borcundan dolayı iflasa tabidirler. Bir şirketin iflasa tabi olması yani iflas ehliyeti, ticaret siciline tescil edilip tüzel kişilik kazanmasından, tüzel kişiliğin sicilden terkin edilmesine kadar devam eder. Sermaye şirketleri ve kooperatiflerin işletme sermayesinin, 2/3 kısmını kaybetmeleri halinde, TTK 324 ve Kooperatifler Kanunu'nun, 63.maddesinde, iflas erteleme kurumu düzenlenmiştir.

Dünya piyasalarında ve Türkiye'de ekonomik krizlerin meydana gelmesi nedeniyle bu hükümler yetersiz kalmıştır. Yeniden düzenleme yapılması ihtiyacı oluşmuştur. Türk hukuk sisteminde, 4949 sayılı ve 5092 sayılı yasalar ile bu konularda kapsamlı değişiklikler yapılmıştır. Böyle bir düzenlemeye aşağıdaki nedenlerle ihtiyaç duyulmuştur:

Sermaye şirketleri ve kooperatiflerde borca batıklık ve iflas halinde genel kural, şirketin alacaklılarına karşı malvarlığı ile sorumlu olmasıdır. Şirketin ortakları, gerçek kişiler ve şahıs şirketlerinden ayrı olarak şirkete koydukları sermaye payları kadar sorumludurlar. (TTK 269. Mad.)

Sermaye şirketleri, ekonomik alanda çok önemli yer tutarlar. Sermaye hareketleri, üretim, istihdam alanlarında söz sahibidirler. Piyasalardaki ekonomik dalgalanmalardan önemli ölçüde etkilenirler. Bunların sermayelerini kaybetmeleri, ödeme sıkıntısı içine girmeleri alacaklıları olumsuz etkiler. Ayrıca, üretimi azaltmaları, işçi çıkarmaları sonucunu doğurur. İstihdamı da, olumsuz etkiler. Makro düzeyde bu olumsuz etkilerin artışını engellemek için borca batıklık emarelerinin görülmesi ile şirketin kendi haline bırakılmaması düşüncesi bu kurumun geliştirilmesinde etkin olmuştur. Uygulamada, anonim ve limited şirketler bu yola başvurmaktadırlar. İcra İflas Kanunu'muz da alacaklı ve borçlu arasındaki dengenin sağlanması açısından da iflas erteleme önemlidir.

Türkiye'de, özellikle son on yıl içerisinde ekonomik alanda yapısal değişiklikler yapılmıştır. Gerçekleşen ekonomik krizler ve sorunlar nedeniyle yenilikler yapılmış, bu uygulamaların hayata geçirilmesi için hukuk alanında da düzenlemeler yapılması gerekmiştir.

Şirketlerin ödeme dengelerinin bozulması halinde uygulama alanı olan, konkordato ve uzlaşma suretiyle yeniden yapılandırma kurumları ihtiyacı karşılayamaz hale gelmiştir. İcra iflas Kanunu'nda ki bu düzenlemeler de ihtiyacin sonucudur.

Konkordato ve uzlaşma suretiyle yapılandırma halinde inisiyatif, alacaklılarda bulunmaktadır. Alacaklıların rızası olmadan hiçbir işlem yapılamaz. İflas ertelemesi halinde ise şirket malvarlığı üzerindeki denetim, daha ziyade hakim kontrolünde, borçlu şirkette bulunmaktadır. Bu nedenle, iflas erteleme kurumu diğerlerine nazaran 
daha fazla talep edilmektedir.

İsviçre Borçlar Kanunu'nda da, bu konuda benzer nitelikte düzenlemeler bulunmaktadır. Son yıllardaki Türk sistemindeki düzenlemeler ve uygulamalar daha ileri düzeye gitmiştir.

İflas erteleme, borca batık hale gelmiş bir şirket için son bir şans verilmesi olarak da değerlendirilebilir. Şirketin iflası halinde, yok olmasını ve tasfiye edilmesini önlemek için şirketin tüzel kişiliği ayakta tutularak, hakim kontrolünde bir proje çerçevesinde, yeniden ekonomi alanına kazandırılması da amaçlanmıştır. İflas kararı kesinleşene kadar her aşamada mahkemeden istenebilir.

Ekonomik kriz, yanlış bir yatırım sermaye şirketini ya da kooperatifi aniden zor duruma sokabilir. Kısa vadede ödenmesi gereken borçlarını ödeyemez. İşçi ücreti ve vergilerini ödeyemez duruma girer. Borçları, mal varlı̆̆ından fazla duruma gelirse, bu şirket borca batık duruma düşer. Ancak, bu şirketin kurulu bir düzeni, piyasada ticari itibarı,işleyen mekanizması varsa, kendisine zaman tanınması halinde hayata geçirilecek projesi varsa, bu projeyi gerçekleştirip borçlarını ödeyerek tekrar ödemeler dengesinin sağlanması, borçlarının ödenmesi için kendisine tanınan tasfiyenin ertelenmesi iflas ertelemedir. Alacaklıların yararı da ön planda tutulmaktadır.

Şirkete, hakim denetiminde, beş yıla kadar süre verilmektedir. Bu süre içerisinde, şirket projesini uygulayamaz, durumu düzeltemez ,ekonomik krizde gerekli tedbirleri almaz, alacaklıların alacaklarına kavuşmaları tehlikeye girer se, iflas ve tasfiye kaçınılmaz hale gelir.

İflas erteleme deyimi, iflas etmiş bir şirketin iflasının ertelenmesi anlamına gelmez. İflas kararının mahkeme tarafindan verilmesi halinde bu kararın uygulanmasını durdurmaz. Tasfiye işlemleri, iflas idare memurları tarafından devam ettirilir. İflas ertelemeye tabi olacak şirket hakkında verilmiş ve kesinleşmiş iflas kararı bulunmamas1 gerekir

Yapılan açıklamalardan sonra, iflas ertelemesini şu şekilde tanımlayabiliriz: Sermaye şirketinin yada kooperatifin borca batık olduğunu ticaret mahkemesine bildirmesi ile şirketin ya da alacaklılarının talebi ve iyileştirme projesinin sunulması, bu projenin ciddi inandırıcı uygulanabilir olduğuna mahkemenin kanaat getirmesi ile bu şirkete yada kooperatife beş yıla kadar iflasının ertelenmesi hakkı verilerek yeniden ticari hayata kazandırılmasını sağlayan hukuki bir yoldur.

Yargıtay kararlarında da bu amaç şu şekilde izah edilmiştir; Sermaye şirketi ve kooperatifin ekonomi içerisinde kalarak faaliyetinin devamını sağlamak ve alacaklıların iflasa nazaran alacaklarının tahsilinin daha kötü bir duruma düşmesini önlemektir.

Makro ekonomi sistemi içerisinde önemli bir yer tutan ve ekonomik dengelerin oluşmasını sağlayan sermaye şirketleri ve kooperatiflerin ekonomi içerisinde kalmasında ticari hayatın yararı vardır. Alacaklıların ve borçluların yararları ile birlikte, iş̧̧ilerin ,ülke ekonomisinin, kamu yararının bulunduğu açıktır.

\section{Türk Hukukunda Yasal Düzenleme}

Türk Hukuk sisteminde, TTK 324. Madde ve İ.I.K. 179. Ve 179/ b maddelerinde yer alan iflas erteleme kurumu, bir nevi geçici hukuki koruma tedbiri mahiyetindedir.TTK' nin şirketler hukuku ile icra iflas kanununun birlikte uygulanmasını gerektirir.

\section{3 İflas Ertelemenin Şartları}

İflas ertelemenin aşağıda gösterilen dört şartı vardır. Bu şartlar seçimlik değil kümülatiftir. Buna göre iflasın erteleme kararı verilebilmesi için;

- Anonim, limited, sermayesi paylara bölünmüş komandit şirket ve kooperatif şeklinde sermaye şirketi bulunmalidır.

- Şirket, borca batık olmalıdır.

- İyileştirme projesinin ciddi ve inandırıcı olması gerekir.

TTK 324 ve İIK 179-179/b maddeleri uyarınca aranan şartların gerçekleşmesi halinde sermaye şirketinin veya kooperatifin iflasının ertelenmesine karar verilir. Aksi halde karar verilmez. Ancak, şirket ya da kooperatifin borca batık hali belirlenip de erteleme şartlarının gerçekleşmediği kabul edilirse iflasa karar verilir. Borca batık olmadığı belirlenip, şartlarında gerçekleşmediği, iyileştirme projesinin ciddi ve inandırıcı olmadığı kabul edilirse erteme talebi reddedilir. Gerçek kişiler bu haktan faydalanamazlar.

\section{4 İflasın Ertelenmesi Talebi Mahkemenin İncelemesi ve İlanı}

İflasın ertelenmesi kararı verilebilmesi için, borçlunun ticaret sicilindeki kayıtlı muamele merkezinin bulunduğu Ticaret Mahkemesi başkanlığına yazılı talepte bulunulması gerekir. (İiK 152. Mad) Mahkeme res'en bu yönde bir karar veremez.

Şirketi idare ve temsile yetkili olanlar, şirket yada kooperatif alacaklıları ile tasfiye memuru mahkemeden istemde bulunabilir. 
Yönetim kurulunun borca batıklığı mahkemeye bildirme yükümlülüğü vardır. Ortaklığın iflasını ister. Ancak ortaklığın iflasının ertelenmesini talep zorunluluğu yoktur. Yasamızda, iflasın ertelenmesini isteyebilir şeklinde düzenleme vardır. Buna göre, yönetim kurulunun iflasın ertelenmesini istememesi halinde hukuki sorumluluğuna gidilemez.

Ortaklığın borca batık olduğunun, yani aktiflerinin alacaklıların alacağını karşılamaya yetmediği durumda şirket yönetim kurulu ya da tasfiye halinde ise tasfiye kurulunun mahkemeye bildirimde bulunması zorunludur. Bildirilmemesi İcra İflas Kanunu 345/a maddesine göre suç oluşturur. Bu durumda şirket alacaklıları tarafından sorumlu kişiler aleyhine icra tektik merciinde şikayette bulunulabilir. Borca batıklığın zamanında bildirilmemesi, şirketin bu şekilde faaliyetine devam etmesi, şirket mal varlığının azalması sonucunda alacaklıların, pay sahiplerinin ve işçilerin zararına olabilir. Yasa şirket pay sahiplerine sorumluluk davası açma hakkı tanımıştır. (TTK 336/1 maddesi)

Milli ekonominin karşılıklı güven prensibi içerisinde, sağlıklı bir şekilde işlemesi amacıyla yönetim kurulunun şirketin borca batık olduğunu bildikleri halde, mahkemeye bildirim yapmadan şirketin faaliyetlerini sürdürüp bu durumları bilmeyen üçüncü şahıslardan mal ve ödünç para alıp borçlanmaları, şirketin iflas durumuna gelerek bu borçları ödeyemez duruma düşmesi, taksiratlı iflas olarak kabul edilir. İIK 310 ve TCK 507 maddesi uyarınca cezai sorumluluğu vardır. Hile ile bu sonuç gerçekleşirse, TCK 536 ve İIK 310 maddesi uyarınca cezai sorumluluk söz konusudur.

Ortaklar kurulu ve kooperatiflerde yönetim kurulu kararı ile iflas erteleme talebinde bulunabilirler. Limited şirketlerde şirketi idare ve temsile yetkili müdürlerde talepte bulunabilir. Şirketin tüm aktif ve pasiflerini gösteren bilançonun mahkemeye sunulması gerekir. Bilanço, ticari işletmenin belli bir zaman diliminde sahip olduğu mal varlıklarını ve bunların karşılandığı kaynakları gösteren mali bir tablodur.

$\mathrm{Bu}$ tablo ile birlikte, dayanağı belgelerinde mahkemeye gerçeği yansıtır şekilde tam olarak sunulması gerekir. Ancak bu halde, mahkeme yapacağı incelemede ortaklığın borca batık olup olmadığı konusunda isabetli bir sonuca ulaşabilir. Bilançoda gösterilen varlıkların değerinin o tarihteki piyasadaki cari fiyatlar esas alınarak gösterilmesi gerekir. Yargıtay 19 Hukuk Dairesi'nin kararları ve uygulaması da bu yöndedir. Tüm aktiflerin paraya çevrilme değerleri yani muhtemel bir satış sırasında gerçekleşecek fiyatlardan bilançoda gösterilmesi gerekir.

Borca batıklık ve 1slahın yani iyileşmenin mümkün olup olmayacağı bilirkişilere tespit ettirilir. Bu tespit, hakimin hakimlik mesleği gereği bilebileceği bir husus olmayıp, özel ve teknik bilgi gerektirir. Şirket alacaklılarının listesinin de mahkemeye bildirilmesi gerekir. İcra takipleri başlamış ise bu dosyalarının da bildirilmesi gerekir. Mahkeme bu alacaklılara duruşma gününü bildirir. Bunları dinler, beyanlarını alır.

Sayılanların dışında asıl önemlisi, borca batık şirketin iyileştirilmesine yönelik bir projenin mahkemeye sunulması gerekir.

Mahkemenin, böyle bir ümidin varlığı konusunda kanat edinebilmesi için, iyileştirme tedbirlerinin nelerden ibaret olduğunun, ne şekilde şirket mali yapısında düzeltme sağlayacağının projede açıkça gösterilmesi ve dayanak belgelerin bu projenin ciddi ve inandırıcı olduğunu kanıtlaması gerekir.

İyileştirme, borca batıklığın ortadan kaldırılarak daha iyi duruma getirilmesi işletmenin külli bir tasfiyeden kurtulup iflasının önlenmesi olarak izah edilebilir.

İflas erteleme talebi ve kararının ilanı, iyileştirme tedbirlerinin ve şirketin mal varlığının korunması ile ilgili tedbirlerin uygulanması için atanacak kayyım heyetinin ücretleri için mahkemenin takdir edeceği avans, verilen süre içinde yatırılmalıdır.

İIK 319.maddesi uyarınca, ekonomik kriz halinde Bakanlar Kurulu belirli bir süre için borçluların fevkalade mühletten yararlanmasına karar verebilir. İ̈K 329/a maddesine göre, şirket ya da kooperatif fevkalade mühlet elde ettiği takdirde, mühletin bitiminden itibaren,bir yıllık süre içerisinde iflasın ertelenmesinden yararlanamaz.

Erteleme kararı ile alacaklıların, alacaklarını tahsil etme ihtimalinin iflas kararı verilmesi halinde daha kötü bir hale gelip gelmeyeceğinin değerlendirilmesi gerekir. Erteleme kararı üzerine, alacaklıların katlanmak zorunda kalacakları zarar, derhal iflasa karar verilmesi halinde katlanmak zorunda kaldıkları zarara göre daha fazla görülüyor ise talebin kabulü mümkün olmaz.

İyileştirme projesinde alternatif olarak derhal iflas kararının verilmesi halinde alacaklıların alabilecekleri alacak miktarının da gösterilmesi gerekir. Bu varlıkların cari gerçek değerleridir. Erteleme sonucunda iyileşme halinde yapılacak ödeme miktarının da karşılaştırılması için bu konu önemlidir. Mahkeme bu sayede iflasın mı ,ertelemenin mi alacaklılar yararına olacağı konusunda isabetli bir karar verebilir. Şirketin düzeninin sağlanıp alacaklıların en az zarar ile alacaklarına kavuşmalarının amaçlanması gerekir.

İflas erteleme talebini alan mahkeme bu belgeler üzerinde yaptırdığı ön bilirkişi incelemesi sonucunda projeyi ciddi ve inandırıcı mahiyette bulursa alacaklıların yararına ve şirket projesinin uygulanmasına imkan verilmesi için ihtiyati tedbir kararı verebilir. Bunlar, şirket aleyhine başlatılan icra takiplerinin (baskısının) durdurulması, icra satışlarının önlenmesi, şirket yönetiminde olanların mallarının ve şirket mallarının devrinin önlenmesi, şirket harcamalarının ve gelirlerinin yönetiminin kayyıma bırakılması vs tedbirlere karar verebilir.İhtiyati tedbire karar 
verilmemesi halinde iyileştirme projesinin gerçekleştirilmesi imkanı dava sonucuna kadar ortadan kalkar.Dava konusu kalmayabilir.

Yargılama usulü ,acele işlerden sayılır.Basit usule göre en kısa zamanda sonuçlandırılması gerekir.Yapılan incelemeler ve alacaklıların dinlenmesi sonucunda,borca batık şirketin durumunun iyileştirilmesi mümkün görülür ise İIK 179 maddesine göre, bir yıl süre ile erteleme kararı verilir. Borca batık olup da iyileştirme imkanı görülmez ise iflas kararı verilir.

İflas erteleme kararının verilmesi ile mahkeme bir takım tedbirlere de hükmeder. Bunlar, projenin uygulanarak sonuca ulaşılabilmesi ve hakim denetimi için önemlidir. Ayrıca, İIK 179/a maddesi uyarınca, ortaklık ve kooperatifin malvarlığını korunması için gerekli tedbirlerin alınması zorunludur.

\section{5 İflas Erteleme Kararı ile Verilen Muhafaza Tedbirleri}

İflas erteleme yönünde verilecek kararda,şirketin iyileştirme projesinin hayata geçirilebilmesi için bir takım koruma tedbirleri kararda gösterilmelidir.Aslında bu tedbirlere uygulamada talep mahkemeye ulaştıktan sonra ön inceleme sonucunda ihtiyati tedbir kararı ile birlikte karar verilmektedir.

Yargıtay kararında, "iflas ertelemesi talebinin amacı gözetildiğinde tedbirlerin işletmenin faaliyetlerini sürdürerek durumunu düzeltmesine engel olmaması gerekir.” demek suretiyle açıklık getirmiştir. Tedbirlerin aynı zamanda, alacaklıların haklarının özüne zarar verecek mahiyette de olmaması gerekir.Talep üzerine mahkeme her zaman verilen tedbirlerde değişiklik yapabilir.

Erteleme kararı ile birlikte,şirketin mallarının envanterinin çıkarılarak defterinin tutulmasına karar vermesi de gerekir.Defteri tutulan mallar açısından borçlu şirket veya kooperatif daha dikkatli davranmaktadır.

Kayyım atanmasına karar verilir.Şirket yönetimi ve denetimi kayyıma bırakılır.Derhal göreve başlayarak şirket mallarının envanterini çıkartır ve defter tutmaya başlar. Kayyım, iflası ertelenen şirket ya da kooperatifin yönetim organlarının yetkilerinin tamamını kullanmak ya da yönetim organlarının hak ve yetkileri baki kalarak bunların iş ve işlemlerini denetlemek, onaylamak suretiyle görev yapar.Bunlardan birincisine yönetim , ikincisine denetim kayyımı denir.

Esas görevi şirketin ya da kooperatifin iyileştirme projesinin uygulanmasını gözetmek ve denetlemek olan kayyım aynı zamanda şirket ile iş yapan üçüncü şahıslar yönünden olumlu etki bırakır.Bu şahıslar daha güvenli bir muhatap ile karşı karşıya olduklarını düşünürler ve şirket işleri daha güvenli işler.Mahkeme şirketin mali yapısı ve iş hacmini dikkate alarak birden fazla kayyım da atayabilir.Ücretlerini buna göre belirler.

Erteleme kararı,İIK 179/a ve 166/II maddesine göre yurt genelinde yayınlanan ve tiraj1 50.000'in üzerinde olan bir gazete ile borçlunun muamele merkezinin bulunduğu yerdeki bir gazetede ve ticaret sicil gazetesinde ilan yapilir.

Diğer tedbirlere de karar verebilir.Bunlar şirketin atıl durumdaki projenin uygulanması açısından gerekli olmayan menkul malların satışı ve sermayeye ilave edilmesi,şirketin gelir getirmeyen işletme faaliyetlerinin durdurulması gibi ancak bu tedbirler için kayyım görüşü de alınır.

\section{Ertelemenin Etkileri}

Erteleme halinde, İ̇K 179/b maddesine göre icra takipleri durur.Bu husus erteleme kararı verildiği aşamada kalması anlamına gelir.Yargıtay uygulamaları da bu yönde olup hacizlerin kaldırılması, hacizli malın şirkete iadesi söz konusu değildir.Ayrıca işletme malları üzerinde yeniden haciz uygulanmaz.İcra takibi başlatılamaz.

Bir kısım yazarlar, üretim faaliyetine devam eden işletmenin malları üzerindeki haczin devam etmesinin projenin başarısız olmasına yol açacağını iflasa götüreceğini savunmaktadırlar. İcra iflas kanununun, 179/b maddesinde, takip hukukunun imkanları kullanılarak iflasın ertelenmesinin başarıya ulaşmasının engellenmesinin önlenmesi amaçlanmıştır. İcra baskısı, zorlama tedirginlik, umutsuzluktan borçlu şirket ve kooperatifin korunması amaçlanır.

Erteleme süresinin başarısızlıkla sonuçlanması halinde iflasa karar verilir.Bu karar ile birlikte tüm icra takipleri durur , kesinleşme ile birlikte, İIK 193 maddesine göre, icra takipleri düşer.Haciz koydurmuş bir alacaklının, haciz koydurmayan diğer alacaklıdan farkı kalmaz. Müflis işletmenin tüm mal varlığı bir masa oluşturur.

İflas ertelenmesi kararı ile işletmenin iflasına karar verilmesi ile doğacak etkiler geçici bir süreliğine ertelenmektedir. İflas kararı verilmemiştir. Mahkeme kararında, iflasın bir yıl ertelenmesine karar verilmesi, bu bir yıllık sürenin kesin olduğunu göstermez.Bu süre bir yıldan fazla olabileceği gibi kayyım raporlarına göre bir yıldan az da olabilir.

İflas erteleme kararı ile birlikte şirketin ya da kooperatifin tüzel kişiliği sona ermez.Hak ve fiil ehliyetleri devam eder. Ancak, alacaklıların yararına tasarruf yetkisine sınırlandırmalar getirilir.Yönetim kayyımlığına karar verilmesi halinde, şirket ya da kooperatifin tasarruf yetkisi daha fazla sınırlandırılır, denetim kayyımlığında ise sinırlandirma daha azdir.

Tasarruf yetkisinin kısıtlanmasındaki ölçünün ne olacağı konusunda, denetim yapan hakim, kayyım görüşünü 
de alarak karar verir. Burada, şirketin mal varlığının korunması, alacaklıların haklarının zayi olmaması, iyileştirme projesinin uygulanmasının sağlanması gibi ilkeler gözetilir.

Tasarruf yetkisini aşan işlemlerin geçerliliği konusunda da aynı kuralların uygulanması gerekir. İflas ertelemenin iflas ve itirazın iptali davası dışında açılacak ya da görülmekte olan davalara bir etkisi söz konusu değildir. Doğrudan bu davaları etkilemez. Görülmeye devam eder. Ancak sonuçlarını etkiler. İflas davasının, görülmesi gerekir. Erteleme sonucu beklenmelidir.

Erteleme davası, görüldüğü sırada ihtiyati tedbir ile icra takibi durdurulmuş ise bu icra takibi için itirazın iptali davası görülemez. Erteleme kararı ile birlikte icra takibi de yasal olarak kendiliğinden duracağından yine bu aşamada da itirazın iptali davası görülemez. Yargıtay 19. Hukuk Dairesinin görüşleri de bu yöndedir.

İflas erteleme kararı ile birlikte İIK/179/b-I maddesine göre, kamu alacakları da dahil, borçluya karşı yeni takip yapılamaz, başlamış takiplerde bulunduğu aşamada durur. İflas erteleme aşamasında, rehinli malı paraya çevrilmesi yolu ile takip yapılması mümkündür. Başlamış takibinde devamına engel olunamaz. Ancak bu serbestlik mutlak değildir. Rehinli malların muhafaza altına alınması ve satılması mümkün değildir. İşleyecek faizler yönünden ek teminat verilir.

Erteleme süresi içerisinde, alacaklar yönünden faiz işlemeye devam eder.

İK'nun 206. maddesinde birinci fikrada sayılan imtiyazlı alacaklar bakımından da istisna getirilmiştir. Bu sayılan alacaklar yönünden iflas erteleme kararına rağmen takip yapılabilir. Bunlar;

- İşçilerin iflasın açılmasından önceki bir yıl içerisinde tahakkuk etmiş, ihbar ve kıdem tazminatları, alacakları, iş ilişkisinin sona ermesi nedeniyle hak etmiş oldukları kıdem ve ihbar tazminatları için açılmış veya açılacak dava ve takipler iflasın ertelenmesi kararından etkilenmez.

- İşverenin iş̧iler için oluşturulan yardım sandıkları ve tüzel kişilik kazanmış bulunan tesislere veya derneklere olan borçları bunlar için haciz ve muhafaza ile satış işlemi yaptırılabilir.

\section{Sonuç}

Ülkenin ekonomisi içerisinde önemli yer tutan sermaye şirketinin mali yapısının düzeltilmesi yeniden ekonomiye kazandırılması yollarından birisi de iflasın ertelenmesidir. Ifflasın ertelenmesine borca batık sermaye şirketinin ciddi ve inandırıcı bir iyileştirme projesi sunulduğunda hakim tarafından karar verilmektedir. $\mathrm{Bu}$ kararın alınmasıyla borca batık şirket icra takibine uğrama tehdidinden kurtularak finansal olarak rahatlamaktadır. İflasın ertelenmesi sürecinde hakim denetimi altında, kayyım yönetimi ile şirket yeni baştan yapılandırılarak işler hale gelip borçlarını kendi kazancı ile ödemeye başladığı zaman hakim denetimi sona ermekte ve şirket gerçek yöneticilerine bırakılmaktadır.

\section{Kaynaklar}

- Atalay, 2007. Borca Batıklık ve İflasın Ertelenmesi, İzmir.

- Bilgen, 2010. İflasin Ertelenmesi, Ankara.

- Çavdar,ve Biçkin, 2006. İflas ve İflasın Ertelenmesi, Ankara.

- Deliduman, 2009. İflas Ertelemenin Etkileri, İstanbul.

- Ermenek, 2010. İflasın Ertelenmesi, Ankara.

- Kuru,1997. İcra ve İflas Hukuku, İstanbul.

- Kuru, 2006. Hukuk Muhakemeleri Hukuku, İstanbul.

- Öztek, 2007. İflasin Ertelenmesi, İstanbul.

- Türk, 1999. Anonim Ortaklıkta Sermaye Kaybı ve Borca Batıklığın Hukuki Sonuçları, Ankara.

- Uyar, 2007. İcra İflas Kanunu, İzmir. 


\title{
Sermaye Şirketlerinde Mali Durumun İyileştirilmesi Yolu Olarak Yeniden Yapılandırma
}

Adnan Deynekli (Supreme Court, Turkey)

\section{Restructuring as a Way to Improve the Financial Situation in Capital Stock Companies}

\begin{abstract}
Because of unexpected changes in economic situations, capital stock companies that can carry their economic entities may be faced with danger to stop their activity because of they cannot afford to pay promptly paid debts. This danger threatens the workers who are faced with the situation of being unable to receive their money as much as debtors. This threat effects legal and national economy. In the situations like this, providing them to continue their economic lifes with restructuring the capital stock companies that have an opportunity to continue their economic entity, is to the advantage of everybody.

Restructuring of capital stock companies and cooperatives with compromise way,is an institution that is accepted in Turkish law, in 2003. This institution based on the thought of providing to continue their activities in the situation of saving this company is possible, instead of deciding bankruptcy of company that is improved in last years in the world and is in financial straits.

Capital stock company or cooperative that is in financial straits compose with majority of creditors who have an amount of credits that are said in law, about restructuring debts. System works under the surveillance of court and acceptance or refuse require interference of judicial body. Under this heading, process of delaying bankruptcy, conditions and the way of practising will be explained.
\end{abstract}

JEL Code: K22

\section{Giriş}

Sermaye şirketleri sermaye birikimi sağlayarak ülkenin ekonomik hayatına faydalı katkıları bulunan kuruluşlardır. Sermaye şirketlerinde mali durumun bozulması sadece yöneticileri, pay sahiplerini ve işçileri değil, şirketlerle ilişki halinde bulunan diğer gerçek ve tüzel kişileri ve hatta Sosyal Güvenlik Kurumu ve Vergi İdaresini de etkilemektedir.

Mali durumu bozulan sermaye şirketlerinin iflasına karar verilmesi halinde bu durumdan şirketin işçileri, alacaklıları, şirket ortakları ve ülke ekonomisi olumsuz etkilenmektedir. Sermaye şirketlerinin ekonomi içinde yaşamaya devam etmesi, şirket ortaklarının, alacaklıların ve çalışanların olumsuz yönde etkilenmemesi için mali durumunu iyileştirebilecek sermaye şirketlerinin iflas etmekten kurtulması amaciyla bazı düzenlemeler yapılmıştır. Mali durumu bozulan sermaye şirketlerinin, artması sonucunda bunları kurtarmak amacıyla Türkiye'de yapılan düzenlemeler ana hatlarıyla şunlardır:

3332 sayılı uygulama da Şirket Kurtarma Kanunu olarak bulunan bu Kanun 31.03.1987 tarihli 19417 sayılı Resmi Gazete de yayınlanarak yürürlüğe girmiş, daha sonra yürürlükten kaldırılmıştır.

4743 sayılı uygulamada İstanbul Yaklaşımı olarak ifade edilen "Mali Sektöre Olan Borçların Yeniden Yapılandırılması ve Bazı Kanunlarda Değişiklik Yapılması Hakkında Kanun" 31.1.2002 tarih ve 24857 sayılı Resmi Gazetede yayınlanarak yürürlüğe girmiştir. Bu Kanunun 2.maddesi uyarınca BDDK tarafindan 11.05.2002 tarihinde yönetmelik çıkarılmış ve Bankalar Birliği de çerçeve anlaşmasının BDDK'nun onayından itibaren üç yıl süreyle geçerli olduğu kabul edilmiştir.

Tacir olsun olmasın adi konkordato tüm borçlular için yaşama şansı veren bir cebri icra kurumudur. Konkordatonun bir tasfiye usulü mü yoksa bir iyileştirme usulü mü olduğu konusundaki tartışmalar bir yana konkordatonun tasdiki sonucunda borçlu sermaye şirketi alacaklılarla anlaşarak borçlarını ödemekte ve ekonomik hayat içinde varlığını devam ettirmektedir. Bu nedenle adi konkordatoyu iyileştirme yöntemi olarak kabul edebiliriz.

İ̇K nun 326.maddesinde düzenlenen fevkalade hallerde mühlet ve tatil kurumu vardır. Ekonomik kriz hallerinde Bakanlar Kurulu kararıyla uygulanabilecek bu durum siyasi iktidarın başarısızlığını kabul anlamına geleceğinden uygulama alanı bulunmamaktadır.

Íflasın ertelenmesi ve sermayesi şirketleri ve Kooperatifleri yeniden yapılandırılması da iyileştirme kurumlaridır.

Bu çalışmada sermaye şirketlerinin uzlaşma yoluyla yeniden yapılandırılmasının şartları, usulü ve sonuçları üzerinde durulacaktır. 


\section{Uzlaşma Yoluyla Yeniden Yapılandırma Talep Etmenin Şartları}

Yeniden yapılandırma, sermaye şirketleri ve kooperatiflerin başvurabileceği bir yoldur. Bu kurum 21.1.2004 tarihinde 5092 sayllı Kanunla İIK'nun 309/m-309/ü maddeleri arasında düzenlenmiştir.

Bir sermaye şirketinin yeniden yapılandırma talep edebilmesi için;

i. Muaccel para borçlarını ödeyemeyecek durumda olması,

ii. Mevcut ve alacaklarının borçlarını karşılamaya yetmemesi

iii. $\quad \mathrm{Bu}$ hallerden birine düşme tehlikesiyle karşı karşıya kalmasının kuvvetle muhtemel bulunması gerekir.

Yeniden yapılandırma talep edilebilmesi için üç halden birinin varlığı gerekir.

i. Ödeme güçlüğü veya aciz hali, borçlunun muaccel borçlarını ödeyebilmek için gerekli ödeme araçlarından geçici olmayan yoksulluk hali olarak tanımlanabilir.

ii. Borca batıklık, mevcut ve alacaklarına borçları karşılamaya yetmemesi hali olarak tanımlanabilir.

iii. Aciz hali veya borca batıklığa düşme tehlikesinin kuvvetle muhtemel olması da yeniden yapılandırmaya başvurmak için bir neden olarak kabul edilmiştir.

Şartların mevcut olup olmadığı konusunda tam ispat değil yaklaşık ispat aranmaktadır. Gerçeğe yakınlık ispatı ile yetinilmelidir.

\section{Başvuru Usulü}

Sermaye şirketi önceden görüşülmüş ve projeden etkilenen alacaklılar tarafından gerekli çoğunluk sağlanarak kabul edilmiş olan yeniden yapılandırma projesi ile birlikte muamele merkezinin bulunduğu yerdeki ticaret mahkemesine uzlaşma yoluyla yeniden yapılandırma için başvurabilir.

Projenin birden fazla alacaklı sınıfı içermesi halinde, her alacaklı sınıfının kendi içinde projeyi gerekli çoğunluk ile kabul etmiş olması gerekir.

Mahkeme başvuru üzerine başvurudan itibaren 30 günlük süre içinde bir duruşma günü belirler ve talebi ilan eder. Mahkemece ayrıca borçlu veya alacaklılardan birinin talebi üzerine nihai karar verilinceye kadar geçecek dönem için sermaye şirketinin mal varlığını korumaya yönelik gerekli tedbirleri alır.

Mahkeme nihai karar verilinceye kadar geçen dönemde sermaye şirketinin faaliyetlerinin sevk ve idaresini üstlenecek veya bunları denetleyecek bir veya birkaç ara dönem denetçisi atayabilir. Alacaklılar ve borçlular ara denetçiyi seçemezlerse mahkeme resen ara denetçi atayabilir.

\section{Yeniden Yapılandırma Talebinin Kabulü İçin Gerekli Şartlar}

Mahkeme yeniden yapılandırma başvurusunun tasdikine karar verebilmesi için şu şartlar bulunmalıdır.

i. Borçlular yeniden yapılandırmaya iyiniyetle başvurmuş olmalıdır.

ii. Yeniden yapılandırma projesi önceden müzakere edilmiş olmalıdır.

iii. Projeden etkilenen alacaklıların çoğunluğu tarafından kabul edilmiş olmalıdır.

iv. Projeye eklenmesi gereken belgeler ve proje kanun ve yönetmeliğe göre hazırlanmış bulunmalıdır.

v. Projeyi reddetmiş olan her alacaklının projeyle eline geçecek miktarın en az iflas tasfiyesi sonunda eline geçecek miktara eşit olduğu ispat edilmelidir.

\section{Taleple İlgili Verilebilecek Kararlar}

Mahkemece yeniden yapılandırma talebinin kabulü için gerekli şartların varlığının tespiti halinde yeniden yapılandırma talebinin tasdikine aksi halde reddine karar verilir. Uzlaşma yoluyla yeniden yapılandırma talebinin tasdikine karar verilmesi halinde mahkeme projenin yerine getirilmesini denetleyecek bir veya birkaç proje denetçisi tayin edebilir. Kararlara karşı temyiz süresi 10 gündür. Karar düzeltme yolu kapalıdır.

Talebin reddine karar verilmesi halinde mahkemece daha öne tedbirler kalkar ve durmuş olan dava ve takiplere devam edilir.

Yeniden yapılandırmanın kısmen veya tamamen feshi istenebilir. Tamamen feshi halinde projeden etkilenen alacaklar sermaye şirketinin iflasını isteyebilirler. Projeden doğan yükümlülüklerin ihlali halinde de sermaye şirketinin iflası istenebilir.

Tasdik talebinin reddi borçlunun iflası için bir neden oluşturmaz. Zira İIK'nun 301.maddesindeki gibi düzenlemeye yer verilmemiş̧ir. Ancak borca batıklık nedeniyle dayanarak yeniden yapılandırma koşullarının bulunmadığı tespit edilirse borca batık durumdaki sermaye şirketinin iflasına İİK'nun 179.maddesi uyarınca karar verilebilir.

İflasın ertelenmesi ile uzlaşma yoluyla yeniden yapılandırma arasındaki ilişki de üzerinde durulması gereken bir konudur. İflas erteleme süresi içinde yeniden yapılandırma talep edilmesine engel yoktur. Ayrıca iyileştirme tedbiri olarak da yeniden yapılandırma talep edilebilir. 
Erteleme süresi içinde yeniden yapılandırma projesinin tasdiki ertelemeyi kaldıran bir neden olarak kabul edilemez. Zira yeniden yapılandırma ile bozulan bir ödeme planı sunmaktadır. Ödeme planının kabul edilerek projenin tasdiki sermaye şirketinin borca batıklıktan kurtulduğu, iyileşmenin sağlandığı anlamına gelmez.

Konkordato ile yeniden yapılandırma ilişkisine değinmekte yarar var. Bu iki kurumun yan yana veya ardı ardına kullanılıp kullanılamayacağı konuları tartışmalıdır.

\section{Sonuç}

Mali güçlük içinde bulunan sermaye şirketlerinin yeniden yapılandırma prosedürü uygulanarak kurtarılması özellikle Amerika Birleşik Devletlerinde uygulanan bir yöntemdir. Türk Hukukuna 21.01.2004 tarihinde 5092 sayılı Kanunla giren bu kurum ABD’nin federal hukukunu oluşturan İflas Kanununun 11.Bölümünde (Chapter, 11) ki düzenlemeden esinlenerek Türk İcra ve İflas Kanununa alınmıştır.

Uzlaşma yoluyla yeniden yapılandırmanın amacı sermaye şirketinin mali durumunu yeniden yapılandırarak çalışmaya devam etmesini sağlamak ve böylece işçilerini, alacaklıların ve şirket ortaklarının olumsuz yönden etkilerini önlemektir. Bu kurumun uygulanmasıyla işçiler işlerini kaybetmemekte, alacaklılar iflasa nazaran daha fazla alacaklarına kavuşmaktadırlar.

Uzlaşma yoluyla yeniden yapılandırma prosedürü karmaşık ve masraflıdır. Sermaye şirketlerinin tercih ettiği bir yol değildir. Türkiye'de kurumun yürürlüğe girdiği 21.01.2004 tarihinden bu yana birkaç kez uygulama alanı bulmuştur. Sermaye şirketleri genellikle iflasın ertelenmesi talebinde bulunmaktadır.

Uzlaşma yoluyla yeniden yapılandırma kurumunun işlevsel hale getirilerek uygulamasının yaygınlaştırılması ekonomik hayatı olumlu yönde etkileyecektir.

\section{Kaynaklar}

- Pekcanitez, Atalay, Sungurtekin Özhan, Özekes, 2009. İcra ve İflas Hukuku, Ankara.

- Güngör, 2007. ABD Hukukunda Yeniden Örgütlenme Talebinin Kabulünün Sözleşmelere Etkisi, İstanbul.

- Kılıçoğlu, 2007. İflasın Ertelenmesinin Konkordato ve Uzlaşma Yoluyla Yeniden Yapılandırma Kurumlarıyla Karşılaştırılması, İstanbul.

- Oy, 2009. Uzlaşma Yoluyla Yeniden Yapılandırma, İstanbul.

- Taşpınar Ayvaz, 2006. İcra ve İflas Hukukunda Yeniden Yapılandırma, Ankara.

- Erten, 2006. Mali Durumu Bozulan Sermaye Şirketlerinin Uzlaşma Yoluyla Yeniden Yapılandırılması, Ankara.

- Ulusoy, 2007. Ticaret Hukuku Açısından Uzlaşma Yolu İle Borçların Yeniden Yapılandırılması, İstanbul. 


\section{Author Index}

Abdieva, Raziahan, Kyrgyzstan-Turkey Manas University, Kyrgyzstan .......................................................335

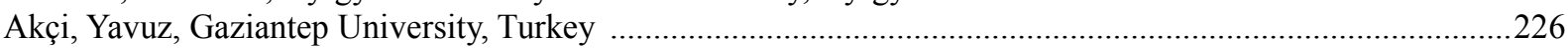

Akmoldoev, Kiyalbek, International Ataturk Alatoo University, Kyrgyzstan ...............................................197

Akova, Orhan, Istanbul University, Turkey ……………............................................................210, 382

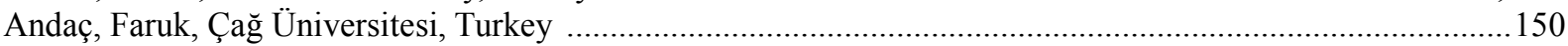

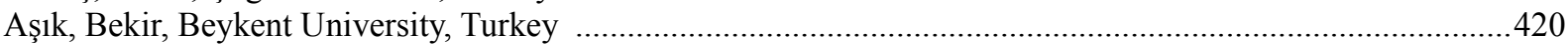

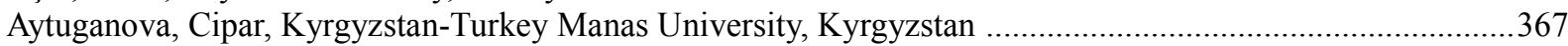

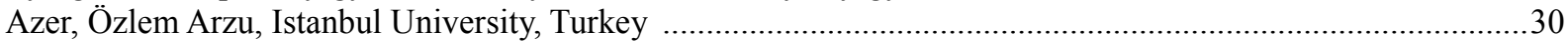

Baigonushova, Damira, Kyrgyzstan-Turkey Manas University, Kyrgyzstan ……………..................................57

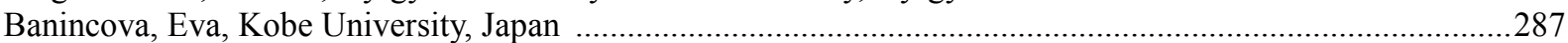

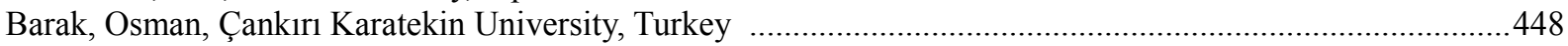

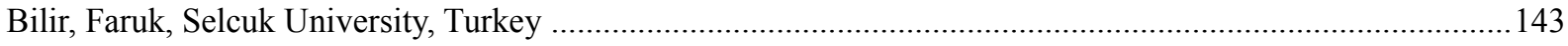

Budaichieva, Aidai, International Ataturk-Alatoo University, Kyrgyzstan .......................................................197

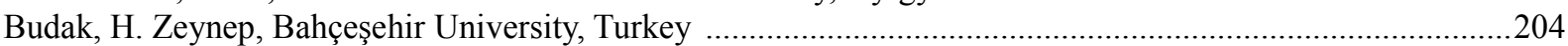

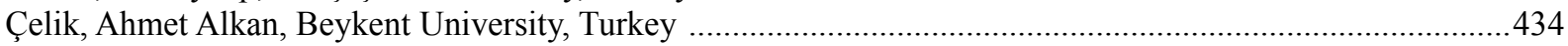

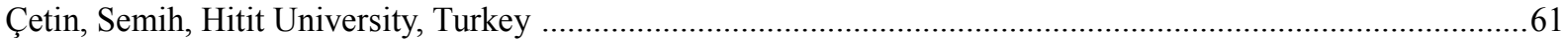

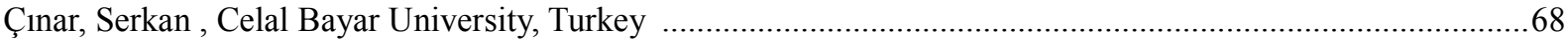

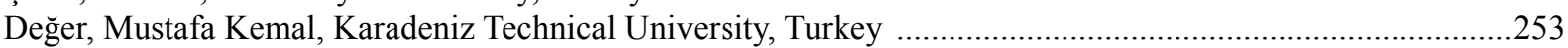

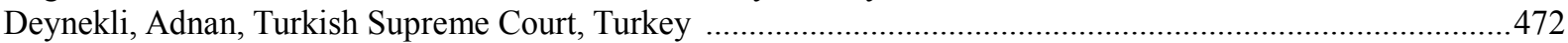

Doğan, Harun, Kyrgyzstan-Turkey Manas University, Kyrgyzstan ……………………………………............343

Dönmez, Dilek, Çanakkale Onsekiz Mart University, Turkey ...........................................................................382

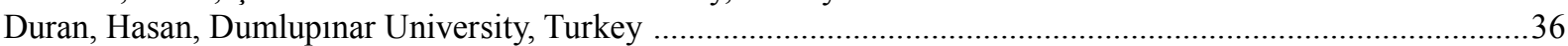

Dzhailov, Dzhumabek, Ministry of Agriculture, Kyrgyzstan ..........................................................................78

Egeli, Hüseyin Avni, Dokuz Eylül University, Turkey ………………………………................................412

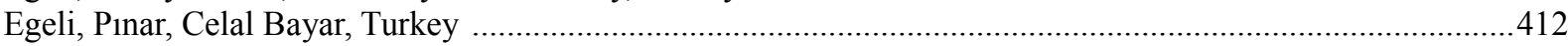

Ekmekçioğlu, Ercan, Kyrgyzstan-Turkey Manas University, Kyrgyzstan ..........................................................192

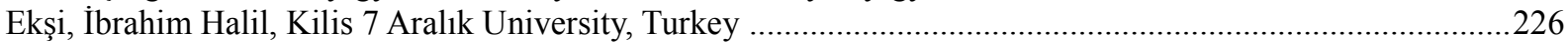

Emsen, Ömer Selçuk, Erzurum Atatürk University, Turkey ......................................................124, 253, 350, 440

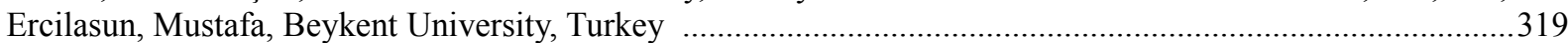

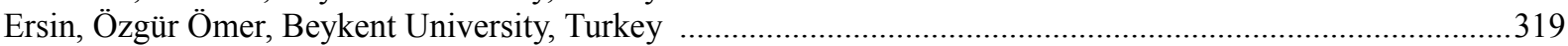

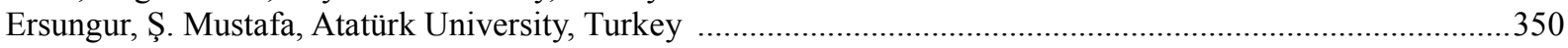

Gaidarov, Ruslan, Kyrgyz-Russian Slavic University, Kyrgyzstan ………………………….............................94

Ganiev, Cunus, Kyrgyzstan-Turkey Manas University, Kyrgyzstan .................................................................57

Gazioğlu, Şaziye, Hatay M.Kemal University \& Middle Eastern Technical University, Turkey ..............................1

Gencer, Ayşen Hiç, Istanbul Aydın University, Turkey .........................................................................319, 440

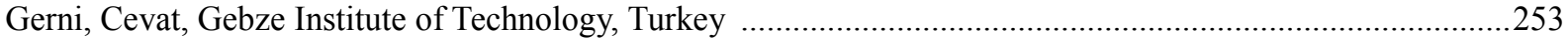

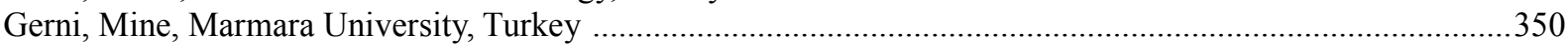

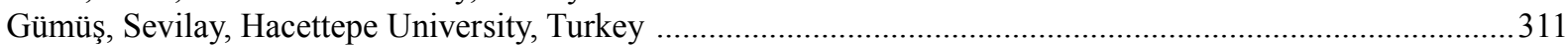

Hacıoğlu Deniz, Müjgan, Istanbul University, Turkey …………………………………………..... 160, 232

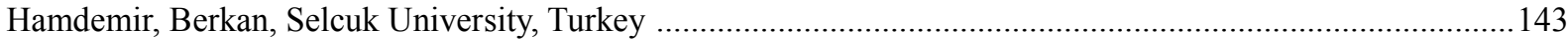

Haykır Hobikoğlu, Elif, Istanbul University, Turkey ……………………......................................160, 232

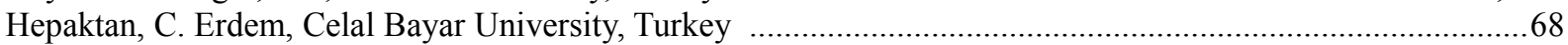

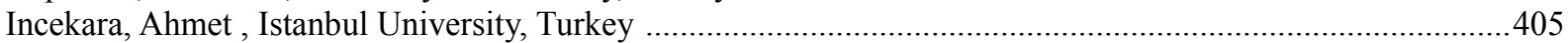

Japarova, Damira, Kyrgyzstan-Turkey Manas University, Kyrgyzstan ...........................................................186

Junushbaeva, Jarkyn, International Ataturk-Alatoo University, Kyrgyzstan ....................................................197

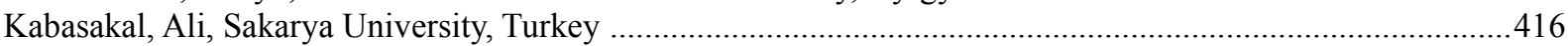

Kahyaoglu, Hakan, Dokuz Eylül University, Turkey ………………………………….............................412

Kaliev, Gani, Academy of Agricultural Sciences, Kazakhstan ......................................................................... 178

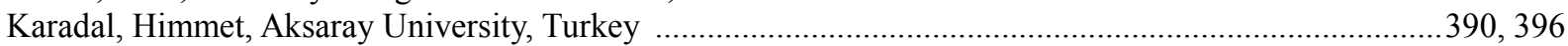

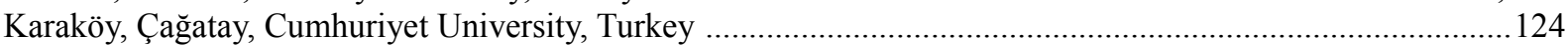

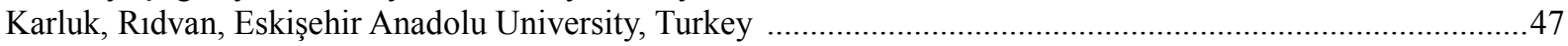

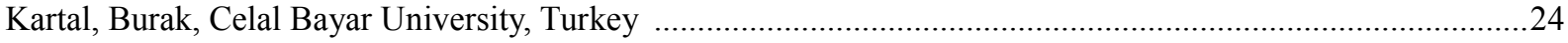

Kayumov, Nuriddin, Tajikistan Academy of Sciences, Tajikistan ......................................................................

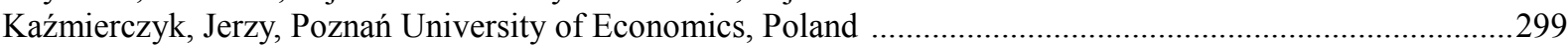

Kılıç, Cemil Hakan, İstanbul Chamber of Commerce, Turkey …………………………………………….......440

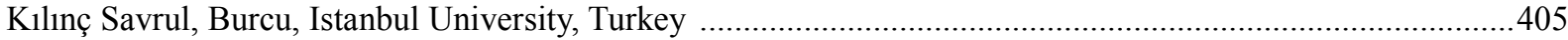

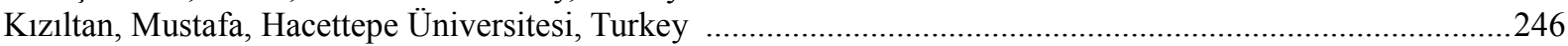

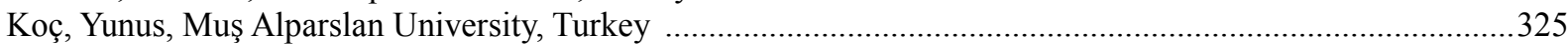

Koychuev, Turar, Kyrgyzstan-Turkey Manas University, Kyrgyzstan ......................................................276, 363 
Kupsuralieva , Elmira, Kyrgyzstan-Turkey Manas University, Kyrgyzstan .......................................................78

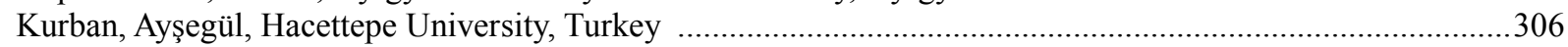

Kuş̧̧, Sinan, Prime Ministry Maritime Undersecretary, Turkey ………………….........................................138

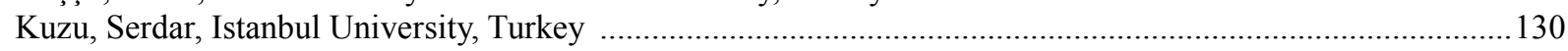

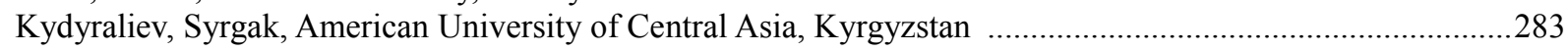

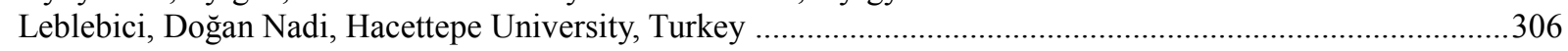

Macarenko, Larisa, Kyrgyz-Russian Slavic University, Kyrgyzstan ................................................................ 89

Manasov, Zamirbek, Middle East Technical University, Turkey ……………………..................................... 17

Moldashev, Altynbek, Research Institute of Agricultural Economics and Rural Development ..........................183

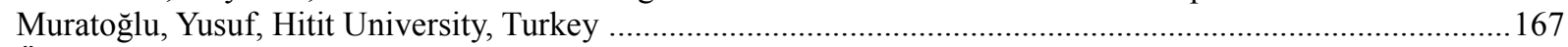

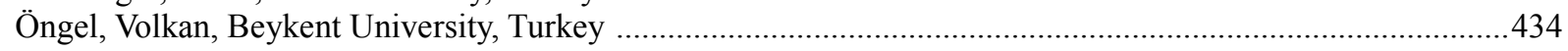

Orlova, Valentina, Donetsk National University of Economics and Trade, Ukraine ...........................................372

Oskonbaeva, Zamira, Kyrgyzstan-Turkey Manas University, Kyrgyzstan .......................................................426

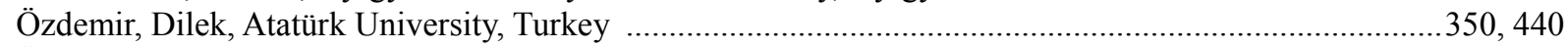

Özdil, Tuncer, Kyrgyzstan-Turkey Manas University, Kyrgyzstan .................................................238, 335, 426

Özgün, Tevfik Orçun, Hacettepe Üniversity, Turkey ...................................................................................... 44

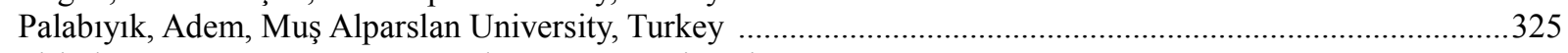

Pirimbaev, Jusup, Kyrgyzstan-Turkey Manas University, Kyrgyzstan .............................................................335

Pyshkina, Tatiana, Academy of Economic Studies of Moldova (ASEM), Moldova …………............................120

Rad, Nataliya, Donetsk National University of Economics and Trade, Ukraine ...............................................293

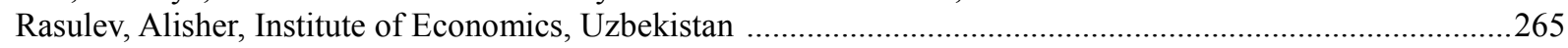

Ravanoglu, Galip Afsin, Kyrgyzstan-Turkey Manas University, Kyrgyzstan .................................................138

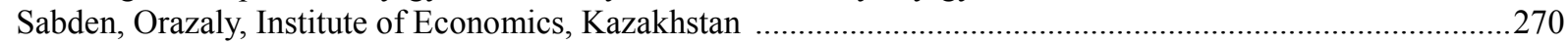

Sabyrbekov, Rahat, American University of Central Asia, Kyrgyzstan ..........................................................400

Salam Lodhi, Abdul, (ZEF b) University of Bonn, Germany 109

Sariev, Farkhad, Zh. Alyshbaev Cooperation Institute of Issykkul, Kyrgyzstan ...............................................78

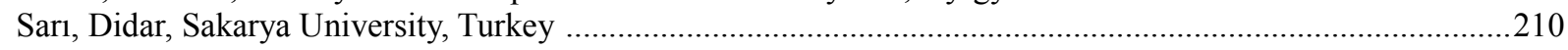

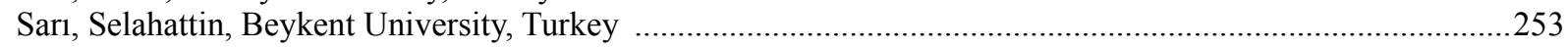

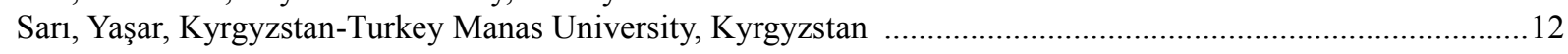

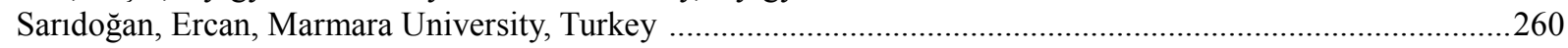

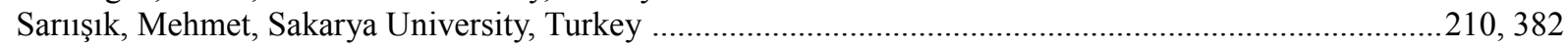

Saygin, Muhammet, Aksaray University, Turkey ……………………………...........................390, 396

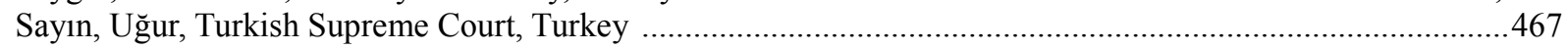

Şen, Lütfi Mustafa, Sakarya University, Turkey ………………………………………………………......217

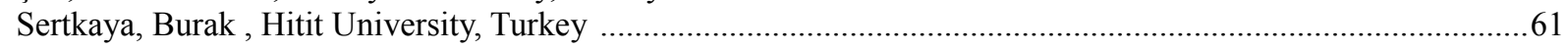

Singh, Joginder, Centre for Agricultural Reseach \& Rural Development, India ...............................................102

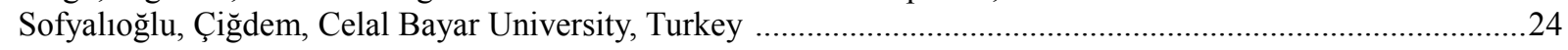

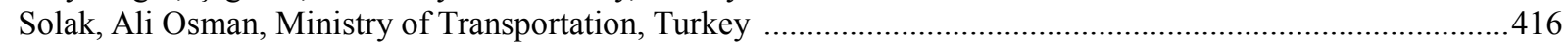

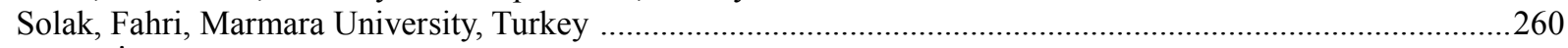

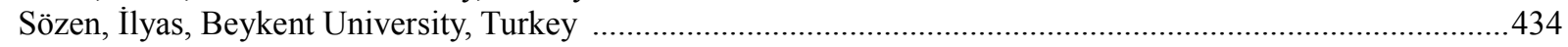

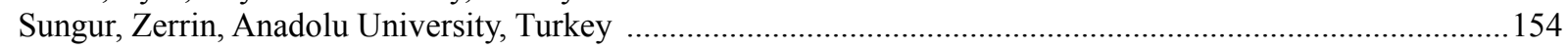

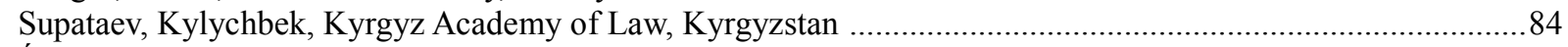

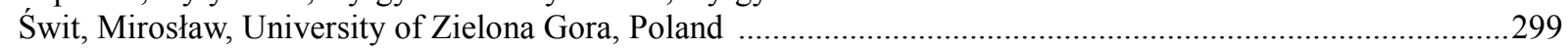

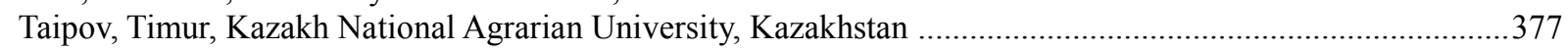

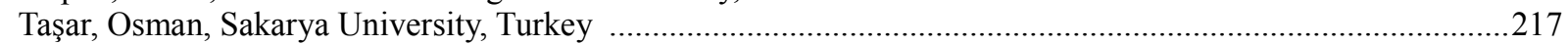

Tonkoshkurov, Igor, Khakassia State University named after Nikolaj Katanov, Russia .....................................116

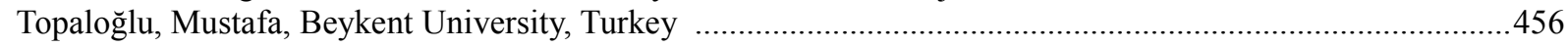

Tsuladze, Iuri, State Committee for Science and Technologies, Georgia ………..................................................26

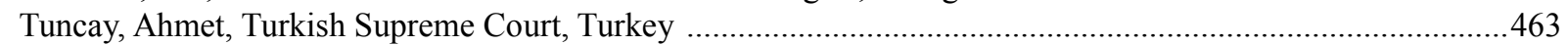

Turdalieva, Aynura, Kyrgyzstan-Turkey Manas University, Kyrgyzstan ...............................................238, 426

Türkay, Oğuz, Sakarya University, Turkey …………………………………………………………....210

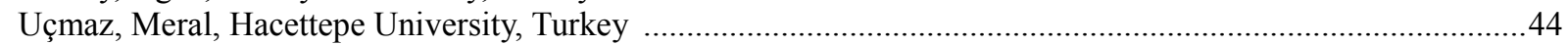

Umarov, Khodjamakhmad, Institute of Economics, Tajikistan ........................................................................ 174

Urdaletova, Anarkül, Kyrgyzstan-Turkey Manas University, Kyrgyzstan ........................................................223

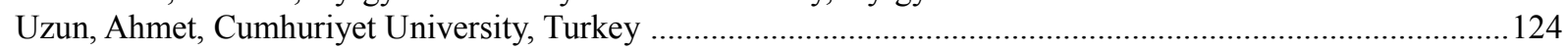

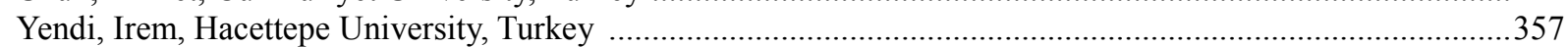

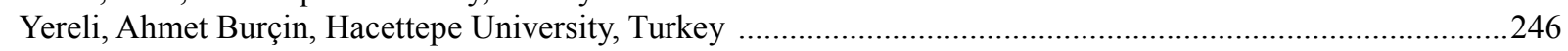

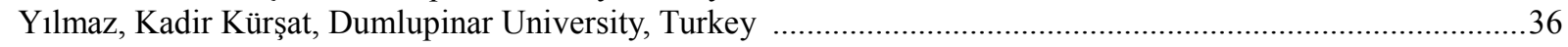

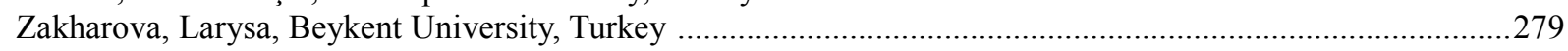

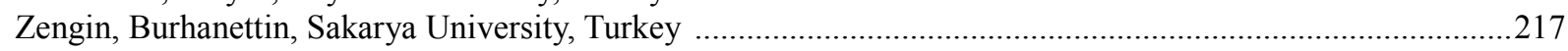

